Eduardo de Almeida

Reflexões sobre estratégias de projeto e ensino 


\section{Eduardo de Almeida}

Reflexões sobre estratégias de projeto e ensino

Tese apresentada para obtenção do título de Doutor em Arquitetura e Urbanismo

Faculdade de Arquitetura e Urbanismo da Universidade de São Paulo

Curso de Pós-Graduação

Área de Concentração: Projeto de Arquitetura

Orientação: Professora Doutora Helena Aparecida Ayoub Silva

Cesar Shundi Iwamizu

São Paulo, 2015 
Autorizo a reprodução e divulgação total ou parcial deste trabalho, por qualquer meio convencional ou eletrônico, para fins de estudo e pesquisa, desde que citada a fonte.

E-mail do autor: shundi@siaa.arq.br

Iwamizu, Cesar Shundi

Eduardo de Almeida. Reflexões sobre estratégias de projeto e ensino / Cesar Shundi Iwamizu. --São Paulo, 2015.

$$
545 \text { p. : il. }
$$

Tese (Doutorado - Área de Concentração: Projeto de Arquitetura) - FAUUSP.

Orientadora: Helena Aparecida Ayoub Silva

1.Projeto de arquitetura 2.Arquitetura (Estudo e ensino)

3.Estratégia de projeto 4.Almeida, Eduardo Luiz Paulo Riesencampf

de, 1933- I.Título

CDU 72.011 .22 




\section{AGRADECIMENTOS}

A realização desta pesquisa foi fruto de um trabalho coletivo realizado ao longo dos últimos cinco anos, quando foi iniciado o plano de pesquisa que originou esta tese, concomitantemente ao desenvolvimento de outros projetos de arquitetura e diversas experiências didáticas que, direta ou indiretamente, colaboraram na elaboração deste trabalho. Agradeço a todos os envolvidos:

Bibliotecas da FAU USP, Vilanova Artigas e Sérgio Milliet;

Miriam Afonso, pelo suporte junto ao arquivo do escritório Eduardo de Almeida; Flávio Goddoy, pela digitalização dos desenhos de grandes dimensões;

Adriana Shima e Erwin Rezelman, pelas traduções;

Artur Mei, pelo filme The Fountainhead;

Silvio Oksman e Rita da Costa Aguiar, pela colaboração na bibliografia;

Paula Santoro e Mariana Vaz, pela companhia no Sertão;

Mirela Geiger, por fornecer os projetos presentes nos Arquivos da Fundação para o

Desenvolvimento da Educação (FDE);

Milton Braga, pelos desenhos da estação de metrô Ibitirama;

Paulo Fujioka, pelas conversas e bibliografia sobre a obra de Frank Lloyd Wright;

Melissa Paro e Ana Paula Pontes, pelas informações sobre Sérgio Bernardes;

Fausto Lima, pelas informações sobre a casa Aroldo Fuganti, em Londrina;

João Xavier, Roberto Strauss, Dirceu Furquim, Marcos Lanna, Edson Hiroyama, Roberto

Zocchio, Maira Rios, Leonardo Sette e Maressa Bronsztein pelo fornecimento de diversas fotografias que ilustram este trabalho;

Mariana Tassinari e Thomas Piper, pela participação no filme Eduardo de Almeida - arquiteto da medida justa; 
Alberto Tassinari e Marina Grinover, pelas conversas;

Dulce Marino e Miwako Iwamizu, pelo apoio;

Bruno Salvador, Andrei Barbosa, Rafael Carvalho, Eduardo Gurian, Guto Arruda, Henrique Costa, Fernanda Britto, Leonardo Nakaoka, Luca Caiaffa, Natália Balak, Cecília Torrez, Daniel Nobre, Francesco Perrota Bosch, Rafael Goffinet, Anita Freire e Alexandre Gervásio, pela convivência e colaboração no escritório; Anderson Freitas, Pedro Barros, Acácia Furuya e Carlos Ferrata pelas parcerias dos últimos anos; Marcelo Pontes, Paula Zemel e Eduardo Gurian, pelo espaço compartilhado;

Anália Amorim, Ciro Pirondi, Álvaro Puntoni, Fábio Valentim, Anderson Freitas, Eduardo Ferroni, Francisco Fanucci, José Maria Macedo, Eduardo Gurian, Guilherme Petrella, Cristiane Muniz, Pablo Hereñú, Pep Pons e João Yamamoto pelo convívio na Escola da Cidade na organização da disciplina arquitetura IV e, agora, no Estúdio Vertical;

Rogério Bueno, Eduardo Gurian, Maira Rios, Felipe Notto, Gaú Manzi, Caio Faggin, Moracy Amaral, Apoena Amaral, Pablo Hereñú, Fábio Onuki e Kátia Pestana, pelas conversas no grupo de pesquisa da área de concentração de Projeto de Arquitetura da FAU USP;

Julio Roberto Katinsky, pela orientação inicial;

Antonio Carlos Barossi e Mônica Junqueira, pelo exame de qualificação;

Arthur Rozestraten, pela orientação geral sobre a pesquisa em diversos momentos;

Alessandra Figueiredo e Renata Sério, pelo tratamento das imagens, catalogação, diagramação e apoio em todas as etapas deste trabalho;

João Yamamoto, pelas conversas, idealização e programação do site; 
Haifa Sabbag, pela revisão técnica e gramatical do trabalho;

Eduardo de Almeida, por permitir acesso irrestrito ao acervo do escritório, pela realização de tantos projetos e, sobretudo, pelo aprendizado constante;

Helena Ayoub Silva, pela orientação entusiasmada, não só nesta tese, mas também no enfrentamento profissional e acadêmico ao longo destes últimos 20 anos.

Dedico este trabalho a Mirella, a Nara e à pequena que chegará em breve... 


\section{ABSTRACT}

This thesis covers the complete works of architect Eduardo Riesemcampf de Almeida.

For the first time, his sketches, study, execution and perspective drawings and photographs, were digitalized, organized and catalogued creating the first comprehensive analysis of his life's work. In addition to the graphic material, numerous interviews highlight his personal view of various projects, providing a reflection and deep analysis of the design process throughout his career.

The work of Eduardo de Almeida spans more than fifty years. It may be categorized in phases aligned to the partnerships and sources of influence prevalent to each period. This subsequently revealed changes in expression and construction techniques according to the specific project needs.

Despite these changes, it is possible to identify recurring design strategies that unify and characterize his work; even in projects with different use, scale and context.

The analysis also reveals the relationship between the architect's design techniques and his teaching. As a respected professor, at the Sao Paulo University's Architectural School, his work is continuously referenced in new generations of architects' works, embodied by his former students and coworkers.

This still-unpublished material is intended to reveal Almeida's extensive architectural work to the general public. It should serve as reference for future studies about the architect as well as the Brazilian and Sao Paulo Modern Architecture.

Keywords: Eduardo de Almeida; architectural projets; project strategy; architectural education; 


\section{RESUMO}

Reunida em um único volume pela primeira vez, a obra completa do arquiteto Eduardo Riesencampf de Almeida foi catalogada, digitalizada e organizada para esta tese, permitindo a compreensão do conjunto dos trabalhos desenvolvidos a partir de estudos, projetos executivos, perspectivas, croquis e fotografias. Tal material se somou a inúmeras entrevistas que não só permitiram leituras específicas sobre alguns projetos, como possibilitaram reflexões sobre os procedimentos projetuais aplicados durante seu percurso profissional.

Realizada ao longo de mais de cinquenta anos, pode-se notar que a obra de Eduardo de Almeida passou por diferentes fases e, dependendo das influências ou das parcerias estabelecidas em cada período, revela mudanças de linguagem e emprego de técnicas construtivas variadas, de acordo com o enfrentamento específico de cada projeto.

Apesar destas variações, é possível identificar a recorrência de estratégias projetuais que garantem unidade e caráter ao conjunto de sua obra, mesmo nos trabalhos destinados a diferentes usos, escalas ou contextos.

Este material, ainda inédito, permite revelar a um público mais amplo a produção arquitetônica de Eduardo de Almeida e ser utilizado como orientação para novos estudos sobre seu trabalho e, consequentemente, sobre a Arquitetura Moderna Paulista e Brasileira.

A abordagem permite ainda uma reflexão sobre estas táticas de projetar e suas relações com o ensino, uma vez que a obra de Eduardo de Almeida não se dissocia de sua atuação como professor, pois refletese na produção de novas gerações, ex-alunos e ex-colaboradores.

Palavras Chave: Eduardo de Almeida; projeto de arquitetura; estratégia de projeto; ensino de arquitetura; 



\section{SUMÁRIO}

Introdução

Metodologia da pesquisa

Capítulo 1

A obra completa de Eduardo de Almeida | Projetos e obras

Capítulo 2

Reflexões sobre as estratégias projetuais presentes na obra de Eduardo de Almeida

a. Desenho: trabalho e ensino

b. Orgânico e racionalista

303

c. Indústria, volumetria e programa

339

d. Parte e o todo

387

e. Lugar, construção e transparência

427

f. Tecnologia e tradição

Considerações finais

Referências bibliográficas 



\section{INTRODUÇÃO}

Esta tese visa publicar o acervo do arquiteto Eduardo de Almeida acumulado em mais de cinquenta anos de atividade profissional, pela primeira vez digitalizado, catalogado e sintetizado de forma completa.

No Capítulo 1 - A obra completa de Eduardo de Almeida / Projetos e obras - o conjunto de trabalhos foi organizado por meio de fichas dispostas em ordem cronológica, onde cada página sintetiza as informações necessárias ao entendimento de cada projeto.

A leitura desse conjunto permitiu identificar estratégias recorrentes nas obras de Eduardo de Almeida, possibilitando estabelecer pontos de contatos com as obras de outros arquitetos, com suas experiências didáticas na FAU USP e com o processo de trabalho em seu escritório.

No Capítulo 2 - Reflexões sobre as estratégias projetuais presentes na obra de Eduardo de Almeida - foram selecionadas algumas destas estratégias, organizadas em seis itens, para ilustrar a realização de diversos projetos, relacionando-os com aspectos ligados à teoria, à história, à crítica e ao ensino de arquitetura.

Cada um destes temas pode ser lido de forma independente, como capítulos autônomos, já que se trata de um recorte pontual realizado a partir de uma obra bastante variada que, inclusive, poderia ser estendida à leitura de outros projetos não incluídos nesta análise. Analogamente, podemos dizer que as mesmas obras poderiam suscitar outras questões, já que muitas delas tangenciam diversos assuntos que não foram abordados por esta tese. 
Em 'Desenho: trabalho e ensino' foi realizado um breve ensaio sobre a principal ferramenta de Eduardo de Almeida - o desenho -, tanto em suas atividades no escritório, quanto em sua didática. Os projetos realizados nos primeiros dez anos como arquiteto' ${ }^{1}$, foram agrupados em 'Orgânico e racionalista', aproximação de caráter histórico que retrata a produção arquitetônica de Eduardo de Almeida, ora sob influência wrightina, ora de acordo com os preceitos racionalistas.

Após o retorno de Eduardo de Almeida de uma viagem à Itália, onde cursou desenho industrial na Universidade de Florença, há uma série de projetos que retratam esta influência - e também o início de sua atuação como docente na FAU USP - aqui agrupados em 'Indústria, volumetria e programa:

Em 'Parte e o todo' é apresentado um estudo específico sobre a casa da rua Carangola, projetada para sua própria família em 1977. Ao resgatar os desenhos de diferentes etapas foi possível compreender a evolução do processo, sobretudo no modo como a escolha de um pormenor - no caso, o bloco de concreto como elemento de construção - redefine o objeto arquitetônico como um todo.

As relações dos edifícios com seu sítio foram abordadas em 'Lugar, construção e transparência'; na obra de Eduardo de Almeida, as condicionantes do terreno direcionam as soluções formais e técnicas de cada projeto, sendo uma premissa a continuidade entre interior e exterior, entre o edifício e a paisagem.

Aparentemente contraditórios, elementos ligados à 'tecnologia e tradição' aparecem com clareza na produção realizada em conjunto com Arnaldo Martino entre 1978 e 1988, e

${ }^{1}$ Eduardo de Almeida se forma na FAU USP em 1960, mas antes disso já realizava projetos com seus colegas no escritório Horizonte Arquitetos. 
permanecem como questão na obra de Eduardo de Almeida até os dias de hoje.

Este conjunto de seis temas compõe as 'Reflexões sobre as estratégias projetuais presentes na obra de Eduardo de Almeida', iniciando uma pesquisa que se mantém aberta e inconclusa, dada a quantidade de material publicado e disponível a novas aproximações desta obra.

Entende-se o início deste trabalho como uma colaboração à 'Pesquisa em Projeto', dado que ainda se faz necessário encontrar novos caminhos para as pesquisas ligadas ao fazer, ao projetar, nem sempre totalmente preenchidas pelos campos específicos da teoria, da história, da crítica e da tecnologia.

A adaptação do conteúdo desta tese para uma página na internet visa amplificar o alcance desta pesquisa, permitindo sua atualização constante a partir de novos projetos de Eduardo de Almeida ou pelo resgate de informações perdidas - desenhos, registros de obras ou fotografias - que não puderam ser disponibilizadas neste momento. 



\section{METODOLOGIA DA PESQUISA}

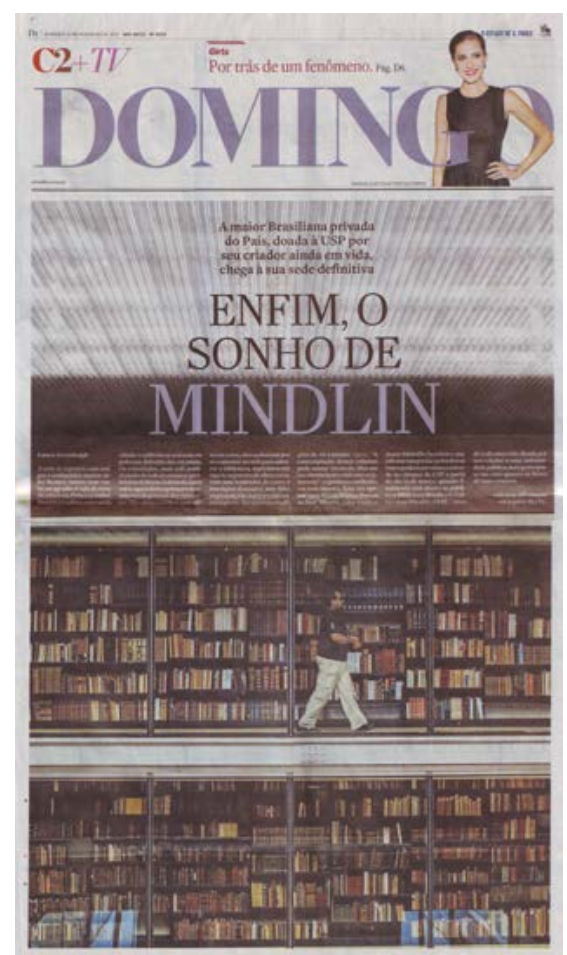

Publicação sobre a Biblioteca Guite e José Mindlin e o IEB. RORIZ, Jonne. Enfim, o sonho de Mindlin. $O$ Estado de São Paulo, São Paulo, fev. 2013.
A elaboração desta tese consistiu em um processo de trabalho baseado em pesquisas bibliográficas e, posteriormente, em um estudo aprofundado sobre os projetos e obras presentes no Acervo Técnico do Escritório Eduardo de Almeida Arquitetos Associados.

Primeiramente, o levantamento de todas as publicações em jornais, revistas e livros dedicados aos seus projetos e obras, desde o início de sua atuação profissional, foram agrupadas no Trabalho Programado I, como parte das atividades previstas no curso de Pós-Graduação da FAU USP.

Foram realizadas consultas nas Bibliotecas da FAU USP, da Escola da Cidade e do Centro Cultural Vergueiro, além de pesquisas nos acervos pessoais do arquiteto e do autor da tese. Também foram efetuadas buscas pela internet, considerando os acervos digitais de periódicos e sites especializados de arquitetura.

O material encontrado foi digitalizado ou fotografado e organizado em um Trabalho Programado, conformado por três capítulos - Revistas, Livros e Jornais - seguindo a ordem cronológica das datas de publicação. Cada reportagem apresenta dados da mídia impressa veiculada e o nome do projeto publicado, contendo ainda a reprodução da matéria e, quando possível, a capa da edição.

Foram contabilizadas 39 publicações em revistas especializadas de arquitetura, construção ou decoração e inúmeras reportagens recentes sobre a inauguração da Brasiliana USP - conjunto que abriga a Biblioteca Guita e José Mindlin e o IEB, Instituto de Estudos Brasileiros - em revistas e periódicos destinados a um público não especializado. 
Do total de publicações, a maior parte das reportagens dedica-se a projetos residenciais, exceção feita à publicação de obras construídas como a Brasiliana USP, o edifício de escritórios da SAP, empresa de desenvolvimento de softwares implantada em São Leopoldo - RS, o restaurante construído na Vila Madalena e uma escola para a FDE, Fundação para o Desenvolvimento da Educação, localizada em Guarulhos.

Foram publicados também alguns projetos não construídos - Torre Pluralista, Concurso da Secretaria de Agricultura, Concurso do Museu Constantini e estudo para a Galeria Prestes Maia - além de um depoimento de Eduardo de Almeida sobre Flávio Motta, na Revista Caramelo, e uma retrospectiva apresentada na seção Documento da revista AU, organizada pelo arquiteto Edson Hiroyama.

Dos projetos residenciais apresentados em revistas especializadas, foi registrada a publicação de vinte diferentes residências unifamiliares, considerando que cinco obras - Sigrist, Belinky, Praia Vermelha e as duas casas feitas para seu filho Lalo de Almeida -aparecem duas vezes em diferentes revistas, e a Fazenda Água Comprida e a casa da rua Carangola foram mostradas, respectivamente, três e quatro vezes.

Com exceção da revista japonesa Process número 17, edição de 1980 dedicada à arquitetura moderna brasileira, todas as demais publicações encontram-se em revistas nacionais.

Das publicações em livros, a obra de Eduardo de Almeida organiza-se novamente com maioria absoluta de residências unifamiliares construídas - Sigrist, Carangola, Belink, Tassinari, Fazenda Água Comprida, Praia Vermelha, Lalo de Almeida - além do edifício de habitação multifamiliar Gemini e três escolas públicas, em diferentes catálogos organizados pela FDE Fundação para o Desenvolvimento da Educação.

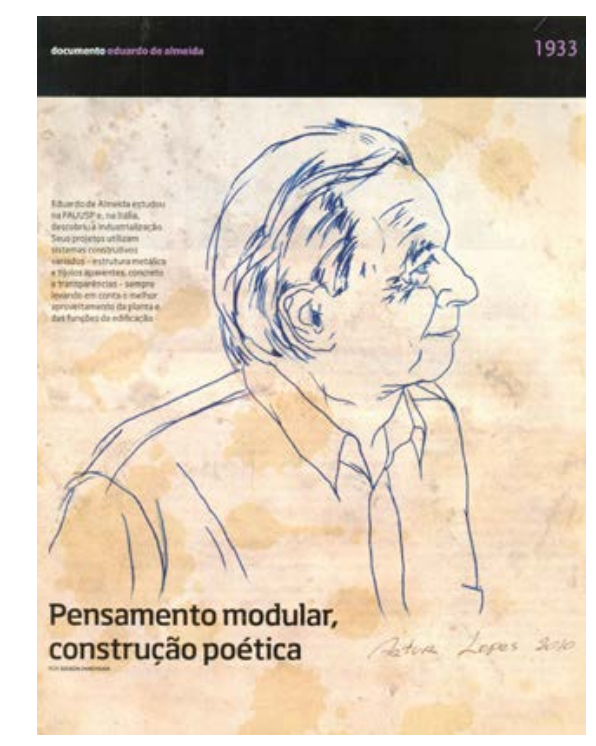

Retrospectiva da obra de Eduardo de Almeida HIROYAMA, Edison. Pensamento modular, construção poética. Revista $A u, n .202$, jan. de 2011, pág. 66-69. 
O projeto realizado em parceria com o arquiteto Fábio Penteado para a Santa Casa de Misericórdia - do qual Eduardo participou apenas até a etapa de anteprojeto - está presente em publicação da própria instituição.

Foram localizados dois depoimentos do arquiteto em outras publicações: o primeiro em uma coletânea de arquitetos brasileiros organizada pela Asbea, e o segundo para a FAU USP sobre a produção acadêmica e arquitetônica de seus professores.

A veiculação da obra de Eduardo de Almeida em jornais limita-se a um artigo sobre o edifício Gemini e uma série de reportagens sobre a inauguração da Biblioteca Guita e José Mindlin, além de um texto crítico de Guilherme Wisnik, publicado no jornal Folha de São Paulo, a propósito do lançamento de seu primeiro livro no Brasil, editado pela Romano Guerra, com

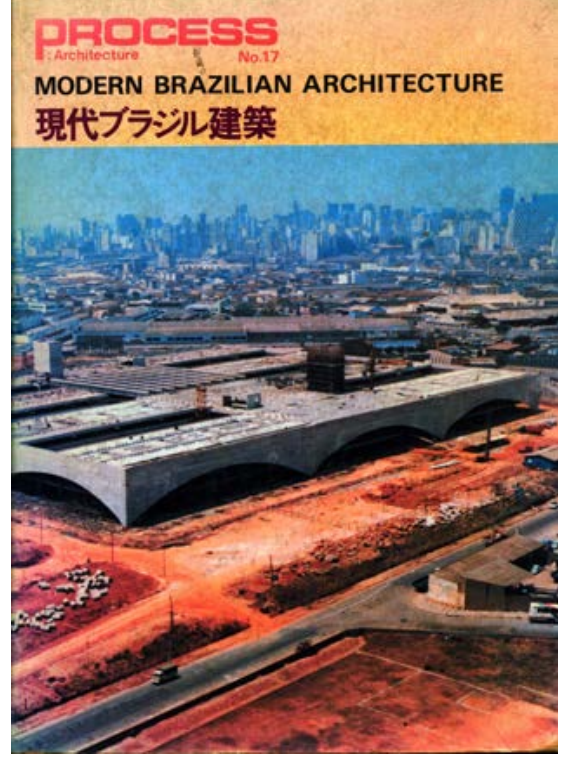

Publicação das residências Max Define, Sigrist e Carioba.

Process, n. 17, 1980, pág. 126-133. texto crítico de Luís Espallargas a respeito de dez casas qu e fizeram parte da exposição da $6^{a}$

Bienal Internacional de Arquitetura de São Paulo, realizada em 2005.

A esta publicação soma-se o livro organizado por Hélio Piñon também em 2005, da editora da UPC - Universidade Politécnica da Catalunha - e da ETSAB - Escola Técnica Superior de Arquitetura de Barcelona - constituído de texto crítico sobre a obra de Eduardo de Almeida, com desenhos e fotografias de seis obras: casas Tassinari, Carangola, Sigrist e Define, e também o edifício Gemini e o escritório da rua Chilon.

São as duas únicas publicações dedicadas exclusivamente à obra de Eduardo de Almeida, além das pesquisas acadêmicas de Maria Isabel Imbronito em sua Dissertação de Mestrado - Três Edifícios de Habitação para a Formaespaço: Modulares, Gemini e Protótipo - e em sua Tese de Doutoramento - Procedimentos de projeto com base em retícula: estudo de casas de Eduardo de Almeida. 
Reunido, este conjunto revela um olhar sobre a obra de Eduardo de Almeida que se concentra de maneira recorrente em determinados projetos, comprovando que boa parte de sua produção permanece desconhecida, tanto para os arquitetos quanto para um público mais abrangente.

Este primeiro Trabalho Programado permitiu também a compreensão precisa de como é vista a obra do arquiteto Eduardo de Almeida; por meio das reportagens e dos textos críticos sobre seus projetos se reafirma a qualidade, a simplicidade ou a sofisticação desta arquitetura; no entanto, valoriza-se apenas uma parte desta produção - os projetos das casas, considerando que algumas foram reproduzidas inúmeras vezes.

Os poucos depoimentos publicados pelo arquiteto são fundamentais para ampliar a compreensão sobre sua obra, pois revelam seu posicionamento sobre questões relacionadas à arquitetura, à cidade, às suas referências e ao seu processo de projetar, como a recente entrevista reproduzida pela Universidade Sapienza de Roma na Rassegna Di Architettura e Urbanistica 142/143.

Estas duas maneiras de se aproximar da obra de Eduardo de Almeida - através da opinião dos críticos e de sua própria visão de arquiteto - constituíram um ponto de partida para esta tese a respeito de um trabalho circunscrito e conhecido - em direção a descobertas presentes neste universo ainda inexplorado.

A ideia de realizar a coleta de informações não é original e a metodologia da pesquisa se valeu da experiência de inúmeros trabalhos acadêmicos dedicados a outros arquitetos, mas, de alguma maneira, o maior incentivo para realizar o trabalho programado desta forma partiu do próprio Eduardo de Almeida, quando em uma das muitas conversas em

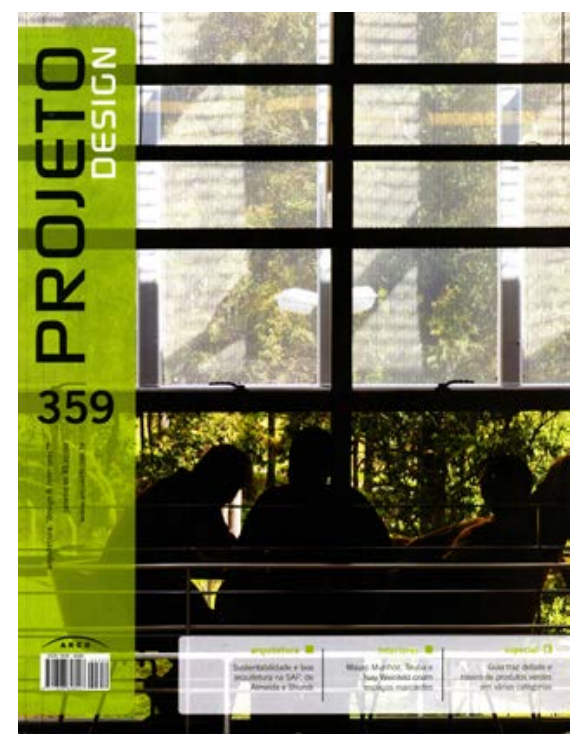

Publicação sobre o edifício de escritórios SAP. Projeto Design, n. 359, janeiro de 2010, pág. 38-49. 


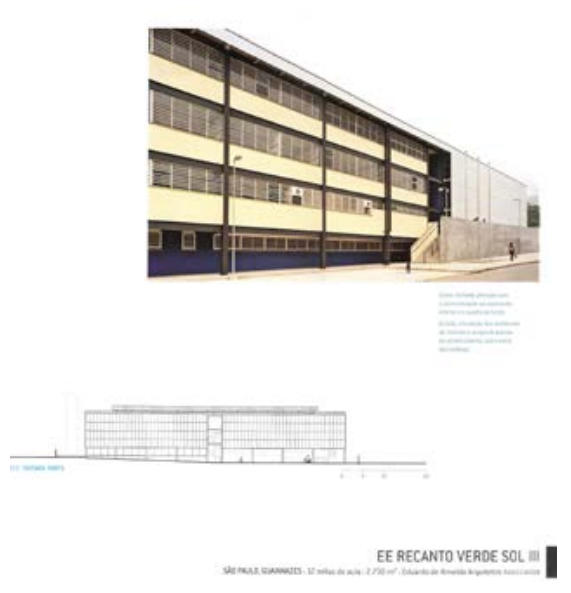

Escola Recanto Verde Sol III.

FERREIRA, Avany de Francisco; de MELLO,

Mirela Geiger. Arquitetura Escolar Paulista:

estruturas pré-fabricadas, 2006, $1^{a}$ edição, p. 155. seu escritório, relatou que antes mesmo de ingressar no curso de Arquitetura e Urbanismo da FAU USP, seu interesse pela disciplina era tanto que uma de suas atividades preferidas consistia em colecionar recortes de jornais e revistas com as obras que lhe interessavam, agrupados em um álbum de referências que serviria como repertório para seus primeiros projetos na faculdade.

Infelizmente este álbum se perdeu; não temos mais acesso as suas primeiras referências, mas podemos afirmar que o ponto de partida desta pesquisa foi a formatação de nosso próprio álbum sobre a obra de Eduardo de Almeida.

Paralelamente à realização deste álbum, foi iniciado um segundo Trabalho Programado que consistiu na pesquisa, digitalização e catalogação dos projetos realizados pelo seu escritório, ao longo de mais de cinquenta anos de atividade profissional.

Do ponto de vista metodológico, este trabalho partiu da própria organização do acervo do arquiteto - desenhos guardados em tubos e caixas e imagens em diferentes mídias - e exigiu a análise do material encontrado, seguido da seleção dos exemplares considerados significativos e, posteriormente, da compilação dos projetos em ordem cronológica.

Utilizou-se também o arquivo da Fundação para o Desenvolvimento da Educação (FDE) para complementar as informações sobre as escolas projetadas em diversos períodos - Fundo Estadual de Construções Escolares (FECE), Companhia de Construções Escolares do Estado de São Paulo (CONESP) e, mais recentemente, da própria FDE - possibilitando a comparação entre os projetos executivos e os estudos preliminares e anteprojetos pertencentes ao acervo do arquiteto. 
Muitos destes projetos para edificações escolares contaram com a colaboração do arquiteto Arnaldo Martino, a partir de 1978, em uma parceria que produziu também uma grande quantidade de residências unifamiliares, edifícios de habitação coletiva e edifícios institucionais diversos que aparecem compilados aqui, com exceção daqueles que ficaram sob responsabilidade de Arnaldo Martino após a dissolução da sociedade em 1988, e que poderão ser incorporados a este conjunto posteriormente.

Após à banca de qualificação, foram incluídos no Trabalho Programado II os projetos desenvolvidos com o uso do computador como ferramenta de trabalho a partir de 1995 até os dias de hoje, tais como a sede para o MAC USP, para um terreno localizado na Barra Funda, a proposta para o Museu Constantini em Buenos Aires e também os diversos projetos para a Brasiliana USP - conjunto que abriga a Biblioteca Guita e José Mindlin e o IEB, Instituto de Estudos Brasileiros -, inaugurado recentemente no Campus da Universidade de São Paulo.

Desta forma, foram catalogados mais de 240 projetos que, reunidos em um único volume, permitem a compreensão do conjunto da obra por meio de perspectivas, croquis, desenhos técnicos e fotografias.

Ao longo de seu percurso profissional, a obra de Eduardo de Almeida passou por diferentes fases e, dependendo das influências ou das parcerias estabelecidas em cada período, revela mudanças de linguagem e emprego de técnicas construtivas variadas, de acordo com o enfrentamento específico de cada projeto.

Apesar destas variações, é possível identificar a recorrência de estratégias projetuais que garantem unidade e caráter a sua obra, mesmo considerando trabalhos destinados a diferentes usos, escalas ou contextos.

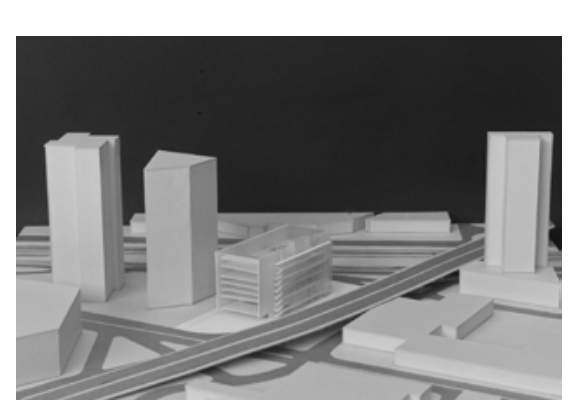

Maquete para o concurso MAC USP Acervo Eduardo de Almeida 


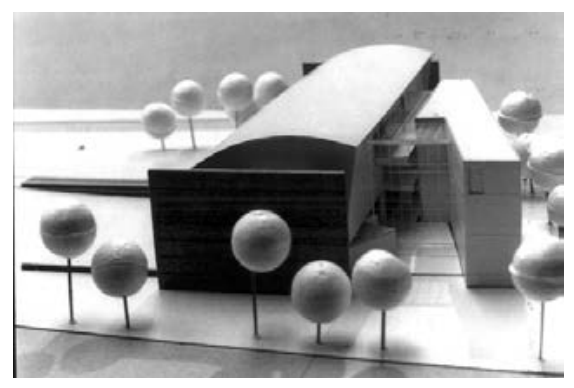

Maquete para o concurso Museu Constantini Acervo Eduardo de Almeida
A quantidade de projetos reunidos aqui também altera a impressão de que Eduardo de Almeida tenha se dedicado somente a poucas e requintadas casas. Ao contrário, revela uma produção ampla que reafirma a mesma qualidade espacial e o rigor construtivo presentes em obras amplamente divulgadas - como as casas Defini, Sigrist e Almeida - e em muitos outros projetos.

Do material agrupado, foram identificados cerca de 106 projetos para residências unifamiliares, sete para conjuntos de habitação coletiva horizontal e cerca de 26 edifícios residenciais verticalizados, além de quatro projetos de reforma de apartamentos.

Também foram contabilizados sete projetos para fazendas que, dependendo da escala do empreendimento, envolveram casas-sede ou habitações para caseiros, administradores e colonos, além de outros equipamentos. Tal conjunto se soma a quatro planos urbanísticos destinados à implantação de condomínios ou conjuntos habitacionais.

Foram acrescentados ainda 18 projetos destinados a edifícios de escritórios, tanto para empresas específicas quanto para a criação de conjuntos comerciais, que se somam a três edifícios industriais e sete projetos para lojas e serviços de menor escala.

Complementando este material, foram reproduzidos 15 projetos de escolas públicas e três para instituições privadas de ensino, além de outros 16 de caráter público, destinados a usos diversos, muitos deles realizados para Concursos Públicos de Arquitetura.

O critério para a ordenação cronológica dos projetos considerou as datas encontradas em cada uma das pranchas, sempre privilegiando a data dos estudos iniciais (quando identificada) em detrimento das datas presentes nos projetos executivos ou da conclusão 
da obra. Na ausência destas informações foram utilizadas outras fontes como publicações, documentos ou depoimentos do arquiteto.

Em alguns casos não foi possível identificar o local do projeto, o cliente ou até mesmo a data de realização. Assim, os projetos foram incorporados ao conjunto de acordo com as características encontradas no desenho, considerando as particularidades de representação gráfica apresentadas nas diferentes fases da produção de Eduardo de Almeida.

Alguns projetos de longa duração em diferentes etapas, ou aqueles que sofreram adições ou reformas significativas, estão reunidos subvertendo a ordem cronológica do conjunto da obra, mas privilegiando a leitura do projeto como um todo.

Projetos que apresentaram diferentes versões em sua fase inicial de concepção também foram agrupados, dependendo da relevância do projeto - caso da Biblioteca Mindlin na USP e da Ópera de São Paulo no Parque Villa-Lobos - ou pelo interesse arquitetônico da proposta alternativa, como a segunda versão para a casa projetada para seu irmão Flávio de Almeida, realizada no início de sua carreira.

Deste amplo conjunto, encontram-se projetos desenvolvidos em diferentes estágios, como estudos preliminares, anteprojetos e projetos executivos; deste total, estima-se que cerca de $60 \%$ tenha sido construído, apesar dos registros da maioria serem escassos e de muitas obras terem sido demolidas ou completamente desfiguradas.

Durante o período final da pesquisa foram realizados registros fotográficos daqueles projetos efetivamente construídos e que ainda permanecem em razoável estágio de conservação, para complementar a catalogação.
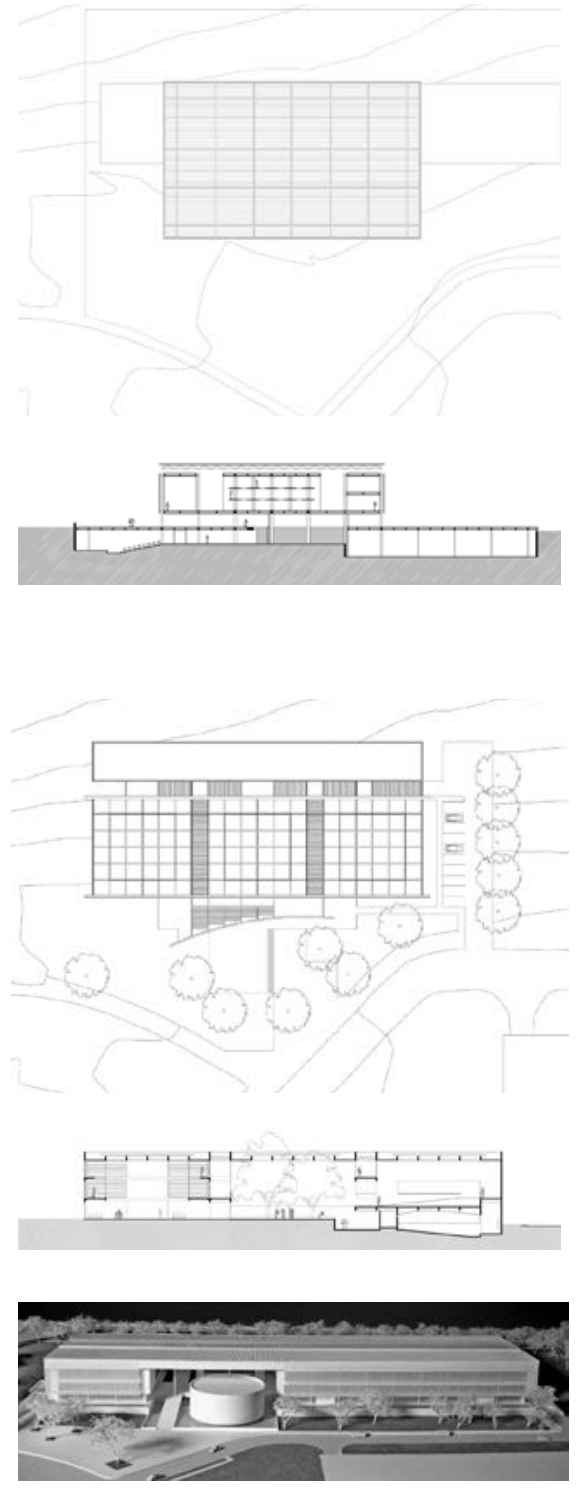

Diferentes versões e maquete da proposta final para Biblioteca Mindlin na USP Acervo Eduardo de Almeida 

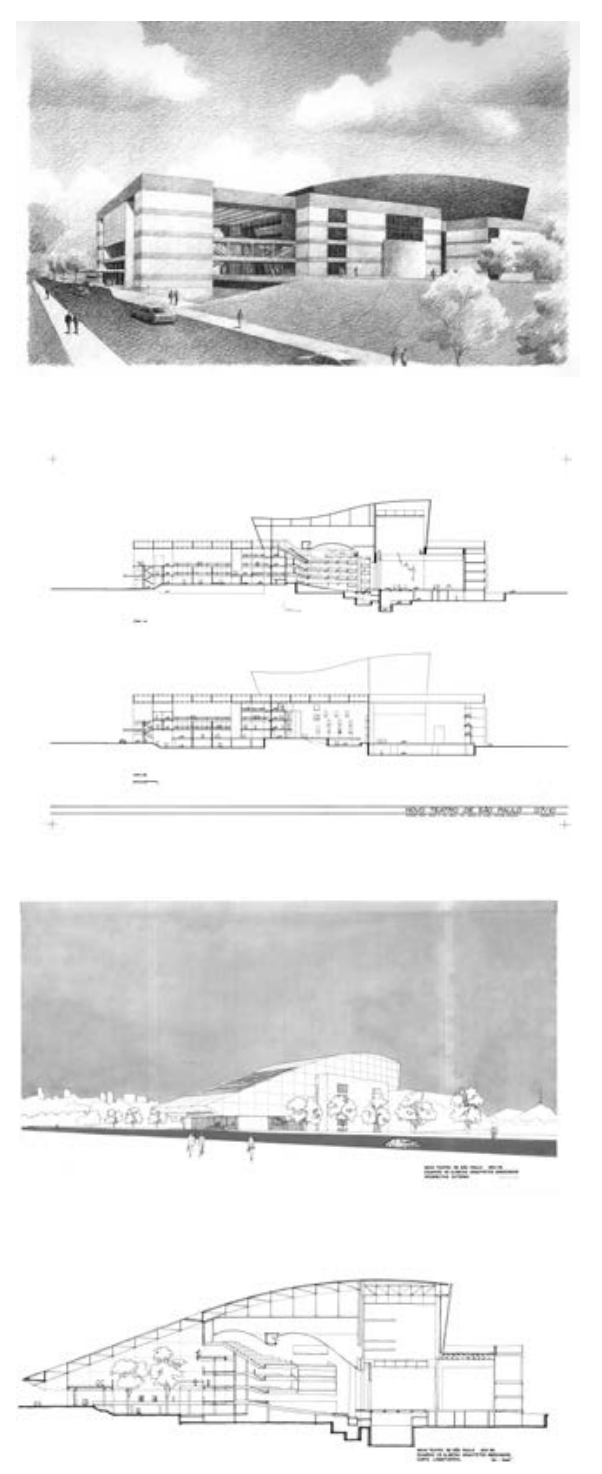

Diferentes versões para Ópera de São Paulo no Parque Villa-Lobos

Acervo Eduardo de Almeida
Todo o material passou por processo de edição e síntese, evitando redundância de informações ou apresentação excessiva de desenhos, proporcionando uma leitura panorâmica da obra de Eduardo de Almeida, e permitindo pesquisas futuras por meio de aprofundamentos, já que boa parte do material catalogado, digitalizado e tratado ainda não estará disponível nesta tese. ${ }^{2}$

A síntese de cada projeto exigiu seleção de fotografias e desenhos capazes de explicitar o partido arquitetônico adotado em uma única página, sempre complementado por informações técnicas.

Foram criados pequenos textos que acompanham cada projeto, baseados na observação do material organizado e nas informações obtidas nas inúmeras entrevistas realizadas com o arquiteto, coletadas à medida em que os invólucros onde estavam arquivados eram abertos em seu escritório.

Estes documentos - bem como o processo de pesquisa e catalogação - permitiram novas leituras sobre sua obra e guiaram a revisão do plano de pesquisa e do planejamento de capítulos que fazem parte desta tese, considerando também as observações e críticas apresentadas pela banca de qualificação.

Por outro lado, os projetos apresentados de forma sintetizada, assim como todo o material gráfico, foram pensados de modo a permitir a criação de uma exposição dedicada à Eduardo de Almeida, que poderá ser complementada com modelos tridimensionais e desenhos originais do acervo do escritório.

\footnotetext{
${ }^{2}$ Em alguns projetos, dada a coerência desenvolvida na realização dos desenhos, foi digitalizado o conjunto completo de desenhos, estudos, anteprojetos e executivos, elementos que permitirão leituras sobre o processo de projeto em suas diferentes etapas.
} 
Visando uma divulgação ainda maior deste material, a formatação também foi organizada de modo a inaugurar uma página na internet, denominada Arquivo Eduardo de Almeida: www.arquivoeduardodealmeida.com.

Inicialmente, este site apresentará apenas o material síntese da tese, embora tenha sido pensado como uma plataforma passível de ampliação, não apenas por meio de todo o material bruto já catalogado, digitalizado e tratado, mas também pelo resgate de outros materiais ou informações que poderão surgir.

Resta dizer que o arquiteto Eduardo de Almeida encontra-se em plena atividade e, certamente, seus futuros projetos deverão ser incorporados a este arquivo.

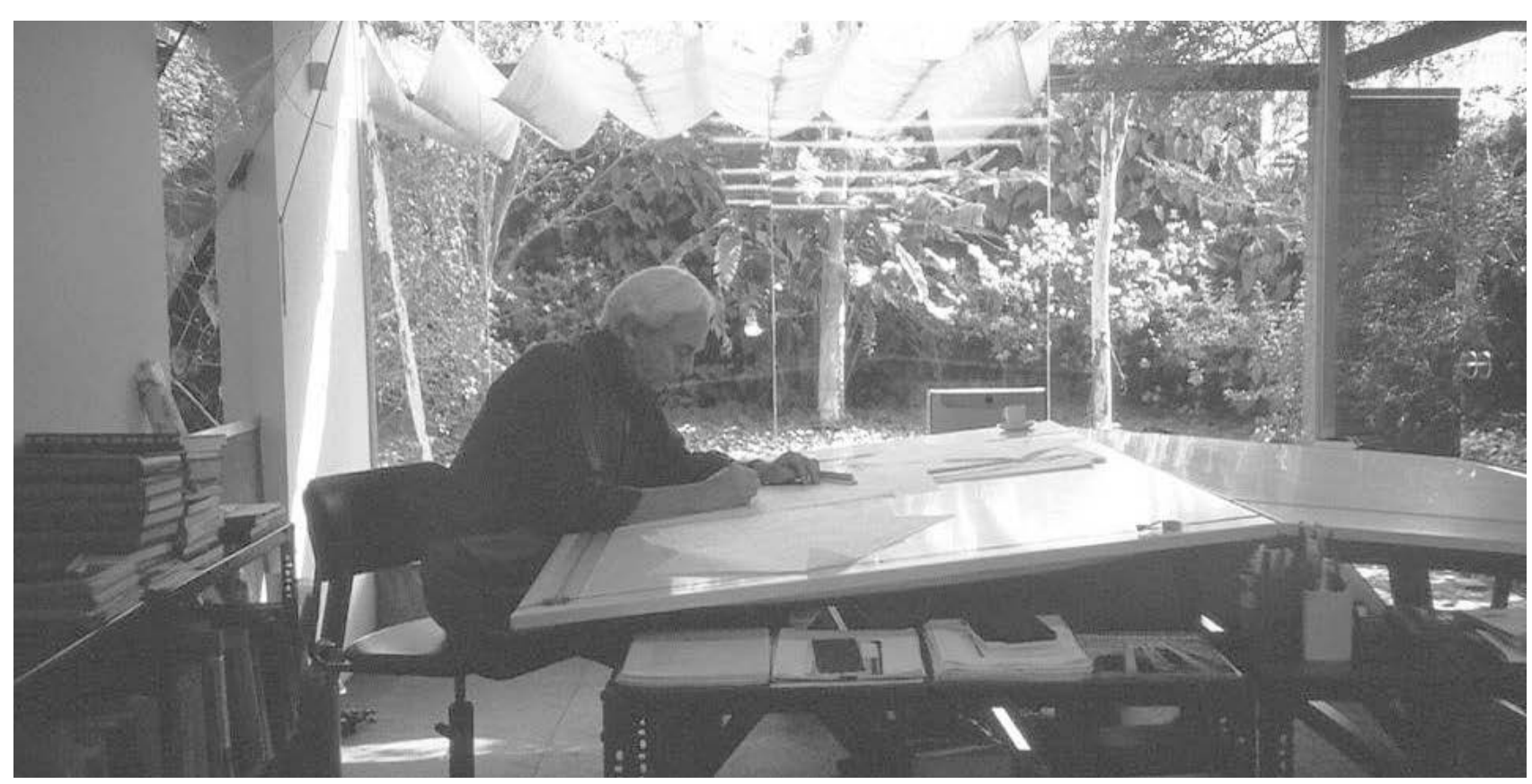


Capítulo 1

A obra completa de Eduardo de Almeida I Projetos e Obras 

Sumário de obras e projetos 
$01 \quad$ Edifício Sergipe

Residência Celso Amarat

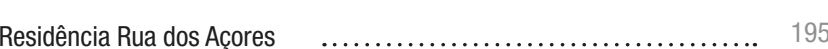

Residência Umberto Moruzzi $\quad \ldots \ldots \ldots \ldots \ldots \ldots \ldots \ldots \ldots \ldots \ldots \ldots \ldots . . \ldots 1959$

Edifício Guaianases $\quad$........................................... 1959

Residências Hans Nobiling _.................................... 1960

Residência Carlo Raffaeli $\quad$..................................... 1960

Ginásio Estadual Vila dos Lavradores

Edifício Martinico Prado _....................................... 1960

Residência Jean Louis Pilon

Residência Av. dos Eucaliptos $\quad$................................ 1960

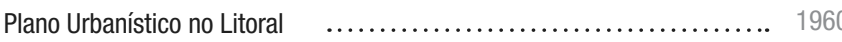

Ginásio Estadual de Silveiras . .................................... 1960

Escritórios CAC ............................................... 196

Banco de São Paulo _............................................. 196

Residência Flávio Pinho de Almeida I proposta $01 \quad$................... 196

Residência Flávio Pinho de Almeida | proposta 02 .................... 1961

Edifício Alameda Itu ................................................ 1962

Residência Dr. Renato de Andrade

Lampadina Componibile _...................................... 1962

Residência Maria Mistrorigo

Residência Roberto Alves Motta $\quad$................................ 1963

Edifício de Apartamentos Bela Cintra

Edifício Franca _........................................ 1963

Ginásio Estadual Alto da Mooca ................................... 1964

Residência Ubatuba $\quad$....................................... 196

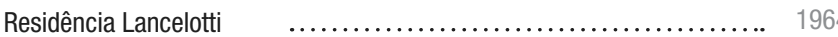

Estudo para um Edifício $\quad$.......................................... 1964

Residência Pinto e Silva

Residência Pedro Tassinari

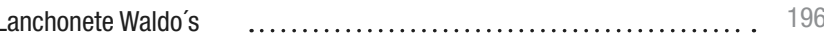

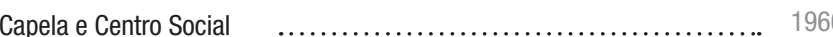

Residência Marcos Ferreira da Rosa $\quad$................................ 1966

Residência José Fernando Martins edifício de habitação coletiva $\quad \ldots \ldots \ldots \ldots \ldots \ldots \ldots \ldots \ldots \ldots \ldots \ldots$ concreto

residência unifamiliar _............ concreto | metálica | alvenaria

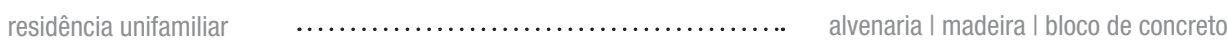

residência unifamiliar $\quad$........................................ tijolo I madeira

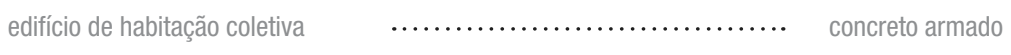

conjunto residencial horizontal $\quad \ldots \ldots \ldots \ldots \ldots \ldots \ldots \ldots \ldots \ldots \ldots \ldots \ldots \ldots \ldots$ alvenaria de tijolo

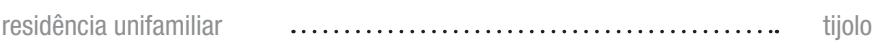

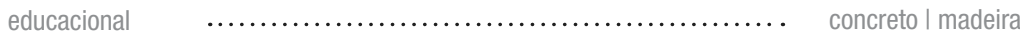

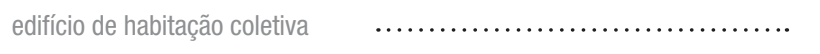

residência unifamiliar

residência unifamiliar

plano urbanístico

educacional

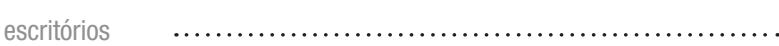

institucional

residência unifamiliar $\quad$........................................ metálica

residência unifamiliar $\quad$............................................ -

edifício de habitação coletiva $\quad$ …............................ alvenaria

residência unifamiliar $\quad$..........................................

desenho do objeto $\quad$.................................... -

residência unifamiliar $\quad$......................................

residência unifamiliar $\quad \ldots \ldots \ldots \ldots \ldots \ldots \ldots \ldots \ldots \ldots \ldots \ldots \ldots \ldots . \ldots \ldots \ldots$ alvenaria $\mid$ concretol madeira | metálica

edifício de habitação coletiva $\quad$ …............................. -

edifício de habitação coletiva $\quad$................................. alvenaria I concreto

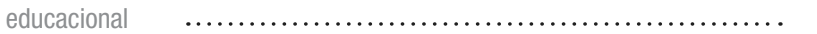

residência unifamiliar $\quad$............................................ alvenaria I madeira

residência unifamiliar $\quad$..................................... -

edifício de habitação coletiva $\quad$ ….............................. -

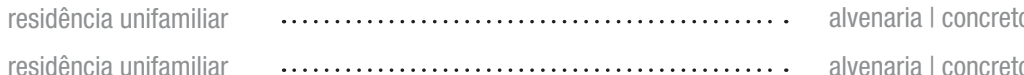

comercial

institucional _......... alvenaria I concreto

residência unifamiliar $\quad$......................................... concreto

residência unifamiliar $\quad$................. alvenaria I concreto | madeira 
residência unifamiliar

\section{educacional}

residência unifamiliar

Residência Jean Nadim

Secretaria da Agricultura

Residência Rua Baluarte

Estação Telefônica e Escritórios

Hospital Escola Júlio de Mesquita

Pavilhão Brasil Expo 70 - 0saka

Loja Altemio Spinelli

Residência Fernando de Almeida

45 Residência Levy Rubinstein

$47 \quad$ Solar Vila Mariana

Edifício Modular Coronet

Edifício Modular Lark

Edifício Modular Rodrigues Alves

Residência José L. Niemeyer dos Santos

Residência Jacob Kipnis

Residência Egberto Penido

Residência Aroldo Fuganti

Edifício Jesuíno Arruda

Edifício Comercial Av. Faria Lima

Apartamento Yolanda Penteado

Centro Georges Pompidou

Marino Comercio de Papeis

Residência Luís Alberto Guimarâes

Residência José G. Nogueira Moutinho

Fábrica Altemio Spinell

Banco Comercial do Paraná .

Chácara dos Bambus - Pasárgada

Edifício Albert Sabin

Banco Safra

967

1967

968

1969

1969

1969

1969

1969

1969

1970

1970

1970

1970

1973

1973

1974
1970

1970

1970

1971

1970
1971
1971

1971
1971

197

197

1971
1971

1972

1972

1973

1973

1973

1973

1973 institucional

conjunto residencial horizontal

escritórios

residência unifamiliar

residência unifamiliar $\quad$.................................... alvenaria | metálica

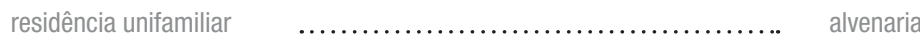

edifício de habitação coletiva

edifício de habitação coletiva

edifício de habitação coletiva $\ldots \ldots \ldots \ldots \ldots \ldots \ldots \ldots \ldots \ldots \ldots \ldots \ldots \ldots$ bloco de concreto $\mid$ concreto

edifício de habitação coletiva

edifício de habitação coletiva

residência unifamiliar

residência unifamiliar

residência unifamiliar

residência unifamiliar

edifício de habitação coletiva

escritórios

reforma de apartamento

instituciona

comercial

residência unifamilia

residência unifamilia

industria

escritórios

conjunto residencial horizont

escritórios

escritorios

escritórios alvenaria I concreto

bloco de concreto I concreto

bloco de concreto

alvenaria I concreto

concreto I madeira

concreto

concreto

bloco de concreto I concreto

alvenaria

alvenaria I concreto 


Metalúrgica Orlândia $\quad$........................................ 1973

residência unifamiliar

concreto

industria

Metalúrgica Orlândia I Fábrica

Metalúrgica Orlândia I Edifício Administrativo

Metalúrgica Orlândia I Setor de Serviços

Metalúrgica Orlândia I Clube

industrial I fábrica

concreto

industrial I administração

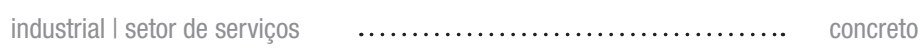

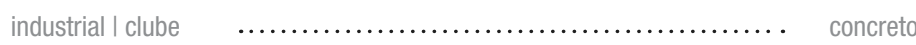

Metalúrgica Orlândia I Vestiários _........................... 1977

Metalúrgica Orlândia I Centro de Processamento de Dados ............. 1987

Loteamento em Ibiúna $\quad$........................................ 1974

Residência Eugene Gordon ..................................... 1974

Residência Elias Miguel Haddad ............................... 1974

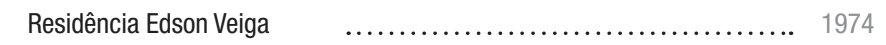

Fábrica lcovel _........................................... 1974

Fazenda Taiuva ......................................... 1975

Residências em Ponta Grossa _.................................. 1975

Residência Max Define $\quad$........................................... 1975

Residência da Rua Carangola _.................................. 1975

EEPG Jardim Nova Europa $\quad$........................................ 1976

EEPG Vila Buenos Aires

EEPG Parque Brasília

Residência Patrimônio do Carmo 01

Residência Patrimônio do Carmo $02 \quad$............................... 1976

Metalúrgica Orlândia | Escritório São Paulo

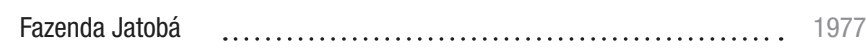

Residência Cláudio M. Grisolia

Sede Fazenda Campo dos Bois $\mid$ proposta $01 \quad \ldots \ldots \ldots \ldots \ldots \ldots \ldots \ldots . . \ldots 1978$

Sede Fazenda Campo dos Bois I proposta 02

Kosmos Foto _............................................ 1978

EEPG Anchieta Vila Carmozina 1978

00 DU PONT Brasil

101 Residência Donald Ting _....................................... 1978

102 Projeto Rio Delta 1978

industrial I cpd $\quad$............................................. concreto

plano urbanístico $\quad$....................................... -

residência unifamiliar $\quad$.....................................

residência unifamiliar $\quad$.................................... bloco de concreto I concreto

residência unifamiliar $\quad$....................................

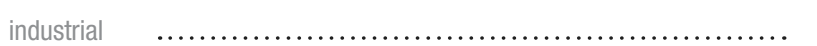

fazenda

conjunto residencial horizontal $\quad$.............................. alvenaria I madeira

residência unifamiliar $\quad$.........................................

residência unifamiliar $\quad \ldots \ldots \ldots \ldots \ldots \ldots \ldots \ldots \ldots \ldots \ldots \ldots \ldots \ldots \ldots$ alvenaria $\mid$ concreto

educacional

educacional $\quad$..................................................

educacional

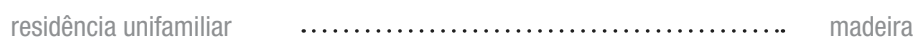

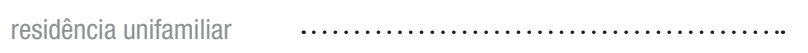

escritórios …...................................... concreto

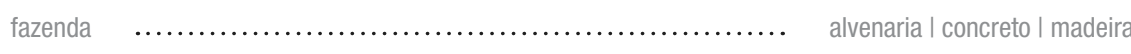

residência unifamilia

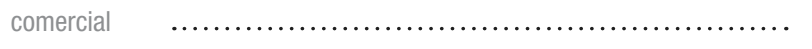

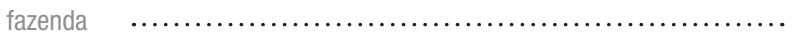

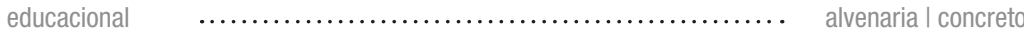

escritórios $\quad$..............................................

residência unifamiliar

edifício de habitação coletiva 
conjunto residencial horizonta

residência unifamiliar

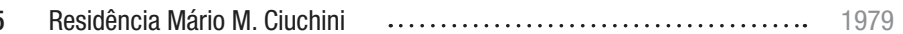

106 Ampliação Sede Fazenda Olaria …............................... 1980

107 Residência José Manuel Riveros $\quad$ …............................ 1980

108 Residência Luigi Giavina _...................................... 1980

109 Residência Belinky ........................................ 1980

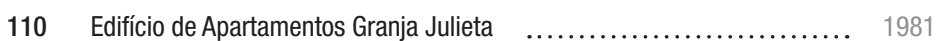

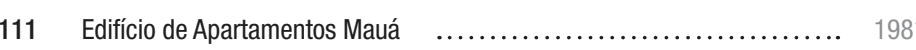

112 Edifício de Apartamentos na Rua Rudge Ramos .................... 198

113 Conjunto de Residências em Osasco f............................. 1981

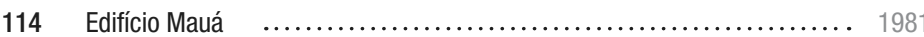

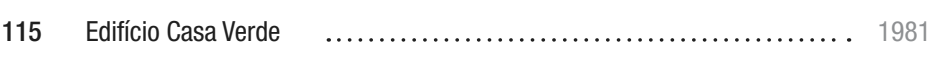

116 Residência Porto ................................................ 1981

117 Ampliação Residência Porto …............................... 1981

118 Apartamento Edifício Seridó _................................... 2002

119 Colégio Porto Seguro ...................................... 1981

120 Residência Renata Tassinari $\quad$................................ 1982

121 Ampliação Residência Renata Tassinari ........................ 2002

122 Residência Requejo ........................................... 1982

123 Residência Rodrigo Lacerda Soares Neto _........................... 1982

124 Residência Oppenheim ….................................. 1983

125 Residência Roberto Bielawski

126 Residência Luiz Augusto Barros _................................. 1983

127 Residência Roni Gotthilf f....................................... 1983

128 Residência Gelpi ............................................. 1984

129 Residência Ricardo Guimarães …................................ 1985

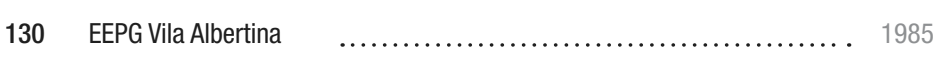

131 EEPG Parque Bela Vista _...................................... 1985

132 UBS Campo Limpo _....................................... 1985

133 Projeto de Reforma Avenida dos Eucaliptos _...................... 1985

134 EEPG Jardim Julieta ........................................... 1986

135 Residência Rubens Porto ......................................... 1986

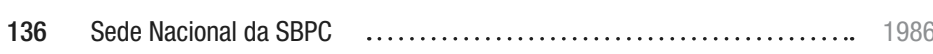

137 Escritório Rua Chilon

fazenda

residência unifamiliar

residência unifamiliar

residência unifamiliar

edifício de habitacão coletiva

edifício de habitação coletiva

edifício de habitação coletiva

residência unifamiliar

edifício de habitaç̃ão coletiva

edifício de habitação coletiva

reforma de apartamento

residência unifamiliar

residência unifamiliar

educaciona

residência unifamiliar

residência unifamiliar

residência unifamiliar

residência unifamiliar

residência unifamiliar

residência unifamiliar

residência unifamiliar

residência unifamilia

residência unifamiliar

residência unifamiliar

educaciona

educacional

institucional

comercial

educacional

residência unifamiliar

escritórios

escritórios alvenaria I concreto

alvenaria | madeira

bloco de concreto I concreto I metálica

madeira

alvenaria | metálica

concreto

alvenaria I concreto

alvenaria

concreto I madeira

alvenaria I concreto

metálica

alvenaria | metálica

concreto | metálica

alvenaria | bloco de concreto I metálica

metálica

metálica

alvenaria | metálica

concreto I madeira

metálica

concreto

metálica

concreto

alvenaria | concreto | metálica 
140 Residência Isio Bakalenik

residência unifamiliar

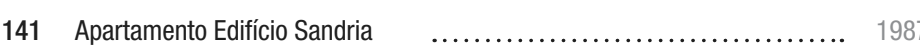

142 Residência Ricardo Alves Lima $\quad$................................... 1987

143 Paço Municipal do Votorantim

144 Residência Sigrist _........................................... 1987

145 Edifício Roque Petroni Jr.

146 Coldex Frigor Escritórios …................................. 1988

147 llha do Pasto _............................................... 1988

148 Fazenda Água Comprida I Implantação _.......................... 1988

149 Fazenda Água Comprida I Casa dos trabalhadores _................. 1988

150 Fazenda Água Comprida I Casa do administrador $\ldots \ldots \ldots \ldots \ldots \ldots . . . . . . . . .1988$

151 Fazenda Água Comprida I Centro comunitário _................... 1988

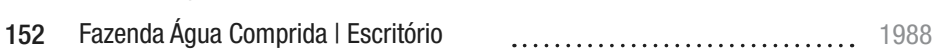

153 Fazenda Água Comprida I Depósito _.............................. 1988

154 Fazenda Água Comprida I Fábrica de ração _........................ 1988

155 Fazenda Água Comprida I Lavador de café e garagem …......... 1988

156 Fazenda Água Comprida I Caixa d'água $\quad$............................ 1988

157 Fazenda Água Comprida I Tulha _................................. 198

158 Fazenda Água Comprida I Sede 1998

159 Residência Guimarães _.......................................... 1988

160 Residência Marchetto 1989

161 Estação lbitirama _............................................. 1989

162 Edifício TCV

163 Residência Bracher _........................................ 1989

164 Residência Bracher | Pavilhão esportivo _........................... 2000

165 Residência Bracher I Ampliação _................................. 2000

166 Residência Bracher I Piscina _...................................... 2000

167 Torre São Paulo ................................................ 1990

168 Apartamento J. C. Pupin _......................................... 1990

169 Residência Silvio Eid ......................................... 1990

170 Sítio Mont Blanc 1990

171 Edifício Vila Olímpia ......................................... 1991

172 Residência Alain Costilhes _..................................... 1991

residência unifamiliar $\quad$........................................ concreto

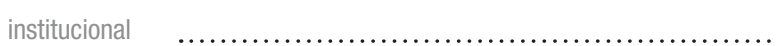

residência unifamiliar $\quad$...................................... alvenaria

edifício de habitação coletiva

escritórios

plano urbanístico

fazenda

fazenda I conjunto residencial

fazenda | residência $\quad$........................................... concreto

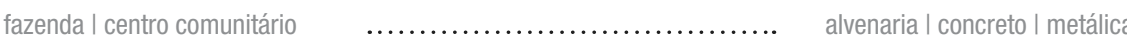

fazenda l escritório (.......................................... alvenaria I concreto

fazenda | depósito _........................................ alvenaria I metálica

fazenda | fábrica _........................................... alvenaria | metálica

fazenda | lavador de café $\quad$....................................... metálica

fazenda | caixa d'água $\quad$...................................... metálica

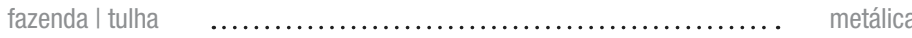

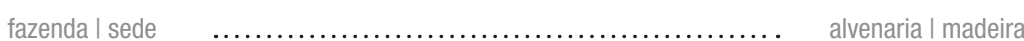

residência unifamiliar $\quad$....................................... concreto

residência unifamiliar $\quad$............

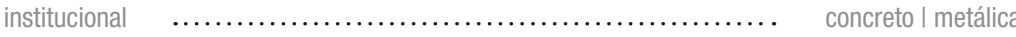

edifício de habitação coletiva
residência unifamiliar $\quad \ldots \ldots \ldots \ldots \ldots \ldots \ldots \ldots \ldots \ldots \ldots \ldots \ldots \ldots \ldots \ldots \ldots \ldots \ldots \ldots \ldots \ldots \ldots \ldots \ldots \ldots \ldots \ldots \ldots \ldots \ldots \ldots \ldots \ldots \ldots \ldots \ldots \ldots \ldots \ldots \ldots \ldots \ldots$
metálica

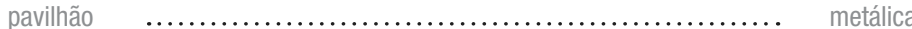

residência unifamiliar $\quad$.......................................... metálica

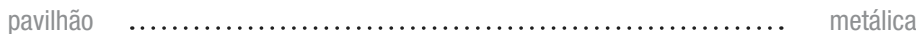

edifício de habitação coletiva $\quad$......................................

reforma de apartamento $\quad$.........................................

residência unifamiliar $\quad$............................................

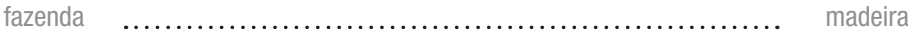

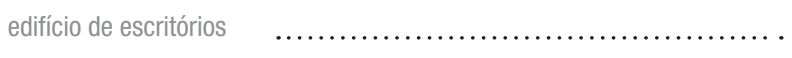

residência unifamiliar 
residência unifamiliar

76 Residência da Vila

177 Sede Beter

residência unifamilia

escritórios

metálica

17 EEPG V. Jardim Carmella

79 Residência Luis A. M. Rodrigues

educacional

concreto

80 Galeria Prestes Maia

181 Residência Pacheco e Silva

182 Novo Teatro de São Paulo | Proposta 01

183 Novo Teatro de São Paulo I Proposta 02

184 Haras Santa Edwiges

185 Residência Filizola

86 Residência Reichstul

187 Novo Campus FGV

188 Residência Lalo I

189 Museu Constantini

190 Residência em Laranjeiras

91 Residência Eduardo Tess _ Morumb

Bblioteca Fundação Guita e José Mindlin I Proposta 01

193 Biblioteca Fundação Guita e José Mindlin | Proposta 02 ............... 2003

194 Biblioteca Brasiliana Guita e José Mindlin e IEB _................. 2006

195 Residência Pedro Luis F. da Silva 2000

196 Residência Ricardo Lacerda f................................... 200

197 Residência Carlos Alberto Rossi ................................... 2000

198 Residência Campos do Jordão _.................................. 2000

199 Residência Mato Grosso do Sul ................................. 2000

200 Residência Ricardo Guimarães _................................ 2000

201 Edifício Taboão da Serra $\ldots$

202 Restaurante Rua Girassol _................................. 2000

203 MAC Cidade 2001

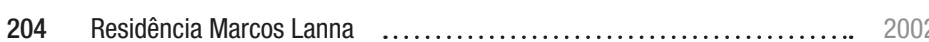

205 Residência Eduardo Tess _...................................... 2002

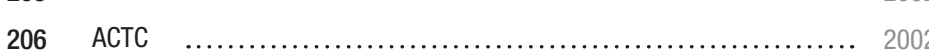

207 Residência Jean Marc Benaron _................................. 2002

residência unifamiliar

institucional

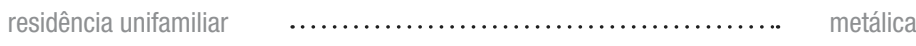

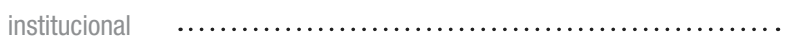

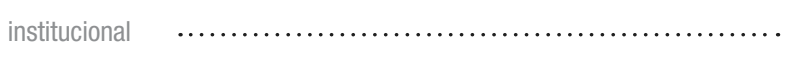

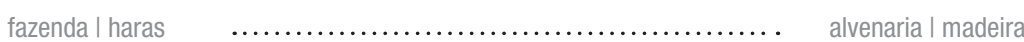

residência unifamiliar $\quad$....................................... metálica

residência unifamiliar $\quad$....................................... -

educacional _................................................

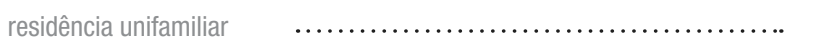

institucional $\quad$....................................... -

residência unifamiliar

institucional

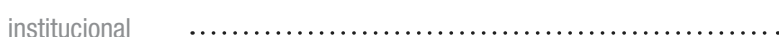

institucional

residência unifamiliar $\quad$........................................ madeira

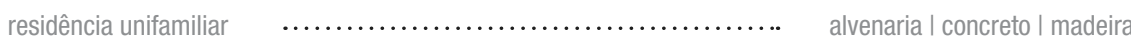

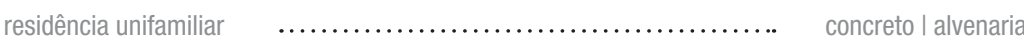

residência unifamiliar $\quad$....................................... metálica

residência unifamiliar $\ldots \ldots \ldots \ldots \ldots \ldots \ldots \ldots \ldots \ldots \ldots \ldots \ldots \ldots \ldots$ alvenaria $\mid$ madeira

residência unifamiliar $\quad$.......................................... metálica

edifício de habitação coletiva ................................. -

comercial …............................................. metálica

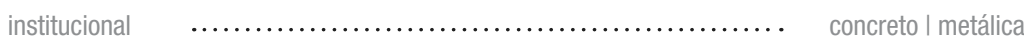

residência unifamiliar ......................................

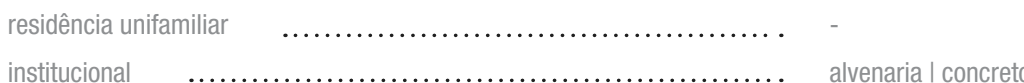

residência unifamiliar $\quad$......................................... 
210 Residência Patrick Sigrist

residência unifamiliar

residência unifamiliar

residência unifamiliar

residência unifamiliar

alvenaria | metálica

212 Residência Lalo || | Estúdio

213 Residência Felipe Sigrist

214 Fazenda Sabiá

residência unifamiliar

metálica

educacional

metálica

15 FDE Recanto Verde do Sol III

216 FDE Jardim Bronzato

educacional

metálica

institucional

residência unifamiliar

residência unifamiliar

educacional

residência unifamilia

plano urbanístico

conjunto residencial horizontal

residência unifamiliar

residência unifamiliar

residência unifamiliar

residência unifamiliar

residência unifamiliar

escritórios

28 Residência Oppenheim _Bah

229 SAP

230 Ampliação SAP

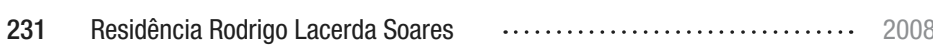

232 Residência Fernando e Verônica de Almeida …..................... 2009

233 Residência Pinho de Almeida ….............................. 2010

234 Residência Antônio da Mota Figueiredo …...................... 2010

235 Residência Renata Zuccolotto _................................. 2011

236 Residência Debelian ............................................ 2011

237 FDE Campinas _.............................................. 2011

238 Residência São Bento do Sapucaí ................................ 2012

239 Residência Rubens e Mariana Vidigal _............................ 2012

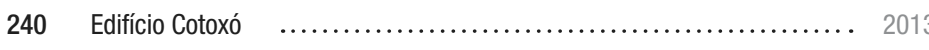

241 Anexo da Biblioteca Nacional _.................................... 2014

escritórios …............................................. metálica

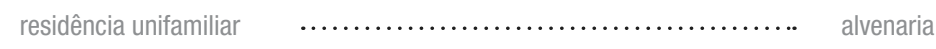

residência unifamiliar

residência unifamiliar $\quad$......................................... -

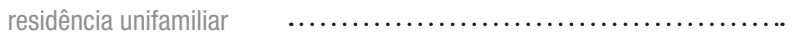

residência unifamiliar $\quad$.......................................

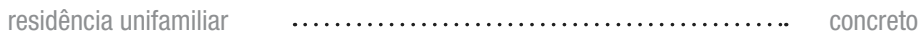

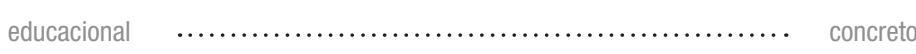

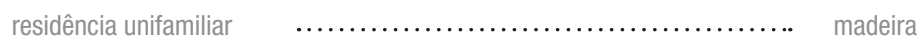

residência unifamiliar $\quad$........................................

edifício de habitação coletiva $\quad$................................... bloco de concreto I concreto

institucional 
As obras e projetos de Eduardo de Almeida 



\section{EDIFICIO SERGIPE I 1958}

Uso

Edifício de Habitação Coletiva

Cliente

Flávio Pinho de Almeida

Equipe

Horizonte Arquitetos - Arthur Fajardo Netto, Dácio Ottoni Eduardo de Almeida, Henrique S. Pait e Ludovico Martino

\section{Localização}

Rua Sergipe, São Paulo, SP

Estágio

Estudo Preliminar

Observações

Não Construído

Características

Estudo de viabilidade para um edifício a ser implantado

na Rua Sergipe.

Eduardo de Almeida, ainda estudante, realiza o projeto

em conjunto com o escritório Horizonte Arquitetos para

o seu irmão Flávio Pinho de Almeida, empresário que

encomendou inúmeros projetos posteriormente.
Foram realizadas duas versões para um edifício con

dois apartamentos por pavimento e núcleo de circulação

central. As soluções apresentam pequenas diferenças

no desenho adotado para a cozinha, sala de jantar e

escritório, além da representação, em uma das versões,

de um jardim na sala e outro no acesso do apartamento.

Uma terceira versão com uma unidade por pavimento

também foi realizada. Em todos os três casos, apesar

de não terem sido encontrados cortes ou elevações, é

possivel notar as premissas relacionadas à modulação,

à flexibilidade da planta e à soluç̃o do estrutura con

duas ou três linhas de pilares.

Acervo

Tubo 13
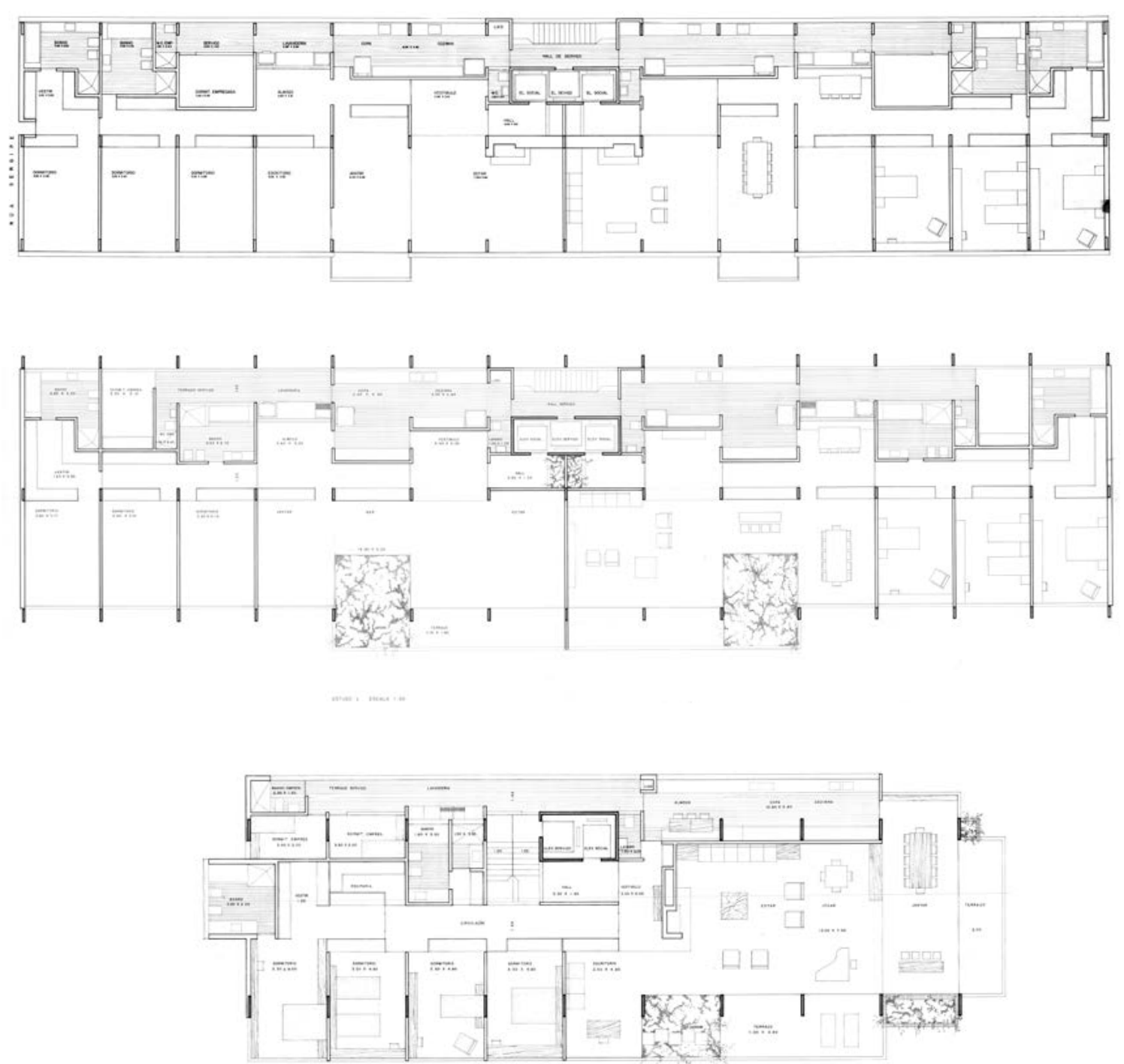


\section{RESIDÊNCIA CELSO AMARAL I 1958}

Uso

Residência Unifamiliar

Cliente

Dr. Celso F. Amaral

Equipe

Horizonte Arquitetos - Arthur Fajardo Netto, Dácio Ottoni, Eduardo de Almeida, Henrique S. Pait e Ludovico Martino

\section{Localização}

Alameda Gabriel Monteiro da Silva, São Paulo, SP

Estágio

Estudo Preliminar

Observações

Projeto de reforma, não construído

\section{Características}

Projeto de reforma de uma residência localizada próxima à Rua Groenlândia. 0 corpo principal da casa é caracterizado por uma ocupação em 'cruz' que libera os quatro cantos do volume retangular como terraços e varandas tanto no pavimento térreo quanto no superior, realizando a transição entre os ambientes internos e externos, excessão feita à cozinha que ocupa uma das varandas e se conecta à tradicional edícula que abriga a garagem e dependências de serviços. Estrategicamente posicionada a escada organiza as prumadas hidráulicas e a circulação dos dormitórios e da sala, desenhados ao redor da lareira posicionada no centro do volume.

Acervo

Tubo 69
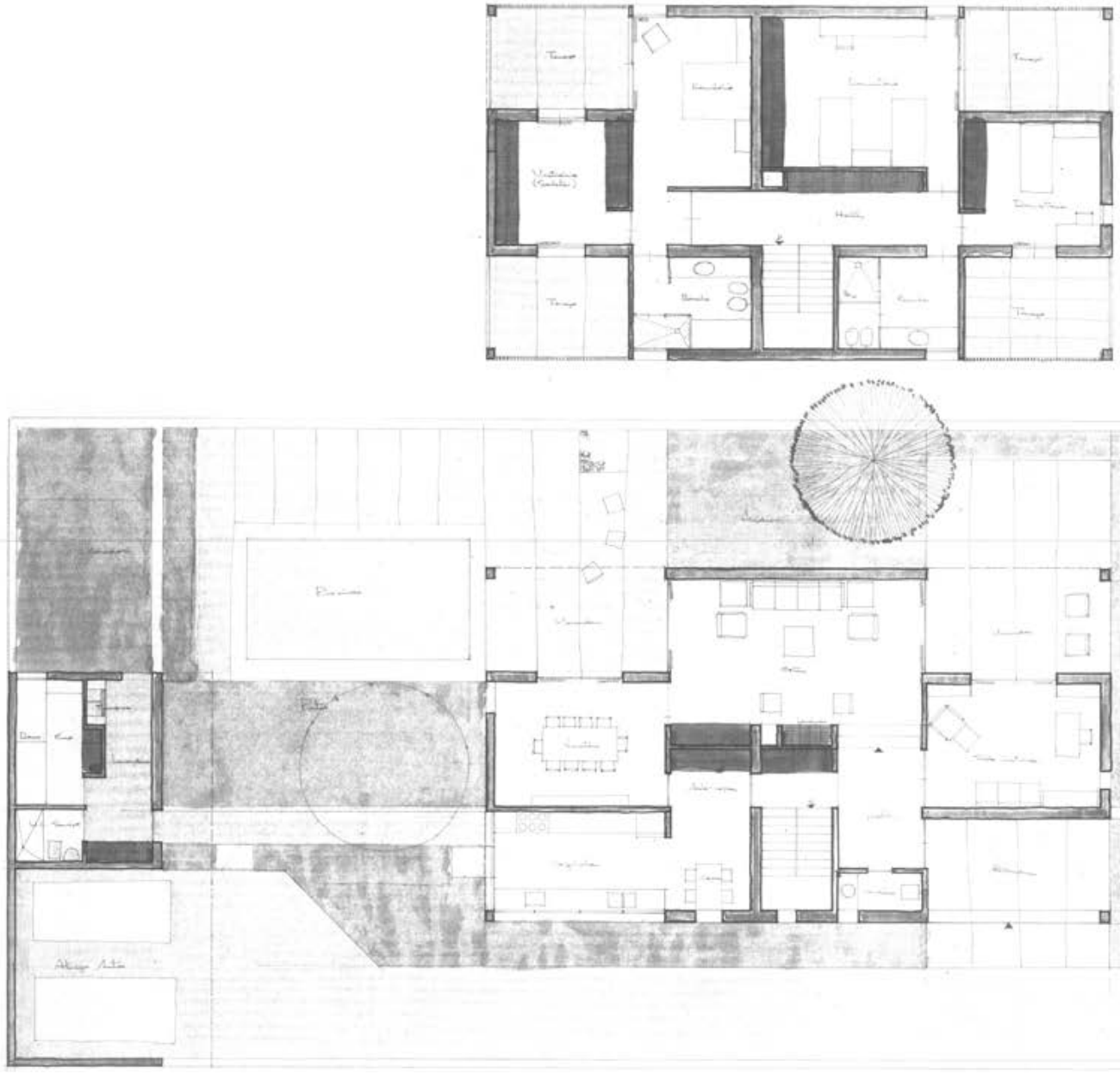
Uso

Residência Unifamiliar

Cliente

Eduardo de Almeida

Equipe

Horizonte Arquitetos - Arthur Fajardo Netto, Dácio Ottoni, Eduardo de Almeida, Henrique S. Pait e Ludovico Martino

\section{Localização}

Rua dos Açores 90, São Paulo, SP

\section{Estágio}

Projeto Executivo

\section{Observações}

Construída em 1960, ampliada em 1965 e

posteriormente modificada

\section{Características}

Primeira residência projetada por Eduardo de Almeida para sua família, inicialmente construída com dois dormitórios e posteriormente ampliada. Aproveitando a geometria do lote em esquina, os acessos à residência estão posicionados em uma de suas extremidades, permitindo relações amplas entre as salas de estar, jantar e dormitórios e os jardins, enquanto os ambientes de serviços e sanitários voltam-se ao recuo de fundos. 0 telhado de duas águas assimétricas solucionam a cobertura do volume em "L", utilizando as alvenarias de bloco aparente como apoio para as estruturas de madeira. De acordo com o depoimento do arquiteto, sendo muito jovem e inexperiente, o projeto seguiu as lições aprendidas com 0 arquiteto Cláudio Gomes em seu projeto para 0 conjunto habitacional no Jaçanã desenhados sob a influência de Frank Lloyd Wright.

Acervo

Tubo 04

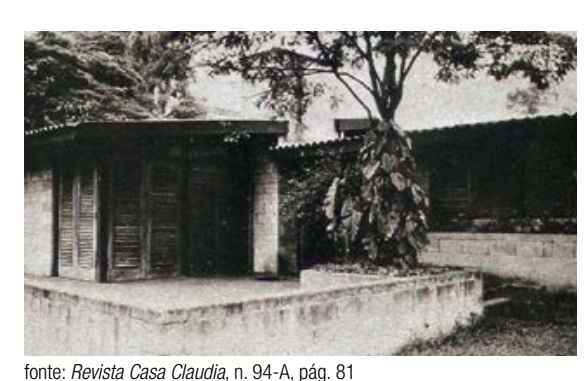

fonte: Revista Casa Claudia, n. 94-A, pág. 81
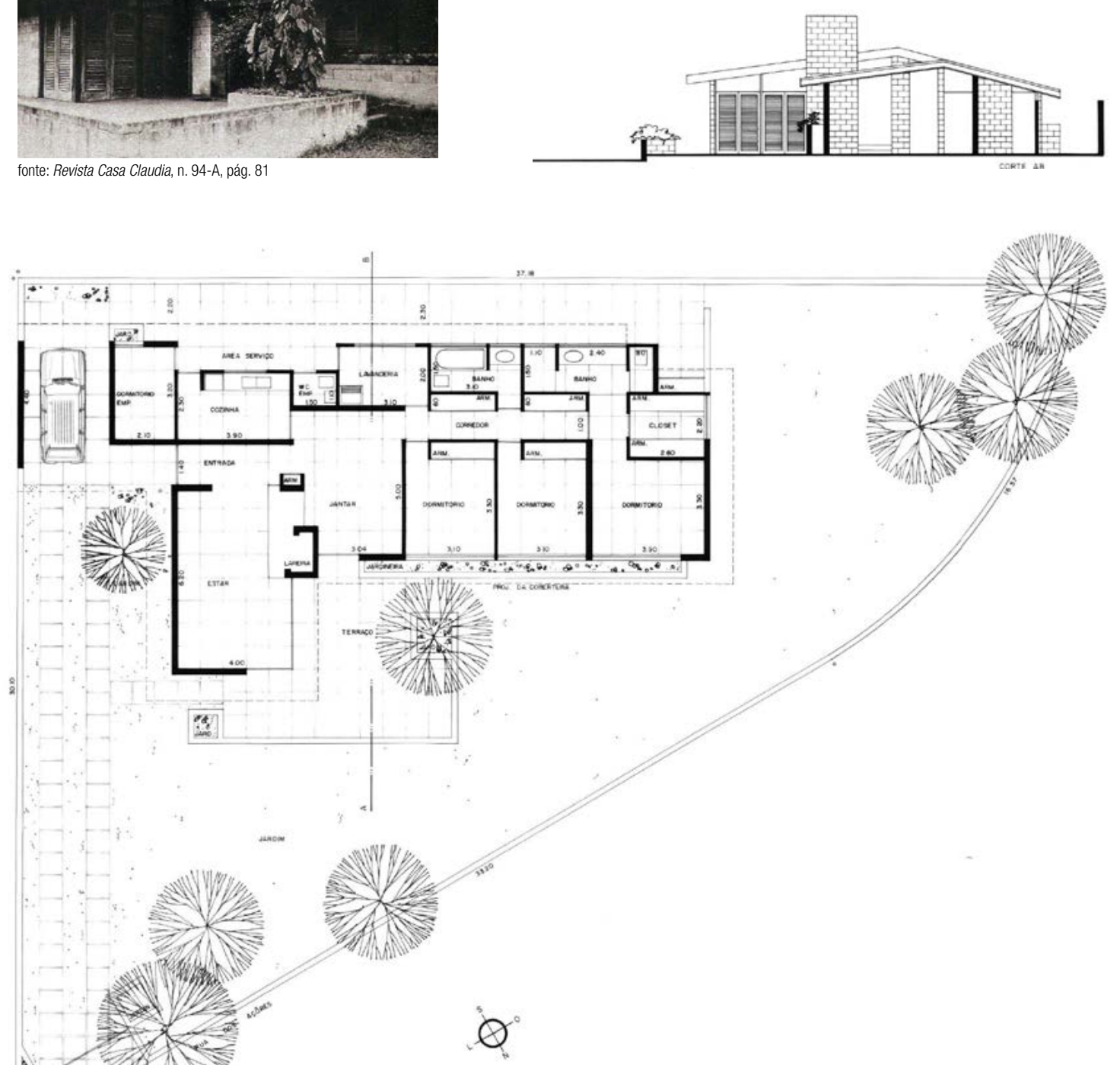

Q

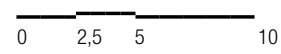


Uso

Residência Unifamiliar

Cliente

Umberto Moruzzi

Equipe

Horizonte Arquitetos - Arthur Fajardo Netto, Dácio Ottoni Eduardo de Almeida, Henrique S. Pait e Ludovico Martino

\section{Localização}

Jardim Virginia, Guarujá, São Paulo, SP

Estágio

Anteprojeto

Observações

Não Construído

\section{Características}

Cliente italiano apresentado a Eduardo de Almeida por Carlo Rafaelli, amigo que também havia encomendado um projeto para uma casa a ser implantada no Morumbi. A planta se divide claramente em um setor voltado para os ambientes de estar e cozinha e outro para os dormitórios. Nestes dois setores, os espaços destinados aos servicos e sanitários voltam-se ao recuo lateral menor, enquanto as grandes janelas dos quartos e da sala voltam-se para um jardim lateral que aproveita o desenho do lote em esquina. As janelas de canto, 0 desenho da planta que define os ambientes em conjunto com os armários e demais mobiliários, a solução da estrutura de cobertura de madeira em duas águas assimétricas e com largos beirais e pergolados revelam a influência de Frank Lloyd Wright, mas tambén de Richard Neutra.

Acervo

Tubo 69
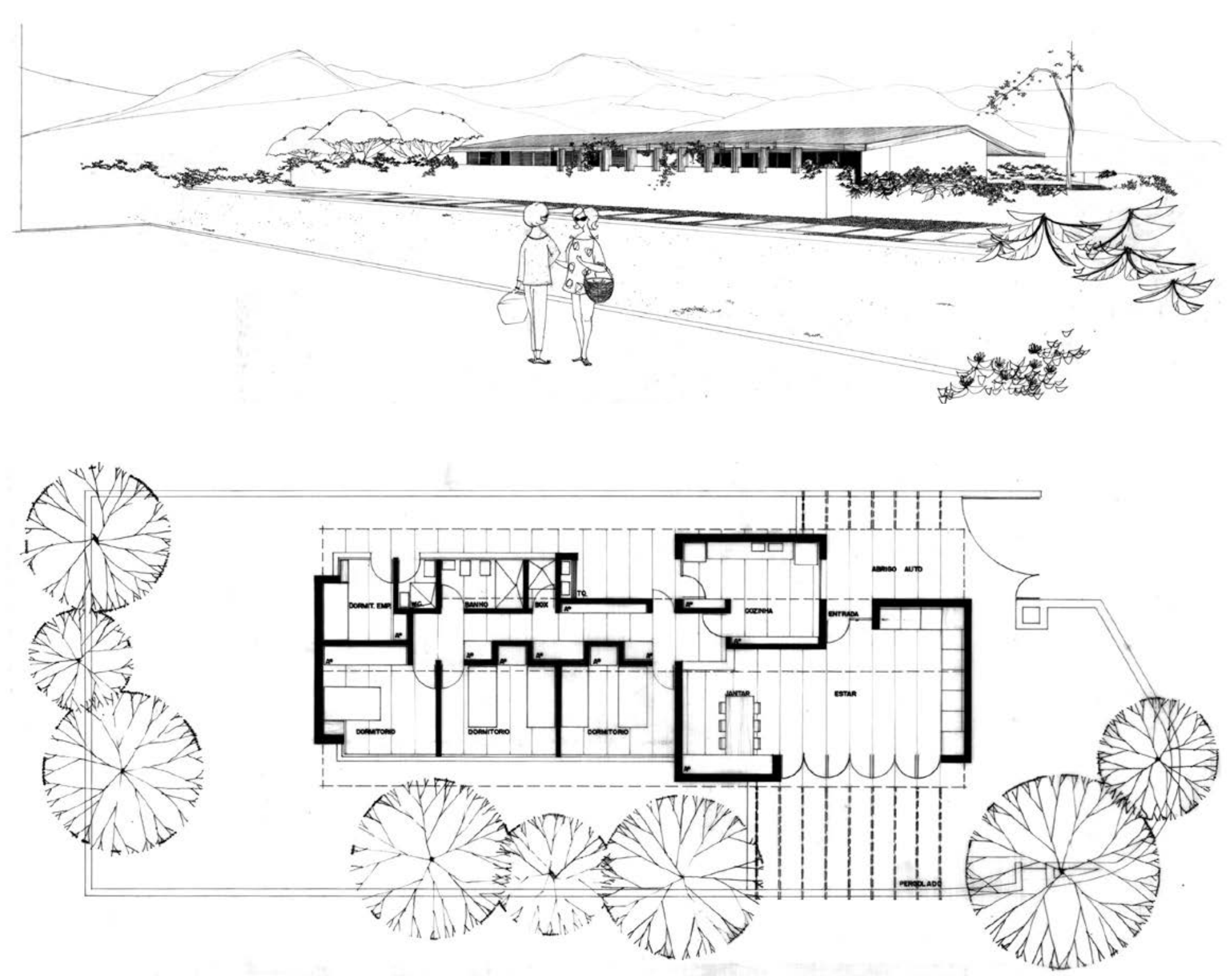
Edifício de Habitação Coletiva

Cliente

Eduardo de Almeida

Equipe

Eduardo de Almeida

Localização

Rua Guaianases, São Paulo, SP

Estágio

Estudo de Viabilidade

Observações

Não Construído

\section{Características}

Estudo de viabilidade para a realização de um edifício

de habitação multifamiliar de dez pavimentos e duas

unidades por andar, a ser implantado no terreno onde

se localizava a casa em que Eduardo de Almeida

passol a infância A planta organiza-se om dois blocos

articulados pela to

do nátio centriti

dos ambientes de serviços. Os dormitórios e a sala

aproveitam as fachadas principais, que são desenhadas

em função da modulação da estrutura, das venezianas

dos dormitórios e da varanda criada pelo recuo do

caixilho da sala. 0 desenho da elevação ainda revela a

intenção de se adotar uma solução em meio-nível para o

acesso dos moradores.

\section{Acervo}
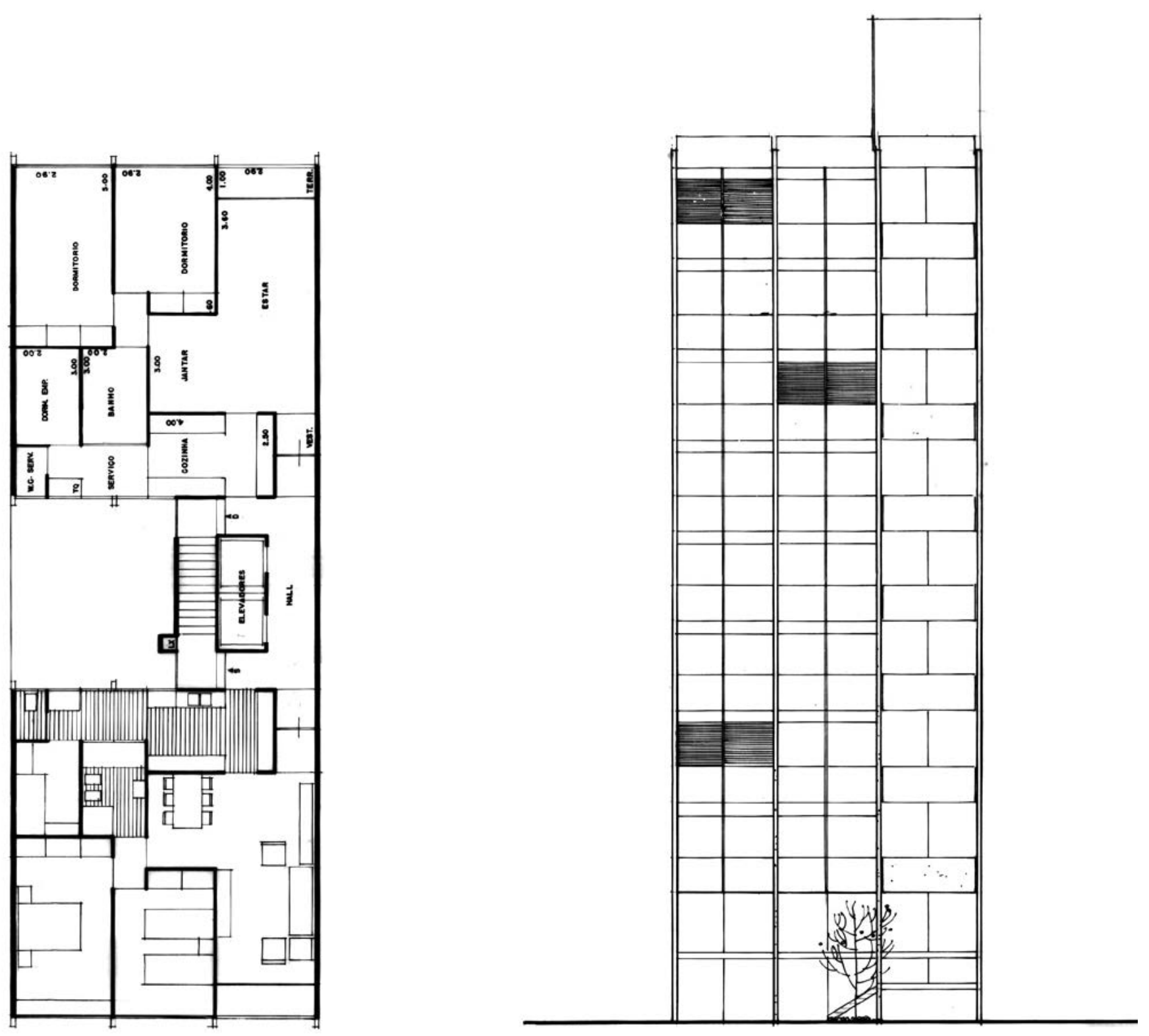
Uso

Conjunto residencial - 4 casas

Cliente

Companhia Construtora de Osasco

Equipe

Horizonte Arquitetos - Arthur Fajardo Netto, Dácio Ottoni, Eduardo de Almeida, Henrique S. Pait e Ludovico Martino

\section{Localização}

Rua Hans Nobling, Pinheiros, São Paulo, SP

Estágio

Projeto Executivo

Observações

Construído e demolido

\section{Características}

Conjunto de quatro casas construidas e, infelizmente, demolidas. Apesar da semelhança na organização da planta e nas dimensões dos ambientes, todas as unidades apresentam solucõos próprias: duas delas unidades a cozinha e serviços voltadas para a rua e, consequentemente, ambientes de estar abertos para os jardins de fundos, enquanto as demais invertem esta lógica. As primeiras organizam a circulação vertical por uma escada de dois lances, já as duas outras utilizam escadas lineares. No pavimento superior, 0

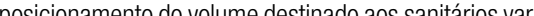
de acordo metria do conjunto e garantindo especifidade a cada uma das casas, mesmo com 0 caráter unitário dos materiais, dos telhados e, sobretudo, das pérgolas que continuam através dos lotes. As obras foram realizadas fielmente pelos engenheiros Toshio Tone e Roberto Martins de Mello.

Acervo

Tubo 28
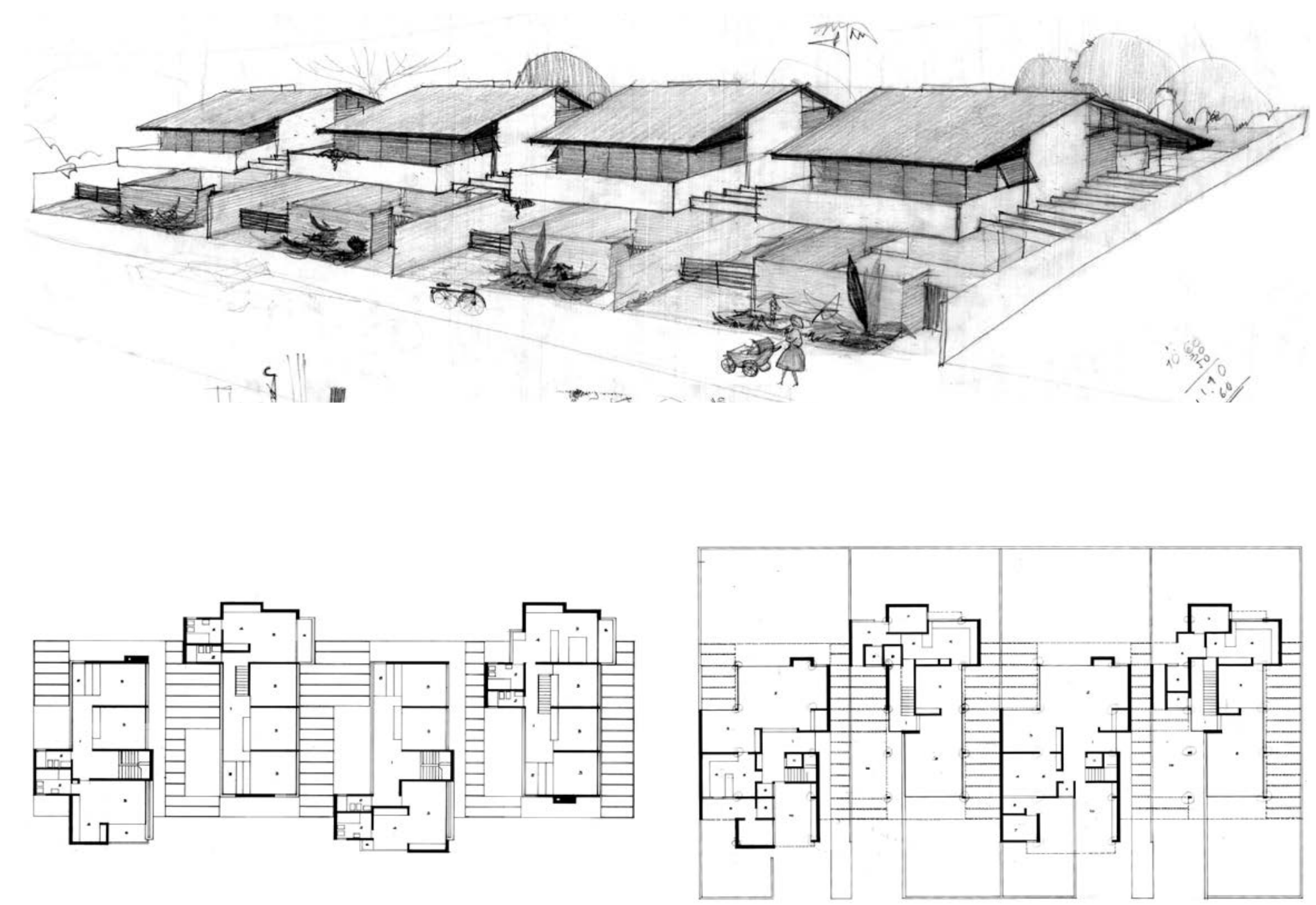
Uso

Residência Unifamiliar

Cliente

Carlo Raffaeli

Equipe

Horizonte Arquitetos - Arthur Fajardo Netto, Dácio Ottoni,

Eduardo de Almeida, Henrique S. Pait e Ludovico Martino

Localização

Morumbi, São Paulo, SP

Estágio

Anteprojeto

Observações

Não Construído

Características

Residência unifamiliar organizada em dois blocos,

0 primeiro - posicionado perpendicularmente à rua

- abriga os espaços de serviço e estar, enquanto 0

segundo - paralelo à rua - abriga os dormitórios no

segundo pavimento e a garagem e 0 escritório no térreo.

As soluções de planta, corte e perspectivas adotam a

linguagem de Frank Lloyd Wright.

\section{Acervo}

Tubo 09
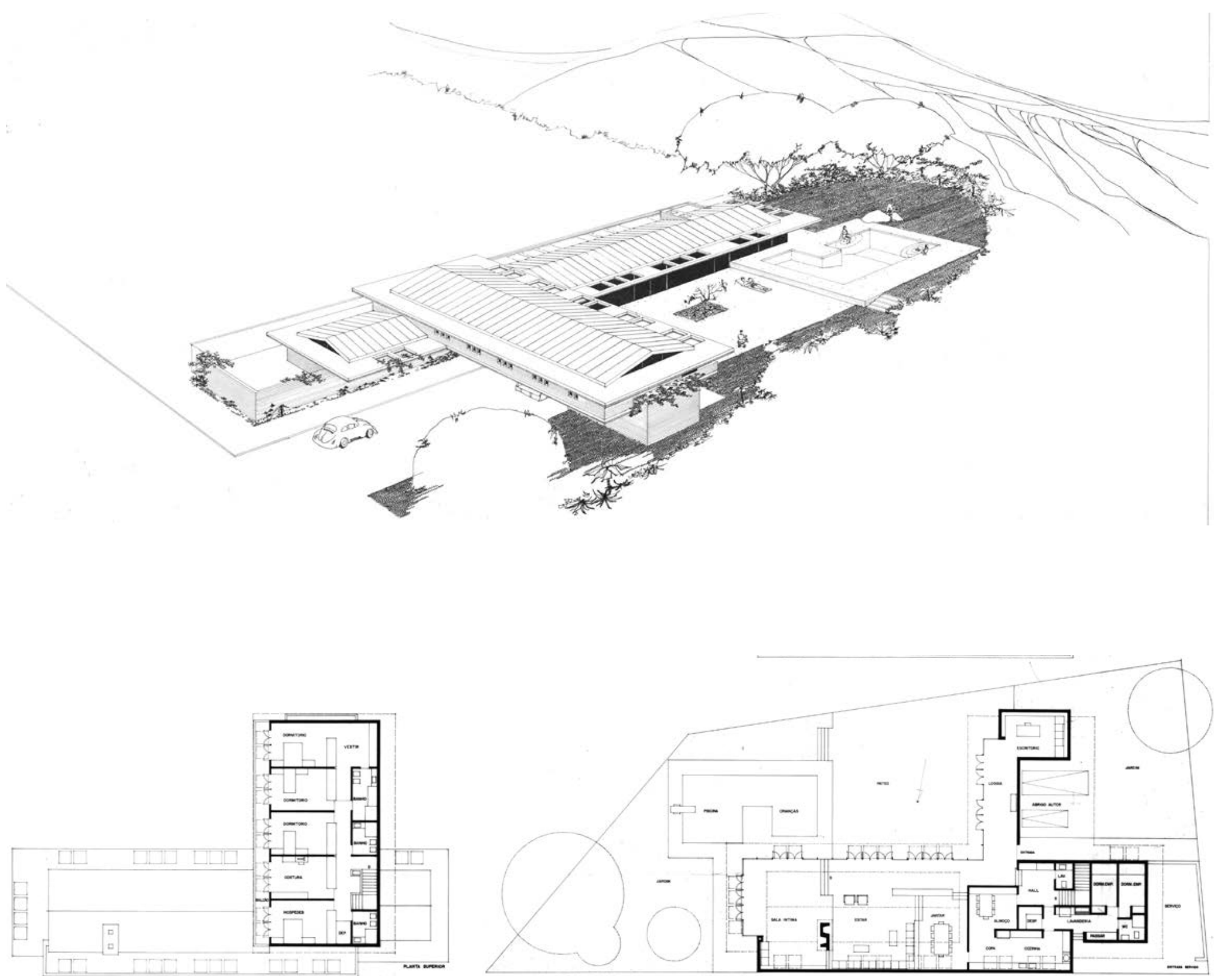
Uso

Escola

Cliente

IPESP - Instituto de Previdência do Estado de São Paulo

Equipe

Horizonte Arquitetos - Arthur Fajardo Netto, Dácio Ottoni,

Eduardo de Almeida, Henrique S. Pait e Ludovico Martino

\section{Localização}

Botucatu, SP

Estágio

Projeto Executivo

Observações

Construído

\section{Características}

0 projeto desta escola implantada em Botucatu segue a volumetria de três blocos interligados pelo espaço

do galpão, utilizando a mesma cobertura de águas

inclinadas desenhadas assimetricamente nos três

blocos. Tais blocos foram posicionados no terreno

de acordo com sua topografia e com a orientação do

sol. A obra finalmente construída segue os padrões

construtivos de outras escolas realizadas pelo IPESP,

embora os desenhos do estudo preliminar indiquem

a influência de Frank Lloyd Wright sobretudo pela

presença de pórticos de madeira associados a muros de

concreto ciclópico à maneira de Taliesin West.

Acervo

Tubo 15

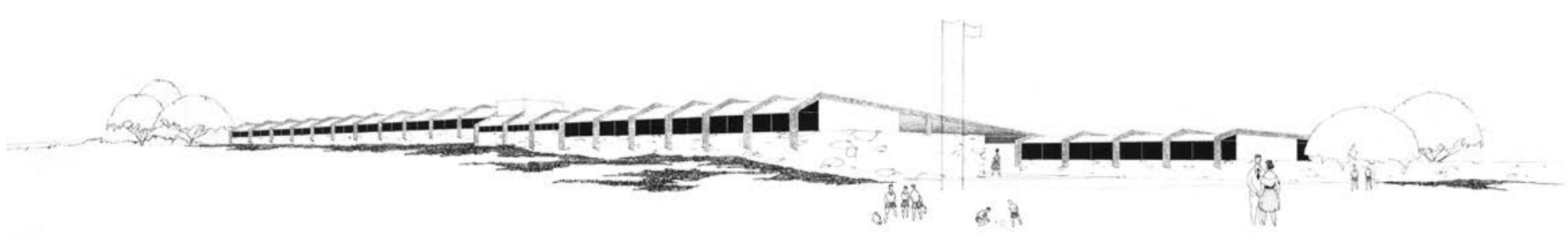

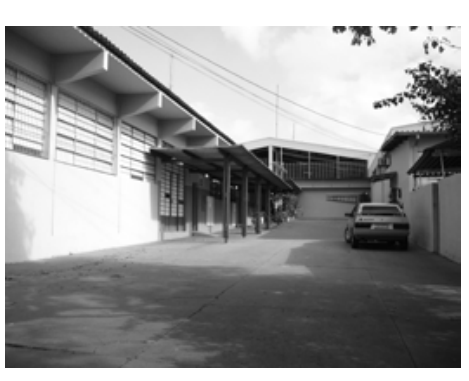

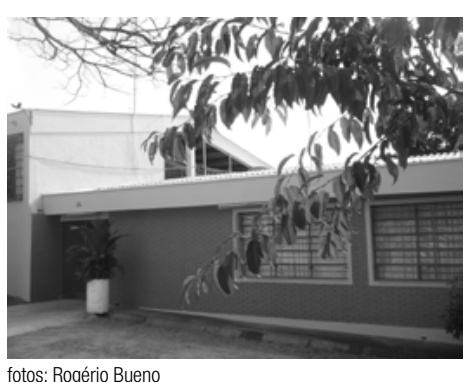

otots: Rogério Bueno

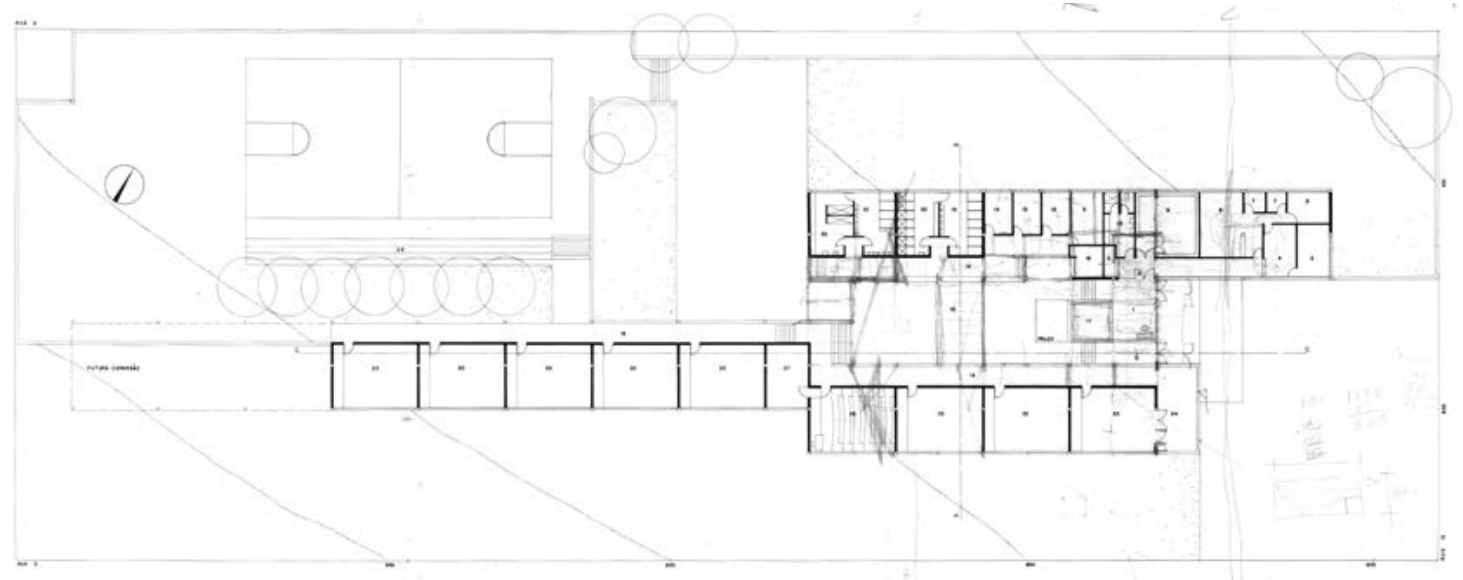

\begin{tabular}{l|l|l|l|l|l|}
\hline+ & \\
\hline
\end{tabular} 
Edifício de Habitação Coletiva

Cliente

Companhia Construtora de Osasco

Equipe

Horizonte Arquitetos - Arthur Fajardo Netto, Dácio Ottoni, Eduardo de Almeida, Henrique S. Pait e Ludovico Martino

\section{Localização}

Rua Dr. Martinico Prado 305, São Paulo, SP

Estágio

Projeto Executivo

Observações

Construído

Características

Edifício de apartamentos com doze pavimentos e dois apartamentos de três dormitórios por andar, acessados por uma torre central de escada e elevadores. A simetria da planta é rompida pelas duas extremidades do edifício onde a rotação dos dois dormitórios do apartamento da frente parece valorizar a presença da rua, solução ressaltada pela empena que percorre todos os andares interrompendo a janela linear em fita composta por venezianas. Estas mesmas empenas definem 0 espaço comercial localizado no pavimento térreo, separando-0 do acesso lateral destinado aos moradores. Apesar das janelas de canto, da geometria irregular da planta ou da pérgola que se insinua na cobertura, a aparência final do edifício se distancia da influência de Frank Lloyd Wright, referenciando-se em outras obras da arquitetura moderna de São Paulo do mesmo período. A versão final não seguiu exatamente as mesmas características deste estudo preliminar, mas foi o primeiro Edifício de Habitação Coletiva construído por Eduardo de Almeida.
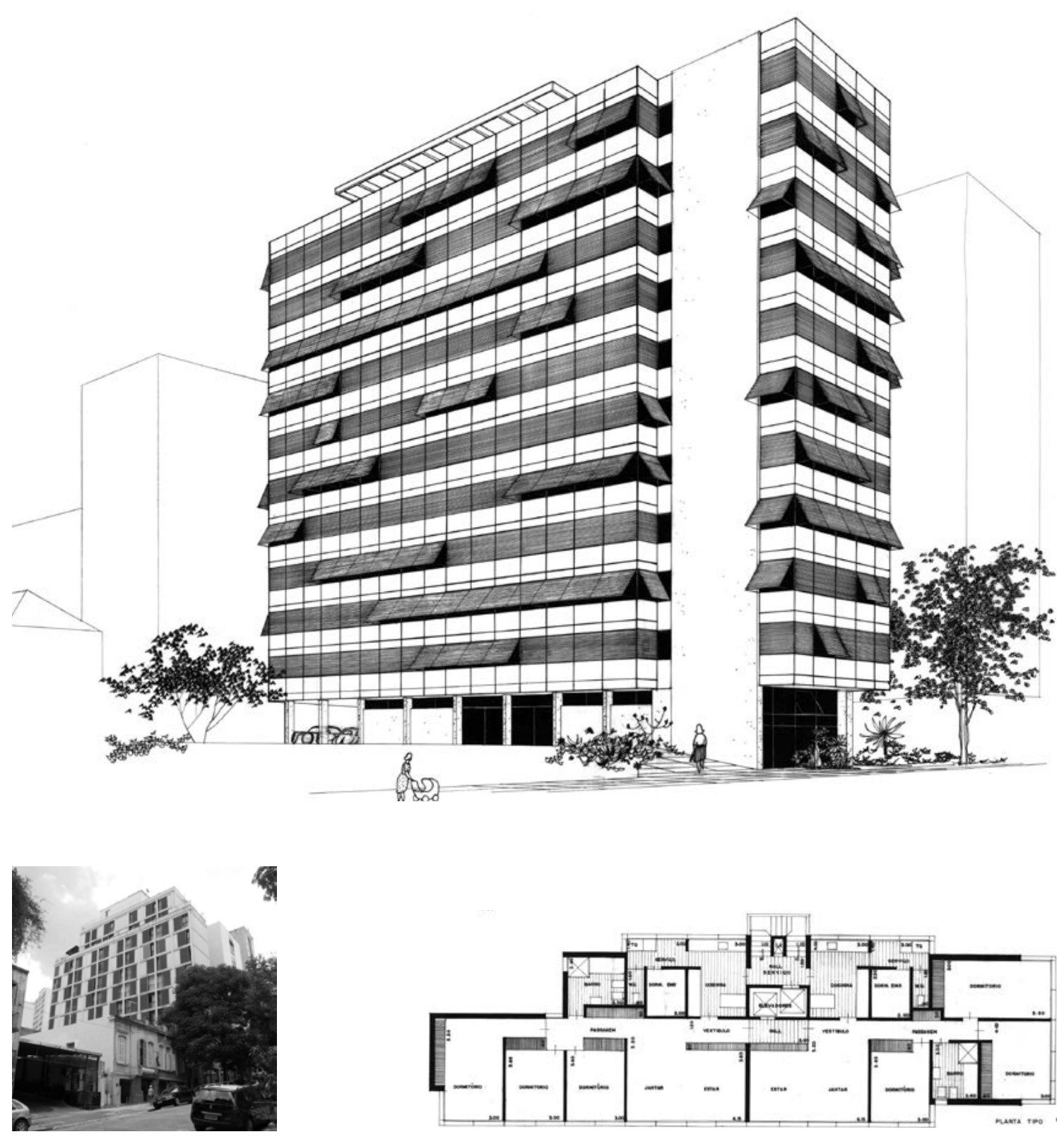
Uso

Residência Unifamiliar

Cliente

Jean Louis Pilon

Equipe

Eduardo de Almeida

Localização

Curitiba, PR

Estágio

Projeto Executivo

Observações

Construído

\section{Características}

Projeto realizado para o filho do arquiteto Jacques Pilon, seguindo os padrões apresentados de uma residência projetada por Giancarlo Gasperini em São Paulo, por determinação do cliente.

Nesta primeira versão - posteriormente modificada - a

lacão entre os dois volumes dá-se pela geometria dos

telhados assimétricos e pela continuidade dos muros

externos. A inclinação dos tetos permite a criação de

espaços levemente rebaixados, mezaninos voltados a

pátios internos e espaços de pé-direito variados.

Acervo

Tubo 56 e Caixa 3600
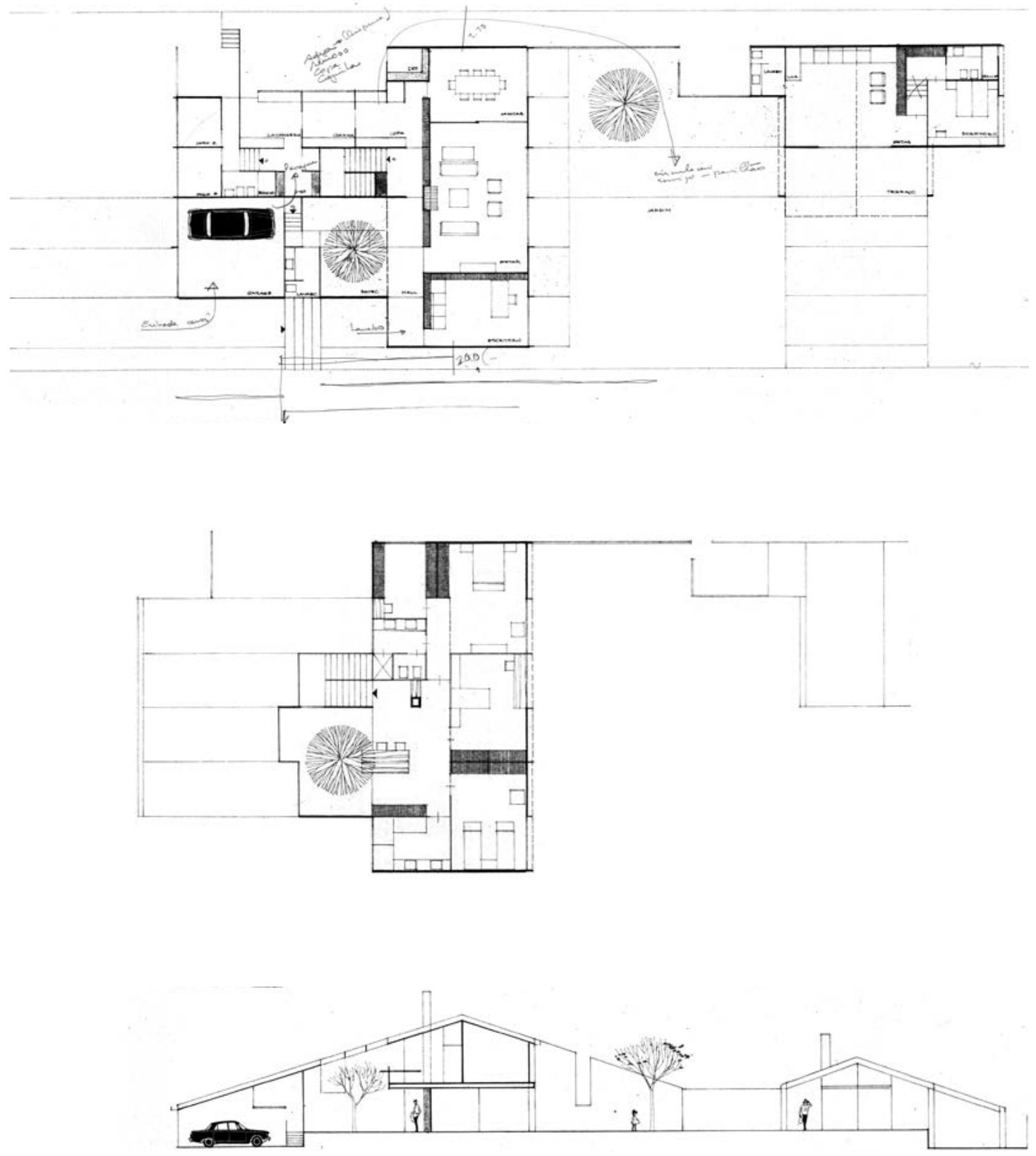
Uso

Residência Unifamiliar

Cliente

Luis Lucio Constabile Izzo

Equipe

Eduardo de Almeida

Localização

Av. dos Eucaliptos, Moema, São Paulo, SP

Estágio

Projeto Legal

Observações

Construído

\section{Características}

Construção de duas residências unifamiliares compactas

e econômicas.

As duas unidades geminadas apresentam sala

cozinha e serviços no térreo, além de três dormitórios

e sanitários no pavimento superior. A geometria do lote

exigiu curiosa solução para o volume da edícula.

Acervo

Tubo 31
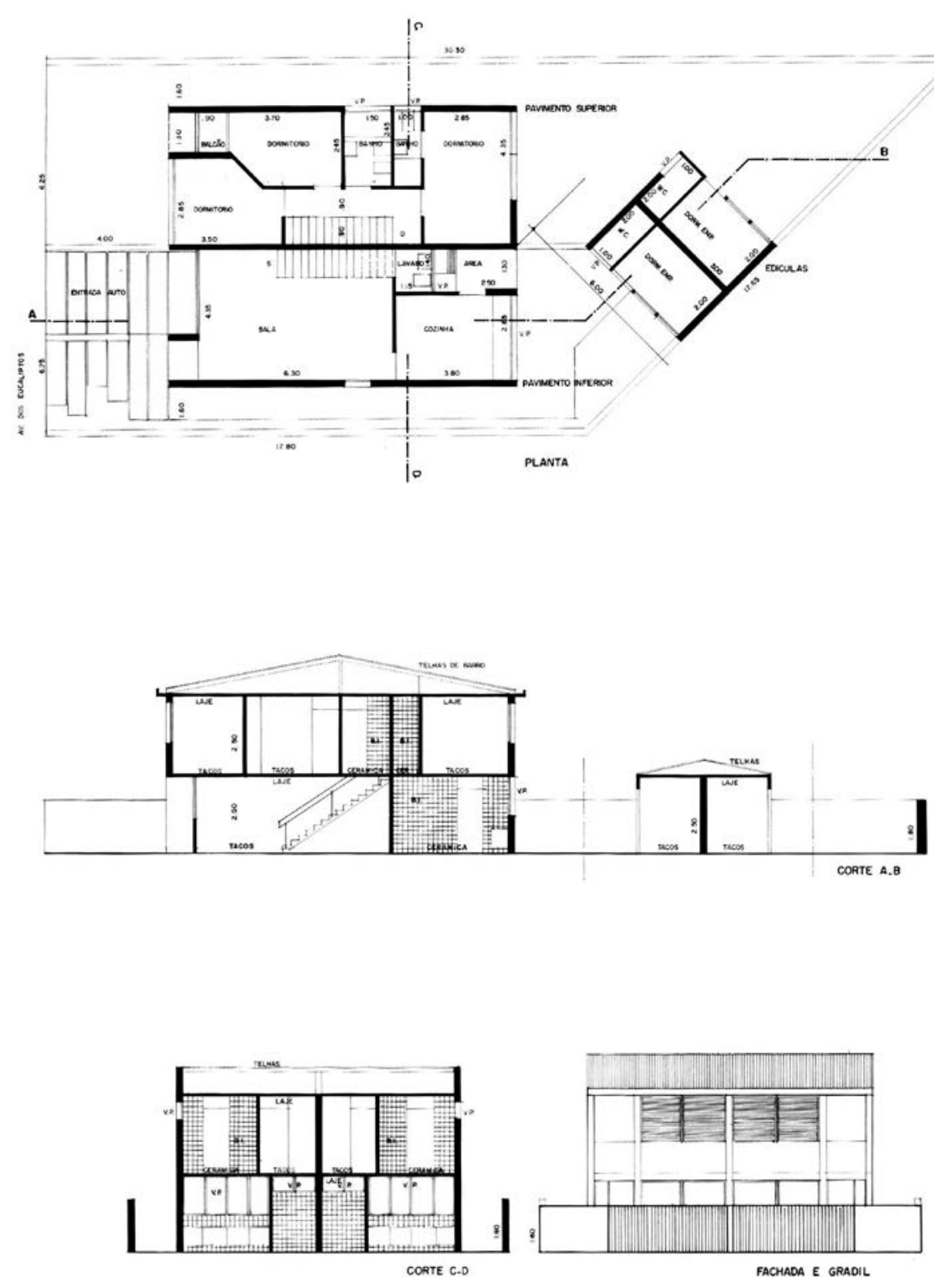
Uso

Plano Urbanísitco

Cliente

Não Identificado

Equipe

Eduardo de Almeida

Localização

Não Identificado

Estágio

Estudo Preliminar

Observações

Não Construído

Características

A única informação remanescente deste plano urbanístico é esta implantação. Nenhum outro documento foi encontrado e, de acordo com os depoimentos, Eduardo de Almeida não se recorda deste projeto.

Pelas informações contidas neste desenho, trata-se de um estudo para a implantação de um loteamento de um estudo para a implantação de um loteamento
no litoral organizado em sete diferentes setores, desenhados especificamente de acordo com as características geográficas, com os usos e com as relações estabelecidas entre as construções e o meio natural circundante.

Acervo

Não Identificado

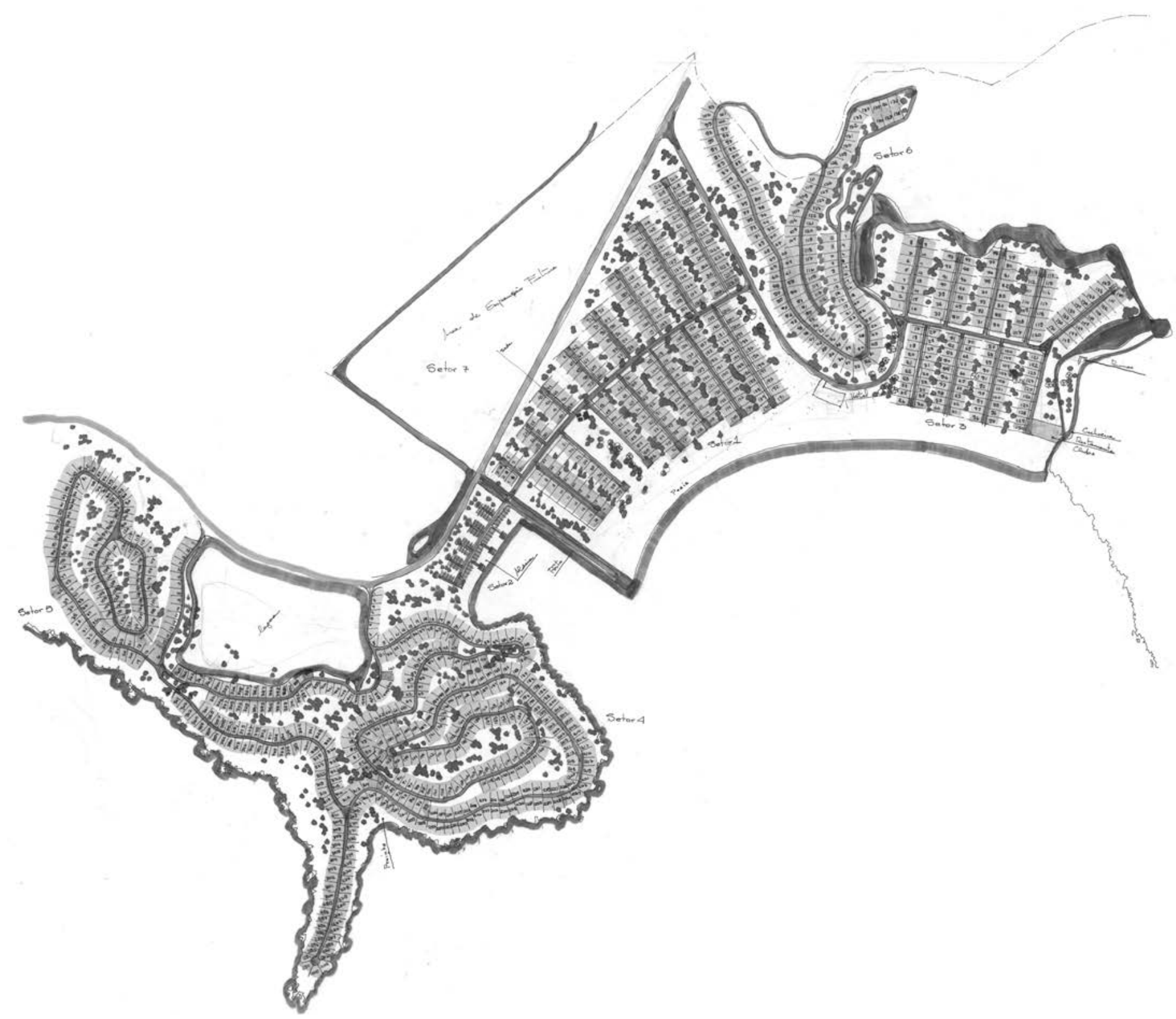


Uso

Escola

Cliente

IPESP - Instituto de Previdência do Estado de São Paulo

Equipe

Horizonte Arquitetos - Arthur Fajardo Netto, Dácio Ottoni Eduardo de Almeida, Henrique S. Pait e Ludovico Martino

\section{Localizaçao}

Av. Cyro Moreira Andrade, 1461, São Paulo, SP

Estágio

Projeto Executivo

Observações

Construído

\section{Características}

Projetada para o IPESP - Instituto de Previdência do Estado de São Paulo - e seguindo as soluções apresentadas no projeto do Ginásio Vila dos Lavradores, esta escola foi implantada de acordo com a orientação e a topografia do terreno. 0 telhado de duas águas se desdobra assimetricamente no espaço destinado ao galpão e área administrativa. A solução construtiva da obra realizada segue os padrões de economia e simplicidade de outras escolas realizadas no mesmo período, embora a perspectiva do estudo preliminar indique 0 desejo de se adotar uma liguagem presente nos projetos de Frank Lloyd Wright, sobretudo no que diz respeito ao contraponto entre as estruturas de madeira da cobertura e os muros de arrimo de concreto ciclópico.

Acervo
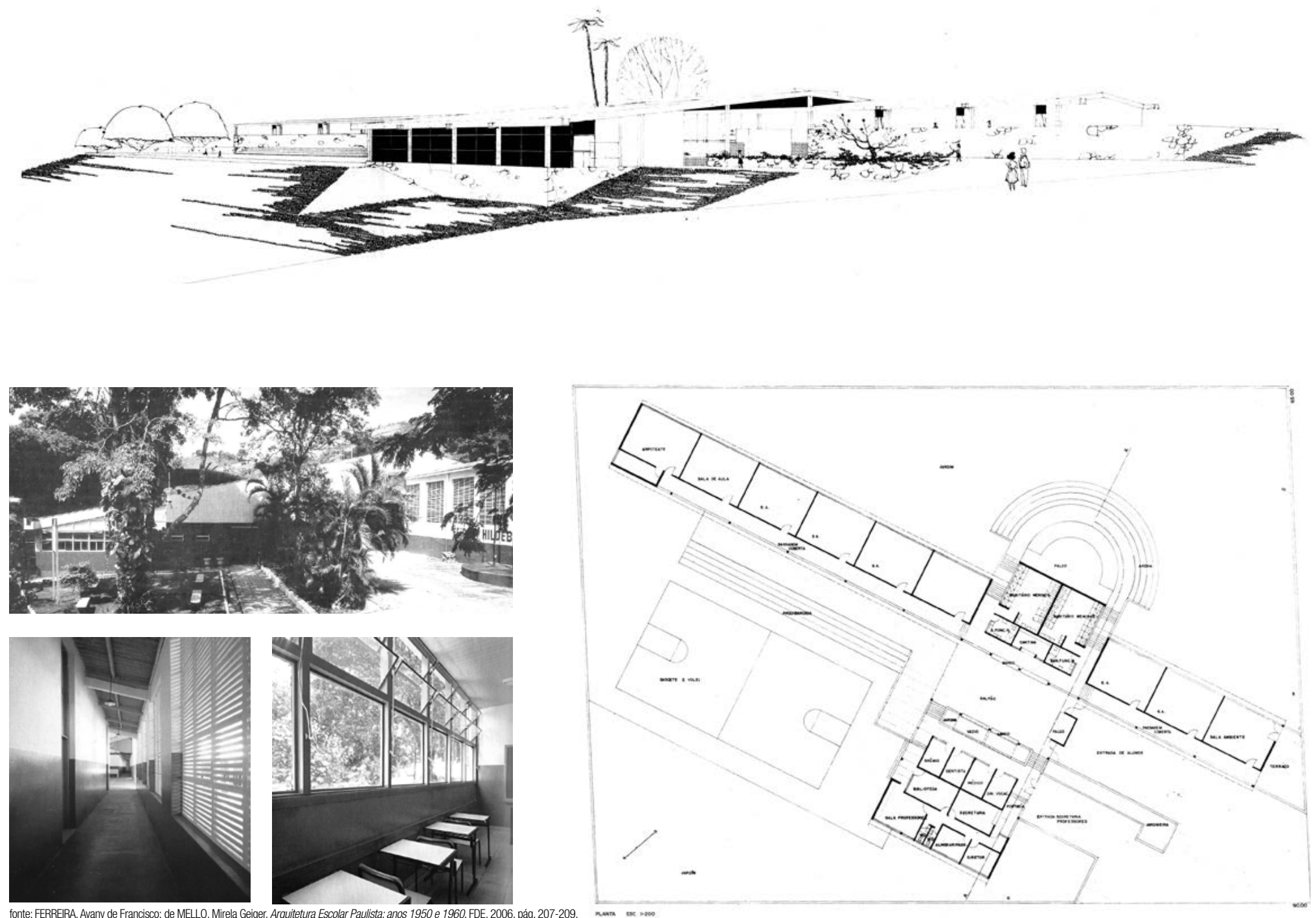
Uso

Projeto de Layout

Cliente

Construtora CAC Ltda.

Equipe

Eduardo de Almeida

Localização

Rua 3 de Dezembro, Sé, São Paulo, SP

Estágio

Projeto Executivo

Observações

Não Construido

\section{Características}

Projeto de ocupação de uma laje de um edifício

de escritório para a diretoria da empresa CAC, de

propriedade de seu irmão Flávio Pinho de Almeida.

\section{Acervo}

Tubo 13
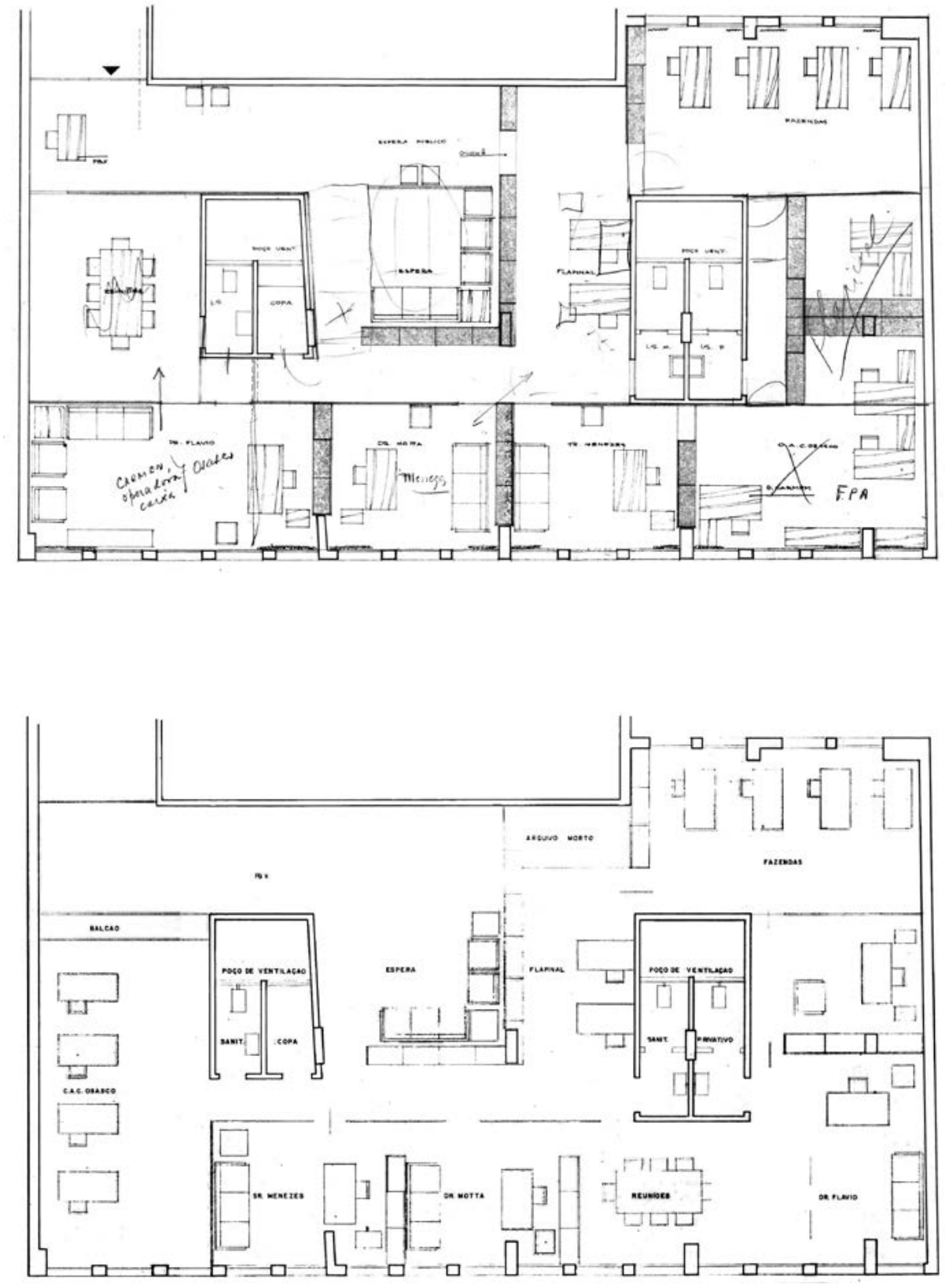
Uso

Projeto de Layout

Cliente

Banco de São Paulo

Equipe

Eduardo de Almeida

Localização

Rua São Bento com a Praça Antônio Prado, Sé, São

Estágio

Estudo Preliminar

\section{Observações}

Projeto de layout não construído

Características

Estudo para a instalação da diretoria do Banco de

São Paulo, localizado no Edifício Banco de São Paulo,

exemplar de arquitetura Art Déco projetado por Álvaro

de Arruda Botelho na Praça Antônio Prado, com acesso

secundário pela Rua São Bento.

0 projeto de ocupação respeita as características do

edifício, aproveitando a circulação perimetral ao redor

do pátio central e posicionando divisórias e armários em

função dos pilares e das alvenarias da fachada.

Acervo

Tubo 13

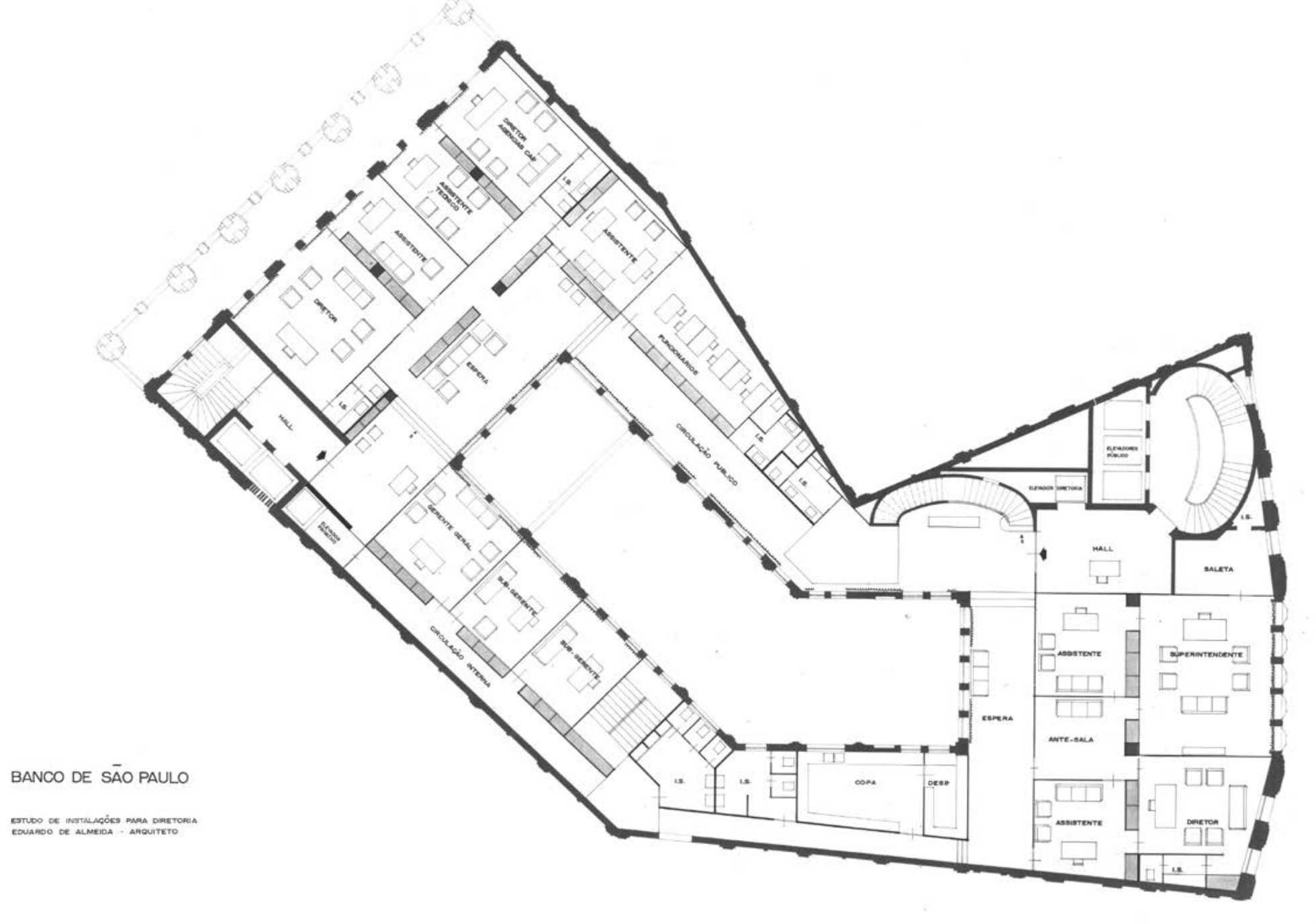


Uso

Residência Unifamiliar

Cliente

Flávio Pinho de Almeida

Equipe

Horizonte Arquitetos - Arthur Fajardo Netto, Dácio Otton Eduardo de Almeida, Henrique S. Pait e Ludovico Martino

Localização

Rua Carlos Ferreira, Morumbi, São Paulo, SP

Estágio

Projeto Executivo

Observações

Construído

Características

Projetada para seu irmão no bairro do Morumbi, esta residência foi implantada paralelamente à rua de acesso criada junto à divisa do lote de grandes dimensões.

A casa volta-se à piscina e ao jardim arborizado definido por um muro curvo próximo ao limite do lote, tanto no pavimento térreo - onde se posicionam os ambientes de estar e serviços - quanto no pavimento superior destinado aos dormitórios. 0 projeto utiliza estrutura mista com pilares metálicos associados à caixilharia, lajes de concreto e planos de alvenaria aparentes. A laje plan da cobertura dos domithe teto de duas águas assimétricas, criando um espaço de pé-direito variável na sala. Por conta de questões relacionadas à orientação dos quartos, foi realizada uma versão com o corredor do pavimento superior invertido, posteriormente abandonada.

Acervo

Tubo 24, 24A e 24B

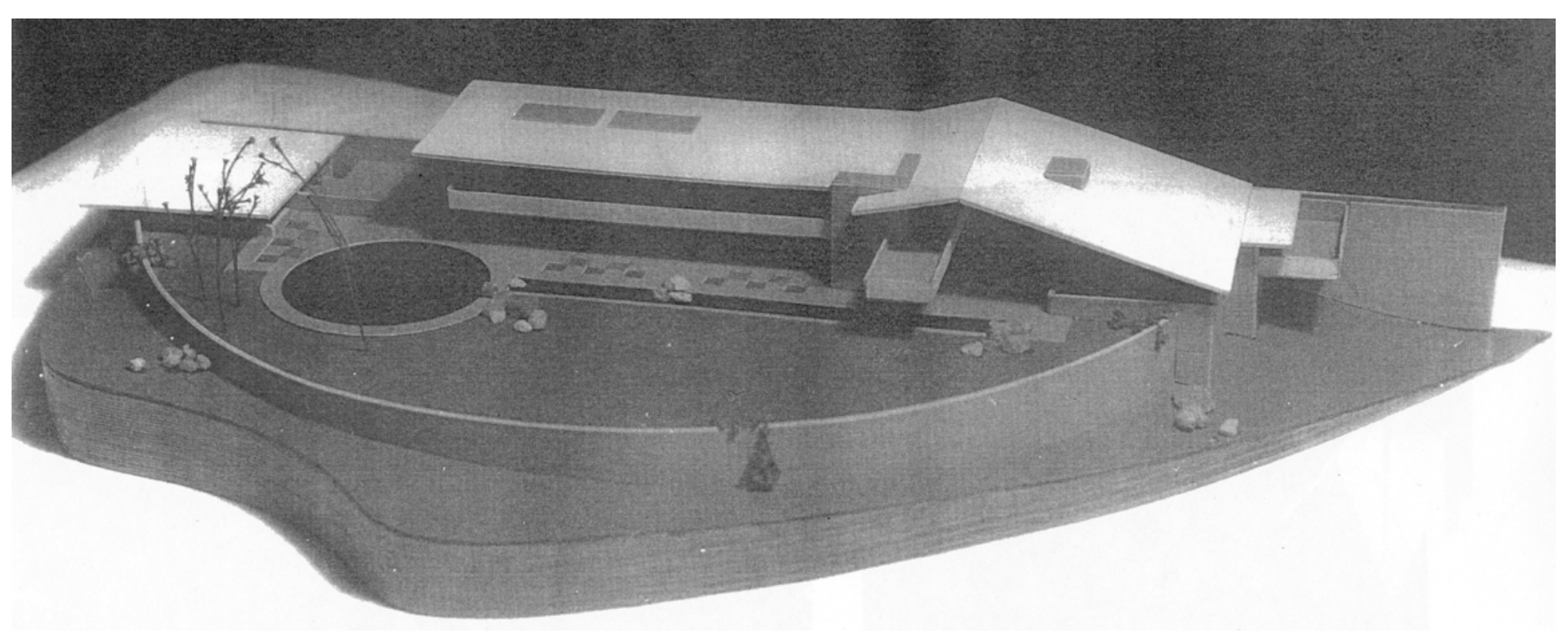

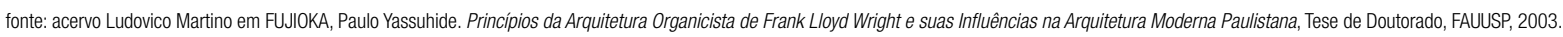
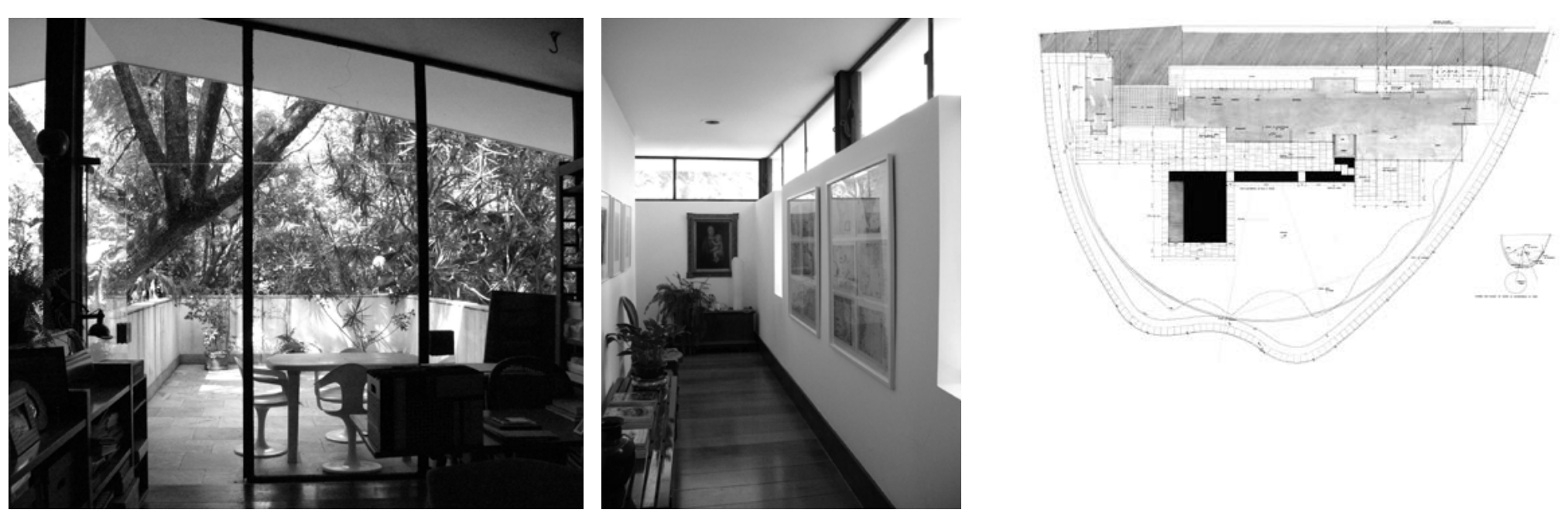
Uso

Residência Unifamiliar

Cliente

Flávio Pinho de Almeida

Equipe

Horizonte Arquitetos - Arthur Fajardo Netto, Dácio Ottoni, Eduardo de Almeida, Henrique S. Pait e Ludovico Martino

\section{Localização}

Rua Carlos Ferreira, Morumbi, São Paulo, SP

Estágio

Projeto Executivo

Observações

Não Construído

Características

Durante a realização dos estudos para corrigir a questão da orientação dos quartos, foi realizado este segundo estudo - segundo Eduardo de Almeida, com partido definido por Ludovico Martino, - que previa a disposição da maioria dos programas em um único pavimento. Enquanto os dormitórios e os serviços se organizavam em cada uma das alas laterais, o conjunto de salas se posicionava em quatro volumes quadrados centrais, cobertos por telhados de quatro águas de cobre $e$ dotados de iluminação natural.

Acervo

Tubo 24, 24A e 24B

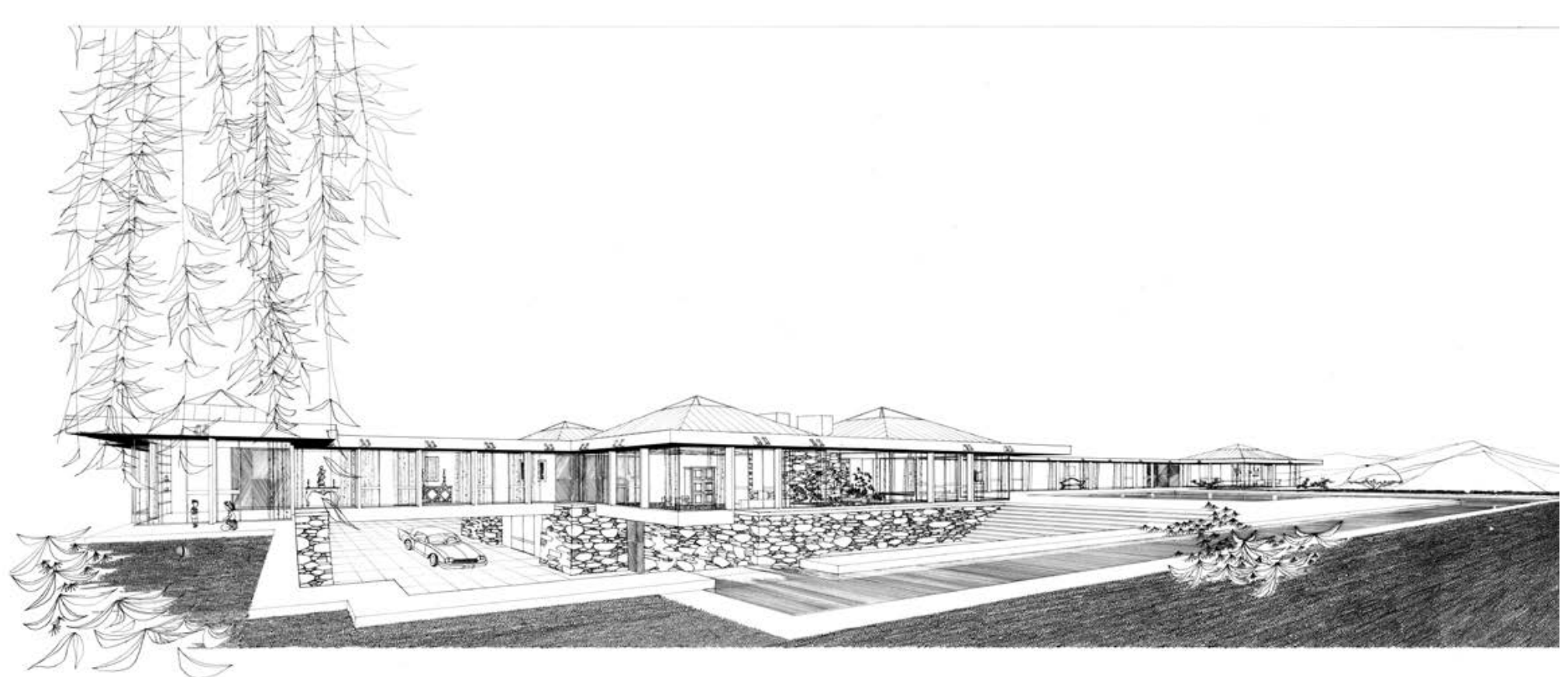

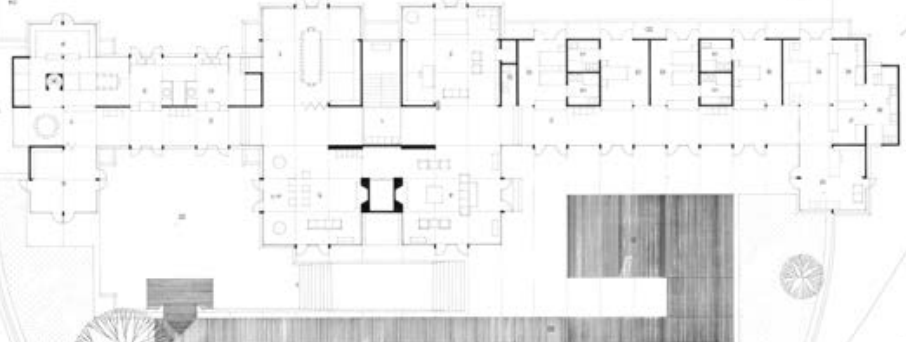
(2)

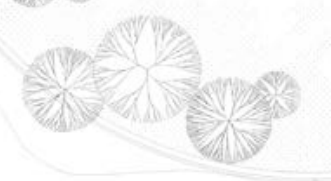


Uso

Edifício de Habitação Coletiva

Cliente

Companhia Construtora de Osasco

Equipe

Horizonte Arquitetos - Arthur Fajardo Netto, Dácio Ottoni, Eduardo de Almeida, Henrique S. Pait e Ludovico Martino

\section{Localização}

Alameda Itu, 254, Jardim Paulista, São Paulo, SP

Estágio

Projeto Executivo

Observações

Construído

\section{Características}

Edifício de apartamentos com duas unidades por andar e dez pavimentos. Destaca-se a solução dada à estrutura aos caixilhos verticais recuados e à volumetria saliente dos planos cegos de alvenaria, armários em balanço e torre de circulação vertical. Apesar da perspectiva indicar o desenho de linhas horizontais das alvenarias, à semelhança de alguns projetos de Frank Lloyd Wright, 0 projeto efetivamente construído teve acabamento tradicional em pastilhas cerâmicas.

\section{Acervo}

Tubo 47 e Caixa 4900
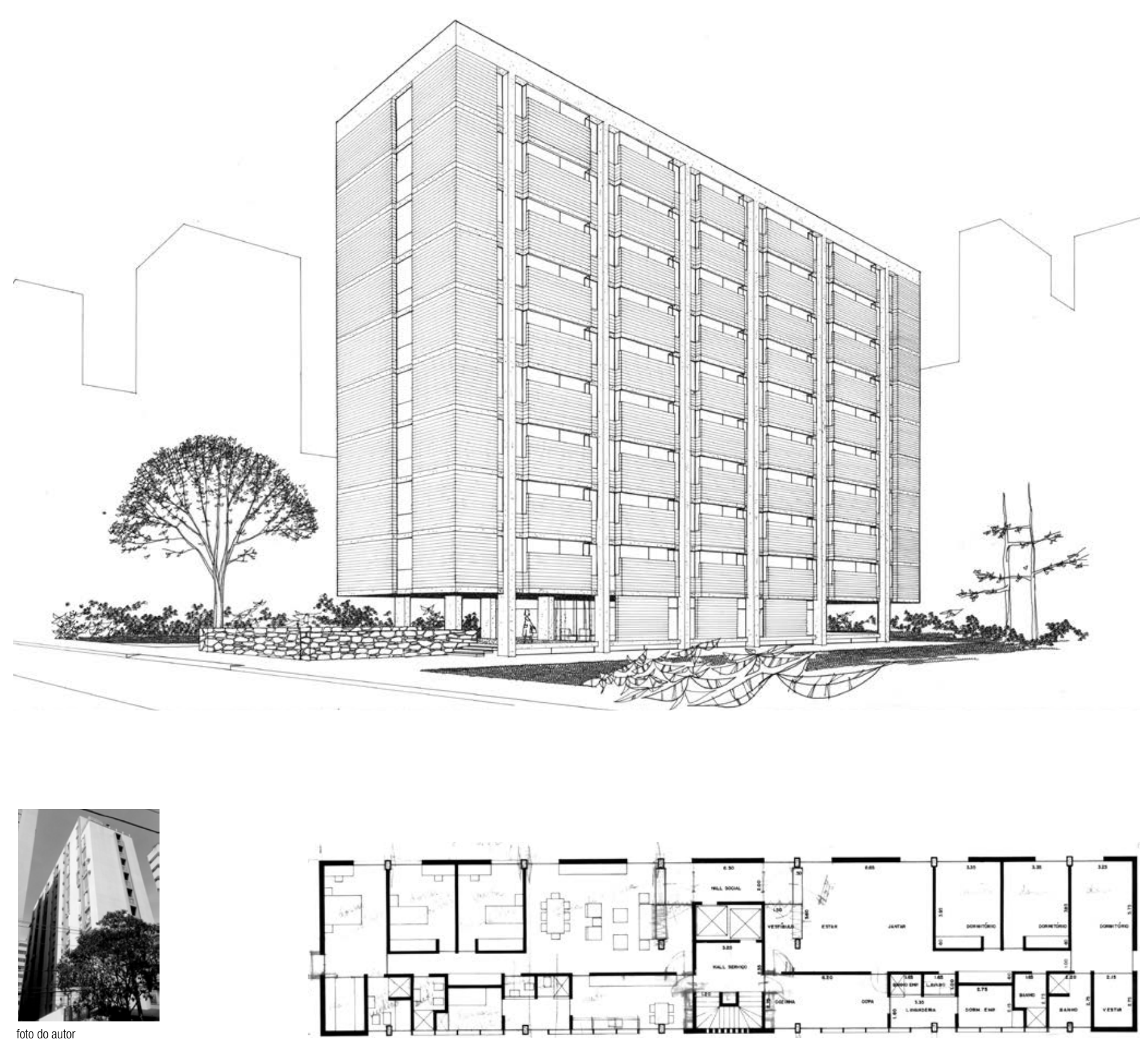

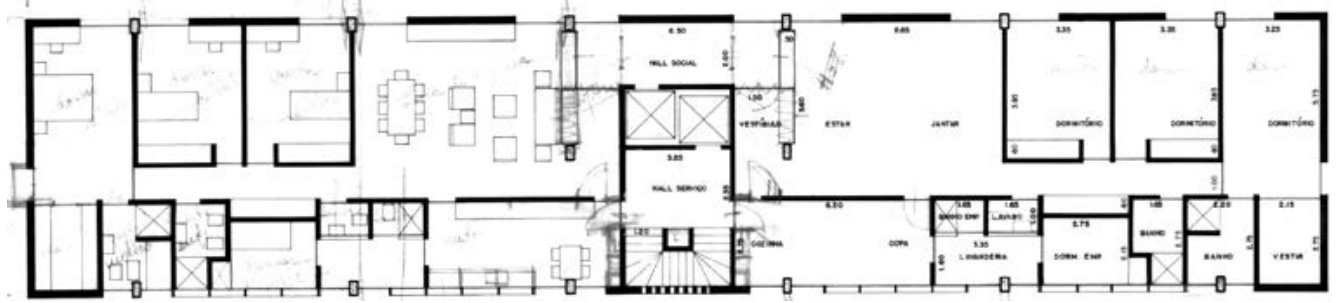


Uso

Residência Unifamiliar

Cliente

Renato de Andrade

Equipe

Eduardo de Almeida

Localização

Não identificada

Estágio

Estudo Preliminar

Observações

Não Construído

\section{Características}

Estudo para a construção de uma residência unifamiliar

com dois pavimentos e quatro dormitórios. Segundo

Eduardo de Almeida, enquanto os desenhos se

utilizam da influência de Sérgio Bernardes - uso de

papel milimetrado e canetas hidrogŕficas coloridas

- a solucão dida a projto segue a organizacio dos

programas en torno de un palo centra a exemplo da

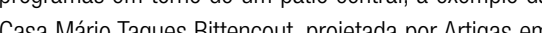

1959

Acervo

Tubo 34
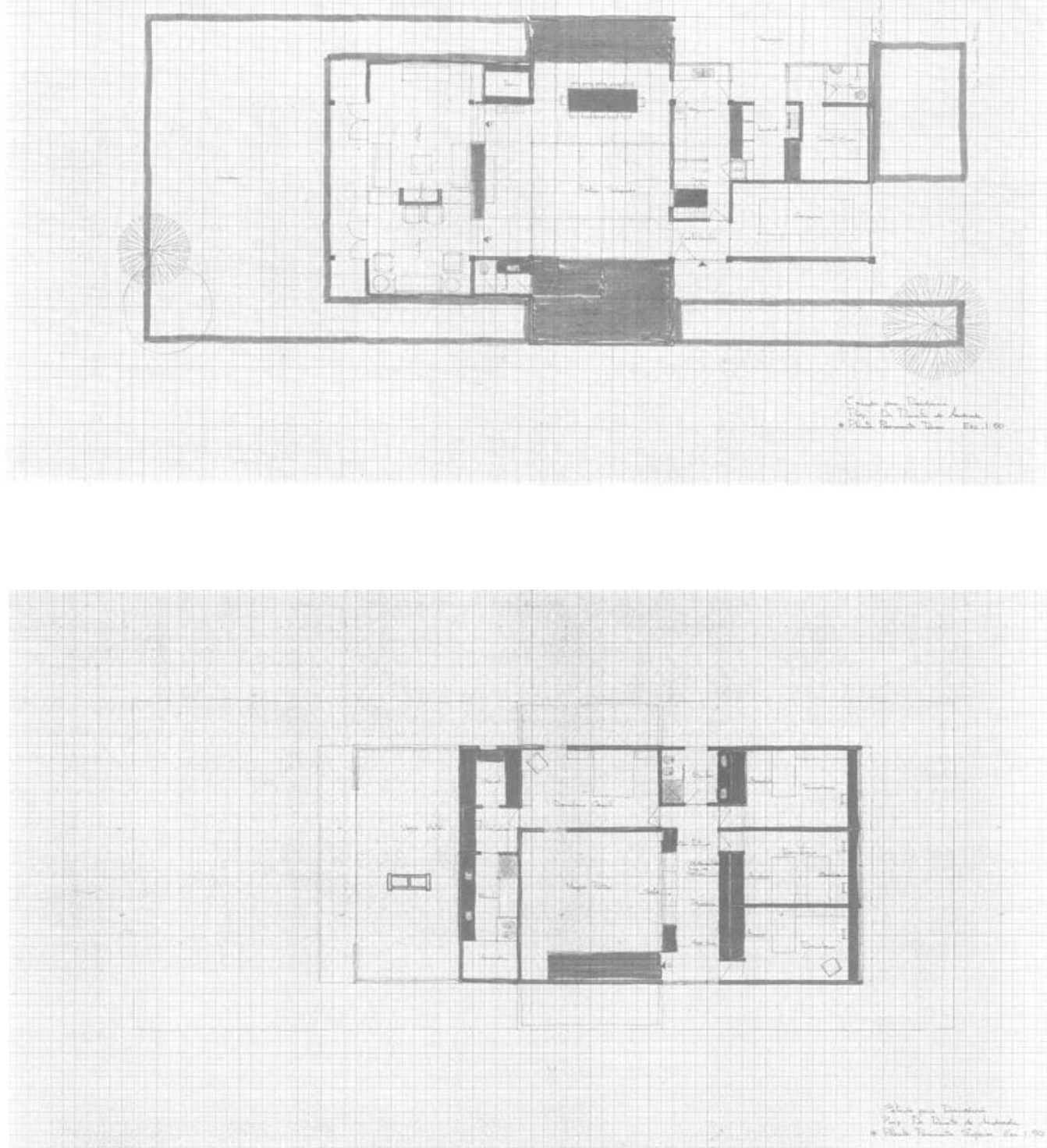
Uso

Luminária componivel

Equipe

Eduardo de Almeida

Estágio

Projeto Executivo

Observações

Trabalho final de curso, não construído

Características

Projeto de uma luminária componivel para o trabalho

de conclusão do curso Proggetazione Artistica per

I'industria da Faculdade de Arquitetura e Urbanismo de

Florença, ministrada pelo professor Pier Luigi Spadolini

por ocasião da bolsa de estudos obtida junto à Fundação

Amerigo Rotellini, quando Eduardo de Almeida também

teve a oportunidade de assistir ao Curso de História da

Arte de Leonardo Benevolo.

Seguindo a influência de designers italianos da época,

como Achille Castiglione, o projeto busca atingir uma

solução capaz de refletir a essência de um determinado

objeto. Neste caso, ao se pensar em um desenho de

Iuminária, Eduardo de Almeida decide fazer o projeto das

próprias lâmpadas.

Acervo

Tubo 69

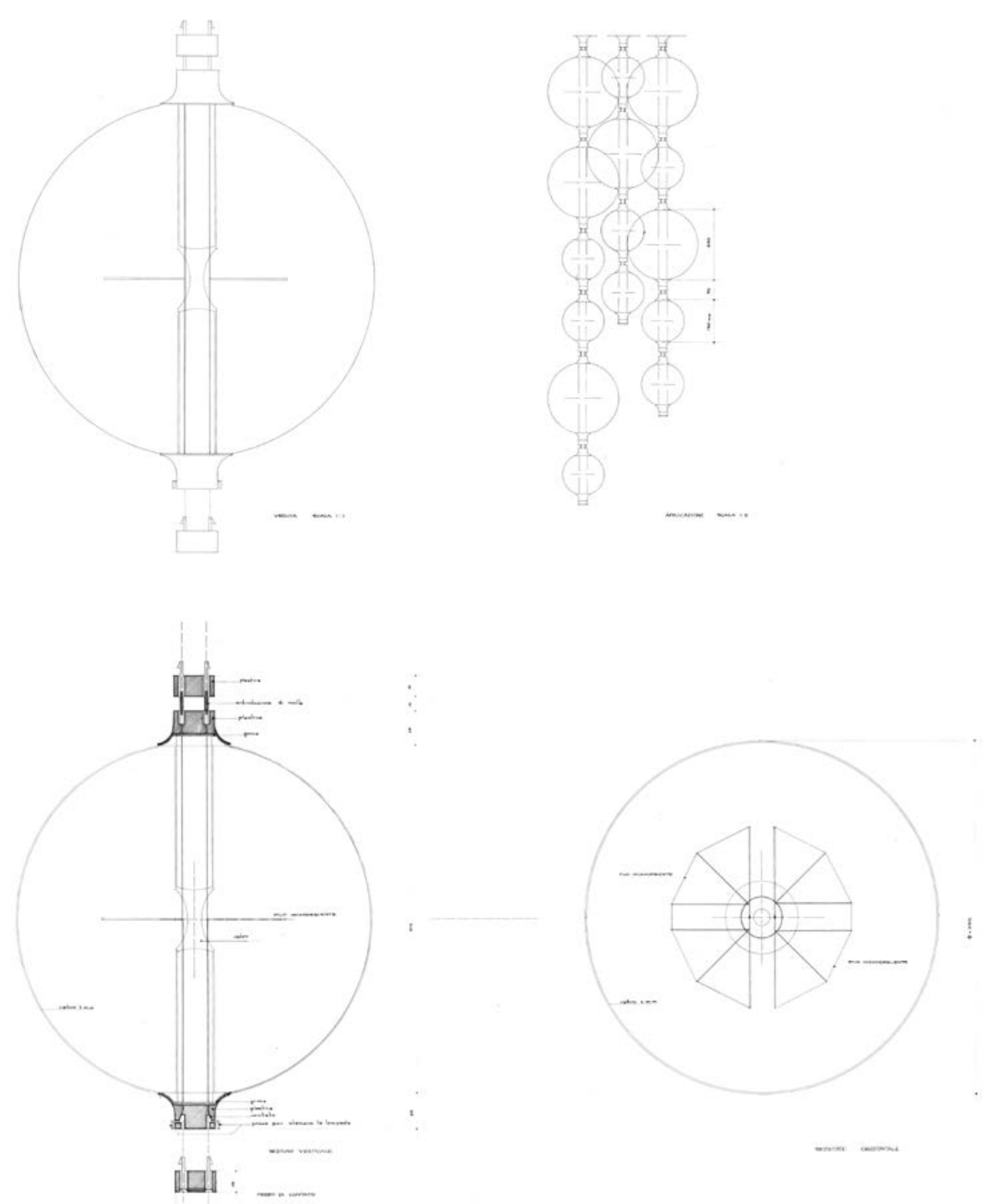


Uso

Residência Unifamiliar

Cliente

Maria Mistrorigo

Equipe

Eduardo de Almeida

Localização:

Praia de Pernambuco, Guarujá, SP

Estágio

Projeto Executivo

Observações

Projeto de reforma construído

Características

Projetada para sua sogra, esta reforma de uma casa

de praia aproveita 0 desenho da cobertura inclinada

para solucionar os dormitórios em dois pavimentos,

conformando também espaços de estar com pé-direito

elevado e variável. Assim como outras obras realizadas

posteriormente, esta casa foi totalmente revestida

e pintada de branco, valorizando a volumetria e seu

contraponto com as aberturas.

\section{Acervo}

Tubo 76
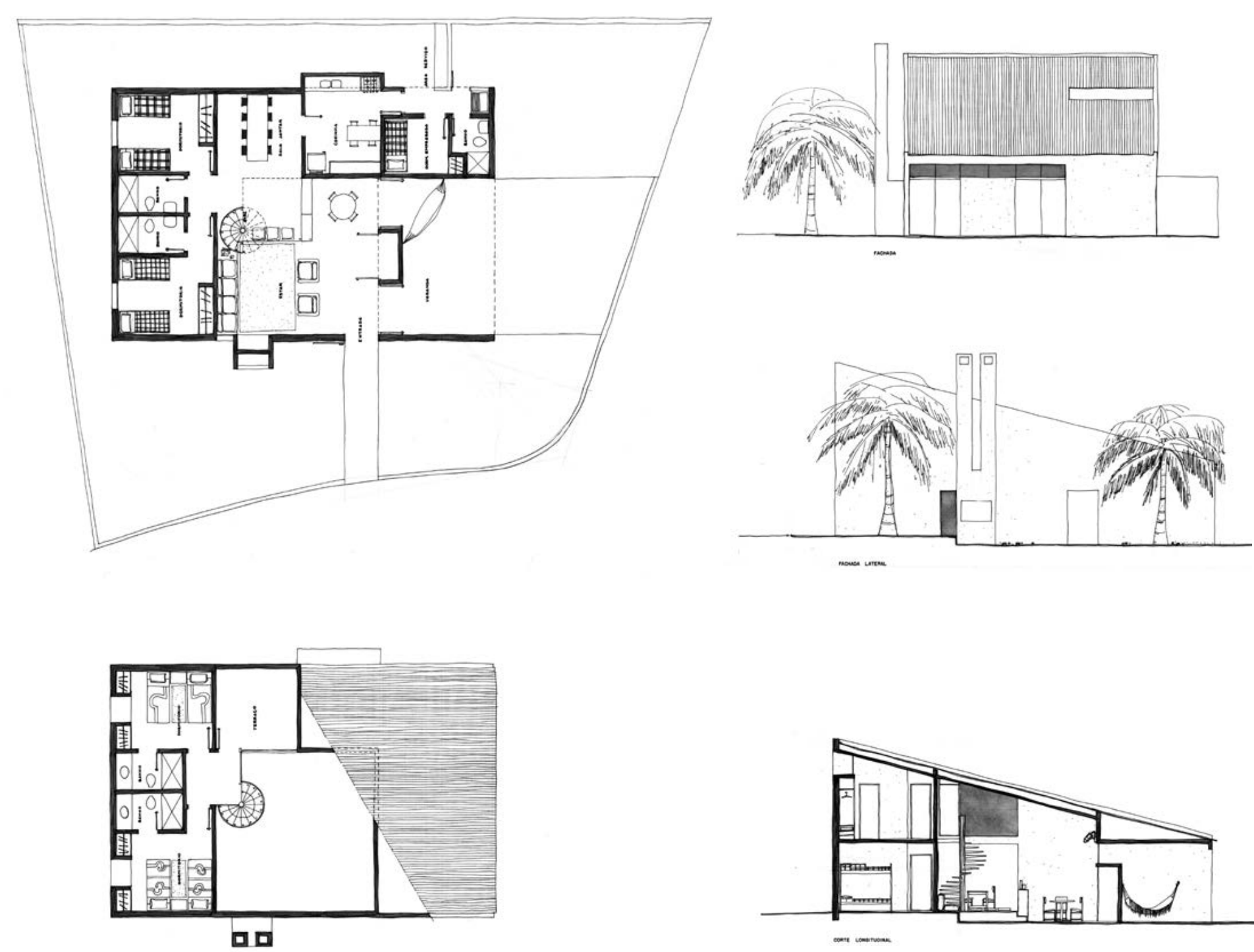

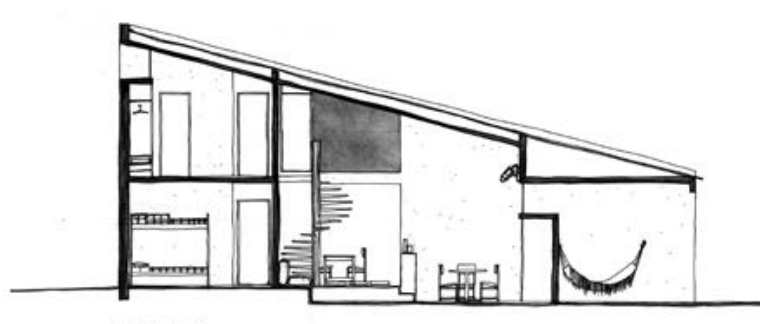


Uso

Residência Unifamiliar

Cliente

Dr. Roberto Alves Motta

Equipe

Arthur Fajardo Netto, Dácio Ottoni, Eduardo de Almeida,

Henrique S. Pait

\section{Localização}

Rua Alberto Faria, Alto de Pinheiros, São Paulo, SP

Estágio

Projeto Executivo

Observações

Construído

\section{Características}

Esta residência unifamiliar apresenta estrutura de concreto armado, pilares metálicos, alvenarias de tijolo aparente e caixilharia de madeira, sempre protegidas por largos beirais A utilizacão destes materiais remete por pros belis. A u a õo irmão de Eduardo, também responsavel pela indicação deste cliente. Merece especial atenção o conjunto de desenhos realizados sobre papel milimetrado, com detalhamentos realizados à mão-livre, nanquim e hidrográficas coloridas, seguindo 0 padrão gráfico utilizado nos projetos de Sérgio Bernardes

Acervo

Tubo 41

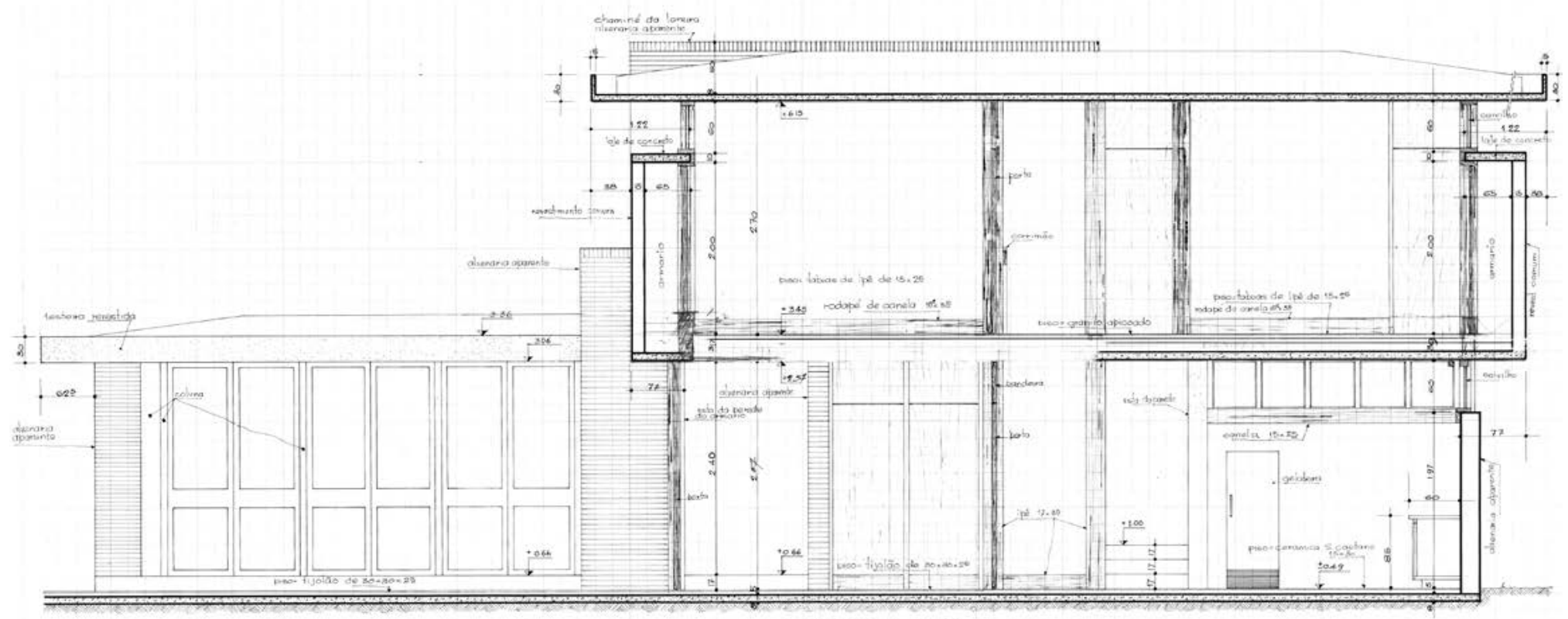

CORTE AA

$\overline{0,5} \quad \overline{1}$
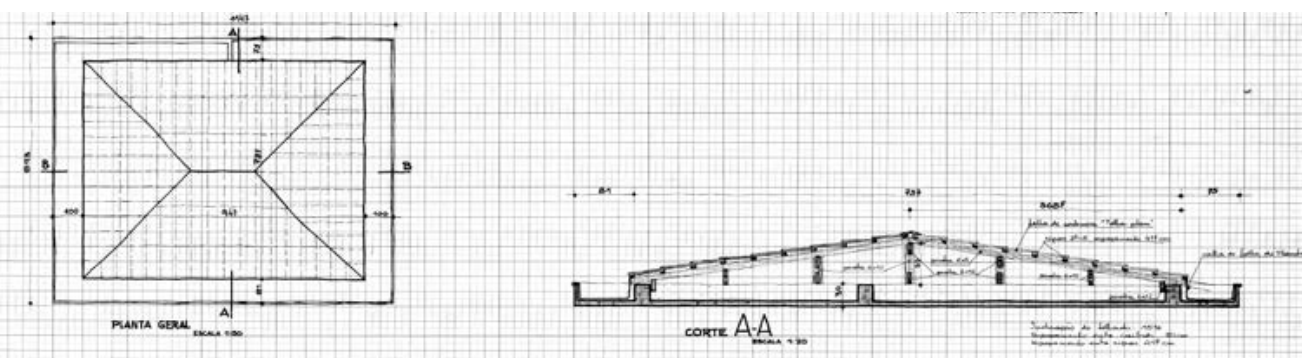

ATENÇĀO : VERIFICAR MEDDAS NA OBRA

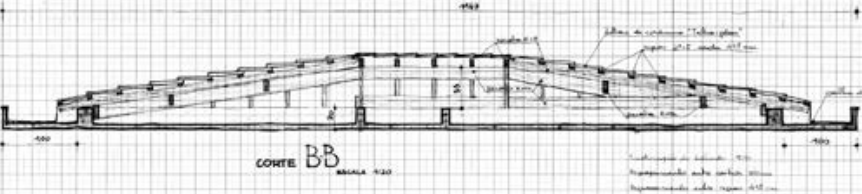


Uso

Edifíiio de Habitação Coletiva

Cliente

Flávio Pinho de Almeida e Roberto de Abreu Sodré

Equipe

Horizonte Arquitetos - Arthur Fajardo, Dácio Ottoni Eduardo de Almeida e Henrique S. Pait

\section{Localização}

Rua Bela Cintra, São Paulo, SP

Estágio

Estudo Preliminar

Observações

Construído

\section{Características}

Estudo de viabilidade para um lote de dimensão tradicional em São Paulo. Foram realizados diversos estudos considerando a construção de seis apartamentos com duas torres de circulação vertical seis apartamentos com três torres de circulaçãa vertical e duas unidades associadas a uma única prumada.

Em todos os casos, fica evidente a preocupação de Eduardo de Almeida no desenho da estrutura, sua modulação e correlações com os ambientes posicionamento das alvenarias e caixilharia A primeira versão com seis apartamentos por andar associados a duas torres de circulação foi utilizada como referência para o projeto do Edifício Jesuíno Arruda, realizado em 1971.

Acervo

Tubo 26

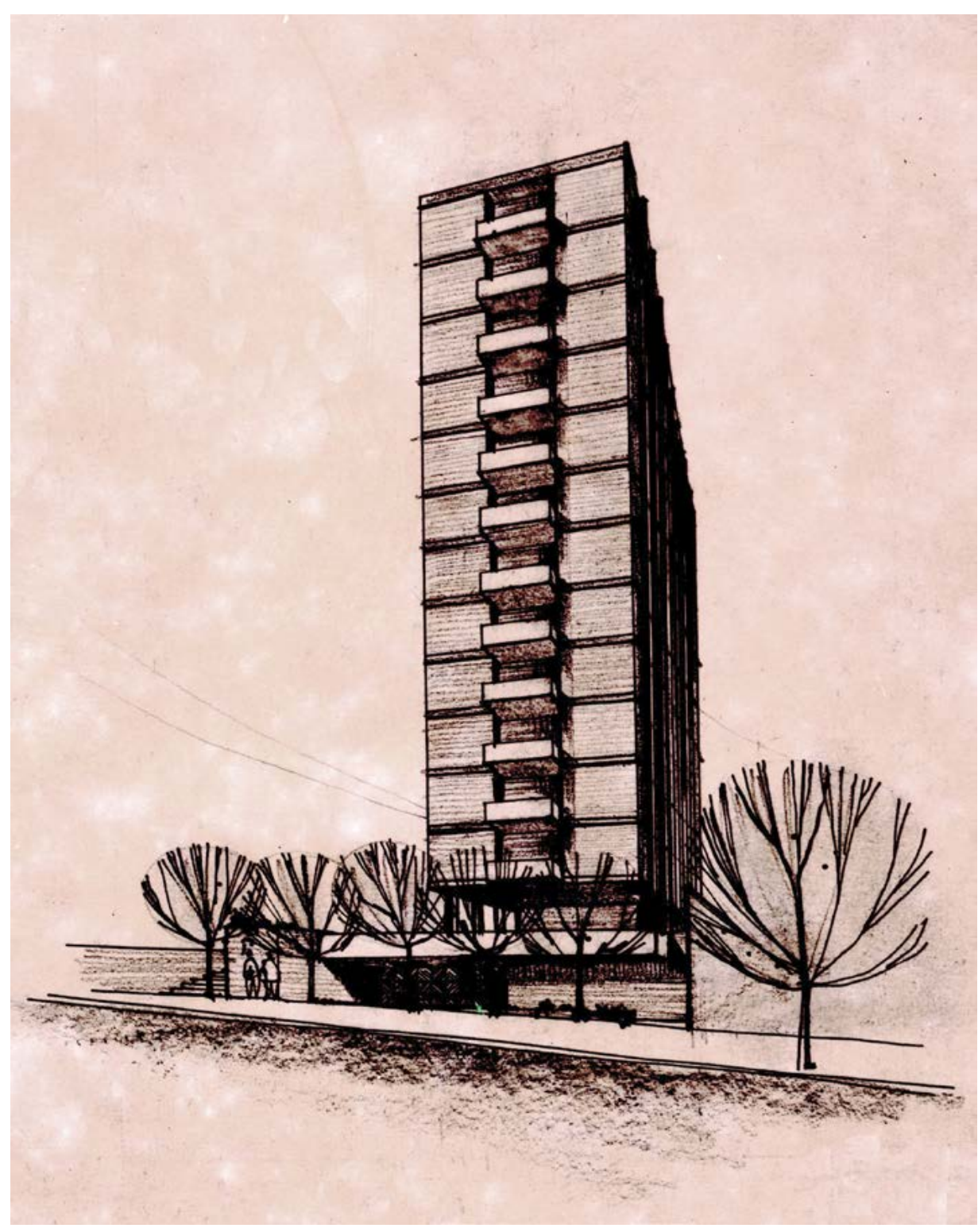

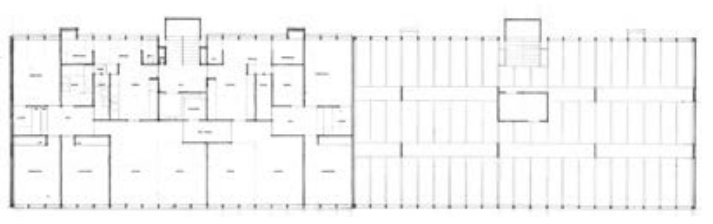

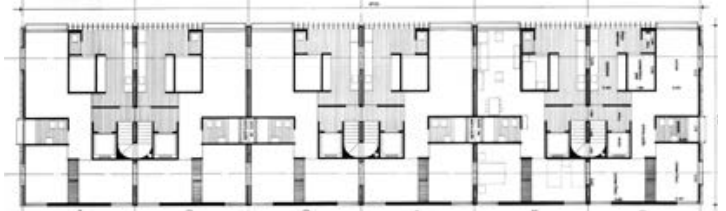

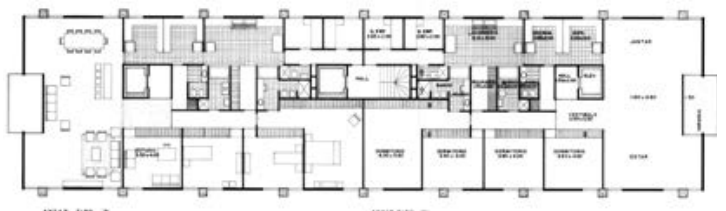


Uso

Edifício de Habitação Coletiva

Cliente

Companhia Construtora de Osasco

Equipe

Horizonte Arquitetos - Arthur Fajardo Netto, Dácio Ottoni,

Eduardo de Almeida e Henrique S. Pait

\section{Localização}

Alameda Franca, Jardim Paulistano, São Paulo, SP

Estágio

Estudo Preliminar

Observações

Não Construído

\section{Características}

Edificio de onze pavimentos organizado em dois blocos articulados por uma circulação vertical central. Este edifício com quatro unidades por pavimento apresenta

a demarcação da estrutura de concreto aparente

em contraste com os planos de alvenaria revestidos,

ressaltados pela adoção da caixilharia recuada em

relação ao plano da fachada.

Tal solução será retomada posteriormente em projetos

como os edifícios Granja Julieta, Mauá e Palacete da

Aquias, respectivamente de 1979, 1981 e 1986

Acervo

Tubo 69
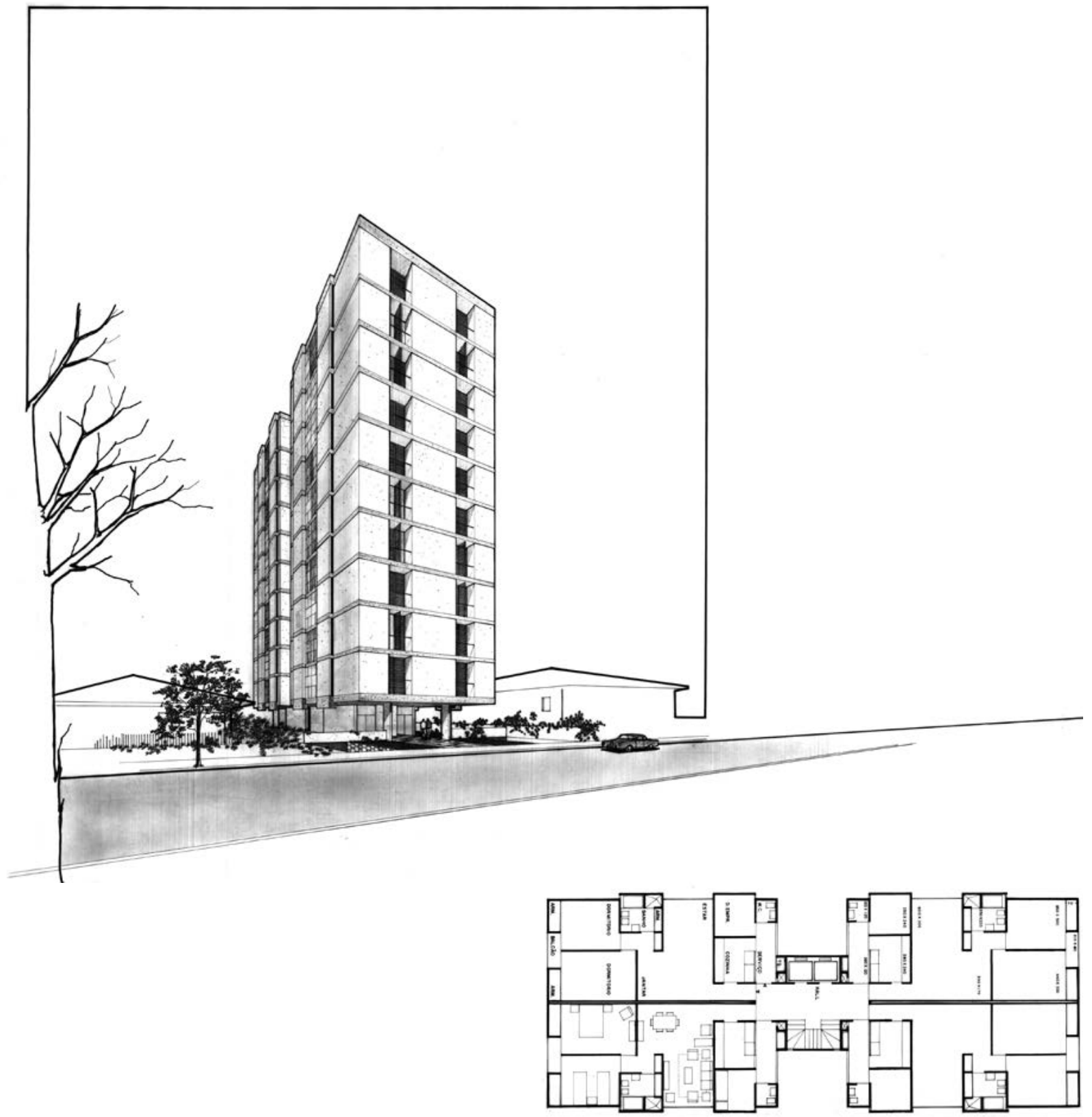
Uso

Escola

Cliente

FECE - Fundo Estadual de Construções Escolares

Equipe

Eduardo de Almeida e Dácio Ottoni

Localização

Alto da Mooca, São Paulo, SP

Estágio

Anteprojeto

Observações

Não Construído

\section{Características}

Seguindo os padrões estabelecidos pelo FECE, o projeto desta escola cria um único volume próximo à rua, organizando os programas em torno de um pátio central descoberto. Uma segunda versão para o mesmo terreno foi realizada posteriormente seguindo uma implantação

em dois blocos, semelhante ao partido adotado no Ginásio de Silveiras.

\section{Acervo}

Tubo 15

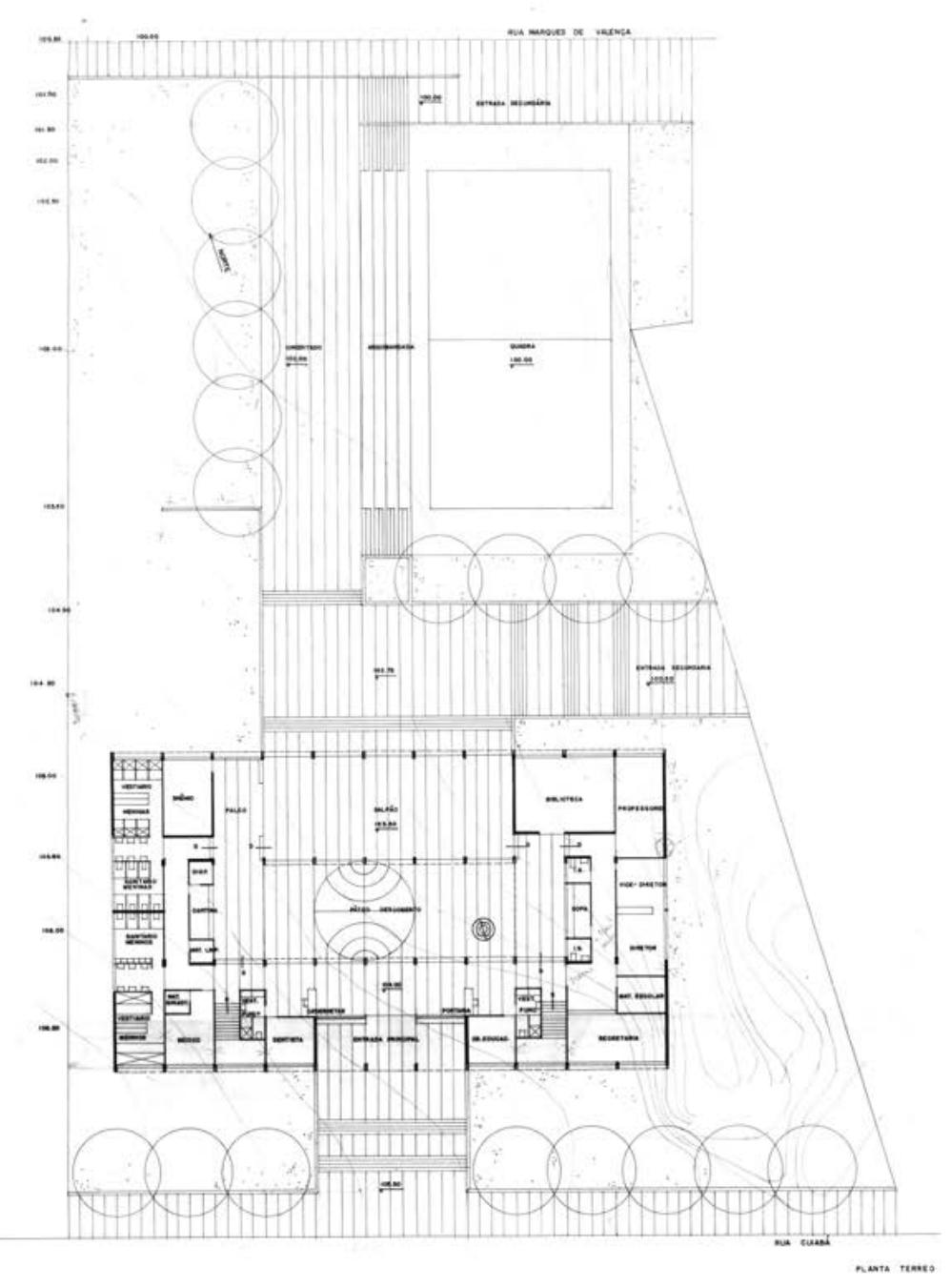

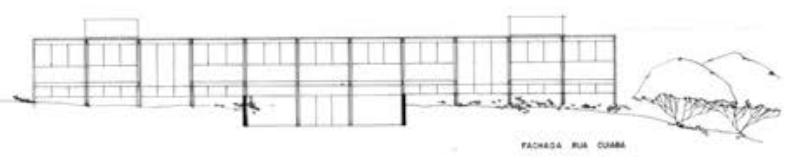

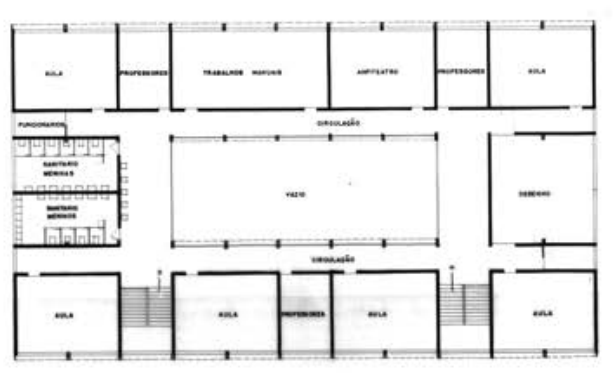

num sures

GINASIO ESTADUAL DO ALTO DA MOOCA escana 1200 F.E.C.E. - D.O.P.

EDUARDO DE ALMEIDA - DACIO A. B. OtTON 
Uso

Residência Unifamiliar

Cliente

Dr. Paulo de A. Toledo

Equipe

Eduardo de Almeida

Localização

Praia das Toninhas, Ubatuba, SP

Estágio

Projeto Executivo

Observações

Construido

\section{Características}

Residência unifamiliar construída em Ubatuba a partir da organização em dois blocos, um destinado aos dormitórios e outro aos ambientes de uso coletivo. A disposição geral do conjunto revela a preocupação com a inserção dos volumes na paisagem, e também com a inserção dos volumes na paisagen, e tambem com as relaçōes visuais dos ambientes internos com a praia, 0 mar e a vegetaçáa, como atestam as perspectivas apresentadas no estudo preliminar.

0 projeto executivo, feito unicamente por Eduardo de Almeida, conta com detalhamento preciso das estruturas de madeira, dos planos de alvenaria - também utilizados como elementos vazados - e pelas caixilharias de madeira. Todo o piso da casa utiliza um único elemento: lajotas cerâmicas de $30 \times 30 \mathrm{~cm}$

Acervo

Tubo 24, 24A e 24B
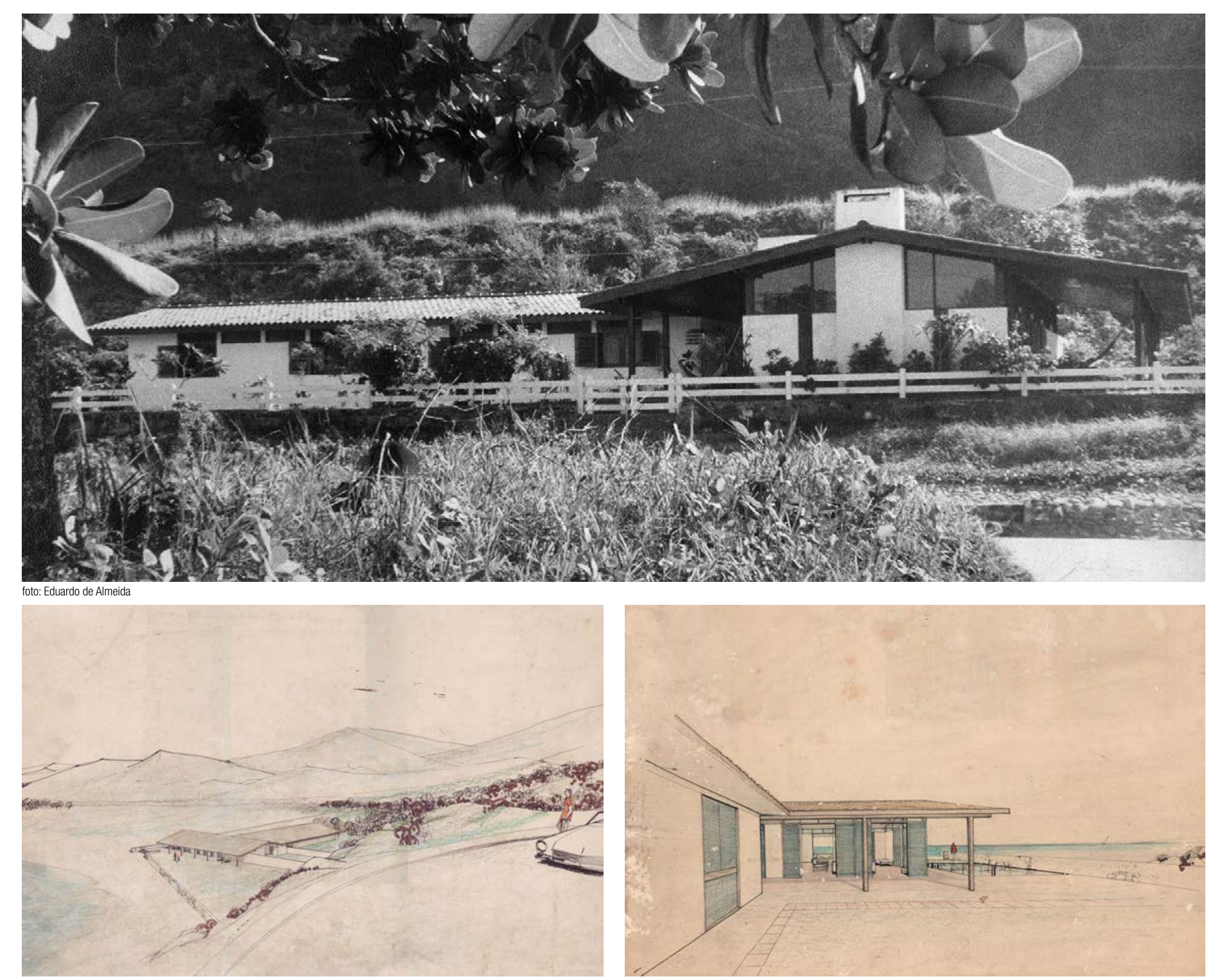
Uso

Residência Unifamiliar

Cliente

Carlos A. Lancelotti

Equipe

Arthur Fajardo Netto e Eduardo de Almeid

perspectiva | Luiz Paulo Baravel|

Localização

Rua Manágua, Morumbi, São Paulo, SP

Estágio

Projeto Executivo

Observações

Construído

\section{Características}

Residência projetada para uma prima de Eduardo de Almeida implantada em frente a um de seus primeiros projetos (casa para Bernardino Barbosa 1959, infelizmente, sem registros). A sala envidraçada do pavimento térreo se abre para 0 jardim latera de grandes proporções, também aproveitado pelos dormitórios localizados no pavimento superior. A edícula posicionada ao fundo do lote abriga a área de serviços e a garagem. Merece especial atenção a circulação que conecta os dois volumes e a escada de dois lances em balanço que marca o acesso social da casa.

Acervo

Tubo 10, caixa 200

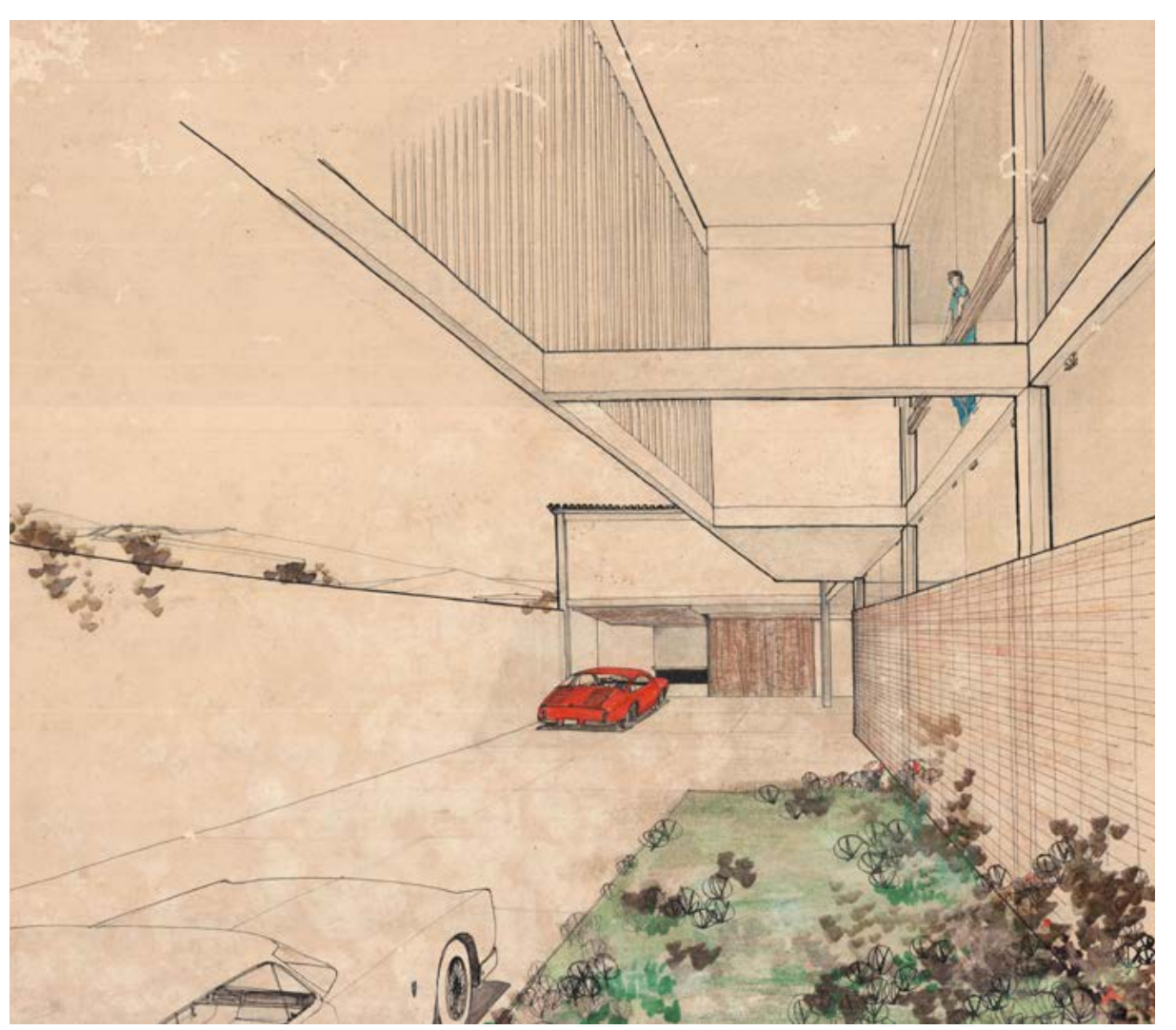

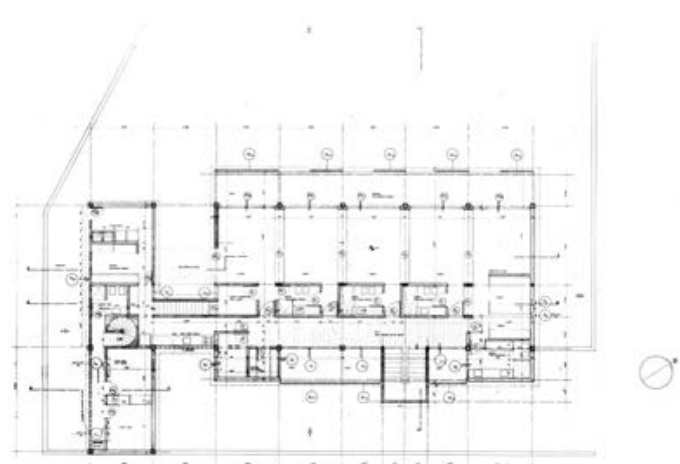


Uso

Edifício de Habitação Coletiva

Cliente

Companhia Construtora de Osasco

Equipe

Eduardo de Almeida

Localização

São Paulo, SP

Estágio

Estudo Preliminar

\section{Observações}

Não Construído

\section{Características}

Estudo para um edifício de habitação com uma unidade por pavimento. Enquanto a sala de estar volta-se para a rua, levemente rebaixada em relação ao acesso da unidade, os dormitórios e a sala de jantar voltam-se para um dos recuos laterais, enquanto os demais ambientes de serviços utilizam o outro. Esta solução, somada ao desenho da circulação e ao emprego da parede curva desenho da circulação e ao emprego da parede curva
na sala de jantar, parecem sofrer influência do Edifício na sala de jantar, parecem sofrer influência do Edifício na rua Haddock Lobo em 1962. 0 desenho do térreo cria diferentes acessos, gerando uma hierarquia dos espaços destinados aos veículos, servicos e moradores, organizados pelas áreas ajardinadas e pelas juntas de piso desenhadas de acordo com a modulação da estrutura do edifício e da garagem.

Acervo

Tubo 69

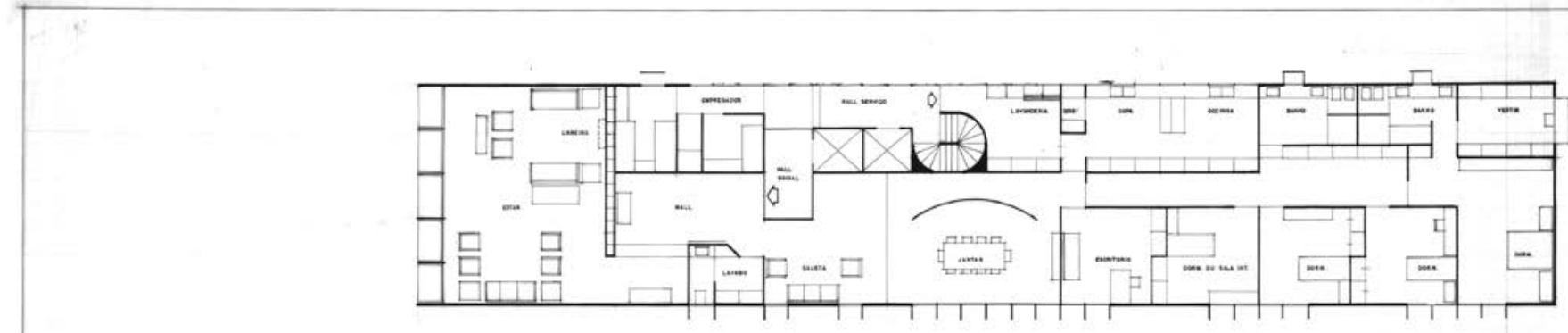

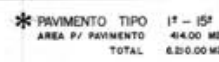
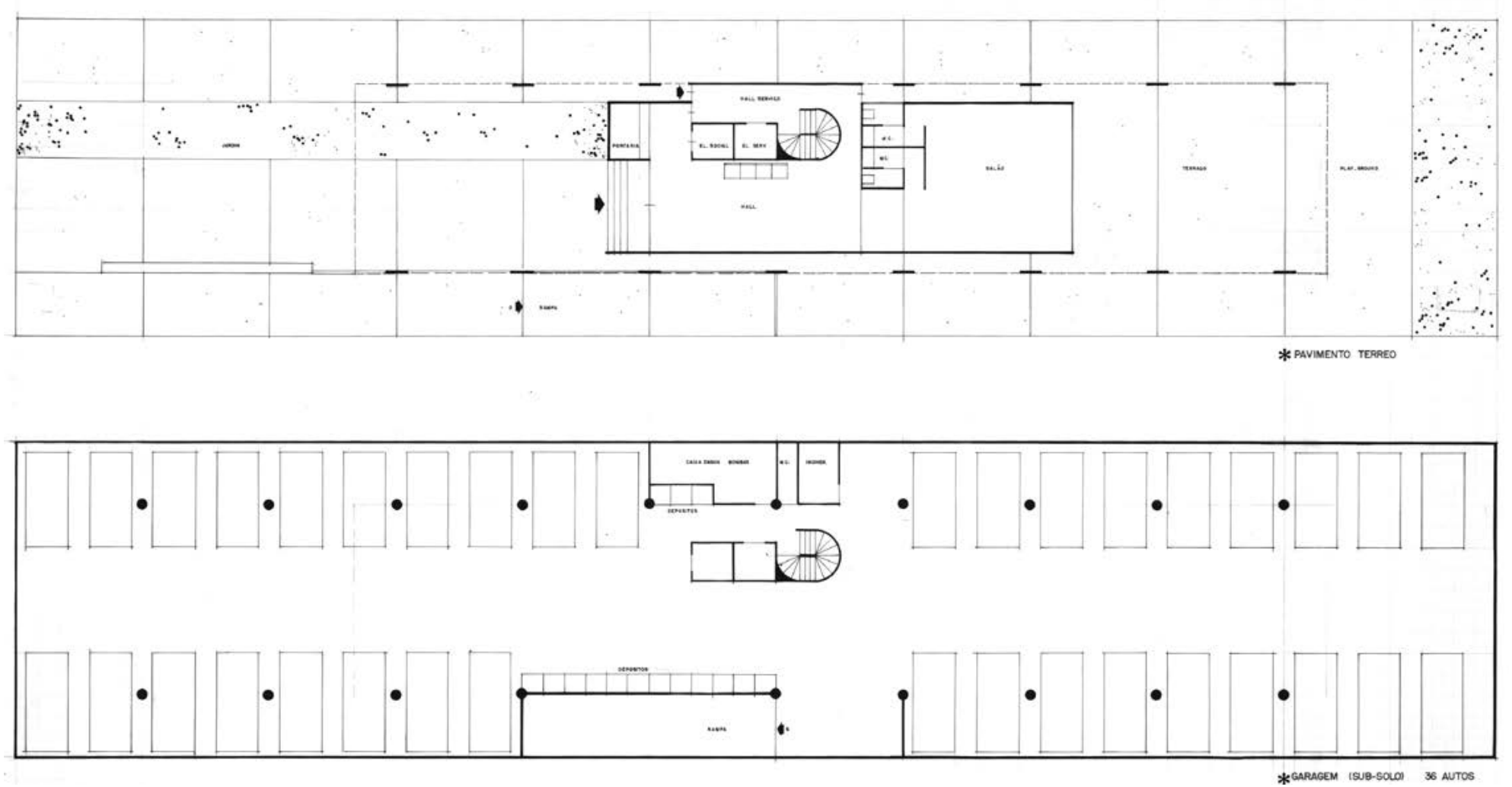
Uso

Residência Unifamiliar

Cliente

Pinto e Silva

Equipe

Arthur Fajardo Netto e Eduardo de Almeida

perspectiva | Luiz Paulo Baravel|

\section{Localização}

Não identificada

Estágio

Projeto Executivo

Observações

Construído e demolido

\section{Características}

Construída em concreto armado moldado in loco e alvenarias de tijolos aparentes, esta casa se utiliza da modulação da estrutura como elemento de organização

do espaço, tanto para a definição dos programas no pavimento térreo quanto para os dormitórios posicionados no pavimento superior. Os acréscimos de módulos junto ao recuo de fundos foram apropriados como varandas e a supressão de coberturas em módulos internos permitiram a criação de pátios internos ao lado dos ambientes de estar.

Acervo
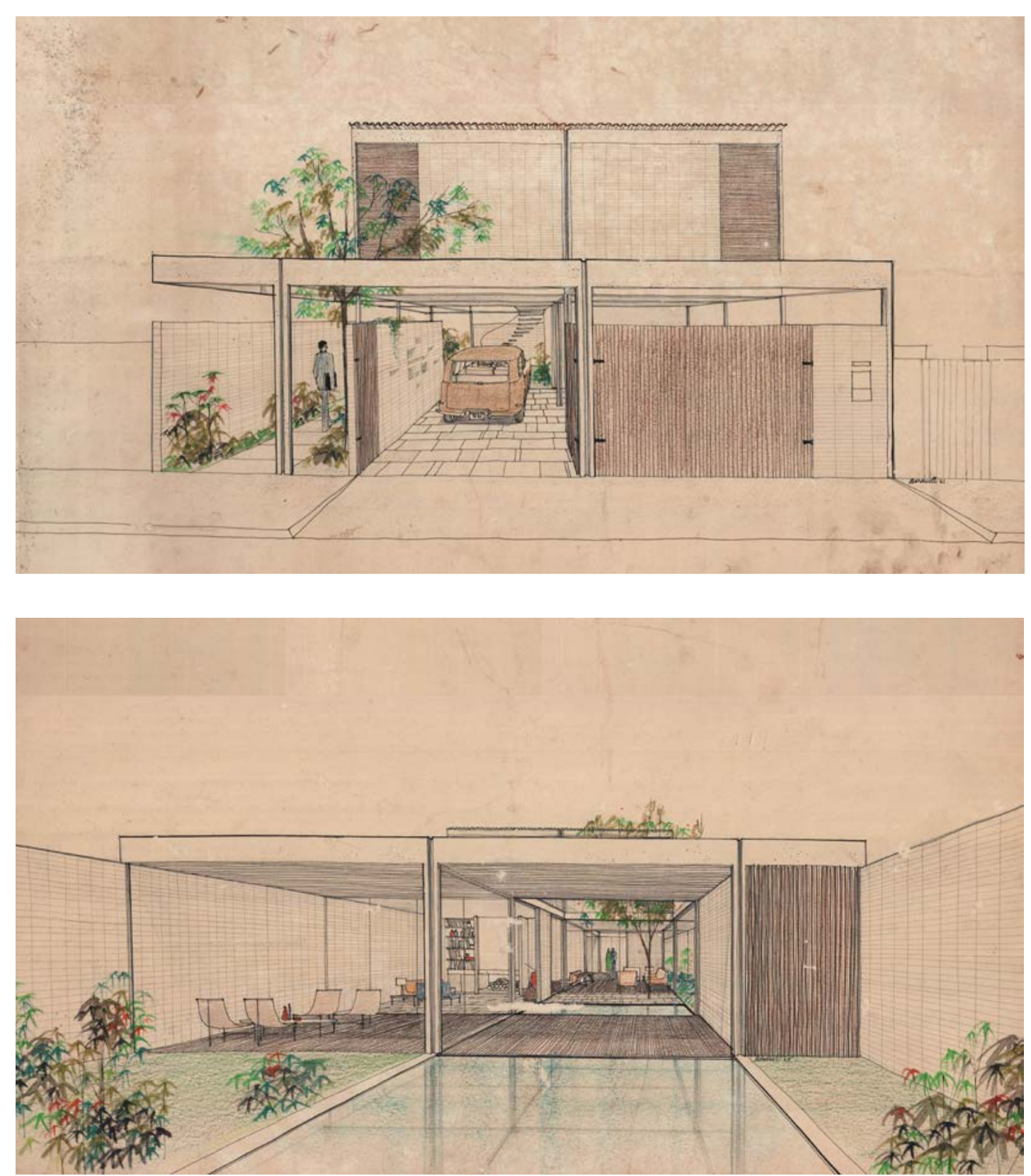
Uso

Conjunto Residencial - 2 casas

Cliente

Maurício Leite de Moraes e Marcelo de Almeida Toledo

Equipe

Eduardo de Almeida e Lélio Machado Reiner

Localização

Rua Dr. João Neves Netto 282, São Paulo, SP

Estágio

Projeto Executivo

Observações

Projeto construído e depois adaptado para Pedro Tassinari

\section{Características}

Projetadas para Maurício Leite de Moraes e Marcelo de Almeida Toledo, as duas residências foram construídas em um mesmo lote como um conjunto definido pelo emprego da estrutura em abóbodas. A exemplo de mbras de outos stas no mesmo período,
stas tal solução segue a influência das casas Jaoul de Le Corbusier. Neste caso, ao invés do tijolo, Eduardo de Almeida utiliza concreto armado moldado in 1oco, associado a alvenarias revestidas e caixilhos de vidro temperado. Uma das casas foi adquirida por Pedro Tassinari, sendo concluída com pequenas adequações realizadas pelo arquiteto, iniciando uma colaboração e amizade que se estenderiam em inúmeros projetos, como a Casa na Baleia e a série de edifícios para a Morlan.

Acervo
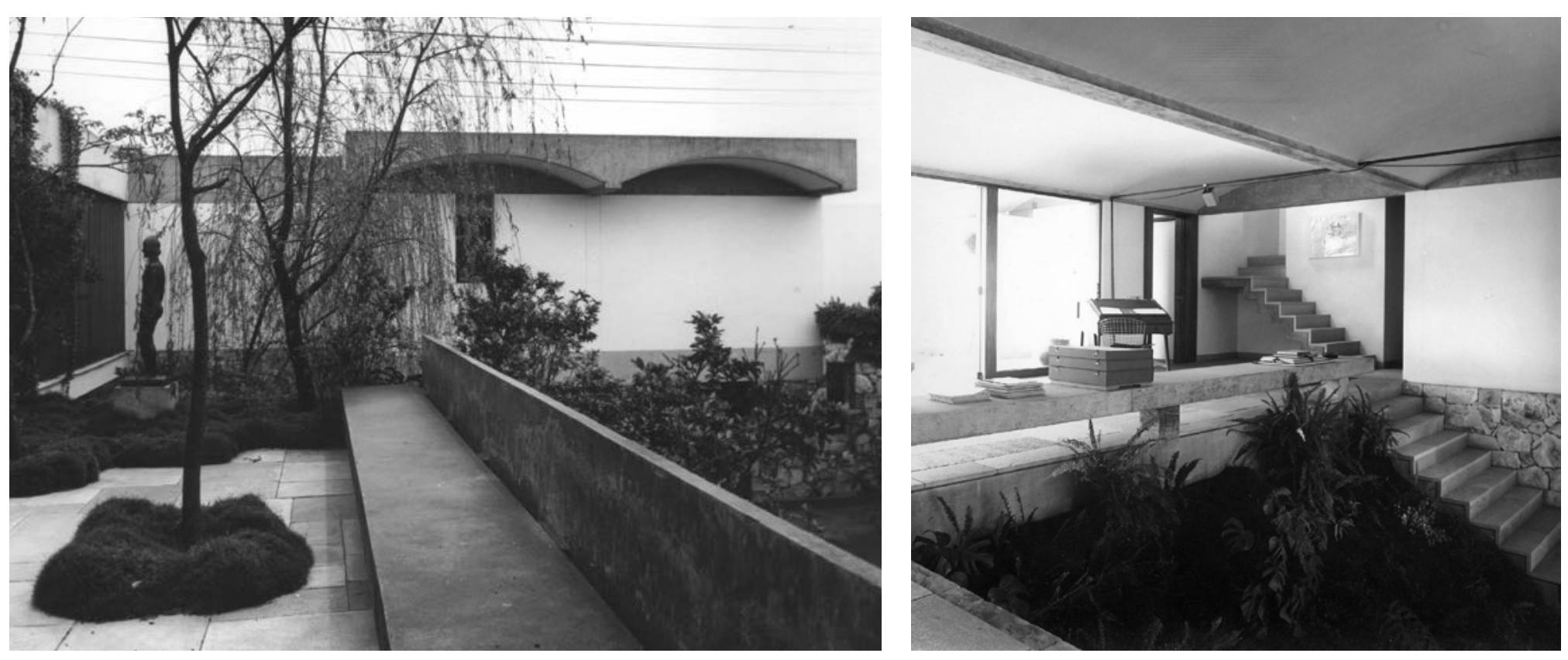

fotos: Juilio Abe Wakahara
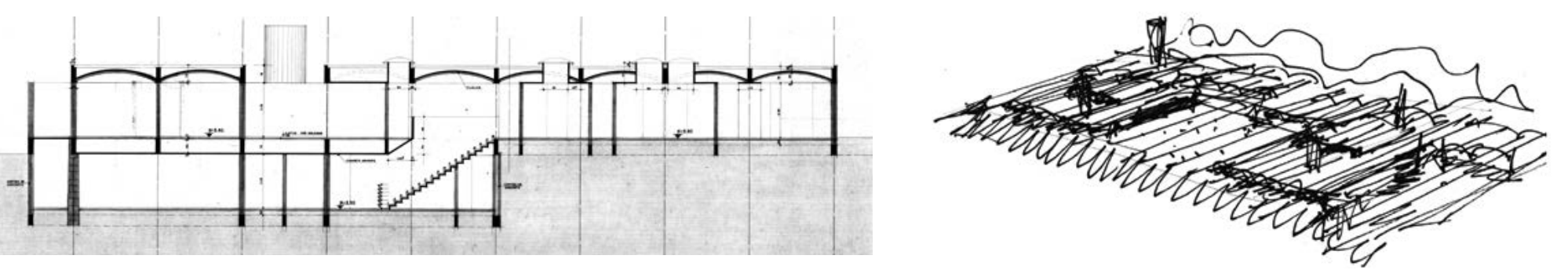

Tubo 61 e $61 \mathrm{~A}$ 
Uso

Lanchonete

Cliente

Sr. W. Zuardi

Equipe

Eduardo de Almeida

Localização

Praça Oswaldo Cruz, Paraíso, São Paulo, SP

Estágio

Projeto Executivo

Observações

Projeto de reforma construído e demolido

\section{Características}

Projeto de reforma para instalação de uma casa de

lanches. 0 Projeto Executivo revela 0 detalhamento

completo do projeto considerando todos os balcões, as

mesas, solucõoes técnicas para a cobertura e até mesmo

construção da fachada com sua comunicação visual.

Acervo

Tubo 11
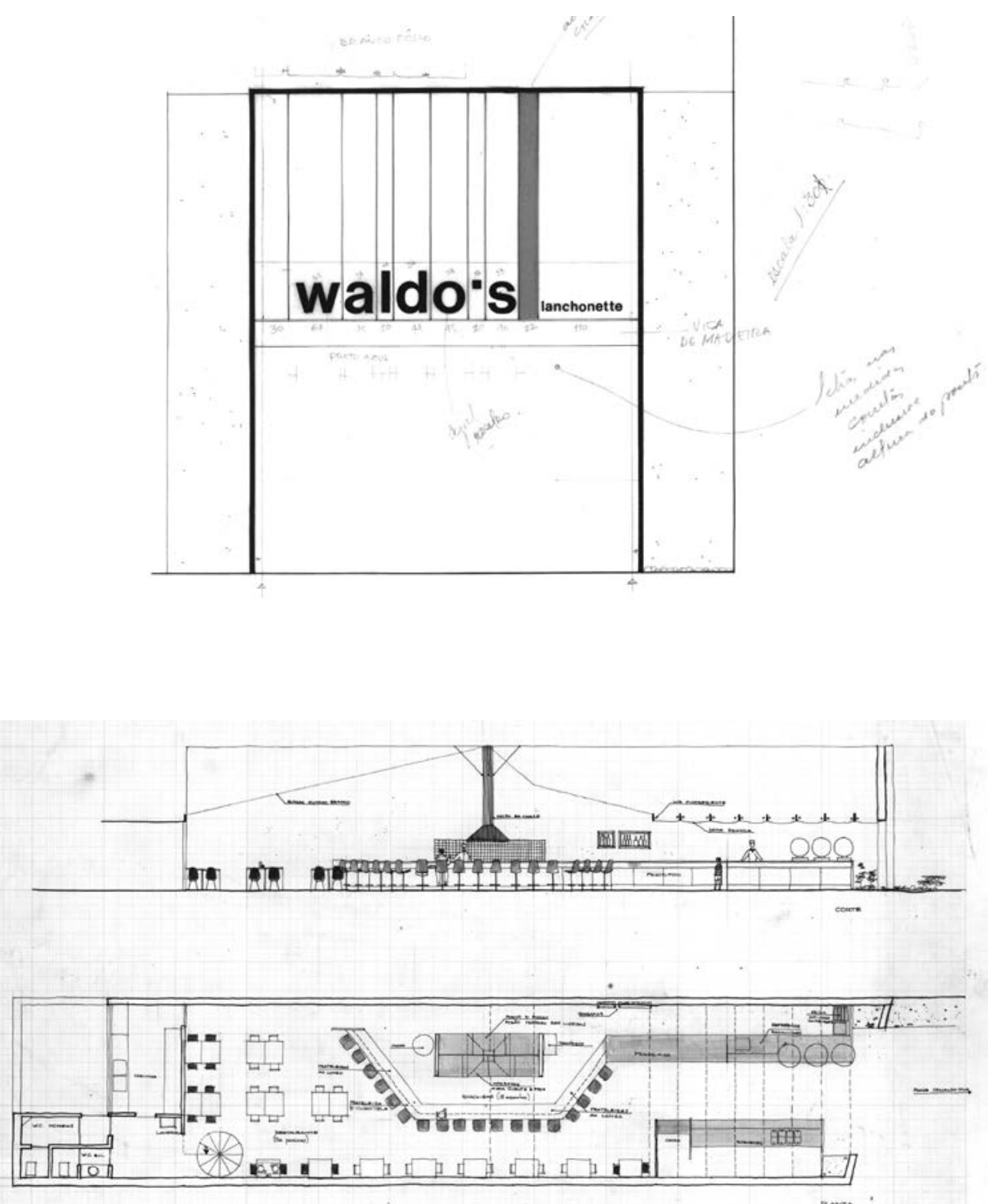

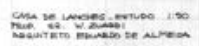


Uso

Capela e Centro social

Cliente

Ninho Jardim Condessa Marina Crespi

Equip

Eduardo de Almeida

Localização

Mooca, São Paulo, SP

Estágio

Estudo Preliminar

Observações

Não Construído

\section{Características}

Construção de uma capela com refeitório e salas de trabalho no subsolo. Este edifício funciona como um anexo de uma construção existente e é definida pelo emprego de estruturas de concreto armado e alvenarias de tijolo aparente. 0 plano inclinado da cobertura cria uma iluminação indireta para 0 interior da capela de pé direito elevado.

Segundo depoimento de Eduardo de Almeida, este projeto sofreu influência de Jacob Rutchi e seu projeto para a Capela Anglicana Santíssima Trindade de 1950.

Acervo

Tubo 82

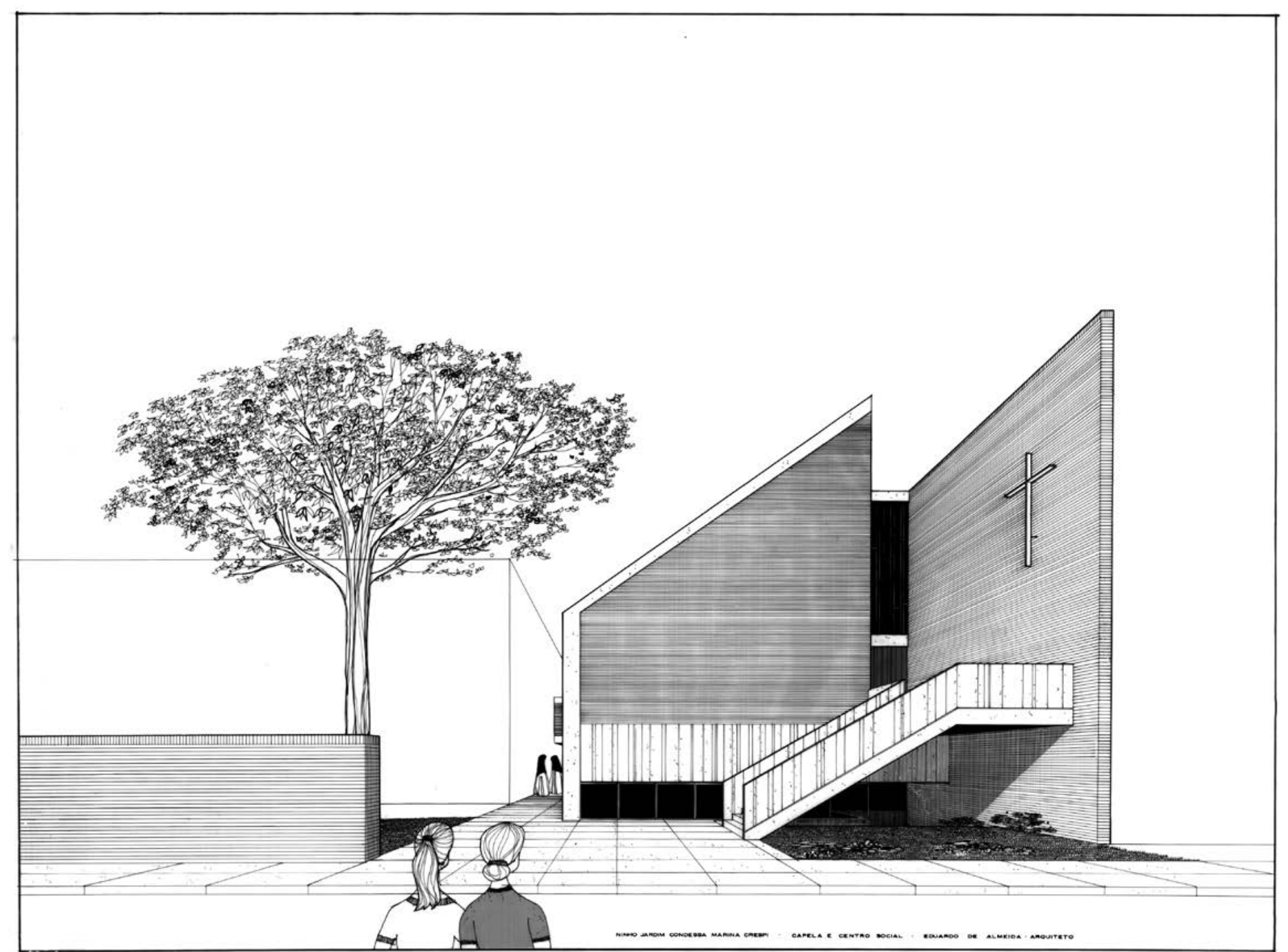


Uso

Residência Unifamiliar

Cliente

Marcos Ferreira da Rosa

Equipe

Eduardo de Almeida

desenhos I Lélio Machado Reinert

Localização

Rua Puréus, Jardim Guedala, São Paulo, SP

Estágio

Projeto Executivo

Observações

Construído

\section{Características}

Construída em concreto armado aparente, esta casa é definida pelo uso de uma cobertura inclinada continua $e$ pela organização do programa em meios níveis, sala cozinha no pavimento inferior, acesso pela cota da rua e dormitórios no pavimento superior.

Desenhos de apresentação em papel schoeller realizados por Lélio Machado Reinert.

Acervo

Tubo 56 e Caixa 3600
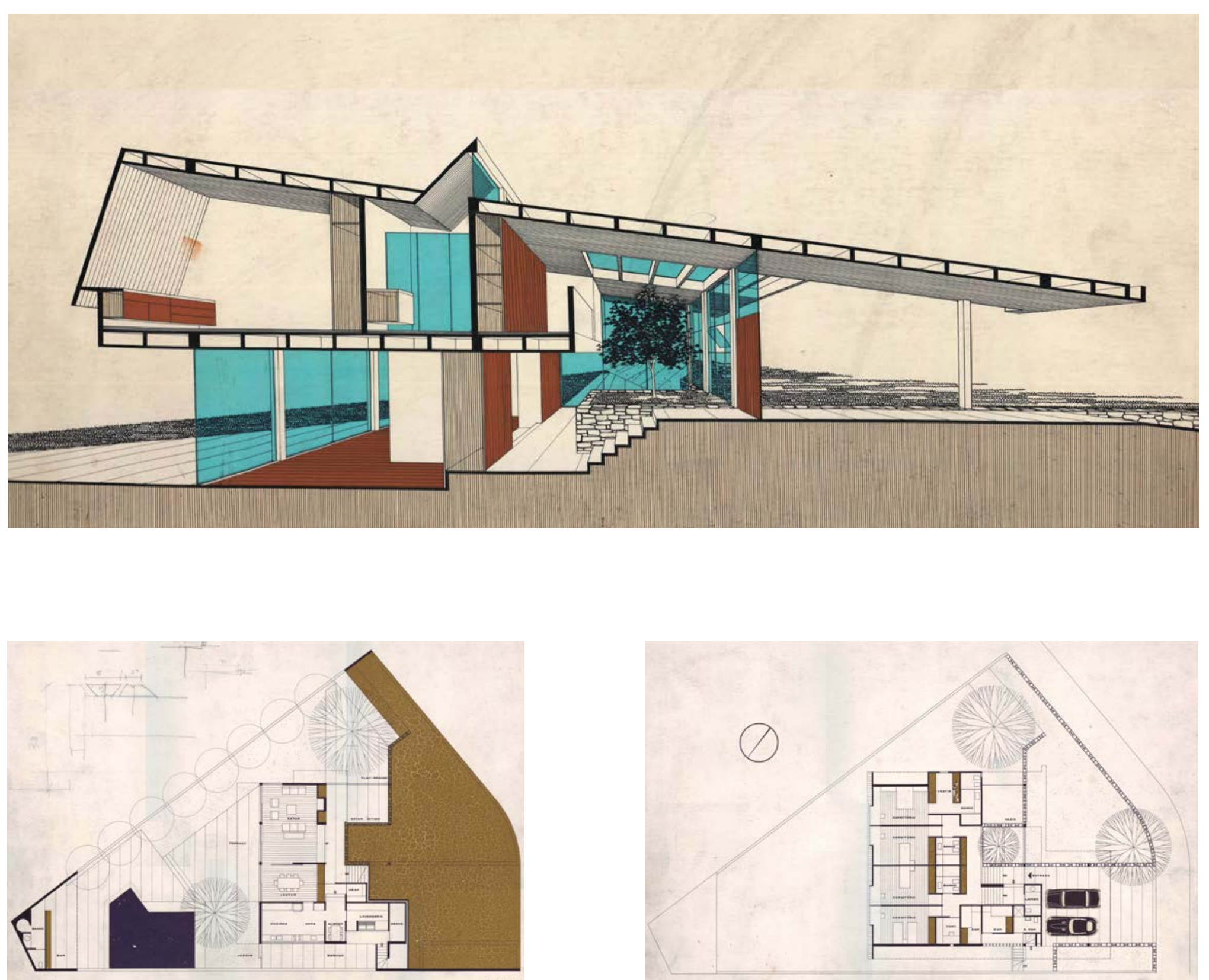
Uso

Residência Unifamiliar

Cliente

José Fernando Martins

Equipe

Eduardo de Almeida

Localização

Moema, São Paulo, SP

Estágio

Projeto Executivo

\section{Observações}

Construído

\section{Características}

Realizado para um amigo de infância, este projeto fol implantado de acordo com a topografia do terreno. Organizado em dois pavimentos, todas as atividades de uso coletivo se posicionam no pavimento térreo, enquanto os três dormitórios se localizam no pavimento inferior, solução semelhante à utilizada por Artigas na casa Ivo Viterito. Neste caso, a casa utiliza alvenaria de

blocos aparentes associada a pilares e vigas-calha de

concreto e estrutura de madeira com telhado cerâmico

em duas águas.

Acervo

Tubo 69
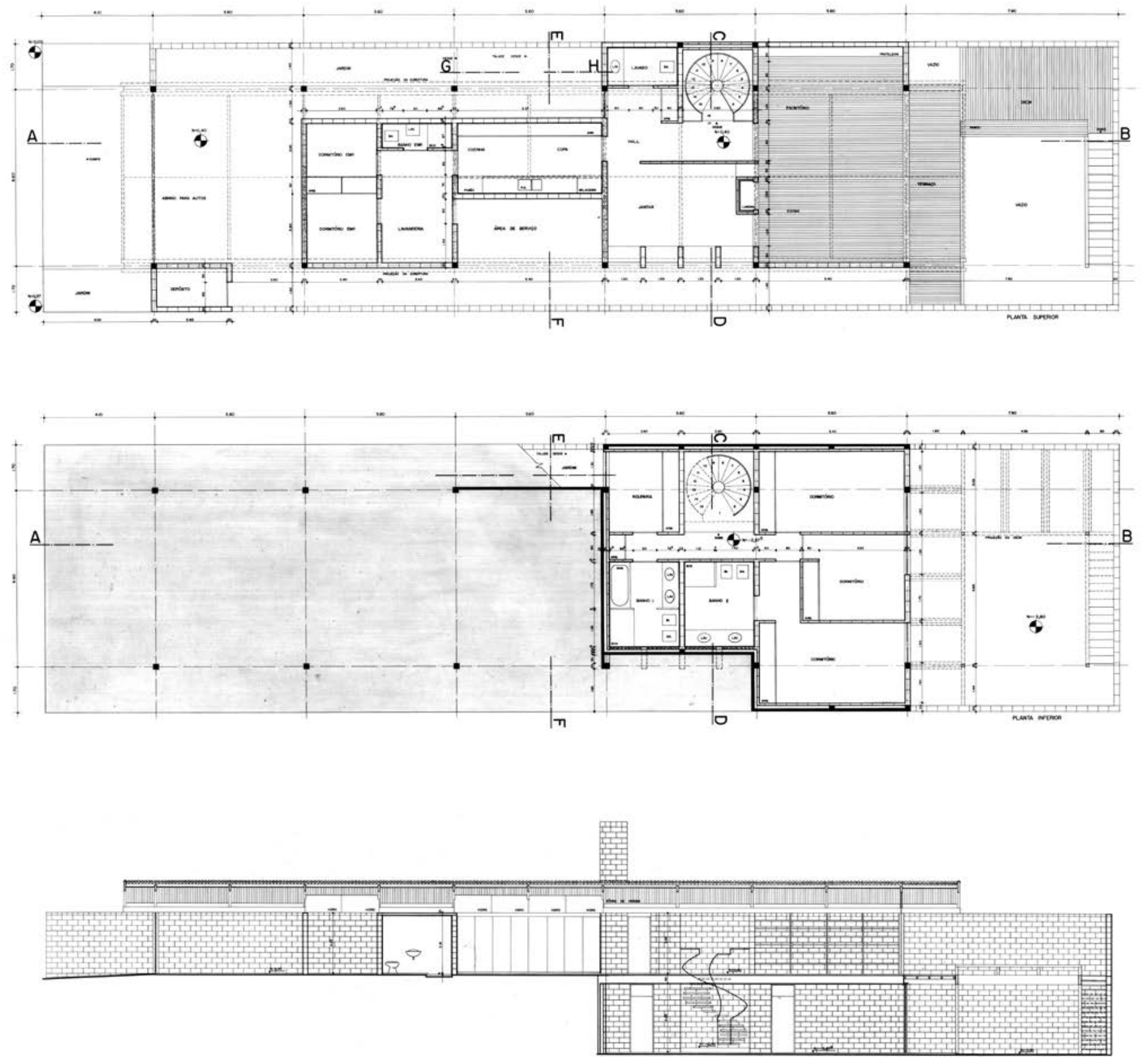
Residência Unifamiliar

Cliente

João Guilherme Whitacker

Equipe

Eduardo de Almeida

Localização

Mococa, SP

Estágio

Projeto Executivo

Observações

Construído

\section{Características}

Inicialmente pensado como um projeto que associava

muros revestidos com coberturas de duas águas e

estruturas duplicadas para a construção de calhas

intermediárias, o projeto sofreu grandes alteracõos,

sendo efetivamente construído com a definiçãa de dois

blocos paralelos de duas áquas.

Acervo

Tubo 30

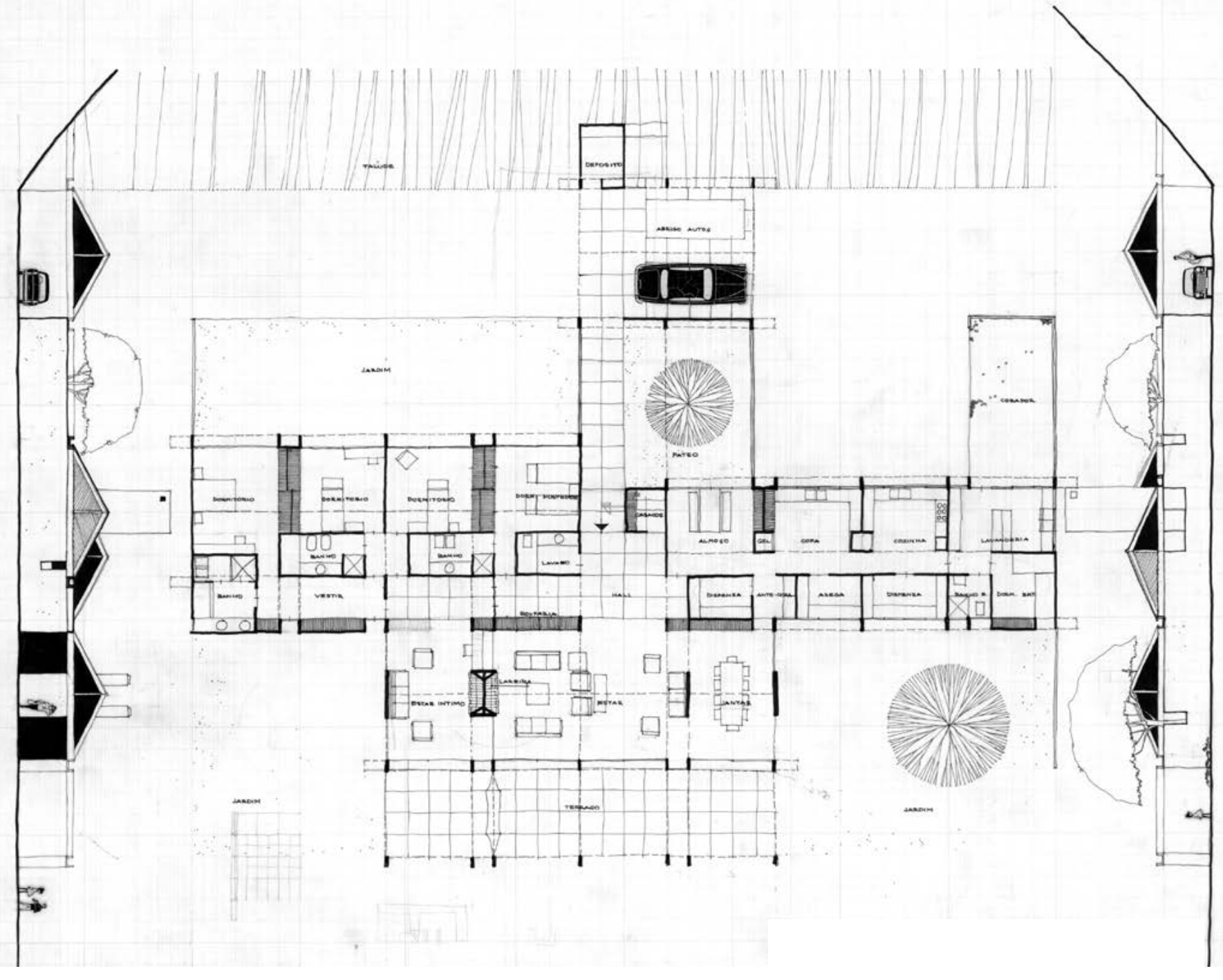


Uso

Escola

Cliente

FECE - Fundo Estadual de Construções Escolares

Equip

Eduardo de Almeida

Localização

Pereira Barreto, SP

Estágio

Projeto Executivo

Observações

Construído

\section{Características}

Realizado para o FECE - Fundo Estadual de Construções

Escolares - este projeto foi organizado pela criação de

dois blocos paralelos com cobertura inclinada de uma

água, intermediados pelo galpão coberto com estrutura

de madeira em shed. No encontro de cada um destes

volumes foram criadas lajes planas de conexão, solução

utilizada por Eduardo de Almeida em inúmeros outros

projetos. Posteriormente, este projeto foi implantado

em Guaratinguetá pela FDE - Fundação para o

Desenvolvimento da Educação.

Acervo

Tubo 69 e caixa 3700
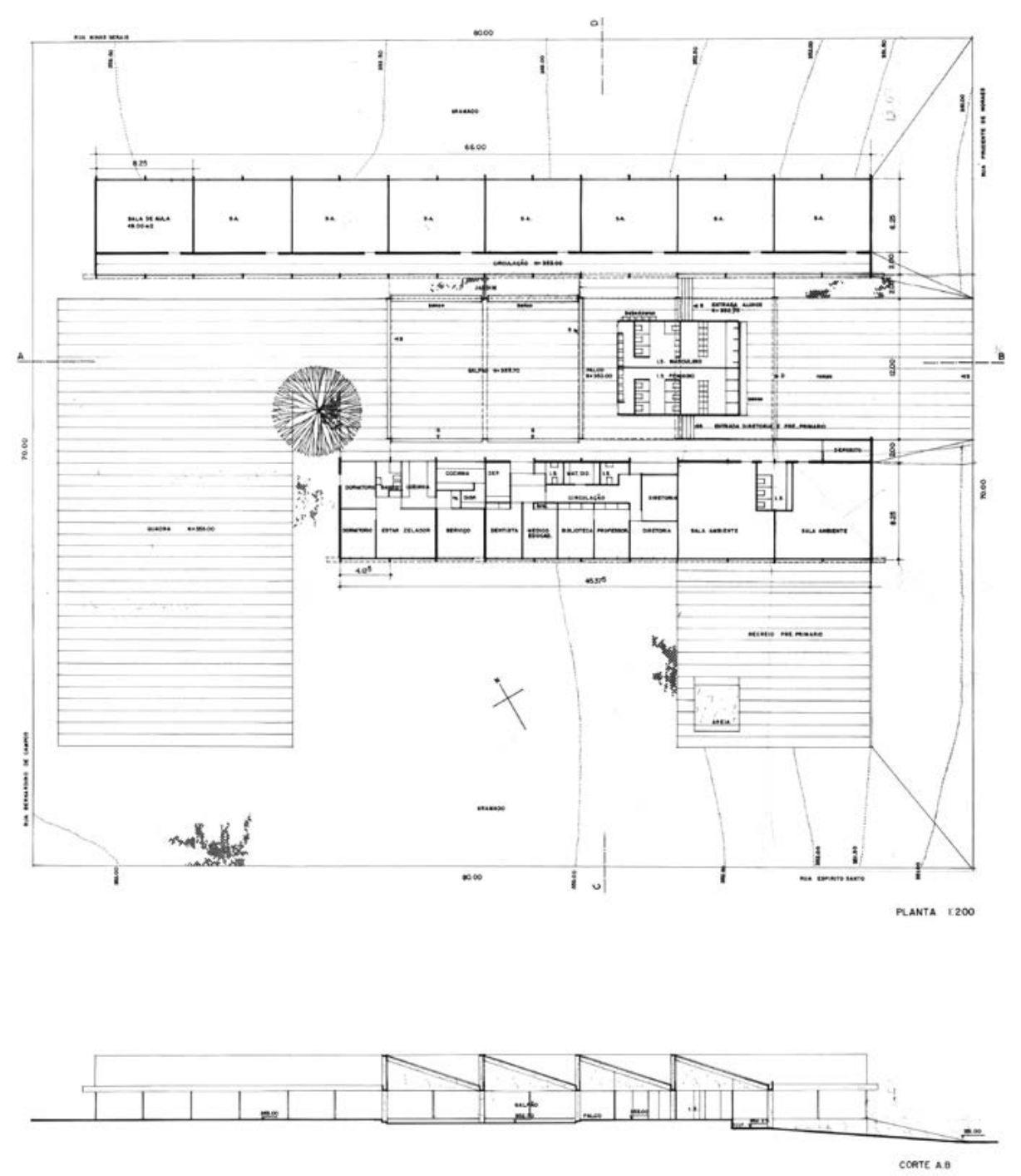

conerte As

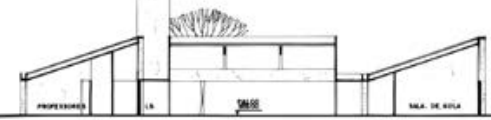


Uso

Residência Unifamiliar

Cliente

Jean Nadim

Equipe

Eduardo de Almeida

Localização

Rua Monsenhor Alberto Pequeno 112, São Paulo, SP

Estágio

Projeto Executivo

\section{Observações}

Construído

\section{Características}

Residência unifamiliar de dois pavimentos construída

em concreto armado moldado in loco, fechamentos

em alvenaria revestida e planos inclinados de cobertura

capazes de iluminar e ventilar naturalmente os sanitários

e circulações presentes no centro da planta. Assim como

no Ginásio de Pereira Barreto, a justaposição de três

volumes é intermediada por lajes de concreto.

Acervo

Tubo 55
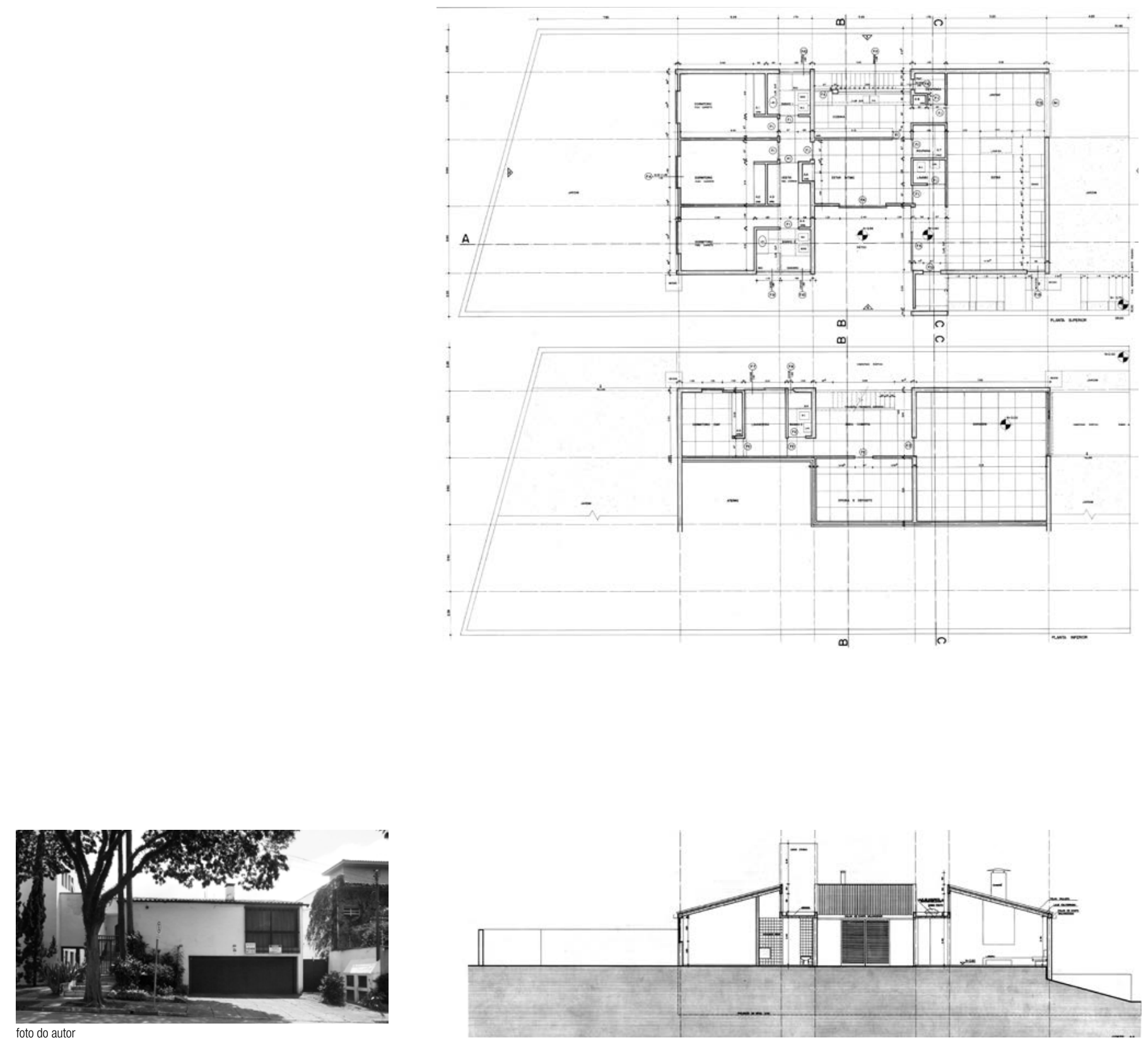

O 
Uso

Secretaria da Agricultura

Equipe

Arthur Fajardo Netto, Eduardo de Almeida e Henrique S.

estrutura | Armando S. Colotto

Localização

São Paulo, SP

\section{Estágio}

Anteprojeto

\section{Observações}

Não Construído

Projeto premiado em $2^{\circ}$ Lugar no Concurso Nacional de

anteprojetos para a sede da Secretaria da Agricultura do

Estado de São Paulo, em 1968

\section{Caracteristicas}

Anteprojeto para a implantação do conjunto destinado à Secretaria de Agricultura, premiado em segundo lugar no concurso. Além da organização do programa em diversos blocos distribuidos pelo terreno o projeto conta

com um edifício de planta quadrada para a sede da

instituição. Organizado em três pavimentos 0 edifício se

estrutura com uma modulação também quadrada e cria

um vazio de pé direito triplo em seu interior que articula

todas as funções necessárias ao program

Acervo

Tubo 20
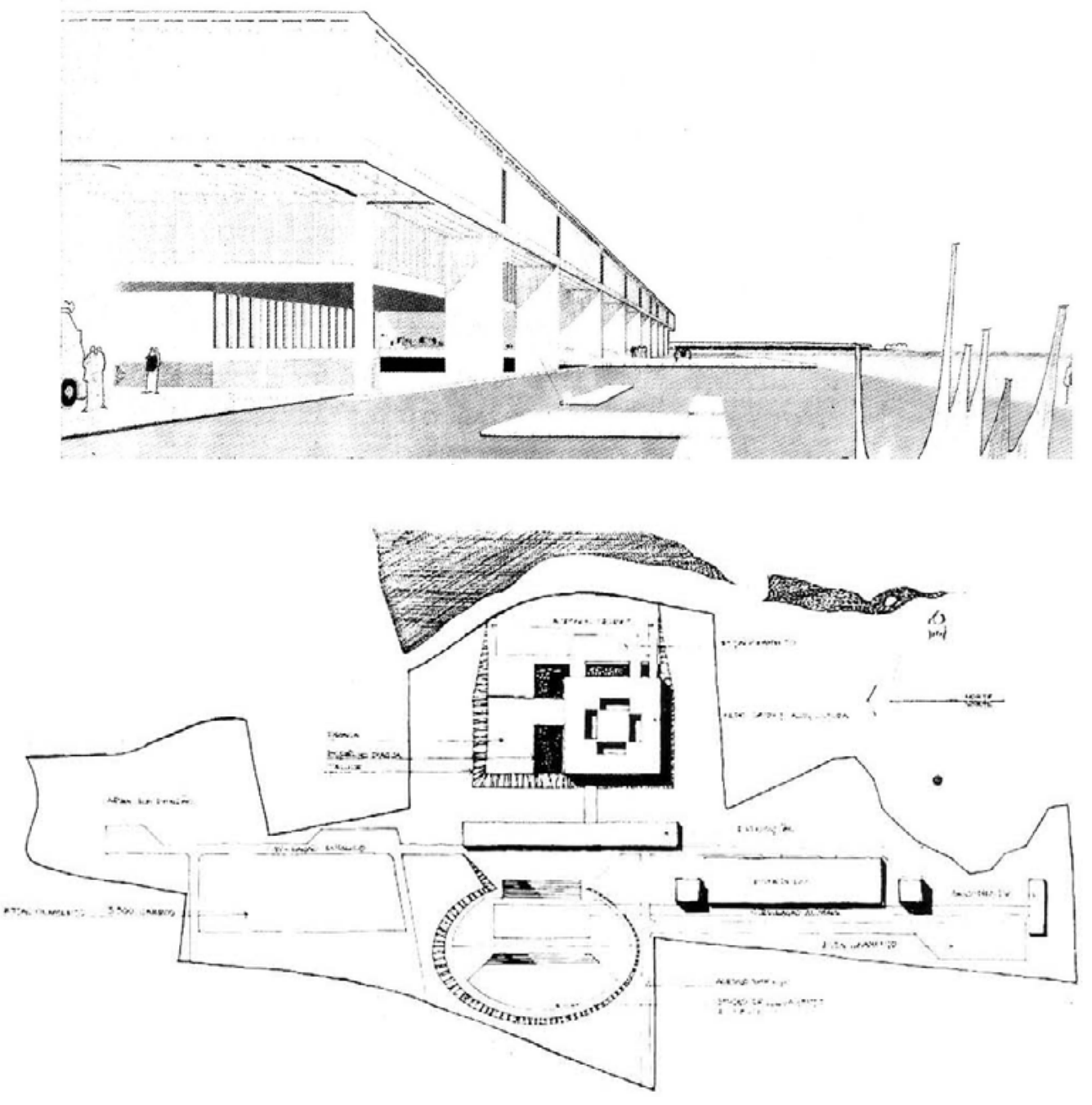

Cortes transversais

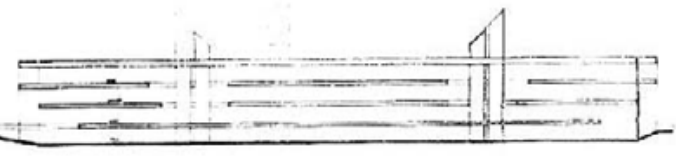


Uso

Conjunto Residencial - 6 casas

Cliente

Construtora Paulista S.A.

Equipe

Eduardo de Almeida

Localização

Rua Baluarte 513, Moema, São Paulo, SP

Estágio

Projeto Executivo

Observações

Construído e modificado

\section{Características}

Conjunto de seis residências unifamiliares geminadas.

A planta em "L" de cada unidade se articula de modo

alternado, propiciando a criação de pequenos patios

laterais específicos para cada unidade. Ao mesmo

tempo a continuidade do volume dos quartos garante a

unidade do conjunto.

Acervo

Caixa 200
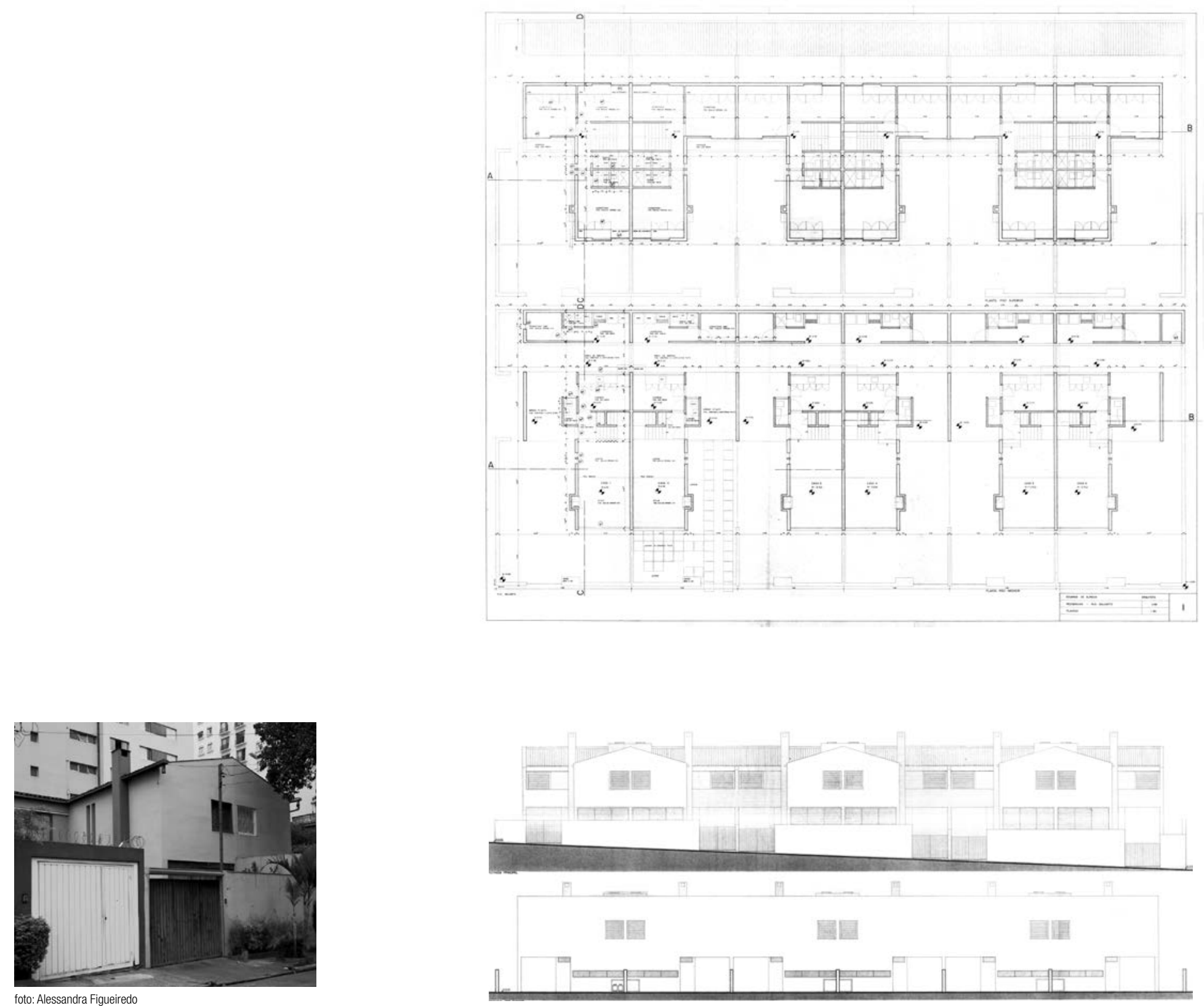

$\ominus$

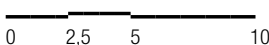


Uso

Estação Telefônica e Escritórios

Cliente

Companhia Telefônica Brasileira

Equipe

Dácio Ottoni, David Ottoni e Eduardo de Almeida

Localização

Sorocaba, SP

Estágio

Projeto Executivo

Observações

Construido

\section{Características}

Seguindo a geometria irregular do lote, este edifício de cinco pavimentos - incluindo um mezanino e um subsolo - implanta-se em dois blocos, de acordo com as necessidades funcionais do programa de acentuado caráter técnico, mas também respeitando as limitacõos impostas pela geometria irregular do terreno impostas pela geome , localizado em uma área central do municipio de Sorocaba. A parceria com os irmãos Dácio e David Ottoni para este projeto coincide com a mudança de Eduardo de Almeida para um escritório na Avenida Paulista, vizinho ao espaço de trabalho de Dácio e David, coincidência que viabilizou a relizacão deste e de outros projetos, cinco anos após a saída de Dácio Ottoni do escritório Horizonte Arquitetos.

\section{Acervo}

Caixa 4400
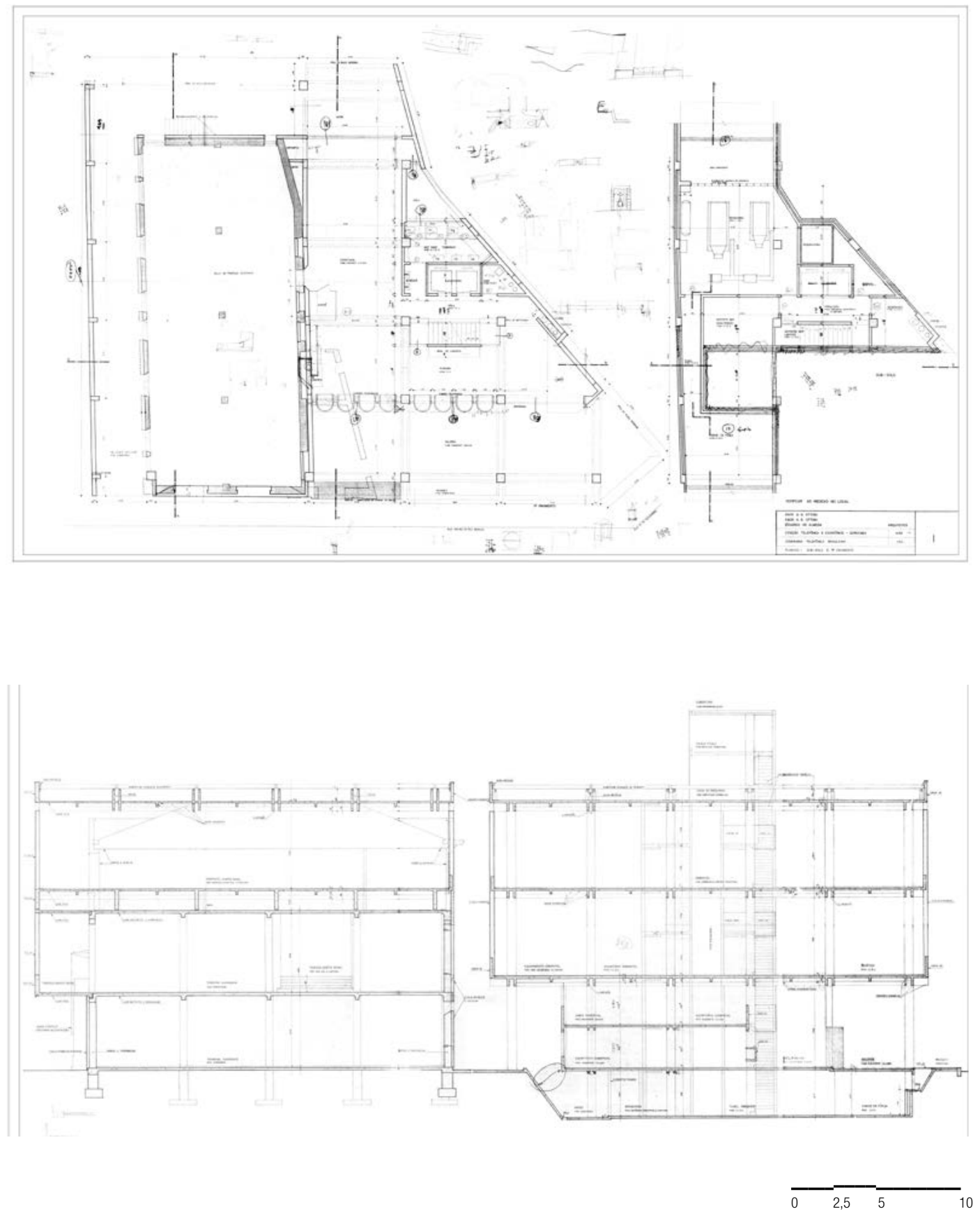
Uso

Hospital e Escola de medicina

Cliente

Santa Casa de Misericórdia de São Paulo

Equipe

Alfredo S. Paesani, Eduardo de Almeida, Fábio Penteado e Teru Tamaki

gráfica I Luis A. Valandro Keating

estrutura I Oswaldo Moura Abreu, Waldemar Tietz e

Nelson de Barros Camargo

Localização

Barra Funda, São Paulo, SP

Estágio

Estudo Preliminar

Observações

Construído

Características

Anteprojeto para o Hospital Escola Júlio de Mesquita que considerava a criação de blocos específicos destinados

a cada funcão prevista no programa. Tal solução

permitiria a construção em etapas e também trazia questôes relacionadas à flexibilidade e industrialização na construção civil. 0 projeto finalmente construído

não contou com a participacão de Eduardo de Almeida

embora muitas questões relacionadas ao programa se

mantiveram na solução final.

Acervo

Tubo 96
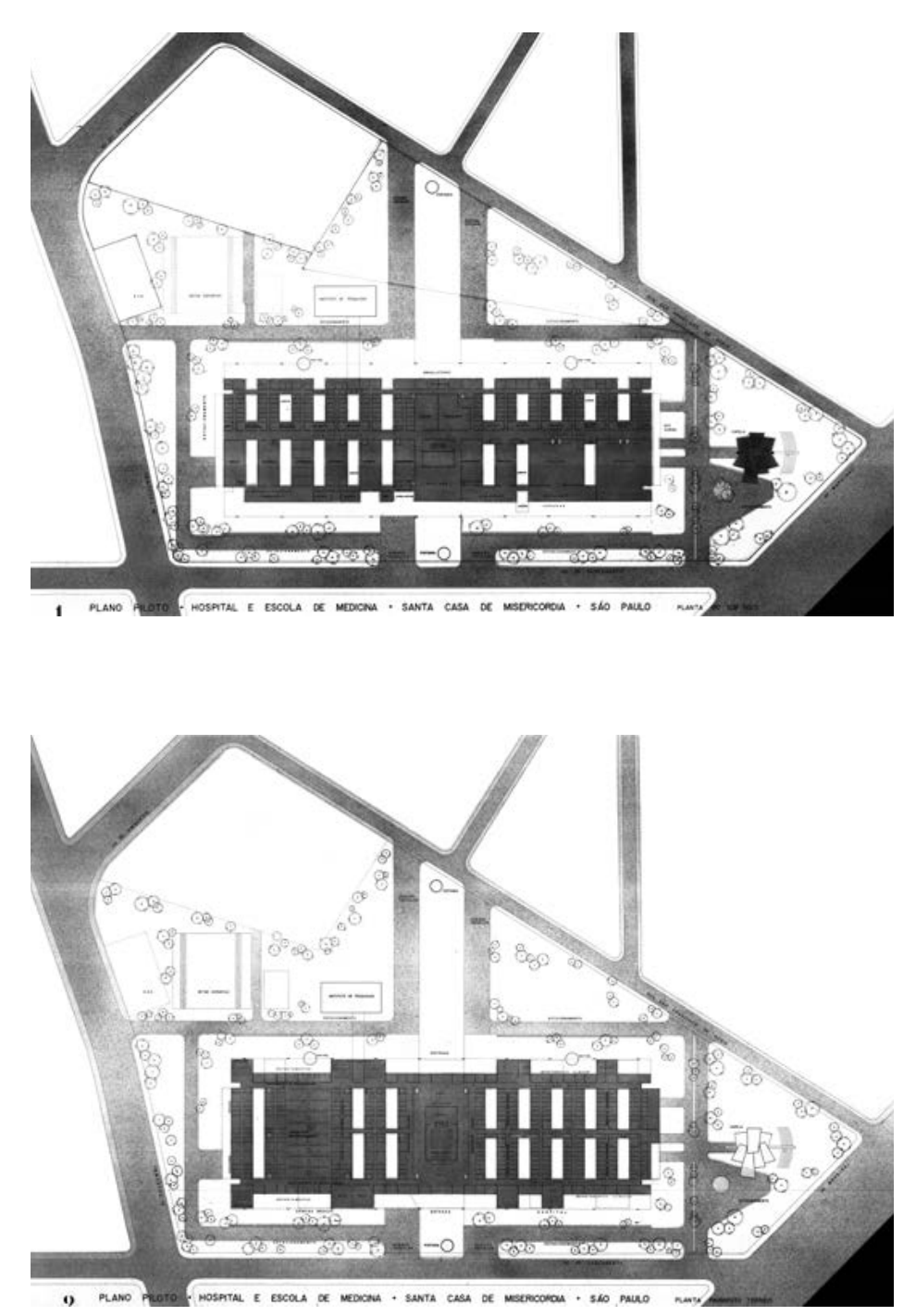
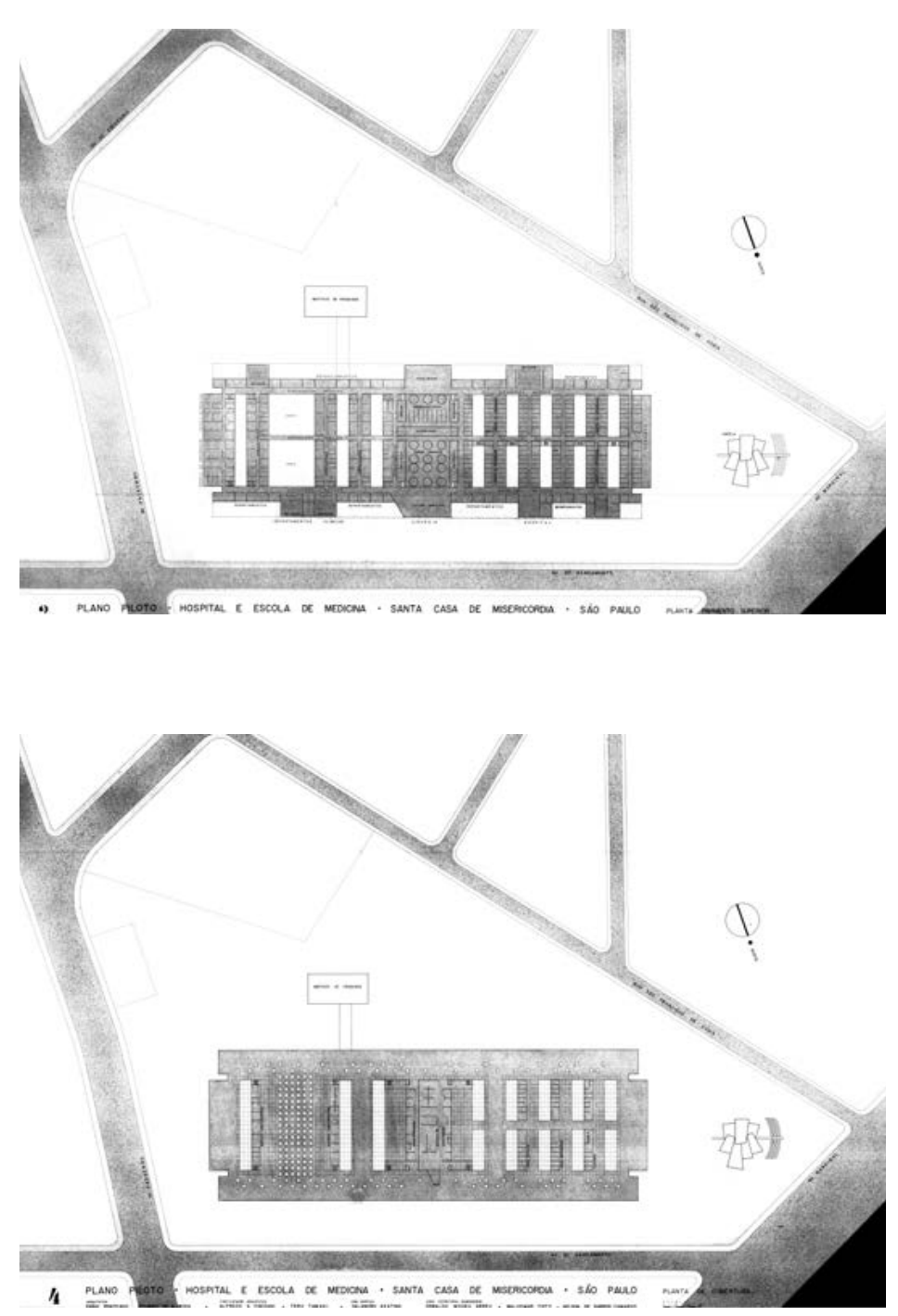
Uso

Pavilhão

Equipe

Eduardo de Almeida e José Carlos Priester

Maquete I José Antônio Seixas

Perspectivas I Luis A. Valandro Keating

Localização

Osaka, Japão

Estágio

Anteprojeto

Observações

Não Construído

\section{Características}

A proposta para o Concurso do Pavilhão do Brasil em

Osaka, Japão, foi elaborada a partir do contraste entre a

complexa geometria do edifício e suas grandes aberturas.

A justaposição de volumes com planta triangular, de

acordo com a malha das treliças metálicas utilizadas na

estrutura, terminavam por ser revestidas com chapas

de alumínio polido e vidro 0 projeto foi pensado cono

uma constrcya

do emprego de materiais e técnicas provenientes da

indústria da construção civil. 0 projeto expográfico era

composto pela sobreposição de imagens e músicas,

talvez inspirado pela aula inaugural do curso de design

na FAUUSP com João Carlos Cauduro, onde imagens

foguetes e espaçonaves eram passadas ao som de A

day in a Life, dos Beatles.

\section{Acervo}

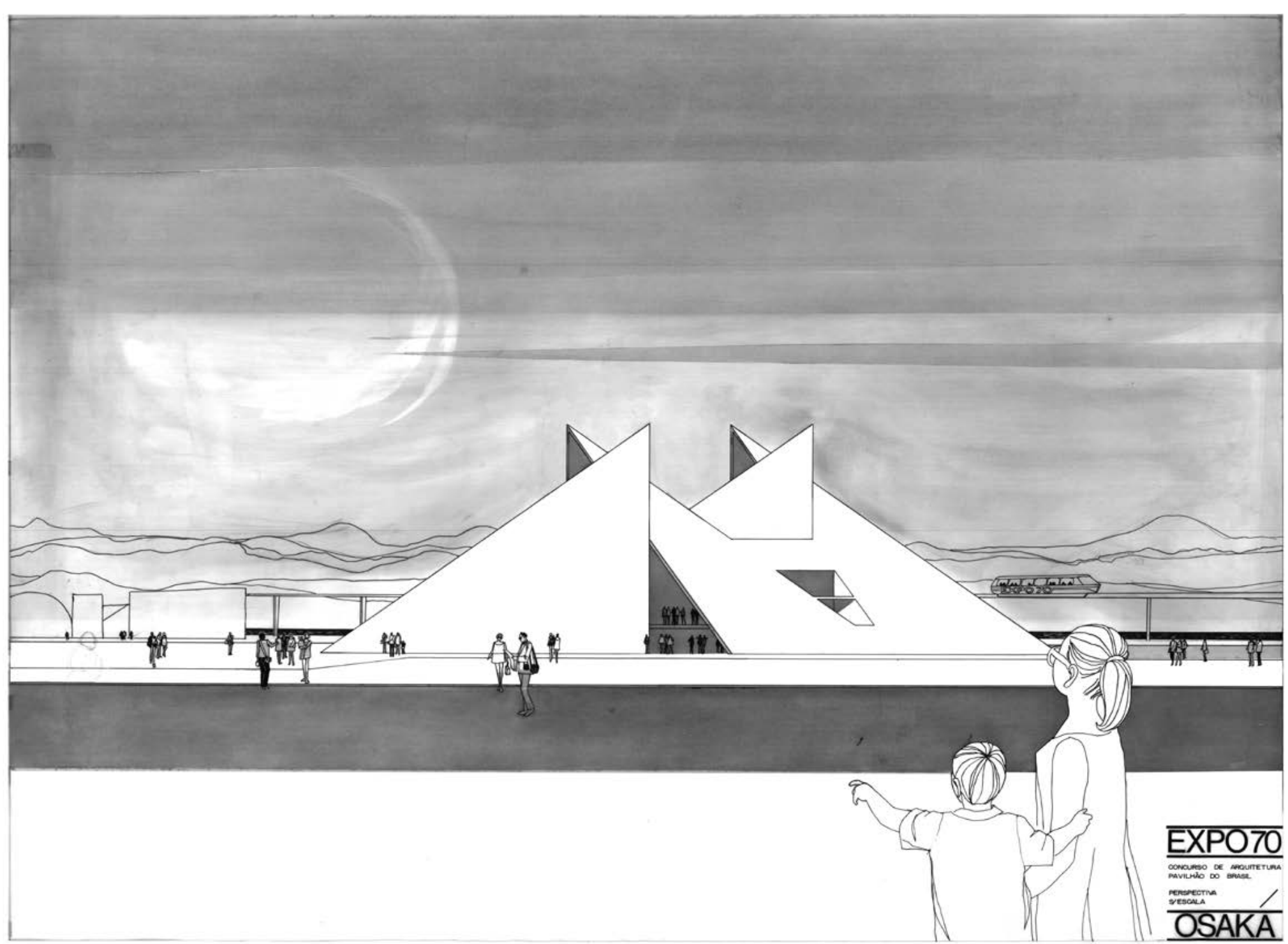


Cliente

Altemio Spinelli

Equipe

Eduardo de Almeida

Localização

Rua Oscar Freire, Cerqueira Cesar, São Paulo, SP

Estágio

Projeto Executivo

Observações

Projeto de reforma com posterior ampliação

\section{Características}

Intervenção em residência unifamiliar para a acomodação do novo uso como loja de sapatos. 0 projeto criava uma circulação com cobertura curva e com 0 emprego de chapas metálicas, elemento capaz de interligar a rua ao salão da loja localizada no fundo

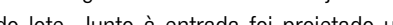

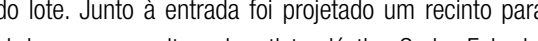
abrigar uma escultura do artista plástico Carlos Fajardo. A vitrine da loja posicionada junto ao corredor de acesso se estendia para a sala principal e, como uma fita continua, solucionava a iluminação da loja. Tal desenho de acentuado caráter gráfico considerava a influência de diverses referencias como a Morris Shop de Frank de diversas car Lloyd Wright ou 0 filme 2001 Uma Odisseia no Espaço" de Stanley Kubrick. Em um segundo momento a loja fo ampliada, ocupando todo o cômodo frontal da casa.

Acervo

Tubo 3, Caixa 100
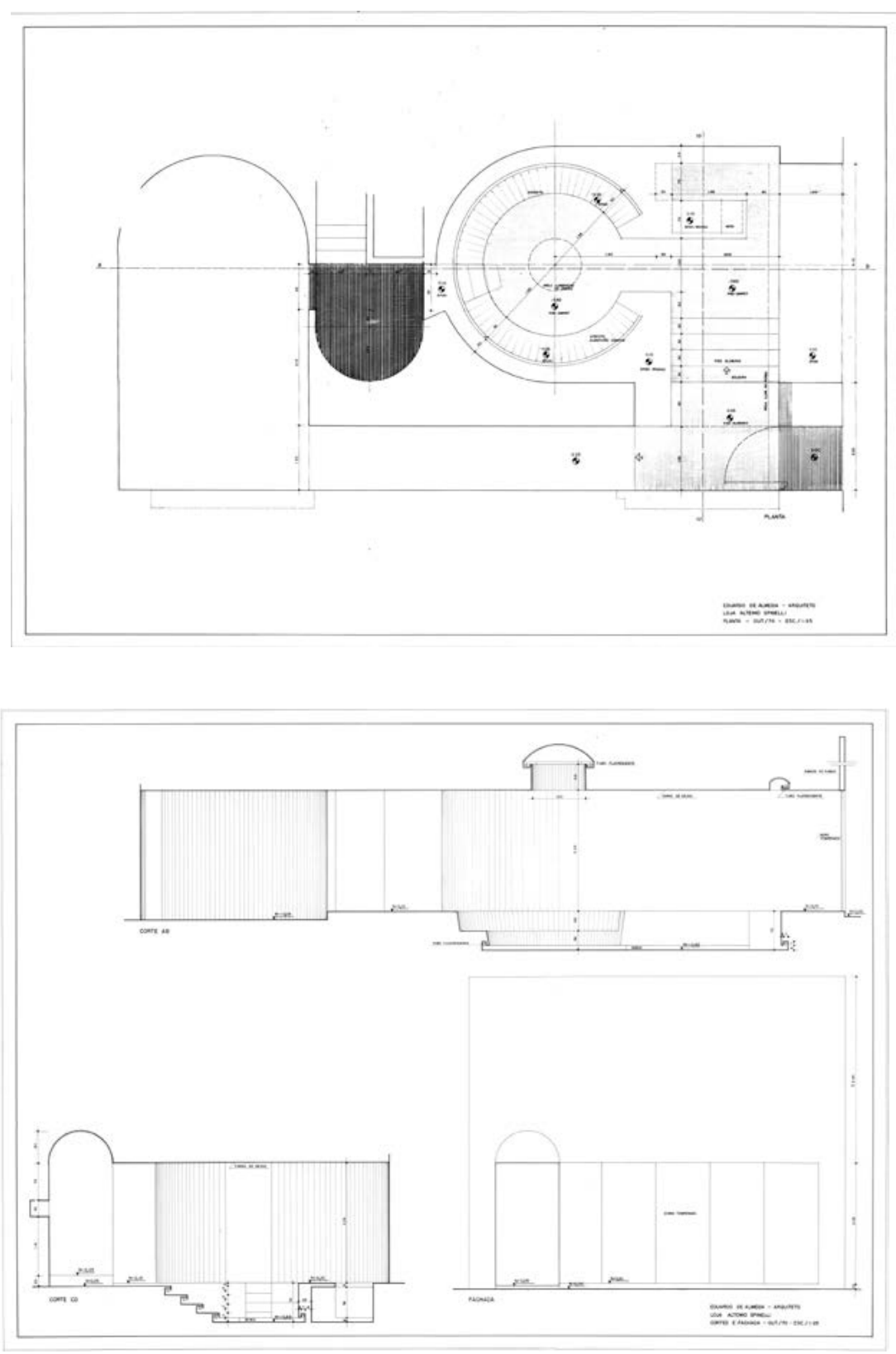
Residência Unifamiliar

Cliente

Fernando de Almeida

Equipe

Eduardo de Almeida

Localização

Rua Rino Levi 244, Vila Mariana, São Paulo, SP

Estágio

Projeto Executivo

Observações

Construído

\section{Características}

Residência unifamiliar com estrutura de concreto e fechamentos de alvenaria revestidos e pintados de branco. Assim como no projeto do Pavilhão de Osaka a volumetria do edifício é contrastada pelos planos de

fechamento em vidro tomperado sem cairithos Segundo

Eduardo de

obtida nas obras

a nado aparise motvaram a criação de uma soluçãa

tecnica mais econômica e de fácil execução.

Acervo

Tubo 69

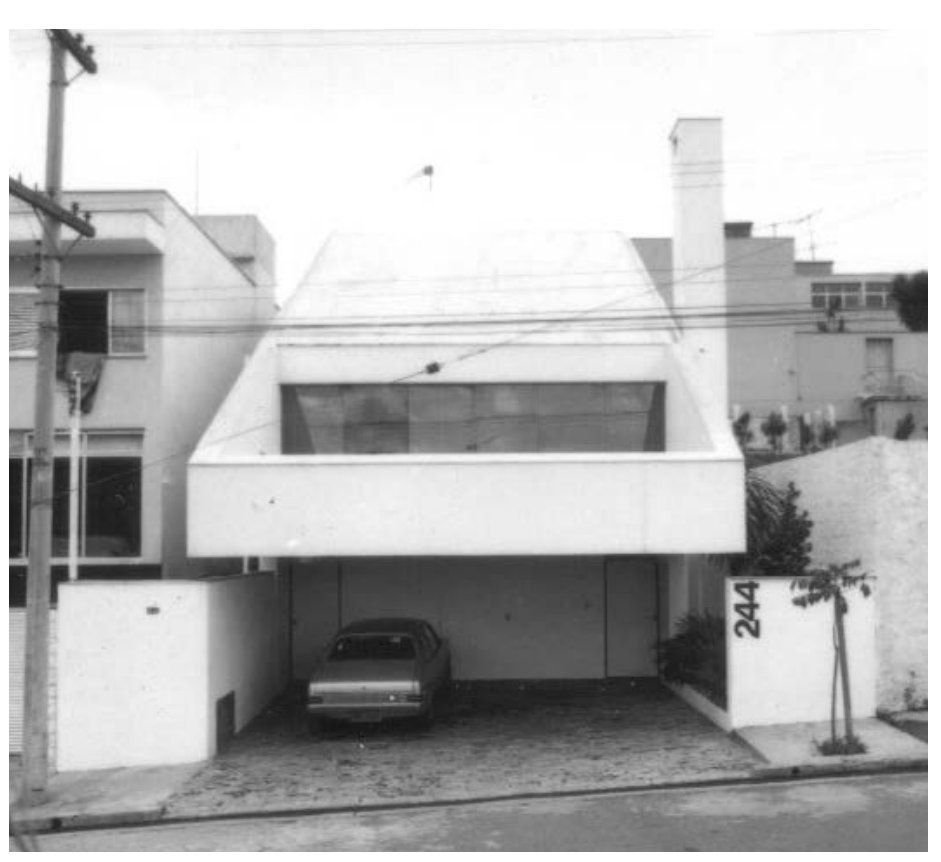

foto: Júlio Abe Wakahara
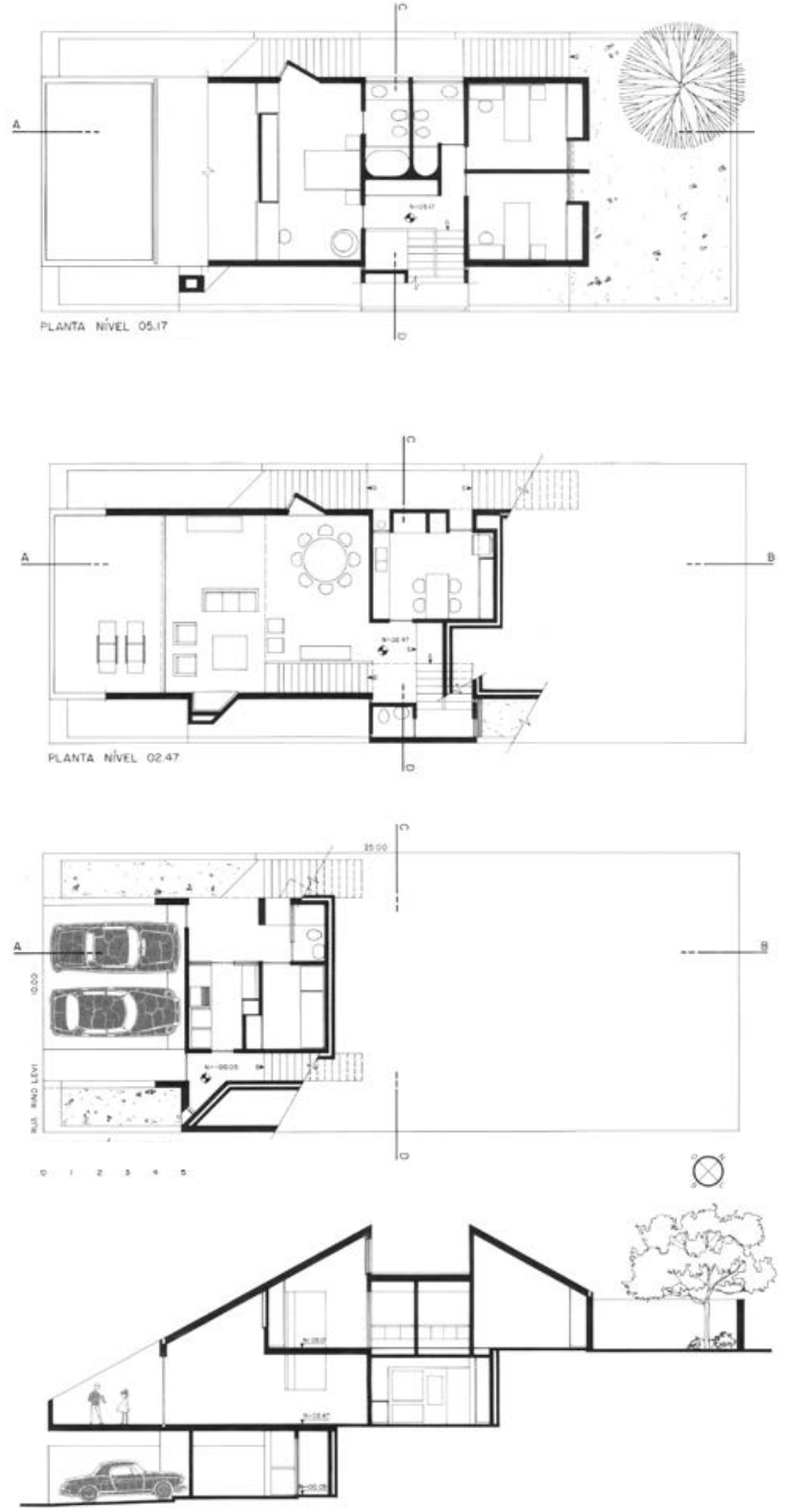

$\Theta \quad \overline{0} \overline{12,5}$ 
Uso

Residência Unifamiliar

Cliente

Levy Rubinstein Neto

Equipe

Eduardo de Almeida

Localização

Rua Comandante Lira 338, São Paulo, SP

Estágio

Projeto Executivo

Observações

Construído

\section{Características}

Seguindo a experiência da residência Fernando de Almeida e de outras obras do mesmo período, este projeto busca simplificar a construção e valorizar a expressividade da volumetria, em seu contraste entre os planos brancos de alvenaria e o desenho das aberturas. Por este motivo, os fechamentos utilizam-se de planos de vidro temperado sem caixilho e o detalhamento dos batentes dá-se por meio de perfis metálicos em ' $L$ ' chumbados diretamente na alvenaria que, masseados e pintados, simplesmente desaparecem. Tais soluções

são retomadas em importantes projetos realizados posteriormente, como a casa Sigrist ou a pequena casa reformada para seu filho Lalo. A representação das duas fachadas em um único desenho, criando uma elevação oblíqua ao volume, segue a influência de alguns projetos realizados por Siegbert Zanetini.

Acervo

Tubo 84
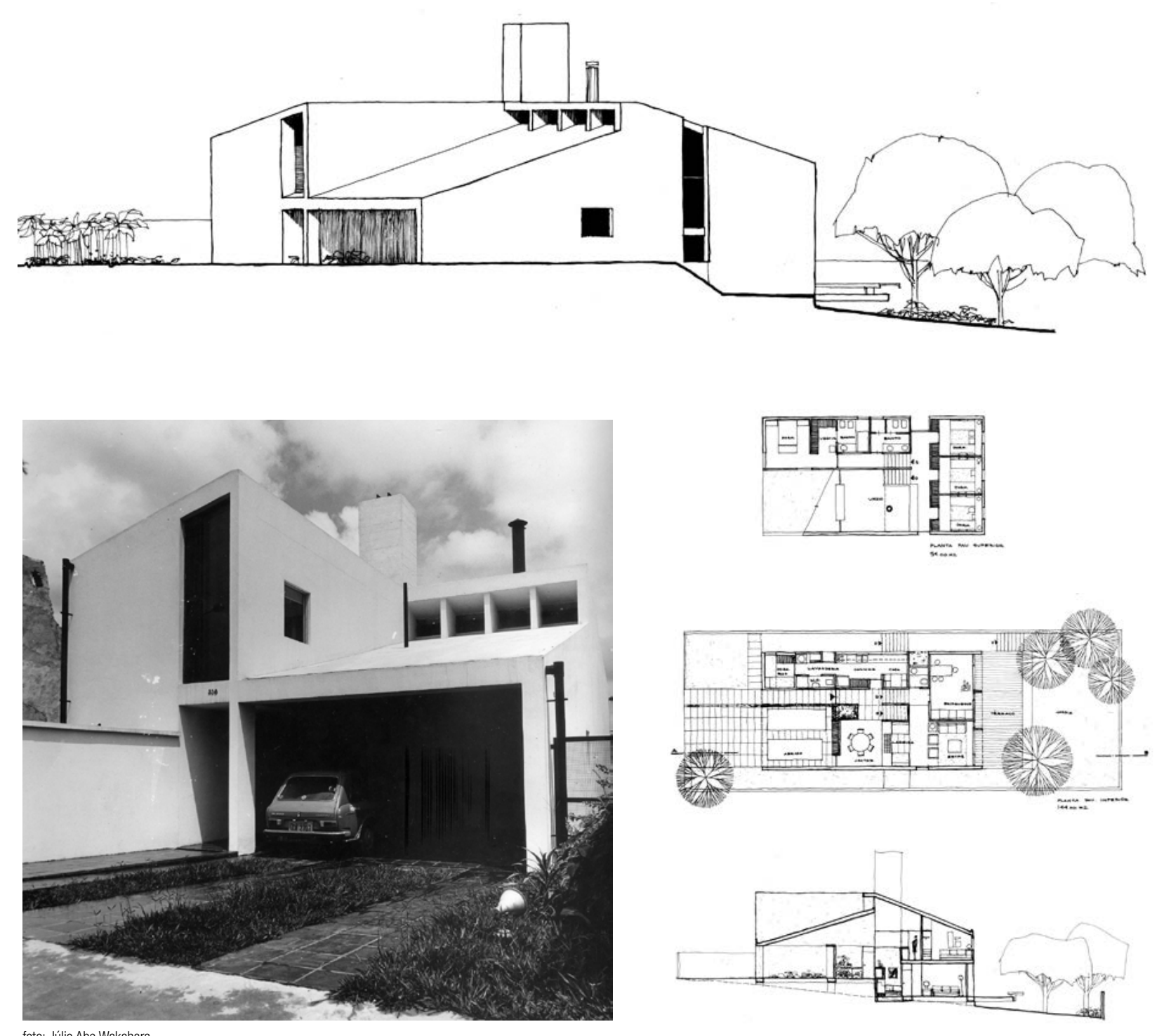

foto: Júlio Abe Wakahara 
Uso

Residência Unifamiliar

Cliente

Joaquim Muller Carioba

Equipe

Eduardo de Almeida e Pedro Antônio Galvão Cury

maquete I José Antônio Seixas

Localização

Av. Mariory Prado, Guarujú, SP

Estágio

Projeto Executivo

Observações

Construído

Características

Seguindo a mesma lógica das casa Levy Rubinstein e Fernando de Almeida, a casa apresenta a construção de volumes com cobertura inclinada de alvenaria e concreto revestidos. Neste caso, dois volumes se articulam por meio de uma torre de circulação vertical.

Enquanto o primeiro volume volta-se à rua de acesso,

o segundo é rotacionado em 90 graus, tirando partido do recuo lateral do lote e da configuração de rua sem saída, que permitiu a ampliação do jardim e a criação de uma piscina.

Acervo

Tubo 84
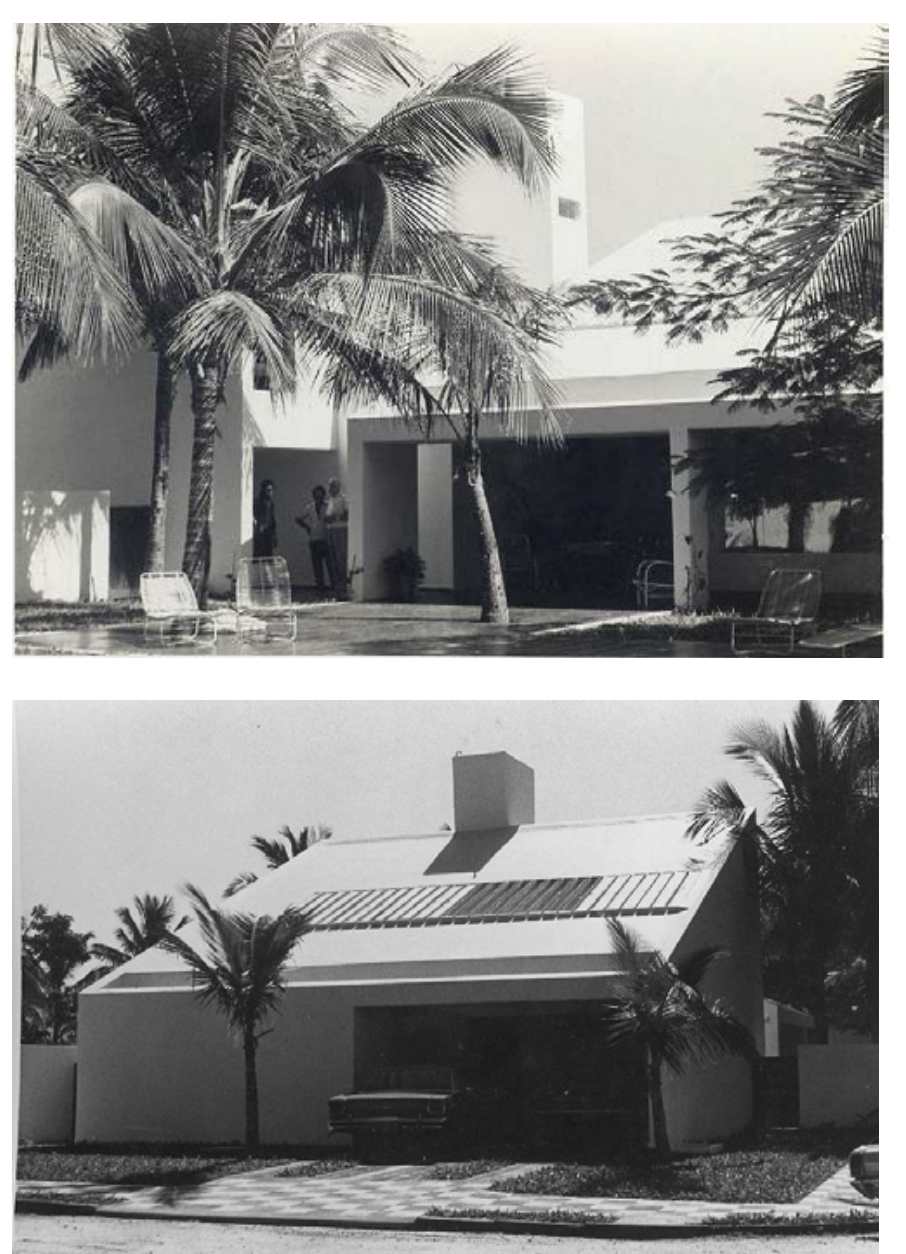

fotos: Eduardo de Almeida
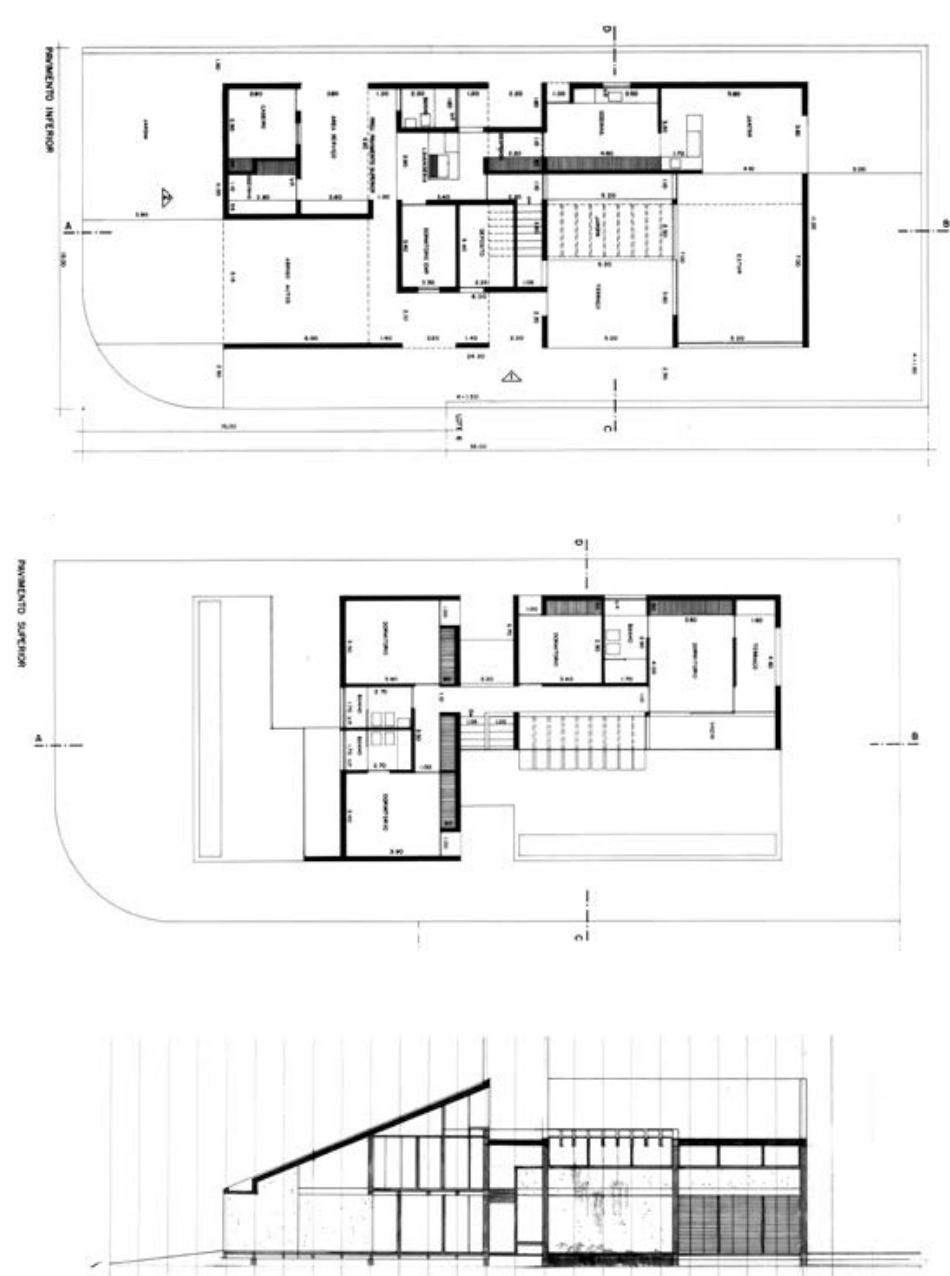
Uso

Edifício de Habitação Coletiva

Cliente

Construtora Adolpho Lindenberg

Equipe

Eduardo de Almeida

Localização

Rua França Pinto 319, Vila Mariana, São Paulo, SP

Estágio

Projeto Executivo

Observações

Construído

\section{Características}

Para este edifício de treze pavimentos e quatro unidades por andar, foram criados dois blocos articulados por uma torre de circulação central. Por motivos de custo, a solução construída perdeu 0 tratamento da fachada com brises verticais e janelas dos dormitórios recuadas em relação ao plano da fachada. Este projeto foi realizado por indicacção do Engenheiro Armando Colotto, conhecido de indicação do Engenheiro Armando Colotto, conhecido de de tentar modificar o padrão de prédios neoclássicos utilizado pela construtora Adolpho Lindenberg.

\section{Acervo}

Tubo 43
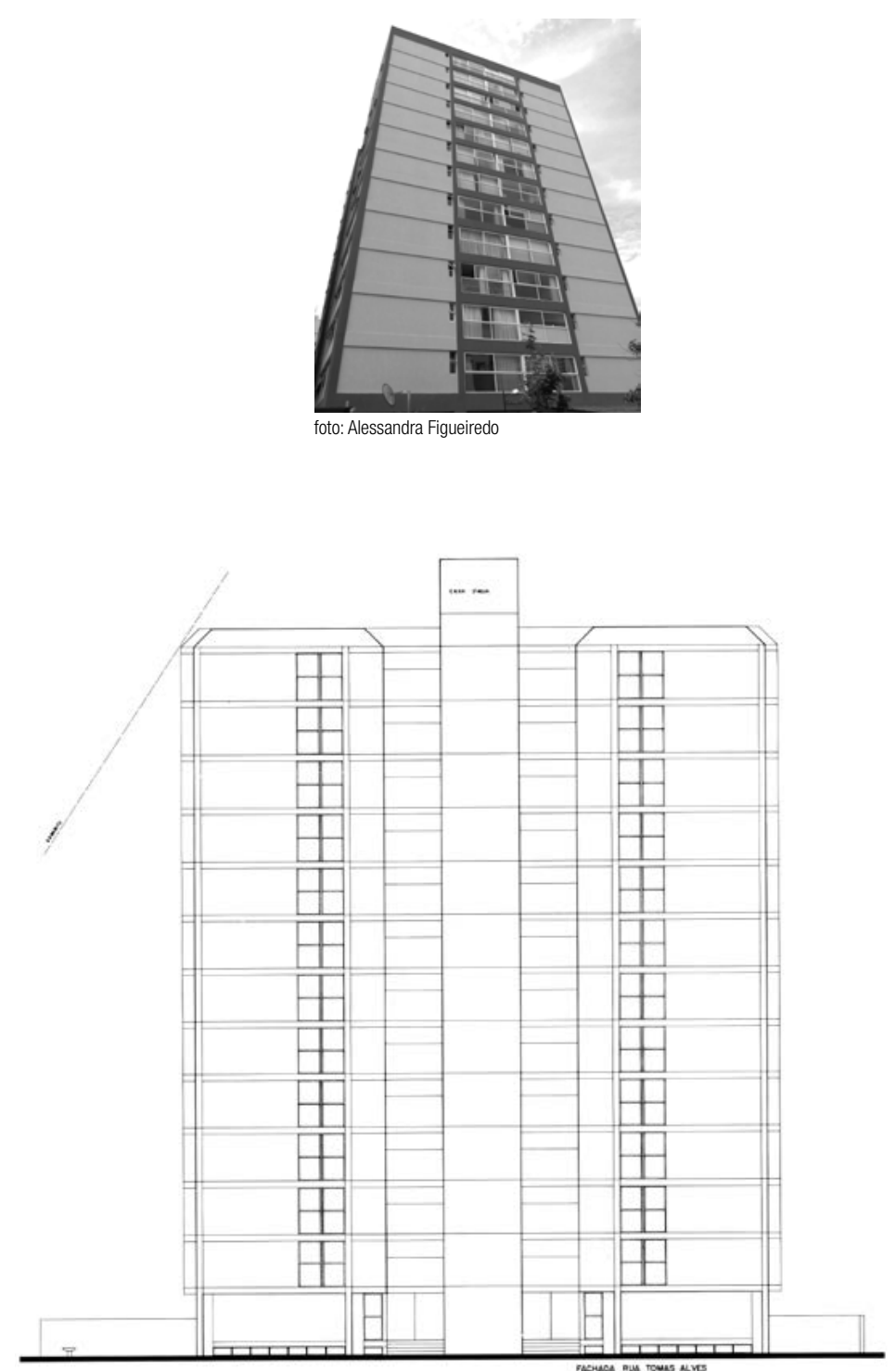

\section{$\ldots+\ldots$}
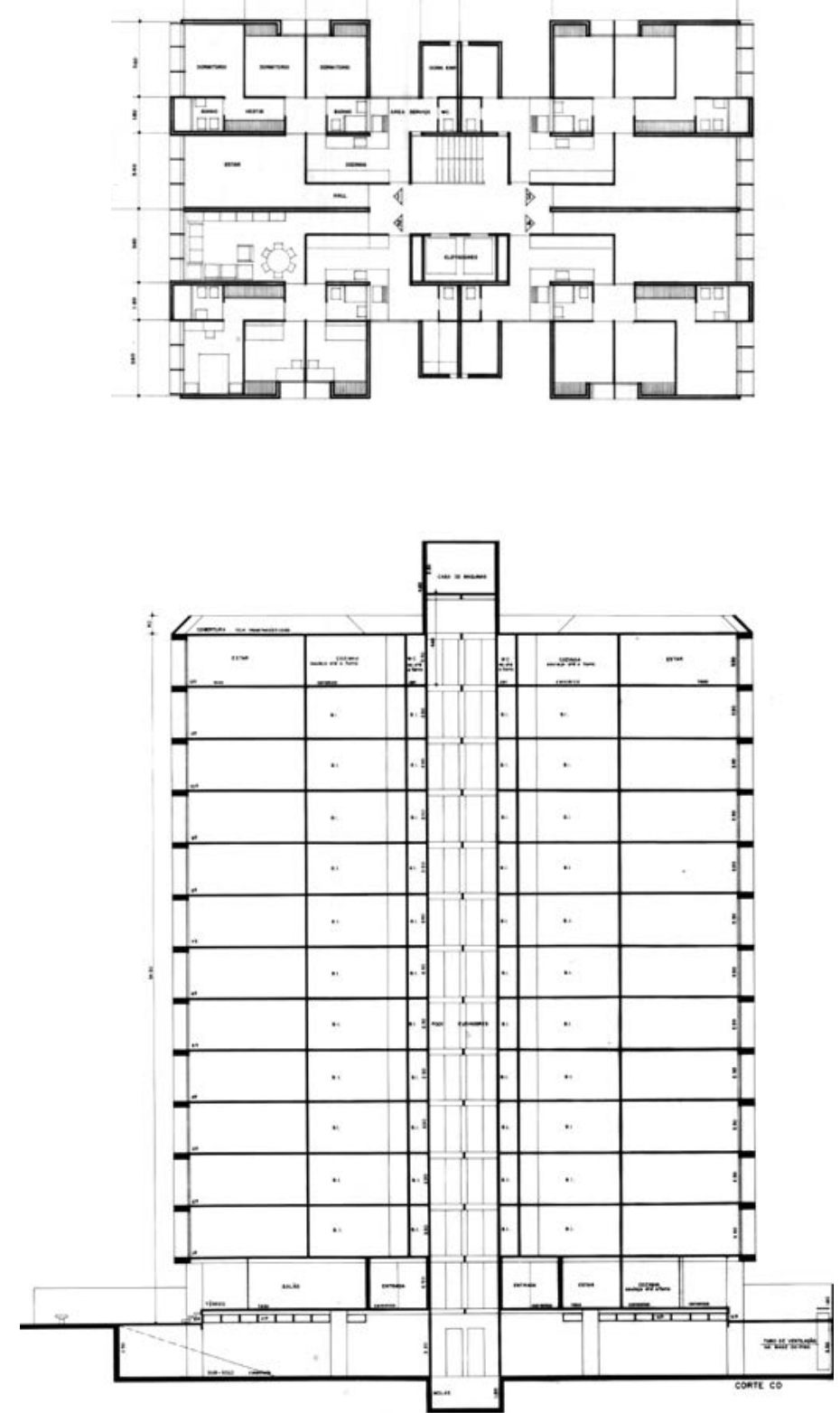
Uso

Edifício de Habitação Coletiva

Cliente

Construtora Formaespaço

Equipe

Eduardo de Almeida

Localização

Rua Graúna 419, Indianópolis, São Paulo, SP

Estágio

Projeto Executivo

Observações

Construído

Prêmio na Categoria "Habitação Coletiva - Obra

Construída", pela premiaç̃̃o anual do IAB, em 1974

\section{Características}

Vencedor na Categoria Habitação Coletiva (obra construída) na Premiação do IAB do ano de 1974, este projeto encomendado pela Construtora Formaespaço cria dois blocos de dez pavimentos, utilizando uma planta quadrada capaz de abrigar quatro apartamentos por andar organizados ao redor da circulação vertical central. A justaposição de dois blocos levemente defasados aproveita a configuração do lote em esquina, mas também se referencia a projetos como o Lake Shore Drive de Mies Van der Rohe (1950) e, consequentemente, aos edifícios Santa Candida e Santa Francisca de Salvador Candia (1963). Utilizando estrutura de concreto moldado in $10 c 0$ com pilares e vigas aparentes, a volumetria do edifício alterna planos de fechamento de alvenaria de tijolos aparentes com caixilhos de ferro de piso a teto para os dormitórios e sala de estar. Tais planos de fechamento foram inicialmente pensados como painéis pré-moldados de fachada proietados pelo arquiteto João Honório Filho, posteriormente abandonados por motivos de custo de obra.

Acervo

Tubo 52 e 53, Caixa 1400
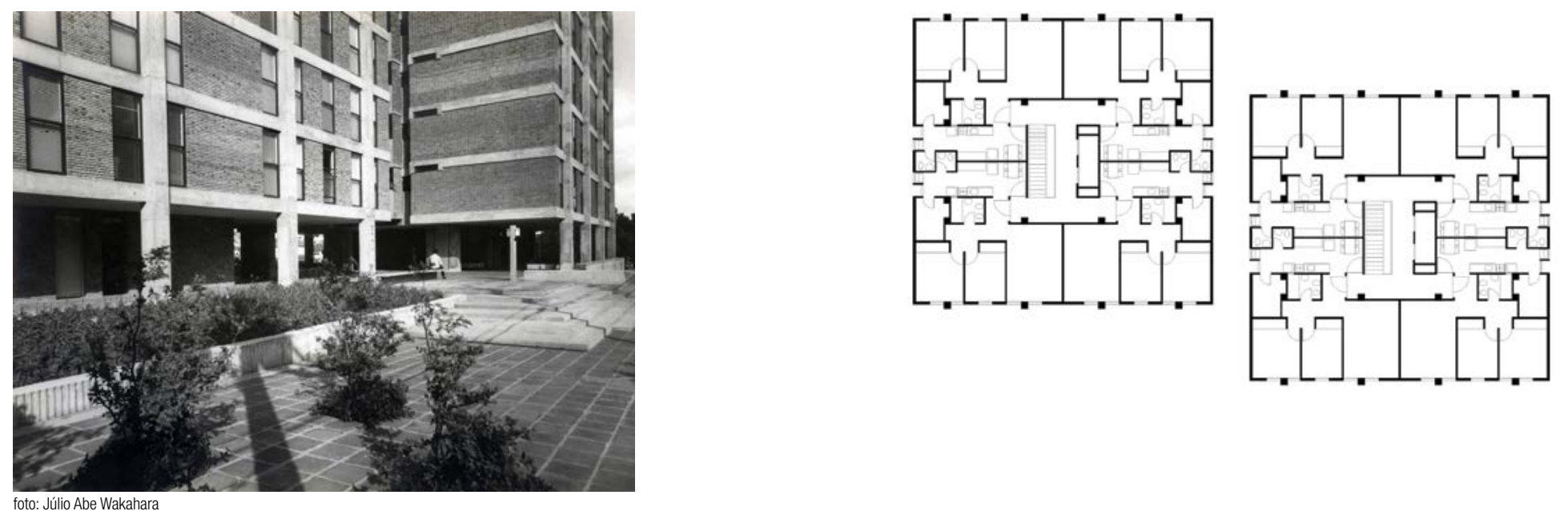

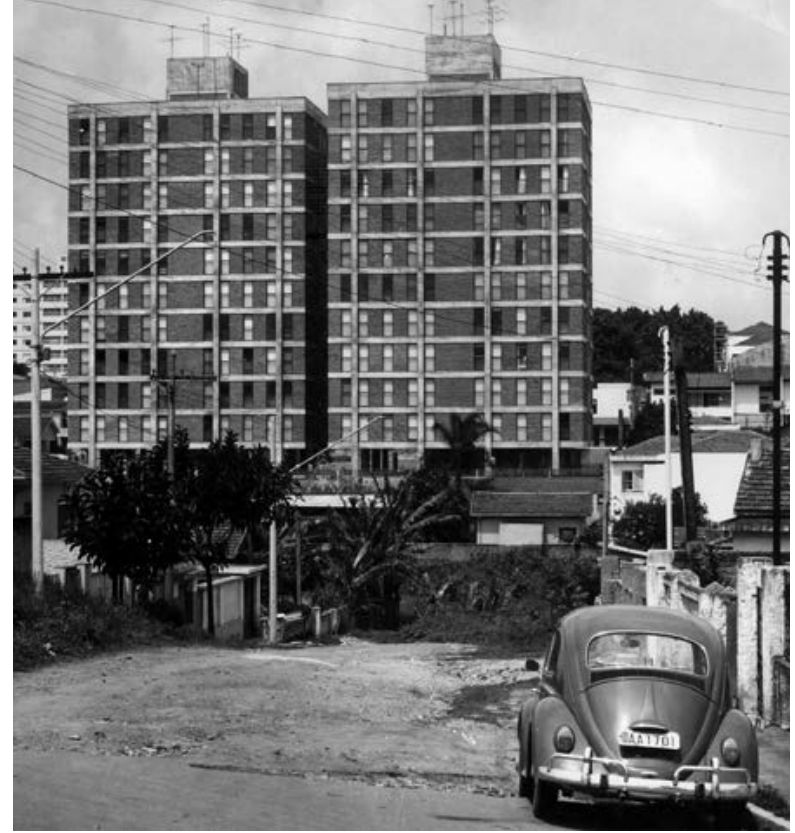

foto: José Moscardi

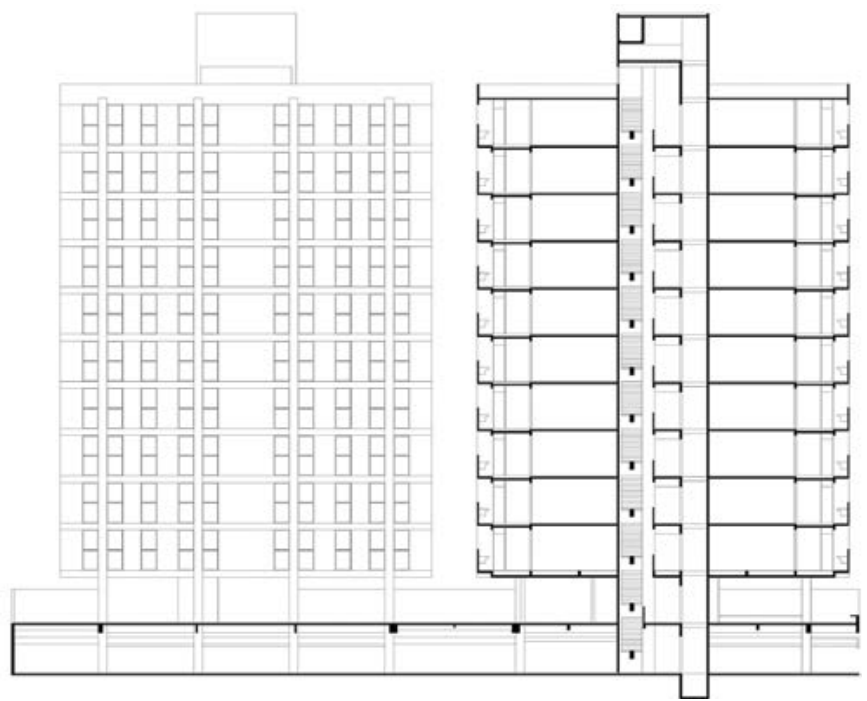

O 
Uso

Edifício de Habitação Coletiva

Cliente

Construtora Formaespaço

Equipe

Eduardo de Almeida

Localização

Rua Cancioneiro Popular 116, São Paulo, SP

Estágio

Projeto Executivo

Observações

Construído

Características

Assim como no projeto para o edifício Gemini, esta proposta segue a implantação de dois blocos defasados, de acordo com a geometria do lote em esquina. Neste caso, ao invés dos planos de alvenaria de tijolos aparentes, foi utilizado um bloco de concreto com vértices chanfrados especialmente desenhados para esta obra, resultando em uma fachada marcada pelas linhas verticais das juntas entre os blocos. Além disso, a estrutura de concreto do módulo central foi simplificada, permitindo um outro arranjo para a cozinha e área de serviços.

Acervo

Caixa 1400
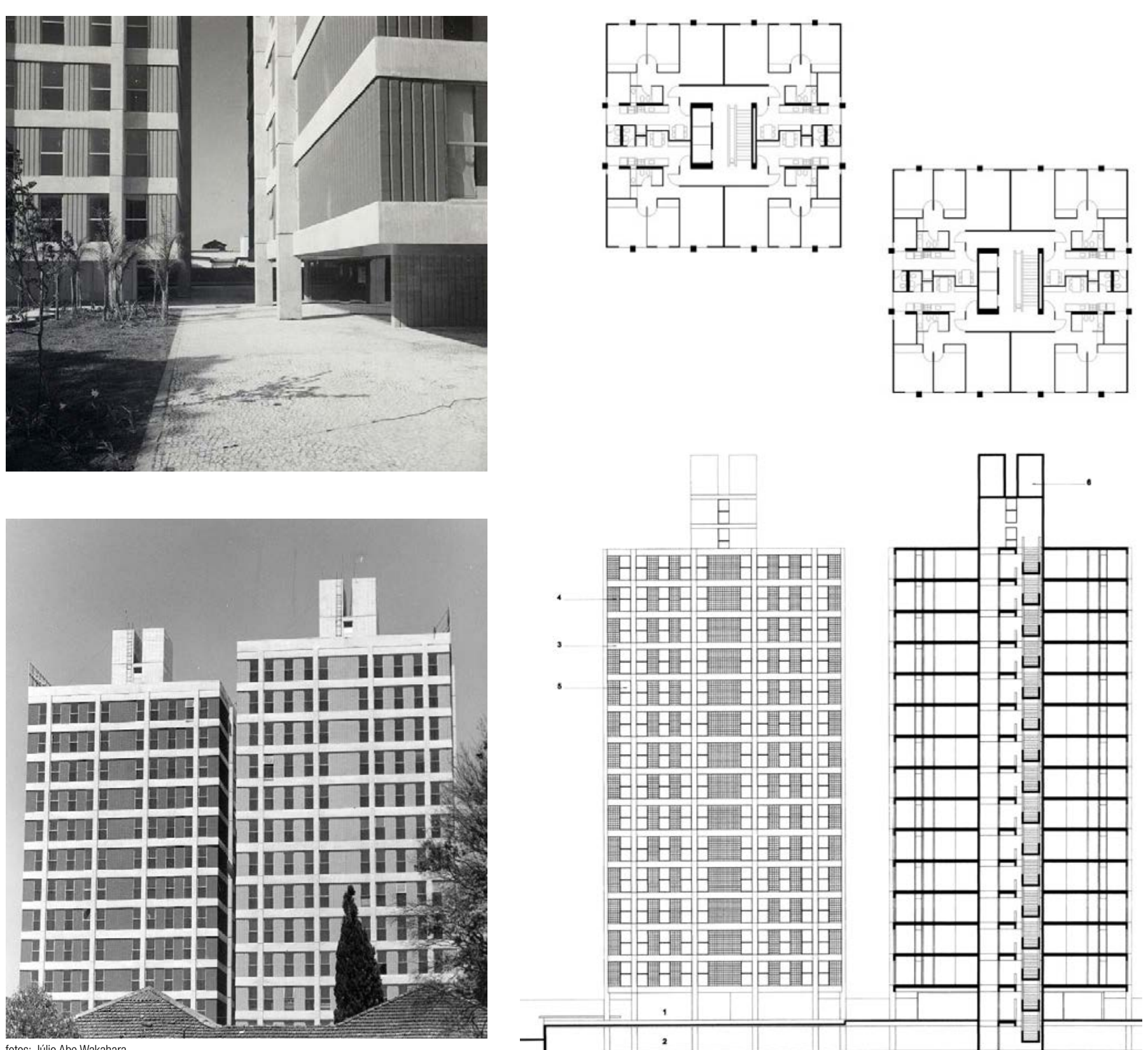

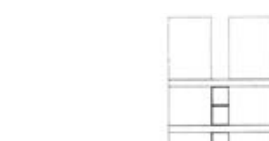

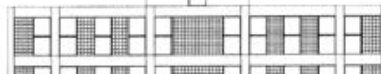

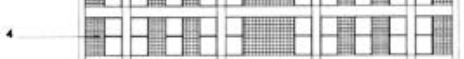

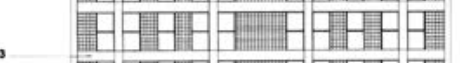

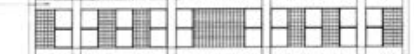

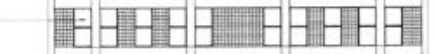

PHAPA

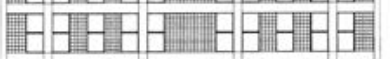

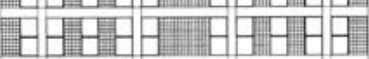

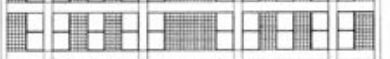

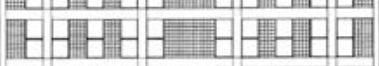

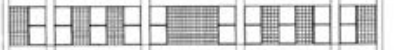

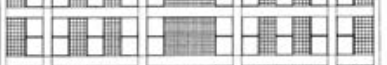

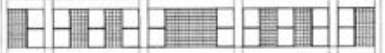

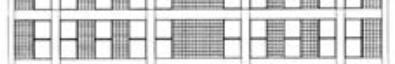

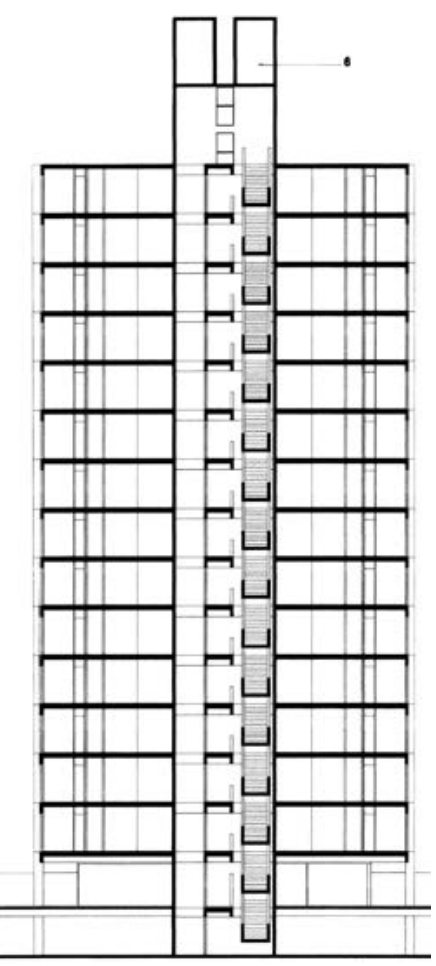


Uso

Edifício de Habitação Coletiva

Cliente

Construtora Formaespaço

Equipe

Eduardo de Almeida

Localização

Rua Monte Alegre 1159, Perdizes, São Paulo, SP

Estágio

Projeto Executivo

Observações

Construído

\section{Características}

Utilizando a mesma solução do edifício Coronet, o projeto para este novo conjunto destaca-se pela implantação: o lote estreito e alongado possibilita a implantação de dois blocos alinhados, articulados por um pátio interno inclinado que, assim como a garagem, tiram partido da topografia do lote para evitar movimentações de terra além do estritamente necessário.

Acervo Caixa 1400
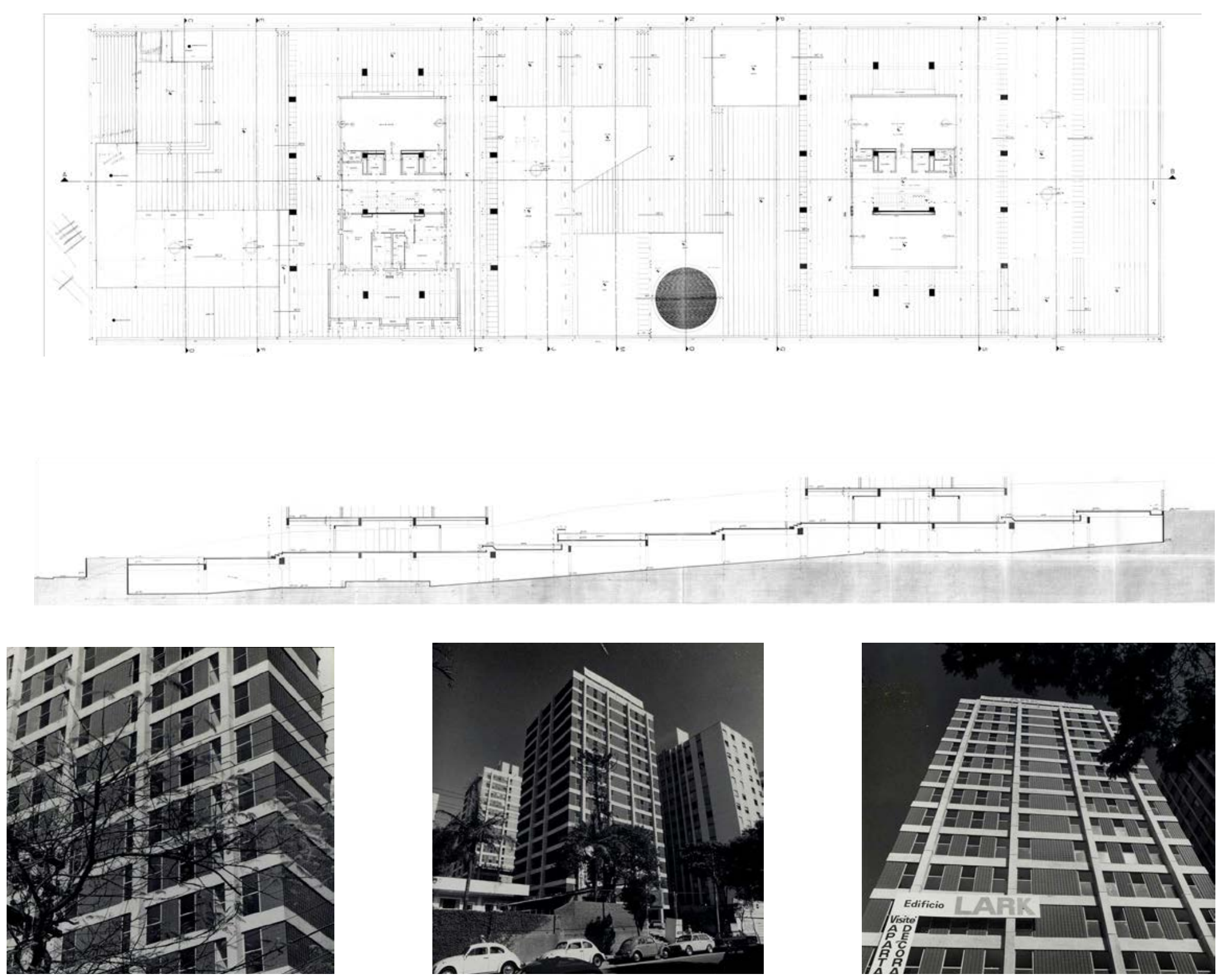
Uso

Edifício de Habitação Coletiva

Cliente

Construtora Formaespaço

Equipe

Eduardo de Almeida

colaborador I José Antônio Seixas

Localização

Rua Conselheiro Rodrigues Alves, São Paulo, SP

Estágio

Projeto Executivo

Observações

Não Construído

Características

Seguindo 0 padrão estabelecido pelos edifício Gemini

Lark e Coronet, este projeto considera a implantação de

um único volume, devido às limitações do lote. Neste

caso, o edifício se posiciona sobre um embasamento de

dois pavimentos (um subsolo) e cria um espaço de uso

comum elevado.

Acervo

Caixa 1400
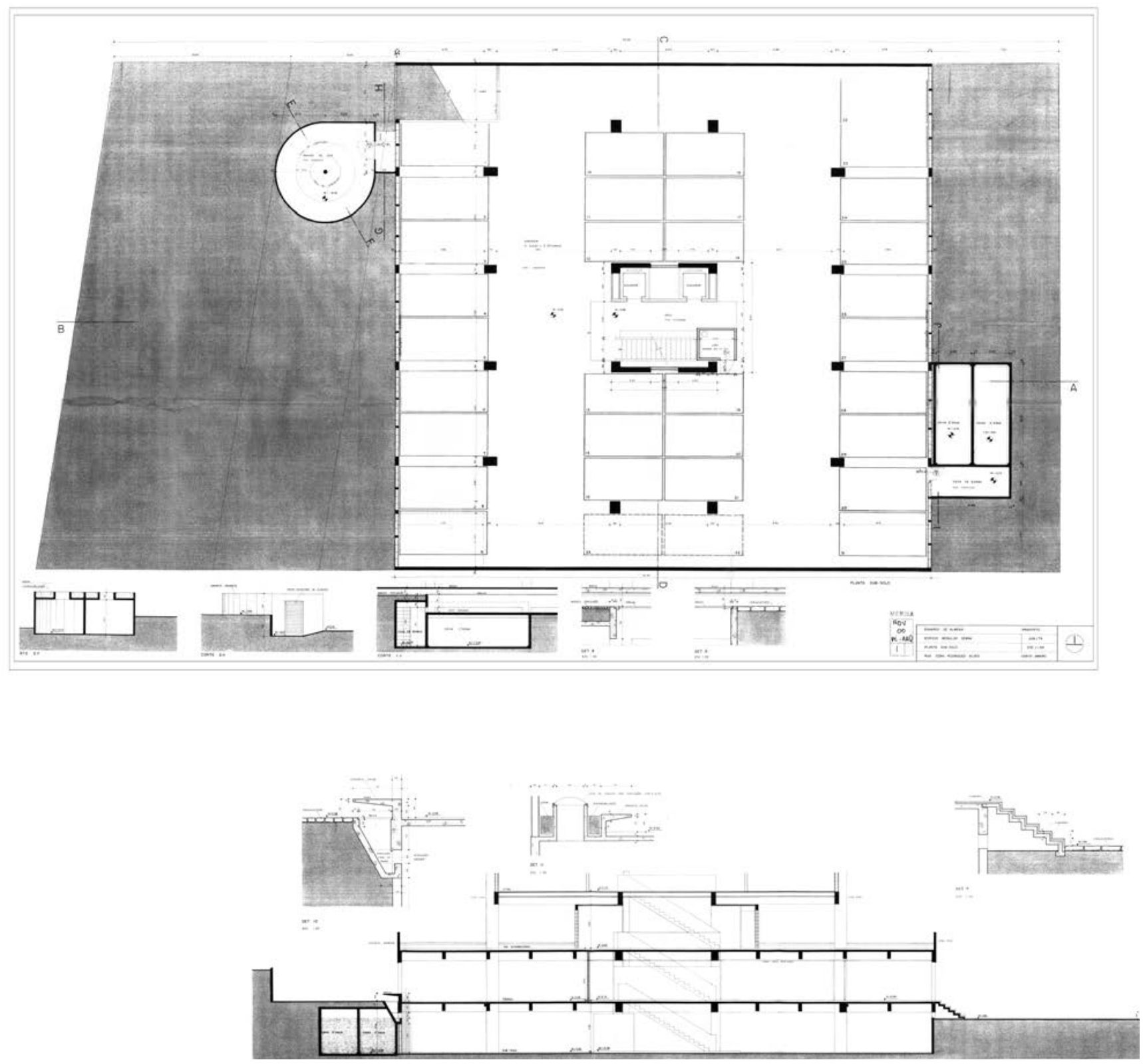

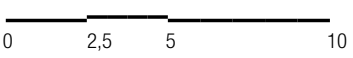


Uso

Residência Unifamiliar

Cliente

José L. Niemeyer dos Santos

Equipe

Eduardo de Almeida

Localização

Rua Décio Reis 191, São Paulo, SP

Estágio

Projeto Executivo

Observações

Construido

\section{Características}

Seguindo a topografia do terreno em aclive, o projeto para esta residência unifamiliar foi organizado em blocos funcionais justapostos, desenhados de modo a garantir a continuidade espacial entre os ambientes. Segundo Eduardo de Almeida 0 emprego de estrutura de conceto, blocos de concreto e lajes pre labicatas, todos aparentes, fazem referência à simplicidade construtiva e à austeridade presentes nos projetos de Carlos Millan. Cada um destes elementos construtivos aparecem reunidos em desenhos de grande qualidade executados por José Antônio Seixas. Especial atencão à solucão dada aos fechamentos dos quartos: venezianas e vidro temperado (associado à peças horizontais de madeira) que correm externamente aos planos de alvenaria por meio de trilhos de alumínio.

Acervo

Tubo 38
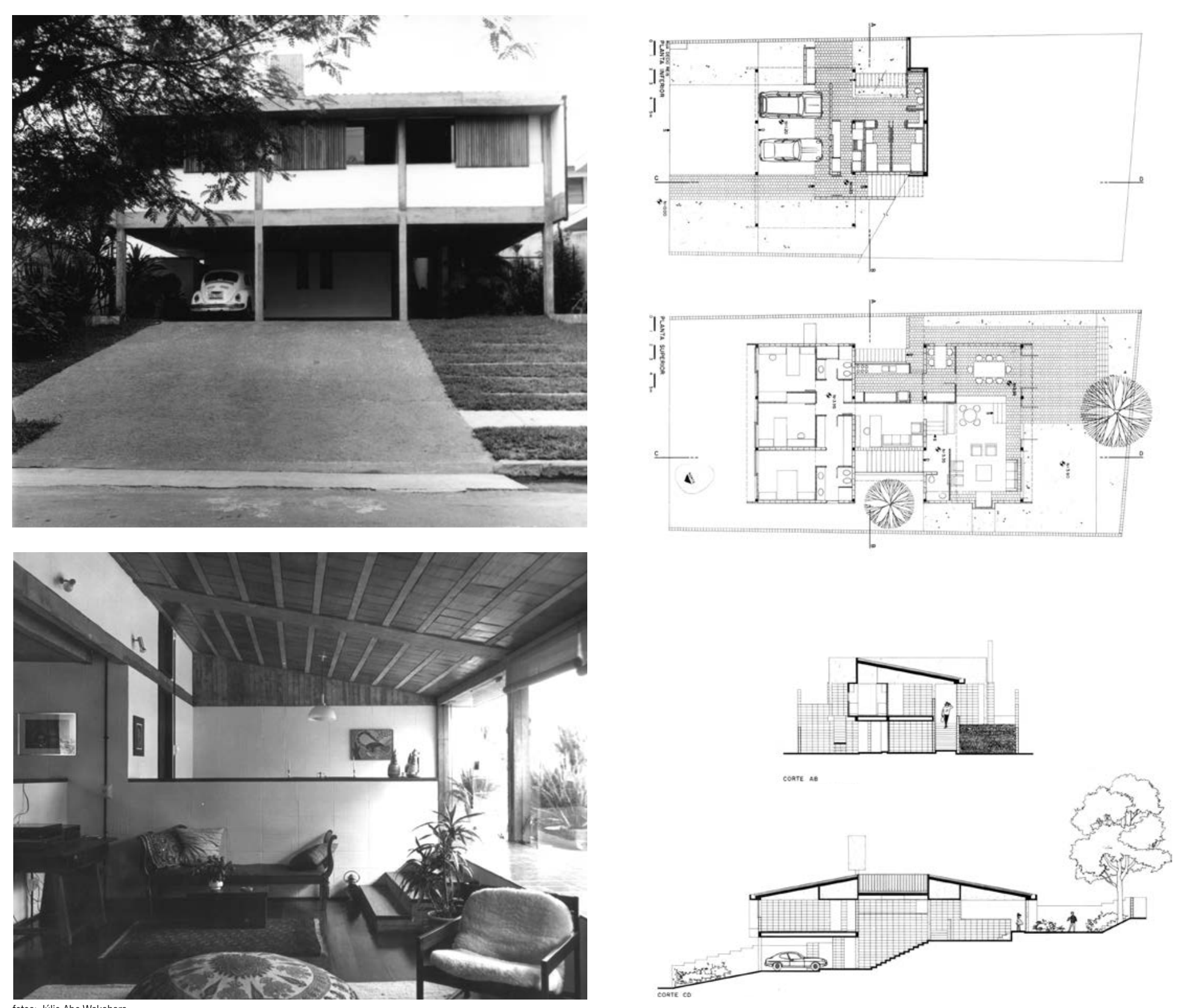

0

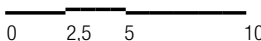


Uso

Residência Unifamiliar

Cliente

Jacob Kipnis

Equipe

Eduardo de Almeida

Localização

Rua dos Escultores, Boaçava, São Paulo, SP

Estágio

Projeto Executivo

Observações

Construído

\section{Características}

Seguindo a experiência da residência projetada para José Niemeyer dos Santos, esta casa também se implanta de acordo com a topografia do lote, agora em declive, e também se utiliza da coordenação modula entre estrutura e blocos de concreto - sempre aparentes - e caixilharia de vidro temperado. Neste caso, a organização do programa em volumes aproveita-se do pátio interior ajardinado criado entre eles, onde também se posiciona o elemento de conexão vertical e horizontal em uma das extremidades.

A dimensão do volume destinado às salas de jantar e estar cria uma área avarandada no pavimento inferior $\mathrm{e}$

um terraço ajardinado junto ao quarto principal.

Acervo

Tubo 44 e 44A
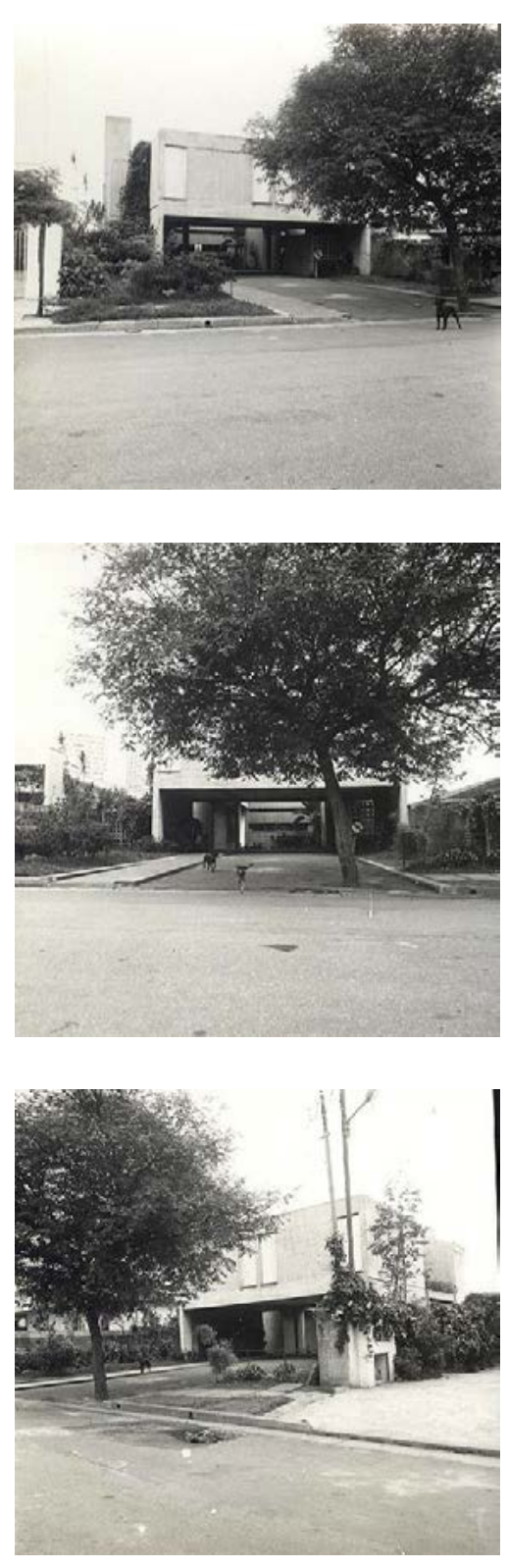

fotos: Júlio Abe Wakahara
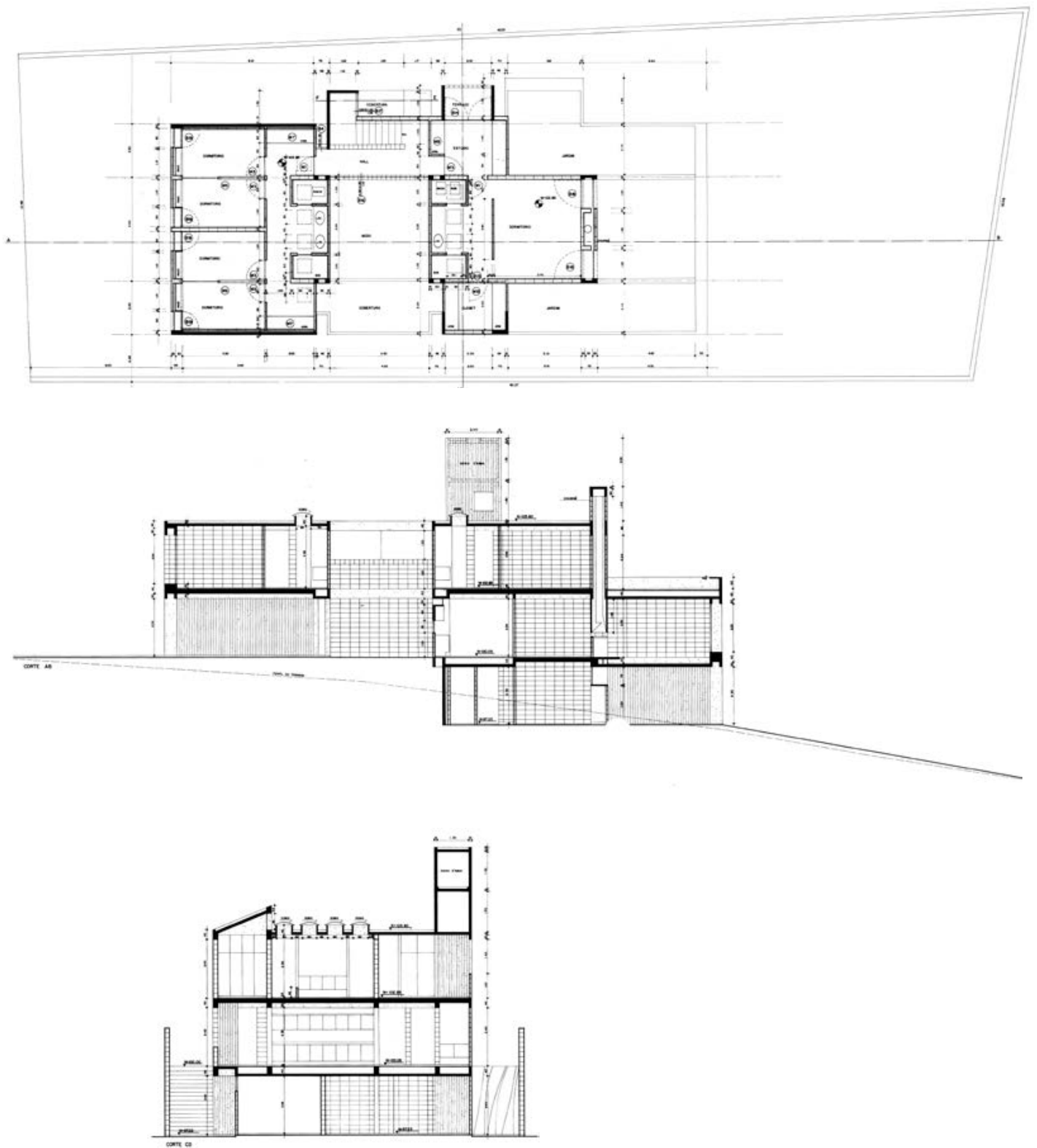
Uso

Residência Unifamiliar

Cliente

Egberto Penido

Equipe

Eduardo de Almeida

Localização

Rua Des. Joaquim Barbosa de Almeida 96, Alto de

Pinheiros, São Paulo, SP

Estágio

Projeto Executivo

Observações

Construído

Características

Residência unifamiliar de dois pavimentos construída com estrutura de concreto moldado in 1000 fechamentos de alvenaria de tijolos aparentes. Extremamente singela, a planta soluciona os ambientes de estar, jantar e cozinha no pavimento térreo e todos os dormitórios - inclusive os de serviços - no pavimento superior. Enquanto os sanitários, no centro da planta, são iluminados e ventilados zenitalmente, todos os espaços principais se voltam ao jardim localizado nos fundos do terreno. Além da coordenação entre todos os ambientes e a estrutura, todo o encaminhamento das infra-estrutruras de hidráulica e elétrica organiza-se em shafts acessíveis junto ao corredor de circulação. Do ponto de vista formal, a volumetria da casa a partir da rua destaca-se por um vazio de pé-direito duplo en contraste com os planos cegos da fachada, semelhante ao projeto realizado na Rua Suécia por Oswaldo Bratke em 1956.

Acervo

Tubo 46
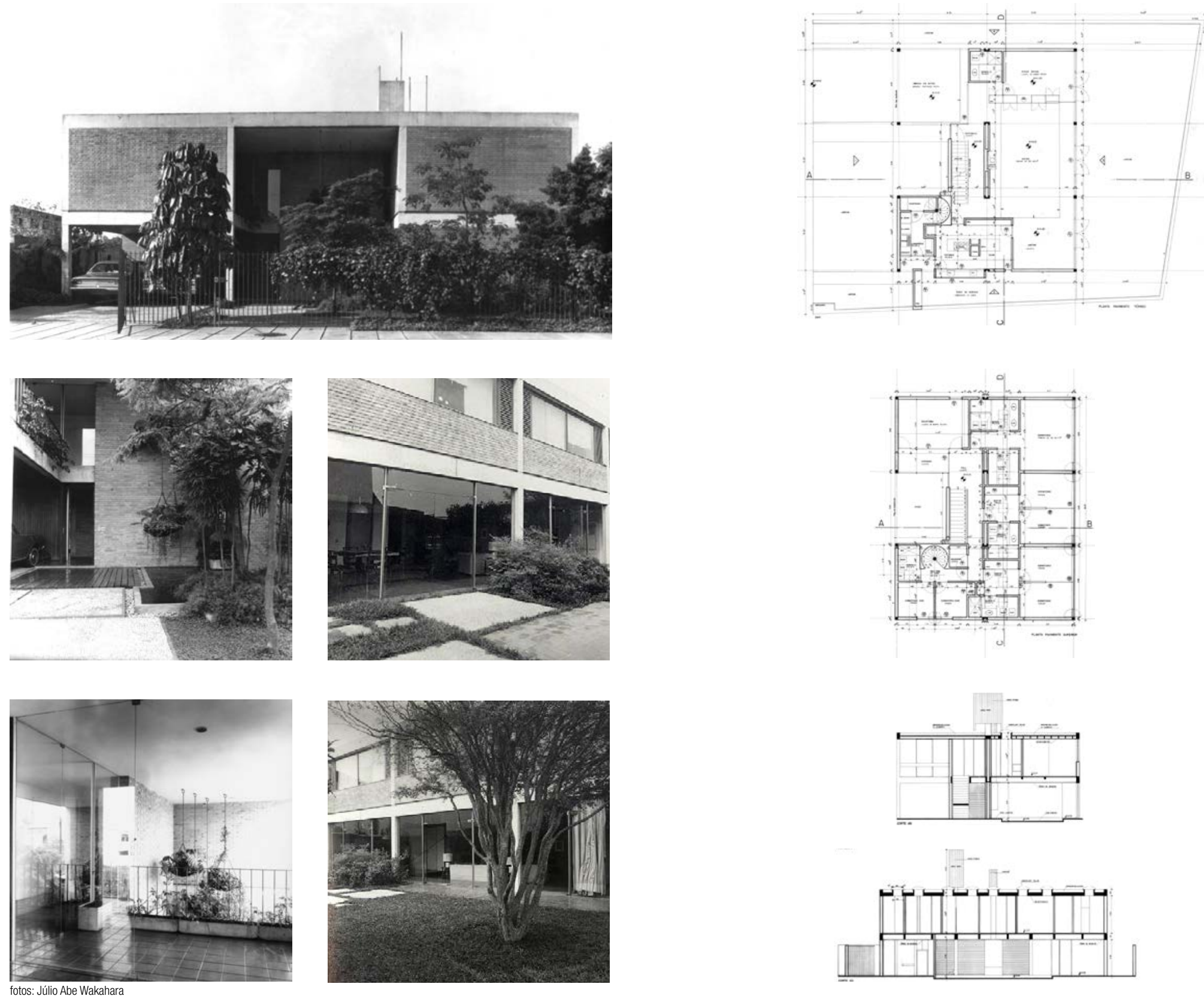
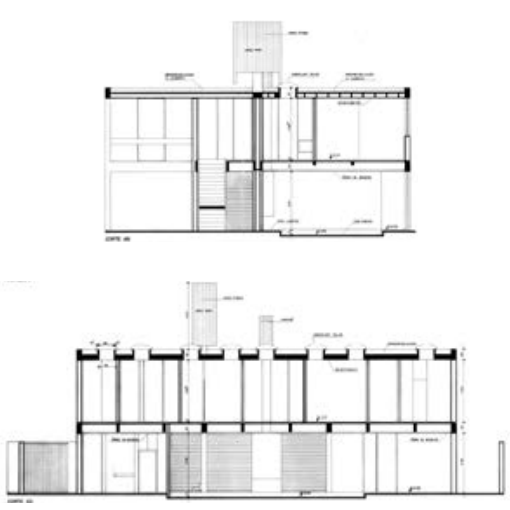
Uso

Residência Unifamiliar

Cliente

Aroldo Fuganti

Equipe

Eduardo de Almeida

Localização

Rua Piauí, Londrina, Paraná

Estágio

Projeto Executivo

Observações

Construído e demolido

\section{Características}

Residência unifamiliar construída em estrutura de concreto armado e telhado de madeira com duas águas de dupla inclinação. 0 volume principal implanta-se junto à rua e, ao aproveitar a topografia do lote, cria um patamar em relação de meio-nível destinado à cozinha e à sala de jantar. Tal solução aproxima-se de projetos realizados posteriormente, como a casa de Renata Tassinari construída em Orlândia em 1981

Acervo

Tubo 1, Caixa 100
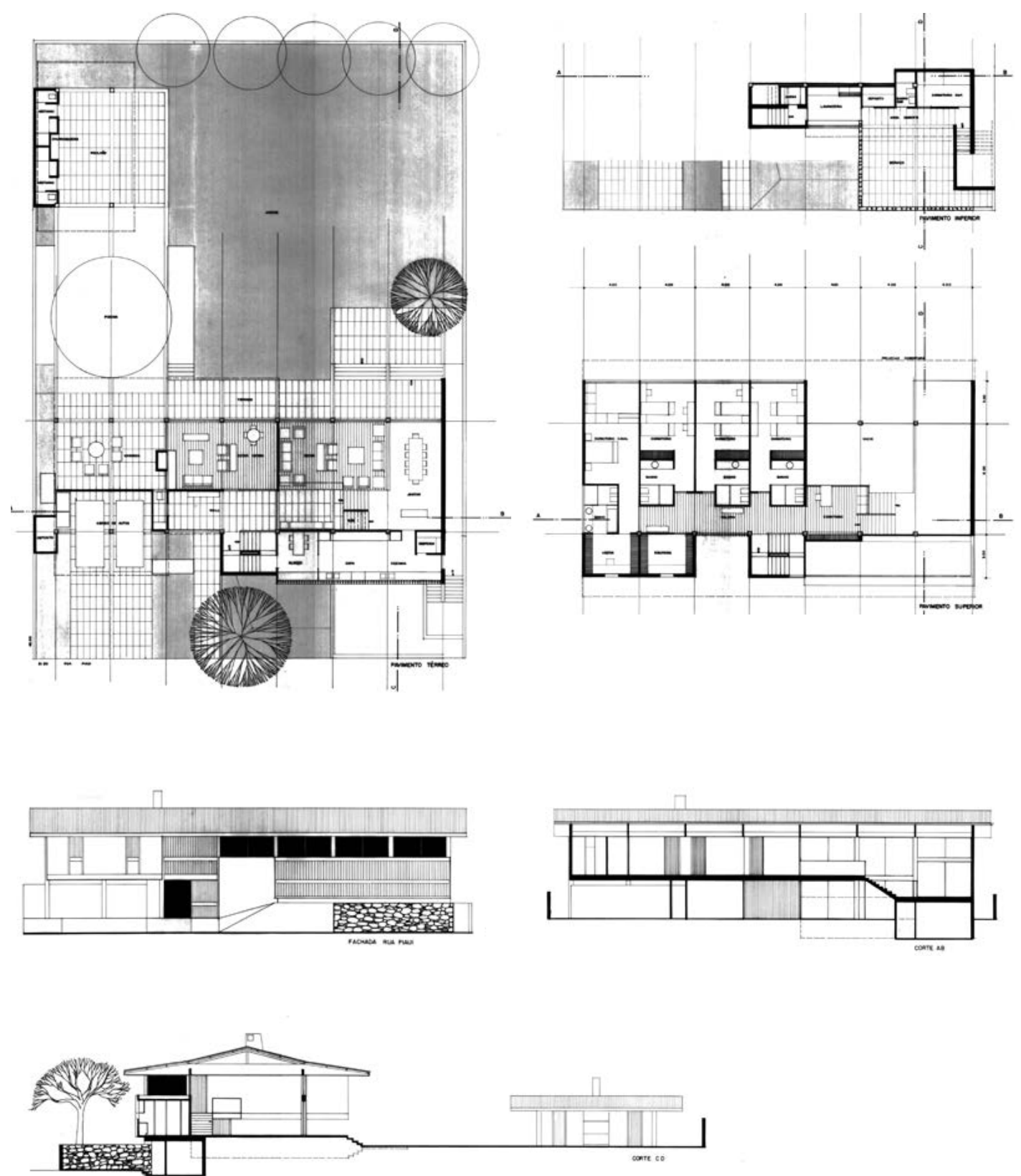
Uso

Edifício de Habitação Coletiva

Cliente

Construtora Paulista S.A.

Equipe

Eduardo de Almeida

Localização

Rua Jesuíno Arruda 254, Itaim Bibi, São Paulo, SP

Estágio

Projeto Executivo

Observações

Construido

Características

Edifício de apartamentos com nove pavimentos, duas circulações centrais de escadas e elevadores e seis unidades por andar. Tal solução repete um dos estudos de viabilidade apresentado anteriormente para 0 Edifício Bela Cintra, que utilizou outra configuração em seu prolo finat Neste caso, toda a estrun projto fina. Neste caso, to da a estutra armado moldada in 1000 e deixada aparente, sendo complementada por painéis dotados de textura vertical nas empenas frontal e posterior. Em contraponto a estes elementos, todas as alvenarias ao longo das fachadas laterais eram pintadas em azul, amarelo e laranja solução alterada posteriormente pelos moradores do condomínio.

Acervo

Caixa 1200
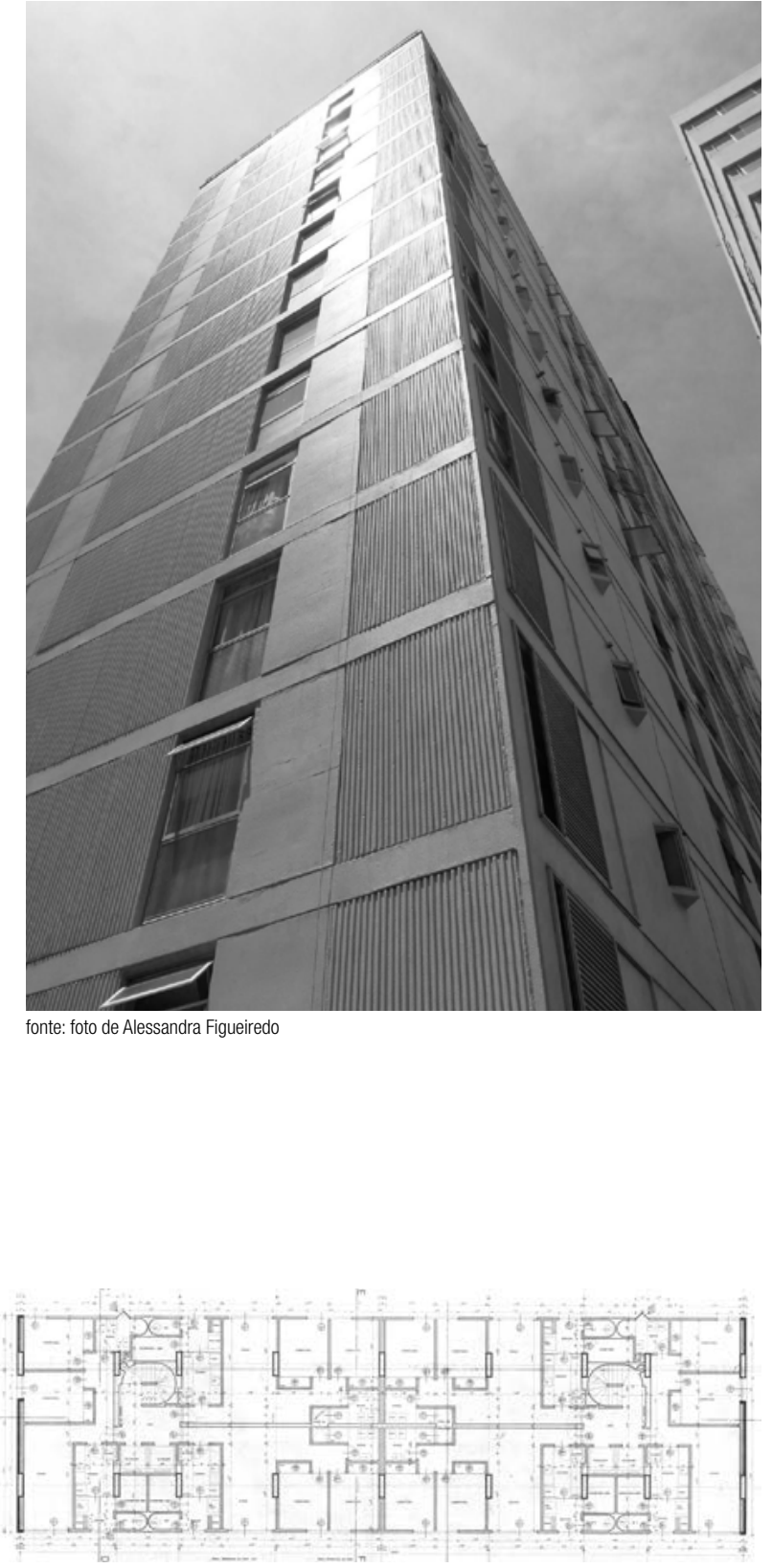
Uso

Edifício comercial

Cliente

Construtora Paulista S.A.

Equipe

Eduardo de Almeida

Localização

Av. Brigadeiro Faria Lima, São Paulo, SP

Estágio

Estudo Preliminar

Observações

Não Construído

\section{Características}

Estudo preliminar para um edifício comercial de vinte e

dois pavimentos na Avenida Faria Lima. No pavimento térreo foi implantado um embasamento comercial de geometria trapezoidal, de acordo com a configuração do

lote em esquina. Com acesso independente das áreas comerciais, o edifício de escritórios apresenta-se como uma torre de planta quadrada com núcleo central e áreas de trabalho periféricas.

Interessante notar a racionalidade estrutural do projeto utilizado como elemento expressivo das fachadas da torre, já que a secção dos pilares em 'L' diminui de acordo com 0 aumento dos andares. Em planta, este mesmo princípio também considera a justaposição de mesmo principio também considera a justaposiçăo de
módulos quadrados, criando pilares que se modificam de acordo com as cargas propiciadas por cada trecho de laje.
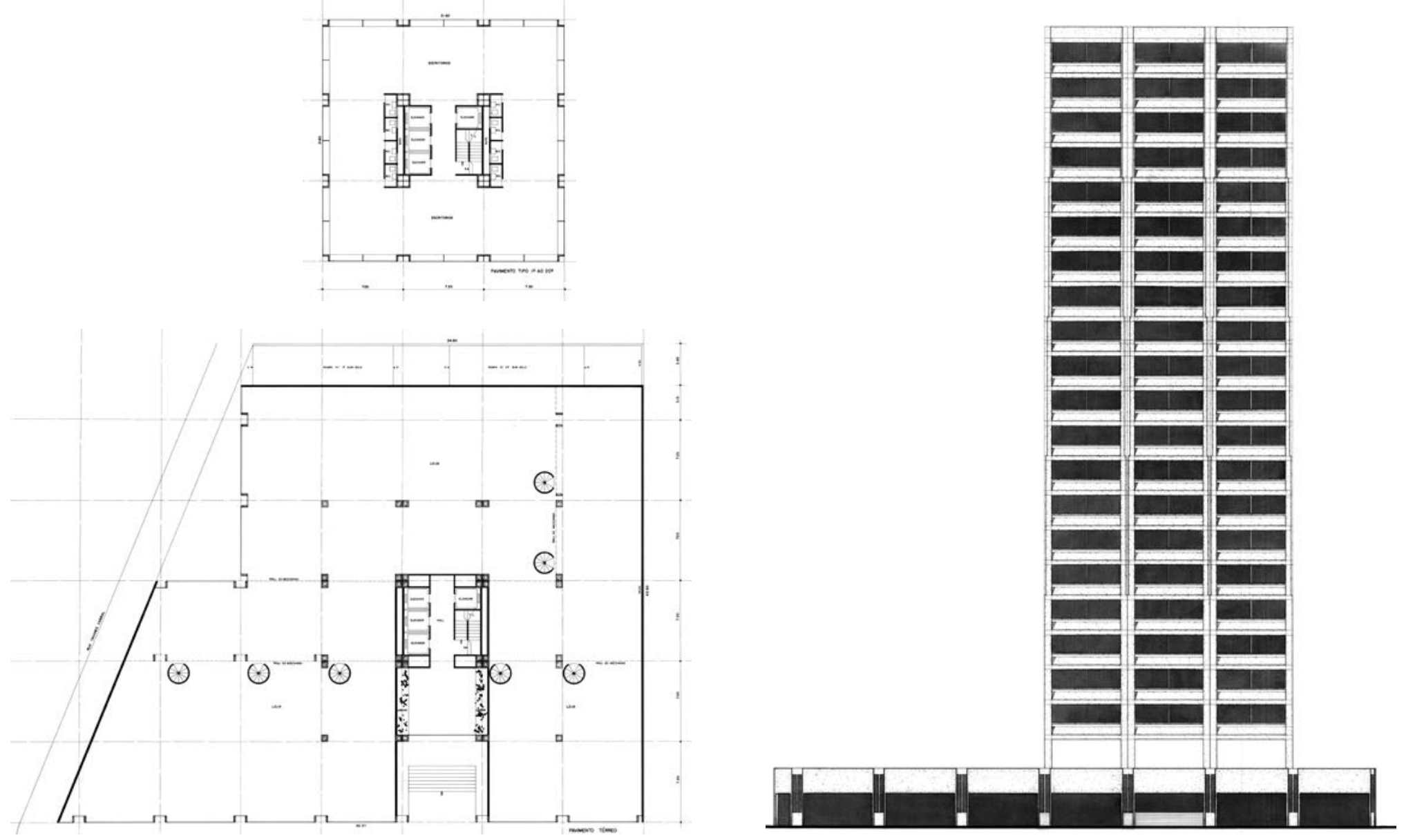

Acervo

Tubo 59 e Caixa 4000 
Uso

Unidade Habitacional

Cliente

Yolanda Penteado

Equipe

Eduardo de Almeida

Localização

Rua Agelina Maffei Vita, Pinheiros, São Paulo, SP

Estágio

Projeto Executivo

Observações

Construído

\section{Características}

Projeto de reforma de apartamento para Yolanda Penteado, esposa de Cicillo Matarazzo, com quem organizou a primeira Bienal de São Paulo no Trianon, a segunda Bienal no Parque Ibirapuera, por ocasião das comemoracões do IV Centenário. Seu acervo pessoal originou a coleção do Museu de Arte Moderna de São Paulo, posteriormente doada ao Museu de Arte Contemporânea da USP. Seguindo o espirito da moradora - moderno e ligado ao universo das artes plásticas - 0 projeto cria a abertura da cozinha para a sala com mobiliário extremamente singelo, solucão pouco usual na época Segundo Eduado além das inúmeras obras de arte, 0 apartamento todo tinha um revestimento de piso de cerâmicas realizadas pelo artista Francisco Brennand.

Acervo

Tubo 80
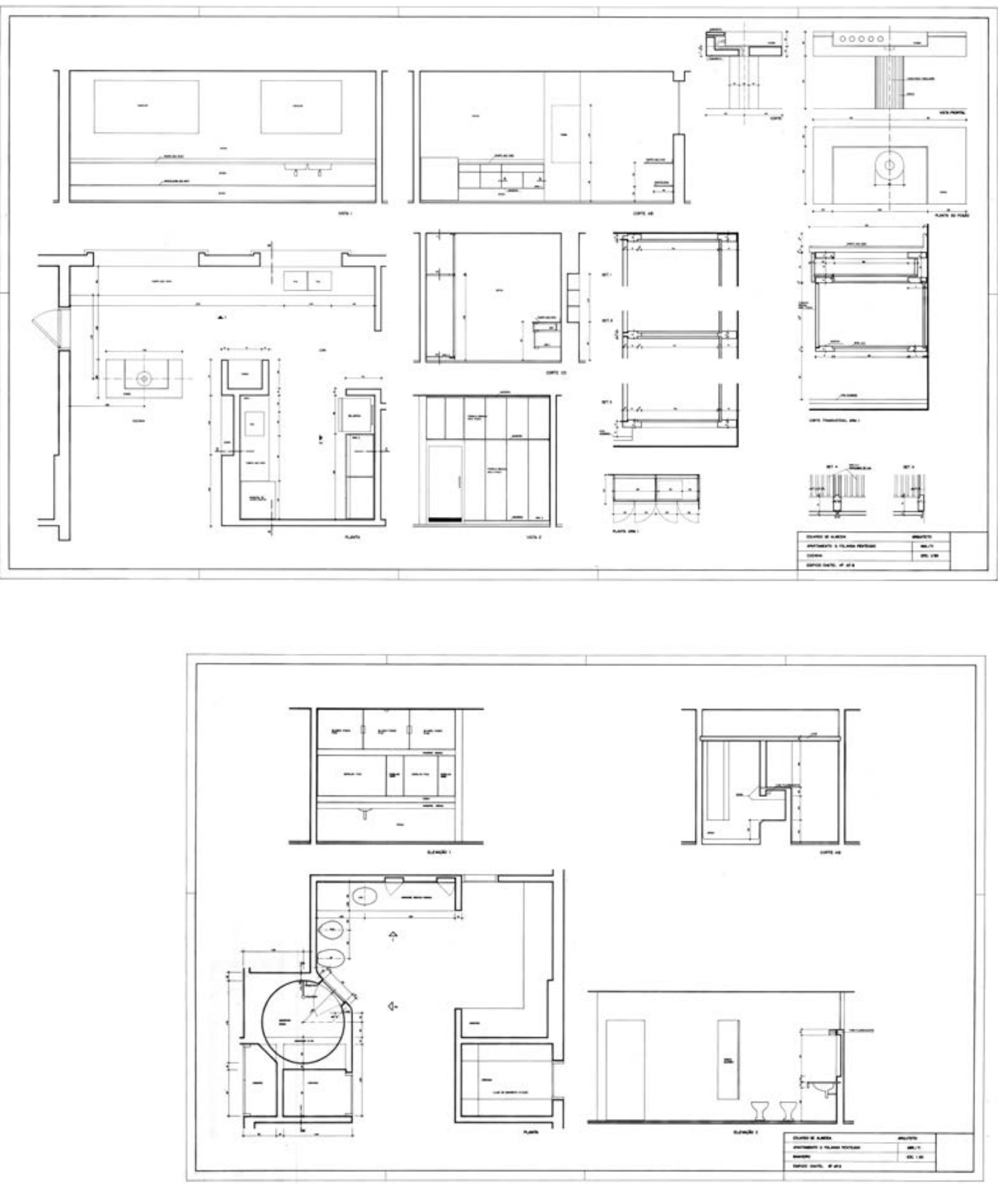

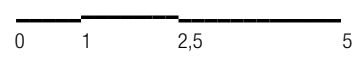


Uso

Centro Cultural

Equipe

Dácio Ottoni, David Ottoni e Eduardo de Almeida

Localização

Paris, França

Estágio

Anteprojeto

Observações

Não Construído

\section{Características}

Retomando a parceria com Dácio e David Ottoni, este

projeto de extrema radicalidade cria uma solução

constituída por duas ações: um subsolo de grandes

dimensões - com os programas organizados ao redor

de um pátio central $-\mathrm{e}$ um volume suspenso por meio

de quatro pilares associados a uma estrutura de treliças

espaciais, conformando um espaço coberto. Entre estes

dois elementos um vazio desenhado pelas fachadas do

tradicional bairro de Paris, o Marais. Tal investigação

parece sintonizada com as experiências daquele

momento de Buckiminster Fuller - referência para as

aulas de design de Eduardo de almeida na FAUUSP -

do grupo inglês Archigram e, sobretudo, do projeto da

praça central coberta da Exposição Universal de Osaka

coordenado por Kenzo Tange em 1970.

Acervo

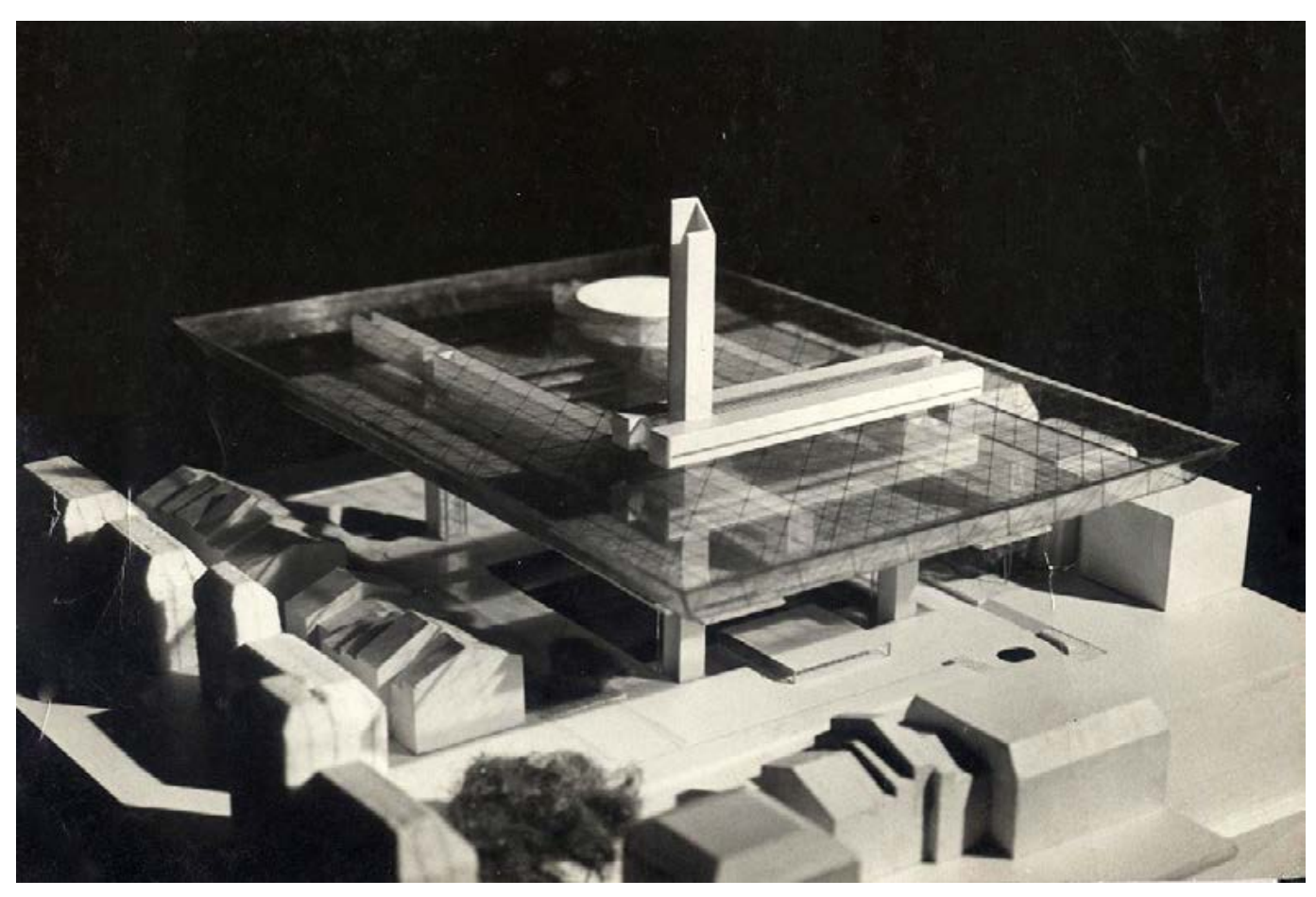

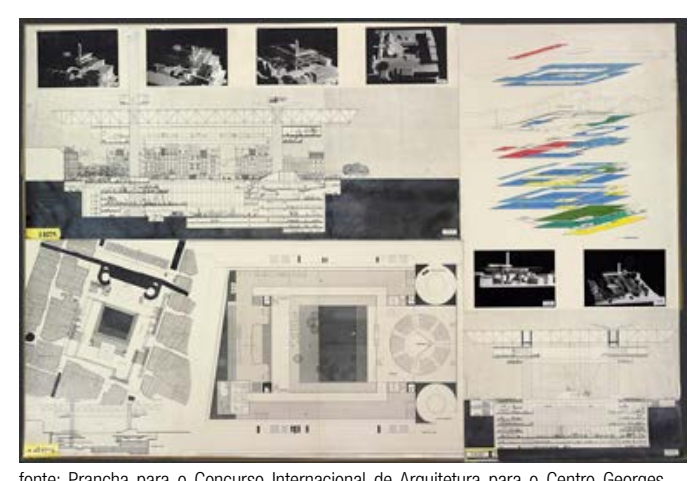

fonte: Prancha para o Concurso Internacional de Arquitetura para o Centro Georges rEnkgrr > Acessado em 9 de dezembro de 2014.

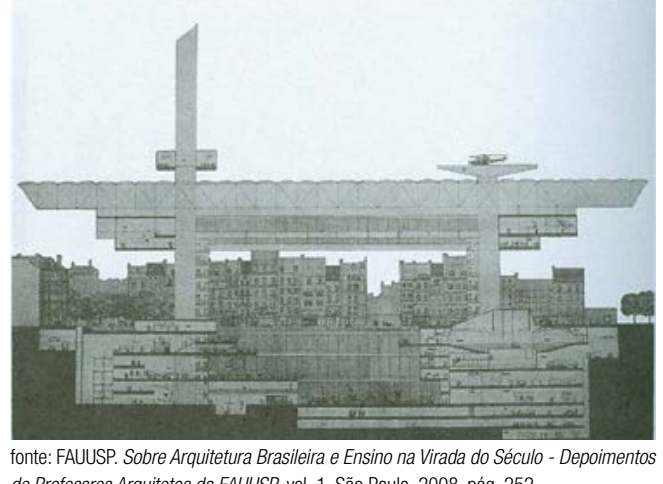

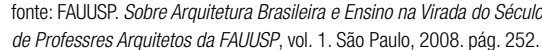


Uso

Loja

Cliente

Marino Comércio de Papéis

Equip

Eduardo de Almeida

Localização

Rua Visconde de Parnaíba, Mooca, São Paulo, SP

Estágio

Projeto Executivo

Observações

Construído e demolido

\section{Características}

Projeto para empresa de comércio de papéis. 0 projeto se organiza pela utilização de coberturas em abóboda tanto para 0 bloco administrativo de um pavimento quanto para 0 galpão de pé direito elevado destinado à armazenagem de matéria prima. Posteriormente o projeto foi ampliado com um terceiro galpão mas, infelizmente, todos foram demolidos por conta de uma desapropriação para uma obra pública.

Acervo

Tubo 63, Caixa 4100
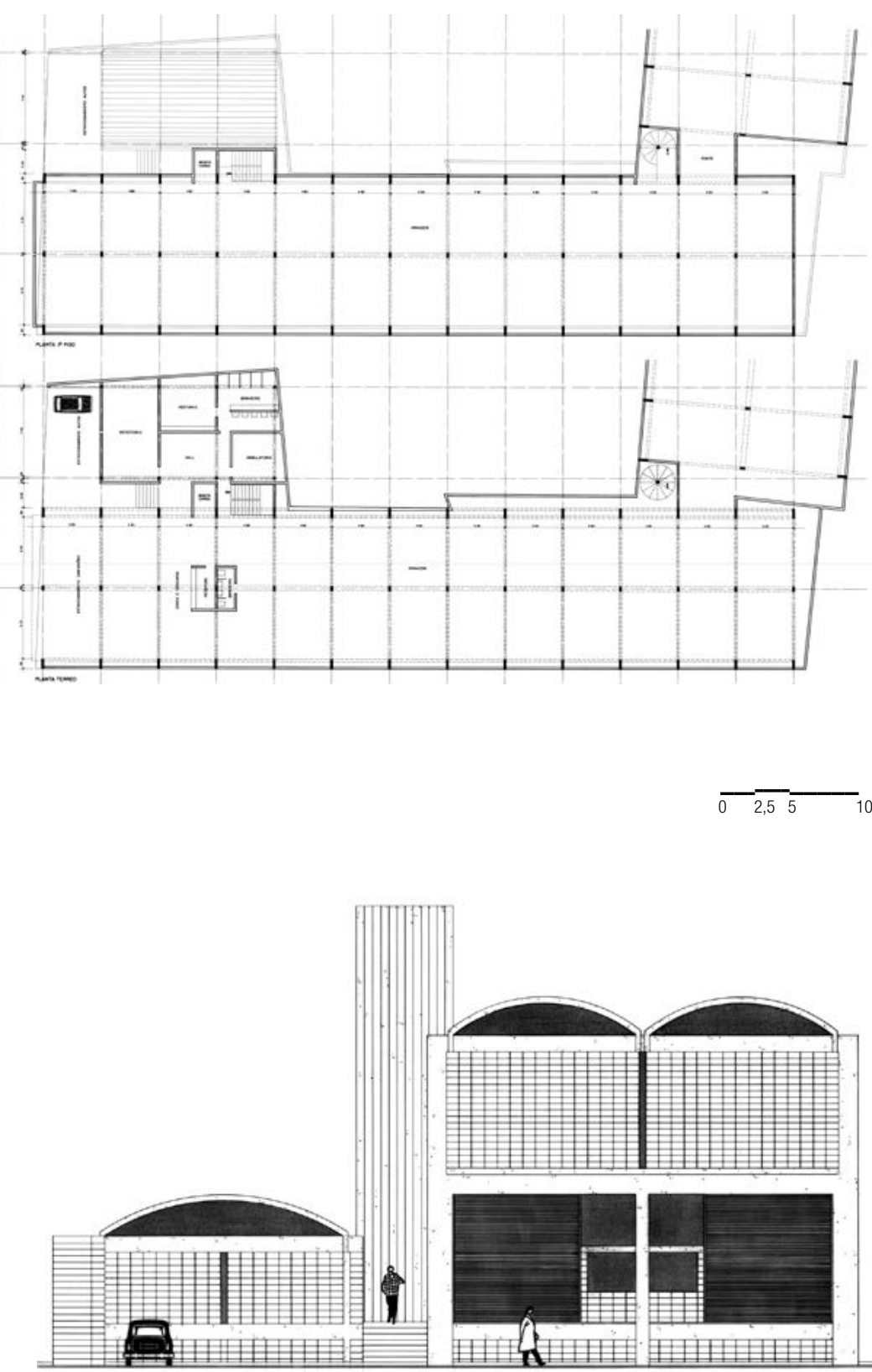
Uso

Residência Unifamiliar

Cliente

Luís Alberto Guimarães

Equipe

Eduardo de Almeida

Localização

Rua Filadelfo Aranha 147, Alto de Pinheiros, São Paulo, $\mathrm{SP}$

Estágio

Projeto Executivo

Observações

Construído

\section{Caracteristicas}

Seguindo o mesmo partido das residências projetadas para Jean Nadin (1967) e José Luís Niemeyer (1970), o projeto organiza-se pela justaposiçãa de três volumes com cobertura inclinada. Neste caso, aproveitando 0 lote em esquina e a inclinação da rua, foi criado um acesso independente para a garagem e para o piso dos dormitórios por uma entrada encimada por um arco pleno, permitindo as relações da cozinha e da sala com o jardim localizado no piso inferior. Construtivamente a casa diferencia-se das duas outras pelo emprego de estrutura de concreto associada a alvenarias de tijolo aparente e caixilharia de madeira

Acervo

Tubo 27
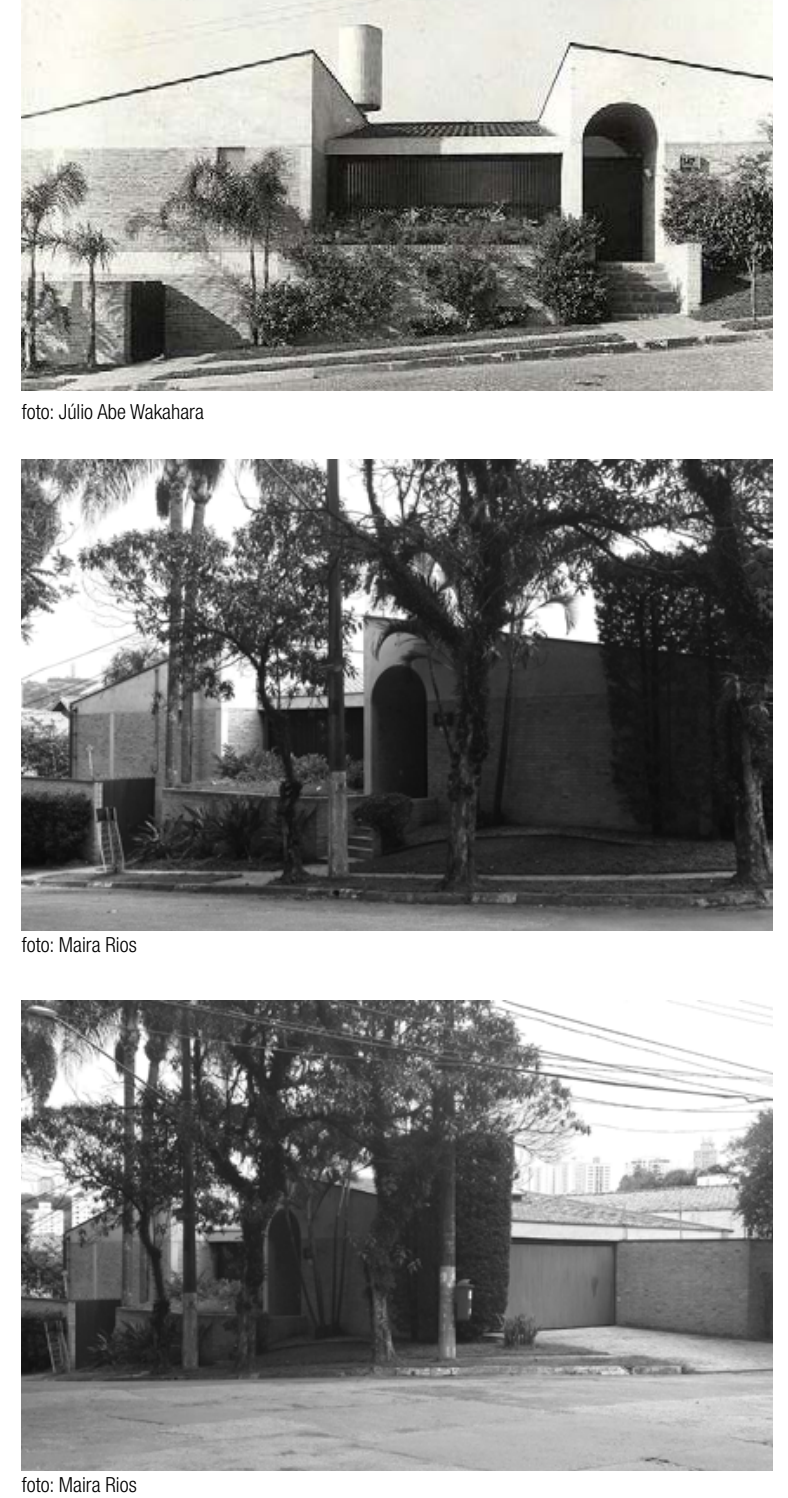
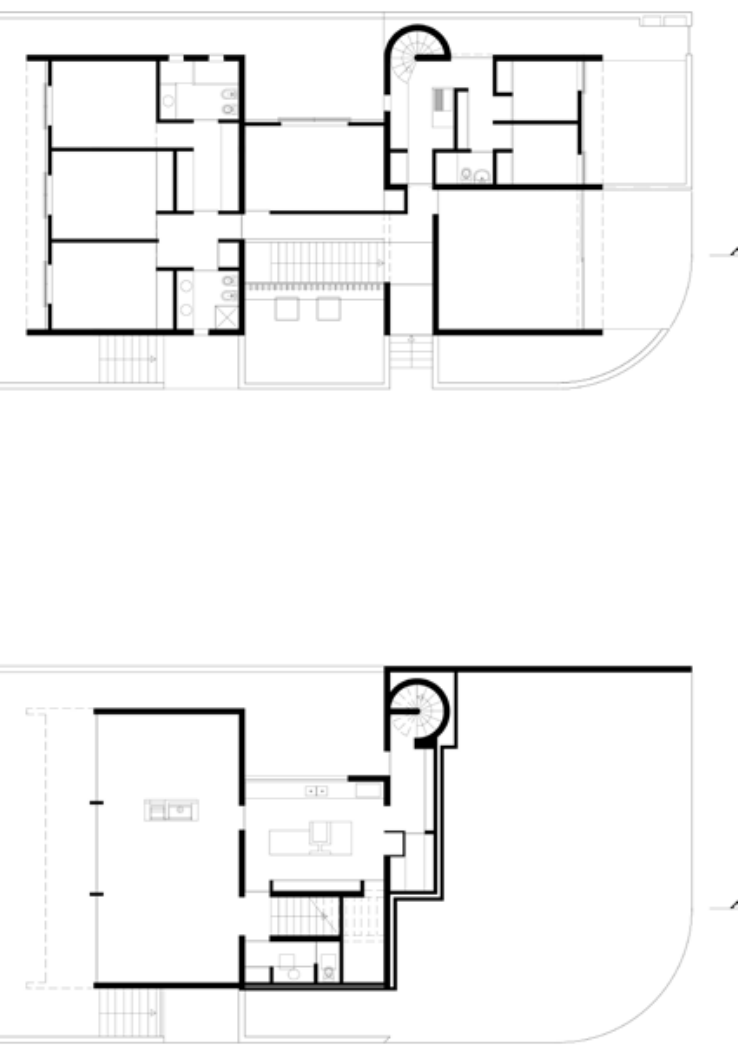

$\mid$

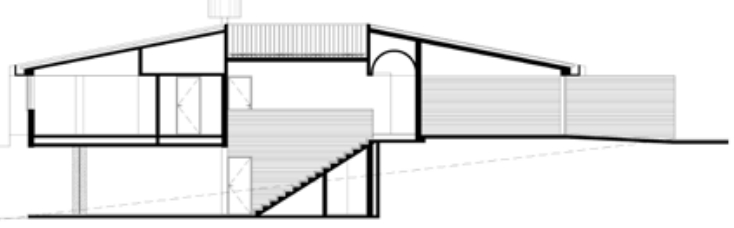


Uso

Residência Unifamiliar

Cliente

José G. Nogueira Moutinho

Equipe

Eduardo de Almeida

Localização

Butantã, São Paulo, SP

Estágio

Estudo Preliminar

Observações

Não Construido

\section{Características}

Estudo para uma residência unifamiliar com volumetria definida por duas lajes inclinadas ao lado de uma cobertura plana central. Enquanto 0 segundo pavimento abriga 0 dormitório e os escritórios do

casal, a planta do térreo apresenta todos os ambientes

de servico agrupados em um volume pos

independentemente das duas enpens poricter

configuram o espaço interno da casa.

Acervo
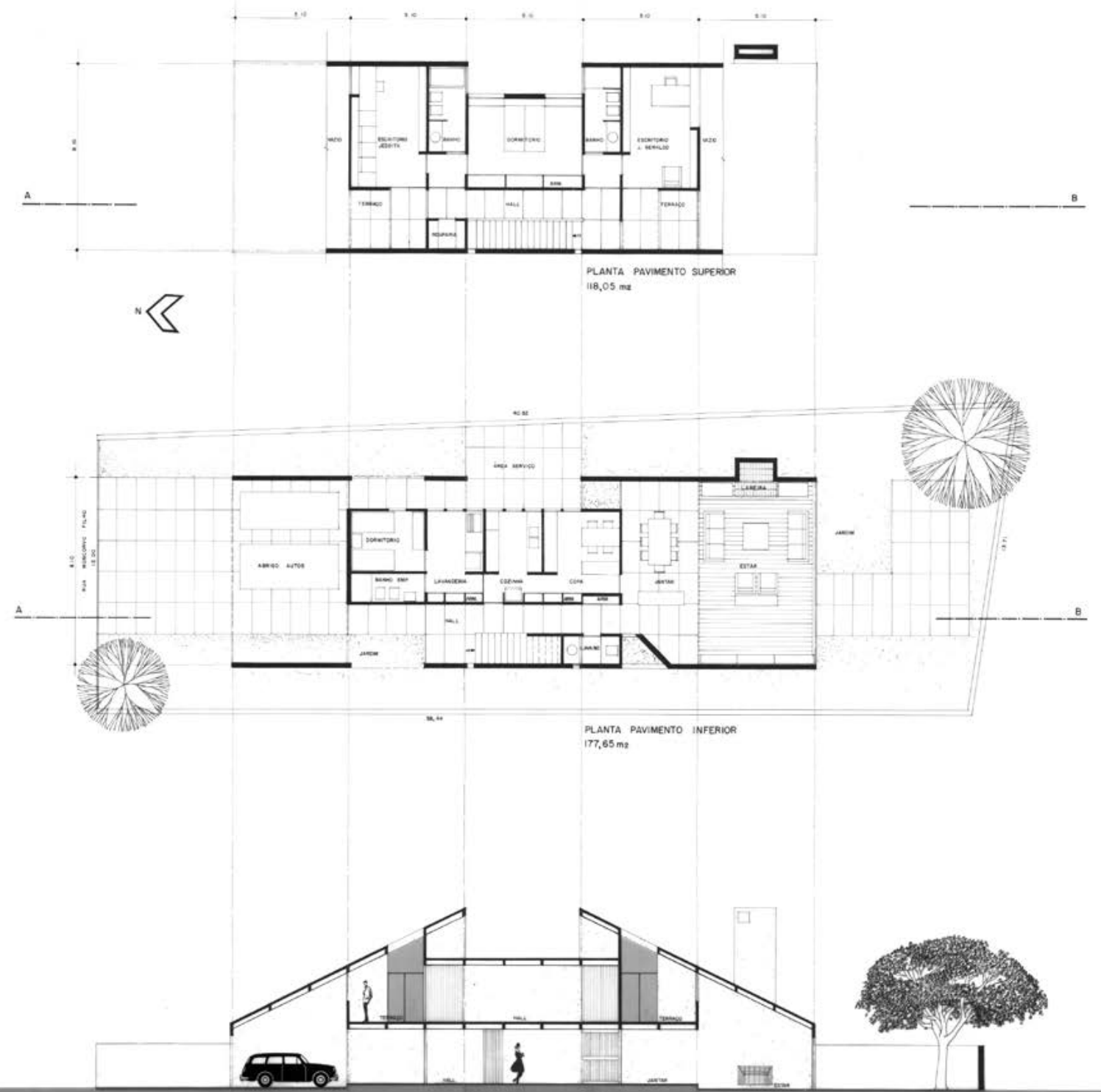
Uso

Fábrica

Cliente

Altemio Spinell

Equipe

Eduardo de Almeida

Localização

Rua Funchal, Itaim Bibi, São Paulo, SP

Estágio

Projeto Executivo

Observações

Construído com outra solução

\section{Características}

Projeto para a fábrica de sapatos de Altemio Spinelli que envolveu aprofundado estudo da linha de produção e do funcionamento da empresa. No estudo preliminar, além do galpão industrial, estava prevista a construçãa de uma residência para seus proprietários, aproveitando a geometria irregular do lote. Seguindo as investigações construtivas do Pavilhão de Osaka e do Centro Georges Pompidou, o galpão industrial proporcionou a oportunidade de aplicar as treliças espaciais como estrutura de cobertura e fechamento em um projeto a ser construído em São Paulo. 0 projeto finalmente construído adotou a organização geral do programa mas a estrutura foi realizado com treliças pré-fabricadas em arco, fornecidas a baixo custo por um amigo dos proprietários.

Acervo

Tubo 3, Caixa 100

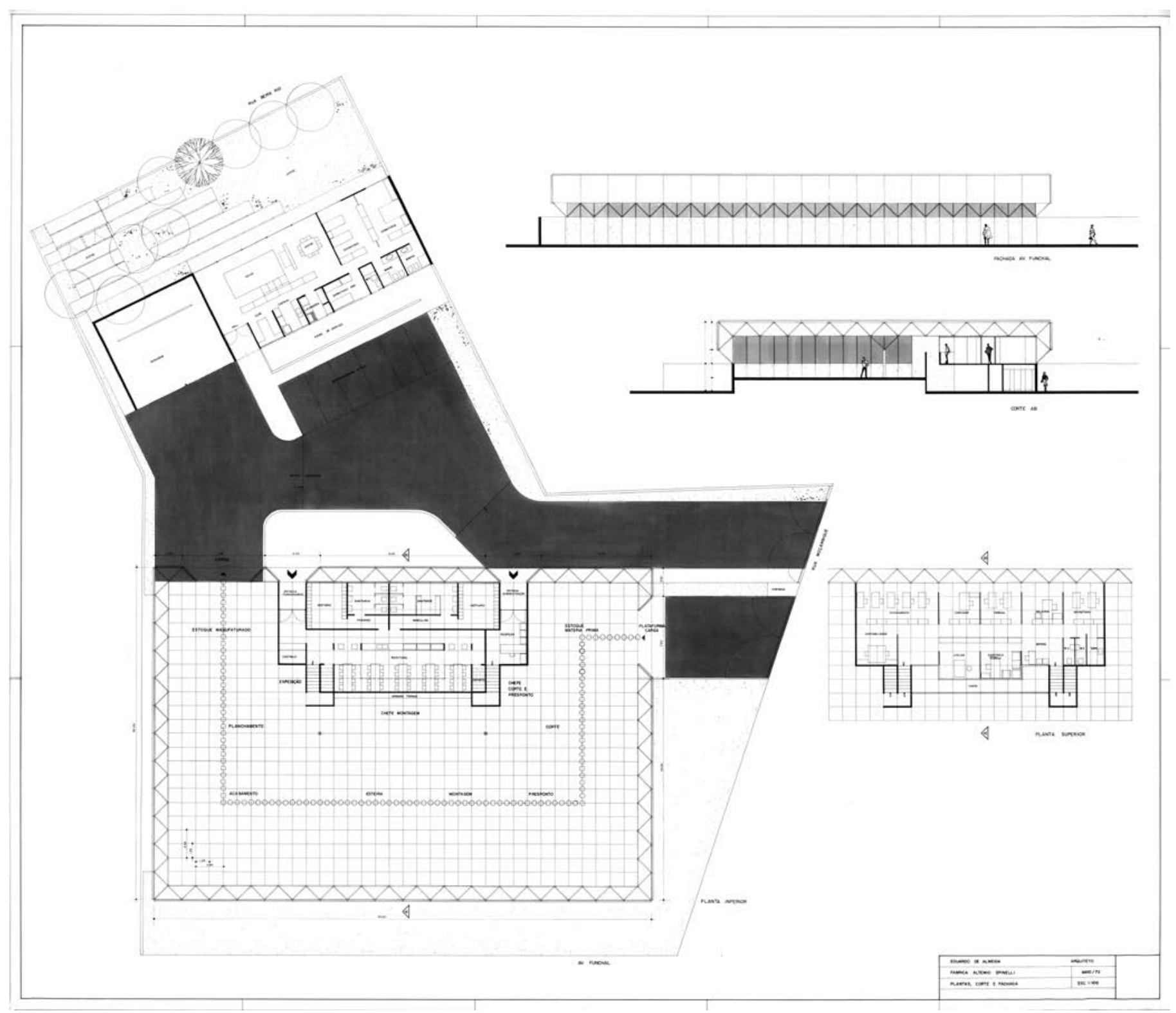


Uso

Edifício de Escritórios

Cliente

Banco Comercial do Paraná

Equipe

Eduardo de Almeida

Localização

Rua do Ouvidor, Rio de Janeiro, RJ

Estágio

Projeto Executivo

Observações

Construído

Características

Edifício de escritórios implantado na área central do Rio de Janeiro, o projeto considera a construção de paredes estruturais junto às divisas permitindo a criação de plantas livres sem pilares. A fachada foi construída com placas de concreto pré-moldado com acabamento texturizado, talvez influênciado por projetos do arquiteto norte-americano Marcel Breuer. Enquanto o pavimento térreo utiliza fechamentos de vidro temperado, a solução dada aos demais pavimentos segue 0 padrão da caixilharia de alumínio Fichet com persianas internas, moduladas de acordo com os painéis de concreto. Especial atenção foi dada ao desenho das empenas junto às fachadas que permite um encontro respeitoso com os edifícios vizinhos.
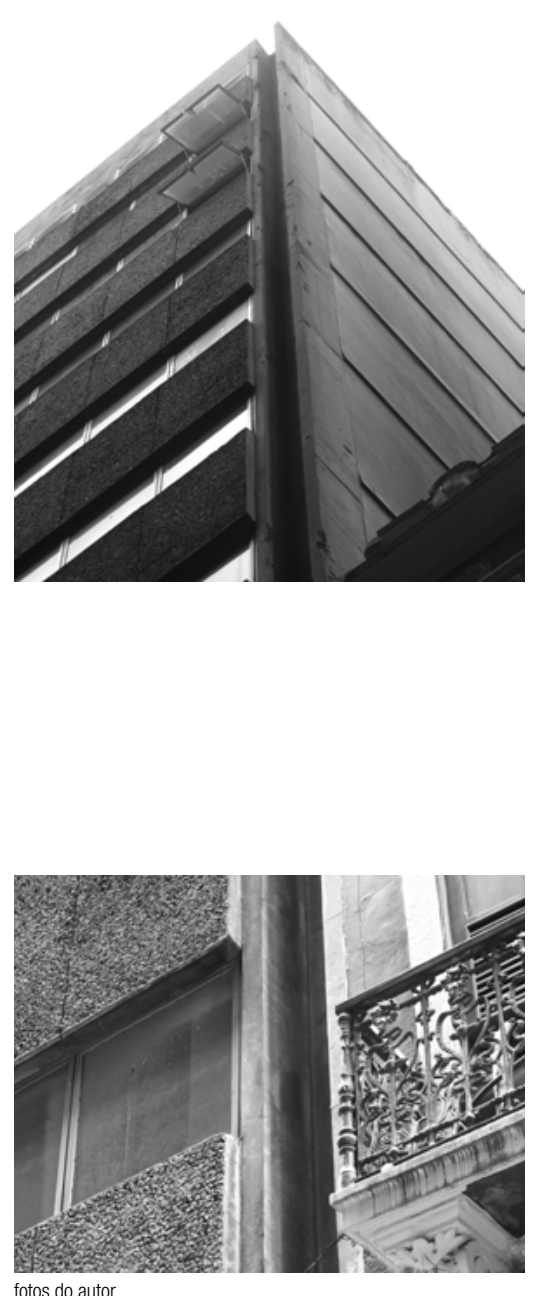

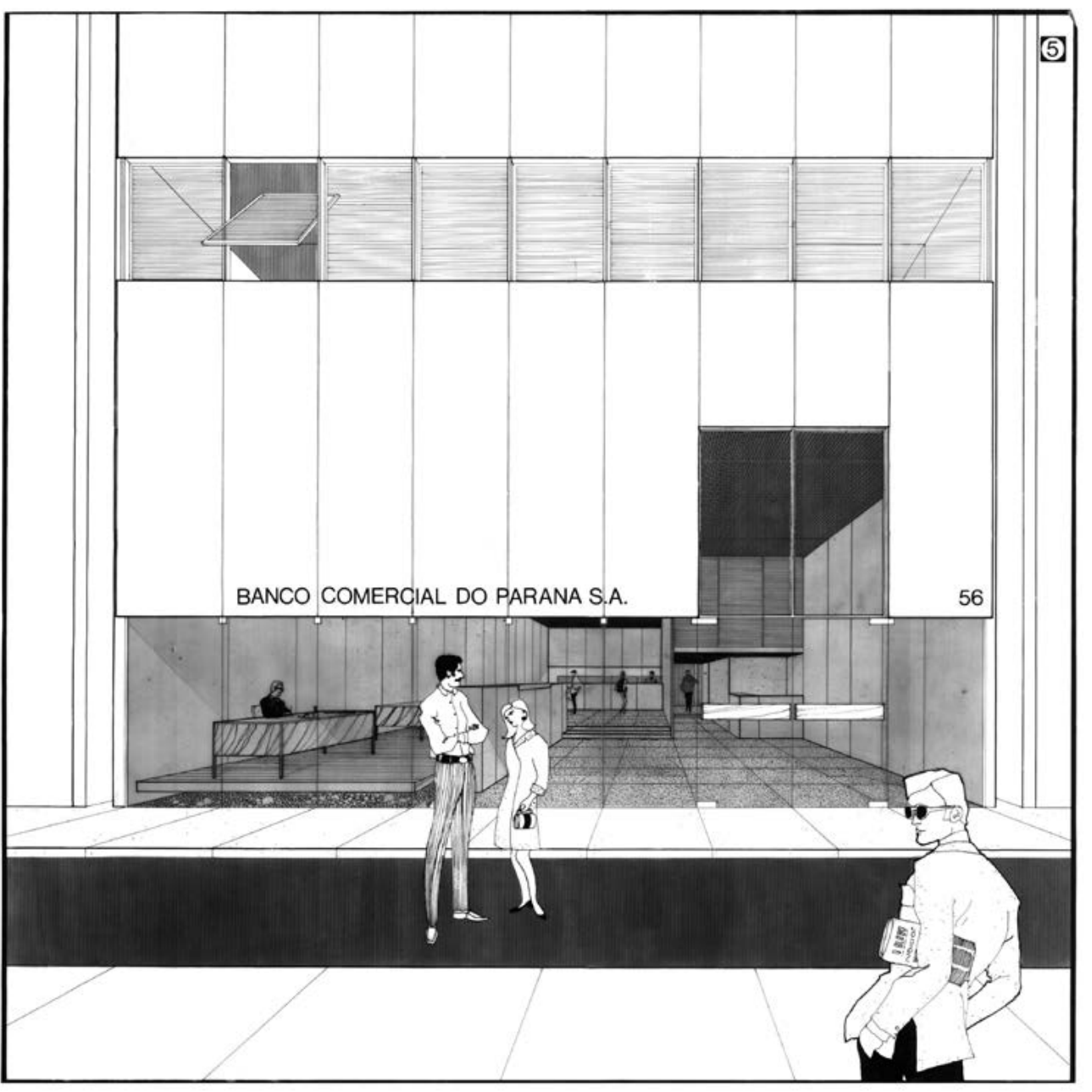


Uso

Sistema para criação de casas em grande escala

Cliente

Construtora Formaespaço

Equip

Eduardo de Almeida

Localização

Granja Viana, São Paulo, SP

Estágio

Projeto Executivo

Observações

Projeto parcialmente construído

Características

Conjunto habitacional realizado pela Construtora Formaespaço com plano urbanístico de Fábio Penteado e projetos das residências realizados por diversos arquitetos. A proposta de Eduardo de Almeida para a criação de casas produzidas em grande escala $e$ adaptáveis às especificidades de cada lote, baseouse em módulos quadrados $(6,40 \mathrm{~m} \times 6,40 \mathrm{~m})$ capazes de abrigar os setores destinados aos quartos, aos ambientes de estar, à garagem e outro para a cozinha e serviços. Construídos em estrutura de concreto armado associada a vedos de blocos de concreto aparente, tais módulos poderiam ser associados lateralmente ou verticalmente de diferentes maneiras, permitindo articulações variadas de acordo com a orientação, a topografia ou até mesmo com a disposição funcional desejada. Elementos secundários como escadas, lavabos ou lareiras também foram projetados como componentes e, dispostos de acordo com cada projeto permitindo ampliar a diversidade de soluçōes.

Acervo

Tubo 14 e Caixa 300

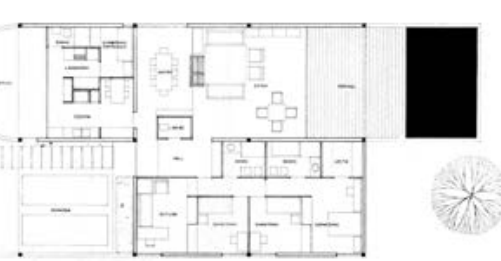

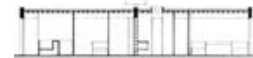

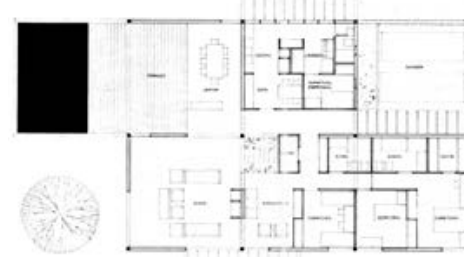

14

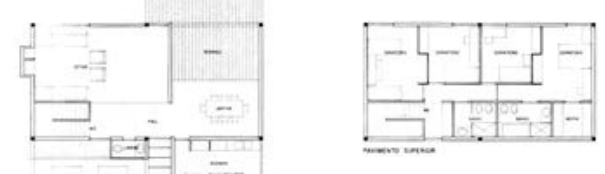

当的穴

$-\quad=-\frac{1}{1-2}$

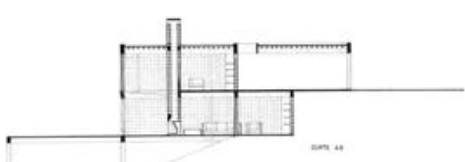

प⿴囗十
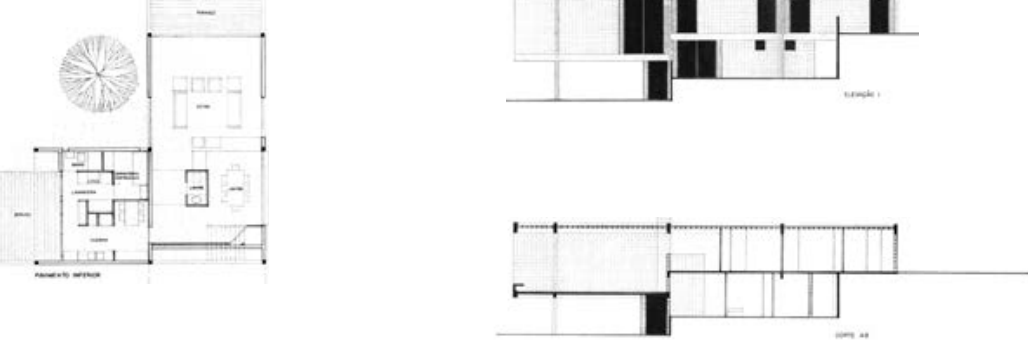

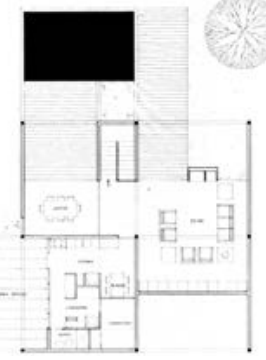

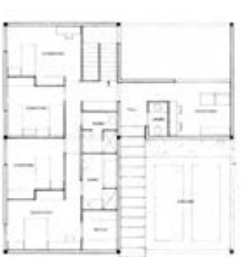

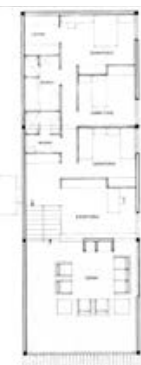


Uso

Edifício de Consultórios Médicos

Cliente

José Leon Spiwak

Equipe

Eduardo de Almeida

Localização

Rua Três Rios 131, Bom Retiro, São Paulo, SP

Estágio

Projeto Executivo

Observações

Construido

Características

Edifício de consultórios encomendado pelo engenheiro José Leon Spiwak - também responsável pela obra da segunda casa de Eduardo de Almeida, na Rua Carangola - para atender a solicitação de um grupo de médicos. Partindo das divisas do terreno, o edifício verticaliza-se por meio de uma estrutura composta por oito pilares periféricos desenhados em conjunto com as paredes de alvenaria, possibilitando a criação de duas salas flexiveis associadas a uma torre central de circulação vertical. Articulado em uma relação de meio-nível, o pavimento térreo levemente elevado em relação à rua, permite a existência de um espaço comercial e fácil acesso aos subsolos.

Externamente, a volumetria do edifício destaca-se pelas empenas laterais salientes, seguindo 0 alinhamento da rua, e pelo conjunto de brises horizontais de alumínio associados às vigas de borda de cada andar e destacados da caixilharia.

Acervo

Tubo 2
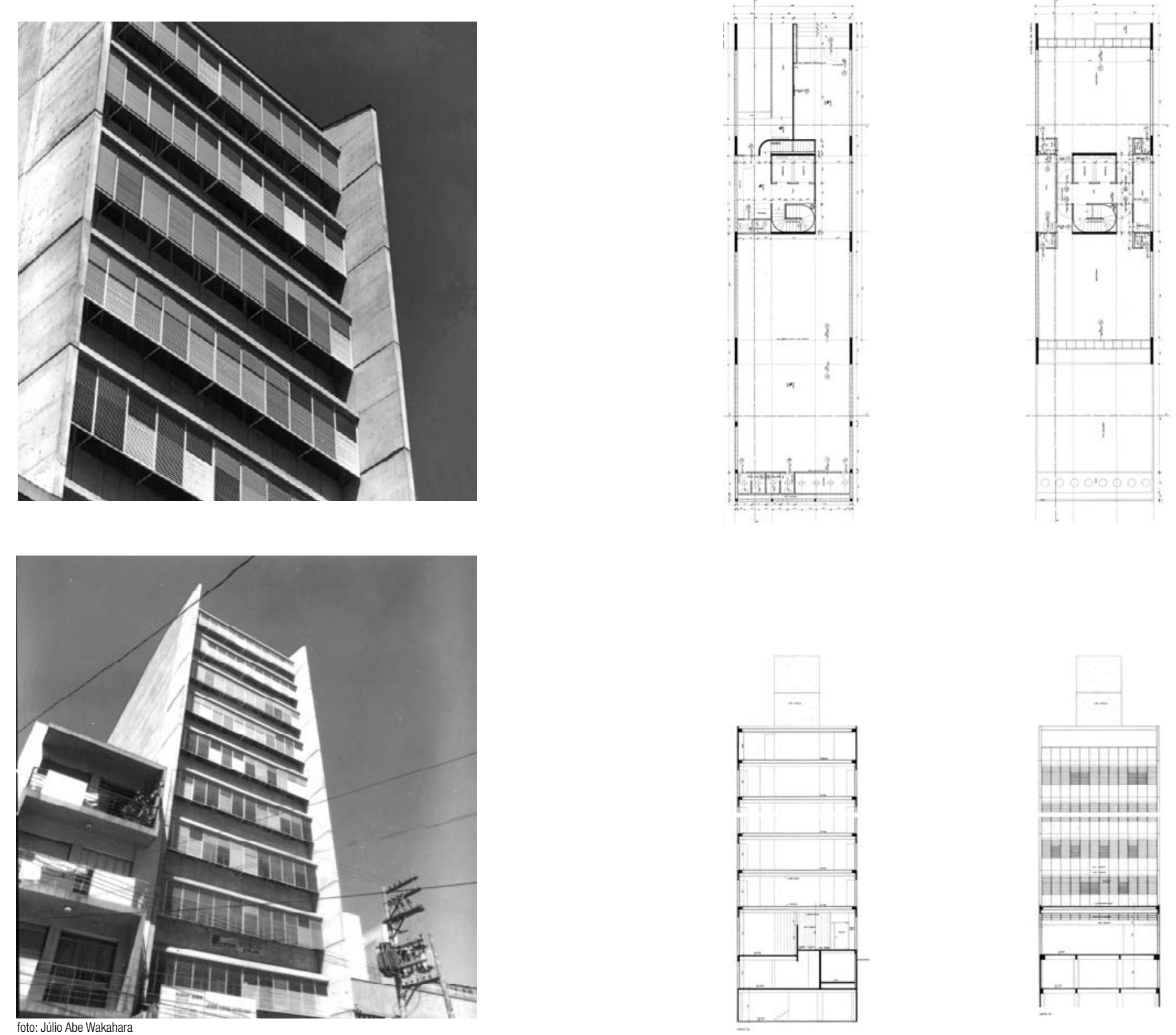
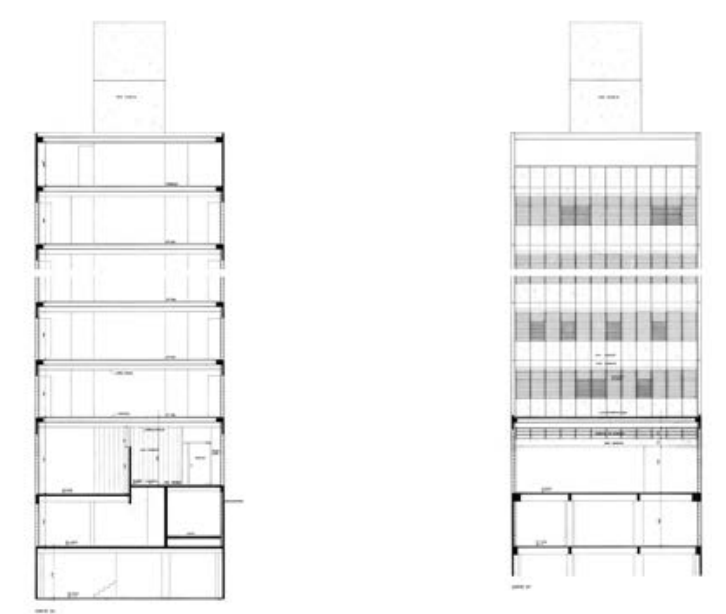
Edifício de Escritórios

Cliente

Construtora Formaespaço

Equipe

Eduardo de Almeida

Localização

Rua Canário, São Paulo, SP

Estágio

Anteprojeto

Observações

Não Executado

\section{Características}

Encomendado pela Construtora Formaespaço, este edifício de quatro pavimentos destinado a abrigar sua sede foi pensado a partir da coordenação modular entre a malha estrutural de concreto armado, a modulação da alvenaria de blocos aparentes, a caixilharia de alumínio e demais elementos que compõem a construcãa. Especial atenção à perspectiva isométrica realizada por Especial atenção à perspectiva isométrica realizada por Edo sistema construtivo a partir do detalhamento de um único módulo junto ao balanço frontal do edifício Gradativamente 0 detalhe desaparece, sem deixar de insinuar a volumetria do todo.

Acervo

Caixa 3600
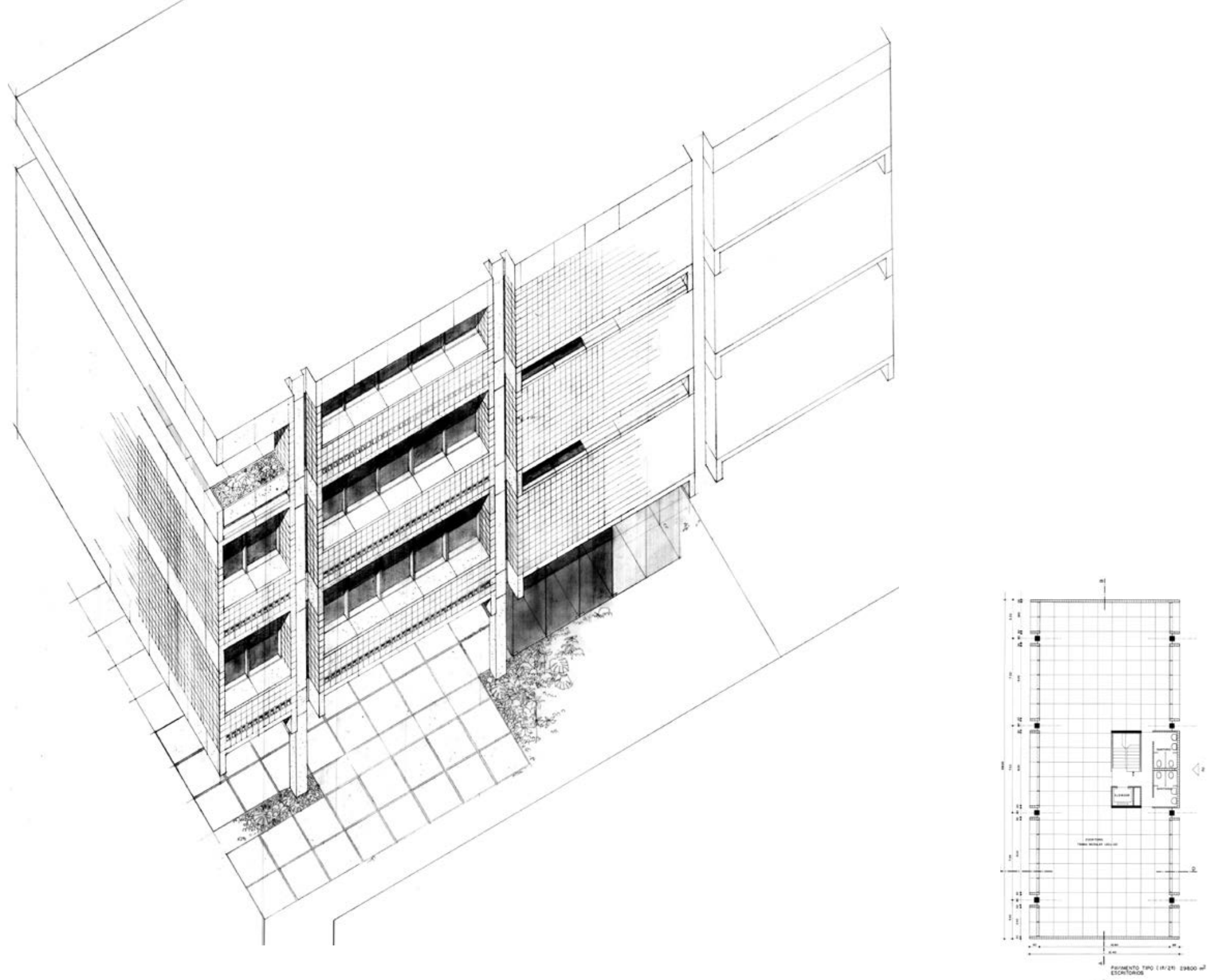
Uso

Edifício de Escritórios

Cliente

Banco Safra

Equipe

Eduardo de Almeida e Henrique S. Pait

Localização

Av. Paulista, São Paulo, SP

Estágio

Estudo Preliminar

Observações

Não Construído

\section{Características}

Estudo para edifício administrativo do Banco Safra na Av. Paulista na esquina com a Rua Augusta. A solução proposta se utilizava de fachadas curvas desencontradas que propiciavam a criação de jardim laterais em cada um dos pavimentos. 0 pavimento térreo considerava acessos pelas duas ruas, aproveitando o desnível existente. Um segundo estudo preliminar foi apresentado com a solução de uma torre de circulação vertical e sanitários assimétrica, de acordo com uma modulação mais regular.

Acervo

Tubo 7

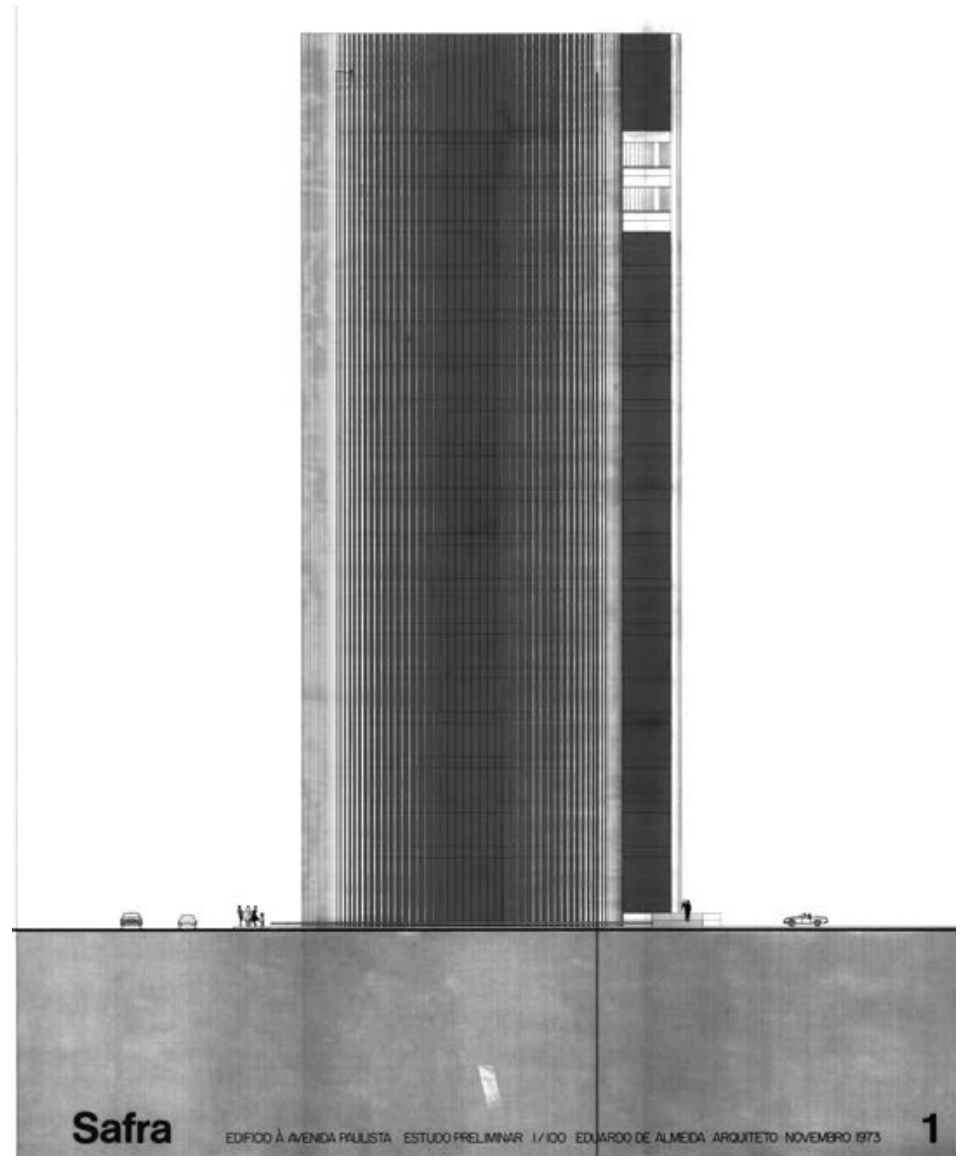

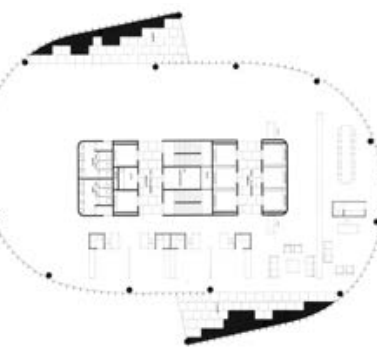

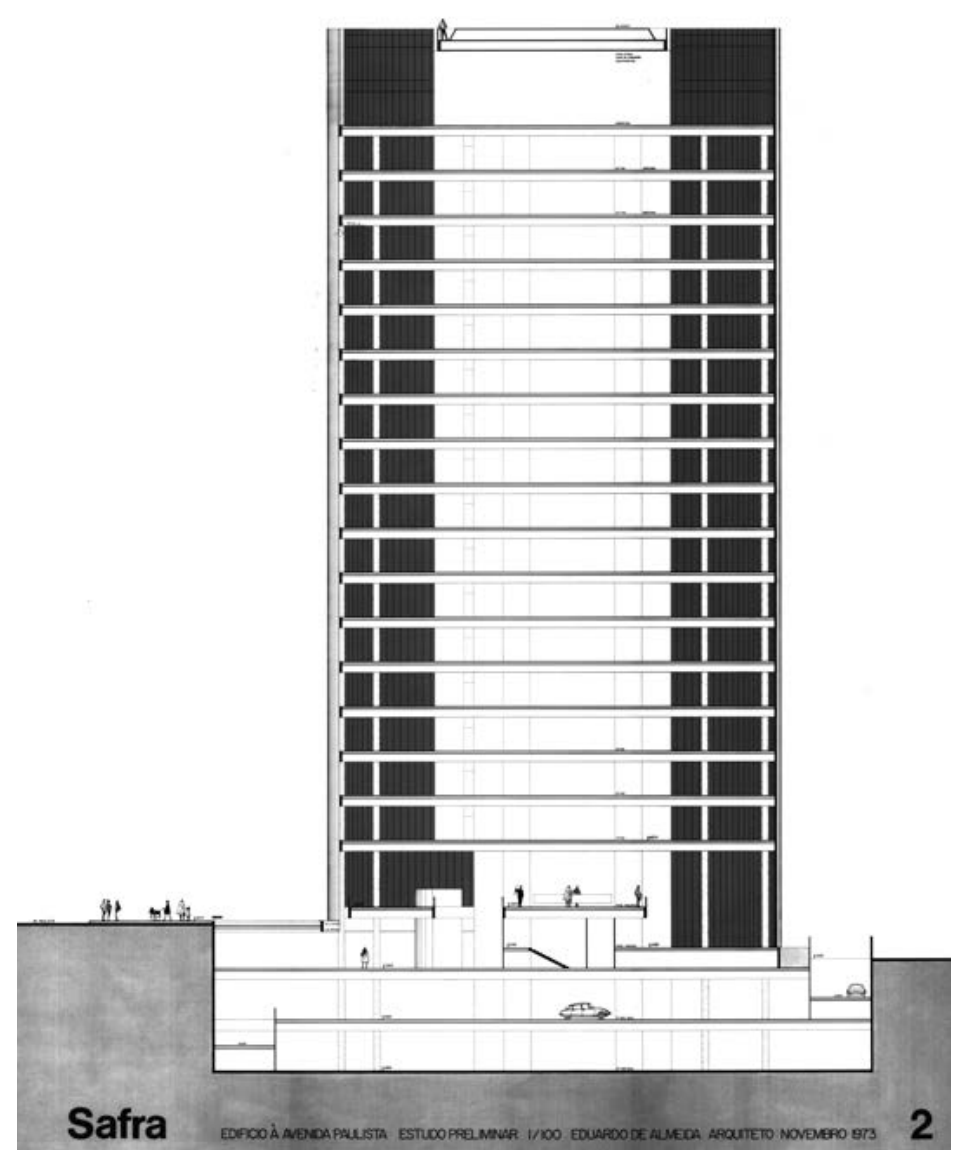


Uso

Residência Unifamiliar

Cliente

Jean Sigrist

Equipe

Eduardo de Almeida

maquete e desenhos I José Antônio Seixas

Localização

Rua David Pimentel 84, Morumbi, São Paulo, SP

Estágio

Projeto Executivo

Observações

Construído

\section{Características}

Essa residência se destaca por sua implantação radical na acentuada topografia deste lote. Segundo o depoimento do autor, tal partido arquitetônico surgiu após a constatação de que as construcões vizinhas ignoravam as características do terreno e impunham a implantação de blocos isolados no centro do lote. Desta forma a casa se organiza em patamares específicos a cada função, enquanto o plano inclinado da cobertura reconstitui a declividade original do terreno. Os espaços semienterrados se voltam a amplos terracos em cad um dos pavimentos, garantindo a qualidade dos espacos internos.

Acervo

Tubo 50, 50 A, 50 B e $50 \mathrm{C}$
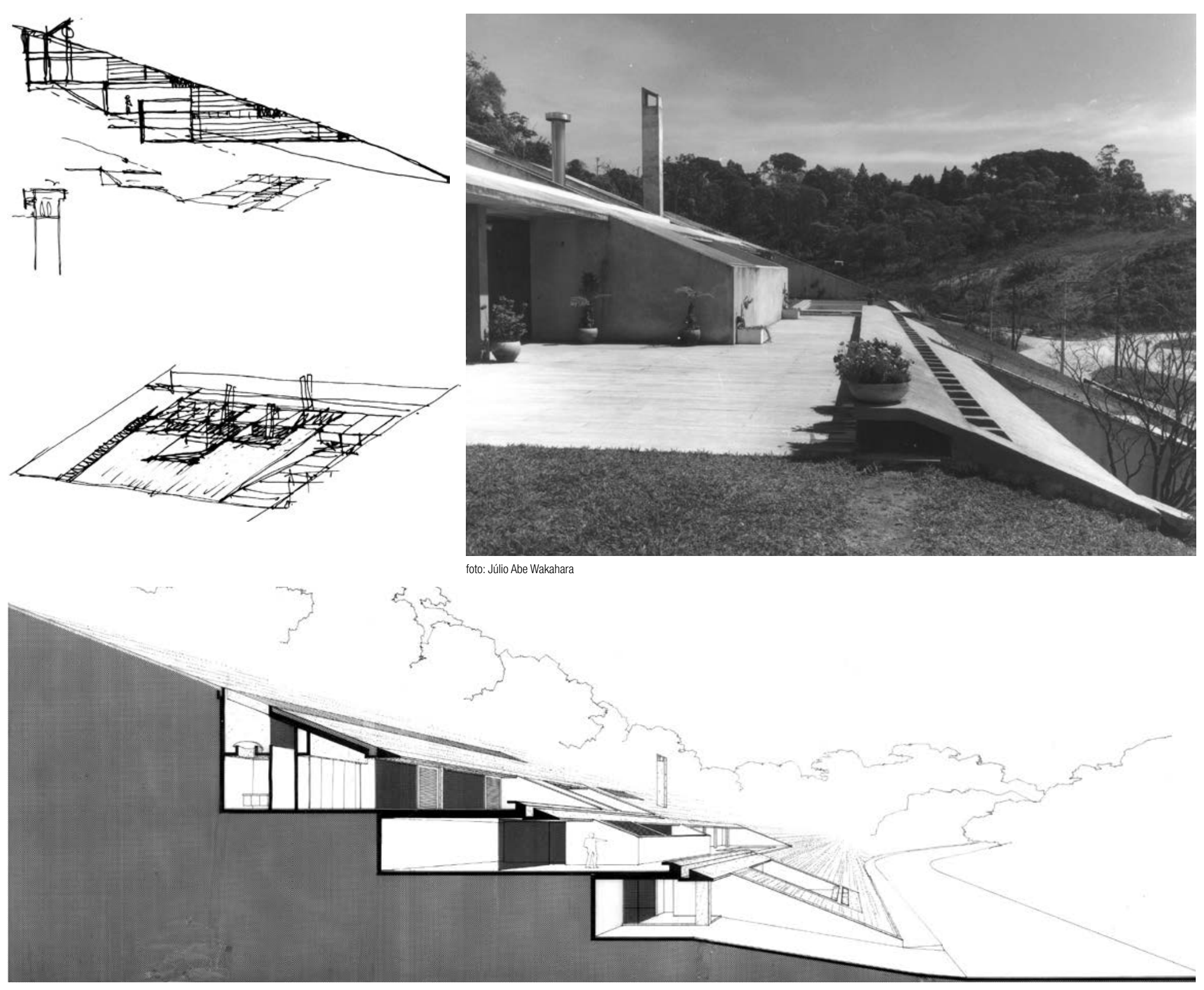
Uso

Residência Unifamiliar

Cliente

Pedro Tassinari

Equipe

Eduardo de Almeida

Localização

Praia da Baleia, São Sebastião, SP

Estágio

Projeto Executivo

Observações

Construído

Características

Seguindo a mesma linguagem adotada em outras obras - pavilhões com cobertura inclinada associados por lajes de concreto de conexão - este projeto destaca-se pela organizacão dos programas ao redor de um pátio central, solucão utilizada em importantes proietos realizdos posteriomente conn a Casa Define (1975) ou a Sede da Fazenda Água Comprida (1998). Neste caso, a disposição dos volumes cria aberturas deslocadas em direção ao exterior em cada um dos vértices do jardim, sempre demarcadas pelos pilares duplos que, assimetricamente, configuram 0 vazio central densamente arborizado, adequado ao clima e à paisagem natural circundante.

Acervo

Tubo 65 e 65 A
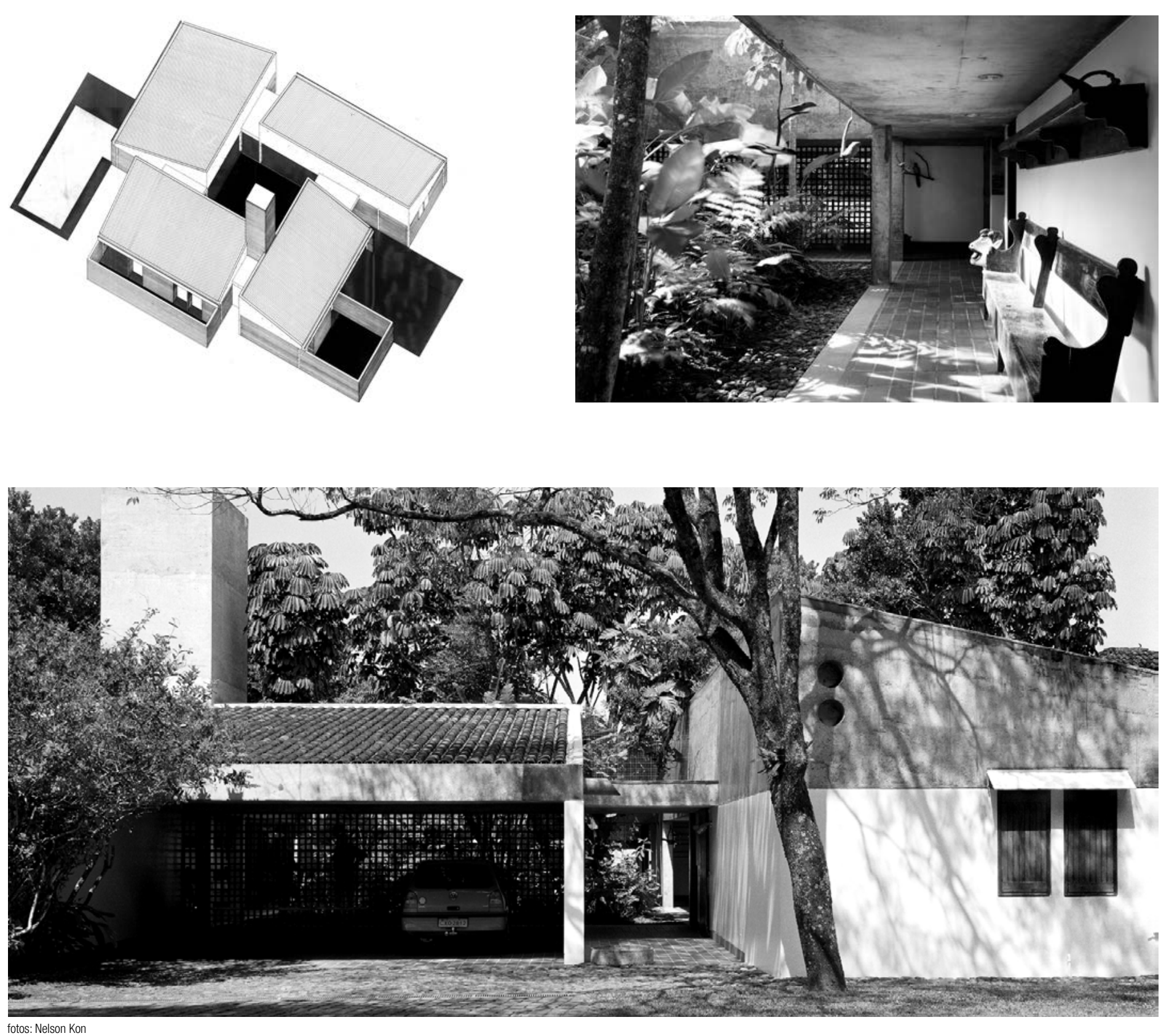
Uso

Residência Unifamiliar

Cliente

Pedro Tassinari

Equipe

Eduardo de Almeida

colaboradores I José Antônio Seixas, Maria Isabella de

Almeida e Yolanda Akamine

estrutura I Faustino Máximo da Silva

paisagismo I Célia Tassinari

Localização

Praia da Baleia

Estágio

Projeto Executivo

Observações

Construído

Características

Posicionado em continuidade a uma das aberturas

criadas junto ao pátio central, este anexo viabiliza

a criação de um novo dormitório com sala de estar e

escritório para os proprietários da casa, além de um

salão para jogos. Utilizando a mesma técnica construtiva

do edifício original, a ampliação dá-se de modo discreto

e, utilizando movimentação topográfica, possibilita vistas

privilegiadas em relação ao mar.

Acervo

Tubo 65 e 65 A

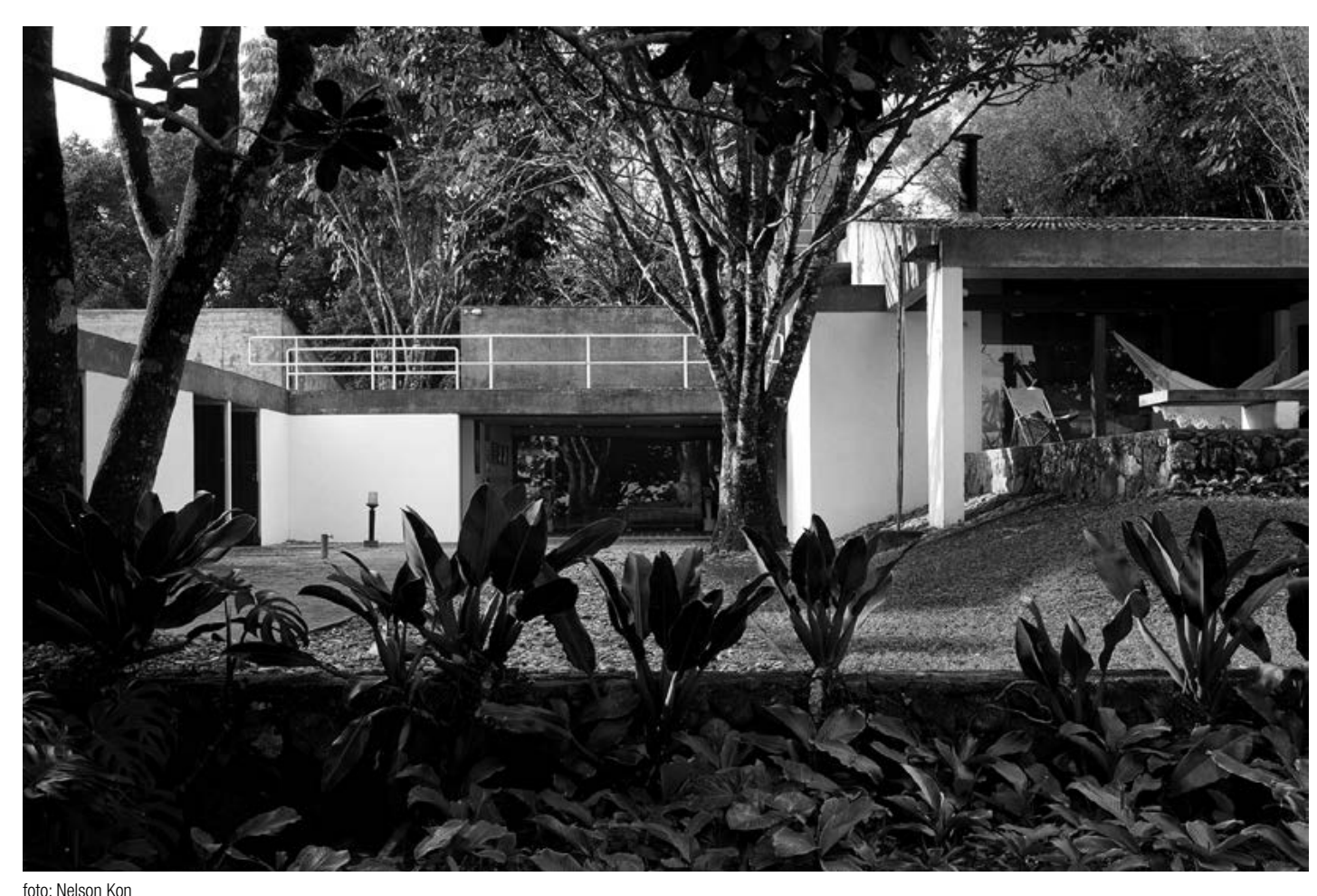

foto: Nelson Kon
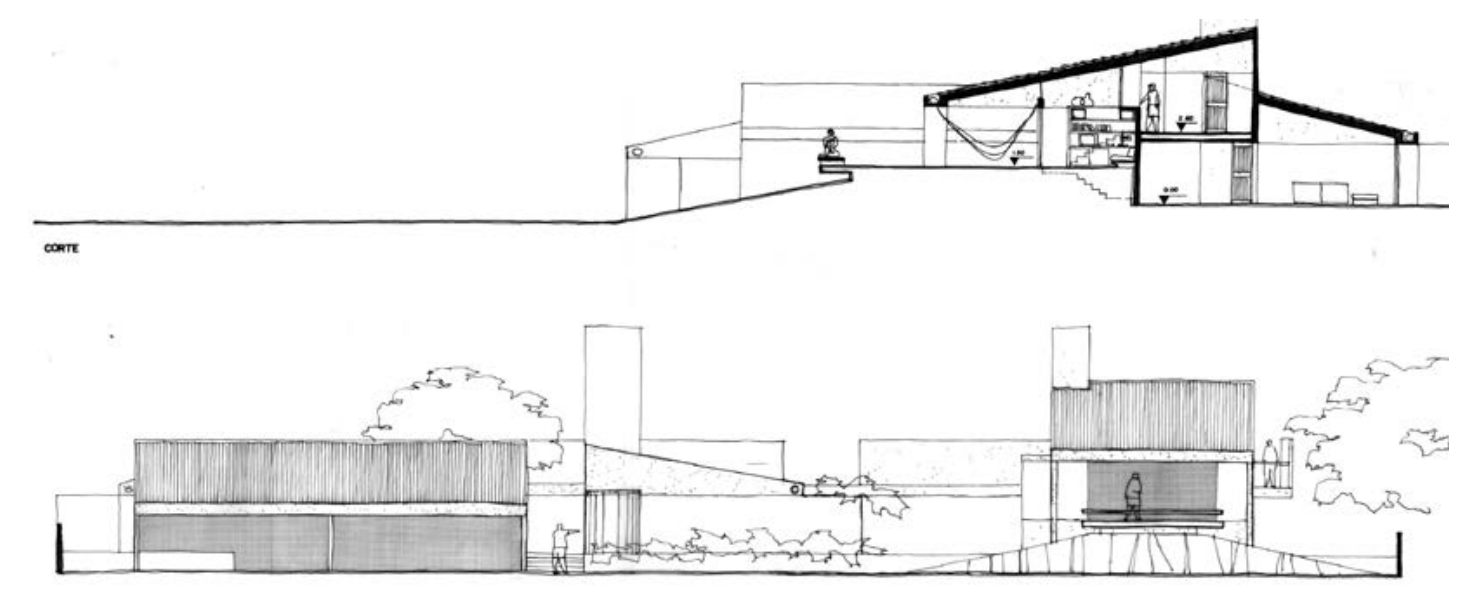
Uso

Conjunto - Fábrica

Cliente

Morlan

Equipe

Eduardo de Almeida

Localização

Orlândia, SP

Estágio

Projeto Executivo

Observações

Construído

\section{Características}

Encomendado por Pedro Tassinari, o projeto para a Metalúrgica Orlândia consiste em um plano para a ocupação de uma grande gleba para a implantação de todos os edifícios necessários ao funcionamento da indústria. Ao longo de 15 anos foram desenvolvidos os projetos para o galpão industrial, áreas de vestiários refeitório, edifício administrativo, clube destinado aos funcionários e, por fim, para o Centro de Processamento de Dados da empresa.

Posteriormente, para o mesmo cliente, foi projetado o edifício de escritórios em São Paulo.

Acervo

Tubo 64 D
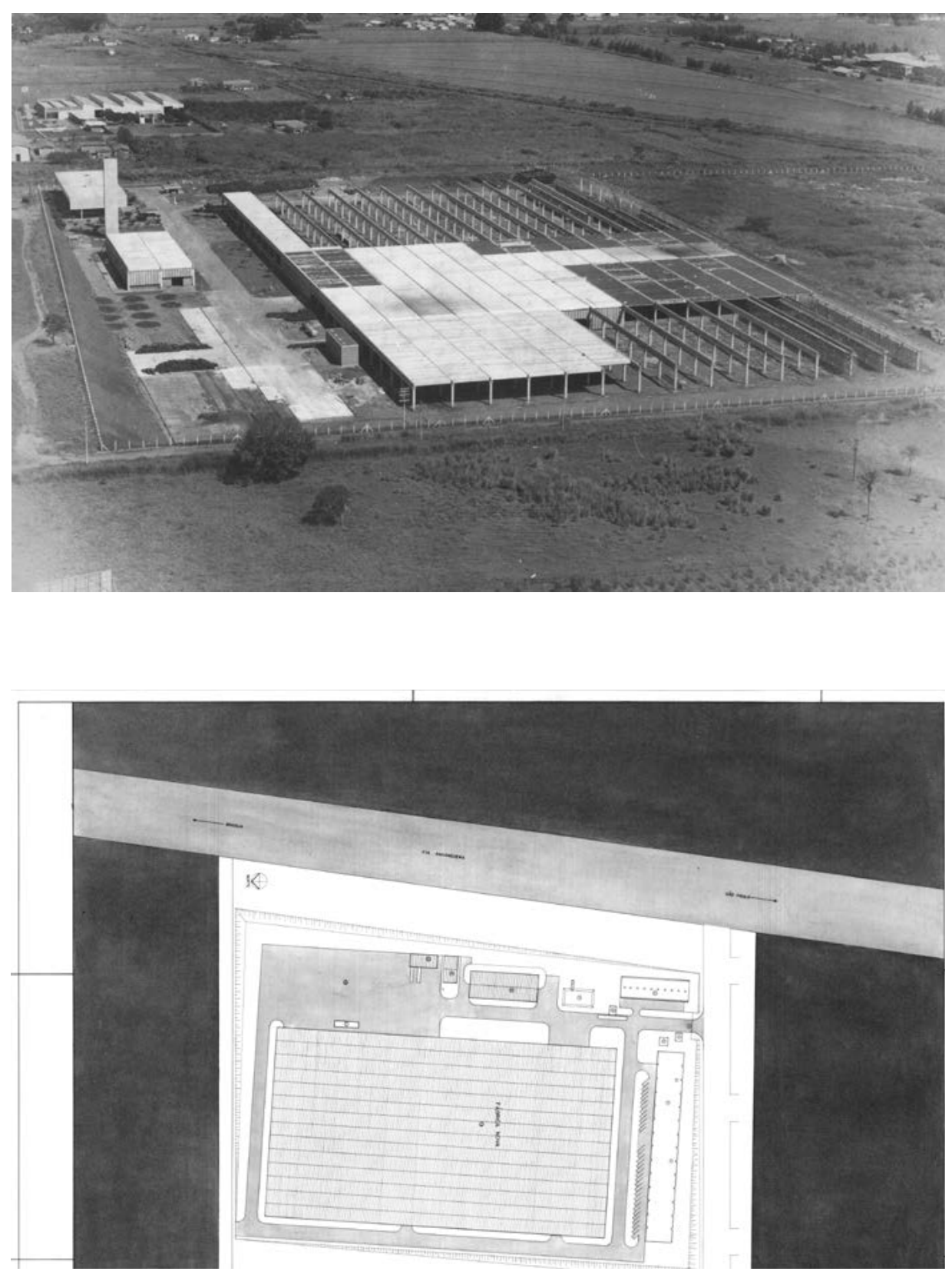

(1) 
Uso

Galpão industria

Cliente

Morlan

Equip

Eduardo de Almeida

Localização

Orlândia, SP

Estágio

Projeto Executivo

Observações

Construído

Características

0 projeto para 0 galpão previa a construção de uma estrutura pré-moldada de concreto modulada em vãos de $10 \times 10$ metros. Tal desenho permitiu a implantação inicial parcial da indústria e seu posterior crescimento de acordo com o planejamento da empresa, até atingir o tamanho final com cerca de 35.000 metros quadrados.

Este projeto considera a implantação de núcleos de apoio também modulados capazes de solucionar sanitários e reservatórios distribuídos ao longo da planta industrial. Além das vigas e telhas pré-moldadas de concreto, Eduardo de Almeida também utiliza tellas de fibrocimento posicionadas verticalmente, elementos de fachada produzidos industrialmente capazes de proteger o espaço interno e garantir sua ventilação natural.

Acervo

Tubo 64
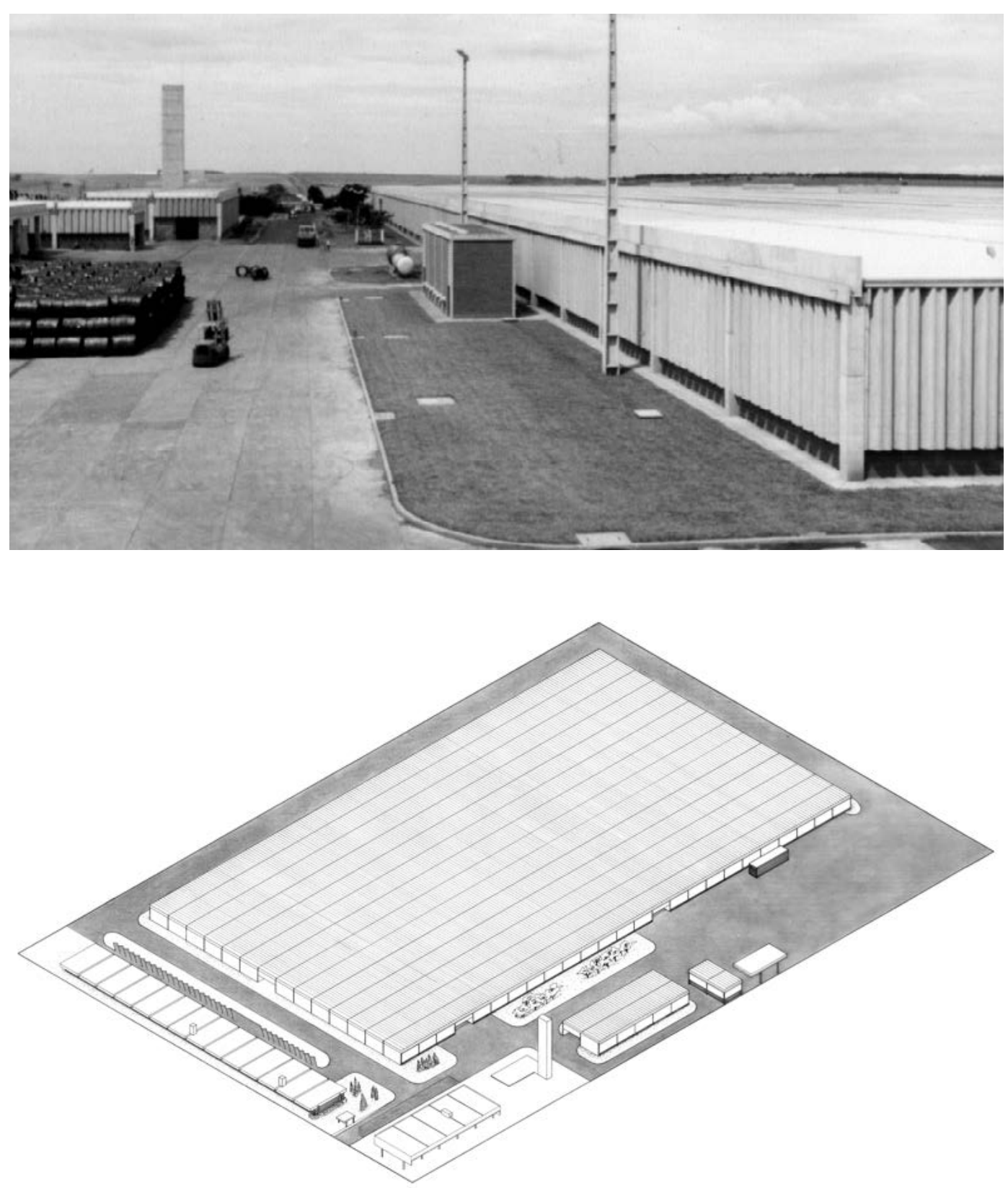
Uso

Edifício Administrativo

Cliente

Morlan

Equipe

Eduardo de Almeida

Localização

Orlândia, SP

Estágio

Projeto Executivo

\section{Observações}

Construído

\section{Características}

Também posicionado junto ao acesso do complexo, o

edifício administrativo de três pavimentos - subsolo,

térreo e superior - foi construído com uma estrutura

de concreto armado moldado in loco, a partir de duas

linhas de pilares e vigas duplas dotadas de grandes

balanços. Tal solução, reforçada pelos grandes beirais

e empenas cegas laterais, faz referência às obras da

Escola Paulista, sobretudo à residência de Paulo Mendes

da Rocha no Butantã.

Acervo

Tubo $64 \mathrm{D}$
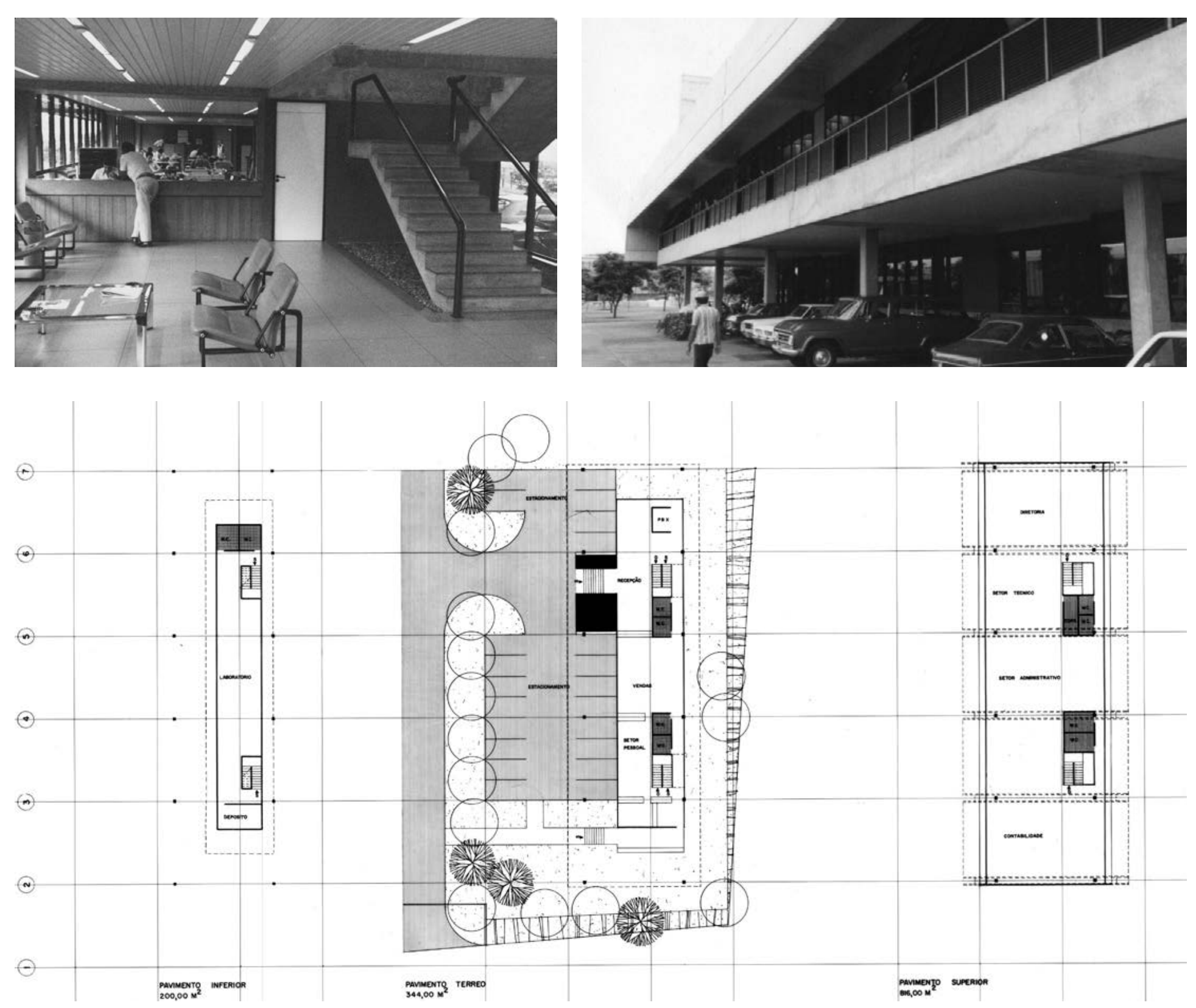

(1) 
Uso

Refeitório, vestiários e ambulatório

Cliente

Morlan

Equipe

Eduardo de Almeida

Localização

Orlândia, SP

Estágio

Projeto Executivo

Observações

Construído

\section{Características}

Seguindo a mesma modulação da planta industrial, 0

edifício de apoio destinado aos funcionários implanta-

se próximo à portaria de acesso, com um pavimento

e pé-direito de 2,60 metros. Além dos vestiários e do

refeitório também foi desenhado um auditório.

Acervo

Tubo 64 B, Caixa 4810
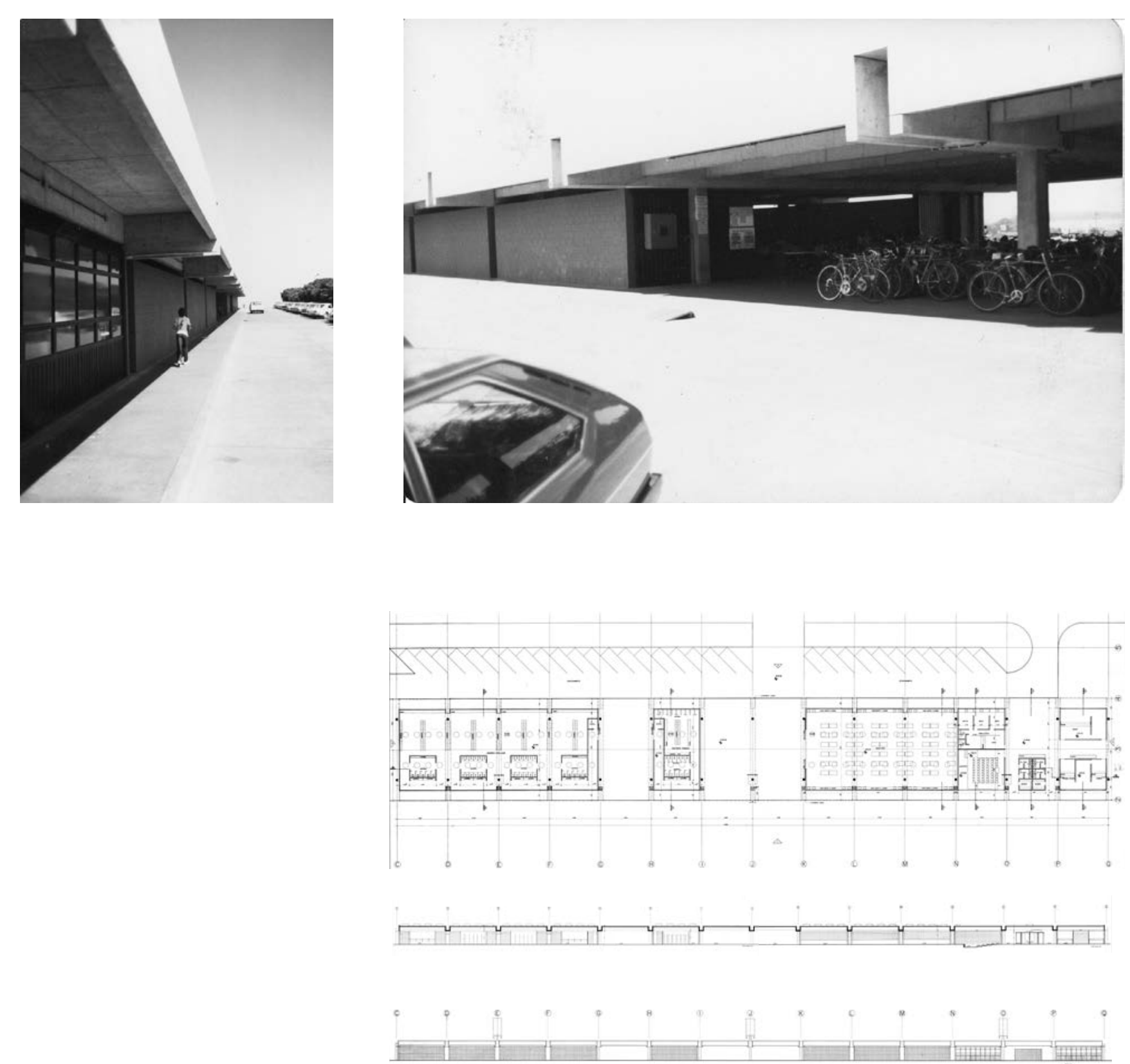
Uso

Cliente

Morlan

Equipe

Eduardo de Almeida

Localização

Orlândia, SP

Estágio

Projeto Executivo

Observações

Construido

\section{Características}

Localizado ao lado da indústria, o projeto para o clube conta com a utilização de coberturas em cascas de concreto armado moldado in loco, desenho que parece contrastar com os demais edifícios do conjunto.

Enquanto o salão principal e a área destinada aos vestiário são compostos por duas cascas associadas por uma viga calha - apoiada em uma linha central de pilares -, a quadra de bocha é composta por um único pavilhão linear implantado paralelamente aos demais.

Este projeto também considera o projeto das piscinas,

do campo de futebol e outros edifícios de apoio, além da alameda de chegada com portaria e estacionamentos.

Acervo

Tubo 64 B, Caixa 4810
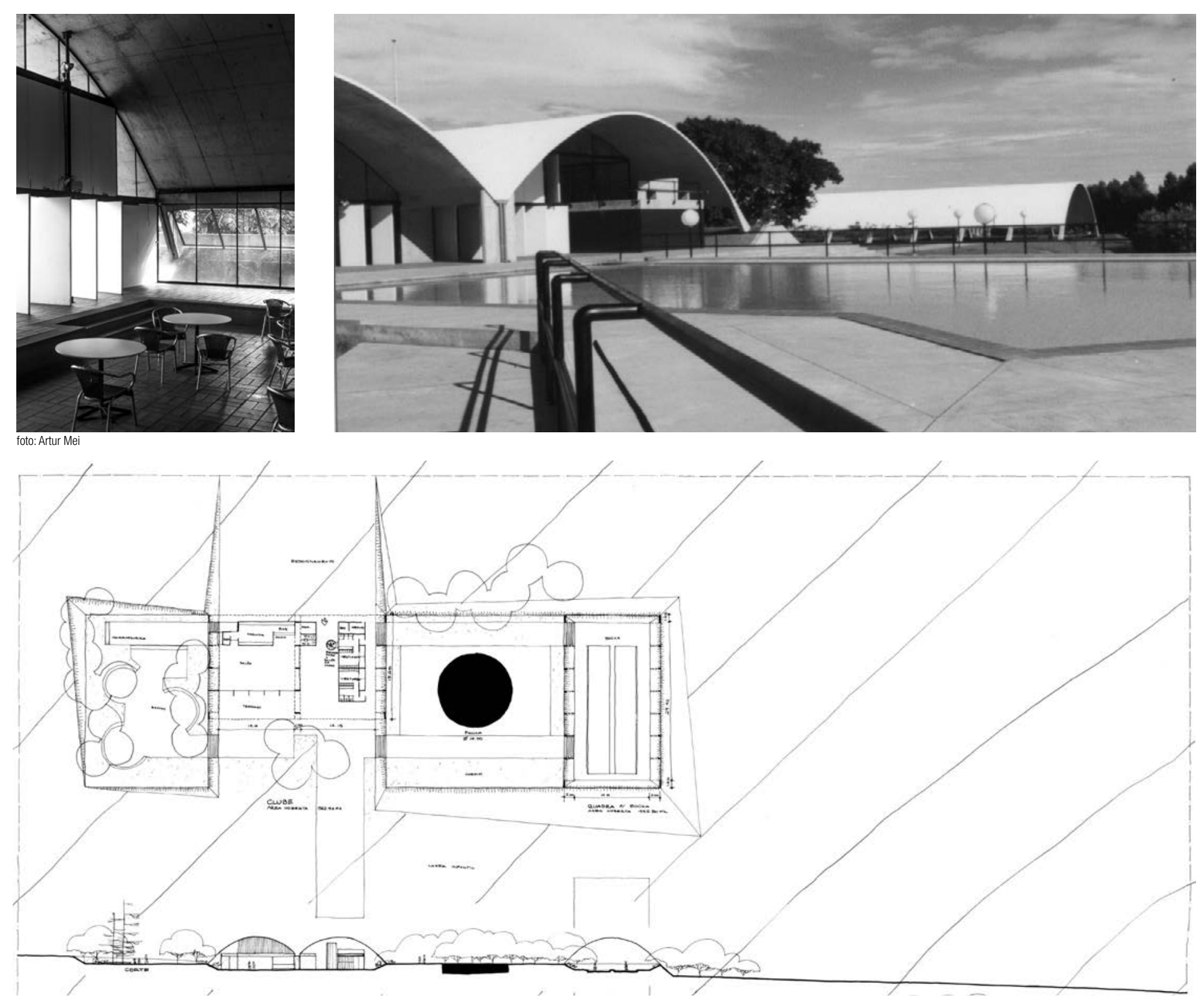

$\ominus$ 
Uso

Vestiários para Campo de Futebol

Cliente

Morlan

Equipe

Eduardo de Almeida

Localização

Orlândia, SP

Estágio

Projeto Executivo

Observações

Construído

Características

Acervo

Tubo 64 B, Caixa 4810
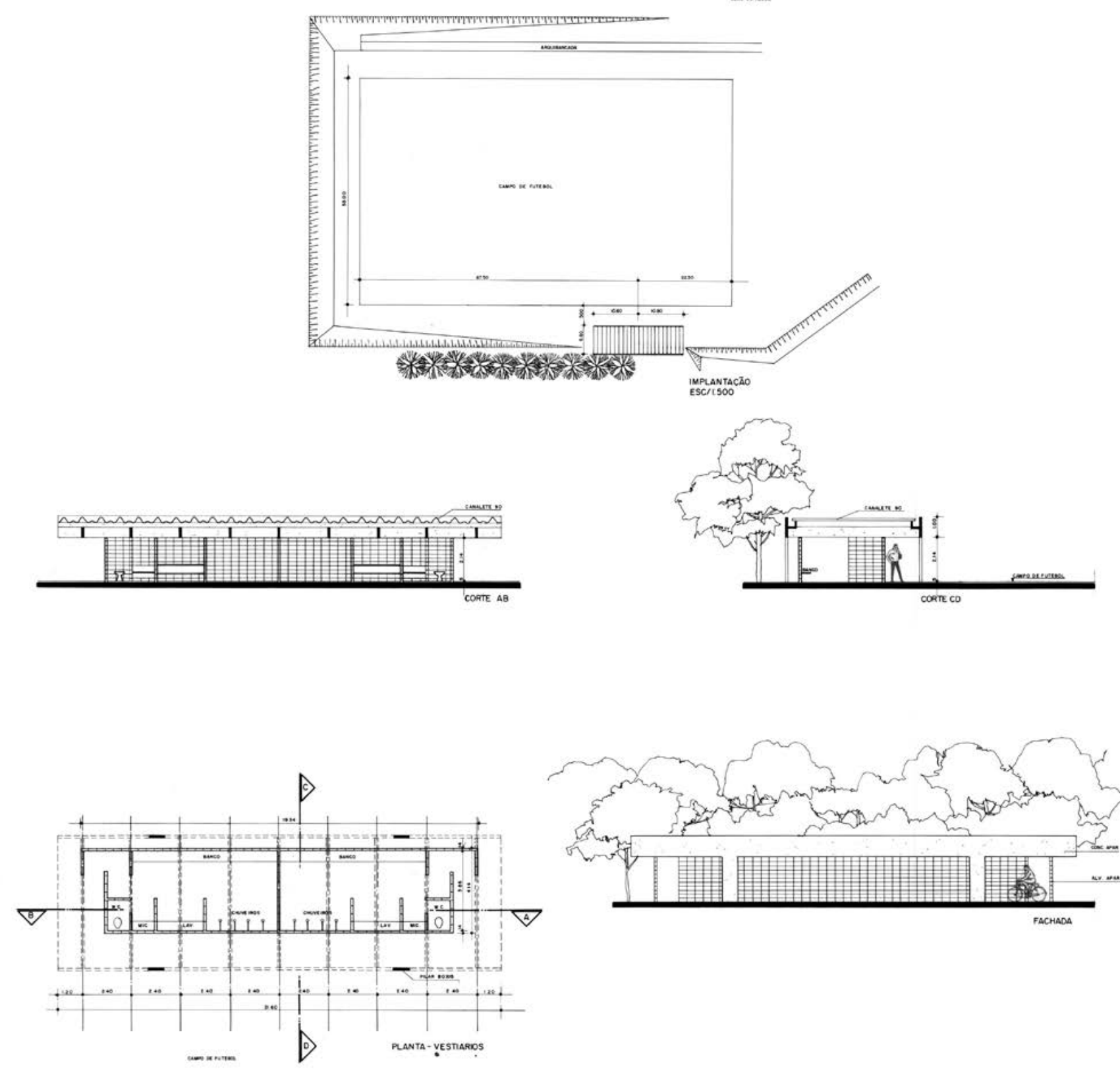
Uso

Centro de Processamento de Dados

Cliente

Morlan

Equipe

Eduardo de Almeida

Localização

Orlândia, SP

Estágio

Projeto Executivo

\section{Observações}

Construído

\section{Características}

Construído posteriormente para prover a infra-estrutura

de informática da empresa, 0 Centro de Processamento

de Dados foi desenhado de maneira semi-enterrado,

próximo ao edifício administrativo. Sua estrutura de

cobertura segue as mesmas soluções do edifício

principal.

Acervo

Tubo 64 B, Caixa 4810
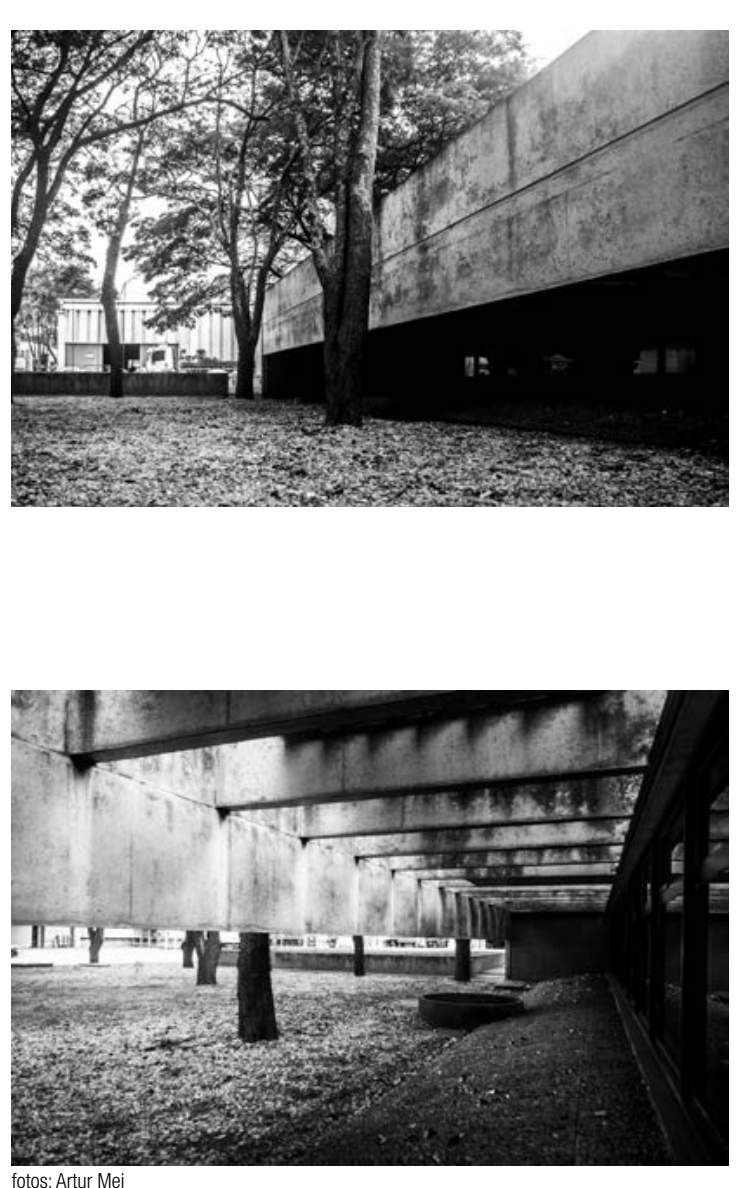
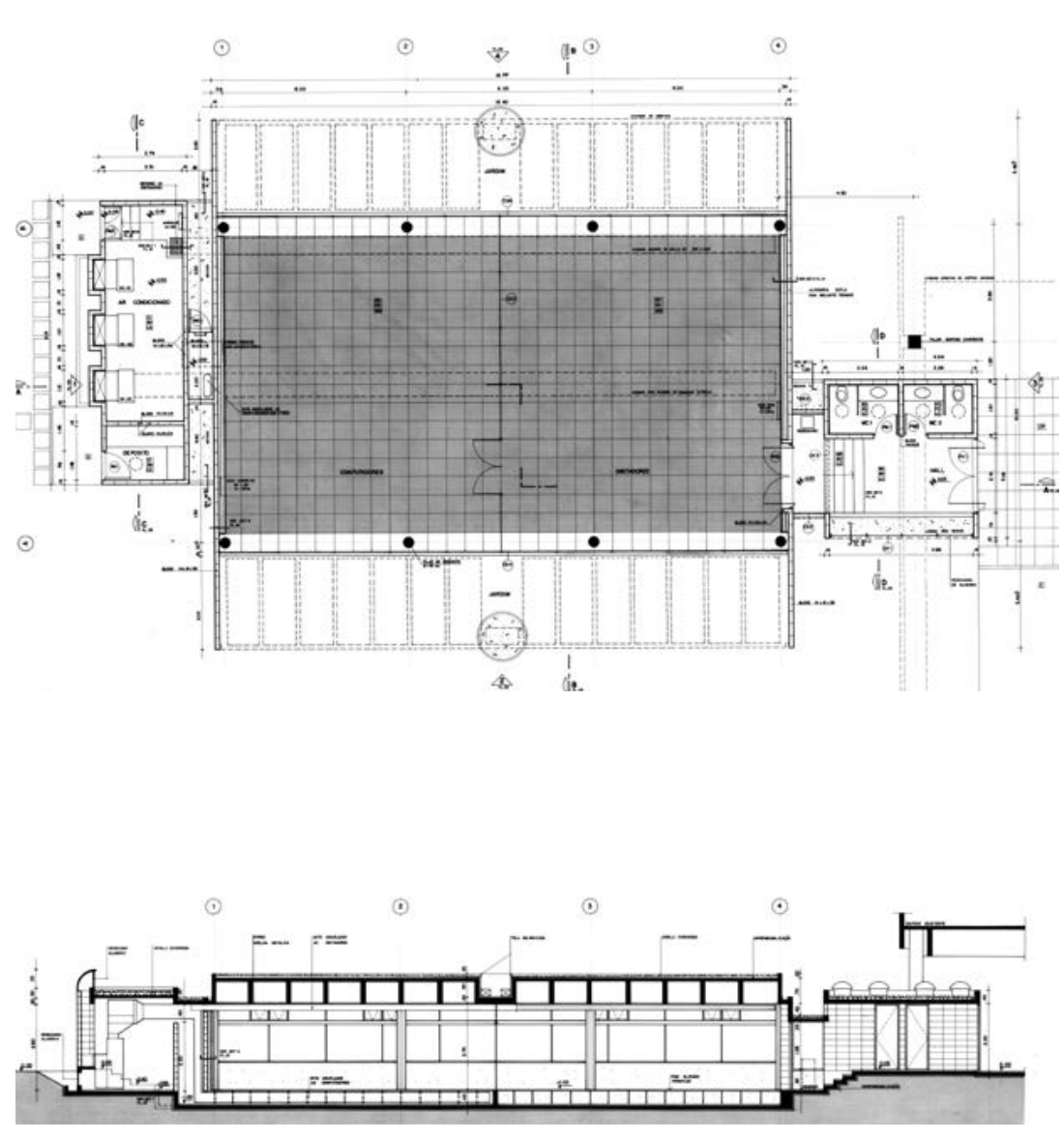
Uso

Loteamento

Cliente

Eugene Gordon

Equipe

Eduardo de Almeida

Localização

Ibiúna, SP

Estágio

Estudo Preliminar

Observações

Não Construído

Características

Atendendo à solicitação de um dos proprietários da

Construtora Formaespaço, Eduardo de Almeida projetou

um loteamento em uma gleba ocupada por uma antiga

fazenda. Além do sistema viário periférico, foi criada

uma rua transversal de acesso a 10 lotes caraterizados

por um pequeno declive em direção ao lago. Na parte

mais alta do terreno, junto a uma grande área destinada

à preservação de um lago menor, estabeleceu-se um

platô para a construção da casa do proprietário do

empreendimento, Eugene Gordon.

Acervo

Tubo 49
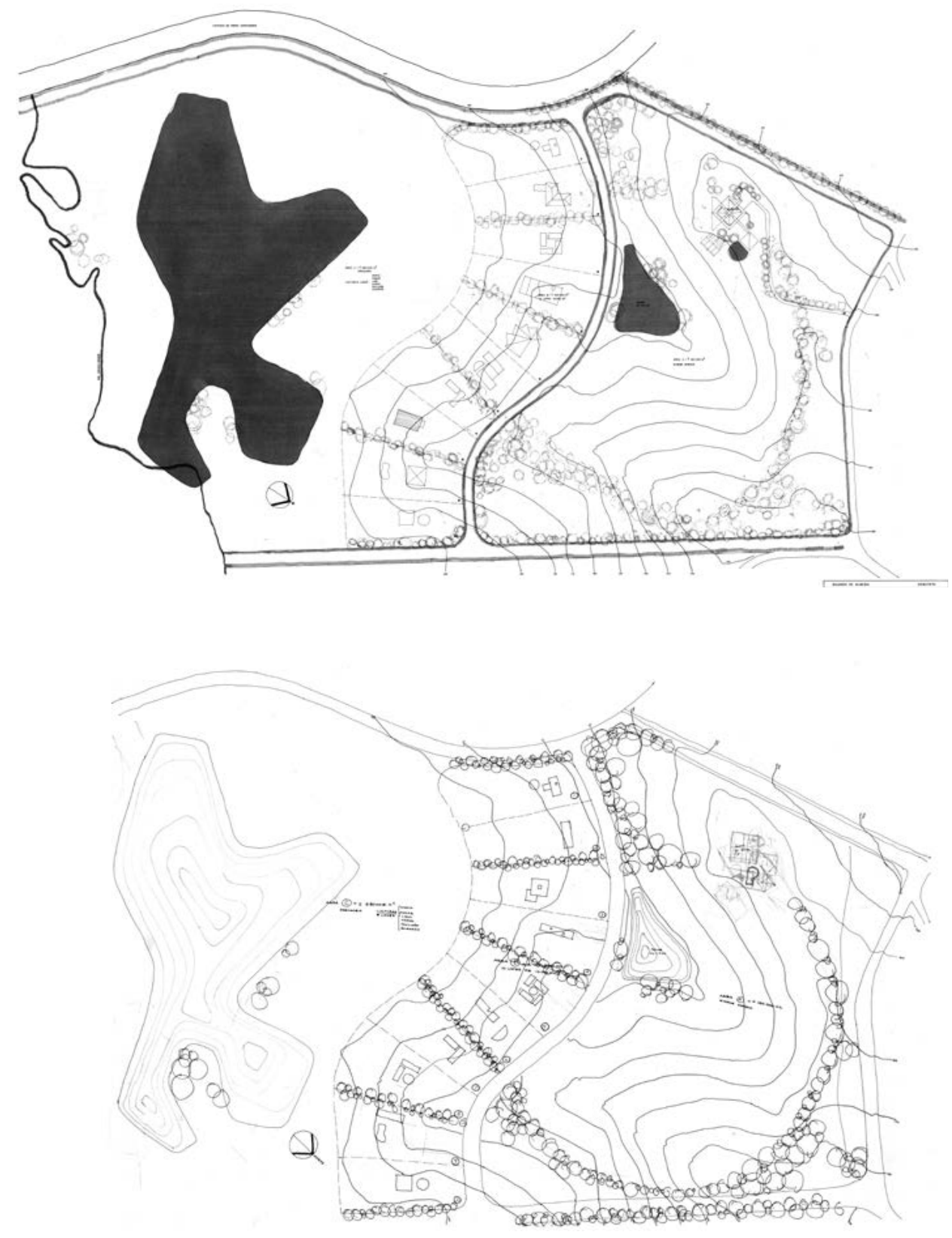
Uso

Residência Unifamiliar

Cliente

Eugene Gordon

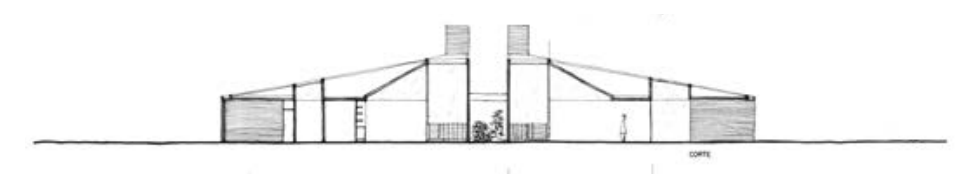

Equipe

Eduardo de Almeida

Localização

Ibiúna, SP

Estágio

Estudo Preliminar

Observações

Não Construído

\section{Características}

Foram realizados dois diferentes estudos para a casa de Eugene Gordon.

Enquanto o primeiro utilizava-se de partido semelhante

ao projeto da Casa na Baleia, com quatro blocos com

cobertura inclinada de uma água, organizados ao redor

de um pátio central; 0 segundo projeto criava uma

composição geométrica de quatro volumes de planta

quadrada que, somados, conformavam um quadrado

de grandes dimensões entrecortado por um vazio

cruciforme, ora utilizado como circulação transversal,

ora utilizado como jardim. 0 conjunto de quatro

salas centrais também contava com quatro lareiras

posicionadas diagonalmente às áreas de estar.

Acervo

Tubo 49
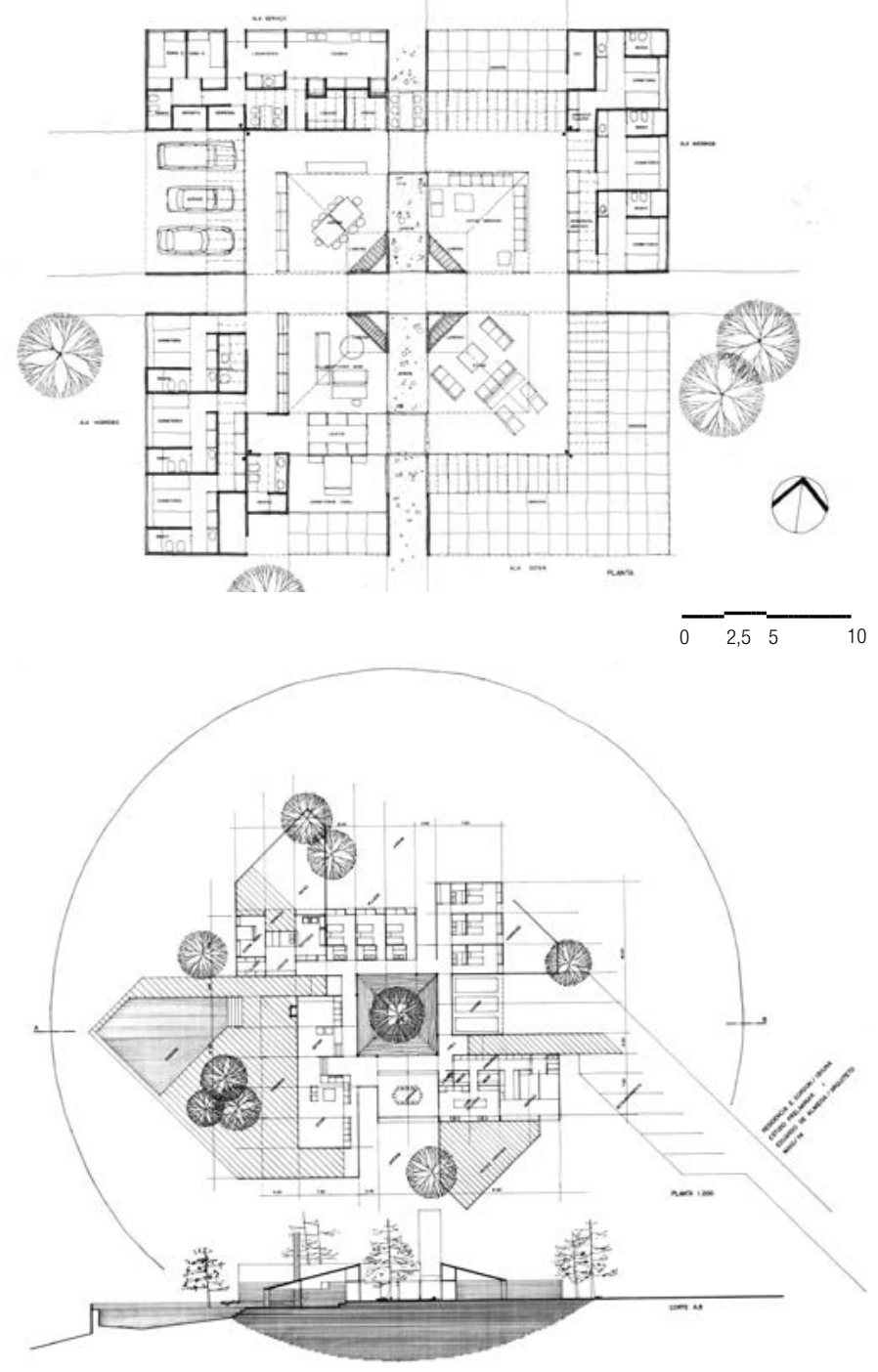
Uso

Residência Unifamiliar

Cliente

Elias Miguel Haddad

Equipe

Eduardo de Almeida

Localização

Guarujá, SP

Estágio

Estudo Preliminar

Observações

Não Construído

\section{Características}

Buscando aproveitar as vistas do entorno, praticamente

todo o programa da residência foi elevado em torno de

um vazio central, espaço que também organiza os blocos

destinados à sala, à cozinha e aos dormitórios. Prevendo

uma estrutura de concreto armado e blocos de concreto

aparente, 0 projeto desta residência referencia-se ao

projeto de Carlos Millan para a casa em Barroquinha do

Salmorão, projetada em 1966.

\section{Acervo}

Tubo 22
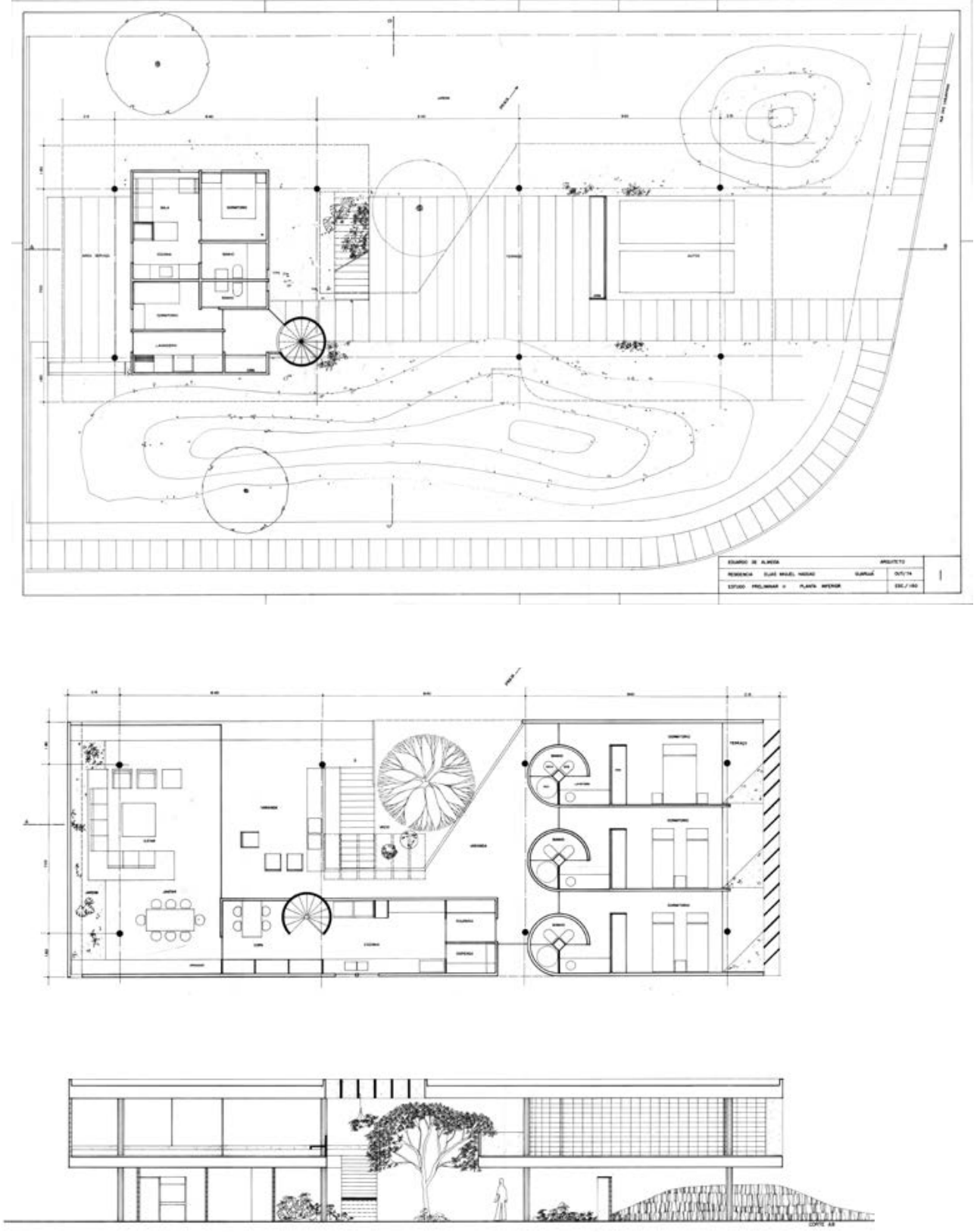
Uso

Residência Unifamiliar

Cliente

Edson Veiga

Equipe

Eduardo de Almeida

Localização

Rua Emboabas, Campo Belo, São Paulo, SP

Estágio

Projeto Executivo

Observações

Construído

\section{Características}

Organizada em meios níveis, esta casa cria 0 acesso

pelo nível intermediário e, no bloco posterior, apresenta

os dormitórios no pavimento superior e os ambientes

de estar no piso inferior. A condição deste projeto era

criar um ambiente estimulante de onde fosse possivel

apreender todos os andares da casa principalmente a

partir da sala localizada no piso de acesso.

Acervo

Tubo 47
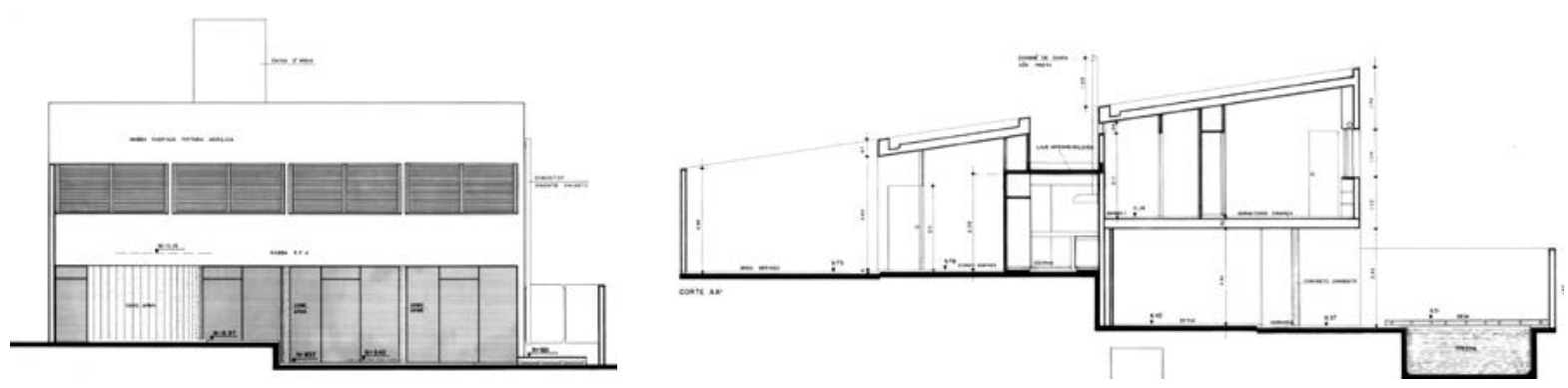
Uso

Indústria de Veículos Elétricos

Cliente

Icovel - Indústria de Comércio de Veículos

Equip

Eduardo de Almeida

Localização

Itú, SP

Estágio

Projeto Executivo

Observações

Parcialmente Construído

\section{Características}

0 projeto se utiliza de sistemas construtivos de baixo

custo, tanto para o bloco administrativo e de serviços

quanto para 0 galpão fabril, ao mesmo tempo, a

qualidade do espaço é garantida pela presença de

espaços abertos, como o jardim central que organiza

0 espaço de trabalho e a manutencão das construcōos

originais da fazenda.

Acervo

Tubo 37
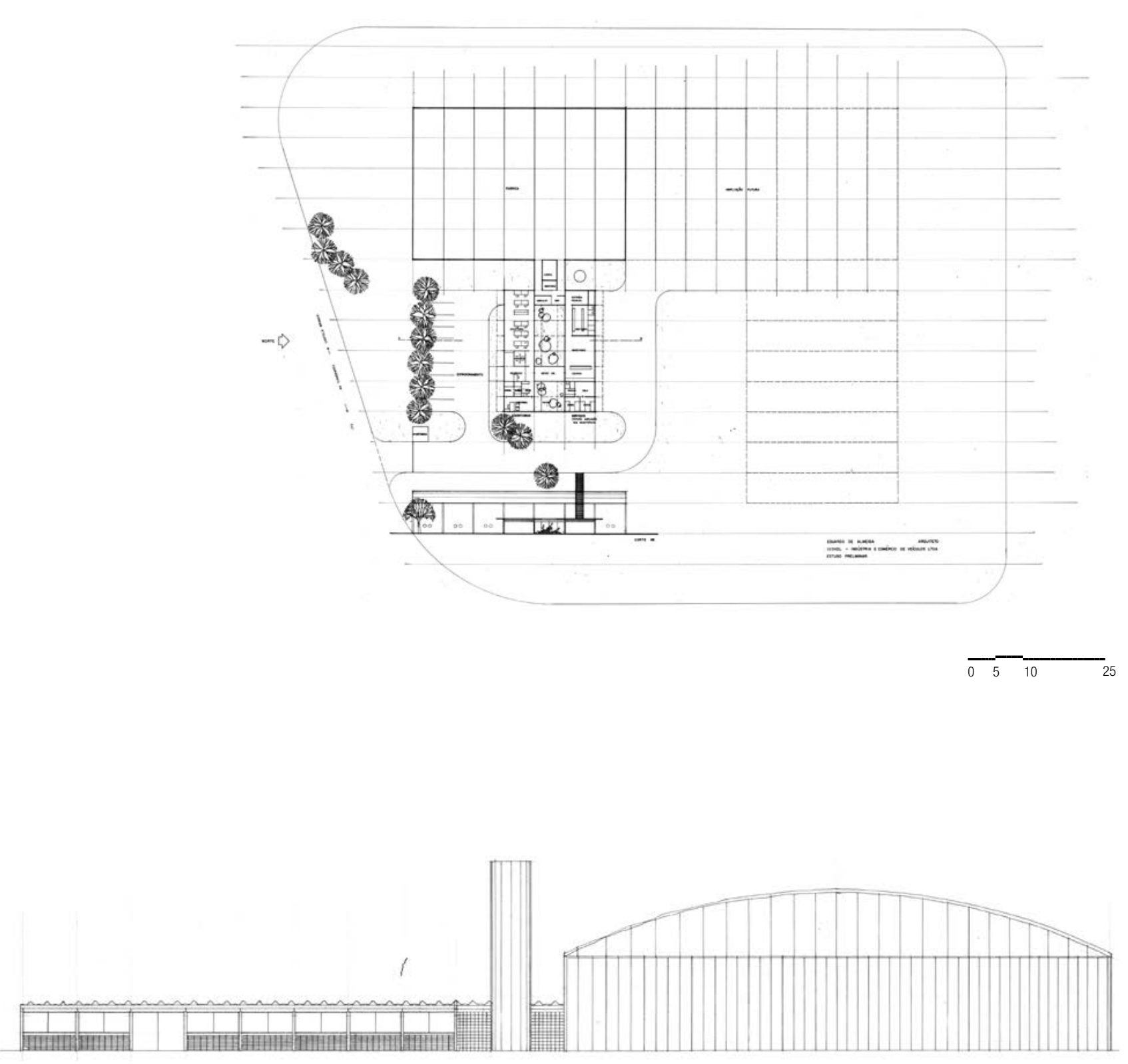
Loteamento

Cliente

Paulista S.A Ltda.

Equipe

Eduardo de Almeida, Fernando Magalhães Chacel e

Sidney Linhares

Localização

Indaiatuba, SP

Estágio

Estudo Preliminar

Observações

Não Construído

Características

Realizado em conjunto com Fernando Chacel, este

projeto de loteamento considera 0 aproveitamento

das características topográficas do terreno e, mais

importante, a adequação em relação aos cursos d'água,

ao projeto paisagístico e a manutenção dos projetos

originais da fazenda.

Acervo

Tubo 45
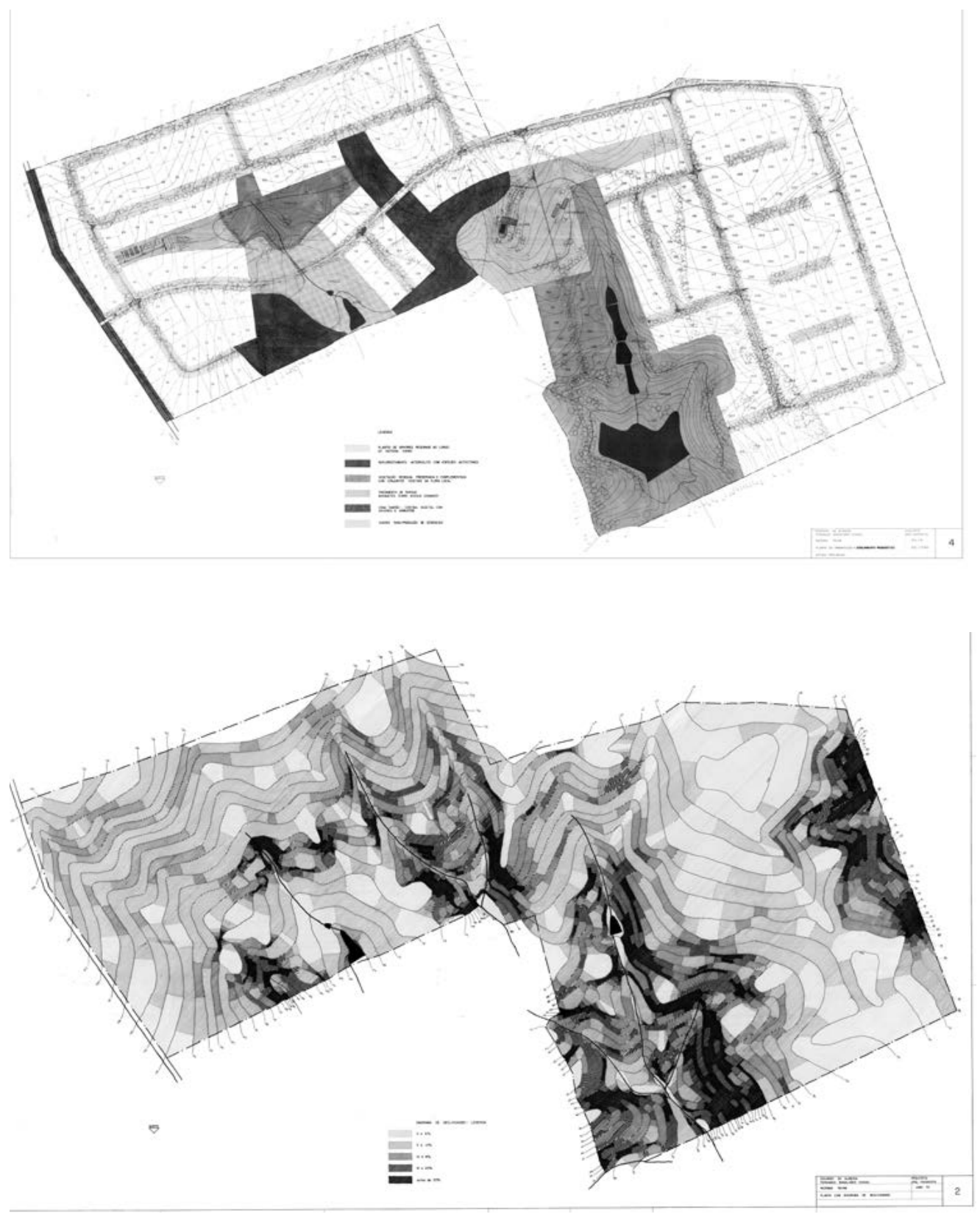
Uso

Conjunto Residencial - 3 casas

Cliente

Bernardino Barbosa

Equipe

Eduardo de Almeida

Localização

Ponta Grossa, PR

Estágio

Projeto Executivo

Observações

Construído

\section{Características}

Projeto para três residências unifamiliares, projetadas

para serem comercializadas. Extremamente

econômicas, as casas foram projetadas com alvenaria

de tijolo e organizadas em patamares posicionados

de acordo com a topografia. Na cobertura foi utilizada

estrutura de madeira e telhas de fibrocimento.

Acervo

Tubo 34
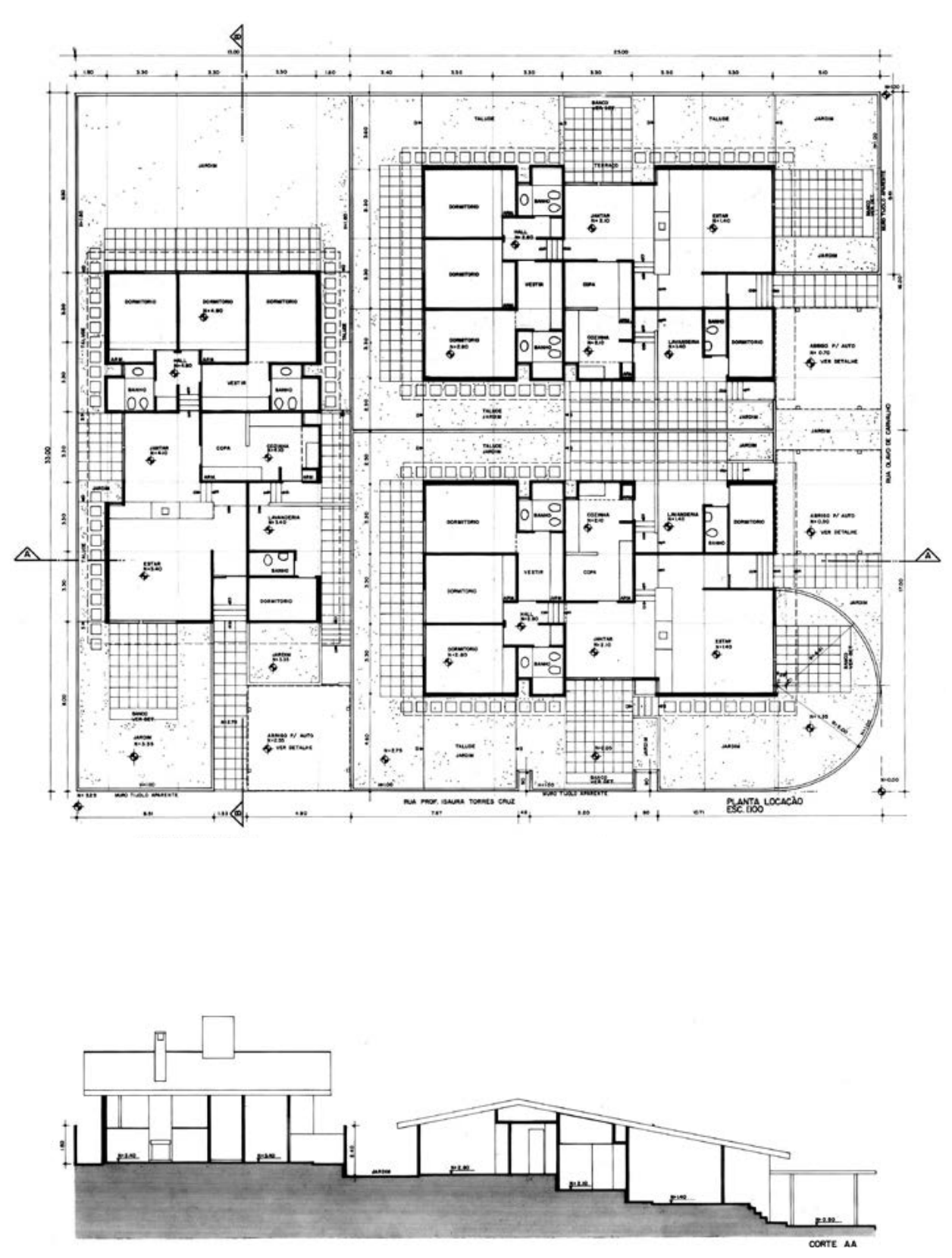
Uso

Residência Unifamiliar

Cliente

Max Define

Equipe

Eduardo de Almeida

colaborador I José Antônio Seixas e Antonio José de

Oliveira Santos

estrutura | Faustino Máximo da Silva

paisagismo | Fernando Chacel

Localização

Av. das Magnólias 1027, Morumbi, São Paulo, SP

Estágio

Projeto Executivo

Observações

Construído

Características

Residência unifamiliar construída como um volume parcialmente apoiado no terreno, gerando um acesso em pilotis. Um vazio central articula e organiza as funcōoses,

pilotis. Um vazio central articula e organiza as funçōes,
orientadas em função das áreas livres remanescentes orientadas em função das áreas livres remanescentes
do terreno. 0 estudo preliminar aprovado pelos clientes e em desenvolvimento adotava uma linguagem próxima a projetos como a casa da Baleia, mas também sofria influência do obra do arquitoto Lovis Kehn. Segundo 0

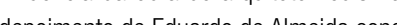
Mendes da Rocha em 1974, com uma outra linguagem.

Acervo

Tubo 39 e 39 A
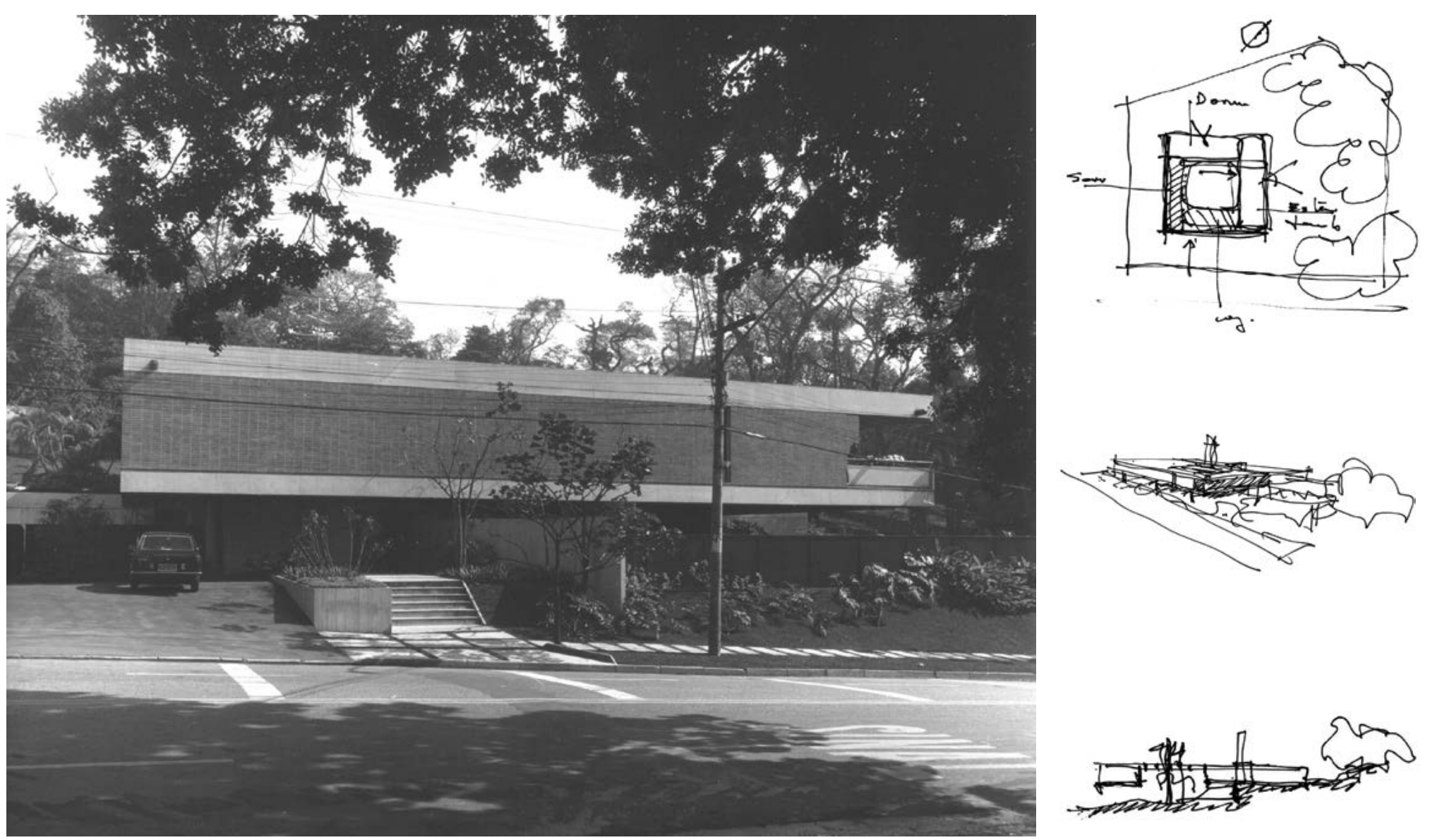

foto: Júlio Abe Wakahara
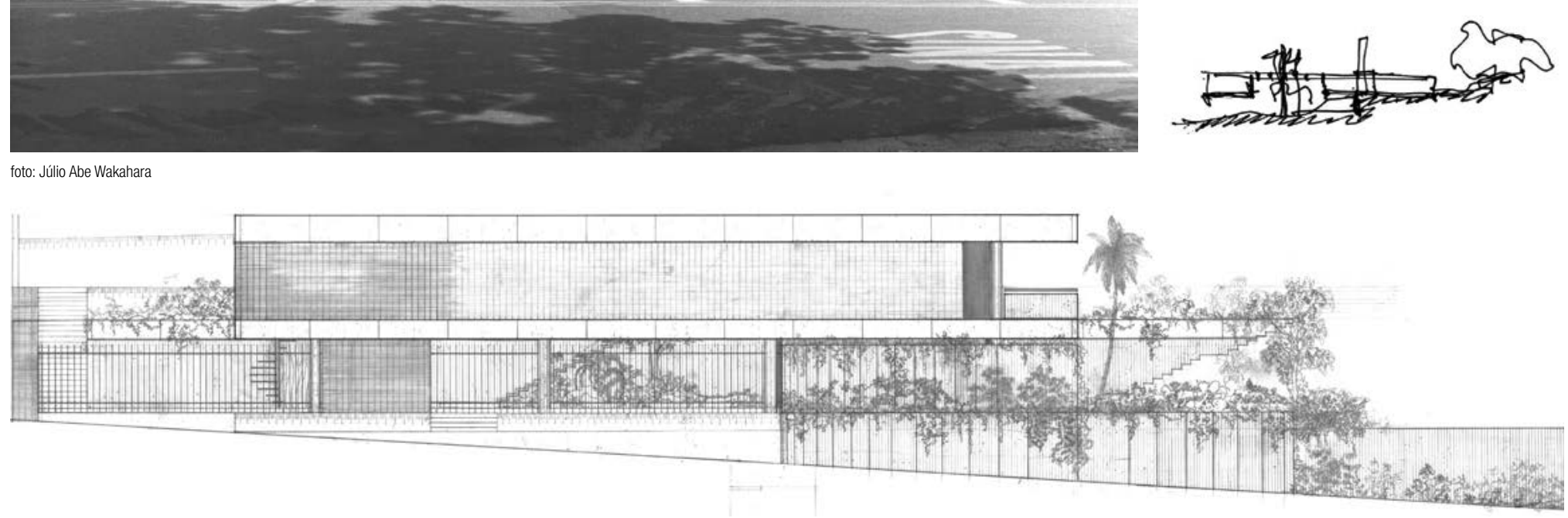
Uso

Residência Unifamiliar

Cliente

Eduardo de Almeida

Equipe

Eduardo de Almeida

colaboradores I José Antônio Seixas

paisagismo I Célia Tassinari

Localização

Rua Carangola 382, Jardim Guedala, São Paulo, SP

Estágio

Projeto Executivo

Observações

Construído

Características

Aproveitando a topografia do terreno, 0 acesso desta casa é realizado por um pavimento intermediário por meio de uma ponte, tanto para veículos quanto pedestres. Deste ponto, por um conjunto de escadas e rampas, possível subir ao pavimento dos dormitórios ou descer aos espaços destinados às salas de estar, cozinha, jantar e, finalmente, às piscinas e ao jardim. Esta circulação cria um percurso através da casa, passando por um jardim interno alongado, espaços de pé-direito simples ou elevado, vistas para o fundo do terreno ou para a rua, relaçôes visuais variadas à medida que se percorre programas específicos posicionados a cada patamar. Construtivamente, a casa segue experiências anteriores no emprego de estrutura de concreto moldado in loco associada a alvenaria de bloco aparente, mas que, neste caso, atingem um alto grau de sofisticação à medida que todos os demais elementos da construcãa seguem o padrão dimensional estabelecido pela unidade do bloco.

Acervo

Tubo 51 e 51 A
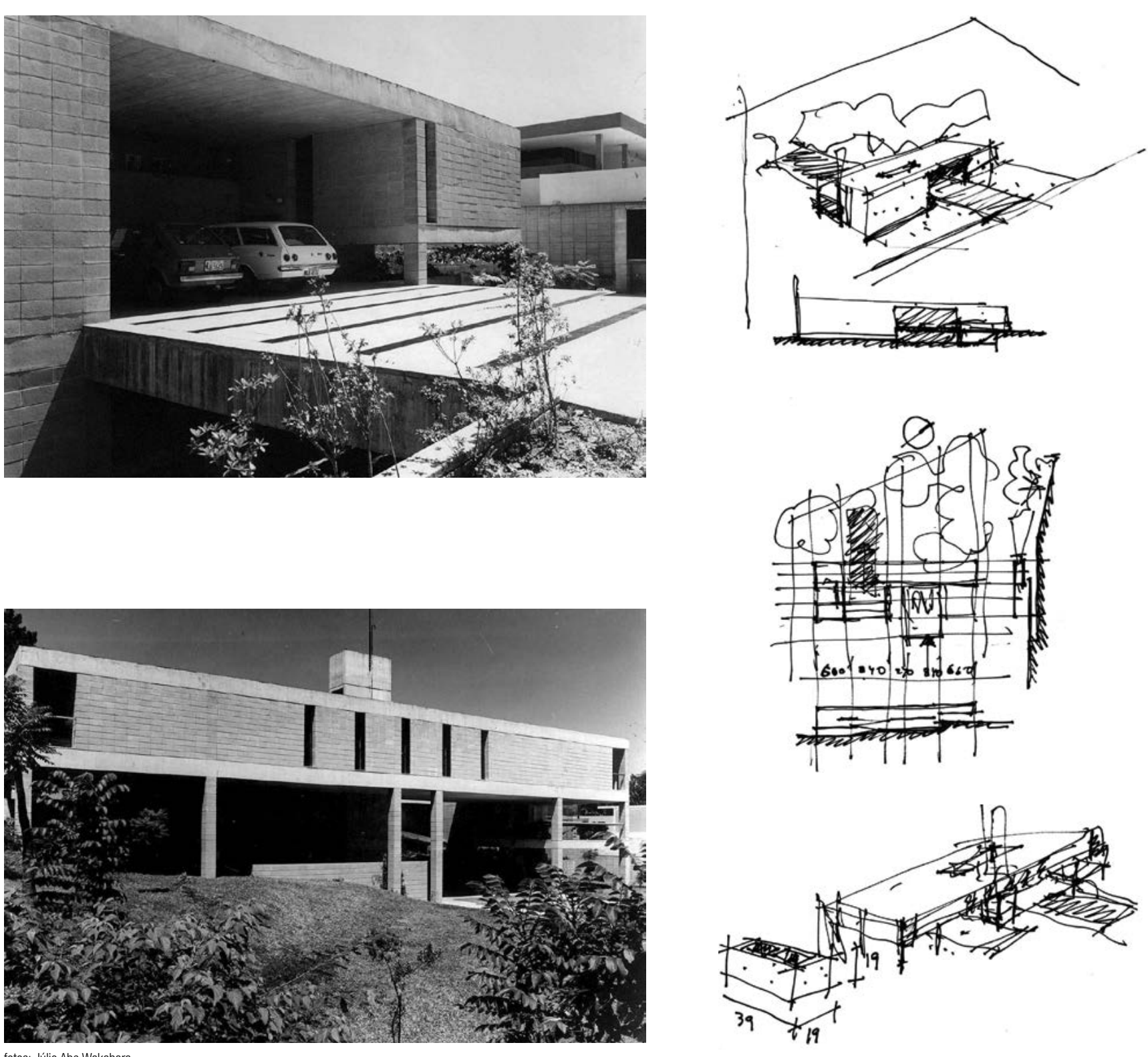


\section{Cliente}

CONESP - Companhia de Construções Escolares do

Estado de São Paulo

Equipe

Eduardo de Almeida

\section{Localização}

Rua Joaquim da Barra, Campinas, SP

Estágio

Projeto Executivo

Observaç̃os

Construído

\section{Características}

Projeto de uma escola para Campinas, enquanto primeiro estudo cria um volume único capaz de abrigar

todo o programa, o projeto finalmente construído

organizado em três blocos: 0 primeiro para as salas de

aula, o segundo para a área administrativa e 0 terceiro

para a área de vivência da escola. Os espaços que se

formam entre os volumes conformam pátios abertos e

ajardinados. De acordo com o programa da CONESP -

Companhia de Construções Escolares do Estado de São

Paulo para este período, as construcões seguem uma

rigorosa coordenação modular e utilizam um sistema

construtivo de extrema simplicidade.

Tubo 17 e Caixa 700
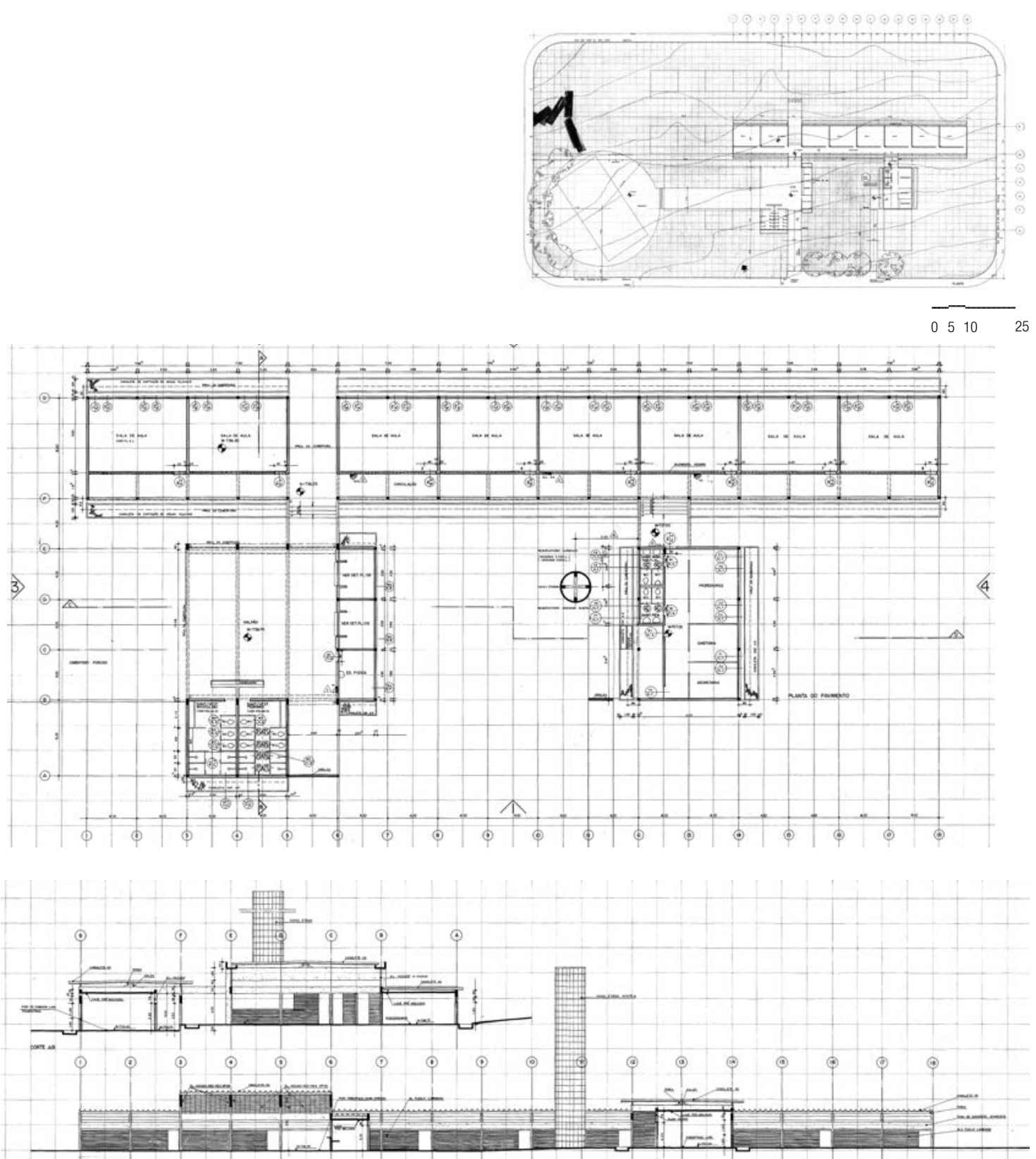
Uso

Escola

Cliente

CONESP - Companhia de Construcões Escolares do Estado de São Paulo

Equip

Eduardo de Almeida

Localização

Rua Santa Etelvina, Guaianases, São Paulo, SP

Estágio

Projeto Executivo

Observações

Construído

\section{Características}

Escola dividida em três blocos, implantados em

patamares conforme a topografia e articulados por uma

circulação horizontal única no primeiro pavimento. Este

projeto utiliza o mesmo sistema construtivo utilizado na

EEPG Vila Nova Europa.

Acervo

Caixa 900
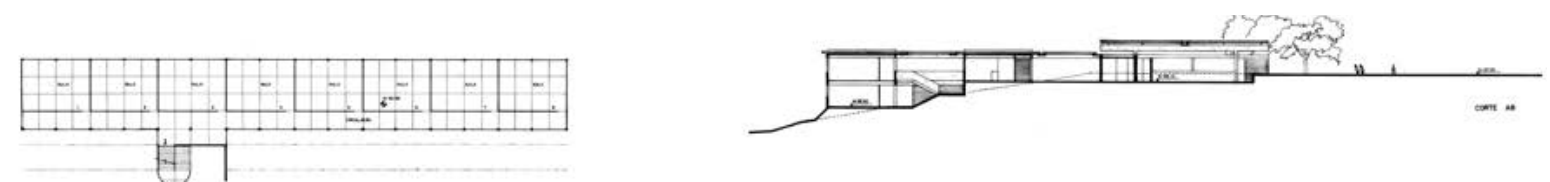

(4)

$-\infty+\infty$

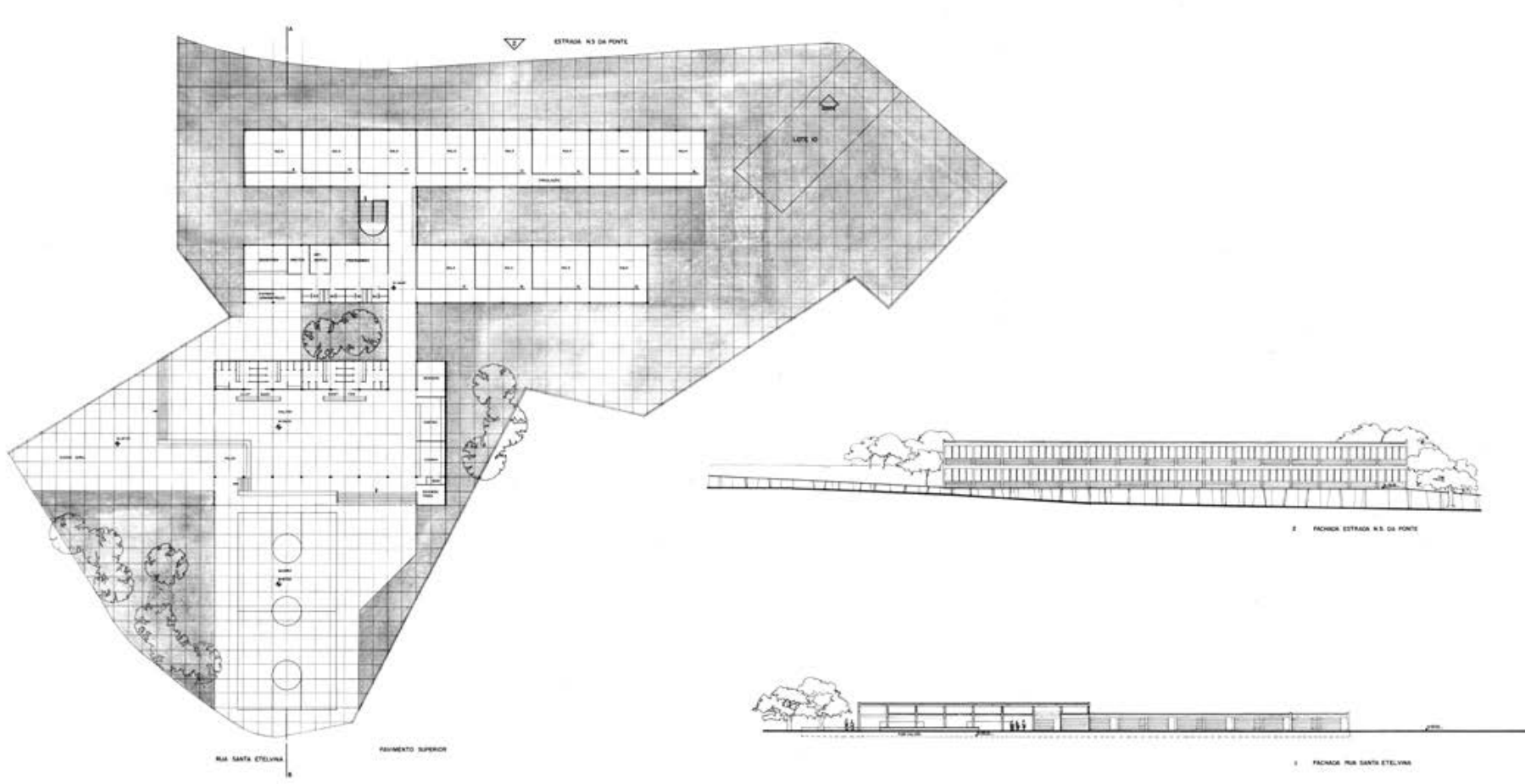

$\triangle$ 
Uso

Escola

Cliente

CONESP - Companhia de Construções Escolares do

Estado de São Paulo

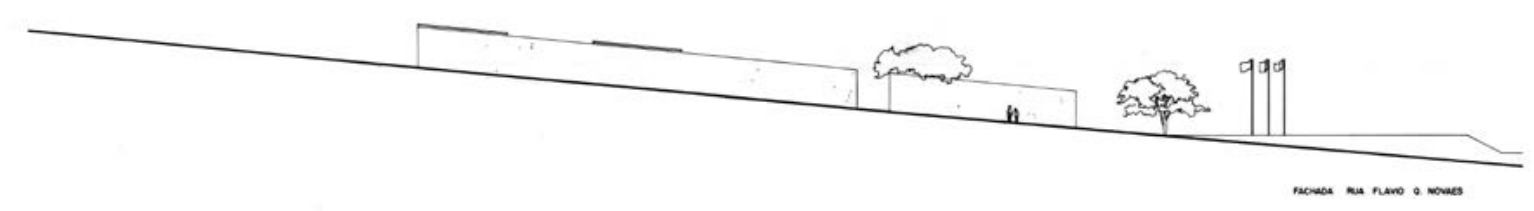

Equipe

Eduardo de Almeida

Localização

Rua Flávio Q. Novaes, Jundiaí, SP

Estágio

Projeto Executivo

Observações

Construído

\section{Características}

Assim como na escola Vila Buenos Aires, o programa está dividido em três blocos acomodados em patamares

na topografia e são articulados por uma circulação

horizontal, mas neste caso, é feita totalmente em um único pavimento.

Segundo Eduardo de Almeida, a realização destes

inúmeros projetos para a Conesp - Companhia de Construções Escolares do Estado de São Paulo também marca 0 início da sociedade com Arnaldo Martino. Além de serem colegas como professores na FAUUSP, a parceria justifica-se pela necessidade de se constituir uma empresa de caráter uniprofissional para a obtenção de contratos com empresas públicas. Desta necessidade prática, surgiu uma colaboraçãa extremamente rica, mesclando a pesquisa de Arnaldo Martino no emprego de estruturas arrojadas, com grandes vãos ou soluçoes atínicas de construção, e a arquitetura singela e ordenada de Eduardo de Almeida.

Acervo

Tubo 16 e Caixa 700

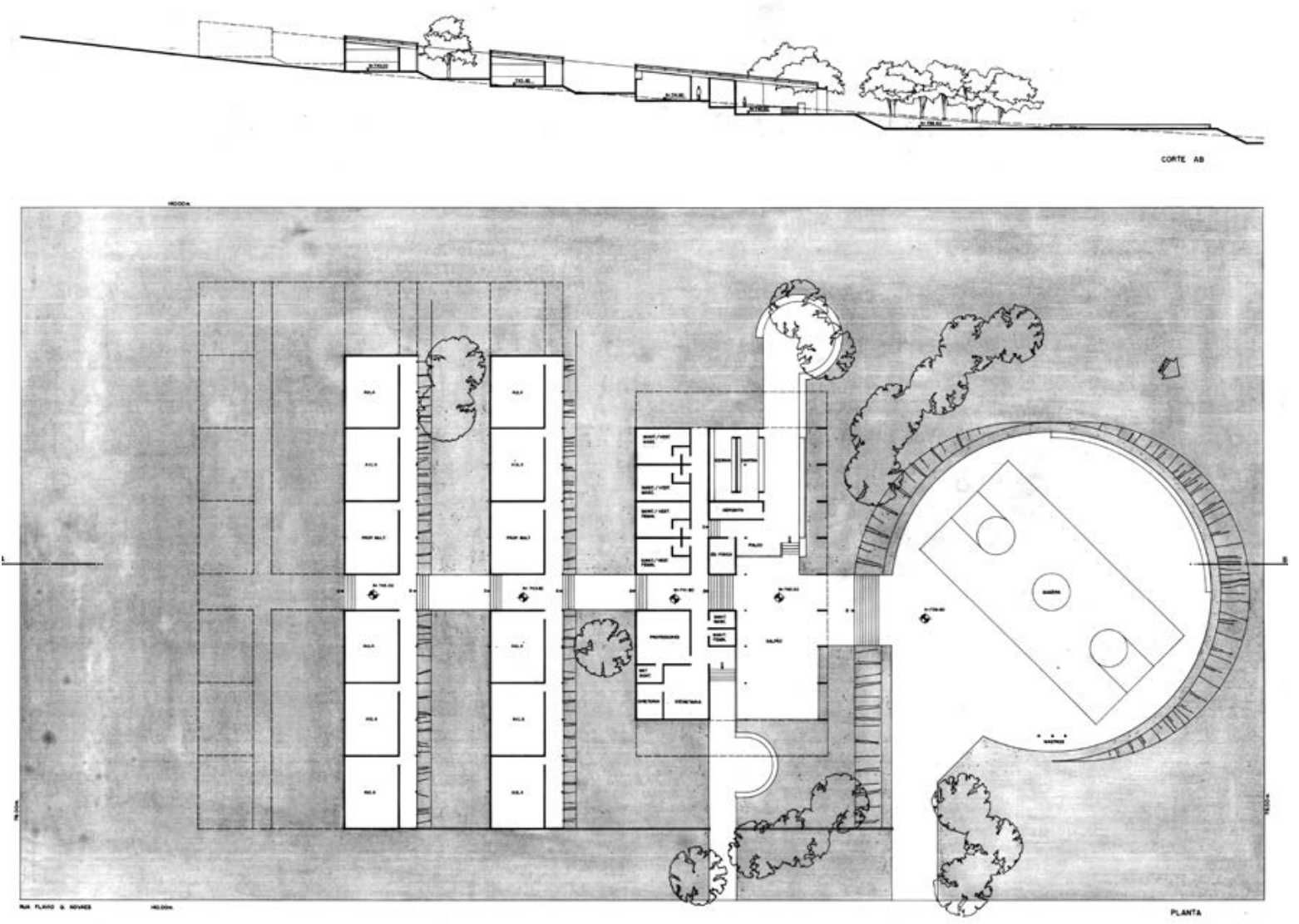


Uso

Residência Unifamiliar

Cliente

Dacacche

Equipe

Eduardo de Almeida

Localização

São Roque, SP

Estágio

Projeto Executivo

Observações

Construído

\section{Características}

Por ocasião da construção de um condomínio de casas de final de semana em São Roque, Eduardo de Almeida foi convidado a projetar três residências em troca de um terreno, demonstrando as possibilidades de ocupação

dos lotes para os futuros compradores. Neste caso, a casa é organizada por uma cobertura com estrutura

independente de madeira e telhas cerâmicas, abrigo

para os quatro volumes dos dormitórios que organizam a planta quadrada e 0 espaço interior destinado ao ambiente de estar.

Acervo

Tubo 71 ,Caixa 4300 e 4300a
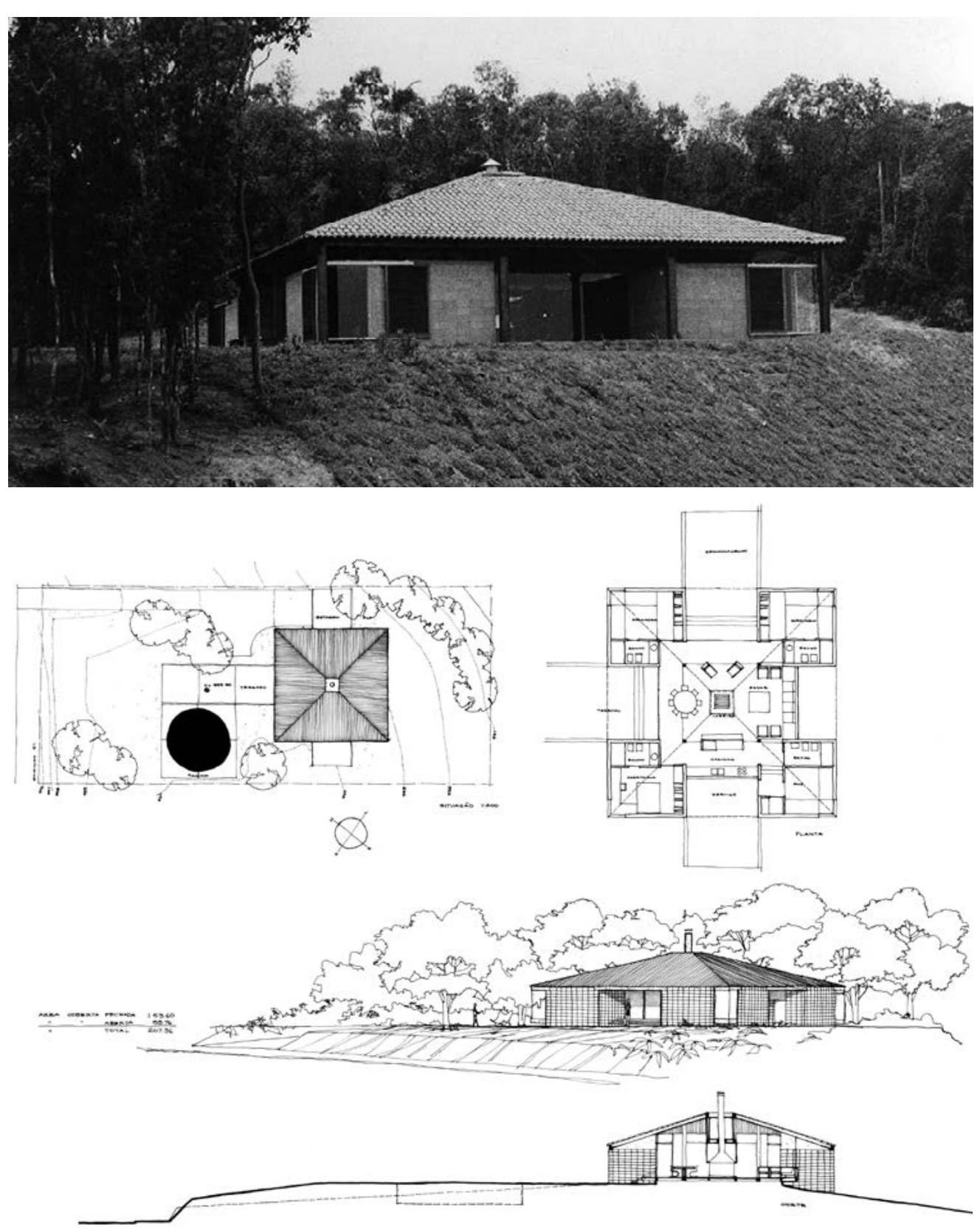
Uso

Residência Unifamiliar

Cliente

Dacacche

Equipe

Eduardo de Almeida

Localização

São Roque, SP

Estágio

Projeto Executivo

Observações

Não Construído

\section{Características}

0 segundo projeto para o mesmo condomínio utiliza

uma solução completamente diferente da primeira casa.

Neste caso, considerando a topografia do terreno, todos

os ambientes se encontram semienterrados, iluminados

e ventilados por aberturas zenitais (dormitórios $e$

sanitários) ou por uma janela horizontal em direção às

vistas (estar, jantar e cozinha).

Acervo

Tubo 16 , caixa 4300 e $4300 \mathrm{~A}$

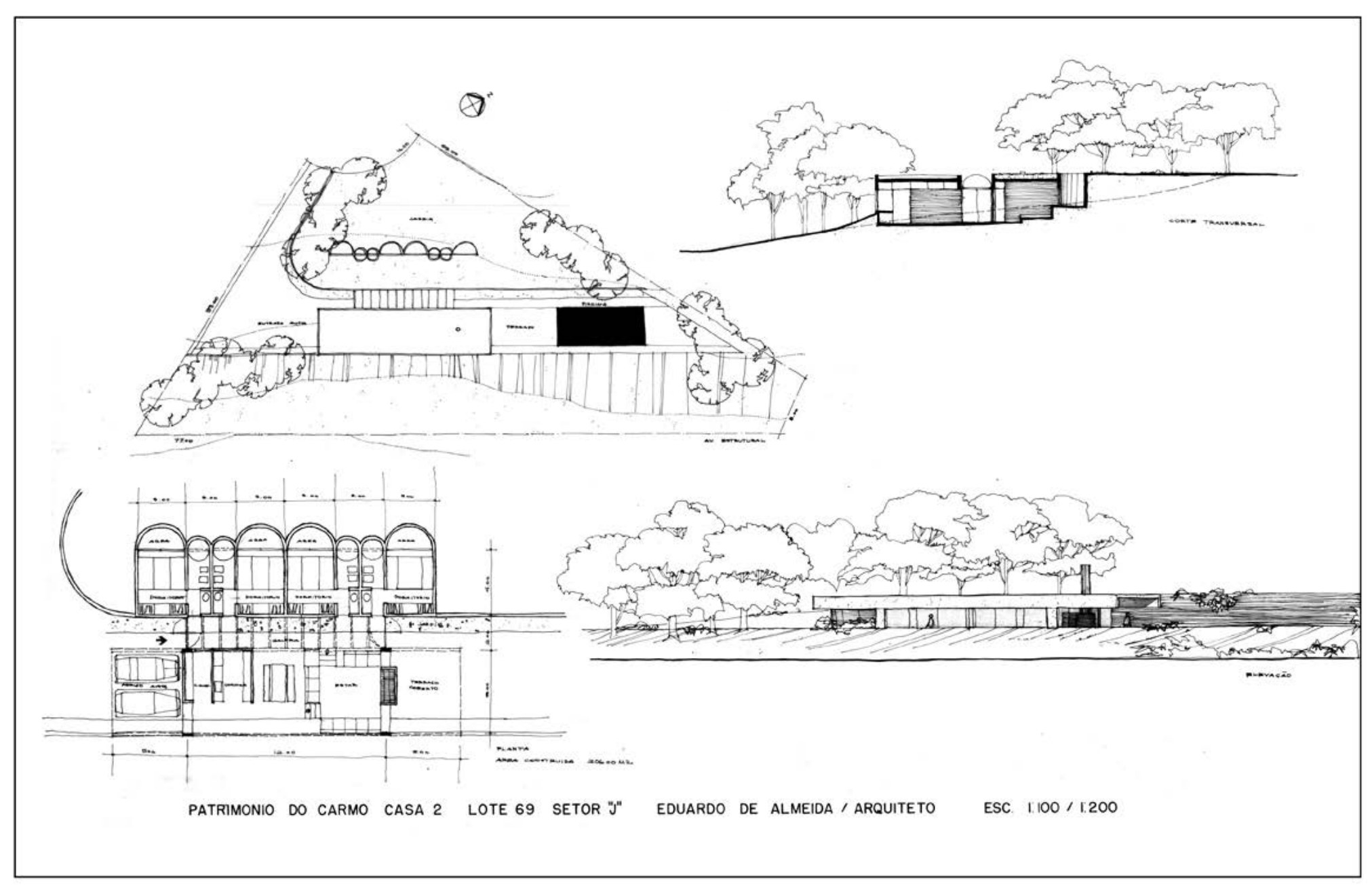


Uso

Escritório

Cliente

Morlan

Equipe

Eduardo de Almeida

colaborador I José Antônio Seixas

Localização

Rua Cojuba 42, Itaim Bibi, São Paulo, SP

Projeto Executivo

Observações

Construído

\section{Características}

Em continuidade a uma série de experiências com 0 uso de treliças espaciais no início da década de 70, Eduardo de Almeida realiza esta obra em São Paulo após conhecer a fábrica de estruturas Mero, empresa alemã que desenvolveu um sistema produzido em escala industria , composto por barras de seccão circular rosquedas a um nó esférico.

Neste caso, foram criadas duas empenas de concreto junto às divisas laterais capazes de suportar a grelha de cobertura que vence 0 vão da largura do lote, sem a presença de nenhum apoio intermediário. Abaixo do plano de cobertura, implanta-se a área destinada aos escritórios em uma laje de concreto apoiada em quatro pilares centrais e duas empenas presentes em cada uma de suas extremidades. Este salão, seccionado por uma faixa destinada aos sanitários e escada, é ocupado por um escritório panorâmico de um lado e, do outro, salas menores criadas por divisórias especialmente projetadas por Eduardo de Almeida para esta obra Nos pavimentos térreo e inferior localizam-se as docas de carga e descarga depósitos, garagem e demais áreas técnicas.

Acervo

Tubo 64, Caixa 4700
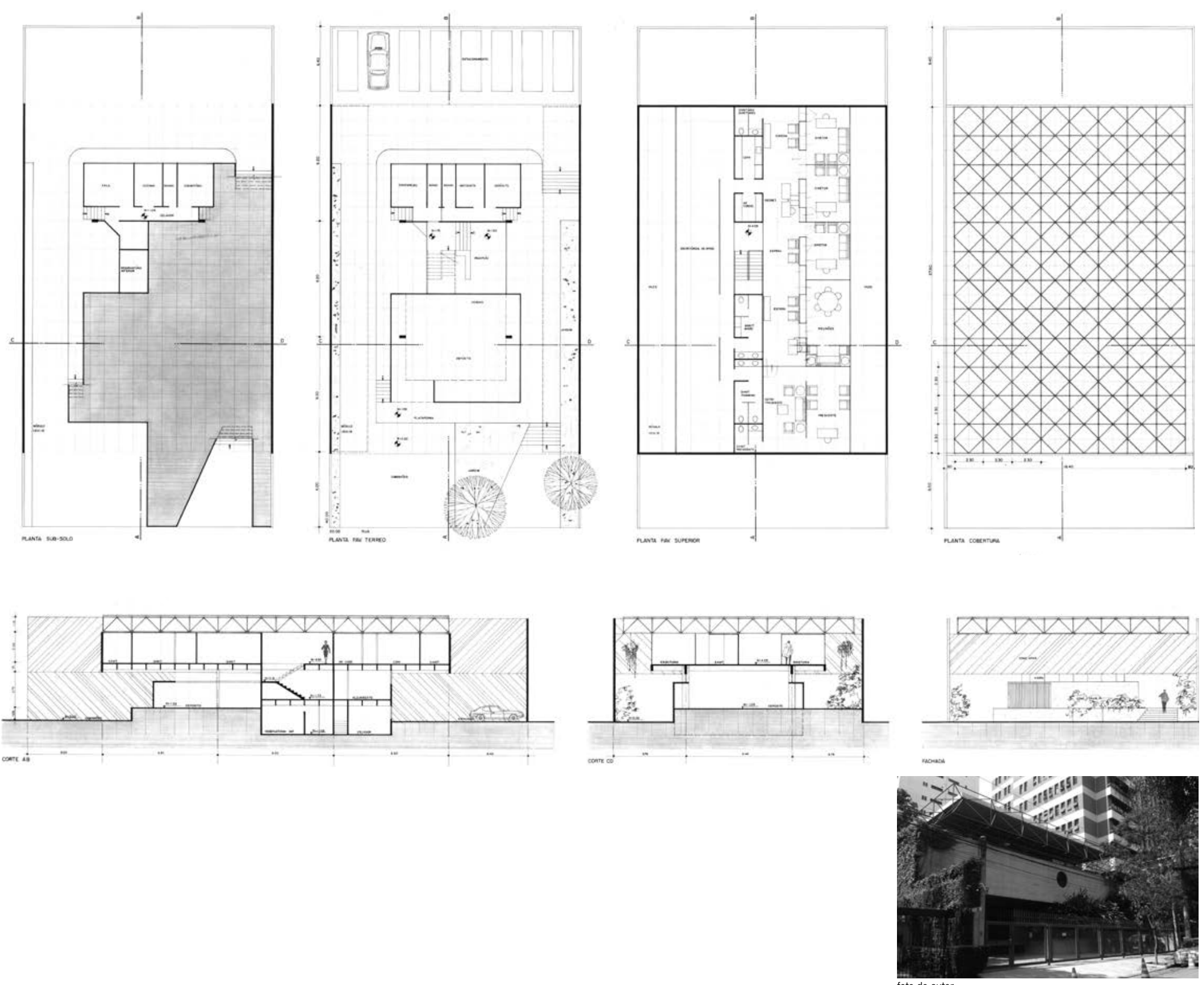

(1) 
Uso

Fazenda

Cliente

G. Mistrorigo

Equipe

Eduardo de Almeida

Localização

Ribeirão Bonito, SP

Estágio

Projeto Executivo

Observações

Parcialmente construído

\section{Características}

Projeto para a sede de uma fazenda que envolveu o desenho do sistema viário de acesso, a casa para os caseiros, a sede e demais espaços de esporte lazer. 0 partido da casa principal segue a experiência da organização dos programas ao redor de um pátio central, neste caso, a partir de uma malha regular de central, neste caso, a partir de uma malha regular de pilares em pedras associados a vigas-calha de concreto armado (também desenhadas em função das alvenarias, realizada em madeira e utilizou cobertura de telhas cerâmicas.

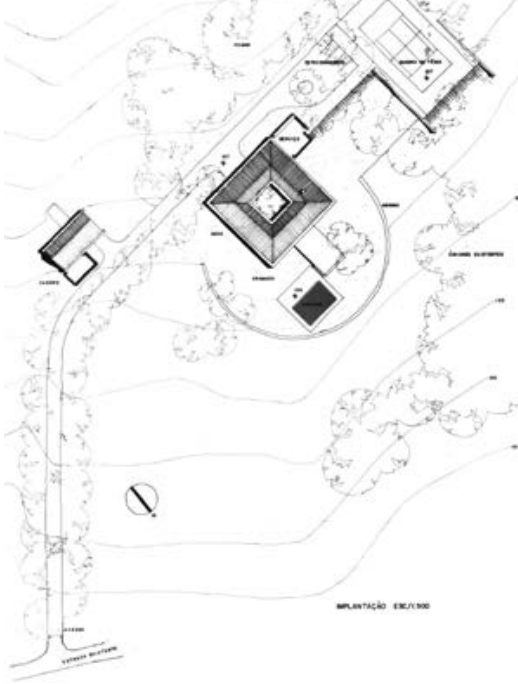

Acervo

Tubo 21

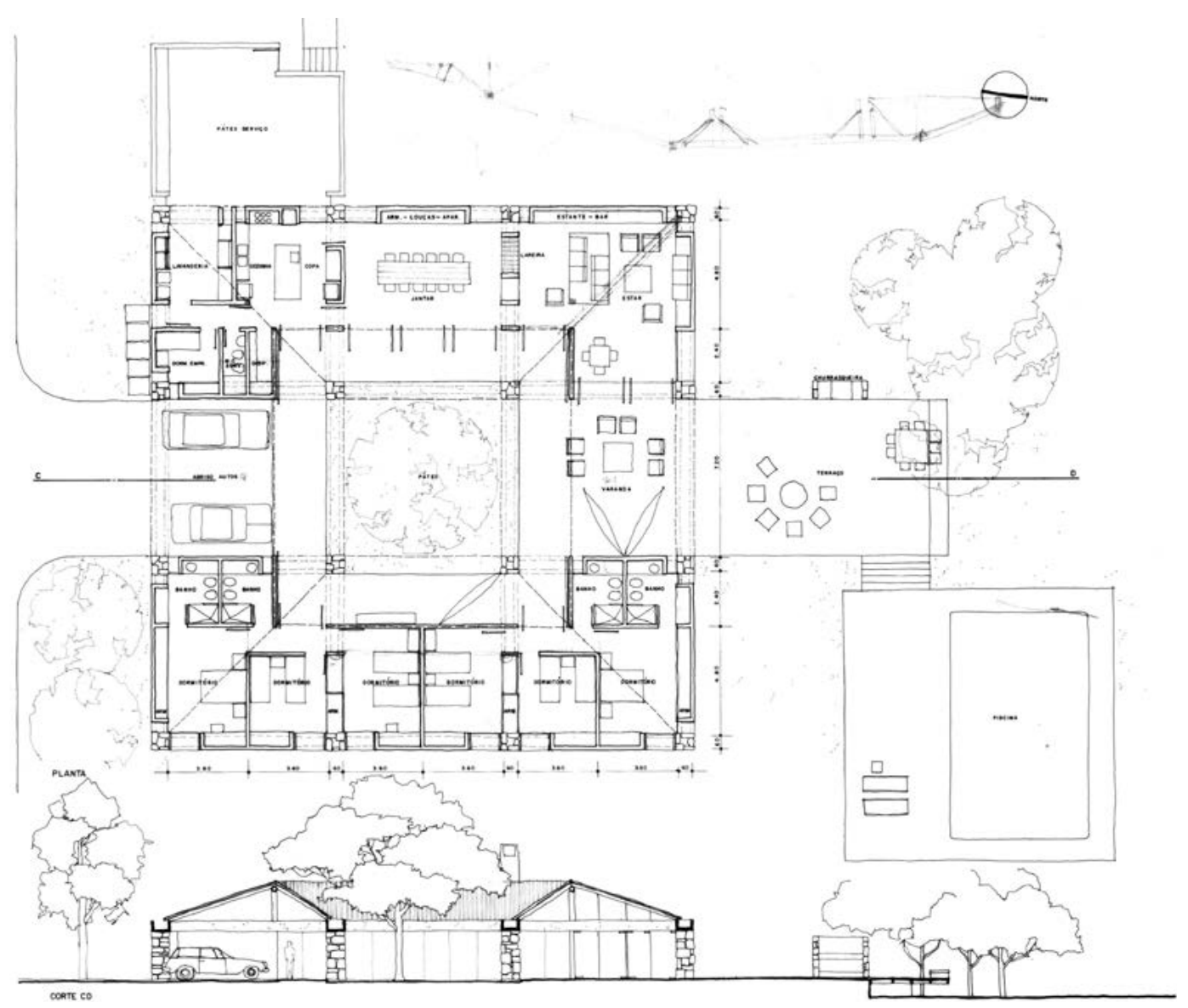


Uso

Residência Unifamiliar

Cliente

Cláudio M. Grisolia

Equipe

Eduardo de Almeida

Localização

Rua Paiaquas, Tupã, SP

Estágio

Estudo Preliminar

Observações

Não Construído

\section{Características}

Projetada para um amigo de infância no interior de São Paulo, esta casa de um pavimento tira partido da organização em blocos destinados a cada função, sempre articulados por meios de pátios e jardins protegidos por pérgolas de madeira. Modulada em faixas de 4,20 metros, a estrutura da casa alterna vigas calha de concreto armado com telhas capazes de vencer os de concreto armado com telhas capazes de vencer os
vãos transversais. Pode-se dizer que este projeto faz referência à Casa Castor Delgado Peres, projetada por Rino Levi em 1958

Acervo

Tubo 69

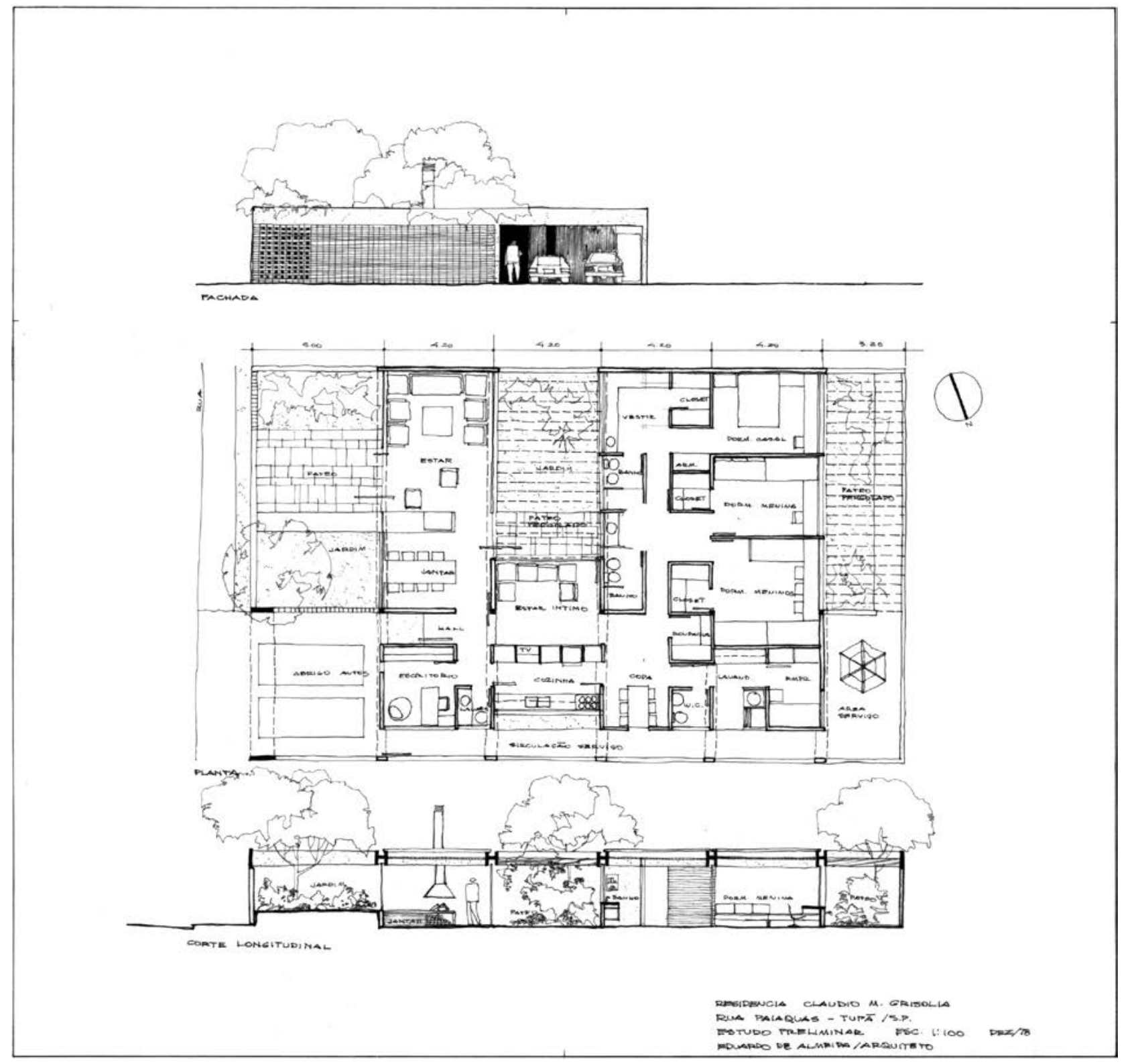


Uso

Fazenda

Cliente

Isabel Junqueira

Equipe

Arnaldo Martino e Eduardo de Almeida

Localização

São Joaquim da Barra, SP

Estágio

Anteprojeto

Observações

Não Construído

\section{Características}

0 primeiro projeto para a casa sede da Fazenda Campo dos Bois segue o mesmo partido da proposta apresentada para a Fazenda Jatobá. Neste caso específico, a solução de cobertura elimina as vigas-calha de concreto e apresenta planos de dupla-inclinação, aproximando-se da linguagem das tradicionais casas de fazenda da arquitetura colonial de São Paulo. Outro de fazenda da arquitetura colonial de São Paulo. Outro
ponto relevante é a utilização de um pequeno subsolo articulado ao corpo principal da casa e que dá acesso ao recinto das piscinas, conformado por um extenso muro de pedras e por taludes ajardinados laterais.

Acervo

Tubo 42

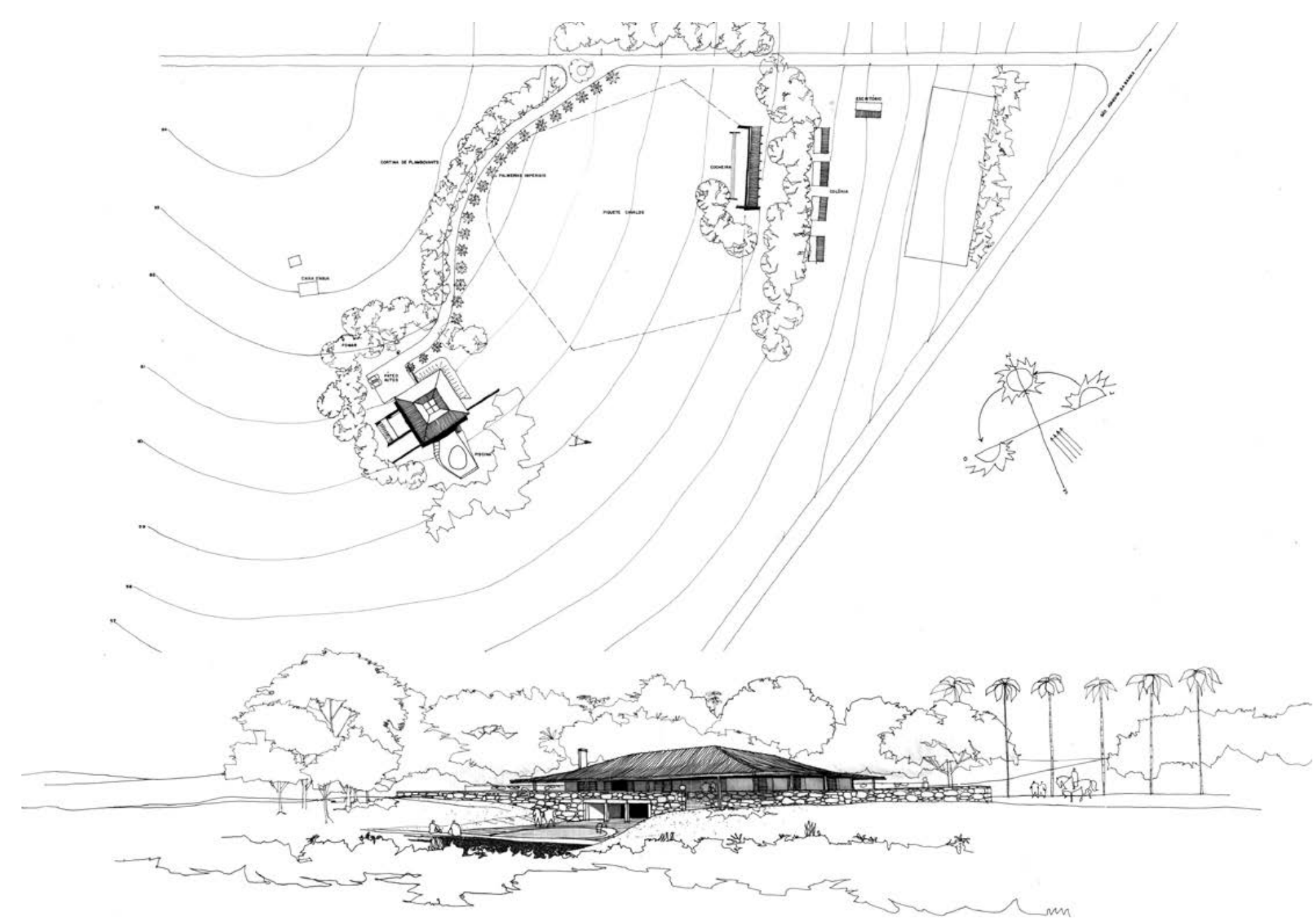


Uso

Fazenda

Cliente

Isabel Junqueira

Equipe

Arnaldo Martino e Eduardo de Almeida

Localização

São Joaquim da Barra, SP

Estágio

Projeto Executivo

Observações

Não Construído

\section{Características}

Nesta segunda versão, a implantação geral da fazenda segue o mesmo partido anterior, sobretudo no desenho do sistema viário, dos edifício de caráter técnico e da área de piquete destinado aos cavalos. № entanto, diferencia-se da idéia inicial no que diz respeito ao projeto da casa s da projeto da casa sede, circulação central - com cobertura em abóboda articula os diversos blocos funcionais ao longo do percurso.

Acervo

Tubo 42
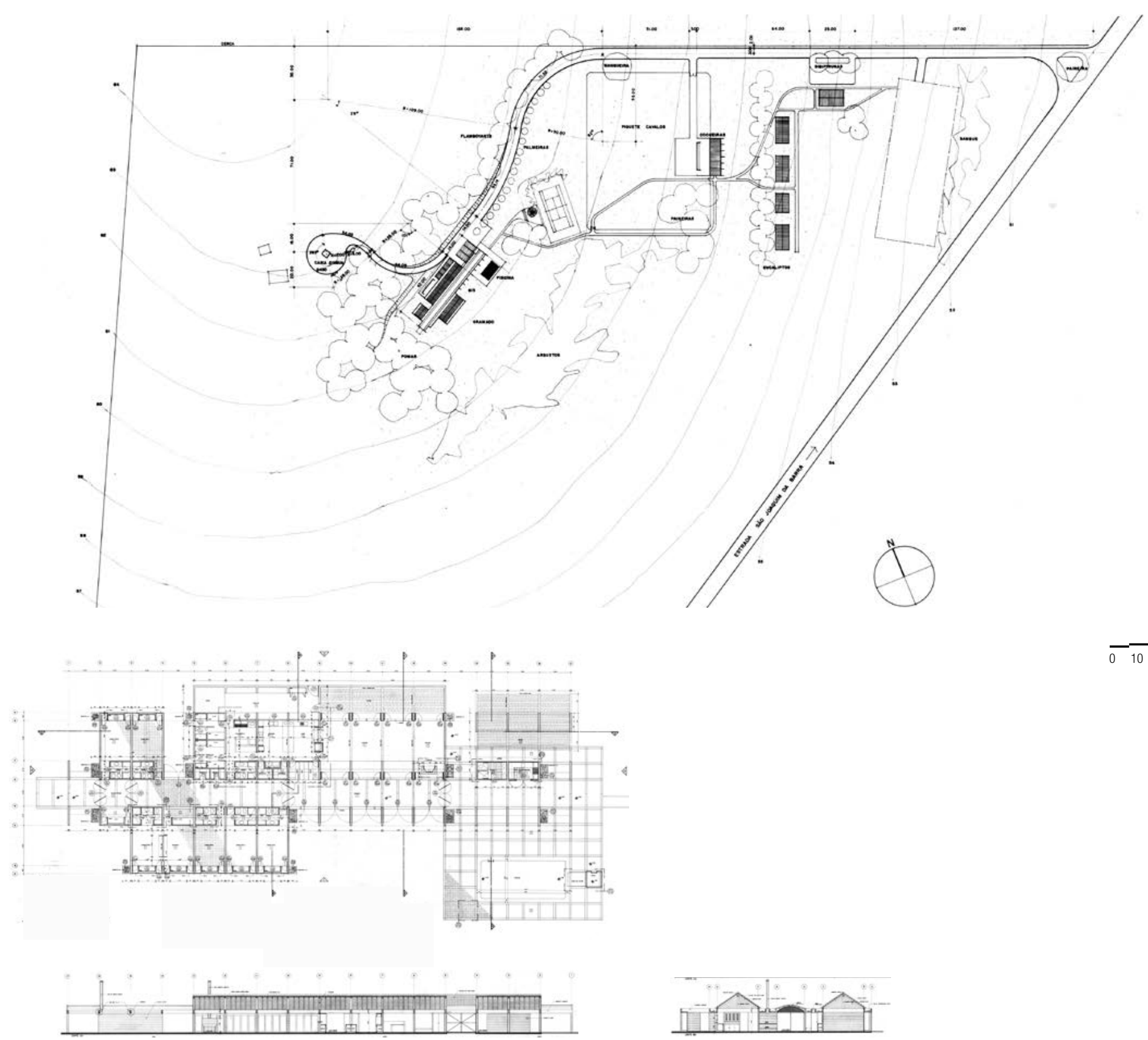
Uso

Cliente

Claudio Lazlo

Equip

Eduardo de Almeida

Localização

Shopping Ibirapuera, Moema, São Paulo, SP

Estágio

Anteprojeto

Observações

Construído

\section{Características}

Projeto de uma pequena loja de equipamentos

fotográficos em um Shopping Center de São Paulo

encomendado pelo fotógrafo Cláudio Lazlo, amigo de

Eduardo de Almeida. Além da distribuicãa interna e das

especificações dos acabamentos, o projeto estende-se

ao mobiliário e à comunicacãão visual.

Acervo

Tubo 21
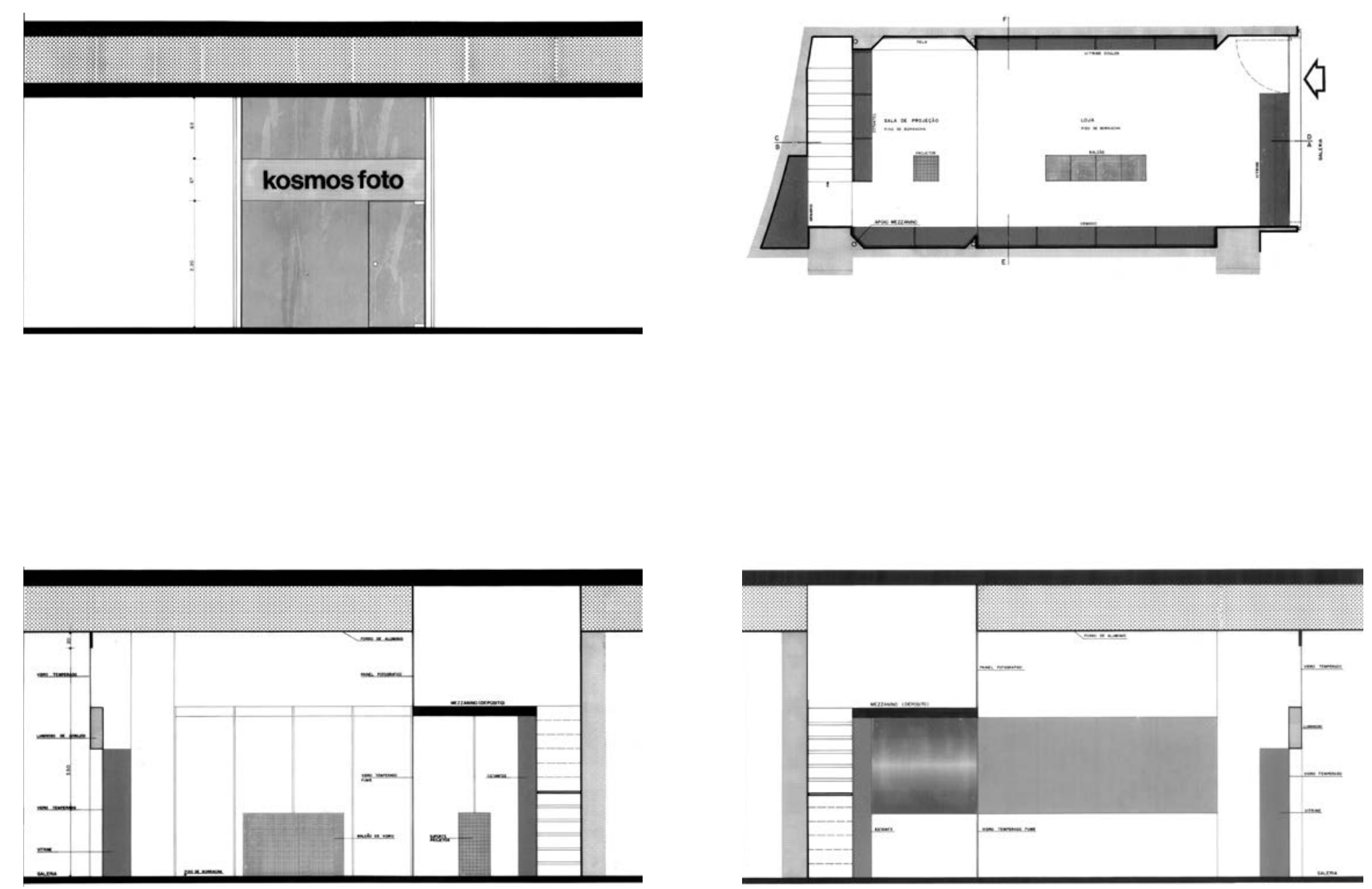

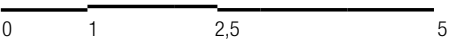


Uso

Escola

Cliente

CONESP - Companhia de Construções Escolares do

Estado de São Paulo

\section{Equipe}

Arnaldo Martino e Eduardo de Almeida

\section{Localização}

Itaquera, São Paulo

Estágio

Projeto Executivo

Observações

Construído

\section{Características}

Projeto de uma escola para a Zona Leste de São Paulo. Implantação de quatro blocos em patamares, de acordo com a topografia em declive e em respeito às árvores existentes no terreno, diferentemente das escolas apresentadas anteriormente este projeto utiliza uma linguagem que associa elementos vazados e alvenaria de tijolos a estruturas de concreto aparente. No caso do galpão, espaço de vivência principal, os pórticos de concreto são associados a vigas-vagão, terças e telhas metálicas. A implantacão dos diversos blocos seguiu a premissa de apror terreno como elementos estruturadores do espaço de entrada ou dos pátios internos.

Acervo
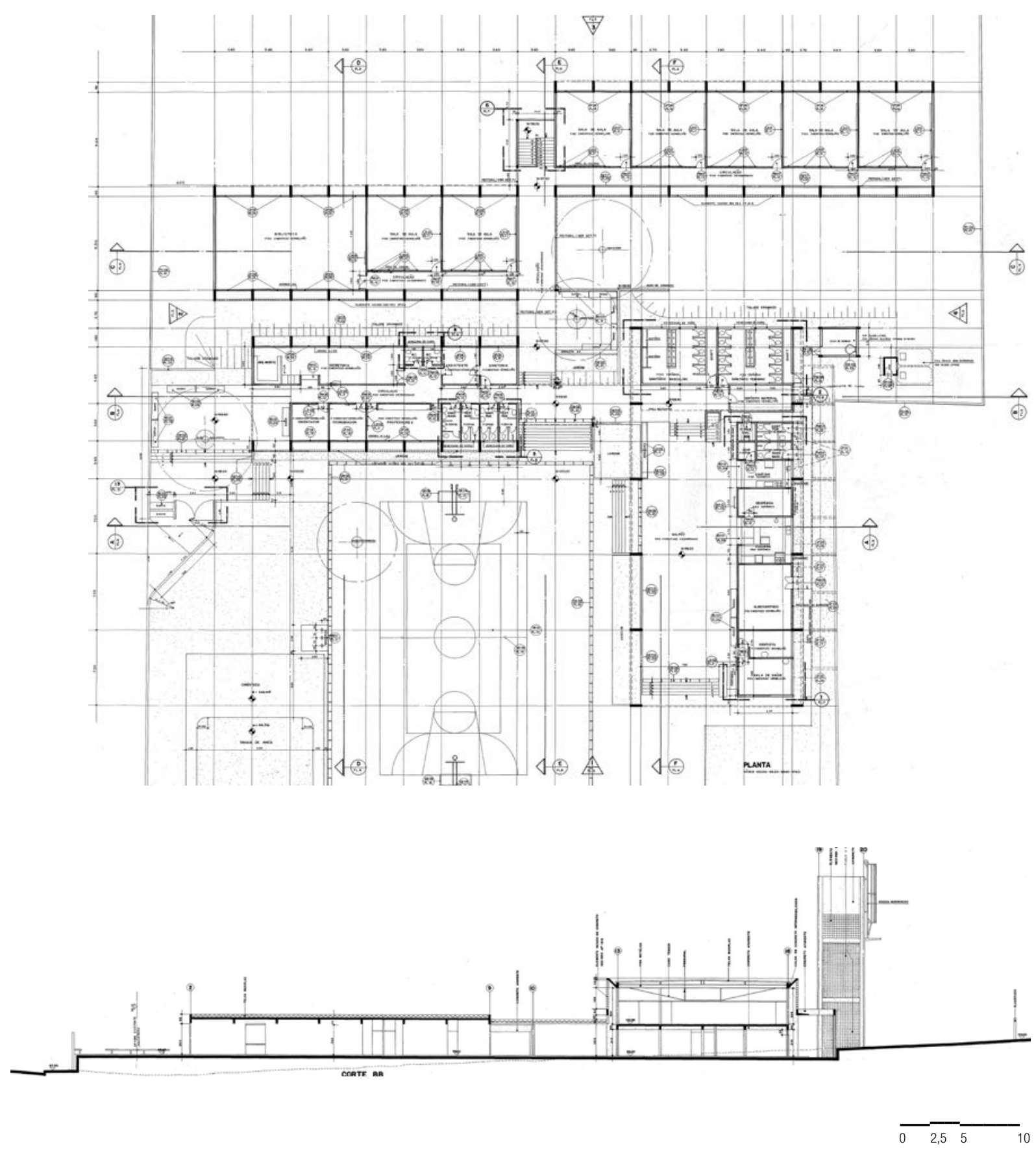
Uso

Edifício de Escritórios

Cliente

DU PONT

Equipe

Arnaldo Martino e Eduardo de Almeida

estrutura | Hugo Todeschini

perspectivas I Vallandro Keating

\section{Localização}

Barueri, SP

Estágio

Estudo Preliminar

\section{Observações}

Não Construído

Características

Edifício de escritórios organizado em três pavimentos:

um subsolo destinado às áreas técnicas, acesso de

funcionários e ambientes de apoio; um pavimento térreo

destinado às atividades de caráter público e áreas de

trabalho e um último piso. Especial atenção à solução de

estrutura de fachada composta por três vigas vagonadas

da altura de um pavimento, capazes de vencer vãos da

ordem de 60 metros

Acervo

Tubo 21
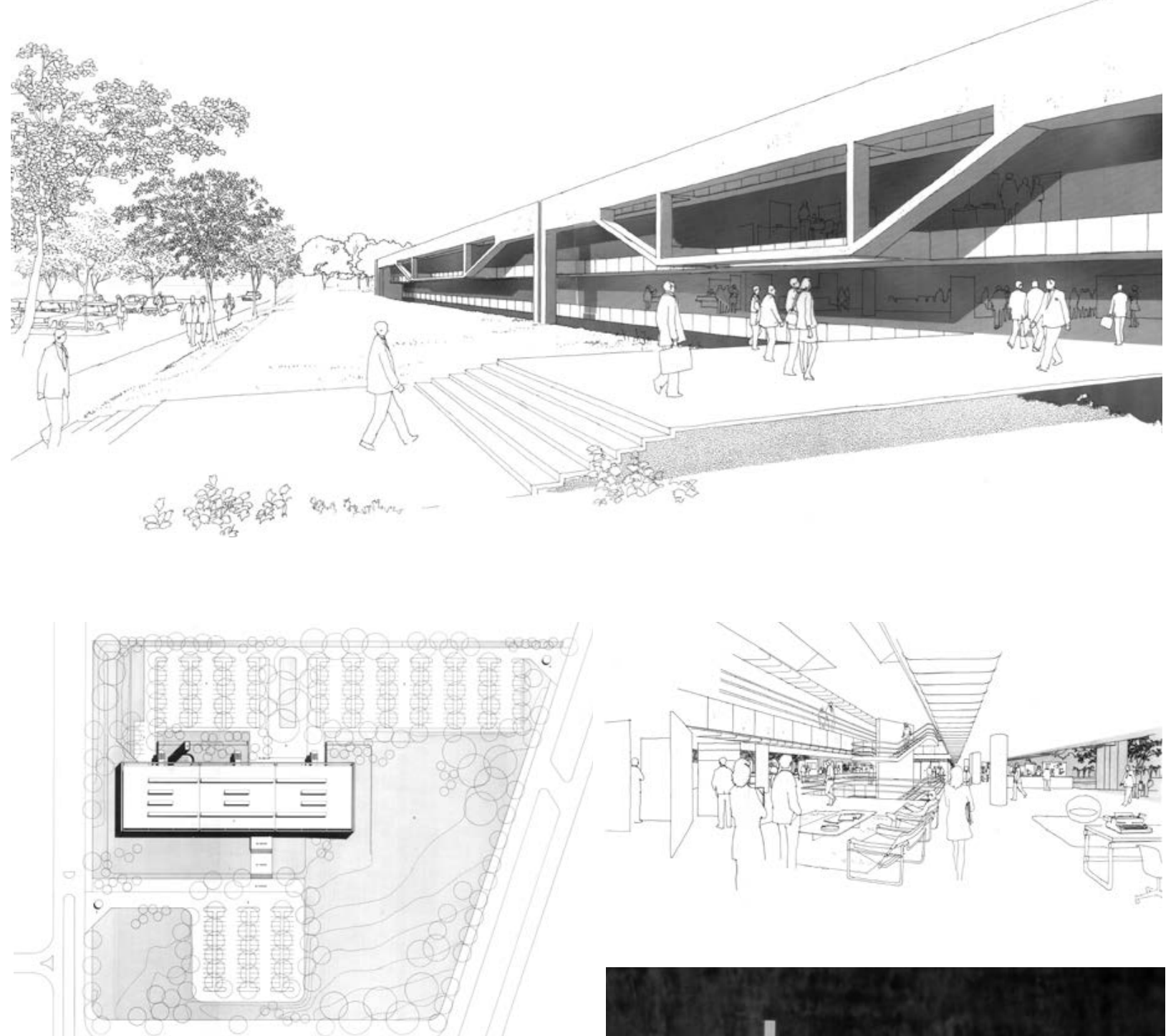

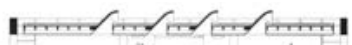

ए $\mathrm{L}$ (1)
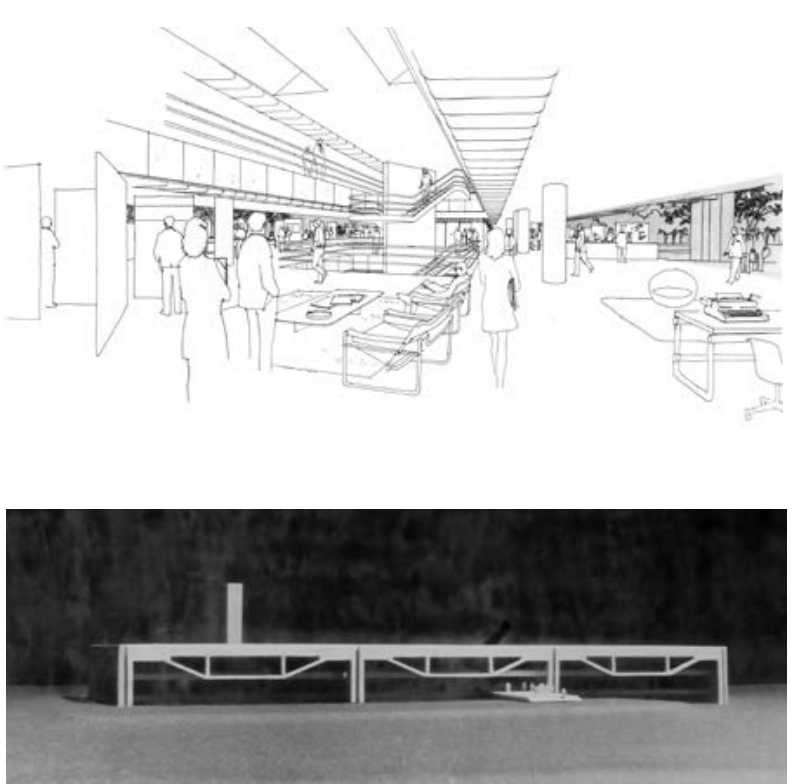
Uso

Residência Unifamiliar

Cliente

Donald Ting

Equipe

Arnaldo Martino e Eduardo de Almeida

Localização

Rua Jabá, Morumbi, São Paulo, SP

Estágio

Projeto Executivo

Observações

Construído

\section{Características}

De acordo com a topografia do lote, esta casa implantase em três pavimentos: acesso de veículos, área de lazer e piscina no piso superior; áreas de serviço e ambientes de estar no intermediário e sala íntima e dormitórios no inferior. Além da implantação incomum, cada um dos ambientes relaciona-se com pátios laterais ou frontais, garantindo continuidade dos ambientes internos ao exterior. Segundo Eduardo de Almeida, por conta da participação de Arnaldo Martino, as obras deste período contam, na maioria dos projetos, com investigações relacionadas aos problemas estruturais.

Acervo
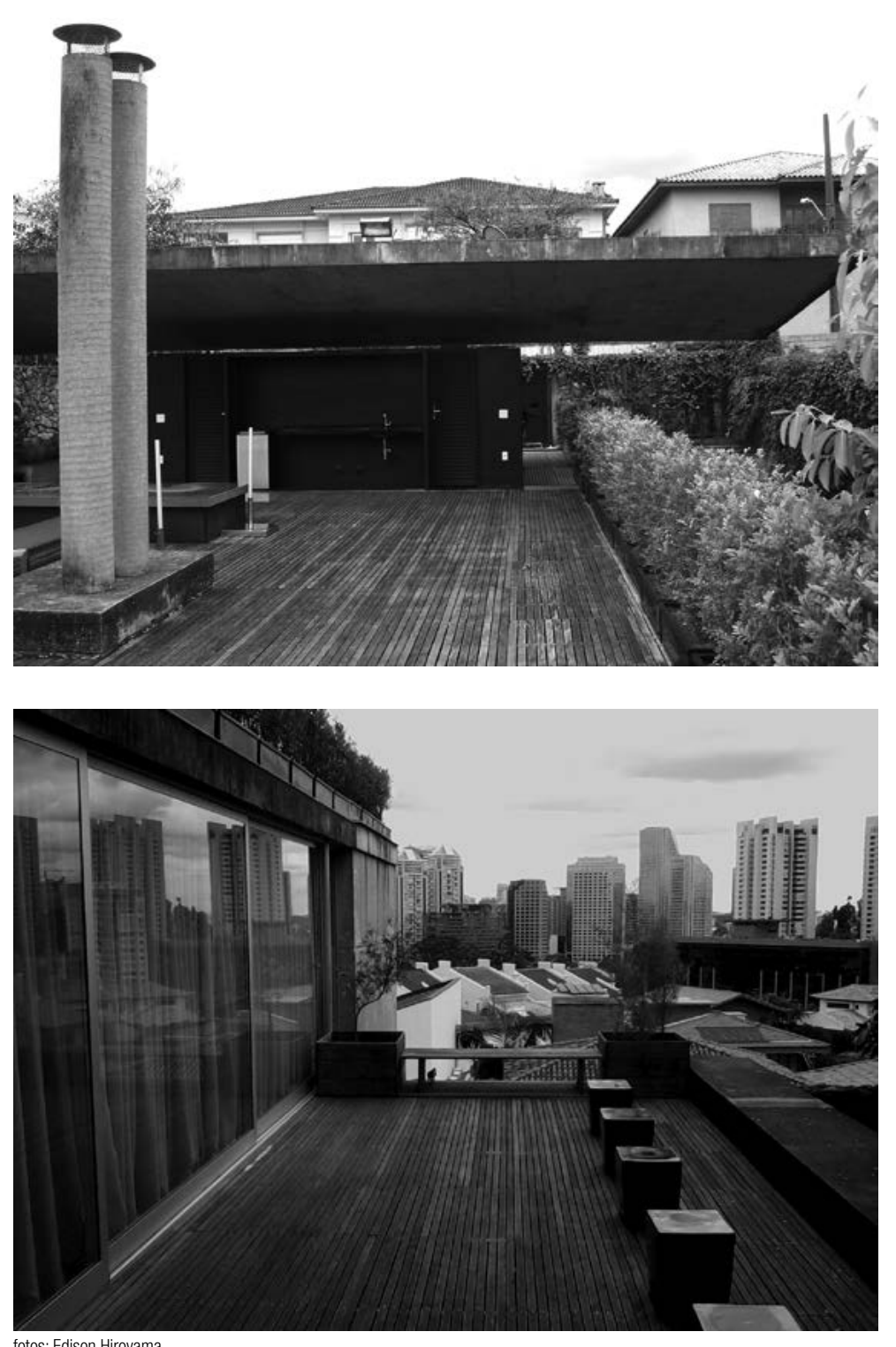

fotos: Edison Hiroyama

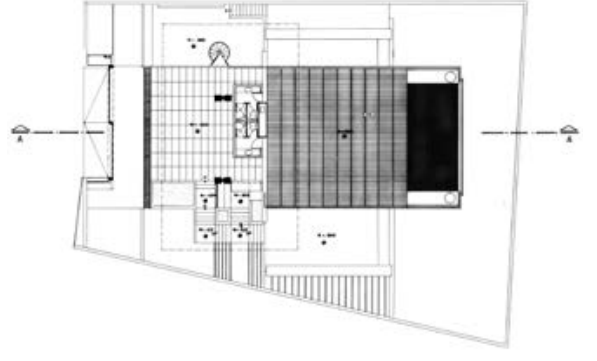

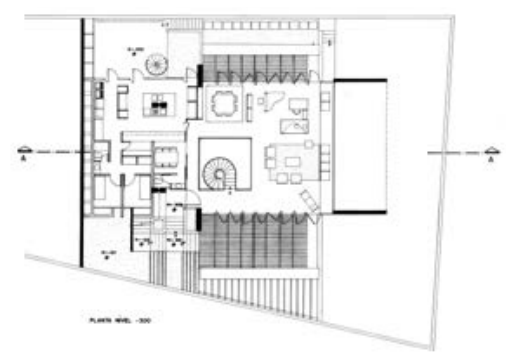
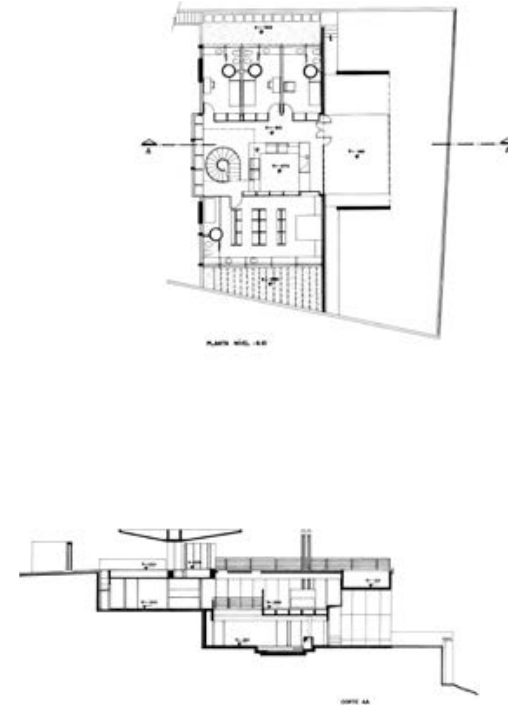
Uso

Plano urbanístico

Cliente

Gesta

Equipe

Arnaldo Martino e Eduardo de Almeida

\section{Localização}

São João do Meriti, RJ

Estágio

Anteprojeto

\section{Observações}

Não Construído

\section{Características}

Este conjunto habitacional de grandes proporções parte da composição de duas unidades distintas de dois e três dormitórios que, justapostas, criam lâminas horizontais associadas a volumes de planta quadrada, sempre desenhados em função das áreas destinadas às circulações verticais. Tal solução organiza alternadamente as áreas de estacionamentos organiza alternadamente as áreas de estacionamentos
descobertos e os pátios ajardinados. Além dos espaços destinados às residências foram criados edifícios de comércio e lazer junto aos acessos principais.

Acervo

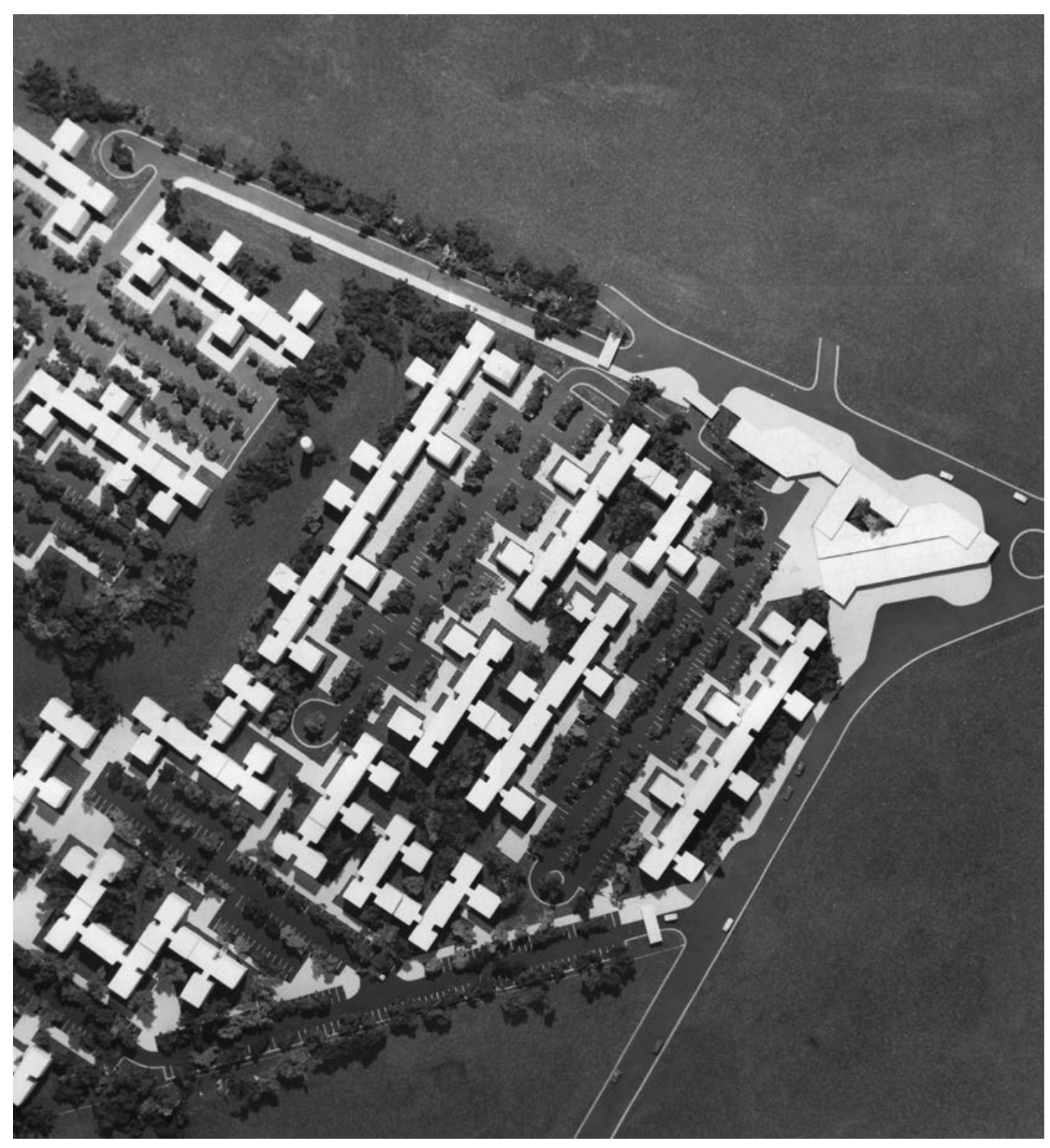

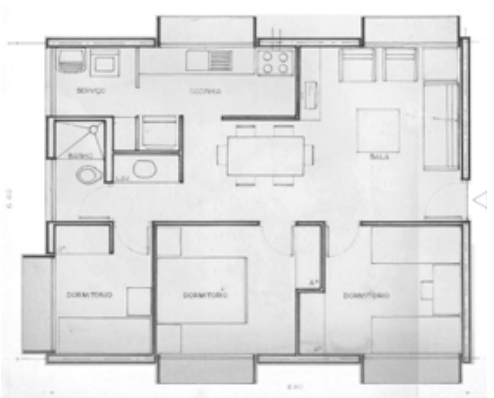

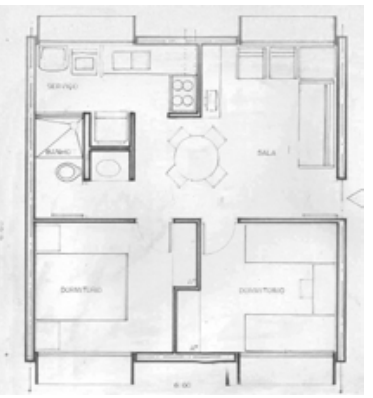


Uso

Conjunto Residencial - 10 casas

Cliente

Construtora Paulista S.A.

Equipe

Arnaldo Martino e Eduardo de Almeida

Localização

Avenida Inajar de Souza com Rua Imaruí, Vila Nova

Cachoeirinha, São Paulo, SP

Estágio

Projeto Executivo

Observações

Construído

\section{Características}

Projeto de dez casas geminadas de três dormitórios e

dois pavimentos. Extremamente econômicas, as casas

são construídas com alvenaria de tijolo aparente, lajes

pré-fabricadas e coberturas de telhas onduladas de

fibrocimento.

Acervo

Tubo 69

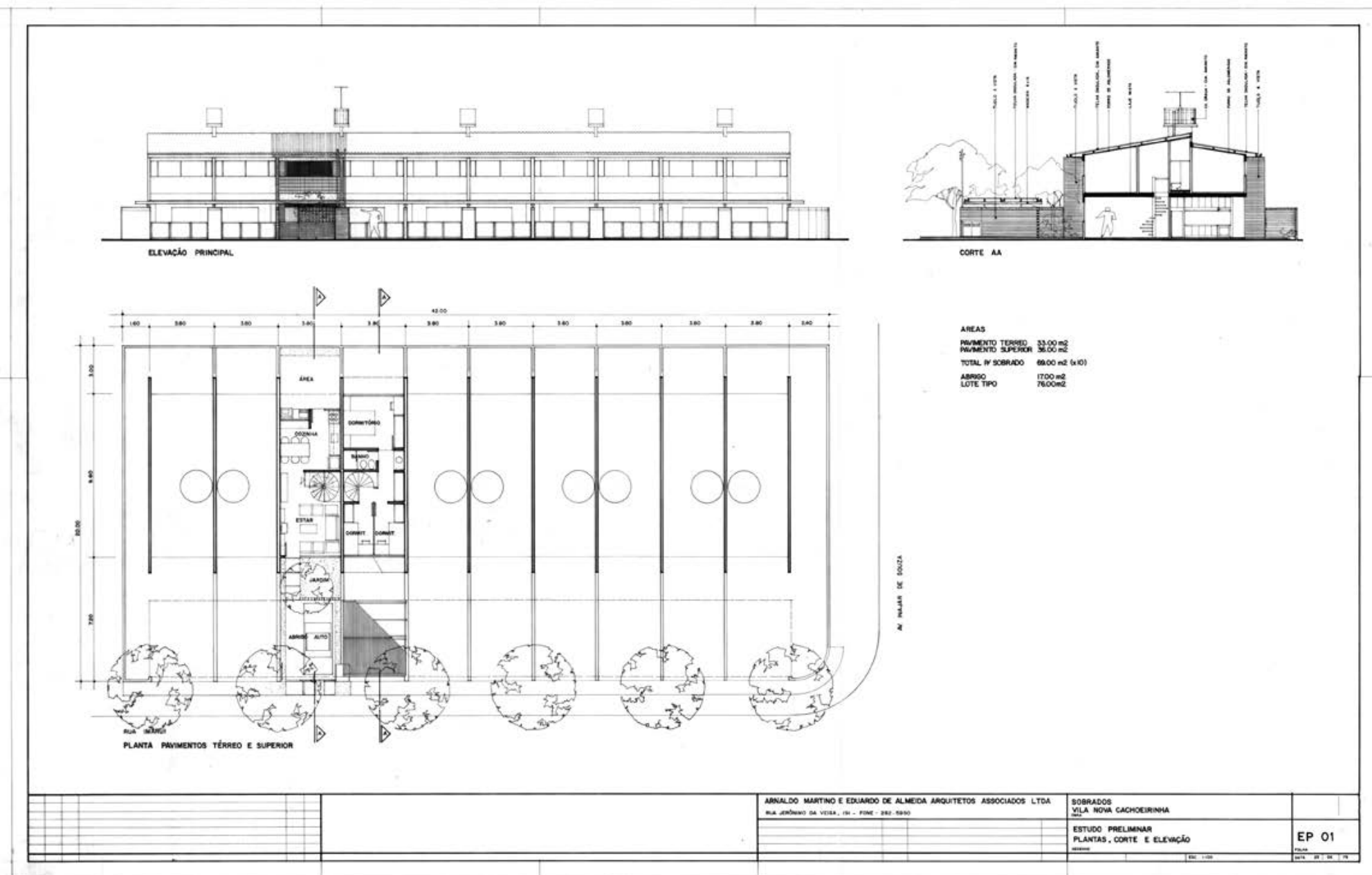


Uso

Conjunto residencial - 2 casas

Cliente

Construtora Paulista S.A.

Equip

Arnaldo Martino e Eduardo de Almeida

Localização

Casa Verde, São Paulo, SP

Estágio

Projeto Executivo

Observações

Construído

Características

Seguindo o partido adotado para os dez sobrados de

Vila Nova Cachoeirinha, Eduardo de Almeida e Arnaldo

Martino também realizam o projeto para estas duas

casas geminadas na Casa Verde, desta vez considerando

o lote em esquina.

Acervo

Tubo 69

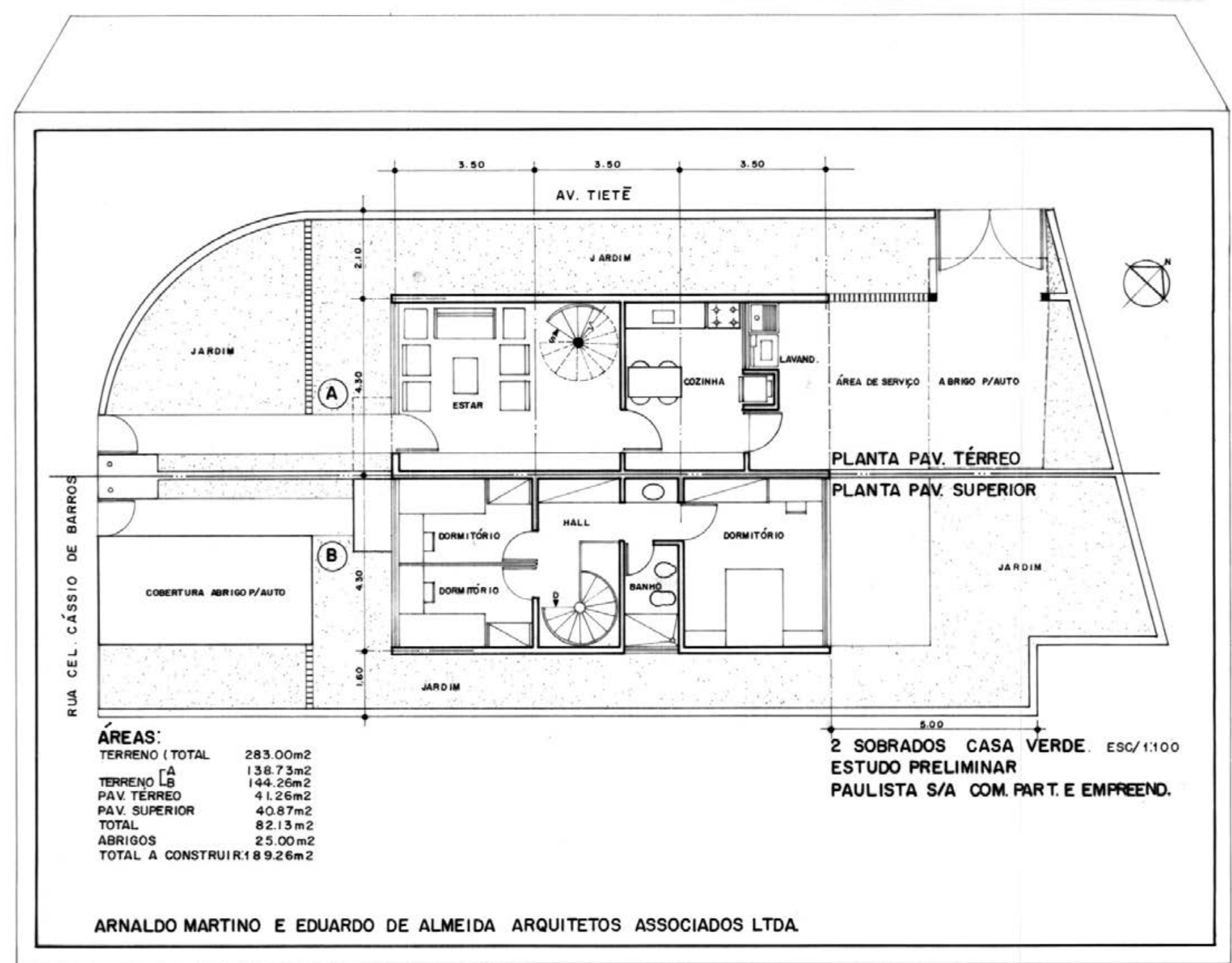


Uso

Residência Unifamiliar

Cliente

Mário Misiano Ciuchini

Equipe

Arnaldo Martino e Eduardo de Almeida

Localização

Av. das Magnólias, 277, Cidade Jardim, São Paulo

Estágio

Projeto Executivo

Observações

Construído

\section{Características}

Após a realização de inúmeros estudos, o partido finalmente adotado para esta residência conforma uma implantação em dois blocos articulados pela escada em meios-níveis. Esta implantação em "L" cria uma grande área aberta ajardinada, onde se posiciona a piscina $e$ para onde se voltam todos os ambientes de estar. Assim como outras obras do mesmo período, a estrutura de concreto é associada a planos de alvenaria de tijolos aparentes.

Acervo

Tubo 77,77A e 77B
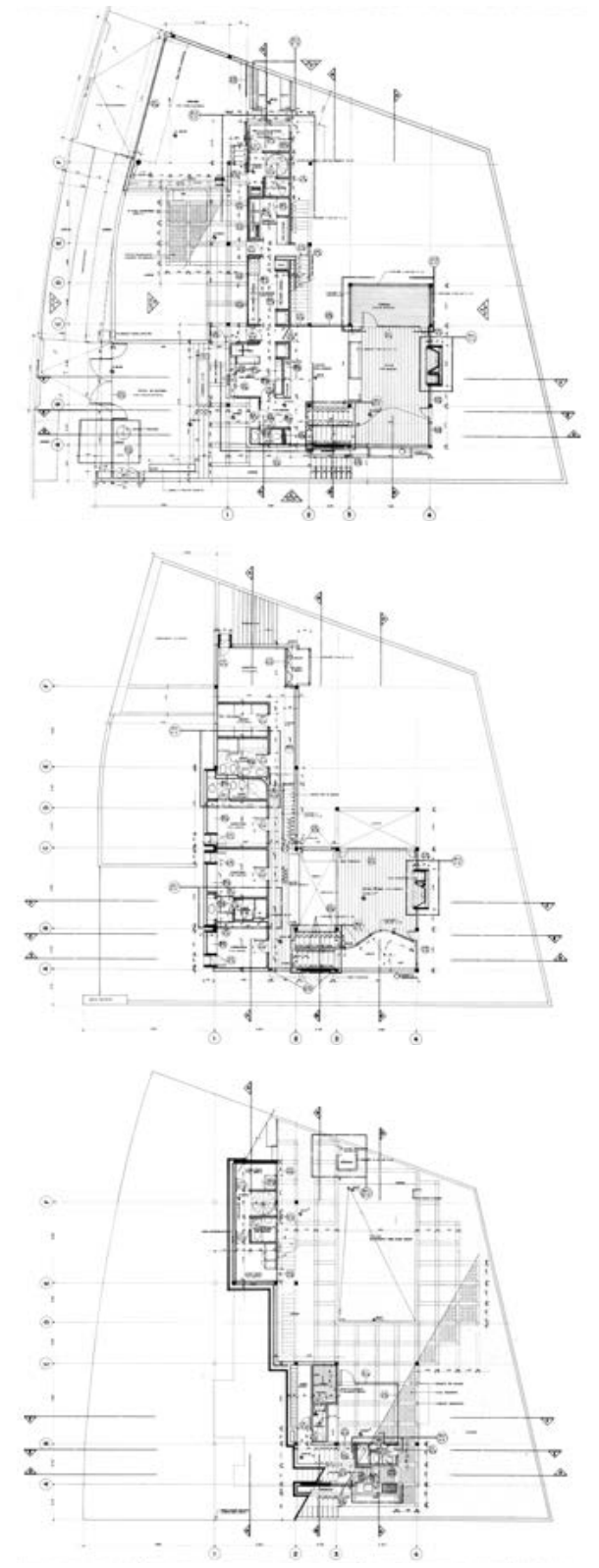

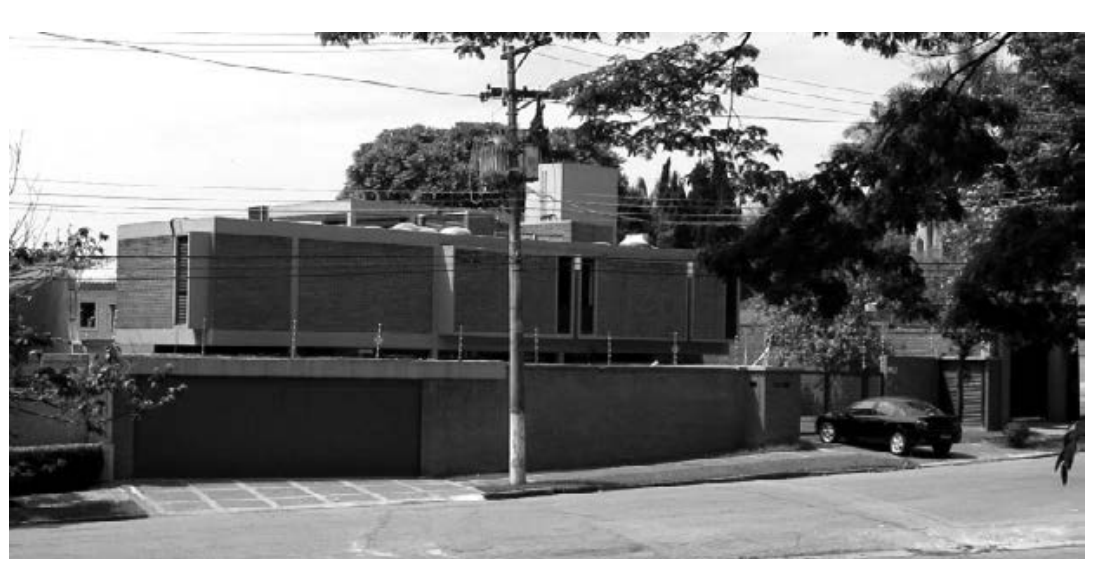

foto: Alessandra Figueiredo
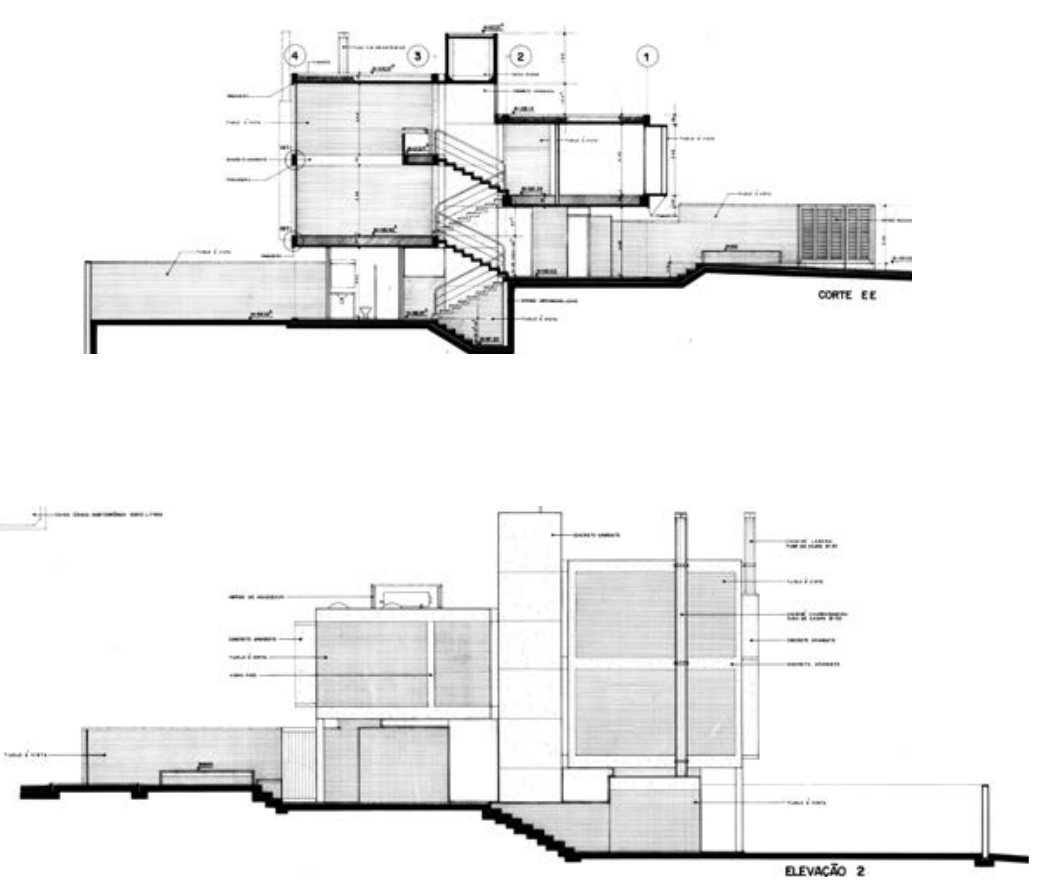
Uso

Fazenda

Cliente

Otávio Leite de Morais

Equipe

Arnaldo Martino e Eduardo de Almeida

Localização

Orlândia, SP

Estágio

Estudo Preliminar

Observações

Não Construído

\section{Características}

A partir da construção pré-existente da casa sede da fazenda, 0 projeto de expansão considera a criação de um volume retangular para a cozinha e área de serviços, volume de transição para a nova ala de quartos, salas e garagem coberta que se desenvolve ao longo de um pavilhão definido por pilares em "placas" de alvenaria pavihão definido por pilares em "placas" de alvenaria com estrutura de madeira

\section{Acervo}

Tubo 92

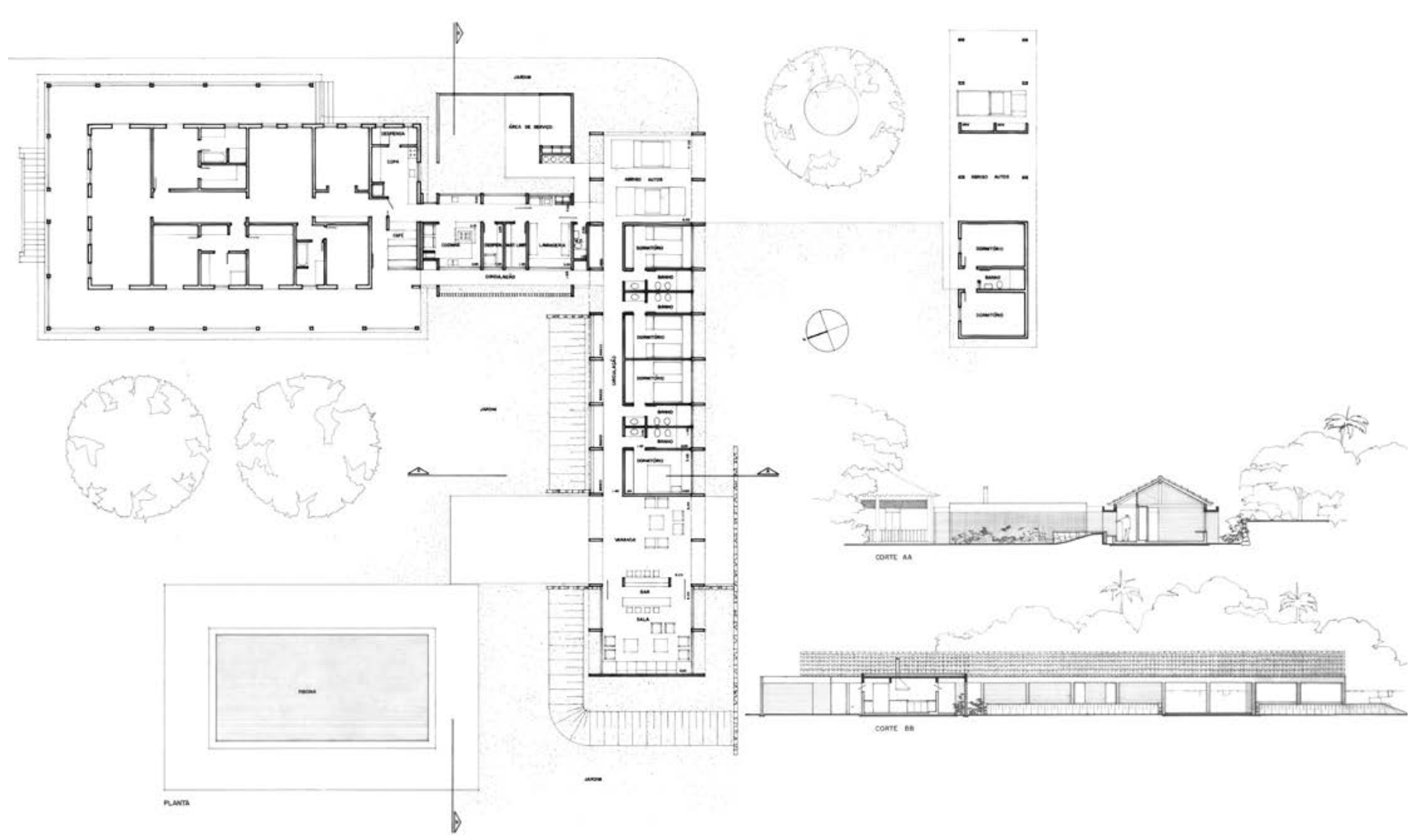


Uso

Residência Unifamiliar

Cliente

José Manuel Riveros

Equipe

Arnaldo Martino e Eduardo de Almeida

Localização

Alameda Panamá, Granja Viana, Cotia, SP

Estágio

Projeto Executivo

Observações

Construído

Características

Utilizando um platô definido por extensos muros de pedra, esta casa organizada em um pavimento estruturase por meio de um eixo central de circulação que articula os diferentes programas. Enquanto a cobertura desta espinha dá-se por meio de uma abóboda de concreto iluminada zenitalmente por tijolos de vidro inseridos durante a concretagem, as coberturas dos ambientes utilizam uma engenhosa solução de estrutura metálica com canaletas de fibrocimento preenchidas por camada de argila expandida. Os pilares em placa das extremidades que definem os ambientes internos foram construídos com blocos de concreto aparentes, mas seguem a lógica dos projetos do período.

Acervo

Tubo 48 e 48A
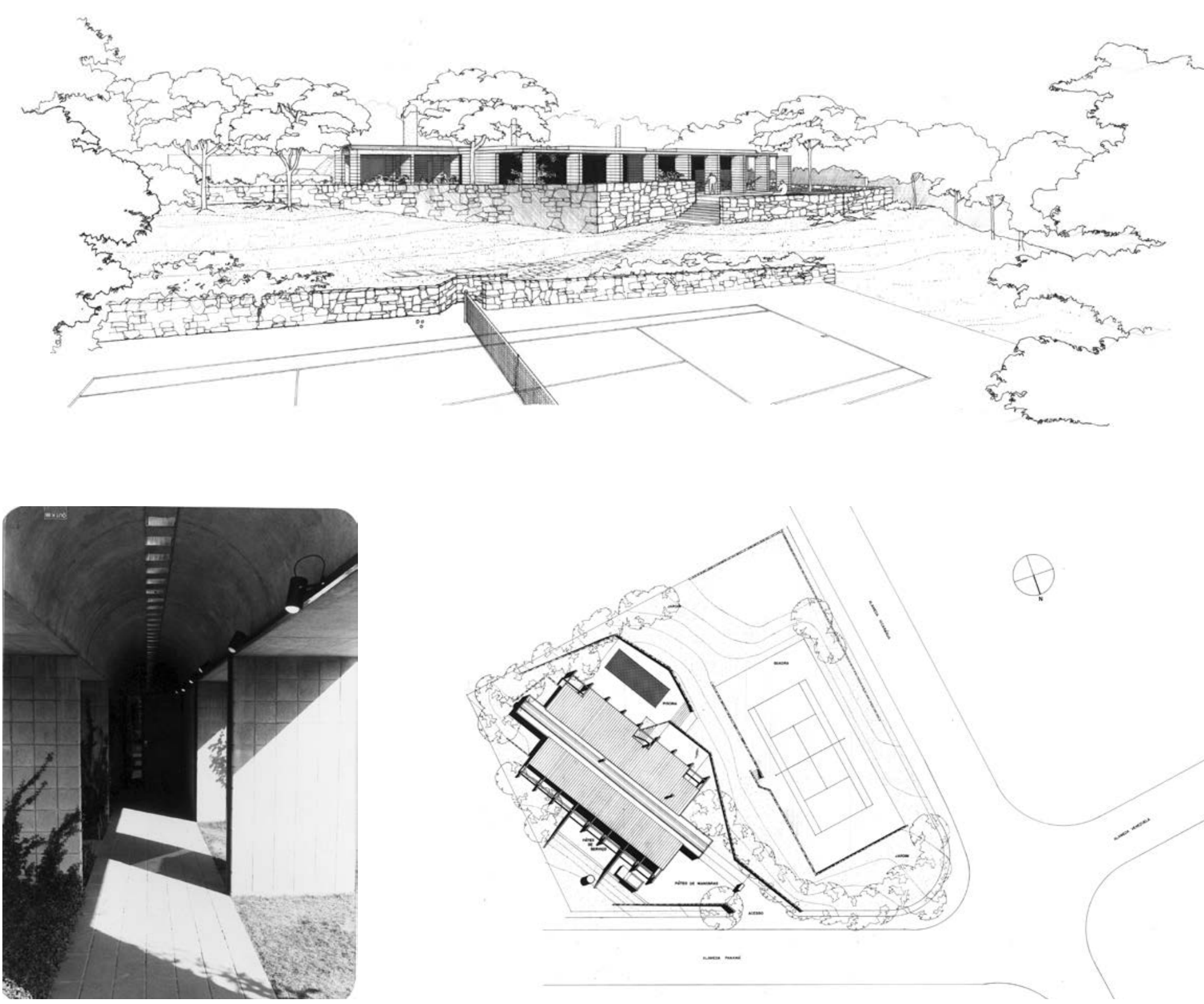

$\theta$

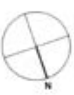


Uso

Residência Unifamiliar

Cliente

Luigi Giavina

Equipe

Arnaldo Martino e Eduardo de Almeida

Localização

Jardim Acapulco, Guarujá, SP

Estágio

Projeto Executivo

Observações

Construído

\section{Características}

Seguindo soluções semelhantes à casa Riveros ou ao segundo projeto da Fazenda Campo dos Bois, o projeto para esta casa de praia também utiliza 0 eixo central abobadado. Neste caso, ele assume a dimensão da varanda e articula os volumes de duas águas e estrutura de madeira destinados à sala, cozinha e dormitórios.

Acervo

Tubo 40 e $40 \mathrm{~A}$

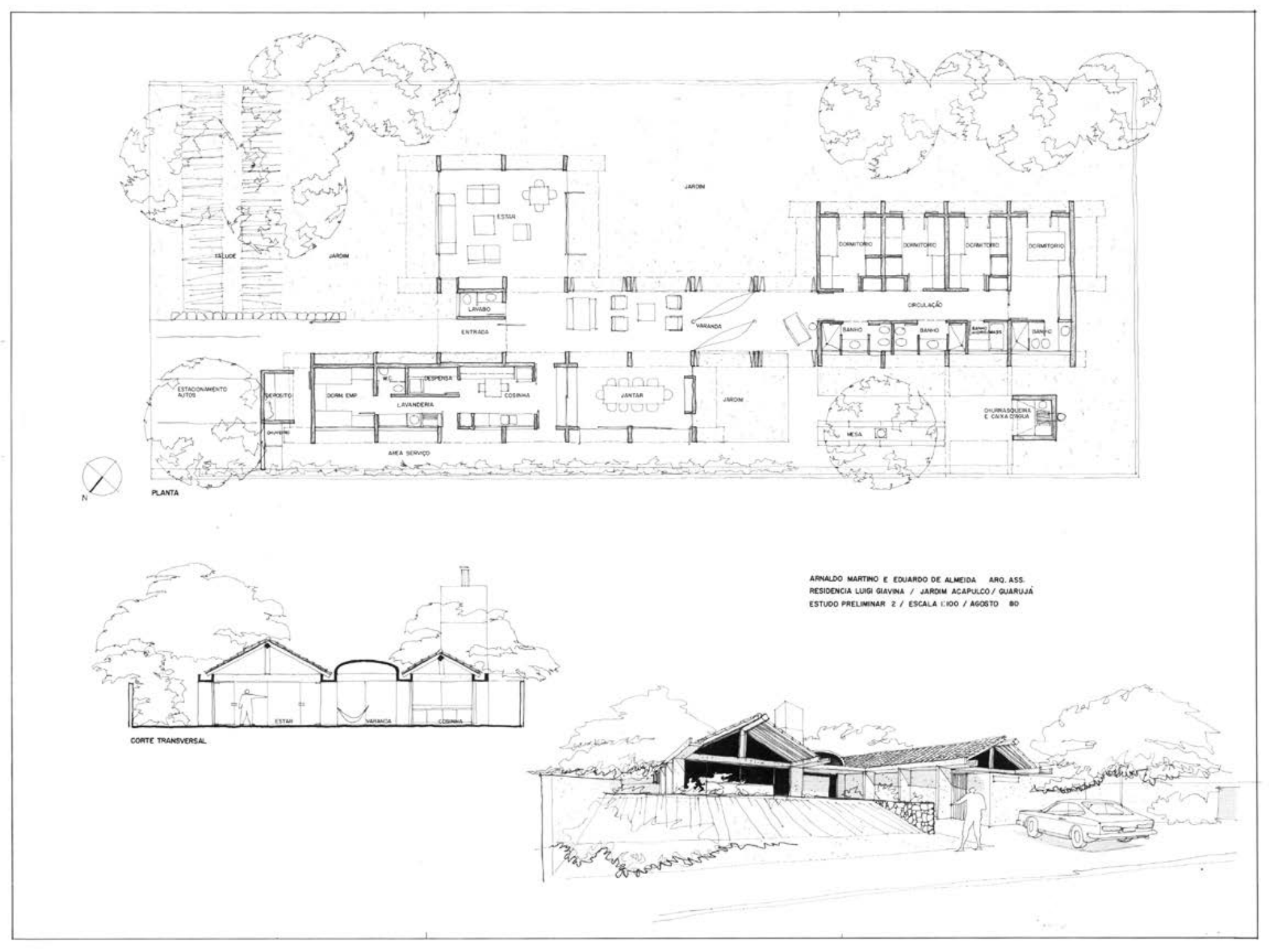


Uso

Residência Unifamiliar

Cliente

Belinky

Equipe

Arnaldo Martino e Eduardo de Almeida

estrutura | Projecta

\section{Localização}

Rua Itajaçu 154, Pacaembu, São Paulo

Estágio

Projeto Executivo

Observações

Construído

Características

Este projeto inaugura uma série de obras que utiliza a estrutura metálica como elemento primordial na definição da construção. Devido a complexidade imposta pela topografia do lote, a estrutura utiliza-se de poucos pontos de apoio e, a partir de uma relação de meionível, os diversos pavimentos organizam o programa ao longo do percurso estabelecido pela escada. Seguindo a influência das obras de Mies van der Rohe em Chicago, o projeto utiliza alternadamente alvenarias aparentes e planos de vidro encaixados na malha de pilares e vigas, exigindo um detalhamento cuidadoso no encontro dos materiais.

Acervo

Não identificado

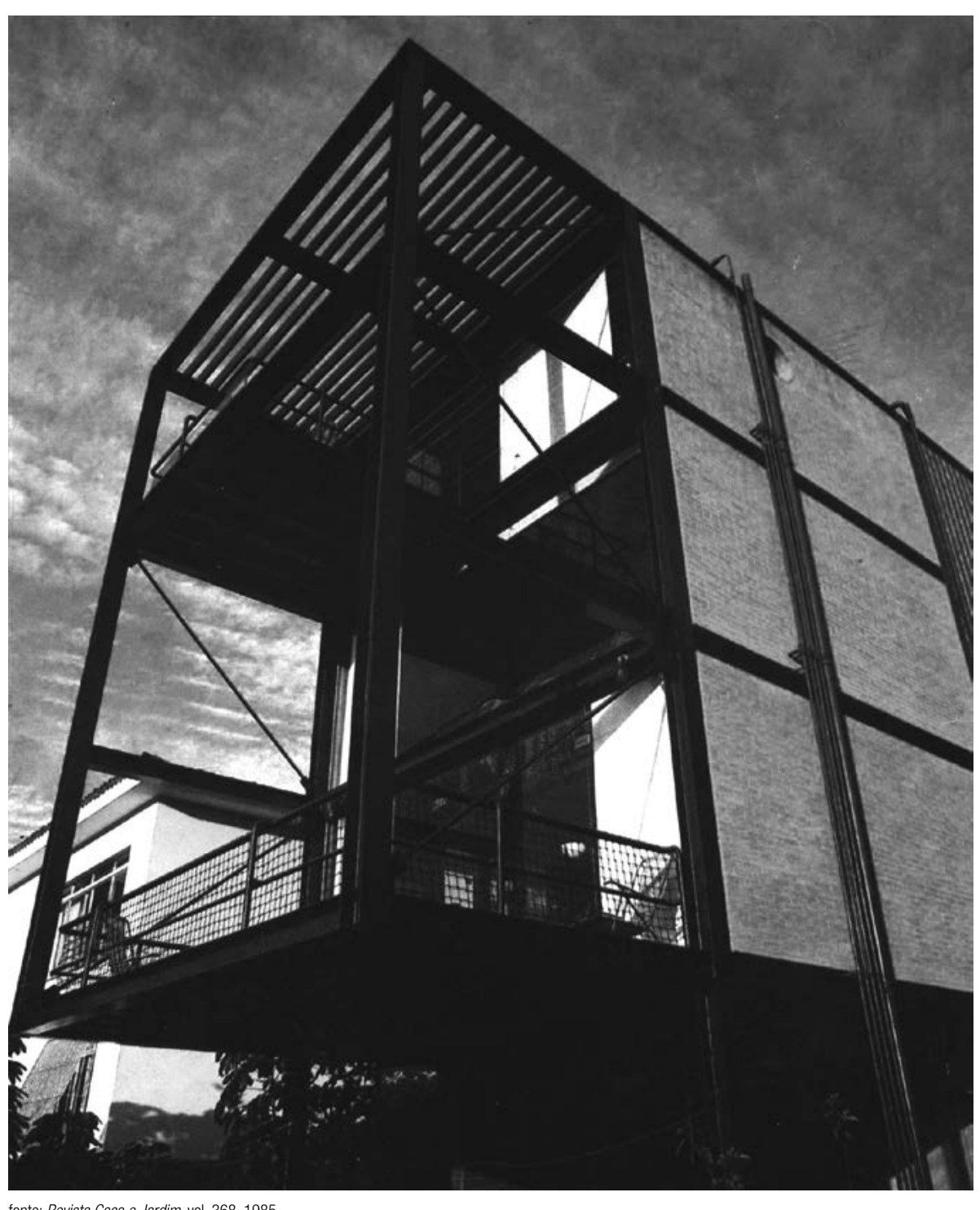

fonte: Revista Casa e Jardim, vol. 368, 1985
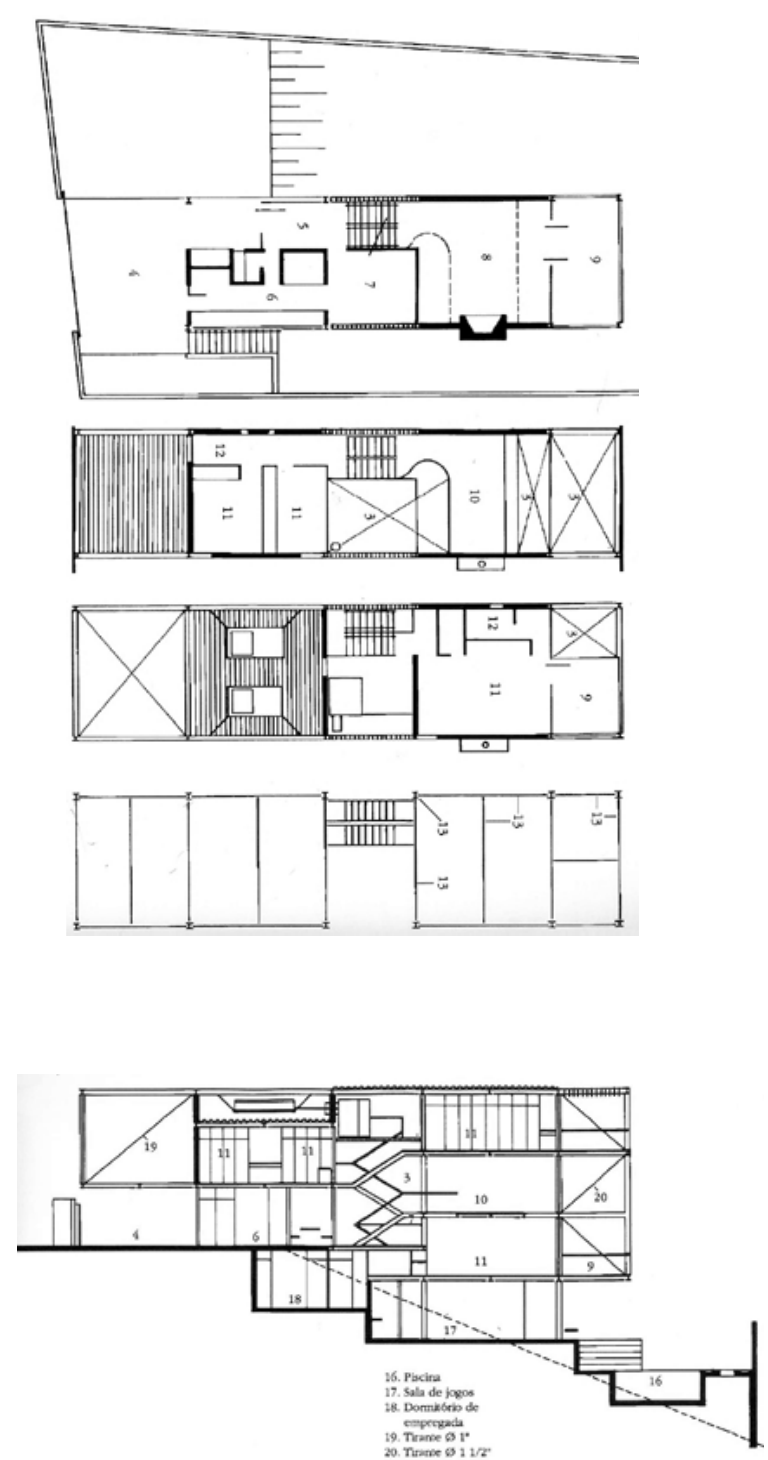

fonte: DAAS, Luis Andrade de Mattos. Edificacóöes de Aço no Brasili, Săo Paulo, Zigurate Editora, páa. 48-49. 
Uso

Edifício de Habitação Coletiva

Cliente

Construtora Paulista S.A.

Equipe

Arnaldo Martino e Eduardo de Almeida

Localização

Granja Julieta, São Paulo

Estágio

Projeto Executivo

Observações

Construído

\section{Características}

Edifício de habitação coletiva com dez pavimentos com

4 unidades por andar. Enquanto as aberturas de todos

os dormitórios posicionam-se nas fachadas laterais,

os espaços de serviços e sala de estar definem as

elevações frontal e de fundos, organizadas por janelas

em fita e marcadas pelas varandas em balanco. A

estrutura de concreto organiza-se por meio de 12

pilares em placa, definidos pelo layout das unidades e

marcados nas fachadas como planos cegos de grandes

dimensões.

Acervo
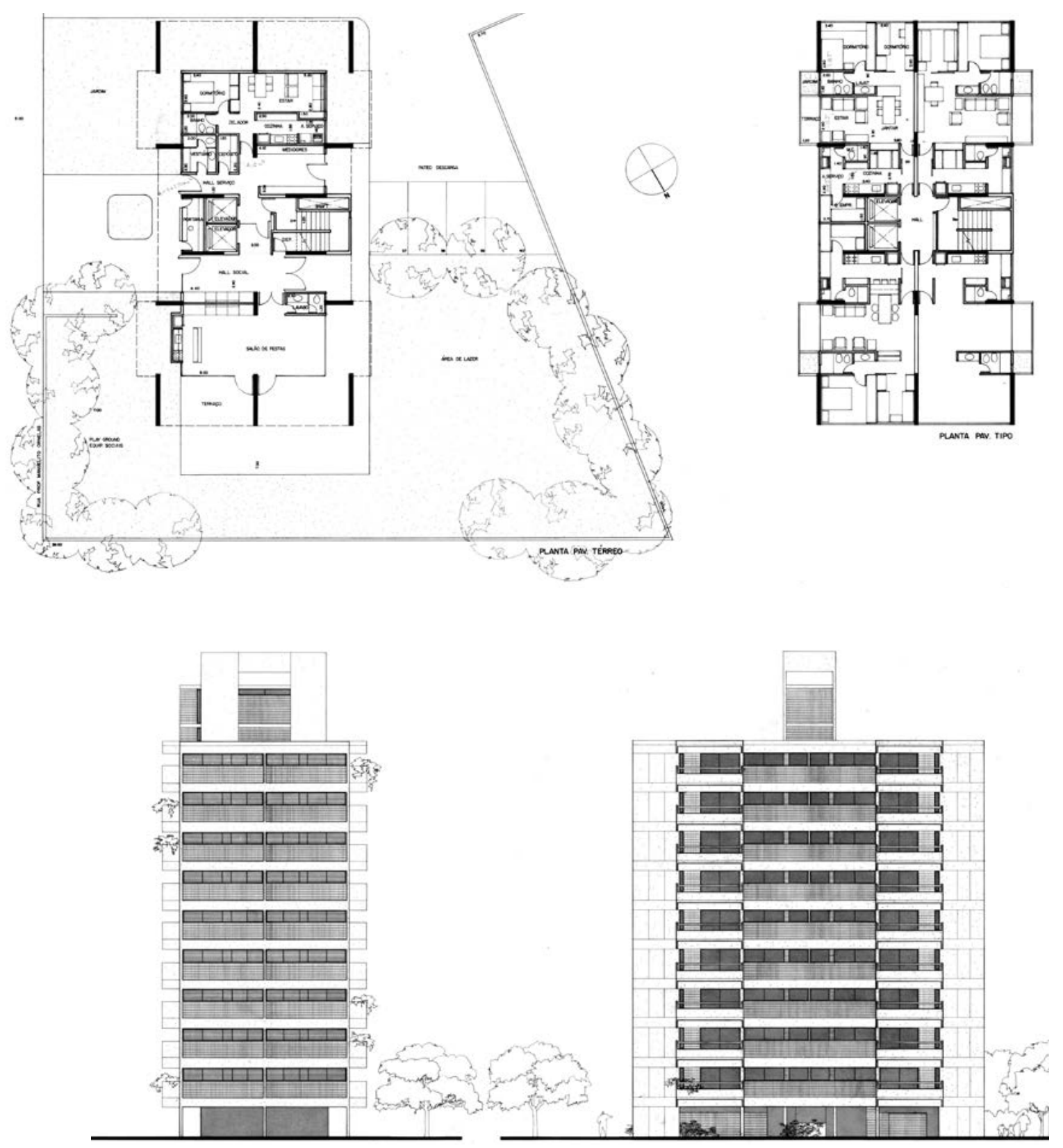

Q

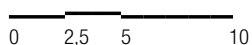


Uso

Edifício de Habitação Coletiva

Cliente

Construtora Paulista S.A.

Equipe

Arnaldo Martino e Eduardo de Almeida

Localização

Mauá, SP

Estágio

Anteprojeto

Observações

Não Construído

\section{Características}

Seguindo solução semelhante ao edifício da Granja Julieta, este edifício de habitação coletiva de nove pavimentos cria quatro unidades por andar, organizados em dois blocos articulados por uma torre central de circulação. A estrutura de concreto aparente é preenchich por planos de alcon elementos vazados que, em conjunto com as jardineiras da sala de estar e as aberturas verticais, compõem a volumetria do edifício. A perspectiva à mão livre é de autoria de Arnaldo Martino.

Acervo

Tubo 59 e Caixa 4000
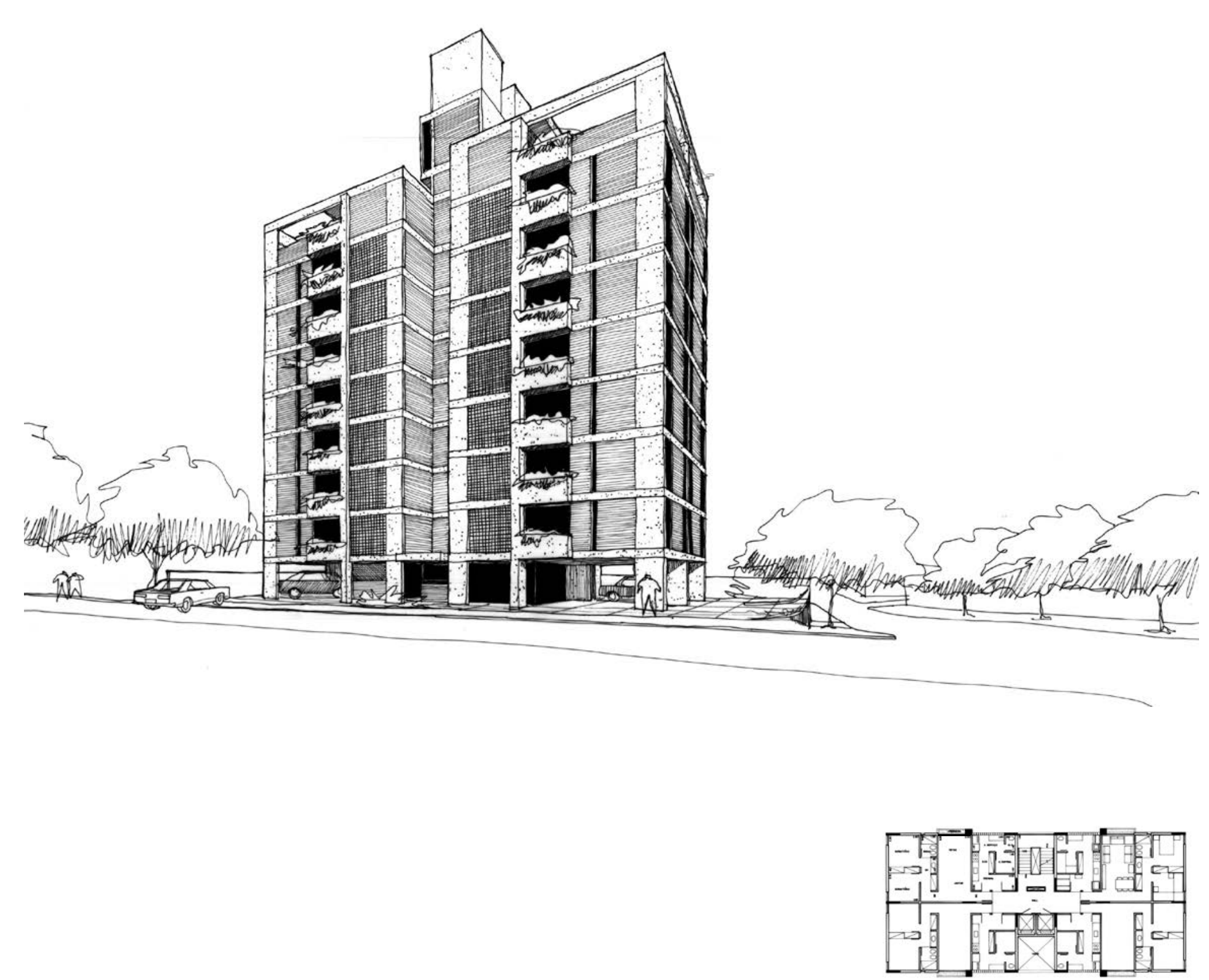
Uso

Edifício de Habitação Coletiva

Cliente

Construtora Paulista S.A.

Equipe

Arnaldo Martino e Eduardo de Almeida

Localização

Rua Rudge Ramos, São Paulo, SP

Estágio

Anteprojeto

Observações

Não Construído

\section{Características}

De acordo com a legislação local, este edifício de uso misto - comércio no térreo e moradias nos andares superiores - é implantado de acordo com a geometria trapezoidal do lote, sem recuos laterais. Uma torre central de circulacão articula as quatro unidades implantadas em cada pavinero, ciando unidades que possuem suas aberturas principals voltadas para a rua ou para o recuo de fundo, enquanto as aberturas dos ambientes de serviços e sanitários utilizam-se dos pátios centrais existentes entre os dois blocos. A perspectiva à

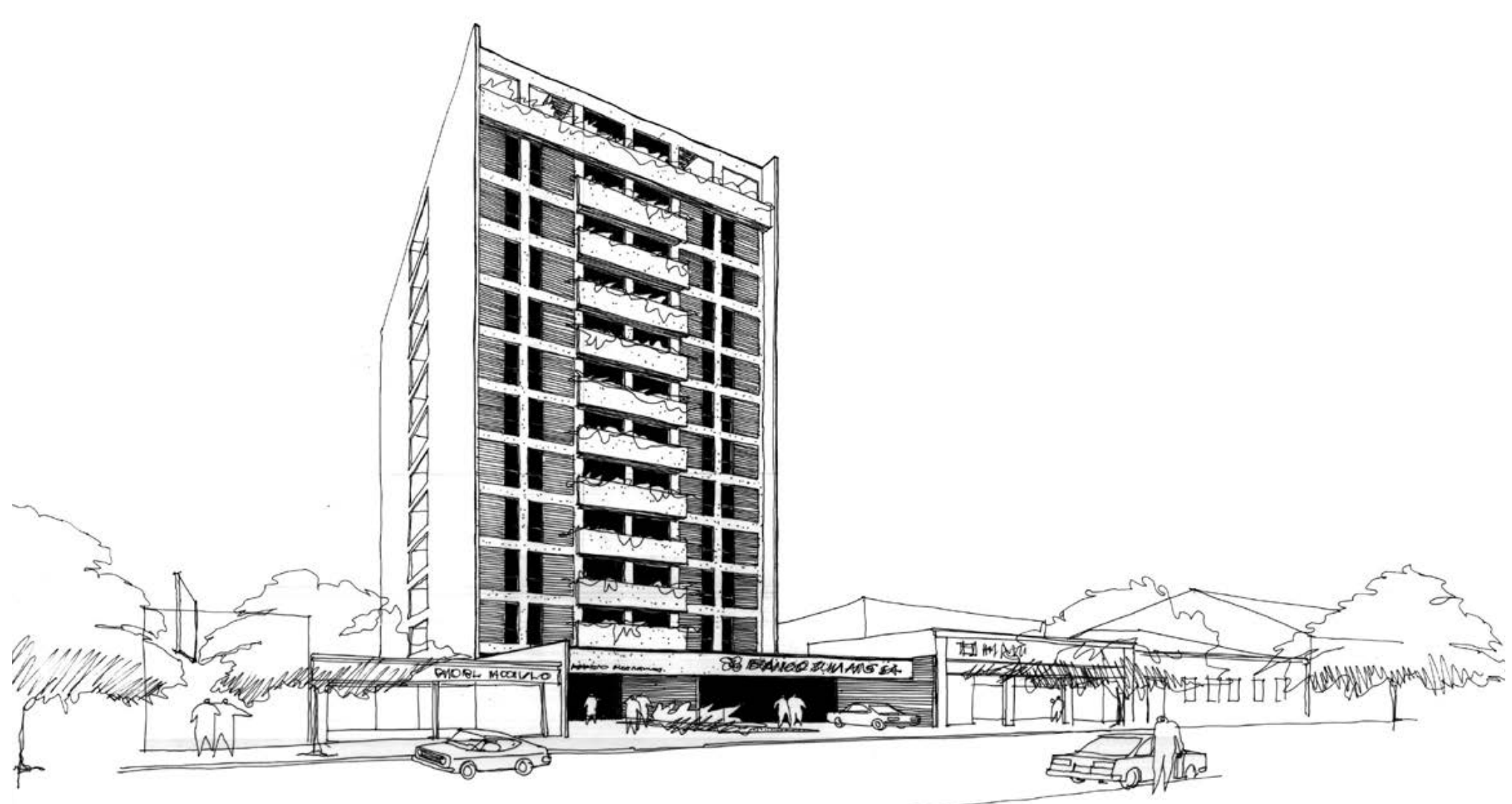
mão livre é de autoria de Arnaldo Martino.

Acervo

Tubo 59 e Caixa 4000

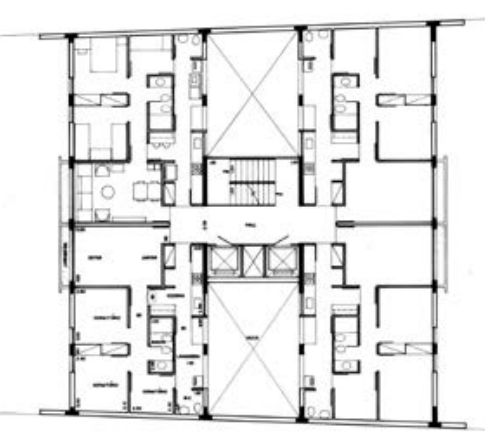


Uso

Conjunto Residencial - 19 casas

Cliente

Construtora Paulista S.A.

Equipe

Arnaldo Martino e Eduardo de Almeida

Localização

Rochdale, Osasco, SP

Estágio

Projeto Executivo

Observações

Construído

\section{Características}

Conjunto de 19 residências unifamiliares, geminadas duas a duas. Utilizando soluções extremamente econômicas - alvenaria revestida, cobertura em telhas de fibrocimento - as casas foram compostas por dois blocos articulados pelo volume do sanitário e da área de serviços. Enquanto 0 primeiro é dedicado à sala $e$ à cozinha, o segundo abriga os dois dormitórios. Foi realizada uma versão com $63 \mathrm{~m} 2 \mathrm{e} \mathrm{outra} \mathrm{com} 72 \mathrm{~m} 2$.

Acervo

Tubo 59 e Caixa 4000
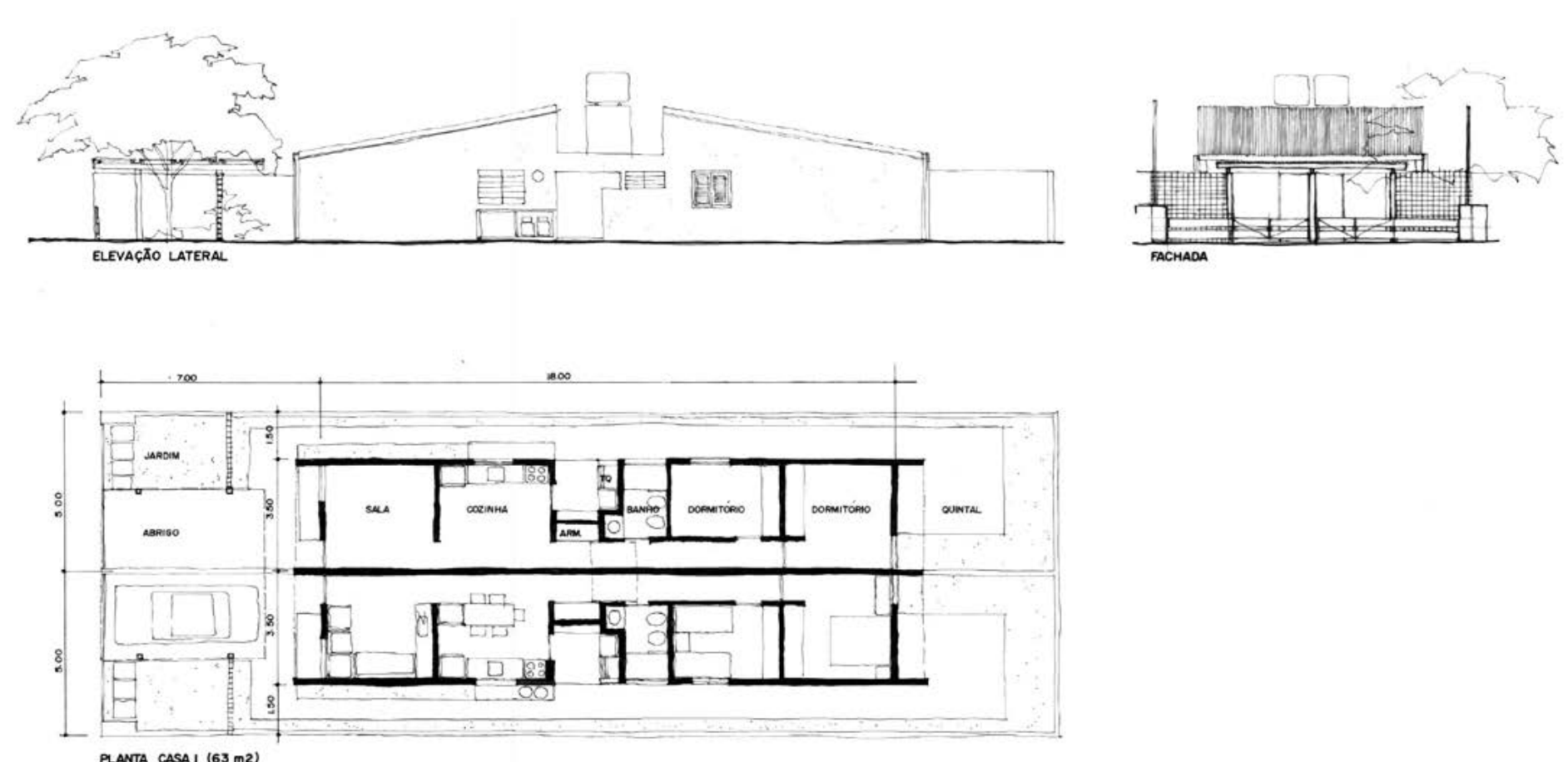

PLANTA CASA I (63 m2)

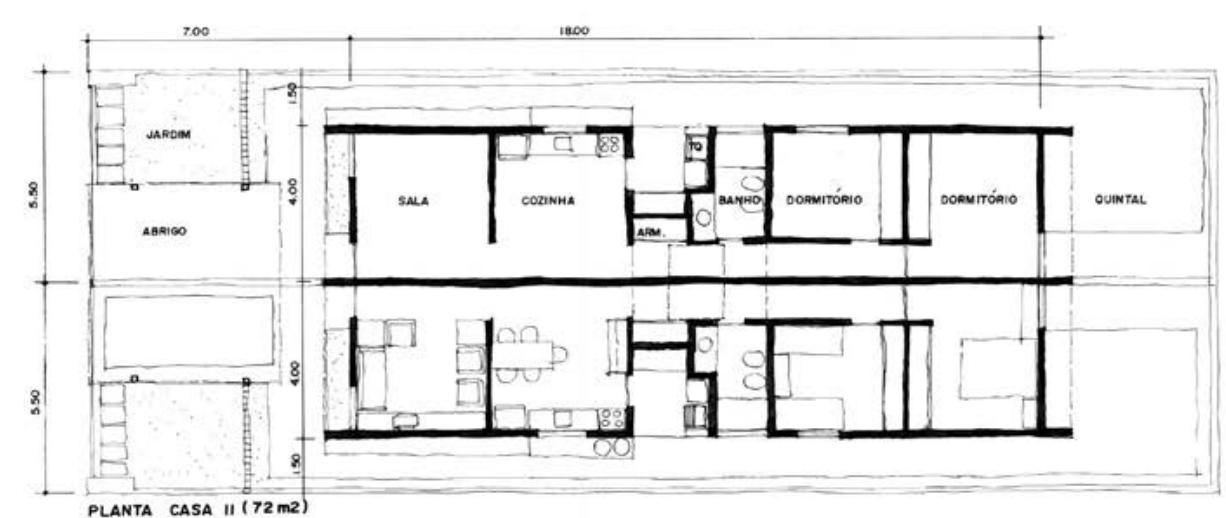

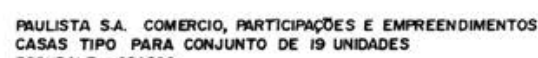

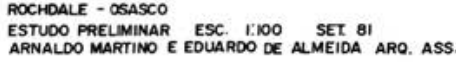


Uso

Edifício de Habitação Coletiva

Cliente

Construtora Paulista S.A.

Equipe

Arnaldo Martino e Eduardo de Almeida

Localização

Mauá, SP

Estágio

Estudo Preliminar

Observações

Não Construído

\section{Características}

Estudo preliminar para um edifício em Mauá desenhado

de acordo com as características do lote em esquina e

em declive. Enquanto 0 estacionamento foi posicionado

junto à parte mais baixa do terreno, 0 acesso aos

apartamentos de por uma cota intermediária

octo

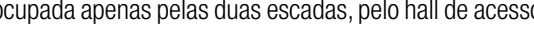

ao edifício e pelo apartamento do zelador. Nos três

andares superiores foram criadas doze apartamentos de

cerca de $70 \mathrm{~m} 2$

Acervo

Tubo 59 e Caixa 4000

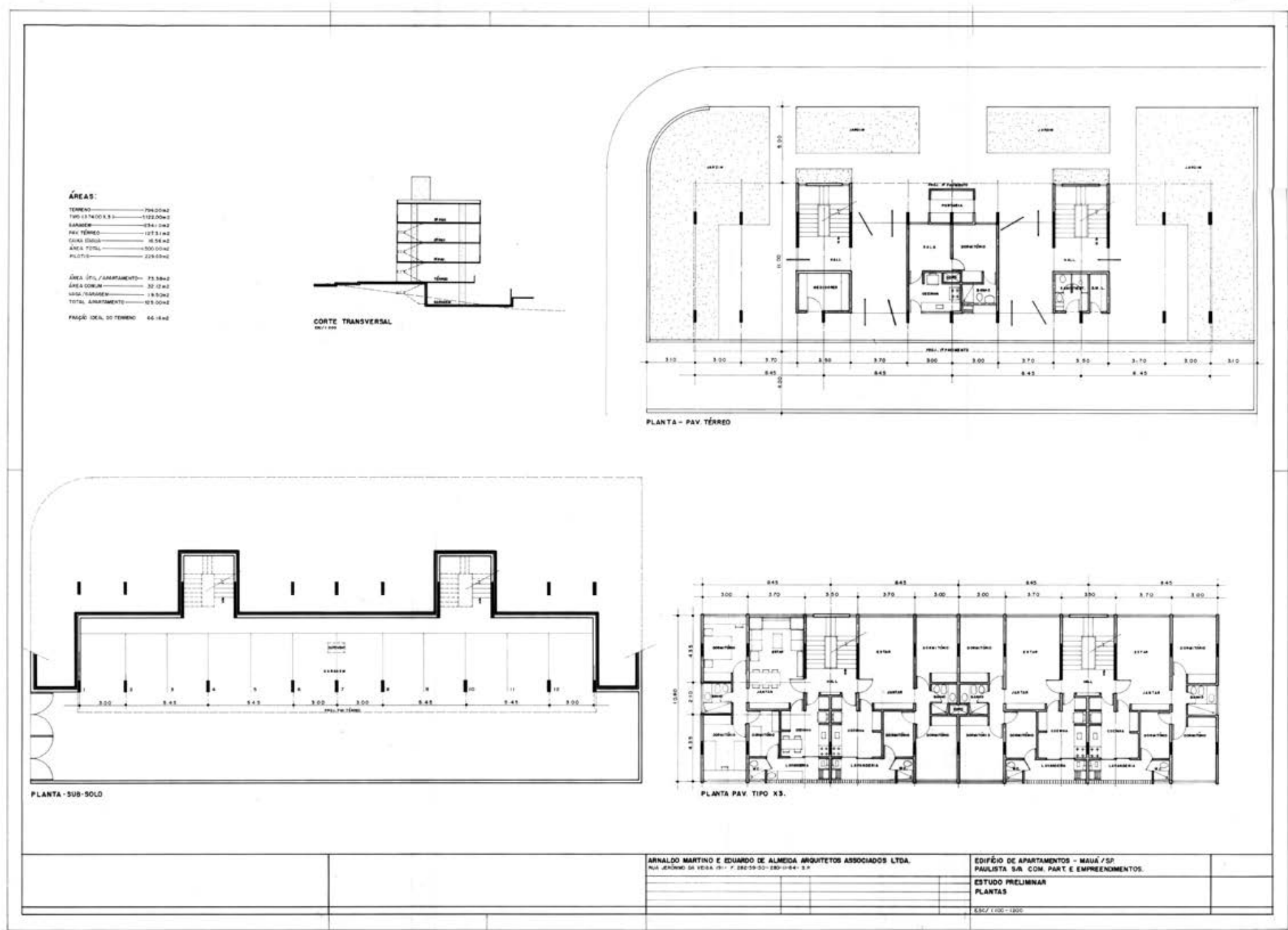


Uso

Edifício de Habitação Coletiva

Cliente

Não identificado

Equipe

Arnaldo Martino e Eduardo de Almeida

Localização

Casa Verde, São Paulo, SP

Estágio

Estudo Preliminar

Observações

Não construído

\section{Características}

Considerando a geometria irregular do lote e a possibilidade de acesso por duas ruas, o edifício Casa Verde cria um conjunto a partir da articulação de três blocos idênticos posicionados em torno de um espaço

de circulação triangular, seguindo os alinhamentos das

divisas do lote. Enquanto os dois primeiros pavimentos

abrigam três unidades, os dois últimos abrigam seis

unidades duplex.

Acervo

Tubo 59 e Caixa 4000

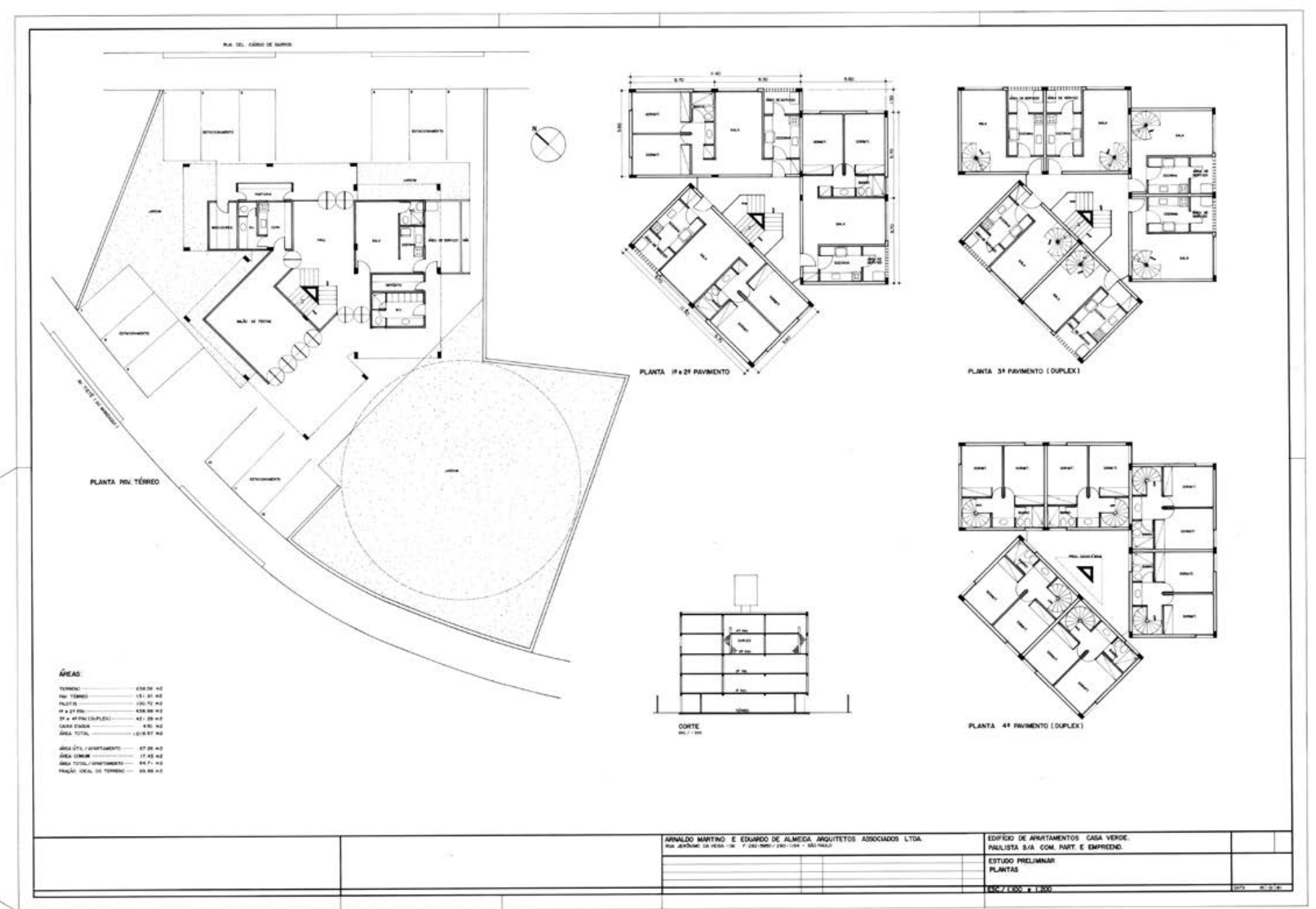


Residência Unifamiliar

Cliente

Rui Porto

Equipe

Arnaldo Martino e Eduardo de Almeida

\section{Localização}

Alameda Sununga, Praia de Toque-Toque Pequeno, São Sebatião, SP

Estágio

Projeto Executivo

Observações

Construído

\section{Características}

Influenciado pelo projeto de Carlos Millan para a casa da Lagoinha, o projeto para esta residência de praia divide 0 espaço da residência em três setores: um dedicado aos três dormitórios, outro dedicado à sala de estar e cozinha e, no centro, uma varanda que cria a conexão entre os dois blocos. A mesma estrutura de madeira com telhado de duas águas cobre estes três setores.

\section{Acervo}

Tubo 69

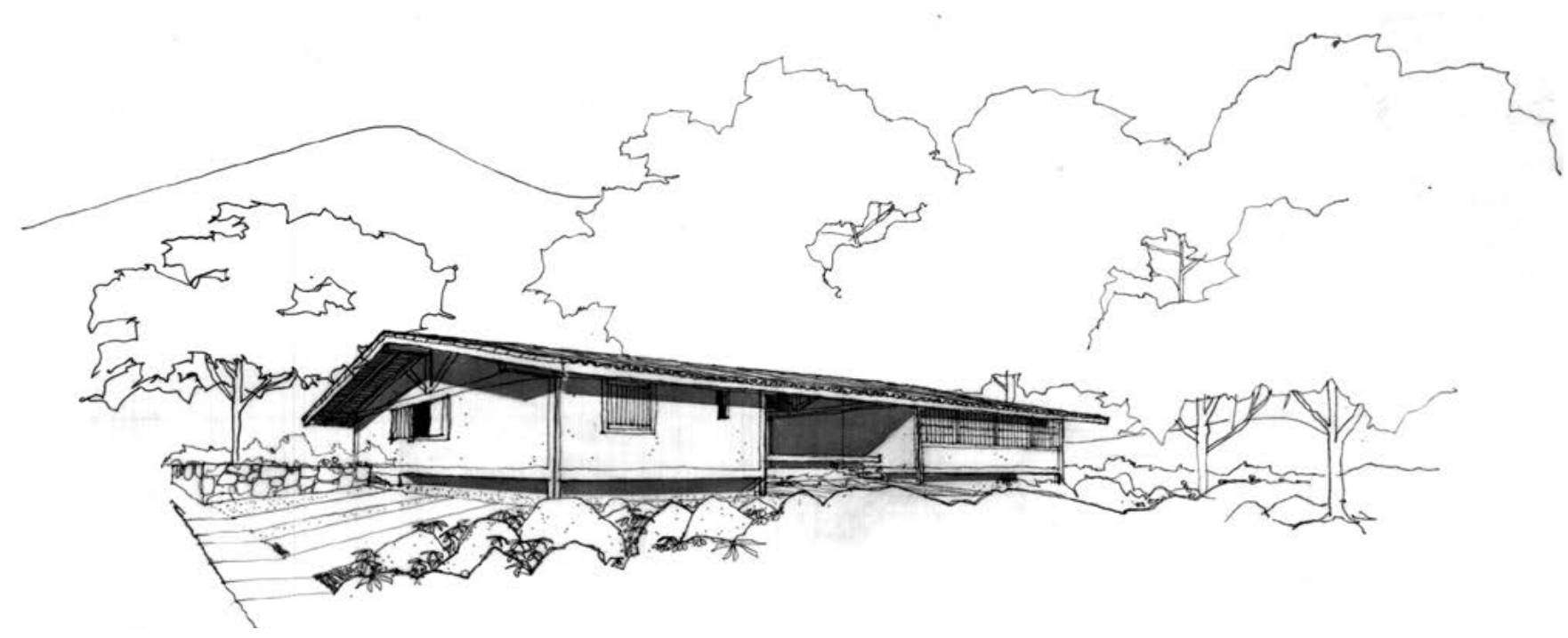

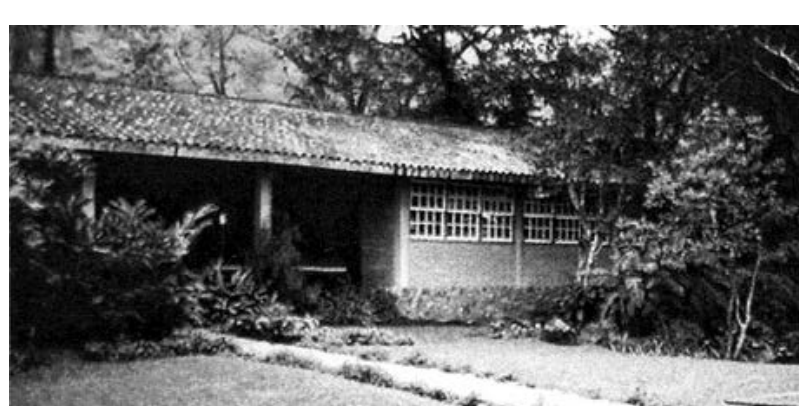
fonte: IMBRONIT, Maria Isabel. Tsese de Doutoramento: Procedimento de projett com base em reticulas

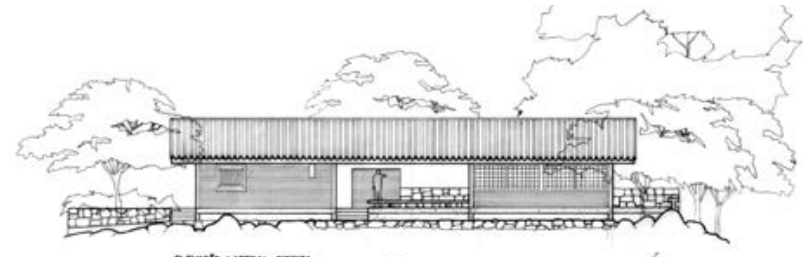

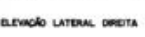
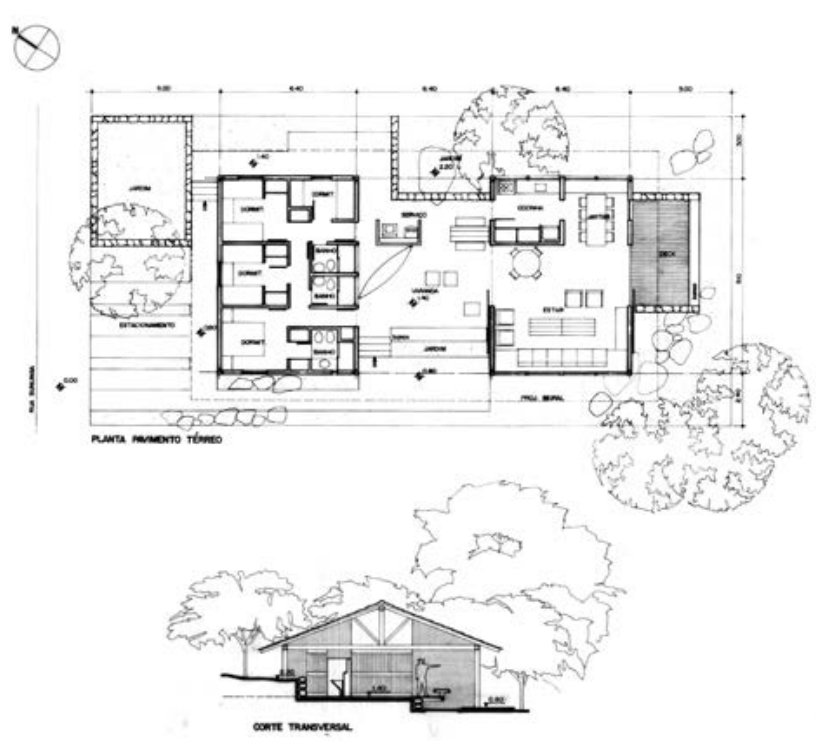
Residência Unifamiliar

Cliente

Maria Helena Pimentel

Equipe

Eduardo de Almeida

Localização

Alameda Sununga, Praia de Toque-Toque Pequeno, São

Sebastião, SP

Estágio

Executivo

Observações

Não Construído

Características

Quase duas décadas depois, um novo proprietário

adquiriu o lote vizinho e solicitou a Eduardo de Almeida

a criação de mais dois dormitórios e uma piscina.

Naturalmente, 0 projeto referencia-se à volumetria

original para criar um anexo que conforma 0 pátio

central onde se posiciona a nova área de lazer.

\section{Acervo}

Tubo 87, Caixa 2600 e Backup 335
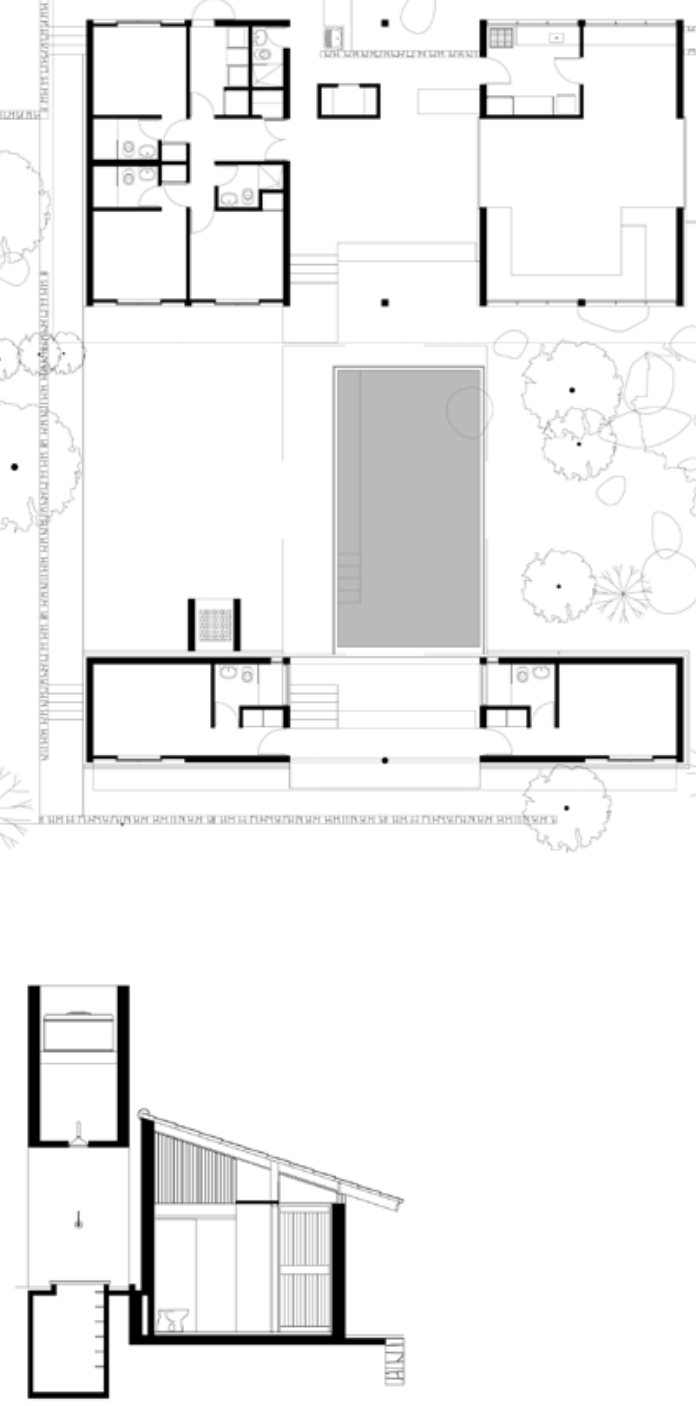
Uso

Reforma de Apartamento

Cliente

Lucia Ramenzon

Equipe

Arnaldo Martino e Eduardo de Almeida

Localização

Rua Seridó, Jd. Europa, São Paulo, SP

Estágio

Projeto Executivo

Observações

Projeto de reforma construído

\section{Características}

Projeto de reforma de um apartamento. Além da demolição e construção de algumas alvenarias para a adequação da planta original às necessidades do cliente, foram revistos todos os acabamentos e móveis que compõem 0 apartamento.

Acervo

Tubo 31

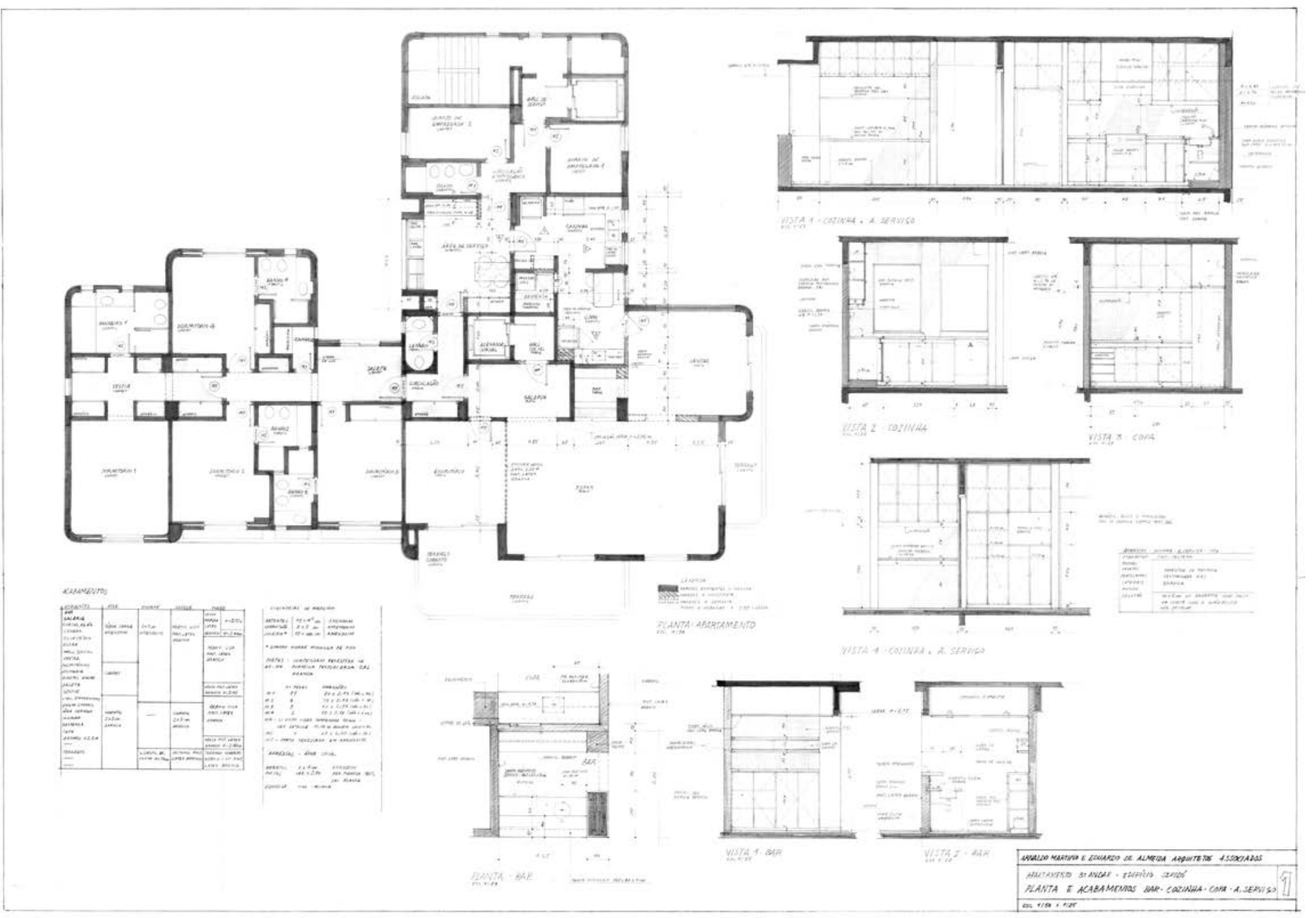


Uso

Escola

Equipe

Arnaldo Martino e Eduardo de Almeida

Localização

Valinhos, SP

Estágio

Anteprojeto

Observações

Não Construído

\section{Características}

Projeto realizado por ocasião de um concurso fechado

de anteprojetos para uma nova unidade do Colégio Porto

Seguro. Seguindo a topografia da gleba, Arnaldo Martino

e Eduardo de Almeida criam um eixo de circulação

coberto que divide o conjunto em dois setores: programas

de caráter público como estacionamento, administração,

teatro, ginásio coberto, quadras poliesportivas e piscina

ocupam o platô superior, enquanto os blocos didáticos

sesicionam transversalmente ao eixo principal

alternando volumes construídos com pátios ajardinados.

Interessante notar que algumas soluções estruturais

foram as mesmas utilizadas em projetos para escolas

publicas construidas com recursos limitados.

Acervo

Caixa 1200
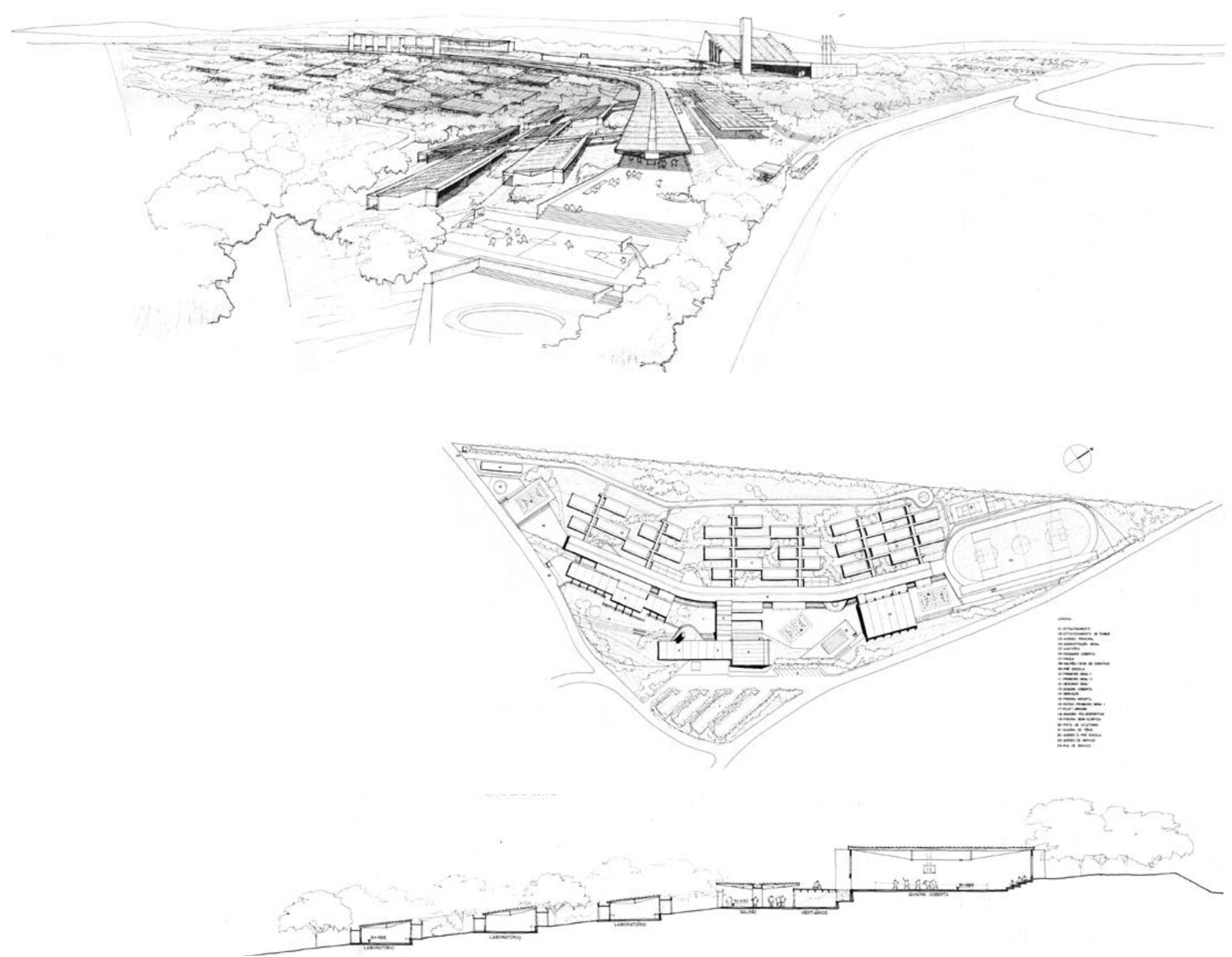
Uso

Projeto de ampliação

Cliente

Pedro Tassinari

Equipe

Arnaldo Martino e Eduardo de Almeida

Localização

Avenida 4, Orlândia, SP

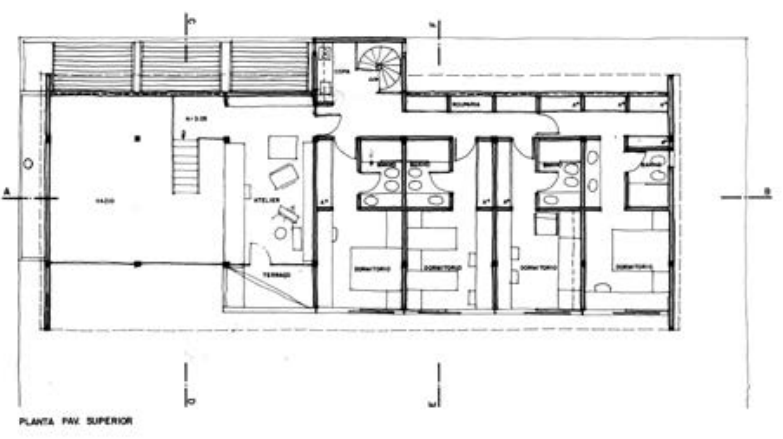

Estágio

Projeto Executivo

Observações

Construído

\section{Características}

Aproveitando o lote de esquina, o volume implanta-se próximo aos recuos de fundo de modo a valorizar o jardim de grandes proporções, para onde se voltam as aberturas das salas de estar, jantar, cozinha e dormitórios. A estrutura de concreto armado foi organizada por duas linhas de pilares com balanços simétricos destinados às áreas de circulação ou à criação de largos beirais. Estes pilares, posicionados a cada 3,6 metros, criam sete módulos capazes de abrigar todos os ambientes previstos pelo programa. Especial atenção ao arranjo em meios-níveis que permite criar uma sala rebaixada e outra elevada, cujo pé-direito duplo permite criar continuidade espacial entre os pavimentos e 0 jardim, além de revelar 0 desenho do telhado inclinado de duas águas e estrutura de madeira.

Acervo

Tubo 85 e Caixa 3400
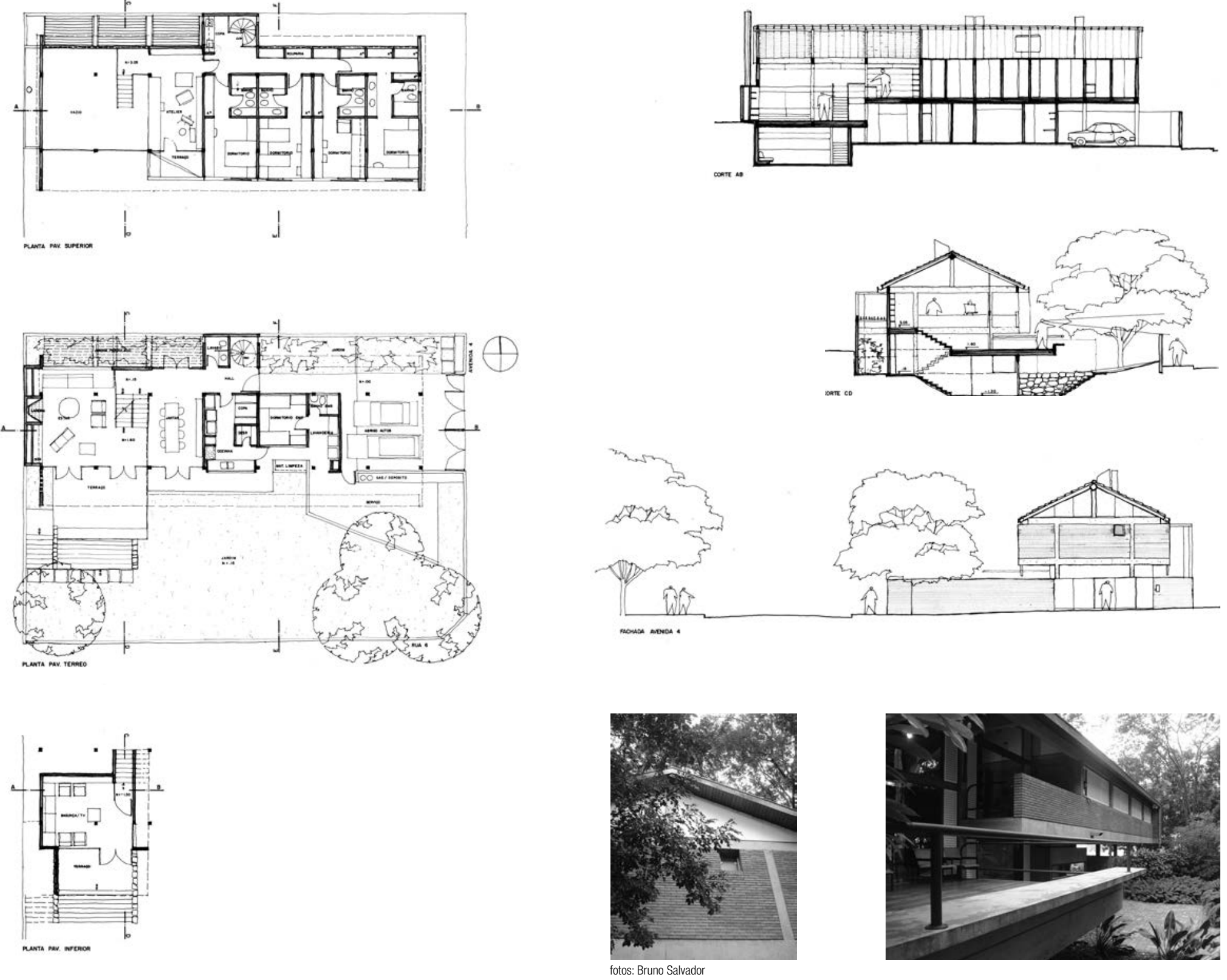
Uso

Atelier e Ampliação da Piscina

Cliente

Renata Tassinari

Equipe

Eduardo de Almeida

Localização

Orlândia, SP

Estágio

Projeto Executivo

Observações

Projeto de reforma construído

\section{Características}

Após vinte anos da construção desta residência, os clientes adquiriram o lote vizinho para viabilizar sua ampliação, considerando a construção de um estúdio para a proprietária, área de lazer com varanda e piscina além de um novo dormitório De acordo com a geometria do lote, um pouco mais profundo que o lote original, for criada uma edícula junto à divisa posterior para 0 ateliê, além de um volume transversal ao corpo original da casa, aproveitando a torre de circulação anexa já existente.

Acervo

Tubo 85, Caixa 3400 e Backup 336
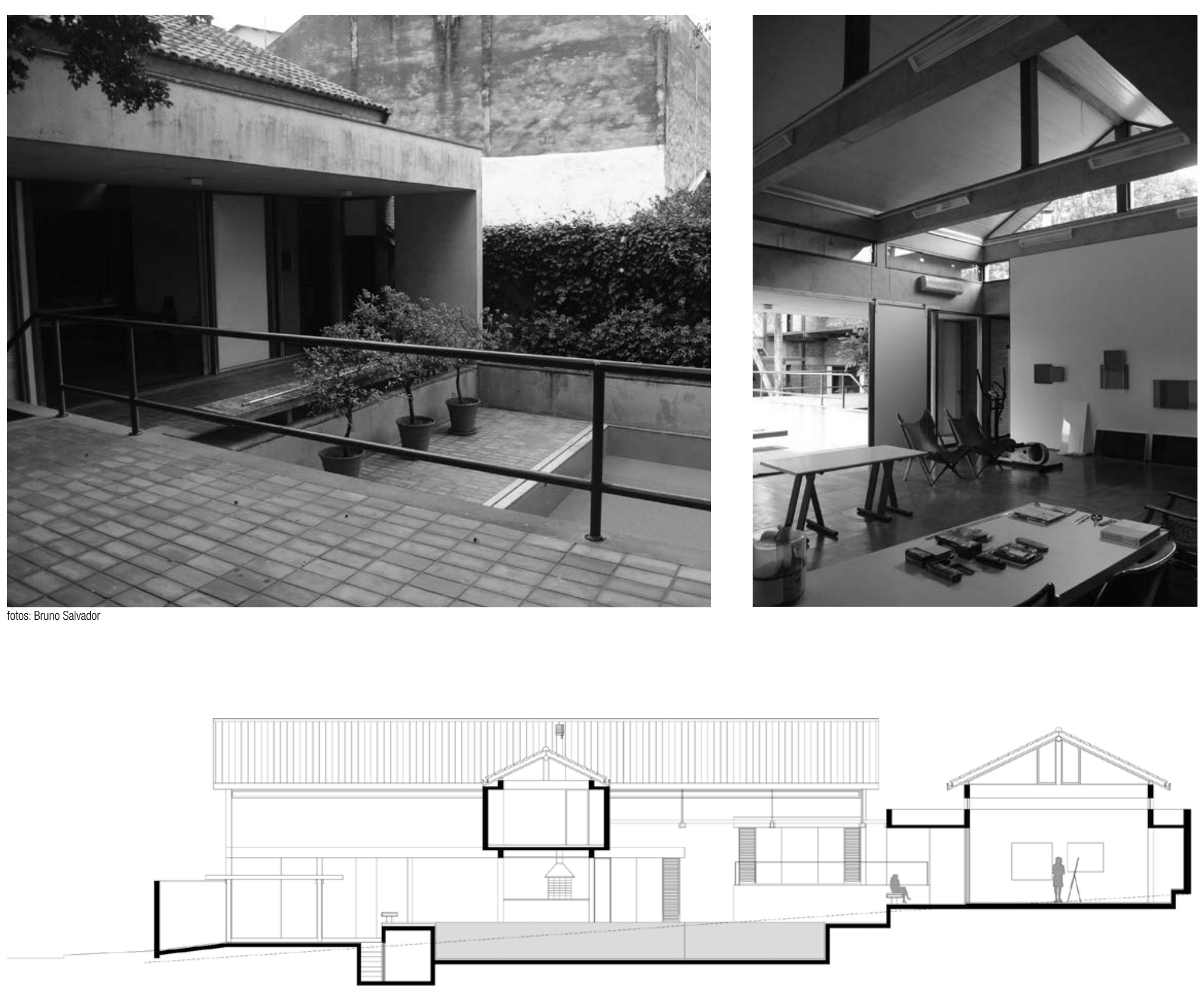
Uso

Residência Unifamiliar

Cliente

Rita Solla Requejo Bonomi

Equipe

Arnaldo Martino e Eduardo de Almeida

Localização

Rua Pio IV, Jardim Vitória Régia, Morumbi, São Paulo, SP

Estágio

Projeto Executivo

Observações

Construído

\section{Características}

De acordo com o lote em aclive, esta casa, encomendada por uma importante artista plástica paulista, tira partido da organização em meios-níveis, ao redor de um vazio central iluminado. A escada desenha-se como um volume anexo ao corpo principal da casa, permitindo para 0 exterior da casa. Construída em concreto armado e com alvenaria de tijolos aparentes, a exemplo de inúmeras obras deste período, pode-se destacar o brise da fachada frontal em concreto armado, uma grelha em balanço extremamente delgada calculada pelo engenheiro Faustino Máximo.

Acervo

Tubo 75
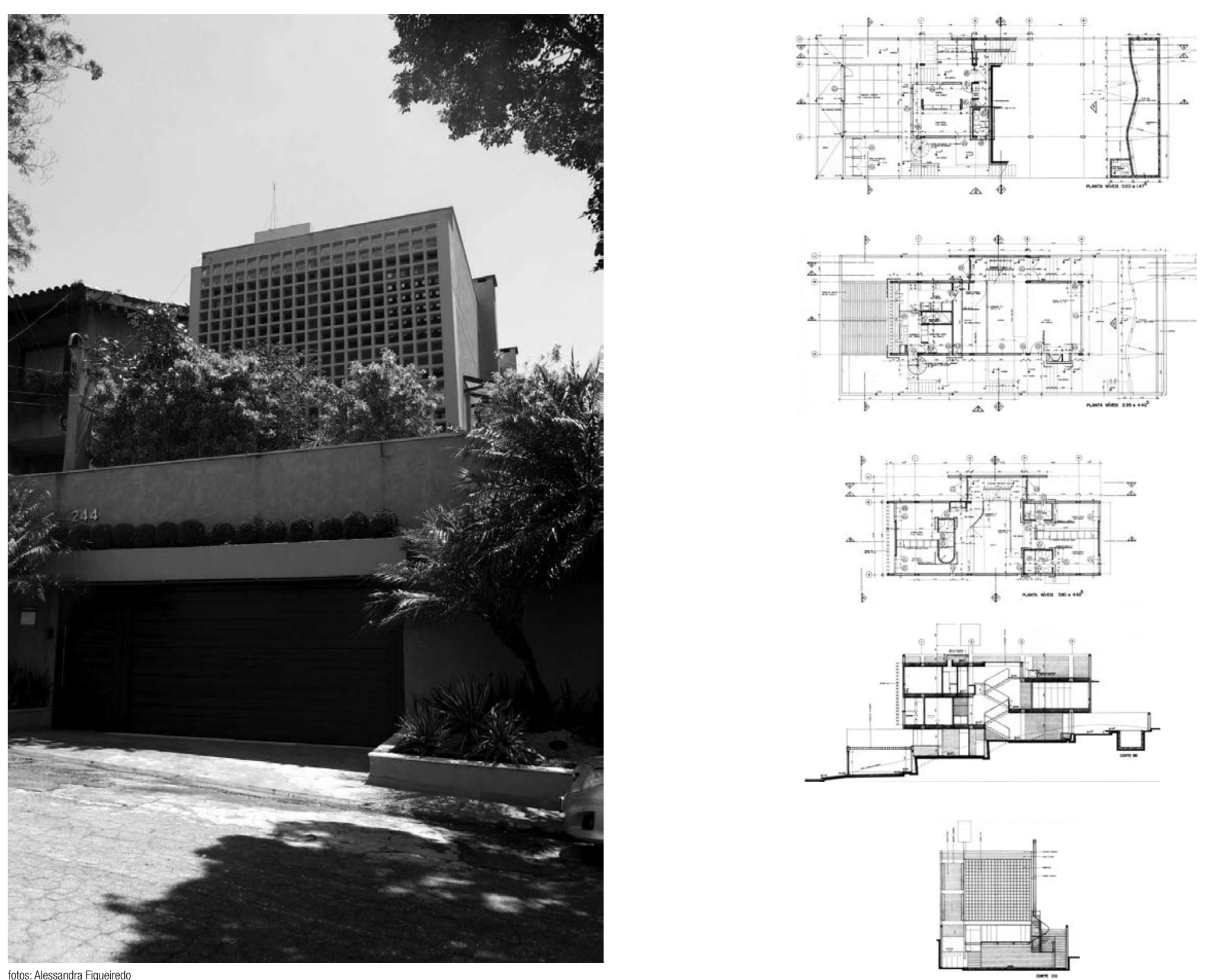
Uso

Residência Unifamiliar

Cliente

Rodrigo Lacerda Soares Neto

Equipe

Arnaldo Martino e Eduardo de Almeida

Localização

Vale da Boa Esperança, Itaipava, Petrópolis, RJ

Estágio

Projeto Executivo

Observações

Construído

\section{Características}

Ao invés de projetar a casa na área plana do terreno, conforme o pedido do proprietário, os arquitetos decidiram posicionar a casa na encosta, não só aproveitando as vistas para o vale, como também criando uma sequência de pavilhões paralelos implantados em diversos platôs, desenhados de acordo com a declividade do terreno. Merece atenção 0 desenho da cobertura em estrutura metálica e telhado cerâmico de duas águas intercaladas por calhas e cumeeiras planas, solução que permite a continuidade dos telhados e a conexão entre cada uma das alas que compõe a casa.

Acervo

Tubo 81
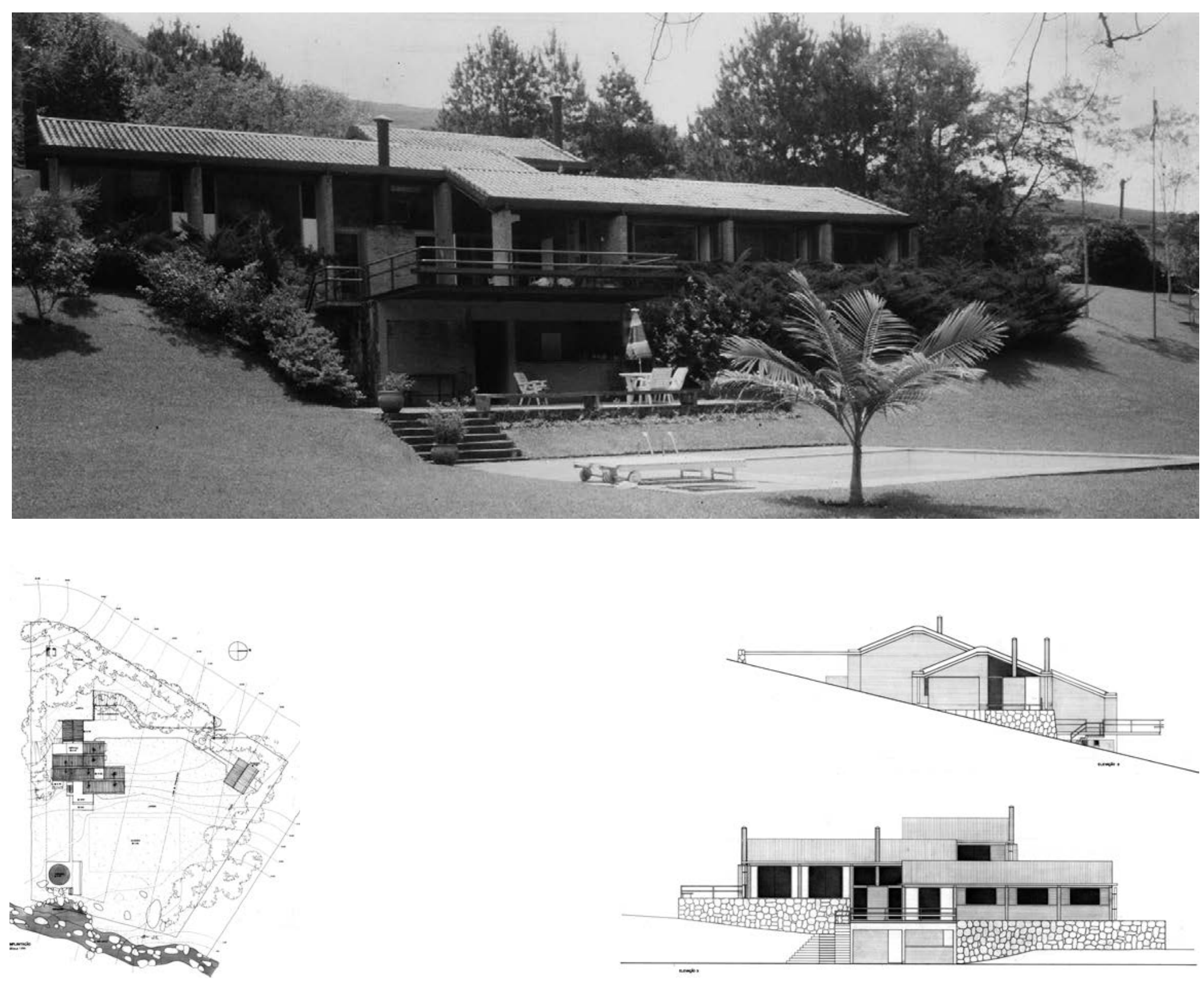

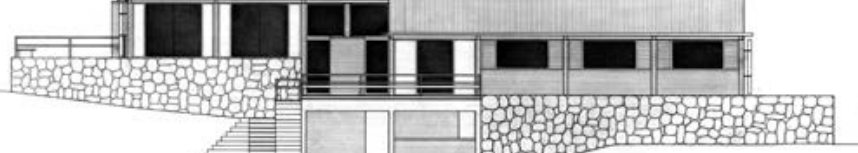


Uso

Residência Unifamiliar

Cliente

Paulo Vitor Oppenheim

Equipe

Arnaldo Martino e Eduardo de Almeida

colaborador I Rossano Terlizzi

estrutura I Concen / Wilson Ramos da Silva Filho

paisagismo | Jamil J. Kfoury

Localização

Avenida A, Parque dos Príncipes, Osasco, SP

\section{Estágio}

Projeto Executivo

Observações

Construído

\section{Características}

Seguindo a investigação do uso de estrutura metálica

associada a planos de alvenaria de tijolos aparentes,

como na casa $B$

pelo pátio asa Belinky,

pelo pátio ajardinado central e pelo rebaixo que amplia

o pé-direito da sala de estar, totalmente desenhada em

continuidade com o deque externo e com a piscina. Além

disso, o pavimento superior abriga a área de serviços

da casa sobre a garagem, no mesmo pavimento dos

dormitórios voltados pera o fundo do lote Além dos perfis

metálicos

wall como elemento da fachada e como fechamento do

shaft horizontal para as instalações hidráulicas.

Acervo

Tubo 80 e Caixa 4400
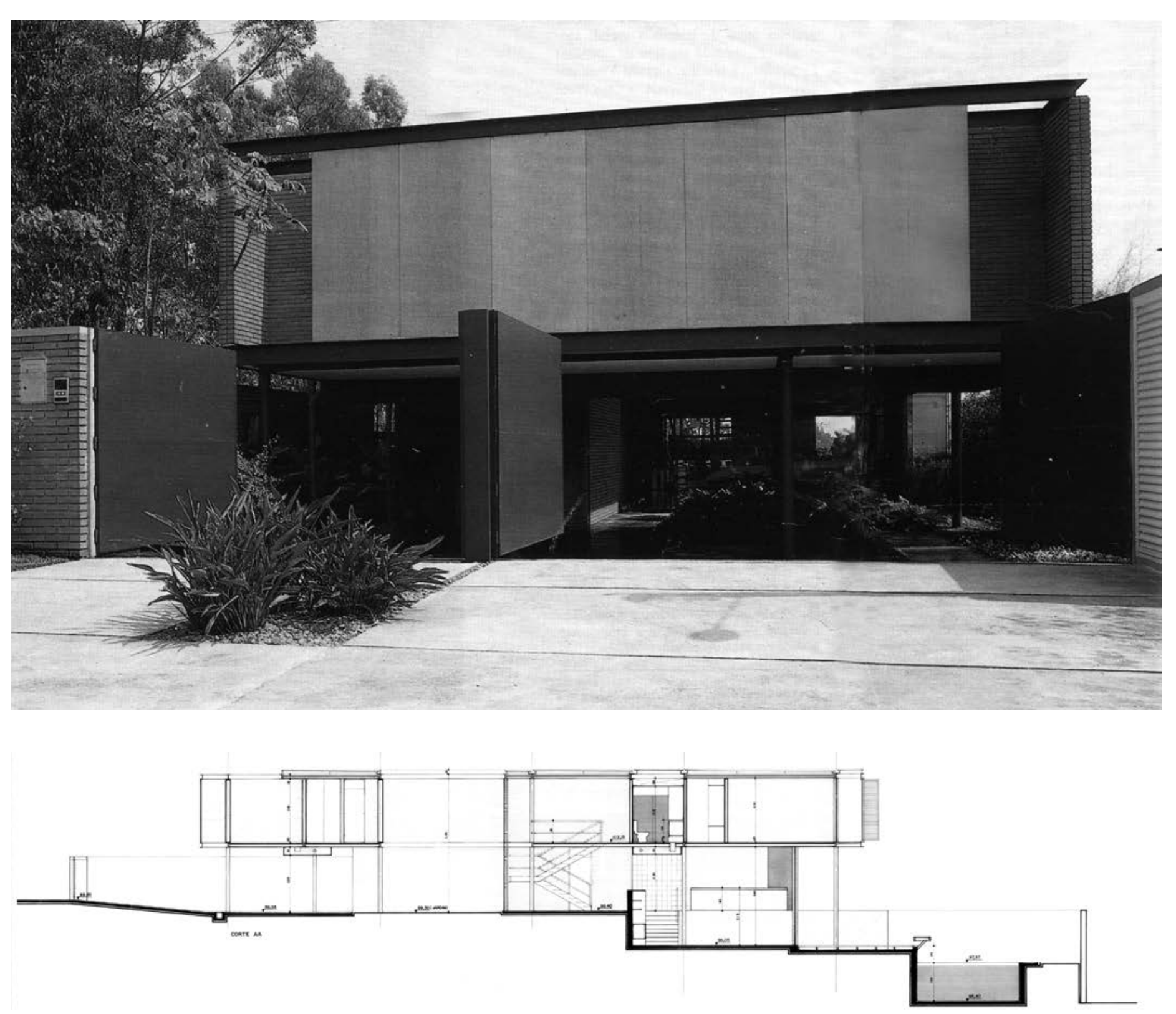
Uso

Residência Unifamiliar

Cliente

Roberto Bielawski

Equipe

Arnaldo Martino e Eduardo de Almeida

Localização

Rua Maguari esq. Rua Canaã, Chácara Flora, São Paulo, $\mathrm{SP}$

Estágio

Projeto Executivo

Observações

Não Construído

Características

Projetada em um terreno extremamente íngreme, esta

residência organiza-se em dois volumes distintos.

Enquanto todos os dormitórios localizam-se em um

bloco vertical com estrutura de concreto armado, 0

volume dos ambientes de estar e serviços posiciona-

se em uma barra horizontal em estrutura metálica -

permitindo a criação de uma garagem no pavimento

inferior e garantindo continuidade espacial entre a sala

e as áreas externas.

Acervo

Tubo 74, 74A e 74B

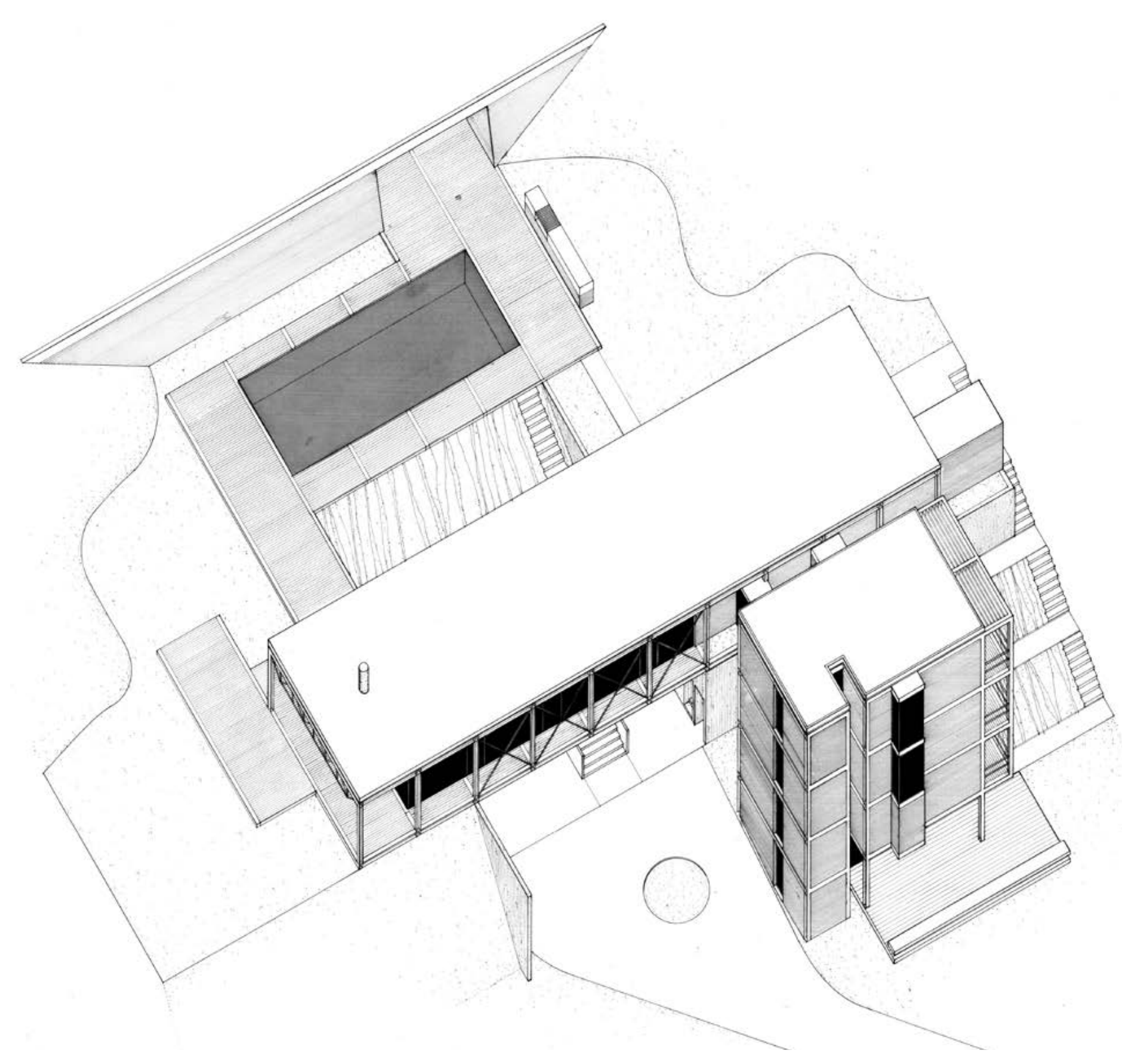


Uso

Residência Unifamiliar

Cliente

Luiz Augusto Barros Barreto

Equipe

Arnaldo Martino e Eduardo de Almeida

Localização

Rua Santa Cristina, Jd. Paulistano, São Paulo, SP

Estágio

Projeto Executivo

Observações

Não Construído

\section{Características}

A exemplo da residência Oppenheim, este projeto também utiliza uma malha estrutural metálica associada a panos de alvenaria ou vidro. Espacialmente, o projeto repete a solução da área de serviç̧o elevada sobre a garagem e também utiliza 0 jardim central como elemento estruturador do espaço. Especial atenção ao desenho das alvenarias em blocos de concreto aparente junto à divisa que define o recinto destinado à casa mas que mantém-se estruturalmente independente de seu volume.

\section{Acervo}

Tubo 40 e 40A
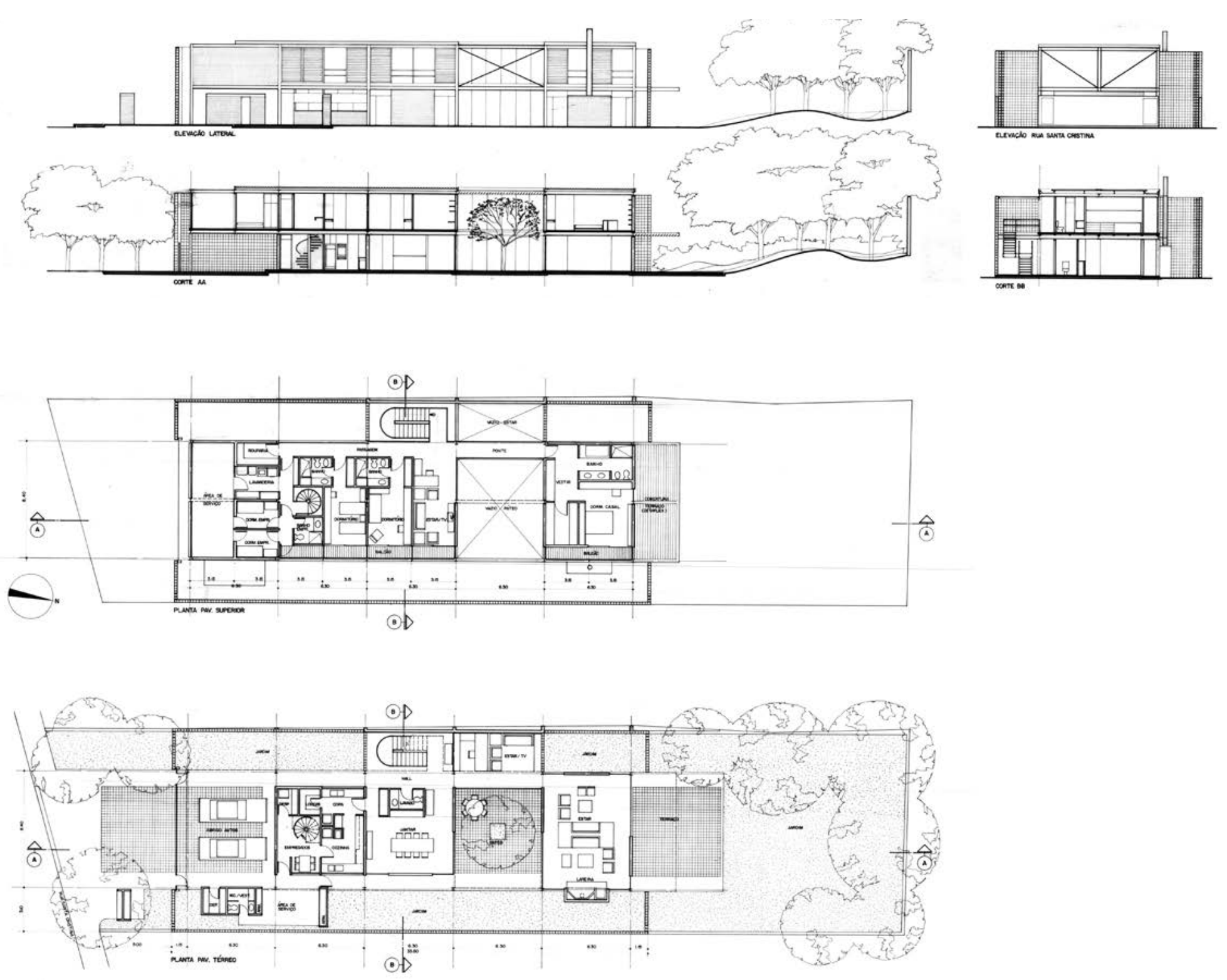
Uso

Residência Unifamiliar

Cliente

Roni Gotthilf

Equip

Arnaldo Martino e Eduardo de Almeida

Localização

Rua José Freitas Guimarães, São Paulo, SP

Estágio

Anteprojeto

Observações

Construído

\section{Características}

Partindo das condicionantes impostas pela construção

pré-existente, o projeto utiliza-se de estruturas metálicas

complementares para viabilizar a criação de novas

coberturas e terraços, alem de reforcos estruturais

capazes de garantir a continuidade espacial dos diversos

ambientes.

Acervo

Tubo 78
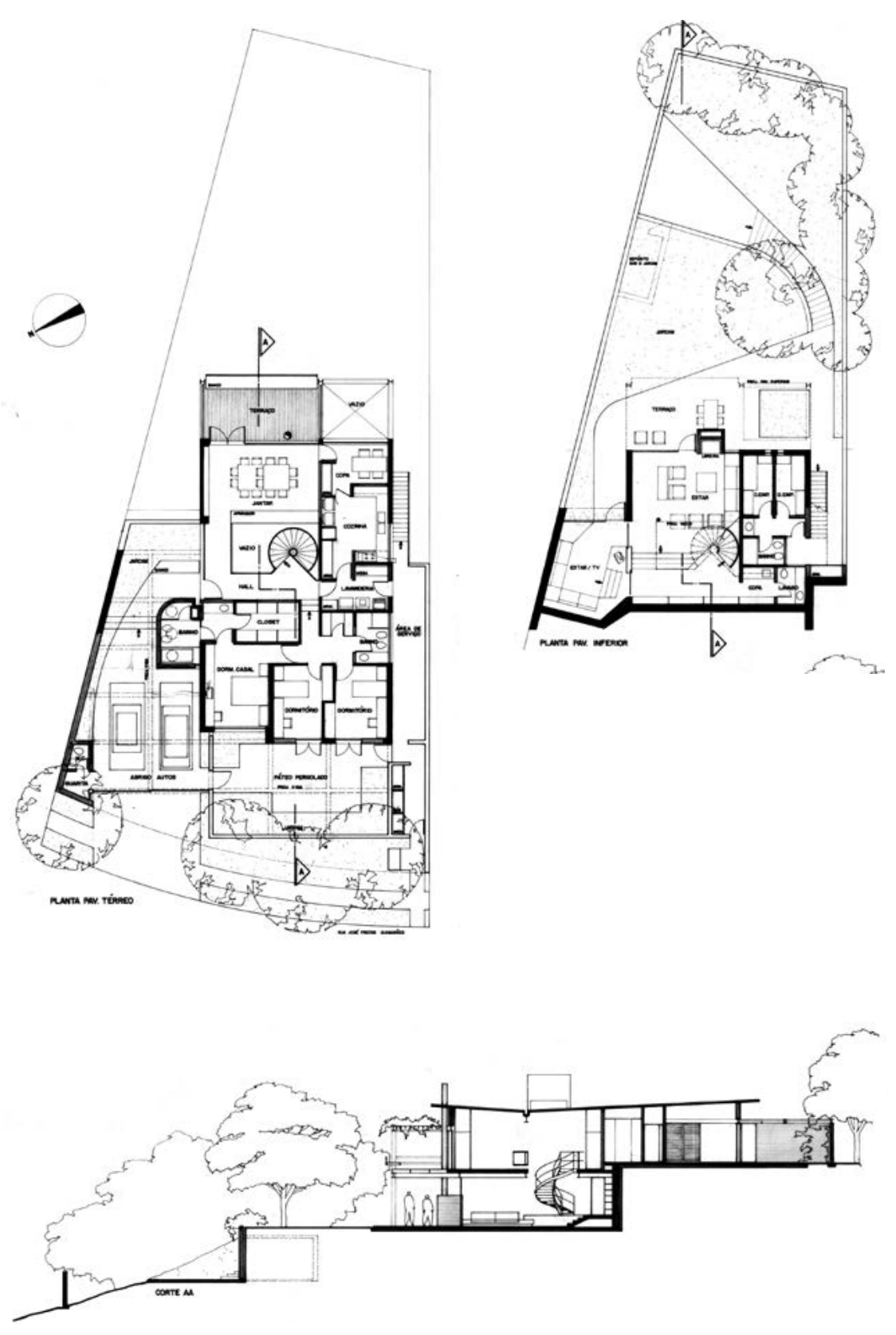
Uso

Residência Unifamiliar

Cliente

Luís Gelpi

Equipe

Arnaldo Martino e Eduardo de Almeida

Localização

Morumbi, São Paulo, SP

Estágio

Estudo Preliminar

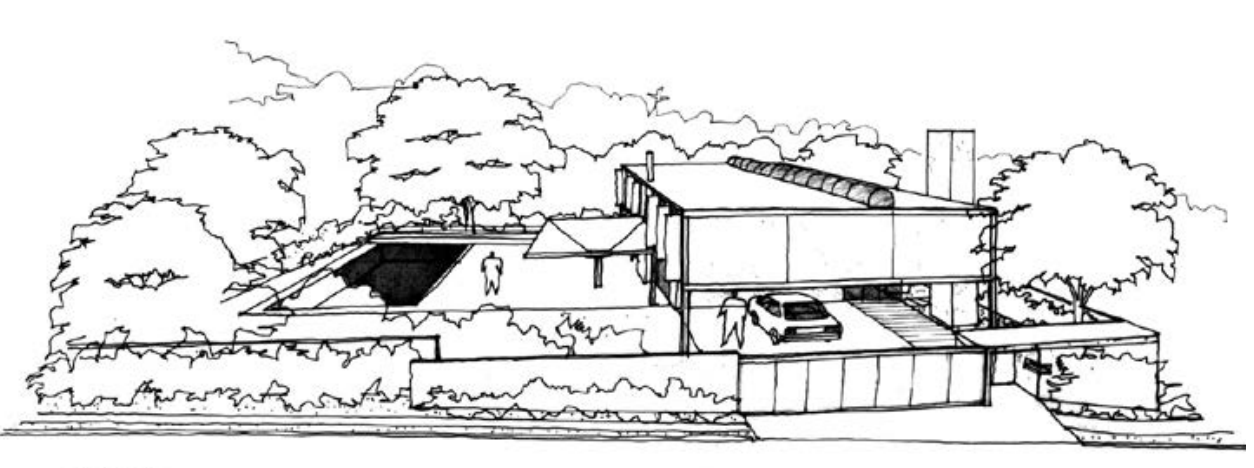

ELEVASĀo

\section{Observações}

Não Construído

\section{Características}

A partir da repetição de três módulos de estrutura metálica, este projeto cria um vazio central capaz de articular o pavimento térreo e 0 andar destinado aos dormitórios. Mais uma vez, o tema principal é a continuidade entre os ambientes de estar e 0 jardim com piscina. A varanda coberta viabiliza-se com a construção de uma estrutura em pirâmide invertida com construção de uma estrutura em pirâmide invertida com
pilar central. Os serviços encontram-se no pavimento inferior - aproveitando a topografia do terreno - e a laje de cobertura é seccionada por uma faixa de iluminação zenital contínua que ilumina a escada e a sequência de sanitários do andar superior.

Acervo

Tubo 70
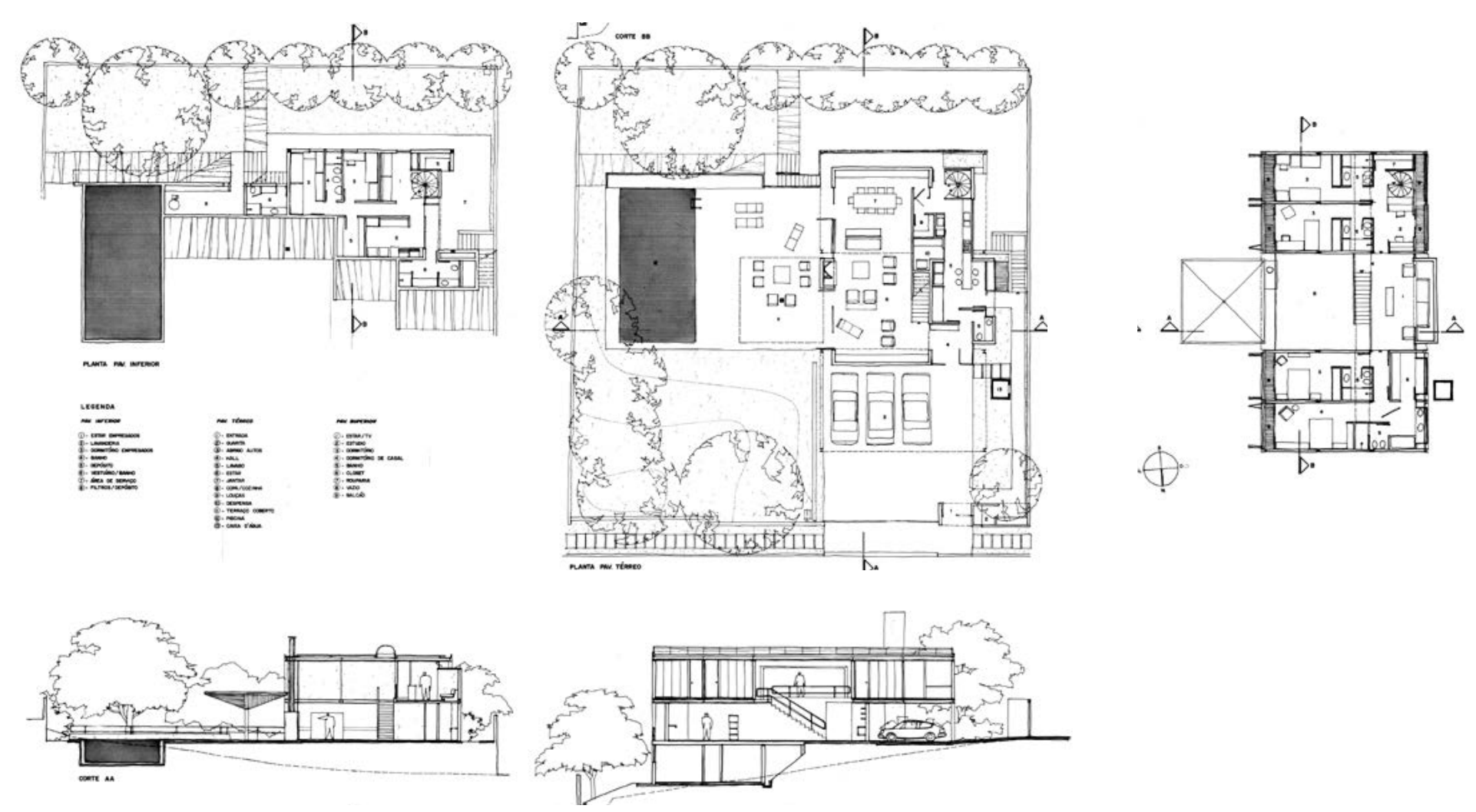
Uso

Residência Unifamiliar

Cliente

Ricardo Guimarães

Equipe

Arnaldo Martino e Eduardo de Almeida

Localização

Jd. Europa, São Paulo, SP

Estágio

Anteprojeto

Observações

Não Construído

\section{Características}

Assim como a residência projetada para Luiz Augusto Barros, o desenho desta residência utiliza-se dos muros de divisa como elementos estruturadores do espaço, enquanto a estrutura metálica posicionada no centro do lote abriga cada um dos ambientes previstos pelo programa. Neste caso, estas alvenarias de divisa também funcionam como paredes estruturais, uma também funcionam como paredes estruturais, uma
vez que um dos recuos é incorporado ao interior da residência para abrigar os ambientes de serviços, estúdio, escada e 0 vazio com pé-direito duplo. Além disso, estas alvenarias suportam as duas vigas metálicas treliçadas que definem as fachadas frontais e de fundo, treliçadas que definem as fachadas frontais e de fundo,
viabilizando o emprego de apenas quatro pilares centrais para a sustentação de todo o pavimento superior.

\section{Acervo}

Tubo 27

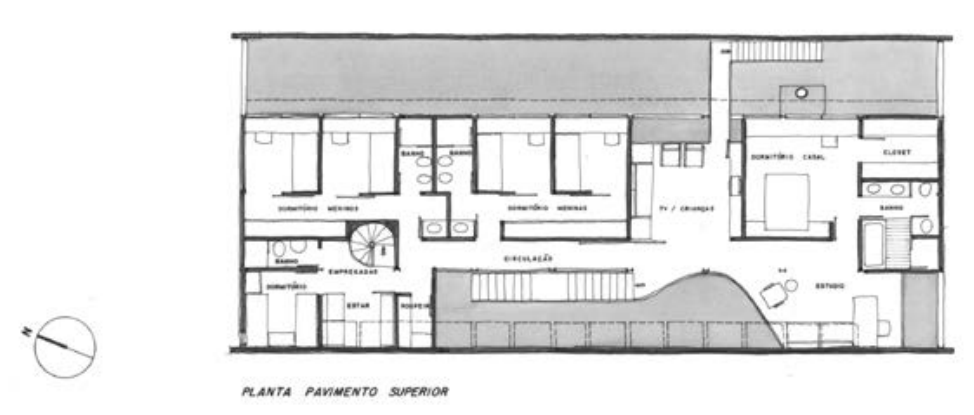

ravra panuento seremion
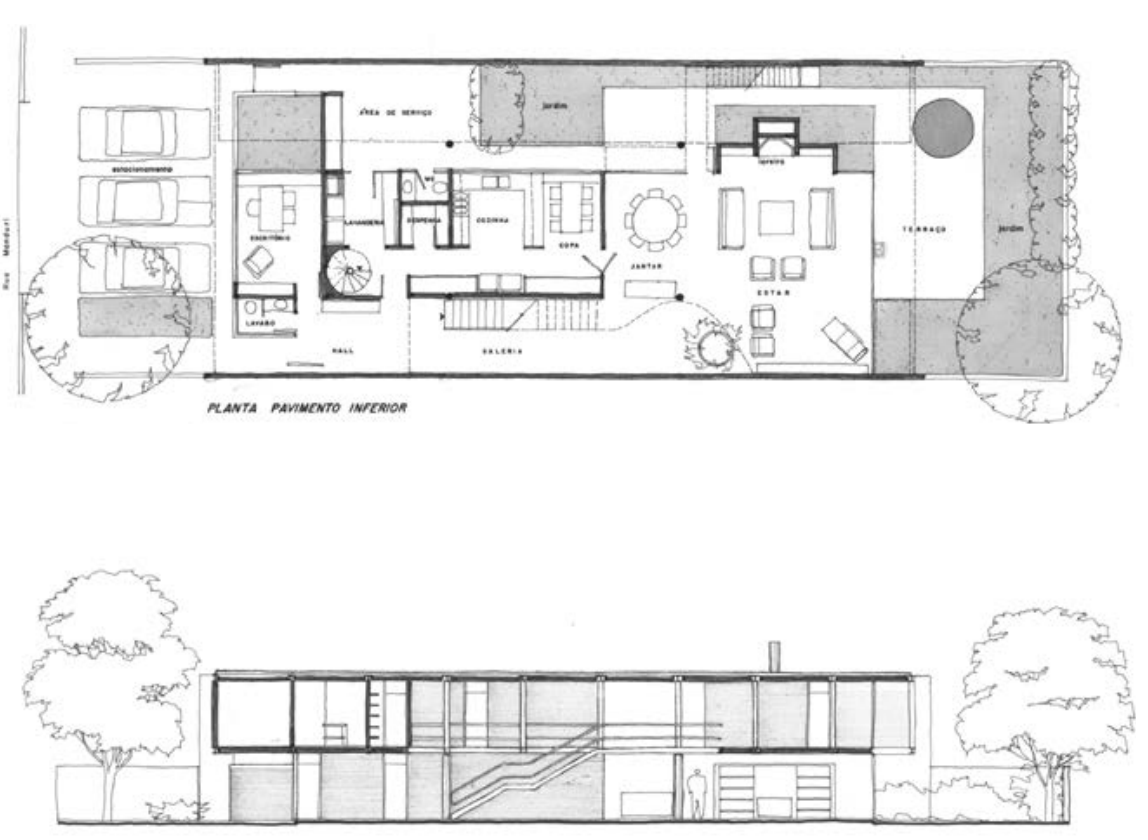

conre conarvasuat

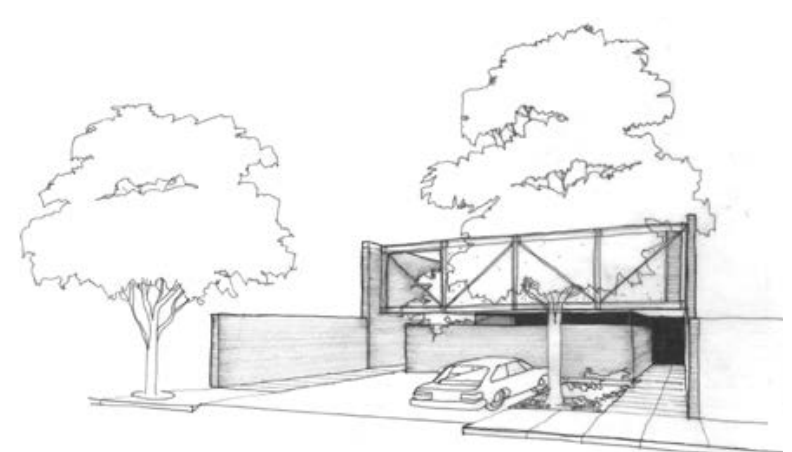

VISTA OA RUA

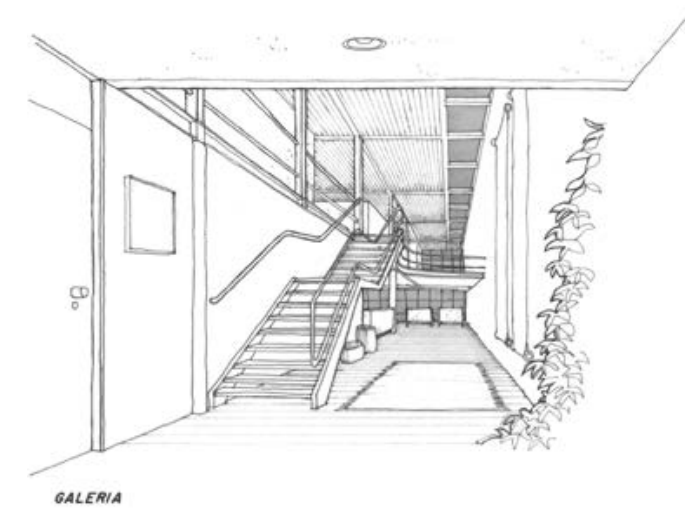


Uso

Escola

\section{Cliente}

CONESP - Companhia de Construções Escolares do Estado de São Paulo

Equipe

Arnaldo Martino e Eduardo de Almeida

estrutura | Hugo Tedeschi

\section{Localização}

Jd. Santa Marcelina, Tucuruvi, São Paulo, SP

Estágio

Projeto Executivo

\section{Observações}

Construído

\section{Características}

A partir das geometria irregular do lote e sua topografia acidentada, o projeto desta escola é organizado pela implantação da quadra poliesportiva junto à divisa da rua e de um único bloco linear de dois pavimentos que explora a dimensão máxima permitida pelas divisas. A única entrada do conjunto permite acesso direto à administração e articula o platô da quadra em uma relação de meio nível com os dois pavimentos da escola 0 desenho da estrutura merece atencão pelas duas linhas de pilares periféricos que se amarram às vigas-calha longitudinais que arrematam a cobertura de duas águas, projetadas como lajes inclinadas sem vigas, apenas amarradas por tirantes horizontais capazes de absorver os esforços de tração da cobertura. 0 espaço do galpão de pé-direito duplo dá continuidade ao pavimento superior pela docada o pela passarel que Iga as duas extremidades, mas também permite ligação com a quadra, por meio de uma escadaria, e para a vista em direção ao vale, por meio de um terraço em balanç̧o.

Caixa 1100
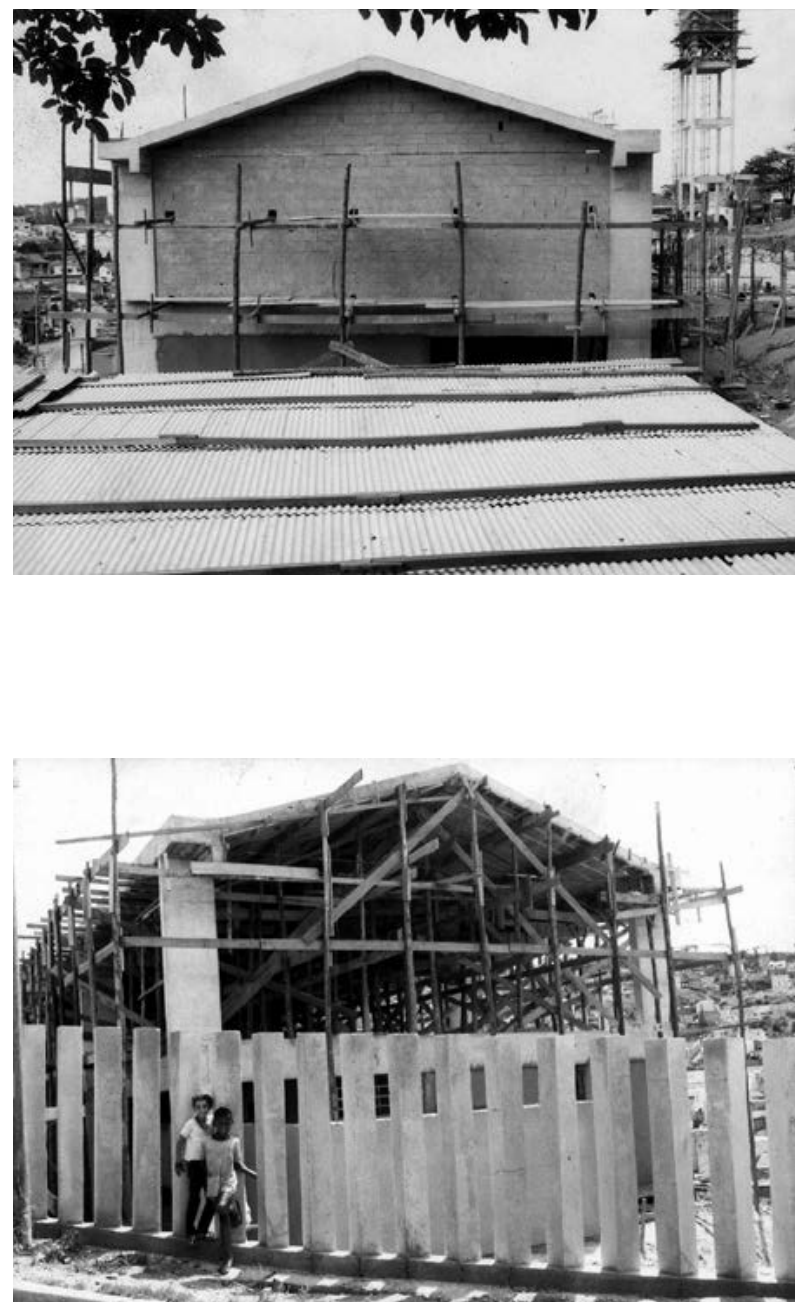

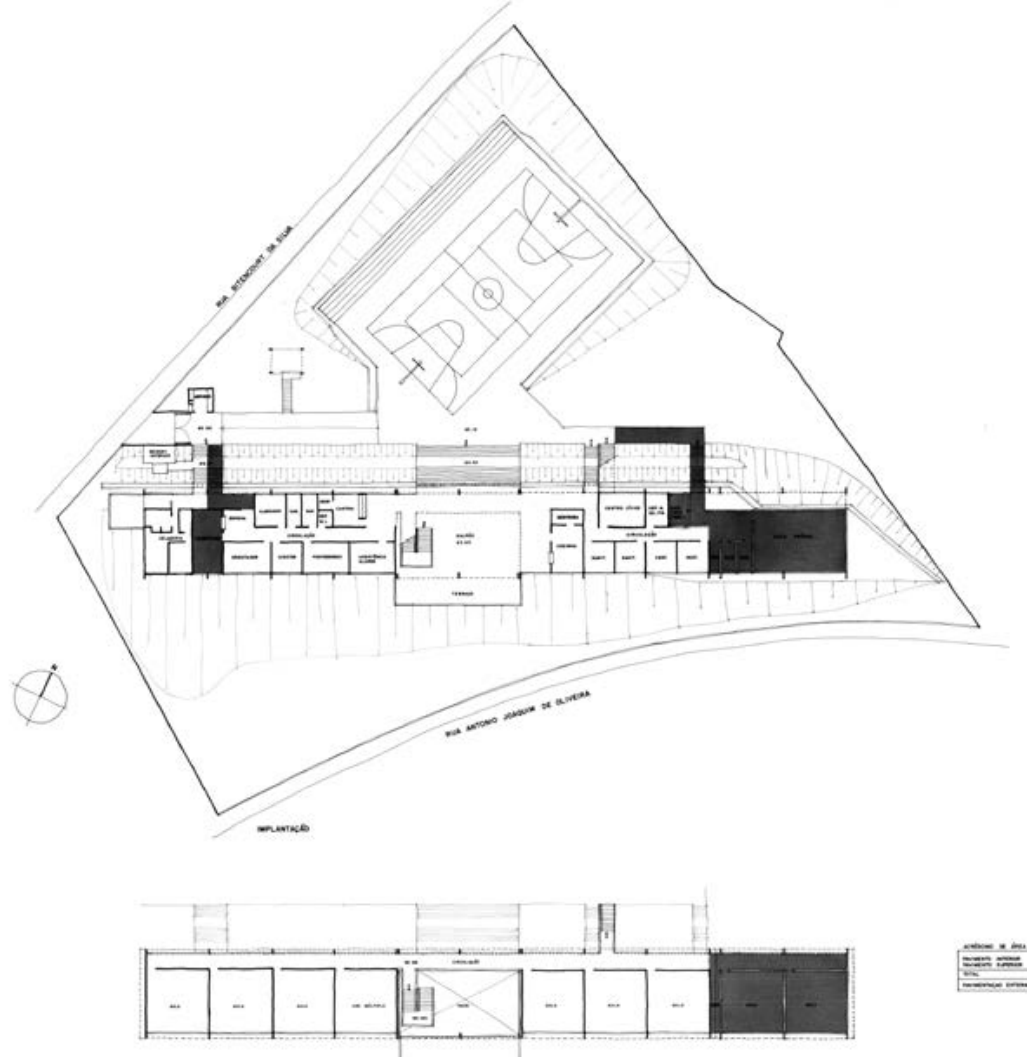
$-m-$
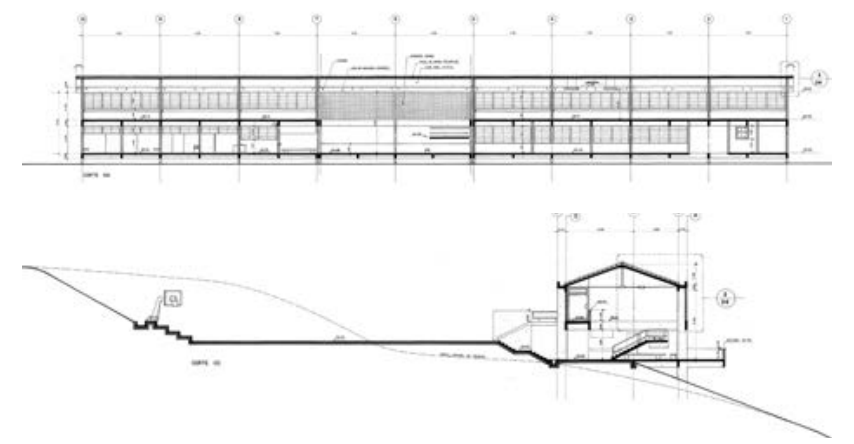
Uso

Escola

Cliente

CONESP - Companhia de Construções Escolares do Estado de São Paulo

Equipe

Arnaldo Martino e Eduardo de Almeida

\section{Localização}

Parque Bela Vista, Morumbi, Votorantim

Estágio

Projeto Executivo

Observações

Construído

\section{Características}

A exemplo de outras edificaçõos escolares, este projeto implanta-se a partir das dificuldades impostas pelo lote e pela padronização dos ambientes e componentes construtivos da Conesp. Neste caso, o programa é definido por quatro volumes justapostos - administração, bloco didático, espaços de serviços e galpão, cada um deles definido por coberturas de duas águas em telhas de barro e estrutura de madeira, sempre articulados por vigas-calha ou lajes de concreto impermeabilizadas. Especial atenção à estrutura do galpão que, além de possuir 0 maior vão, permanece com o pé-direito elevado e com a estrutura aparente, permitindo revelar as tesouras compostas por duas treliças menores de madeira associadas a um tensor

Acervo

Tubo 18 e Caixa 800

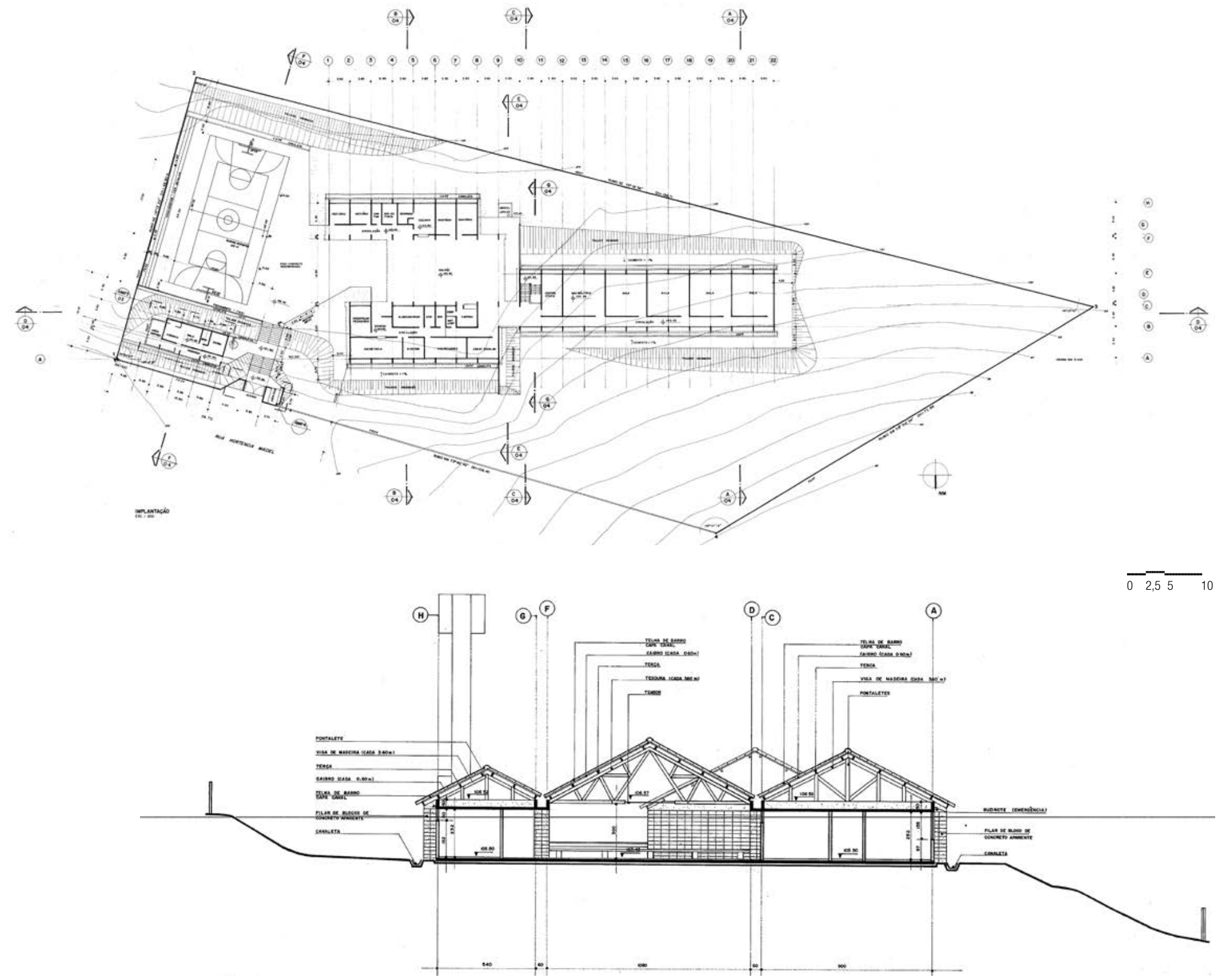


Uso

Centro de Saúde

Cliente

Secretaria de Estado da Saúde

Equipe

Arnaldo Martino e Eduardo de Almeida

Localização

Campo Limpo, São Paulo, SP

Estágio

Projeto Executivo

Observações

Construído

\section{Características}

Parte de um conjunto de projetos realizados no mesmo período por vários arquitetos, esta Unidade Básica de Saúde orienta-se pela padronização preestabelecida pela Secretaria da Saúde. Neste caso a implantacãa deste edifício de um pavimento segue a geometria trapezoidal do lote a partir da justaposição de dois volumes paralelos e deslocados. Além das duas fachadas principais, a e deslocados. Além das duas fachadas principais, a criação de um pátio central e de aberturas posicionadas unto aos eixos de circulação principais.

Acervo

Caixa 2200
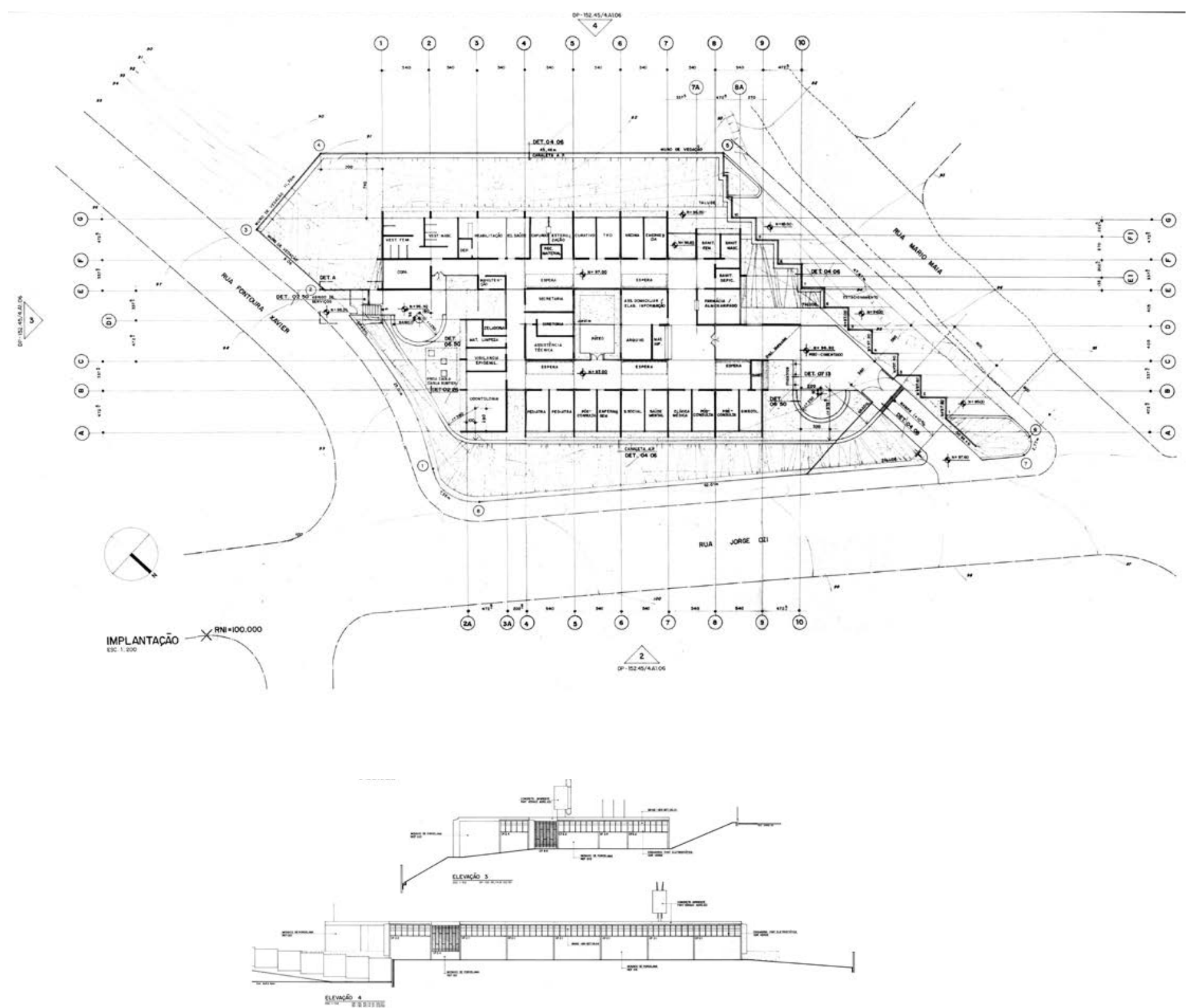
Uso

Galeria de Arte

Cliente

Nicolete L. Soares

Equipe

Arnaldo Martino e Eduardo de Almeida

Localização

Av. dos Eucaliptos, Indianópolis, São Paulo, SP

Estágio

Projeto Executivo

Observações

Projeto de reforma construído

\section{Características}

A proprietária deste imóvel não só encomendou uma série de projetos a Eduardo de Almeida ao longo de sua carreira, como também emprestou um imóvel localizado na Rua Pedroso Alvarenga por cerca de dois anos para ser utilizado como seu escritório de arquitetura. Em agradecimento, foi realizado este projeto de reforma para a criação de uma galeria de arte. A utilização de estrutura metálica permitiu a criação de uma vitrine e varandas como adições à fachada, além da escada e passarela junto ao vazio central. Este mesmo material permitiu o reforço estrutural necessário à estrutura convencional deste sobrado.

Acervo

Tubo 23
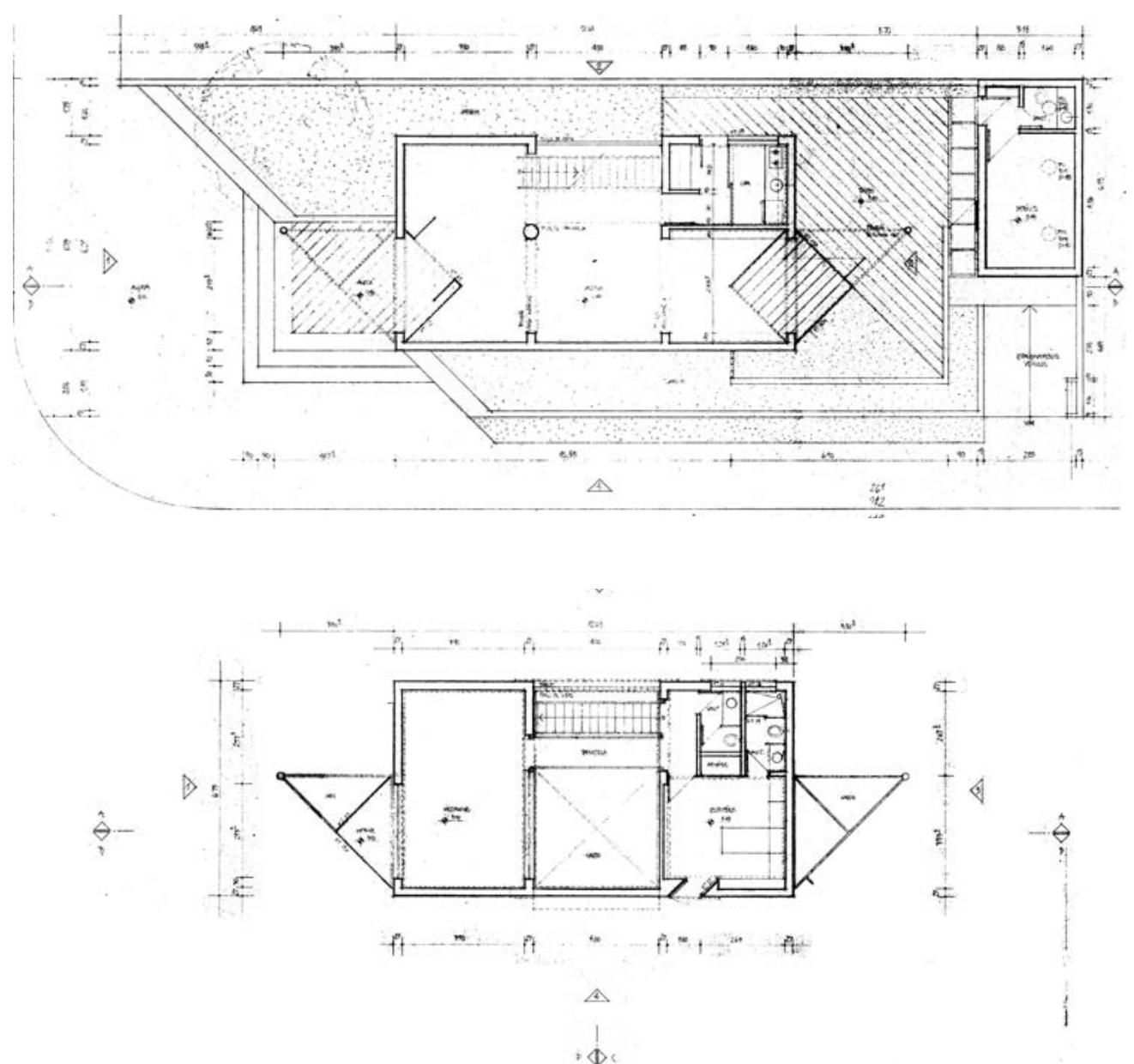

$\cdot 4$

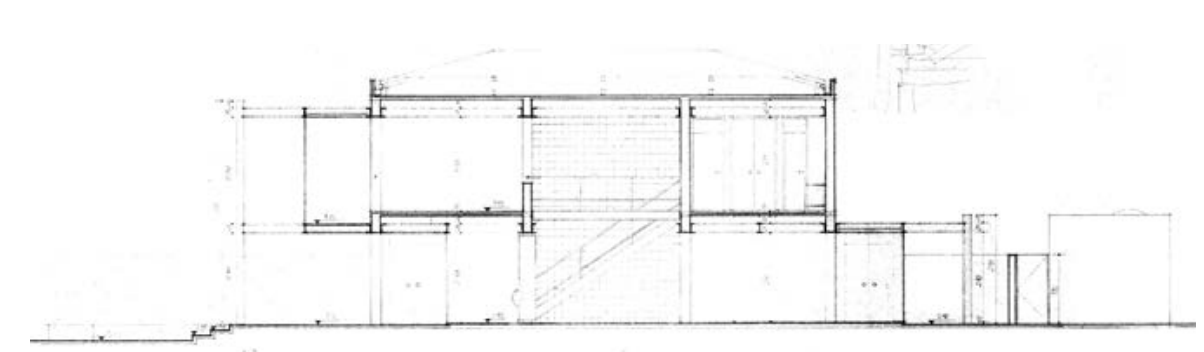


Uso

Escola

Cliente

CONESP - Companhia de Construções Escolares do

Estado de São Paulo

Equipe

Arnaldo Martino e Eduardo de Almeida

Localização

Jardim Julieta, Itapevi, SP

Estágio

Projeto Executivo

Observações

Construído

\section{Características}

Seguindo o mesmo partido estrutural da Escola Vila

Albertina - telhado de duas águas sobre lajes inclinadas

de concreto estruturadas por duas linhas de pilares

cabos de aço - o projeto desta escola organiza-se

em dois blocos implantados paralelamente à quadra

poliesportiva. Devido à topografia do terreno cada bloco

é implantado em patamares posicionados em diferentes

cotas.

Acervo

Tubo 89

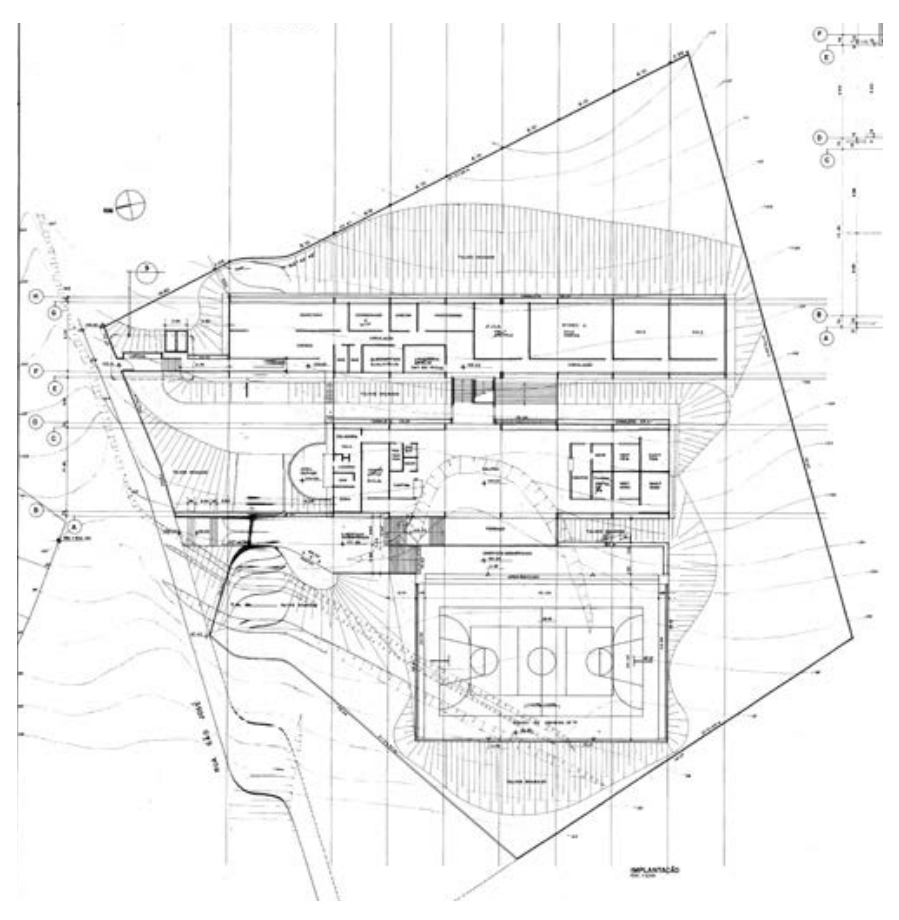

$\overline{0} \overline{2,55} 10$

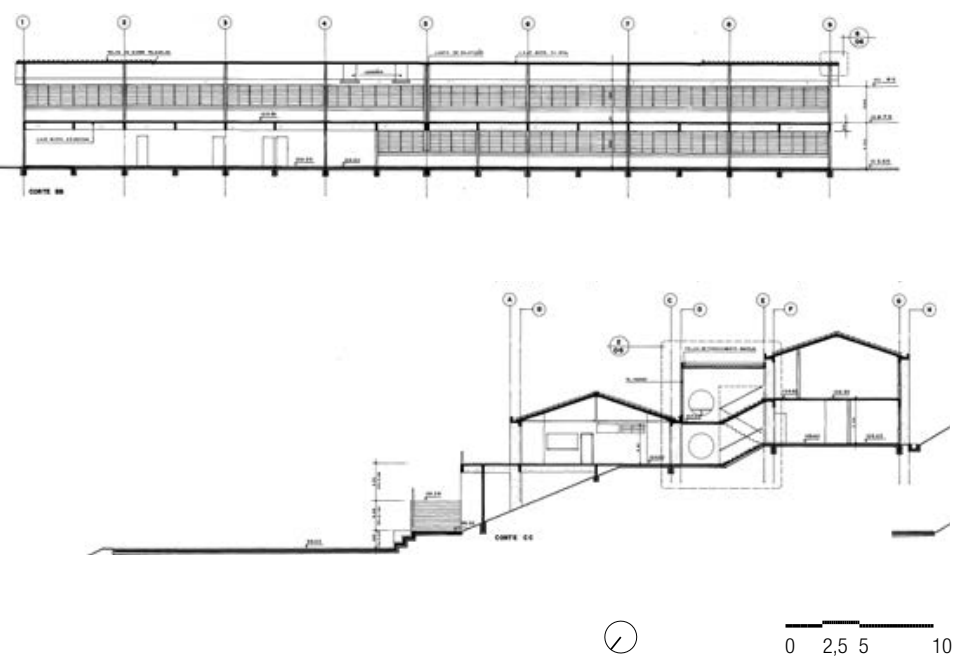


Uso

Residência Unifamiliar

Cliente

Rubens Porto

Equipe

Arnaldo Martino e Eduardo de Almeida

Localização

Rua Prudentópolis, Alto de Pinheiros, São Paulo,SP

Estágio

Projeto Executivo

Observações

Construído

\section{Características}

Aproveitando as características da topografia do lote, esta casa apresenta todo seu programa coletivo no piso inferior e todos os dormitórios no pavimento superior, considerando uma circulação em meios-níveis posicionada entre 0 espaço de pé-direito elevado da sala e os espaços de acesso e garagem. Uma única cobertura inclinada de telhas onduladas sobre estrutura metálica marca a volumetria da casa.

Acervo

Tubo 82 e Caixa 4400
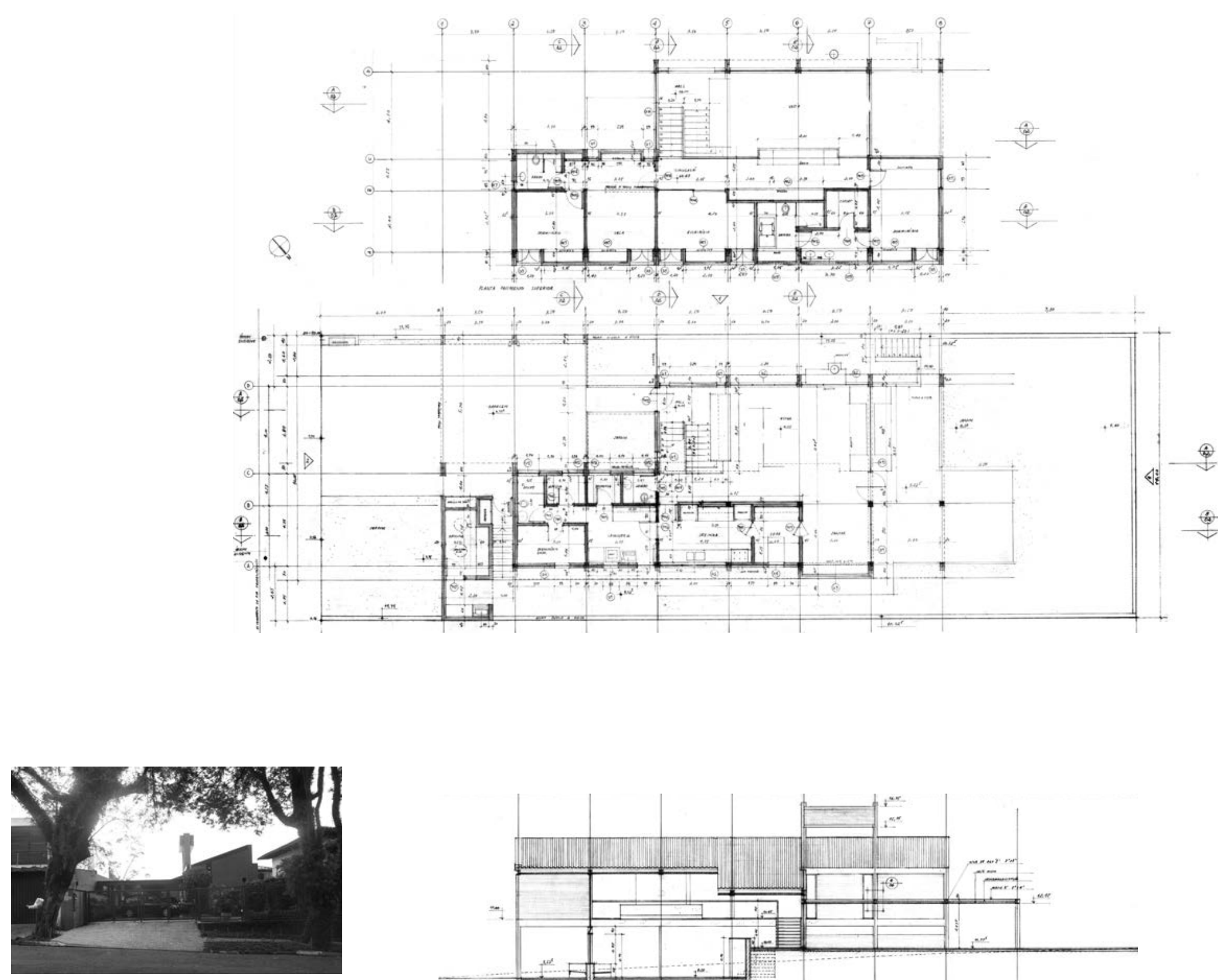

foto: Alessandra Figueiredo

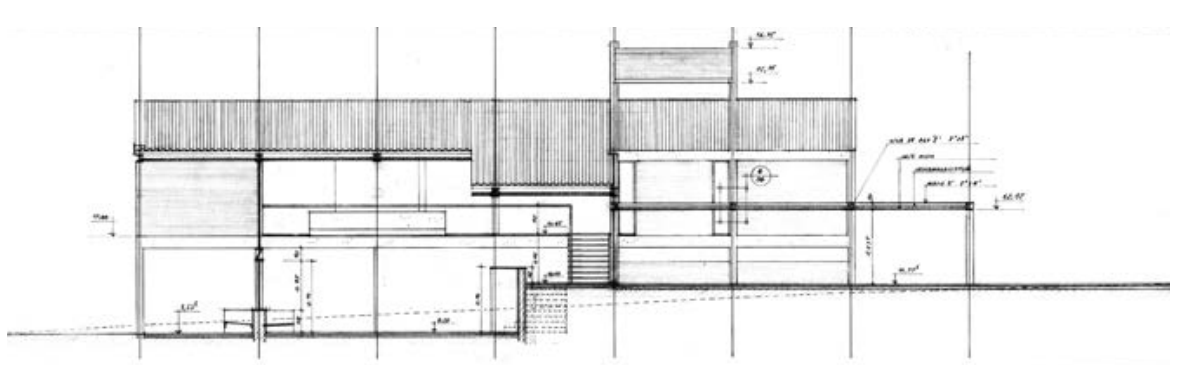

Q 
Uso

Sede Nacional da SBPC

Equipe

Arnaldo Martino e Eduardo de Almeida

Localização

Rua Pedro de Toledo, Vila Mariana, São Paulo, SP

Estágio

Anteprojeto

Observações

Não Construído

Características

A partir do programa de necessidades e das condições geológicas do terreno, o projeto apresentado para este

concurso público configura-se pela criação de um

embasamento horizontal destinado às funções públicas

do edifício e por um corpo vertical para as atividades de

escritório e garagem, talvez influenciado pelos edifícios

localizados no centro da cidade que, a partir do emprego

de elevadores e plataformas giratórias, viabilizam a

criação de estacionamentos de grandes dimensões sem

0 uso de estruturas em subsolo. Neste caso, 0 uso de

vigas de concreto vierendeel com aberturas circulares,

permite a criação de grandes vãos e andares alternados

sem estrutura, além do grande balanço junto ao acesso

do edifício

Acervo

Caixa 300
CONCURSO PUBLICO NACIONAL

DE AROUITETURA PARA O

ANTE PROJETO DA

SEDE NACIONAL DA SBPC

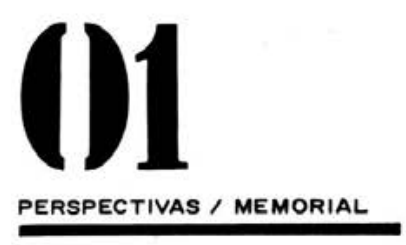

PERSPECTIVAS / MEMORIAL

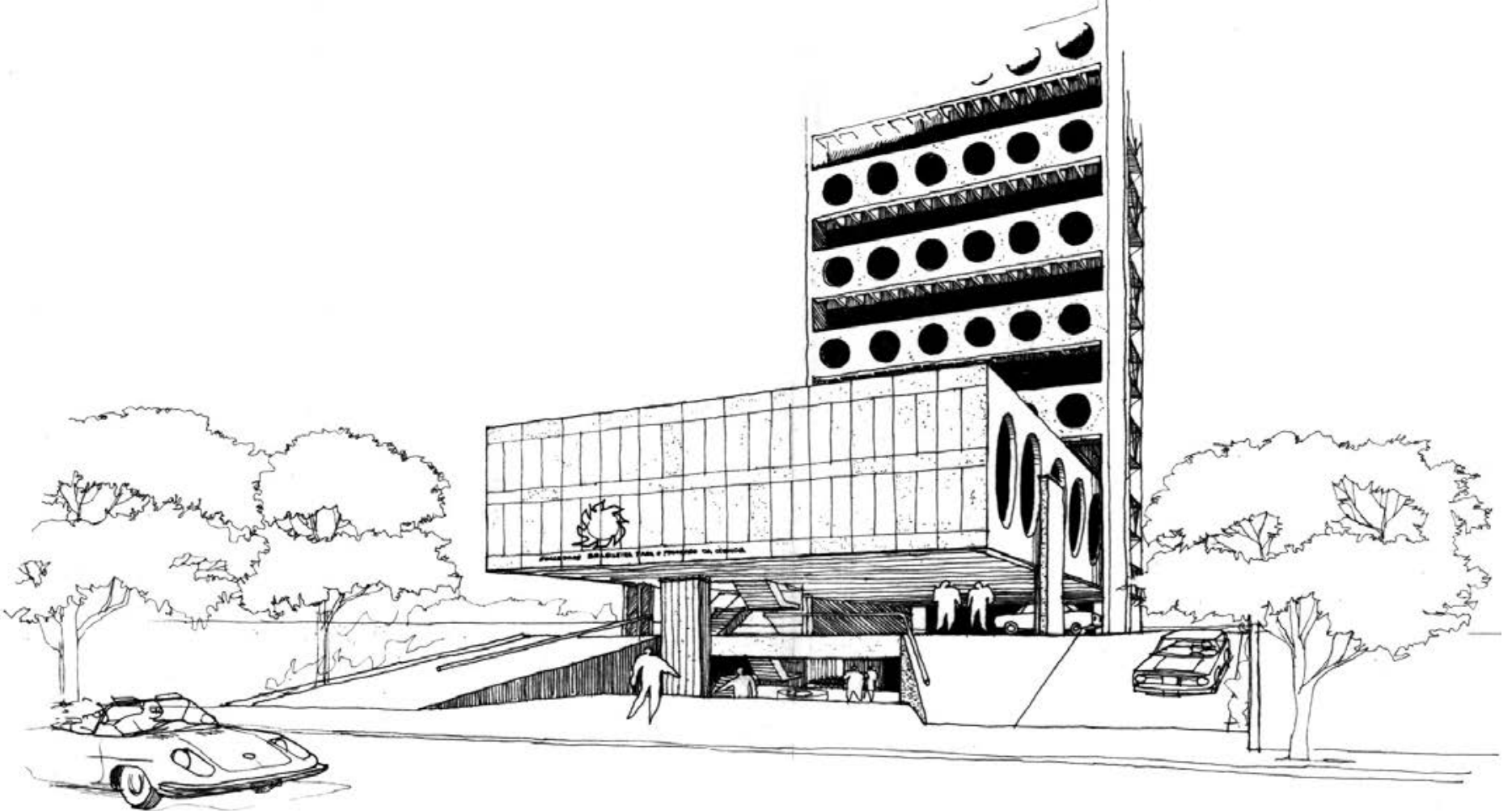

PERSPECTIVA EXTERNA 
Uso

Escritório de Arquitetura

Cliente

Eduardo de Almeida

Equipe

Arnaldo Martino e Eduardo de Almeida

Localização

Rua Chilon, Itaim Bibi, São Paulo, SP

Estágio

Projeto Executivo

Observações

Construido

Características

Seguindo a influência de diversos projetos anteriores, a solução para seu escritório cria uma sequência de módulos estruturais definidos por placas de alvenaria aparente associadas a uma sequência de vigas metálicas. Tal configuração determina a organização de os de apoio e as salas principais. Enquanto os primeiros se instalam sob uma laje de concreto impermeabilizada junto a uma das divisas, as áreas de trabalho implantam-se sob a estrutura metálica, aproveitando as aberturas para os jardins laterais e de fundos, além de contar com subdivisões de alvenaria leve independentes do forro e da estrutura. Realizado de forma extremamente econômica, o projeto considerou 0 reaproveitamento de vidros temperados provenientes de uma outra obra para a criação das janelas laterais. Projetado para abrigar o escritório em sociedade com Arnaldo Martino, a conclusão deste edifício marca o fina desta parceria, já que a utilização deste espaço coincide com o início de uma nova etapa na vida profissional de Eduardo de Almeida.

Acervo

Tubo 60
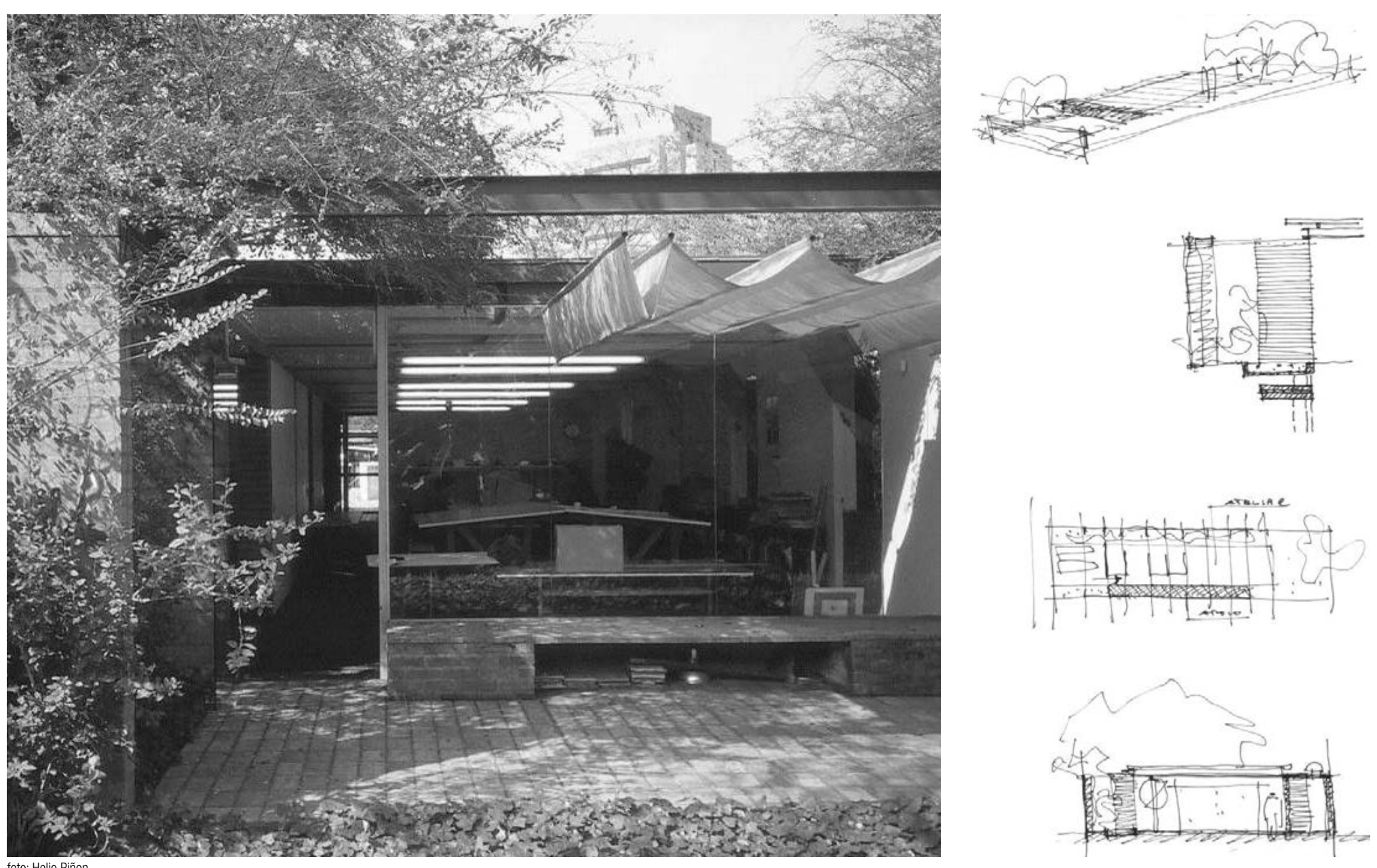
Uso

Residência Unifamiliar

Cliente

Manuel Marcilio Sanches

Equipe

Eduardo de Almeida

Localização

Rua Pianu, 34, Alto de Pinheiros, São Paulo, SP

Estágio

Projeto Executivo

Observações

Construído

\section{Características}

Extremamente singelo, o projeto desta residência de dois pavimentos utiliza-se de alvenarias de tijolos aparentes, pilares de blocos de concreto também aparentes e elementos vazados como brises ou, vedados com vidros, como painéis de fechamento de inúmeros ambientes. Sem nenhum arranjo espacial inesperado, este projeto destaca-se pelo correto dimensionamento da planta, pela organização das circulações ao lado do jardim interior, além das preocupações relacionadas à precisão e a clareza empregada em cada um dos elementos que compõem a construção.

Acervo

Tubo 73
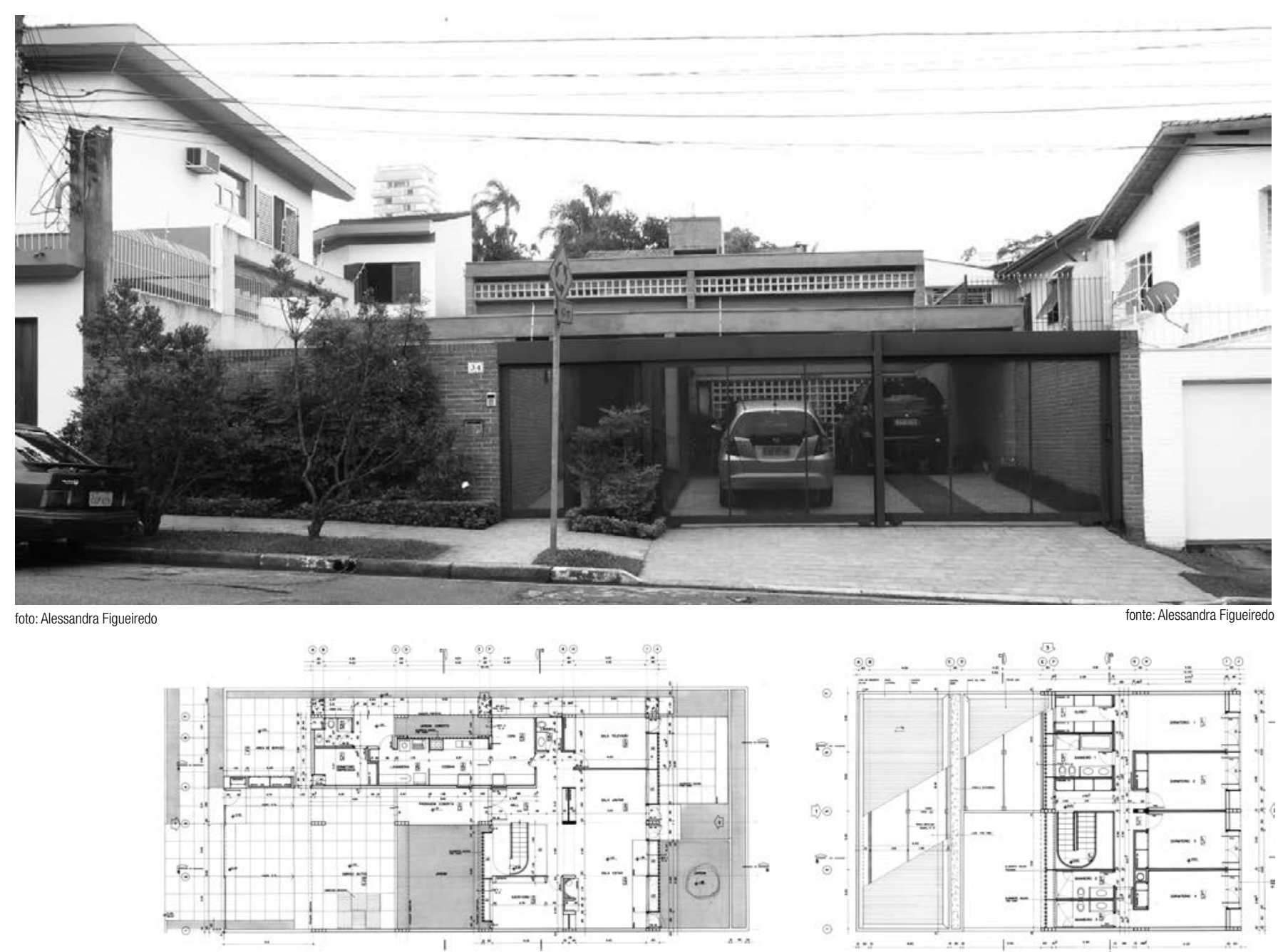

$\odot \odot \odot$

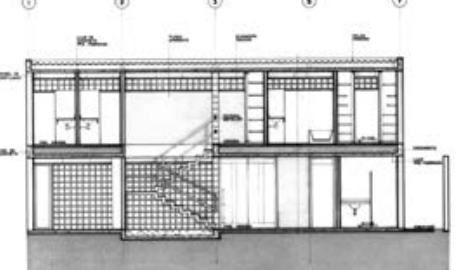


Uso

Edifício de Habitação Coletiva

Cliente

Construtora Paulista S.A.

Equipe

Eduardo de Almeida

colaboradores I Cândido Malta Filho, Fernando de Mello

Franco e Vinicius Gorgati

Localização

Rua Palacete das Águias, São Paulo, SP

Estágio

Projeto Executivo

\section{Observações}

Construído

\section{Características}

Também encomendado pela Construtora Paulista S.A.,

este edifício de dezessete pavimentos com quatro

unidades por andar, utiliza a mesma configuração do edifício Granja Julieta: dormitórios nas extremidades da planta, espaços de serviços junto ao núcleo central de circulações e, entre eles, o espaço vazio destinado à sala e à varanda em balanço.

Acervo

Tubo 59 e Caixa 4000

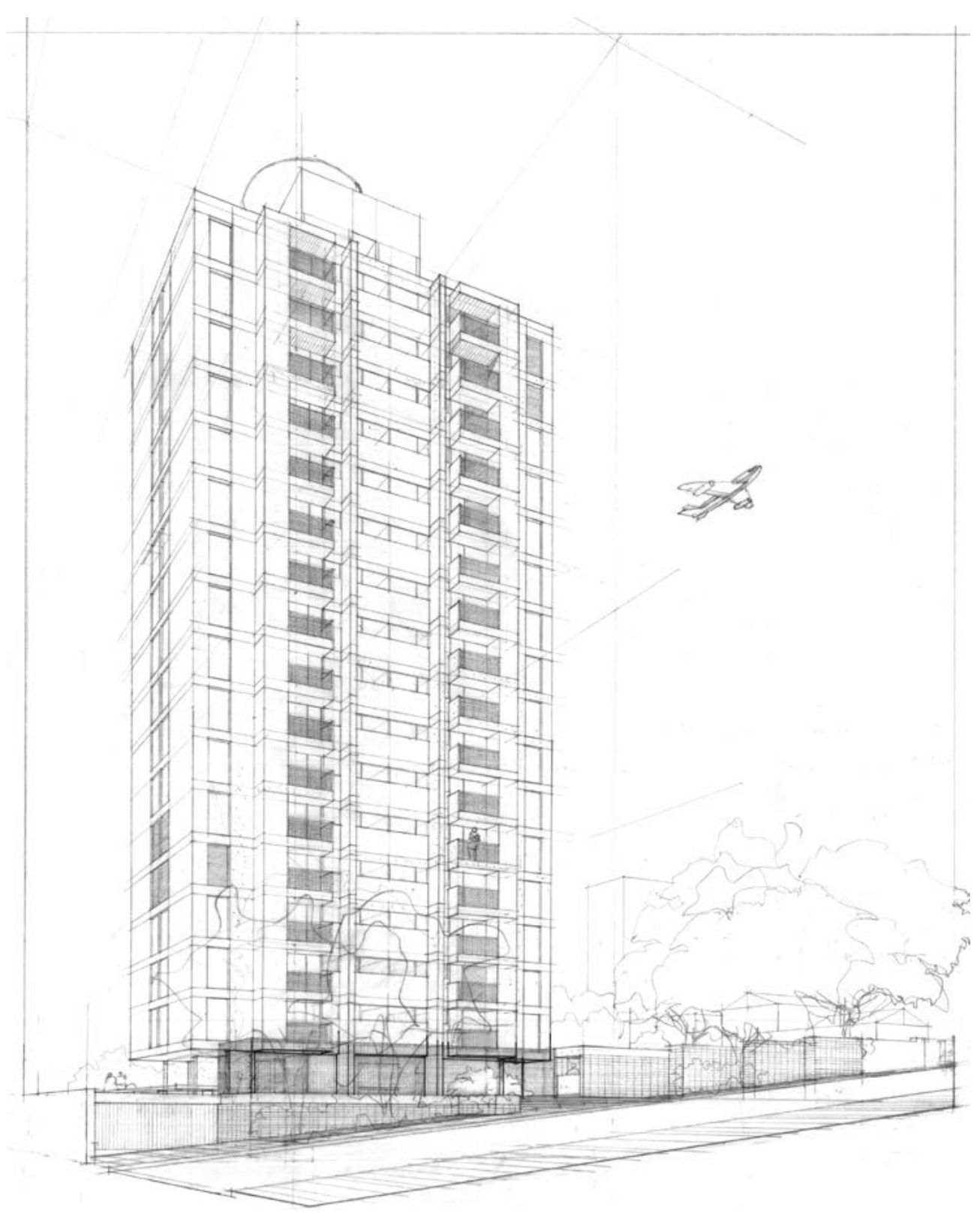

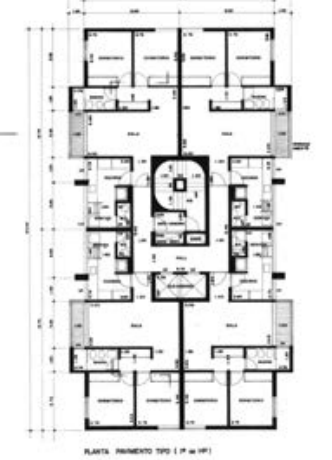
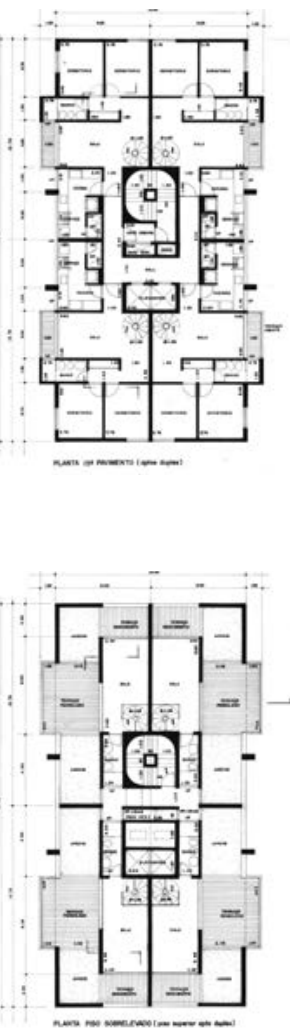
Uso

Residência Unifamiliar

Cliente

Isio Bakaleinik

Equipe

Eduardo de Almeida

colaboradores | Camila Toledo, Fernando de Mello

Franco, Teresa Mas e Vinícius Gorgati

Localização

Rua Bucareste 322, Jardim Europa, São Paulo,SP

Estágio

Projeto Executivo

\section{Observações}

Projeto de reforma construído

\section{Características}

A partir da volumetria de uma casa pré-existente no Jardim Europa, este projeto considera a reorganização

da planta e a adoção de uma nova linguagem

baseada em alvenarias revestidas com massa grossa

desempenada e demarcadas por frisos, contrapondo-se

à nova caixilharia, portões e guarda-corpos metálicos pintada de cor de vinho, a exemplo da cobertura arqueada preenchida com blocos de vidro, posicionada

junto ao acesso. Especial atencão ao desenho da área

externa realizada por Eduardo de Almeida, considerando

o desenho de piso, áreas ajardinadas e espelhos d'água.

Acervo

Tubo 58
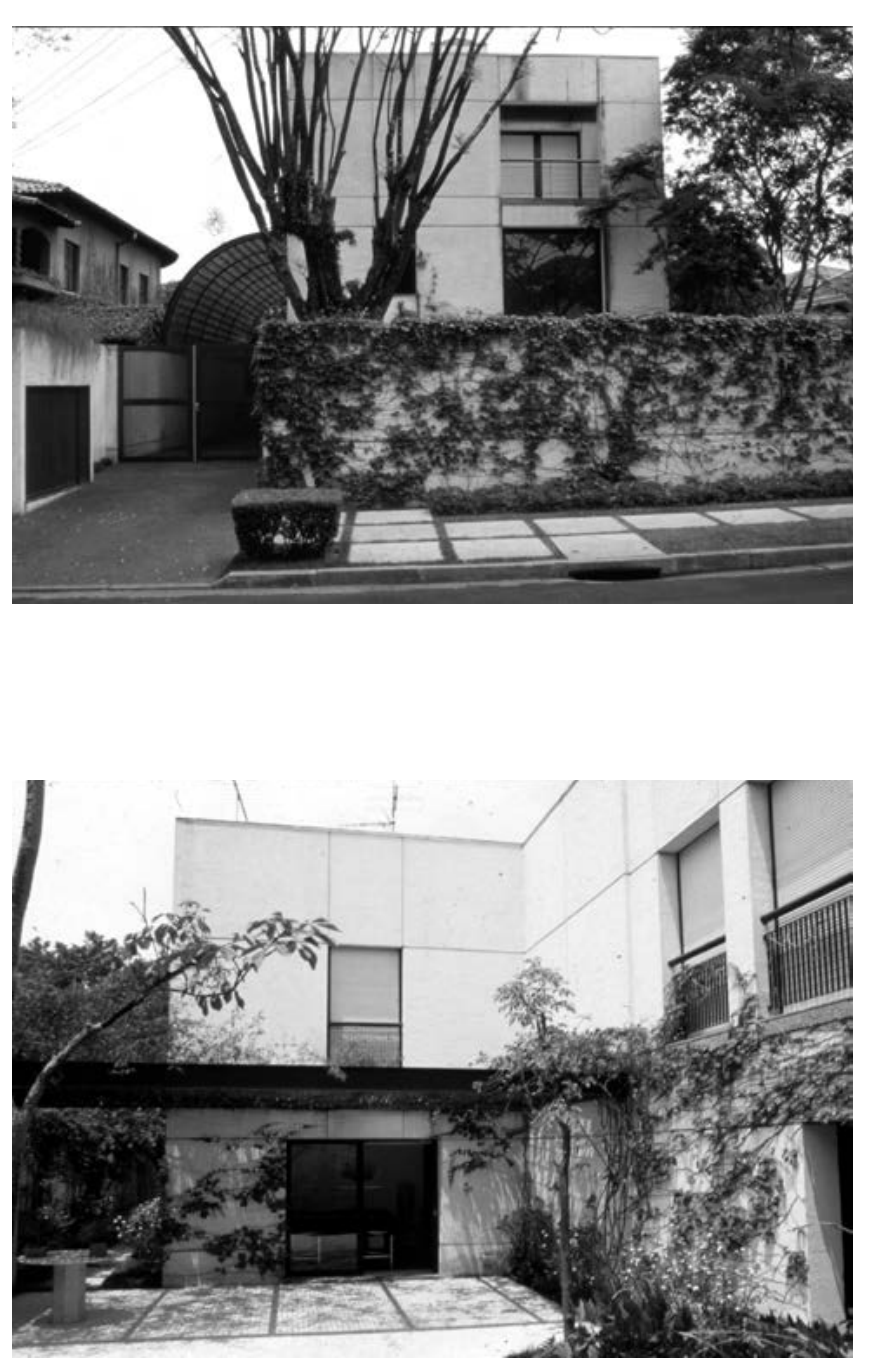
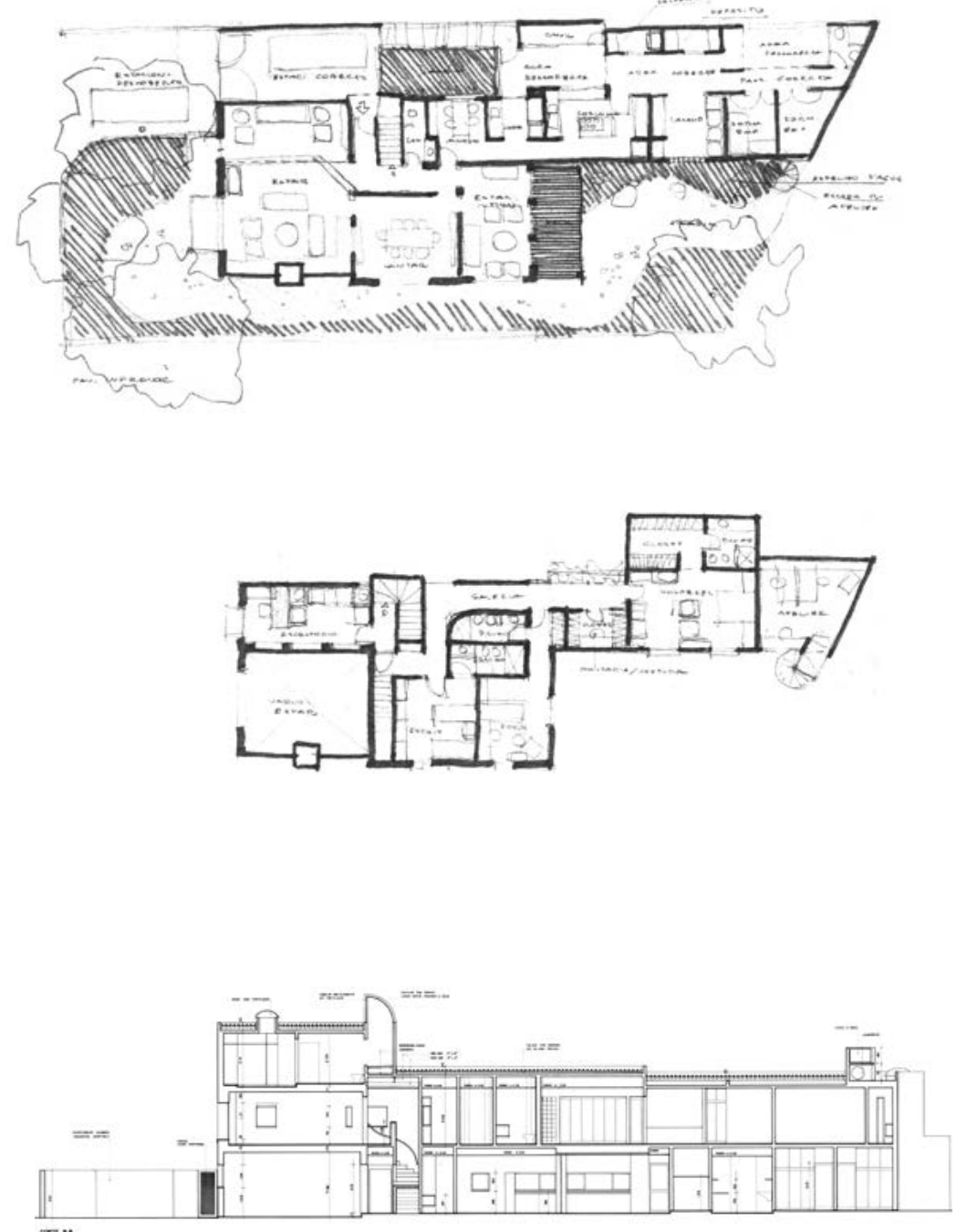
Uso

Reforma de apartamento

Cliente

Lucia Ramenzoni

Equipe

Eduardo de Almeida

Localização

Não identificada

Estágio

Projeto Executivo

Observações

Construído

\section{Características}

Reforma de apartamento para uma amiga ceramista.

Além da reconfiguração de alguns ambientes, o projeto

considera a disposição do mobiliário e 0 detalhamento

de bancadas, armários, estantes e painéis de correr.

Acervo

Tubo 31

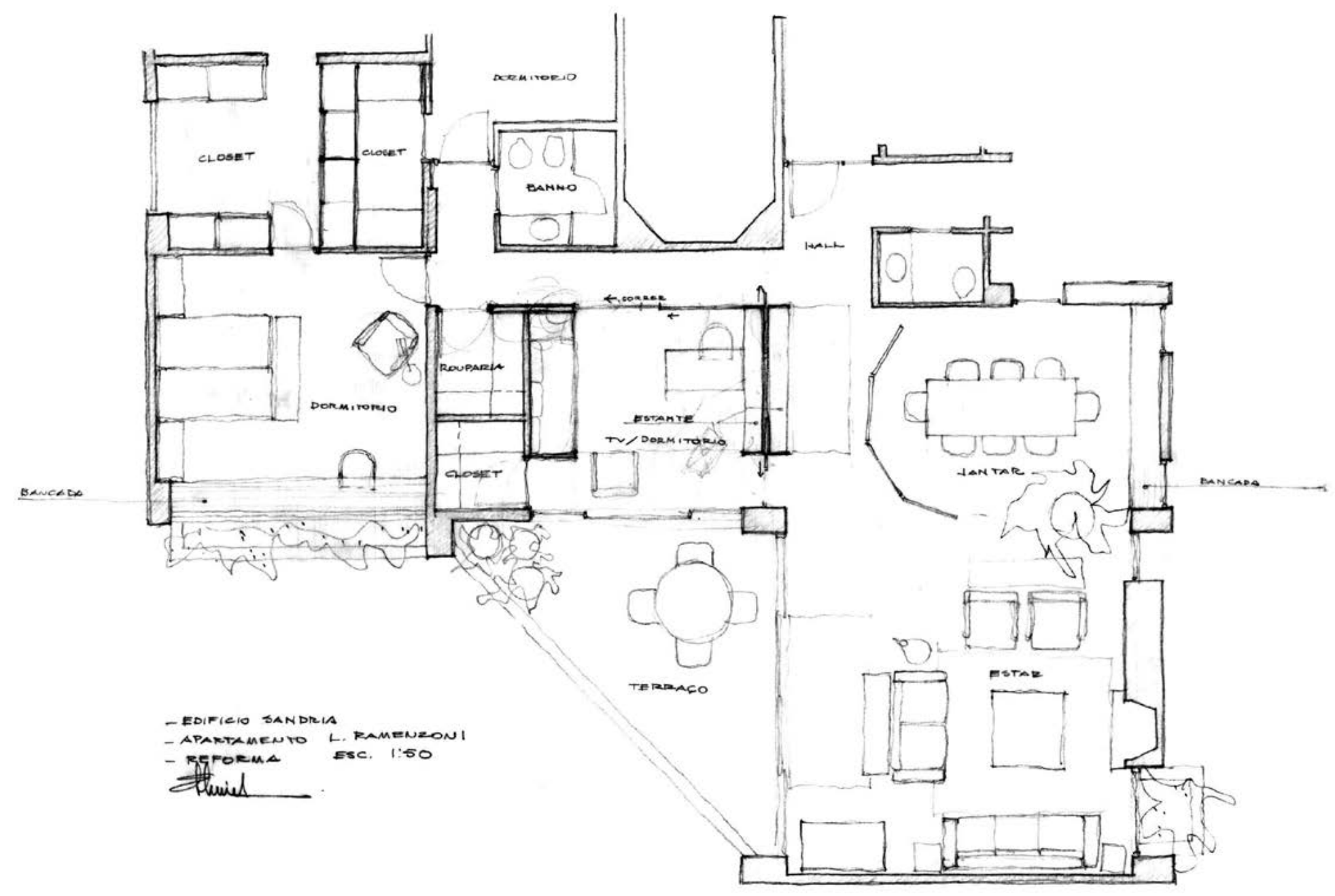


Uso

Residência Unifamiliar

Cliente

Ricardo Alves de Lima

Equip

Eduardo de Almeida

Localização

Jd. Paulistano, São Paulo, SP

Estágio

Estudo Preliminar

Observações

Não Construído

\section{Características}

Semelhante à solução apresentada para a casa de Ricardo Guimarães, este projeto aproveita-se de um dos recuos laterais para a criação de um espaço interior de pé-direito elevado, neste caso, valorizado pela geometria curva ainda mais acentuada que no projeto realizado anteriormente. A solucão da estrutura em concreto armado apresenta-se de forma mais singela, com mais armado apresenta-se de forma mais singe
apoios e sem as vigas treliça de fachada.

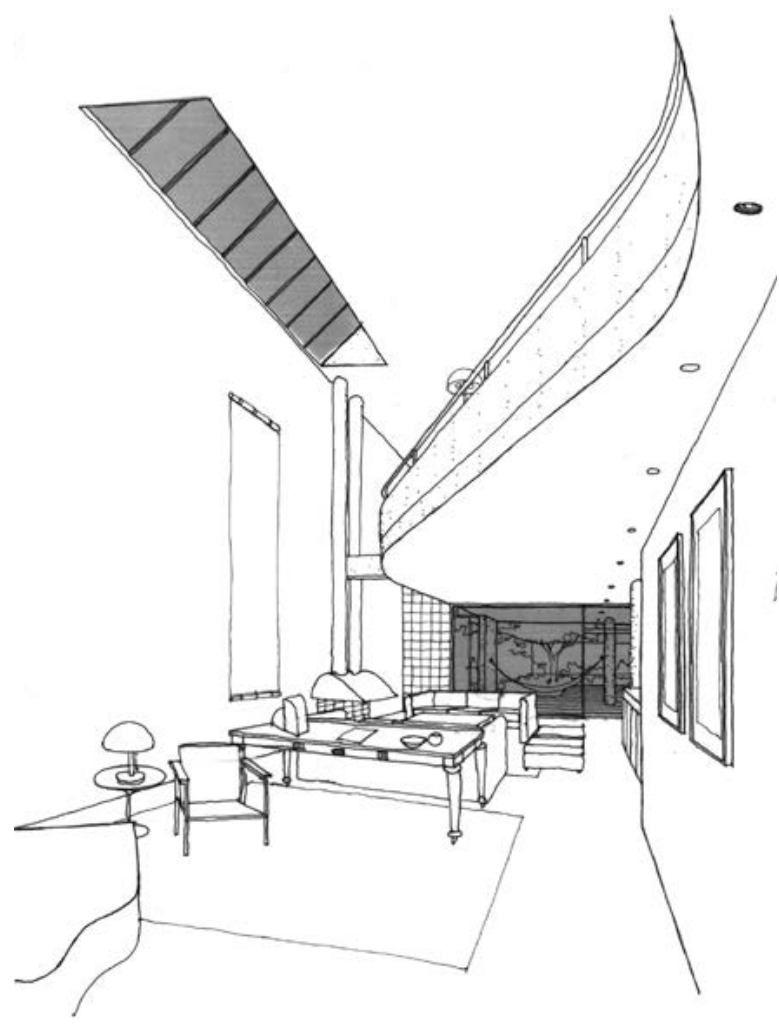

\section{Acervo}

Tubo 69
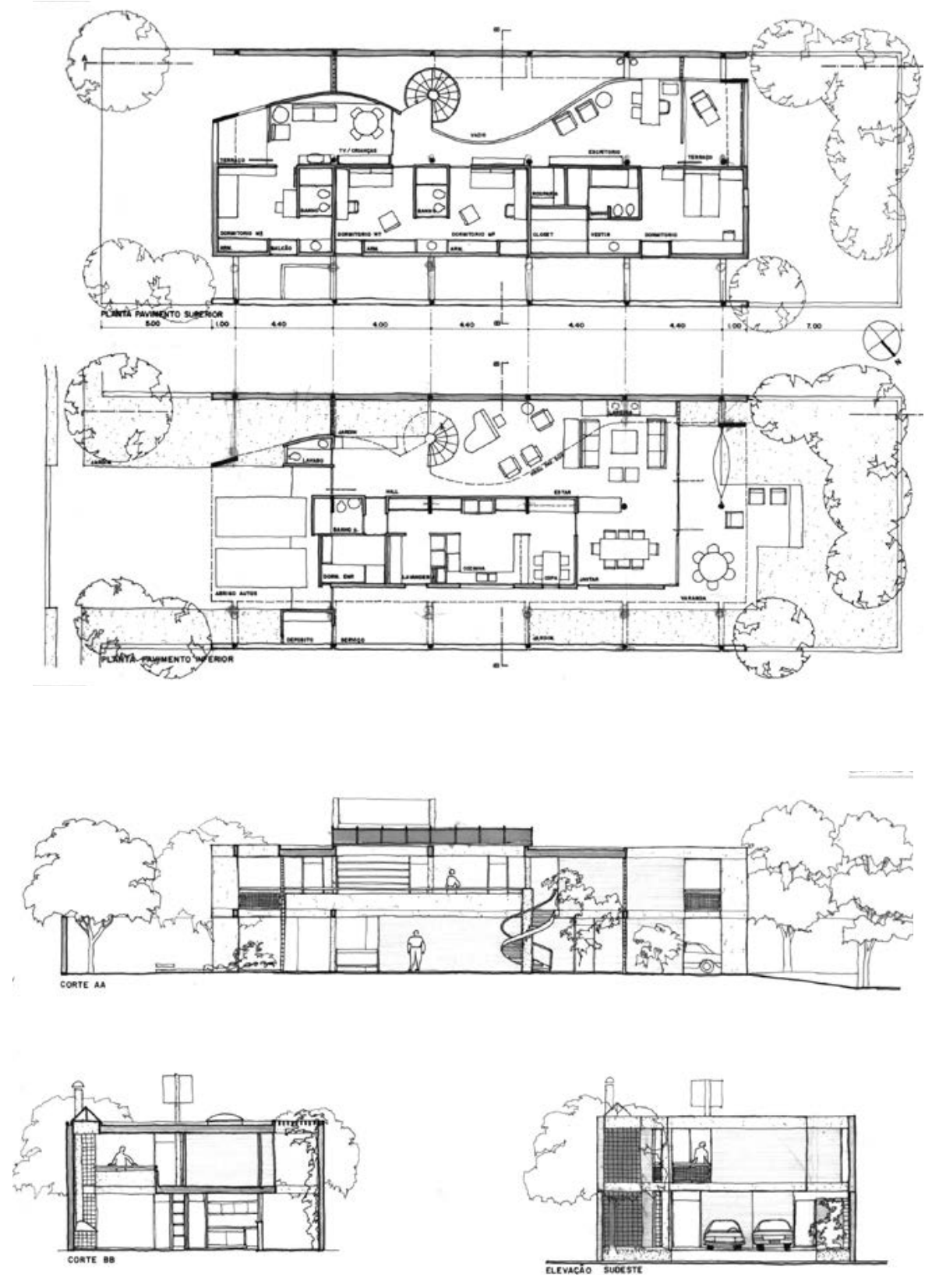
Uso

Centro Cívico

\section{Equipe}

Eduardo de Almeida

colaboradores I Claudio Libeskind, Fernando de Mello Franco, José Claudio Gomes e Vinicius Gorgati

Localização

Votorantim, SP

Estágio

Anteprojeto

\section{Observações}

Não construído

Concurso Público Estadual

\section{Características}

A proposta apresentada para o Centro Cívico de Votorantim parte da morfologia do tecido urbano existente e sua relação com a curva do rio que atravessa a cidade. 0 terreno de grandes dimensões é ocupado por edifícios periféricos que definem uma grande esplanada de caráter monumental em continuidade às ruas da área central do município e às pontes que cruzam 0 rio. Além das lâminas que abrigam a sede da prefeitura e as secretarias, foram criados edifícios de exceção em pontos estratégicos que rompem a linearidade do conjunto e demarcam os acessos junto às ruas. Acompanhando as linhas de palmeiras imperiais foram criados passeios cobertos sob os edifícios, junto aos fechamentos de vidro localizados no pavimento térreo.
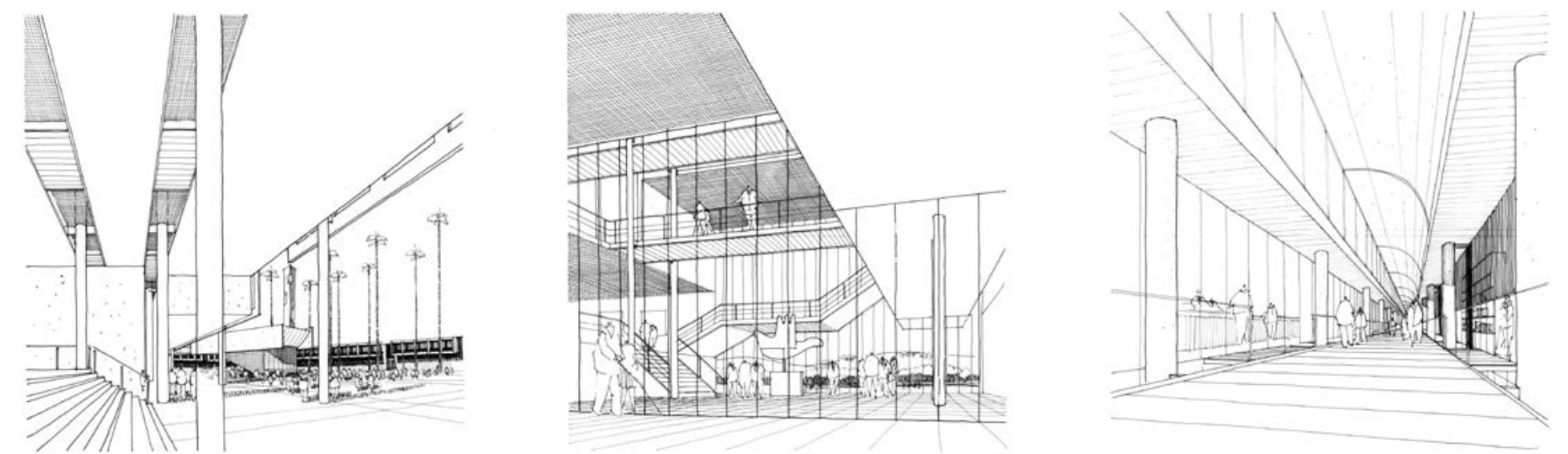

\&
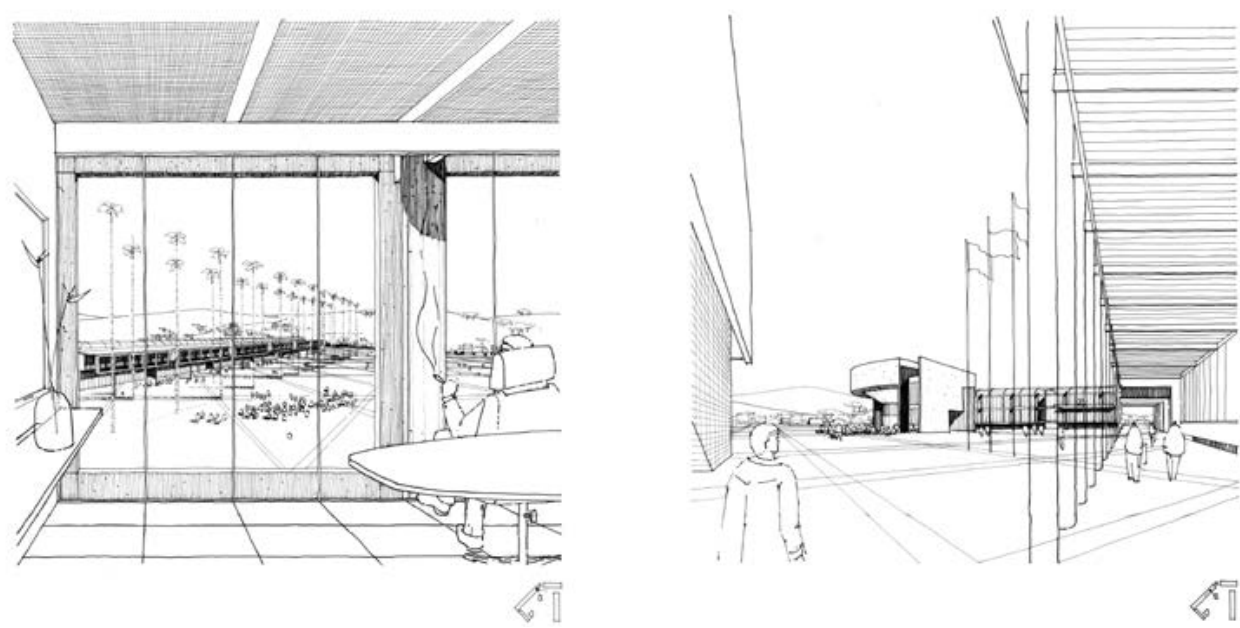

$<0$

\&

2:

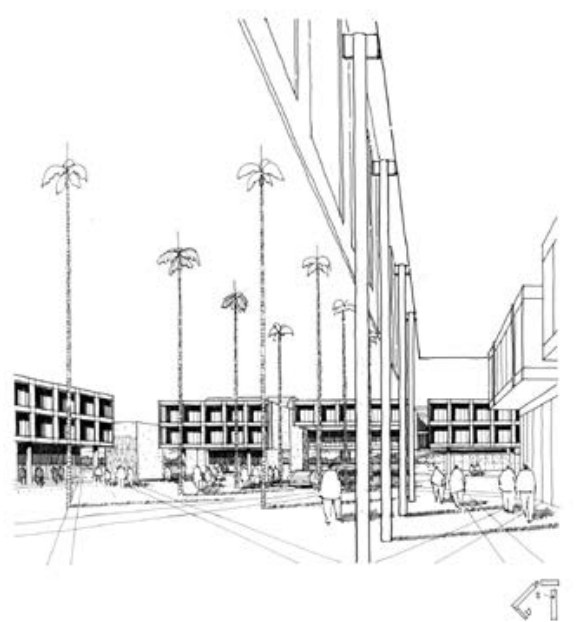

Acervo

Tubo 95

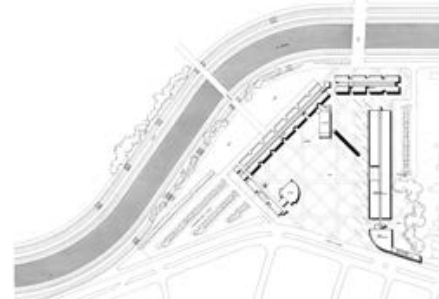


Uso

Residência Unifamiliar

Cliente

Jean M. Sigrist

Equipe

Eduardo de Almeida

colaboradora I Teresa Mass

\section{Localização}

Iha do Araújo, Paraty, RJ

Estágio

Projeto Executivo

Observações

Construído

\section{Características}

Por coincidência da topografia acentuada do terreno este projeto encomendado pela família Sigrist também segue a implantação em patamares com cobertura inclinada da casa realizada em São Paulo. Neste caso, por se tratar de uma obra em uma ilha próxima à Paraty, segundo Eduardo de Almeida, o projeto não só pautouse por elementos de construção possíveis de serem transportados até 0 sítio, como utilizou-se de linguagens das casas tradicionais de Paraty, tanto pela presença de muros de pedra e alvenaria de tijolos, quanto pelas estruturas de madeira com telhado de barro e caixilharia colorida de madeira.

Acervo

Tubo 36

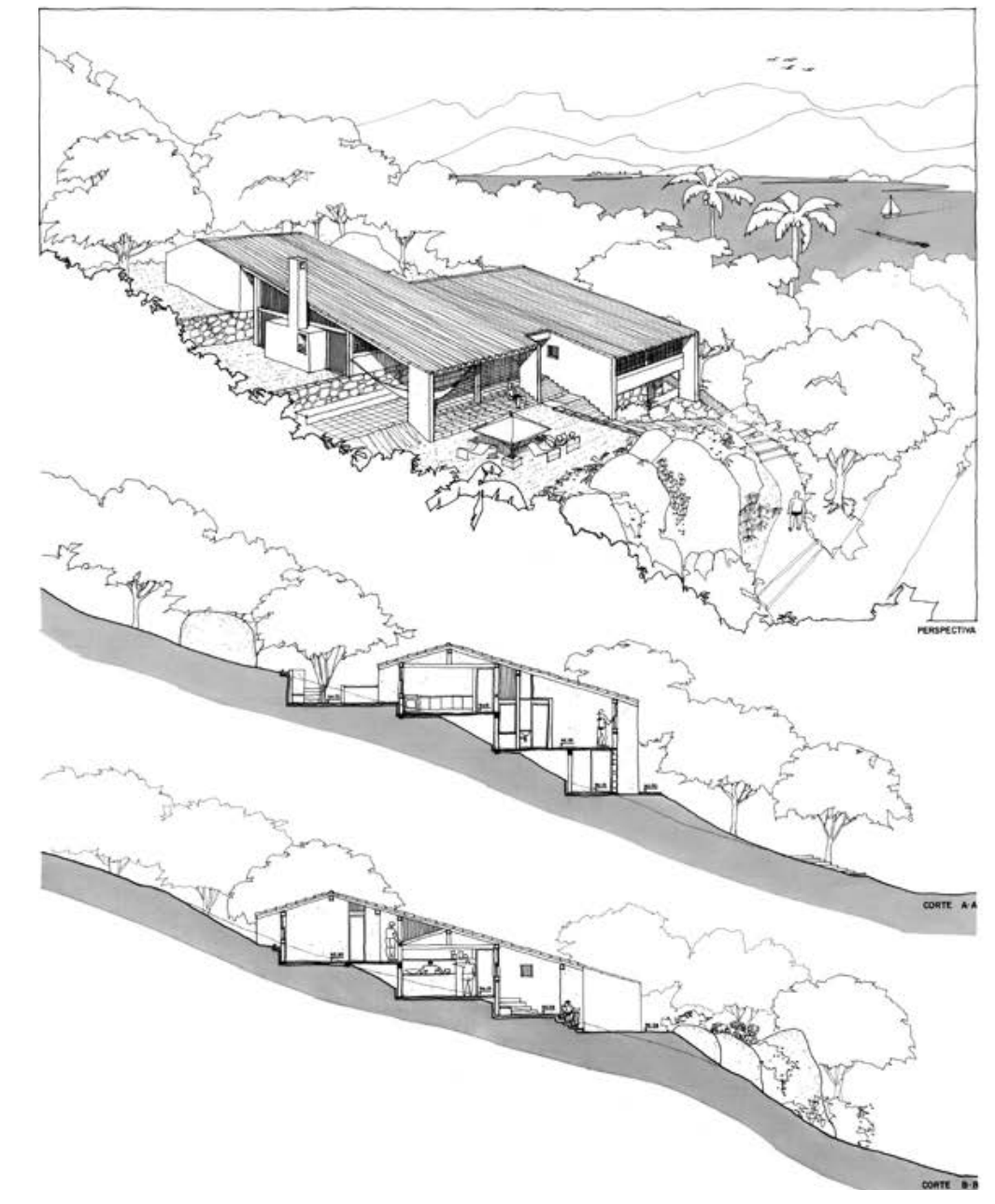

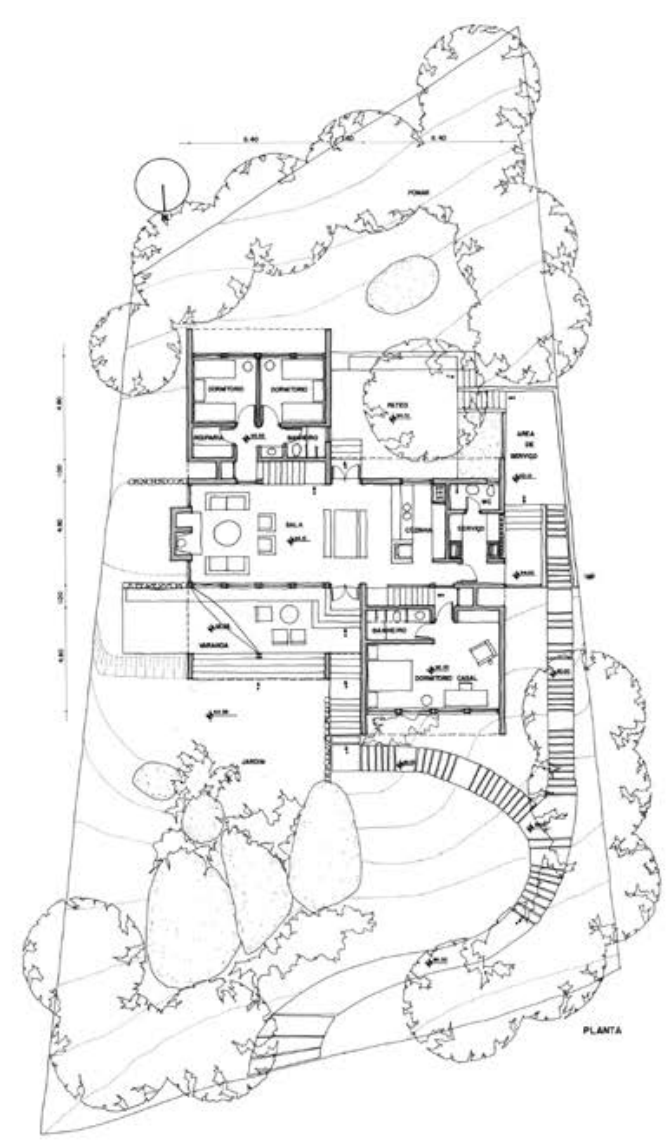

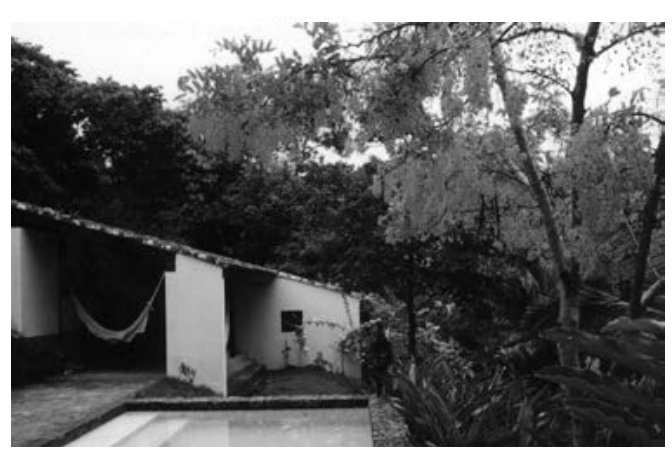


Uso

Edifício de Habitação Coletiva

Cliente

Não Identificado

Equipe

Eduardo de Almeida

Localização

Avenida Roque Petroni Jr., São Paulo, SP

Estágio

Anteprojeto

Observações

Não Construído

\section{Características}

Aproveitando a configuração do lote em esquina, a implantação deste edifício de escritórios cria uma sucessão de lajes em 'L' com prumadas de serviços e escadas de segurança nas extremidades. A circulação de público central volta-se para um átrio envidraçado que termina por configurar a geometria triangular da planta do edifício voltado para a esplanada de acesso. Especial atenção deve ser dada aos acessos de veículos pelas ruas secundárias e pela geometria do estacionamento, cujos pilares coordenam-se modularmente com a estrutura do edifício sem 0 uso de transiçoes. Nas inúmeras conversas com Eduardo de Almeida durante a realização de outros projetos, sempre foi ressaltada a importância de se projetar a garagem concomitantemente ao projeto do edifício: embora pouco visível, a estrutura do subsolo pode ser apreendida pelo desenho do edifícic.

Acervo

Tubo 92

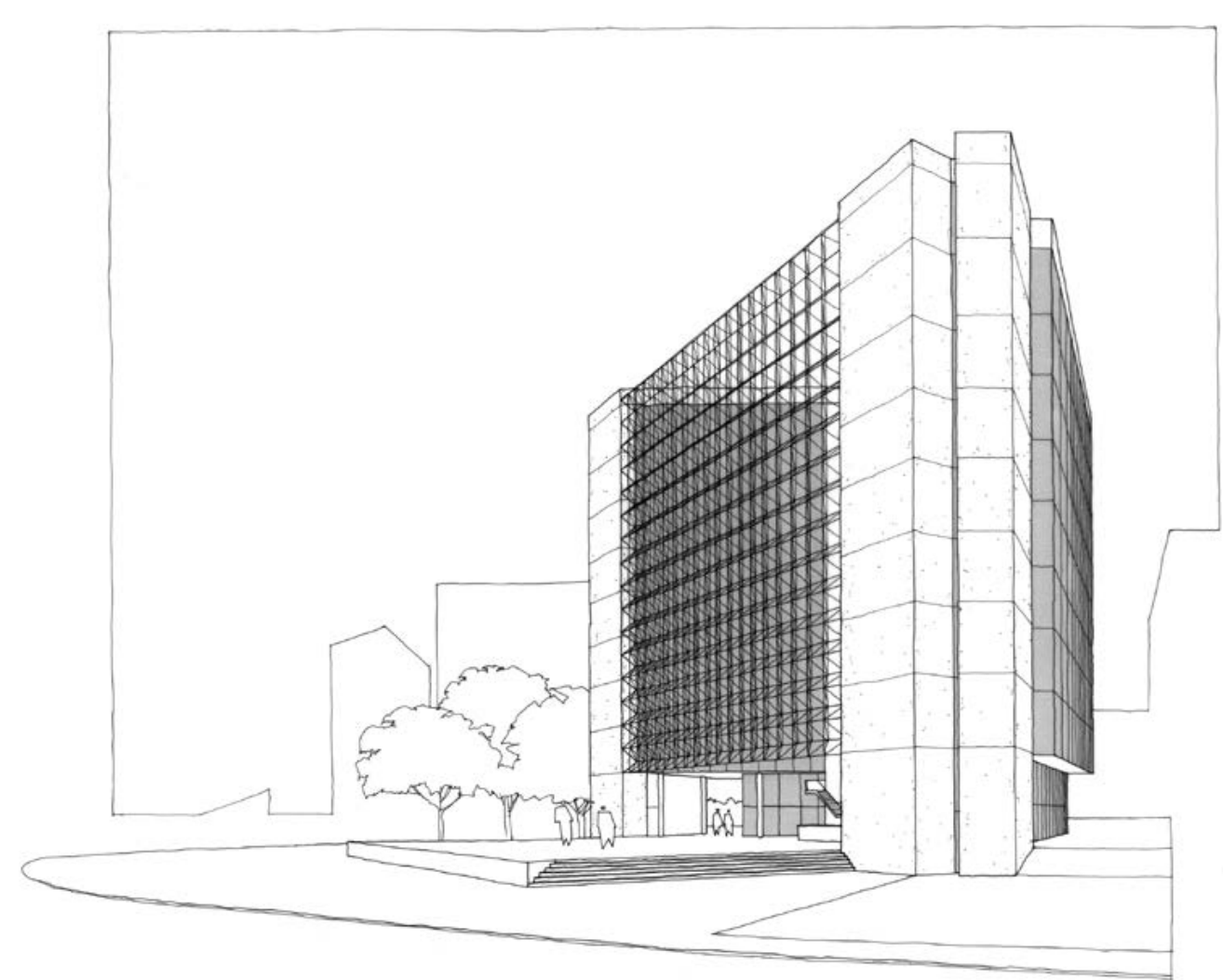

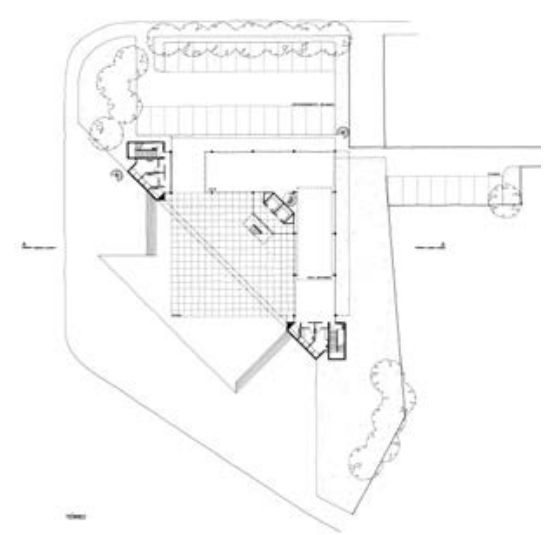

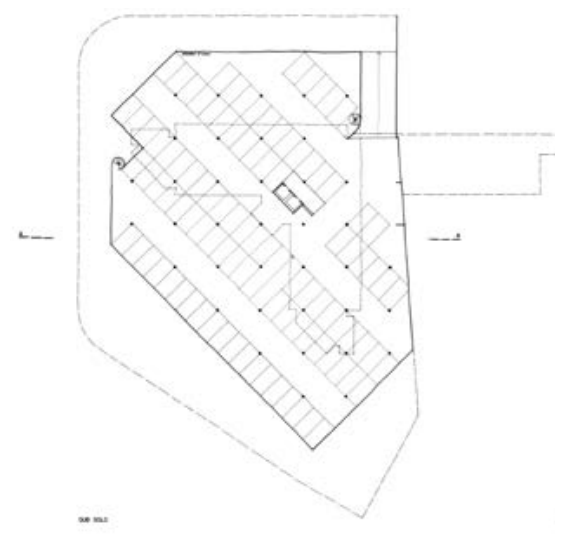


Escritórios

Cliente

Coldex Frigor

Equipe

Eduardo de Almeida

Localização

Não identificada

Estágio

Anteprojeto

Observações

Não Construido

\section{Características}

Projeto de reforma da área administrativa de uma fábrica

de compressores, localizada na parte frontal de um

galpão industrial pré-existente. Além do brise metálico

da nova fachada, o programa foi distribuído ao longo do

segundo pavimento, considerando a criação de um forro

curvo na área de trabalho do escritório.

Acervo

Tubo 69
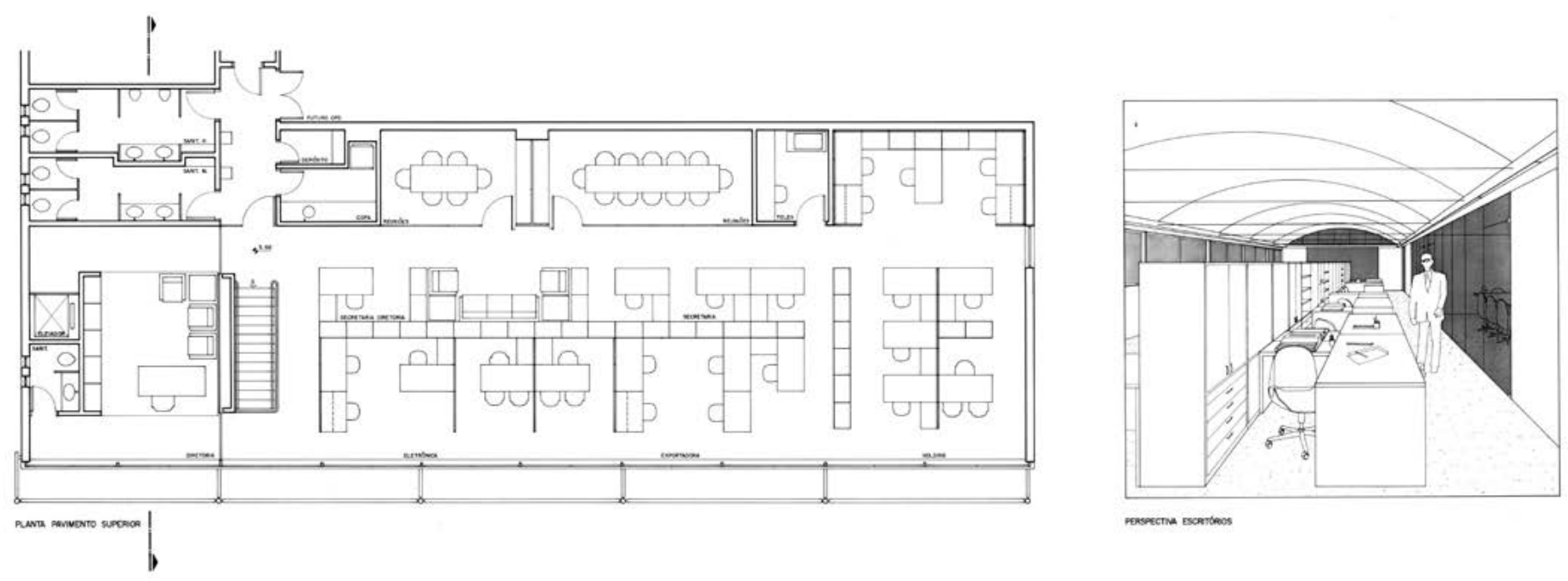
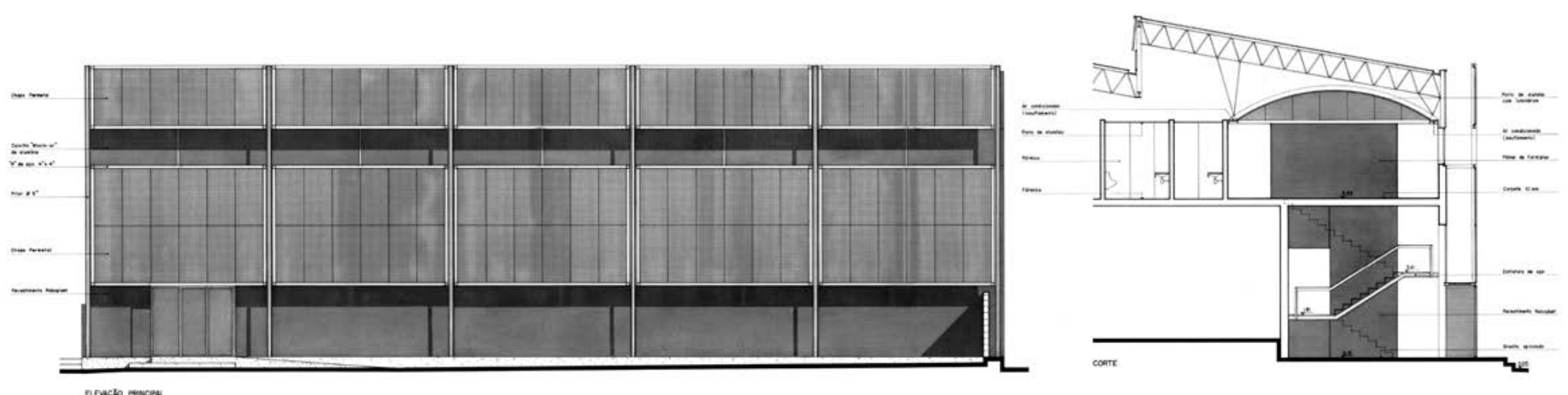
Uso

Conjunto Residencial e Plano de ocupação da ilha

Cliente

Emanuel Prado Lopes

Equipe

Eduardo de Almeida

colaborador I Marta Moreira

Localização

Ulha do Pasto, Angra dos Reis, RJ

Estágio

Estudo Preliminar

Observações

Não Construído

Características

Projeto de ocupação da ilha do Pasto que previa a construção de pousadas, duas tipologias para dezoito residências unifamiliares, área de lazer e esporte junto

a cume e piers de acesso ao redor de todo o perímeto

do itha Implantadas à meia-encosta, as construcões

em estrutura de madeira e telhados cerâmicos de

duas águas foram destacadas em relação ao solo,

aproveitando também a presença da vegetação.

Acervo

Tubo 84

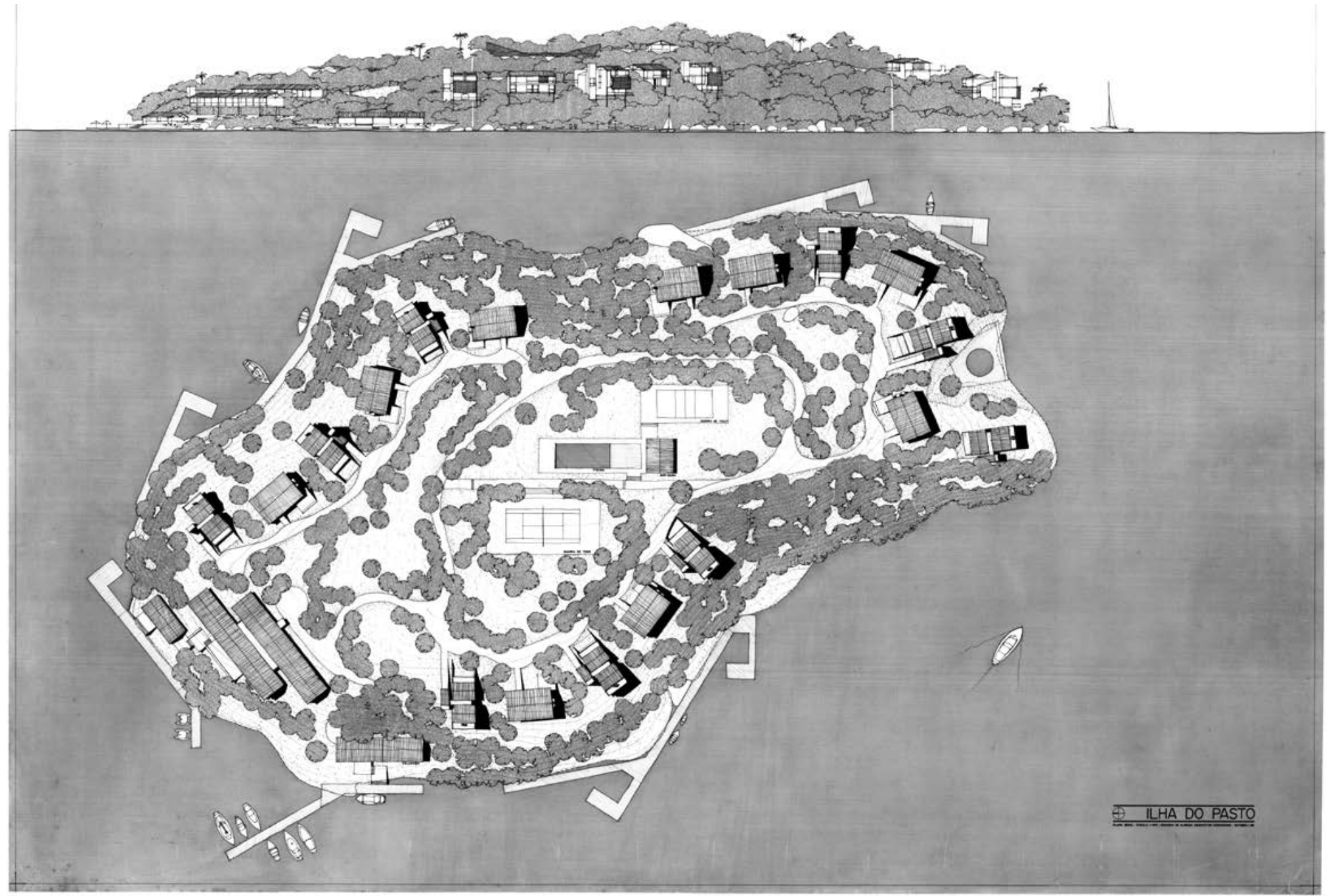


Uso

Fazenda

Cliente

Isio Bakaleinik

Equipe

Eduardo de Almeida

colaboradores | Camila Toledo, Fernando de Mello

Franco e Vinicius Gorgati

maquete I Marta Moreira e Vinicius H. de Andrade

Localização

Uberaba, Minas Gerais

Estágio

Projeto Executivo

Observações

Construído

\section{Características}

Localizada em Uberaba, Minas Gerais, este projeto cria o plano de ocupação e o desenho de todos os edifícios necessários ao funcionamento da fazenda, realizados ao longo de mais de dez anos. Além dos edifícios de caráter técnico vinculados à produção, foram previstos equipamentos de lazer e centro comunitário, vila para os colonos e áreas administrativas, além da casa sede da fazenda.

Tais edifícios são dispostos em dois setores - áreas técnicas e moradias -intermediados pelo centro comunitário. Enquanto o primeiro segue uma implantaçãa de pavilhões paralelos, a vila dos trabalhadores organiza-se em um semi-círculo posicionado próximo à área verde, definindo um recinto central de uso comum.

Acervo

Tubo 54, 54 A e 54 B, Caixa 4500, 4510 e 4520
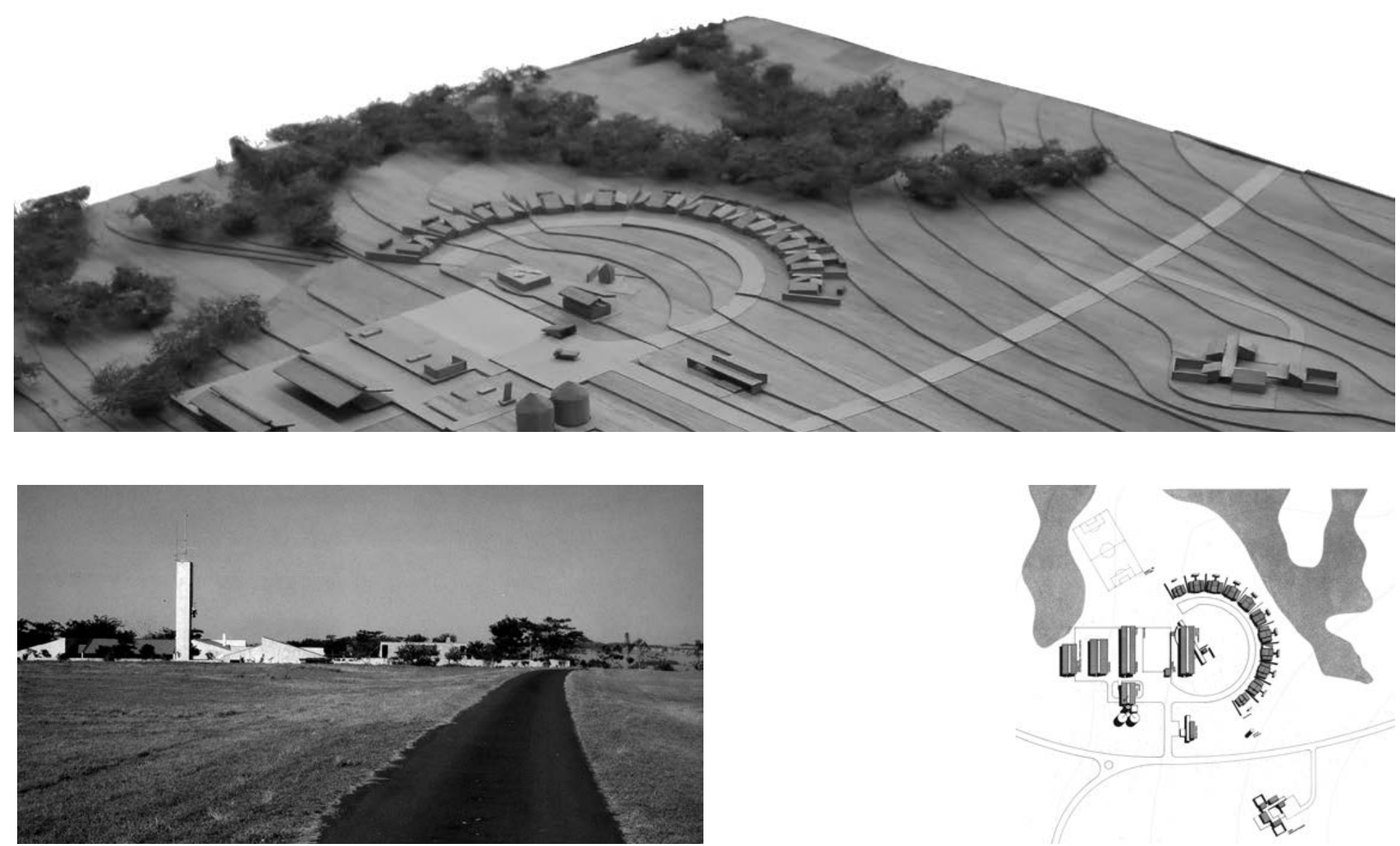

e. 
Uso

Conjunto residencial - 22 casas

Cliente

Isio Bakaleinik

Equipe

Eduardo de Almeida

colaboradores I Camila Toledo, Fernando de Mello

Franco e Vinicius Gorgati

Localização

Uberaba, Minas Gerais

Estágio

Projeto Executivo

\section{Observações}

Construído

\section{Características}

Foram projetadas vinte e duas residências com dois

ou três dormitórios para as famililas dos trabalhadores

da fazenda. Seguindo a implantação radial, as casas

geminadas são compostas por volumes de cobertura

inclinada intermediadas por lajes de concreto sobre

os corredores. Enquanto todos os dormitórios voltam-

se para os recuos laterais, os espaços de uso coletivo

voltam-se para a praça central ou para a mata presente

no fundo dos lotes.

Acervo

Tubo 54, 54 A e 54 B, Caixa 4500, 4510 e 4520
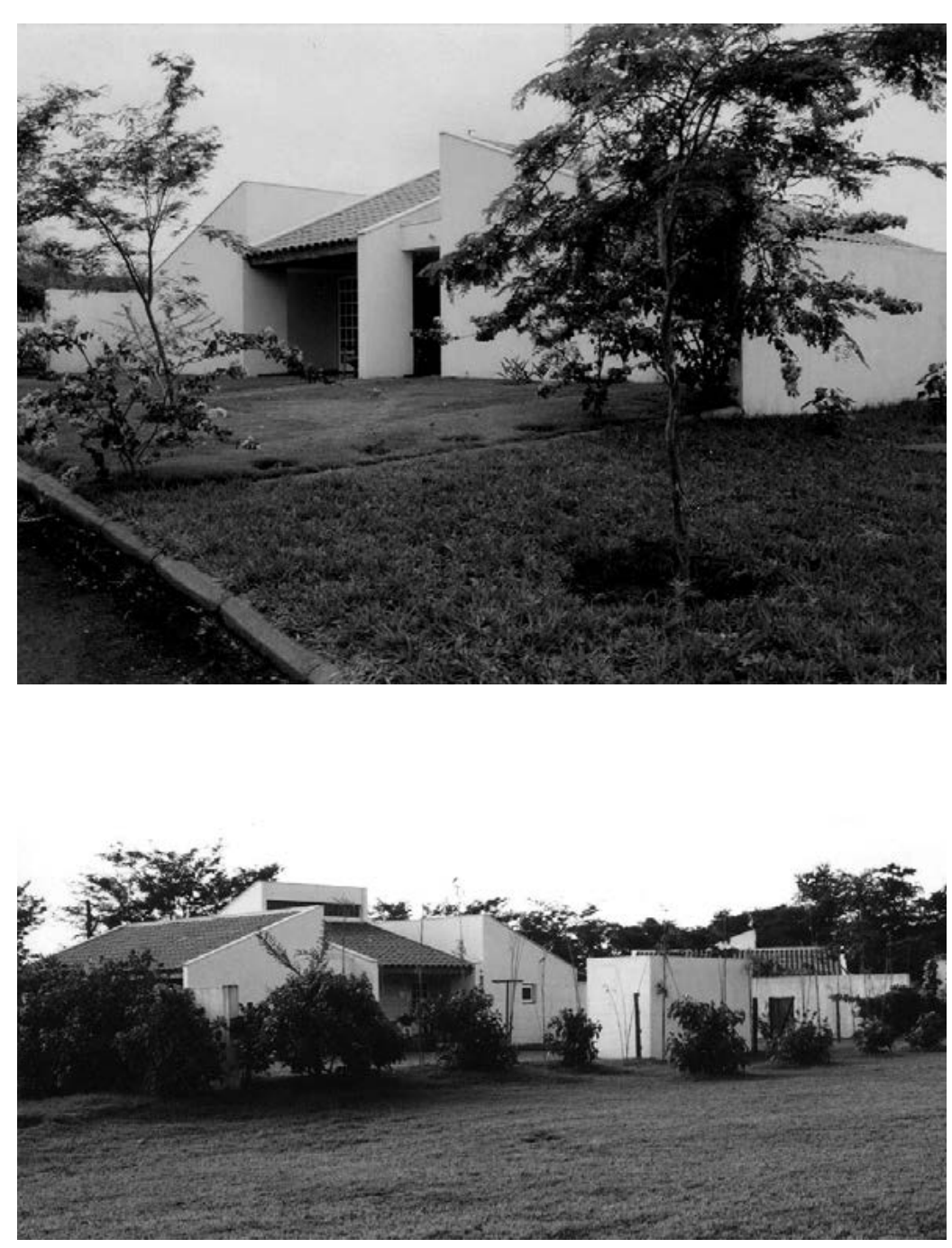
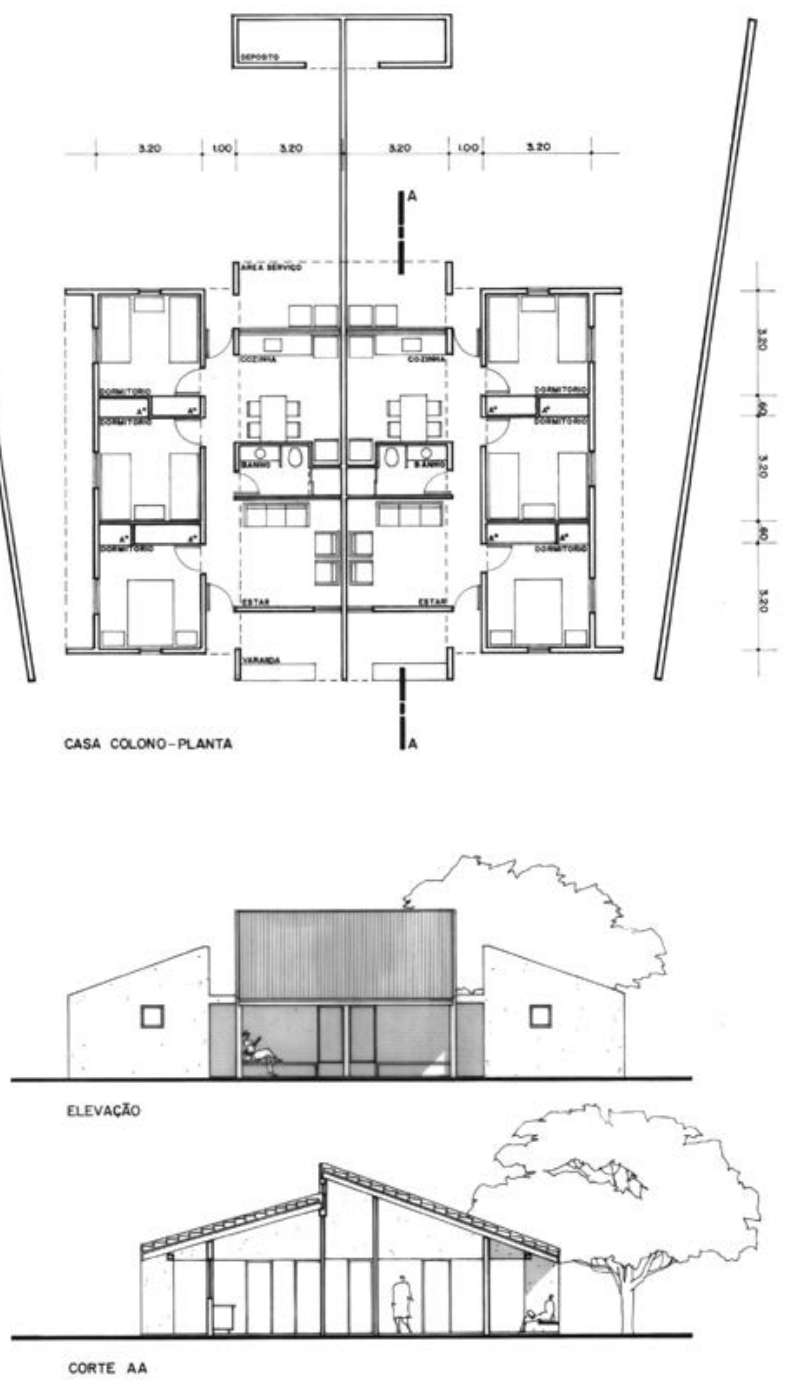
Uso

Residência para administrador e técnicos

Cliente

Isio Bakaleinik

Equipe

Eduardo de Almeida

colaboradores I Camila Toledo, Fernando de Mello

Franco e Vinicius Gorgati

\section{Localização}

Uberaba, Minas Gerais

\section{Estágio}

Projeto Executivo

\section{Observações}

Construído

\section{Características}

Seguindo o mesmo partido construtivo e volumétrico

das demais habitações, a casa dos administradores

apresenta uma implantação em 'L' que concentra

as circulações avarandadas voltadas para um pátio

interior. Ao mesmo tempo, cada um dos blocos abre-

se para o exterior, amparados por muros de fechamento

ou varandas. A implantação deste edifício, apesar de

distante dos demais, apresenta um alinhamento ao eixo

da implantacãa semi-circular da vila dos trabalhadores.

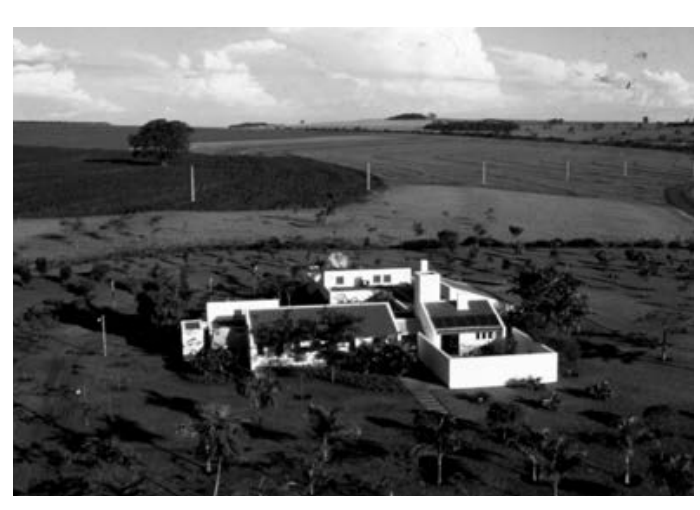

Acervo

Tubo 54, 54 A e 54 B, Caixa 4500, 4510 e 4520

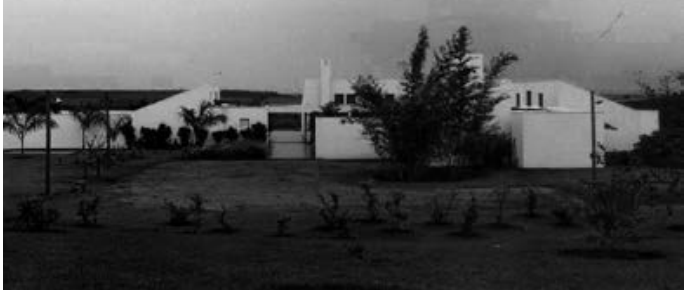

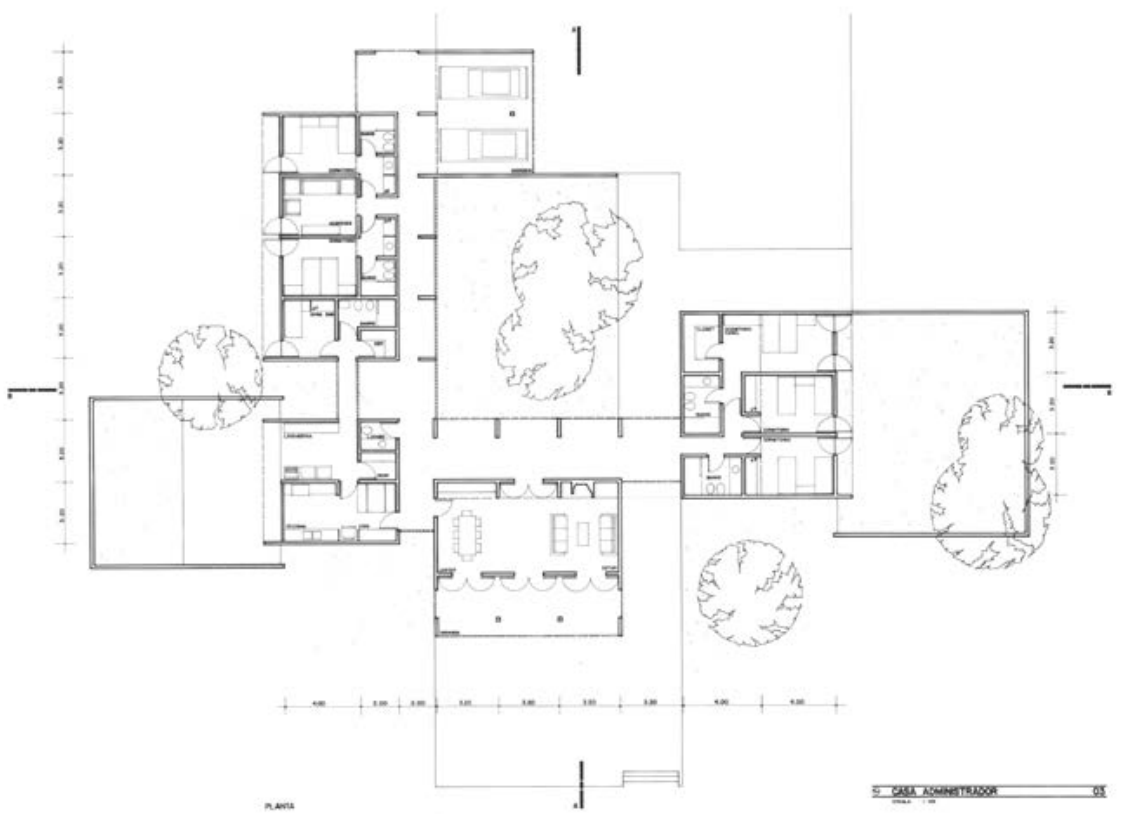

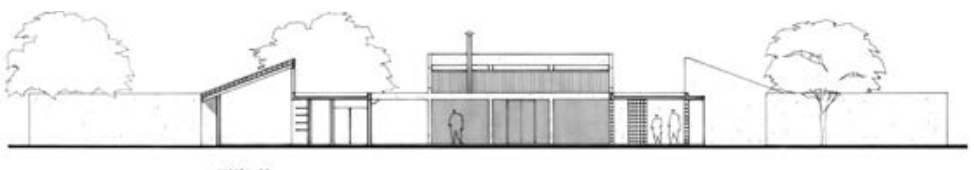


Uso

Centro Comunitário

Cliente

Isio Bakaleinik

Equipe

Eduardo de Almeida

colaboradores | Camila Toledo, Fernando de Mello

Franco e Vinicius Gorgati

Localização

Uberaba, Minas Gerais

\section{Estágio}

Projeto Executivo

\section{Observações}

Não Construído

\section{Características}

Posicionado entre as áreas técnicas e a vila dos colonos,

o centro comunitário da fazenda apresenta uma

disposição geométrica que promove a transição entre

estes dois setores.

Enquanto a marquise de concreto e o volume da

churrasqueira alinham-se ao eixo de implantação da vila,

a cobertura em estrutura metálica segue o paralelismo

dos pavilhões técnicos. Justapostas, as duas estruturas

criam um contraste entre os sistemas construtivos

em alvenaria e concreto - pesados - com as vigas

vagonadas dos galpões - extremamente delicadas.

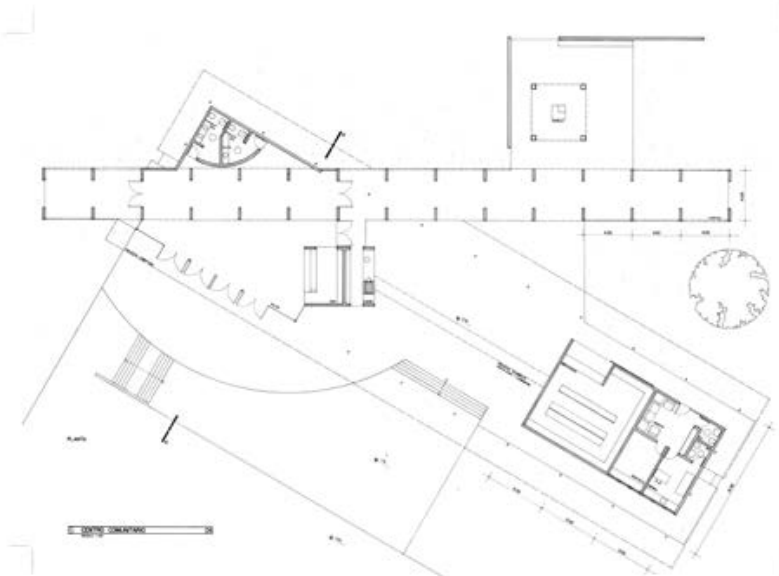

Acervo

Tubo 54, 54 A e 54 B, Caixa 4500, 4510 e 4520 
Uso

Escritório

Cliente

Isio Bakaleinik

Equipe

Eduardo de Almeida

colaboradores | Camila Toledo, Fernando de Mello

Franco e Vinicius Gorgati

\section{Localização}

Uberaba, Minas Gerais

\section{Estágio}

Projeto Executivo

\section{Observações}

Construído

\section{Características}

De acordo com a solução construtiva dos edifícios

habitacionais, 0 projeto para 0 escritório da fazenda

utiliza um volume com telhado inclinado de uma água

associado a uma varanda construída com placas de

alvenaria e laje de concreto impermeabilizada. Além

de criar varandas de chegada assimétricas ao volume

destinado aos programas, a justaposição destes volumes

permite criar sanitários iluminados zenitalmente.

Acervo

Tubo 54, 54 A e 54 B, Caixa 4500, 4510 e 4520
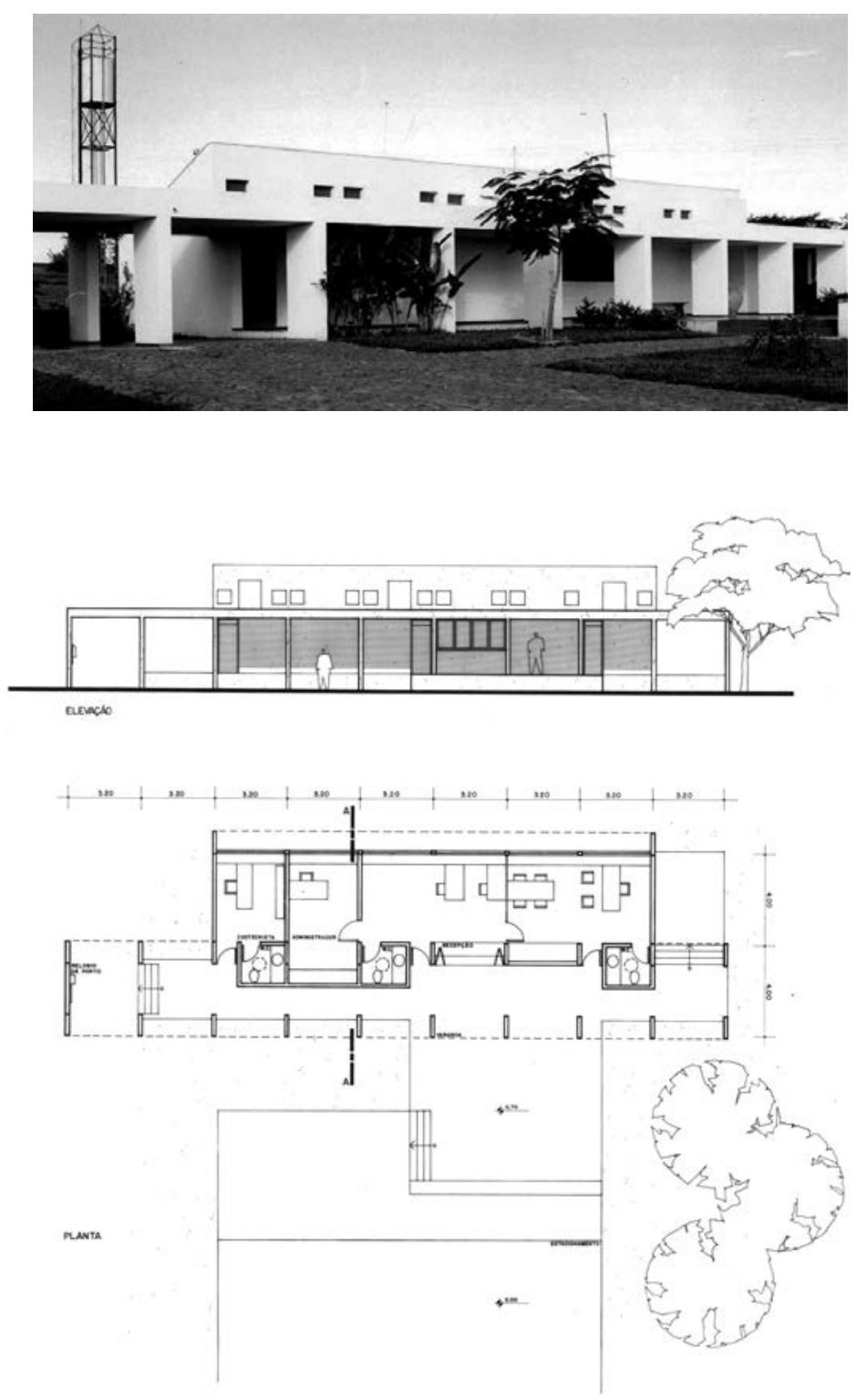
Uso

Depósitos

Cliente

Isio Bakaleinik

Equipe

Eduardo de Almeida

colaboradores I Camila Toledo, Fernando de Mello

Franco e Vinicius Gorgati

estrutura I Concen Construções Metálicas

Localização

Uberaba, Minas Gerais

\section{Estágio}

Projeto Executivo

Observações

Construído

Características

Seguindo o padrão para os edifícios de caráter técnico

este depósito cria uma estrutura metálica extremamente

delgada a partir do emprego de treliças vagonadas para

a cobertura de duas águas que, separadas, permitem a

utilização da cumeeira como local destinado a iluminação

e ventilação naturais. Além das alvenarias baixas, os

fechamentos utilizam telhas metálicas na vertical

bandeiras junto ao beiral. Ao posicionar os denósitos

nas extremidades, 0 acesso aos compartimentos dá-

se por uma varanda coberta que atravessa 0 edifício

transversalmente.

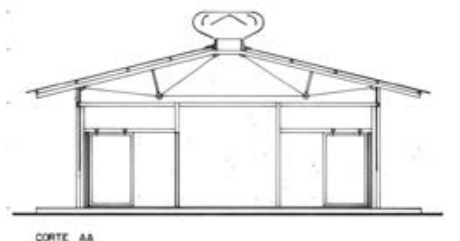

Acervo

Tubo 54, 54 A e 54 B, Caixa 4500, 4510 e 4520

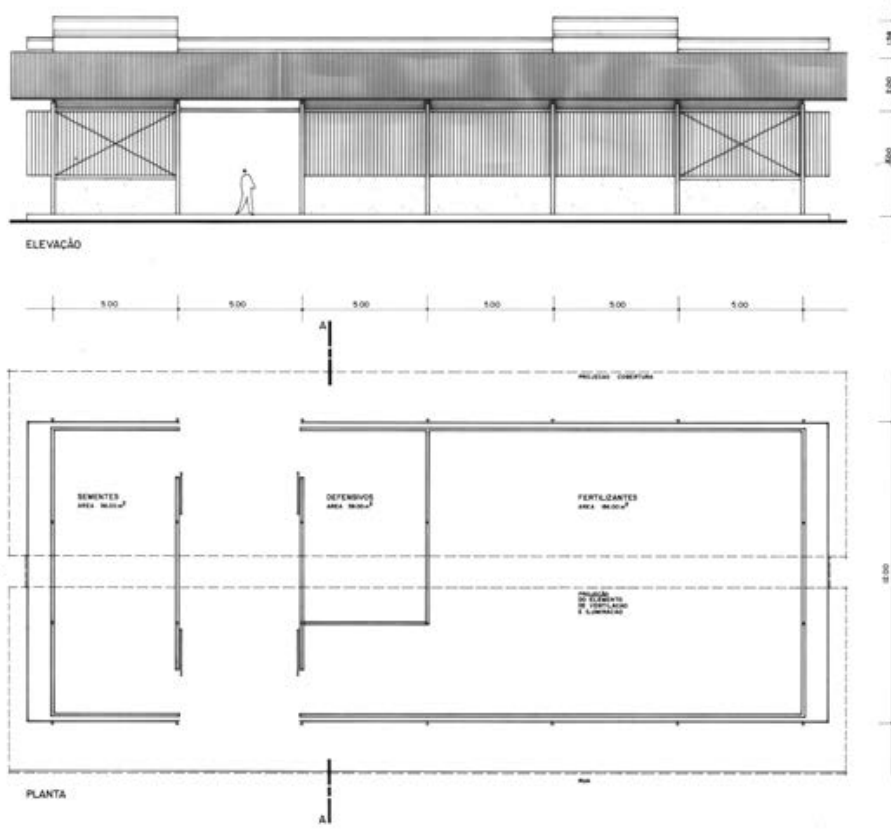


Cliente

Isio Bakaleinik

Equipe

Eduardo de Almeida

colaboradores | Camila Toledo, Fernando de Mello

Franco e Vinicius Gorgati

estrutura I Concen Construcõoes Metálicas

equipamentos I Pinhalense S.A. e Kepler Weber

Localização

Uberaba, Minas Gerais

Estágio

Projeto Executivo

Observações

Construído

Características

Utilizando solução construtiva idêntica ao depósito

de sementes, defensivos e fertilizantes, o galpão

destinado à fábrica de ração implanta-se ao lado dos

silos, elementos de caráter fabril que se incorporam à

linguagem arquitetônica do conjunto.

Acervo

Tubo 54, 54 A e 54 B, Caixa 4500, 4510 e 4520
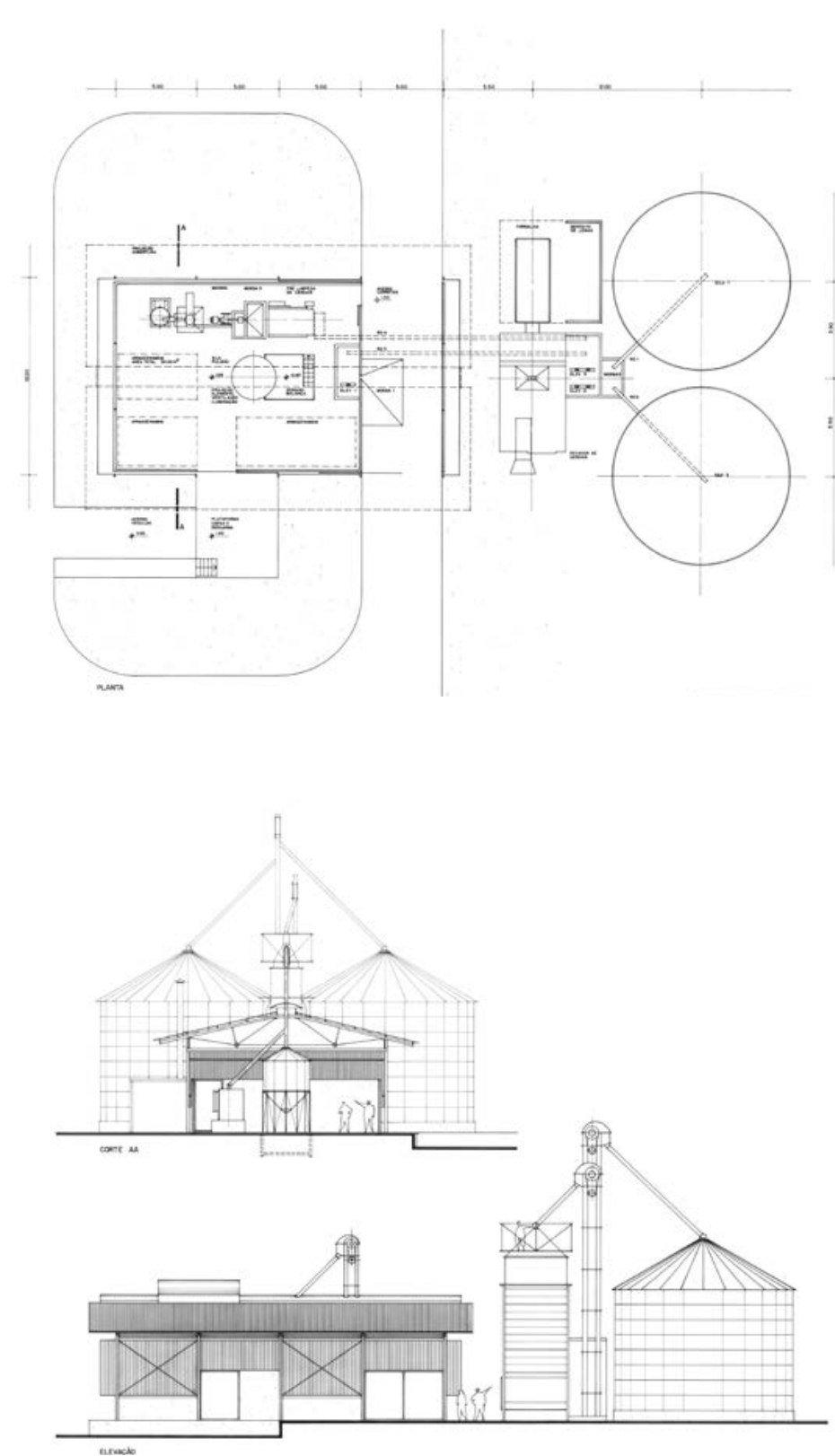
Uso

Fazenda

Cliente

Isio Bakaleinik

Equipe

Eduardo de Almeida

colaboradores I Camila Toledo, Fernando de Mello

Franco e Vinicius Gorgati

estrutura I Concen Construcões Metálicas

equipamentos I Pinhalense S.A. e Kepler Weber

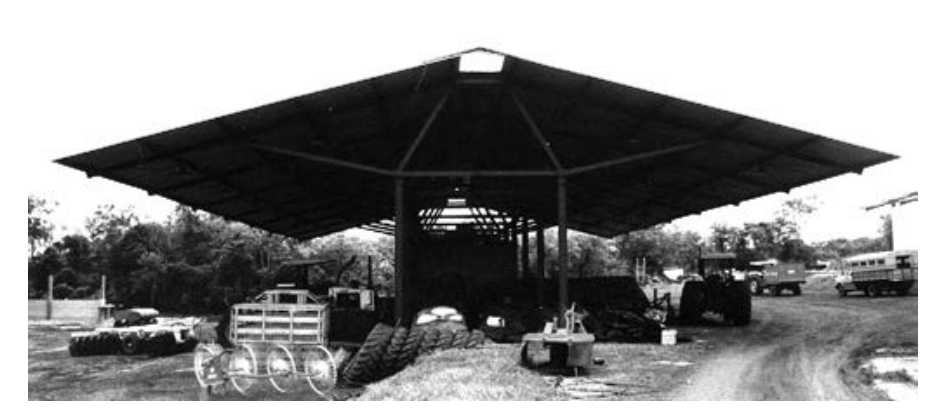

Localização

Uberaba, Minas Gerais

Estágio

Projeto Executivo

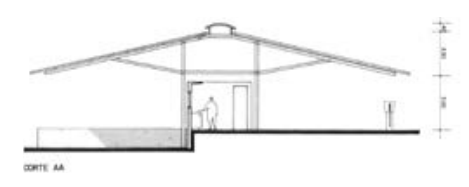

Observações

Construído

\section{Características}

A partir das mesmas soluções apresentadas para os

edifícios técnicos, os espaços destinados à garagem

e ao lavador de café criam áreas sombreadas com

a adoção de estruturas metálicas desenhadas para

garantir grandes balanços. Especial atenção à

implantação destes espaços na topografia, permitindo

a criação de um terreiro de grandes dimensões

desniveis necessários às docas.

Acervo

Tubo 54, 54 A e 54 B, Caixa 4500, 4510 e 4520
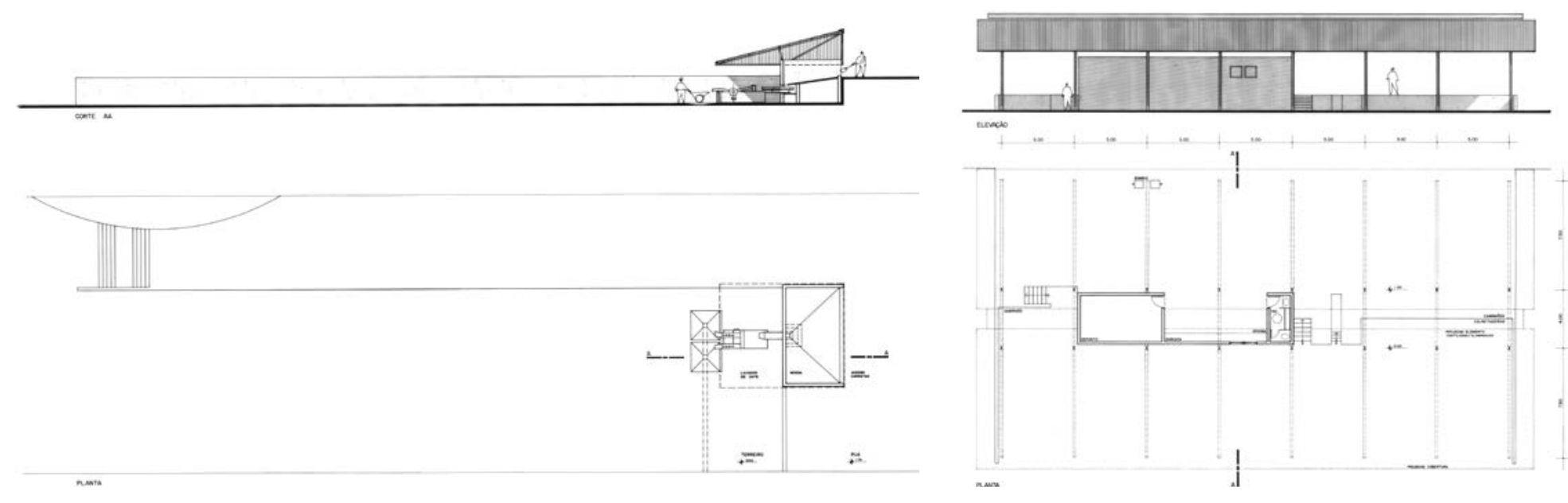
Uso

Fazenda

Cliente

Isio Bakaleinik

Equipe

Eduardo de Almeida

colaboradores I Camila Toledo, Fernando de Mello

Franco e Vinicius Gorgati

estrutura I Concen Construcōoes Metálicas

equipamentos I Pinhalense S.A. e Kepler Weber

Localização

Uberaba, Minas Gerais

Estágio

Projeto Executivo

Observações

Construído

Características

Até mesmo o reservatório de água de todo o conjunto

foi projetado o construído de acordo com o partido

estrutural do conjunto de edifícios técnicos. Uma

estrutura metálica com quatro pilares metálicos

implanta-se sobre um reservatório enterrado de

concreto armado. Estruturas de contravento e tirantes de

fixação junto à base garantem a estabilidade necessária

aos fortes esforcos de vento presentes na região. Apesar

da simplicidade construtiva e da implantação em área

rural no interior do estado, este desenho de caráter

industrial pode ter relação com a arquitetura inglesa

deste período, sobretudo pelas obras de Richard Rogers

ou Norman Foster.

Acervo

Tubo 54, 54 A e 54 B, Caixa 4500, 4510 e 4520
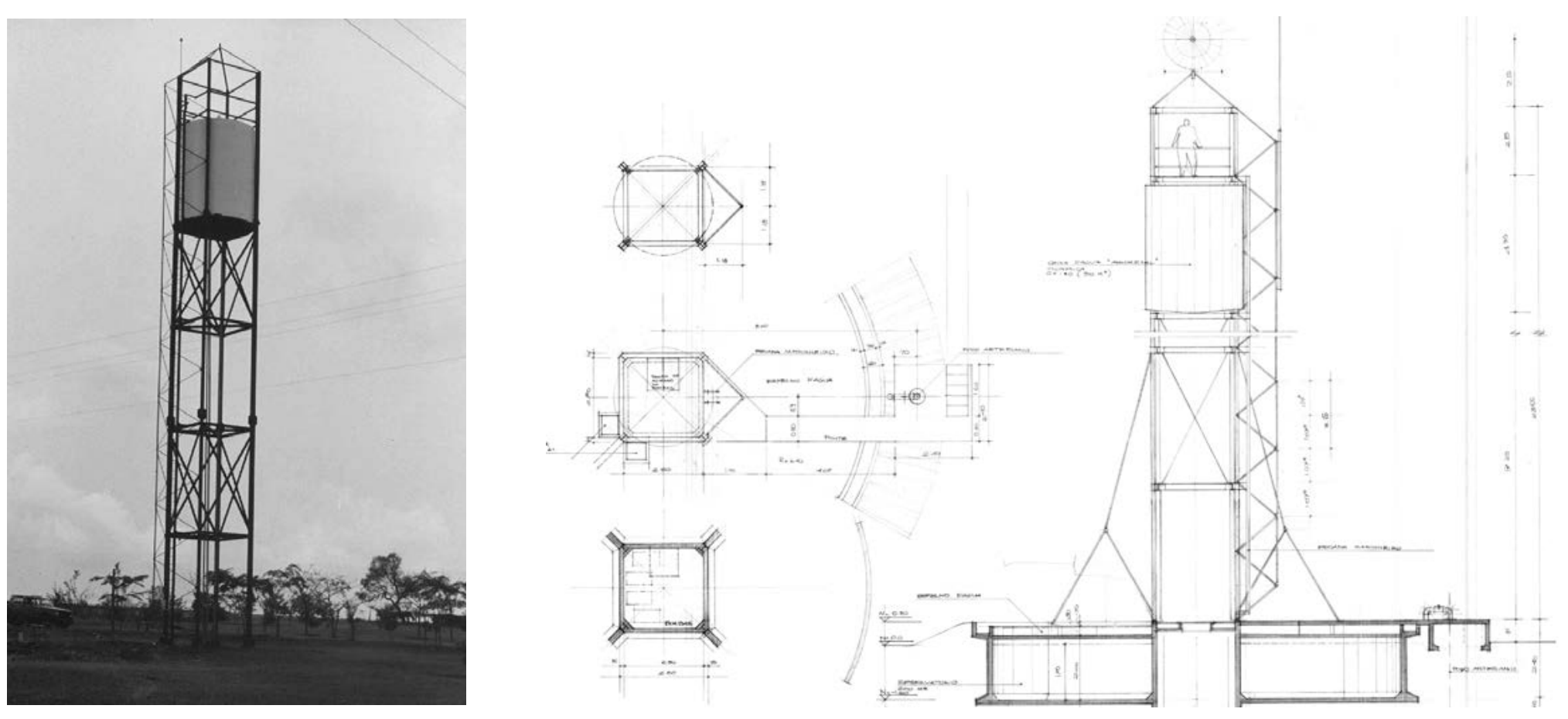
Uso

Fazenda

Cliente

Isio Bakaleinik

Equipe

Eduardo de Almeida

colaboradores I Camila Toledo, Fernando de Mello

Franco e Vinicius Gorgati

estrutura I Concen Construções Metálicas

equipamentos I Pinhalense S.A. e Kepler Weber

Localização

Uberaba, Minas Gerais

Estágio

Projeto Executivo

Observações

Construído

Características

Seguindo o mesmo partido estrutural dos demais edifícios

técnicos, o edifício desenhado para a tulha foi pensado

de acordo com a lógica produtiva e a disposição de seus

equipamentos, inclusive considerando os desniveis no

piso necessários ao funcionamento das máquinas.

Acervo

Tubo 54, 54 A e 54 B, Caixa 4500, 4510 e 4520
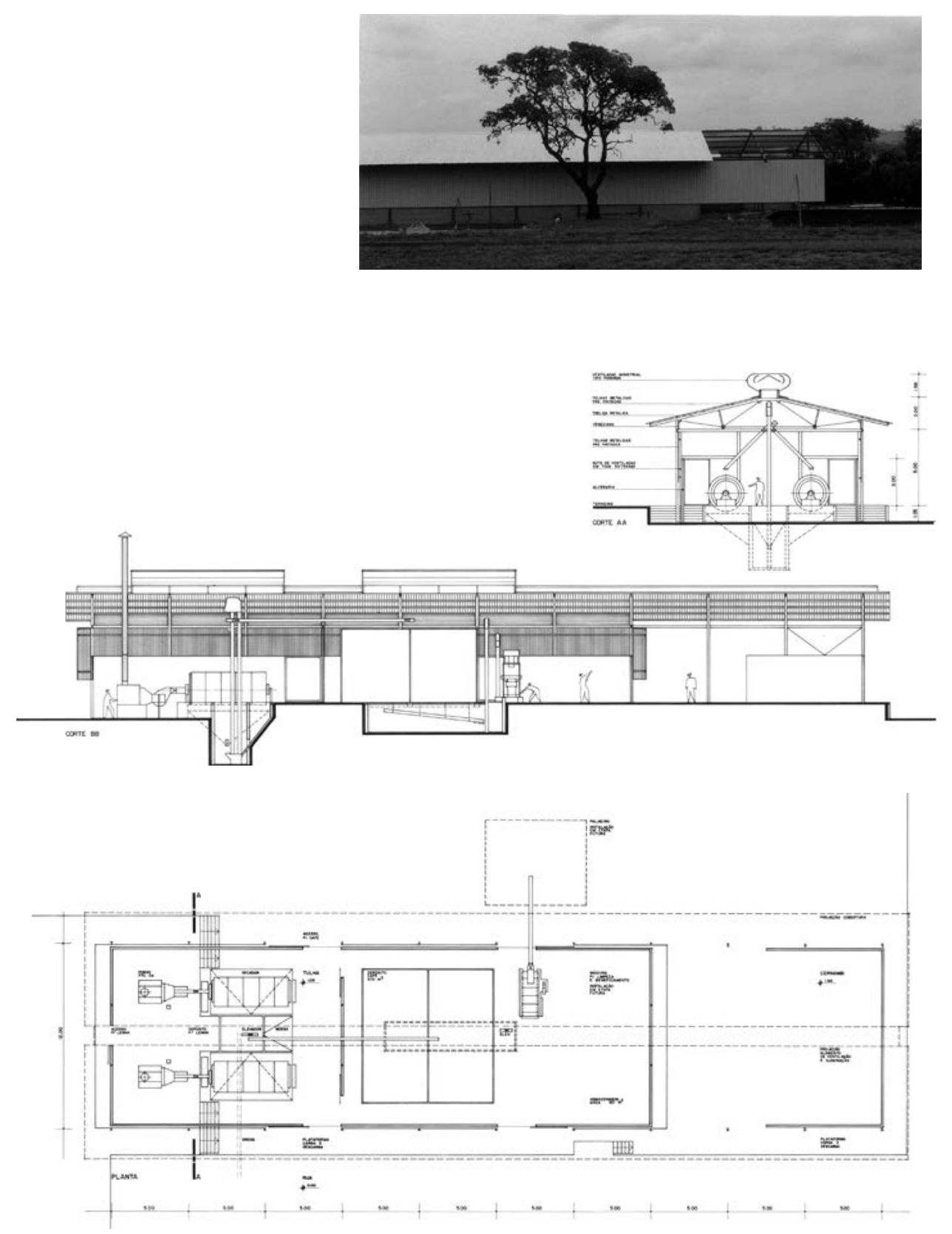
Uso

Casa Sede

Cliente

Isio Bakaleinik

Equipe

Eduardo de Almeida

colaboradores I Adriana Shima Iwamizu, Camila Toledo, Cynthia Callia, Flávia Pagotti Silva e Maria Isabe Imbronito

paisagismo I Fernando Chacel e Sidney Linhares

Localização

Uberaba, Minas Gerais

Estágio

Projeto Executivo

Observações

Construído

Características

Último projeto realizado deste conjunto, a casa sede da Fazenda Água Comprida repete a solução de agrupamento de volumes das demais moradias de agrupamento de volumes das demais moradias realizadas anteriormente, também com alvenaria de tijolos associadas a coberturas de uma água com
estrutura de madeira e telhado cerâmico. Neste caso específico, a disposição dos ambientes ao redor de projetos, como a Casa na Praia da Baleia realizada em 1982. Implantado em um vasto território, o projeto busca enfrentar a relação do edifício com a paisagem, tanto na definição do pequeno pátio interno com árvores e espelho d'água, quanto no emprego de muros de grandes dimensões junto à piscina ou espaços de apoio e serviços.

Acervo

Tubo 54, 54 A e 54 B, Caixa 4500, 4510 e 4520
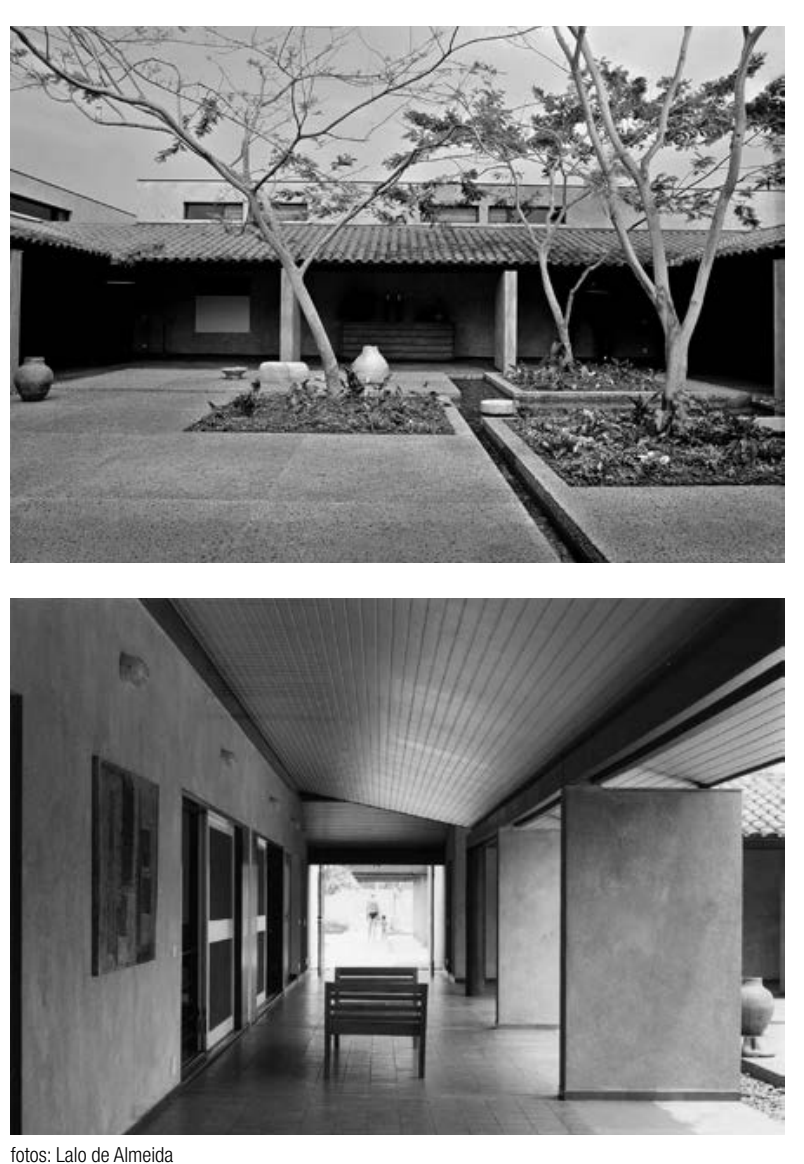

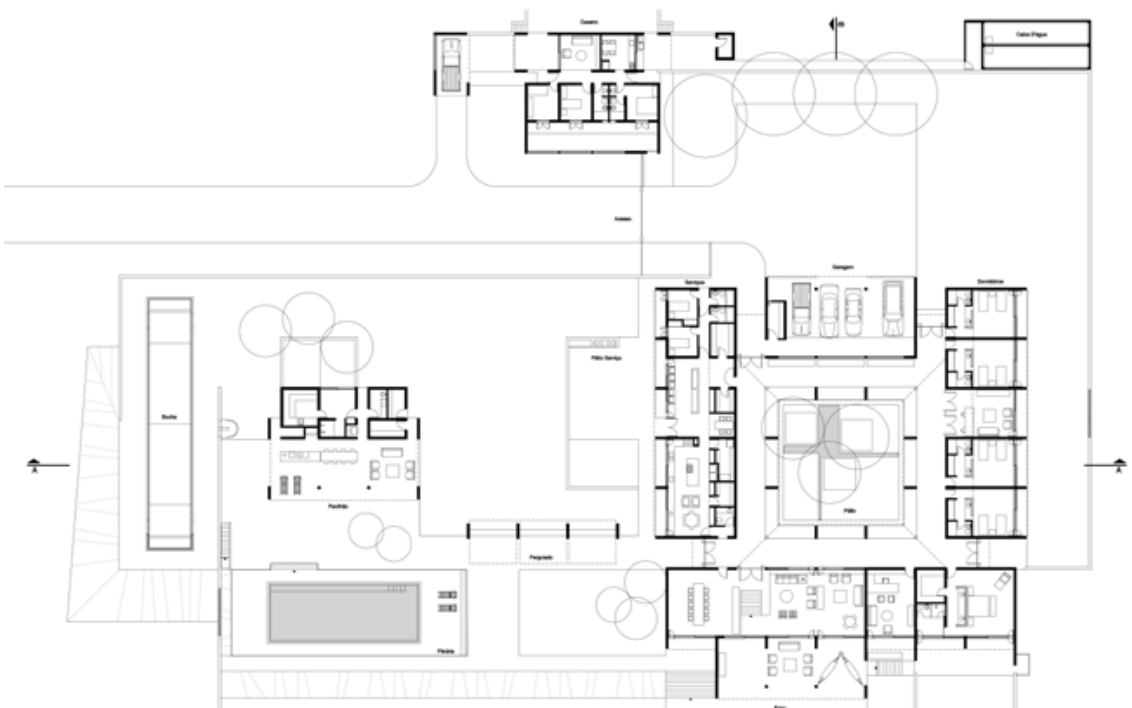

$\operatorname{sog}(1$
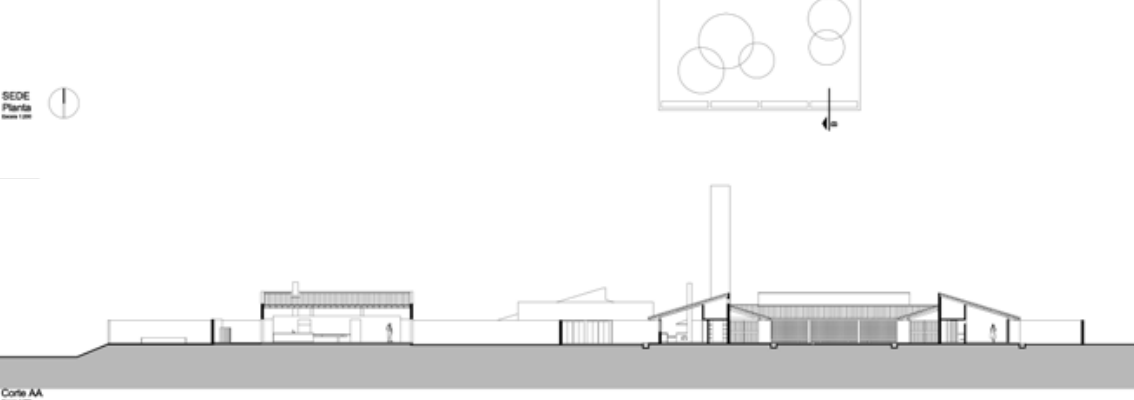
Uso

Residência Unifamiliar

Cliente

Guimarães

Equipe

Eduardo de Almeida

Localização

Rua Elisa Pereira de Barros, Pinheiros, São Paulo, SP

Estágio

Estudo Preliminar

Observações

Construído

\section{Características}

Organizado pela justaposição de três volumes com coberturas inclinadas, os programas desta casa voltamse ao pátio interior ajardinado criado entre os primeiros volumes e ao vazio de pé-direito duplo, iluminado zenitalmente e localizado entre os outros dois últimos. Como é de costume na obra de Eduardo de Almeida, a articulação entre os volumes dá-se por meio de lajes de concreto impermeabilizada.

\section{Acervo}

Tubo 27
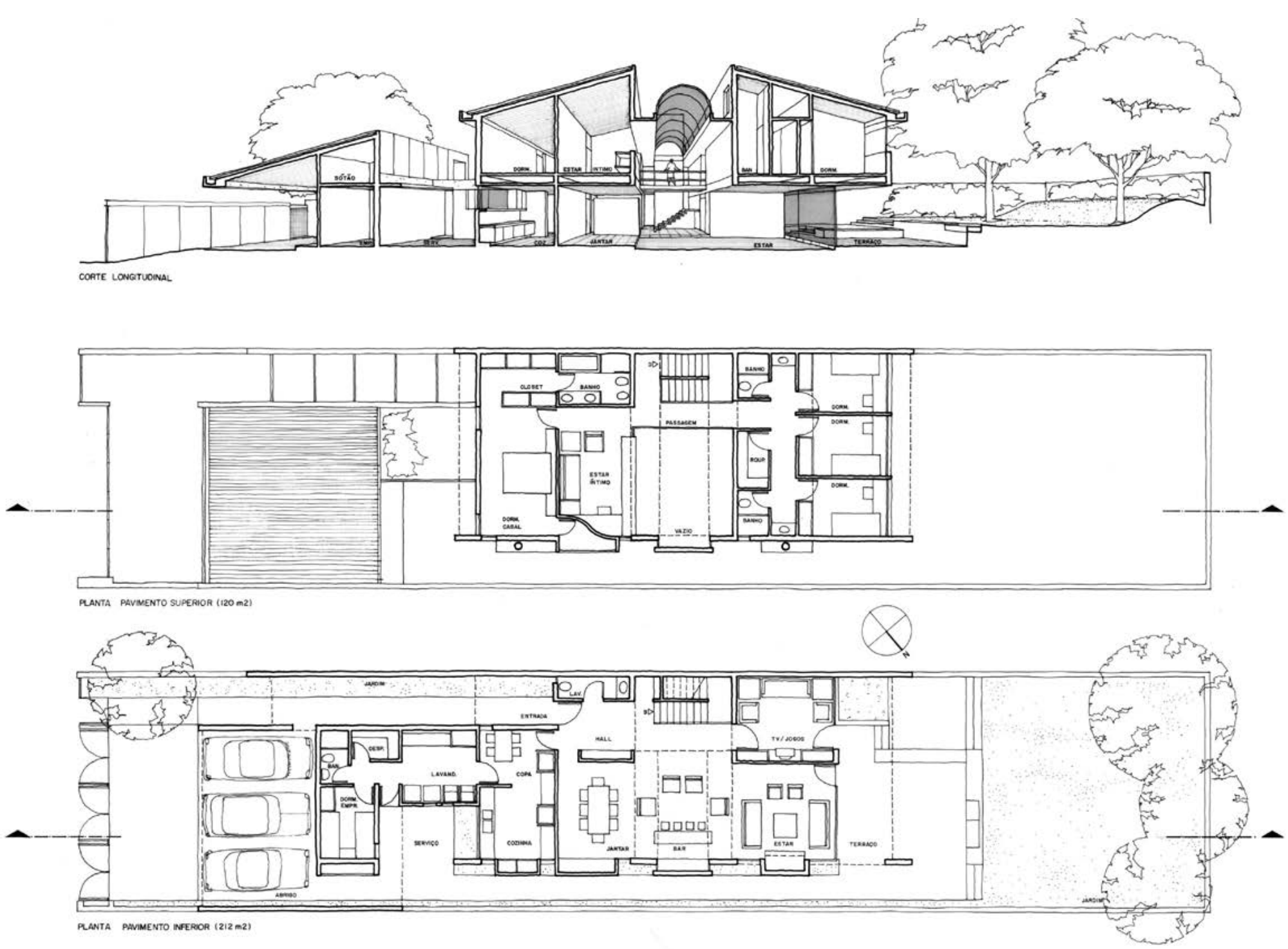
Uso

Residência Unifamiliar

Cliente

Marchetto

Equip

Eduardo de Almeida

Localização

Planalto Paulista, São Paulo, SP

Estágio

Estudo Preliminar

Observações

Não Construído

\section{Características}

De acordo com a topografia do lote, a implantação desta casa dá-se em três patamares distribuídos ao longo do declive. Enquanto o primeiro platô abriga a garagem $e$ os dormitórios de serviços, o segundo foi destinado às salas, cozinhe érea de servicos, permitindo que o plató 0 platô oltado à área de lazer junto ao jardim. Neste arranjo, os dormitórios localizam-se sobre os espaços de estar, acessados por uma pequena passarela no mesmo nível da garagem e da rua.

Acervo

Tubo 69

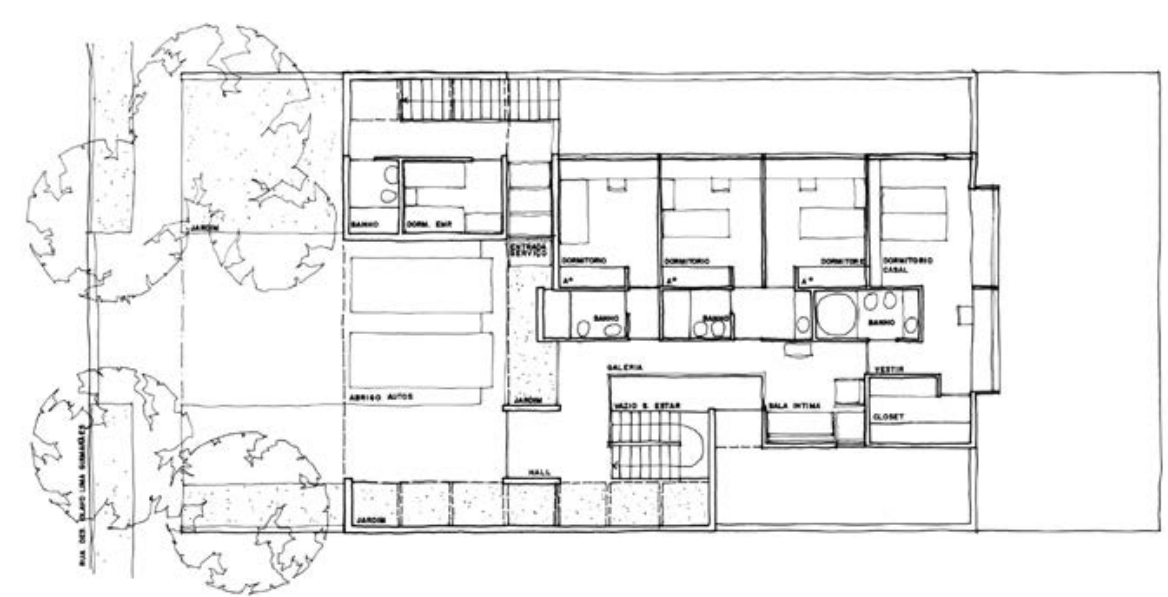

PLANTA PAVMENTO TERPEO
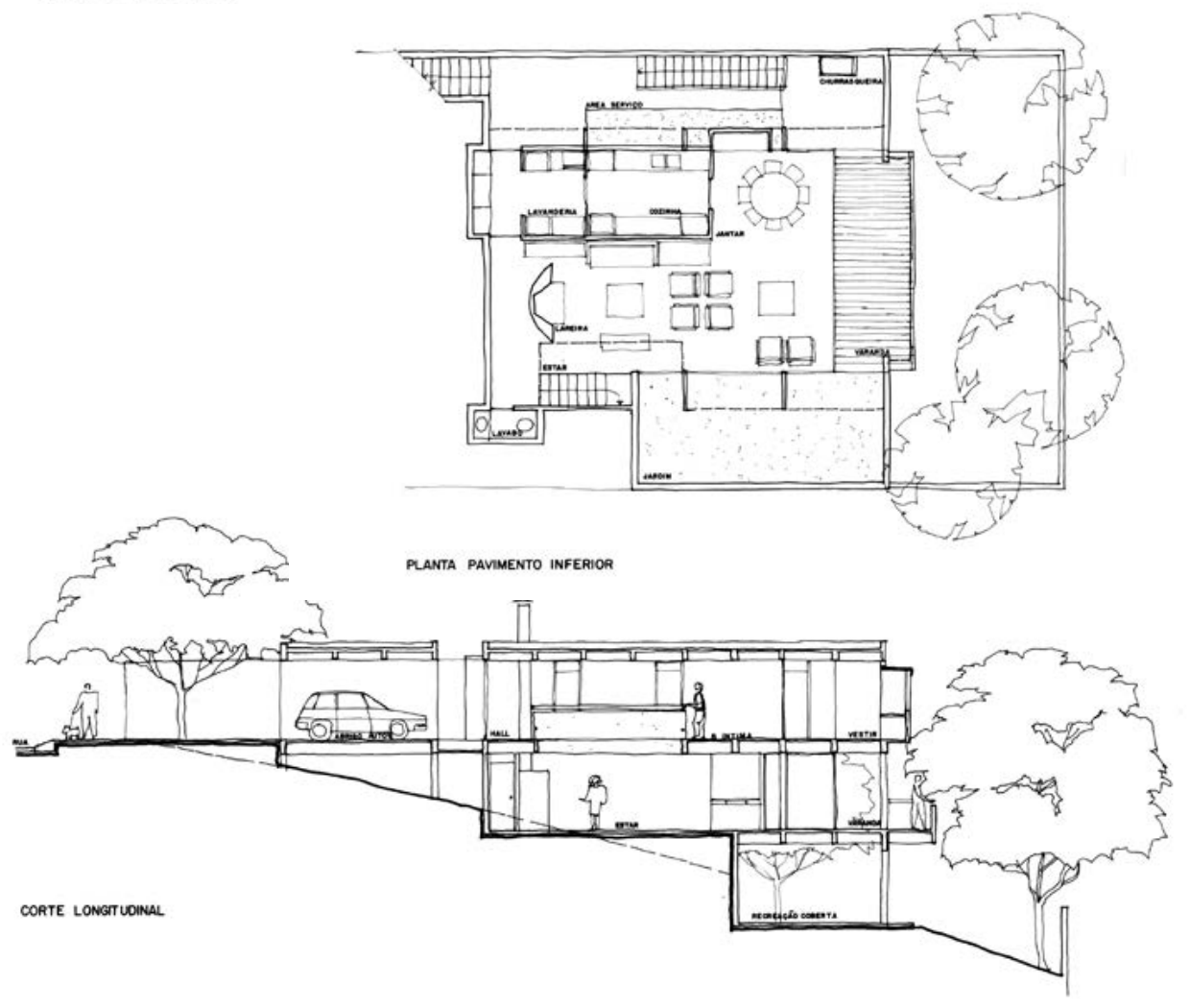
Uso

Estação

Cliente

Companhia do Metropolitano de São Paulo

Equipe

Eduardo de Almeida

colaboradores I Marcos Mendes, Marta Moreira e Milton

Braga

\section{Localização}

Vila Prudente, São Paulo, SP

\section{Estágio}

Projeto Executivo

\section{Observações}

Não Construído

\section{Características}

0 projeto para a estação Ibitirama foi realizado de

acordo com a solução prevista pela nova linha elevada

sobre a avenida. A cota de implantação da plataforma

permitiu a criação de um mezanino inferior acessado

por passarelas capazes de interligar as duas margens

da avenida, configurando uma travessia intermediária

que não só acessa 0 metrô, mas também o terminal

de ônibus posicionado na cota da avenida. No nível

do mezanino, a circulação central que leva ao terminal

desdobra-se em quatro escadas rolantes que dão acesso

às plataform

cerrados que destacam a volumetria das escadas em

balanço ao longo das duas fachadas. A estrutura de

concreto armado que define a estação encerra-se nas

vigas de cobertura localizadas sobre a plataforma,

estrutura que recebe arcos metálicos a cada módulo,

aludindo às coberturas das antigas estações de trem.

Acervo

Caixa 4300

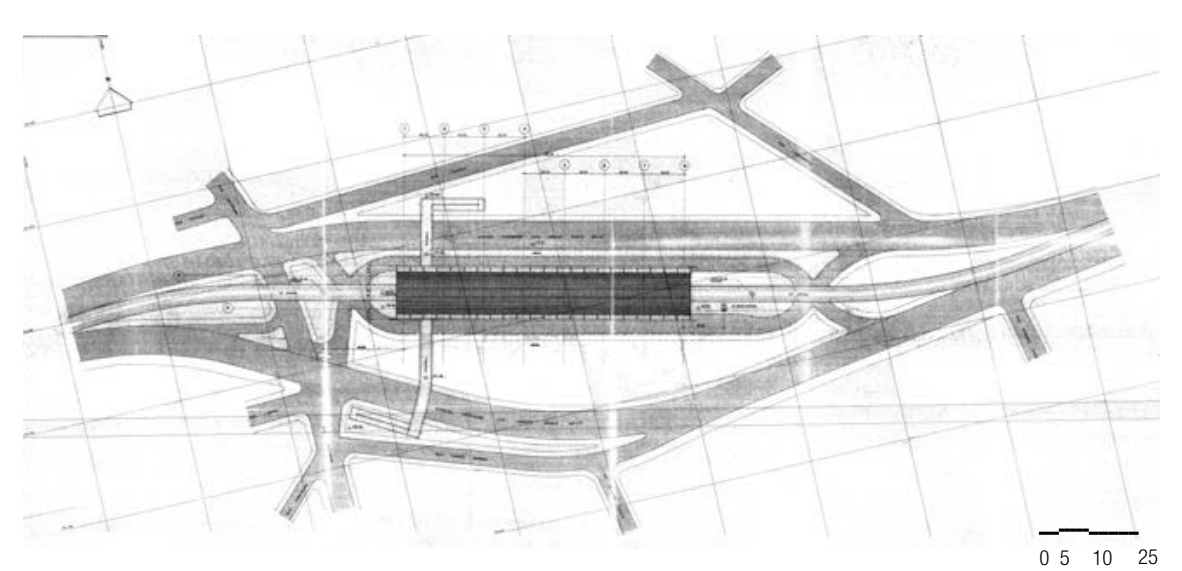

$05 \quad 10 \quad 25$

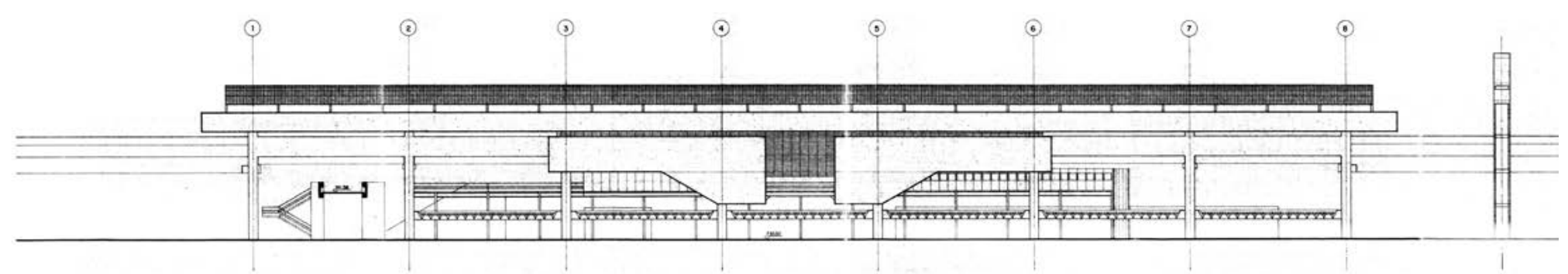

axะ

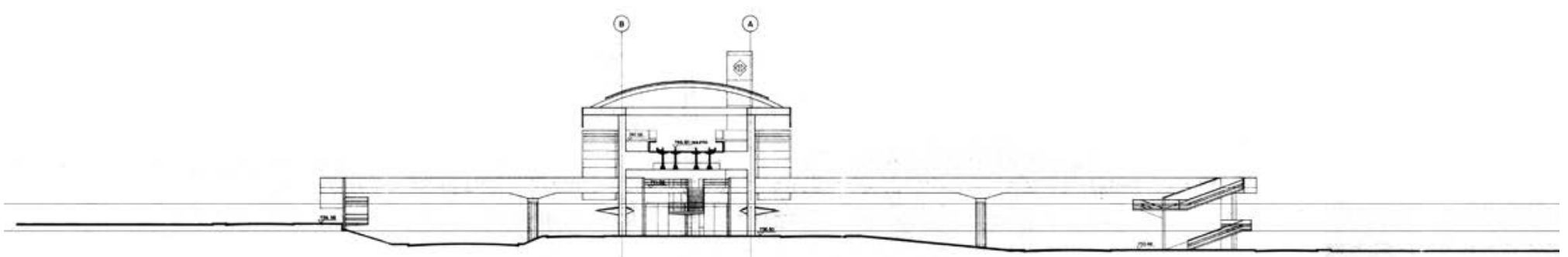

mans: 
Uso

Edifício de Habitação Coletiva

Cliente

Rubens Vidigal

Equipe

Eduardo de Almeida

Localização

Rua Castelhanos, Vargem Grande Paulista, SP

Estágio

Estudo Preliminar

Observações

\section{Características}

Este edifício é organizado por um embasamento -

destinado a estacionamentos e programas de uso coletivo - e por um corpo vertical de dez pavimentos. A planta tipo organiza-se pela torre de circulação vertical central que, simetricamente, desenha as duas unidades a partir de seus acessos pela cozinha ou pela sala $A$ panta de proporsa planta de proporyo a pada de cada aparamento dividida ao meio entro os espaços de uso coletivo e área para dormitórios e sanitários, permitindo iluminação e ventilação pelas três fachadas. A volumetria do edifício destaca-se pelas aberturas verticais dos quartos associadas aos pilares, pelas varandas das salas em balanço e pelo volume destacado da escada.

Acervo

Tubo 76
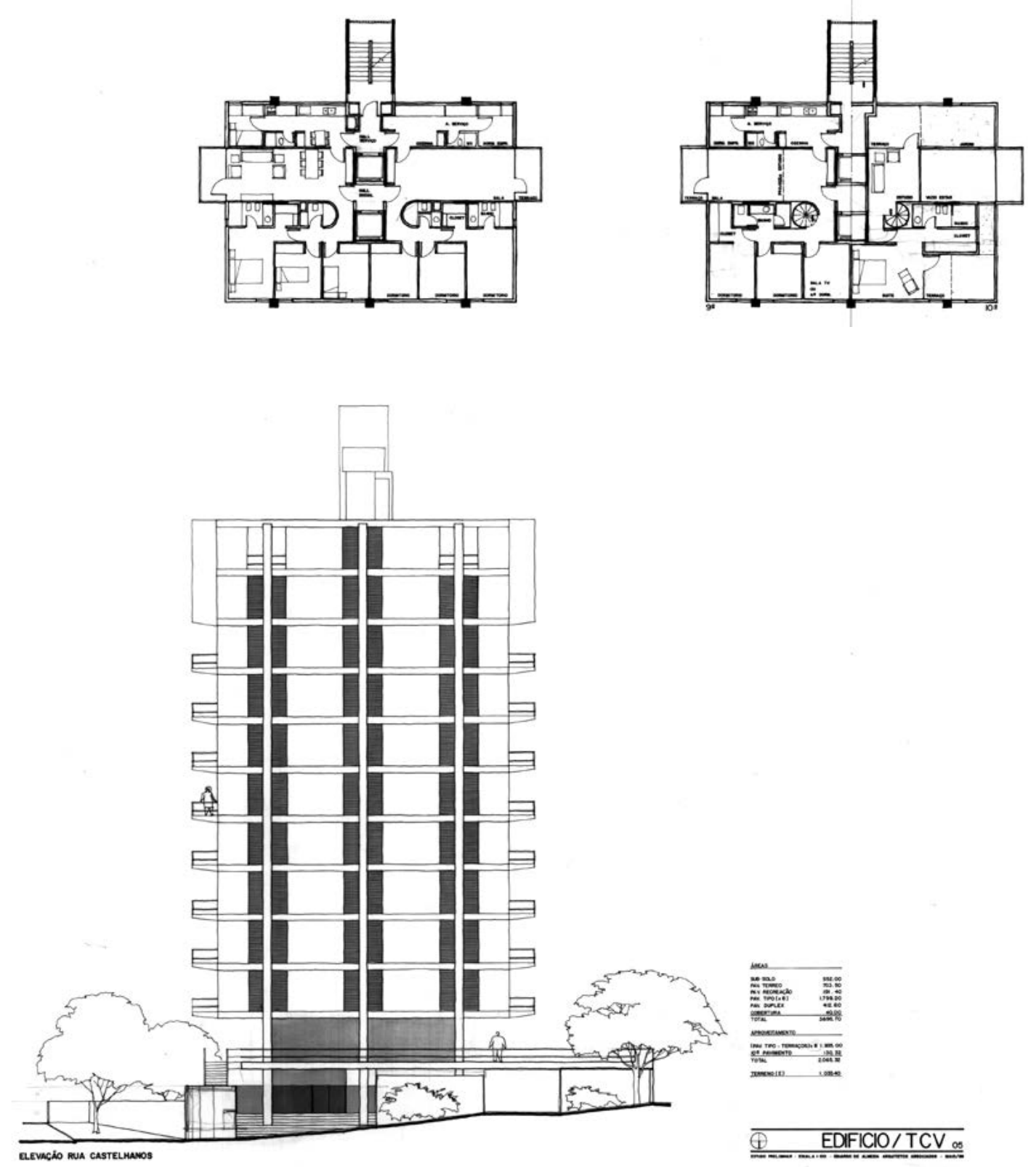
Uso

Residência Unifamiliar

Cliente

Cândido Bracher

Equipe

Eduardo de Almeida

colaboradores | Adriana Shima Iwamizu, Camila Toledo e

José Antônio Seixas

estrutura I Concen - Wilson Ramos da Silva Filho

paisagismo I CAP - Fernando Chacel e Sidney Linhares

Localização

Rua Piacá, Alto de Pinheiros, São Paulo, SP

Estágio

Projeto Executivo

Observações

Construído

Características

Organizada em dois pavimentos, esta residência

caracteriza-se pela associação de uma estrutura

metálica, capaz de criar grandes balanços, com a

cobertura de duas águas de telhas cerâmicas, solução

que une elementos tradicionais com novos sistemas

capazes de otimizar aspectos construtivos como rapidez,

impeza na obra e economia de materiais. Assim como

em outros projetos, o espaço vazio de pé-direito duplo

cria a articulação entre os dois pavimentos através do

percurso estabelecido pela escada e pela passarela que

interligam as duas alas de dormitórios. Este é 0 último

projeto realizado com canetas à nanquim no pape

vegetal, antes do uso do computador, apresentando

um conjunto de desenhos excepcionais, tanto pela

sua capacidade de síntese, quanto pelo detalhamento

preciso de cada uma das partes que compõe a

construção.

Acervo

Tubo 12 e 12A e Caixa 400, 500 e 600
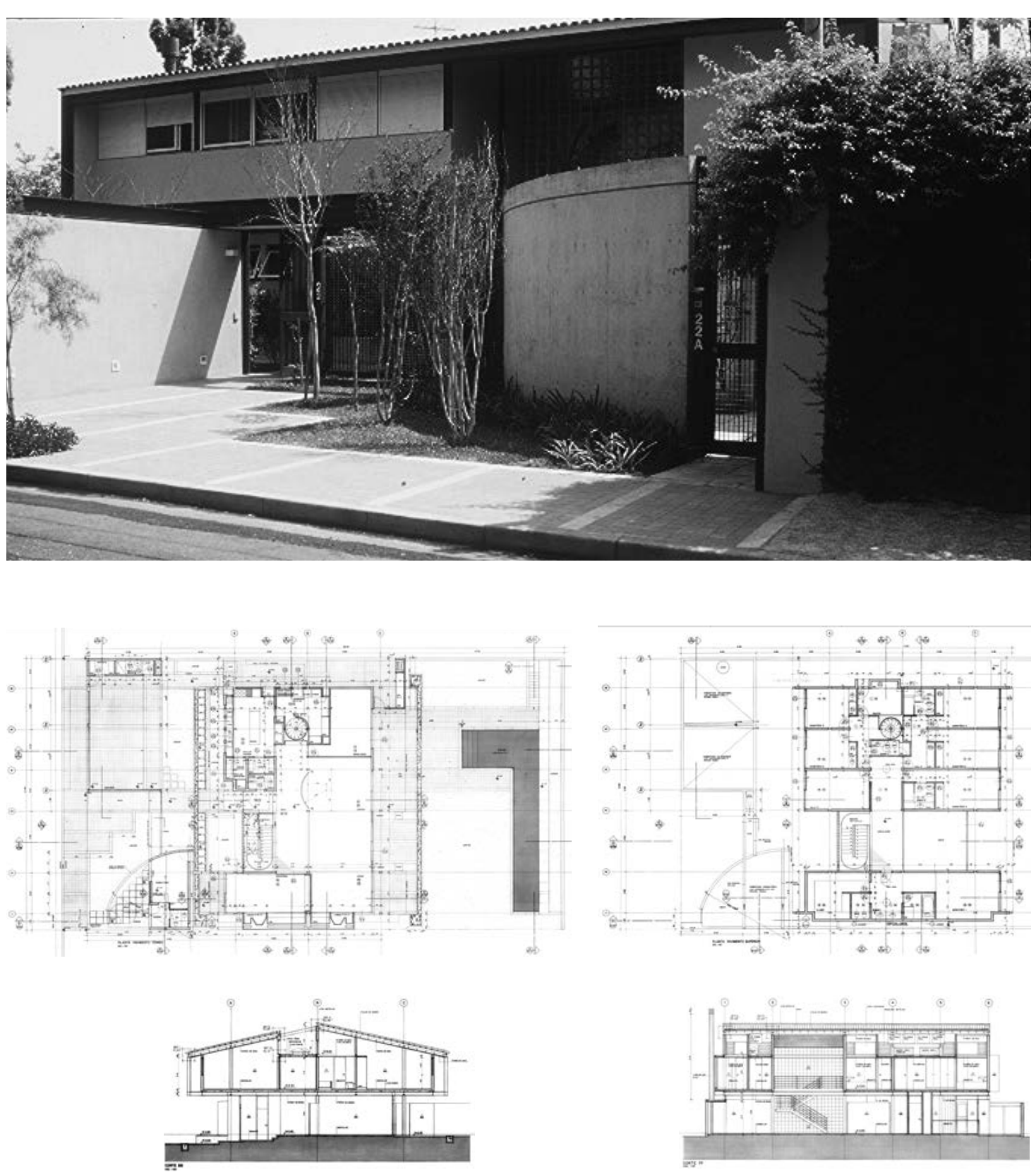
Uso

Pavilhão esportivo

Cliente

Cândido Bracher

Equipe

Eduardo de Almeida

Localização

Rua Piacá com a Rua Massacá, São Paulo,SP

Estágio

Executivo

Observações

Construído

\section{Características}

A partir do projeto do arquiteto Silvio Sawaya para um ateliê localizado ao lado da residência principal, Eduardo de Almeida cria uma reforma do pavilhão a partir da inserção de uma nova treliça metálica capaz de eliminar 0 pilares centrais existentes. Além disso

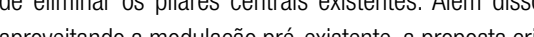
aprovellan do a modusçá pré existenta, a proposta cria novos fechamentos em tijolos de vidro e painéis de vidro temperado retráteis.

Acervo

Tubo 12 e 12 A, Caixa 400, 500 e 600, Backup 324

e 326
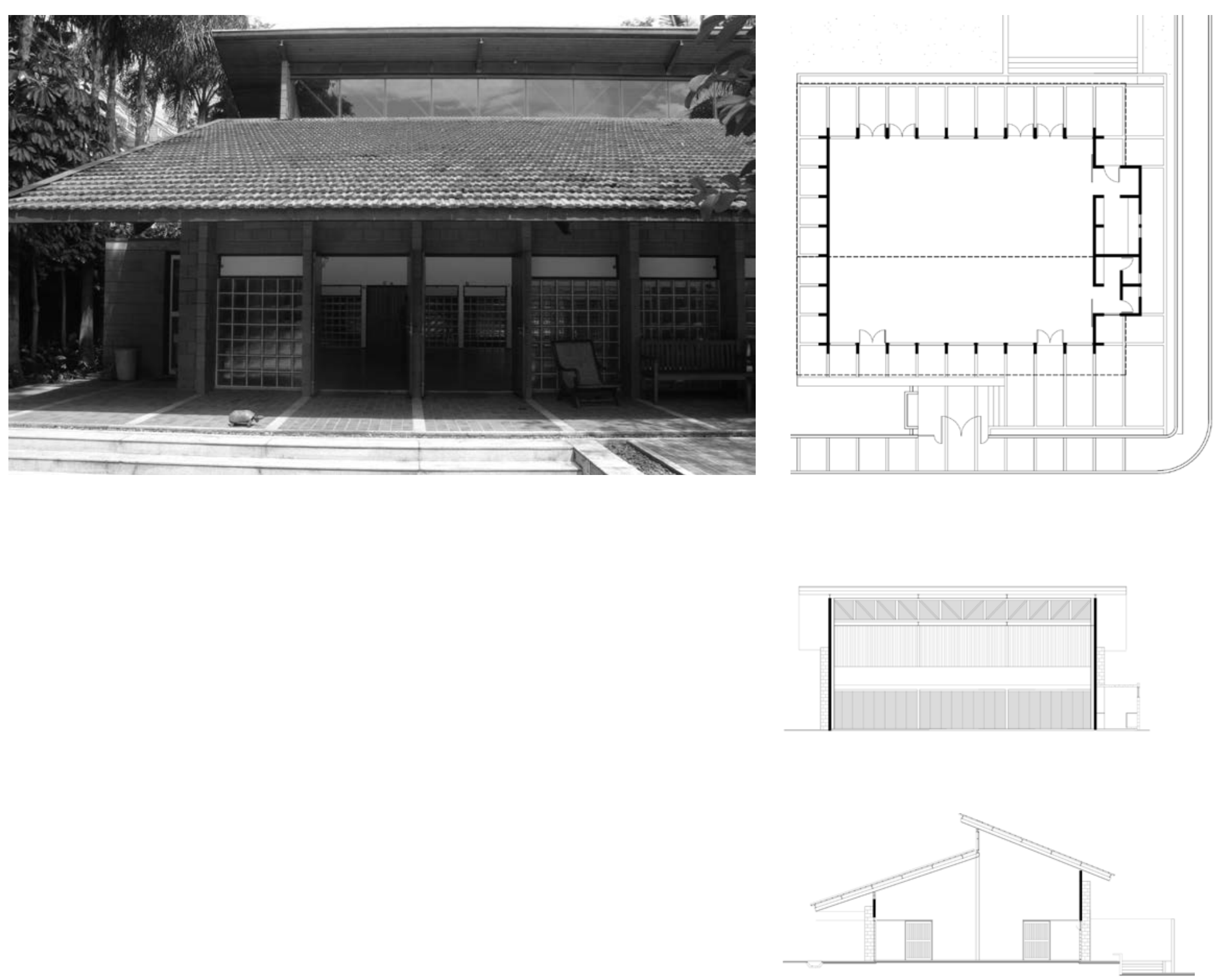

O $\overline{0} \overline{2,5}$ 
Uso

Residência Unifamiliar

Cliente

Cândido Bracher

Equipe

Eduardo de Almeida

colaboradores I Adriana Shima Iwamizu, Akira Tomori,

Camila Toledo e José Antônio Seixas

estrutura I Concen - Wilson Ramos da Silva Filho

paisagismo I CAP - Fernando Chacel e Sidney Linhares

Localização

Rua Piacá, Alto de Pinheiros, São Paulo, SP

Estágio

Projeto Executivo

Observações

Construído

Características

Após concluída a reforma do pavilhão, outros lotes foram incorporados e foi solicitada a ampliação da casa principal, a criação de uma nova piscina e um jardim de grandes proporçỗes que ficou sob a responsabilidade do paisagista Sidney Linhares, sócio de Fernando Chacel. Segundo Eduardo de Almeida, foram realizadas inúmeras alternativas de projeto para a ampliação da casa e, descontente com os resultados, em uma conversa com o proprietério, foi-he sugerido simplesmente dar continuidade à solução utilizada na casa original.

Facilitada pela lógica de montagem da estrutura metálica, uma nova sequência de módulos foi adicionada à construção pré-existente. Por meio de um novo espaço de pé-direito duplo, criou-se uma pausa entre os espaços antigos e os programas novos.
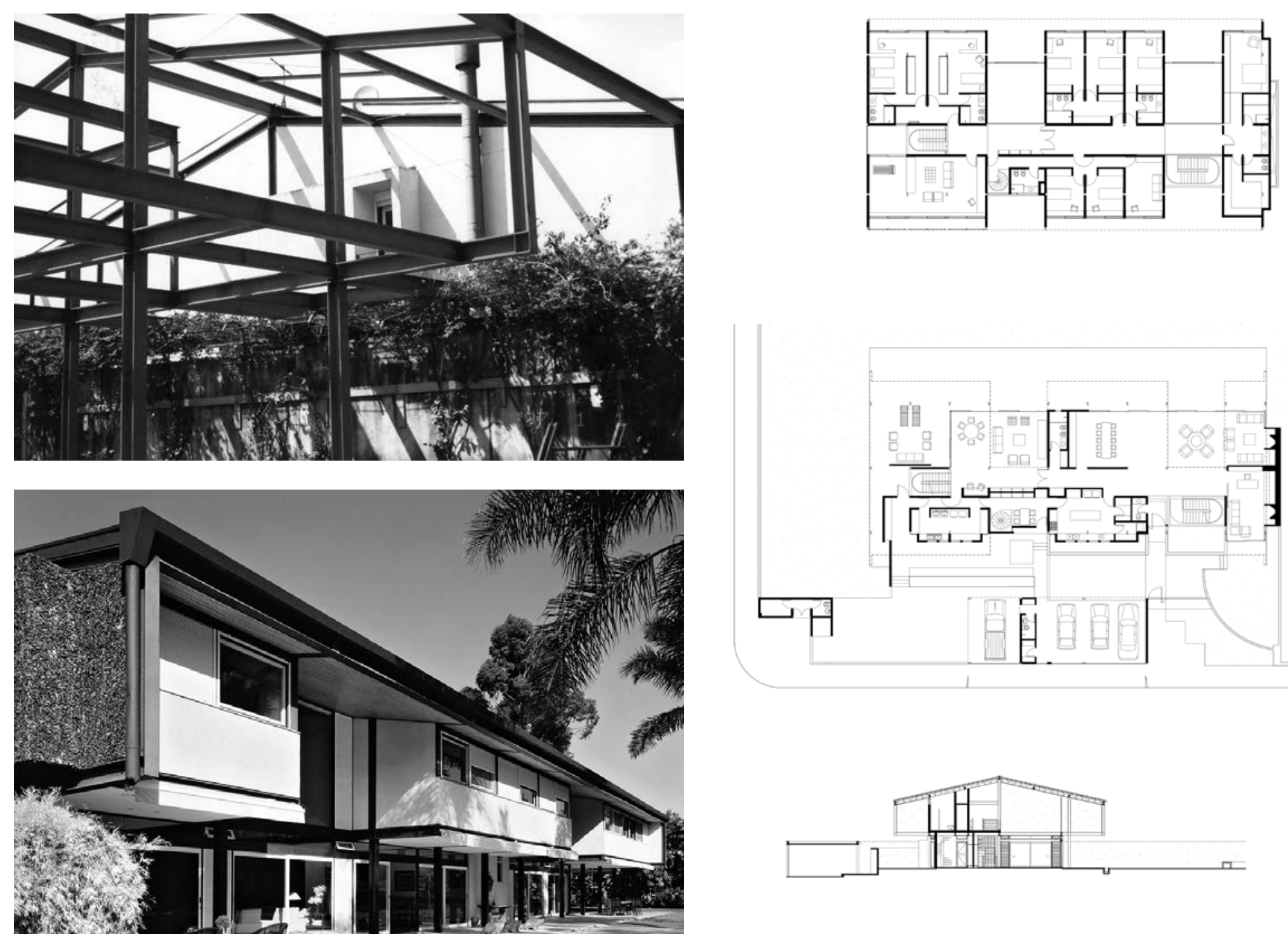

Acervo

Tubo 12 e 12A e Caixa 400, 500 e 600
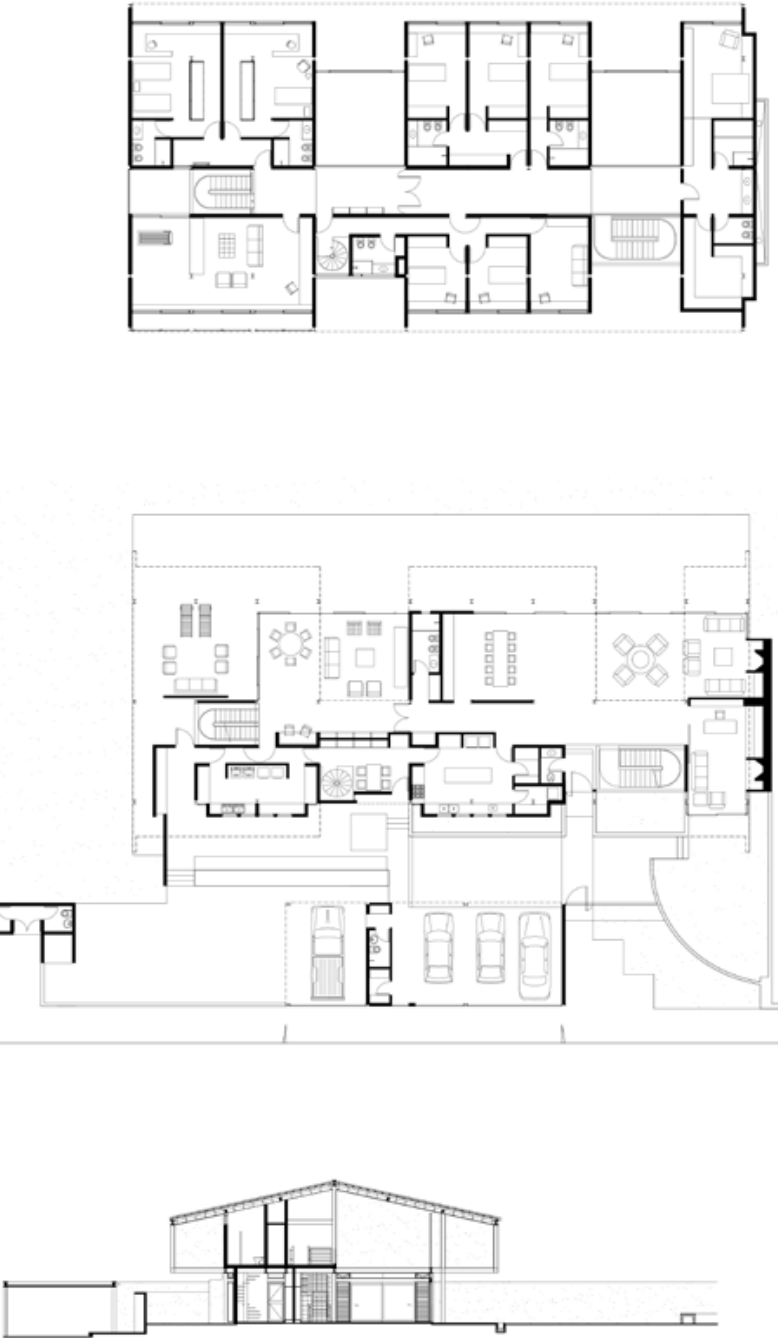
Uso

Piscina Coberta e Jardim

Cliente

Cândido Bracher

Equipe

Eduardo de Almeida

Localização

Rua Piacá com a Rua Massacá, São Paulo,SP

Estágio

Executivo

Observações

Não Construído

\section{Características}

Uma vez concluída a nova piscina, foi solicitado a Eduardo

de Almeida um complexo projeto para a cobertura deste

espaço. Possivelmente inspirada por alguns projetos

de Renzo Piano, foi proposta uma cobertura arqueada

de aço e vidro. Tal edifício ficaria inserido no projeto de

paisagismo, composto por caminhos sinuosos.

Acervo

Tubo 12 e 12 A, Caixa 400, 500 e 600, Backup 324

e 326
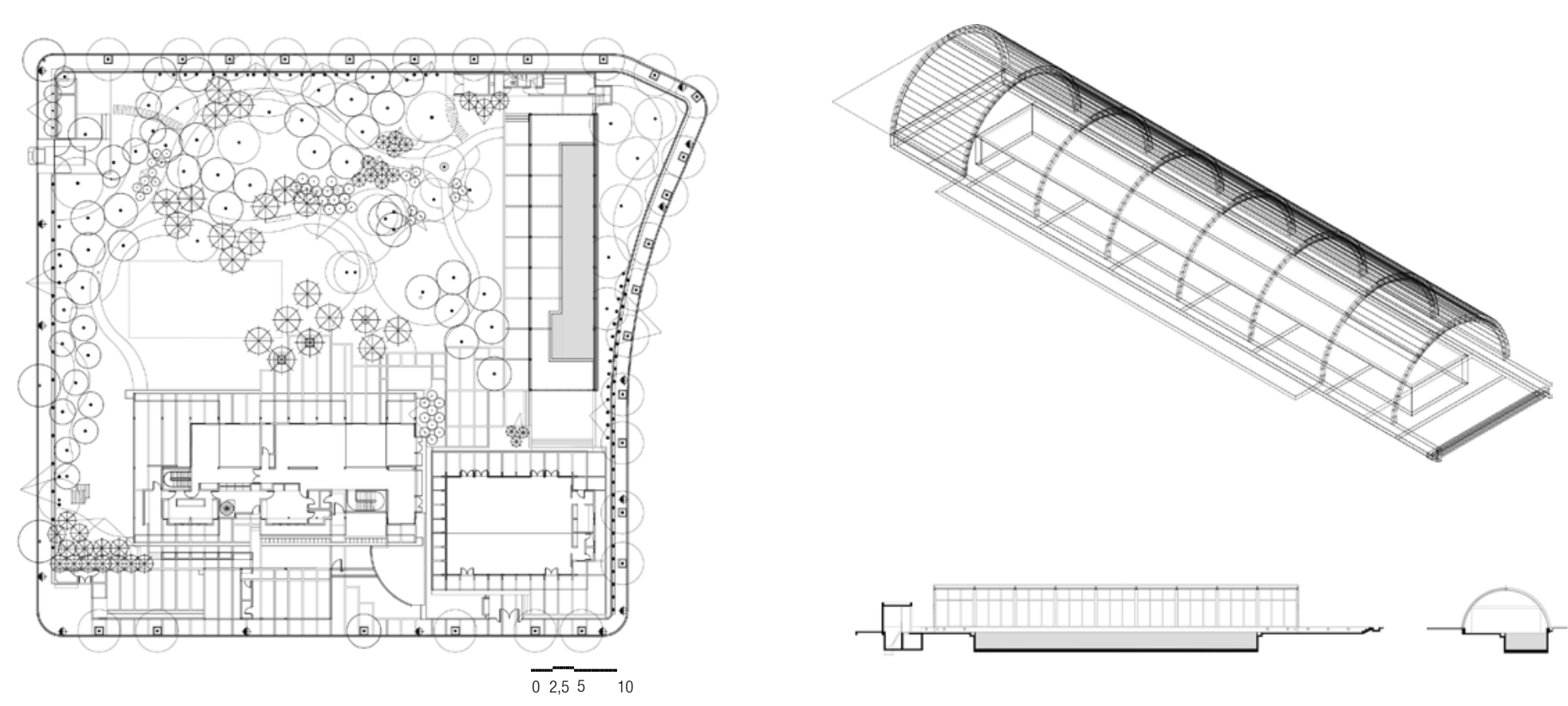
Uso

Unidade de Apartamento em Edifício de Habitação Coletiva

\section{Cliente}

Construtora Método

Equipe

Eduardo de Almeida

\section{Localização}

Campo Belo, São Paulo, SP

Estágio

Anteprojeto

Observações

Não Construído

\section{Caracteristicas}

Idealizado pelo arquiteto italiano Gaetano Pesce para a Construtora Método, este estudo faz parte da Torre Pluralista, polêmico projeto que envolvia a idéia de se criar um edifício vertical capaz de abrigar propostas de diferentes arquitetos a cada dois pavimentos, a partir da definição prévia da estrutura primária, das prumadas de circulação verticais e dos shafts de infra-estrutura de elétrica e hidráulica. A proposta de Eduardo de Almeida extremamente singela, simplesmente criava a ocupação

das duas extremidades do segundo pavimento, interligados por uma passarela metálica associada a uma escada assimetricamente posicionada em um dos vazios de pé-direito duplo. Entre outros arquitetos, participaram do projeto Paulo Mendes da Rocha, Marcos Acayaba e Eduardo Longo. Este último, segundo o depoimento de Eduardo de Almeida, ficou responsáve pelo apartamento de cobertura, talvez pela expectativa dos clientes de que ele projetaria mais uma esfera, mas a resposta foi uma casa simples com cobertura de duas águas e telhas cerâmicas.
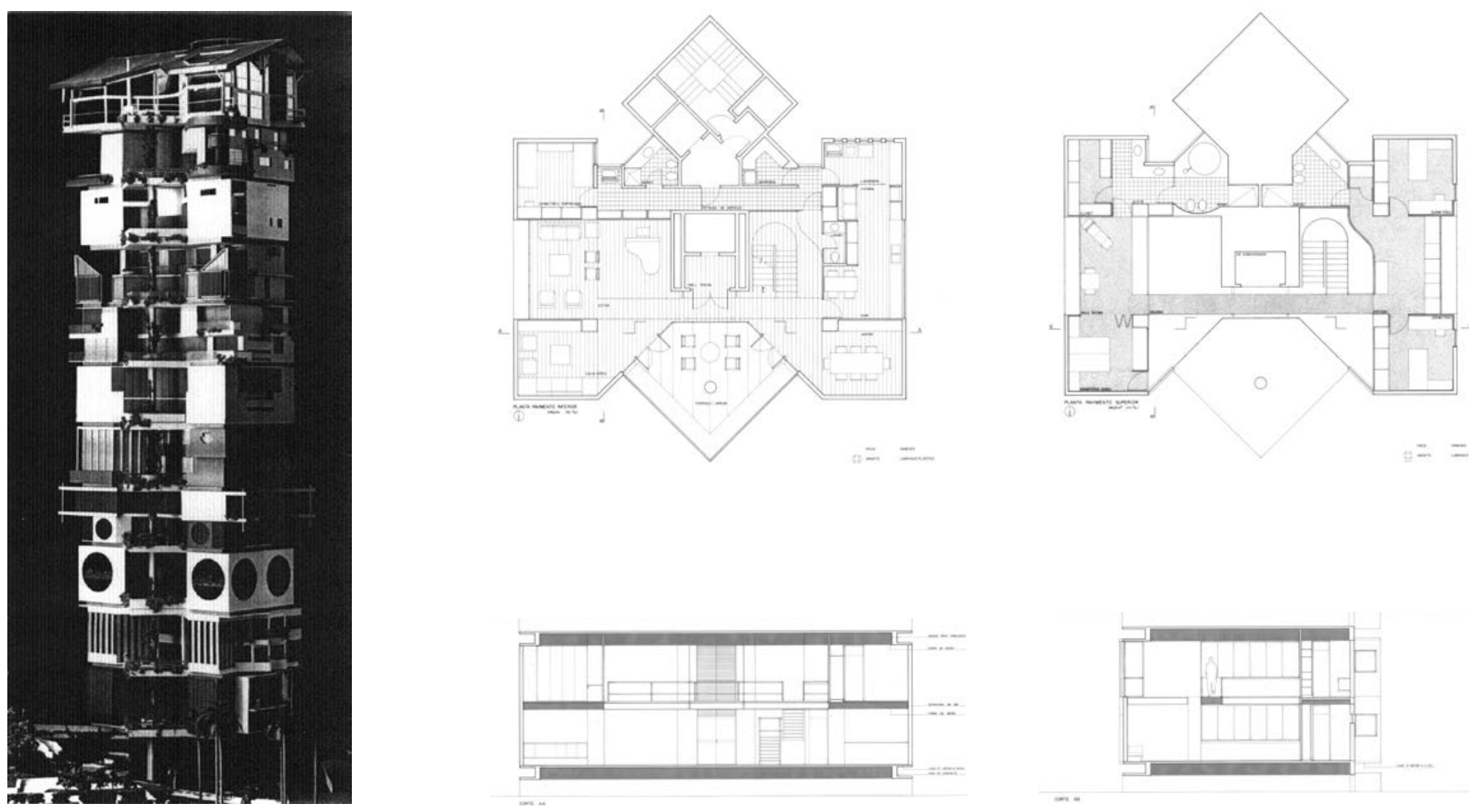

Torre Săo Paulo. Disponivel em: < hitp://cabanodatabauuera. blogspot.com.br/2012/02/teoria-na-pratica.html >. Acessado
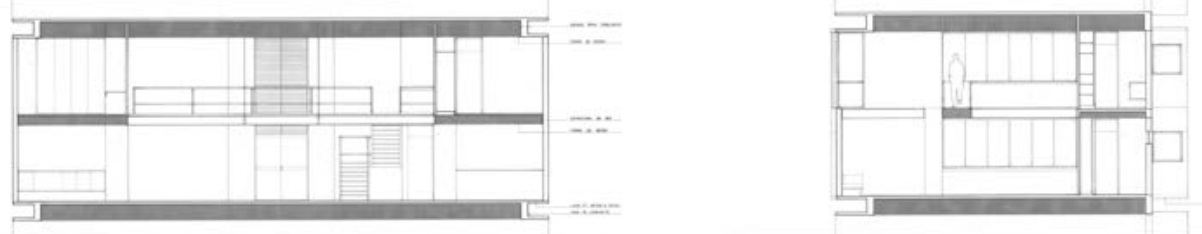
Uso

Reforma de Apartamento

Cliente

J. C. Pupin

Equipe

Eduardo de Almeida

Localização

Rua Alagoas, Consolação, São Paulo, SP

Estágio

Estudo Preliminar

Observações

Não Construído

\section{Características}

Reforma de apartamento em edifício localizado no

bairro de Higienópolis. Respeitando a estrutura original

do edifício, foi realizado um novo estudo de ocupação

do apartamento, incluindo o detalhamento de todo 0

mobiliário.

Acervo

Tubo 69
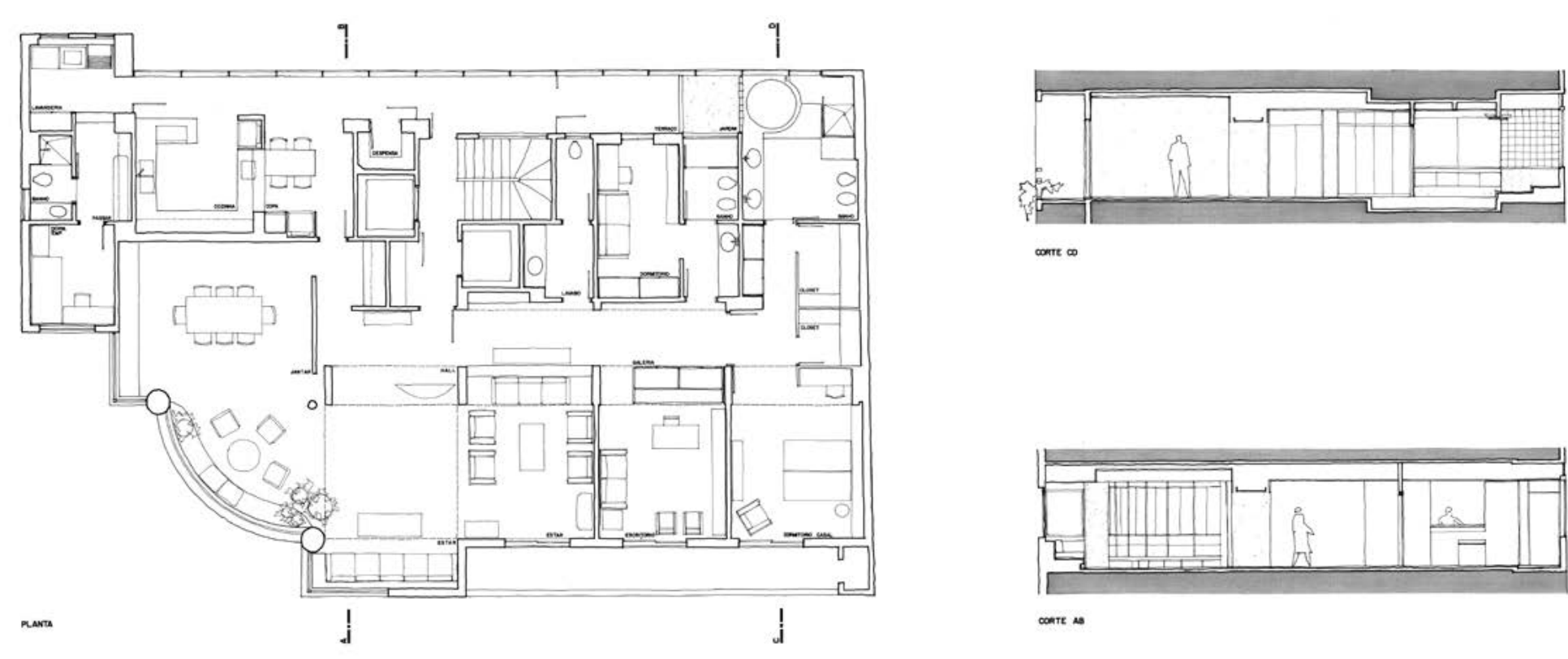

arate $\infty$

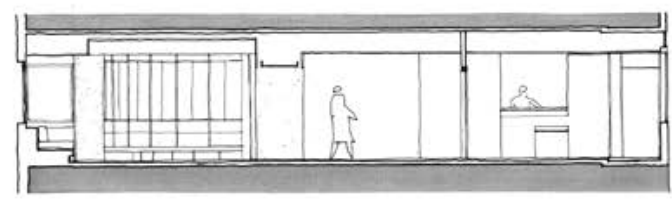

cosit so

Q APTO IC PUPN 
Uso

Residência Unifamiliar

Cliente

Silvio Eid

Equipe

Eduardo de Almeida

Localização

Sumaré, São Paulo, SP

Estágio

Estudo Preliminar

Observações

Não Construído

\section{Características}

A volumetria desta residência segue a geometria trapezoidal do lote, propondo a criação de patamares dispostos de acordo com a topografia. Organizado em meios-níveis, cada patamar abriga um programa diferente, organizando um percurso ao lado do vazio de pé-direito elevado onde foi posicionada a sala de jantar.

Acervo

Tubo 70

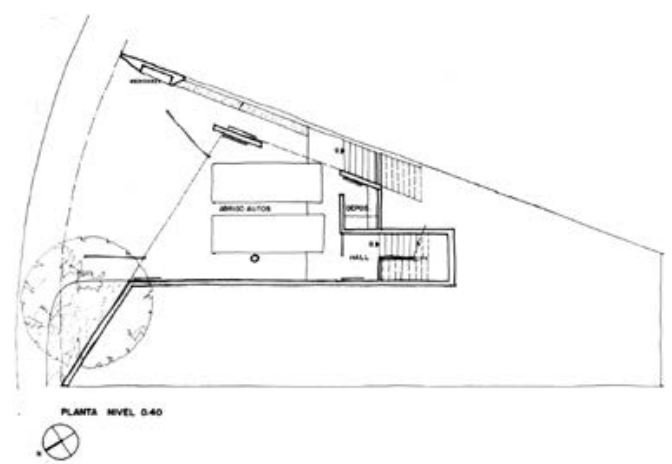

8

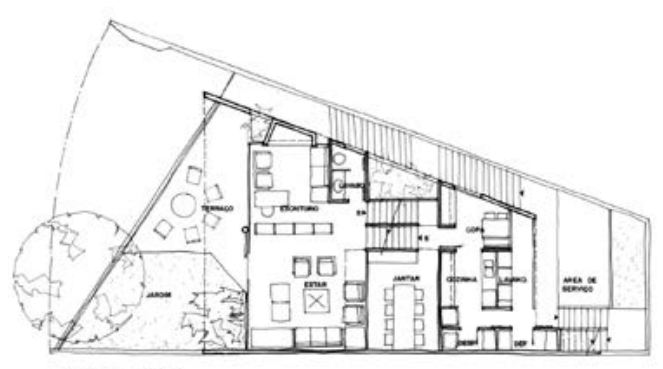

$\infty$

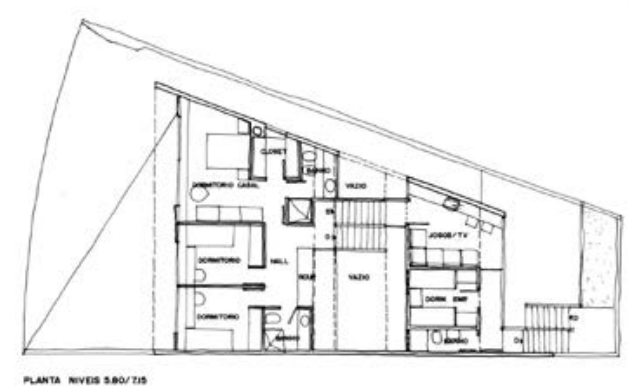

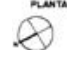

nessomina sino 80

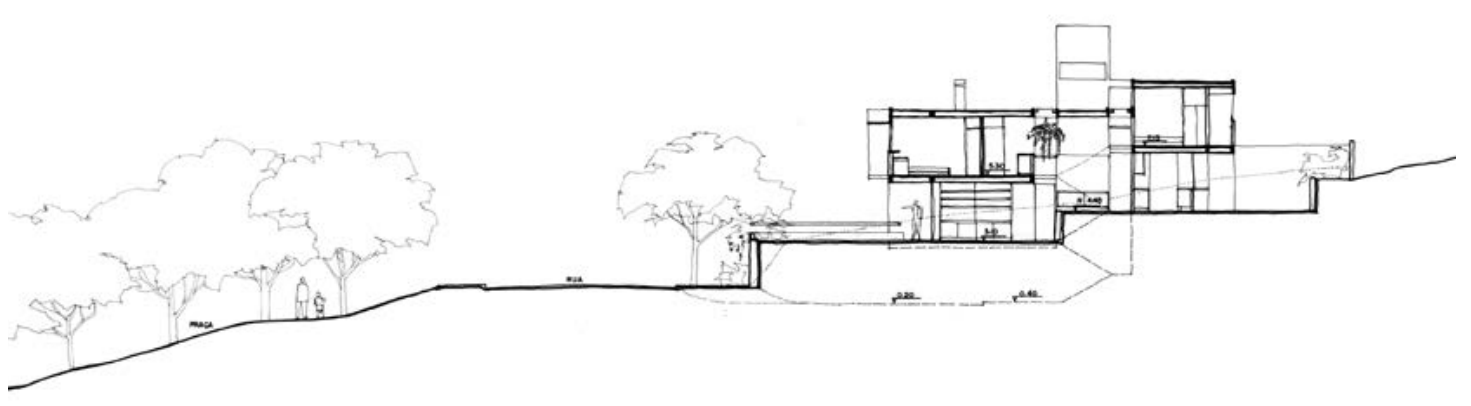


Uso

Sítio

Cliente

Marcelo Lacerda Soares

Equipe

Eduardo de Almeida

colaboradores I Fernando de Mello Franco

\section{Localização}

Valinhos, SP

Estágio

Projeto Executivo

Observações

Não Construído

Características

Considerando a topografia do lote e a presença de grandes rochas no interior do terreno, foram realizadas vias de acessos, além de quatro edificaç̃óes: casa sede,

casa para aluguel, casa para caseiro e uma cocheira.

Aproveitando a matéria-prima presente no terreno, todas

as construções foram definidas pelo emprego de muros

de pedra associados a coberturas de telhas cerâmicas e

estrutura de madeira.

Acervo

Tubo 29 e Caixa 4400
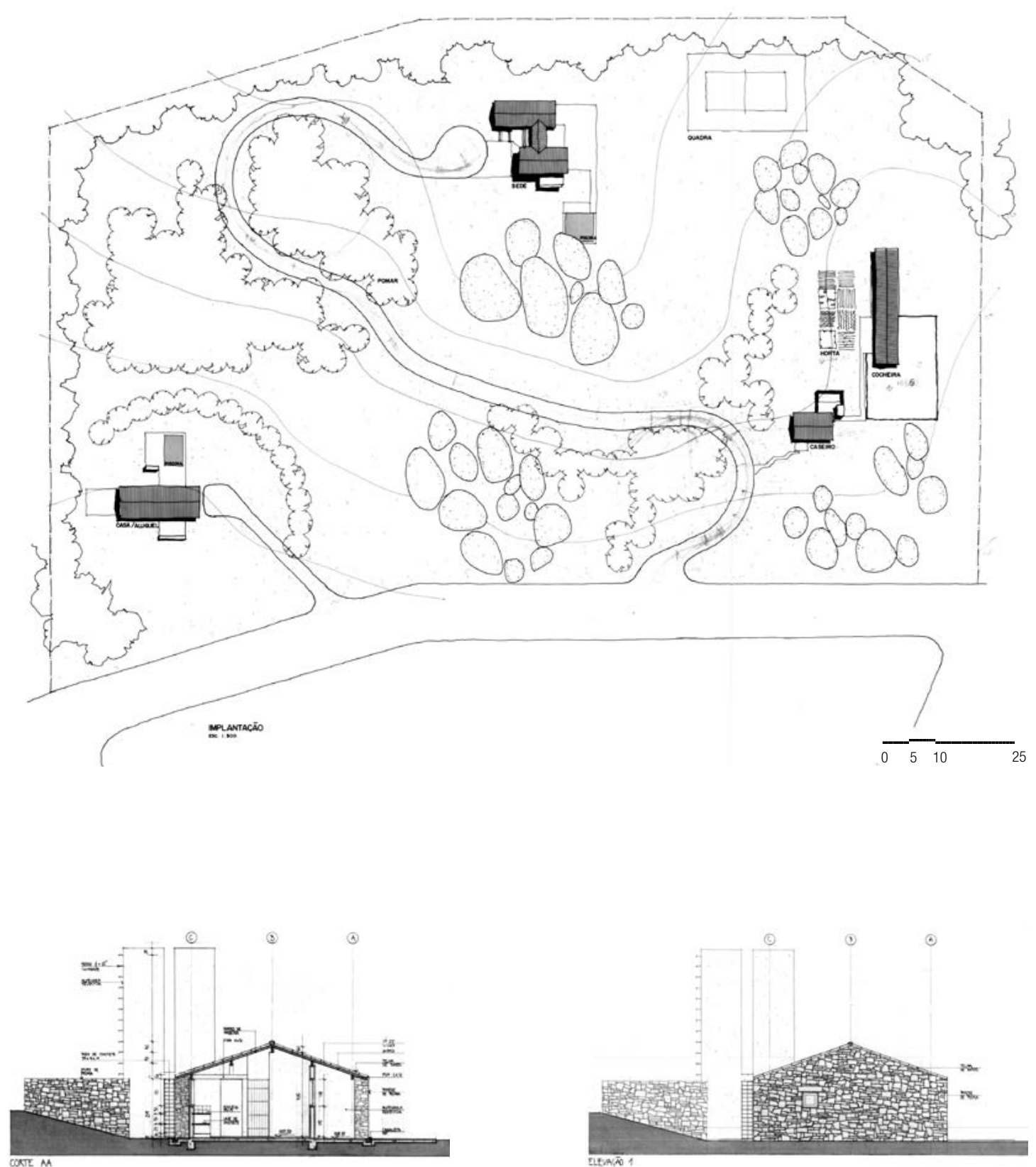
Uso

Edifício de Escritórios

Cliente

Construtora Beter

Equipe

Eduardo de Almeida

Localização

Rua das Olimpíadas, Itaim Bibi, São Paulo, SP

Estágio

Estudo Preliminar

Observações

Não Construído

\section{Características}

Considerando a verticalização que teve início na década de 90 na Vila Olímpia, em São Paulo, Eduardo de Almeida realizou este estudo para a Construtora Beter para um edifício de escritórios de doze pavimentos. Assim como em outros edifícios verticais realizados anteriormente, as estruturas da torre e do subsolo foram pensadas como um conjunto, sem o emprego de transições. Seguindo o princípio de espaços servidos e servidores dos projetos de Louis Kahn, a planta livre de geometria quadrada do pavimento tipo é amparada por duas torres laterais destacadas que abrigam escadas, elevadores e sanitários. Segundo Eduardo de Almeida, uma outra referência foi o estudo para a Torre La Defense projetada por Oscar Niemeyer em Paris.

Acervo

Tubo 9 e Caixa 4400
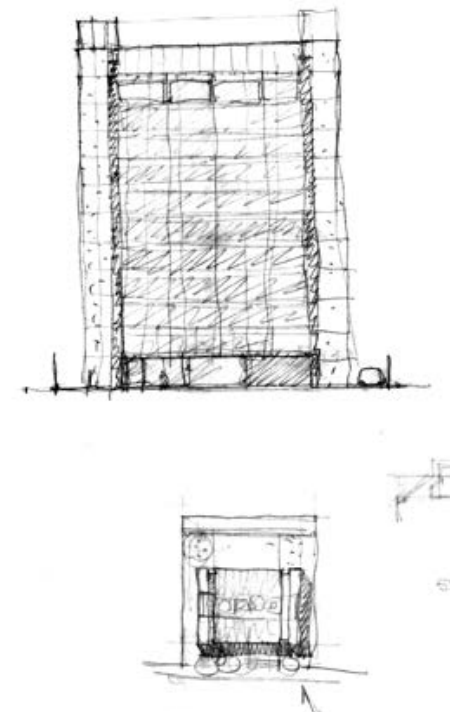
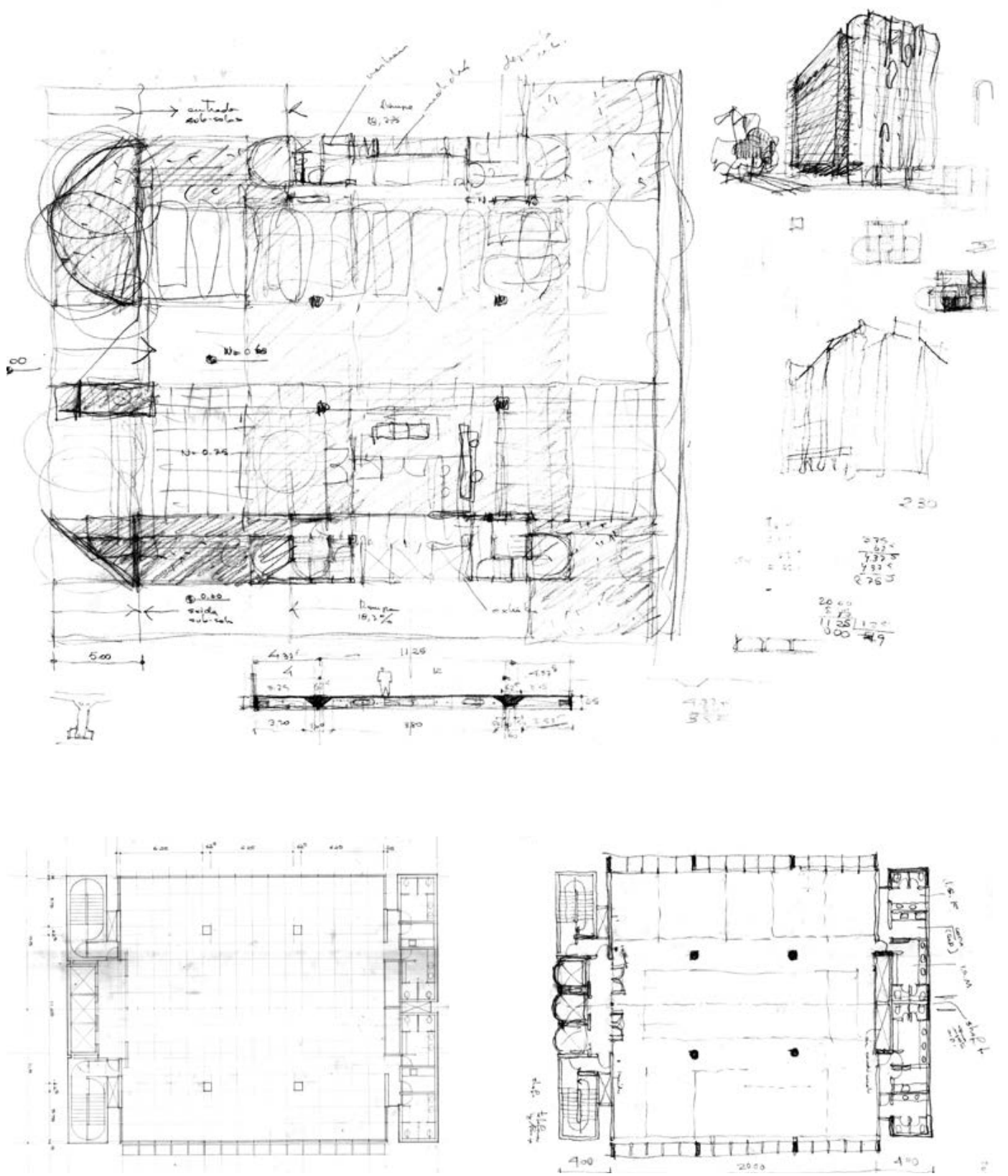
Uso

Residência do Caseiro

Cliente

Alain Costilhes

Equipe

Eduardo de Almeida

Localização

Alameda do Lírios, Guarulhos, SP

Estágio

Projeto Executivo

Observações

Construido

\section{Características}

A partir da encomenda do cliente de um projeto para a casa do caseiro e para uma garagem coberta em 'sintonia' com as edificações pré-existentes, Eduardo de Almeida assume a tipologia do telhado de duas águas inclinadas e a mesma telha ondulada de fibrocimento da residência original. Antes de ser um projeto restritivo, desenhado apenas para atender às imposições do cliente, a solução apresenta uma engenhosa estrutura metálica e um primoroso detalhamento realizado à mão livre com grafite sobre papel manteiga.

\section{Acervo}

Tubo 5
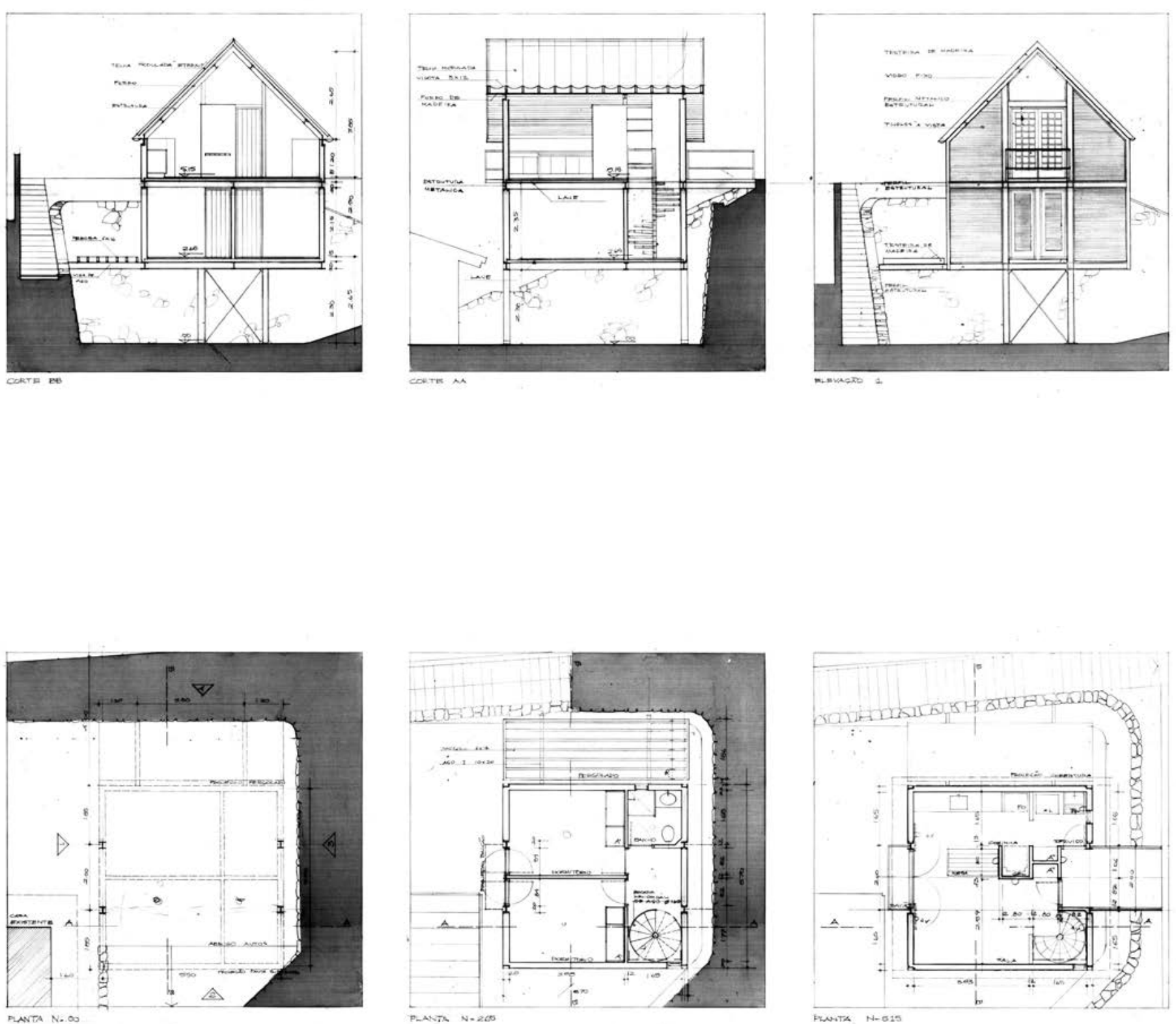

0

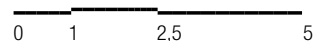


Uso

Edifício Administrativo

Equipe

Eduardo de Almeida

colaboradores I Camila Toledo, Edison Hiroyama, Fernando de Mello Franco, Marta Moreira e Milton Braga

Localização

Rua da Consolação, São Paulo, SP

Estágio

Anteprojeto

Observações

Não Construído

Concurso - Destaque no Concurso de Anteprojetos para Edifício Comercial na FAPESP

Características

Realizada para um Concurso Fechado de Anteprojetos, a proposta considera a criação de uma lâmina de vinte pavimentos implantada perpendicularmente à rua da Consolacãão, viabilizando uma planta tipo que repete a solução de se destacar as prumadas de circulação vertical, sanitários e shafts da laje flexível dos escritórios panorâmicos. Outro ponto de interesse desta proposta reside no projeto do embasamento sob a lâmina que, sensivel às características do lote, cria uma passagem coberta capaz de interligar a rua da Consolação à viela existente ao lado do Edifício Copan, permitindo a continuidade das galerias cobertas características da área central da cidade.

Acervo

Tubo 26 e Backup 313
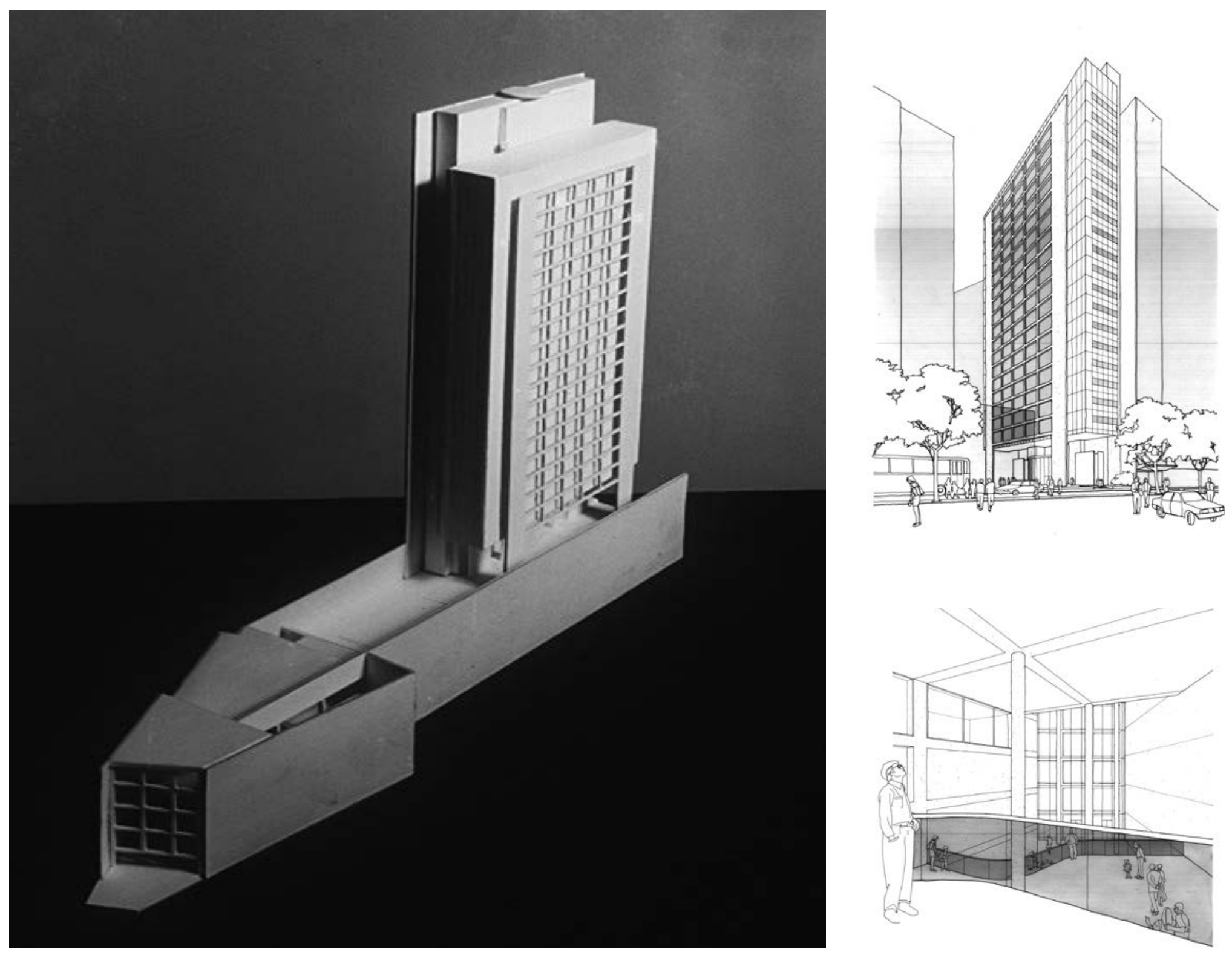
Uso

Shopping Center

Cliente

Golden Shopping

Equipe

Eduardo de Almeida

colaboradores I Marta Moreira e Milton Braga

Localização

Av. Kennedy, São Bernardo do Campo, SP

Estágio

Anteprojeto

Observações

Não Construído

Características

Realizado para um Concurso Fechado de Anteprojetos,

esta proposta cria a ampliação de um Shopping Center

ocalizado em São Bernardo do Campo. Sem tocar no

edifício pré-existente, a ampliação dá-se pela adição

de um novo volume construído em concreto armado e

uma estrutura metálica de conexão entre os volumes.

Neste espaço de pé-direito elevado, passarelas,

escadas convencionais e rolantes conectam os diversos

pavimentos.

Acervo

Tubo 27
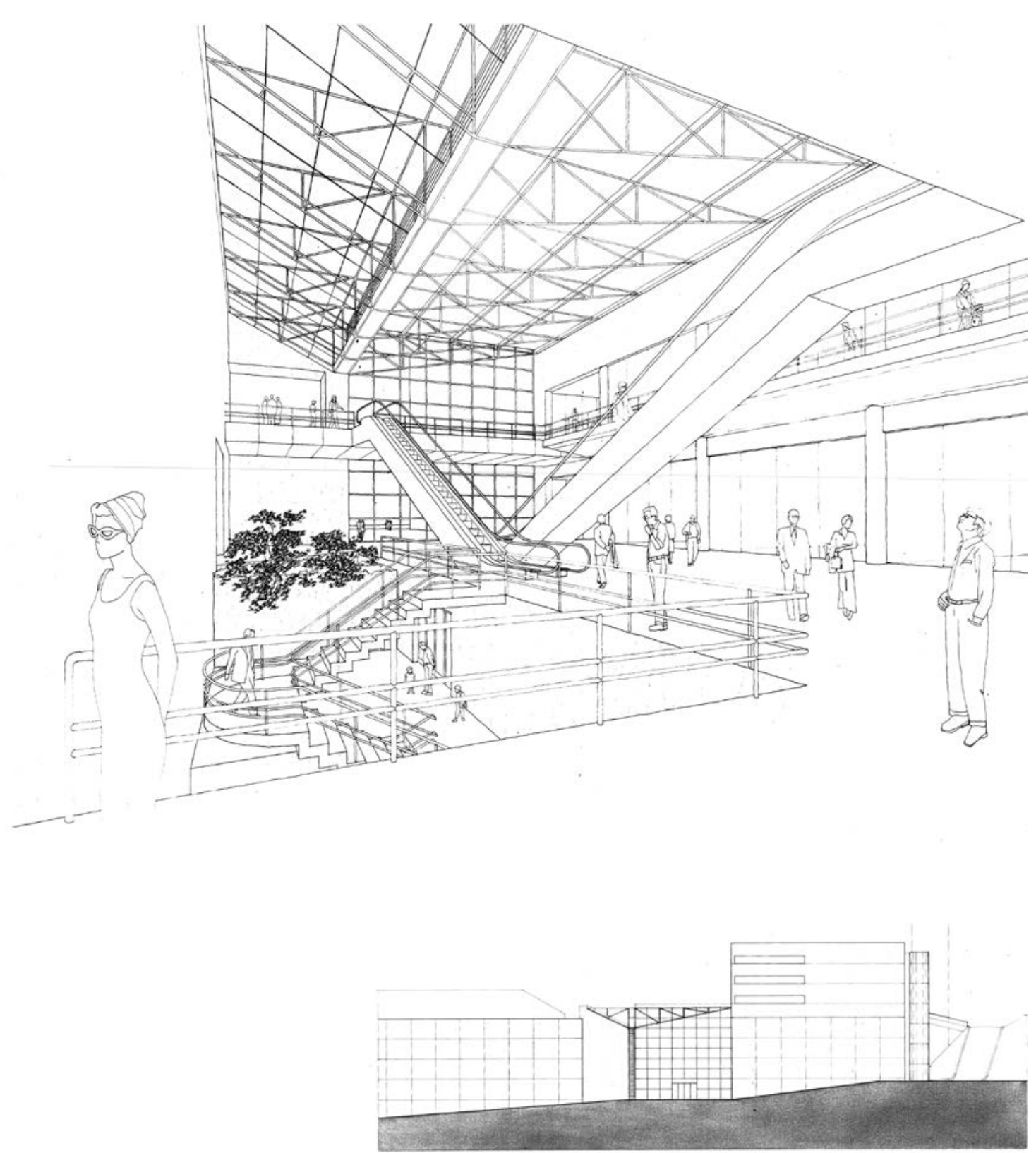
Uso

Residência Unifamiliar

Cliente

Roger Penny

Equipe

Eduardo de Almeida

colaboradores I Marta Moreira

Localização

Barra da Tijuca, Rio de Janeiro, RJ

Estágio

Anteprojeto

Observacõos

Não Construído

Característica

Localizada no Rio de Janeiro, esta residência de grandes dimensões tira partido das relações entre os ambientes internos e os jardins com piscinas e espelhos d'água Seguindo o partido de outros projetos, blocos com coberturas inclinadas conectam-se uns aos outros por meio de lajes de concreto ou coberturas de vidro. A separação dos blocos destinados aos ambientes de estar daqueles voltados às funções de serviços antecipam projetos realizados posteriormente, como a casa Pacheco e Silva, construída em São Paulo em 1993. Depois de inúmeros estudos, o projeto foi abandonado e nunca construído.

Acervo

Tubo 98
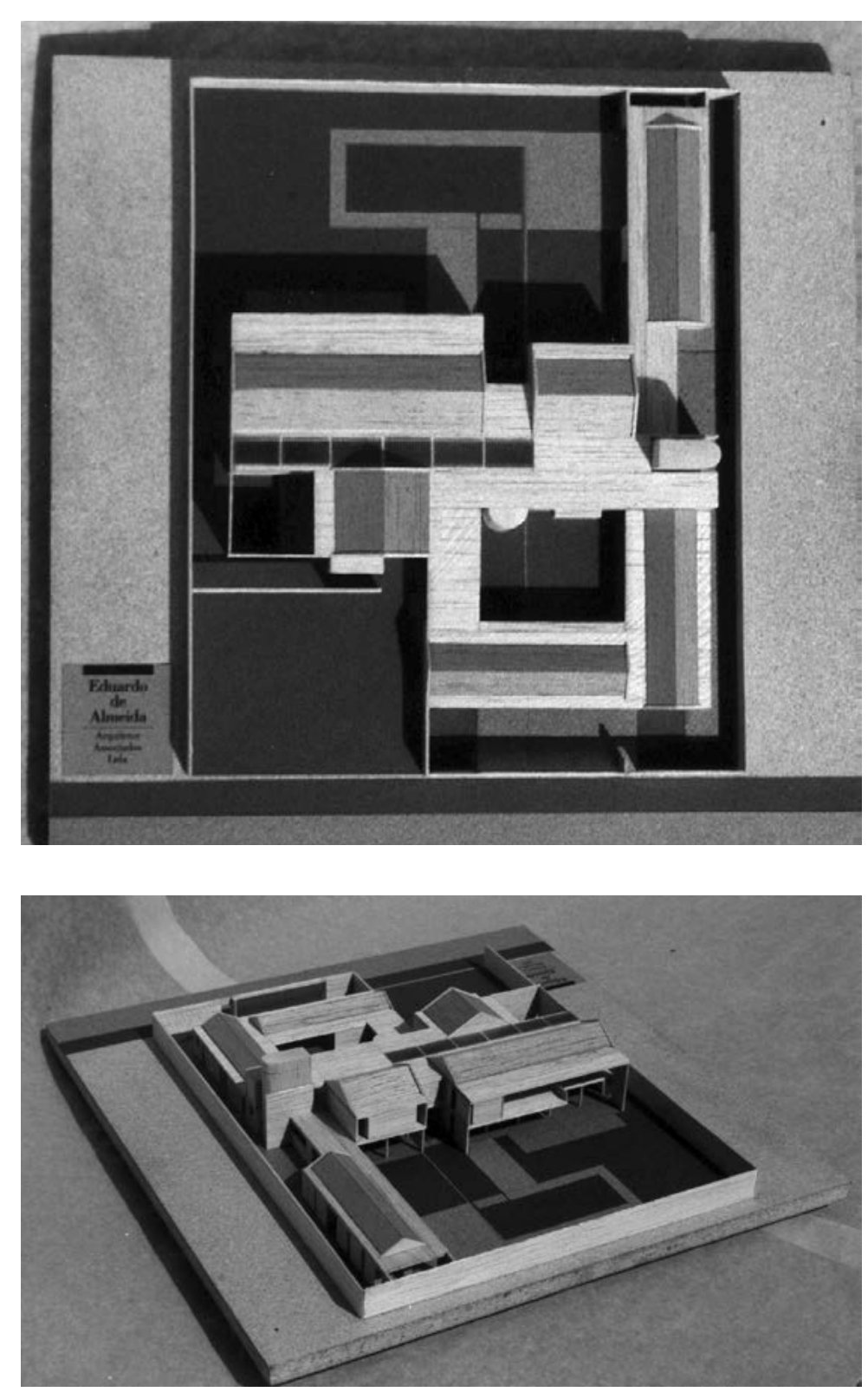
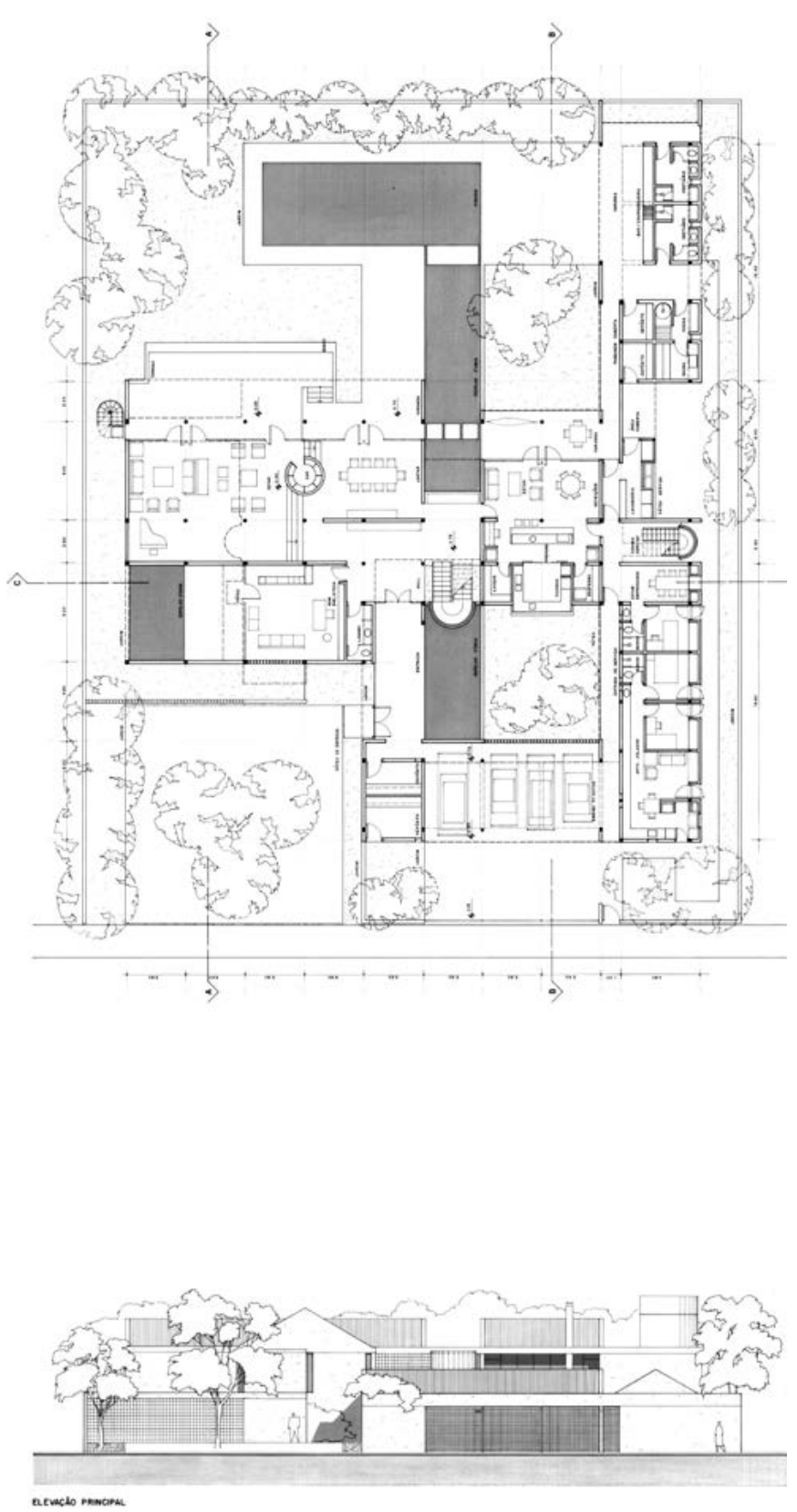

(1) $\overline{0} \overline{2.5} \overline{5} 10$ 
Uso

Reforma de Residência Unifamiliar

Cliente

Marcelo Lacerda Soares

Equipe

Eduardo de Almeida

Localização

Planalto Paulista, São Paulo, SP

Estágio

Projeto Executivo

Observações

Projeto de reforma construído

\section{Caracteristicas}

Estudo de viabilidade para a reforma de uma casa de

vila. Após este estudo, o cliente - cuja família já havia

encomendado uma série de projetos a Eduardo de

Almeida - decidiu adquirir o imóvel e realizar a obra.

\section{Acervo}

Tubo 70

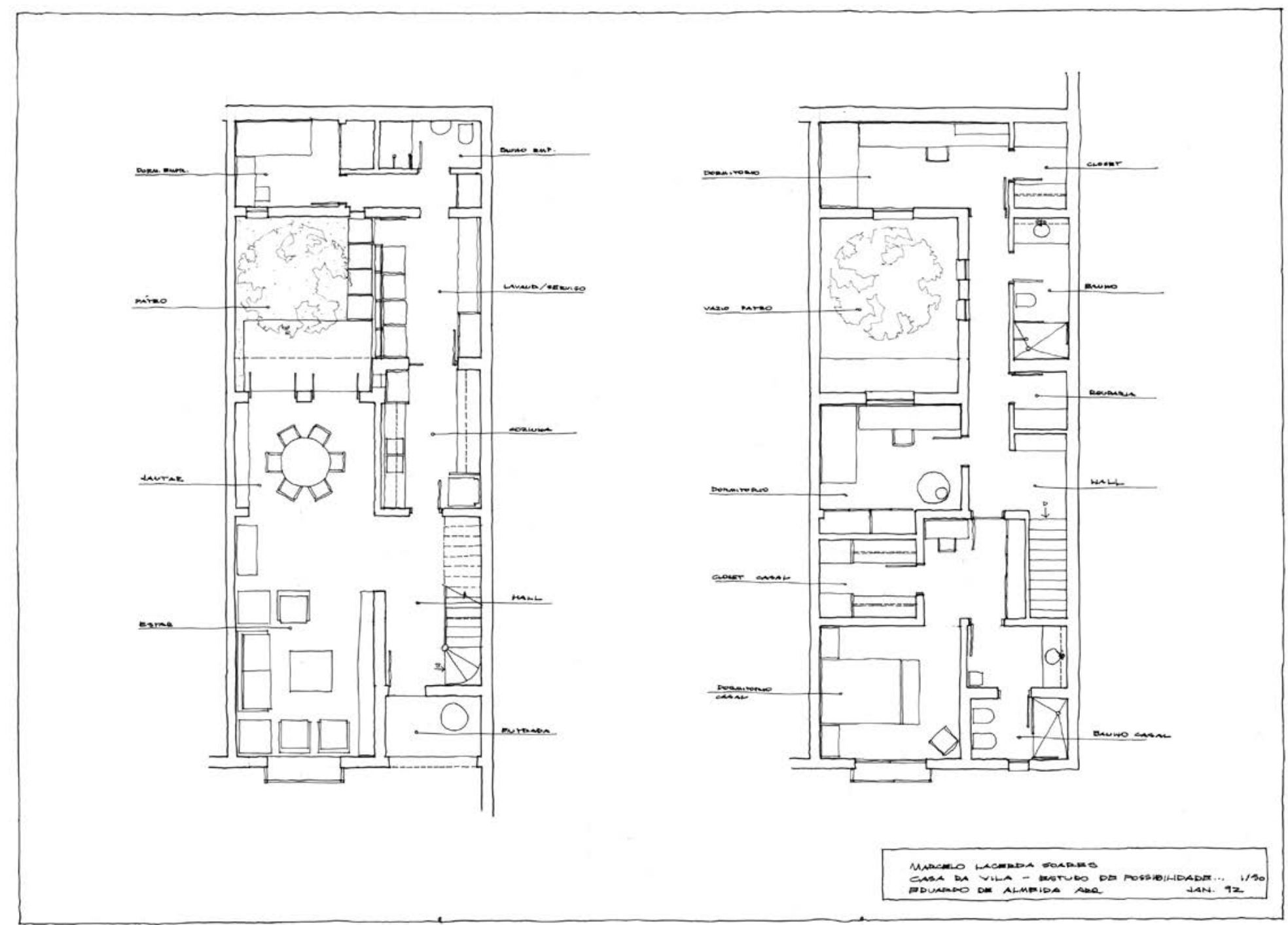


Uso

Edifício Aministrativo

Cliente

Construtora Beter

Equipe

Eduardo de Almeida

Localização

Rodovia Raposo Tavares, São Paulo, SP

Estágio

Estudo Preliminar

Observações

Não Construído

\section{Características}

Implantado em um terreno anteriormente utilizado como depósito da construtora, este projeto para abrigar a sede da empresa previa a criação de quatro pavimentos de escritório panorâmico com recepção e estacionamento coberto no térreo. Seguindo a distinção entre espaços servidos e servidores, à semelhanç̧a dos projetos de Louis Kahn, o projeto cria um contraponto entre as lajes Louis Kahn, o projeto cria um contraponto entre as lajes
livres e flexíveis e as torres de circulação e prumadas de livres e flexíveis e as torres de circulação e prumadas de do edifício. Para as áreas de trabalho, Eduardo de Almeida assumiu a presença de três linhas de pilares duplos na área central da planta, evidenciando o espaço definido como corredor. Nas fachadas, a exposição das treliças metálicas faz referência à obra de arquitetos como Richard Rogers, Norman Foster ou Renzo Piano, ao mesmo tempo em que viabilizam um vão livre de aproximadamente 20 metros.

Acervo

Tubo 9, Caixa 4400
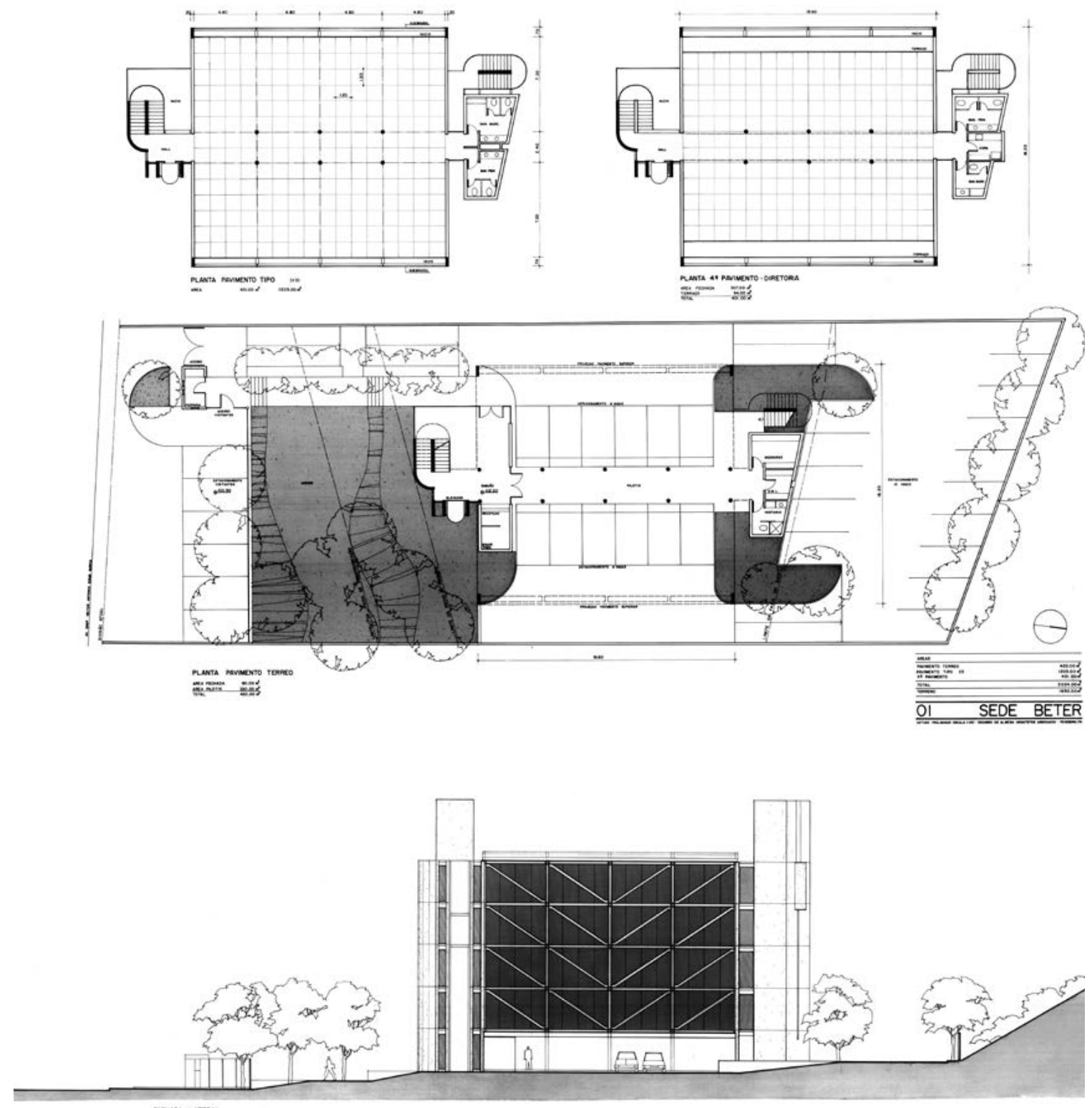
Uso

Escola

Cliente

FDE - Fundação para o Desenvolvimento da Educação

Equip

Eduardo de Almeida

Localização

Rua Manuel Reis da Silva, Guarulhos, SP

Estágio

Projeto Executivo

Observações

Construído

\section{Características}

A partir do terreno em declive, o projeto para esta escola pública segue 0 partido utilizado em outros edifícios de criar blocos funcionais articulados pelos elementos de circulação. Neste caso, um volume linear de três pavimentos, implantado perpendicularmente à rua, abriga as salas de aulas e laboratórios, enquanto outros dois - paralelos à rua - foram destinados aos espaços de apoio e ao galpão, refeitório e administração. Seguindo o padrão construtivo e dimensional da FDE Fundação para 0 Desenvolvimento da Educação - 0 projeto destaca-se também pelos fechamentos em zados inseridos na grelha da fachada estrutura de concreto, solução que dá unidade plástica ao conjunto

Acervo

Tubo 88 e Caixa 2300
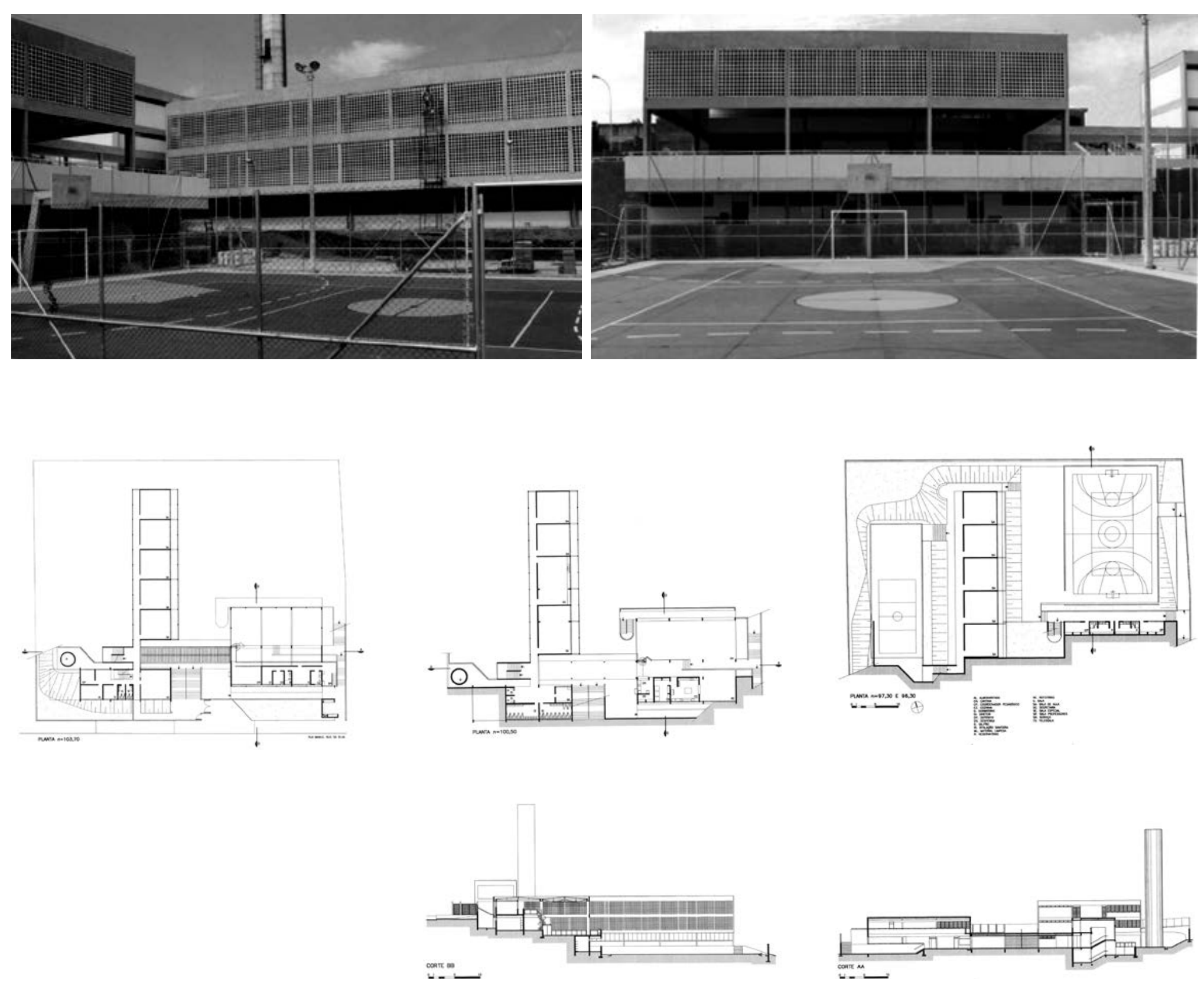
Uso

Reforma de Residência Unifamiliar

Cliente

Dr. Luis Alberto Mendes Rodrigues

Equip

Eduardo de Almeida

Localização

Praça Desembargador Mamede, Jd. Paulistando, São

Paulo, SP

Estágio

Projeto Executivo

Observações

Projeto de reforma construído

Características

A partir da estrutura de uma casa pré-existente, fol

realizado um projeto de adequação às necessidades dos

novos moradores. As intervenções procuram relacionar

as aberturas das salas com os pátios frontal e posterior.

No centro da casa, uma cobertura de vidro inclinada

propicia iluminação natural ao vazio posicionado junto

à escada.

Acervo

Tubo 82
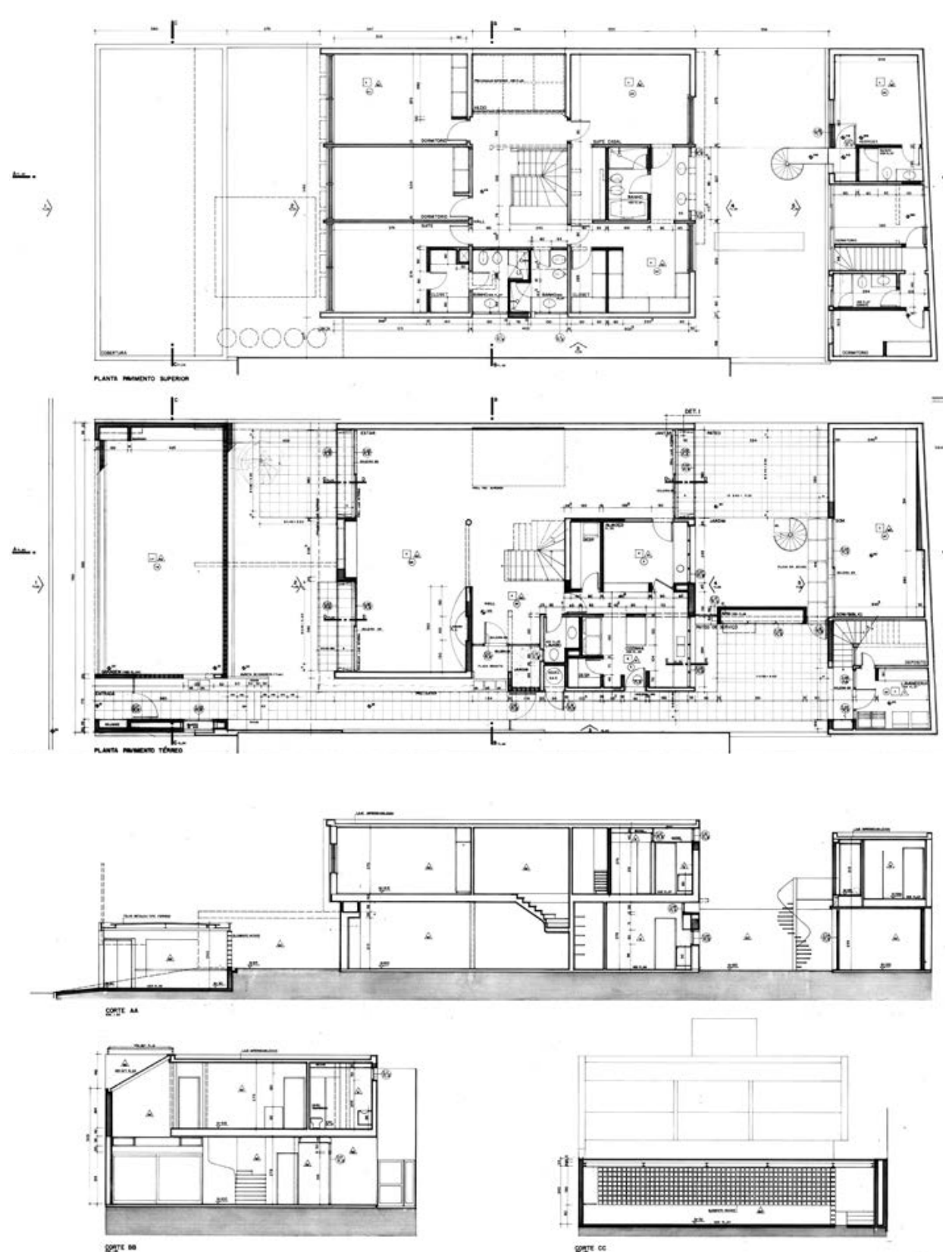
Uso

Intervenção na Galeria Prestes Maia

Cliente

Associação Viva o Centro

Equipe

Eduardo de Almeida

Localização

Praça do Patriarca, Sé, São Paulo, SP

Estágio

Anteprojeto

Observações

Não Construído

\section{Características}

Contratado pela Associação Viva o Centro, este projeto vincula-se à cobertura realizada para a Praça do Patriarca projetada por Paulo Mendes da Rocha neste mesmo período, finalmente construída em 2002. 0s

dois projetos, em conjunto, criavam uma intervenção na passagem desenhada por Elisário Bahiana no projeto do novo Viaduto do Chá inaugurado na gestão Prestes Maia em 1940, de modo a retomar a importância da ligação entre 0 Anhangabaú e a Praça do Patriarca. A intervenção proposta considera a implantação de um piso elevado de geometria triangular para a criação de um café, aproveitando o pé-direito elevado da galeria e criando um contraponto à malha regular da estrutura preexistente.

Acervo

Tubo 71 e Caixa 4300
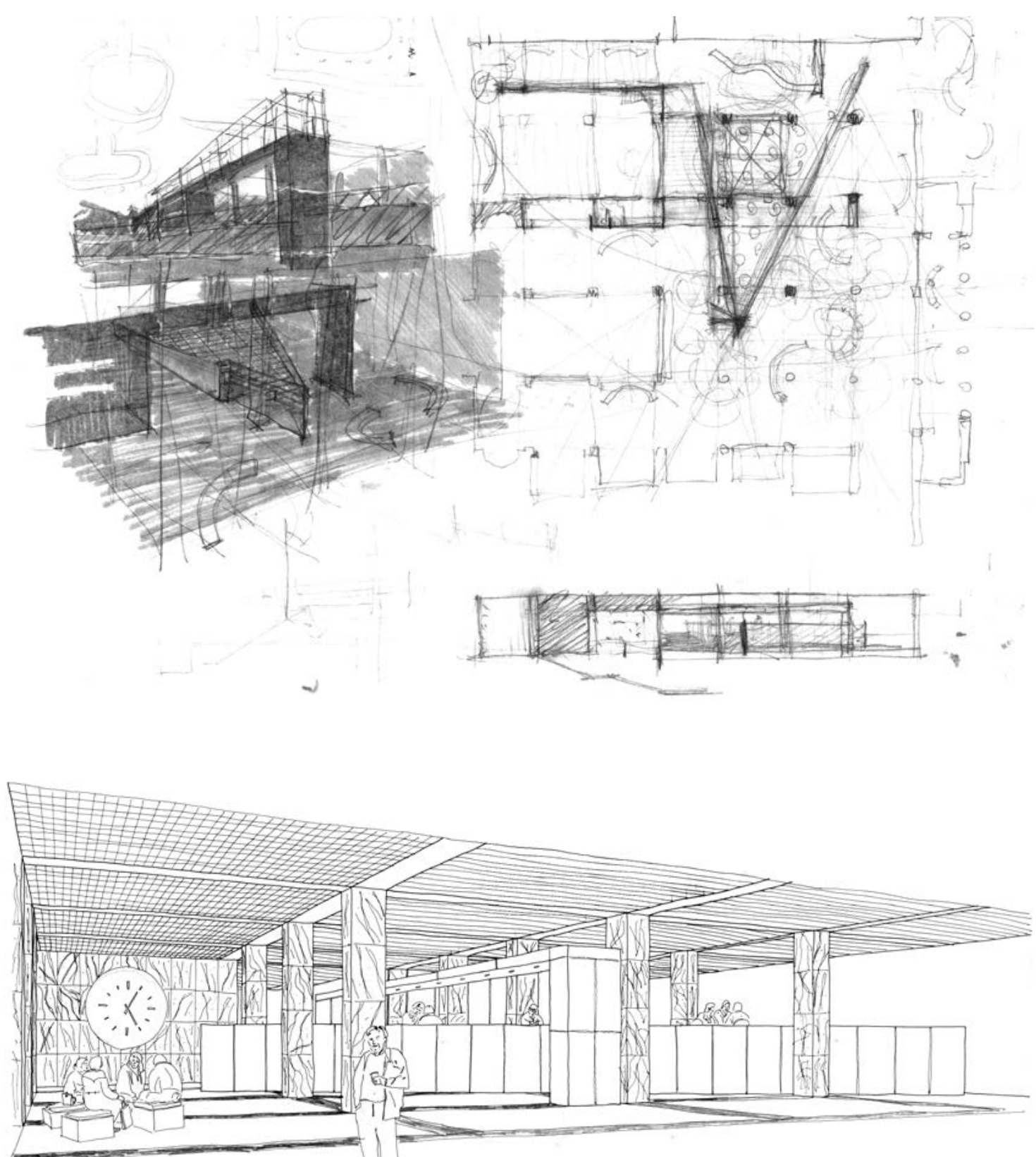
Uso

Residência Unifamiliar

Cliente

Cidinha Brito

\section{Equipe}

Eduardo de Almeida

colaboradores I Flávia Pagotti Silva, Cynthia Callia, José Antônio Seixas

estrutura I Faustino Máximo da Silva (concreto),

Construmet (aço)

paisagismo I CAP

\section{Localização}

Rua Mariana Correia 517, Alto de Pinheiros, São Paulo, SP

Estágio

Projeto Executivo

\section{Observações}

Construído

\section{Características}

De acordo com outros projetos como a casa para Roger Penny (1991), este projeto propõe a separação dos programas em dois volumes: um destinado às áreas de serviço e outro aos espaços de estar. Entre eles, em um espaço de pé-direito elevado e fechado por aço e vidro encontram-se 0 espaço de entrada da casa e a escada que permite vistas para 0 jardim e para 0 espelho d'água. Enquanto o primeiro volume configura-se como un sólido com poucas aberturas, o segundo foi construído em estrutura metálica, abrigando salas envidraçadas no pavimento térro, aproveitando suas relações com o jardim. No segundo pavimento localizam-se os dormitórios, cuja espacialidade destaca-se pela cobertura de duas águas, tanto pela volumetria do frontão triangular na fochach, quanto pela espacialidade interna que garante pé-direito elevado e variado aos espaços.
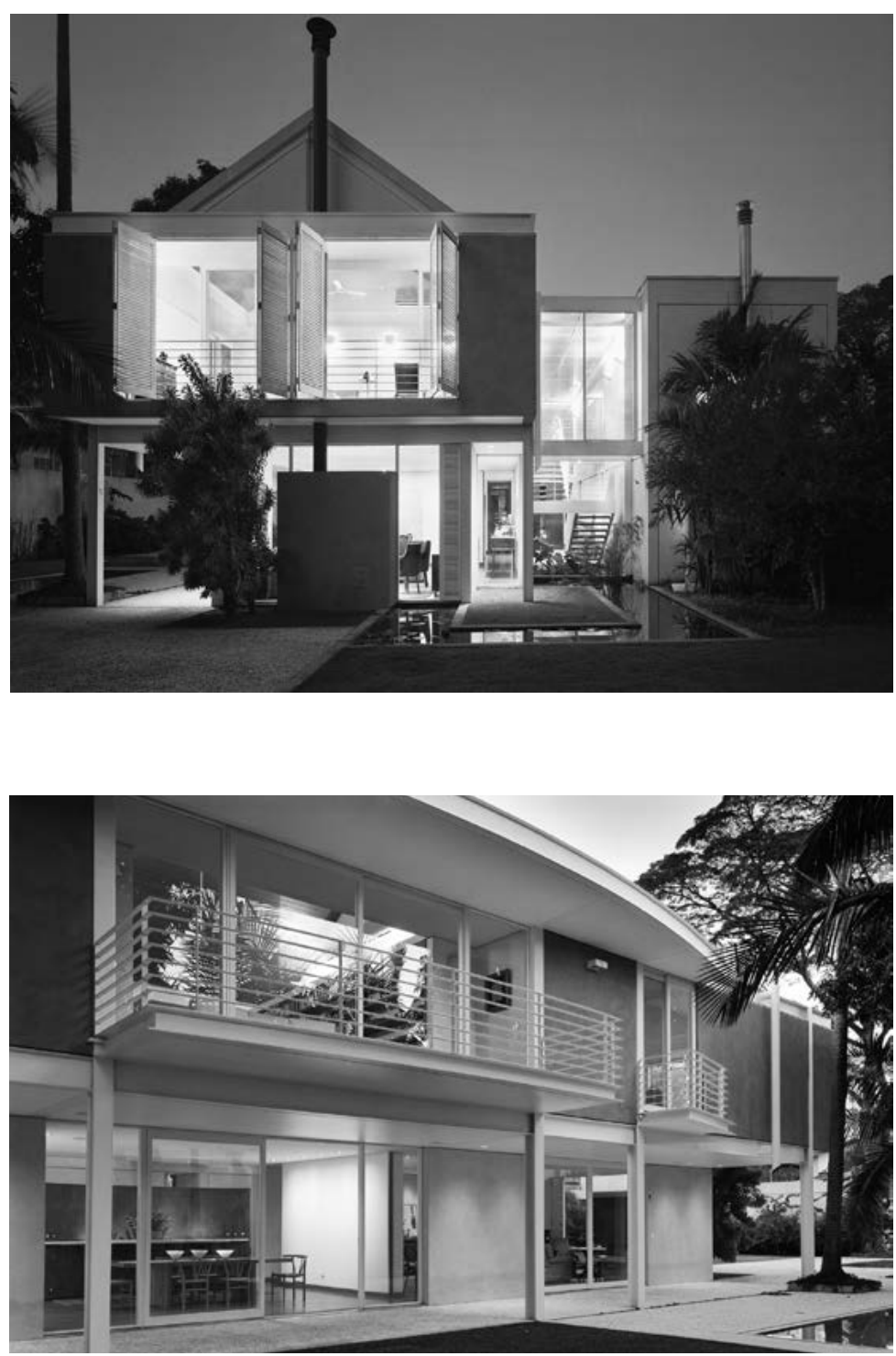

Acervo

Tubo 33, 33 A e 33B, Caixa 4600 e Backup 302 
Uso

Teatro de Ópera

Cliente

Associação NTSP

\section{Equipe}

Eduardo de Almeida

colaboradores I Angelo Bucci, Camila Toledo e Marcos

Mendes
3D I Omar Dalank

Localização

Parque Vila Lobos, São Paulo, SP

Estágio

Anteprojeto

Observações

Não Construído

\section{Características}

Desenvolvido até a etapa de executivo, este importante projeto previa a construção de um novo teatro de ópera para a cidade de São Paulo a ser implantado em uma área localizada junto ao Parque Vila Lobos, próximo à Ponte do Jaguaré A proposta da equipe criava um conjunto composto pela sala de espetáculos propriamente dita $\mathrm{e}$ por um edifício de apoio implantado ao redor deste volume principal. Tal solução não só propicia o amparo necessário à caixa cênica e à plateia, como permite a definição de recintos abertos e fechados para 0 acolhimento de público, junto à esplanada de acesso que corta o edifício. Esta configuração garante protagonismo ao volume da sala que se eleva em relação ao conjunto, destacandose também pela geometria curva de sua cobertura Segundo depoimento de Helena Ayoub, quando a etapa de anteprojeto foi concluída, Eduardo de Almeida convidou uma série de colegas para conhecerem 0 trabalho em seu escritório, como uma espécie de comemoração, ao mesmo tempo esperando um retorno sobre o projeto, antes que este fosse apresentado aos clientes.

Acervo

Tubo 57 e 57 A , Caixa 3900 e 3910
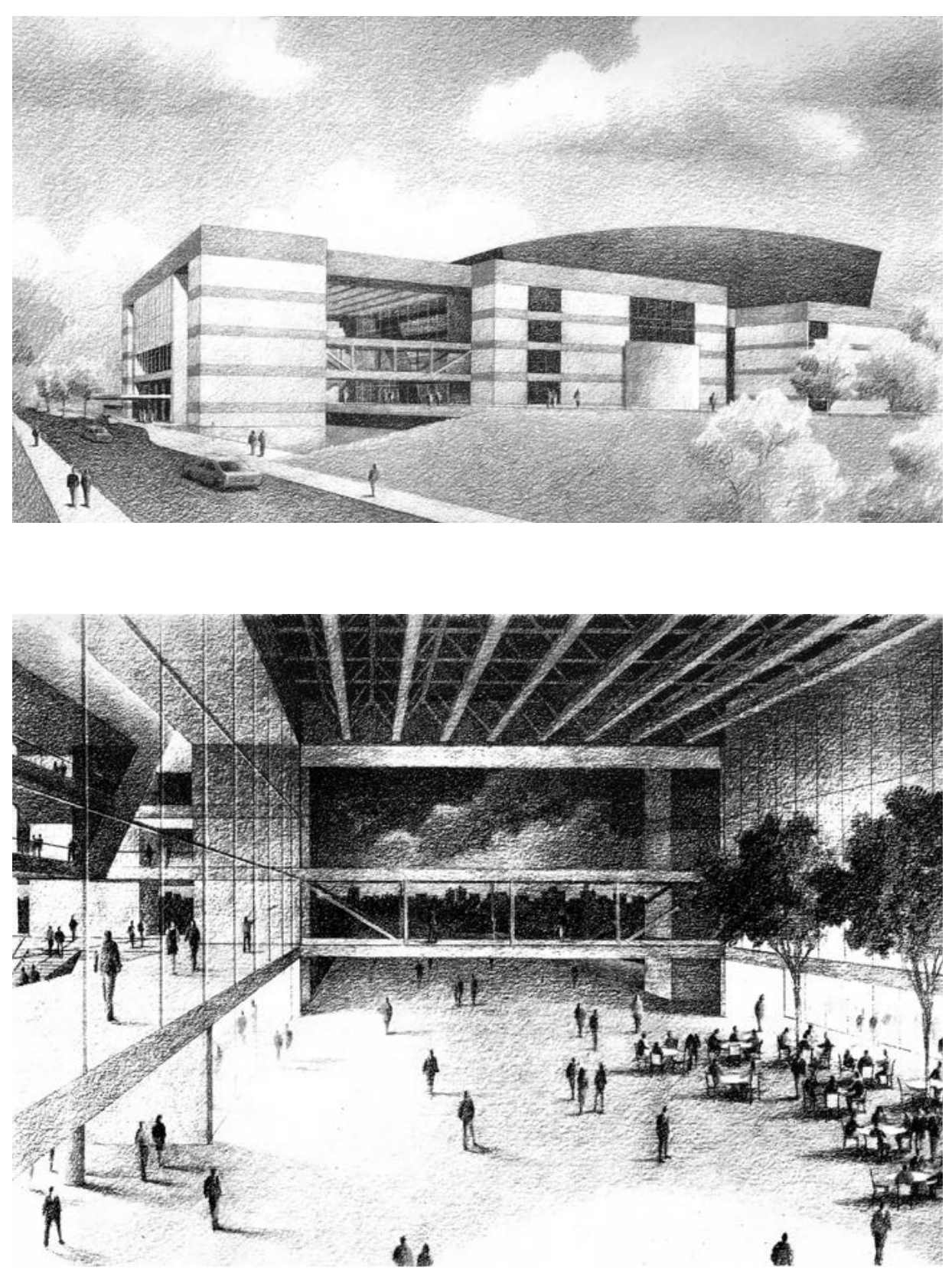
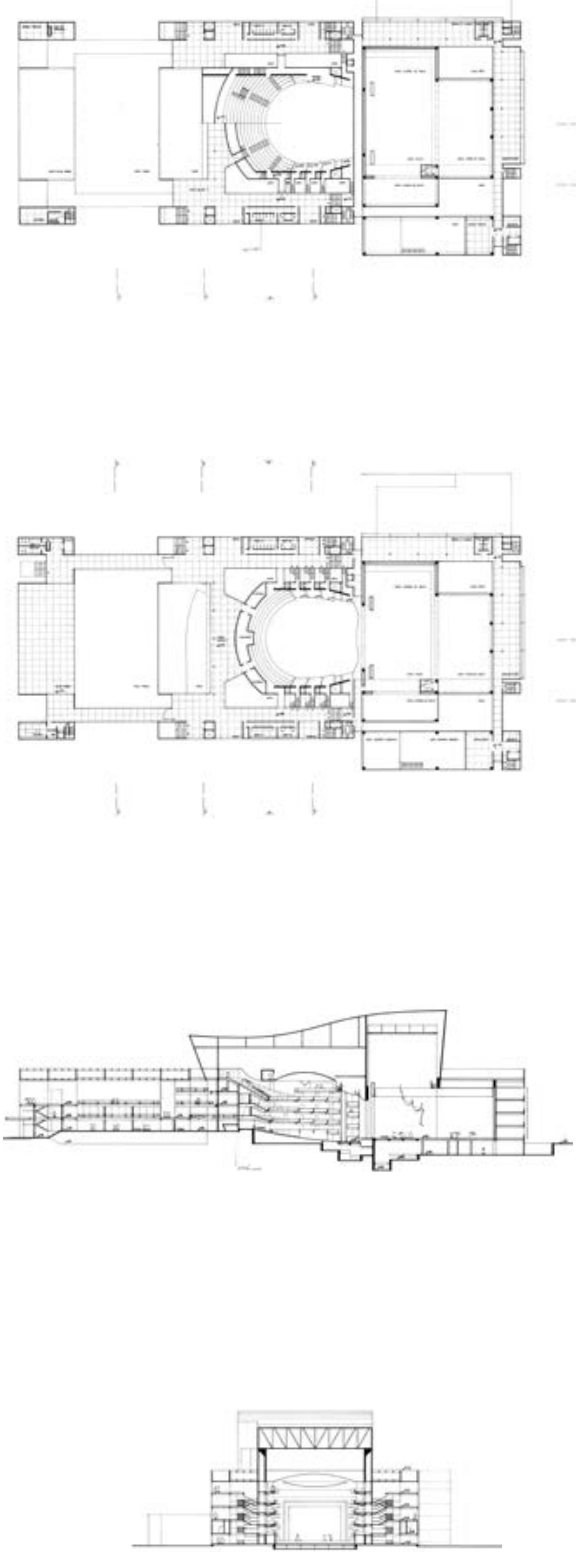
Uso

Teatro de Ópera

Cliente

Associação NTSP

Equipe

Eduardo de Almeida

colaboradores I Angelo Bucci, Camila Toledo e Marcos

Mendes

3D I Omar Dalank

Localização

Parque Vila Lobos, São Paulo, SP

Estágio

Anteprojeto

Observações

Não Construído

\section{Características}

Para um arquiteto como Eduardo de Almeida, a realização de qualquer projeto envolve muita dedicação. Trabalho árduo que, dependendo das dificuldades enfrentadas, resultam em grande desgaste, inclusive enfrentadas, resultam em grande desgaste, inclusive
psicológico. Durante todo o período em que trabalhei no escritório, este projeto era um assunto proibido pois trazia péssimas lembranças a Eduardo - talvez por este motivo este importante projeto nunca tenha sido publicado.

Segundo Eduardo de Almeida, por desinteresse dos clientes 0 primeiro projeto foi abandonado, sob 0 argumento de que 0 custo de obra havia superado as expectativas. Dada esta condição, Eduardo ainda realizou uma segunda proposta, mais compacta, igualmente abandonada.

Acervo

Tubo 57 e 57 A , Caixa 3900 e 3910

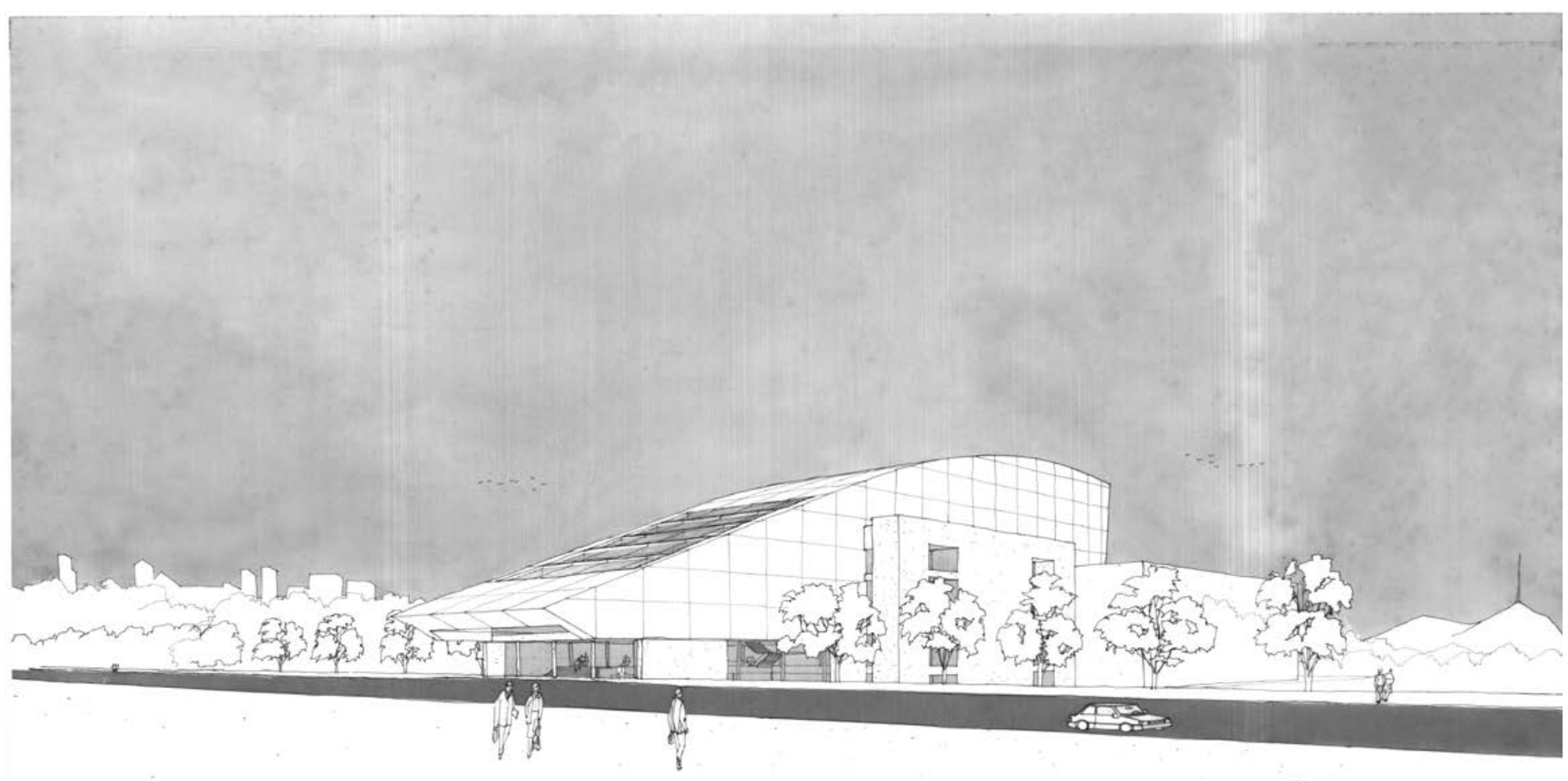

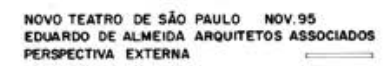

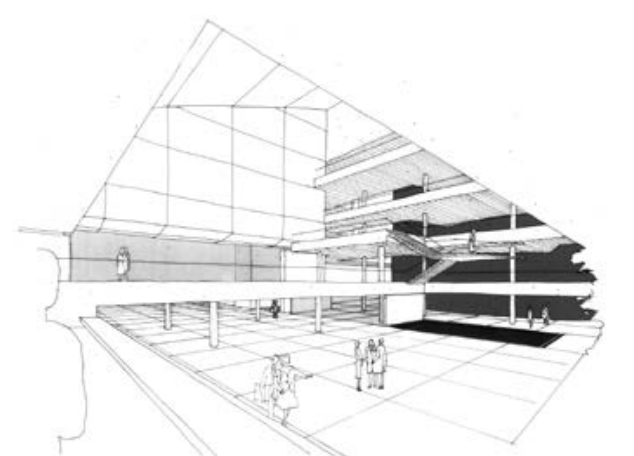




\section{Cliente}

Marcelo L. Soares

Equipe

Eduardo de Almeida

colaborador I Edison Hiroyama

Localização

Porto Feliz, São Paulo, SP

Estágio

Estudo Preliminar

Observações

Não Construído

Características

Outro projeto realizado para a família Lacerda Soares,

o projeto deste haras considera a criação de uma

cocheira, uma casa de planta quadrada e um pavilhão

de lazer próximo à piscina. Todos os edifícios utilizam

estrutura de madeira com cobertura de telhas cerâmicas

e alvenaria convencional. Podemos destacar o platô

definido por um muro curvo para a implantação da casa

e da piscina, e também a estrutura de cobertura de

quatro águas apoiada no pilar utilizado como chaminé

da lareira, elemento central da casa e que ordena 0

posicionamento de todos os programas ao seu redor.

Acervo

Tubo 35
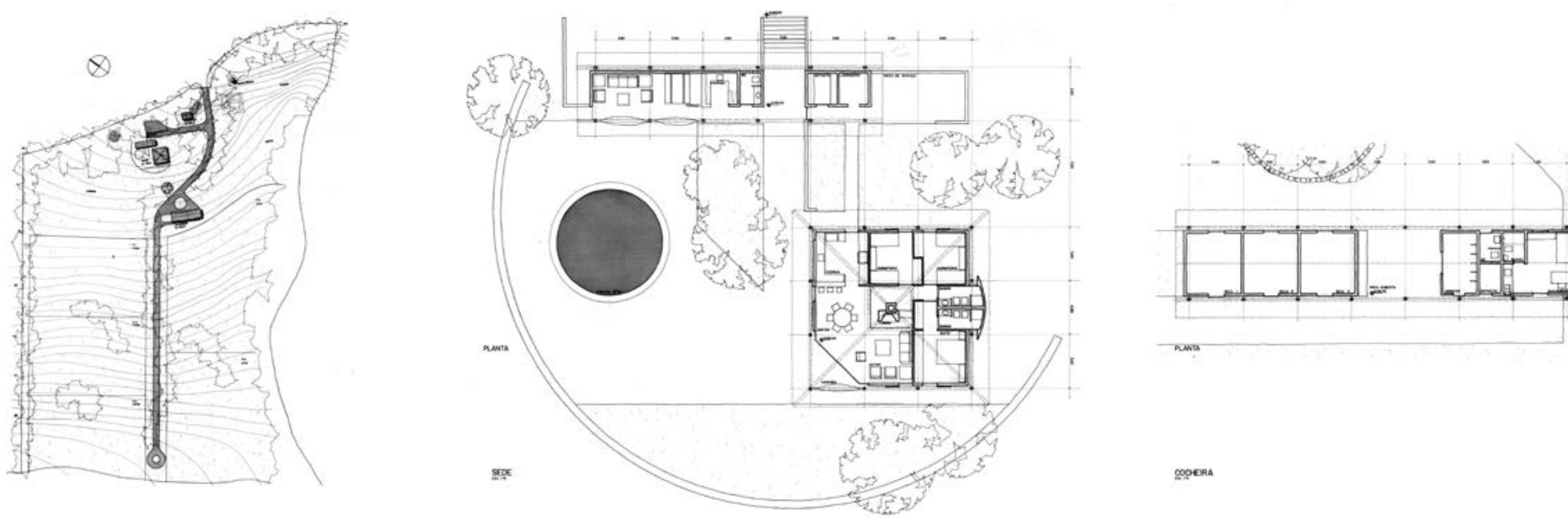

nom

gopeen
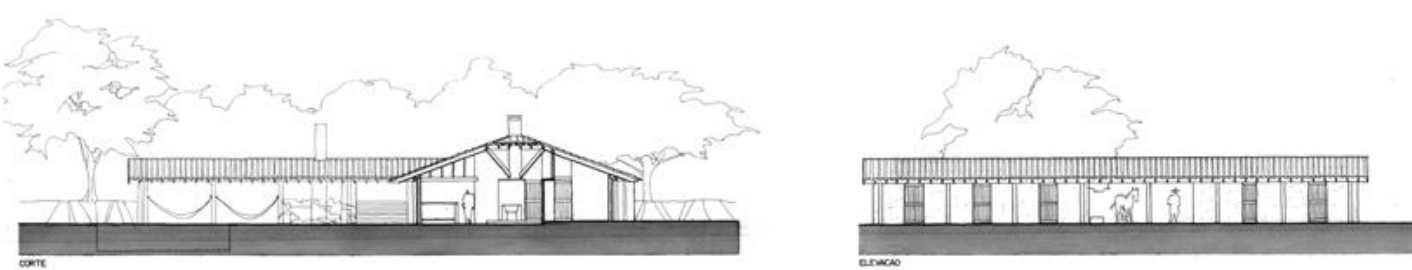
Uso

Residência Unifamiliar

Cliente

Rubens Filizola

Equipe

Eduardo de Almeida

colaboradores I Adriana Shima, Flávia Pagotti Silva e

Maria Isabel Imbronito

\section{Localização}

Rua Circular do Bosque, Cidade Jardim, São Paulo, SP

\section{Estágio}

Projeto Executivo

\section{Observações}

Construído

\section{Características}

Este projeto retoma as experiências das casas Bracher (1989) e Pacheco e Silva (1993) na tentativa de associar elementos tradicionais da construção com novas tecnologias como estruturas metálicas e grandes panos de vidro com caixilharia de aluminio. Neste caso, 0 desenho da estrutura, com duas linhas de pilares e cobertura de duas águas no pavimento superior, define a sequência de espaços destinados aos programas, ao mesmo tempo em que se associam a grandes paredes de pedra cuidadosamente realizadas por um mestre espanhol.

Acervo

Tubo 62, 62 A, 62 B e 62 C, Caixa 3800 e Backup 303
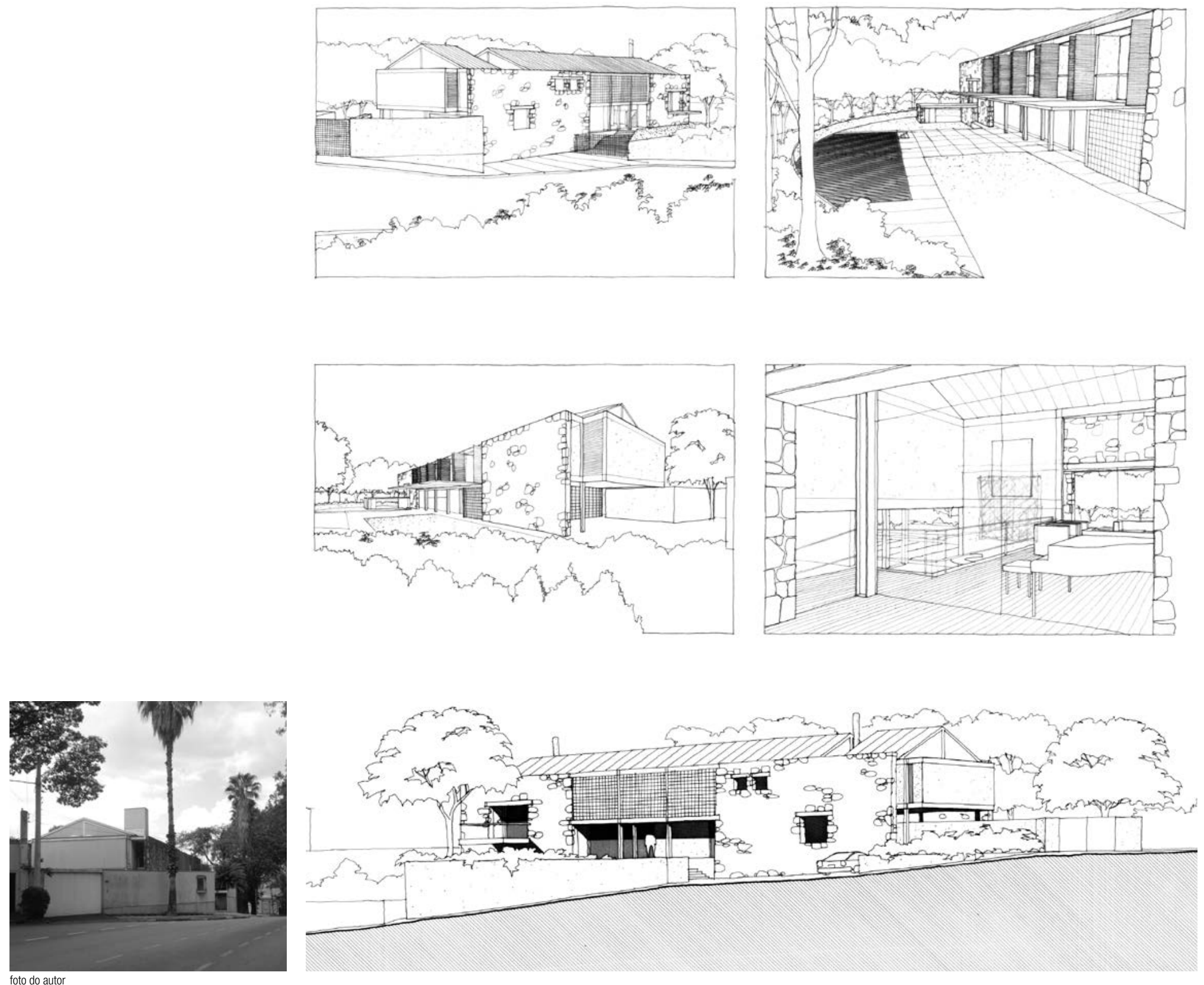
Uso

Residência Unifamiliar

Cliente

Philipe Reichstul

Equipe

Eduardo de Almeida

colaboradores I Flávia Pagotti Silva e Maria Isabel

Imbronito

maquete I Edison Hiroyama

estrutura I Faustino Máximo da Silva

paisagismo I CAP - Fernando Chacel e Sidney Linhares

Localização

Rua Sampaio Vidal, Jardim Paulistano, São Paulo, SP

\section{Estágio}

Projeto Executivo

\section{Observações}

Construído e atualmente em reforma

\section{Características}

A primeira proposta para este projeto realizada ainda

com Arnaldo Martino foi rejeitada pelos clientes por

dificultar 0 acesso às áreas comuns da casa, uma vez

que 0 piso da sala, ao contrário de todos os outros

programas implantados no piso térreo, posicionava-se

em situação mais elevada, propiciando acesso fácil ao

teto ajardinado.

A segunda proposta, mais tradicional, previa uma casa

de dois pavimentos, organizada como uma sequência

de volumes implantados ao redor de duas árvores,

preservadas em um pátio de proporção quadrada. A

anedota que se conta é que, durante o processo de obra

uma das árvores que justificava 0 partido ciul, mas 0

espaço já estava construído.

Acervo

Tubo 69
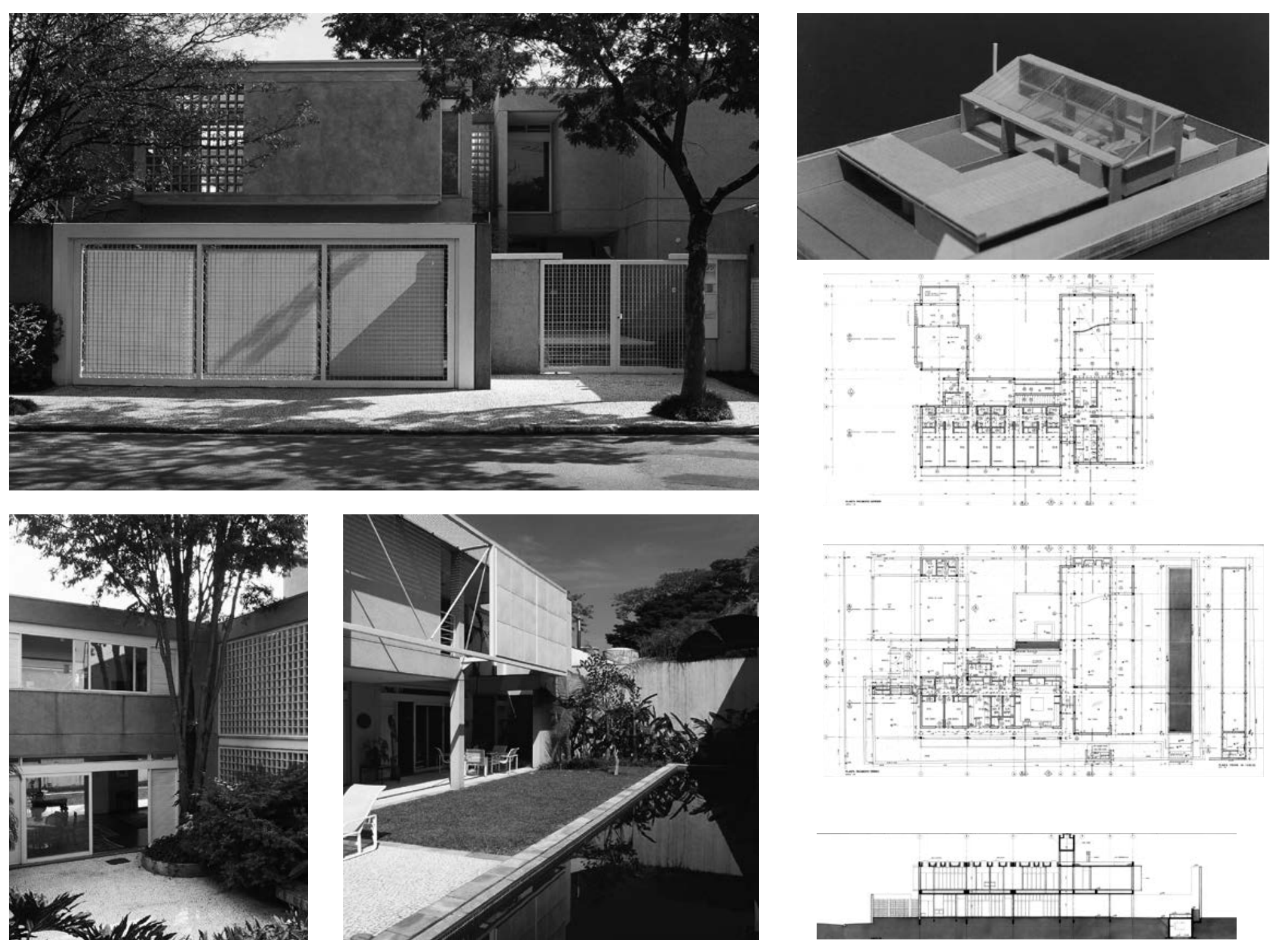

Itos: Nelson Kon 
Uso

Campus Universitário

\section{Equipe}

Eduardo de Almeida

colaboradores I Edison Hiroyama, Katia Pestana e Claudio Diaferia

\section{Localização}

Rodovia Raposo Tavares, São Paulo, SP

\section{Estágio}

Anteprojeto

\section{Observações}

Não Construído

Concurso - projeto vencedor do concurso de Anteprojetos

Novo Campus da EAASP Fundação Getúlio Vargas

\section{Caracteristicas}

Primeiro colocado em um concurso fechado de anteprojetos, a solução proposta para este campus universitário, aproveitando a condição topográfica do terreno, criava uma ocupação de dois volumes posicionados perpendicularmente à uma praça de posicionados perpe dich de proporção quadrada. Este piso que concentra os fluxos do campus e propiciam privilegiadas vistas em direção ao vale arborizado abriga, em seu piso inferior, a biblioteca, assumindo a configuração de um edifício com acentuado caráter topográfico. Identifica-se a influência do projeto do Novo Teatro de São Paulo na geometria curva do auditório posicionado junto à entrada, mas também a referência ao projeto do Centro Administrativo de Votorantim no bloco destinado às salas de aula, uma vez que 0 longo edifício organiza-se pela sucessão de volumes de planta quadrada, alternados pelas prumadas de circulação e sanitários. Dotadas de grandes balancos, o cálculo estrutural desta proposta ficou a cargo do Engenheiro Hugo Tedeschi.

\section{Acervo}

Backup 304
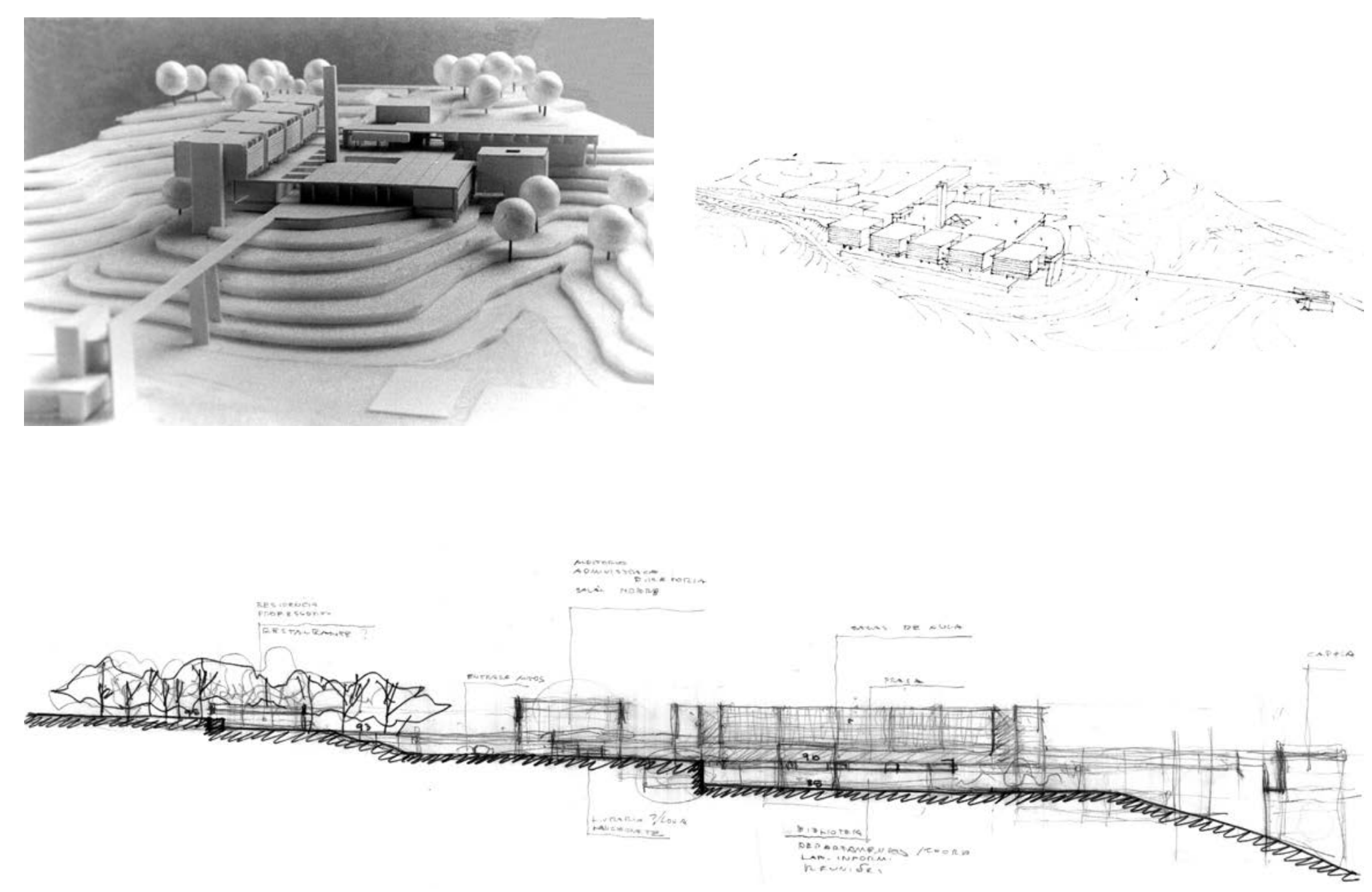
Uso

Residência Unifamiliar

Cliente

Lalo de Almeida

Equipe

Eduardo de Almeida

colaborador I José Antônio Seixas

Localização

Rua Dr. Baeta Neves, Alto de Pinheiros, São Paulo, SP

Estágio

Projeto Executivo

Observações

Construído

Características

A partir de uma construção pré-existente, o projeto de reforma para esta casa de vila cria, em um espaço exíguo, uma área frontal com sala de estar e escritório e, após a escada helicoidal, uma sala de jantar com cozinha e lavabo. No pavimento superior, encontramse um pequeno dormitório, um sanitário, a área de

serviços com terraço externo e, em um mezanino, o quarto do casal. Projetado para seu filho Lalo e sua família, a pequena casa preserva as paredes de tijolos aparentes (agora pintados de branco) e recebe todos os pisos e armários em granilite, assumindo um caráter de despojamento na linguagem da construção.
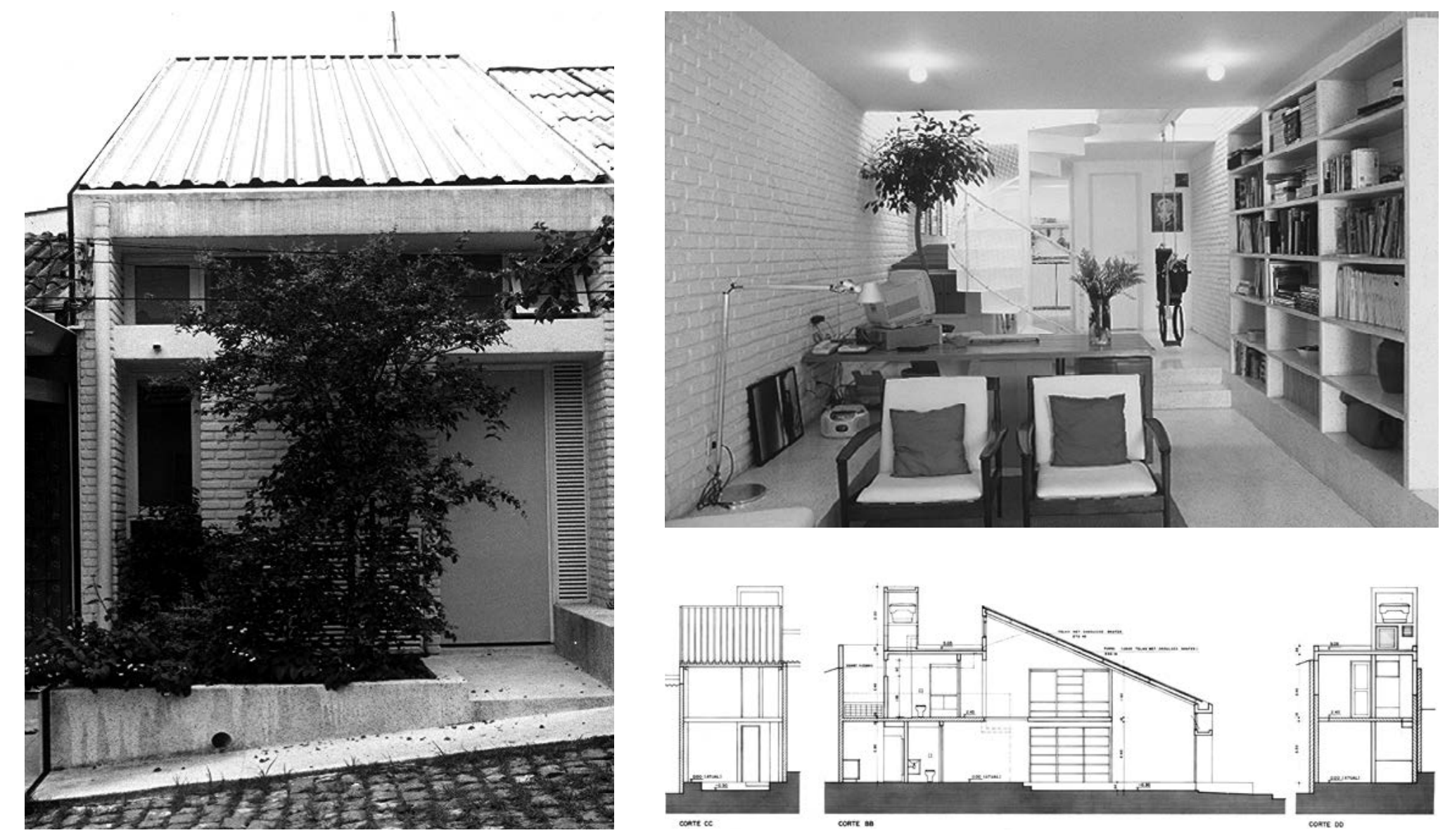

Acervo

Tubo 93, Caixa 1500 e Backup 305 e 330 
Uso

Equipe

Eduardo de Almeida

colaboradores I Camila Toledo, Cynthia Callia, Edison

Hiroyama e Flávia Pagotti Silva

Localização

Buenos Aires, Argentina

Estágio

Anteprojeto

Observações

Não construído

Menção Honrosa no Concurso Internacional de Projetos

\section{Características}

Destacado com menção honrosa, este projeto foi realizado para abrigar a Coleção Constantini por ocasião de um Concurso Internacional de Arquitetura que contou com a participação de 450 projetos provenientes de 45 países diferentes.

A partir de uma cuidadosa leitura do sítio, a solução proposta por Eduardo de Almeida cria o acesso público pela esquina por Eduardo de Almeida cria o acesso público pela esquina
principal do lote, por um vazio configurado por dois volumes principal do lote, por um vazio configurado por dois volumes áreas técnicas e administrativas - e por um pavilhão destinado aos espaços de uso público voltado à praça 0

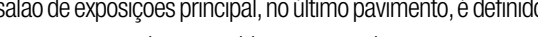

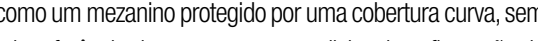
a interferência de estruturas e a tradicional configuração de pequenas salas emparedadas, talvez influenciado pelo salão de exposições do MASP. Os demais pavimentos de uso público relacionam-se visualmente com a praça por meio de um fechamento de vidro inclinado que garante a necessária proteção solar aos ambientes internos, além de configurar proteção solar aos ambientes internos, além de configura praça - térreo e subsolo -, permitindo acesso independente a programas como restaurante e auditório.

Acervo

Tubo 97 e Backup 308
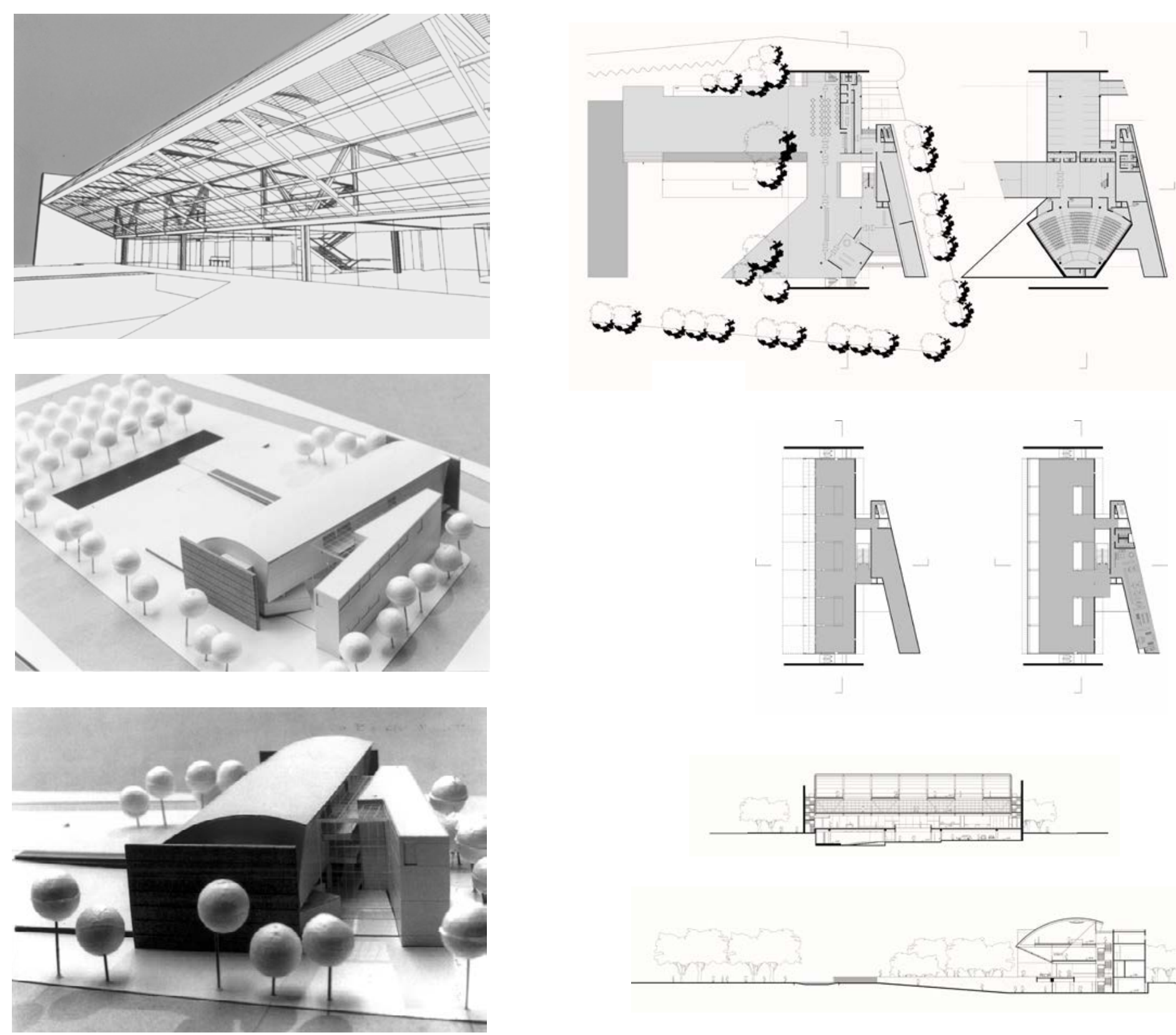
Uso

Residência Unifamiliar

Cliente

Eduardo de Almeida

Equipe

Eduardo de Almeida

colaboradores I Flávia Pagotti Silva e Maria Isabel

Imbronito

Localização

Laranjeiras, Paraty, RJ

Estágio

Projeto Executivo

Observações

Construído

Características

Construída por meio de uma estrutura de madeira fornecida pelo engenheiro Hélio Olga, a cobertura

de quatro águas foi concebida como uma proteção

para a execução da própria obra. Uma vez montada

a grelha estrutual de madeira serviu de gabarito $e$

permitiu a construçãa dos dois volumes laterais de

dois pavimentos, utilizando-se técnicas tradicionais.

Entre eles, foi criado um espaço vazio de pé-direito

duplo destinado à sala, pensada como uma varanda

coberta capaz de interligar os pátios frontal e de fundos.

A planta de geometria quadrada com dois eixos de

simetria referenciam esta casa à obra de Palladio, mas

também à arquitetura bandeirista de São Paulo. Toda a

caixilharia foi pintada de azul e laranja, segundo Eduardo

de Almeida, referência às pinturas dos barcos de pesca

da região.

Acervo

Tubo 91, Caixa 4700 e Backup 309
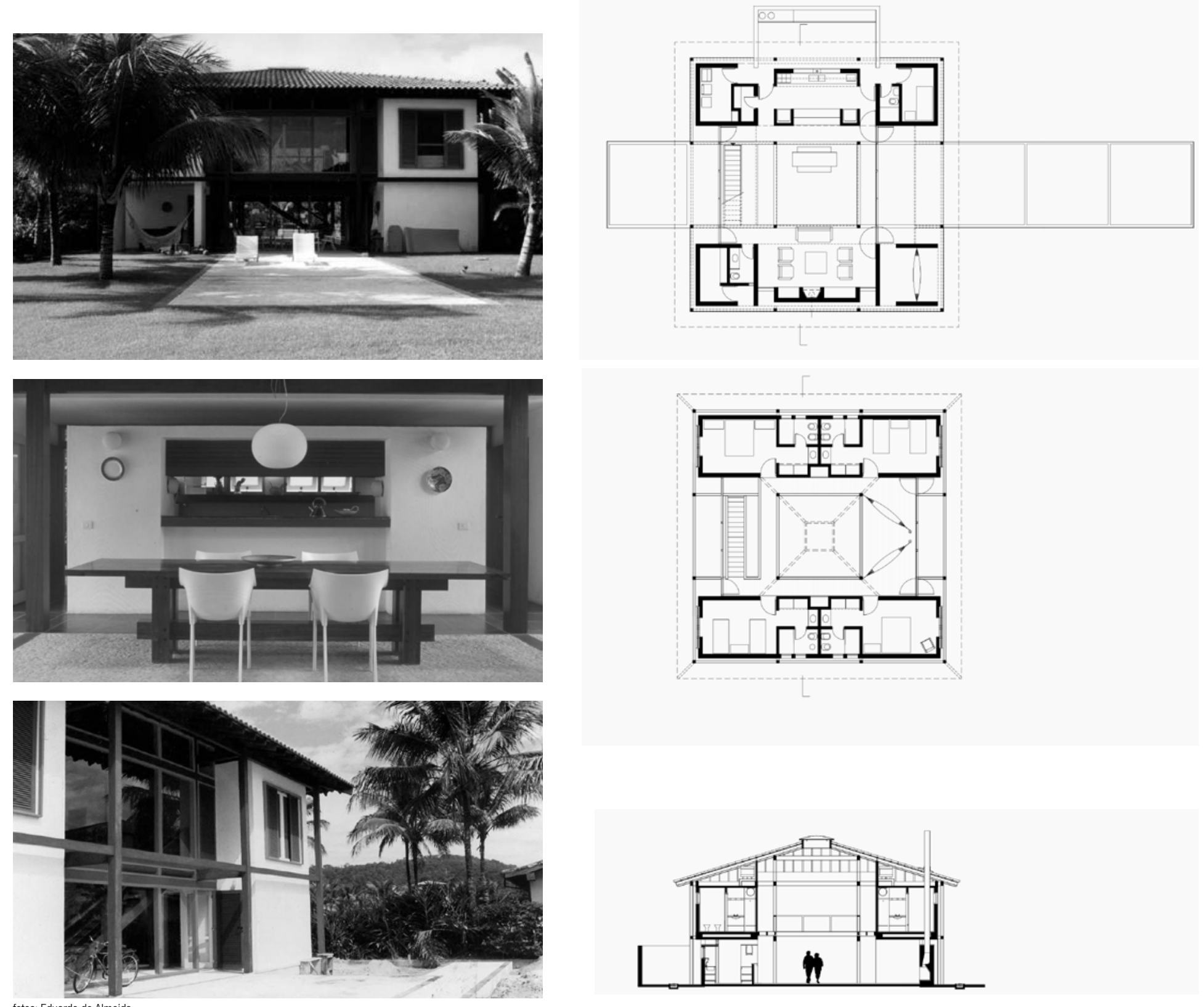
Uso

Residência Unifamiliar

Cliente

Eduardo Tess

Equip

Eduardo de Almeida

Localização

Rua Olegário Mariano, São Paulo, SP

Estágio

Projeto Executivo

Observações

Não construído

Características

Localizada em terreno com acentuado aclive, o projeto desta casa implanta-se em três pavimentos, tirando partido do pátio interior do piso intermediário destinado

aos espaços de uso coletivo. No pavimento destinado

aos quartos, com

foi criado um pátio externo com piscina, aproveitando 0

trecho mais ensolarado do lote.

Acervo

Tubo 68, Caixa 1600 e Backup 315
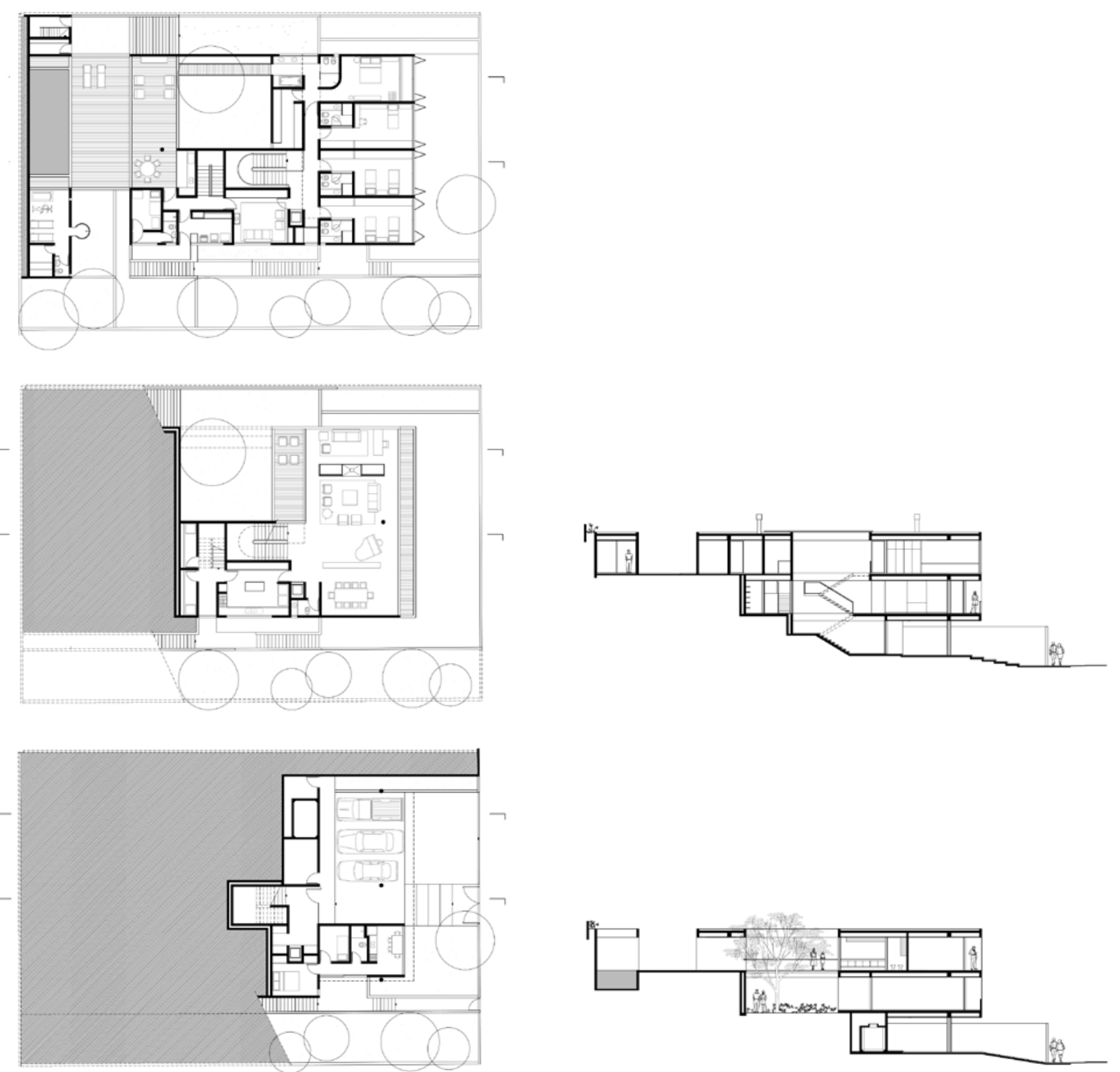
Uso
Biblioteca

Cliente

oteca Guita e José Mindlin

Equipe

Eduardo de Almeida, Flávio Mindlin Guimarães e Rodrigo Mindlin Loeb

Localizacão

Rua da Reitoria, Cidade Universitária, SP

Estágio

Observacões

Não construído

\section{Características}

A realização deste importante projeto foi confiado a Eduardo de Almeida por seu amigo José Mindlin, por ocasião da doação de sua coleção de livros raros para a Universidade de São Paulo. Este primeiro estudo, considerava a criação de um embasamento destinado às funções técnicas e programas de apoio como 0 auditório, foyer e recepção. Esta plataforma, permitia 0 acesso ao edifício junto ao térreo e, por meio de uma escadaria, dava acesso à rua localizada em cota elevada, configurando um edifício desenhado como uma passagem pública. Sobre este embasamento, um conjunto formado por uma lâmina flexível - destinada à área de trabalho - e pelo volume da biblioteca fo articulado por um vazio, onde se implantavam as torres de circulacão vertical. Assim como no projeto final, uma cobertura solta garante a proteção aos recintos que abrigam os livros raros ao mesmo tempo em dá unidade ao volume. Segundo Eduardo de Almeida, na primeira visita ao Campus, inúmeros terrenos foram apresentados pelo reitor da Universidade, mas nenhum atendia às expectativas de Mindlin que, ao final, perguntou pela disponibilidade da encosta localizada junto ao prédio da reitoria, próximo à entrada da Universidade.

Acervo

Caixa 5100, 5110 e 5120 e Backup 350
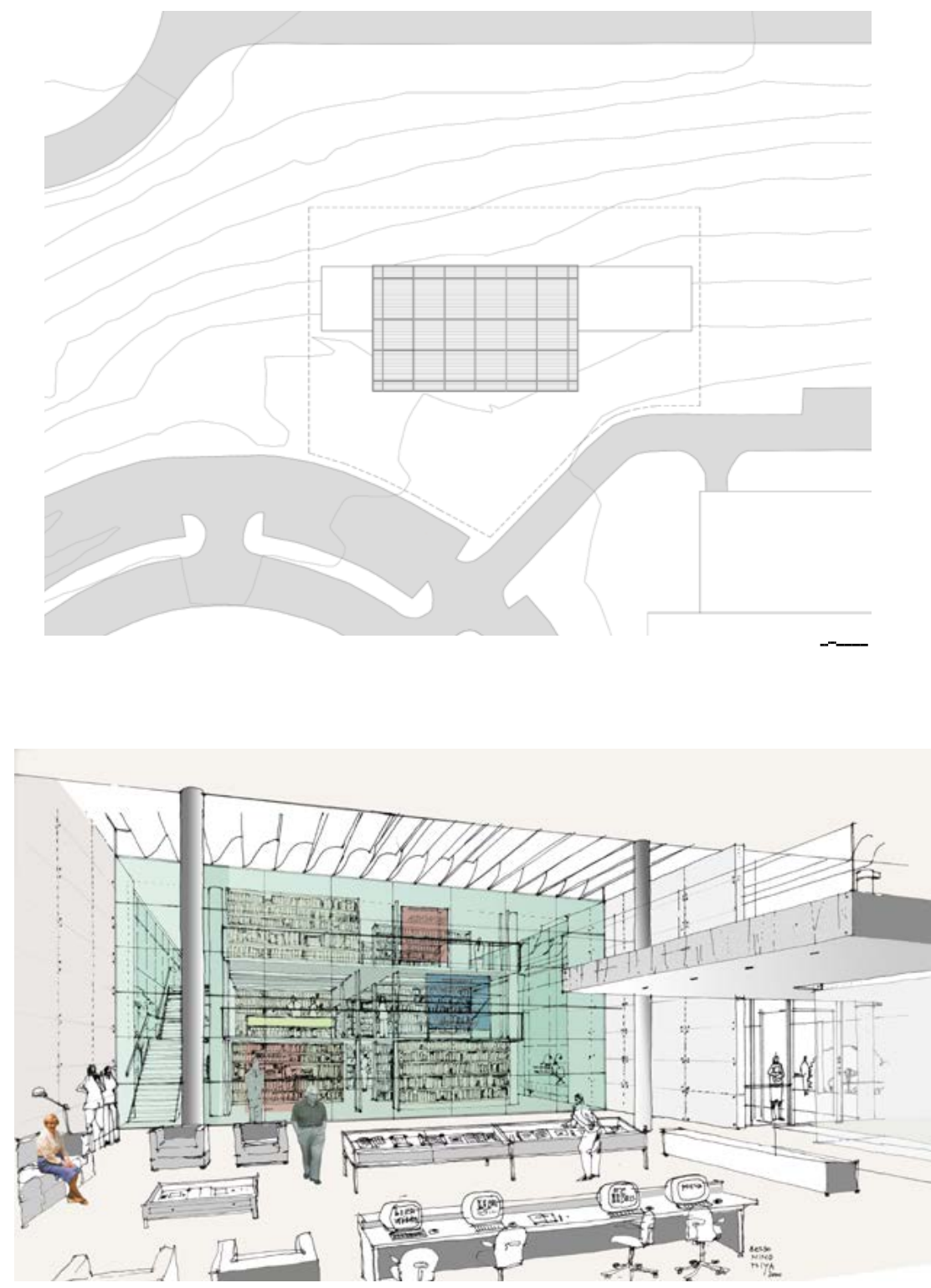
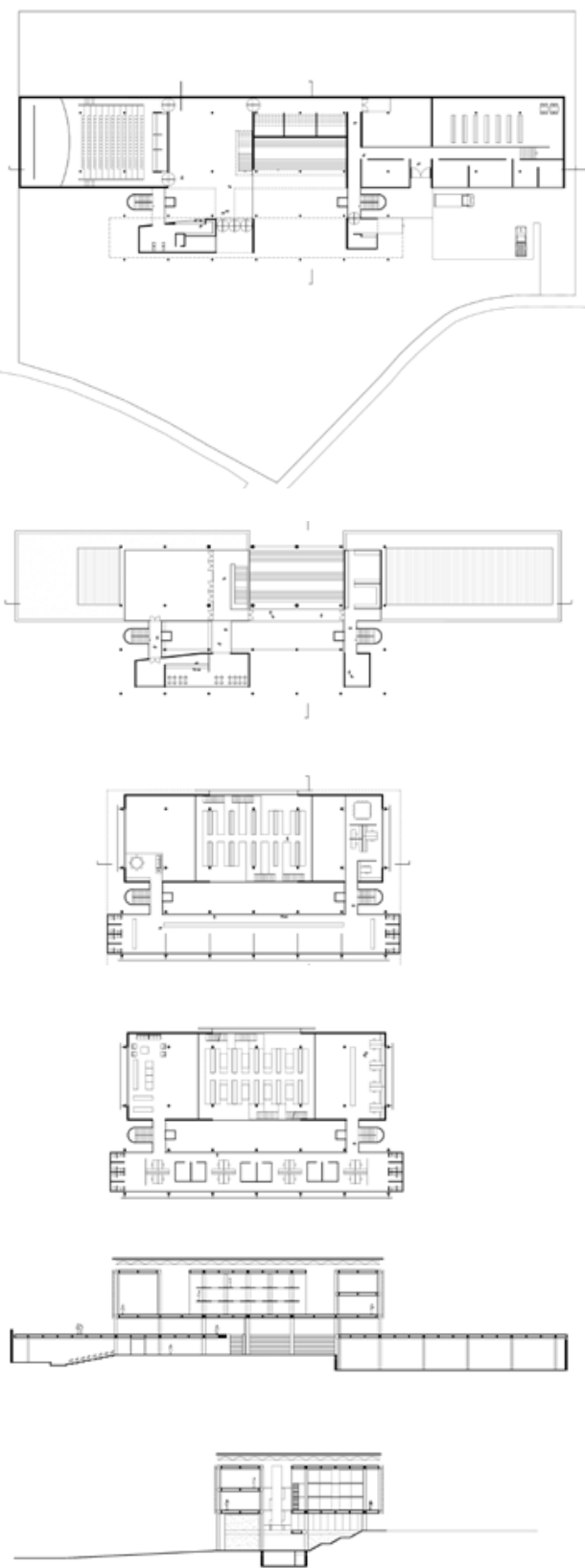
Biblioteca

Cliente

Biblioteca Guita e José Mindlin

Equipe

Eduardo de Almeida e Rodrigo Mindlin Loeb

Localização

Rua da Reitoria, Cidade Universitária, SP

Estágio

Anteprojeto

Observações

Não construído

\section{Características}

Durante o longo processo de realização deste projeto, foi pensada uma segunda proposta para abrigar, além da Biblioteca Guita e José Mindlin, uma coleção brasiliana de artes plásticas. Neste momento surge a proposta de se criar uma praça coberta central destinada a duas instituições que poderiam compartilhar uma infraestrutura de serviços e programas como exposições e auditório. Tal partido apresenta a organização dos livros raros em um anel, de acordo com a solução finalmente utilizada no edifício construído, mas por outro lado, elimina a intenção de se criar uma passagem pública através do edifício. 0 processo de doação da coleção de arte não se concluiu, mas a ideia de ampliar o programa da biblioteca para se criar um Centro de Estudos Brasileiros da USP foi iniciada.

Acervo

Caixa 5100, 5110 e 5120 e Backup 350
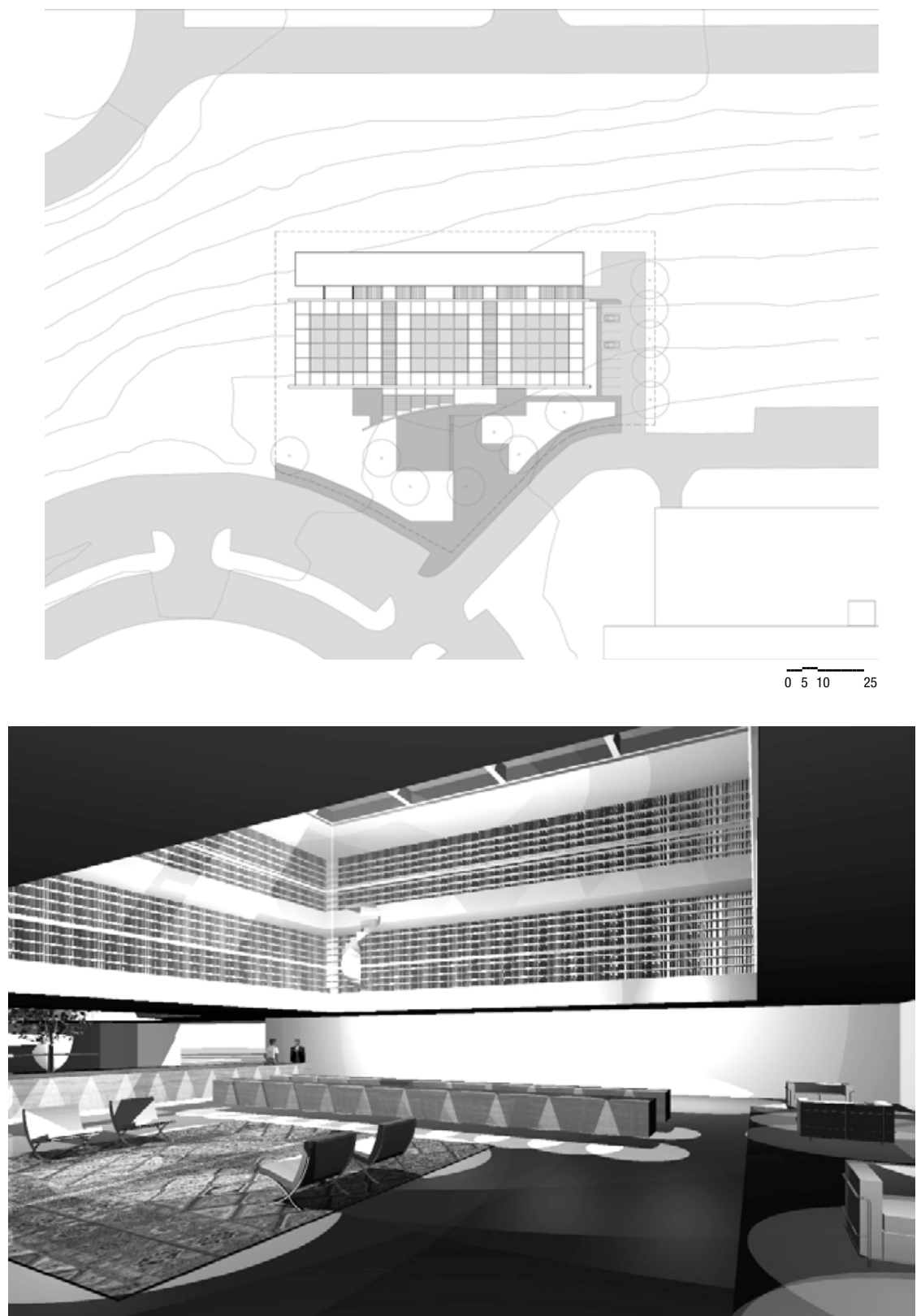
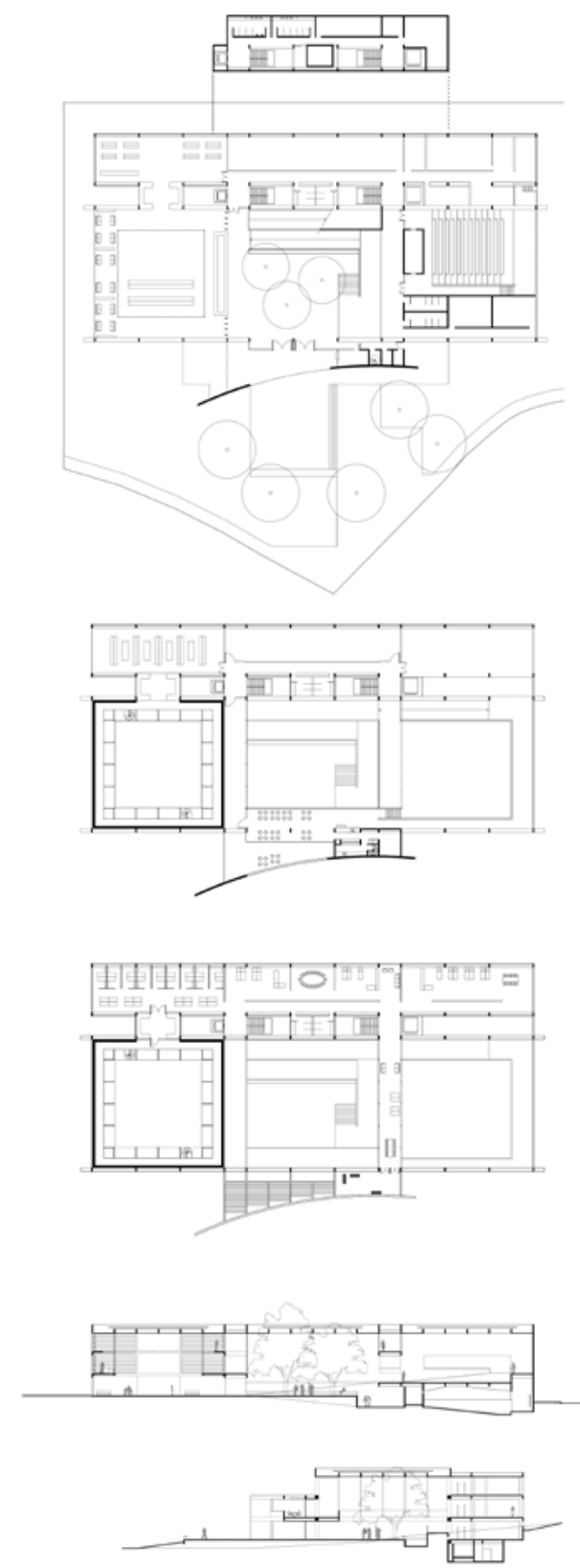
Uso

Biblioteca

Cliente

Biblioteca Guita e José Mindlin e IEB

Equipe

Eduardo de Almeida e Rodrigo Mindlin Loeb

colaboradores I Caio Atilio Dotto, Carlos Sandler, Cecilia Heichstul, Leonardo Sette, Cesar Shundi Iwamizu, Felipe

Noto, Juan Gonzalez Calderón, Jorge Spangenberg

Luana Radesco, Maira Rios, Marina Loeb, Marina

Colonelli, Nana Blanaru e Roberto Zocchio Torresan

Localização

Rua da Reitoria, Cidade Universitária, SP

Estágio

Projeto Executivo

\section{Observações}

Construído

$2^{\circ}$ Lugar na IX Bienal Iberoamericana de Arquitetura

Urbanismo - Rosário, Argentina

Características

Com a colaboração de István Jancsó, então diretor do IEB - Instituto de Estudos Brasileiros, iniciaram-se os primeiros estudos para a criação do Centro de Estudos Brasileiros da USP, agregando a Biblioteca Guita José Mindlin ao IEB e viabilizando a criação de uma praça coberta com auditório, exposições e serviços compartilhados. Ao mesmo tempo em que uma ligaçãa transversal em rampa conecta as duas vias de acesso um eixo longitudinal configura a interligação entre os espacosos vazios da Biblioteca Mindlin e do IEB, espacos de caráter distintos que articulam as diversas funções das duas instituições.

Acervo

Caixa 5100, 5110 e 5120 e Backup 350
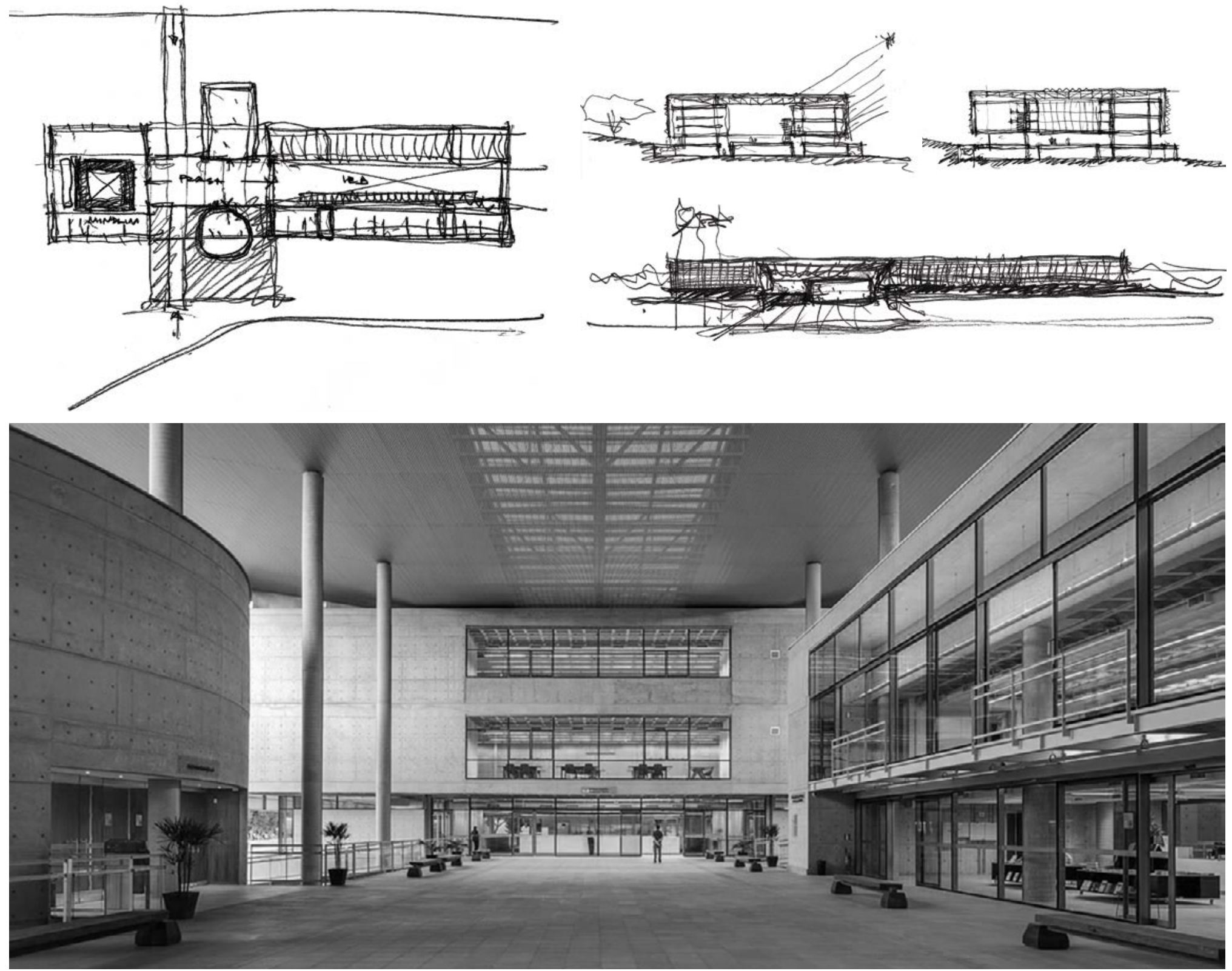

foto: Nelson Kon 
Residência Unifamiliar

Cliente

Pedro Luis Ferreira da Silva

Equipe

Eduardo de Almeida

colaboradora I Maria Isabel Imbronito

\section{Localização}

Rua Dois, Ilha Bela, SP

Estágio

Projeto Executivo

\section{Observações}

Construído

\section{Características}

Utilizando-se estrutura de madeira fornecida pelo engenheiro Hélio Olga, esta casa implantada em Ilhabela

considerou 0 terreno em declive, sendo organizada em

três patamares principais: um piso inferior destinado à

área de lazer com piscina, um piso intermediário com

sala de pé-direito duplo, cozinha e dormitório do casal e,

por fim, um piso com seis dormitórios localizado junto ao

acesso principal da casa.

Acervo

Caixa 2600 e Backup 317
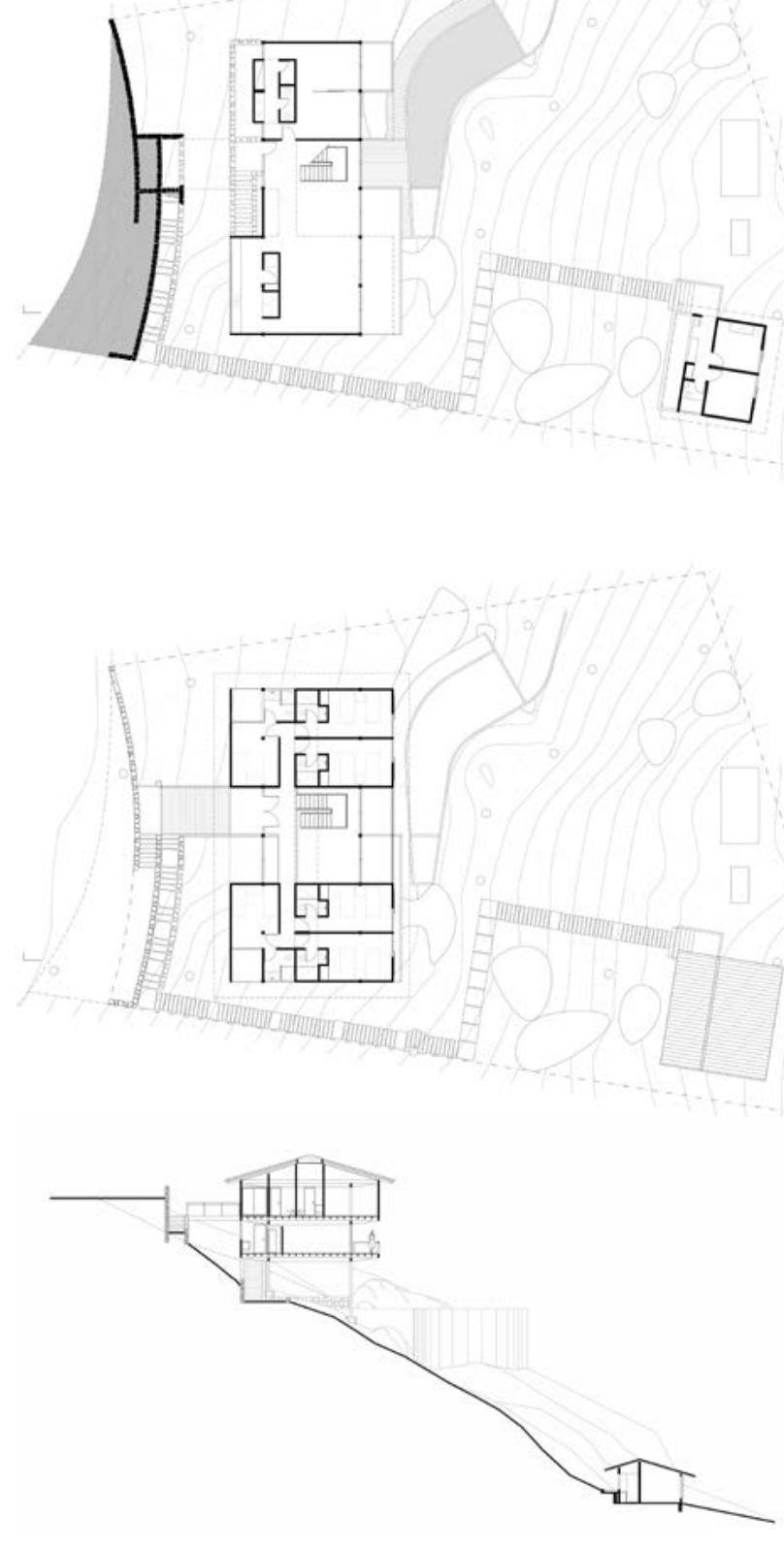
Uso

Residência Unifamiliar

Cliente

Ricardo Lacerda Soares

Equipe

Eduardo de Almeida

colaboradores I Cynthia Callia, Leonardo Sette, Maria

Isabel Imbronito e José Antônio Seixas

estrutura | Hélio Olga Jr.

Localização

Praia Vermelha, Ubatuba, SP

Estágio

Projeto Executivo

Observações

Construído

Características

Dando continuidade às experiências com 0 engenheiro

Hélio Olga, esta casa em Ubatuba foi implantada em

meia encosta, partindo de um platô construído por

muros de pedras e avançando junto ao declive por

meio de uma estrutura de madeira que cria um piso

coberto de chegada. Tal condição permite que seja feita

uma construção de dois pavimentos, considerando o

posicionamento das áreas comuns no térreo e os três

dormitórios no andar superior. Retomando a experiência

das casas projetadas para a llha do Pasto (1988), a

estrutura de madeira é complementada com uma torre

de escadas construída com estrutura de concreto e

fechamentos de alvenaria, além da cobertura de duas

águas com telhas cerâmicas.

Acervo

Caixa 2700 e Backup 318
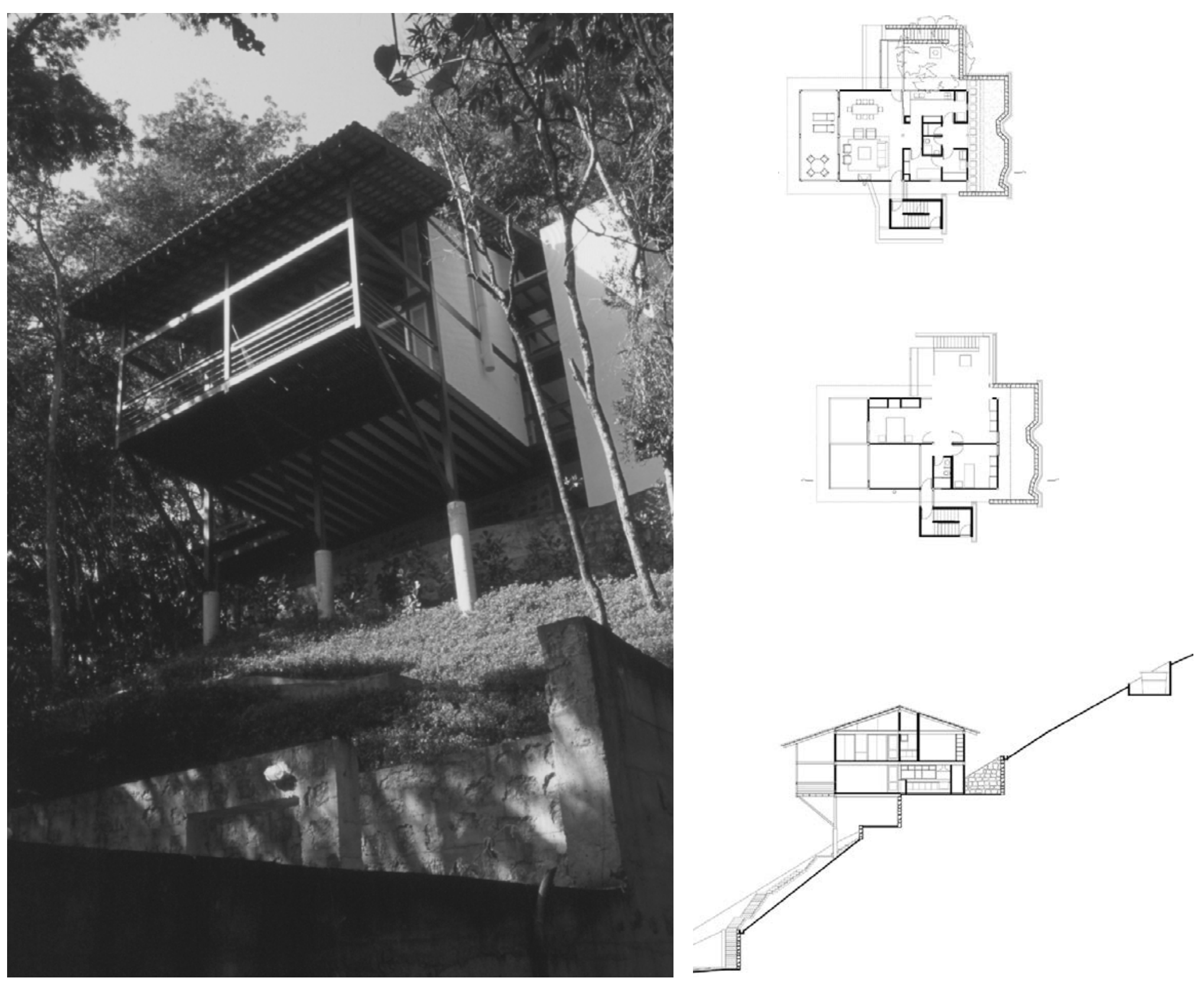
Residência Unifamilar

Cliente

Carlos Alberto Rossi

Equipe

Eduardo de Almeida

colaboradores I José Antônio Seixas e Maria Isabel

Imbronito

Localização

Rua Puréus, Morumbi, São Paulo, SP

\section{Estágio}

Projeto Executivo

\section{Observações}

Reforma com acréscimo de área

\section{Características}

Considerando a geometria do lote em esquina e a

construção pré-existente, Eduardo de Almeida cria um

anexo em estrutura metálica - destinado a um pavilhão

de lazer - e uma contenção com muros de arrimo de

concreto para a criação de uma garagem com acesso

direto da rua.

Acervo

Tubo 93, Caixa 2000 e 2600 e Backup 320 e 321
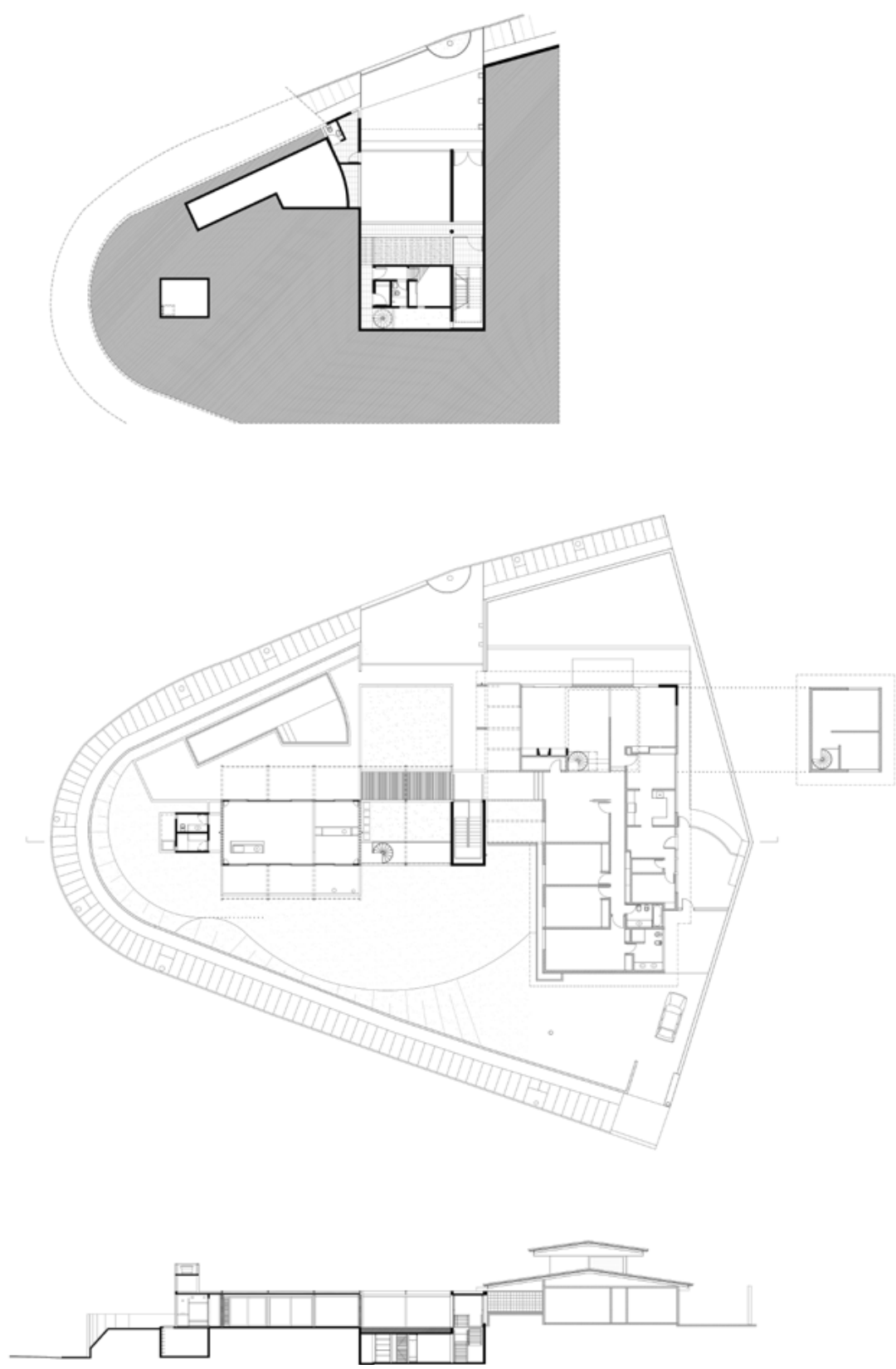

- Construção existente A construir 
Uso

Residência Unifamiliar

Cliente

Carlos Alberto Rossi

Equipe

Eduardo de Almeida

Localização

Campos do Jordão, SP

Estágio

Projeto Executivo

Observações

Não construído

Características

Seguindo o mesmo partido formal da residência Filizola (1995) - emprego de estrutura metálica com cobertura de duas águas associada a muros de pedra de grandes dimensões - esta casa notabiliza-se pela implantacão do volume - en confronto com a acentuada declividade

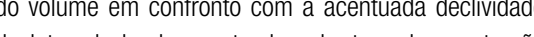
do lote, nivelando a cota de cobertura da construção com o cume da encosta, onde se implanta a área de lazer do conjunto.

Acervo

Tubo 93, Caixa 2000 e 2600 e Backup 320 e 321
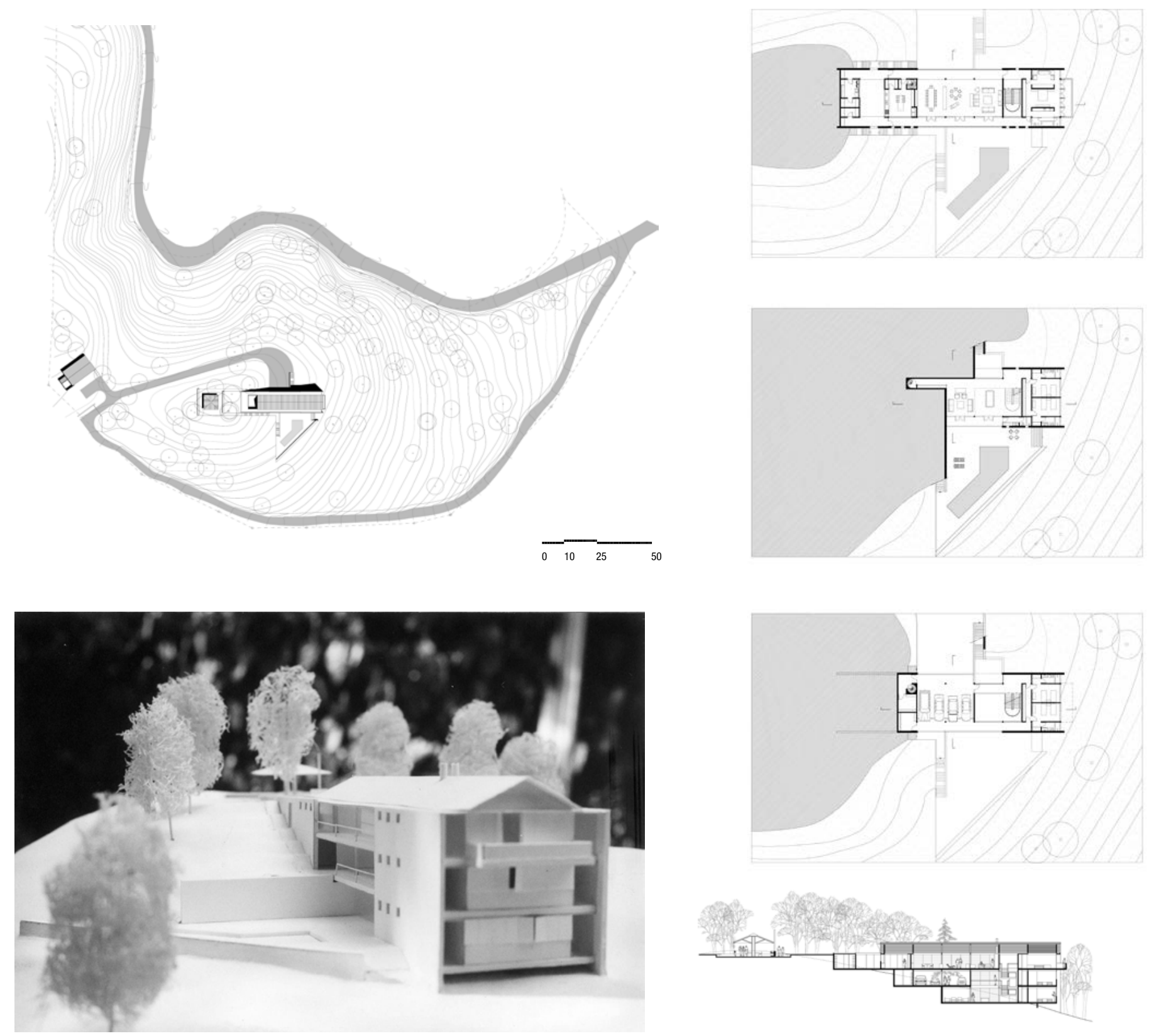
Residência Unifamiliar

Cliente

Cidinha Brito

Equipe

Eduardo de Almeida

Localização

Mato Grosso do Sul

Estágio

Estudo Preliminar

Observações

Não construído

Características

Projetada para a mesma família da casa Pacheco e Silva (1993), Eduardo de Almeida realizou este estudo para a casa sede de uma fazenda, utilizando-se de

técnicas - alvenaria e estrutura de madeira - e partido

arquitetônico tradicionais, já que 0 grande telhado de

quatro águas cria uma varanda perimetral ao redor

da casa e a sala configura-se como um espaço vazio

posicionado entre 0 setor dos quartos e 0 de serviços.

Acervo

Backup 329
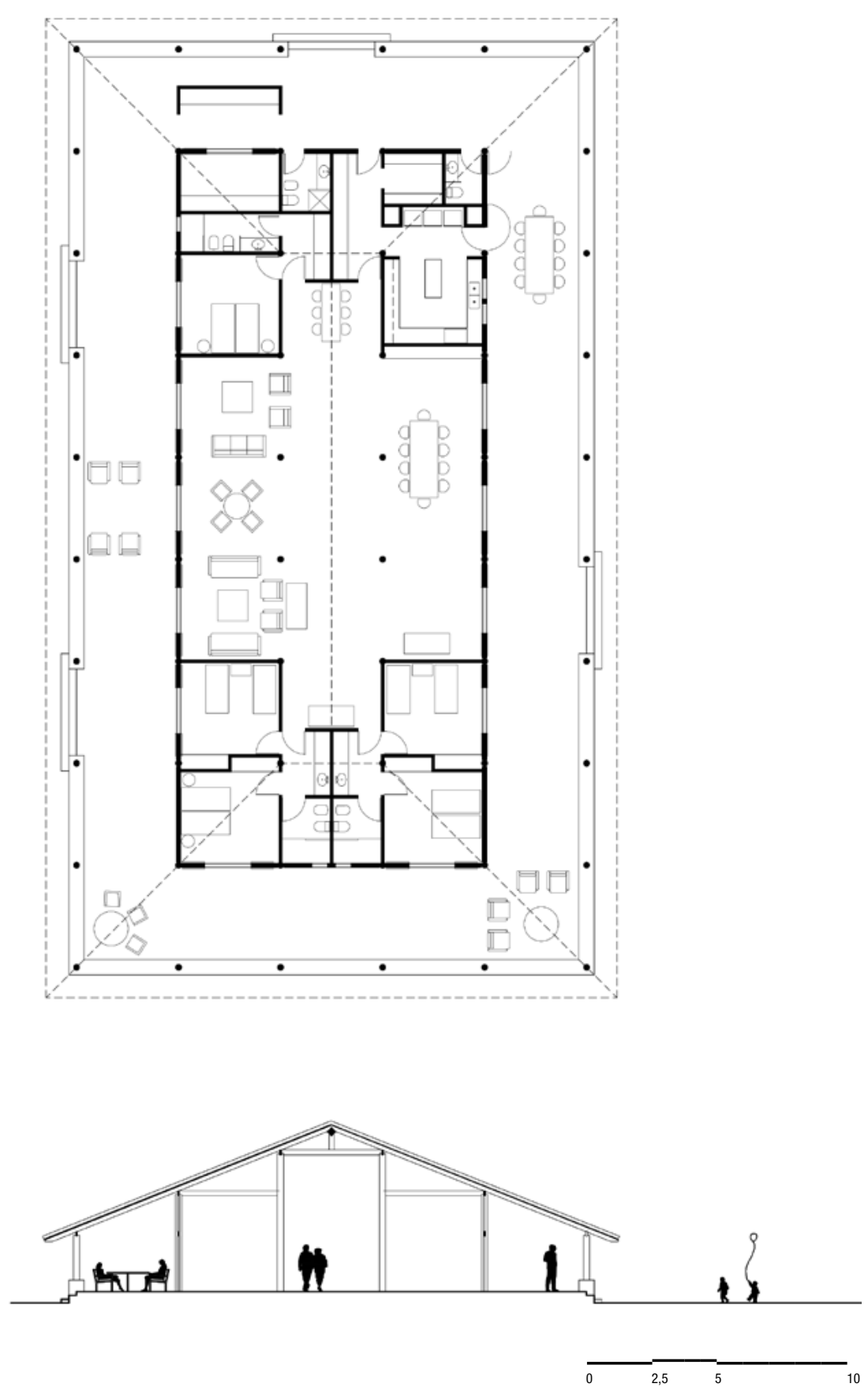
Uso

Residência Unifamiliar

Cliente

Ricardo Guimarães

Equipe

Eduardo de Almeida

colaborador I Leonardo Sette

\section{Localização}

Rua Mariana Correa, São Paulo, SP

\section{Estágio}

Projeto Executivo

\section{Observações}

Não construído

Características

Projetada para o mesmo cliente de uma casa realizada

em conjunto com Arnaldo Martino em 1985, este

projeto retoma algumas das questões apresentadas

anteriomente, dada a semelhança na configuração

do lote e do programa de necessidades. A sequência

de ambientes no pavimento térreo, a implantação da

escada junto a uma das divisas em espaço iluminado

naturalmente, a abertura dos dormitórios para 0 outro

recuo - agora interiorizado como parte do volume apesar

de se configurar como espaço externo - são atributos

que se repetem nesta casa. Neste caso específico,

podemos destacar a simplicidade da estrutura metálica

utilizada, sem a presença de grandes vãos, e a cobertura

em arco do pavimento superior.

Acervo

Backup 327
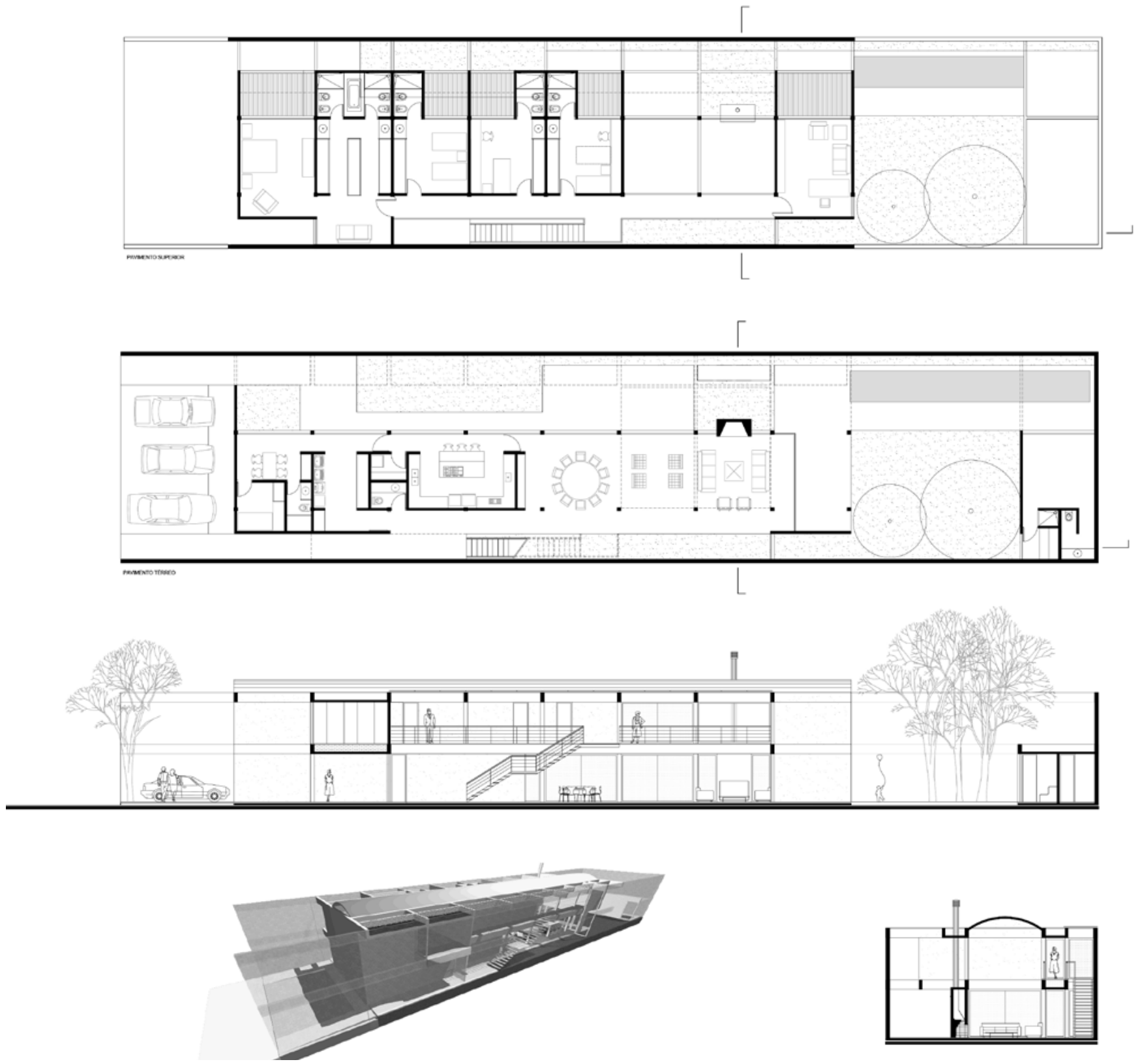
Uso

Edifício de Habitação Coletiva

Cliente

Construtora Paulista S.A.

Equipe

Eduardo de Almeida

Localização

Av. José André de Morais, Taboão da Serra, SP

Estágio

Projeto Executivo

Observações

Não construído

Características

Retomando a experiência de projetos como Edifício Granja Julieta (1979) e Palacete da Águias (1986), este projeto cria uma torre de vinte pavimentos implantada sobre o embasamento da garagem. Neste caso, a acentuada verticalidade do edifício é rompida pela horizontalidade da caixilharia dos dormitórios e da sala, também evidenciadas pela geometria das varandas em balanço.

Acervo

Tubo 72, Caixa 4200 e Backup 312
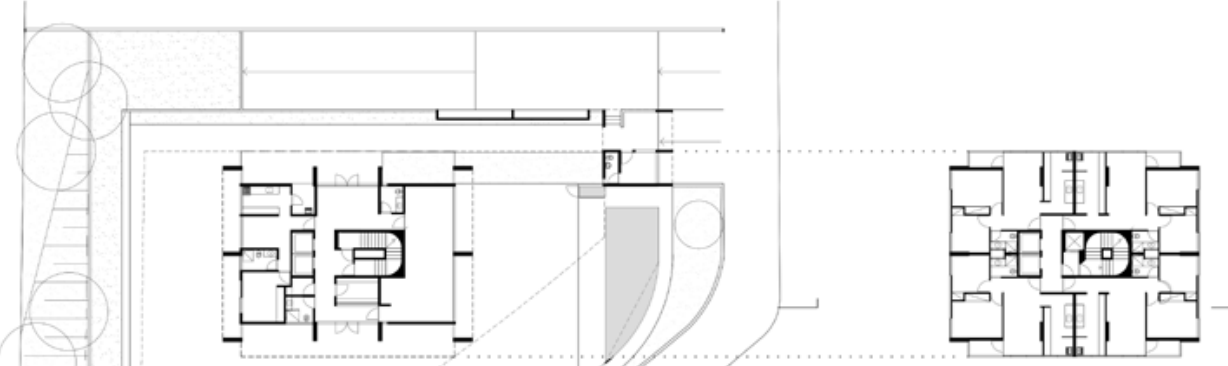
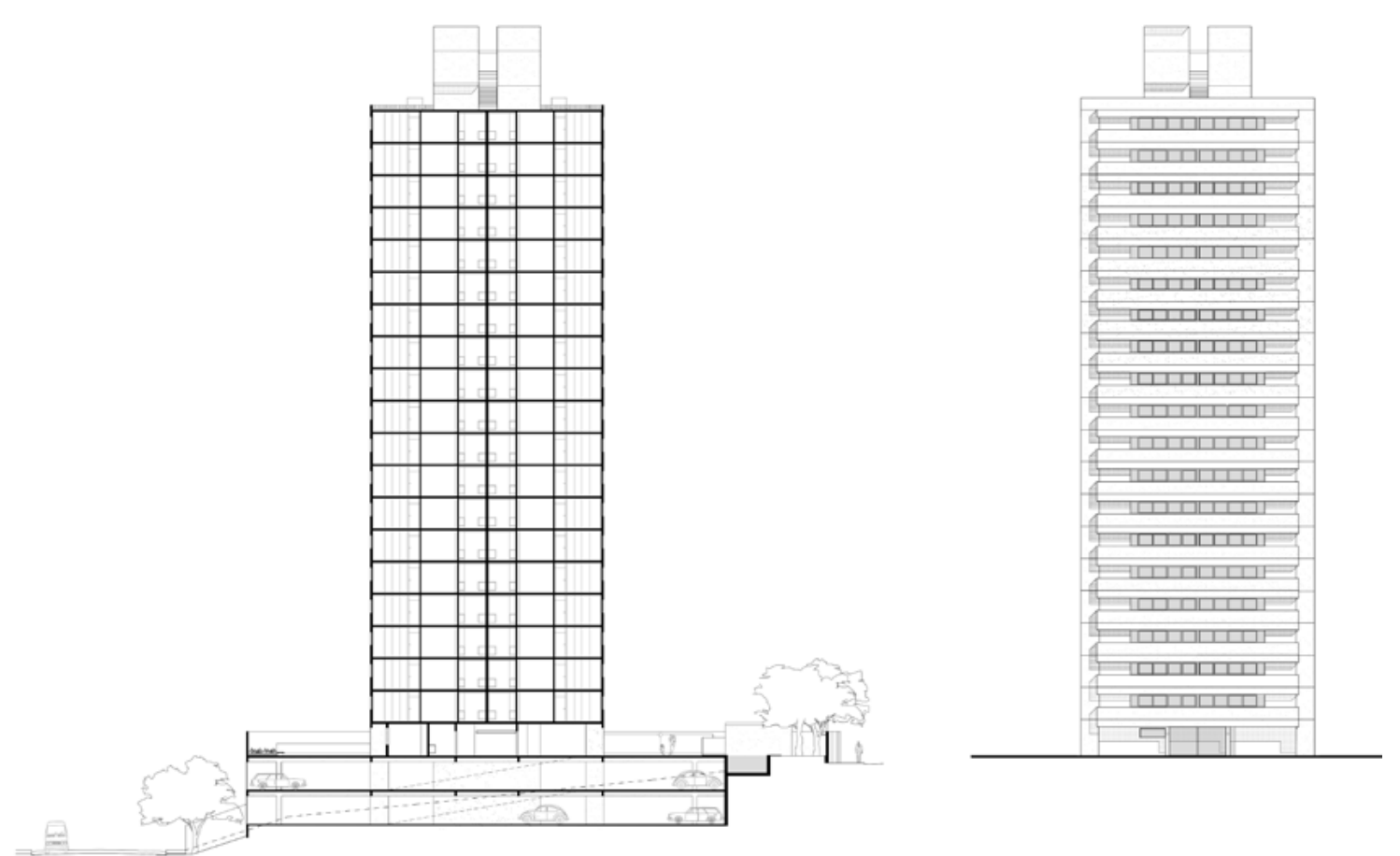
Uso

Restaurante

Cliente

Marcos Ferreira da Rosa

Equipe

Eduardo de Almeida

colaboradores I Cesar Shundi Iwamizu, Cyntia Callia e

Leonardo Sette

\section{Localização}

Rua Girassol, Vila Madalena, São Paulo, SP

Estágio

Projeto Executivo

Observações

Construído

\section{Características}

Inicialmente desenhado como uma salão coberto com

fachada envidraçada, aproveitando a relação com a rua,

o projeto finalmente construído para este restaurante na

Vila Madalena configura-se com a construção de uma

grelha metálica regular em contraponto com o volume

curvo que abriga a entrada e termina por dar hierarquia

aos acessos público e de serviços. Tal geometria, cria um

percurso de entrada que se abre lentamente ao salão do

restaurante de pé-direito duplo, ao mesmo tempo em

que se define o espaço da cozinha e demais servicos.

Acervo

Caixa 2800 e Backup 314
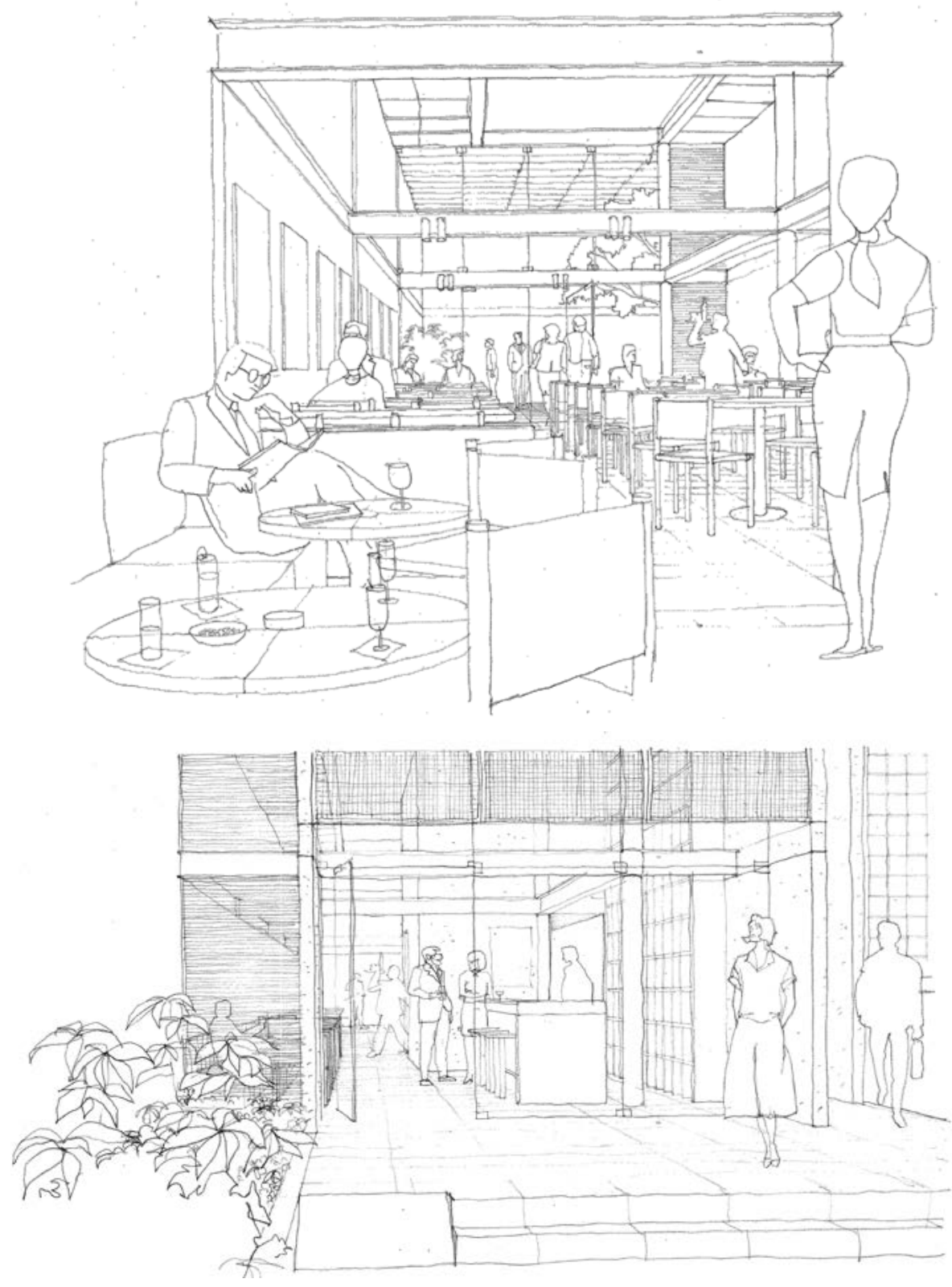
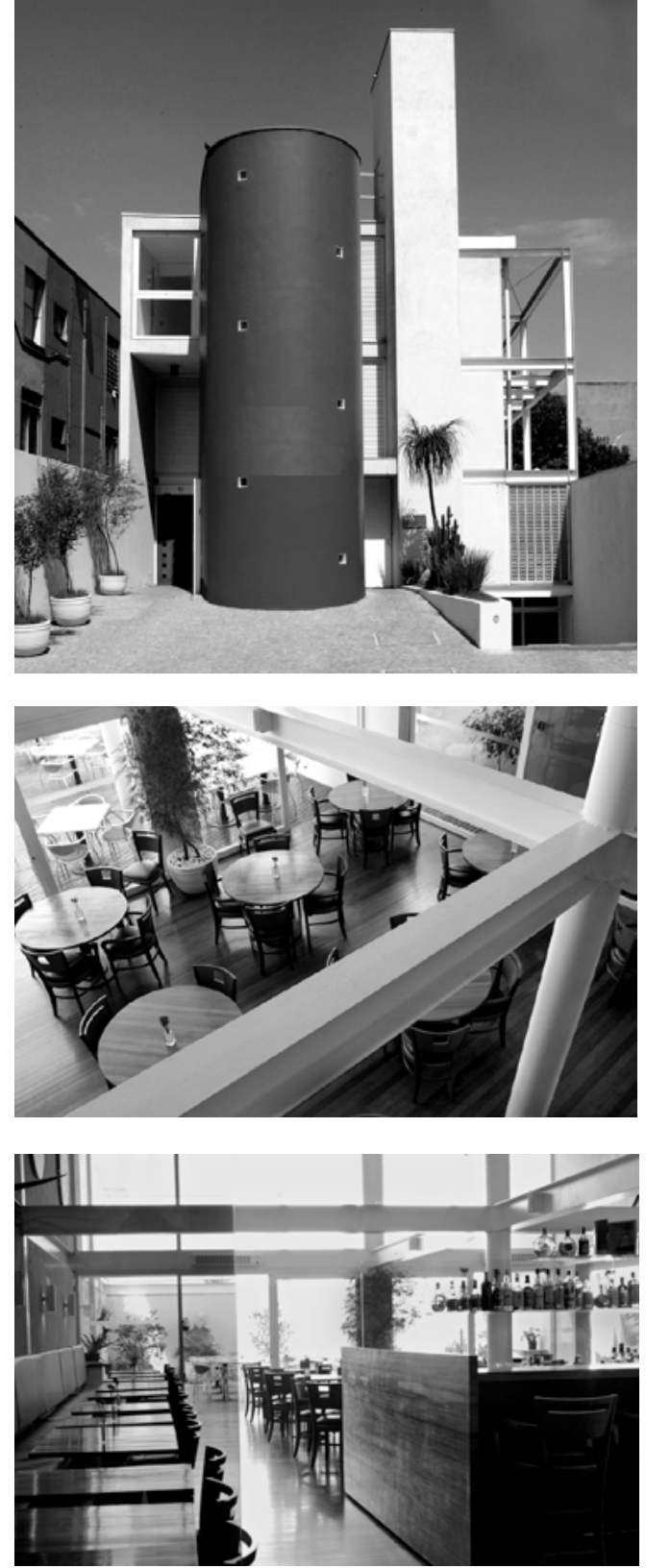
Uso

Museu de Arte Contemporânea

Equipe

colaboradores I Cesar Shundi Iwamizu, Leonardo Sette

e Maria Isabel Imbronito

consultores | Alberto Tassinari e Nuno Ramos

maquete I Eduardo Crafig

\section{Localização}

Barra Funda, São Paulo, SP

\section{Estágio}

Anteprojeto

\section{Observações}

Não construído

\section{Características}

0 processo de trabalho para este projeto, apesar de árduo, foi extremamente rico. Realizado em conjunto com o crítico Alberto Tassinari e com o artista plástico Nuno Ramos, as conversas iniciais revelaram um interessante debate sobre as fronteiras entre arte e arquitetura e se estenderam por um bom tempo, restando um prazo exíguo para as resoluções específicas do projeto de arquitetura, mas revelando também o posicionamento claro de Eduardo de Almeida em defesa das limitações impostas pela técnica e pelo programa em detrimento da liberdade de expressão plástica e retórica no objeto arquitetônico. Após a investigação de inúmeros partidos, a proposta finalmente apresentada foi a de um edifício interiorizado, cujo programa foi organizado ao redor de dois vazios internos, ao mesmo tempo em que toda a circulação acontecia exteriormente pela adição de uma estrutura metálica anexa às empenas de concreto principais.

Acervo

Backup 333
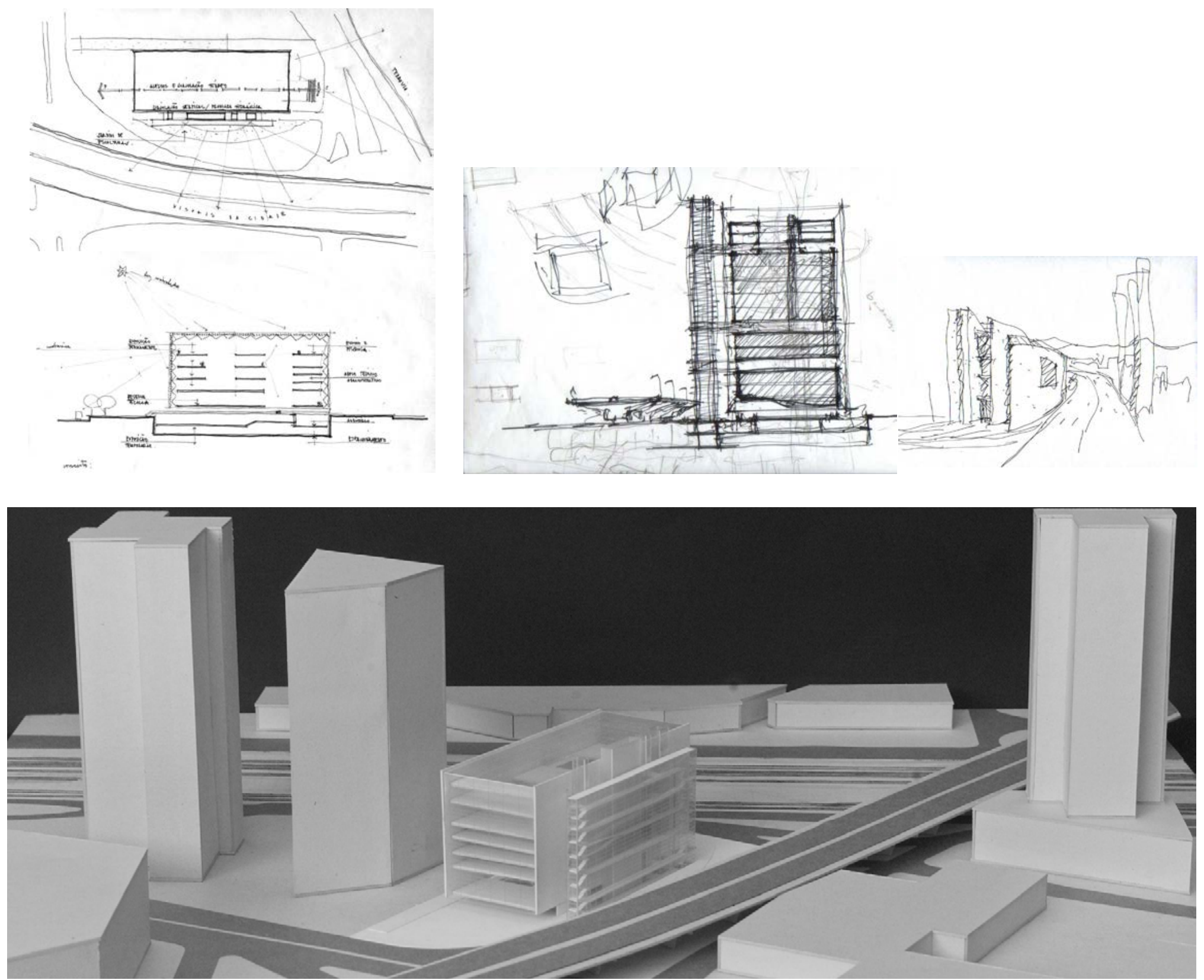
Uso

Residência Unifamiliar

Cliente

Marcos Lanna

Equipe

Eduardo de Almeida

colaborador I Leonardo Sette

\section{Localização}

Curitiba, PR

Estágio

Projeto Executivo

\section{Observações}

Construído

\section{Características}

Considerando o caráter da rua sem saída e a presença da mata localizada no fundo do lote, esta casa implanta-

se em dois pavimentos, privilegiando a relação de

continuidade entre os espacos internos e externos. Ao

enfrentar a topografia do terreno e a geometria do lote,

Eduardo de Almeida cria uma piscina junto ao recuo

lateral, definida pela presença de um muro curvo,

retomando experiências como a das áreas livres da casa

Define (1975), e explicitando a influência dos projetos do

arquiteto japonês Tadao Ando.

Acervo

Caixa 1800 e Backup 332

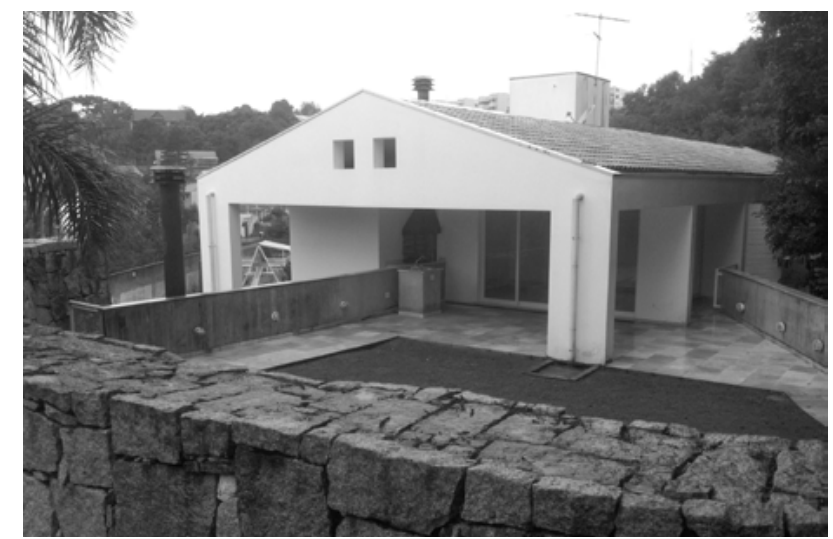

foto: Marcos Lanna
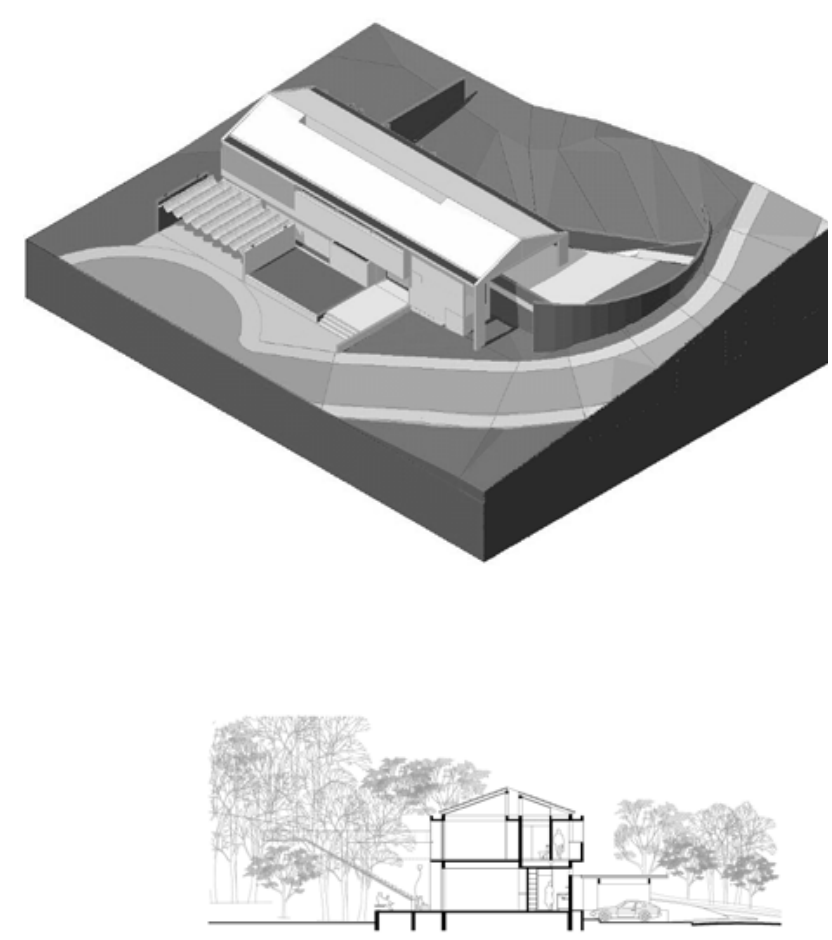
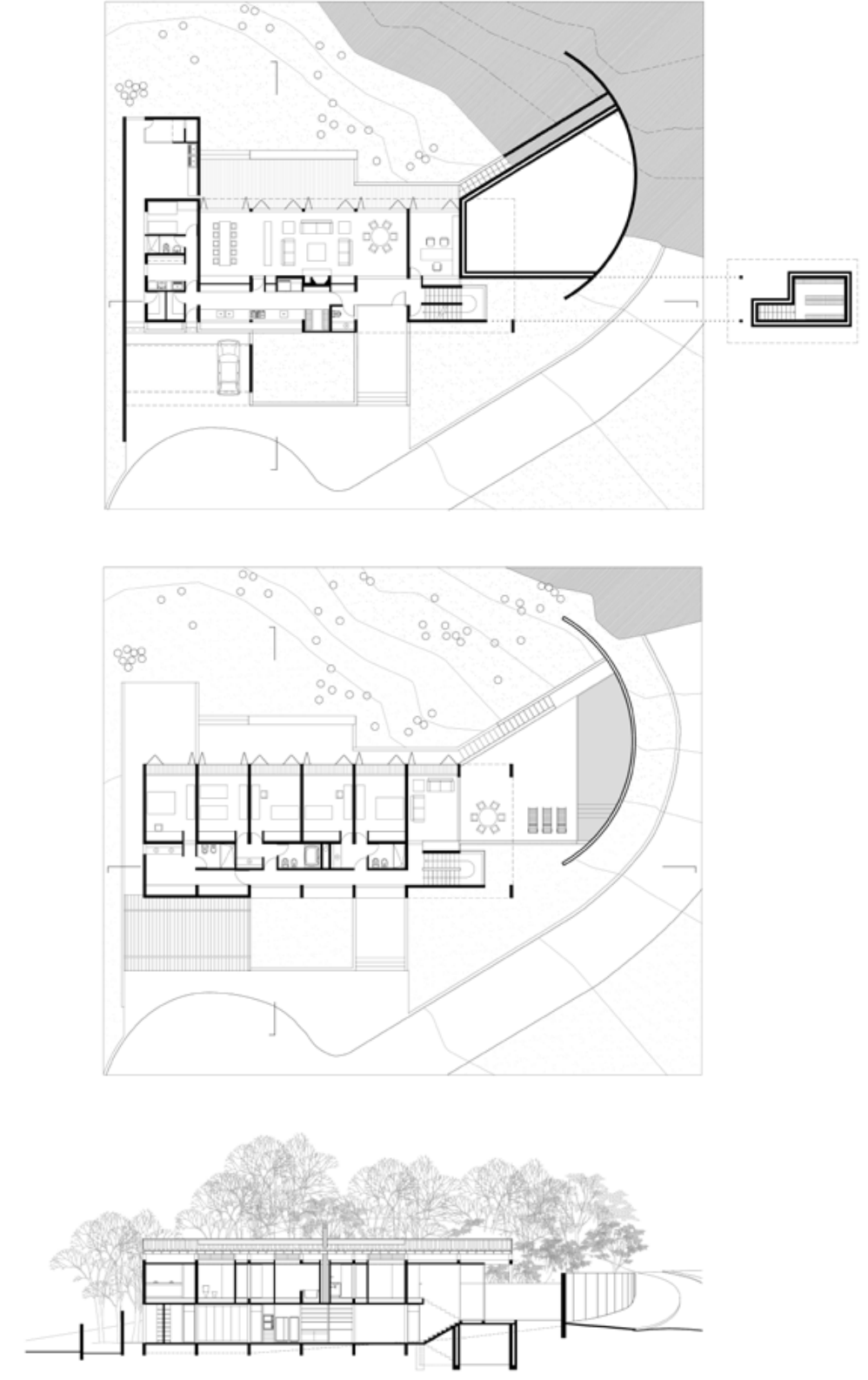
Tipologia

Reforma e ampliação de residência

Cliente

Eduardo Tess

Equipe

Eduardo de Almeida

colaboradores I Cesar Shundi Iwamizu, Leonardo Sette

e Maria Isabel Imbronito

estrutura | Hugo Tedeschi

paisagismo I Fernando Chacel e Sidney Linhares

Localização

Rua Dr. Alberto de Faria, Alto de Pinheiros, São Paulo, SP

Estágio

Projeto Executivo

Observações

Projeto de reforma construído

Projeto original - arquiteta Diana Malzon

\section{Características}

Após desistir da construção da casa no Morumb

(1999), Eduardo Tess adquiriu uma residência

projetada pela arquiteta Diana Malzoni em 1974

uma estrutura de concreto armado com vedações de

alvenaria aparente e organização dos programas em

meios-níveis. A intervencão proposta por Eduardo de

Almeida foi 0 acréscimo de um pavilhão linear de dois

pavimentos destinado a atividades de lazer e serviços,

possibilitando novas relações com 0 jardim e com 0

volume pré-existente. Internamente, a reforma aproveita

a configuração original da casa, mas utiliza 0 espaço

central ao lado das rampas como um pátio ajardinado,

iluminado zenitalmente pelo aum

transversais anteriormente localizados sobr

de rampas.

Acervo

Tubo 68, Caixa 1600 e Backup 315
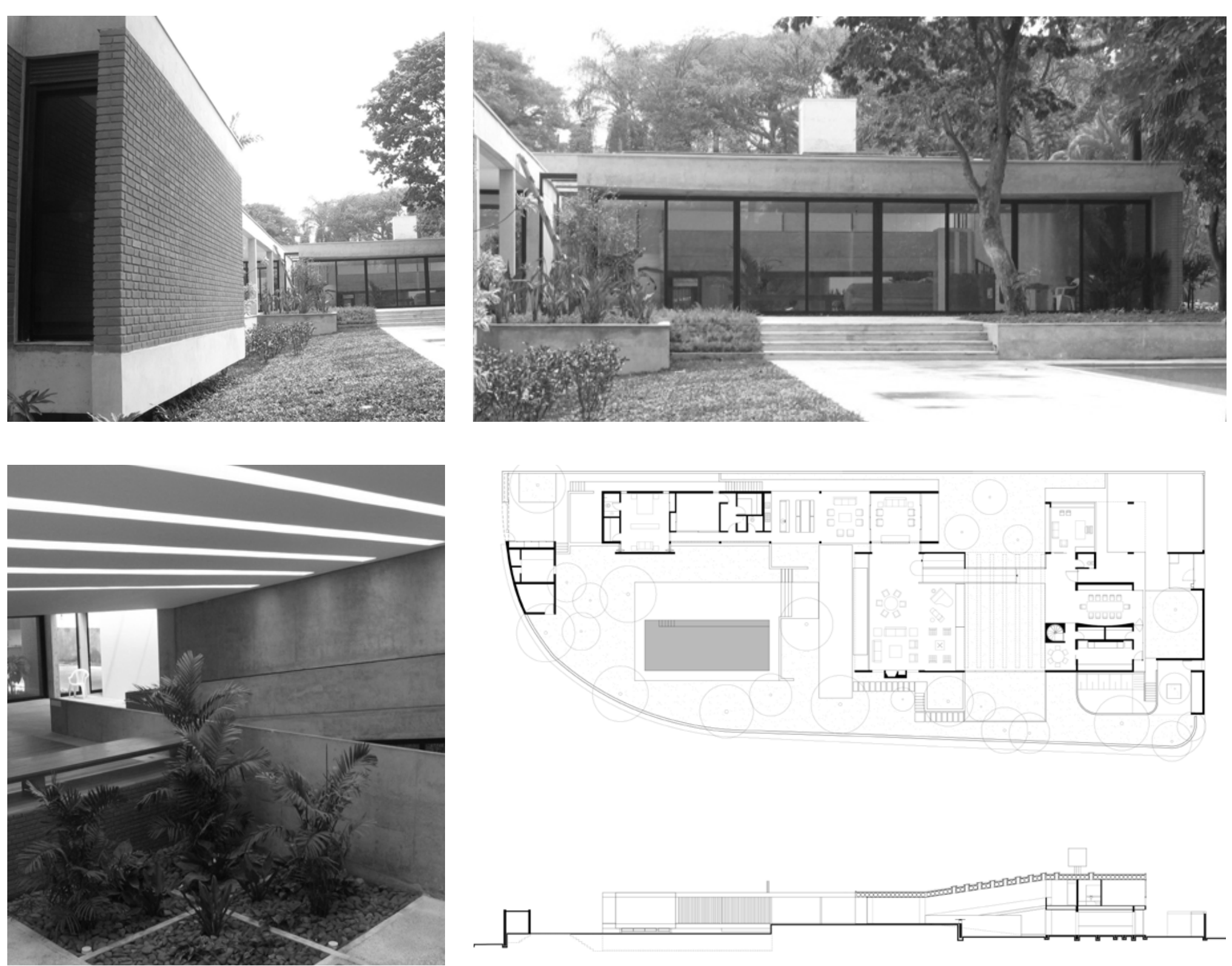
Uso

Centro de Integração Social e Infantil

\section{Cliente}

Associação de Assistência à Criança e ao Adolescente Cardíacos e aos Transplantados do Coração

\section{Equipe}

Eduardo de Almeida

colaboradores I Cesar Shundi I Iwamizu e Maira Rios

Localização

Rua Oscar Freire 1463, São Paulo, SP

Estágio

Projeto Executivo

Observações

Construído

Características

Extremamente singelo, este projeto visa dar abrigo à crianças - acompanhadas de suas mães - que vêm à São Paulo para obter tratamento contra 0 câncer infantil no Hospital das Clínicas. Pautado por esta

questão, o projeto cria uma sequência de dormitórios

amparados por sanitários coletivos no último pavimento,

complementados por área de lazer, estar e trabalho no

pavimento intermediário e, por fim, refeitório, recepção e

loja no pavimento térreo. No bloco principal, a estrutura

de concreto aparente é preenchida por alvenaria

de blocos cerâmicos sem revestimento ou pintura

diferentemente da solução empregada no bloco anexo

destinado aos sanitários, cozinha e circulação vertical.

Acervo

Tubo 68, Caixa 3300 e Backup 334

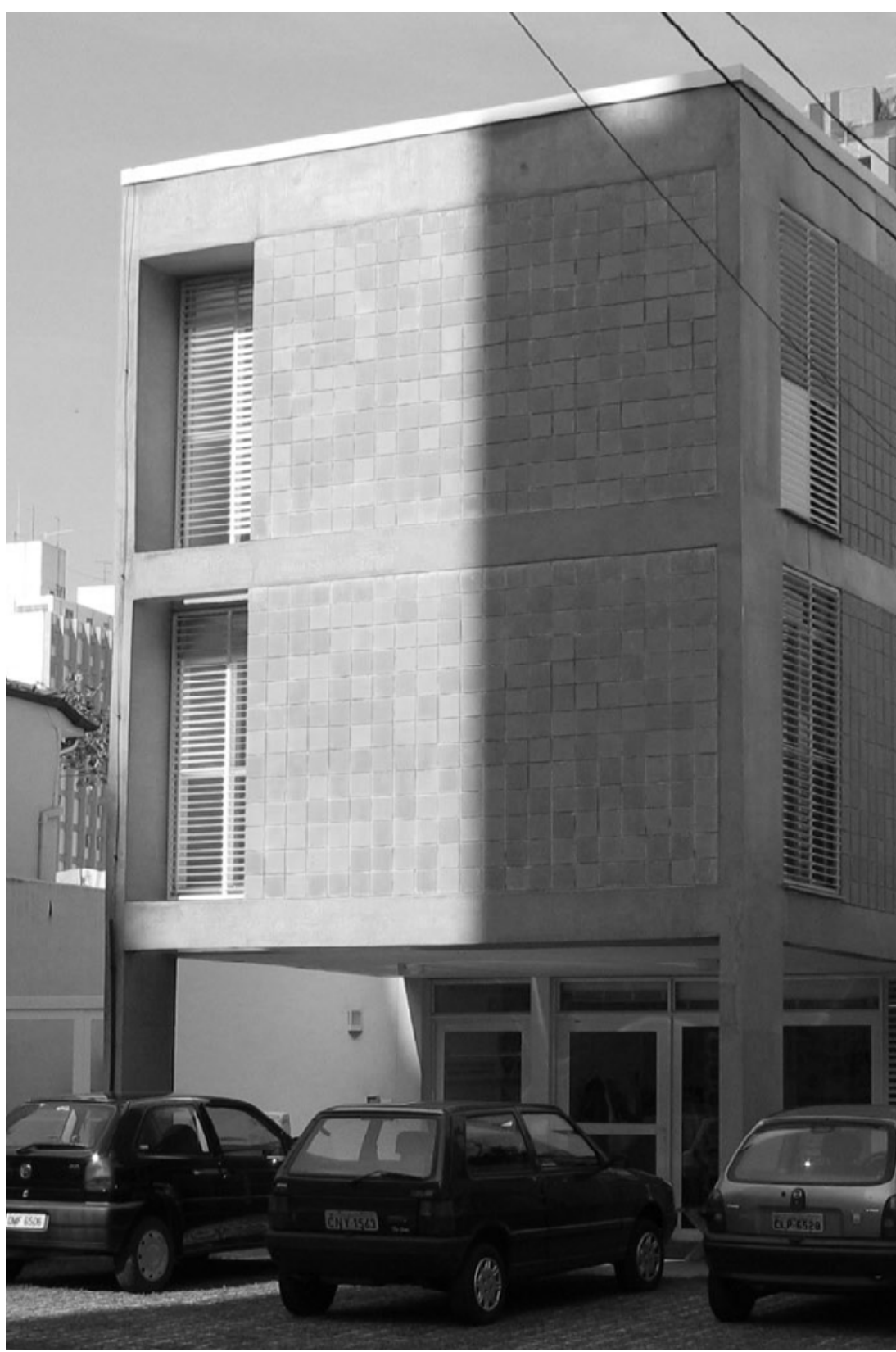

ELERELEI

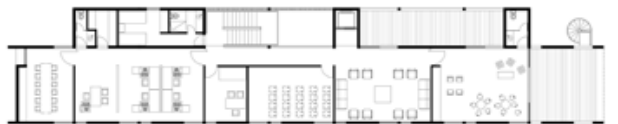

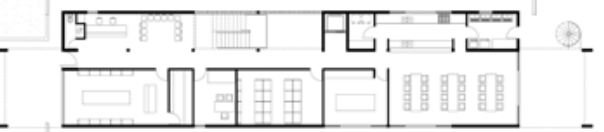
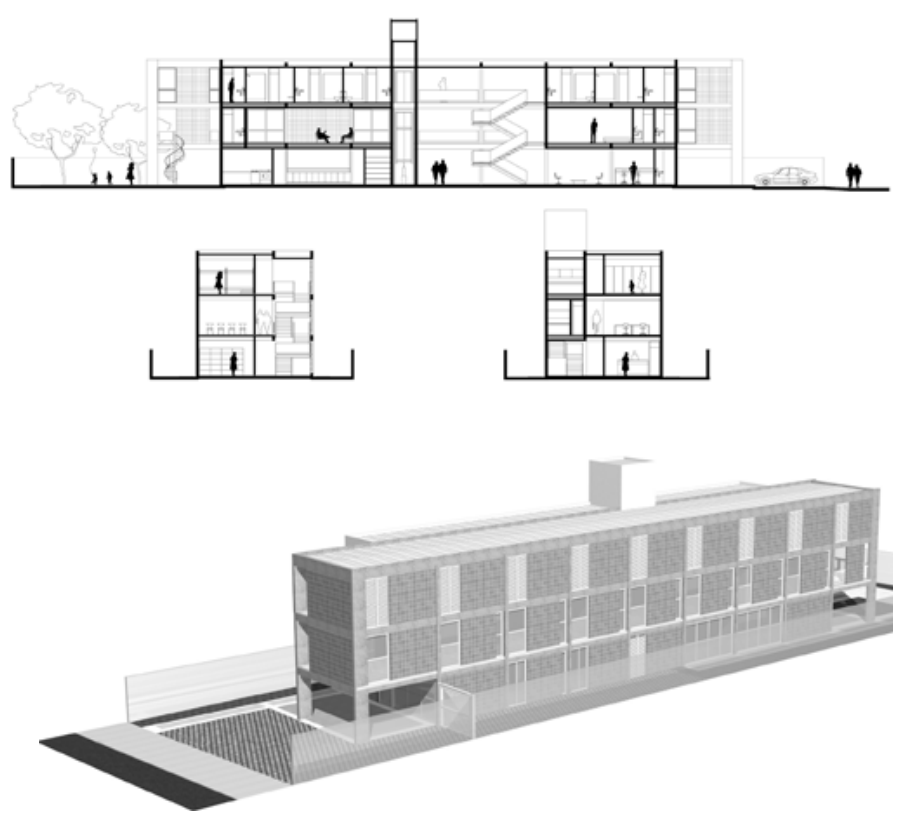
Uso

Residência Unifamiliar

Cliente

Jean Marc Benaron

Equipe

Eduardo de Almeida

colaborador I Leonardo Sette

\section{Localização}

Itha Bela, SP

Estágio

Projeto Executivo

\section{Observações}

Construído

\section{Características}

Inicialmente pensada como uma estrutura metálica

encaixada em um muro de contenção de concreto

armado - intervencão no terreno tratada como parte do

volume do edifício - a segunda proposta, posteriormente

alterada, previa a construção de uma estrutura

simplesmente apoiada no terreno, apresentando

dormitórios no pavimento inferior e ambientes de estar e

cozinha no superior, aproveitando as privilegiadas vistas

para o mar e a área externa conectada à piscina.

Acervo

Caixa 1300 e Backup 338
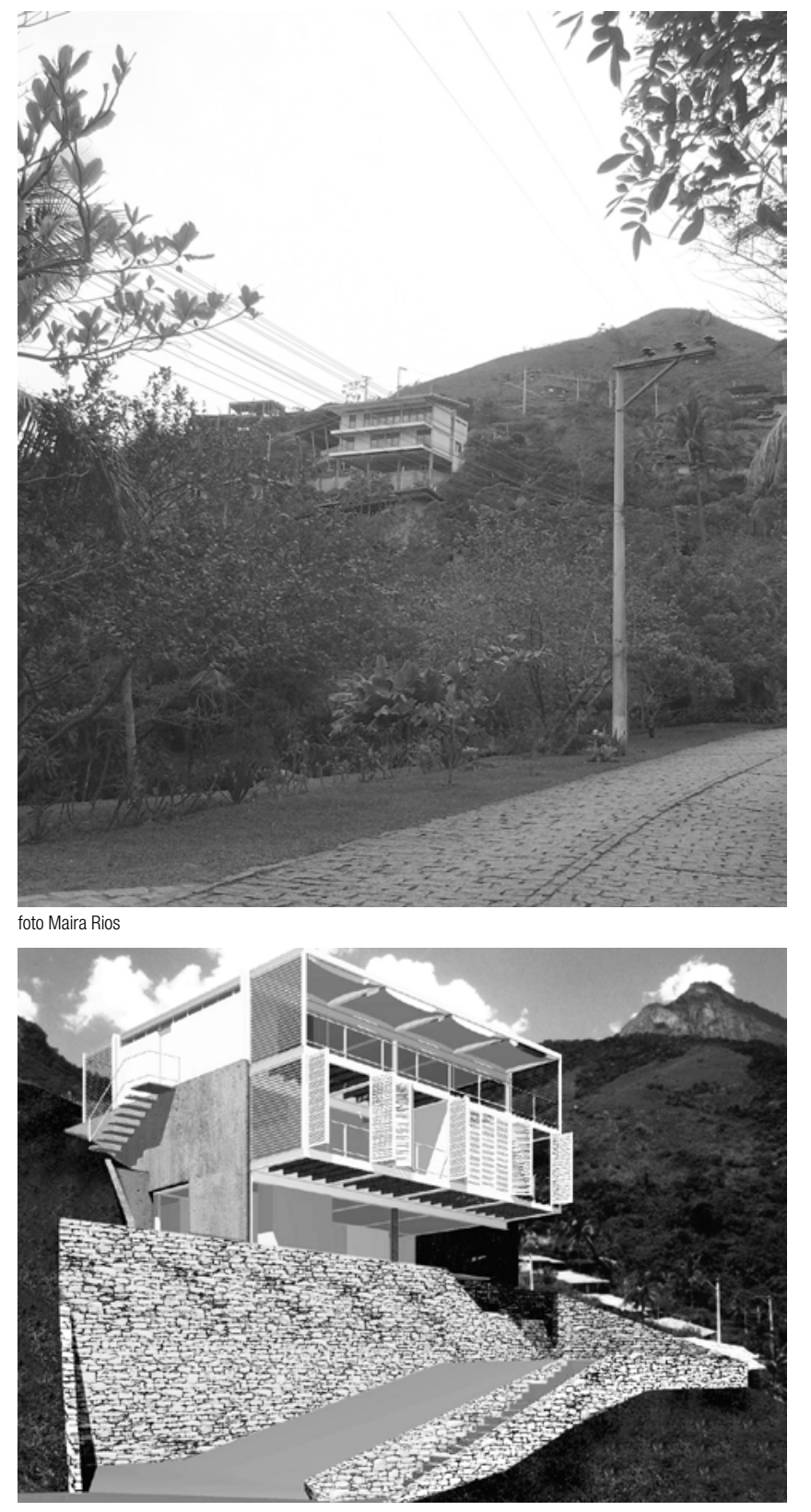

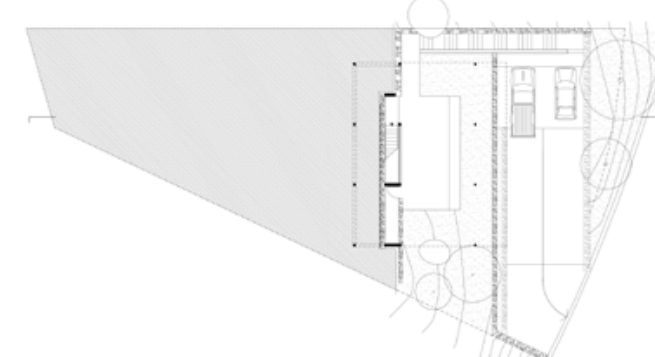

$\square$
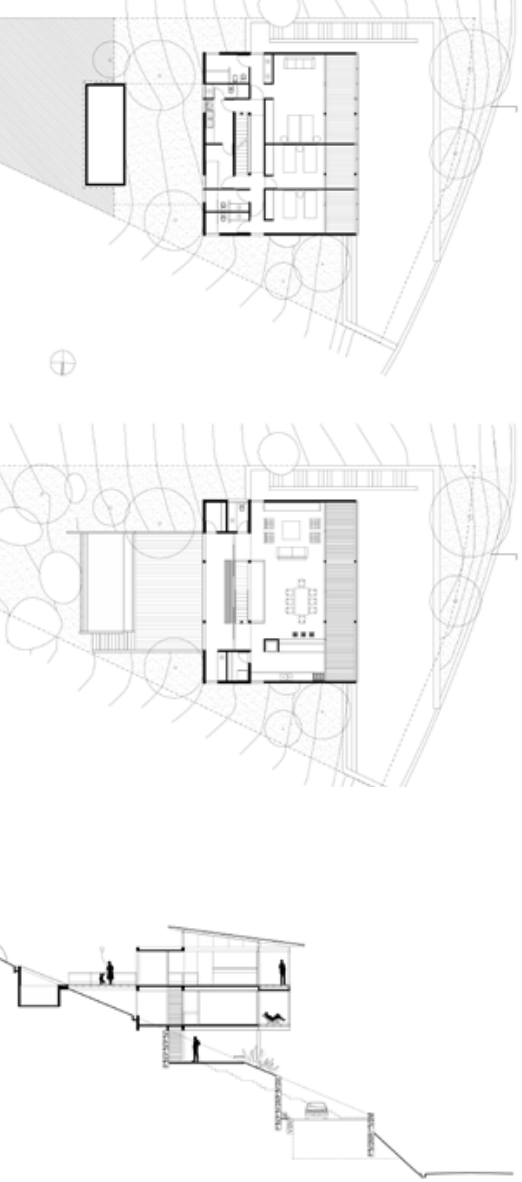
Uso

Residência Unifamiliar

Cliente

Guilhermo Bigliani

Equipe

Eduardo de Almeida

colaboradora I Maira Rios

\section{Localização}

Jaguariúna, SP

Estágio

Projeto Executivo

\section{Observações}

Não construído

Características

Retomando o partido adotado na casa Define, este

projeto também organiza os programas ao redor de um

pátio ajardinado posicionado em um piso inferior Neste

caso, Eduardo de Almeida utiliza estrutura metálica e

alvenaria de tijolos aparentes.

Acervo

Caixa 1900 e Backup 339
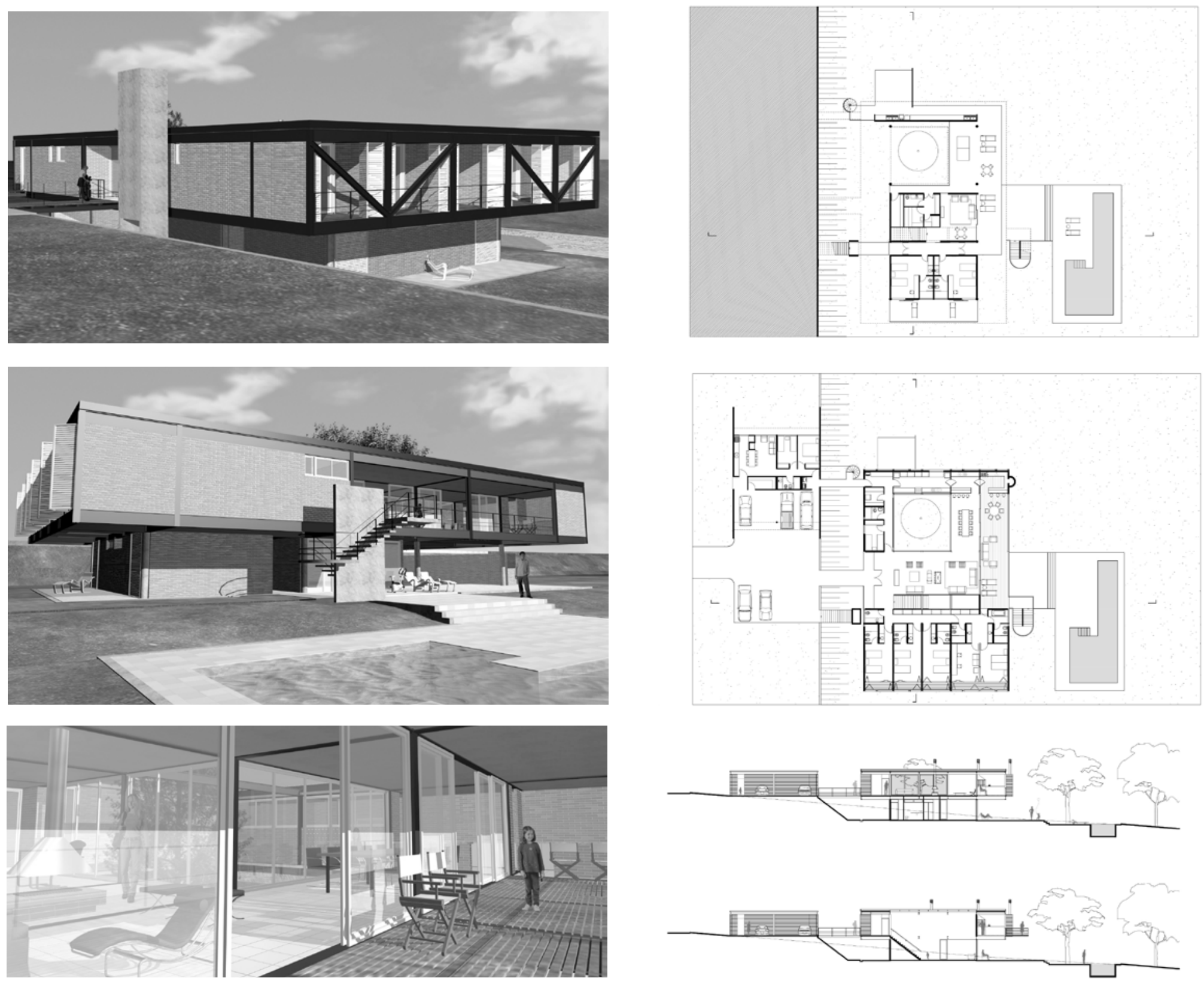

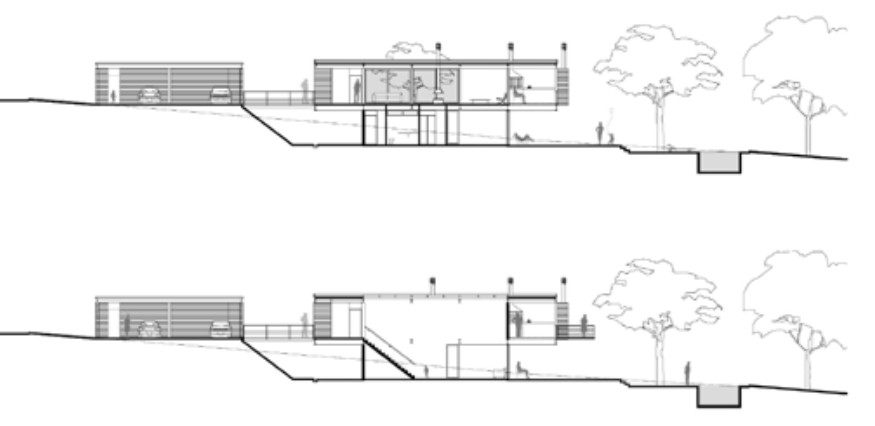

(1) $\overline{0} \overline{2,5} \overline{5}{ }_{10}$ 
Pavilhão

\section{Cliente}

Fausto Penna Moreira

Equipe

Eduardo de Almeida

colaboradores I Cesar Shundi Iwamizu, Maira Rios e

Roberto Zocchio Torresan

estrutura I Heloisa Marangoni

paisagismo | Fernando Chacel e Sidney Linhares

Localização

Rua Banibas 691, Alto de Pinheiros, São Paulo, SP

Estágio

Projeto Executivo

Observações

Construído

\section{Características}

Localizado em um lote de grandes dimensões, este

projeto organiza os programas de apoio - cozinha,

serviços, sanitário e dormitório - junto à divisa oblíqua

do terreno com uma estrutura de concreto armado. Em

contraponto a esta solução, uma estrutura metálica

levemente arqueada se destaca, definindo 0 espaço

interno do pavilhão de lazer e a varanda que se volta

ao jardim.

Acervo

Caixa 2100 e Backup 340
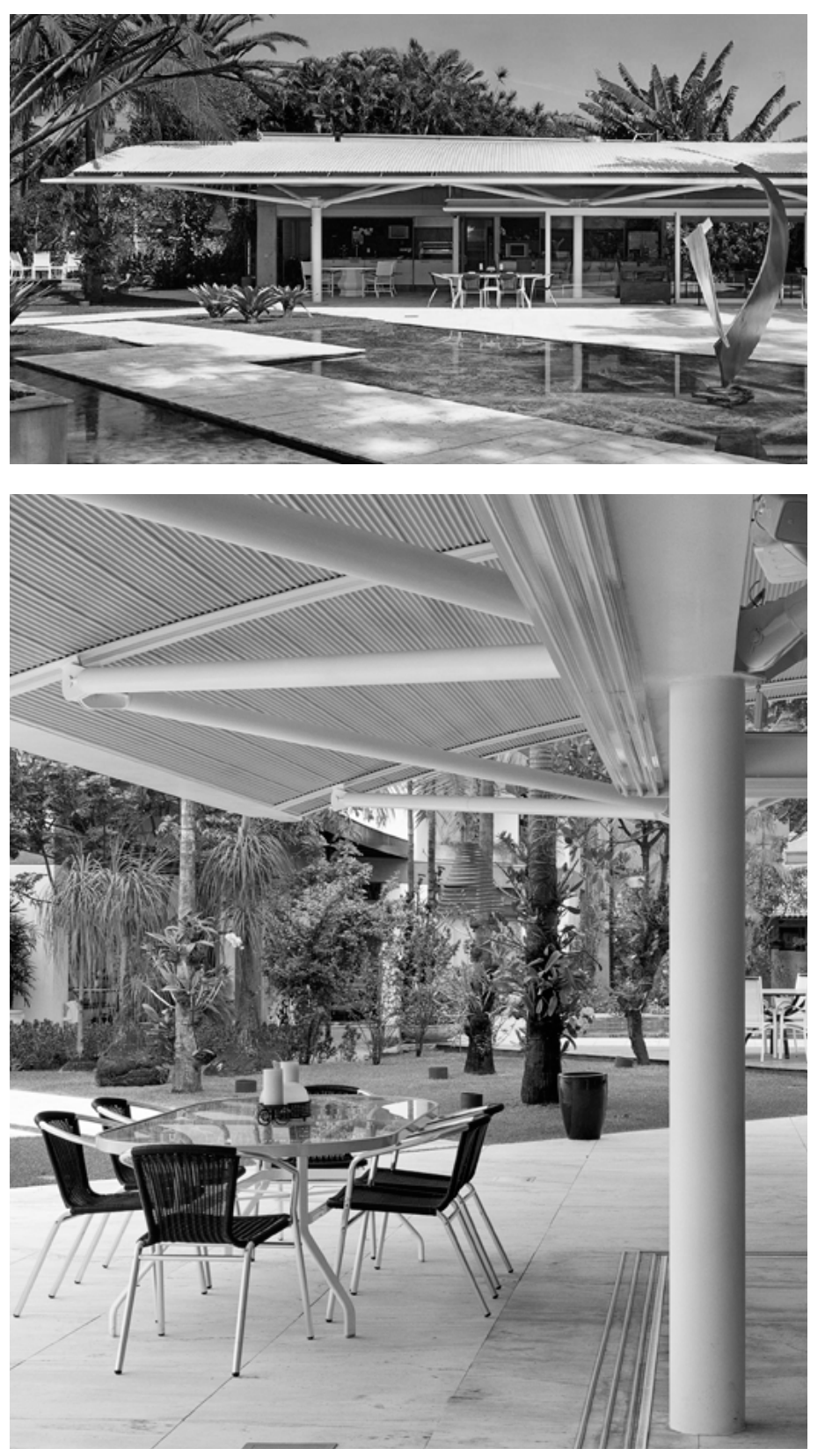

fotos: Nelson Kon

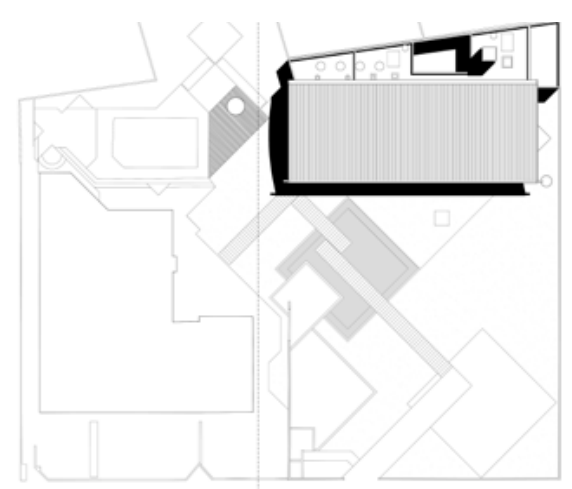

$\overline{02,5 \overline{5}} 10$
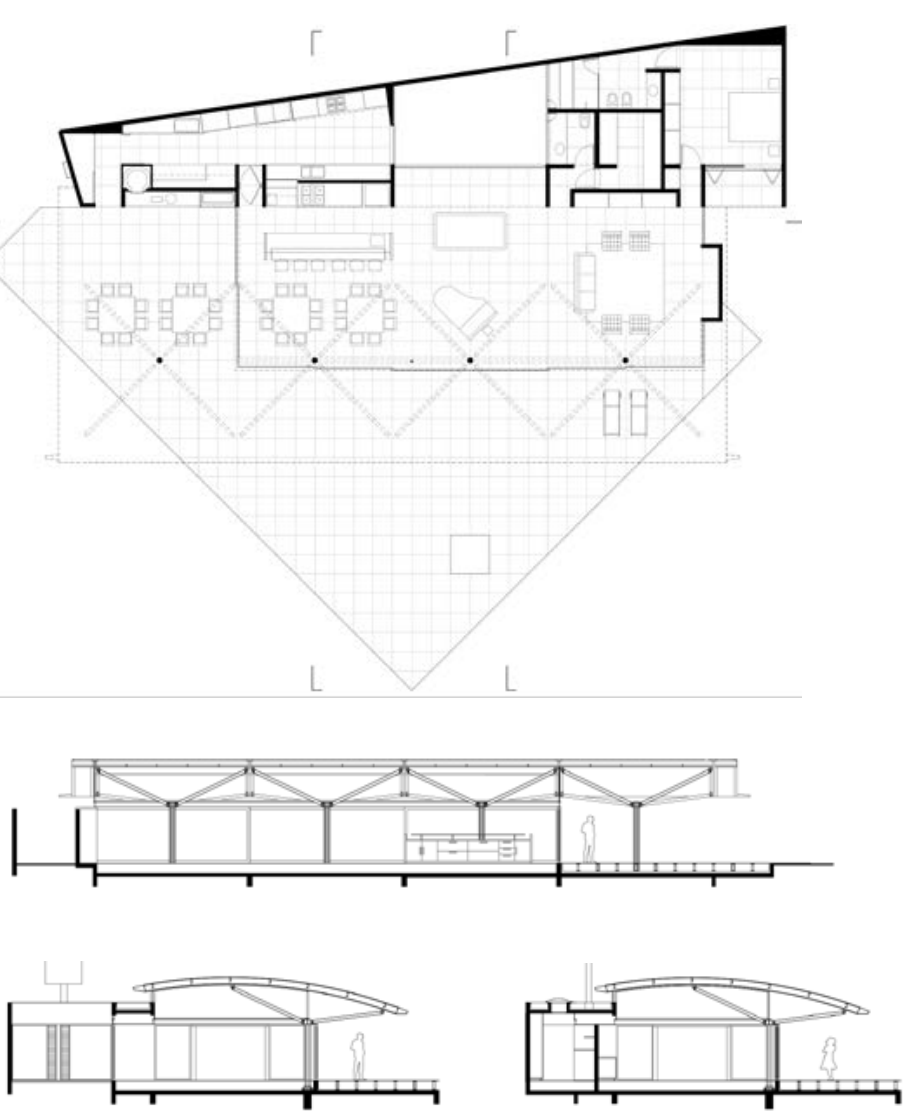

Q $\overline{0}_{2,5} \overline{10}_{10}$ 
Uso

Residência Unifamiliar

Cliente

Patrick Sigrist

Equipe

Eduardo de Almeida

colaboradores I Cesar Shundi Iwamizu, Felipe Noto,

Maira Rios e Roberto Zocchio Torresan

Localização

Jundiaí, SP

Estágio

Projeto Executivo

Observações

Construído

\section{Características}

Considerando a geometria do lote em esquina, o volume desta residência foi organizado em uma implantação em ' $L$ ', considerando uma ala destinada a garagem, serviços e cozinha e outra, em dois pavimentos, capaz de abrigar uma sala junto ao jardim com piscina e os dormitórios em um pavimento inferior. Assim como em outros projetos deste período, a cobertura de duas águas é associada a calhas de grandes dimensões, permitindo distinção entre a espacialidade da sala e os trechos destinados a varandas e beirais.

Acervo

Caixa 3500 e Backup 341
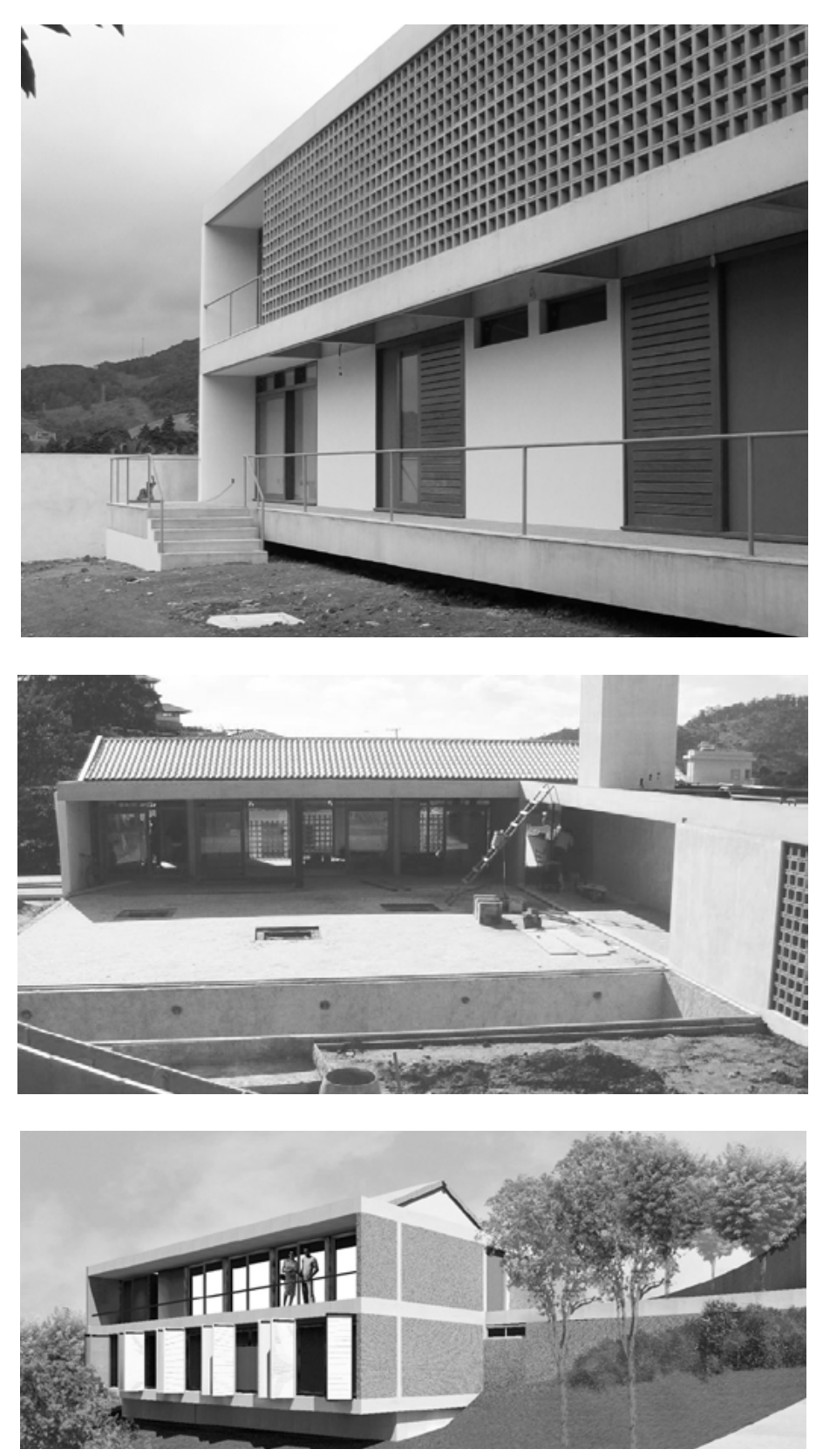
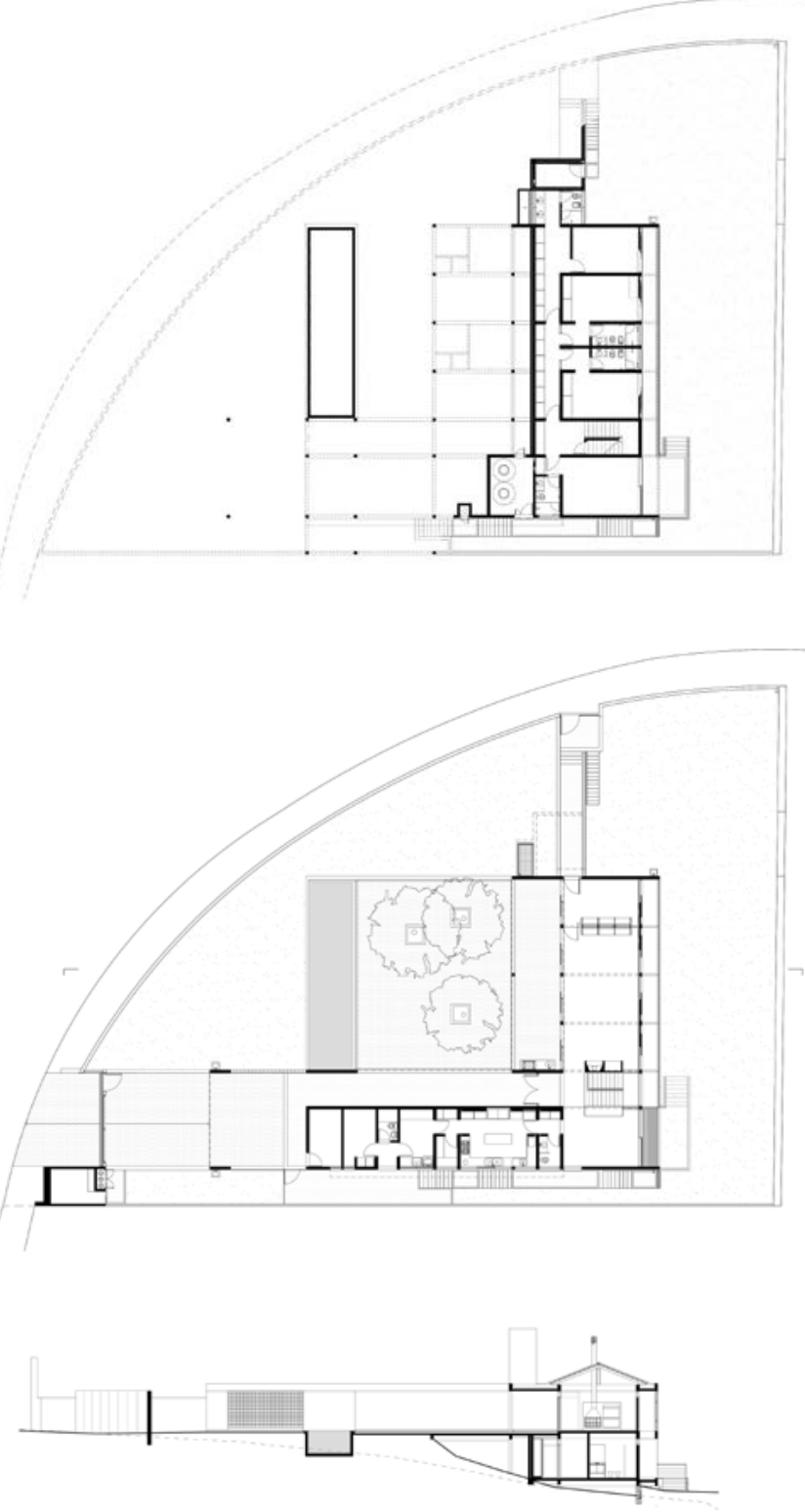
Uso

Residência Unifamiliar

Cliente

Lalo de Almeida

Equipe

Eduardo de Almeida

colaborador I Leonardo Sette

estrutura | Eder Pascoal Besson

Localização

Rua Hilário Magro Jr 588, Butantã, São Paulo, SP

\section{Estágio}

Projeto Executivo

\section{Observações}

Construído

\section{Características}

Nesta segunda casa projetada para seu filho Lalo, Eduardo de Almeida cria um volume de dois pavimentos destacado do chão. Construído em estrutura metálica

com fechamentos de alvenaria aparente, a casa

organiza-se pelo vazio de pé-direito duplo que articula a sala à circulação em balanço dos dormitórios, ao mesmo tempo em que os caixilhos de grandes dimensões garantem continuidade aos espaços externos existentes nos recuos frontal e posterior.

Este projeto foi realizado após a busca de diferentes partidos testados ao longo de um ano, alternando um continuo processo de investigação, desenvolvimento e abandono. Extremamente simples, esta casa foi fruto de um longo e complexo processo de trabalho.

Acervo

Tubo 93, Caixa 1500 e Backup 305 e 330
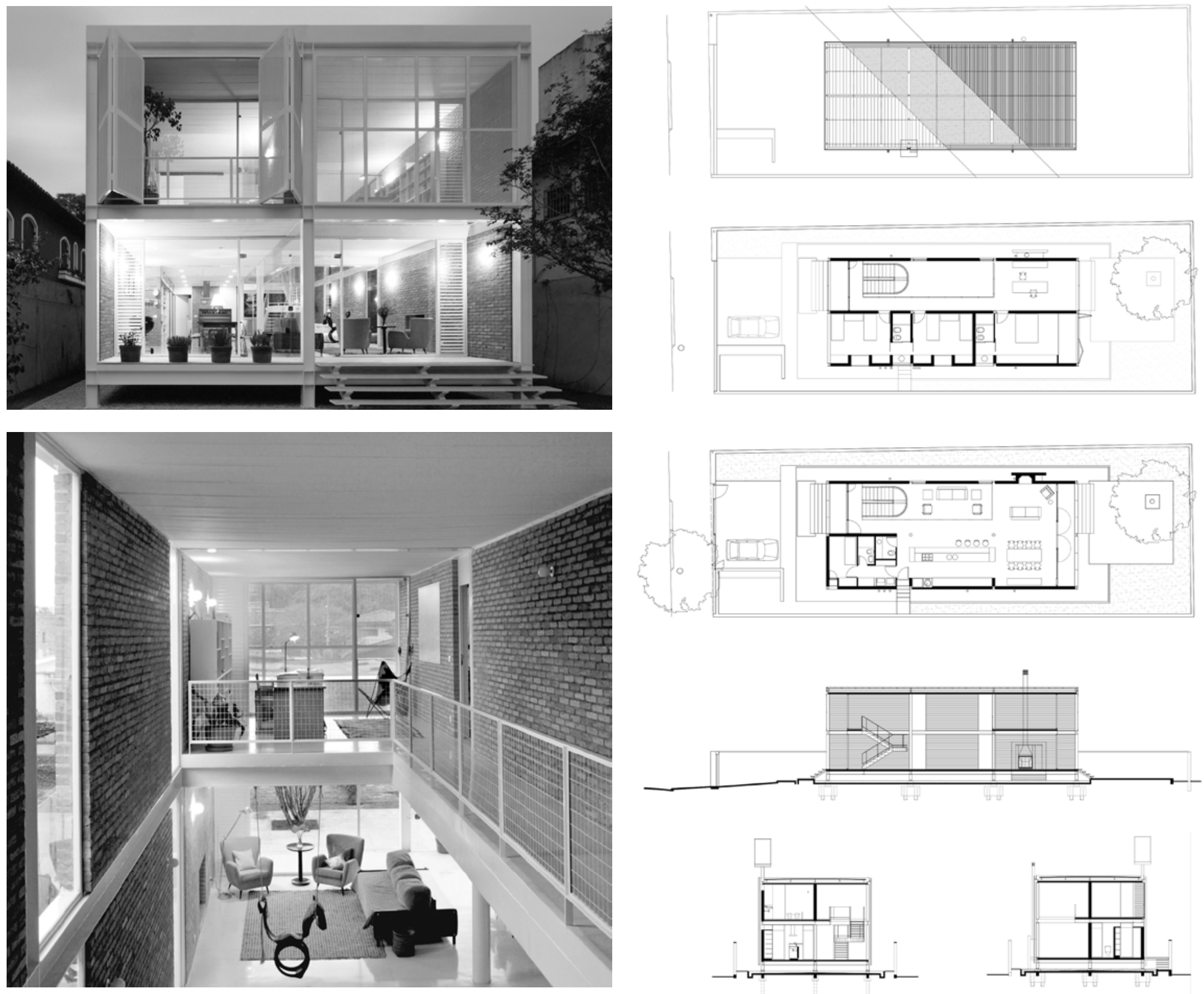


\section{Cliente}

Lalo de Almeida

Equipe

Eduardo de Almeida

\section{Localização}

Rua Hilário Magro Jr 588, São Paulo, SP

Estágio

Projeto Executivo

Observações

Não construído

\section{Características}

Voltado para o pé-direito duplo da sala, o escritório projetado em mezanino mostrou-se inviável considerando os conflitos com os demais usos da casa. Por este motivo, Eduardo de Almeida projetou este volume posicionado junto ao fundo do lote para abrigar um novo escritório. Empregando estrutura metálica e fechamentos leves, o projeto considera uma fachada cega, mas solta do chão, capaz de conferir neutralidade e distinção ao volume pré-existente.

Acervo

Tubo 93, Caixa 1500 e Backup 305 e 330
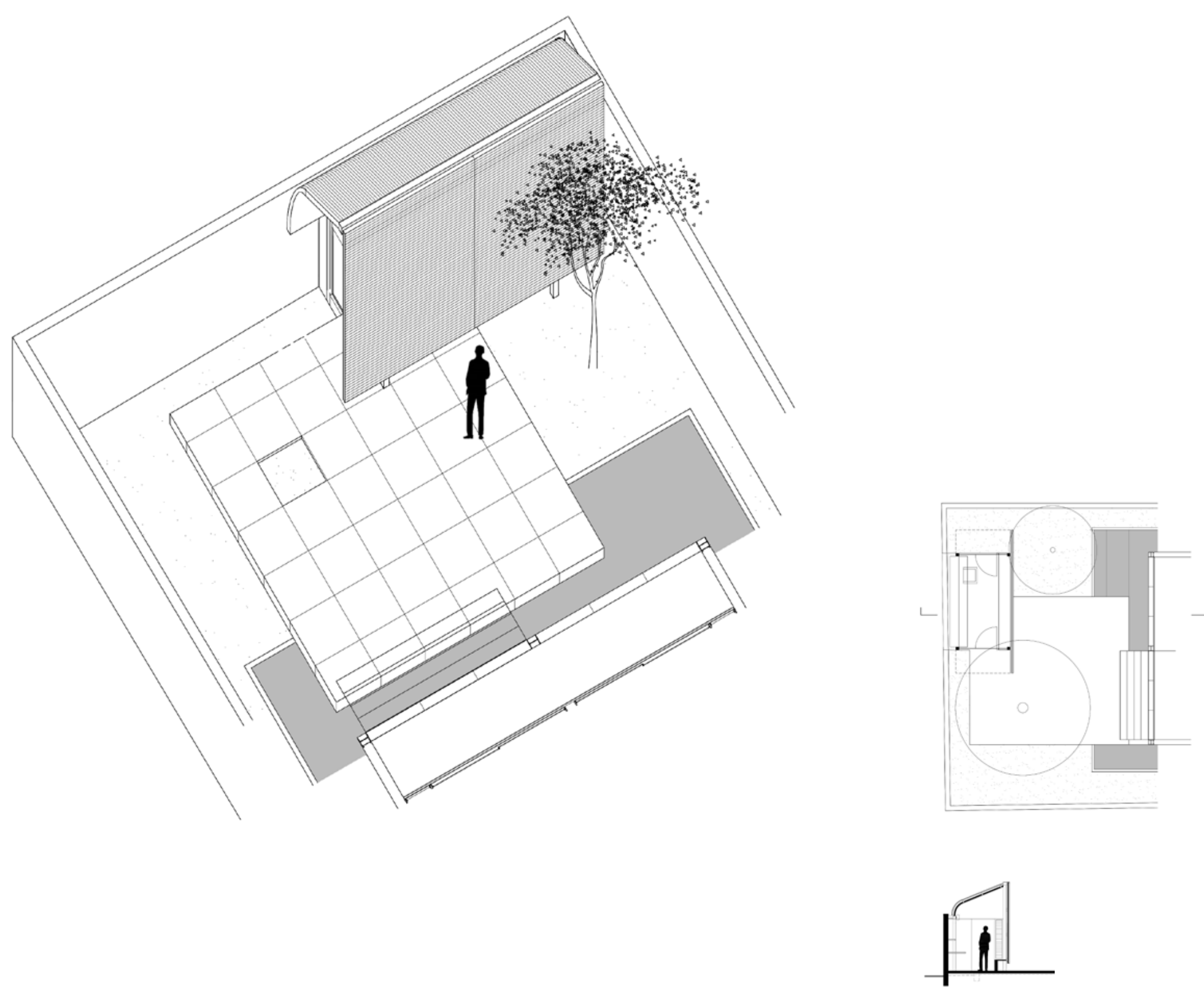
Uso

Residência Unifamiliar

Cliente

Felipe Sigrist

Equipe

Eduardo de Almeida

colaboradores I Cesar Shundi Iwamizu e Maria Isabel

Imbronito

Localização

Rua Laerte Assumpção, São Paulo, SP

Estágio

Projeto Executivo

\section{Observações}

Projeto de reforma construído

\section{Características}

Seguindo a linguagem de obras como a casa Pacheco e Silva (1993), esta residência foi construída com estrutura metálica e a recorrente solução da cobertura de duas águas. Neste caso, a solução de extrema simplicidade

foi complementada após o proprietário adquirir o lote

vizinho, viabilizando a construção de dormitórios de

serviço, escritório, varanda, sala no pavimento superior

e uma nova suíte, além de um pátio arborizado de

proporção quadrada.

Acervo

Tubo 68, Caixa 2500 e Backup 331 e 356
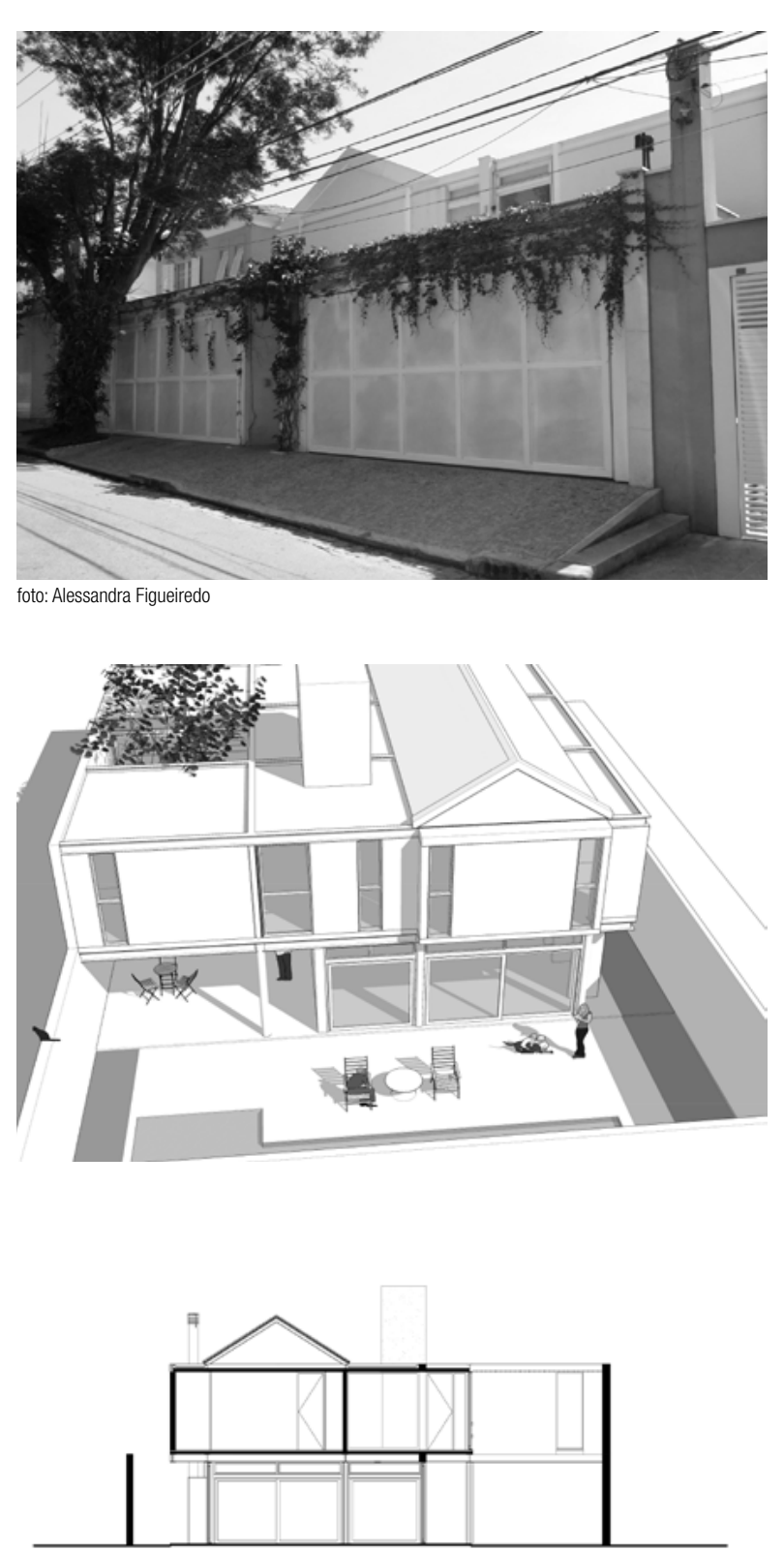
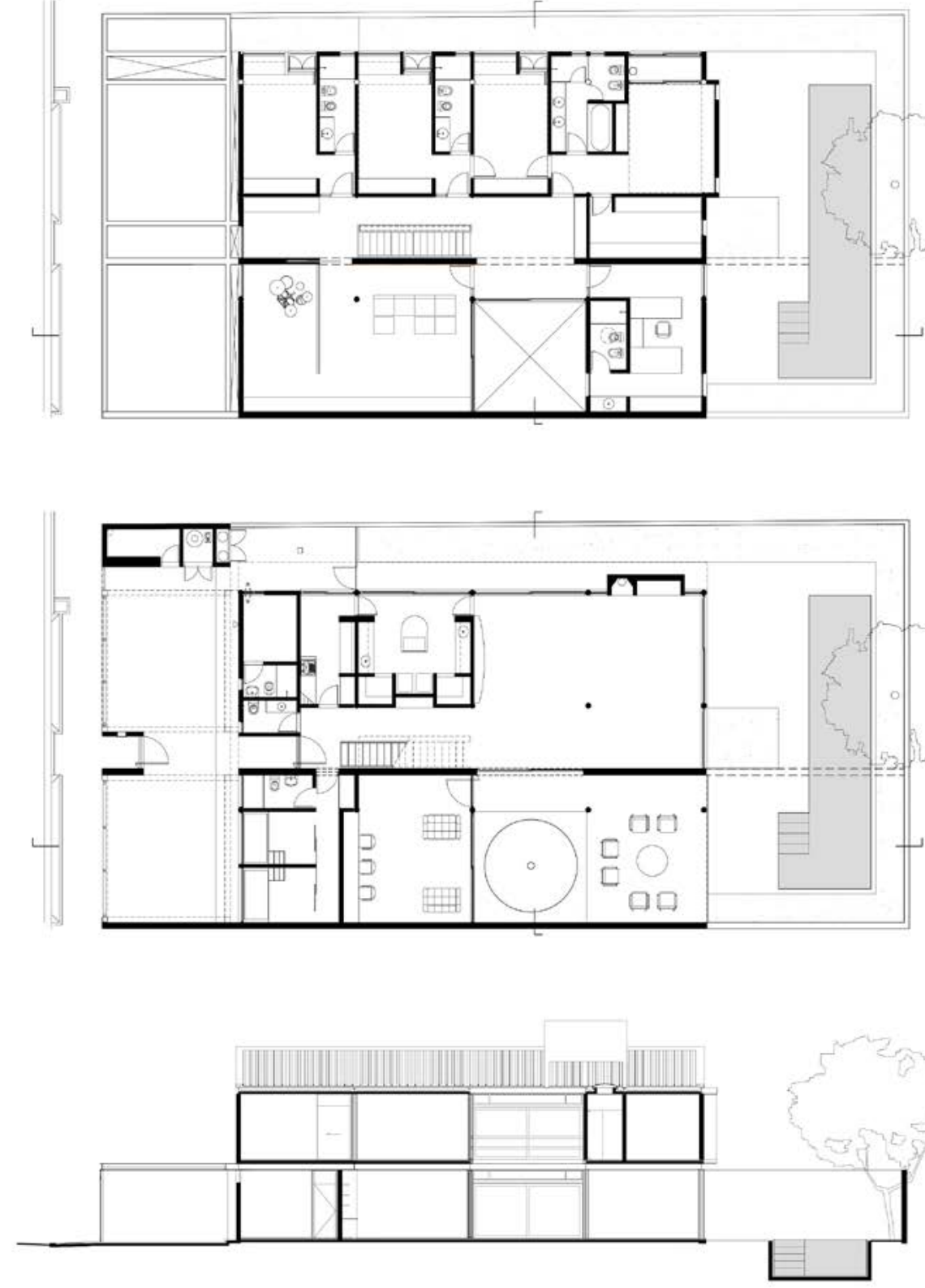
Uso

Residência Unifamiliar

Cliente

Marcelo Lacerda

Equipe

Eduardo de Almeida

Localização

Conchas, SP

Estágio

Projeto Executivo

Observações

Características

Utilizando-se de técnicas e linguagem tradicionais,

esta casa de fazenda implanta-se pela justaposiçãa

de dois volumes posicionados transversalmente. Tal

disposição retoma a separacão dos setores destinados

aos espaços de uso comum e ambientes destinados aos

dormitórios. Um embasamento construído com muros de

pedras delimita as áreas externas, em confronto com a

topografia do terreno.

Acervo

Tubo 70 e Backup 345
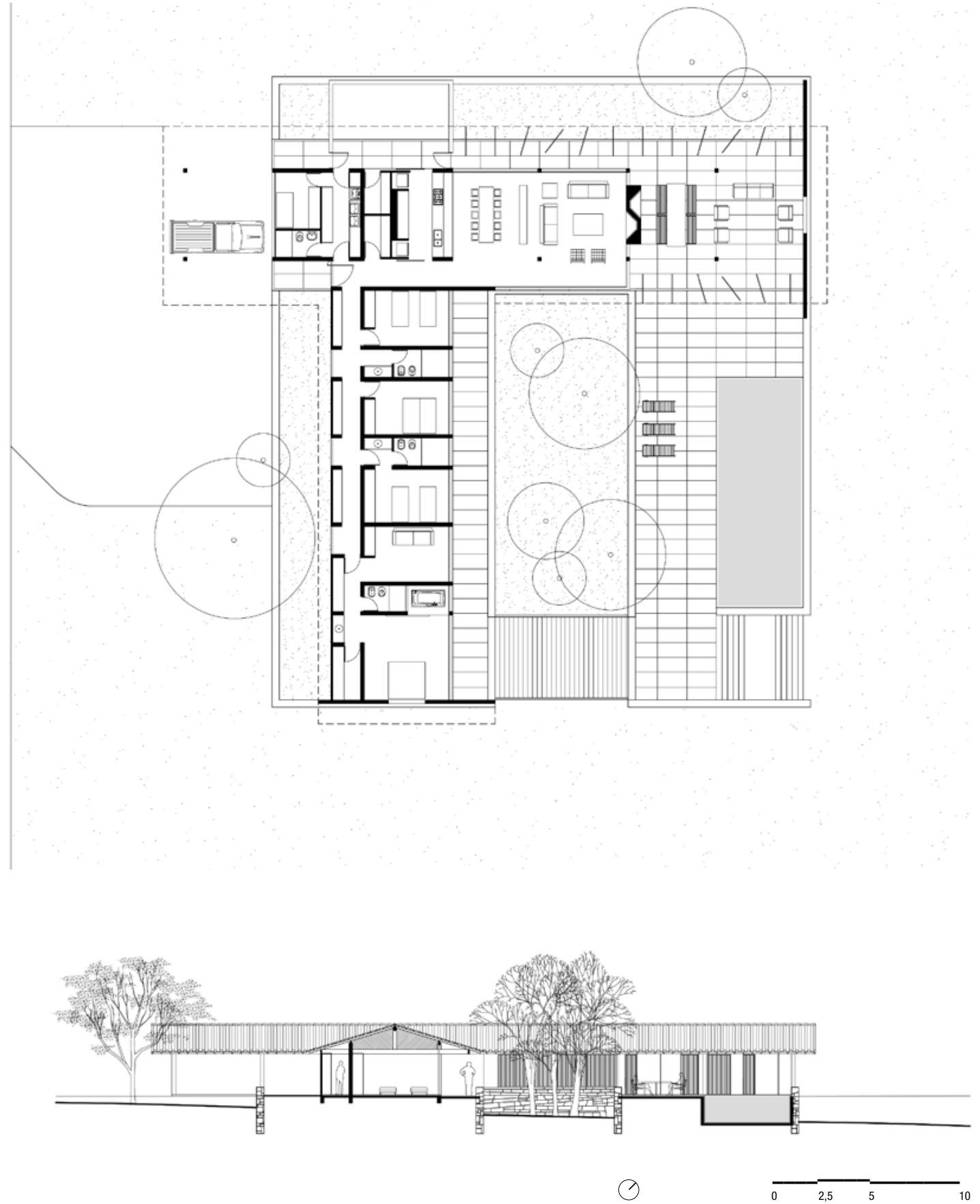
Uso

Escola

\section{Cliente}

FDE- Fundação para o Desenvolvimento da Educação

\section{Equipe}

Eduardo de Almeida

colaboradores I Felipe Noto, Maira Rios e Roberto

Zocchio Torresan

\section{Localização}

Guaianases, São Paulo, SP

Estágio

Projeto Executivo

\section{Observações}

Construído

\section{Características}

Construída no extremo Leste de São Paulo, esta escola segue a tentativa da FDE de ampliar o uso de estrutura metálica em seus projetos, permitindo a rapidez e qualidade de construcão mesmo em terrenos de difícil acesso para as pesadas estruturas de concreto prémoldado. Neste caso, dois volumes - um destinado a quadra coberta e outro para as atividades da escola propriamente dita - articulam-se ao longo de uma faixa ocupada por uma escada criando uma interrupcão ada protegida por bries mets

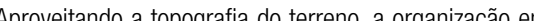
meios-nivers da a ming cozinha e refeitório cria um pé-direito elevado no espaço do galpão, espaço que se extende para os pavimentos de salas de aula através do vazio central localizado entre 0 corredores em balanco, permitindo também o emprego de iluminaç̃ão natural no centro do volume.

Acervo

Caixa 2400 e Backup 346

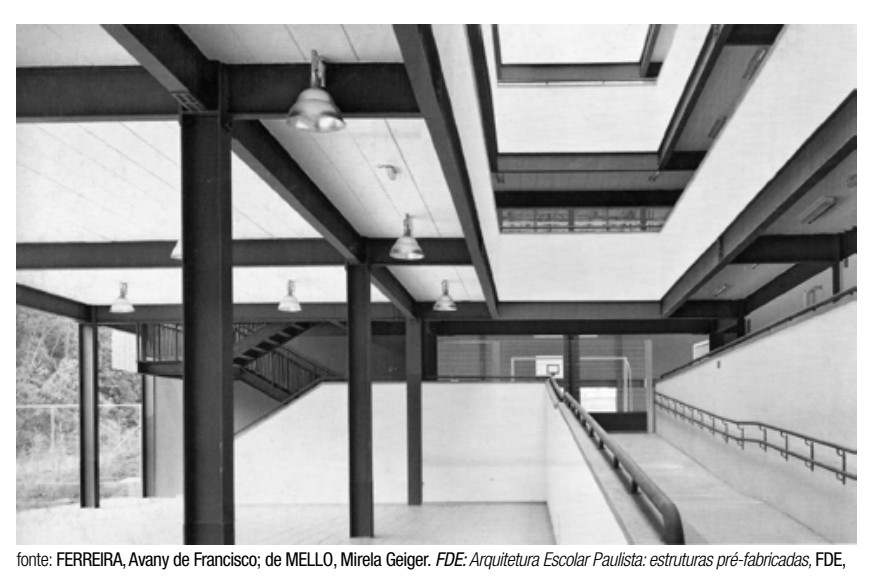

2006, pág. 156-15 .
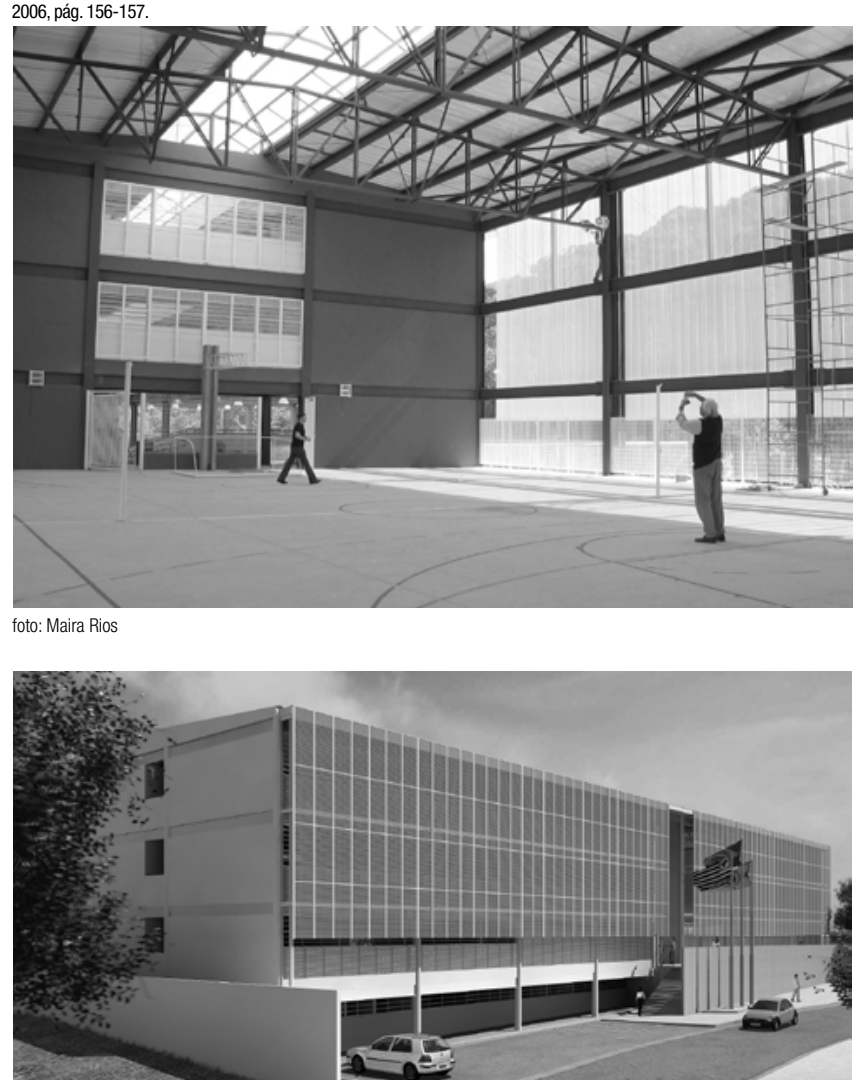

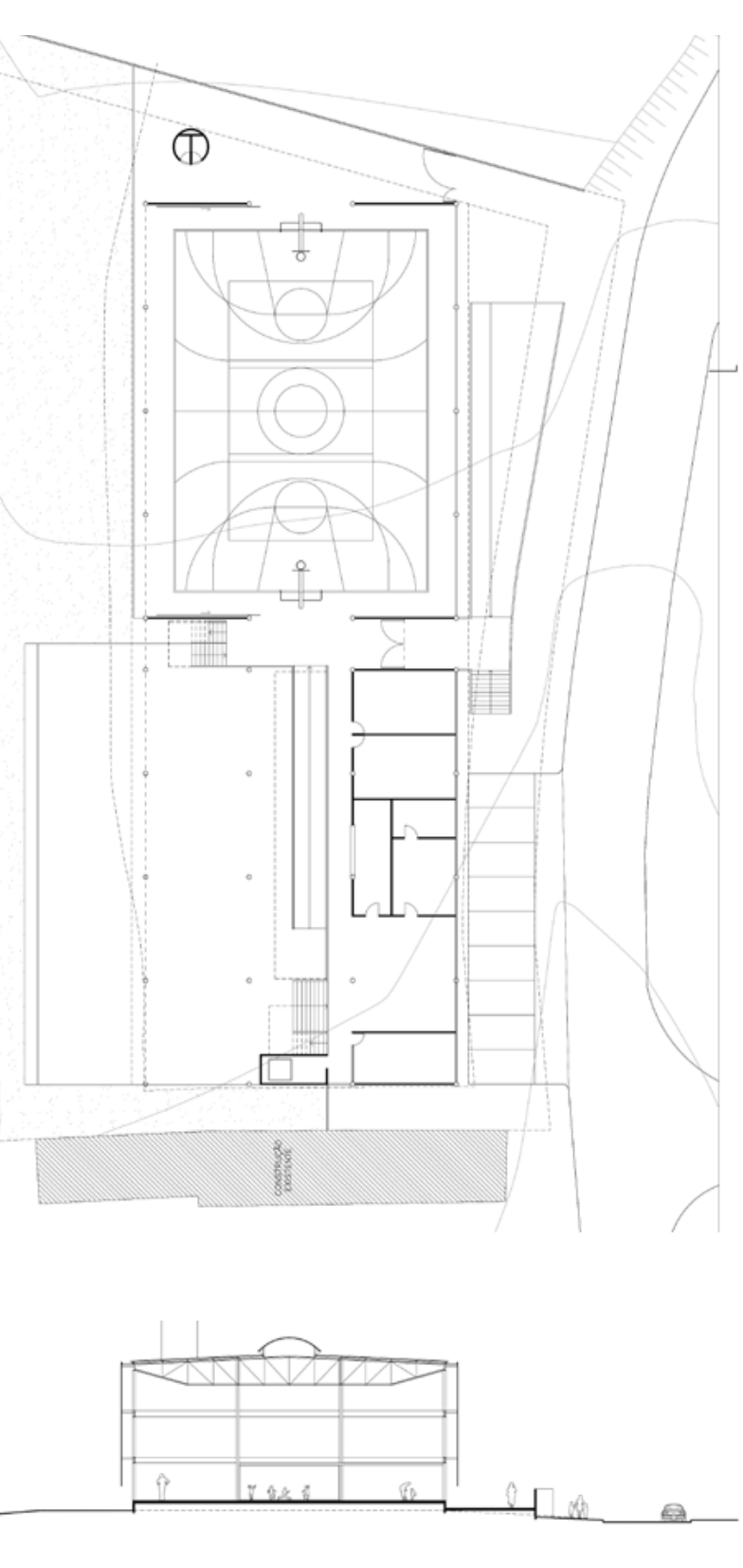


Uso

Escola

Cliente

FDE - Fundação para o Desenvolvimento da Educação

Equipe

Eduardo de Almeida

colaboradores I Felipe Noto e Maira Rios

\section{Localização}

Rua Mario Gonçalves Viana, São Paulo, SP

Estágio

Projeto Executivo

Observações

Construído

\section{Características}

Seguindo as mesmas premissas da escola FDE Recanto Verde Sol, esta escola em estrutura metálica enfrenta a complexa geometria do lote e a opressiva presença da linha de metrô aérea que atravessa o terreno. Tal interferência justifica a implantação de dois blocos paralelos deslocados, articulados pela circulação vertical e pelo pátio descoberto e alongado. 0 acesso principal dá-se por uma pequena praça, semi-coberta pela estrutura do metrô.

Acervo

Caixa 1700 e Backup 349
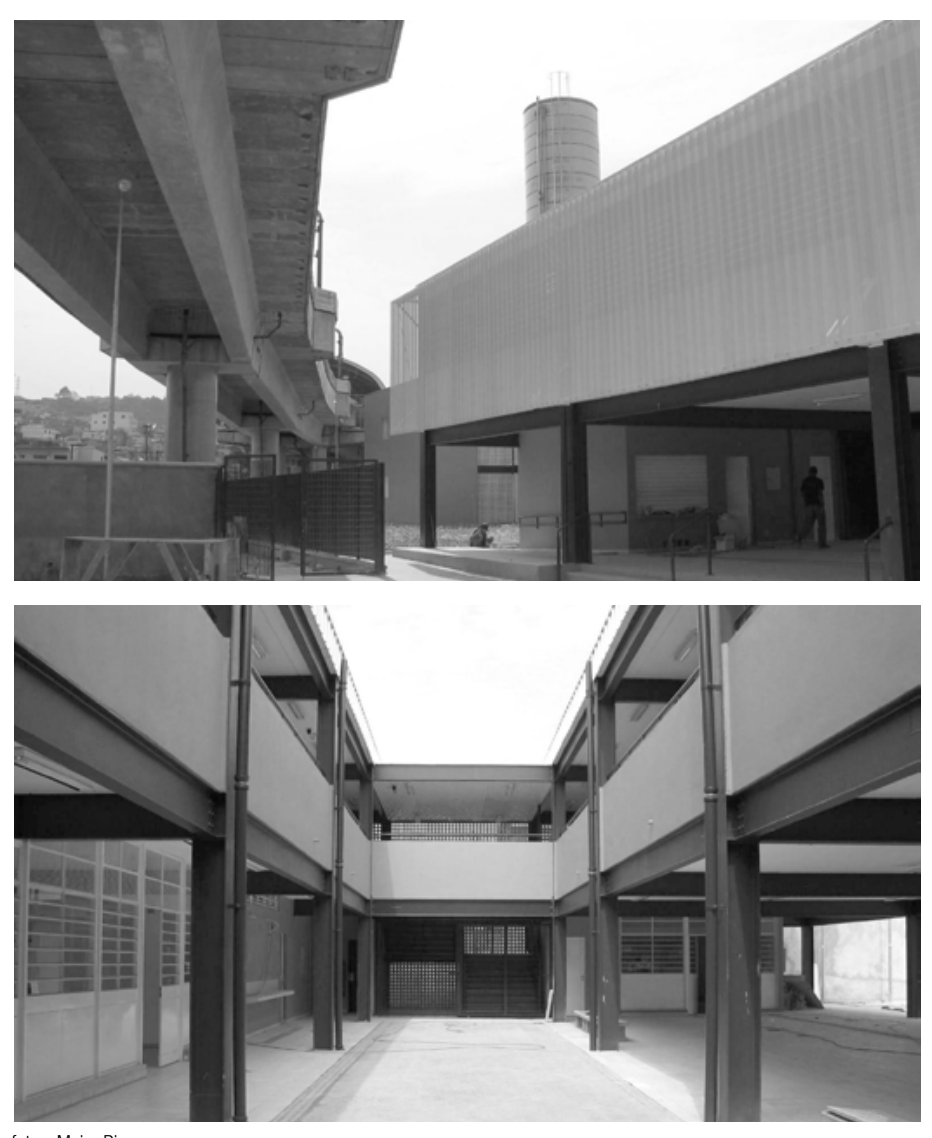

fotos: Maira Rios

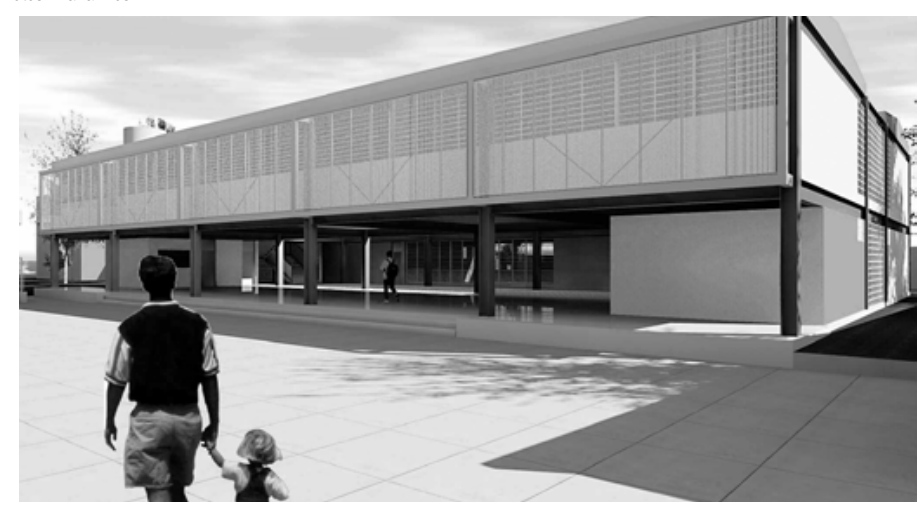

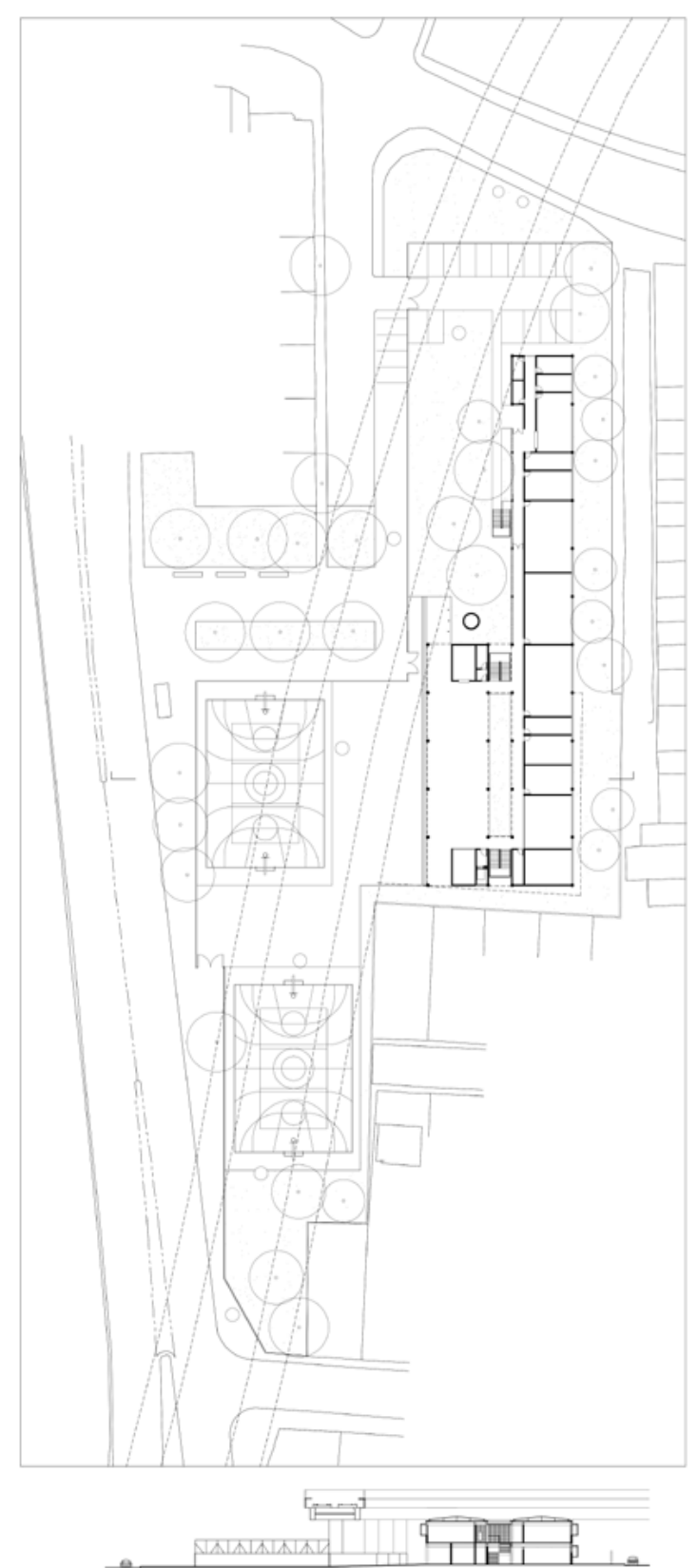


Biblioteca

Equipe

Eduardo de Almeida

colaboradores I Alexandre Mirandez de Almeida, Cesar

Shundi Iwamizu, Edison Hiroyama, Marcelo Pontes de

Carvalho e Ricardo Bellio

Localização

Cidade do México, México

Estágio

Anteprojeto

Observações

Características

Pelo fato de estar envolvido no projeto da Biblioteca de José e Guita Mindlin, Eduardo de Almeida sentiu-se provocado a participar deste concurso internacional para a escolha do projeto para a Biblioteca José Vasconcelos. Considerando a complexidade do programa, mas também a dificuldade do lote ao lado da linha férrea o projeto criado interioriza-se, buscando a luz natura pelas aberturas zenitais posicionadas junto aos muros de limite do edifício, talvez influenciado pela arquitetura de Barragan e seus grandes muros cegos.

Acervo

Não identificado
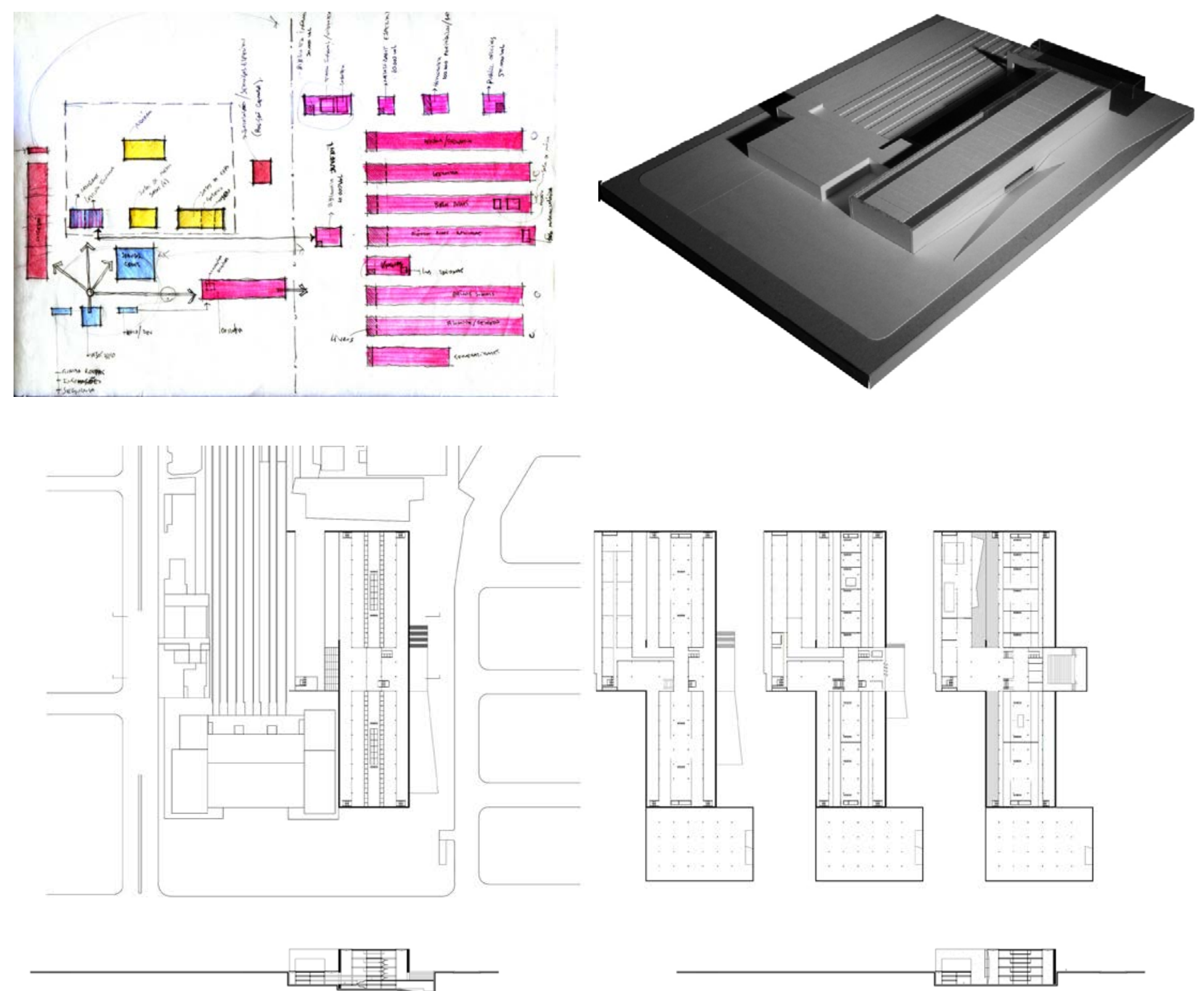

LE 
Residência Unifamiliar

Cliente

Edilah Biaggi

Equipe

Eduardo de Almeida

colaborador I Leonardo Sette

\section{Localização}

Rua Itália, Jardim Europa, São Paulo, SP

\section{Estágio}

Projeto Executivo

Observaç̃os

Não construído

\section{Características}

Projetado como um volume destacado do chão, esta casa de acentuada horizontalidade cria os espaços destinados à sala, cozinha e dois dormitórios no pavimento térreo, enquanto os espaços da garagem, dos serviços e outros ambientes implantam-se em um piso semi-enterrado em relação ao solo. Enquanto os espaços internos voltamse para os jardins criados junto aos recuos frontal $e$ posterior, um trecho central sem laje garante iluminação zenital no interior do volume.

\section{Acervo}

Backup 342
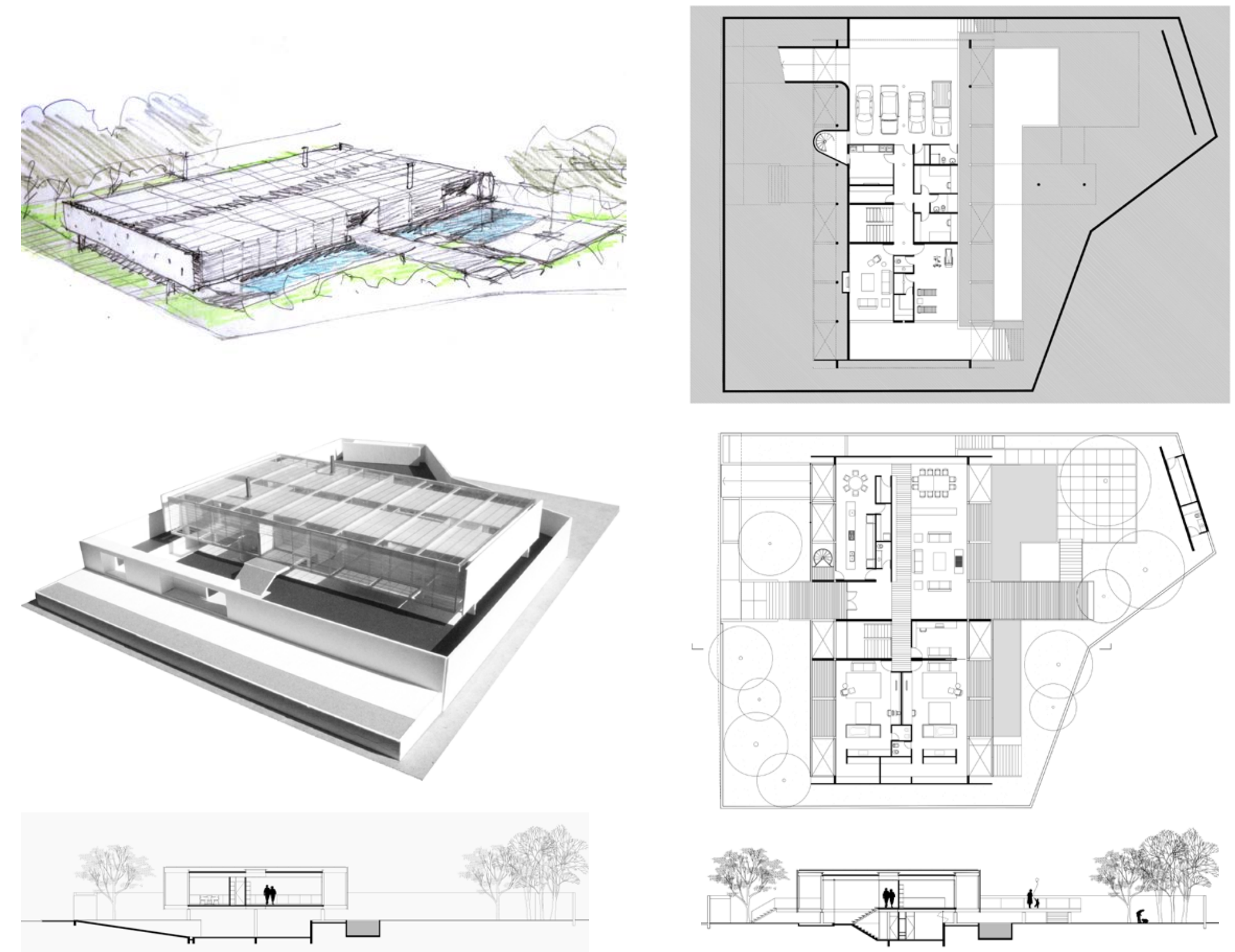
Residência Unifamiliar

\section{Cliente}

Claudine M. de Barros

Equipe

Eduardo de Almeida

Localização

Souzas, SP

Estágio

Anteprojeto

Observações

Não construído

\section{Características}

Projetada para a ex-mulher do arquiteto Fábio Penteado, esta casa organiza-se em dois volumes - um destinado à garagem coberta e outro para a residência -articulados pelo espaço central ocupado pela sala de jantar. Enquanto metade da casa é destinada à sala de pédireito duplo onde se localiza a estante de livros, a outra ala é ocupada pela cozinha e serviços e, no pavimento superior, os dois dormitórios.

Acervo

Backup 352
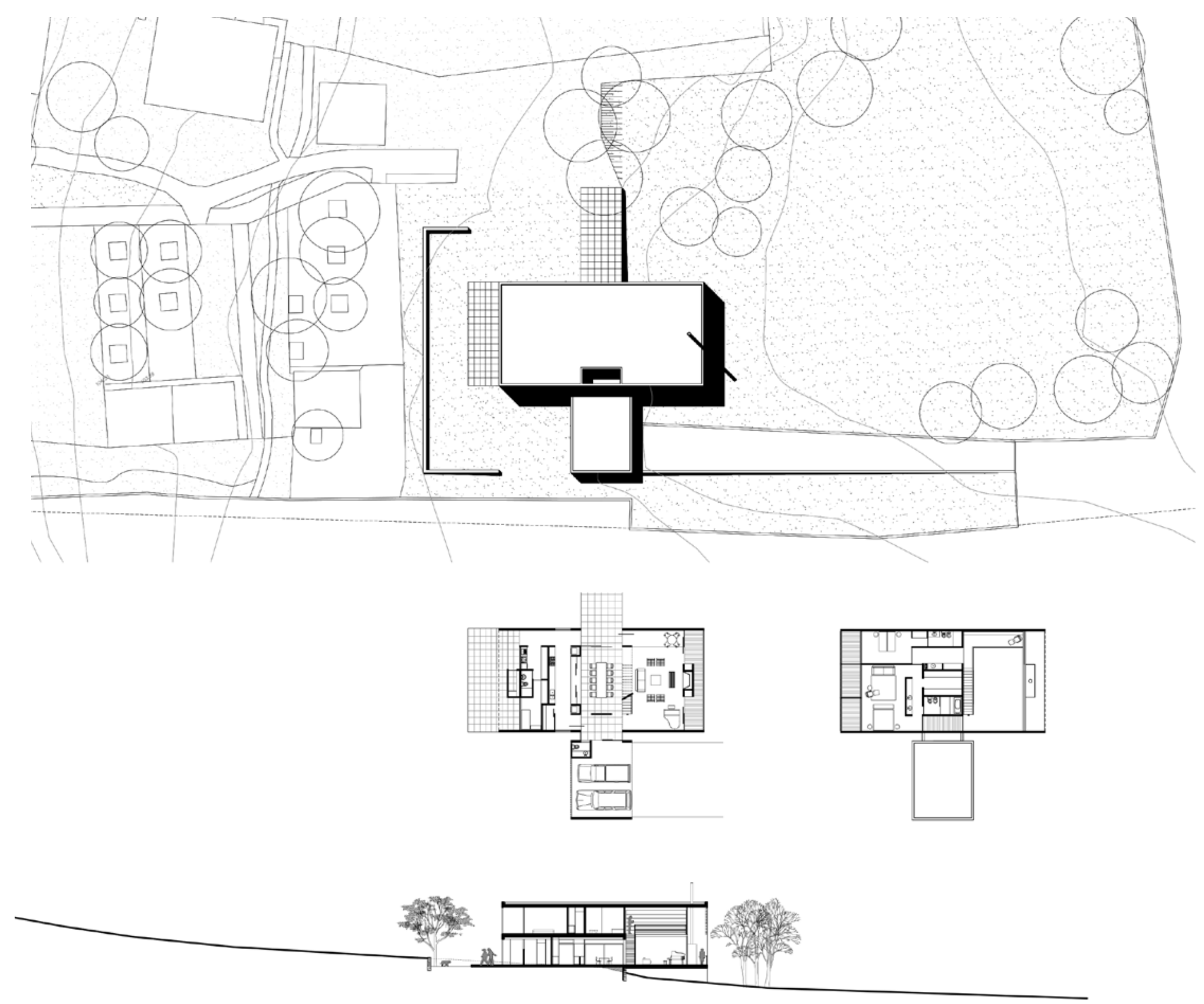
Uso

Campus Universitário - Instituto de Pesquisas Ecológicas

\section{Equipe}

Eduardo de Almeida

colaboradores I Alexandre Mirandez de Almeida, Cesar

Shundi Iwamizu, Joana Filipa Martins Silva, José Paulo

Gouveia, Leonardo Sette, Marcelo Pontes de Carvalho,

Maira Rios, Ricardo Bellio e Rafael Urano

\section{Localização}

Campus Universitário do IPE, São Paulo, SP

Estágio

Estudo Preliminar

\section{Observações}

Não construído

\section{Características}

0 projeto para este concurso fechado visava atender às necessidades deste instituto de pesquisas ambientais, aproveitando as visuais para a represa e a mata considerando o menor impacto ambiental possível na realização da obra. Desta forma, o partido foi estruturado por um eixo transversal destinado a um funicular capaz de interligar quatro platôs principais, interligando os edifícios construídos com telhas e fechamentos metálicos associados a estruturas de madeira.

\section{Acervo}

Tubo 67

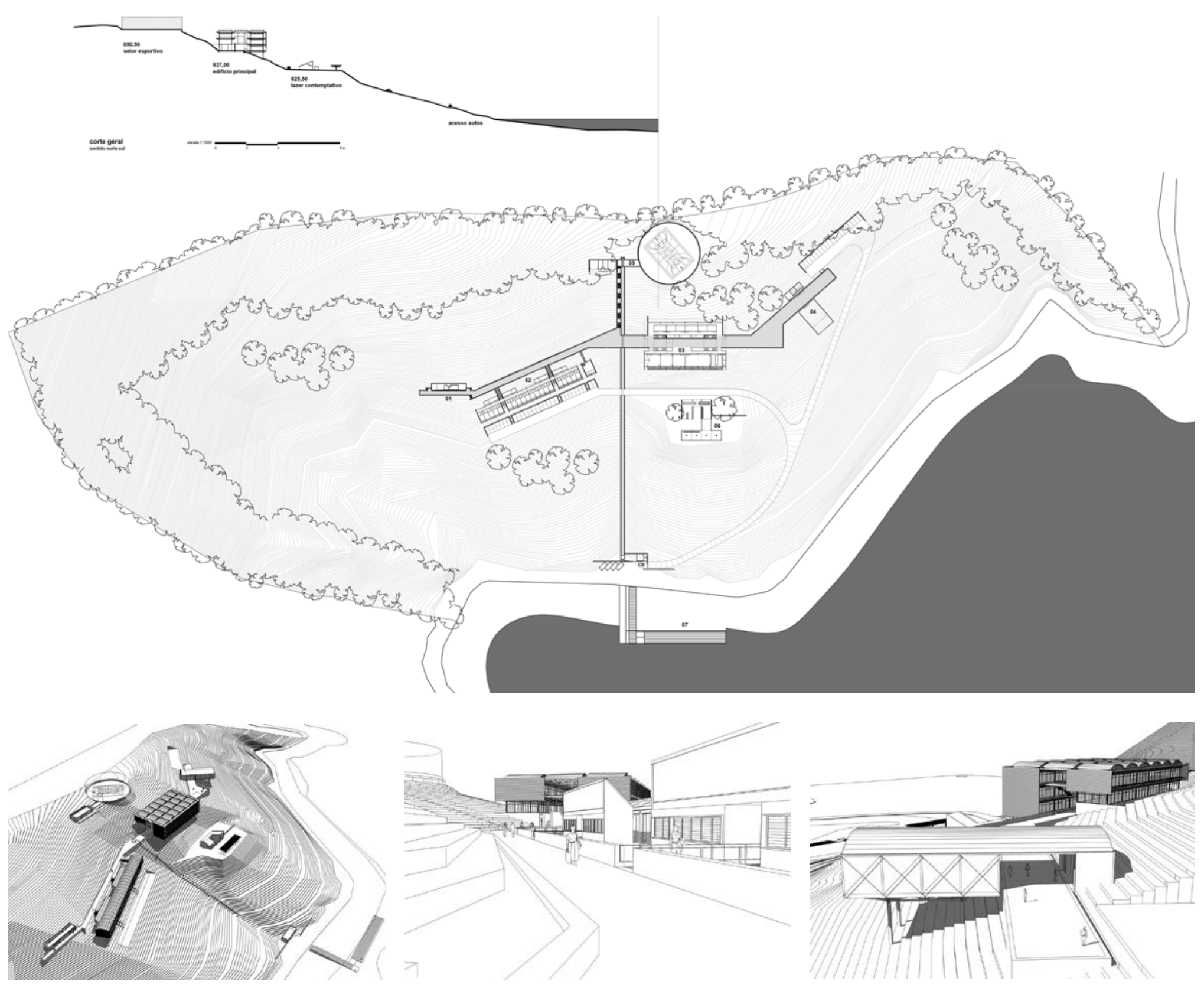


Uso

Residência Unifamiliar

Cliente

Henrique Reinach

Equipe

Eduardo de Almeida

colaboradora I Maira Rios

\section{Localização}

Piracaia, SP

Estágio

Projeto Executivo

\section{Observações}

Construído

\section{Características}

Realizado para o irmão do arquiteto Henrique Reinach responsável pela indicação de Eduardo de Almeida - este

projeto cria uma nova casa ao lado de uma reconhecida

obra do escritório Reinach Mendonça. Aproveitando as

visuais para a represa de Piracaia e a interligação com

um dos acessos da casa pré-existente, o volume eleva-

se em seis pilares, criando um pilotis ocupado pela escada e por espaços de apoio e lazer. No pavimento superior, a casa de apenas um dormitório com varanda de grandes dimensões, destaca-se pela volumetria da cobertura da sala: um plano inclinado que eleva o pédireito, iluminando-a naturalmente e garantindo um volume expressivo sobreposto ao prisma da casa.

Acervo

Caixa 3100 e Backup 343
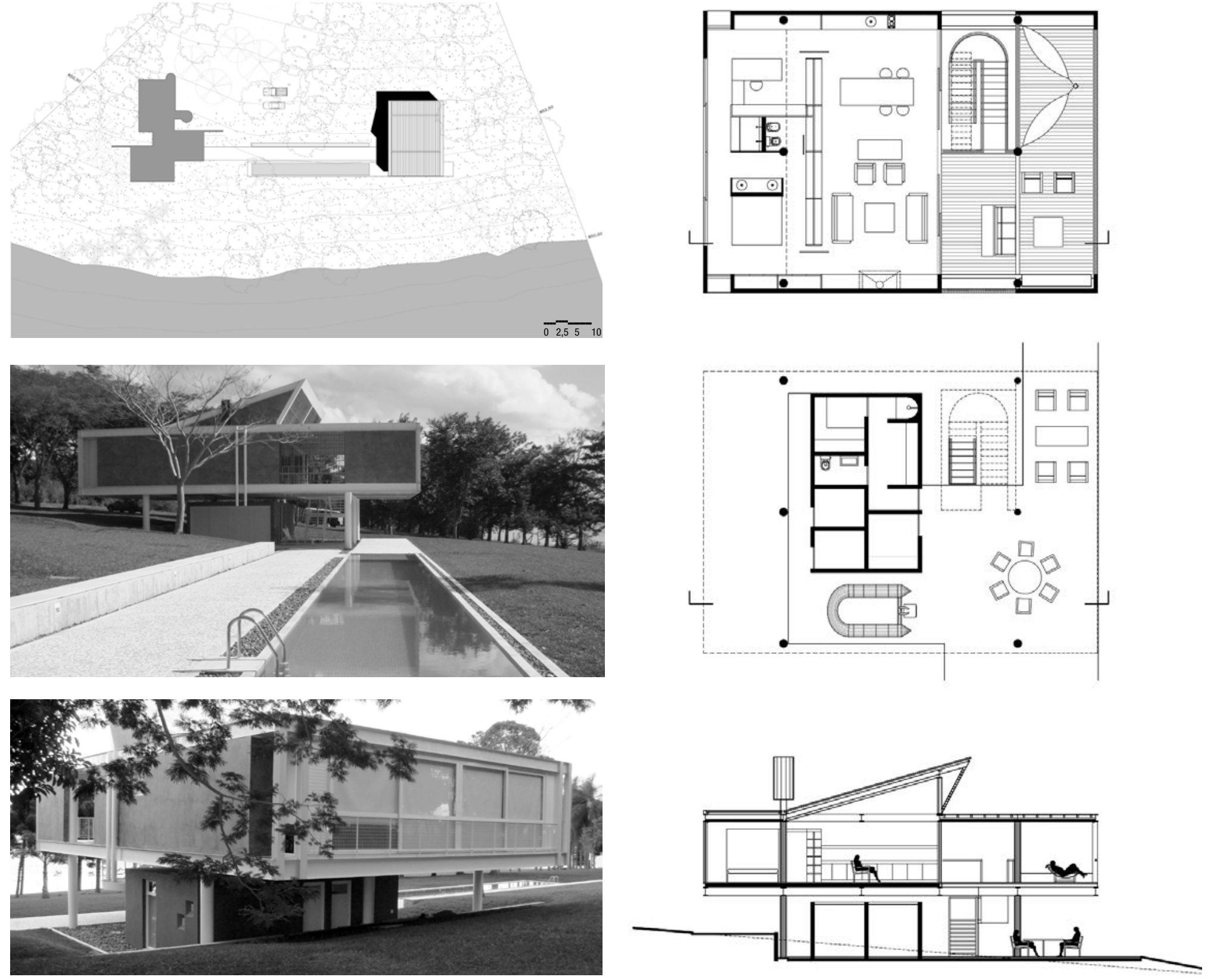
Uso

Plano Urbano

\section{Cliente}

Programa Monumenta - Ministério da Cultura e BID (Banco Interamericano de Desenvolvimento)

\section{Equipe}

Eduardo de Almeida e Estúdio 6 Arquitetos

colaboradores I Alexandre Mirandez de Almeida, Cesar

Shundi Imamizu, Marcelo Pontes de Carvalho e Ricardo

Bellio

Localização

Luz, São Paulo, SP

Estágio

Projeto Básico

Observações

Não construído

Premiação Anual IAB, em 2006, na categoria Urbanismo

\section{Características}

Inicialmente convidado a projetar o Museu do Brinquedo

na área da Luz, esta proposta foi ampliada pelo Programa

Monumenta como um Plano Urbanístico para esta área

Central de São Paulo, considerando que a verba para

o restauro de imóveis tombados deste programa

deveria ser destinada, neste caso complexo, a um

planejamento de ações estratégicos seguindo a vocação

metropolitana da área. Assim, além de planejar as ações

de preservação, a proposta incluía enfrentamentos em

relação à mobilidade urbana - sistema viário, travessias

de pedestres e transporte público - assim como

melhorias dos espaços públicos e investigaç̃os sobre

adensamento habitacional e destinação de quadras

específicas com programas de caráter público.

Acervo

Caixa 3200 e Backup 347
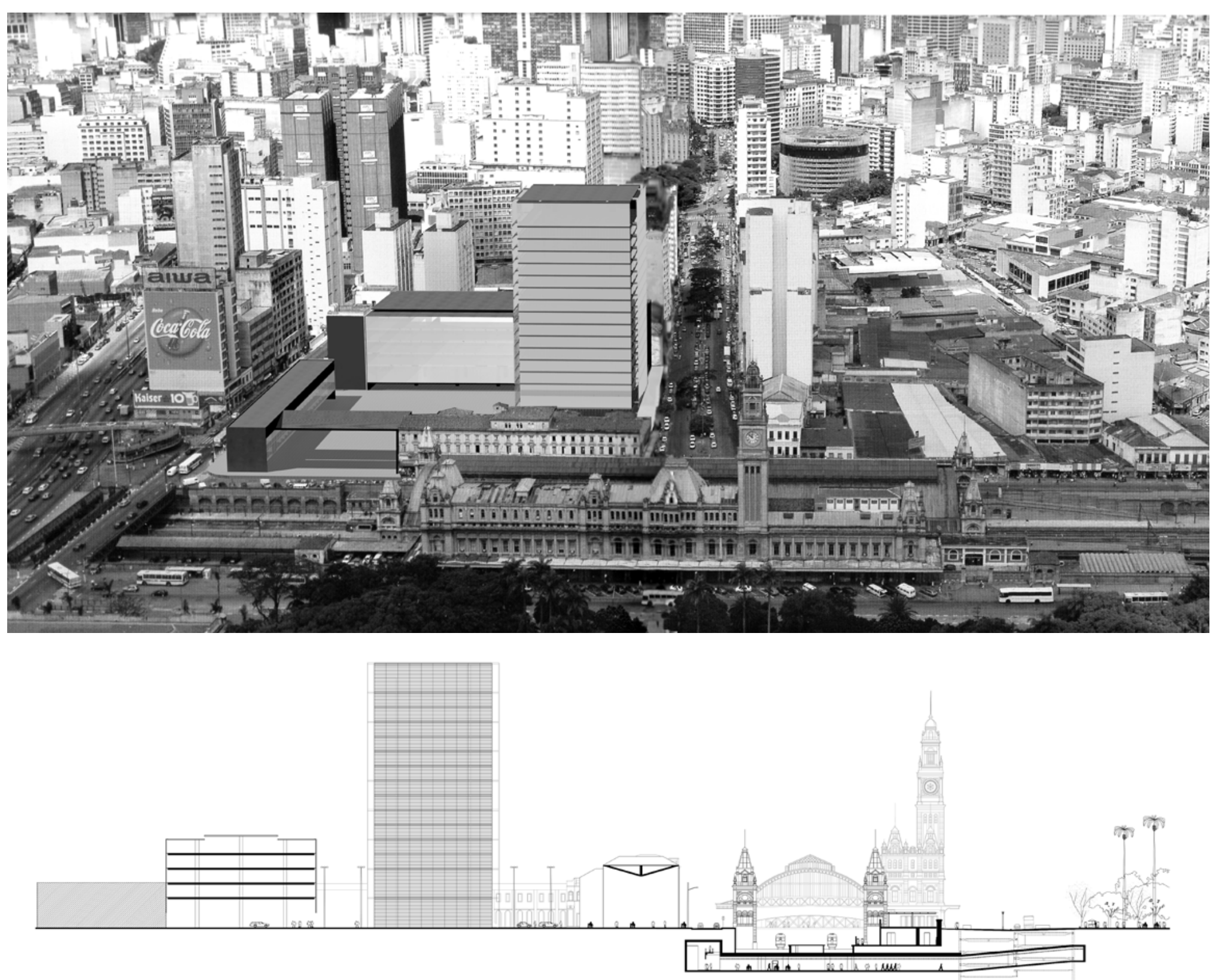
Conjunto Residencial - 2 casas

Cliente

Omar Dekech

Equipe

Eduardo de Almeida

Localização

Rua José Cristo Moreira, São Paulo, SP

Estágio

Anteprojeto

Observações

Características

Aproveitando a topografia do terreno, Eduardo de Almeida realiza este projeto de quatro residências em

função dos dois patamares utilizados como garagem e

área de serviços. Implantadas em uma relação de meio-

nivel, os dois conjuntos criam espaços de estar e cozinha

nos pavimentos intermediários (acessados diretamente

pelo corredor lateral) e quatro dormitórios no pavimento

superior.

Acervo

Backup 348
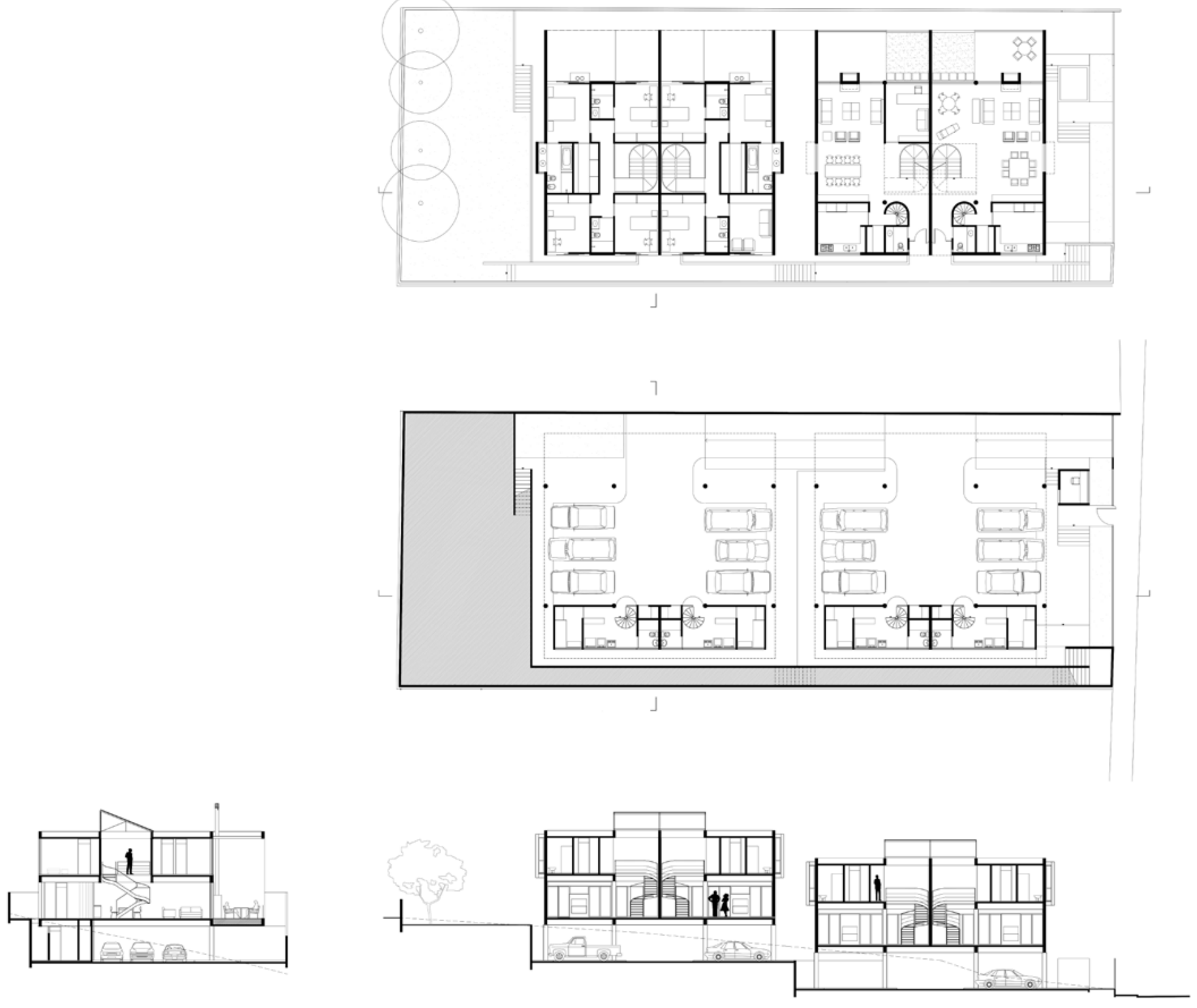
Uso

Residência Unifamiliar

Cliente

Alain e Haydée Belda

Equipe

Eduardo de Almeida

colaborador I Leonardo Sette

Localização

Rua Suécia 114/116, Jardim Europa, São Paulo, SP

Estágio

Anteprojeto

Observações

Não construído

Características

Seguindo a influência do projeto realizado para Edilah Biaggi (2004) este projeto distribui os programas principais no pavimento térreo e os espaços de apoio em um pavimento semi-onterrado. Neste caso, dois pavilhões paralelos articulados por uma passarela compõem um conjunto organizados por jardins internos.

Acervo

Tubo 5 e Backup 353
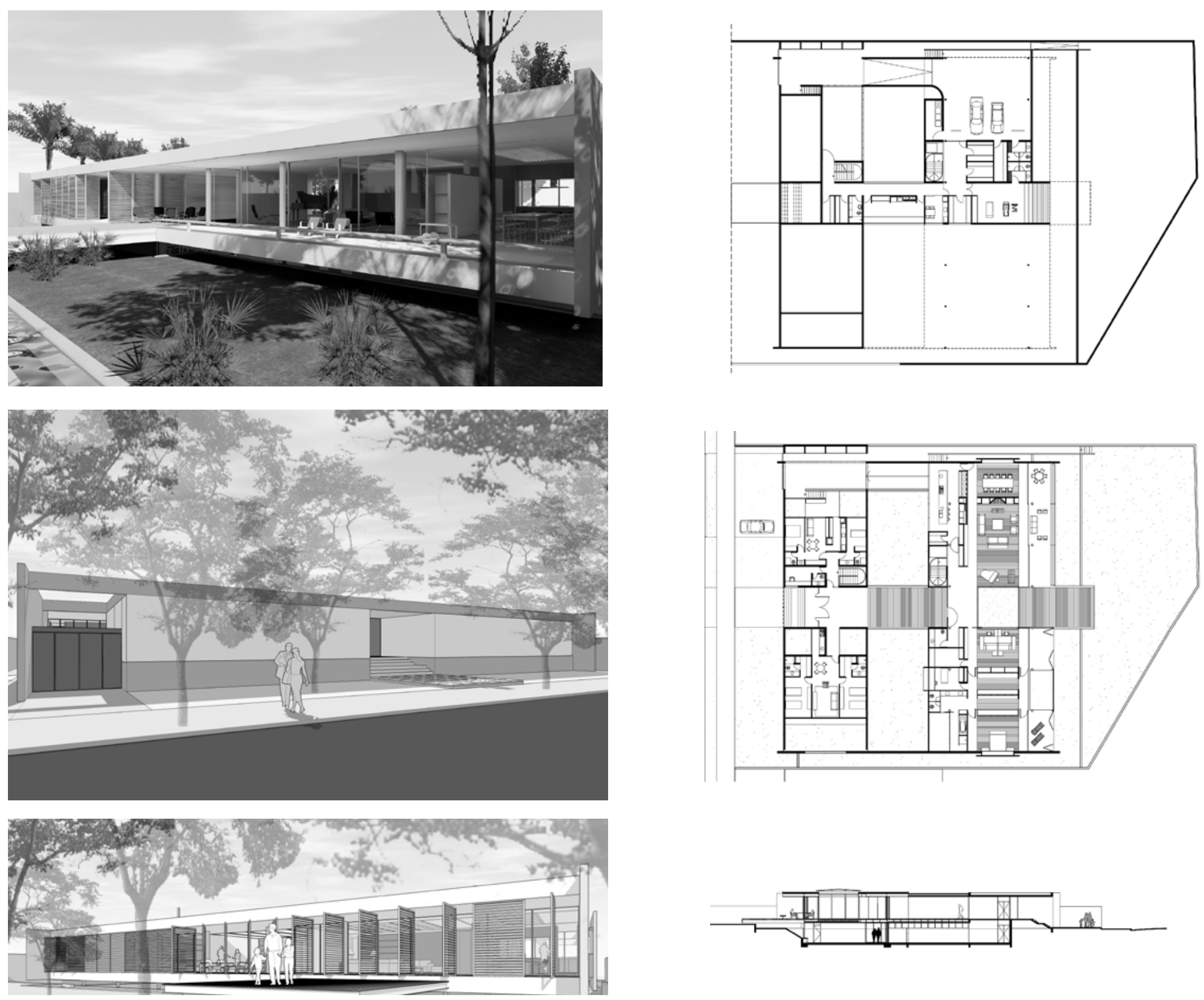
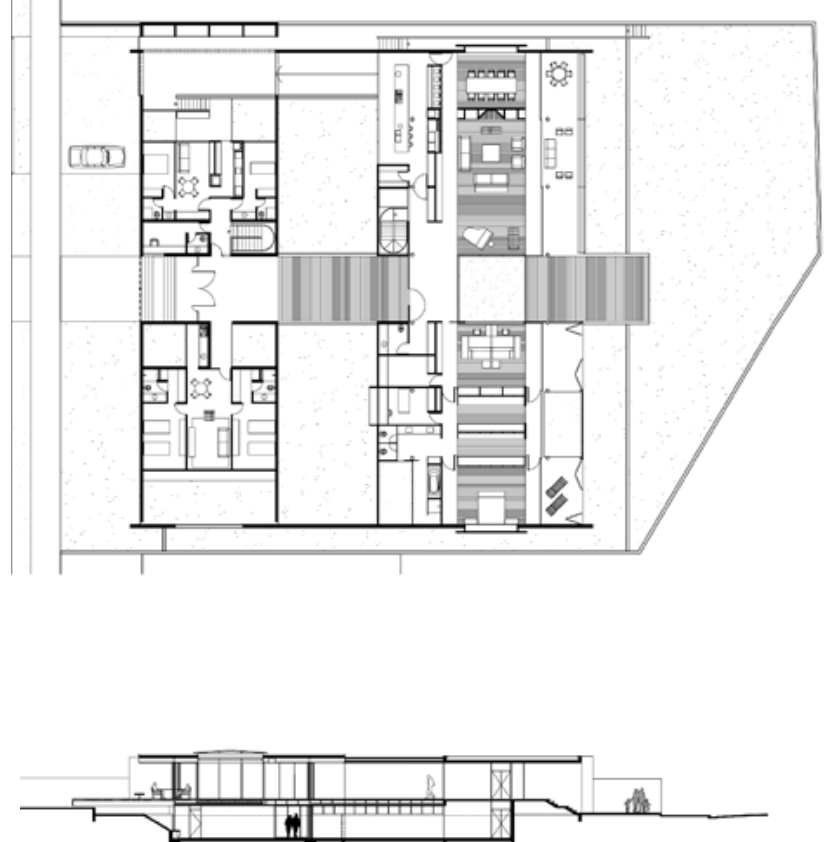
Residência Unifamiliar

Cliente

Marcelo Bresser Pereira

Equipe

Eduardo de Almeida

colaborador I Leonardo Sette

\section{Localização}

Rua Castro Delgado 107, Alto de Pinheiros, São Paulo, $\mathrm{SP}$

Estágio

Projeto Executivo

\section{Observações}

Construído

\section{Características}

Seguindo a geometria do lote de proporção quadrada,

esta casa utiliza uma implantação em 'L' onde os

ambientes dispostos nas duas alas de dois pavimentos

voltam-se para o jardim e a piscina. Neste caso, apesar

de descoberto, 0 jardim aparece interiorizado, por

ser configurado pela parede envoltória vermelha que

define 0 volume da casa. Enquanto este volume exterior

é construído com estrutura de concreto e alvenaria

revestidos, os espacos internos utilizam estrutura

metálica e caixilharia de alumínio e vidro.

Acervo

Caixa 2900 e Backup 355
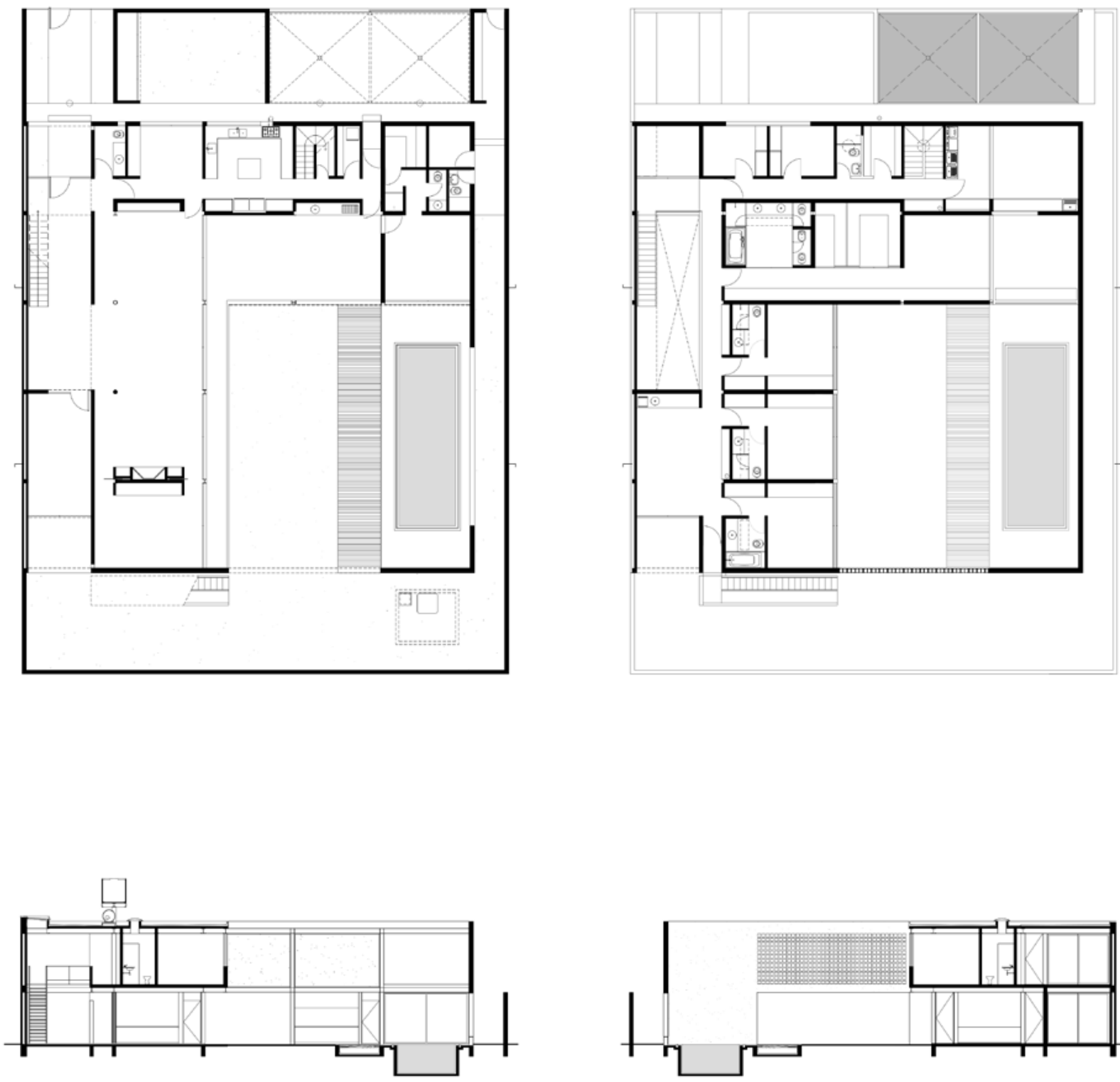

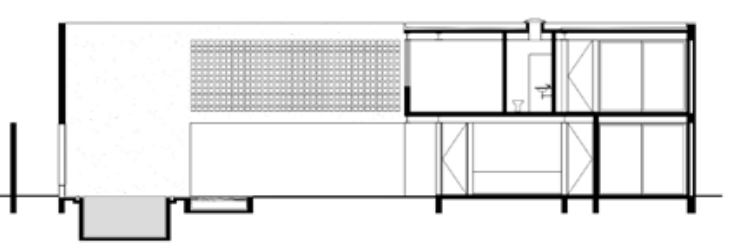


Uso

Residência Unifamiliar

Cliente

Maria Isabella Mistrorigo de Almeida

Equip

Eduardo de Almeida

Localização

Rua João Batista Leme da Silva, São Paulo, SP

Estágio

Projeto Executivo

Observações

Construído

\section{Características}

Extremamente singela, esta casa para sua filha Isabella ocupa um lote de esquina utilizando-se de técnicas convencionais e soluções econômicas. Posicionada junto

às divisas de fundo, o desenho da cobertura possibilita

iluminação e ventilação dos espaços internos.

Acervo

Caixa 1500 e Backup 357
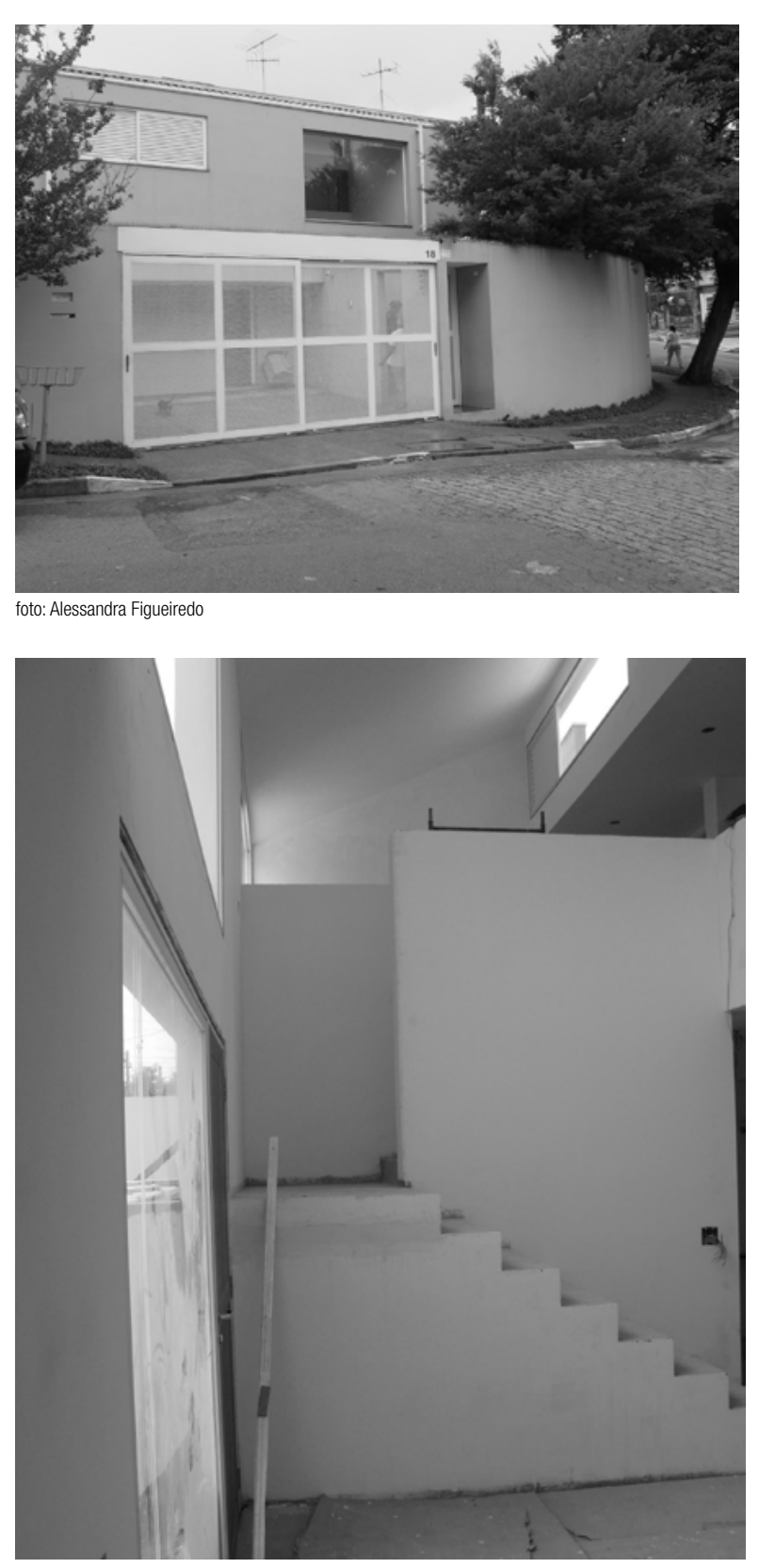
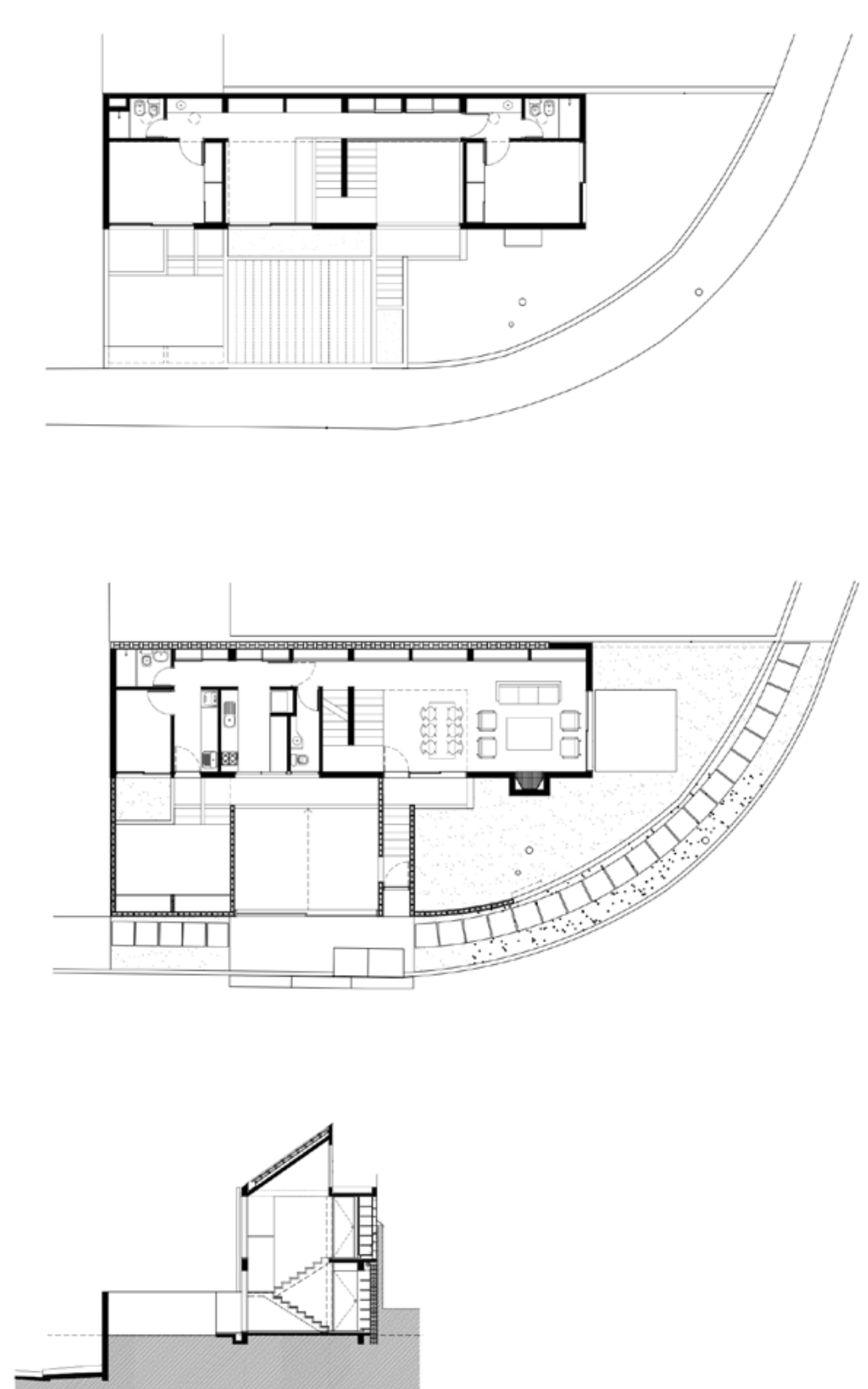
Uso

Residência Unifamiliar

Cliente

Tácito e Fernanda de Almeida

Equipe

Eduardo de Almeida

colaborador I Leonardo Sette

\section{Localização}

Praça Monteiro Lobato 205, São Paulo, SP

Estágio

Projeto Executivo

\section{Observações}

Construído

\section{Características}

Encomendada por seu filho Tito, esta casa constitui-

se por um volume quadrado organizada em dois

pavimentos, considerando um fechamento inclinado

junto à divisa de fundo que define um espaço interior de

geometria trapezoidal. Desta forma, respeita-se a área

construída de acordo com o recuo posterior exigido por

lei, resultando em uma varanda triangular e um espaço

vazio no segundo piso que cria um pé-direito duplo na

área da sala de jantar. Construída em aço e vidro, a casa

conta ainda com paredes divisórias leves e caixilharia de

alumínio.

Acervo

Tubo 80, Caixa 3000 e Backup 111
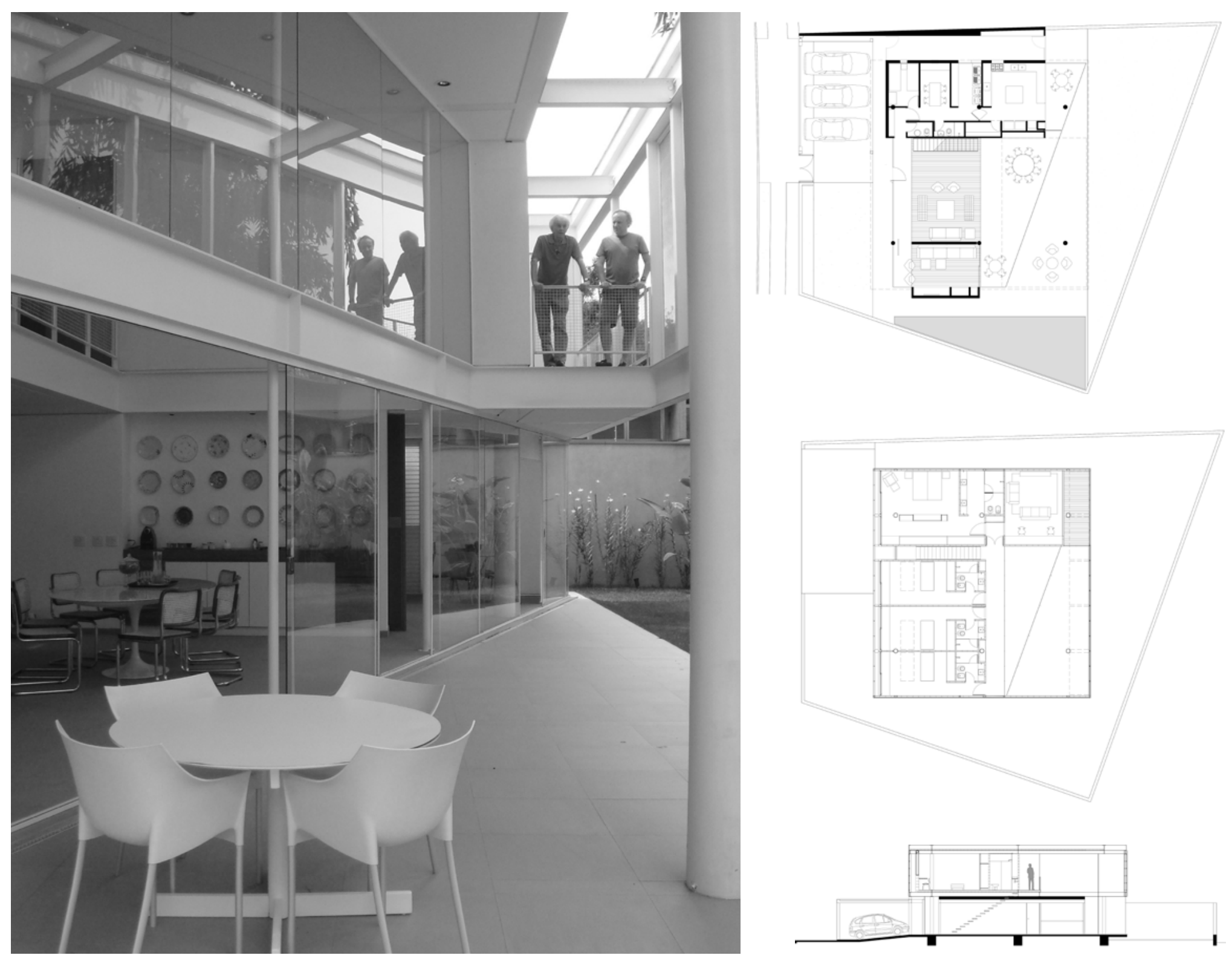
Residência Unifamiliar

Cliente

Paulo Vitor Oppenheim

Equipe

Eduardo de Almeida

colaboradora | Maira Rios

\section{Localização}

Praia do Una, Bahia, BA

Estágio

Projeto Executivo

\section{Observações}

Construído

\section{Características}

Construída para o mesmo cliente de uma obra realizada

em conjunto com Arnaldo Martino (1983), esta casa na

Bahia foi pensada pela justaposição de quatro volumes

de cobertura inclinada, articulados por uma laje de

geometria cruciforme posicionada sobre os espaços de

circulação da casa, a exemplo de inúmeras obras de

Eduardo de Almeida.

Acervo

Caixa 3100 e Backup 359
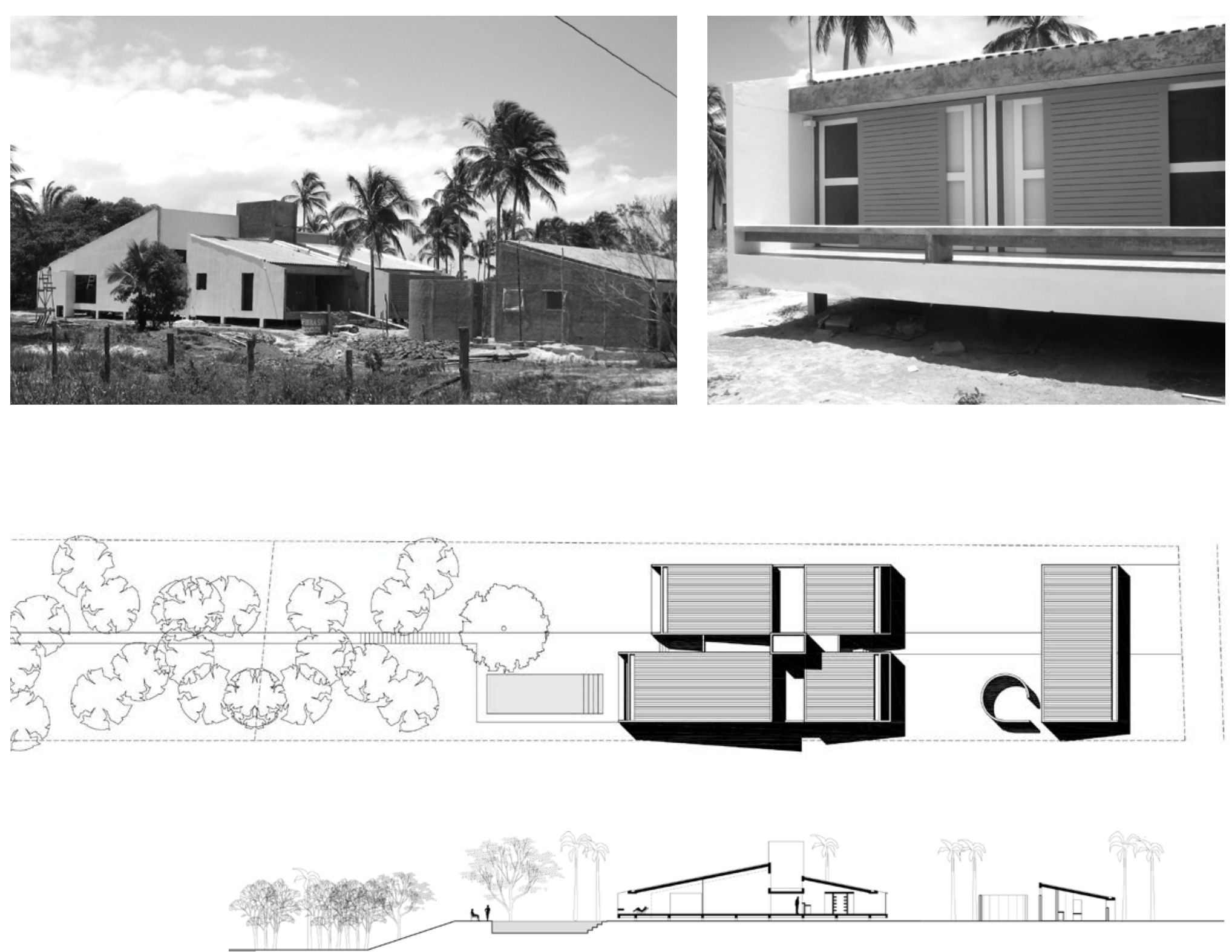
Uso

Sede Administrativa

SAP Labs' Latin America

Equipe

Eduardo de Almeida e SIAA

colaboradores I Alexandre Mirandez, Ana Addor, Cesar

Shundi Iwamizu, Giovana Avancini, Leonardo Sette,

Marcelo Pontes, Rafael Urano, Ricardo Bellio, Cecília

Heichstul, Felipe Notto, Giovana Avancini e Roberto

Zocchio Torresan

\section{Localização}

São Leopoldo, RS

\section{Estágio}

Projeto Executivo

\section{Observações}

Construído

\section{Características}

Selecionado em um concurso fechado de anteprojetos, este edifício de escritórios foi desenhado pela justaposição de dois blocos paralelos, de acordo com a orientação das demais construções presentes no Campus Universitário da Unisinos. Ao mesmo tempo em que as fachadas principais voltam-se para o Norte e para o SUl, um jardim interno permite a iluminacão

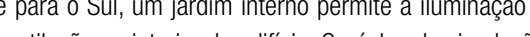
ventilaçáa no interior do edilicio. O núcleo de circulaçãa e de serviços, posicionado assimetricamente em relação ao volume do edifício foi pensado como ponto de conexão com a ampliação já pensada na implantação do conjunto. Este edifício, realizado posteriormente ao terceiro estudo para a Bhir tenolvido e construído anteriormente à obra implantada na USP, situação que permitiu a influência mútua entre as duas obras: enquanto a sede para a SAP foi influenciada pelo partido arquitetônico da Biblioteca, as soluções construtivas e 0 detalhamento da primeira foram apropriadas pelo executivo e obra da segunda.
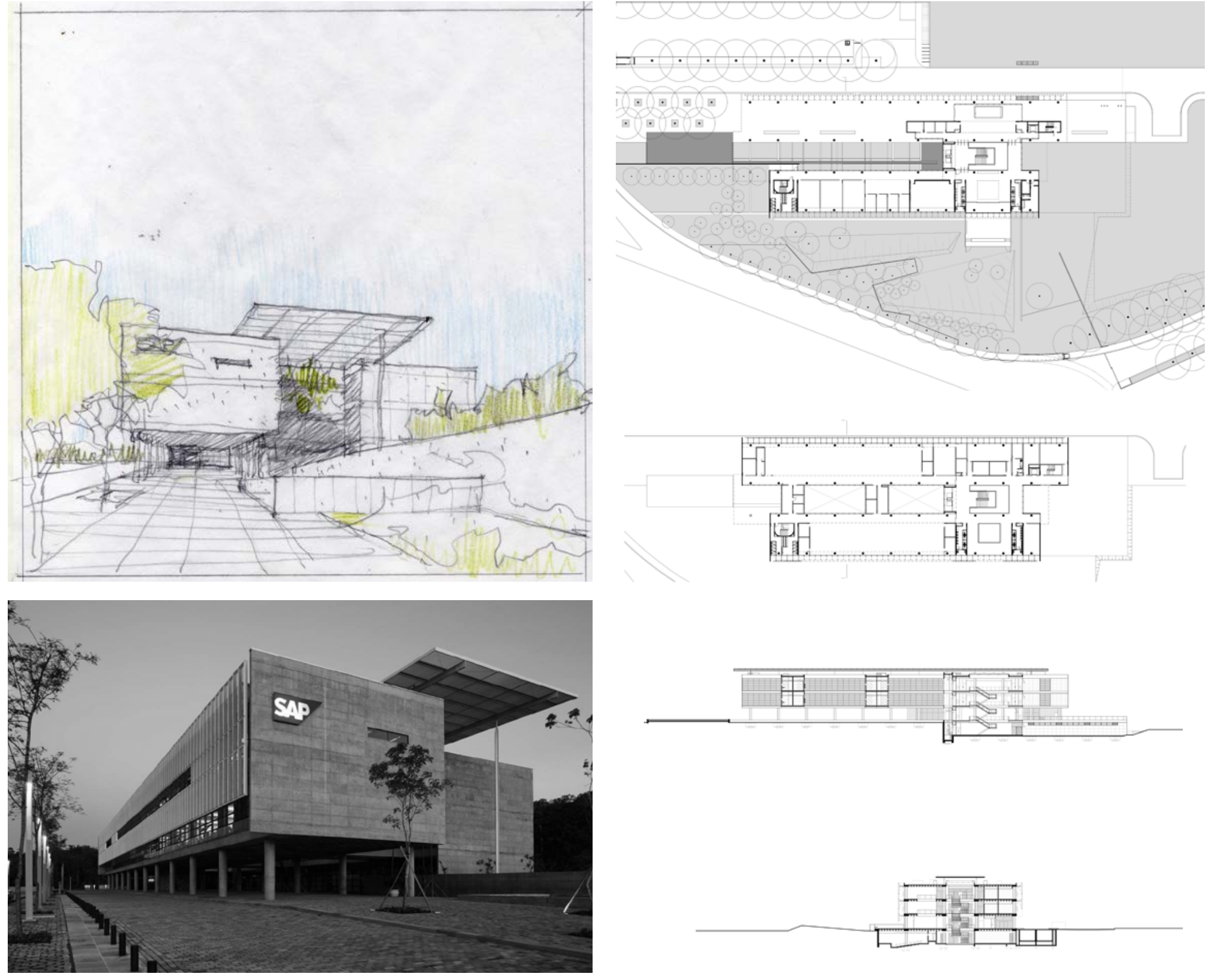

-

otot: Nelson Kon 
Uso

Sede Administrativa

Cliente

SAP Labs' Latin America

Equipe

Eduardo de Almeida e SIAA

colaboradores I Artur Mei, Bruno Valdetaro Salvador,

Cesar Shundi Imamizu, Felipe Noto, Francisco Costardi,

Marina Colonelli, Nicolau Freitas, Rafael Carvalho e

Rafael Goffinet de Almeida

estrutura I Cia. de Projetos

paisagismo I Soma Arquitetos

Localização

São Leopoldo, RS

Estágio

Projeto Executivo

Observações

Construído

\section{Características}

Dando continuidade ao plano de expansão da empresa a capacidade inicial de 400 funcionários foi ampliada para 1000 postos de trabalhos, acompanhados pela ampliação de salas de reunião, sanitários, copa, espaços de estar e sobretudo pela complementação de dois programas, um restaurante - espaço de pé-direito duplo voltado para um pátio externo - e um centro de inovação - volume em estrutura metálica e geometria irregular atirantado à estrutura principal do edifício

Acervo
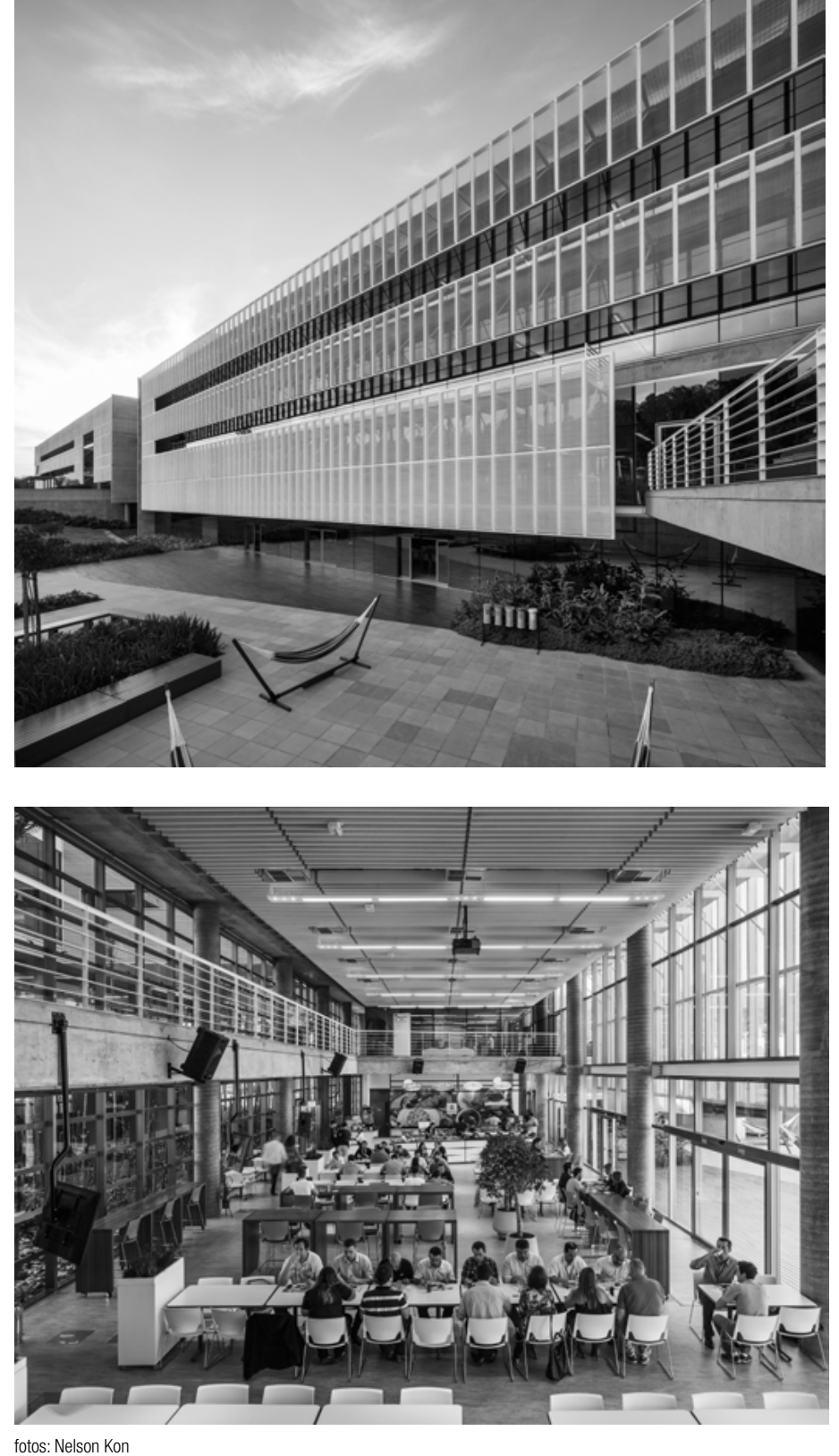
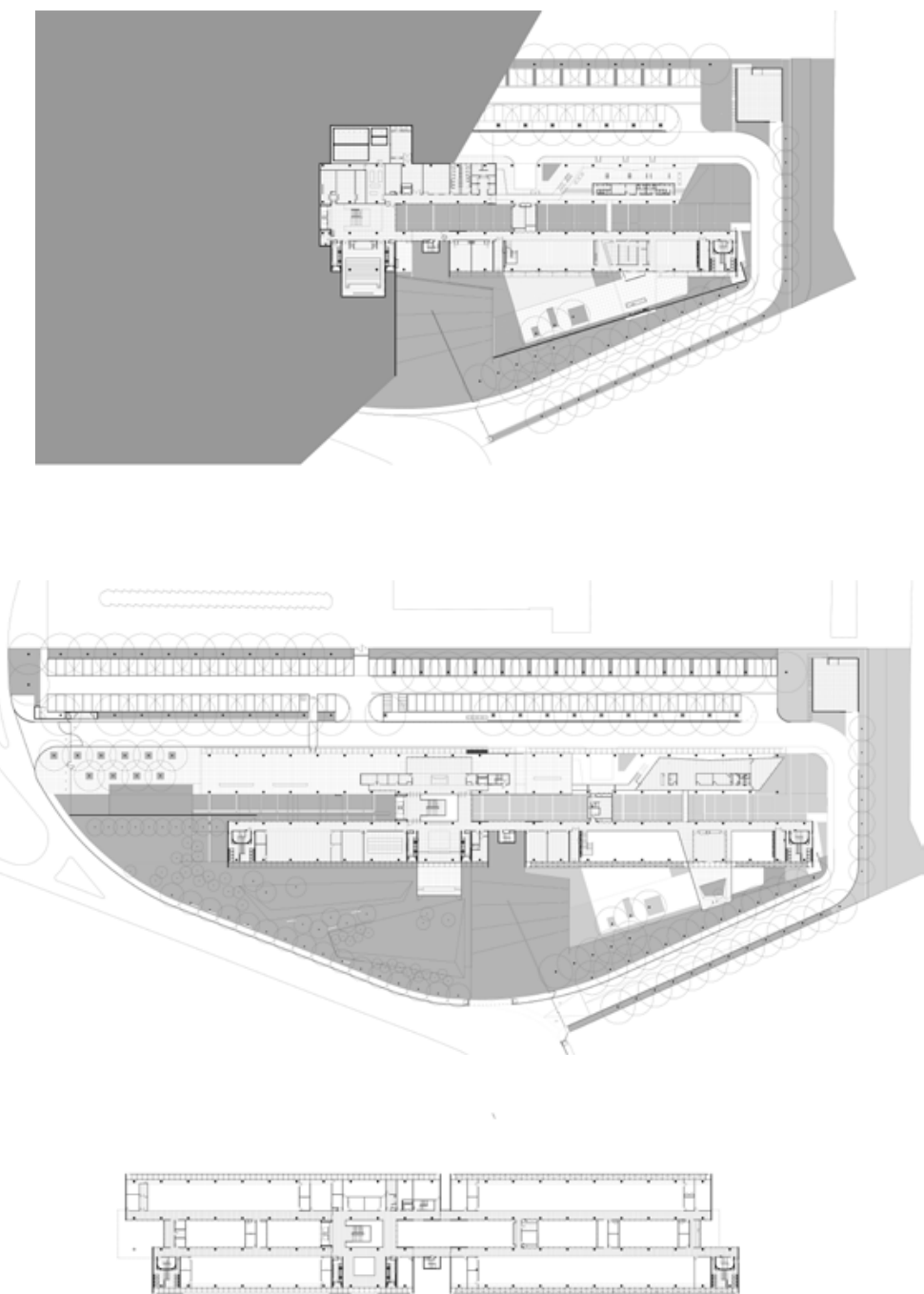

$\mathbb{B}$ 巴 
Residência Unifamiliar

Cliente

Rodrigo Lacerda Soares

Equipe

Eduardo de Almeida

Localização

Vila do Pinhal, SP

Estágio

Estudo Preliminar

Observações

Não construído

\section{Características}

Seguindo o partido de uma casa composta por dois

núcleos, este projeto cria a articulação de um bloco

destinado a dois dormitórios com um volume de dois

pavimentos dedicado à sala e à cozinha, além da súte

do casal no pavimento superior.

Construída com técnicas construtivas convencionais, a

casa alterna planos de fechamentos de alvenaria com

planos envidraçados e proteções de elemento vazado de

concreto.
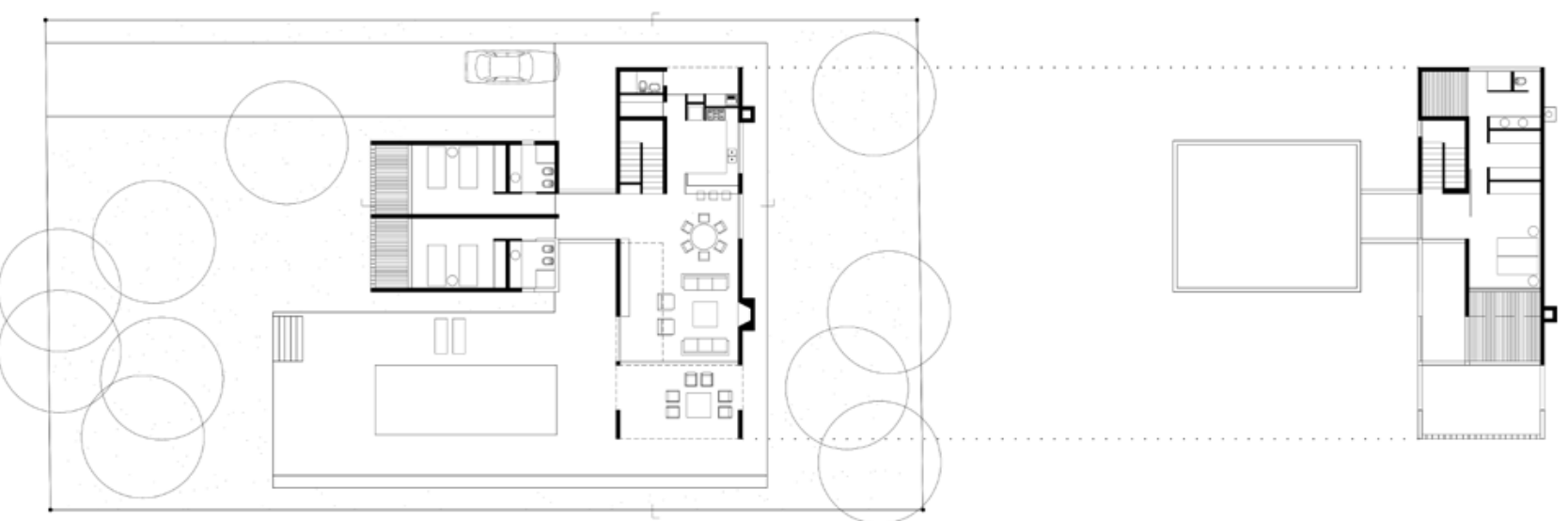

Acervo

Tubo 81 e Backup 361
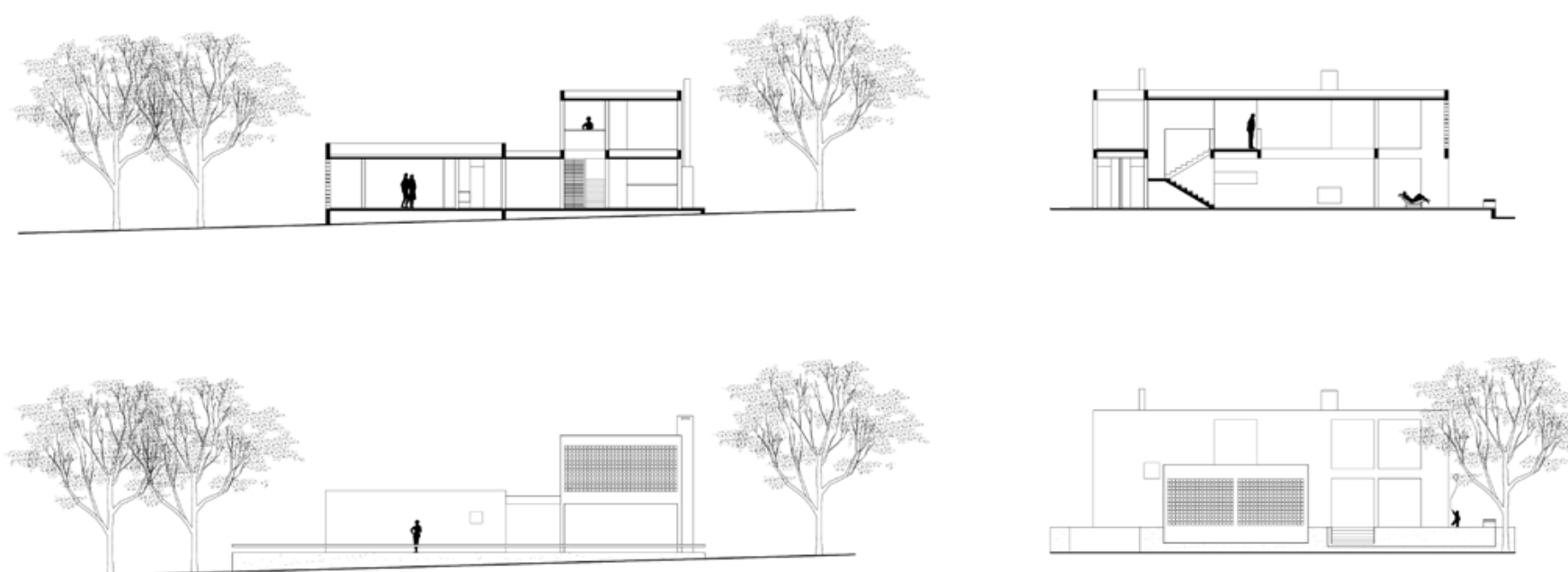
Residência Unifamiliar

Cliente

Fernando e Verônica de Almeida

Equip

Eduardo de Almeida

Localização

Rua Xupé, Vila Madalena, São Paulo, SP

Estágio

Executivo

Observações

Construído

\section{Características}

Construída para seu filho Fernando, este projeto implantado em terreno em aclive cria interessantes relações entre os ambientes internos e 0 exterior, uma vez que a cobertura da garagem é utilizada como pátio externo e que os ambientes de estar voltam-se ao jardim localizado no fundo do lote. Posicionada em meio-nível, uma outra sala foi criada em continuidade a um terraço triangular, aproveitando a topografia e a geometria do lote.

Acervo

Backup 363
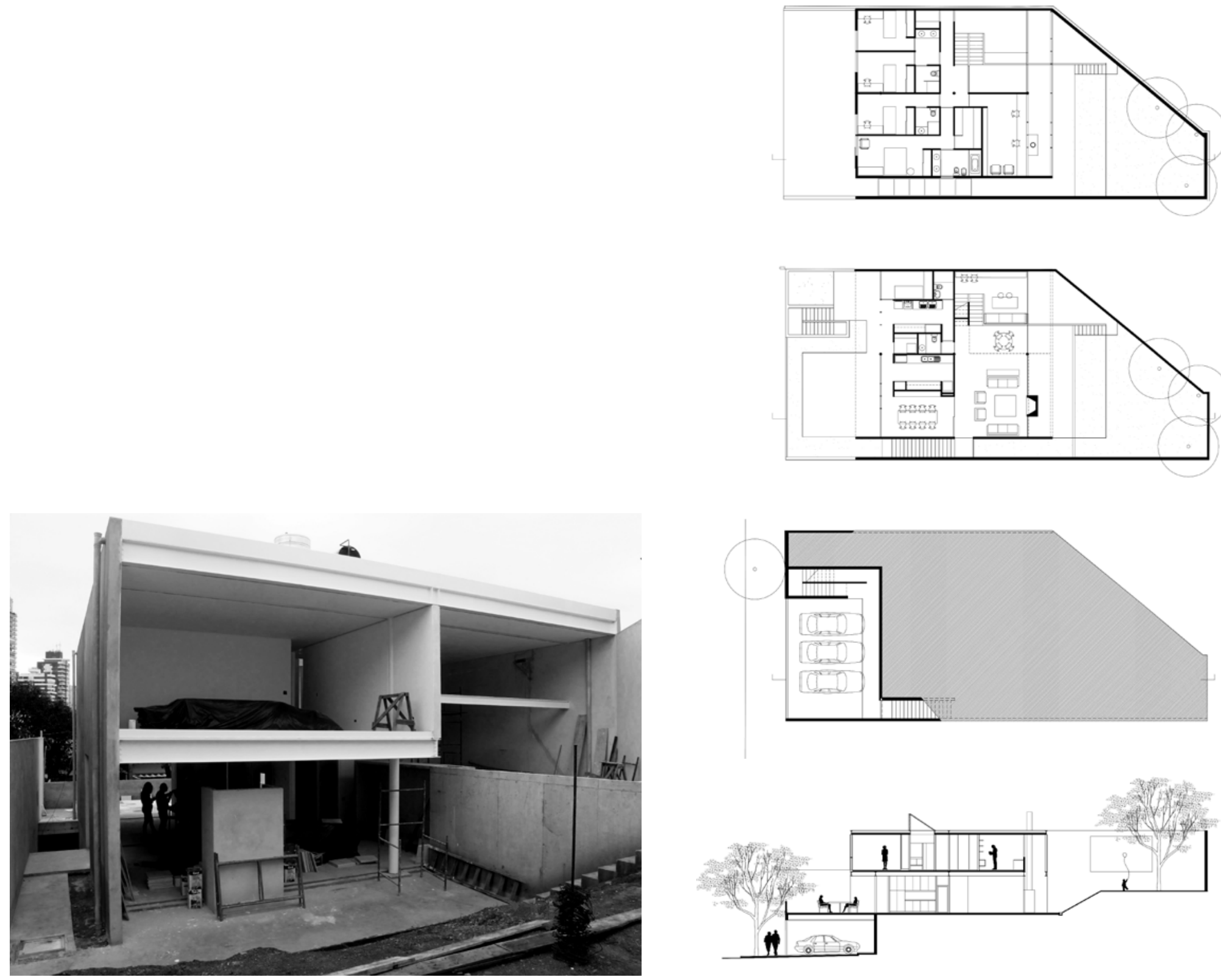
Uso

Residência Unifamiliar

Cliente

Cristina Pinho de Almeida

Equipe

Eduardo de Almeida

Localização

Praia Preta, São Sebastião, SP

Estágio

Estudo Preliminar

Observações

Não construído

\section{Características}

Inúmeros estudos foram realizados para esta casa que, no entanto, não chegou a ser construída. 0 fazer arquitetônico exige, por vezes, grande persistência por parte dos arquitetos já que os projetos parecem ter a obrigação de conciliar interesses distintos como as condições impostas pelo sítio, as necessidades dos clientes, as restrições legais e as aspirações dos próprios arquitetos que, no caso de Eduardo de Almeida referem-se ao equilibrio entre todos estes fatores, conjugados com a técnica, com 0 respeito aos materiais $e$ às investigações estéticas que permeiam 0 conjunto de sua obra.

Acervo

Backup 362

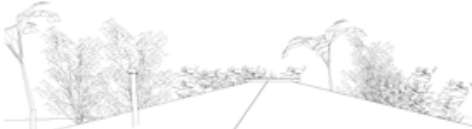
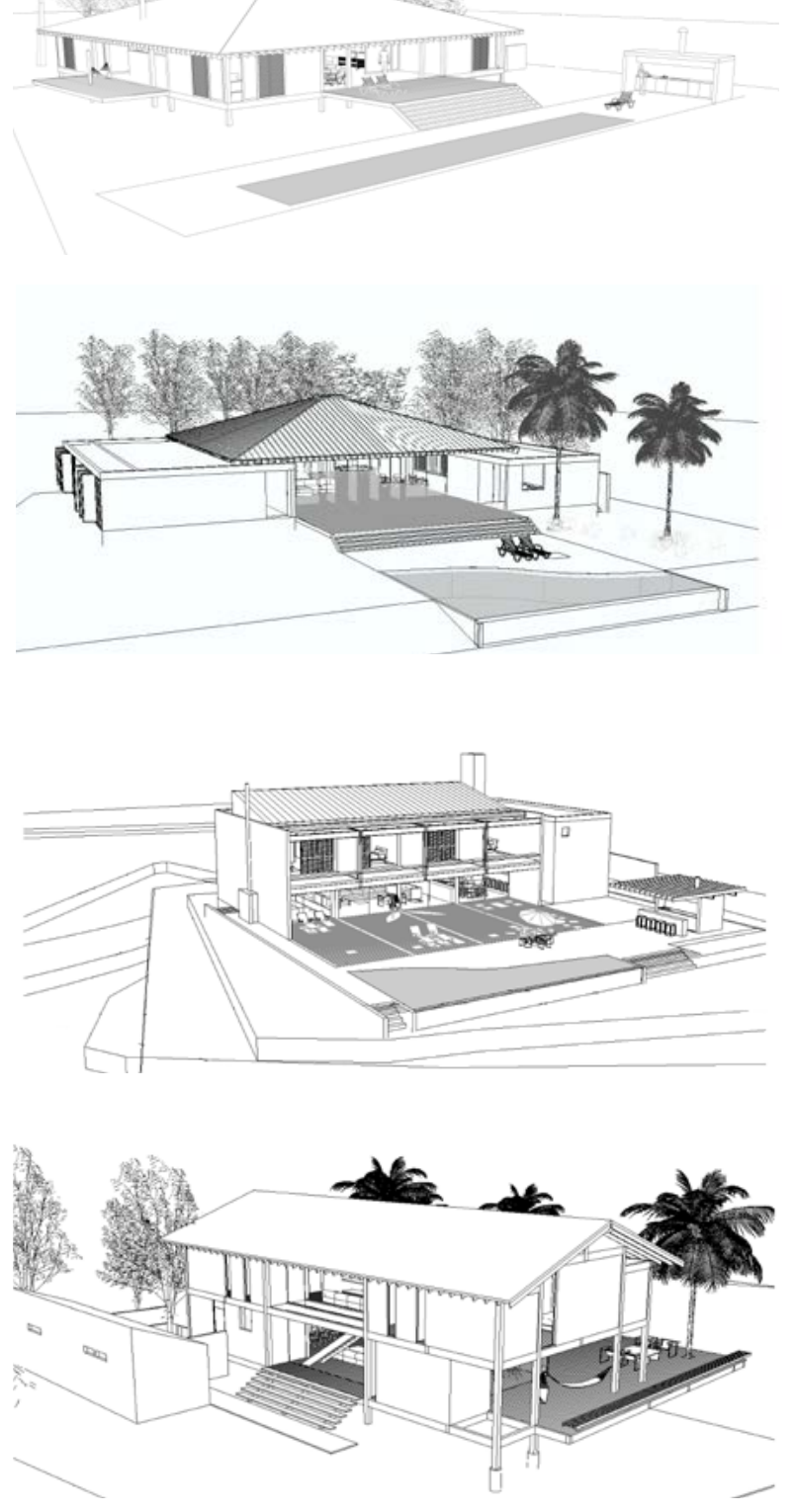
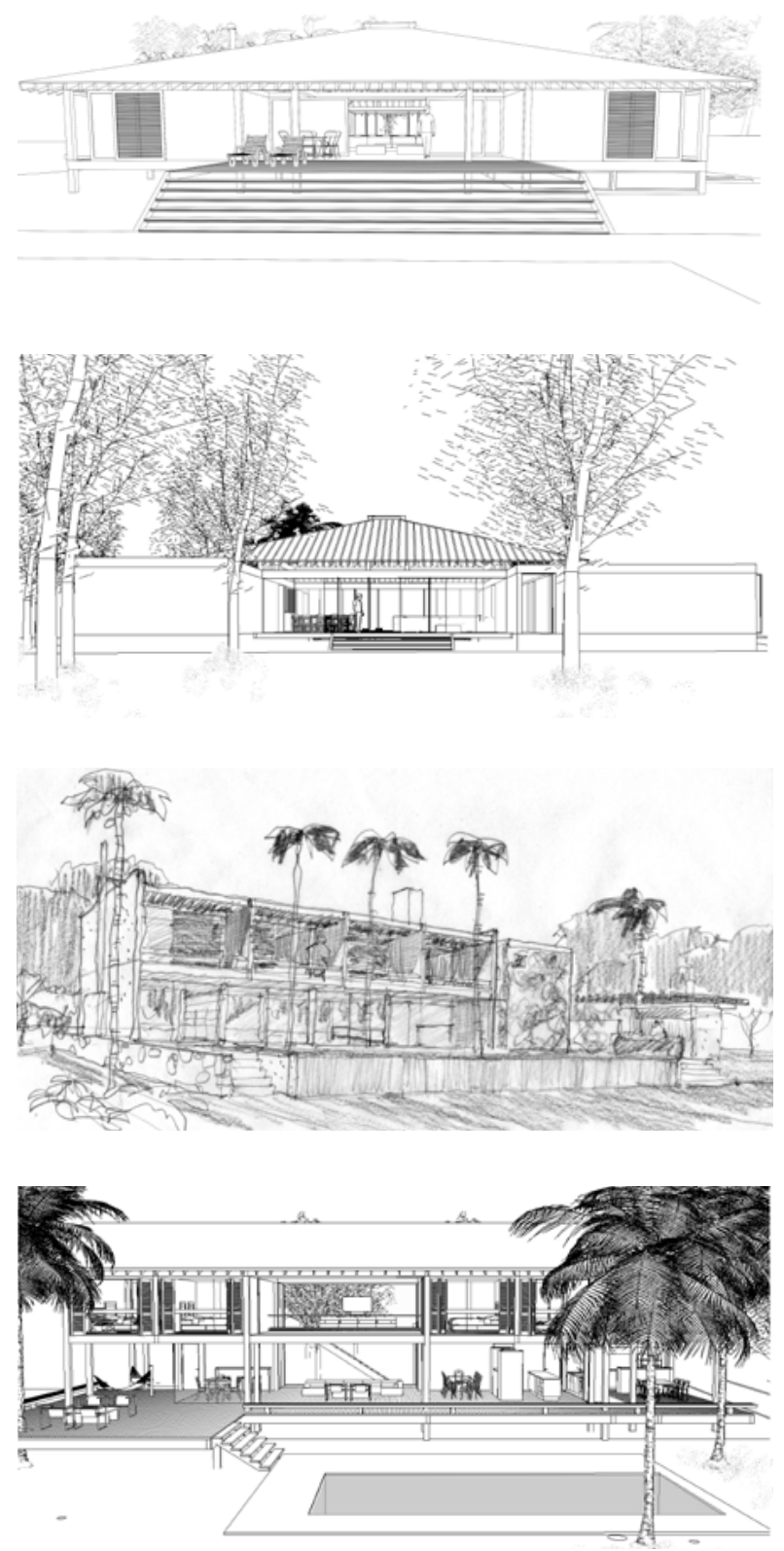
Uso

Residência Unifamiliar

\section{Cliente}

Antônio da Mota Figueiredo

Equip

Eduardo de Almeida

Localização

Condomínio Fazenda da Grama, Vinhedo, SP

Estágio

Projeto Executivo

Observações

Não construído

Características

Realizada por indicação dos clientes da casa Pacheco e Silva, esta residência de dois pavimentos considera a declividade do lote, permitindo acesso ao pavimento superior diretamente do nível da rua por uma passarela ao mesmo tempo em que garante a continuidade do piso inferior com o jardim e a piscina posicionados junto ao fundo do lote. 0 volume da escada implantado no módulo central cria distinção entre a ala destinada aos dormitórios e a ala desenhada para abrigar os ambientes de estar, cozinha e lazer.

Acervo

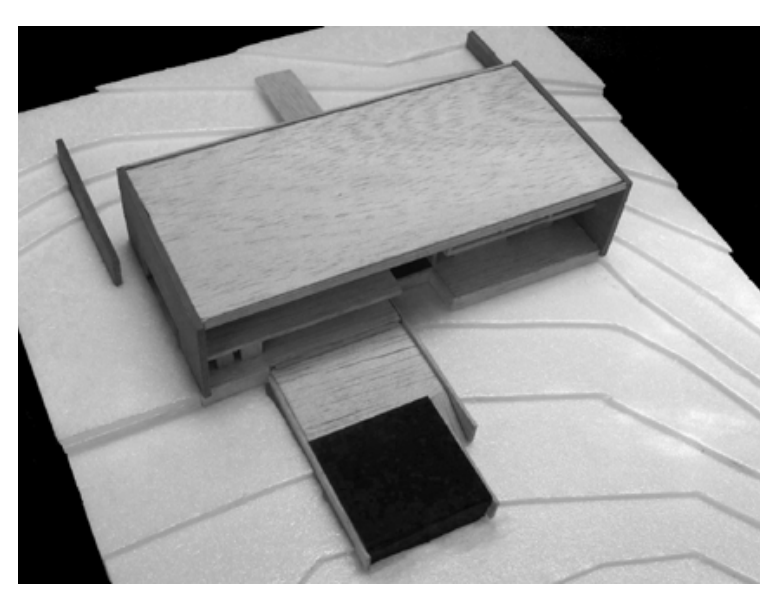

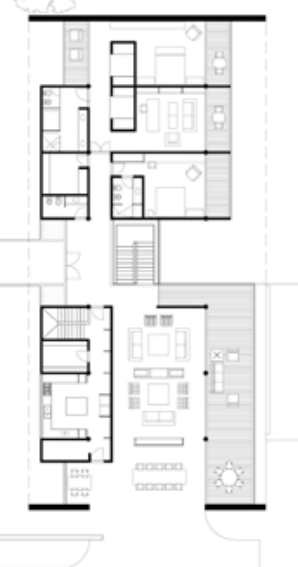
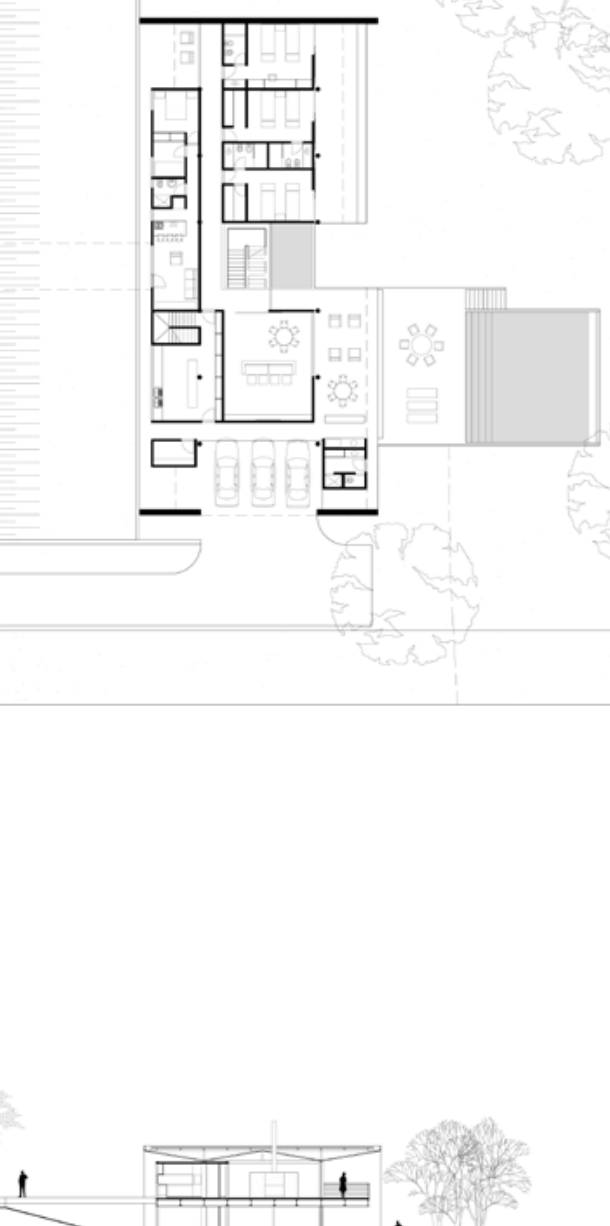
Uso

Residência Unifamiliar

\section{Cliente}

Renata Zuccolotto

Equipe

Eduardo de Almeida

Localização

Rua Pau Brasil, Boaçava, São Paulo, SP

Estágio

Projeto Executivo

Observações

Não construído

Características

Aproveitando as vistas para o Parque Villa Lobos, 0

volume desta casa foi elevado, articulado à garagem

por um pátio ajardinado posicionado junto ao patamar

da escada. Assim como em outros proietos, este vazio

articula os espaços de estar, cozinha e dormitórios.

Acervo

Backup 365
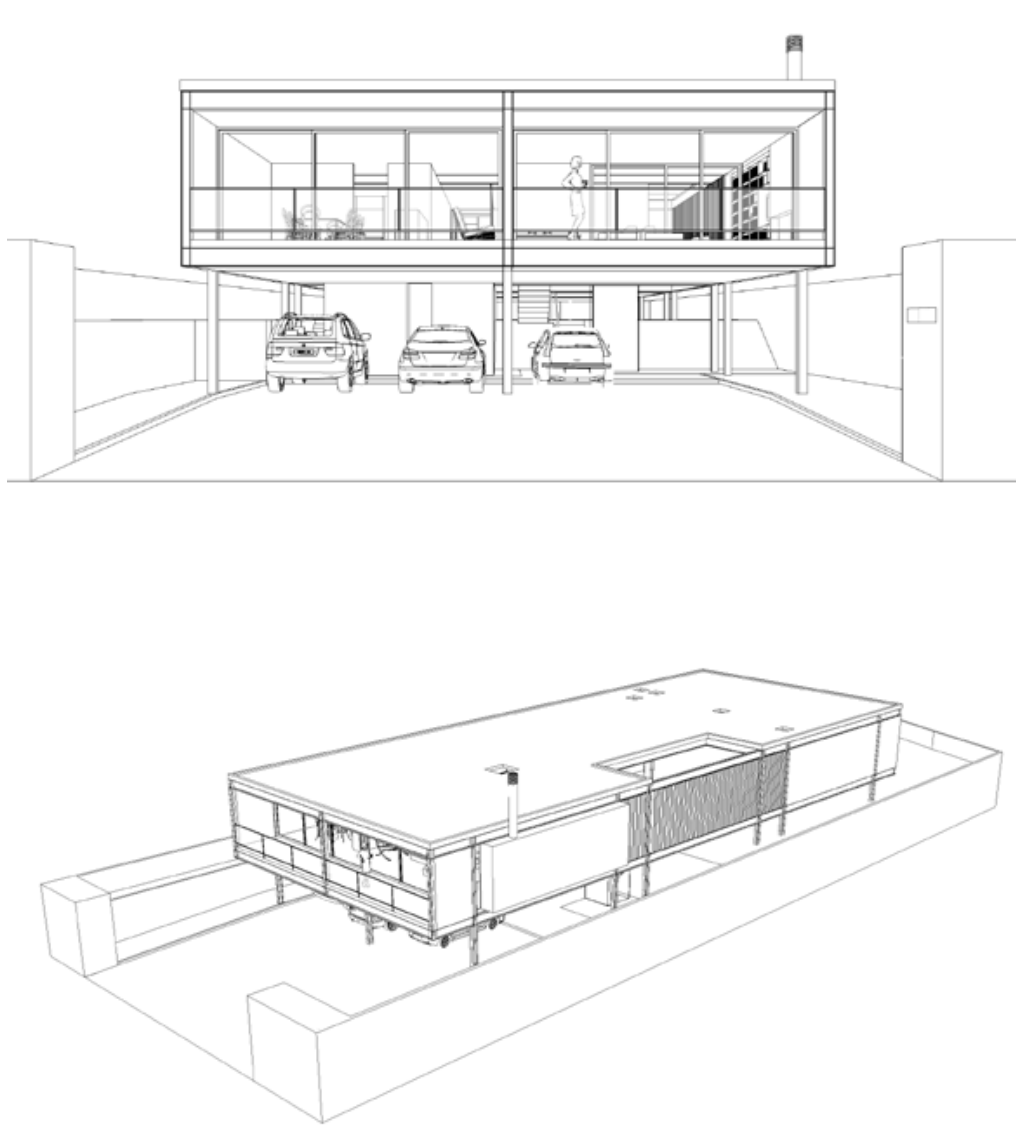
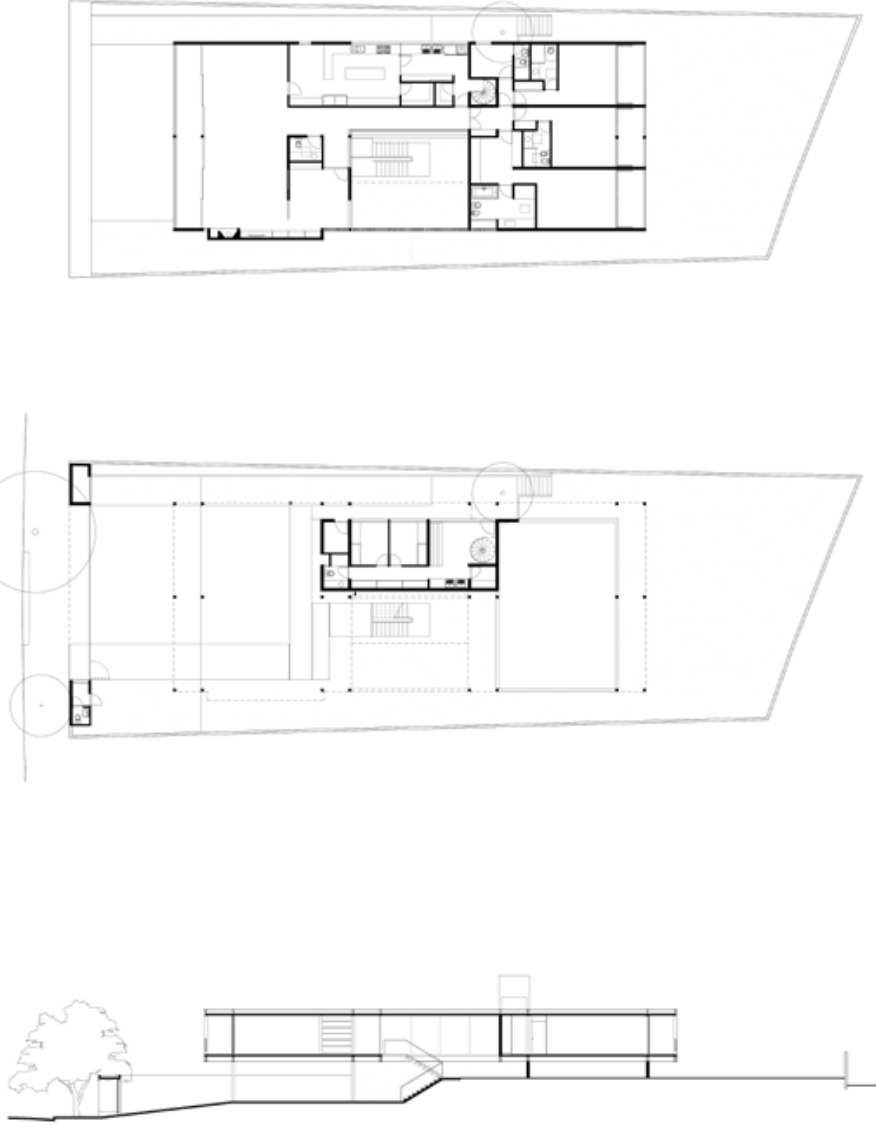
Acesso à Residência

Cliente

Debelian

Equipe

Eduardo de Almeida

Localização

Oslo, Noruega

Estágio

Projeto Executivo

Observações

Construído

Características

Depois de projetar residências para todos os seus filhos

que moram em São Paulo, Eduardo de Almeida realiza

este pequeno anexo para a residência de sua filha Nina

em Oslo, Noruega Um singelo abrigo de concreto, aço

vidro para 0 acesso da residência, garantindo a proteção

necessária ao clima da região.

Acervo

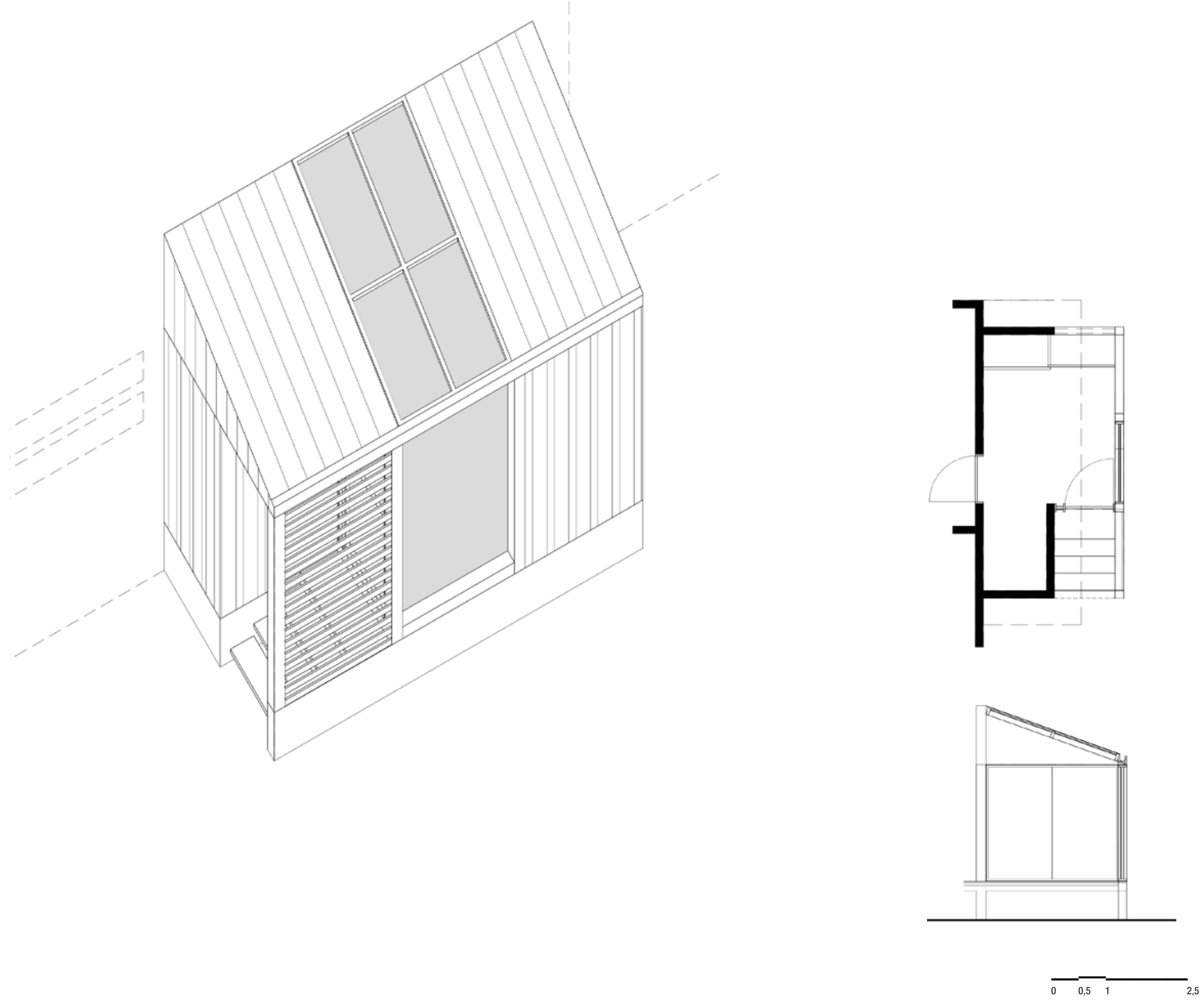


Uso

Escola

Cliente

FDE - Fundação de Desenvolvimento da Educação

Equipe

Eduardo de Almeida

colaborador I Roberto Zocchio Torresan

\section{Localização}

Rua do Hipismo, Campinas, SP

\section{Estágio}

Projeto Executivo

\section{Observaç̃es}

Construído

\section{Características}

Construída em estrutura pré-moldada de concreto,

esta escola reproduz o recorrente partido utilizado por

Eduardo de Almeida: blocos funcionais articulados pela

circulação. Neste caso, os três volumes definem um

espaço vazio iluminado zenitalmente, onde se localizam

escadas e passarelas. As fachadas destes três blocos

também configuram um pátio externo que se extende ao

jardim localizado no fundo do lote, aproveitando também

as vistas em direção ao vale.

\section{Acervo}

Backup 371
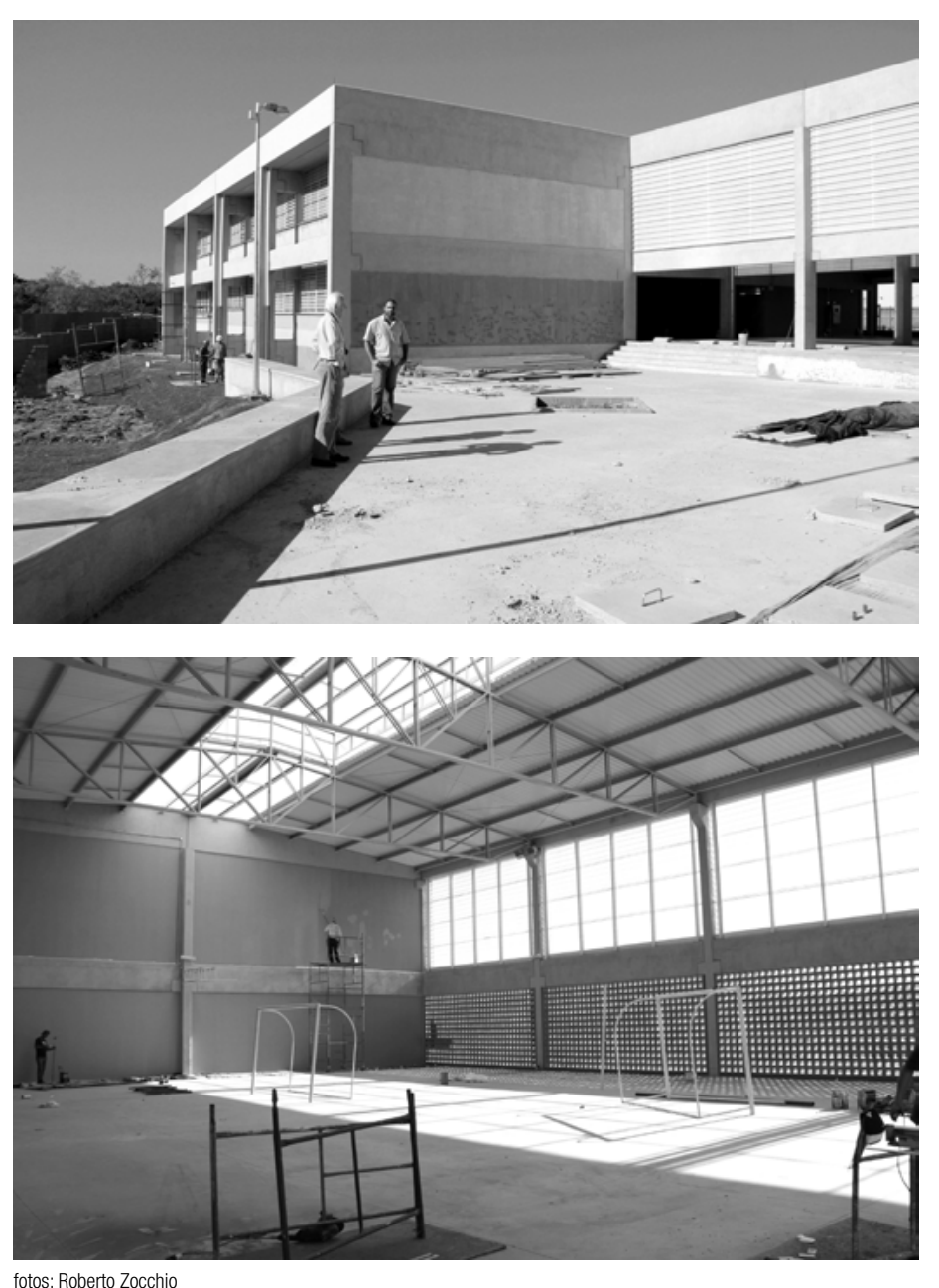
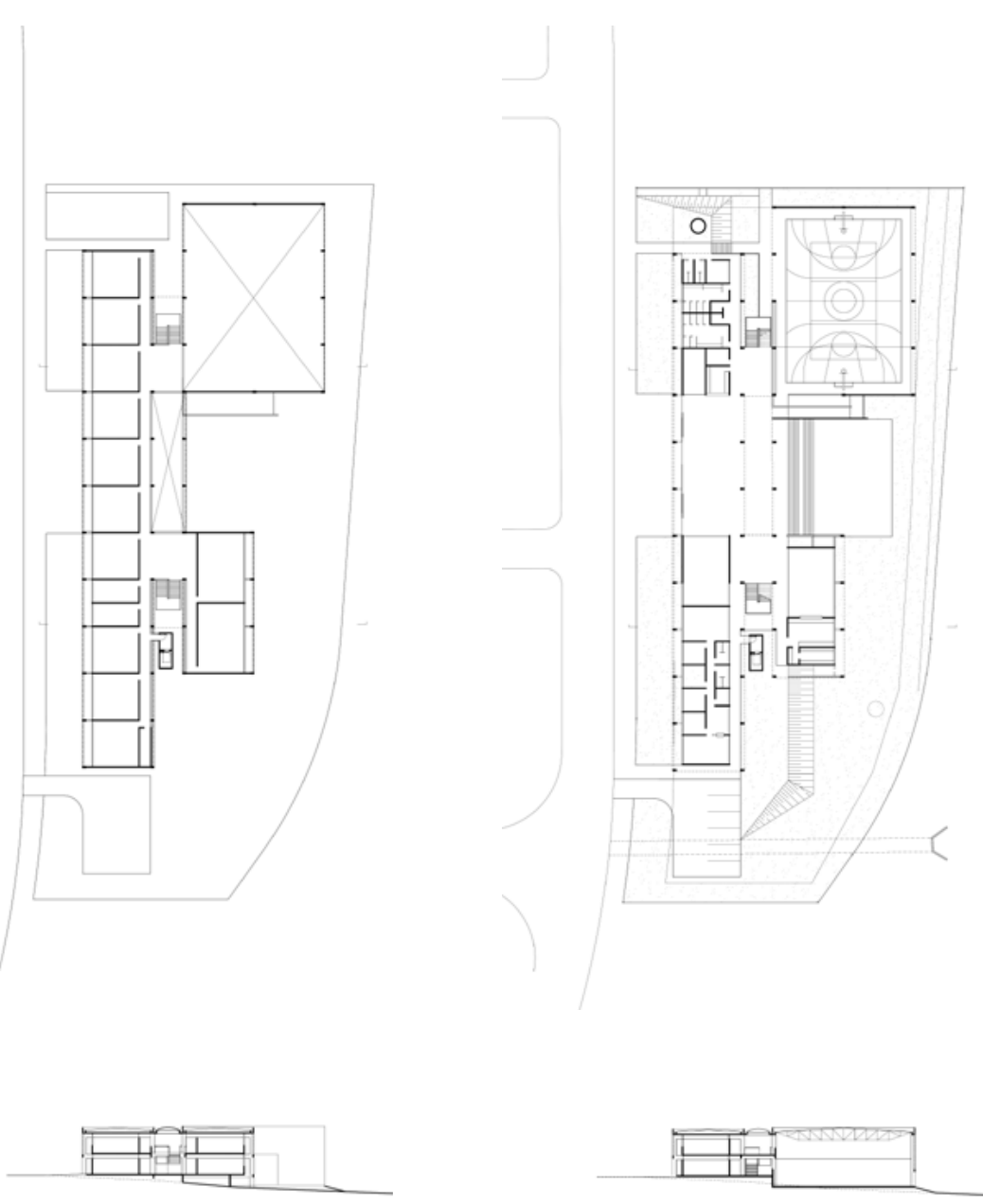

\begin{tabular}{|l|l|}
\hline 1 \\
\hline 1 它
\end{tabular} 
Residência Unifamiliar

Cliente

Patrick e Rosa Sigrist

Equipe

Eduardo de Almeida

Localização

São Bento do Sapucaí, SP

Estágio

Anteprojeto

Observações

Não construído

Características

A partir de uma malha composta por nove módulos

estruturais de planta quadrada, esta casa desenvolve-se

em duas alas articuladas pela cozinha, aproveitado as

aberturas para o pátio - também quadrado - definido

por quatro módulos. Inicialmente pensada como uma

estrutura de madeira destacada do chão, 0 partido

desta casa parece relacionar-se com a pequena casa

projetada por Alvar Aalto em Muuratsalo, em 1953.

Acervo

Caixa 3500 e Backup 341

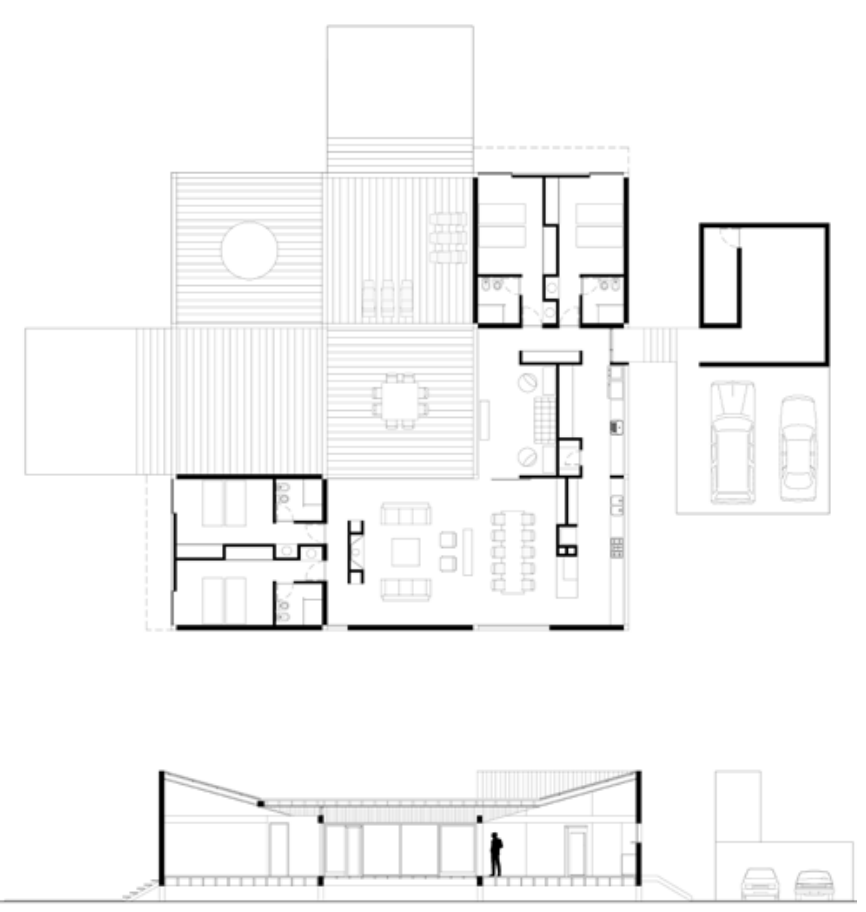


Uso

Residência Unifamiliar

Cliente

Rubens e Mariana Vidigal

Equipe

Eduardo de Almeida

Localização

Jardim Paulistano, São Paulo, SP

Estágio

Projeto Executivo

Observações

Em construção

Características

Considerando a exiguidade do lote e o extenso programa,

esta casa desenha-se com quatro pavimentos: pavimento

inferior para veículos e serviços, térreo com sala, cozinha

áreas externas, dormitórios no segundo pavimento

e, no piso de cobertura, área de lazer com piscina. A

escada linear é desenhada como um volume anexo à

casa, permitindo vistas controladas para o exterior.

Acervo

Backup 374
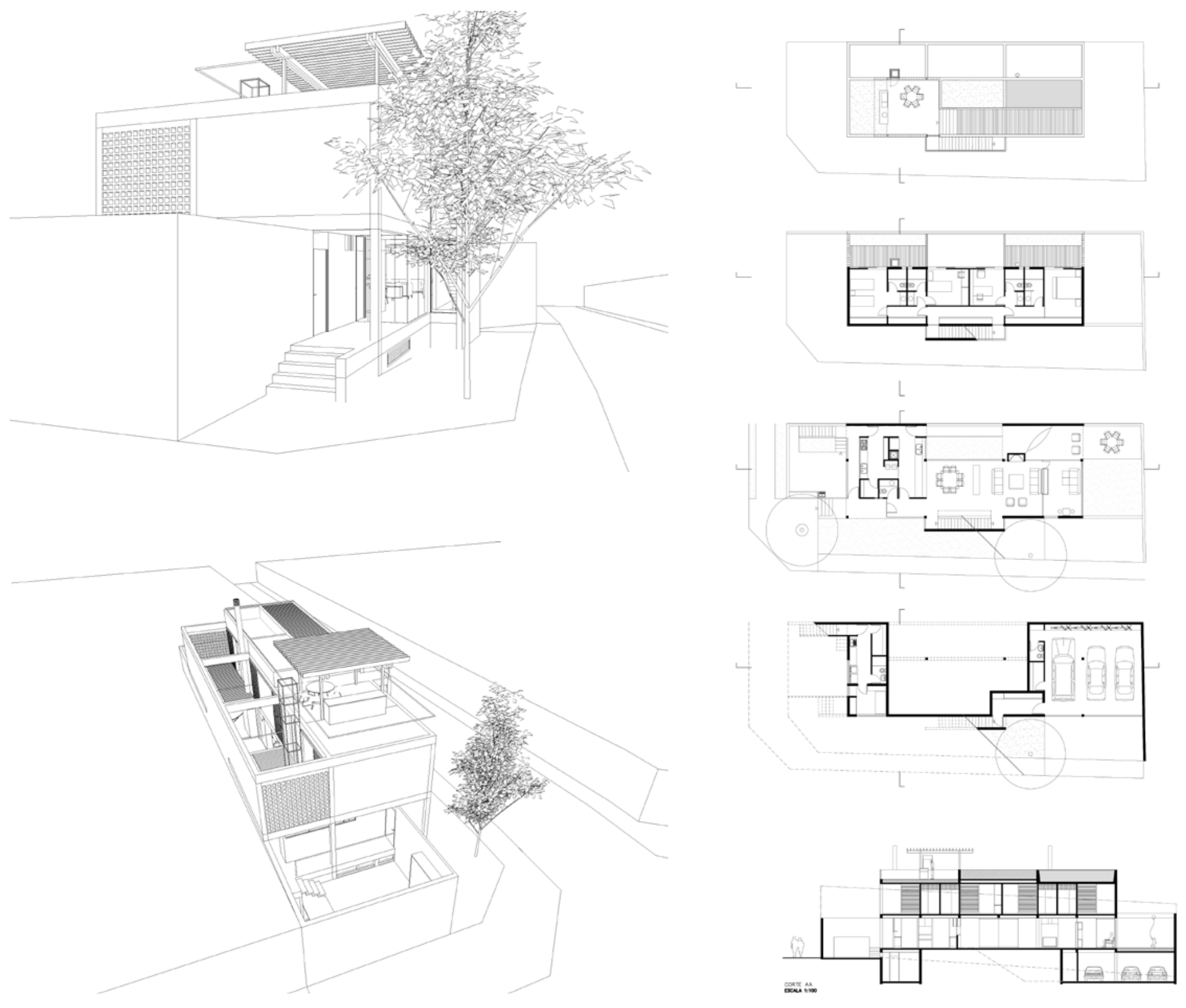
Edifício de Habitação Coletiva

Cliente

Moby Incorporadora

Equipe

Eduardo de Almeida e SIAA

colaboradores | Artur Mei, Bruno Valdetaro Salvador, Carlos Augusto Gomide, Cesar Shundi Imamizu, Fernanda Britto, Henrique Costa, Rafael Carvalho

Localização

Rua Cotoxó, Perdizes, São Paulo, SP

Estágio

Projeto Executivo

Observações

Projeto em andamento

\section{Características}

A partir de um lote de pequenas dimensões, este projeto para uma nova incorporadora - preocupada em restituir a qualidade perdida pelos empreendimentos imobiliários

- cria um edifício de duas unidades por pavimento, privilegiando uma planta flexível com aberturas generosas para 0 exterior. Articuladas por uma torre central de circulações, as duas unidades apresentam uma varanda frontal vazada, aberta para a rua, mas também para 0 vazio interno que ventila e ilumina as cozinhas. Recuado em relação ao alinhamento dos demais edifícios da rua, em relação ao alinhamento dos demais edificios da rua, acesso que, sem gradis de fechamento, colabora com uma relação mais franca entre as calçadas e 0 interior do edifícico.

Acervo

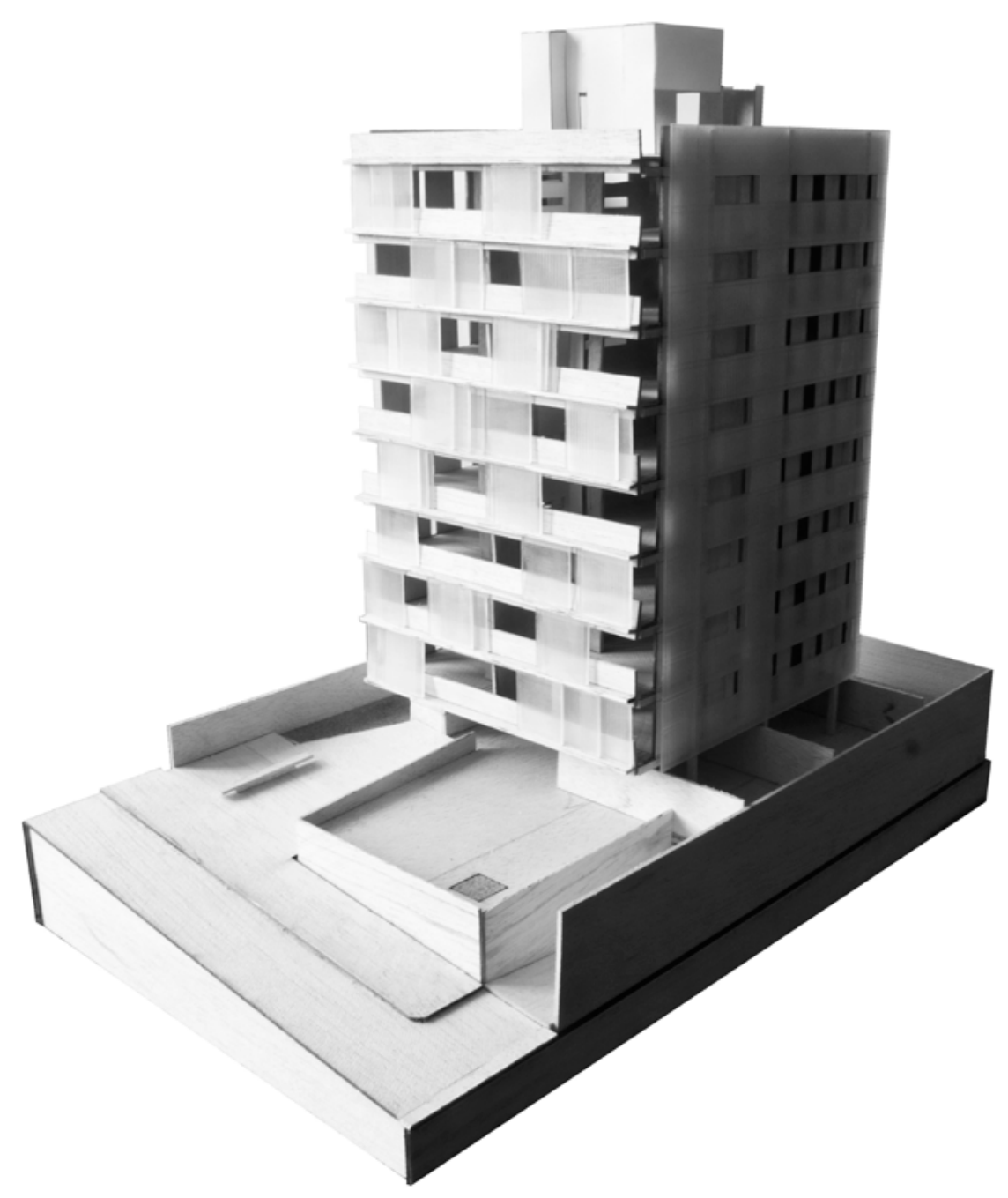


Biblioteca

\section{Equipe}

Eduardo de Almeida, HASAA e SIAA

colaboradores I André Ariza, Andrei Barbosa da

Silva, Alexis Arbelo, Bruno Valdetaro Salvador, Cecilia Prudencio Torrez, Cesar Shundi Iwamizu, Eduardo Pereira Gurian, Fernanda Britto, Francesco Perrota

Bosch, Gustavo Madalosso Kerr, Helena Ayoub Silva,

Bosh Gro Nakack Nakandakari Luca Caifla, Macelo

Arend Madozo, Refel Coratho, Thoms de Ameldo

Ho e Valeria Waligora

\section{Localização}

Avenida Rodrigues Alves, Rio de Janeiro, RJ

\section{Estágio}

Anteprojeto

\section{Observações}

Projeto premiado em $2^{\circ}$ lugar no Concurso Nacional promovido pelo Departamento do Rio de Janeiro do Instituto de Arquitetos do Brasil (IAB-RJ)

\section{Características}

Seguindo as determinações impostas pelo edital e pela geometria irregular do lote, o projeto apresentado para 0 Concurso Nacional de Anteprojetos cria dois volumes de planta triengular ao lado da construcão preexistente. Estas adições são articuladas por três torres de circulacão vertical e por um elemento curvo junto à fachada que não só conecta cada um dos blocos, como também cria uma linha de infra-estrutura que viabiliza as necessidades técnicas do conjunto. 0 pavimento térreo estabelece uma passagem interna através do edifício, articulando as duas praças de acesso aos programas de caráter público: biblioteca, exposições, auditórios, livraria e café.

Acervo
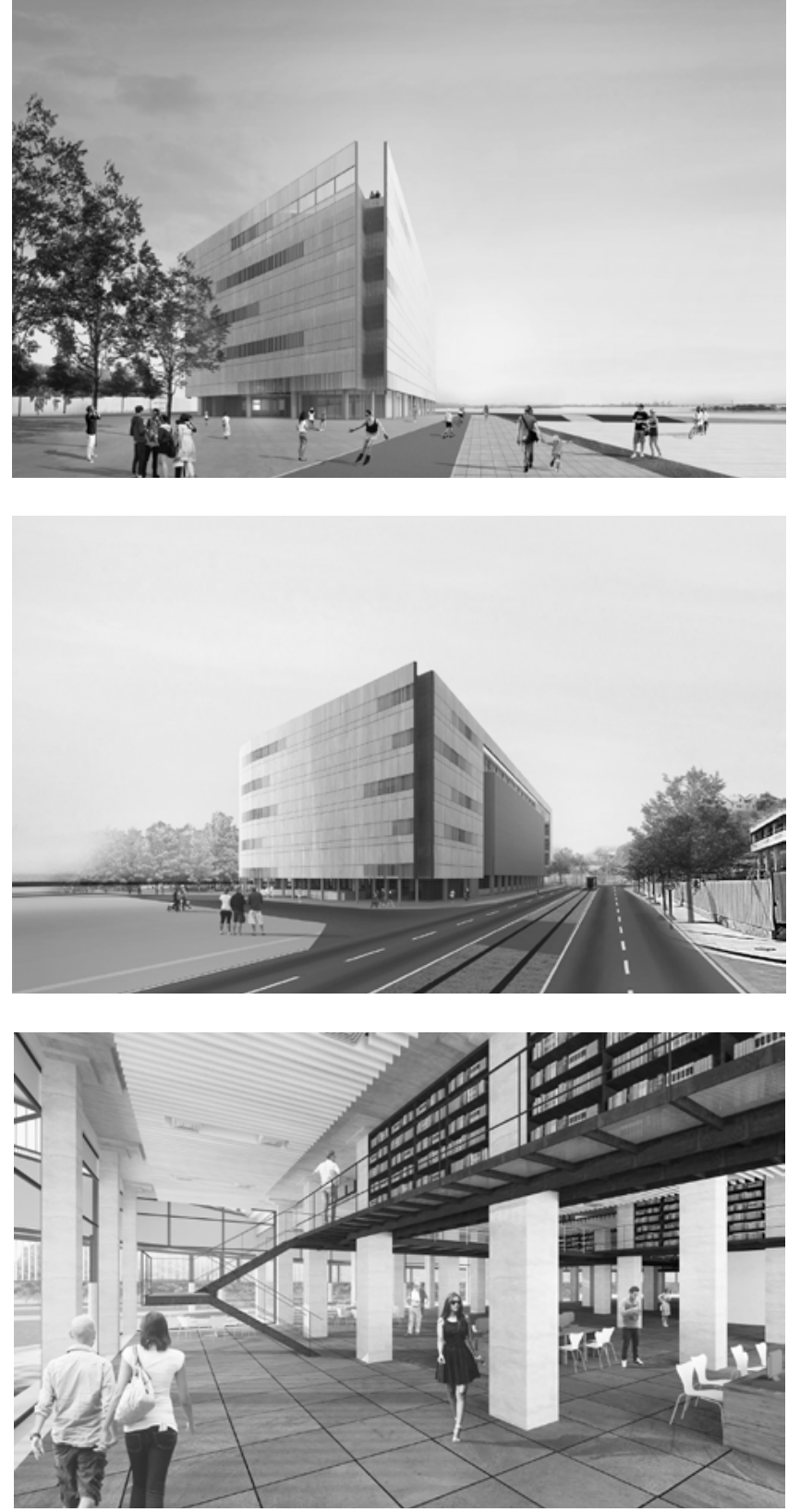
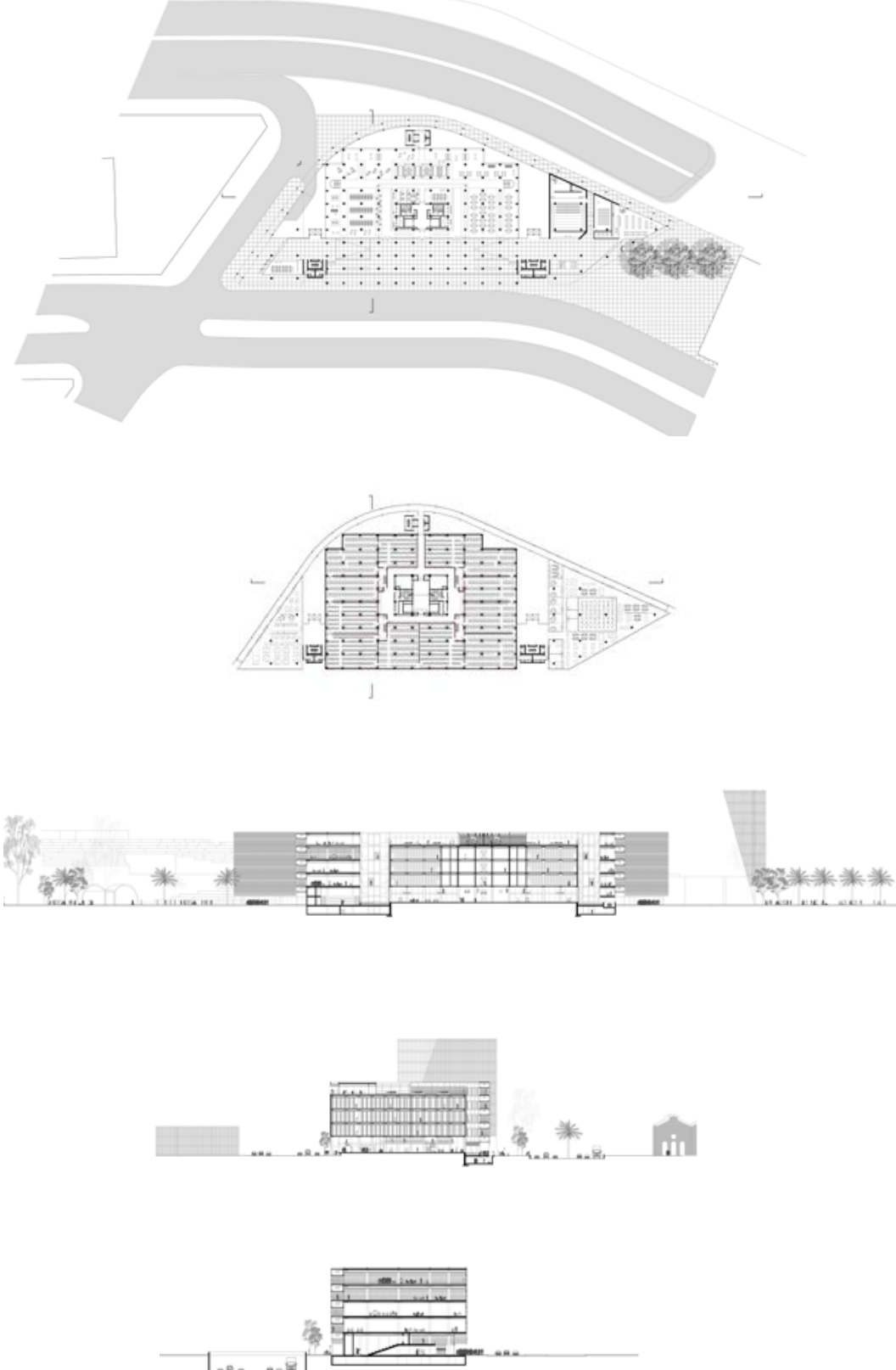

Capítulo 2

Reflexões sobre as estratégias projetuais presentes na obra de Eduardo de Almeida 


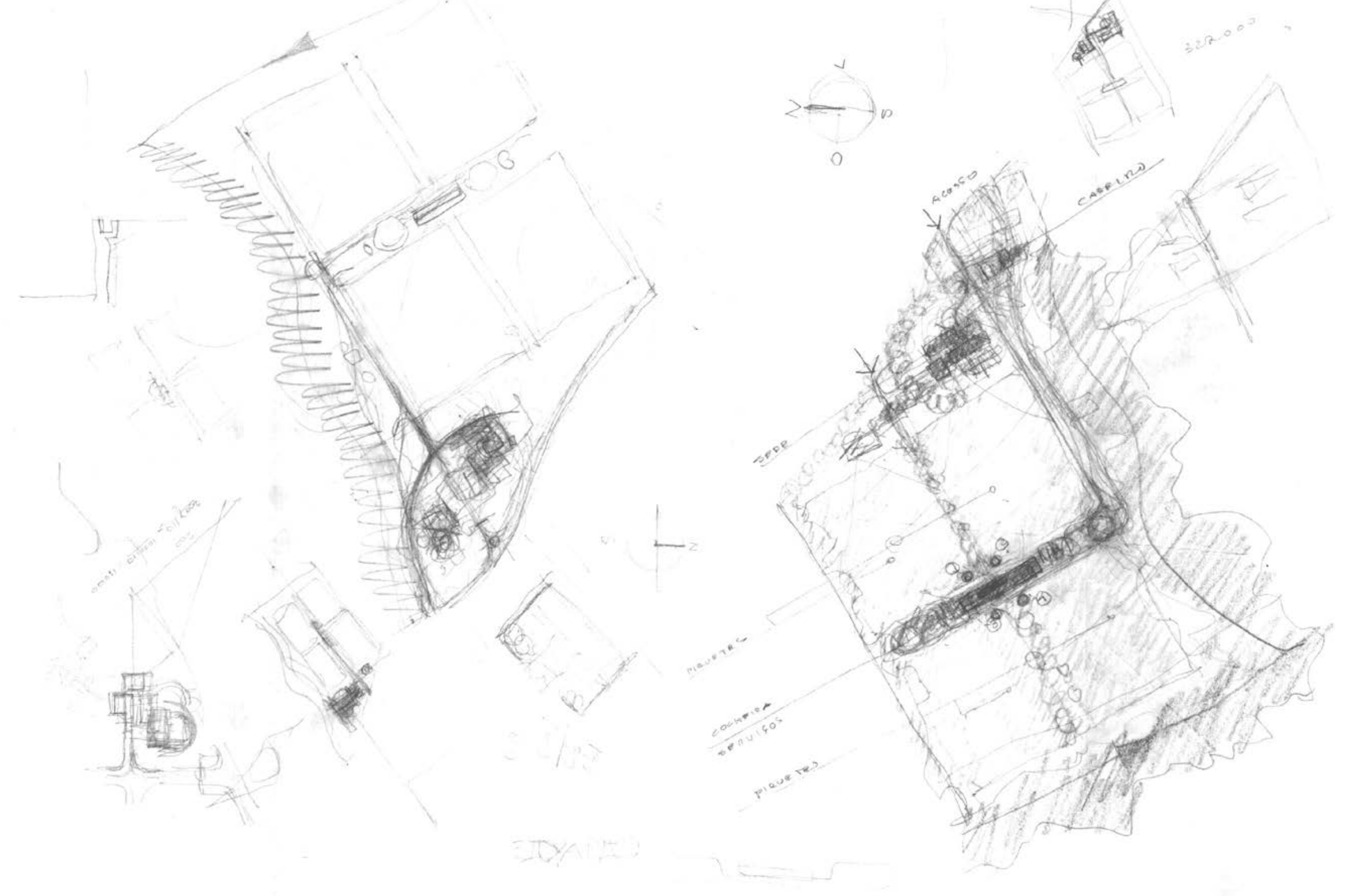


Folha de croquis com estudos de implantação para o projeto Haras Santa Ediwiges

Acervo Eduardo de Almeida
A partir da organização, digitalização, catalogação e síntese das obras completas de Eduardo de Almeida, foi possível apreender que, a despeito de todas as diferenças apresentadas nos projetos realizados ao longo de quase sessenta anos de profissão - independentemente da escala, dos programas, do contexto encontrado ou das referências adotadas - os trabalhos deste arquiteto apresentam uma constante nas estratégias projetuais adotadas.

A repetição destas estratégias permite esclarecer o modo de pensar e fazer que, antes de se tornar uma forma absoluta, estabelece-se como um método que não só foi utilizado na realização dos mais de 240 projetos, mas também na didática de sua atuação como professor na FAU USP, processo relacionado ainda ao ambiente de seu escritório e nas relações de trabalho com seus colaboradores.

O trabalho em conjunto com Eduardo de Almeida sempre envolveu troca de desenhos, ideias, referências e informações de caráter técnico ou legal. A elaboração de um projeto sempre se moldou lentamente a partir do confronto de toda a informação acumulada coletivamente.

Esta atitude democrática de considerar a opinião dos envolvidos - incluídos aí os clientes cria um ambiente de troca que se aproxima de sua atuação como professor: Eduardo nunca orienta um aluno a realizar determinado projeto de uma forma ou de outra. Ao contrário, as convicções, dúvidas ou leituras do aluno orientam o caminho a ser tomado. Neste ponto surgem as interferências do professor - novas possibilidades de organização do programa são apresentadas, outras possibilidades da circulação como elemento estruturante do projeto são identificadas ou ainda, há indicação de novas referências - dele mesmo ou de outros arquitetos - que, entretanto, não são apresentadas a priori, mas vinculadas diretamente aos problemas concretos colocados pelos alunos. 
É inevitável que a obra que construímos como arquitetos sirva de ponto de partida para o nosso ensino, $e$ obviamente o melhor caminho para explicar o que se tem a dizer é fazê-lo com base na experiência prática (...). Em vez de apresentar separadamente cada obra individual e explicar em seguida todos os seus aspectos característicos, os diversos componentes textuais foram organizados de tal modo que, como um todo,

oferecem algo semelhante a uma teoria; é a maneira como os elementos são organizados que transforma a prática em teoria. ${ }^{3}$

Em 'Lições de Arquitetura', Herman Hetzberger não só ressalta a relação entre suas experiências práticas e teóricas, como também relata a metodologia empregada para a organização de suas aulas, posteriormente transformadas em livro. Utilizando determinadas características de projetos - realizados por seu escritório ou por outros arquitetos - o autor ilustra os assuntos ou temas específicos de modo a sistematizar o conteúdo que pretendia repassar aos alunos.

Assim, para se comprovar a hipótese de que existe um método projetual na obra de Eduardo de Almeida, relacionado tanto ao fazer quanto ao ensinar, pretende-se empreender uma leitura do conjunto da obra a partir de alguns pressupostos projetuais, amparando este discurso nos projetos e obras realizadas por ele, mas também em trabalhos de outros arquitetos e estudos relacionados aos campos da história, da teoria e da crítica.

A eleição dos pressupostos e obras a serem analisadas são apenas pretextos; cada uma delas poderia ser analisada mais profundamente em diversos outros aspectos. Neste sentido, podemos dizer que a eleição de determinada característica de uma obra pode acontecer para a abordagem de um tema específico, justificado simplesmente pela conveniência do discurso adotado ou por se constituir em característica marcante da obra que, por sua vez, também não o exclui como objeto de discussão em outros temas, como explicita Herman Hetzberger: 
Quando algo que era um aspecto secundário em uma situação pode se tornar o aspecto principal em outra, ou seja, quando os dois aspectos podem adaptar-se a condições específicas, temos então um sistema de valores em que não há hierarquia de importância entre as partes componentes. E quando, por exemplo, algo em um ordenamento arquitetônico, um elemento ou uma organização de elementos, pode desempenhar diversas funções dependendo de sua colocação em situações diferentes, então seu valor não é mais constante. Cada elemento pode então, dependendo da maneira como foi introduzido, desempenhar uma função fundamental, isto é, pode-se tornar o centro de um sistema; nesse caso, podemos dizer que existe equivalência. ${ }^{4}$

A partir da observação dos projetos realizados por Eduardo de Almeida por meio dos desenhos de diferentes etapas, pode-se identificar as 'equivalências' presentes no conjunto de seus trabalhos, visando explicitar as estratégias projetuais utilizadas pelo arquiteto conforme os itens abaixo:
a. Desenho: trabalho e ensino
b. Orgânico e racionalista
c. Indústria, volumetria e programa
d. Parte e o todo
e. Lugar, construção e transparência
f. Tecnologia e tradição

Tais subdivisões, antes de se apresentarem como respostas completas e definitivas, indicam apenas possibilidades pontuais suscitadas através da leitura dos projetos organizados, podendo ser ampliadas ou redirecionadas a partir de outras temáticas.

Na realidade, as temáticas suscitadas pelos estudos de edifícios, do planejamento urbano ou da paisagem sempre têm sido abordadas em nossa disciplina, sobretudo nos campos da técnica, da história e da crítica, e quase sempre a arquitetura se expressa por questões relacionadas aos processos construtivos, que acabam por se desenvolver em dois caminhos: nos estudos voltados às condições sociais ou ao território da estética.

${ }^{4}$ HERTZBERGER, Herman. Lições de Arquitetura. São Paulo, Martins Fontes, 1999, p.246 
Atualmente, observamos um crescente interesse pelos métodos de trabalho, sobretudo nas áreas afins a do Projeto de Arquitetura, pois parece haver uma busca, não só pelos resultados e pelos discursos presentes na obra dos arquitetos, mas também pelo que fazem, e como trabalham os profissionais voltados ao campo da prática de projeto.

Pretende-se, portanto, uma aproximação da ideia de metodologia, justamente para procurar compreender e sistematizar o conhecimento sobre os modos de produção dos projetos - ainda cercados de certo mistério - dos arquitetos em geral.

Em Eduardo de Almeida, a recorrência dos mesmos procedimentos em diferentes projetos - e aí podemos ressaltar a atuação em variados programas e diferentes escalas - nos permite dizer que existe uma espécie de rotina, de uma estruturação do pensamento no enfrentamento dos problemas reais impostos pelos projetos, ainda que inconsciente e não sistematizado.

Através da leitura dos projetos, é possível aproximar-se deste modo de fazer, aqui chamado de estratégias projetuais, procurando contextualizar esta produção no âmbito da arquitetura moderna brasileira, particularmente a de São Paulo, identificando as semelhanças e diferenças apresentadas em seus projetos.

Seu exemplo parece interessante para discutir questões relacionadas ao método. Conforme já afirmamos, além do enfrentamento prático em seu escritório, ele atuou como professor na FAUUSP de 1967 a 1998, onde desenvolveu, ainda que empiricamente, um trabalho extremamente rico junto aos projetos dos estudantes, resultando em uma relação de proximidade com inúmeros alunos, muitos deles também colaboradores de seu escritório. Pode-se dizer, então, que existe uma relação de proximidade inegável entre o fazer - a prática 
desenvolvida no escritório - e o ensinar - a orientação dos trabalhos dos alunos -, que parece se justificar em sua obra.

A aproximação acerca das estratégias projetuais revela-se um tema fundamental tanto para a prática quanto para o ensino contemporâneos, ressaltando a compreensão de que não basta o projetar e construir de cada obra, também faz-se necessária a abordagem do conjunto de pensamentos capaz de encadear uma sequência de projetos que, ao final, pode expressar sua capacidade discursiva como arquiteto, diante da realidade.

Entende-se 'estratégias projetuais' como o conjunto de atributos - posteriormente transformados em ações - capazes de direcionar os problemas ao conjunto de soluções com um certo grau de qualidade preestabelecida, já que por estratégia tratamos da "arte de aplicar com eficácia os recursos de que se dispõe ou de se explorar as condições favoráveis de que porventura se desfrute, visando alcance de determinados objetivos". ${ }^{5}$ De modo semelhante, na introdução de seu livro 'Inquietação Teórica e Estratégia Projetual', Rafael Moneo apresenta o termo 'estratégia' como o entendimento dos "mecanismos, procedimentos, paradigmas $e$ artefatos formais que aparecem com insistência recorrente na obra dos arquitetos"', naquele caso aplicado ao estudo da obra de arquitetos como Stirling, Siza, Koolhas e Herzog \& De Meuron, entre outros.

Tal comparação parece ser importante, pois assim como no livro de Moneo, a tentativa de esclarecer o modo de pensar e fazer de um arquiteto como Eduardo de Almeida pode colaborar com o processo de formação dos alunos.

${ }^{5}$ Estratégia segundo HOUAISS, Antônio. Dicionário Houaiss. Rio de Janeiro, Objetiva, 2001.

${ }^{6}$ MONEO, Rafael. Inquietação Teórica e Estratégia Projetual ns obra de oito arquitetos contemporâneos (Prefácio). São Paulo, Cosac Naify, 2008, p.9 



\section{Desenho: trabalho e ensino}




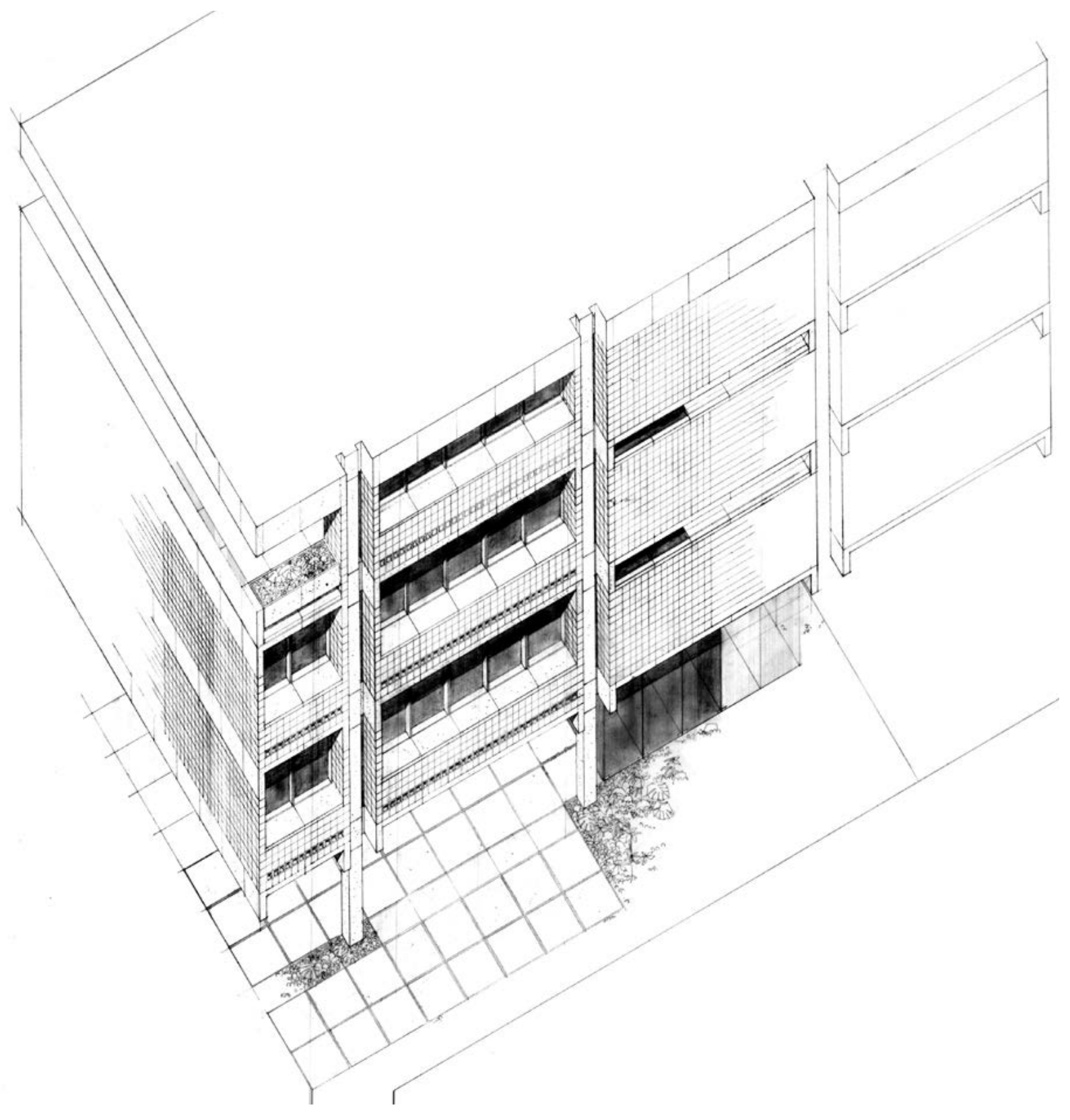




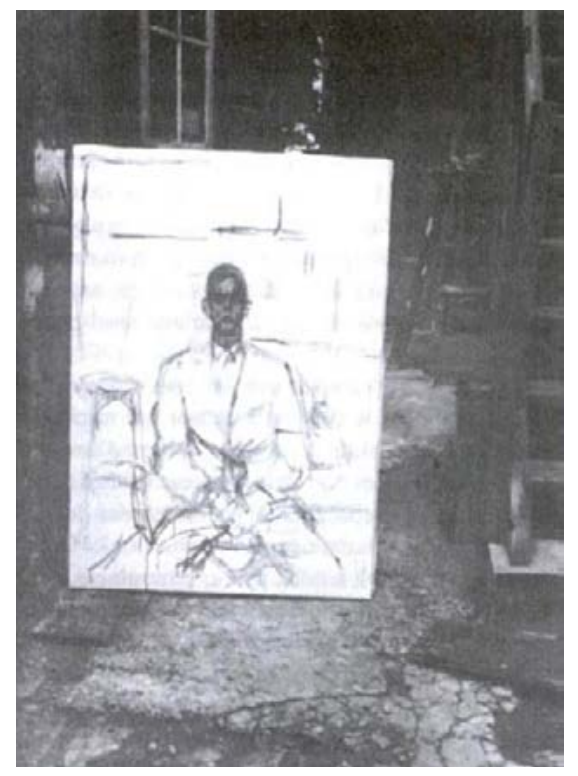

Retrato de James Lord de Alberto Giacometti. LORD, James, Um retrato de Giacometti (Prefácio). São Paulo, Iluminuras, 1998, p.15

Perspectiva de 1973, para um edifício de escritórios da Construtora Formaespaço Acervo Eduardo de Almeida
Em "Um retrato de Giacometti", de James Lord, o narrador relata o processo de trabalho do artista: "Podemos ver como a pintura vai se construindo e destruindo alternadamente de maneira dramática, e de que modo Giacometti recomeça sem cessar o retrato, atualizando permanentemente sua visão. Ele trabalha desfazendo, pois o presente está sempre ultrapassado ou sempre no próximo instante"7. 0 que a princípio era um encontro único para a realização de seu retrato transforma-se numa sucessão de encontros para a realização da pintura, permitindo ao autor estabelecer uma aproximação íntima com o processo de trabalho de Alberto Giacometti.

Assim como nesse processo do artista, Eduardo de Almeida desenha incessantemente até se dar por satisfeito. Desenha, testa modulações e, novamente, redesenha. Sobrepõe a estes desenhos novas alternativas de projetos, consolidando as circulações e a estrutura, na busca de compreender as correlações entre as questões do programa. Verifica a volumetria, retorna aos cortes e elevações e, volta a se debruçar sobre a planta. Descarta tudo e, novamente, recomeça. Tal procedimento envolve profunda dedicação, alternando momentos de entusiasmo e angústia, na busca por uma solução capaz de sintetizar, em equilíbrio, todas as variantes que compõem um projeto.

Essa insistência repetitiva de duvidar de si mesmo não é nele nem uma afetação nem um apelo tranquilizador, mas simplesmente o transbordamento espontâneo de seu profundo sentimento de incerteza quanto à qualidade última do que realiza. ${ }^{8}$

De modo análogo ao retrato de Giacometti, os croquis desenvolvidos por Eduardo de Almeida revelam dúvidas, buscas por alternativas, arrependimentos, ou também, consolidação de determinados pressupostos. Um processo de ir e vir - com desenhos a grafite em papel

${ }^{7}$ EUVALDO, Célia. Giacometti observando e sendo observado. In LORD, James, Um retrato de Giacometti (Prefácio). São Paulo, Iluminuras, $1998, p .10$

${ }^{8}$ LORD, James, Um retrato de Giacometti. São Paulo, Iluminuras, 1998, p.42 


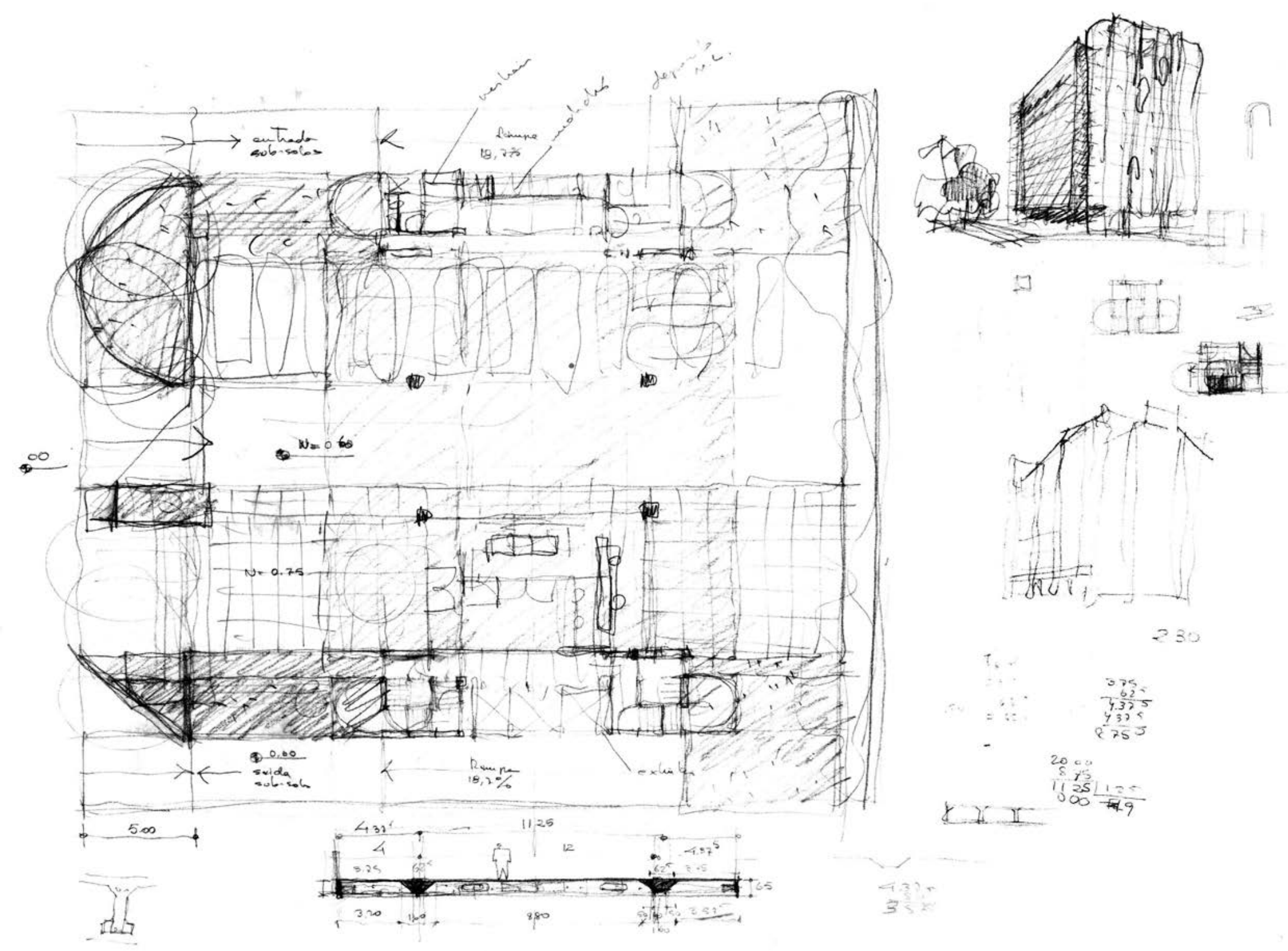


Semelhante a estas pinturas, cuja expressividade advém das marcas do fazer e do refazer, os confusos croquis realizados pelos arquitetos de modo geral se constituem em ferramentas de investigação e busca da solução pretendida, materialização do pensamento a partir da sobreposição contínua de informações que, pouco a pouco, direciona os rumos de um determinado projeto.

Diferentemente dos croquis de síntese, como aqueles realizados por Oscar Niemeyer para explicitar ao público leigo as soluções pretendidas, os croquis de processo se apresentam - a exemplo de uma 'arqueologia projetual' - como uma memória capaz de conduzir ao caminho percorrido pelo arquiteto na definição do projeto e de seus elementos: estrutura, forma, técnica ou programa, entre outros fatores igualmente relevantes.

A despeito da realização destes desenhos naturalmente confusos e contraditórios, o resultado final de um projeto de Eduardo de Almeida busca uma síntese, uma arquitetura voltada a essências, onde todo o esforço despendido para sua consolidação desapareça, como se o resultado final fosse muito natural, simples e óbvio.

Conforme afirma Guilherme Wisnik, em seu depoimento a Thomas Piper no filme 'Eduardo de Almeida, arquiteto da medida justa'

Ele é alguém com uma personalidade muito específica: não se coloca diante das luzes principais ou do foco das grandes atenções. Ele tem uma personalidade modesta, alguém que penetra nos detalhes de um projeto, mas cujo objetivo final é que esse detalhamento não apareça, não apareça enquanto ornamento, não apareça enquanto excesso de trabalho, não apareça enquanto desenho praticamente. ${ }^{9}$

${ }^{9}$ Citação de filme: WISNIK apud PIPER, 2013 


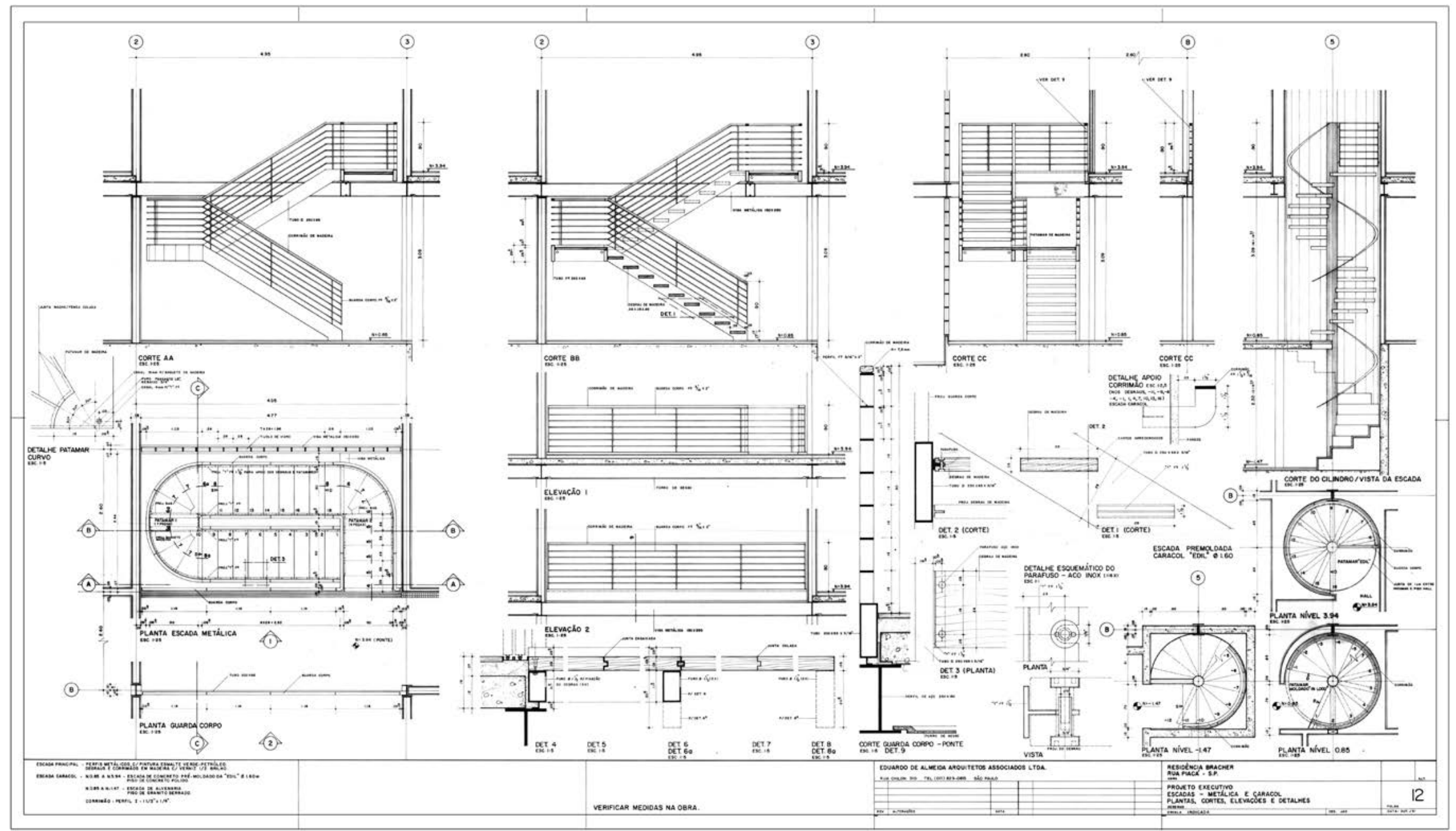


De fato, em suas obras são evitados grandes gestos de apelo formal - presentes em alguns projetos de Niemeyer - assim como estruturas com grandes vãos - a exemplo de arquitetos paulistas como Artigas ou Paulo Mendes da Rocha. Ao contrário, apesar das consonâncias com estes arquitetos em inúmeros exemplos, a tônica é a busca pela simplicidade, concisão e, por que não dizer, discrição.

A discrição em seu projetar não poderia se desvincular da própria personalidade, já que está "implícito na palavra projeto um sentido de distância entre o desejo e a sua satisfação" ${ }^{10}$, de acordo com Vittorio Gregotti em seu livro Território da Arquitetura, onde ainda complementa:

Do ponto de vista da arquitetura, o projeto é o modo através do qual vêm organizados e fixados arquitetonicamente os elementos de um determinado problema. Estes foram selecionados, elaborados, $e$ intencionados através do processo de composição, até chegar a estabelecer entre si novas relações cujo sentido geral (estrutural) pertence, ao final, à coisa arquitetônica, à nova coisa que construímos por meio do projeto. ${ }^{11}$

Uma vez definido o partido de projeto, os croquis são substituídos por desenhos de caráter técnico, elementos de comunicação para o diálogo com os clientes, para a troca e desenvolvimento com a equipe de projetos complementares e, finalmente, com a equipe que ficará responsável pela execução da obra.

Neste segundo momento, o projeto se expressa por meio de plantas, cortes, elevações e perspectivas, desenhos precisos que são realizados tanto para aferir as definições gerais do partido como para permitir o desenvolvimento do projeto: a escolha de um sistema construtivo ou a adoção de um determinado pormenor.

Ao lado, projeto executivo das escadas metálicas da residência Bracher Acervo Eduardo de Almeida
10 GREGOTTI, Vittorio, Território da Arquietura. São Paulo, Editora Perspectiva, 1975, p.12

${ }^{11}$ GREGOTTI, Vittorio, Território da Arquietura. São Paulo, Editora Perspectiva, 1975, p.12 

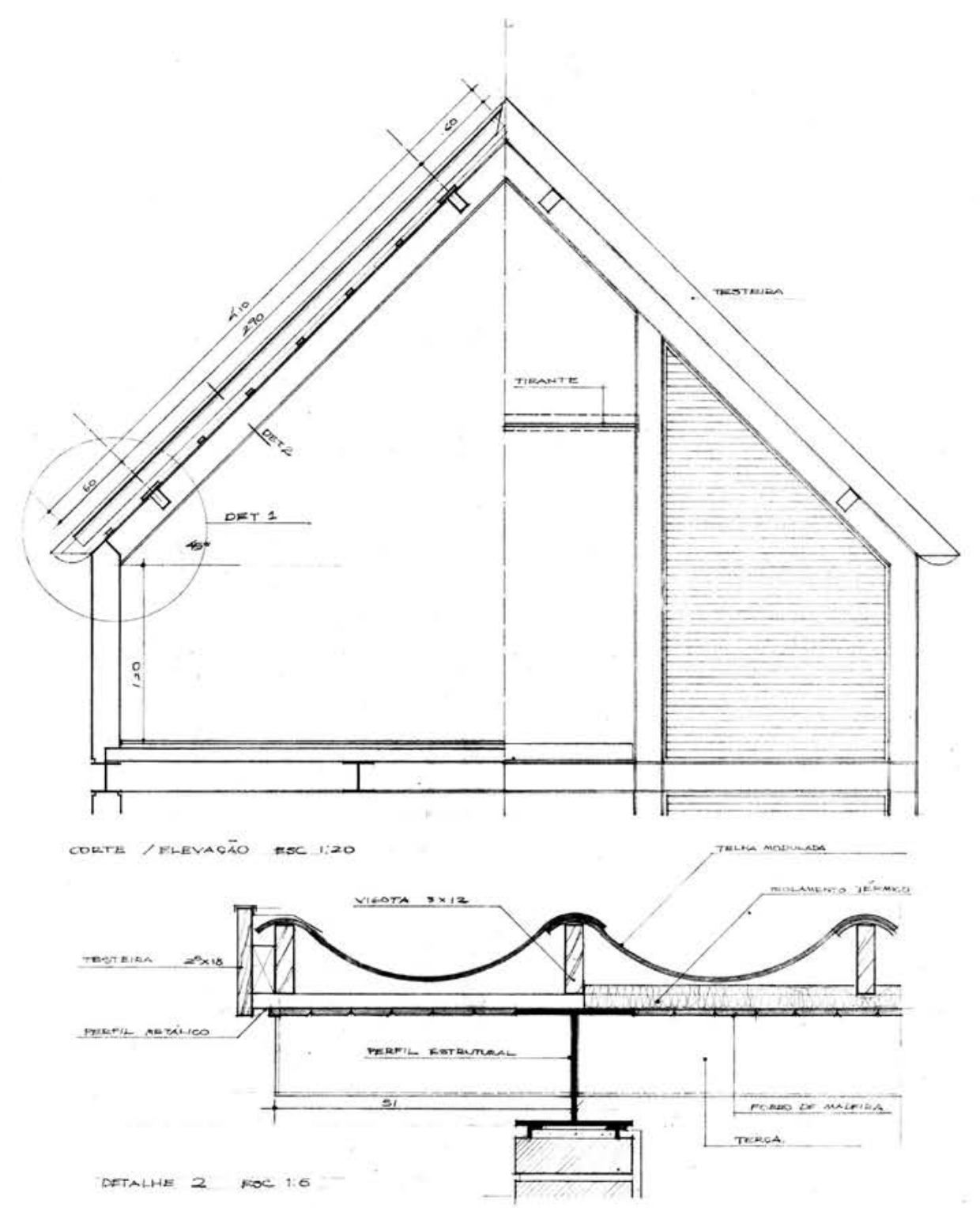

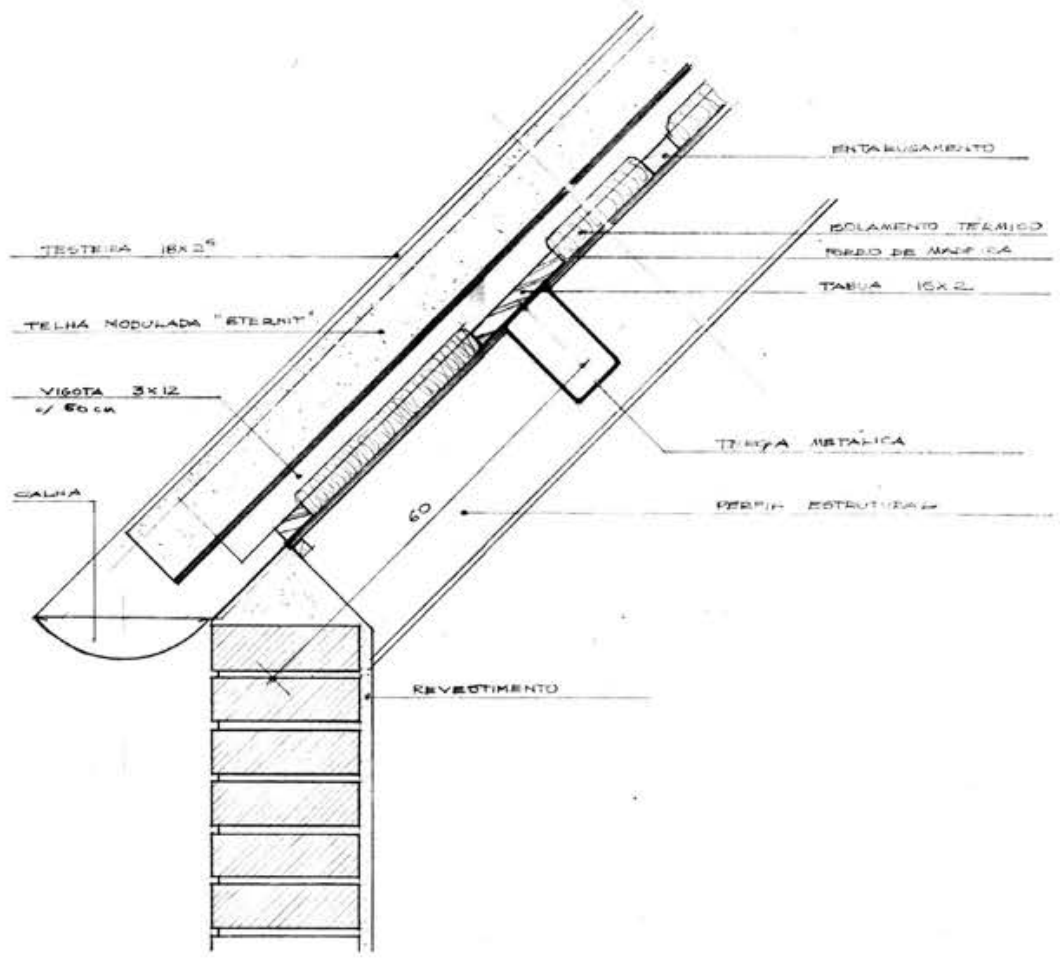

DETALHE 1 ESC $1: 5$

CASA DE CASEIRO/A COOTILHES - CANTAREIRA

CORTES I DETALHES $\quad$ ESC. 120/1:0 
Um arquiteto como Eduardo de Almeida vive intensamente estas duas instâncias - realização de croquis e desenhos técnicos - processos que, no entanto, não se apresentam como etapas isoladas dentro de uma ordem pré-definida. Ao contrário, a realização de um projeto mescla estas duas formas de desenho alternadamente: investigação e síntese como um processo contínuo, onde o primeiro alimenta o segundo e vice-versa, permitindo o desenvolvimento do projeto desde seus desejos iniciais até seus pormenores relacionados à construção.

Quando partimos de uma ordem formal, é importante evitar forçar todos os elementos nesta ordem, porque inevitavelmente os tornaremos subservientes ao todo, isto é, o valor dado às partes será ditado pela ordem que governa o todo. Só partindo de cada elemento individual, e fazendo-o contribuir por si próprio para o todo, é que se pode obter um ordenamento em que cada componente, pequeno ou grande, pesado ou leve, tenha seu lugar apropriado de acordo com o papel específico que desempenha dentro do todo. ${ }^{12}$

Como comprovaremos posteriormente, a simples adoção de um material de construção ou o desenvolvimento de um pormenor específico pode redirecionar o rumo do partido geral adotado em um projeto de Eduardo de Almeida, já que o detalhe, o material ou a estrutura, por exemplo, devem trabalhar juntos pela totalidade, mais que a simples soma dos elementos individuais.
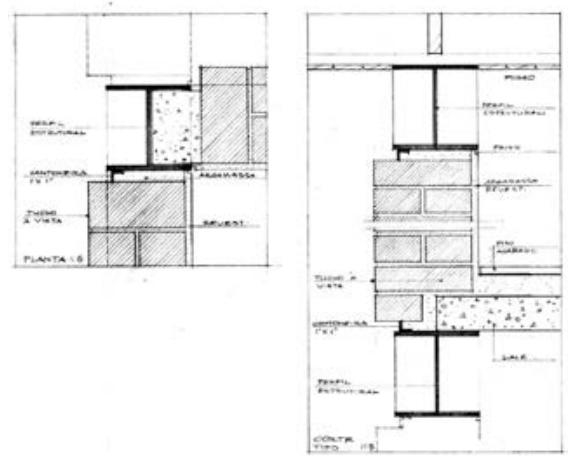

Pormenores da residência Alain Costilhes Acervo Eduardo de Almeida
Tal noção de conjunto parece esclarecer a poética adotada por ele ao longo de sua carreira, já que em sua obra não utiliza necessariamente a expressividade formal normalmente atribuída à arquitetura moderna brasileira. Como também afirma o crítico de arte Alberto Tassinari:

A obra dele não tem formas impregnantes, você não vê, como no Niemeyer, um tampo de uma esfera, ou na obra do Paulo Mendes da Rocha, aqueles cortes certeiros, a relação com o terreno, com as cotas, tudo de uma vez, não é assim que o Eduardo faz o projeto. A obra dele é muito sutil, muito variada porque quando ele elege elementos não são sempre os mesmos, ele não tem um elemento que é característico. Há casas do Eduardo que são feitas de tijolinhos, há outras que são de concreto, há outras que são de ferro pintado. Ele tem muito mais uma poética do que um estilo, e esta poética precisa de uma observação mais detida, mais sutil.13

${ }^{12}$ HERTZBERGER, Herman. Lições de Arquitetura. São Paulo, Martins Fontes, 1999, p.249

${ }^{13}$ Citação de filme: TASSINARI apud PIPER, 2013 


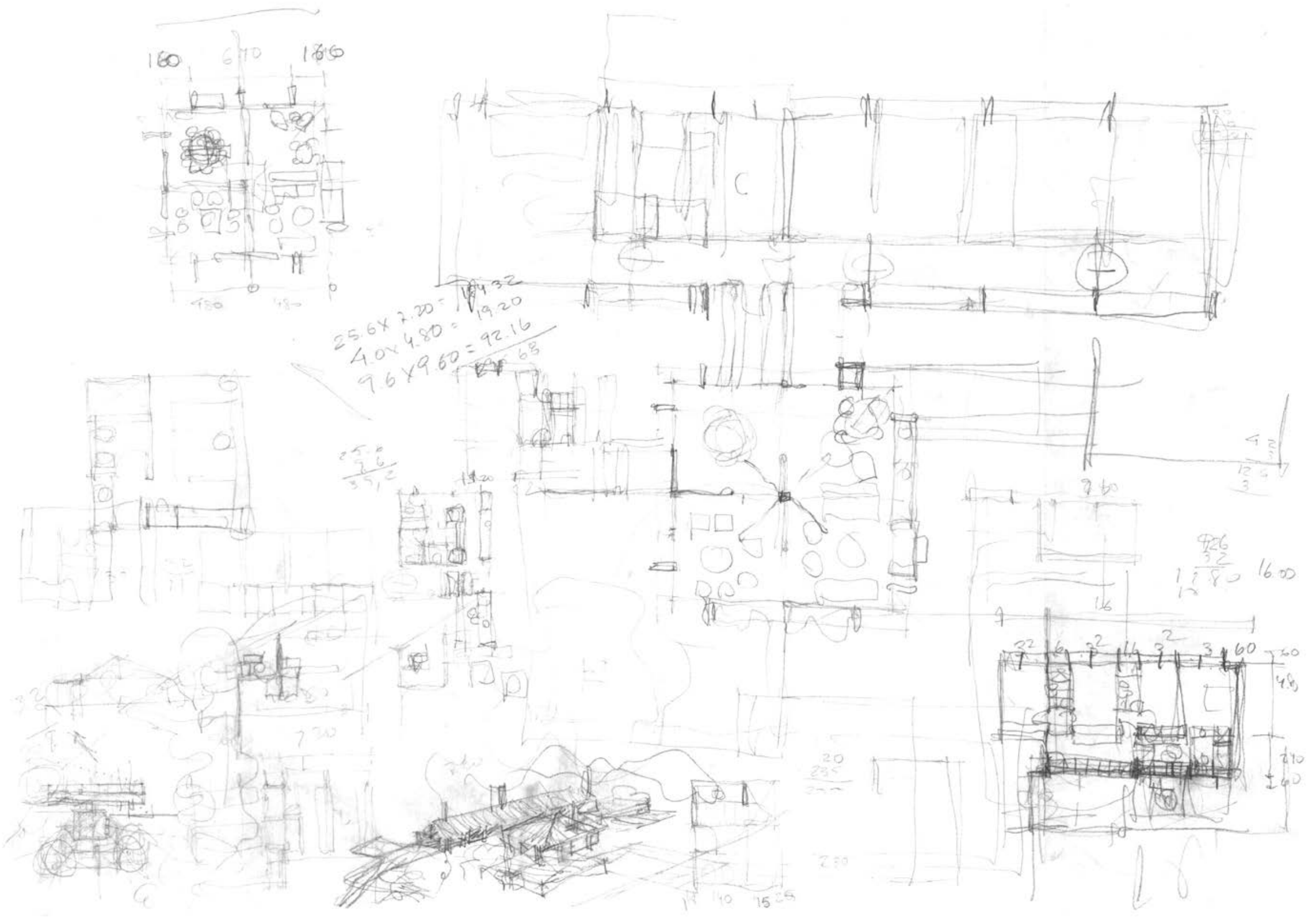


Esse posicionamento reafirma o ideário da obra de Eduardo de Almeida, já que ele não se coloca como um arquiteto isolado, gênio criador de obras espetaculares, mas como parte de um grupo da segunda geração de arquitetos modernos de São Paulo, mais preocupado em consolidar os novos pressupostos da arquitetura por meio de seus projetos exemplares, de extremo rigor e seriedade.

A postura não dogmática o distancia, em inúmeros momentos, da chamada escola paulista, já que nem sempre se utiliza da sintaxe brutalista que notabilizou a obra de vários arquitetos de São Paulo, durante as décadas de 1960 e 1970, tampouco da ideologia marxista impregnada nos discursos dos arquitetos da época.

Mesmo com tais diferenças, ele não se posiciona como antagonista da produção paulista deste período, tanto pelo fato de que inúmeros de seus projetos tangenciam a linguagem corrente desta escola, quanto pela sua participação no grupo de alunos das primeiras turmas da FAU USP e, posteriormente, por sua atuação como importante professor nesta mesma escola.

Normalmente os arquitetos aqui gostam de dar a impressão de que são geniais, de que as idéias vieram do nada, como que inspirações magníficas, e o Eduardo não. E isto é uma grande virtude para um professor. ${ }^{14}$

Folha de croquis de desenvolvimento projeto Haras Santa Ediwiges

Acervo Eduardo de Almeida
(...) o trabalho de Breuer se desenvolve com uma coerência que não conhece crise, aventuras polêmicas, involuções nem tampouco grandes problemas; tanto que, melhor que de coerência, caberia falar de humor constante, de atitude aberta e cordial, de tendência natural a não dramatizar as situações. ${ }^{15}$

${ }^{14}$ Citação de filme: WISNIK apud PIPER, 2013

${ }^{15}$ ARGAN, Giulio Carlo. Marcel Breuer in Projeto e Destino. São Paulo, Ática, 2001, p.288 


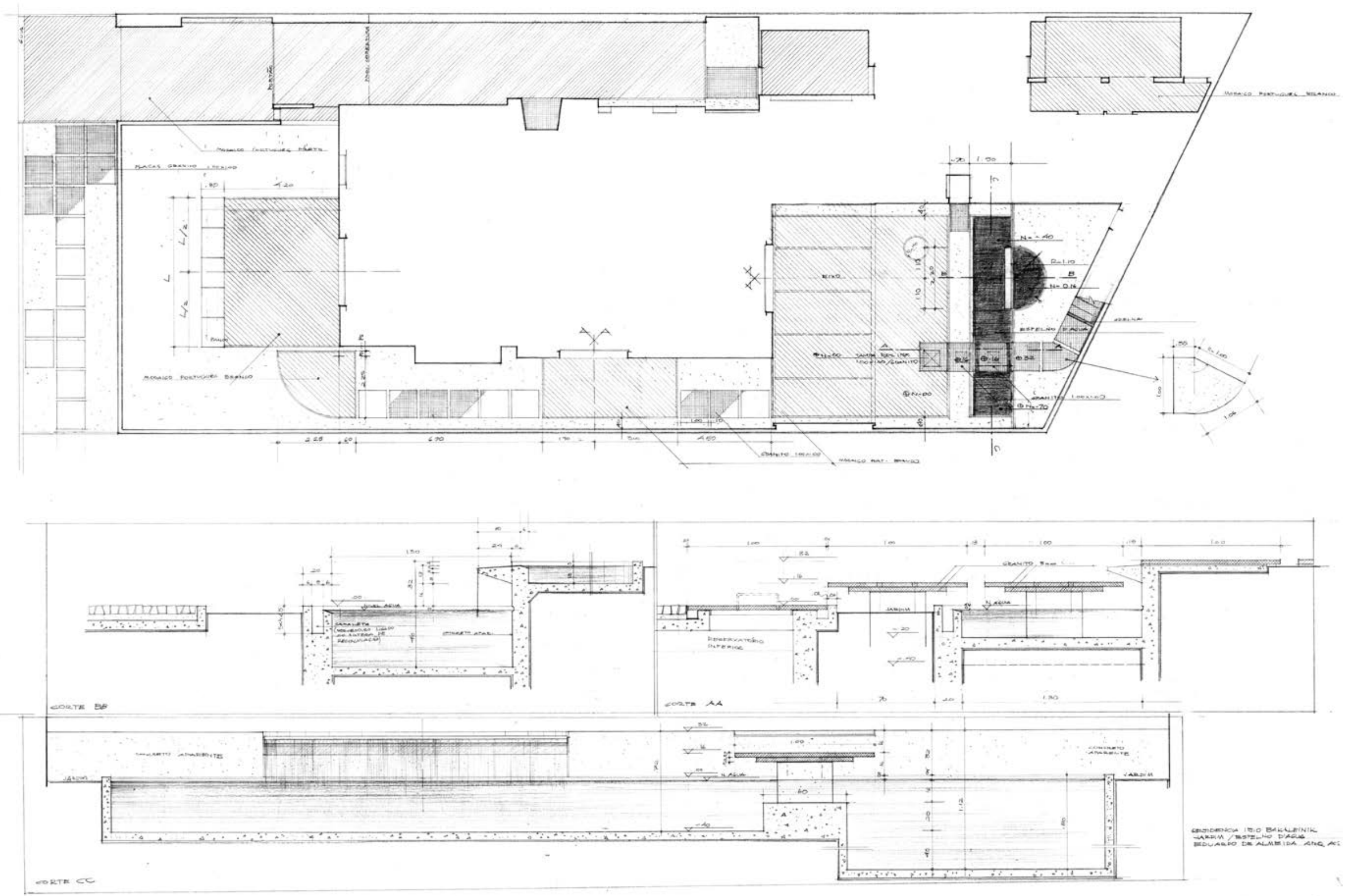


Desenho do jardim e detalhamento do espelho d’água da residência Isio Bakaleinik

Acervo Eduardo de Almeida
Assim como na obra de Marcel Breuer, as diversas mudanças de rumo na arquitetura de Eduardo de Almeida se devem à ausência de preconceitos na concepção dos projetos, como se fosse possível iniciar um trabalho unicamente a partir das sugestões impostas pelo sítio e pelo programa, evitando a adoção de uma linguagem definida a priori: "não se deve iniciar um projeto sabendo qual será a solução final adotada", frase comumente repetida pelo arquiteto durante a realização de projetos variados.

Ao contrário, o conceito de tal método possibilita pensarmos menos em soluções de linguagem ou técnicas pré-definidas do que em uma poética capaz de moldar cada projeto em função de seus desafios específicos, caracterizando cada obra como um objeto único, mesmo que idealizado a partir de uma mesma metodologia projetual. Argan questiona:

Como não reconhecer o mesmo programa ideológico e moral na arquitetura que se chamou exatamente 'racional', e a mesma vontade de uma intempestiva intervenção numa situação histórica profundamente dramática? ${ }^{16}$

E reafirma a metodologia como um modo de determinação das formas que não só atende as necessidades práticas e concretas de nossa existência, no caso da arquitetura, como também amplia o projetar aos espaços subjetivos das sensações e emoções - a exemplo do universo poético das artes plásticas -, evitando-se a idéia da metodologia como a aplicação de fórmulas fechadas e resultados previsíveis.

Ao mesmo tempo, tal processo de descoberta e investigação se soma à própria experiência do arquiteto, tanto pelas realizações anteriores quanto pela influência de outros arquitetos, aparente contradição revelada em seu depoimento:

Cada projeto que eu faço, a impressão que tenho é que nunca fiz nada antes. E, ao mesmo tempo, eu vou me referenciar naquilo que eu fiz antes. ${ }^{17}$

${ }^{16}$ ARGAN, Giulio Carlo. Arquitetura e Arte não figurativa in Projeto e Destino. São Paulo, Ática, 2001, p.142

${ }^{17}$ Citação de filme: ALMEIDA apud PIPER, 2013 

Orgânico e racionalista 


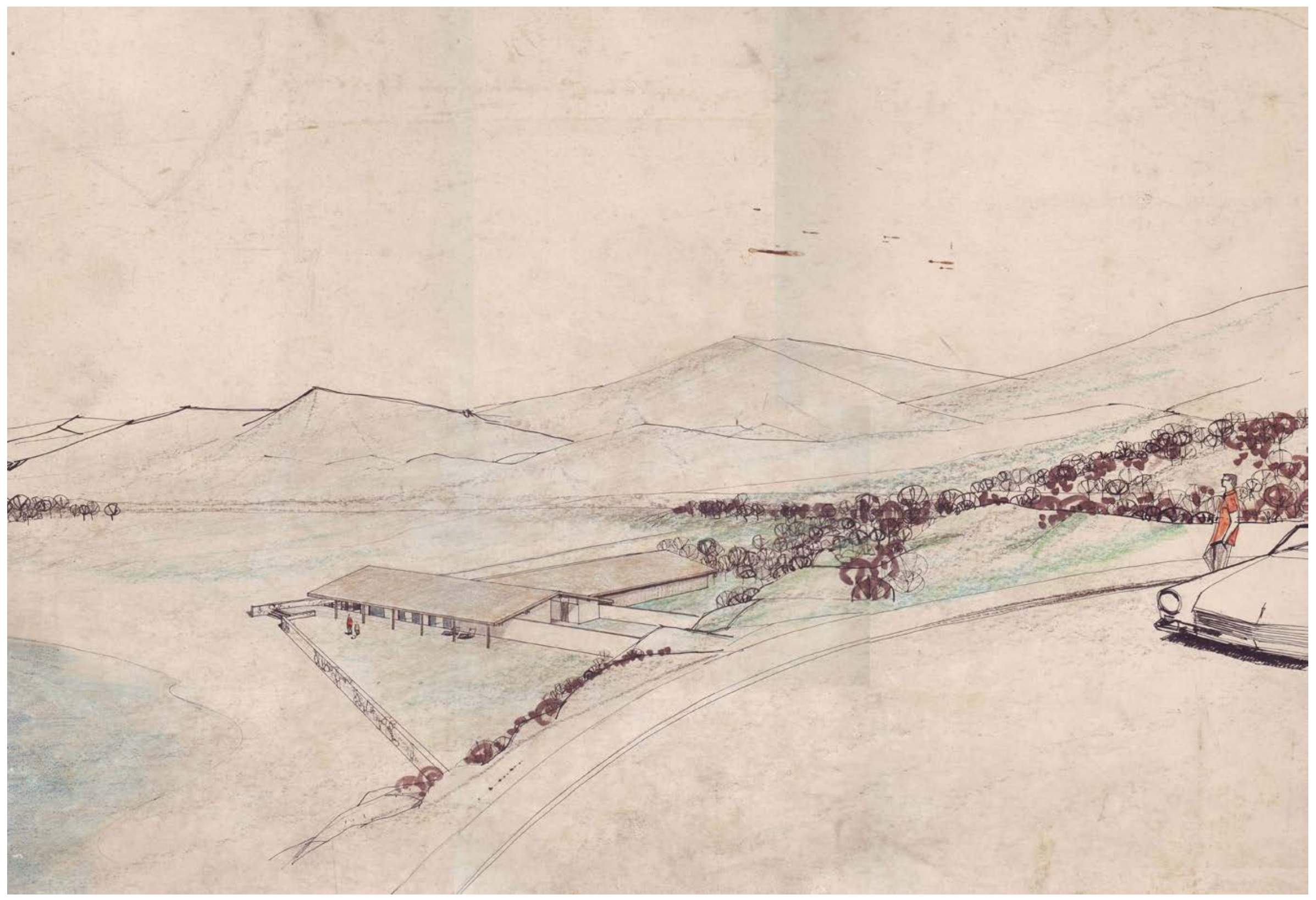




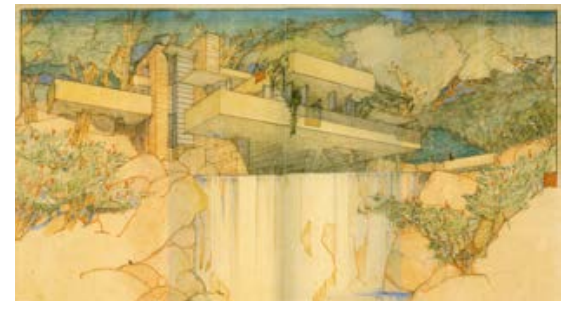

Perspectiva da Casa Fallingwater

KAUFMANN JR, Edgar J.; GIROUARD, Mark (introdução). Fallingwater: A Frank Lloyd Wright Country House. Abbeville Press. New York, 1986, pág. 42-43.

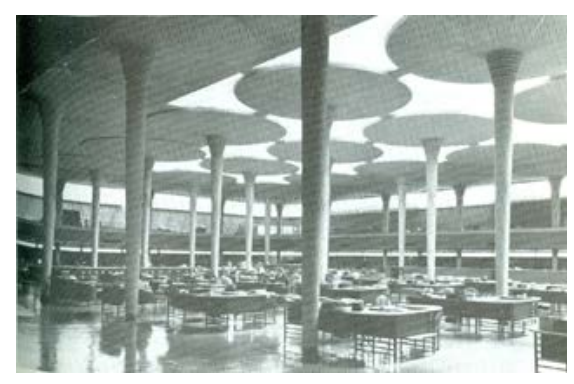

Edifício Johnson Wax

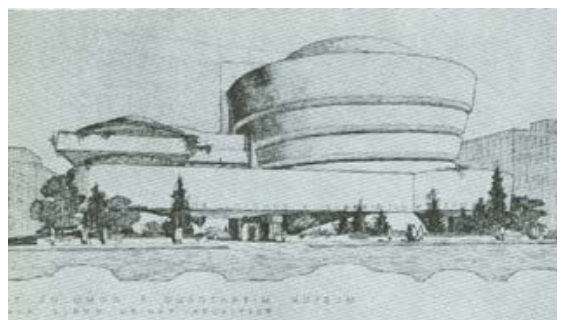

Perspectiva Museu Guggenhein de Nova York ZEVI, Bruno. Frank Lloyd Wright. Barcelona, Editorial Gustavo Gilli, 1993, 5a edição, p. 163 e 252 .

Ao lado, desenho para residência Praia das Toninhas, Ubatuba, feito por Luiz Paulo Baravelli

Acervo Eduardo de Almeida
O início da carreira de Eduardo de Almeida é marcado pela forte influência da arquitetura de Frank Lloyd Wright, autor de obras importantes como Taliesin East em Spring Green (iniciada em 1911), casa Fallingwater na Pensilvânia (1935), edifício para a Johnson Wax em Racine (1936) ou Museu Guggenhein de Nova York (1959).

Wright desenvolveu a maioria de seus projetos nos Estados Unidos, mas também influenciou a arquitetura européia, como por exemplo, na obra de J.J.P. Oud e sua corrente Neoplástica nos anos 1920 e nos estudos teóricos de Bruno Zevi sobre arquitetura orgância a partir de 1945.

No Brasil, a influência inicial de Wright se dá em sua única visita ao país em 1931, para participar da comissão julgadora do Concurso Internacional do Pharol de Colombo. Paralelamente ao concurso, Wright profere uma série de palestras sobre sua arquitetura, conhece a casa de Warchavchik na rua Toneleros e, mais importante, entra em contato com os estudantes brasileiros e os apóia em sua disputa com a direção da Escola Nacional de Belas Artes, que havia destituído Lúcio Costa devido ao confronto entre os novos ideais da arquitetura moderna com os ainda dominantes pressupostos do ensino acadêmico, como nos revela o trabalho de Adriana Irigoyen, 'Wright e Artigas, duas viagens'.

Como se sabe, o rumo tomado pela arquitetura moderna no Rio de Janeiro segue o modelo proposto por Le Corbusier, sobretudo por sua participação no projeto do Ministério da Educação e Saúde, elaborado em 1936 pela equipe composta por Affonso Eduardo Reidy, Jorge Moreira, Oscar Niemeyer, Carlos Leão, Ernani Vasconcelos e, sobretudo, Lucio Costa, que direciona a produção do que veio a ser reconhecida como arquitetura moderna no Brasil.

Diferentemente do Rio de Janeiro, a arquitetura de São Paulo se desenvolvia com o impacto inicial das casas de Warchavchik a partir de 1927 e, simultaneamente, pela atuação de outros 
arquitetos imigrantes como Rino Levi ou Franz Heep, ligados às experiências da arquitetura moderna européia do pós-guerra. Yves Bruand, em "Arquitetura Contemporânea no Brasil", definia São Paulo como uma "cidade provinciana" cujo espírito não favorecia "teorias ou estilos revolucionários", e o estilo de Wright oferecia uma "solução mista, ao mesmo tempo moderna e tranquilizante".18

Arquitetos-engenheiros como Vilanova Artigas e Oswaldo Bratke projetavam e construiam suas obras e pareciam interessar-se pela arquitetura de Wright por sua fácil aceitação por parte dos clientes ainda conservadores, como ressalta Yves Bruand, mas também por reconhecerem virtudes relacionadas ao respeito aos materiais e às relações entre arquitetura e natureza, dois pressupostos da arquitetura orgânica.

No caso de Artigas, a influência de Wright em sua primeira fase de projetos se dá em obras como as casas para Roberto Lacase (1938), Berta Gift Stirner (1940), Rio Branco Paranhos (1943) e Luiz Antônio Leite Ribeiro (1943), além de sua própria residência no Campo Belo, conhecida como 'casinha', projetada em 1942.

(...) as coberturas das casas modernistas deles, tinham um telhado e uma platibanda que escondiam a estrutura e que davam margem a eles fazerem casas com esse aspecto, mas que não tinham nada a ver com a moral construtiva. Era a minha recusa das condições da temática corbusiana, que estava fora do nosso alcance tecnológico. $O$ que eu fiz, não foi esconder meus telhados para fazer cara de moderno, mas fiz telhados com larguras e beirais. ${ }^{19}$

O depoimento de Artigas revela a importância de Wright neste estágio inicial de sua carreira, quando assume a 'honestidade estrutural' e o respeito aos materiais, justificando o emprego de alvenarias de tijolos aparentes, telhados com estruturas de madeira e grandes beirais,

${ }^{18}$ BRUAND, Yves. Arquitetura Contemporânea no Brasil. São Paulo, Perspectiva, 2008, p.271

${ }^{19}$ FERRAZ, Marcelo (org.). Vilanova Artigas: Arquitetos Brasileiros. São Paulo, Instituto Lina Bo Bardi, 1997, p.20

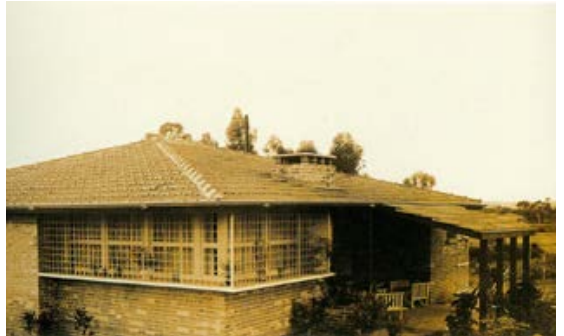

Casa Berta Gift

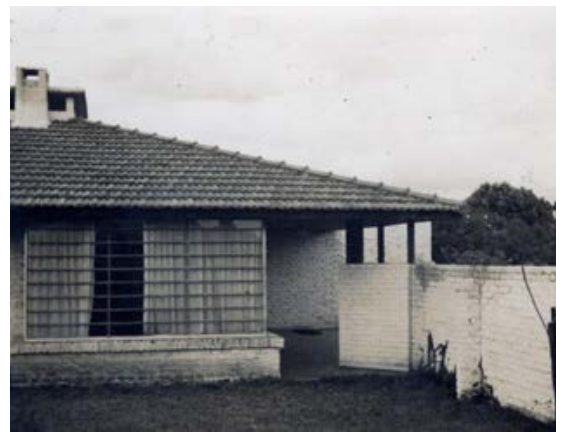

"Casinha" - residência no Campo Belo

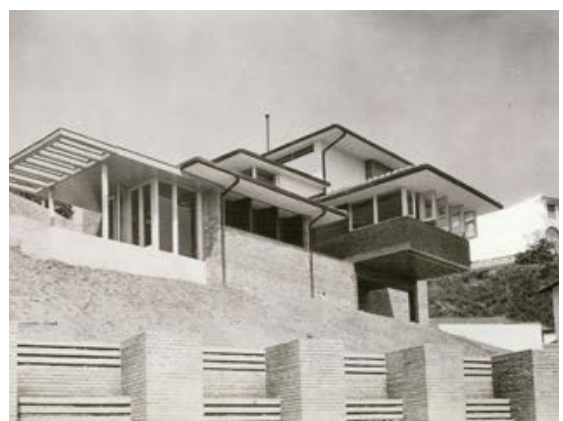

Casa Rio Branco Paranhos

FERRAZ, Marcelo (org.). Vilanova Artigas:

Arquitetos Brasileiros. São Paulo, Instituto

Lina Bo Bardi, 1997, p. 24, 38 e 42. 


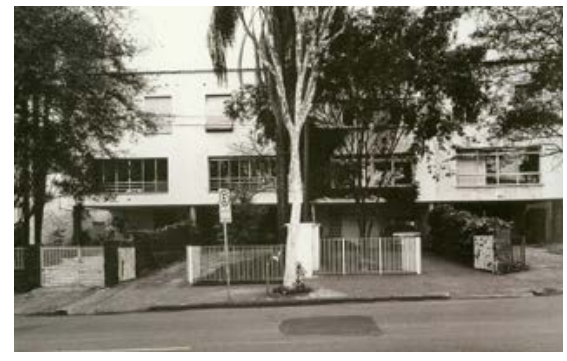

Conjunto de quatro casas localizadas na rua Sampaio Vidal

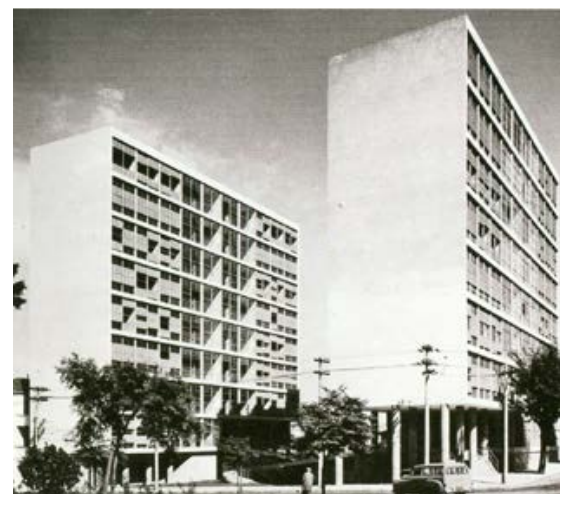

Edifício Louveira

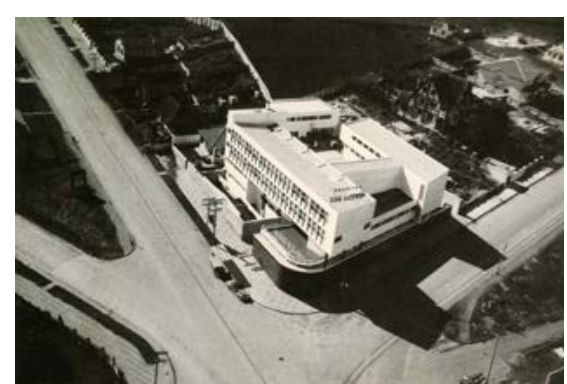

Hospital São Lucas

FERRAZ, Marcelo (org.). Vilanova Artigas: Arquitetos Brasileiros. São Paulo, Instituto Lina Bo Bardi, 1997, p. 42, 50 e 55. pérgolas, mas também a continuidade espacial entre os ambientes internos, as janelas de quina, a inserção do volume da casa em sintonia com o espaço exterior, entre outros aspectos que também relacionam seus projetos à obra de Wright.

Após o fim da sociedade com Duílio Marone, Artigas abandona a influência direta de Wright e assume gradativamente a sintaxe da arquitetura moderna brasileira, iniciada sob a influência de Le Corbusier, mas já com a autonomia conquistada pelas obras de arquitetos cariocas como Niemeyer ou Irmãos Roberto. Este momento de transição se reflete em obras como o conjunto de quatro casas localizadas na rua Sampaio Vidal e a casa para Benedito Levi (ambas de 1944), mas também no Hospital São Lucas (1945) e no Edifício Louveira (1946), projetados pouco antes de ser contemplado com uma bolsa de estudos nos Estados Unidos.

Em conjunto com Artigas, outros arquitetos de São Paulo também assimilaram a influência da arquitetura norteamericana. Oswaldo Bratke, Miguel Forte, Jacob Ruchti, Galiano Ciampaglia e Carlos Millan também apresentaram em diversas obras a influência de Frank Lloyd Wright e de outros arquitetos americanos, e certamente foram responsáveis pelo interesse das gerações posteriores pela arquitetura de Wright.

Nos ateliês, as idéias de Wright e Le Corbusier eram discutidas informal e apaixonadamente. A FAU da Universidade de São Paulo contava com um pequeno grupo de 'wrightianos' desde os anos 50. Ali, o confronto não se limitou a aspectos arquitetônicos, mas assumiu um caráter ideológico. Os grupos raramente se autodenominavam organicistas e racionalistas: eram wrightianos e corbusierianos. Henrique Pait, Luiz Cláudio Gomes, Eduardo de Almeida, Luiz Gastão de Castro Lima, Ludovico Martino, Dácio Ottoni Arthur Fajardo e Oduvaldo Ferreira eram alguns dos integrantes das alas wrightianas. Essa minoria não estava disposta a aceitar a hegemonia da linha racionalista predominante, que contava com o apoio de professores como Vilanova Artigas. ${ }^{20}$

${ }^{20}$ IRIGOYEN, Adriana.Wright e Artigas, duas viagens. São Paulo, Ateliê Editorial, 2002, p.105 


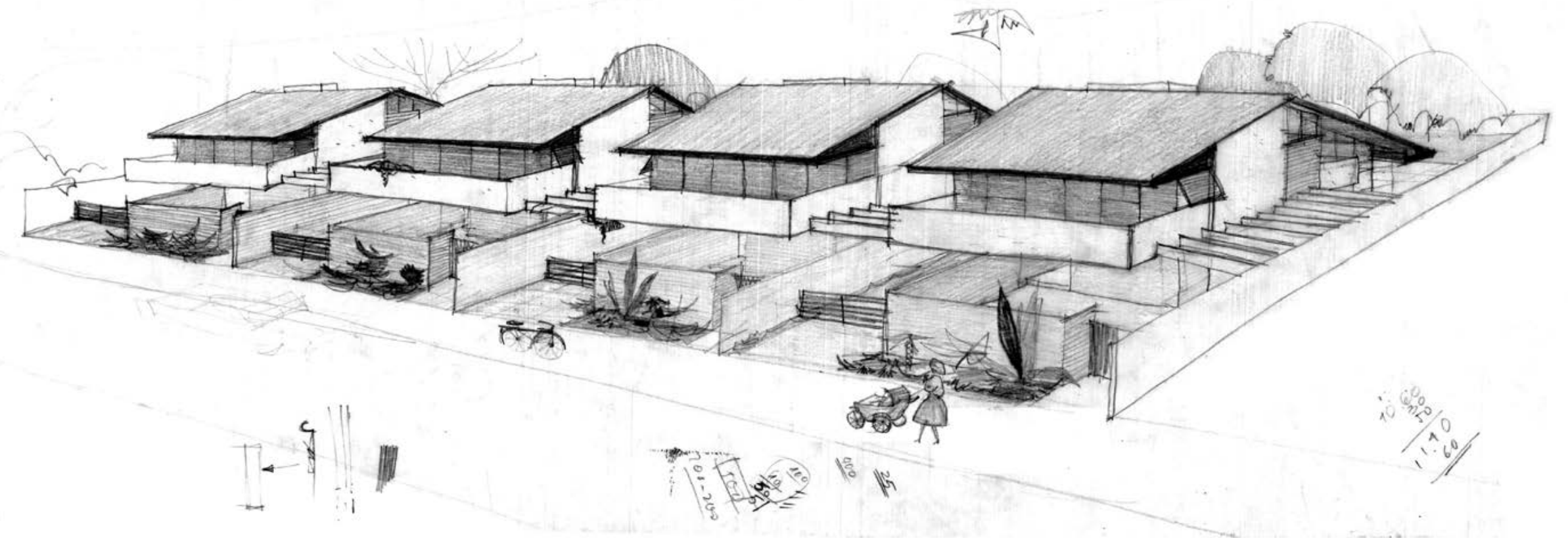




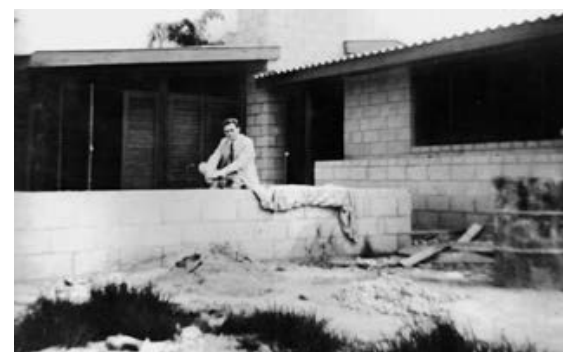

Foto da residência rua dos Açores Acervo Eduardo de Almeida
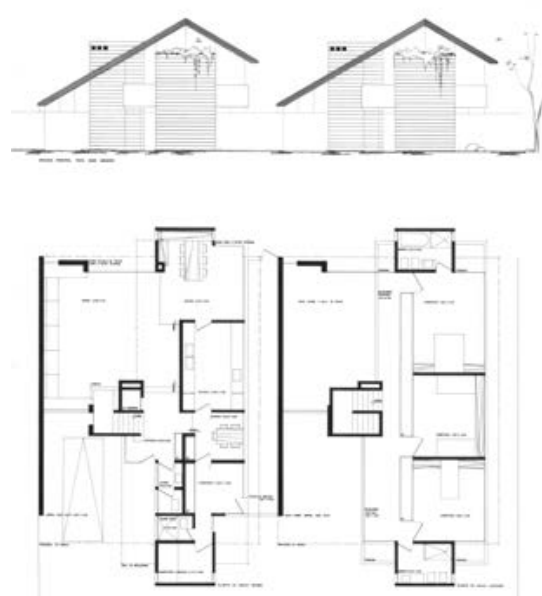

Acima plantas e fachada principal da Residência rua Hans Nobling Acervo Eduardo de Almeida

Ao lado, perspectiva da Residência rua Hans Nobling

Acervo Eduardo de Almeida
Na FAU USP, onde se dava o debate entre arquitetura orgância e racional, personificadas nas figuras de Wright e Le Corbusier respectivamente, moldava-se o grupo wrightiano do qual Eduardo de Almeida faria parte, grupo que incluía os colegas com quem iria realizar seus primeiros projetos a partir de 1957, ainda como aluno, e após 1960, já como arquiteto.

O escritório Horizonte Arquitetos inicia sua produção em 1957, formado por Arthur Fajardo Netto, Dácio A.B. Ottoni, Eduardo de Almeida, Henrique S. Pait e Ludovico Martino (que permanece até 1962), funcionando até 1964, quando Dácio Ottoni se desliga da sociedade. Apesar disso, os arquitetos continuam a trabalhar em conjunto em alguns projetos.

Também influenciados por suas experiências com Carlos Millan, Miguel Forte ou Jacob Ruchti, diversos projetos destes jovens arquitetos reafirmam a presença de Frank Lloyd Wright, a começar pelo próprio nome do escritório que fazia alusão à Horizon Press, responsável pela publicação de muitos livros dedidados à obra de Wright.

Das obras deste período podemos destacar a primeira casa de Eduardo de Almeida, localizada na rua dos Açores (1958), o conjunto de quatro casas implantadas na rua Hans Nobling (1960) e a casa para seu irmão, Flávio Pinho de Almeida, iniciada em 1961 e concluída apenas em 1965. Atualmente, a primeira encontra-se totalmente desfigurada, o conjunto de quatro casas foi demolido para a construção de um edifício e a última está em ótimo estado de conservação.

Assim como este conjunto, também podemos destacar os estudos não construídos para as residências Umberto Moruzzi (1959) e Carlo Rafaelli (1960), definidos pelos pressupostos organicistas de Frank Lloyd Wright, tanto na concepção dos espaços e nos elementos construtivos empregados, quanto na própria representação. 
तll

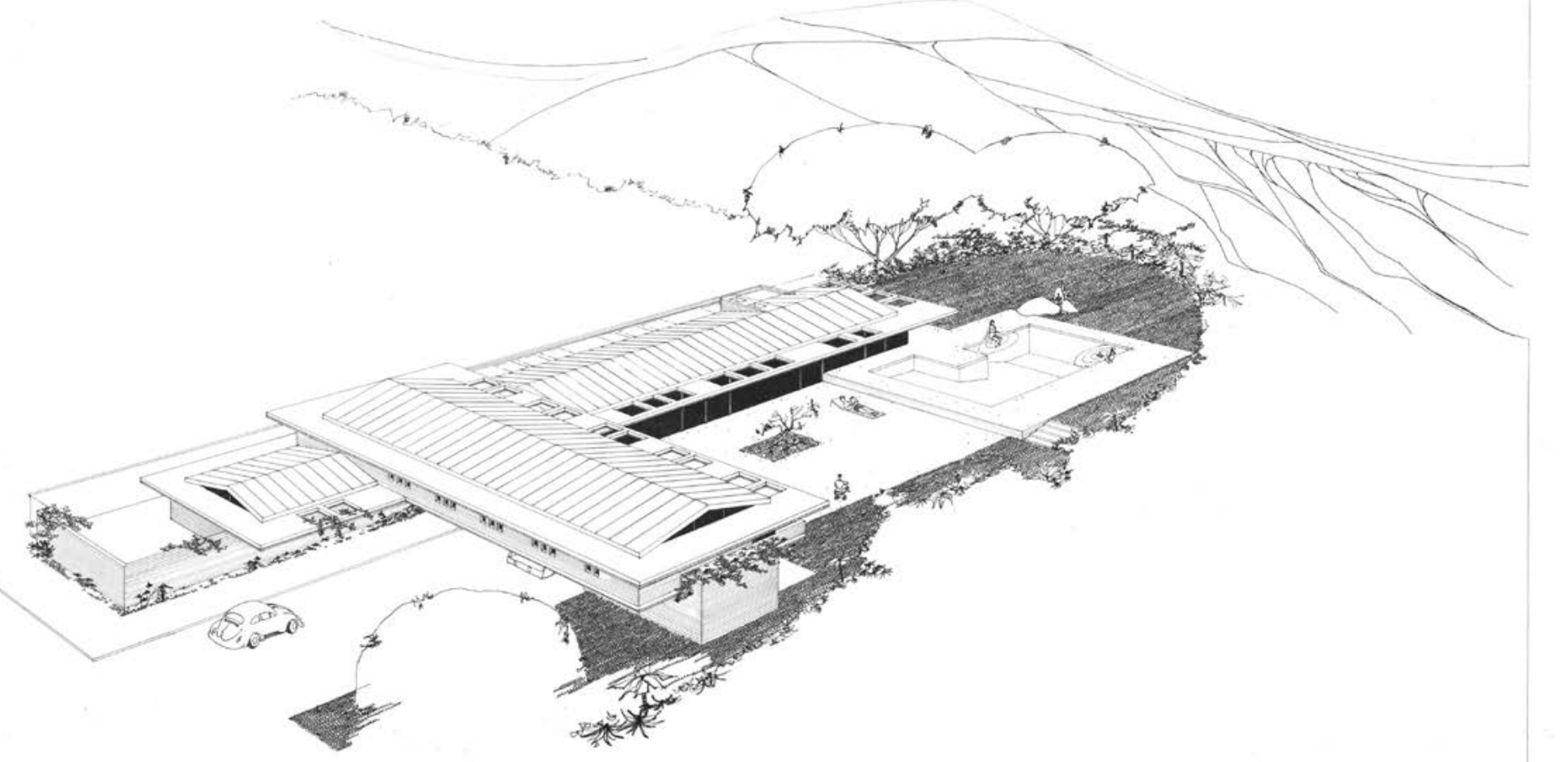

FSOENCA CARLO RAEAELII ANTEPROETO HORIZONTE ARQUITETOS 


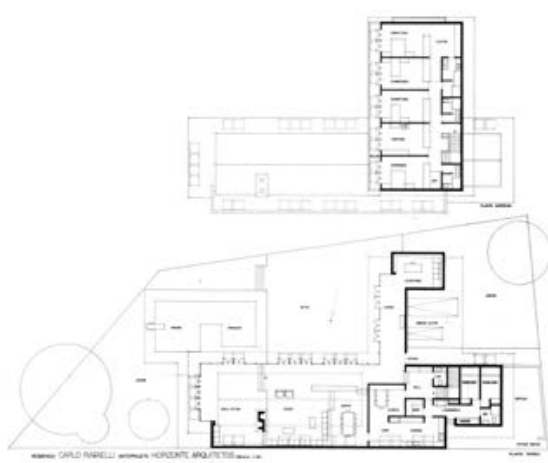

Planta e perspectiva (à esquerda) da Residência Carlo Rafaelli

Acervo Eduardo de Almeida

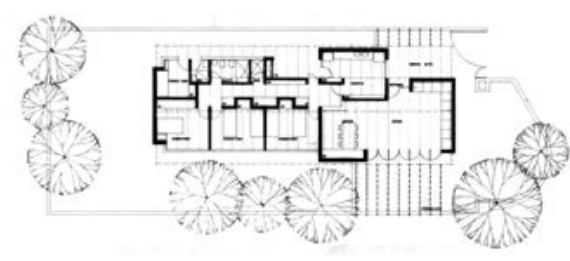

Planta e perspectiva(à direita) da Residência Umberto Moruzzi

Acervo Eduardo de Almeida
Desenhos de grande qualidade, as perspectivas realizadas coletivamente - segundo Eduardo de Almeida, a equipe se dividia e cada arquiteto assumia uma etapa do trabalho, da montagem da perspectiva ao desenho da vegetação ou das escalas humanas - valiam-se da influência das imagens produzidas por Wright na escolha dos pontos de vista, na representação dos materiais empregados e, sobretudo, na relação do edifício com a paisagem circundante.

De fato, a análise detalhada destes projetos revela a presença de Wright nos pressupostos de unidade do edifício na definição dos espaços, tanto por meio de suas modulações quanto por seus sistemas construtivos, cujo princípio de plasticidade poderia garantir a unidade entre os componentes do edifício, sempre em respeito à natureza dos materiais e o emprego racional das estruturas.

Em todos os casos, ficam evidentes os princípios de continuidade interior x exterior, mas também a relação entre os espaços livres e abertos para a natureza circundante, composição sempre reforçada pela horizontalidade do edifício e sua relação com a paisagem.

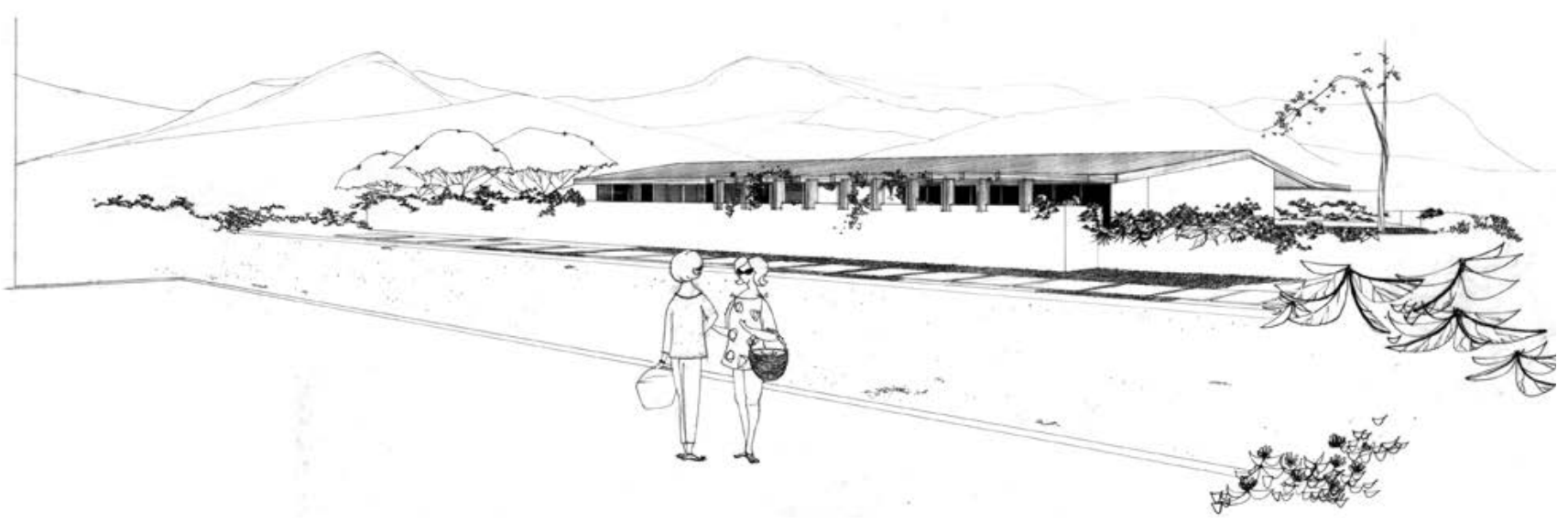


Também fazem parte deste período as duas escolas públicas encomendadas pelo IPESP Instituto de Previdência do Estado de São Paulo - para o Ginásio Estadual Vila dos Lavradores implantado em Botucatu e para o Ginásio Estadual de Silveiras, ambos de 1960.

Nestes dois exemplos, o enfrentamento da obra pública, as limitações técnicas para sua realização e os recursos limitados para a viabilização da obra, parecem ser entraves para a utilização dos princípios wrightianos por completo.

Das perspectivas de acentuado caráter wrightiano para os desenhos realizados durante o projeto executivo - e consequentemente para a obra - muito da natureza material dos muros de arrimo de concreto ciclópico ou dos pórticos de madeira da escola de Botucatu parece se diluir em seu enfrentamento à realidade destas obras relativamente distantes de São Paulo.

Embora os partidos de implantação e de organização geral do espaço permaneçam exatamente os mesmos, a linguagem dos projetos se altera completamente no projeto de execução, já que desaparece o contraste entre as pesadas bases de pedra e as coberturas leves com grandes vãos, e também porque o emprego de soluções padronizadas de caixilhos de ferro e elementos vazados de concreto não parece fazer parte do vocabulário adequado à estética wrightiana pretendida, muito embora estes elementos apareçam em diferentes etapas da obra de Wright.

De qualquer forma, pode-se destacar nestes dois projetos a implantação dos volumes em função da topografia e da orientação. Tirando partido do declive apresentado pelo terreno, ambos se implantam por meio de patamares que consideravam desníveis sempre menores que $1,30 \mathrm{~m}$, reduzindo a movimentação de terra para a execução da obra e, sobretudo, criando edifícios inseridos de modo sensível na topografia. 
Nos dois casos, a distribuição do programa em blocos garante as exigências funcionais exigidas por cada atividade - didática ou administrativa - que sempre aparecem articuladas pelo espaço do galpão, protegido pelas coberturas inclinadas, desenhadas em continuidade às alas definidas por cada um dos blocos, e com pé-direito elevado e variável.

Do ponto de vista espacial, o galpão é o elemento articulador de todos os programas da escola, núcleo central que apresenta plena continuidade com o exterior, tanto nos pátios de acesso dos alunos, quanto no espaço de ligação com as áreas de lazer e esportivas localizadas na parte posterior do lote.

Diferentemente destas duas obras, nas outras três construídas em São Paulo (a primeira casa do arquiteto, as quatro casas da rua Hans Nobling e a casa de seu irmão), a participação direta de Eduardo de Almeida nos processos de execução parece garantir os resultados definidos em projeto, inclusive nas intenções materiais e estéticas previstas.

Concomitantemente a estas obras são realizados inúmeros projetos que, por outro lado, não se pautam pelos direcionamentos organicistas, ao contrário, surgem a partir de outras experiências, como ressalta Paulo Fujioka, a partir de uma das entrevistas com Eduardo de Almeida:

(...) as referências orgânicas não eram somente wrightianas - a discussão sobre a arquitetura de Wright também passava pela experiência de discípulos ou ex-colaboradores, como Richard J. Neutra (1892-1970). Uma exposição da obra de Neutra montada no MASP em 1951 impressionou vários membros do grupo. ${ }^{21}$ 

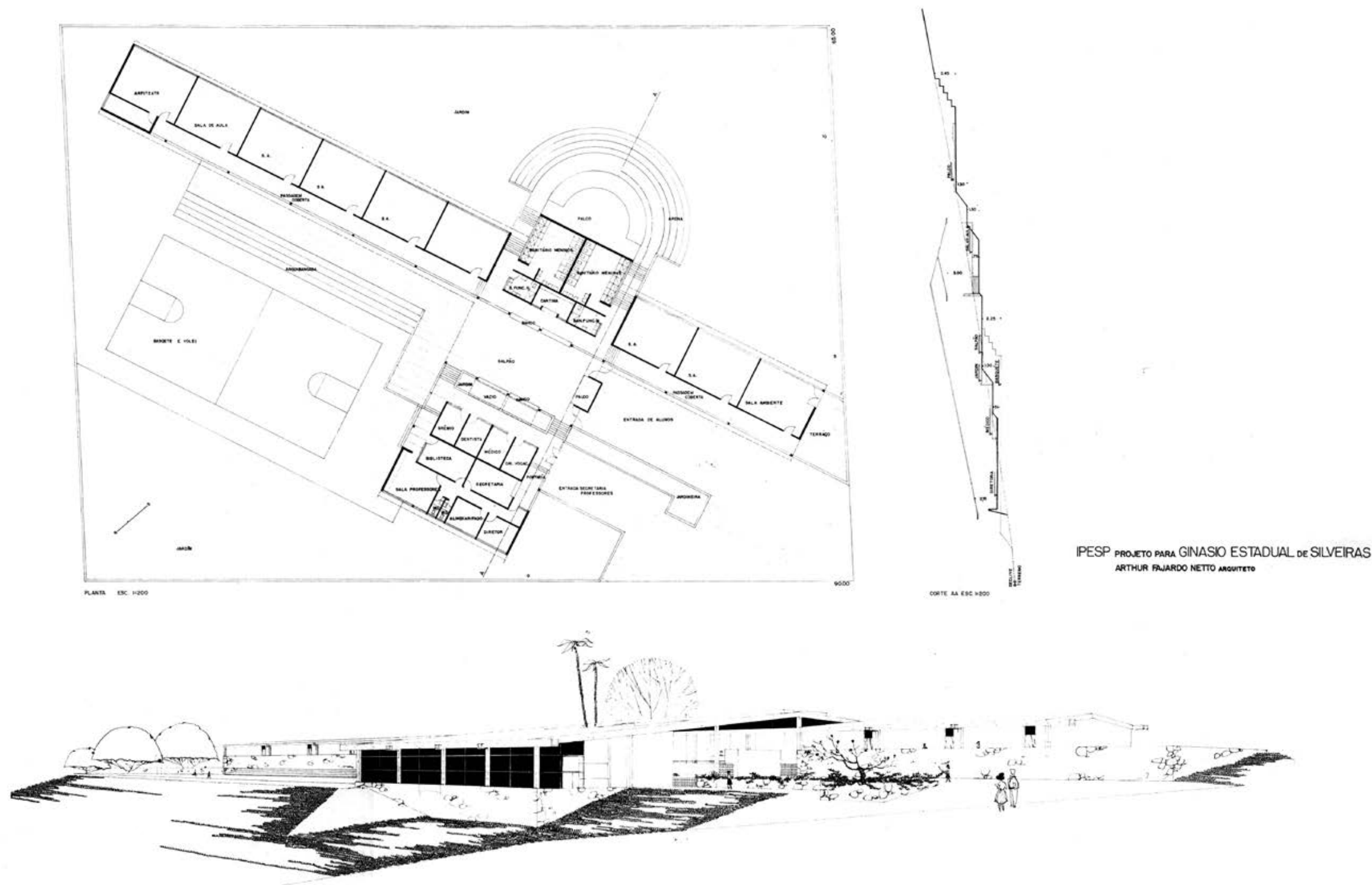

IPESP PRovetr PARA GINASIO ESTADUAL oE SILVEIRAS

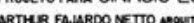

Planta e perspectiva do Ginásio Estadual de Silveiras

Acervo Eduardo de Almeida 


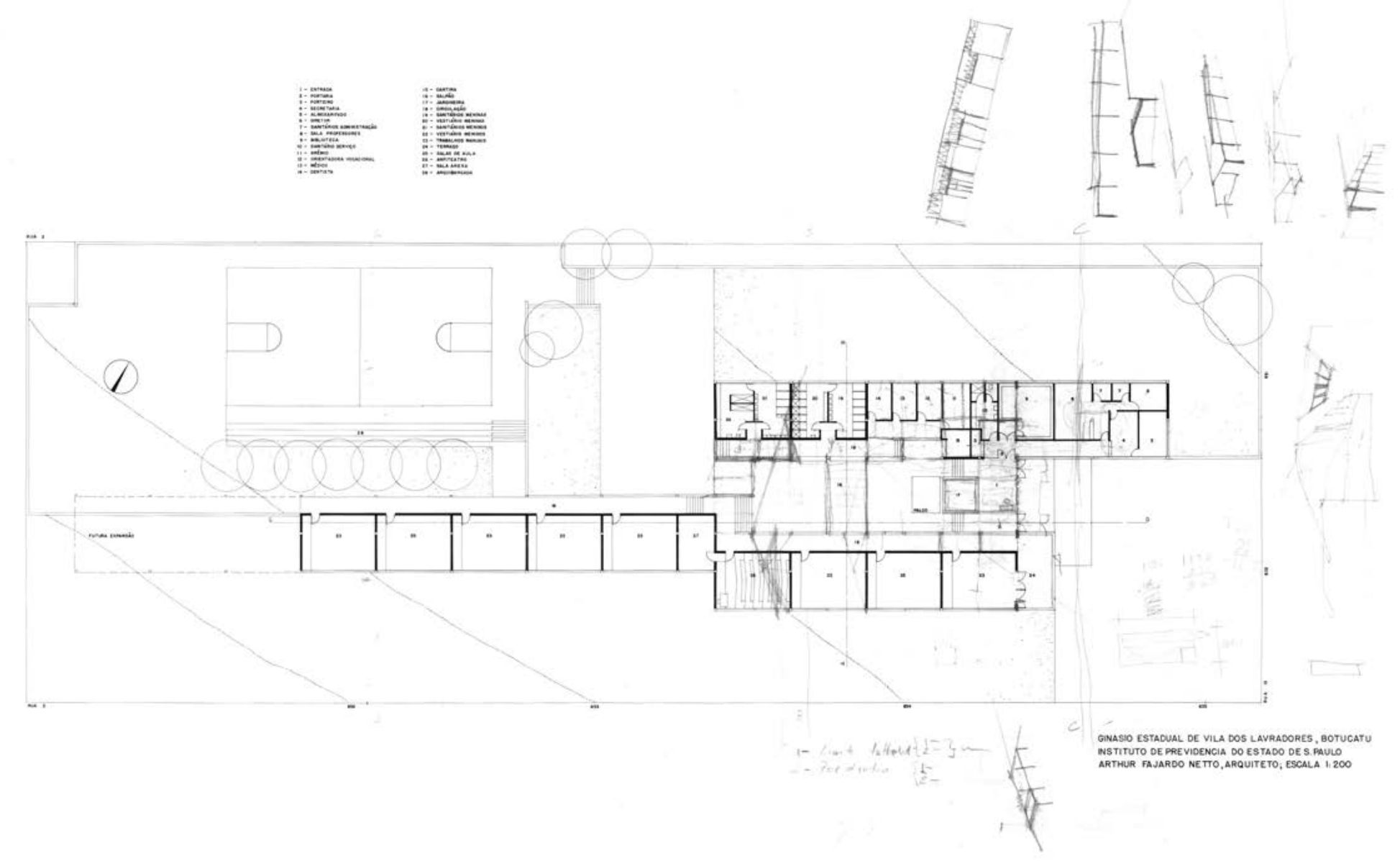

Planta e perspectiva do Ginásio Vila Nova

dos Lavradores

Acervo Eduardo de Almeida 
E acrescenta que outras expressões arquitetônicas poderiam apresentar muitos dos pressupostos de Wright, ainda que com a utilização de outras linguagens. Como ressalta Paulo Fujioka acerca da importância de um arquiteto como Neutra, um bom exemplo "onde a presença de Wright está implícita na relação do edifício com a paisagem, na horizontalidade dos elementos e na dissolução dos limites entre interior eo exterior."22

Essa constatação, na verdade, revela que o grupo de jovens arquitetos, apesar de declaradamente wrightiano, apresentava interesse e conhecimento de inúmeros projetos realizados no mesmo período por arquitetos diversos como Oscar Niemeyer, Franz Heep ou Rino Levi, envolvidos em obras de edifícios de grande porte em São Paulo, como o Edifício Copan (1950), Edifício Itália (1956) e o Hospital Albert Einstein (1958), respectivamente.

Mesmo Vilanova Artigas, Paulo Mendes da Rocha e Carlos Millan apresentam neste período obras importantes que direcionam novos rumos à arquitetura paulista, posteriormente reconhecida, por alguns, como brutalista, já que datam deste período o Ginásio de Itanhaém (1959) e o Ginásio Esportivo do Clube Paulistano (1958), projetados por Artigas e Paulo Mendes da Rocha, respectivamente, mas também pequenas casas de Carlos Millan para Robeto Millan, Nadir Figueiredo e Antônio D’Elboux, todas do início dos anos 1960.

Como observa Paulo Fujioka, apesar das divergências entre wrightianos e corbusianos da FAU USP, não só estavam todos interessados em defender os novos pressupostos da arquitetura moderna brasileira, como, por princípio, o embate entre orgânicos e racionalistas, assumia contornos menos definidos no enfrentamento da realidade de São Paulo por meio dos projetos de arquitetura efetivos.

${ }^{22}$ FUJIOKA, Paulo. Princípios da Arquitetura Organicista de Frank Lloyd Wright e suas influências na Arquitetura Moderna Paulistana. São Paulo, FAU USP, 2003, p.192

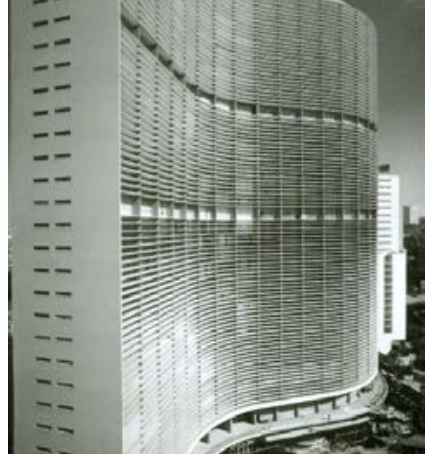

Edifício Copan

ANDREOLI, Elisabetta e FORTY, Adrian (org.) Arquitetura Moderna Brasileira. London, Phaidon, 2002, p. 32.

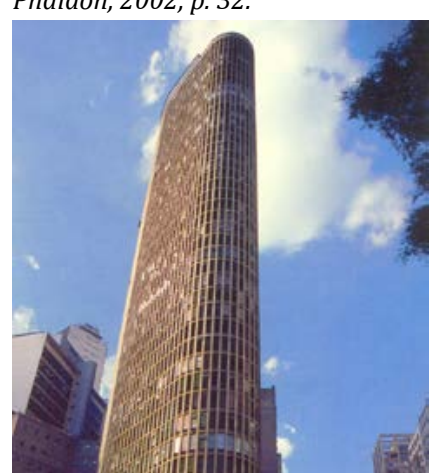

Edifício Itália

REIS FILHO, Nestor Goular; BRITO, Mônica Silvei$r a$. Dois Séculos de Projetos no Estado de São Paulo: grandes obras e urbanização. Imprensa Oficial, São Paulo, 1ª edição, V.3, 2010, p.41.

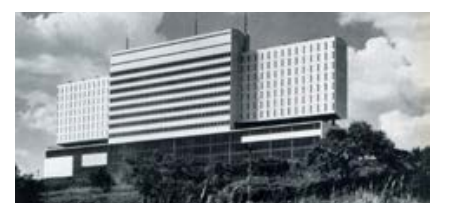

Hospital Israelita Albert Einstein REIS FILHO, Nestor Goulart. Arquitetura de Rino Levi. In: Rino Levi. Milano: Edizioni di Comunità, 1974, p. 119. 


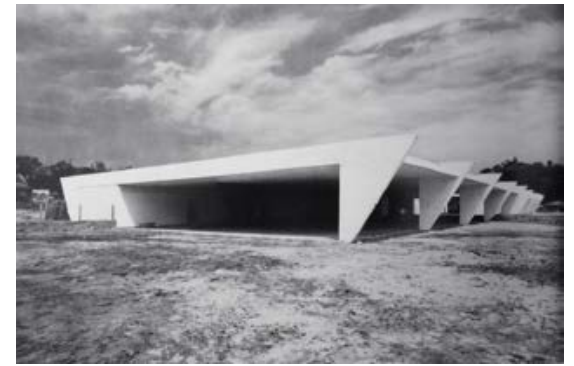

Ginásio de Itanhaém

FERRAZ, Marcelo (org.). Vilanova Artigas: Arquitetos Brasileiros. São Paulo, Instituto Lina Bo Bardi, 1997, p. 86.

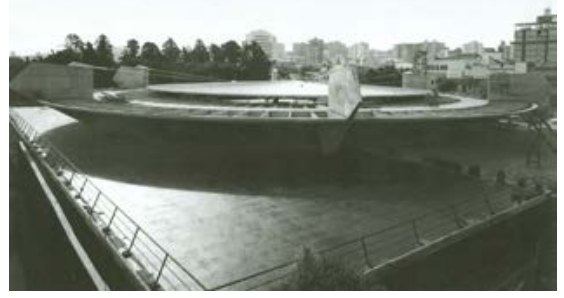

Ginásio Esportivo do Clube Paulistano ARTIGAS, Rosa (org.). Paulo Mendes da Rocha, projetos 1957-1999. São Paulo, Cosac Naify, 2006, p. 84

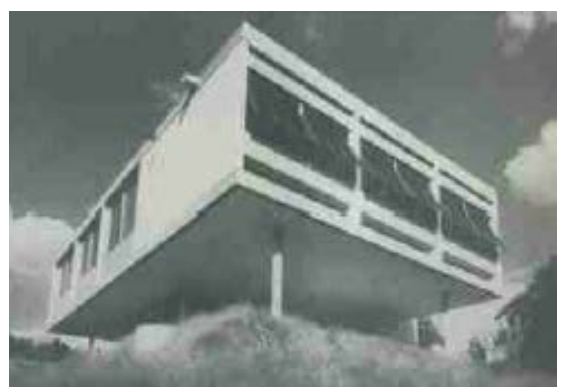

Residência Nadir de Olivera

MATERA, Sérgio. Carlos Millan um estudo sobre a produção em Arquitetura

Dissertação de mestrado, FAUUSP. São Paulo, Página 243.
Parece importante ressaltar que, em inúmeros projetos realizados nesse mesmo período pelo escritório Horizonte Arquitetos, a sintaxe organicista era substituída naturalmente por outras referências, como os estudos para os edifícios localizados nas ruas Sergipe (1958), Guaianases (1959), Martinico Prado (1960), alameda Itú (1962), rua Bela Cintra e alameda Franca, estes dois últimos de 1963.

Naturalmente, o enfrentamento projetual para edifícios de habitação vertical parece exigir referências outras que não a de Frank Lloyd Wright e, embora uma ou outra solução remeta a algum elemento da produção wrightiana - como a expressão gráfica de algumas perspectivas ou a textura horizontal da alvenaria aparente do edifício da alameda Itú - a tônica destes projetos parece ser a arquitetura moderna brasileira, particularmente aquela em desenvolvimento em São Paulo.

Em todos esses casos, o problema do edifício vertical parece exigir o rigor da modulação estrutural do concreto armado, muitas vezes aparente na fachada, sempre com o pré-requisito da planta-livre.

A organização das prumadas de circulação vertical central e de infraestrutura hidráulica refletem o sempre cuidadoso estudo da planta, coerentemente subdividida pelos espaços de estar, dormitórios e serviços.

As fachadas desenhadas como painéis a partir da grelha estrutural ou as janelas em fita ao longo de toda a extensão do volume também ressaltam as características que mostram um direcionamento à arquitetura dita racional. 

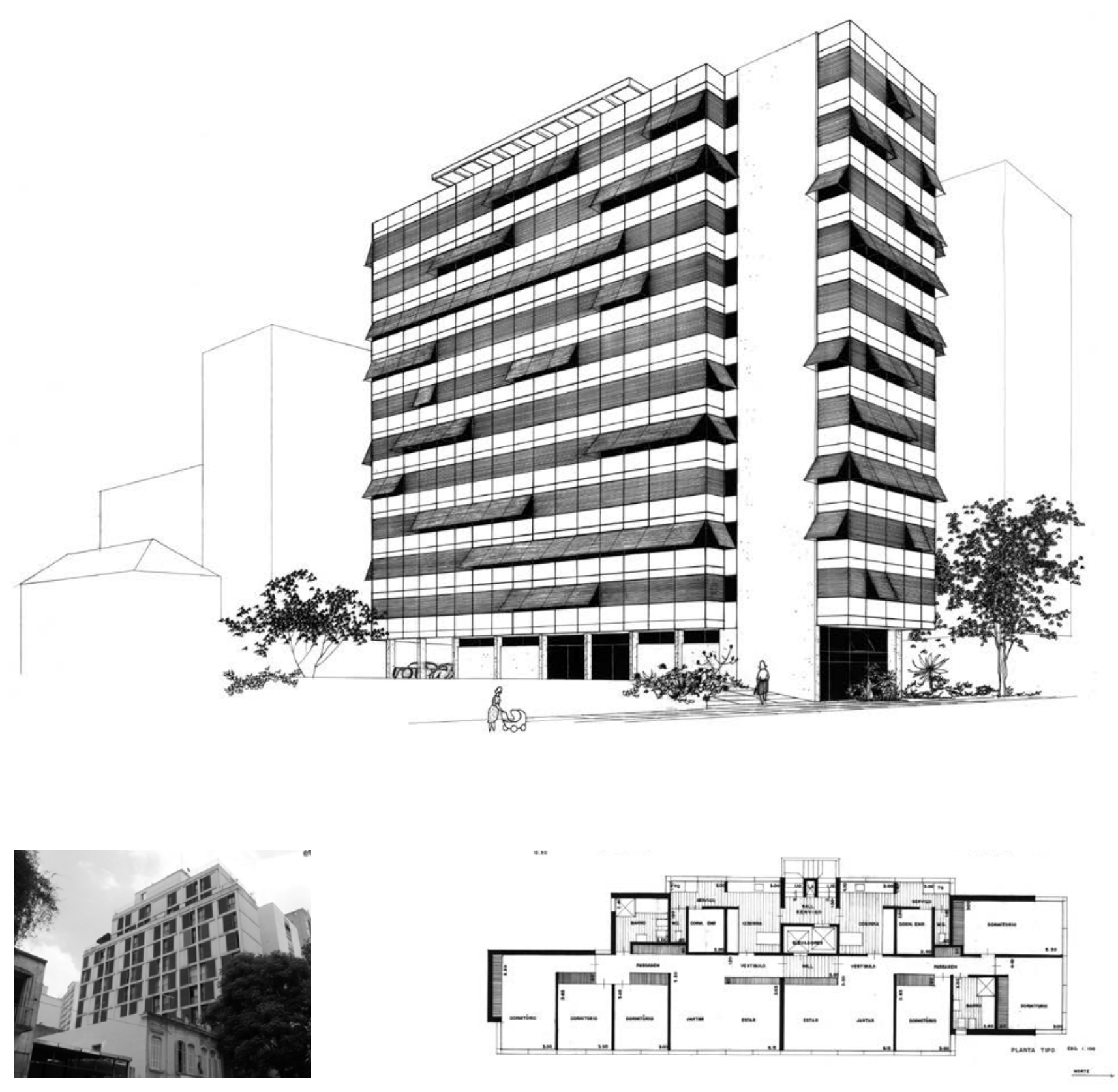

Planta e perspectiva do Edifício da rua Martinico Prado

Acervo Eduardo de Almeida

Foto : Alessandra Figueiredo 
(...) na produção dos arquitetos wrightianos da FAU USP que, desde o início de suas carreiras, a influência organicista passava pelo filtro da reflexão sobre a realidade brasileira e que os princípios wrightianos permaneceram mesmo enquanto a concepção espacial e construtiva dos arquitetos evoluía dentro do quadro da Escola Paulista. De Carlos Millan a Eduardo de Almeida e os irmãos Ottoni, vemos uma progressão que passa da inspiração wrightiana para o cânone de Artigas sem deixar de lado os conceitos de Wright. ${ }^{23}$
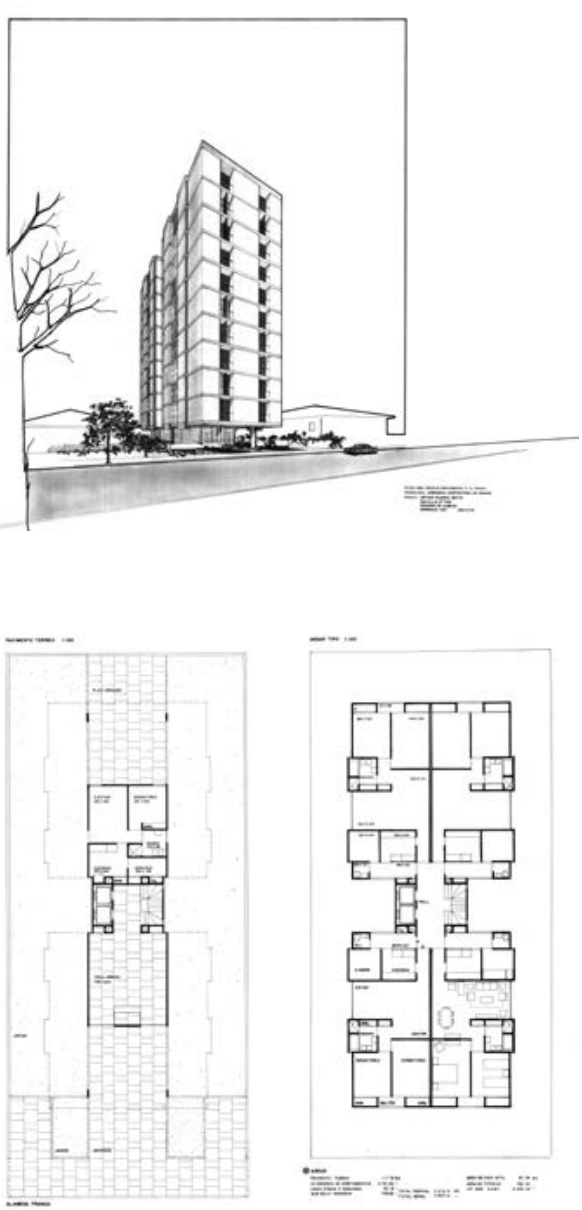

Planta e perspectiva do Edifício da Alameda Franca

Acervo Eduardo de Almeida
A partir desta nova linguagem, podemos dizer que esta série de projetos não abandonou por completo os aprendizados de Wright, uma vez que o respeito aos materiais e a unidade pretendida entre cada um dos componentes que define a construção parecem obedecer a premissa de unidade proposta pela arquitetura orgânica.

A valorização das aberturas, através da continuidade dos ambientes internos para o exterior por meio de grandes planos envidraçados nos ambientes sociais, também parece priorizar a continuidade entre a arquitetura e a paisagem.

Muito embora os projetos apresentem extrema clareza e concisão, nada disto parece ter sido suficiente para viabilizar completamente esta arquitetura. Os dois projetos efetivamente construídos desta série - os edifícios para a rua Martinico Prado e alameda Itu - assim como as escolas do IPESP - Instituto de Previdência do Estado de São Paulo -, parecem não resistir completamente às imposições da obra e, por que não dizer, das necessidades do mercado imobiliário.

No caso do edifício da rua Martinico Prado, a planta-tipo do edifício efetivamente construído foi alterada, a caixilharia horizontal em fita foi substituída por janelas verticais e, mais grave, foram construídos pavimentos recuados nos últimos andares, atendendo aos requisitos da legislação, mas alterando sensívelmente a volumetria do edifício.

${ }^{23}$ FUJIOKA, Paulo. Princípios da Arquitetura Organicista de Frank Lloyd Wright e suas influências na Arquitetura Moderna Paulistana. São Paulo, FAU USP, 2003, p.212 

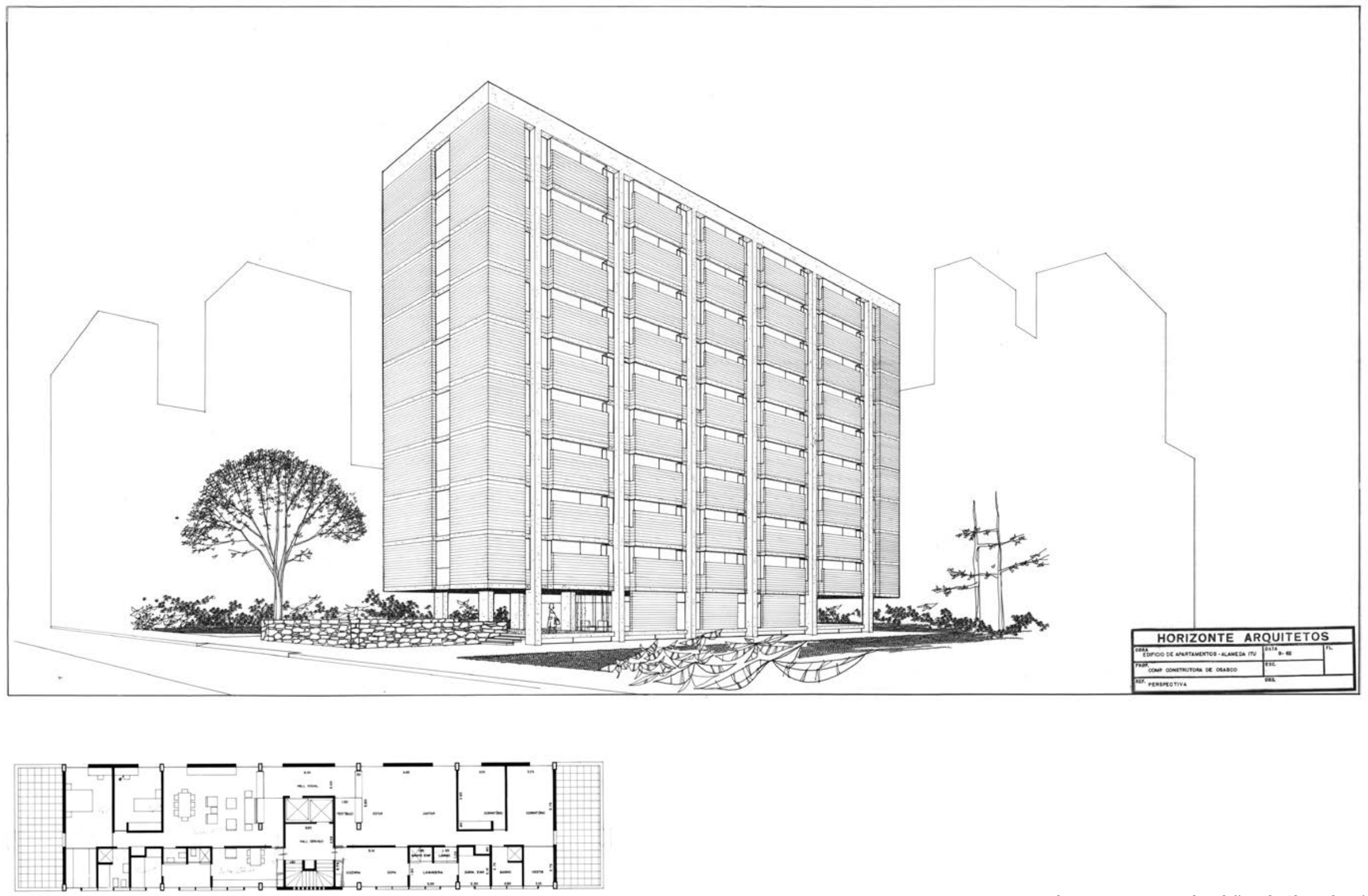

$=$

Planta e perspectiva do Edifício da Alameda Itú Acervo Eduardo de Almeida 


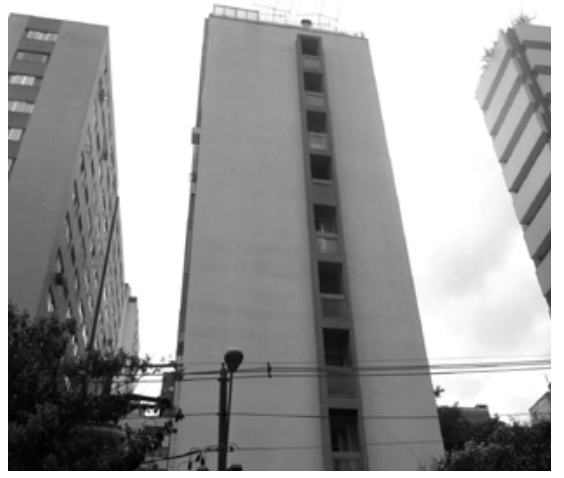

Situação atual do Edifício da Alameda Itú Foto : Alessandra Figueiredo
Fiel às soluções gerais do projeto, o edifício da alameda Itu sofre com as modificações decorrentes dos materiais adotados e também com a alteração da síntese obtida entre estrutura, caixilharia e alvenaria - já que a composição prevista, por meio de avanços e recuos na fachada, previa a marcação das linhas verticais dos pilares, a área envidraçada recuada e as alvenarias em ressalto, destacadas dos demais elementos.

Talvez por esses motivos, estas obras nunca tenham sido publicadas, apesar de sua importância por terem sido os primeiros edifícios verticais projetados por Eduardo de Almeida, e as primeiras experiências no duro embate entre o arquiteto e a realidade dos clientes e das obras.

A realização de todos estes projetos - orgânicos e racionalistas - é intermediada por uma pausa: em 1962, por meio de uma bolsa de estudos obtida junto à Fundação Amerigo Rotellini, Eduardo de Almeida viaja à Itália e cursa a disciplina Proggetazione Artistica per L'industria, sob responsabilidade do Professor Pierluigi Spadolini, e o Curso de História da Arte, ministrado por Leonardo Benevolo, ambos na Faculdade de Arquitetura de Florença. O trabalho final apresentado por Eduardo de Almeida - Lampadina Componibile - segue claramente a influência do desenho industrial italiano da época, a exemplo da obra de Achille Castiglione e de outros designers, em que cada projeto busca atingir a essência de determinado objeto. Neste caso, ao se pensar no desenho para uma luminária, Eduardo decide fazer o projeto das próprias lâmpadas.

Composta por lâmpadas de tamanhos diferentes, a proposta considerava a idéia de uma luminária pendente e componível, onde a sucessão de esferas de diversas dimensões, bem como o agrupamento em diferentes colunas, poderiam criar desenhos variados e específicos de acordo com a necessidade de um determinado espaço. 


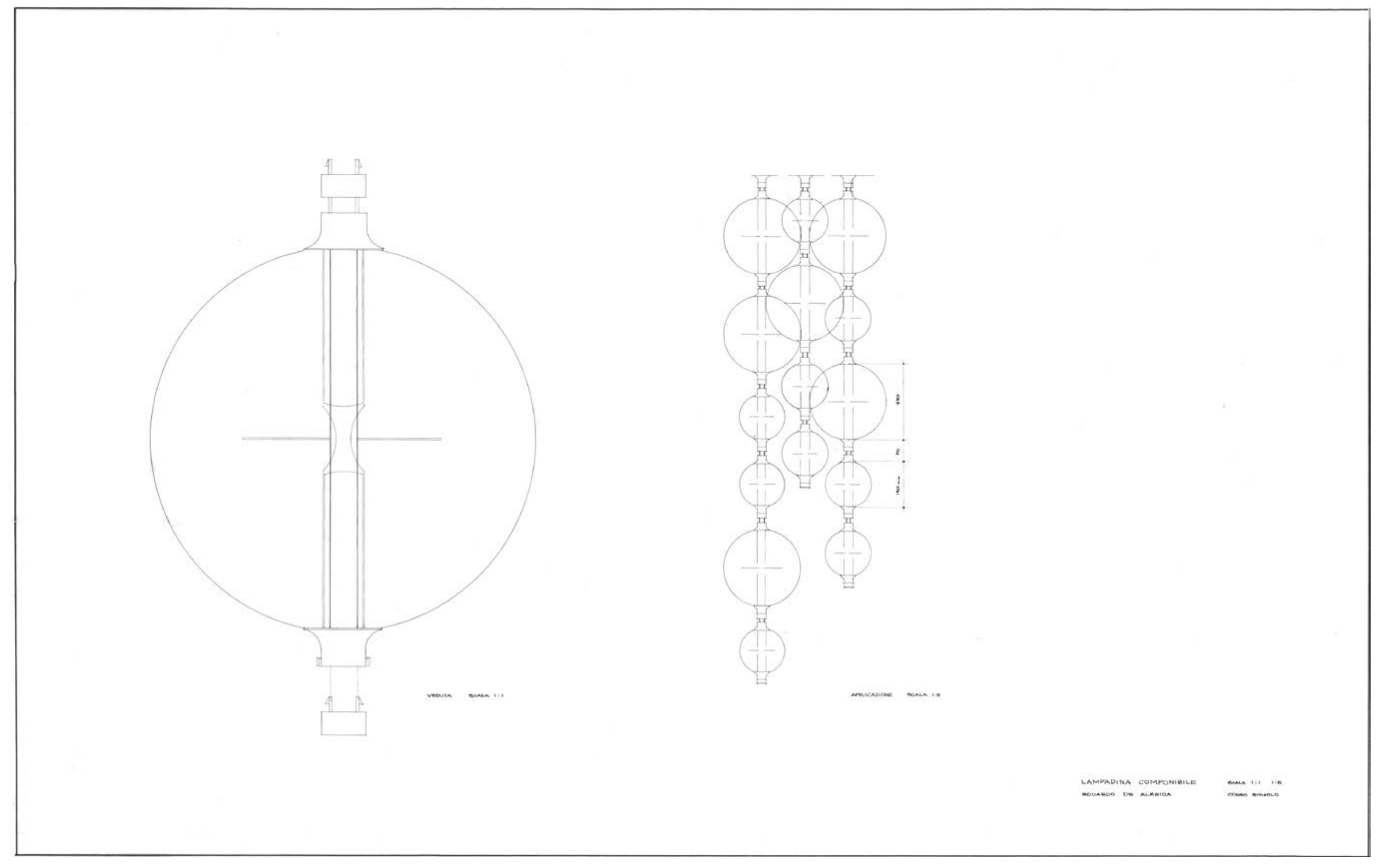



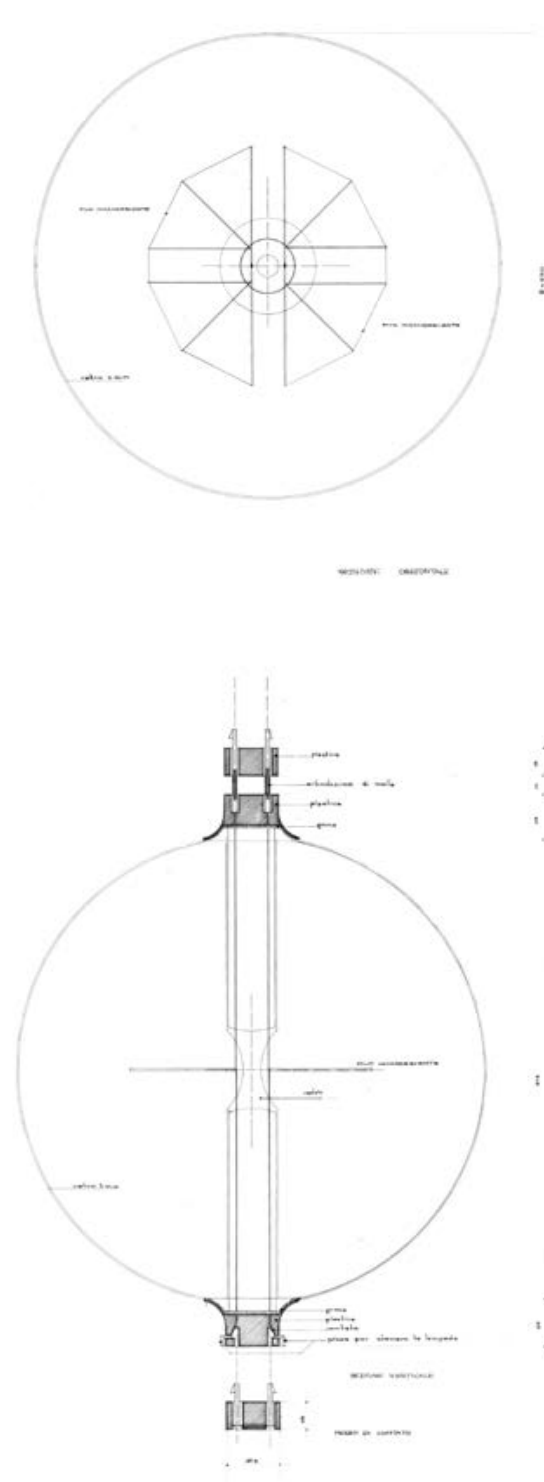

Desenhos Lampadina Componibile Acervo Eduardo de Almeida
Do ponto de vista técnico, o projeto se aprofunda no desenho das conexões entre as esferas, nos materiais dos componentes diversos, e também nos requisitos técnicos para a passagem de energia e para o desenho do filamento necessário à obtenção da luz.

O curso Proggetazione Artistica per L'industria parece dar sequência aos desafios proporcionados pela industrialização, um passo à frente aos embates entre o artesanato e suas primeiras fases, como também explica Argan:

Em termos muito gerais, do ponto de vista das formas, a história do industrialismo moderno tem três fases. A primeira é a da repetição mecânica ou da 'despersonalização' dos motivos e dos processos formais do artesanato: é essa a fase que determina a crise econômica do artesanato, suscita a reação do socialismo utópico e a polêmica de Ruskin e Morris. A segunda é a que constata o caráter racional ou científico dos processos mecânicos, reduz o belo ao prático e o prático ao racional; (...) É esse, historicamente, o momento do racionalismo arquitetônico do segundo pós-guerra e da sua rápida extensão a todas as aplicações possíveis. A partir desse momento, os limites da produção industrial e os da produção artística tendem a fundir-se: pede-se a Gropius o desenho de uma locomotiva ou de uma carroceria de automóvel. ${ }^{24}$

De fato, a experiência na Itália terá grande influência na obra posterior de Eduardo de Almeida. A alternância entre as experiências organicistas e racionalistas teria agora nesta obra um compromisso maior com as regras decorrentes dos processos industriais, ainda que apenas do ponto de vista do projeto, do desenho, como podemos comprovar mais a frente.

Antes de realizar esta viagem à Itália, Eduardo e seus colegas do Horizonte Arquitetos haviam iniciado o projeto para a casa de seu irmão, Flávio Pinho de Almeida, em um lote de grandes dimensões no Jardim Everest, próximo à ponte Eusébio Matoso em São Paulo. Segundo análise de Paulo Fujioka:

Este talvez seja o mais interessante projeto influenciado por FLLW em São Paulo. Sem necessariamente apresentar uma inspiração direta da linguagem wrightiana, constitui uma solução original dentro dos princípios organicistas. A integração com a paisagem é total, com a volumetria da casa inscrita num grande muro de arrimo em curva que impõem um patamar ajardinado sobre a topografia em declive. A casa e a piscina não estão pousadas, mas inseridas num platô que cai em desnível acompanhando a rua. ${ }^{25}$

${ }^{24}$ ARGAN, Giulio Carlo. O Desenho Industrial in Projeto e Destino. São Paulo, Ática, 2001, p.118

${ }^{25}$ FUJIOKA, Paulo. Princípios da Arquitetura Organicista de Frank Lloyd Wright e suas influências na Arquitetura Moderna Paulistana. São Paulo, FAU USP, 2003, p. 204 

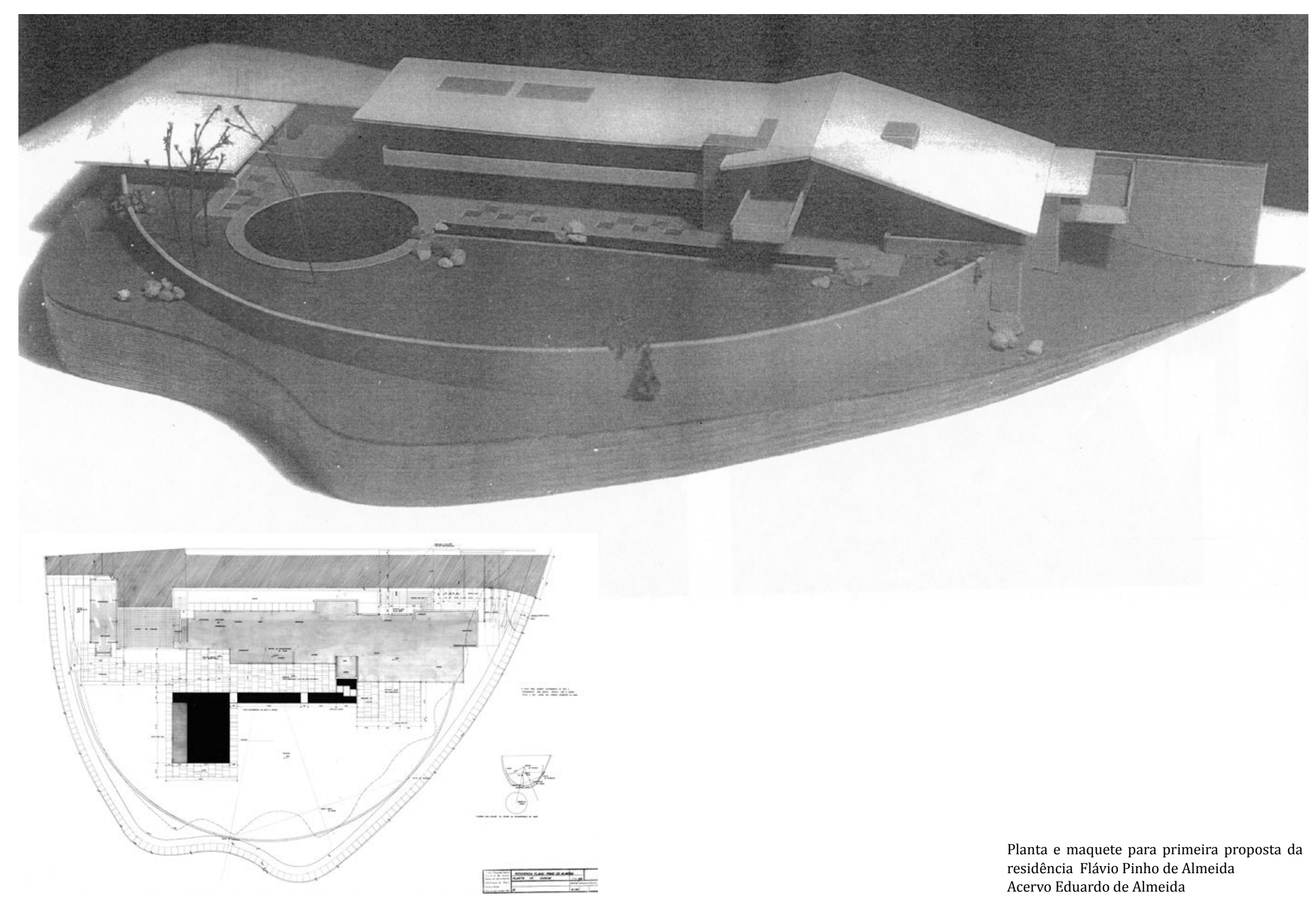

Planta e maquete para primeira proposta da

residência Flávio Pinho de Almeida

Acervo Eduardo de Almeida 

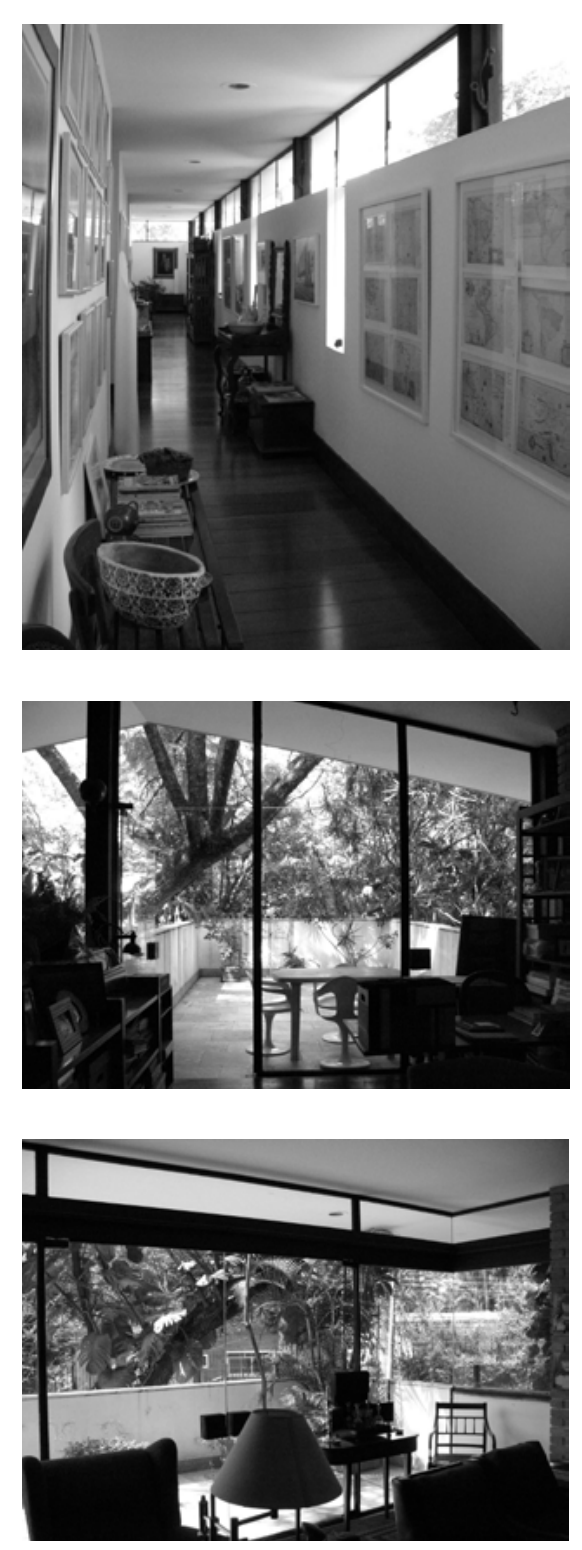

Residência Flávio Pinho de Almeida Fotos : Maira Rios
Conforme o depoimento de Eduardo de Almeida, o partido do projeto foi aprovado pelos clientes, excessão apenas à orientação dos dormitórios que se voltavam para o Sul e que, não só gerou uma solução alternativa para o segundo pavimento, como motivou a criação de um outro projeto idealizado por Ludovico Martino.

Por fim, os clientes decidiram construir o projeto inicial, considerando a relação de continuidade dos dormitórios em direção ao jardim da casa. De qualquer forma, ainda que o partido tenha sido definido anteriormente à viagem de Eduardo de Almeida, o desenvolvimento do projeto executivo e a efetiva realização da obra acontecem somente com seu retorno ao Brasil, viabilizando a execução precisa deste trabalho complexo que considerava uma estrutura mista de aço e concreto, alternando planos de alvenaria de tijolos aparentes com planos revestidos e pintados de branco, além de requintados detalhes na caixilharia com vidro temperado da sala e no emprego da madeira para as venezianas dos dormitórios e outros elementos construtivos.

É importante ressaltar que a existência destes dois projetos de grande interesse revelam os diferentes modos como os projetos do período agregavam influências diversas, ora mais inclinadas a princípios organicistas, ora voltadas às referências racionalistas.

Enquanto na primeira versão o volume da casa se organizava em dois pavimentos principais - além do nível inferior destinado à garagem e demais espaços de apoio -, a segunda proposta distribuía todo o programa em apenas um pavimento, considerando a mesma implantação linear sobre o patamar definido pelo muro curvo e o acesso de veículos por uma cota inferior.

Do ponto de vista formal, a segunda versão se destacava pelo espaço central das salas, demarcado pela justaposição de quatro volumes de planta quadrada e com coberturas 

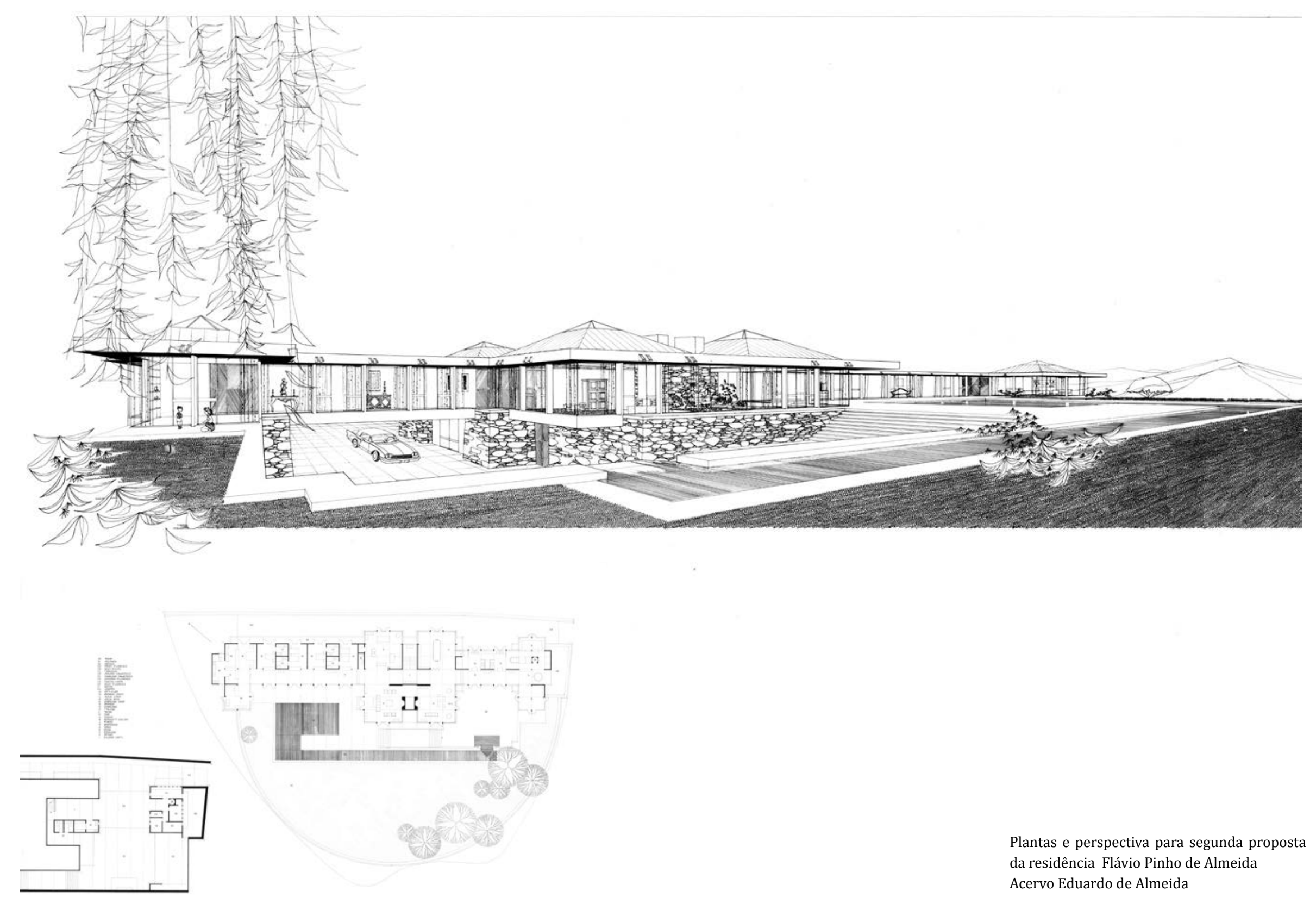

Plantas e perspectiva para segunda proposta da residência Flávio Pinho de Almeida Acervo Eduardo de Almeida 


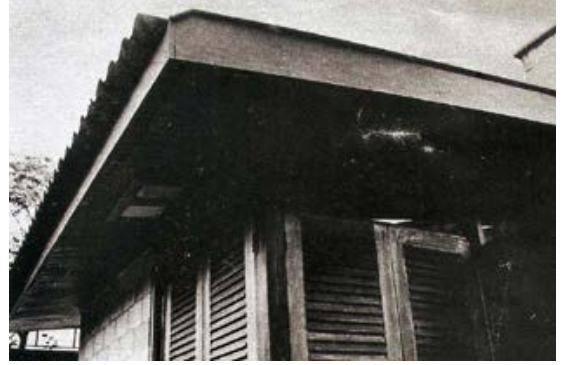

Corte do projeto executivo e foto da residência rua dos Açores

Acervo Eduardo de Almeida independentes de quatro águas, intermediadas pela circulação longitudinal de toda a casa e pelo volume da escada, acesso principal da residência.

Dotados de iluminação zenital, os prismas piramidais das coberturas seriam revestidos de cobre e associados à uma estrutura primária de concreto armado moldado in loco, solução que valoriza a horizontalidade do volume, destacado do pesado embasamento de pedras ao longo da extensa caixilharia de piso a teto, elemento responsável pela transparência dos espaços internos e, consequentemente, pela desejada integração interior e exterior.

Já a primeira versão do projeto parece dar continuidade ao tratamento expressivo das coberturas, semelhante à solução adotada em vários projetos da época: planos inclinados assimétricos e com grandes beirais, utilizados não só nas escolas já descritas como também em diversas obras do Horizonte Arquitetos.

Neste caso, os planos inclinados são desenhados em continuidade à laje plana de cobertura do setor destinado aos dormitórios, criando um espaço de pé-direito elevado e variável na sala de estar localizada no piso térreo.

Assim como na primeira residência de Eduardo de Almeida, implantada na rua dos Açores, a geometria da cobertura desta casa apresenta o contraponto de um volume vertical sólido; enquanto na primeira o telhado é interrompido pela lareira, na casa para seu irmão um volume de tijolos aparentes abriga o bar e o banheiro da suíte. Tal composição é complementada por um balcão estruturado por meio de vigas-peitoril capazes de viabilizar um balanço de 6,40 metros de comprimento, certamente inspirado pelo Bird's Walk de Taliesin East projetado por Frank Lloyd Wright, técnica que reaparece posteriormente nos balcões em balanço da casa Fallingwater. 

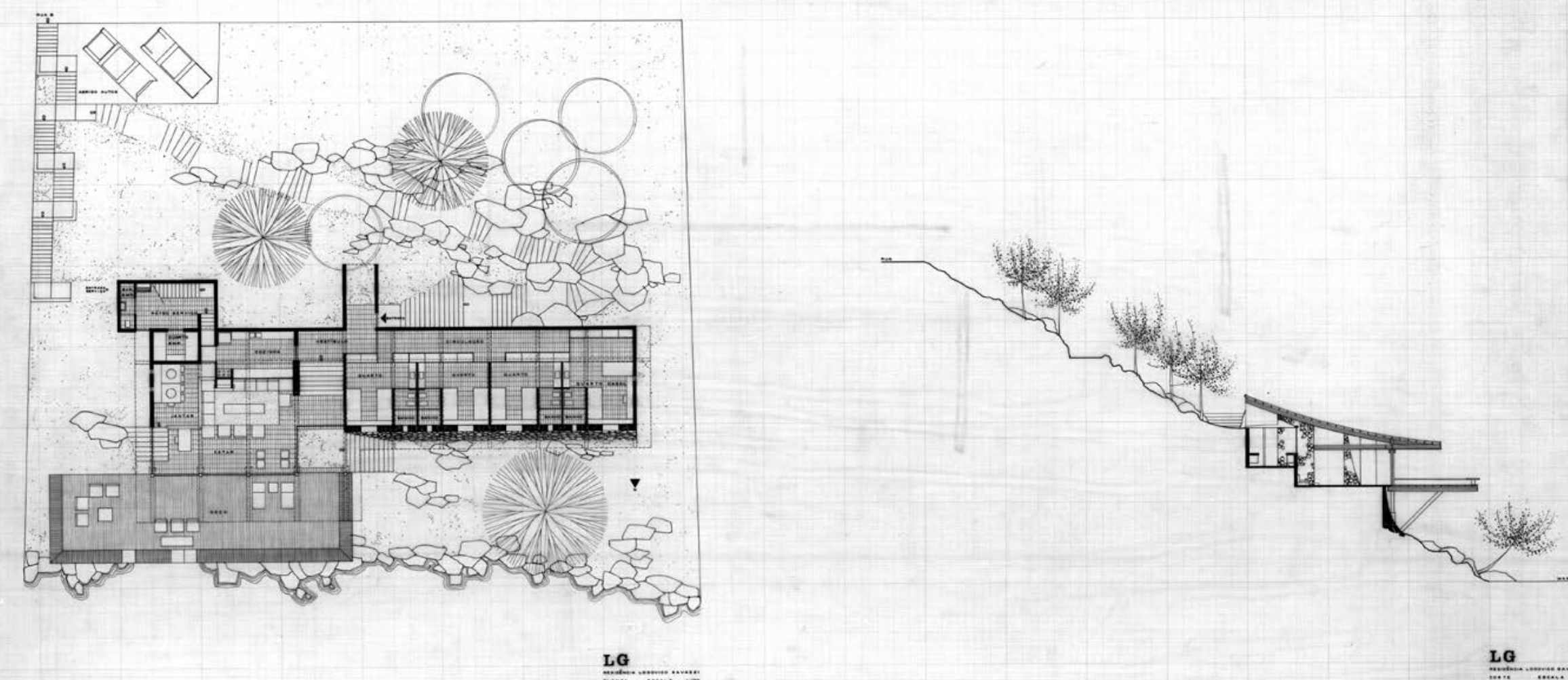

LG 
Neste período, com a saída de Dácio Ottoni e de Ludovico Martino, o escritório Horizonte Arquitetos se dissocia, mas os arquitetos continuam colaborando em projetos específicos em duplas, trios e, em alguns casos, retomando a formação original do grupo - como no projeto para o Concurso Público para a Sede da Secretaria da Agricultura, premiado em segundo lugar -, e também em parcerias com outros arquitetos.

A convite do arquiteto Ennes Silveira Mello, o grupo se associa ao escritório de Sérgio Bernardes para criar uma filial do reconhecido escritório carioca. Inicialmente montado para a realização de um grande projeto em São Bernardo do Campo - o trabalho sequer foi iniciado - possibilitou a criação de uma infraestrutura para desenvolver uma série de residências unifamiliares em São Paulo.

Tal fato é interessante; pouco tempo antes, Sérgio Bernardes estava ocupado com o projeto de sua própria casa em uma encosta entre a Avenida Niemeyer e o mar que, de alguma forma, aproxima-se de alguns pressupostos organicistas nas relações estabelecidas entre a construção e a paisagem, bem como à materialidade construtiva de todo o edifício:

(...) não é simples acaso cronológico o fato de que a casa de Sérgio Bernardes tenha sido concebida apenas alguns meses depois da rápida estadia de Zevi em Brasília, São Paulo e Rio de Janeiro, por ocasião do Congresso Internacional Extraordinário de Críticos de Arte (17 a 25 de setembro de 1959).(..) Sérgio Bernardes, a quem seu estado de espírito tornava particularmente receptivo a toda novidade embora não o predispusesse a tornar-se um discípulo fiel fosse lá do que fosse, não era pessoa que deixasse escapar a ocasião de tentar um passo na direção até então ignorada: ora, nenhum programa prestava-se melhor a esse gênero do que sua própria residência e o local extraordinário, com uma nota romântica, onde pretendia estabelecer-se. ${ }^{26}$

Ao lado, planta e corte da residência Lodovico Gavazzi

Acervo Eduardo de Almeida
Em São Paulo, o encontro destes arquitetos permite a realização de projetos como as residências de Lodovico Gavazzi ou Jayme Souza Dantas, ambas de autoria de Sérgio Bernardes mas com contribuição de Eduardo de Almeida.

${ }^{26}$ BRUAND, Yves. Arquitetura Contemporânea no Brasil. São Paulo, Perspectiva, 2008, p.289 

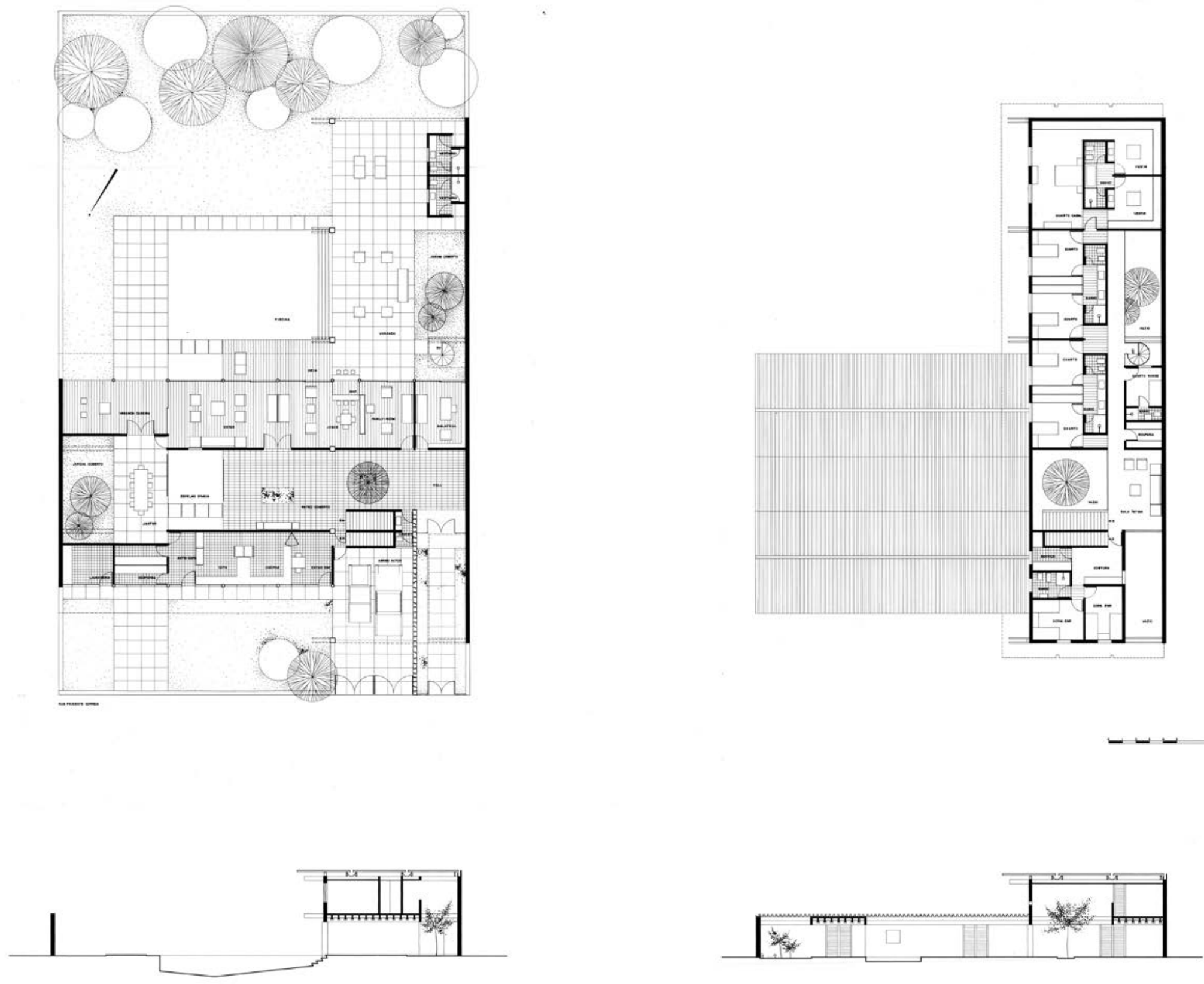

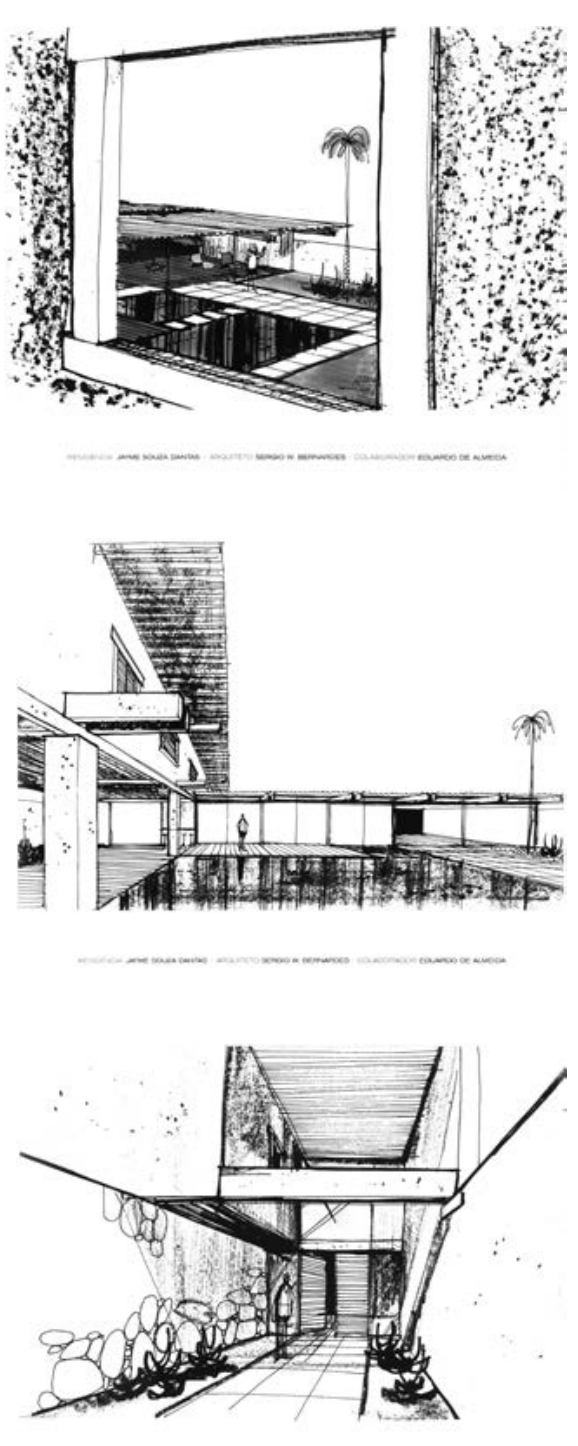

Desenhos e perspectivas da residência Jayme Souza Dantas

Acervo Eduardo de Almeida
Na primeira, assim como na sua própria casa no Rio de Janeiro, Sérgio Bernardes parece tirar partido da topografia íngreme e da relação do edifício com a natureza, conforme destacou Eduardo:

O acesso desta casa está no alto, em uma cota elevada em relação à casa. O acesso se dá por um percurso ao longo da encosta, por entre as pedras existentes no local. É possível ver o mar, a natureza e, de diferentes pontos de vista, a delicada inserção da casa. Me recordo que o Sérgio Bernardes especificou uma cerâmica esmaltada azul para o piso que, de certo modo, visível pela abertura entre o telhado e o arrimo, se confundia com o mar presente ao fundo. $O$ acesso à casa propriamente dito se dava por uma escada, um espaço menor, fechado, e uma vez dentro da casa, tínhamos o contato com a vista, com o mar. ${ }^{27}$

Já na residência Jayme Souza Dantas, sem a presença marcante da natureza, a casa tira partido do jardim de grandes proporções no fundo do lote, e também de pátios ajardinados em seu interior. Um bloco térreo paralelo à rua - destinado à sala e serviços - é complementado pela sobreposição de um volume perpendicular a este que, além de abrigar os dormitórios no segundo pavimento, fornece o abrigo necessário à garagem e ao acesso, e também à varanda que se volta ao jardim. Extremamente simples, a casa retoma algumas experiências do período como a cobertura em telhas tipo canaletas de fibrocimento sobre as vigas aparentes destacadas do volume, exatamente como na casa de Sérgio Bernardes no Rio de Janeiro.

Tais experiências garantem ao grupo enorme aprendizado, não só aproveitando o contato com a construção ao lado, de um arquiteto experiente como Sérgio Bernardes, mas também na própria metodologia para desenvolver e pensar os projetos. Não por acaso, inúmeros projetos de Eduardo de Almeida desenvolvidos posteriormente, foram feitos com o uso do papel milimetrado como base para os desenhos à mão livre, tanto no desenho das plantas e cortes, como no detalhamento dos diversos pormenores.

${ }^{27}$ Depoimento de Eduardo de Almeida ao autor, São Paulo, 2013. 

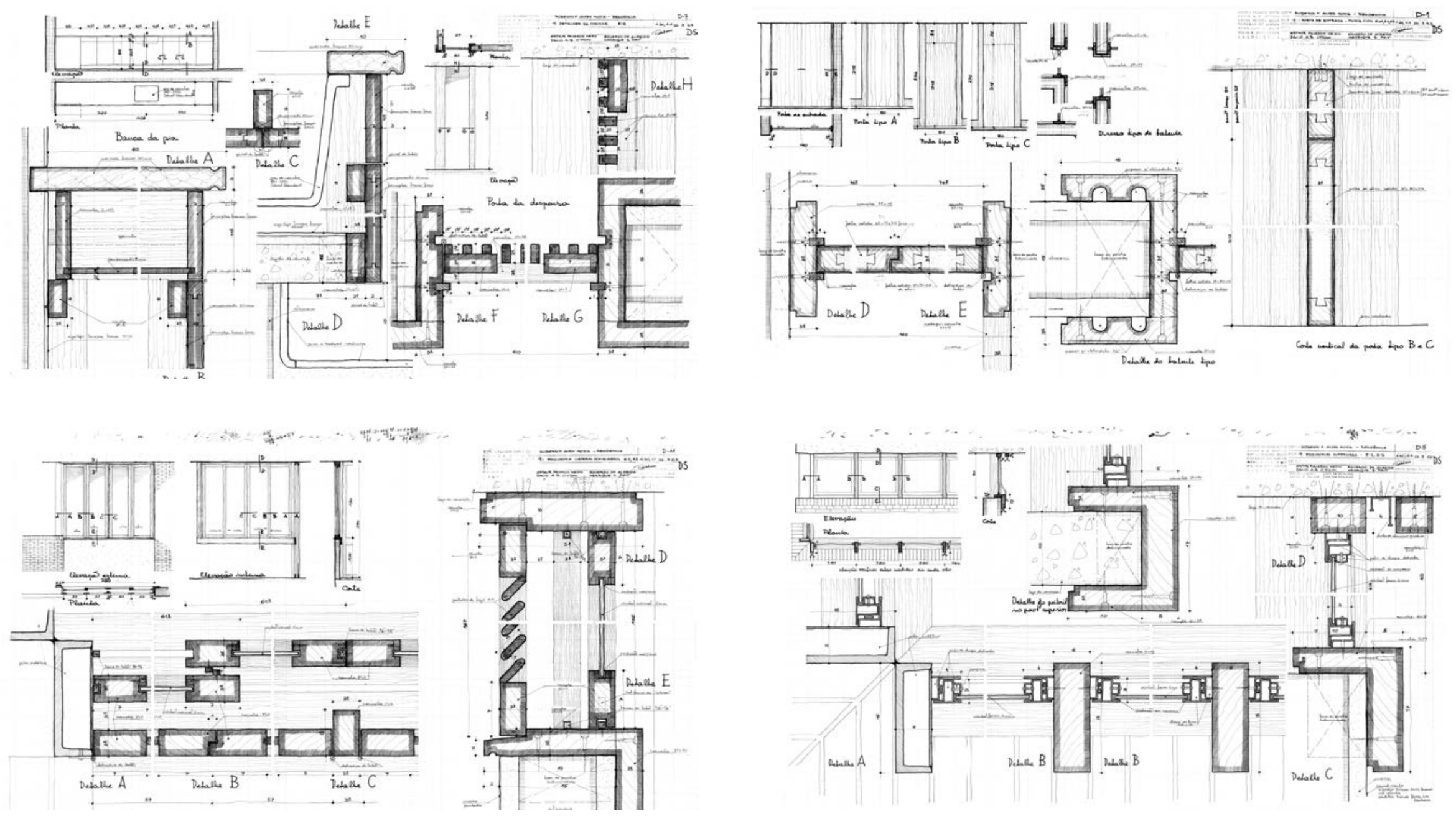
Detalhes feitos com base de papel milimetrado para o projeto da residência Dr. Roberto Alves

Acervo Eduardo de Almeida
Tal ensinamento se reflete, por exemplo, nos primorosos desenhos à mão livre sobre papel milimetrado realizados para o projeto executivo da casa de Roberto Alves Motta em São Paulo.

Extremamente compacta, esta casa de dois pavimentos se constrói pela sobreposição de dois volumes, considerando a geometria quadrada do pavimento dos quartos e a planta linear da sala de estar, distribuída em um volume posicionado perpendicularmente à rua.

A contraposição entre estes dois volumes parece ser enfatizada também pelo contraste entre os largos beirais de concreto e a caixilharia recuada, solução reforçada pelos planos de alvenaria salientes desenhados como armários, soltos em relação ao teto.

0 detalhamento demonstra uma estrutura mista de aço e concreto, semelhante àquela empregada na casa de Flávio Pinho de Almeida, com a caixilharia - neste caso de madeira - associada às colunas de aço, mas também reproduzindo o detalhe utilizado por Sérgio Bernardes nos rodapés e batentes de madeira como caminhos para a fiação elétrica, eliminando o tradicional sistema de conduítes embutidos na alvenaria, que contrariava os princípios construtivos defendidos por estes arquitetos.

Essa solução aparece inclusive em importantes projetos como a casa Define (1975), onde o rigor empregado na construção de uma estrutura de concreto associada a alvenarias independentes de tijolos aparentes não poderia ser ofendido com cortes e posteriores recobrimentos para a passagem de tubulações internas às paredes.

O fato é que a colaboração com Sérgio Bernardes parece enfatizar a tese de que este grupo de arquitetos de São Paulo conseguia agregar de forma natural as diferentes influências, orgânicas ou racionalistas. 

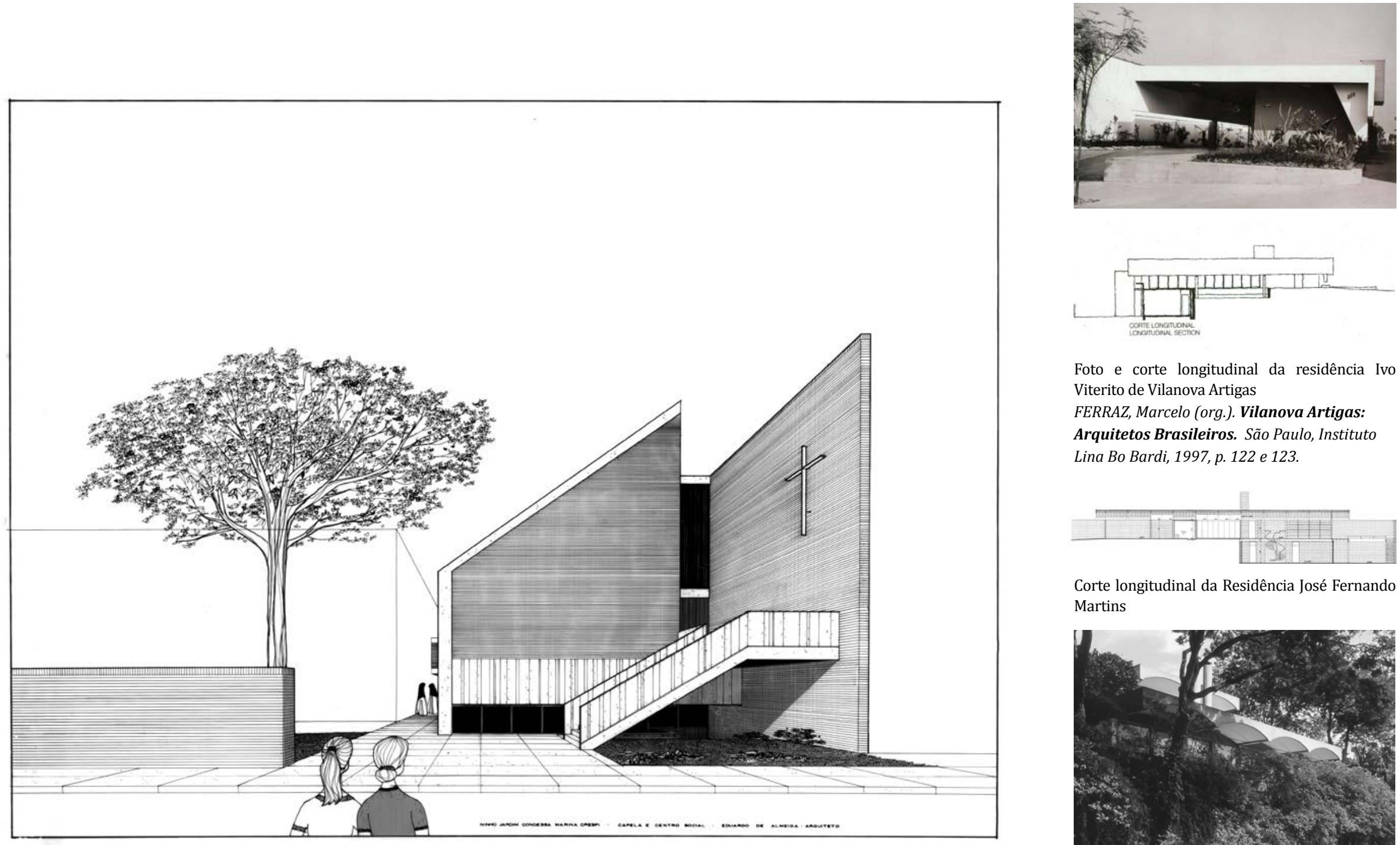

Foto e corte longitudinal da residência Ivo Viterito de Vilanova Artigas

FERRAZ, Marcelo (org.). Vilanova Artigas:

Arquitetos Brasileiros. São Paulo, Instituto Lina Bo Bardi, 1997, p. 122 e 123.

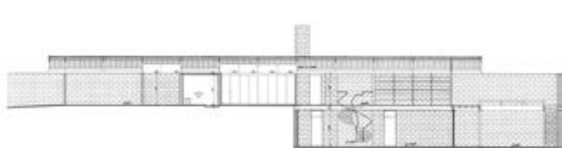

Corte longitudinal da Residência José Fernando Martins

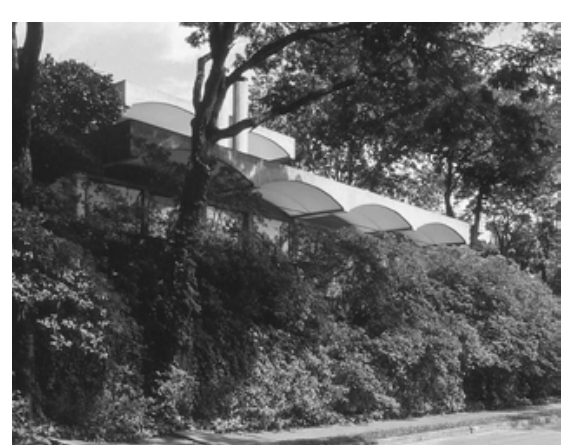

Residência Pedro Tassinari

Perspectiva Capela e Centro Social

Acervo Eduardo de Almeida 


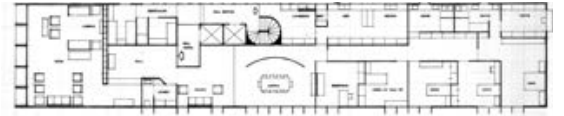

Planta tipo de estudo para um edifício de habitação (1964), para Companhia Construtora de Osasco

Acervo Eduardo de Almeida
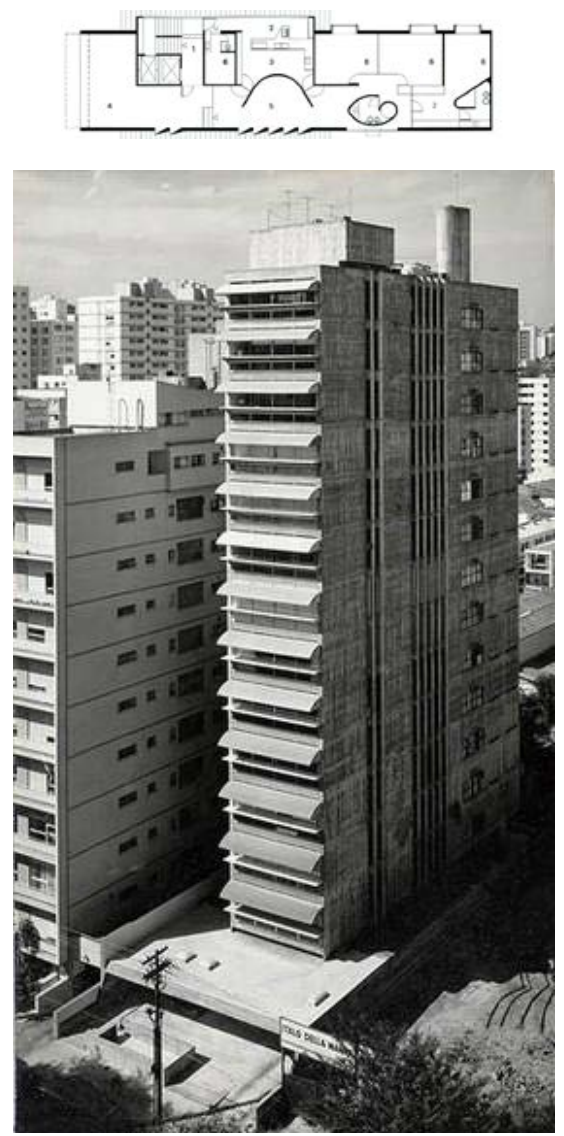

Edifício Guaimbé de Paulo Mendes da Rocha ARTIGAS, Rosa (org.). Paulo Mendes da Rocha, projetos 1957-1999. São Paulo, Cosac Naify, 2006, p. 167 e 168.
Demonstram a diversidade de linguagem e técnica os projetos realizados a partir de 1964 por Eduardo de Almeida para a casa de Paulo Toledo na praia da Lagoinha em Ubatuba, o estudo para um edifício de habitação claramente influenciado pelo Edifício Guaimbé de Paulo Mendes da Rocha, a singela casa Pinto e Silva, as conhecida casas de abóbodas de concreto para Maurício Leite de Moraes e Marcelo de Almeida Toledo (uma delas adquirida posteriomente por Pedro Tassinari), ou o projeto para a Capela e Centro Social para a Fundação Ninho Jardim Condessa Marina Crespi - segundo Eduardo de Almeida, influenciado pela Capela Anglicana projetada por Jacob Ruchti em 1950, bem como a casa para José Fernando Martins, baseada no esquema proposto por Vilanova Artigas para a casa Ivo Viterito.

Tais obras revelam, neste momento, a abertura de Eduardo de Almeida a tantas e variadas influências refletidas em projetos que, apesar da diversidade de linguagem e de suas relações com as diferentes soluções técnicas adotadas, apresentam semelhança em diversas questões.

Os pontos em comum parecem ser obtidos não por alguma questão específica, mas pelos princípios que moldam o projetar de Eduardo de Almeida em cada uma de suas obras: o respeito ao programa estabelecido por cada caso, o desenvolvimento do projeto 'até as últimas consequências' - como ele costuma afirmar - e coerente com as soluções estruturais adotadas, bem como o já habitual respeito aos materiais e à inserção do edifício no terreno.

Esta fase, parece se concluir com o ingresso de Eduardo de Almeida como professor do curso de desenho industrial na FAU USP em 1967, fato que permite, ainda que empiricamente, desenvolver sua didática a partir de suas experiências dos últimos anos.

O fato de ter realizado o curso de desenho industrial na Itália, além do desenvolvimento de projetos cada vez mais alinhados à lógica e aos desejos da produção industrial na construção 
civil - ainda que incipiente no Brasil - parecem favorecer sua atuação como professor, embora Eduardo sempre admita que seu envolvimento inicial com a escola estivesse primeiramente relacionado ao sustento de sua família, já que a regularidade do salário de professor poderia equilibrar a irregularidade dos vencimentos do escritório de arquitetura.

São deste período, os cursos baseados nas experiências da Contracultura Americana e nos estudos relacionados à obra de Buckminster Fuller, que culminam na experiência de construir geodésicas de madeira ou alumínio no Salão Caramelo da FAU USP.

Também nesta época, em conjunto com João Carlos Cauduro e outros colegas, o curso se valia de experiências sensoriais a partir da mistura de músicas e imagens ao som de $A$ day in a Life, dos Beatles. Era o tempo de '2001 - Uma odisséia no espaço' de Stanley Kubrick e também a chegada do homem à Lua, e estes acontecimentos parecem se refletir nos projetos do período, desde pequenas obras como a reforma para a loja de sapatos de Altemio Spinelli, até concursos de arquitetura para o Pavilhão do Brasil em Osaka (1969) e, posteriormente, para o Centro Georges Pompidou em Paris (1971).

No Brasil, a situação política se complicava com o endurecimento do regime militar em 1968 e, na FAU USP, Vilanova Artigas, Jon Matrejain e Paulo Mendes da Rocha são cassados pelo AI-5, impedidos de exercer suas atividades na Universidade no início de 1969.

A difícil situação do país e o tradicional envolvimento politico dos alunos da FAU USP cria, naturalmente, um ambiente desfavorável à prática da arquitetura por meio dos projetos. A contestação dominante se reflete de modo curioso na disciplina de Eduardo de Almeida.

De acordo com seu depoimento, a proposta de se fazer o projeto de uma série de
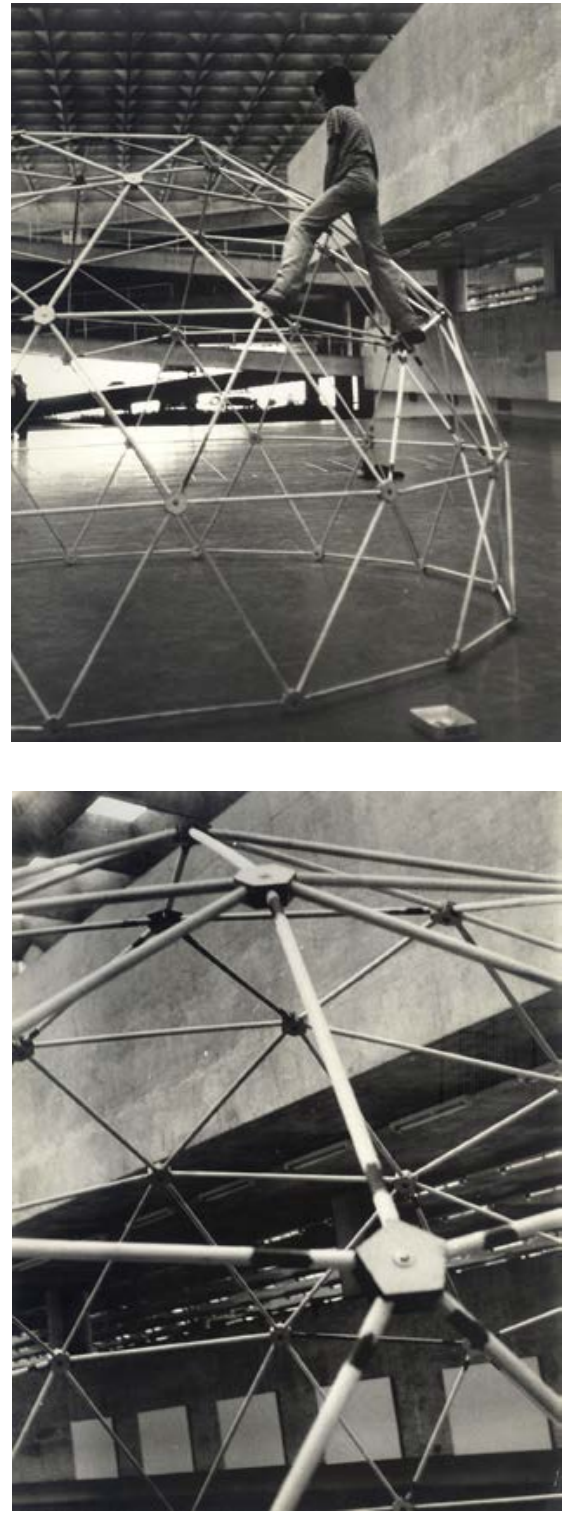

Foto das aulas de construção de geodésicas no Salão Caramelo da FAUUSP. Acervo Eduardo de Almeida 

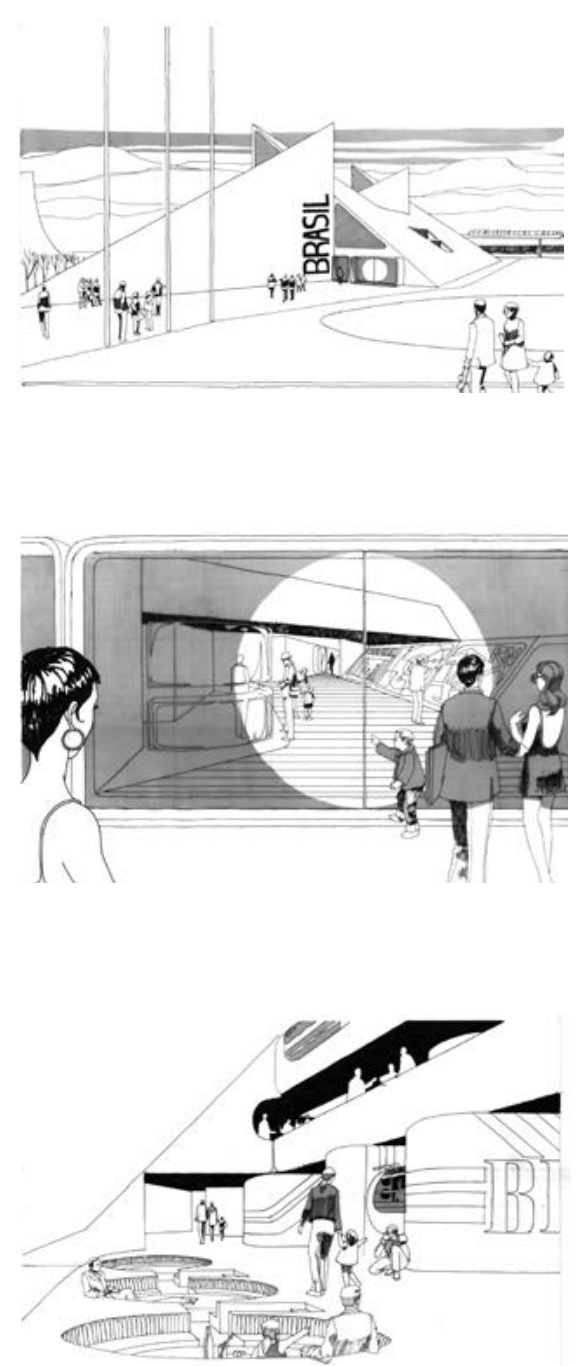

Perspectivas para o concurso Pavilhão do Brasil em Osaka

Acervo Eduardo de Almeida

Ao lado, foto de Eduardo de Almeida na FAUUSP Foto: Roberto Strauss eletrodomésticos - amparada pela leitura de textos de filósofos como Jean Baudrillard - é respondida pelos alunos com a organização de uma 'Feira de Inutilidades Domésticas', em clara referência à UD - Feira de Utilidades Domésticas organizada em São Paulo a partir de 1960.

Após este evento, Eduardo de Almeida decide se transferir para a sequência de projeto, mas sempre recorda deste momento com entusiasmo, pela atitude dos estudantes...

Um dos trabalhos apresentados, por exemplo, foi a reprodução dos ambientes de uma casa burguesa - bem como de seus costumes - utilizando-se das mesas dos estúdios. Carregada de irreverência e ironia, era a crítica dos alunos face às dificuldades vividas pelo país naquele momento.

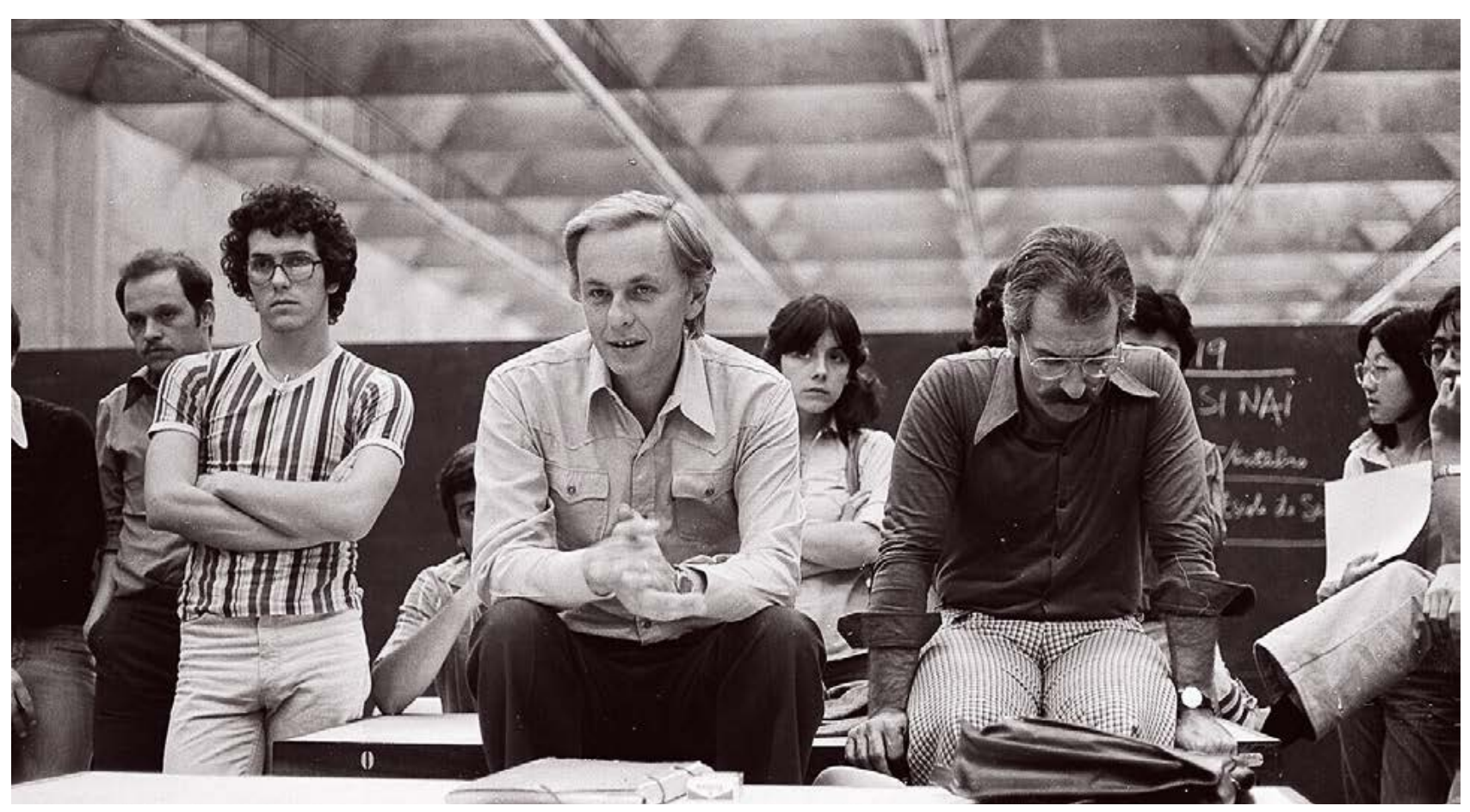



Indústria, volumetria e programa 


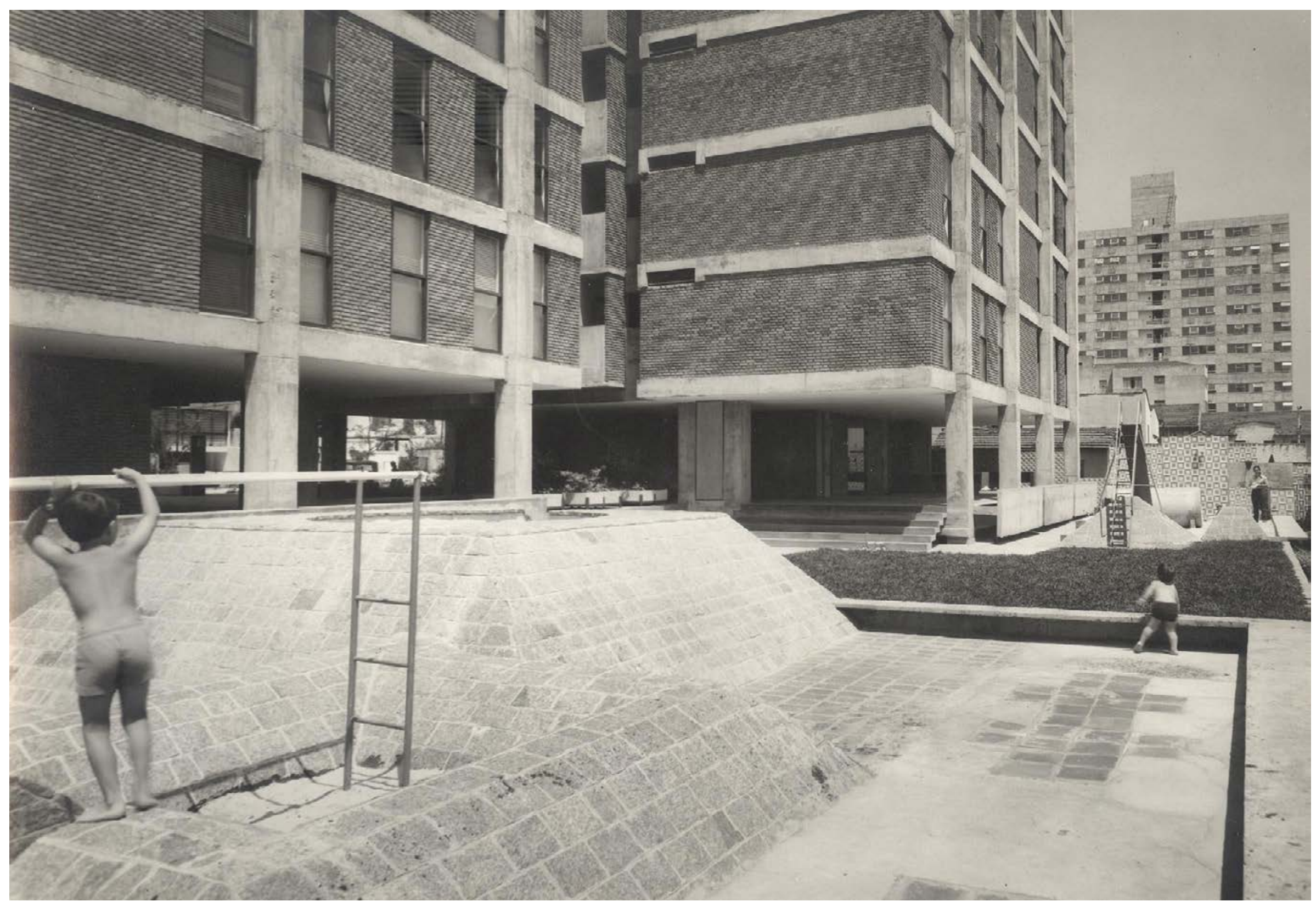


Podemos dizer que, na obra de Eduardo de Almeida, conforme demonstrado anteriormente, os ideais da racionalização - presentes desde seus primeiros projetos - intensificam-se após seu retorno da Itália, consolidando-se com a atuação como professor de desenho industrial na FAU USP.

Como sabemos, o processo de industrialização crescente, ao contrário das primeiras reações ao movimento moderno, permitiu o desenvolvimento de uma nova arquitetura, adequada aos novos tempos, sem necessariamente se desvincular de pressupostos ligados ao valor artístico intrínseco à disciplina, como defende Giulio Carlo Argan:

o fato de os procedimentos operativos estarem dia a dia se transformando e assumindo o caráter de procedimentos industriais e de se traçarem programas para a industrialização total da produção edilícia não justifica, em princípio, nenhum temor acerca da possibilidade de se alcançarem, através desses novos processos, resultados de valor artístico (...). O caráter mecânico do procedimento não é, por si só, um impedimento ou um limite da qualidade artística, do mesmo modo como o mecanismo de algumas fases do processo artesanal não impediu que muitos objetos produzidos artesanalmente tivessem um valor de arte. ${ }^{28}$

Ao lado, Edifício Gemini

Acervo Eduardo de Almeida
A definição de Argan se ampara também na própria história da arquitetura, já que o emprego de elementos pré-fabricados, embora não realizados por processos industriais, aconteceu incontáveis vezes, por exemplo na Idade Média e no Renascimento, nas obras que utilizavam colunas, capitéis e frisos provenientes de edifícios antigos.

Exemplos que se complementam ao emprego, por arquitetos e construtores, de colunas e capitéis produzidos em oficinas especializadas na produção destes artefatos, mas também no uso de simples elementos como o tijolo, fabricado em olarias e empregado como material construtivo principal em arquitetura. Argan avalia com propriedade o valor do tijolo: "existe uma diferença estrutural entre as alvenarias dos vários períodos históricos (...), e a diferença não

${ }^{28}$ ARGAN, Giulio Carlo. Módulo-medida e Módulo-objeto in Projeto e Destino. São Paulo, Ática, 2001, p.93 
depende de um grau diverso de progresso da técnica de alvenaria, mas da diversa concepção da forma arquitetônica." 29

Ou seja, para Argan a atuação do arquiteto por meio de seus projetos, independentemente do grau de desenvolvimento da fabricação de determinado elemento ou sistema construtivo, ampara-se sobretudo na concepção arquitetônica, no modo como tais elementos são integrados ao projeto e, naturalmente, em sua relação com o contexto histórico.

Ainda segundo Argan, tanto a utilização de sistemas construtivos quanto seus desdobramentos nos 'tipos' dos edifícios configuram elementos transmitidos de geração à geração,

conhecimento acumulado que pertence e define a própria idéia de história da arquitetura.

Sabemos que em determinados períodos, as formas arquitetônicas se pautavam por sua codificação em 'ordens' que não pretendiam limitar a inventividade do artista, ao contrário, enfatizavam que a obra criativa advinha essencialmente da composição ou combinação de elementos decorrente de um método em busca da definição de um sistema de relações entre as partes.

Esta constatação nos reporta à produção arquitetônica brasileira no final dos anos 1960, já que ela parte do impulso dos pressupostos defendidos pela arquitetura moderna mas, em seu enfrentamento à realidade brasileira e seu crescente - mas ainda incipiente - processo de industrialização, o trabalho dos arquitetos pauta-se pela busca de alternativas para uma nova arquitetura voltada, por um lado, às tecnologias disponíveis, e por outro, às possibilidade técnicas desejadas.

${ }^{29}$ ARGAN, Giulio Carlo. Módulo-medida e Módulo-objeto in Projeto e Destino. São Paulo, Ática, 2001, p.100
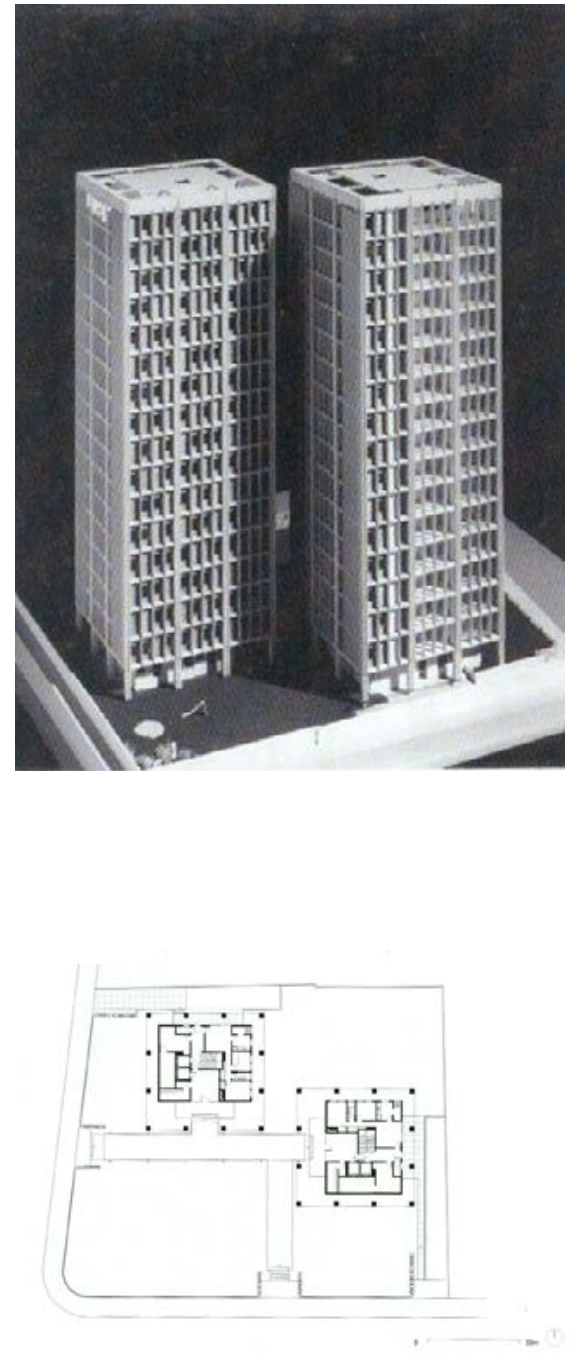

Implantação dos Edifícios Santa Cândida e Santa Francisca

FERRONI, Eduardo. A dimensão urbana do edifício in Salvador Candia. São Paulo, Editora da Cidade, 2013, p. 94 e 96 

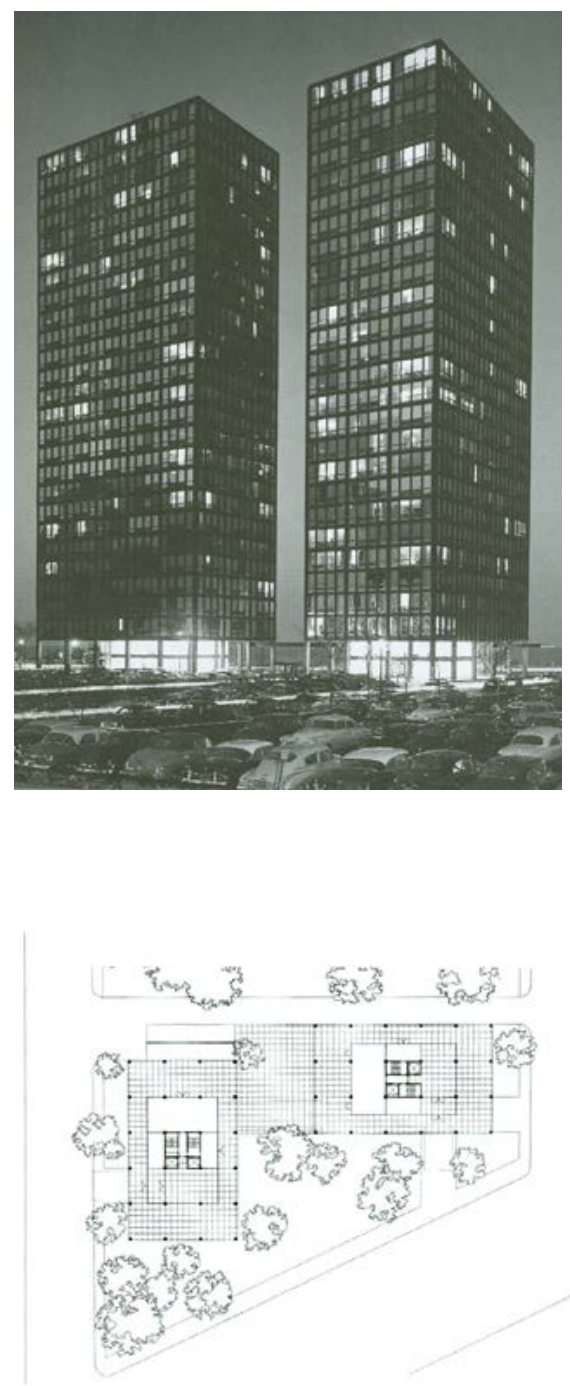

Plantas tipo do Lake Shore Drive

CARTER, Peter. Mies van der Rohe at work.

London, Phaidon, 1999, p. 38 e 52
Neste período, a construtora Formaespaço convidou arquitetos como Abrahão Sanovicz, Eduardo de Almeida e Paulo Mendes da Rocha para projetar edifícios de habitação coletiva para a classe média em São Paulo, de acordo "com as possibilidades que o Banco Nacional da Habitação - BNH colocava para o mercado imobiliário". Ainda segundo Helena Ayoub Silva, estes projetos deveriam considerar "a previsão de que pudessem ser repetidos em diferentes terrenos; deveriam ser procurados métodos construtivos racionalizados e componentes industrializados de modo a tornar a construção mais econômica".30

Dentro deste contexto, Eduardo de Almeida projeta o Edifício Gemini (1969), possivelmente influenciado por Salvador Candia e seus edifícios Santa Cândida e Santa Francisca (1963), desenhados de acordo com os exemplos de Mies van der Rohe, mas considerando sua difícil transposição para a realidade da construção civil brasileira.

Além da implantação de dois volumes deslocados, assim como no Lake Shore Drive de Mies, a solução proposta por Candia se vale de edifícios de planta quadrada com núcleo de circulação central. A modulação de sua estrutura se reflete no desenho da fachada que, subdividida em módulos idênticos, revela a intenção de se empregar painéis e caixilhos pré-fabricados como elementos de composição, muito embora tenham sido efetivamente construídos com técnicas tradicionais de construção, como afirma Eduardo Ferroni:

Candia experimenta, em certos projetos, o partido das torres com núcleo central de circulação, com implantações análogas àquela consagrada por Mies(...). Entretanto, diante da impossibilidade de adoção dos procedimentos construtivos industrializados que caracterizam aquela arquitetura, a obra de Candia se problematiza e se diversifica: enquanto a linguagem construtiva na obra de Mies está diretamente associada ao processo de fabricação e montagem dos elementos que compõem o edifício, os projetos de Candia se confrontam com uma indústria incipiente da construção. ${ }^{31}$

${ }^{30}$ SILVA, Helena Aparecida Ayoub. Abrahão Sanovicz: o projeto como pesquisa. Volume 1. São Paulo, FAU USP, 2004, p. 176 ${ }^{31}$ FERRONI, Eduardo. A dimensão urbana do edifício in Salvador Candia. São Paulo, Editora da Cidade, 2013, p.19 


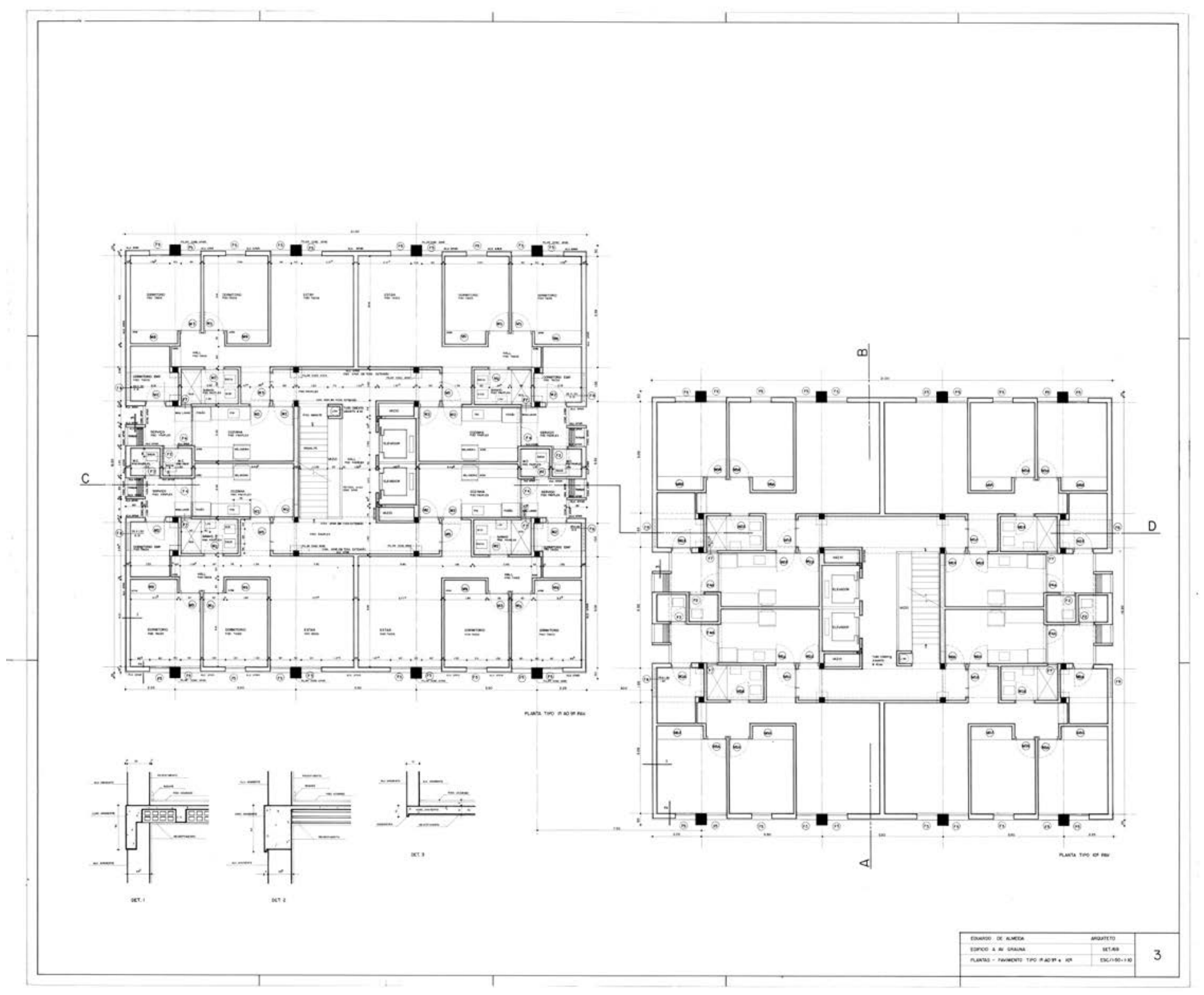



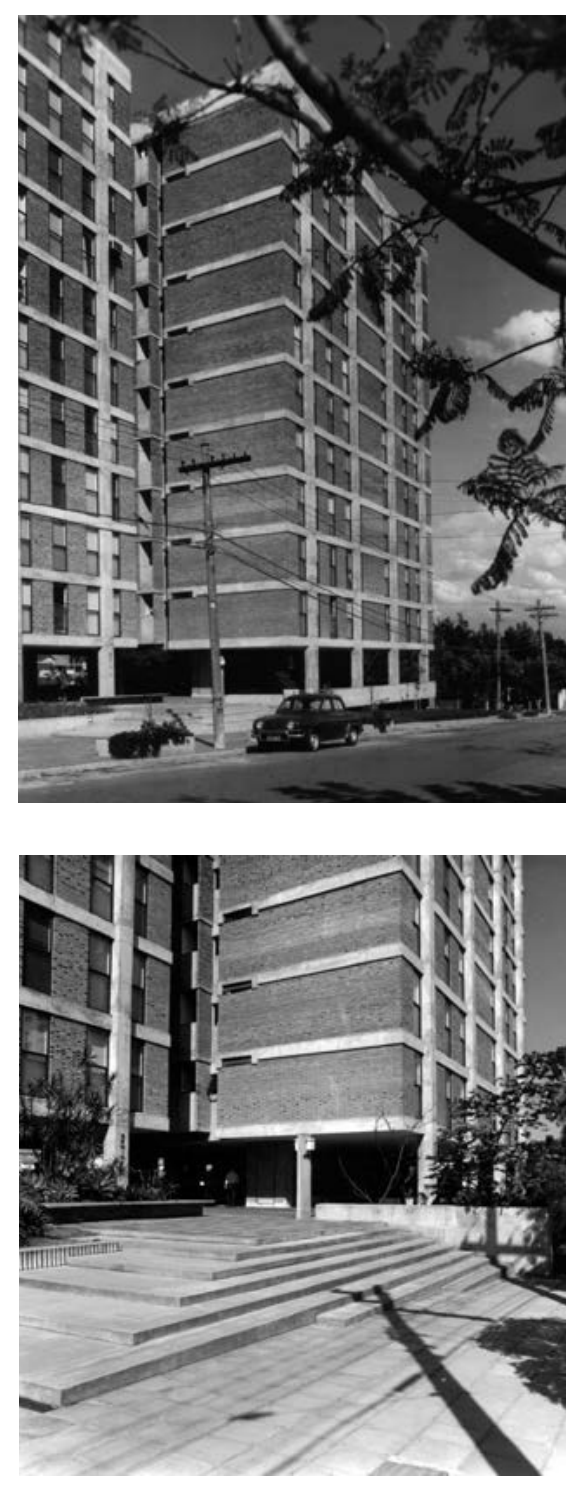

Fotos e plantas tipo do projeto executivo do Edifício Gemini

Acervo Eduardo de Almeida
Mais do que a realização efetiva de projetos baseados em processos de construção industrializados, a obra dos arquitetos deste período revelam a intenção de atingir uma imagem ligada à industrialização, como se a adoção desta linguagem pudesse impulsionar tais processos. Talvez seja esse o motivo do compromisso desses arquitetos de realizar propostas efetivas a partir da coordenação entre os diversos elementos - programa, estrutura, vedos e componentes - em função de um sistema de relações.

Ao mesmo tempo, diferente de uma visão meramente técnica, a mudança conceitual dos pressupostos se ampara em um 'impulso moral', como ressalta mais uma vez Argan, ao afirmar que tal arquitetura visa não 'dissimular o praticismo e o utilitarismo da sociedade moderna'; de fato, busca reexaminar os conceitos de forma e espaço em função de uma reforma social como um todo, acompanhando a atualização dos últimos progressos da ciência e da tecnologia:

O tema fundamental (e basta recordar, no começo deste século, a polêmica de um Loos, de um Van de Velde) é o apelo à pureza das formas, à sinceridade e clareza positiva dos procedimentos técnicos: portanto, a luta pelo objeto autêntico contra o falso, pela operação lúcida e ordenada contra as astúcias e as hipocrisias de uma indústria mascarada de artesanato. Uma janela que seja uma janela e não bífore, florão ou seteira; uma porta que seja uma porta e não um falso portal ou uma porteira; uma casa que seja finalmente uma casa e não um castelo feudal ou um palácio florentino em miniatura e, é claro, de papelão. ${ }^{32}$

De fato, na realização do edifício Gemini para a construtora Formaespaço, a solução construtiva adotada é a alvenaria de tijolos aparentes que, intercalada por pilares de concreto armado moldado in loco e caixilhos piso-teto de ferro, foi pensada como planos que, ainda que sejam vistos como elementos independentes, não pretendem simular sua execução como painéis préfabricados, ao contrário, assumem a materialidade do tijolo de barro - "irregular na forma, cor, textura, pobre na qualidade de fabricação e instável no comportamento físico" - em contraste com a volumetria pura das torres, conforme observa Maria Isabel Imbronito. ${ }^{33}$

${ }^{32}$ ARGAN, Giulio Carlo. Módulo-medida e Módulo-objeto in Projeto e Destino. São Paulo, Ática, 2001, p.100

${ }_{33}$ Almeida, op. cit., p.19. in IMBRONITO, Maria Isabel. Dissertação de mestrado: Três edifícios de habitação para a Formaespaço: Modulares, Gemini e Protótipo. São Paulo, FAU USP, 2003, p. 36 

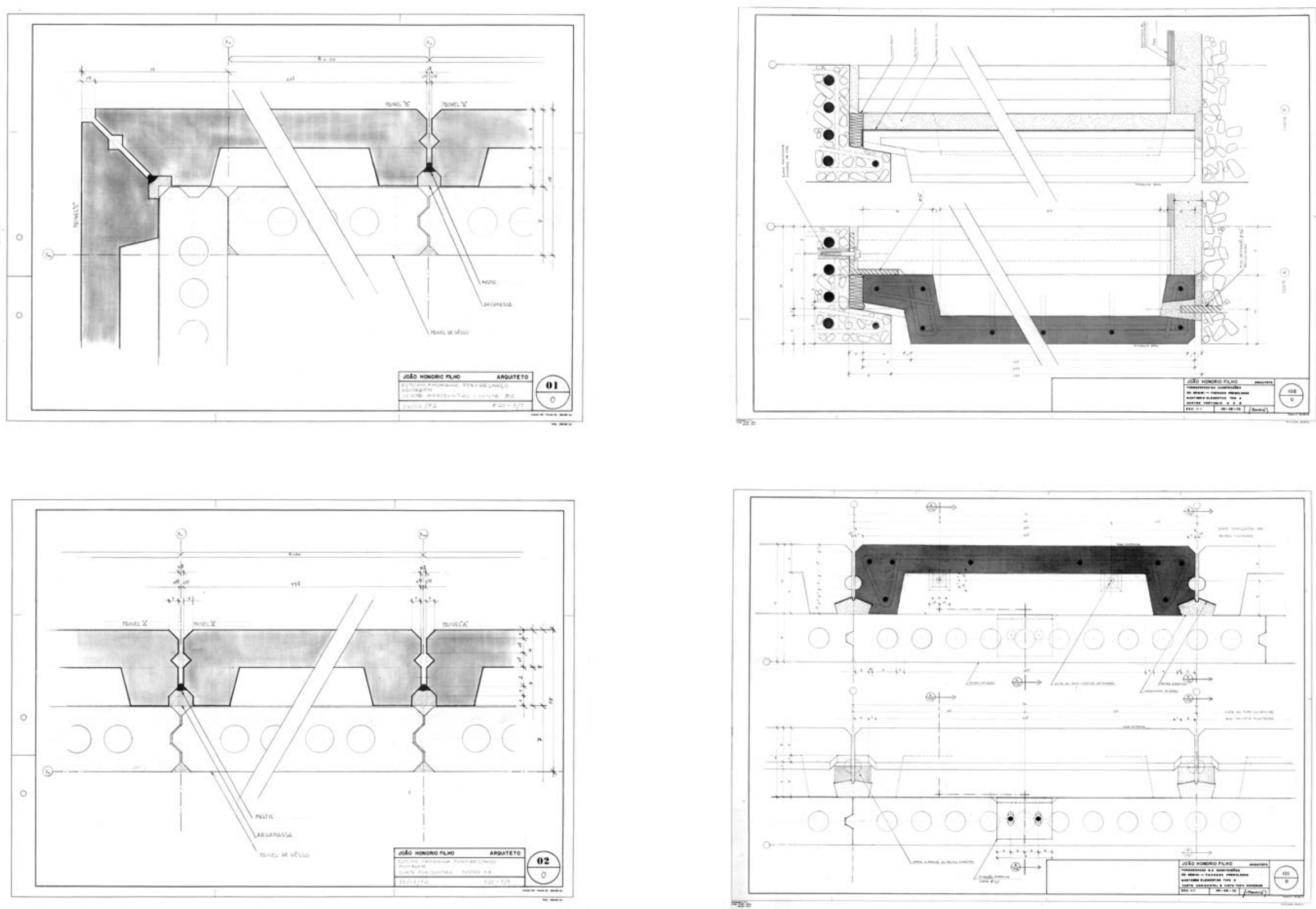


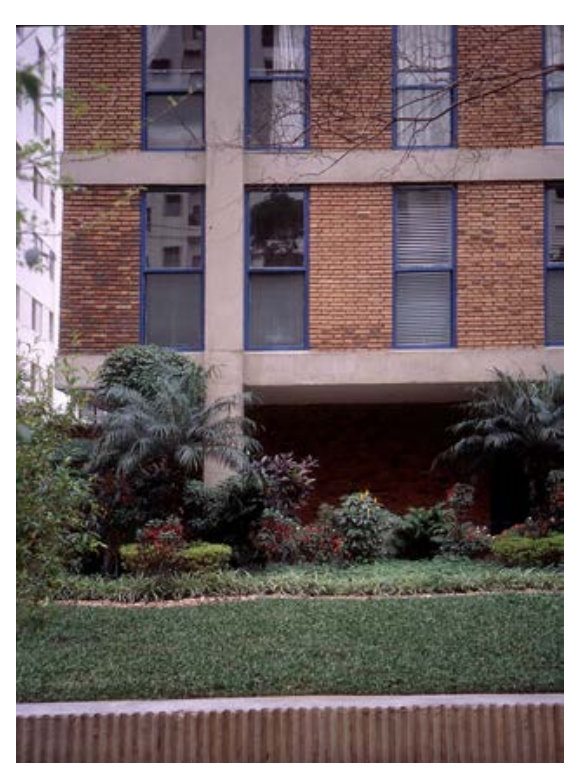

Foto fachada do Edifício Gemini Acervo Eduardo de Almeida

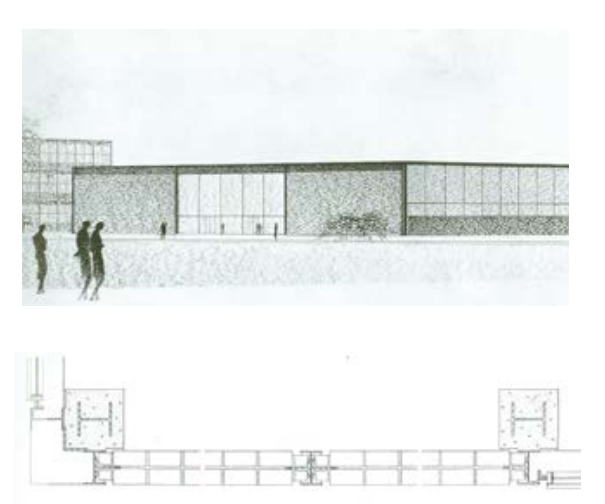

Illions Institute of Tecnology

CARTER, Peter. Mies van der Rohe at work London, Phaidon, 1999, p. 73 e 77.

Detalhes de painel pré-fabricado para o Edifício Gemini

Acervo Eduardo de Almeida
Para um arquiteto formado por princípios organicistas como Eduardo de Almeida, nada mais natural do que adotar o tijolo como tijolo, sem revestimentos, tirando partido da materialidade como elemento importante nas fachadas do edifício pois, ao tentar simular o desenho de um painel pré-fabricado, talvez estivesse negando um dos aprendizados de Wright: o respeito à natureza dos materiais.

A solução parece mesmo ter a influência de Mies van der Rohe, já que o arquiteto utiliza uma persiana interna embutida nos montantes das janelas, de modo a ressaltar a uniformidade dos rasgos verticais na fachada, independentemente de cada unidade de moradia ou do uso dos ambientes como sala ou dormitórios, assim como as cortinas aplicadas de forma indistinta por toda a caixilharia de Lake Shore Drive.

Tal influência também pode ser reforçada por alguns dos edifícios projetados por Mies para o conjunto do IIT - Illinois Institute of Technology - que apresentavam planos de tijolos inseridos em uma grelha estrutural secundária em estrutura metálica.

Não que Eduardo de Almeida fosse contrário à ideia da industrialização da construção e de seus pressupostos - economia, rapidez e conceito de 'obra-limpa' em sua execução -, ao contrário, quando solicitado a ele novos estudos para a implantação do Gemini em outros terrenos, foi realizada uma versão com o emprego de painéis pré-fabricados.

Esse projeto, realizado a partir dos estudos de Eduardo de Almeida, foi amplamente detalhado, inclusive seus processos de fabricação, mas não chegou a ser implantado devido a custo e viabilidade, como relata Maria Isabel Imbronito: 


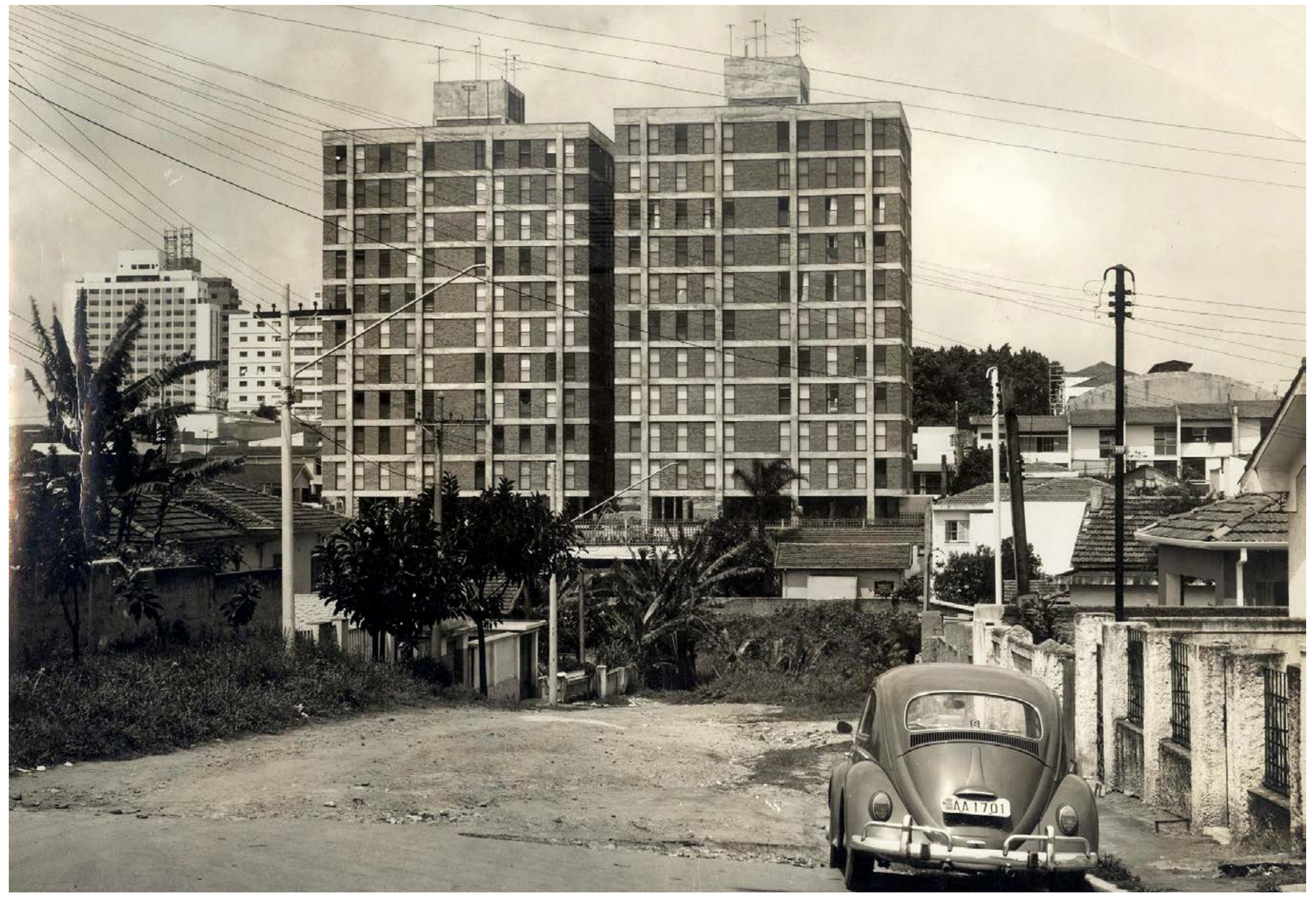




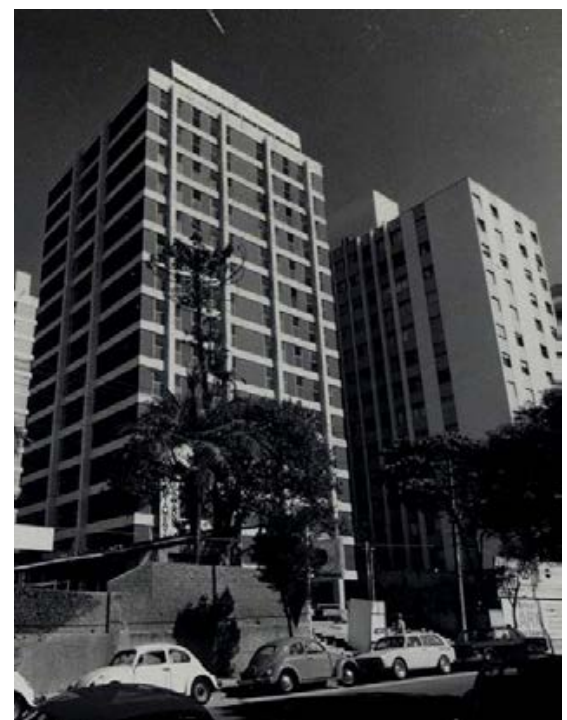

Edifício Lark

Acervo Eduardo de Almeida

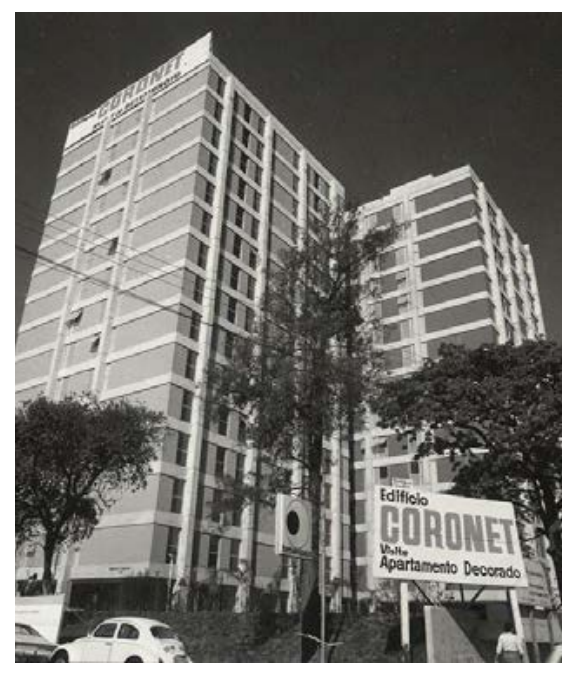

Edifício Coronet e Edifício Gemini (à esquerda) Acervo Eduardo de Almeida
Como alternativa ao tijolo de barro, foi inicialmente estudado um fechamento externo do edifício com painéis pré-fabricados de concreto com agregado leve e gesso na face interna. Este detalhe foi desenvolvido pelo arquiteto João Honório de Mello Filho e não se viabilizou. Segundo o arquiteto, estrutura de concreto moldada in loco não comporta o rigor necessário para a adoção de elementos pré-fabricados. Além disso, a instabilidade da economia brasileira desestimulou o investimento na pré-fabricação, que exige uma continuidade do processo de produção uma vez que os custos iniciais são altos. ${ }^{34}$

Após esta tentativa, segundo Eduardo de Almeida, a solução finalmente adotada para os edifícios Lark e Coronet foi a substituição da alvenaria de tijolos por blocos de concreto aparente que, fabricados especialmente para estas obras, apresentavam um pequeno chanfro de 45 graus em suas extremidades, gerando um friso vertical devido ao assentamento em junta à prumo destes blocos.

Esta solução apresentava melhor relação custo-benefício em relação ao uso do tijolo, sobretudo por sua rapidez de execução e, ao final, apresentava uma textura de linhas verticais na fachada que, pelo menos do ponto de vista da linguagem, aproximava-a da solução do prémoldado prevista inicialmente.

De modo geral, a solução da planta para os edifícios Lark e Coronet foi a mesma empregada no Gemini, com modificações na cozinha e sanitários para melhor otimização das prumadas hidráulicas, assim como o desenho da estrutura - os pilares duplos posicionados junto aos sanitários foram substituídos por dois pilares junto à área de serviços, aparentes na fachada.

Mais altos que o Gemini, os dois edifícios diferiam do primeiro em suas implantações no desenho de térreo, sobretudo o Lark que, em função da geometria e da topografia do lote, foi implantado em aclive - estacionamento e pilotis - e sem o deslocamento de volumes que caracterizava o primeiro.

${ }^{34}$ IMBRONITO, Maria Isabel. Dissertação de mestrado: Três edifícios de habitação para a Formaespaço: Modulares, Gemini e Protótipo. São Paulo, FAU USP, 2003, p. 37 

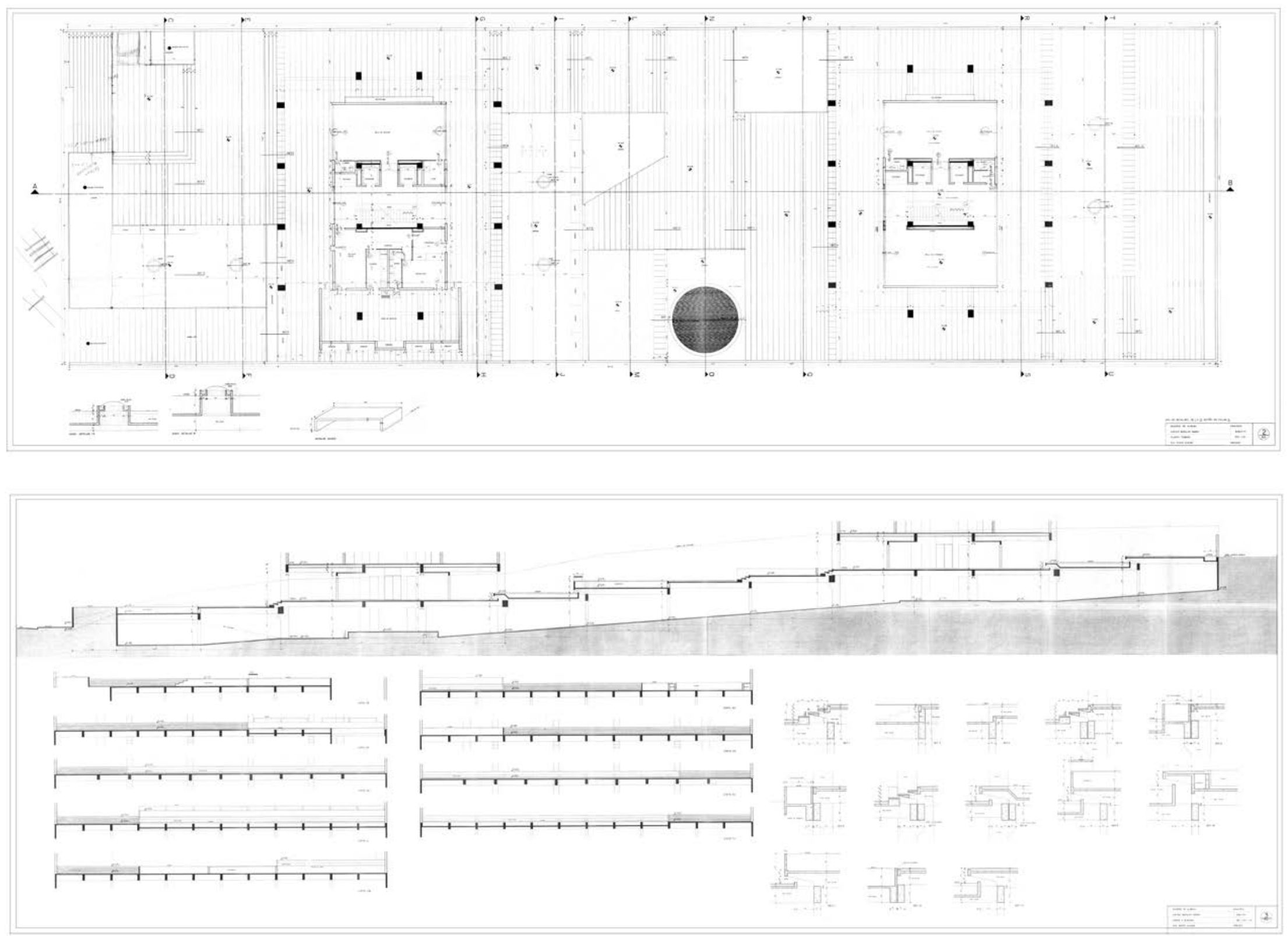

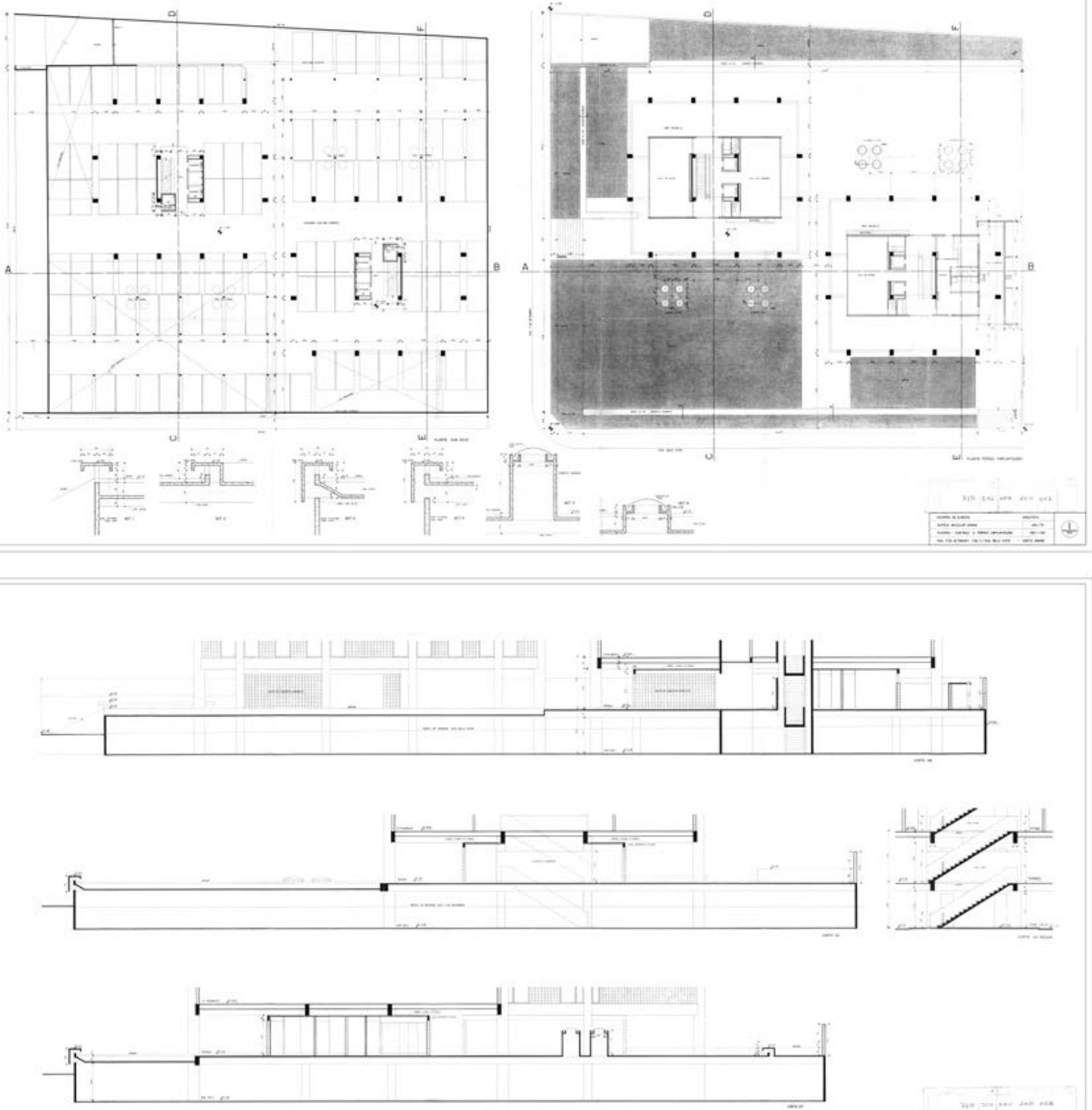


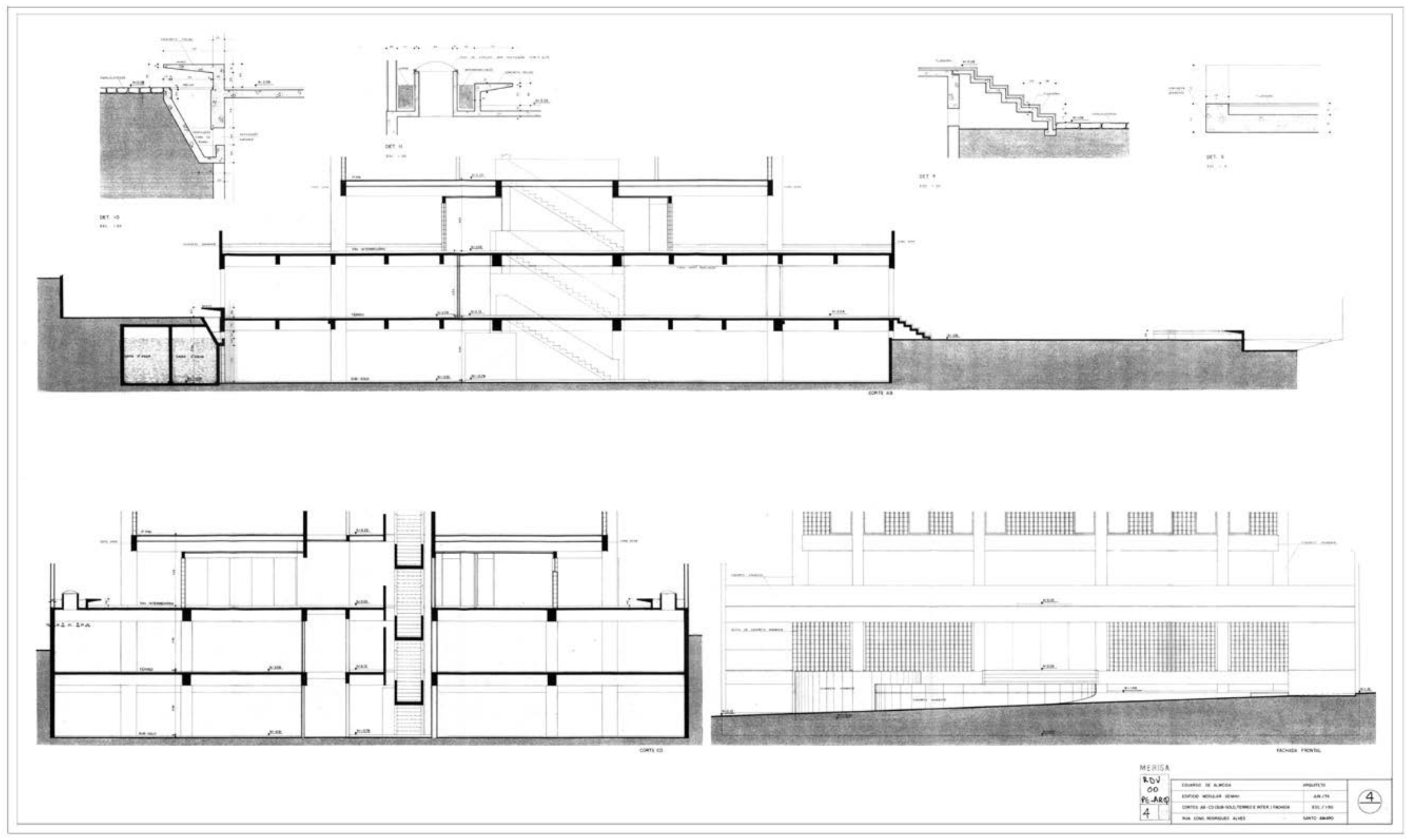



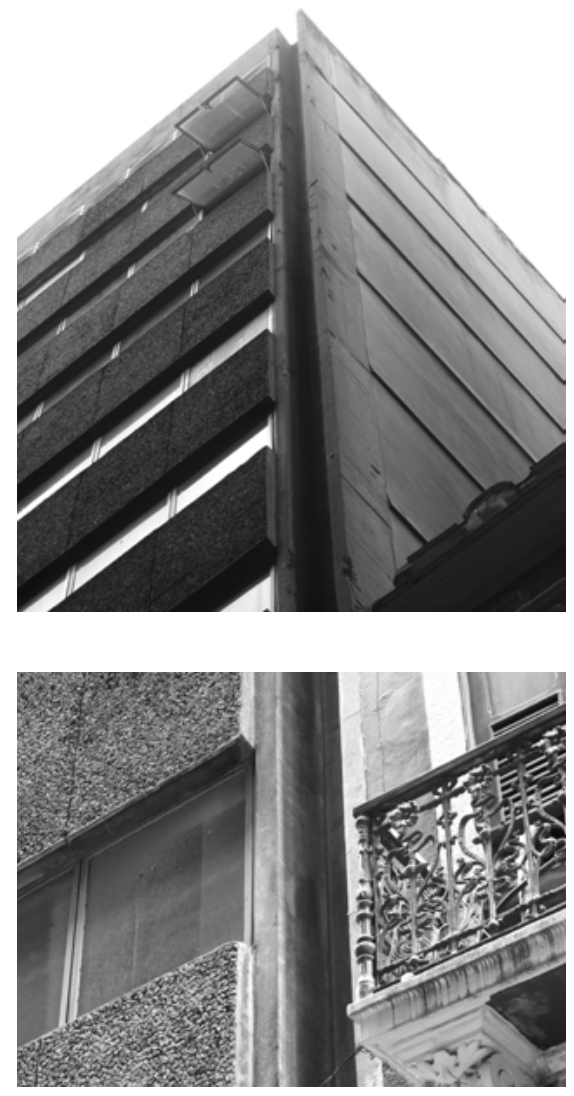

Banco Comercial do Paraná

Ao lado, cortes do Edifício Rodrigues Alves Acervo Eduardo de Almeida
Ainda foi realizada uma quarta versão deste projeto - com uma única torre - a ser inserido na rua Conselheiro Rodrigues Alves, além de um estudo para um conjunto composto por duas torres 'Gemini', intercaladas por dois edifícios 'Modulares' de Abrahão Sanovicz em terreno localizado na rua Vieira de Moraes, mas nenhum dos dois projetos chegou a ser construído, apesar de demonstrarem versatilidade de solução.

Interessante notar que apesar das investigações relacionadas ao emprego de elementos pré-fabricados não terem se viabilizado integralmente nestes projetos da construtora Formaespaço, nesse mesmo período Eduardo de Almeida realiza a construção de dois projetos que se utilizam destes mesmos conceitos.

Mesmo que em pequena escala, o projeto para o Banco Comercial do Paraná, na rua do Ouvidor, área central do Rio de Janeiro, ocupa um lote estreito e profundo e se utiliza de uma estrutura periférica para a criação de uma área de trabalho flexível nos pavimentos superiores e uma agência bancária junto ao térreo envidraçado.

Se, por um lado, os pilares periféricos e a estrutura da laje nervurada decorrente adotaram concreto armado moldado in loco como solução estrutural, a fachada do edifício foi pensada por meio de painéis pré-moldados, associados a caixilhos industrializados fornecidos pela Fichet ${ }^{35}$.

Assim como no projeto para o edifício Gemini, as persianas ficavam encaixadas nas básculas da caixilharia, definindo uma janela 'em fita' em cada pavimento, alternada por faixas compostas por painéis de pequenas dimensões de concreto armado pré-fabricado.

${ }^{35}$ Fichet \& Scharts-Haumont, empresa sediada no ABC paulista que forneceu caixilhos a diversas obras como a FAU USP de Vilanova Artigas, o edifício Paulicéia de Giancarlo Gasperini e Jacques Pilon, além do Edifício Nestlé (1965) de autoria de Alberto Botti e Marc Rubin, implantado na rua da Consolação e, segundo Eduardo de Almeida, referência para os caixilhos adotados no edifício da rua do Ouvidor. 

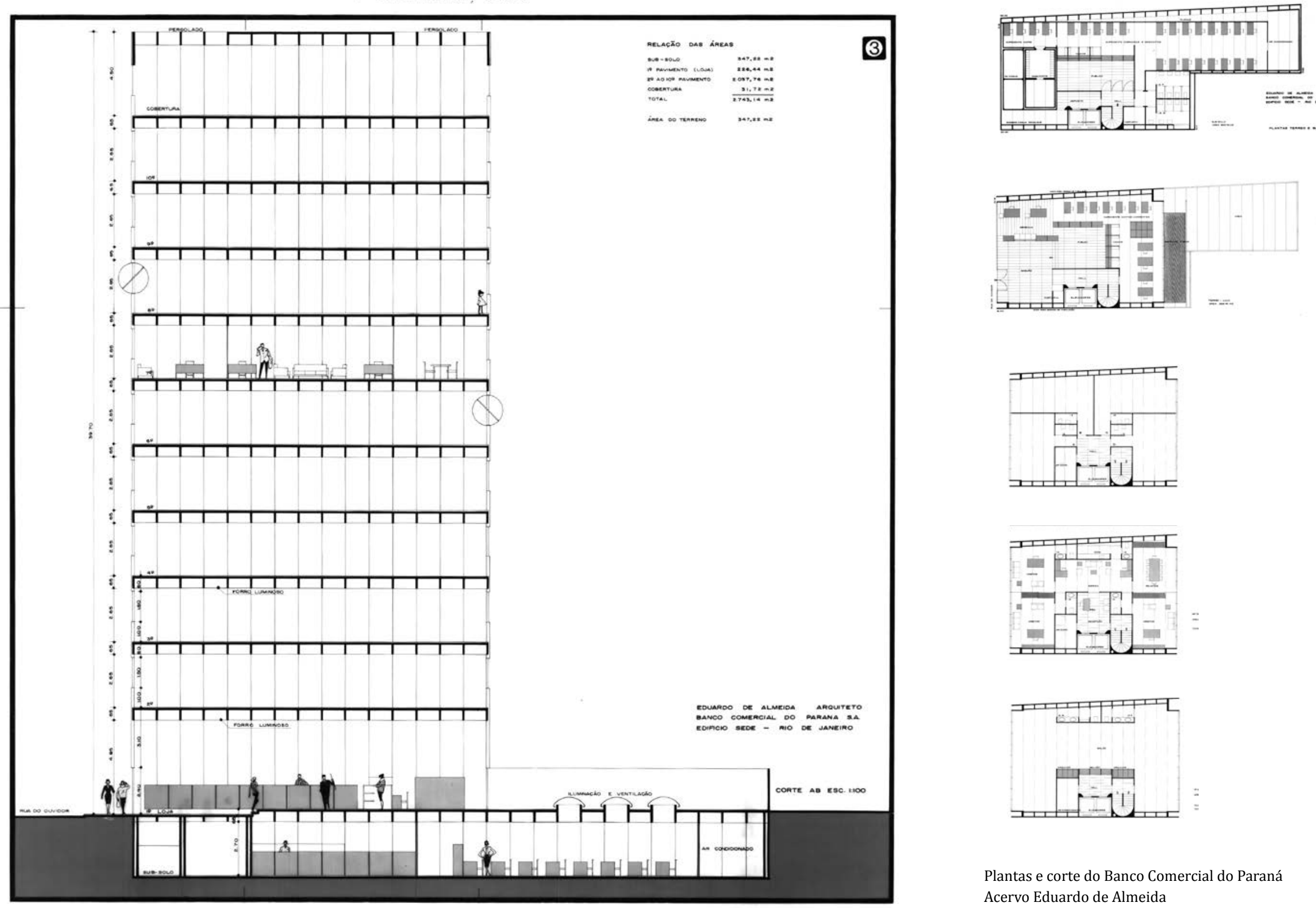

(2)
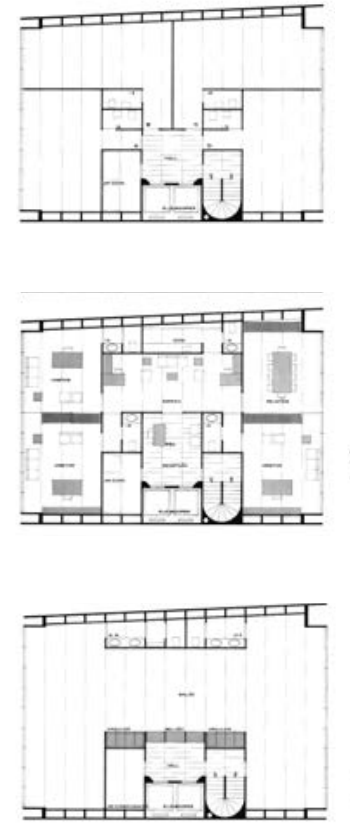

Plantas e corte do Banco Comercial do Paraná Acervo Eduardo de Almeida 

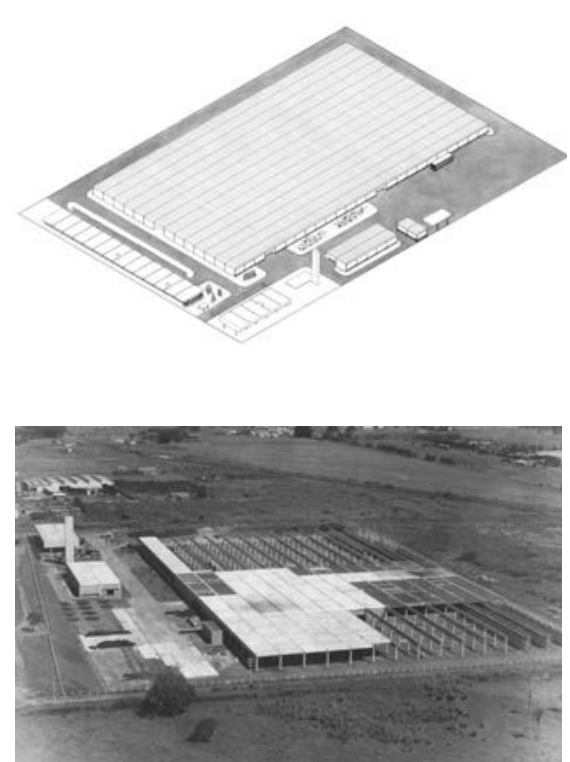

Perspectiva e foto da montagem do galpão da fábrica Morlan

Acervo Eduardo de Almeida
Neste caso, as placas apresentavam um acabamento de acentuada rusticidade decorrente dos agregados aparentes na concretagem do painel, mais uma evidência da influência da arquitetura norte-americana - Marcel Breuer, Richard Neutra ou Walter Gropius e seu grupo TAC - The Architects Collaborative Inc. - que comumente alternavam grandes áreas envidraçadas com planos cegos marcados por texturas de painéis pré-moldados, concreto, pedras ou tijolos.

Vale ressaltar que nesta fachada, os pilares periféricos de concreto armado se apresentam como um rebaixo na fachada, pequeno detalhe que revela o cuidado de Eduardo de Almeida no tratamento desse novo edifício em relação às construções pré-existentes.

Esta investigação sobre o emprego de peças industrializadas na construção civil parece ter desdobramento natural, neste mesmo período, no projeto para a Indústria Morlan, em Orlândia, São Paulo. Projetada por solicitação de Pedro Tassinari em 1973, oito anos após à reforma de uma das conhecidas casas em abóboda de concreto para seu uso próprio e simultaneamente à realização do projeto para a sua casa na praia da Baleia, em São Sebastião.

No caso desta indústria, uma estrutura de grande escala para abrigar a produção de uma metalúrgica, parece natural que Eduardo de Almeida adotasse um partido baseado na industrialização da construção e, pensando nos temas relacionados à ampliação da infraestrutura e à necessária flexibilidade da planta, na criação de um sistema e não de um edifício como objeto isolado.

O projeto do galpão industrial, portanto, parte da definição de uma malha quadrada de 10 metros de lado, dimensionada a partir do estudo dos processos produtivos da indústria e, simultaneamente, indicando o dimensionamento consequente da solução estrutural adotada. 


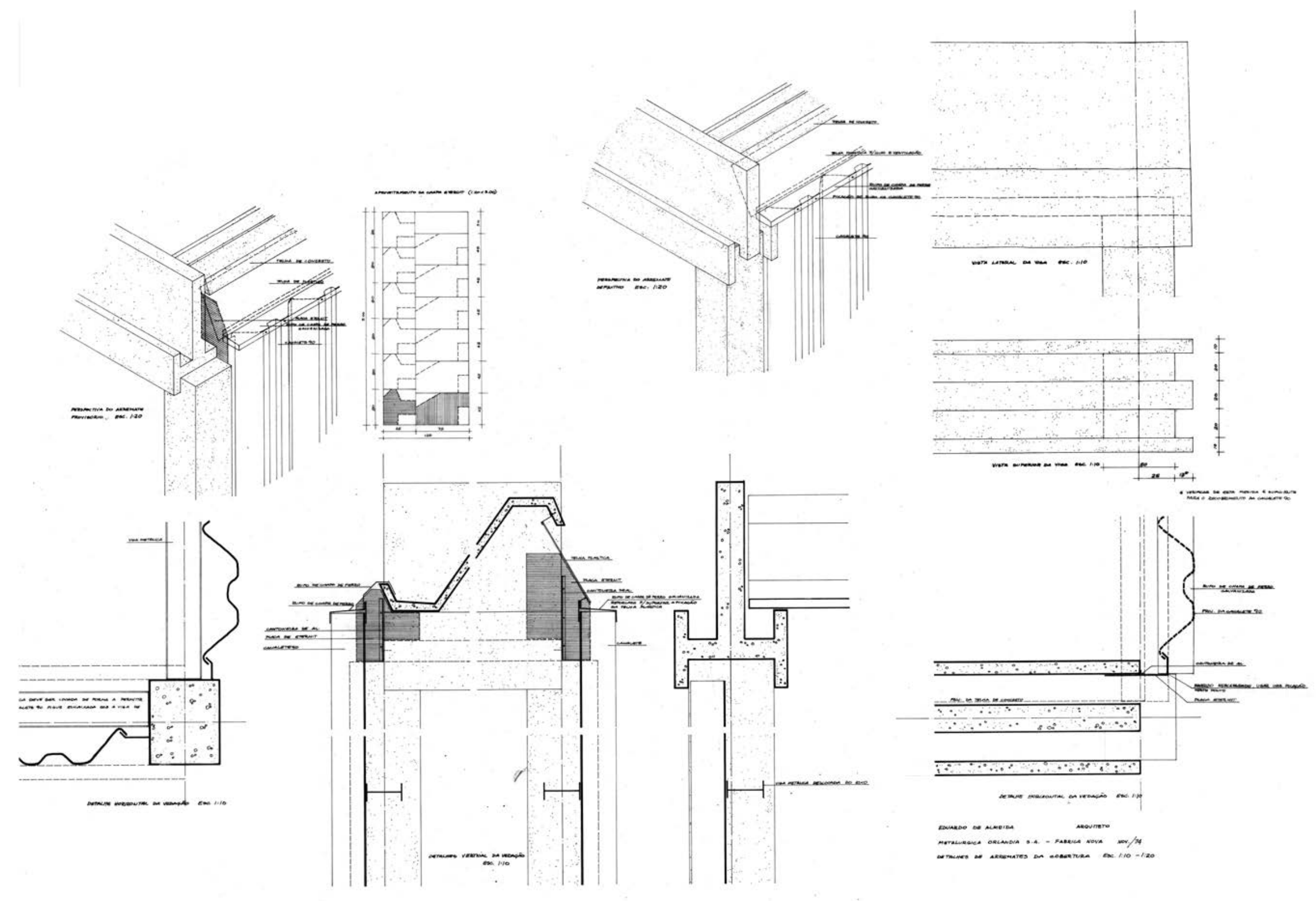


Ao lado, detalhe de arremate da cobertura Acervo Eduardo de Almeida
0 projeto se desenvolve pela malha de pilares de concreto pré-moldados na obra, responsável pela sustentação de vigas-calha logitudinais, também pré-moldadas in loco. Tal composição cria uma malha estrutural, um esqueleto, que recebe elementos pré-fabricados - produzidos externamente em grande escala - que acabam por ser simplesmente montados em obra.

Como cobertura, são utilizadas telhas de concreto com perfil trapezoidal de 'catálogo', comumente empregadas nos galpões industriais da época, associadas a elementos de fibra de vidro responsáveis pela iluminação natural e pela exaustão do ar quente.

Nas fachadas, Eduardo de Almeida subverte o uso de canaletas de fibrocimento, produzidas industrialmente para coberturas, e as emprega como painéis, posicionadas junto à grelha estrutural de modo a permitir a entrada de ar externo no interior do galpão.

Como parte do sistema, também foram criados módulos especiais destinados a espaços de trabalho menores e sanitários - estes últimos sempre posicionados no segundo pavimento inclusive com a criação de uma engenhosa caixa d'água, desenhada como uma viga capaz de vencer o vão de 10 metros da malha estrutural proposta.

Segundo Eduardo de Almeida, a clareza do sistema permitiu que o galpão - construído inicialmente a partir de uma geometria irregular decorrente do desenho imposto pela linha de produção - tenha sido ampliado até sua geometria final pelo proprietário, sem assistência do arquiteto.

Dentro da ideia de sistema, todos os demais edifícios que fazem parte do complexo da indústria - excessão feita ao clube para os funcionários - partem da retícula de 10 metros que organiza a estrutura da fábrica, enfatizando a relação de conjunto e ao mesmo tempo respeitando as especificidades de cada bloco. 


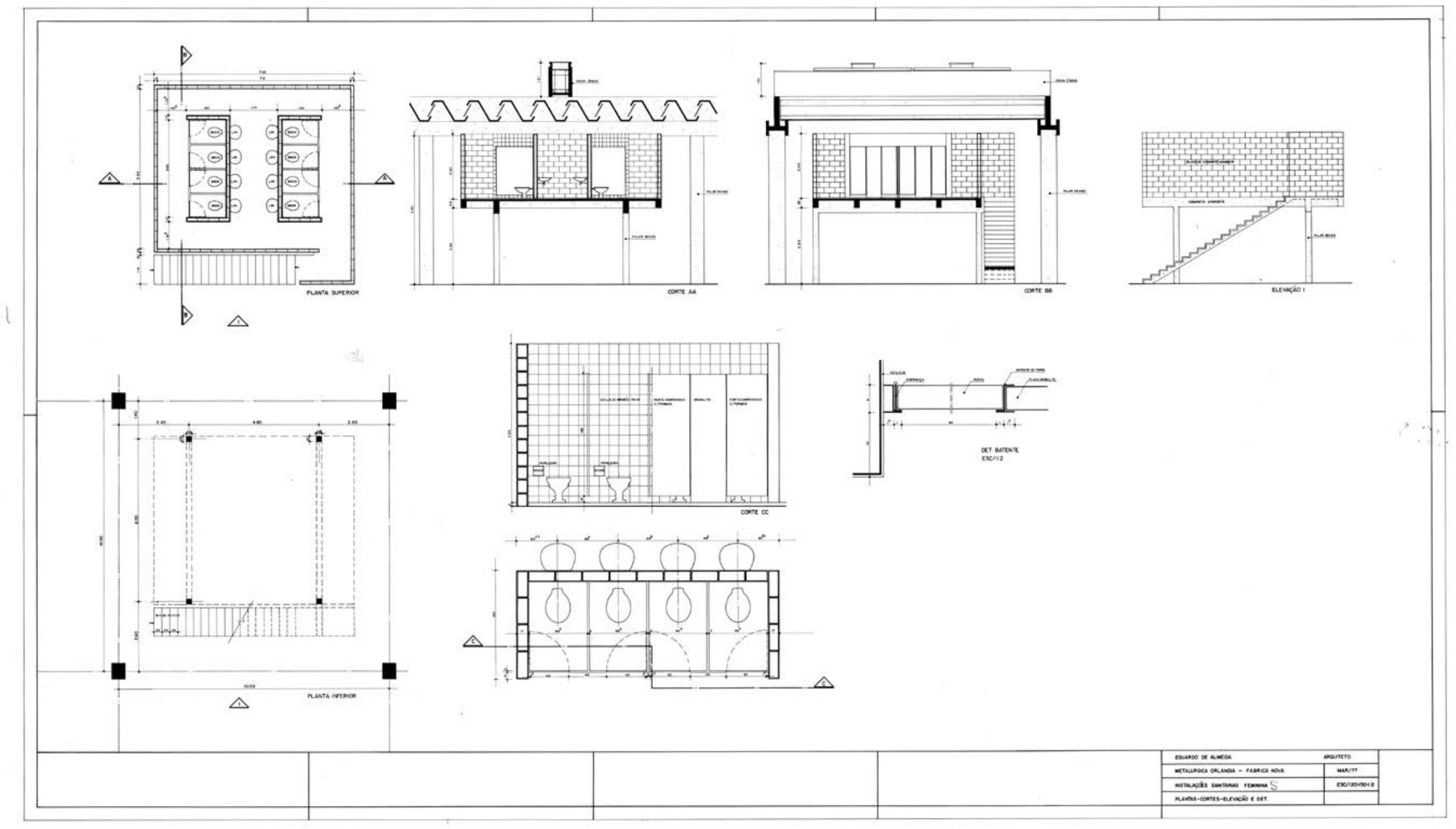

Desenho executivo das instalações sanitárias e

da caixa d'água dos sanitários (à direita)

Acervo Eduardo de Almeida 


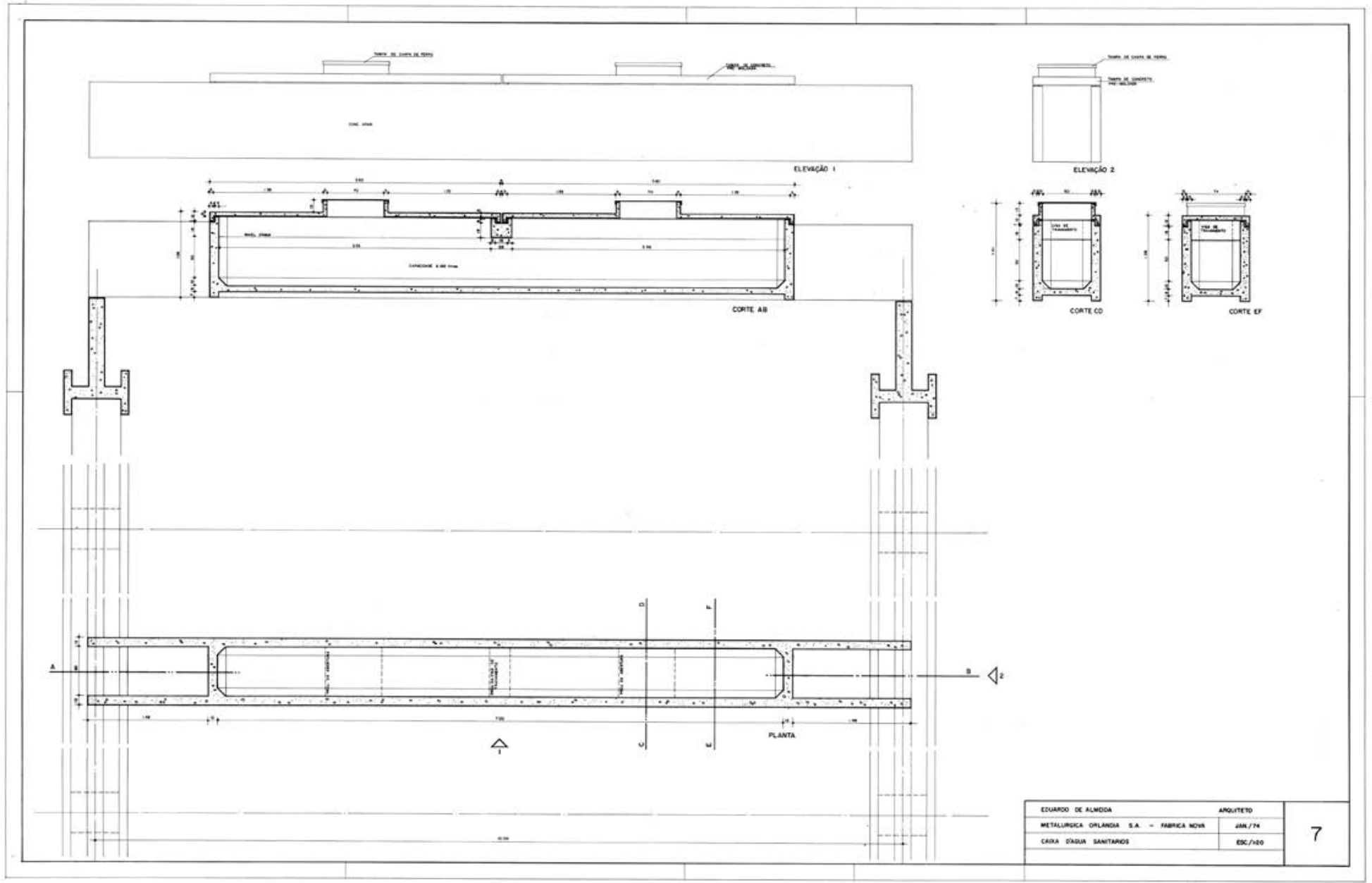



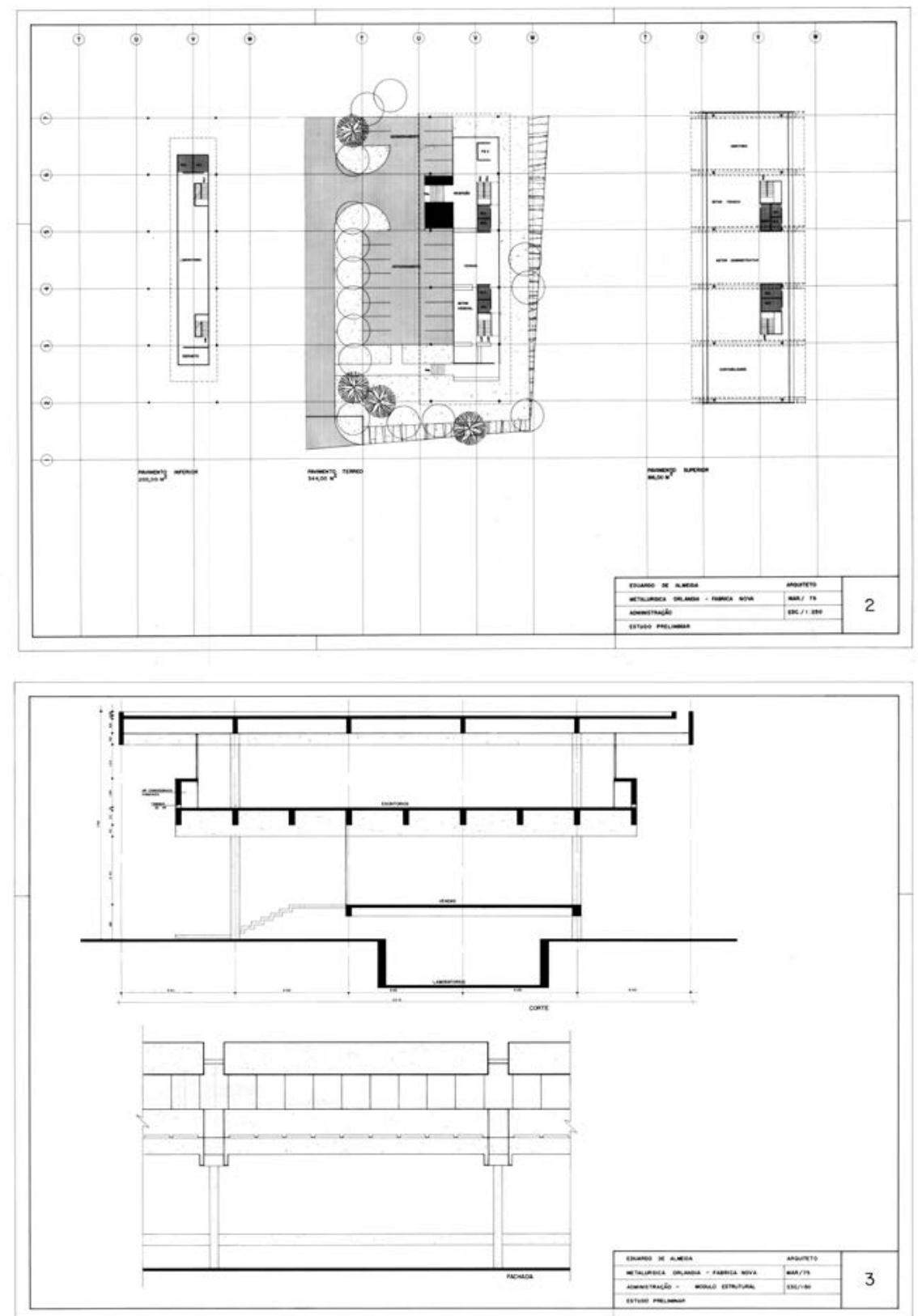

Desenhos e fotos do Edifício administrativo 

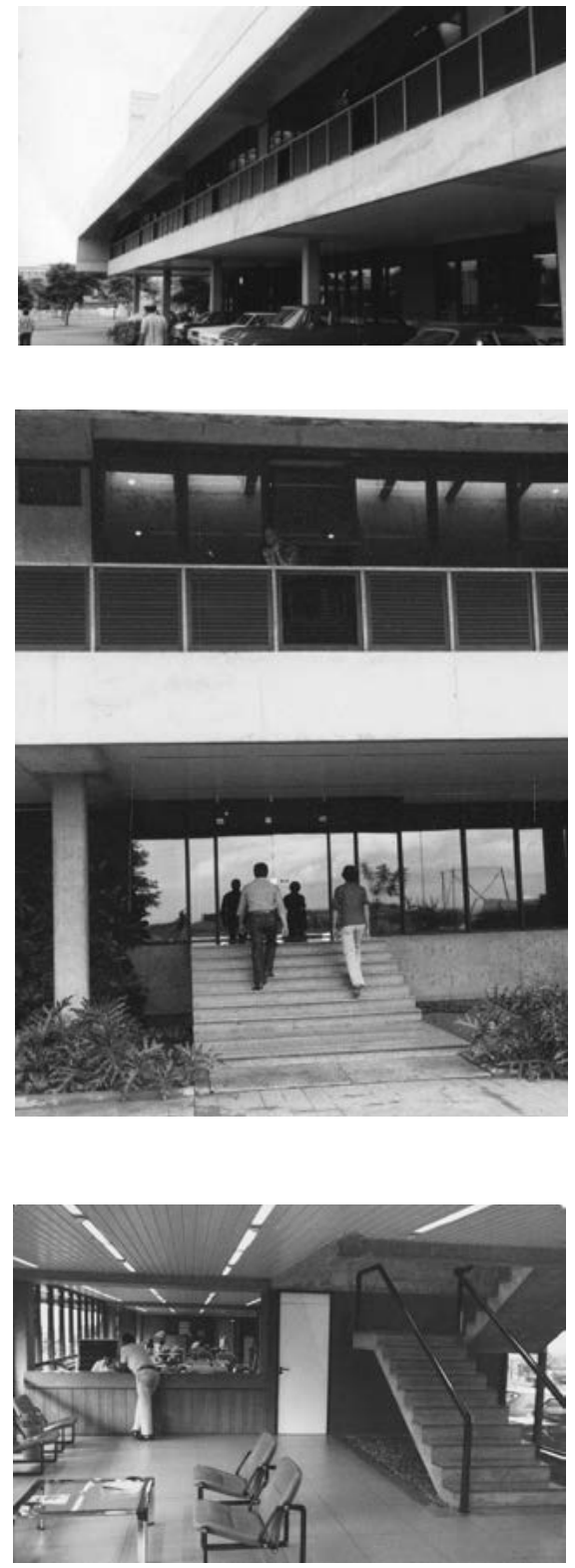

Enquanto o edifício administrativo se organiza em três pavimentos - espaço rebaixado para o laboratório, térreo elevado e área de trabalho no segundo pavimento - o edifício destinado ao setor de serviços abriga todos os programas em apenas um andar, em correspondência direta ao galpão fabril.

No primeiro, a modulação da estrutura e a faixa longitudinal central destinada à escada e espaços de apoio parecem direcionar a ocupação da área de trabalho flexível, alternando linhas de salas fechadas com espaços de escritório panorâmicos.

No segundo, os módulos de 10 metros são ocupados por diferentes programas como vestiários, refeitório, cozinha e um pequeno auditório, sempre alternando os marcados volumes com espaços abertos, ampliando o contraste entre cheios e vazios, mas também criando abrigo para o grande volume de pessoas no acesso aos diferentes programas.

Em ambos os casos, ressaltando a influência da linguagem de Paulo Mendes da Rocha e Vilanova Artigas, as estruturas se utilizam de vigas capazes de vencer grandes vãos, prolongando-se em largos beirais para garantir a proteção adequada ao clima quente da região.

Nestes dois exemplos, os eixos dos pilares, definidos a partir da modulação de 10 metros do galpão, sempre suportam vigas duplas de concreto armado que parecem pensadas como um ideal construtivo ligado à montagem de peças pré-moldadas - talvez influência das primeiras propostas de industrialização, presentes no conjunto habitacional Zezinho Magalhães Prado em Guarulhos -, apesar de terem sido construídos de modo convencional, por meio de concreto moldado in loco, assim como no projeto de Artigas. 

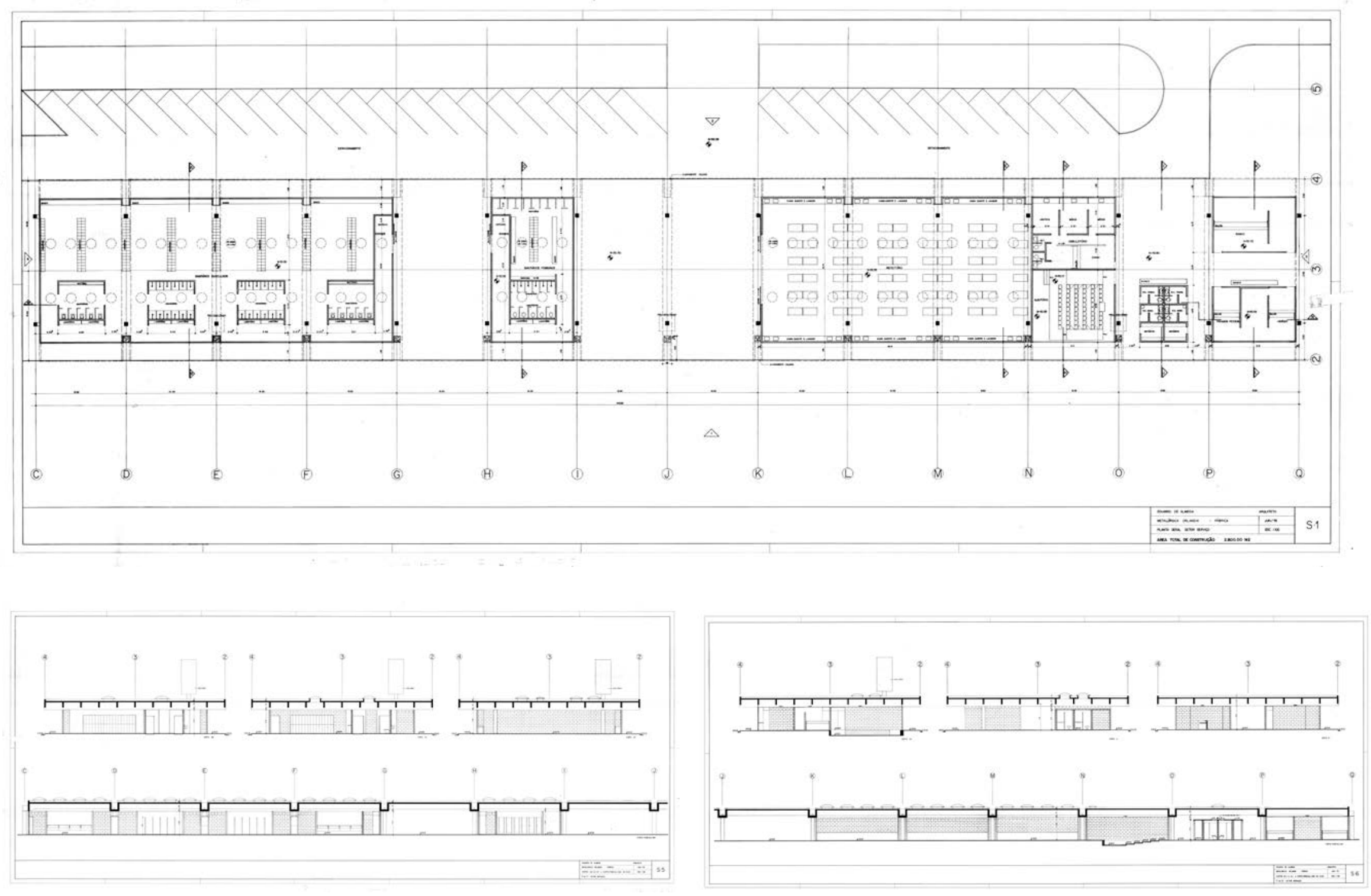

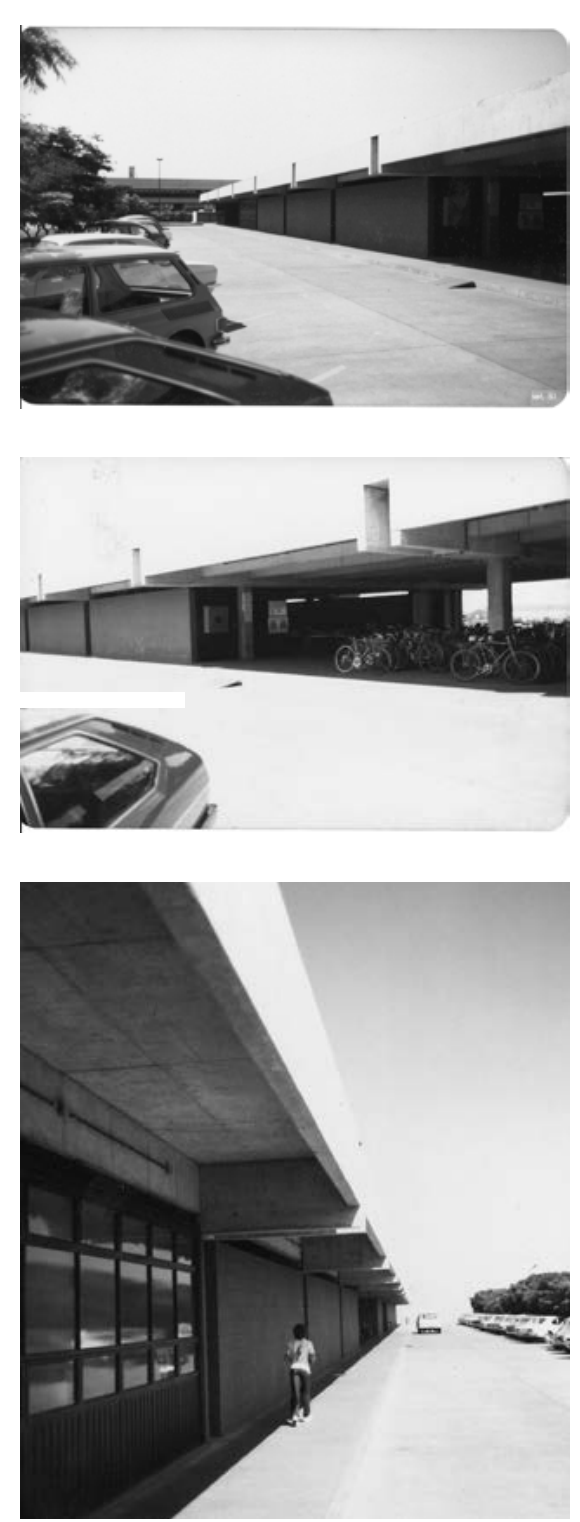

Fotos e desenhos do Edifício de serviços da Morlan

Acervo Eduardo de Almeida
No caso do edifício de serviços tal observação é enfatizada pela adoção de calhas entre as duas vigas e também pela expressividade da estrutura em suas extremidades, já que tal solução parece ressaltar a construção deste longo edifício pela justaposição de diversos módulos, como uma composição do todo a partir de peças independentes.

Na verdade, nesta fase do percurso de trabalho de Eduardo de Almeida, boa parte de seus projetos parece se organizar pela ideia de justaposição de volumes, talvez por seu interesse em relacioná-los ao ideal construtivo de peças, naturalmente vinculados à imagem de uma produção industrial pensada a partir do projeto. Conforme escreve Argan:

Existe necessariamente uma lógica, uma coerência do planejamento e da elaboração do projeto; e ela é dada pelo fato de que, num processo de planejamento contínuo, tende-se sempre à superação, num plano ou projeto ulterior, dos resultados alcançados. (...) O que se espera de um objeto bem projetado é que seja um ponto bem determinado naquela dimensão lógica, um elo daquela coerência: somente quando a forma do objeto se fundamentar nesses elementos simples e os combinar num esquema associativo correto, o objeto poderá explicar sua própria função específica no âmbito daquela função geral, unitária e contínua que éo comportamento social do homem moderno. ${ }^{36}$

A observação de Argan afigura-se importante para ressaltarmos dois aspectos da obra de Eduardo de Almeida, tomado pelo espírito moderno e pela obrigação de definir os novos espaços necessários ao homem contemporâneo: todos os projetos, independentemente da escala ou função, parecem ser temas a serem enfrentados sob esta nova ótica produtiva, assim como cada projeto deve ser visto como parte de um processo, como realização que aprimora o projeto anterior e, certamente, direciona o pensamento para os próximos.

Traçando um paralelo à sua atuação como professor, parece coerente a didática de Eduardo de Almeida de valorização do processo - do percurso estabelecido pelo aluno no enfrentamento de um projeto - e não apenas do resultado obtido em uma entrega final.

${ }^{36}$ ARGAN, Giulio Carlo. Qualidade, função e valor do desenho industrial in Projeto e Destino. São Paulo, Ática, 2001, p.128 


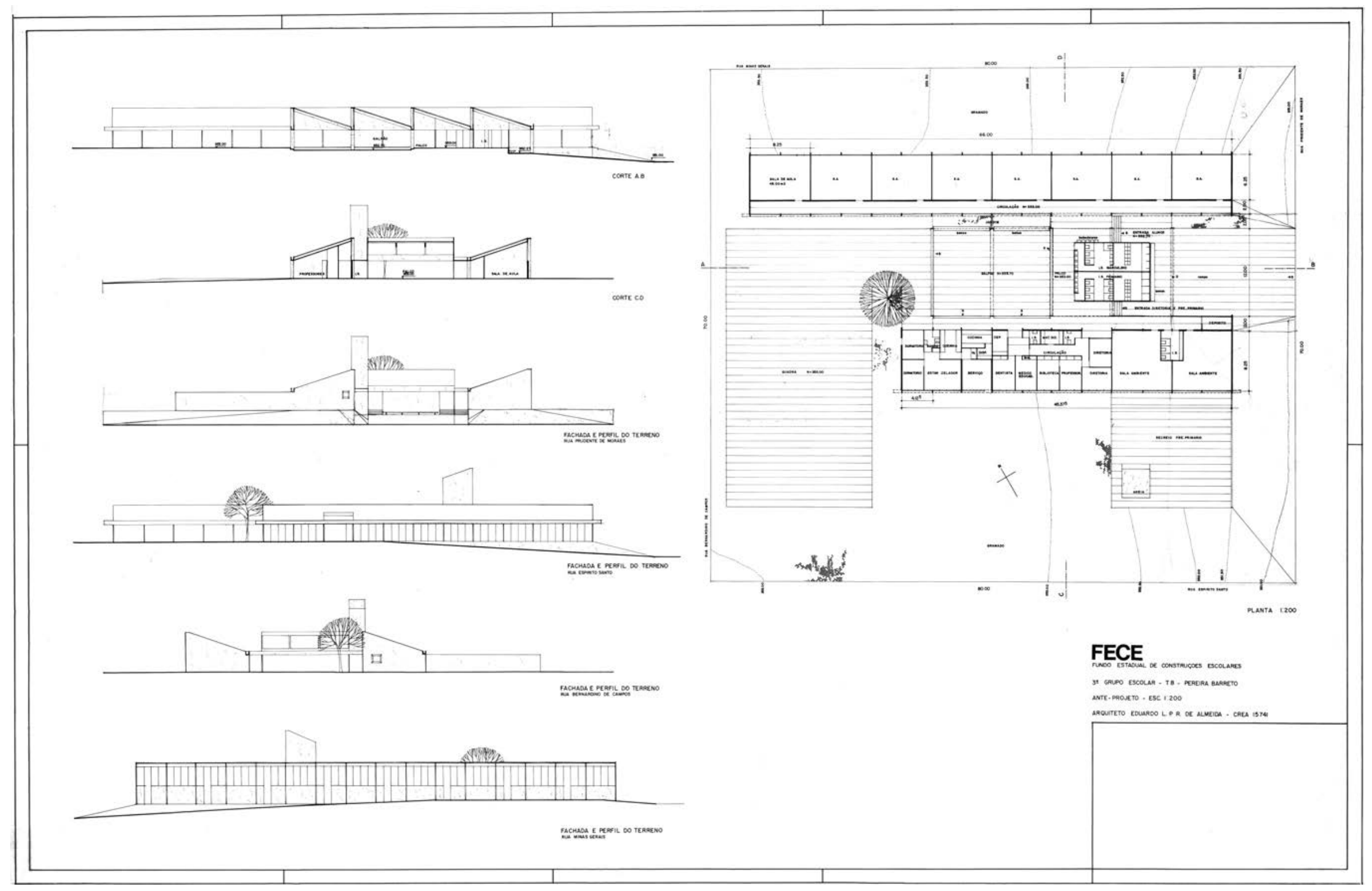


Esse procedimento se ampara nas orientações coletivas, já que 'o problema de um aluno em um determinado projeto pode ser a solução para o projeto de um outro', mas também porque tal didática permite revelar a todos o desenvolvimento do projeto desde a ideia à materialização do edifício e, mais importante, todos os seus percalços: os avanços, os retrocessos, as dúvidas e as conclusões.

Analogamente a este comentário em relação à sua experiência didática, considerando o início da atuação como professor de desenho industrial na FAU USP, Eduardo de Almeida realiza dois interessantes projetos no ano de 1967: o Grupo Escolar de Pereira Barreto e a residência Jean Nadim.

Estas singelas obras apresentam semelhança técnica e formal, apesar de todas as suas diferenças, já que os projetos parecem se pautar pela definição de blocos funcionais específicos a cada atividade, justapostos para a composição do edifício como um todo.

Em ambos os casos, cada um dos blocos possui autonomia volumétrica e independência construtiva em relação ao todo, articulados uns aos outros por meio de lajes planas de concreto armado que, ao mesmo tempo, conectam cada parte do programa, mas destacam por sua neutralidade - os espaços principais do edifício, não por acaso definidos por prismas marcados por coberturas inclinadas.

Desta maneira, o Grupo Escolar em Pereira Barreto articula dois blocos - um destinado às salas de aula e outro à administração e espaços de apoio - posicionados paralelamente, definindo um espaço central protegido por uma cobertura em shed, destinado ao galpão, sanitários e acessos administrativos e de alunos. 

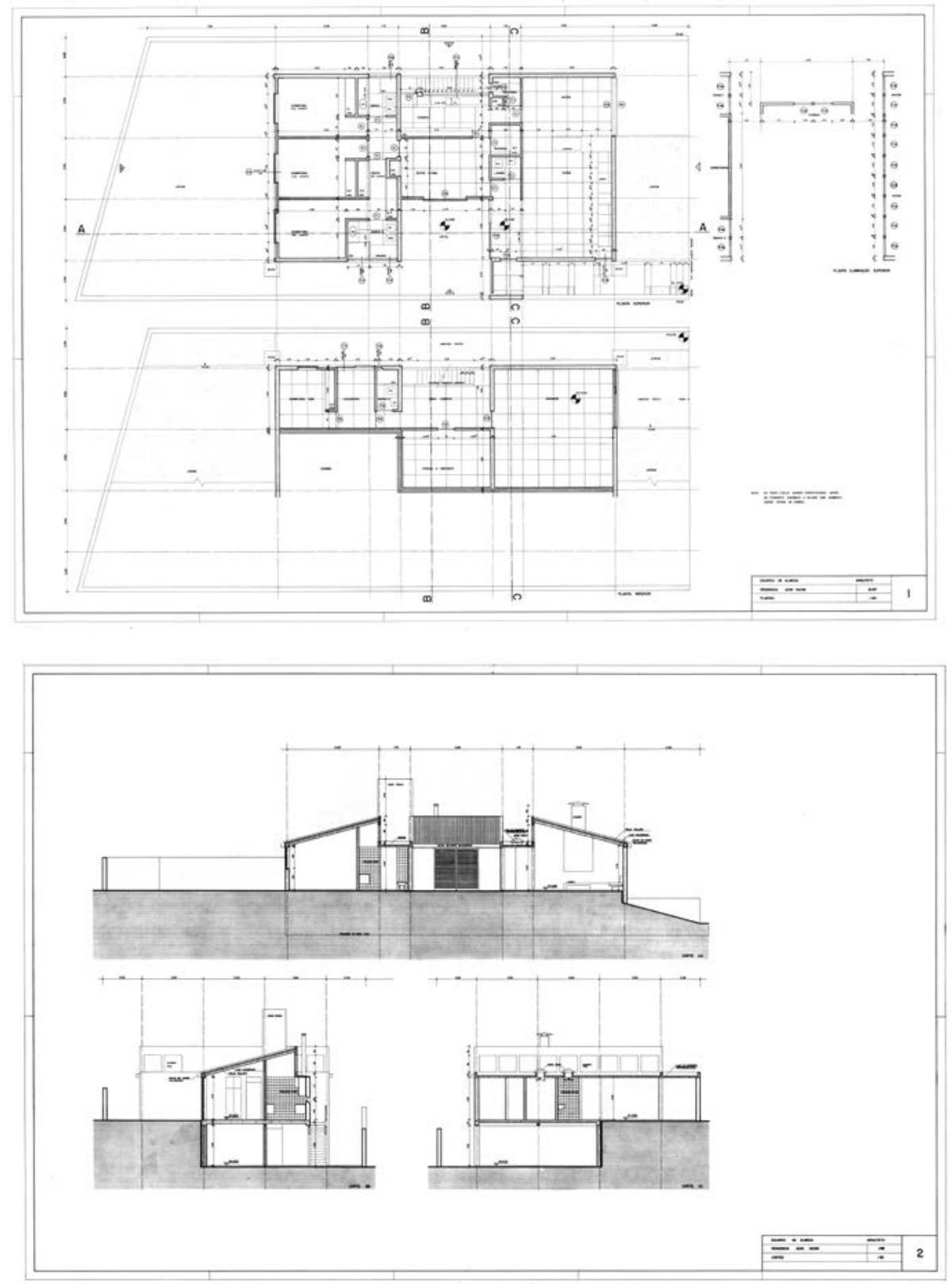

Plantas e cortes do projeto executido da

residência Jean Nadim

Acervo Eduardo de Almeida 
Os volumes de coberturas inclinadas são pensados a partir da repetição de módulos em função dos ambientes e das propriedades construtivas da estrutura, onde os demais elementos caixilhos, alvenarias e portas - são definidos em função do todo a partir do pressuposto de sua repetição como componentes.

Dado que cada volume possui uma cobertura inclinada para cada lado - buscando a orientação desejada bem como a iluminação e ventilação específicas - a laje plana de conexão parece evitar o encontro indesejável entre os volumes, não só eliminando patologias decorrentes destas conexões, como conferindo clareza à ideia de composição de volumes.

Sob a laje plana impermeabilizada, situa-se uma marquise de conexão entre os blocos ou, dependendo de cada caso, corredores cobertos de circulação para cada ambiente ou espaços de apoio, normalmente menores e com funções secundárias, a exemplo dos espaços 'servidores' em contraponto aos 'servidos', conceituados por Louis Kahn em projetos como os laboratórios do Instituto Richards da Universidade da Pensilvânia.

Seguindo os mesmos pressupostos, mas sem a continuidade espacial interior e exterior do galpão da escola, a residência Jean Nadim se organiza pela justaposição de três volumes, o

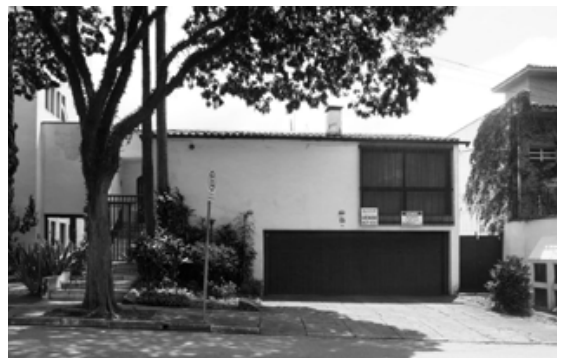

Situação atual da Residência Jean Nadim Foto: Alessandra FIgueiredo primeiro destinado à sala de estar, o segundo a uma saleta e cozinha e, por fim, um volume destinado aos três dormitórios.

Assim como na escola, entre tais volumes se implantam duas lajes de conexão que viabilizam a ligação entre os ambientes, abrigam espaços menores iluminados zenitalmente e garantem a independência volumétrica de cada parte, além de permitir a locação do volume elevado da caixa d'água. 
Importante notar que, no projeto da casa, apesar dos volumes frontal e posterior apresentarem programas diversos em uma relação de simetria com o espaço central, eles são idênticos, tanto nas dimensões quanto nos sistemas construtivos adotados.

A ideia de repetição de volume parece ser a tônica nos projetos de Eduardo de Almeida neste período, talvez pela influência de questões relacionadas à industrialização, mas também por considerar que cada obra faz parte de um pensamento mais amplo, mesmo que muitas delas - sobretudo as residências unifamiliares - não estejam sintonizadas com os princípios de produção em escala.

Segundo depoimento do arquiteto, logo após a realização de suas primeiras obras em concreto aparente, com especial atenção ao detalhamento dos encontros dos materiais ou demais componentes como portas, caixilhos e mobiliário, surge o problema da mão de obra, muitas vezes sem qualificação, mas, sobretudo, não acostumada com o rigor e precisão dos projetos.

Por este motivo, obras como as residências Fernando de Almeida (1969), Levy Rubinstein e Carioba (1970) utilizam-se de uma linguagem também baseada na justaposição de volumes, mas agora dotadas de revestimentos e pintadas de branco, sem nenhuma alusão ao desenho da estrutura e, mais radicalmente, sem coberturas de telhas cerâmicas repetidas anteriormente, tampouco de lajes planas de conexão entre os volumes.

Tais experiências parecem sintonizadas com a proposta para o Concurso Nacional do Pavilhão de Osaka que, embora se utilize de uma construção com estruturas metálicas treliçadas e fechamento de painéis de alumínio, vale-se de uma certa força escultórica por meio da geometria expressiva de seus volumes, aliada a poucas e precisas aberturas.

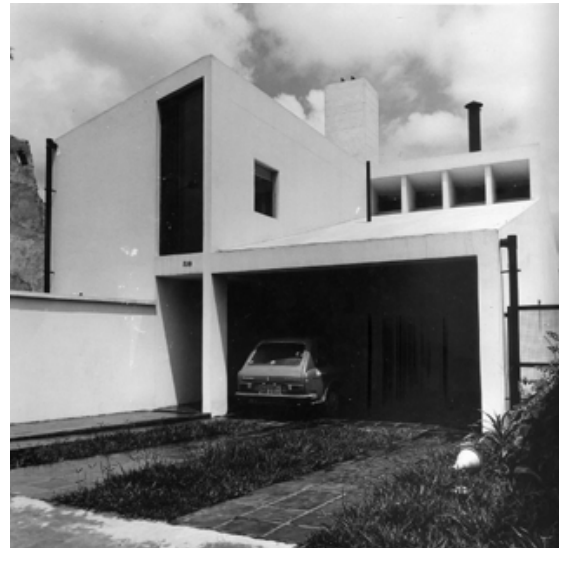

Residência Levy Rubinstein

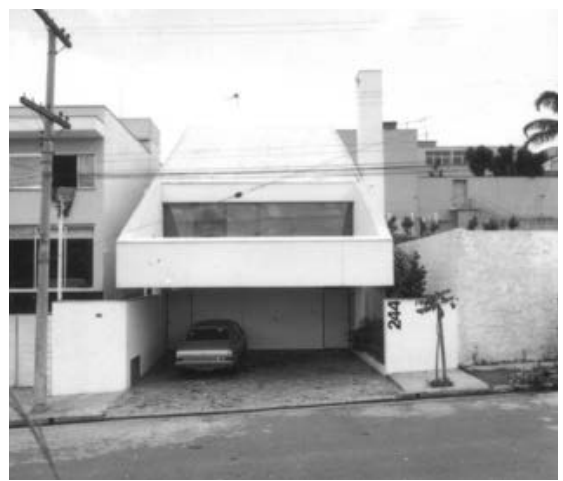

Residência Fernando de Almeida

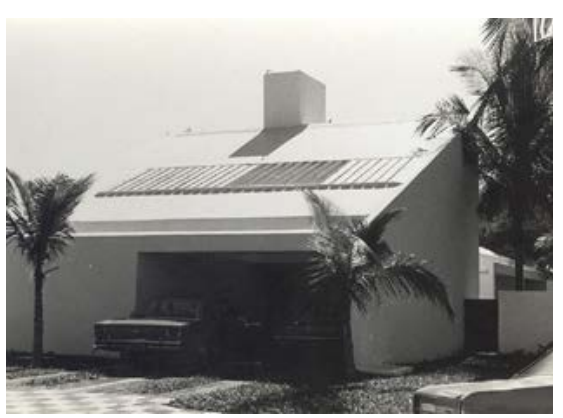

Residência Carioba

Acervo Eduardo de Almeida 
Como decorrência destas intenções, nas três residências os volumes pintados de branco se comunicam com o exterior por meio de aberturas pontuais, cujos fechamentos de vidro, normalmente recuados do plano da fachada, foram planejados sem caixilhos a partir da tecnologia do vidro temperado. Ao que parece, para o arquiteto até mesmo um requadro de caixilho poderia comprometer o contraste entre a força plástica do volume e suas aberturas.

Talvez por esse mesmo motivo os três projetos se utilizem de aberturas zenitais para a iluminação e ventilação em diversos ambientes pois é justamente do confronto entre os diversos volumes que surgem as possibilidades de se criar novas aberturas oriundas da própria composição espacial.

Mesmo sendo de grande interesse, estas três obras - revestidas e pintadas de branco aparecem como uma pausa na obra de Eduardo de Almeida, talvez como uma busca que não tenha atingido os resultados pretendidos pelo arquiteto de forma satisfatória.

A resposta a esta polêmica afirmação se deve a projetos realizados posteriormente que, apesar de apresentarem o mesmo princípio de composição volumétrica, parecem retomar uma expressão plástica decorrente da disposição precisa de cada elemento que compõe uma casa: pilares, lajes, coberturas, alvenarias, caixilhos, portas ou outros componentes da construção.

São deste período as residências para Niemeyer dos Santos (1970), Alberto Guimarães (1971), Nogueira Moutinho (1972) e a casa de praia para Pedro Tassinari (1973), que claramente se organizam pela justaposição volumétrica, cada uma responsável pelo abrigo de determinada funções.

Perspectiva Concurso Nacional do Pavilhão de Osaka

Acervo Eduardo de Almeida 


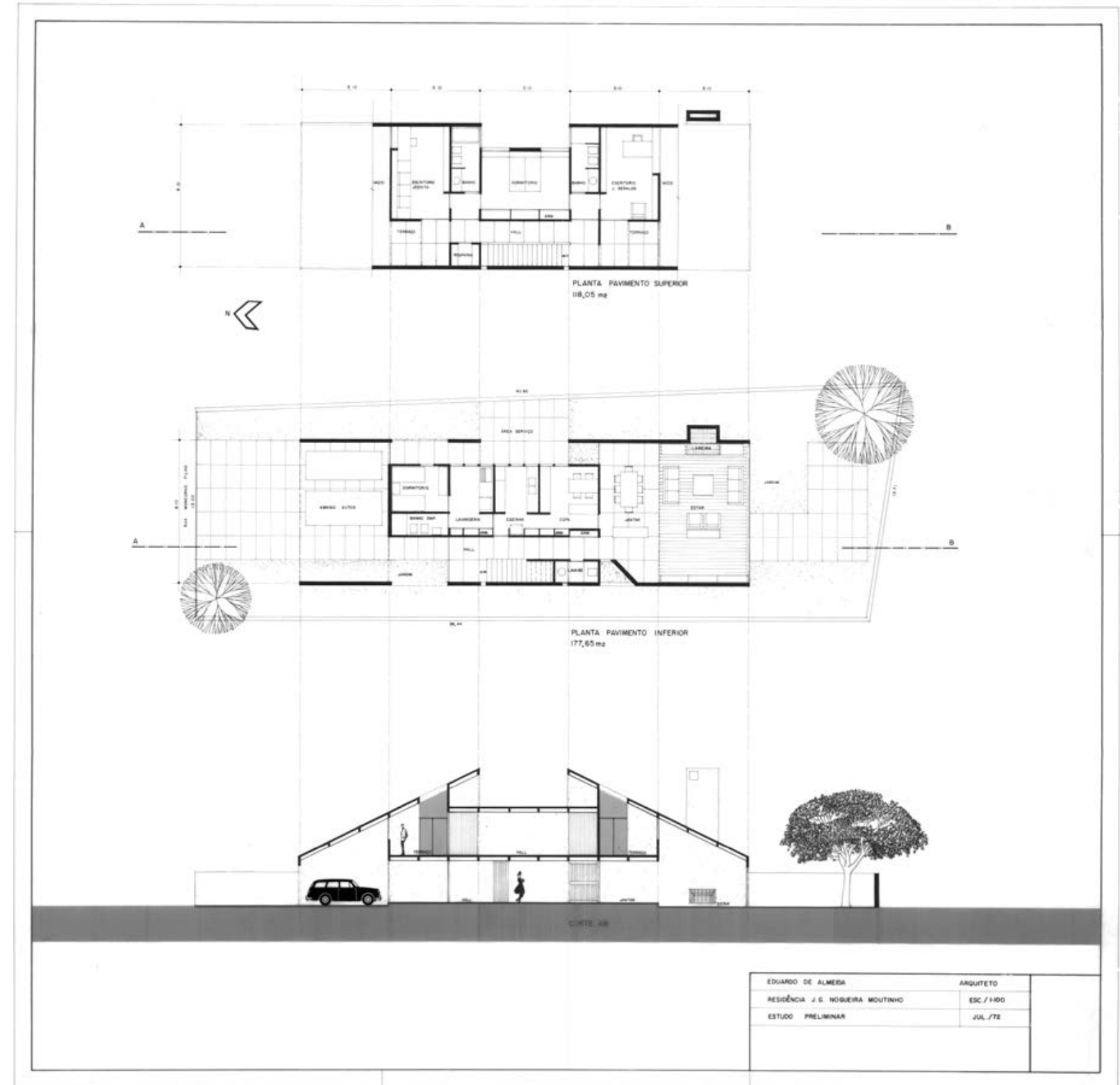

Plantas e cortes do projeto executido da residência Jean Nadim 
A diferença destes exemplos, no entanto, parece justamente apresentar, diante dos problemas relacionados à execução e à incipiente industrialização, uma resposta contundente a favor de projetos extremamente consistentes, desenvolvidos 'até as últimas consequências', como costuma afirmar Eduardo de Almeida até hoje.

Antes de alterar os pressupostos estéticos e construtivos para viabilizar a obra, ele parece disposto a seguir com os conceitos ligados a uma moral construtiva, cuja única solução a seu alcance parece ser o desenvolvimento total e completo de cada projeto, em cada um de seus pormenores, mas também se alinhando à produção paulista do momento, atenta às investigações da arquitetura brutalista inglesa de Alison e Peter Smithson:

A arquitetura brutalista abriu a possibilidade de abordar a construção a partir de um crivo moral e ético, que se estabelece pelo entendimento de sua inserção como sistema produtivo realizado no presente. Defende-se aqui a 'verdade dos materiais', expressão que sintetiza a busca de uma arquitetura despojada de refinamentos construtivos e que valoriza a aparência própria dos materiais empregados. ${ }^{37}$

Vale ressaltar, também de acordo com Ana Paula Koury, que neste movimento inglês se apresenta uma relação estética x moral construtiva já presente nas obras de arquitetos como Boullée e Ledoux - responsáveis pela arquitetura revolucionária francesa do século XVIII ou Violet-le-Duc - representante do racionalismo estrutural do século XIX -, cujo conceito de 'verdade dos materiais', entretanto, “aparece para resgatar uma unidade entre projeto e produção que a idealização da sociedade maquinista e o modelo de produção industrial baseado no parcelamento das tarefas haviam separado".

Em São Paulo, como sabemos, a partir dos ideais de Artigas na definição de uma relação entre arte e técnica, a arquitetura se desenvolveu em duas vertentes, que ficaram conhecidas por Brutalismo Paulista e Arquitetura Nova; apesar de baseadas nos mesmos princípios espaciais,

${ }^{37}$ KOURY, Ana Paula. Grupo Arquitetura Nova. São Paulo, Romano Guerra, Edusp, Fapesp, 2003, p.41 
em sintonia com a abordagem de uma moral construtiva, apresentavam divergência nas 'estratégias de ação', enquanto a primeira - elaborada por Artigas - 'voltada para o lado formal, na organização de plantas, no espaço, no uso do concreto', e voltada a uma arquitetura como um 'produto singular do limite da capacidade técnica instalada no país', a segunda - defendida por Sérgio Ferro, Rodrigo Lefévre e Flávio Império - voltada à relação da arquitetura com o canteiro e seu 'agenciamento racional de experiências construtivas simples, cuja otimização tinha como objetivo aumentar o desempenho de produção e o acesso à arquitetura'. Ainda, segundo Koury, "a crítica ao canteiro de obras é o pressuposto da poética da economia e estabelece os fundamentos para a Arquitetura Nova, que vai se debruçar sobre suas próprias condições de produção para elaborar uma nova estética." ${ }^{\prime 38}$

Essa divergência se desdobra na FAU USP, no Fórum de 1968; com o endurecimento do regime militar, as duas correntes se desenvolvem em posições ainda mais radicais: de um lado a defesa do desenho - alinhada à orientação de Artigas e do Partido Comunista -, de outro, o enfrentamento ao regime por meio de uma ação revolucionária, de luta armada - a partir da filiação dos membros da Arquitetura Nova à Ação Libertadora Nacional de Mariguella.

O conhecido depoimento de Artigas esclarece bem o momento:

'Fechemos as escolas, vamos fazer guerrilhas'. Temos colegas numerosamente classificados que elaboram essa tese e não aceitam que se entre na Faculdade de Arquitetura para fazer um curso de Arquitetura, mas aprender a ser guerrilheiro. Como pode ser isso? No fim não sai nem guerrilheiro nem arquiteto. A revolução que nós vamos fazer prescindirá do conhecimento técnico e de uma visão artística do mundo? Se ela puder prescindir, então vamos fechar todas as escolas. ${ }^{39}$

Dentro desta polarização, o debate político na FAU USP se reflete na realização simultanêa de duas revistas produzidas por estudantes, Desenho e Ou..., que defendem estas duas vertentes:

${ }^{38}$ KOURY, Ana Paula. Grupo Arquitetura Nova. São Paulo, Romano Guerra, Edusp, Fapesp, 2003, p.64

${ }^{39}$ THOMAZ, Dalva Thomaz. Um olhar sobre Vilanova Artigas e sua contribuição à arquitetura brasileira. Dissertação de Mestrado, FAU USP 1997, p. 320 
A revista Desenho, como era de se supor, defendia a ação profissional acima de qualquer outra. O editorial do primeiro número reproduz trechos da aula de Artigas de 1967: 'Desenhar é fazer história como iniciativa humana'. Assim, não há porque deixar de projetar, a questão é saber 'como.'(...) A revista Ou..., por sua vez, nasceu provavelmente inspirada pelas aulas de Sérgio Ferro de 1968 e 1969, nas quais fazia a crítica à divisão do trabalho no canteiro de obras e à separação decorrente entre trabalho intelectual e manual. ${ }^{40}$

Não se pretende aprofundar aqui este tema mas parece importante notar que Eduardo de Almeida certamente acompanha o embate entre as duas vertentes e, apesar de não se pronunciar ou fazer apologias, pode-se dizer que sua posição pelo trabalho de arquiteto indica uma decisão a favor do desenho.

Tal crença em relação ao projeto se reflete nas obras desse período por meio de desenhos precisos, onde o domínio técnico do objeto se dá pela conjugação entre as diversas partes e componentes que definem a arquitetura, como podemos apreender no projeto da casa Niemeyer dos Santos, talvez o exemplo mais significativo desta fase e que ilustra bem o sentido de sua obra nesse contexto.

Ao final, sempre questionei muito meu próprio trabalho, por isso minhas obras são tão diferentes. Sempre me pareceu que meus amigos e colegas me consideravam indeciso, um arquiteto que não se decidia por uma postura concreta. Não pertenço à escola de arquitetura paulista, mas sim pertencem a esta escola todos os amigos que tenho acompanhado e com cujos projetos, finalmente, me envolvi. Não obstante, nunca me converti, não fui convencido. ${ }^{41}$

Apesar de se utilizar de concreto aparente, em nenhum momento este projeto indica a aproximação às investigações estruturais comumente utilizadas no que veio a ser reconhecido como Brutalismo Paulista; ao contrário, o desenho da estrutura se apresenta totalmente modulado a partir de pequenos vãos, sempre definidos de modo preciso em conjunto com a organização dos espaços.

${ }^{40}$ ARANTES, Pedro Fiori. Arquitetura Nova. São Paulo, Editora 34, 2002, p.91

${ }^{41}$ ALMEIDA apud ESPALLARGAS in PIÑON, Hélio. Eduardo de Almeida. Barcelona, Edicions UPC, 2005, p.18 


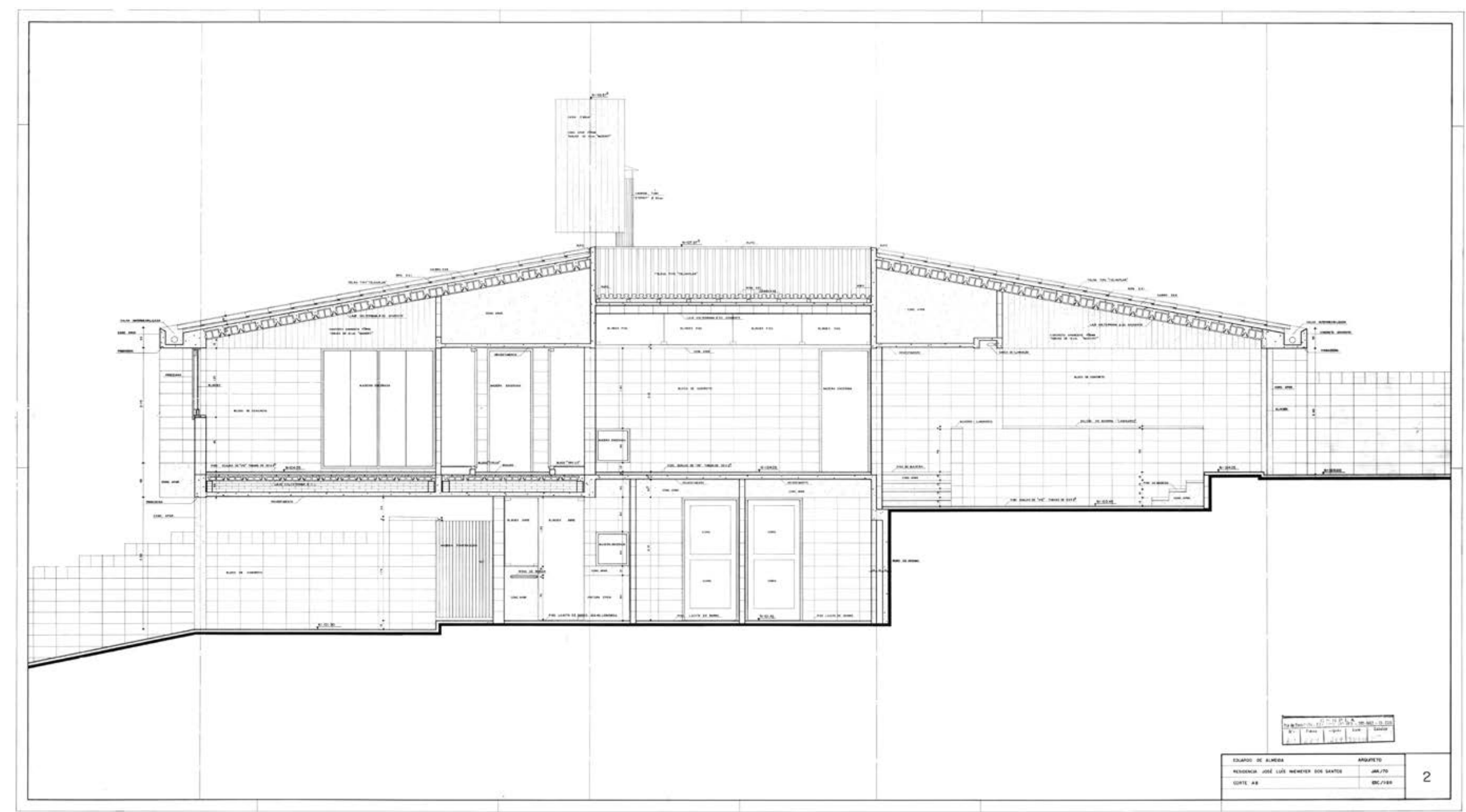



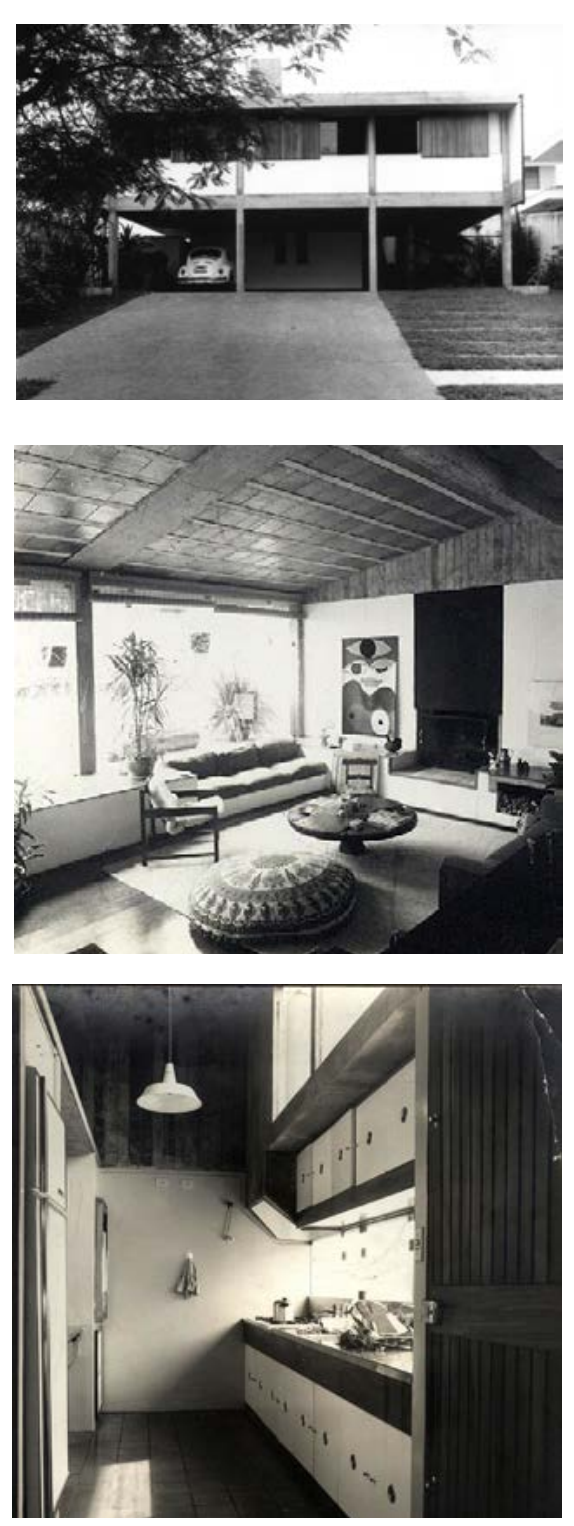

Fotos e corte do projeto executivo da residência Niemeyer

Fotos: Júlio Abe Wakahara
Ao mesmo tempo, o uso de concreto, blocos e pré-lajes aparentes denota o respeito ao rigor construtivo e, mais do que isso, um despojamento baseado na expressão dos materiais, sem nenhum tipo de revestimento que pudesse vir a mascarar a materialidade da obra ou os procedimentos construtivos.

Em sua relação com a obra, a realização de desenhos excepcionais, como o corte longitudinal em $1 / 20$ realizado por José Antônio Seixas ${ }^{42}$, parece estabelecer um contato maior entre os trabalhos do escritório e do canteiro.

Nem brutalismo, nem arquitetura nova, Eduardo de Almeida aproxima-se das duas vertentes por diferentes motivos ao mesmo tempo em que não se filia a nenhuma delas. Antes de tudo parece mesmo voltar seu olhar às casas e obras do arquiteto Carlos Millan, cujos desenhos e soluções eram reconhecidos por sua geração pela concisão e economia de meios.

Na casa Niemeyer dos Santos, a partir de solução volumétrica decorrente do projeto para Jean Nadim, a proposta inverte a disposição entre os blocos destinados à sala e aos dormitórios - sem nenhuma dificuldade, dada a simetria e dimensão idêntica dos mesmos - de modo a favorecer a continuidade dos ambientes de estar para o jardim existente no fundo do lote.

Ao mesmo tempo, a definição desta malha estrutural só pode ser concluída de modo preciso após o desenvolvimento de todas as alvenarias, em um processo de coordenação modular contínuo entre os elementos diversos, já que tudo está previsto em função da dimensão do bloco de concreto aparente em sua conjugação com todos os demais elementos: os planos de

${ }^{42}$ José Antônio Seixas começou a trabalhar no escritório de Eduardo de Almeida aos dezenove anos de idade e sem formação em arquitetura, indicado por seu irmão José Seixas, arquiteto formado pela FAU USP que trabalhava com Jacob Ruchti. Depois de trabalhar com arquitetos como Lélio Machado Rainer, Abraão Sanovicz e Arnaldo Martino, retornou ao escritório de Eduardo de Almeida, onde permaneceu até 2003. Segundo Eduardo de Almeida, José Antônio Seixas participou exaustivamente no detalhamento de sua própria casa, bem como em inúmeros projetos desenhados de forma exemplar, como a casa Niemeyer. 


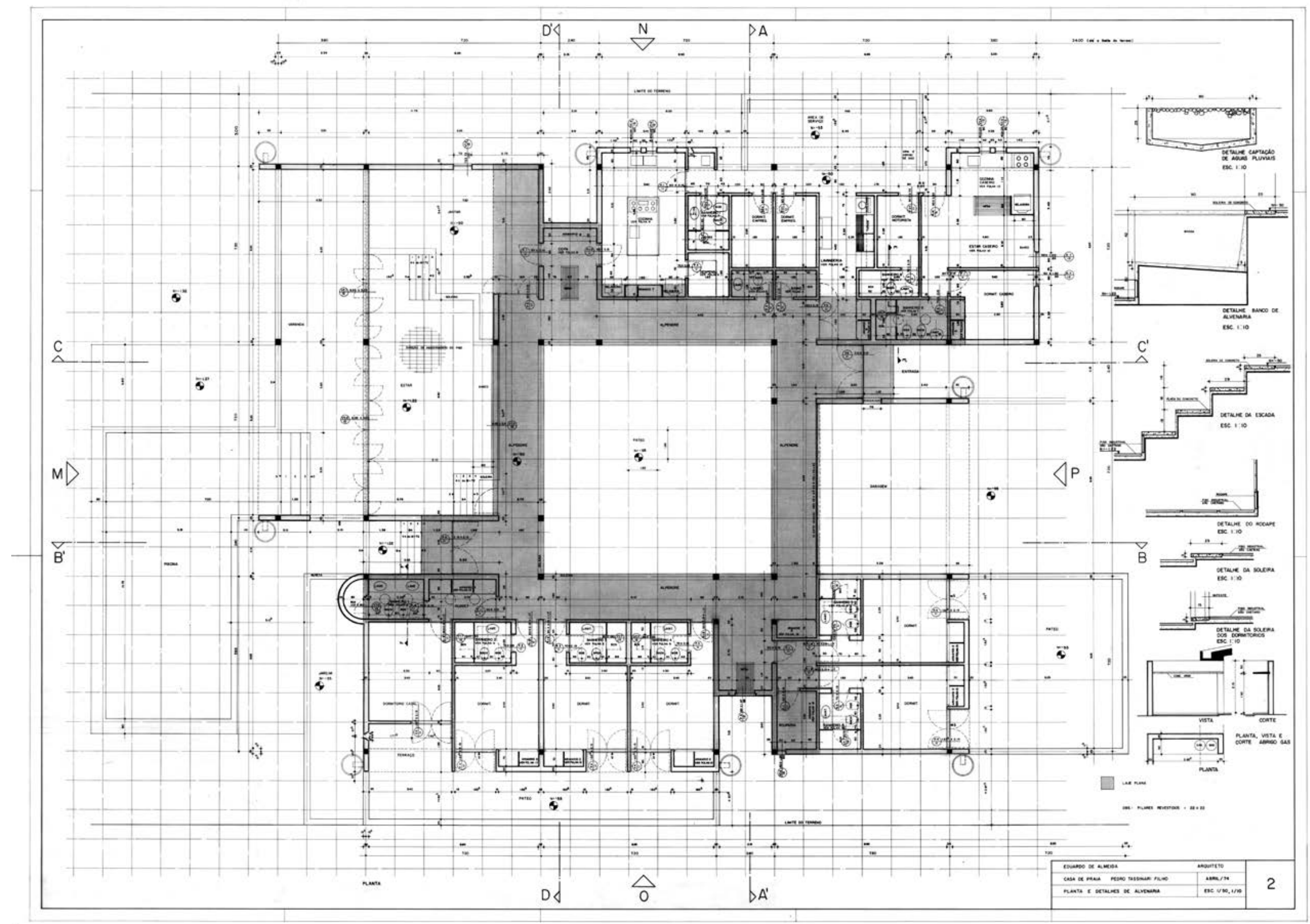




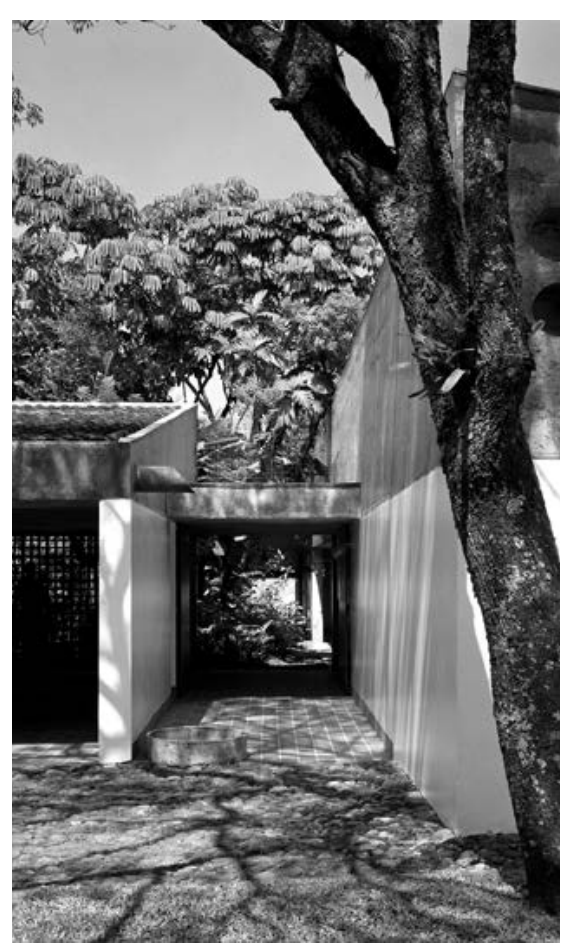

Residência Praia da Baleia Foto: Nelson Kon

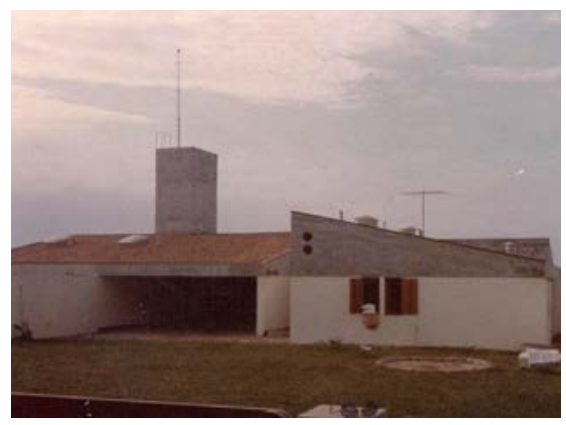

Foto e planta do projeto executivo da residência na Praia da Baleia

Acervo Eduardo de Almeida vidro temperado, os fechamentos de madeira desenhados para esta obra, também associados a planos de vidro, às pré-lajes aparentes nas coberturas inclinadas, tudo desenhado de modo preciso para a definição de uma casa singela: despretensiosa na forma e agradável em sua espacialidade.

Outra preocupação que me parece importante refere-se ao fato de que a pessoa não deve tropeçar na casa. A casa tem que estar relacionada com a pessoa que vai habitá-la de modo amigável, cordial. Não quero falar de poesia nem nada disso. Só quero me concentrar na forma agradável. (...) Sempre me pareceu importante criar um ambiente amável a partir de um contexto construtivo rigoroso: alcançar a uma organização espacial fluida e agradável. (...) É tão habitual ver um espaço contemporâneo rude, relacionado à história da arquitetura 'brutal'da década de 60, em que o arquiteto agride, maltrata a pessoa. Ao contrário, se conseguisse fazer uma arquitetura imperceptível, feita de sensações agradáveis, estaria feliz. Qualquer um que disfrutasse destes espaços, fossem o que fossem - residência, hospital ou cidade - deveria encontrar possibilidades de uma convivência cordial. ${ }^{43}$

Tal espírito parece fazer parte do projeto para a casa na praia da Baleia, em São Sebastião, encomendada por Pedro Tassinari em 1973. Neste caso, utilizando-se da justaposição de quatro volumes com coberturas inclinadas ao redor de um pátio, conectados por lajes planas de concreto armado, o projeto se pauta pelo 'agrupamento e deslocamento de módulos' ${ }^{\prime 4}$, como ressalta o crítico de arte Alberto Tassinari:

A invenção para ele não está na volumetria inicial, numa volumetria impactante. Ao contrário, ele procura um elemento menor, mas não um detalhe, e na conjugação destes módulos é que o projeto acontece. (...) A arquitetura do Eduardo é de tal maneira sofisticada, que ela também é muito simples. Quando ele acha estes módulos, eles juntos, é como se fossem quatro tijolos, neste caso aqui já está pronta a obra. O Mies dizia: 'quando você junta dois tijolos, se for bem juntados, você já está fazendo arquitetura'. Metaforicamente, pode ser dito isto. (...) As casas do Eduardo são bem proporcionadas não só no sentido das medidas, mas porque elas realmente proporcionam experiências. Quando eu disse que com dezoito anos fui morar em uma casa dele, realmente foi uma experiência muito forte, não foi o impacto de uma ou outra forma, foi o impacto de várias visadas, de vários momentos que eu tinha enquanto eu estava convivendo com a casa. ${ }^{45}$

${ }^{43}$ ALMEIDA apud ESPALLARGAS in PIÑON, Hélio. Eduardo de Almeida. Barcelona, Edicions UPC, 2005, p.20

${ }^{44}$ Depoimento de AlbertoTassinari ao autor, São Paulo, 2014.

${ }^{45}$ Citação de filme: TASSINARI apud PIPER, 2013 


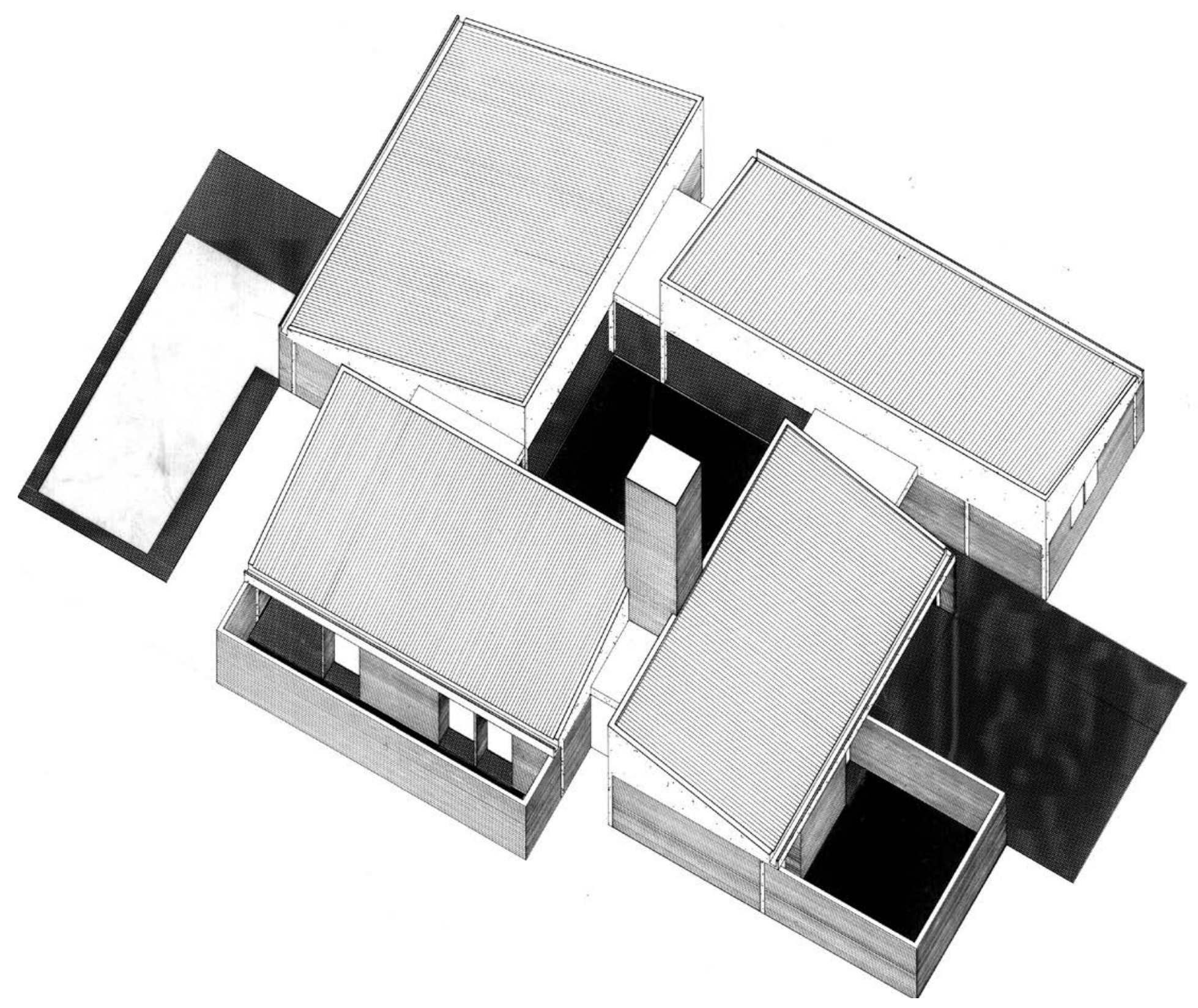


O exemplo dessas obras nos permite afirmar que a arquitetura de Eduardo de Almeida parece estar atenta ao atendimento das solicitações dos clientes na criação de espaços adequados aos usos, mas também às relações espaciais sensíveis ao sítio e à criação de espaços agradáveis ao convívio humano. Vale remeter a Argan quando se refere a forma de Marcel Breuer:

O que ele quer alcançar não é a forma nova, inventada, surpreendente, mas a forma nova que responde a todo um conjunto de necessidades e de desejos, que é a aguardada como a solução de uma série de pequenos ou grandes problemas e que por isso se tornará subitamente habitual, entrará no ciclo da existência sem provocar nenhuma perturbação. ${ }^{46}$

A descrição de Argan sobre as casas de Marcel Breuer parece estar em sintonia com as casas de Eduardo de Almeida. Não por acaso, as casas binucleadas deste arquiteto sempre foram exemplos importantes nas suas aulas, na demonstração de uma arquitetura capaz de se pautar pela leitura dos usos, da resposta espacial adequada às características sugeridas pelo programa.

Além de estar vinculada a uma lógica de desenho decorrente do ideal de industrialização, a organização através de blocos funcionais também decorre das leituras dos programas como elementos importantes para o desenvolvimento inicial do projeto.

Antes de se pautar por um funcionalismo estrito - 'a forma segue a função' - podemos conceituar esta arquitetura como 'suporte', como a delimitação de um espaço capaz de abrigar as ações humanas em suas diversas atividades.

Convém reforçar que o próprio temperamento de Eduardo de Almeida faz com que o atendimento às solicitações dos clientes seja uma demanda a ser buscada, às vezes subvertida, mas sempre atendida à perfeição, de tal forma sintetizada no desenho da planta que a simples

Ao lado, perspectiva da residência na Praia da Baleia

Acervo Eduardo de Almeida mudança de uma porta poderia desequilibrar todo o arranjo, inviabilizando a solução desenhada.

${ }^{46}$ ARGAN, Giulio Carlo. Marcel Breuer in Projeto e Destino. São Paulo, Ática, 2001, p.288 
Tal equilíbrio parece sempre ser atingido pela organização do programa em setores, faixas comumente vinculadas ao próprio desenho da estrutura, como ressalta Luís Espallargas Gimenes:

E não seria equivocado afirmar que uma de suas primeiras preocupações, ao iniciar uma planta, seja a de estabelecer medidas estruturais que pautem os ritmos e decisões seguintes de compartimentação. (...) São constantes as malhas estruturais de intervalo variado que quase sempre servem para pautar zonas ordenadas com as partes semelhantes dos programa.(...) Dessa maneira ficam estabelecidas as formas que estruturam ambientes maiores e zonas com espaços menores que constroem a justaposição dos ambientes principais aos ambientes de serviço e, claro, as condições construtivas verticais do corte. ${ }^{47}$

Nas experiências de projeto que tivemos no escritório com Eduardo de Almeida, podemos relembrar que um dos primeiros e importantes passos sempre foi procurar compreender as demandas reais do programa, não só a listagem fornecida pelo cliente, mas também o próprio caráter que cada espaço ou setor do edifício deveria assumir.

Antes de ser uma leitura sistemática, processo empírico e intuitivo - por vezes desorganizado - o programa era lentamente incorporado ao projeto, ao desenho, já interpretado como forma arquitetônica, como esclarece Viollet-le-Duc acerca deste tema:

Digamos que um arquiteto tenha um edifício para construir; foi-lhe enviado um programa confuso (...), cabe a ele dar ordem a esta primeira matéria. Deve satisfazer às necessidades e aos serviços diversos; (...) em cada uma das partes deste programa, percebe um ponto principal e o faz sobressair; (...) Logo busca juntar estas partes estudadas separadamente, ele ainda está simplificando; (...) sente que a este corpo falta unidade, pode-se perceber as emendas, (...) de repente, acredita ter percebido em seu programa uma ideia principal, dominante (....). A luz se faz: em vez de começar seu projeto pelos detalhes para chegar à combinação do conjunto, inverte sua operação; vislumbrou o edifício, o modo em que os diversos serviços devem se submeter a uma disposição ampla, comum a todos. (...) Encontrada a ideia mãe, as ideias secundárias classificam-se por si mesmas e chegam no momento oportuno. ${ }^{48}$

${ }^{47}$ GIMENES, Luís Espallargas. O melhor detalhe é aquele que não se vê. in GUERRA, Abílio. Eduardo de Almeida. São Paulo, Romano Guerra, 2006, p.16

${ }^{48}$ VIOLLET-LE-DUC, E.E. . Entretiens sur L'Architecture. Bruxelas, Mardaga, 1977, p. 192. In MARTINEZ, Alfonso Corona. Ensaio sobre o Projeto. 
Podemos contrapor tal processo à metodologia empregada por Joaquim Guedes como professor de projeto na FAU USP, procedimento nem sempre seguido à risca por ele mesmo em seus muitos e variados projetos.

A proposta didática empreendida por Guedes se iniciava pelo estudo minucioso do programa, não só de cada ambiente e de cada área, mas também da melhor utilização do espaço para uma determinada função, incluindo aí o mobiliário e as circulações internas específicas, bem como o posicionamento das aberturas adequados a cada caso.

Somente após a realização destes estudos e da consolidação de um organograma funcional capaz de relacionar o conjunto dos ambientes e suas dimensões - denominado 'varal' - é que o enfrentamento do projeto efetivo poderia ser iniciado.

Para Eduardo de Almeida, ao contrário, os estudos cuidadosos do programa aparecem como um meio, como uma ferramenta de entendimento, e não como um fim neles mesmos na busca pela definição do projeto. Ao final, este entendimento do programa aparece sintetizado no dimensionamento preciso de cada ambiente, sempre acompanhado pelo desenho de mobiliário que ilustra a ocupação do espaço:

Outra maneira de entender a adesão moderna de seus projetos consiste em observar, nas plantas, o layout do mobiliário e equipamento dos ambientes. Correspondem à verificação que confirma a eficácia do processo conceptivo do arquiteto, a relação entre a forma e o uso. Não o uso entendido como função a cumprir, mas o uso estetizado pela forma irretocável e por seu ajuste perfeito às medidas e proporções. $O$ ajuste entre mobiliário e seus ambientes faz pensar na importância que essa confirmação tem para o arquiteto e nos tempos em que o mobiliário e seu desenho davam sentido e certeza à arquitetura (...). ${ }^{49}$ 

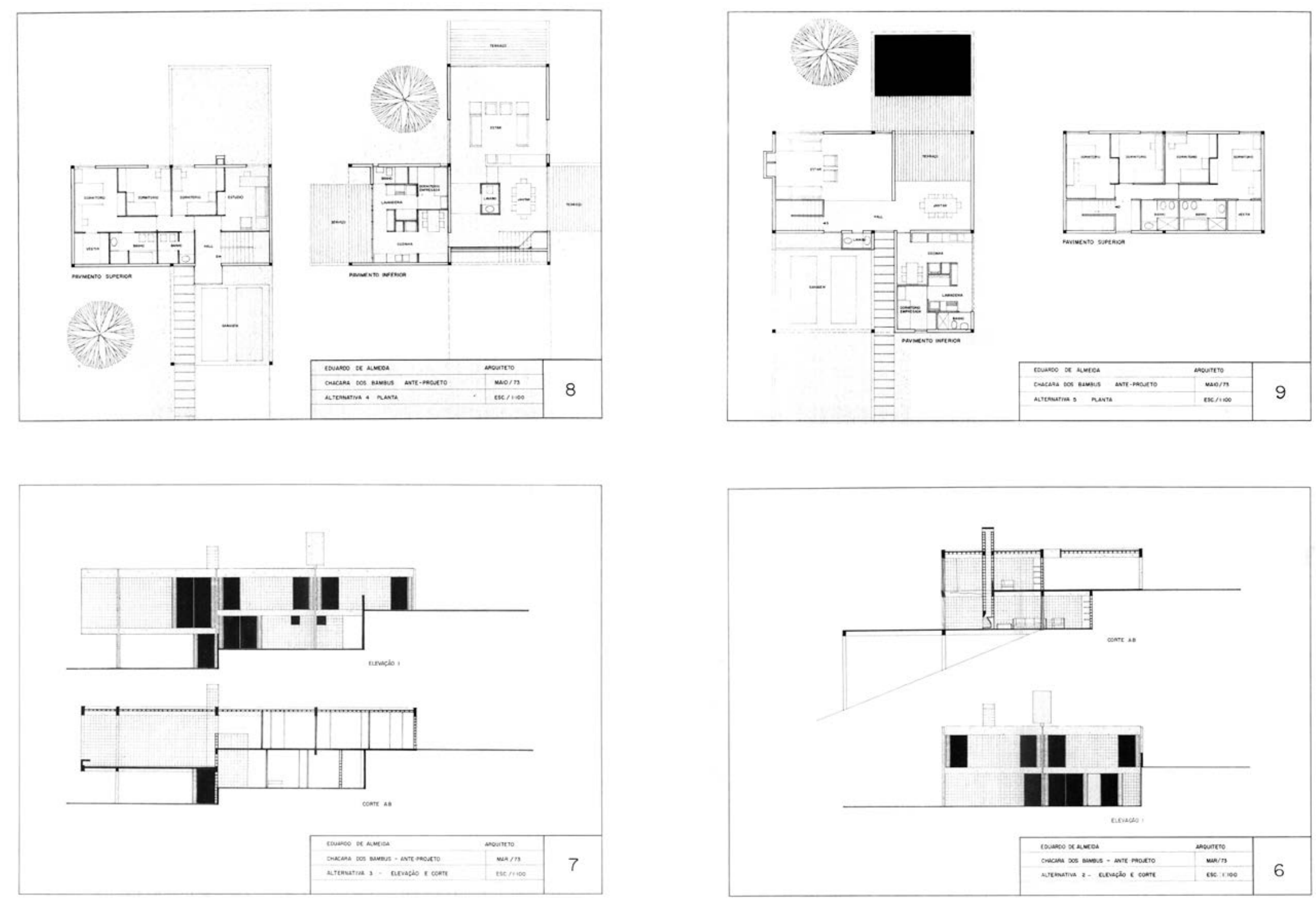

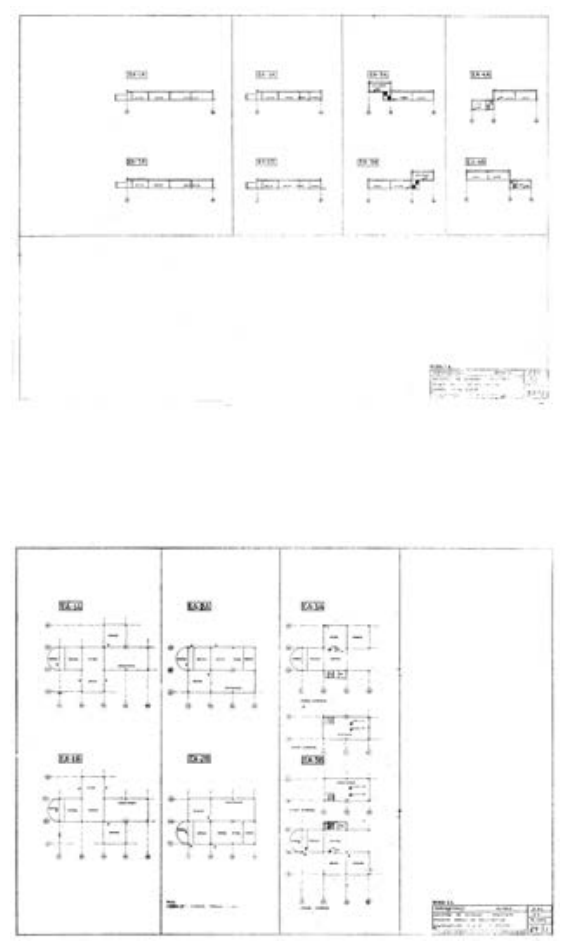

Projeto para as casas do Condomínio Pasárgada e esquemas com possibilidade de articulação de módulos

Acervo Eduardo de Almeida
A consistência atingida na sua obra, sobretudo na conjunção dos fatores ligados ao contexto brasileiro da industrialização, à consequente estratégia de justaposição de volumes e à resolução do programa de modo atento aos usos, parece se materializar claramente nos exemplos citados anteriormente.

No entanto, tais obras, vistas sob a ótica de processo, parecem se justificar por duas experiências extremamente importantes que, embora não construídas, reforçam os pressupostos que guiaram estes projetos realizados após a fase de Wright e Sérgio Bernardes até os primeiros anos da década de 1970.

A primeira se refere ao sistema de casas para o Condomínio Pasárgada, encomendado pela construtora Formaespaço em 1973. Seguindo um plano urbanístico desenhado por Fábio Penteado, a ideia era oferecer aos compradores projetos de diferentes arquitetos como Ennes Silveira Mello, Eduardo de Almeida, Paulo Mendes da Rocha, Fleury de Oliveira, além do próprio Fábio Penteado e seu sócio Teru Tamaki.

A proposta de Eduardo de Almeida, em sintonia com projetos da mesma época, como a casa para Jacob Kipnis, utiliza-se de um módulo estrutural quadrado de 6,4 metros de lado, de concreto armado moldado in loco, associado a vedações de bloco de concreto aparente ou fechamentos de vidro.

Sistema utilizado para criar três blocos básicos para serviços, dormitórios e ambientes de estar que, em conjunto com componentes padronizados para escada, lareira ou lavabo, poderiam ser agrupados de diferentes maneiras, permitindo arranjos diversos de acordo com as necessidades dos moradores ou de acordo com as características do terreno. Embora 


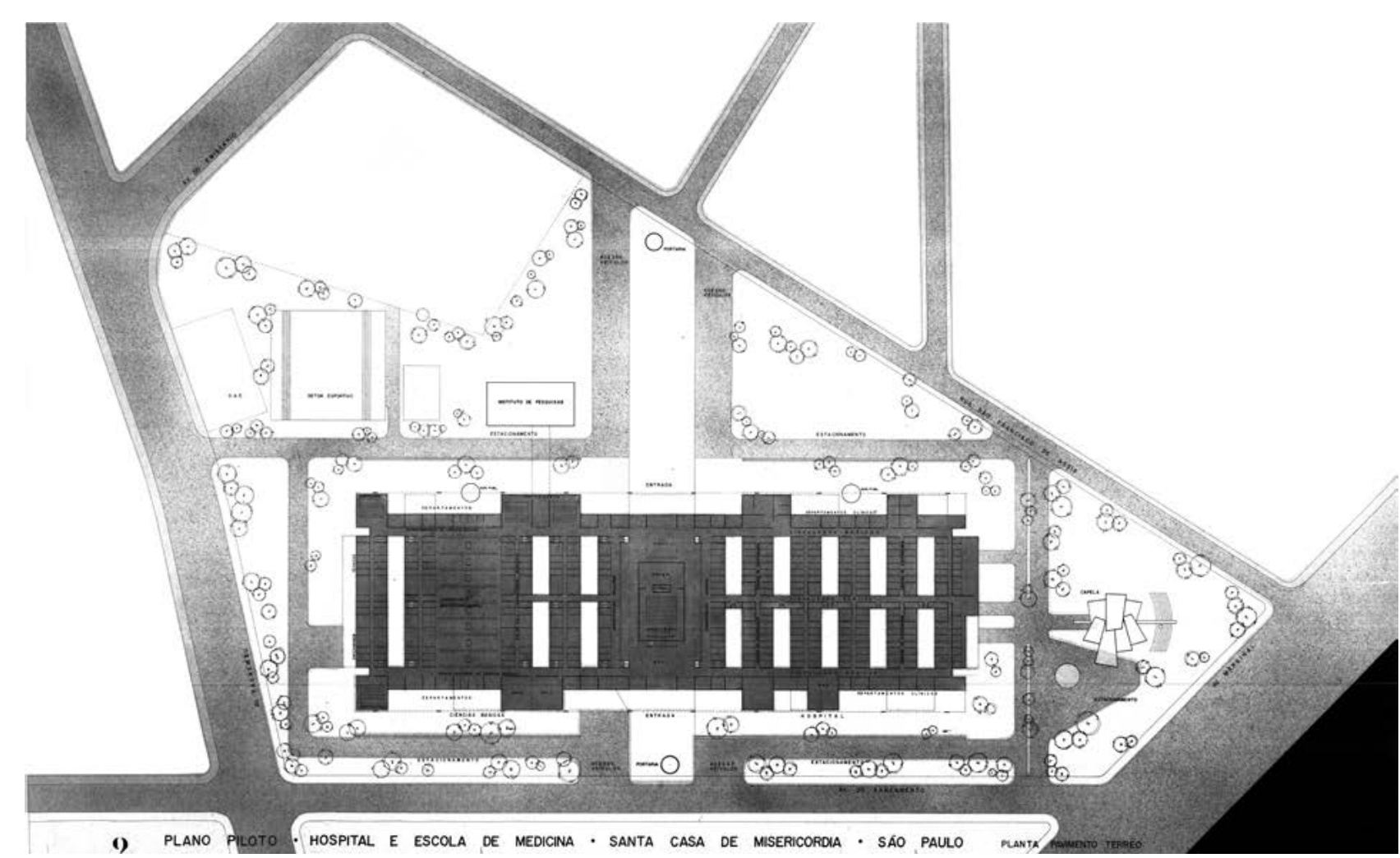

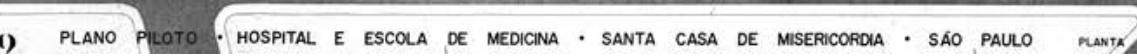

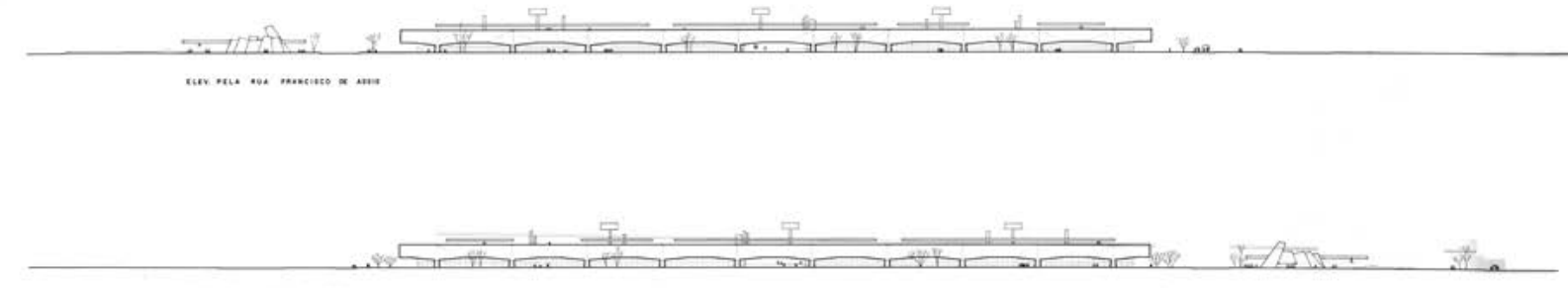

5 PLANO PILTTO . HOSPITAL E ESCOLA DE MEDICINA. SANTA CASA DE MISERICOROIA . SAO PAULO 


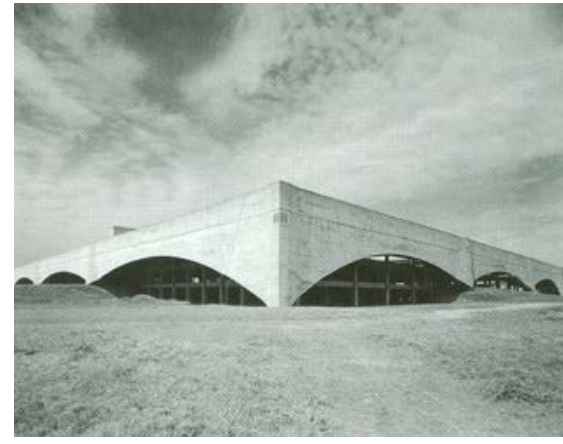

Hospital-Escola Júlio de Mesquita Filho CAMARGO, M. J.; LEMOS, J. A.; SULTANI, A. Fábio Penteado / Ensaios de Arquitetura. 1. ed. São Paulo, Empresa das Artes, 1998, p. 72
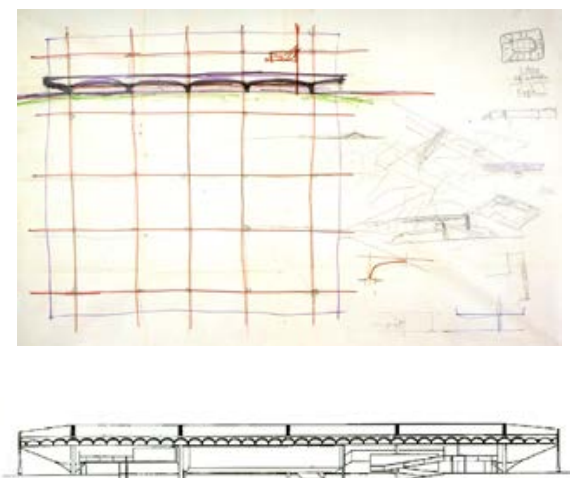

Croqui e corte da Escola Técnica de Santos, projeto feito em conjunto por Vilanova

Artigas, Fábio Penteado e Paulo Mendes da Rocha

FERRAZ, Marcelo (org.). Vilanova Artigas: Arquitetos Brasileiros. São Paulo, Instituto Lina Bo Bardi, 1997, p. 156

Ao lado, planta do térreo e cortes do Hospital Escola Santa Casa de Misericórdia

Acervo Eduardo de Almeida construído com sistemas convencionais, o princípio de repetição é patente e, do ponto de vista de projeto, propõe uma sistematização extremamente engenhosa que, apesar de muito simples, possibilita arranjos complexos a partir da justaposição dos diferentes volumes funcionais.

A convite da Santa Casa de Misericórdia, Eduardo de Almeida viaja, em 1968, para os Estados Unidos para conhecer a produção da arquitetura hospitalar daquele país, e projetar um Hospital Escola a ser implantado na Barra Funda, em equipe também composta por Fábio Penteado e Teru Tamaki.

O partido linear do anteprojeto nasce do estudo minucioso do programa e, coerente com suas investigações da época, do agrupamento de volumes funcionais ao longo de três linhas paralelas de circulação longitudinal, intercaladas por pátios de diferentes dimensões.

Segundo Eduardo de Almeida, tal solução partia da leitura funcional do edifício, mas também se ancorava na ideia de construção por etapas, já que havia limitação de recursos por parte dos clientes para a realização de todo o empreendimento.

Durante o processo de desenvolvimento do projeto, surge um novo partido defendido por Fábio Penteado, certamente influenciado por seu projeto para a Escola Técnica de Santos, realizado no mesmo ano em conjunto com Vilanova Artigas e Paulo Mendes da Rocha. Nesta proposta, a organização volumétrica e funcional do anteprojeto serve de base para um partido que, a despeito de sua organização por meio de pavilhões, apresenta uma volumetria exterior única, destacando a presença marcante de quatro empenas de concreto armado aparente, desenhadas pela sequência de três arcos, cada um com 68 metros de vão. 
Eduardo de Almeida se retira silenciosamente, como convém à sua personalidade, mas talvez também por respeito às opiniões de um arquiteto importante e experiente como Fábio Penteado.

Se por um lado, em seus depoimentos, ficam claras as dificuldades iniciais de suas dúvidas em relação a um caminho ou outro, por outro lado podemos afirmar que Eduardo de Almeida parece ter clareza do que não deseja fazer e de quais caminhos não pretende percorrer. A não participação na continuidade do projeto enfatiza o posicionamento do arquiteto diante de seus ideais.

De qualquer modo, a estratégia projetual empregada nos projetos para o Hospital Escola da Santa Casa de Misericórdia ou para o sistema de casas do Condomínio Pasárgada parece ser recorrentemente utilizada em projetos posteriores, ao longo de diferentes etapas de sua carreira.

Não por acaso, nos diversos projetos para edificações escolares - idealizados sob a lógica dos catálogos de ambientes e componentes -, ou até mesmo nos projetos de inúmeras casas, aplicam-se princípios de organização a partir da justaposição modular e funcional, sempre afeitos a uma produção pautada pelo rigor técnico e pelo anseio aos procedimentos técnicos da industrialização. Conforme esclarece Hetzberger:

Um edifício, mas também parte de um edifício, explica a si mesmo ao mostrar como funciona e para que serve. Tentamos tornar cada elemento claramente legível isoladamente e em sua relação com os outros, tornando-o dessa maneira não apenas parte de uma estrutura maior, como também de um todo autônomo. Assim os detalhes podem reivindicar uma prioridade completa onde é importante: neste aspecto, não há muita diferença em comparação com a abordagem do edifício como um todo. $O$ todo e as partes se definem mutuamente e requerem o mesmo grau de atenção. ${ }^{50}$

${ }^{50}$ HERTZBERGER, Herman. Lições de Arquitetura. São Paulo, Martins Fontes, 1999, p242. 


\section{Parte e todo}



É difícil fazer arquitetura. Pois o ato de projetar exige atenção constante em relação à realidade e uma sutil sabedoria na manipulação das relações entre as necessidades do homem e a construção do espaço. Compreender o contexto, interpretar as relações sociais, desenhar formas, dominar a técnica, integrar as partes ao todo, ajustar proporções são desafios cotidianos que cada projeto nos propõem..$^{51}$

A obra de Eduardo de Almeida é reconhecida pela síntese que seus projetos apresentam ao responder, em igual importância, a questões tão amplas quanto o atendimento ao programa, a definição dos espaços necessários a um determinado edifício, o emprego adequado e oportuno dos sistemas construtivos e o respeito ao contexto ao qual se destinam.

Esta síntese, conforme inúmeros depoimentos do arquiteto, só é atingida por meio de um exaustivo processo de criação não linear que vai, pouco a pouco, definindo o caráter de uma arquitetura em função das ambivalências das questões pertinentes a cada caso, e não do uso de imagens predeterminadas ou soluções definidas a priori.

Talvez por este motivo, sua obra apresente grande diversidade formal e seus projetos adotem soluções variadas com estruturas em concreto armado, madeira ou aço - para ficarmos em apenas um aspecto construtivo - sem deixar de apresentar um desenvolvimento consoante com o partido geral adotado, e também com os pormenores que surgem sistemicamente encadeados ao conjunto.

Em trabalhos mais significativos, o projeto é desenvolvido em função da construção e, independentemente da técnica construtiva escolhida, a forma é definida em respeito à natureza dos materiais e, portanto, a partir de uma relação direta entre o meio e o fim, entre a parte e o todo: uma vez concluída, pode-se compreender como se articulam seus elementos constituintes, como ela foi projetada e construída.

${ }^{51}$ Depoimento de Eduardo de Almeida in PADOVANO, Bruno. Arquitetos Brasileiros. São Paulo, ASBEA, sem data. Publicação decorrente de uma exposição de arquitetura brasileira organizada por esta instituição. 


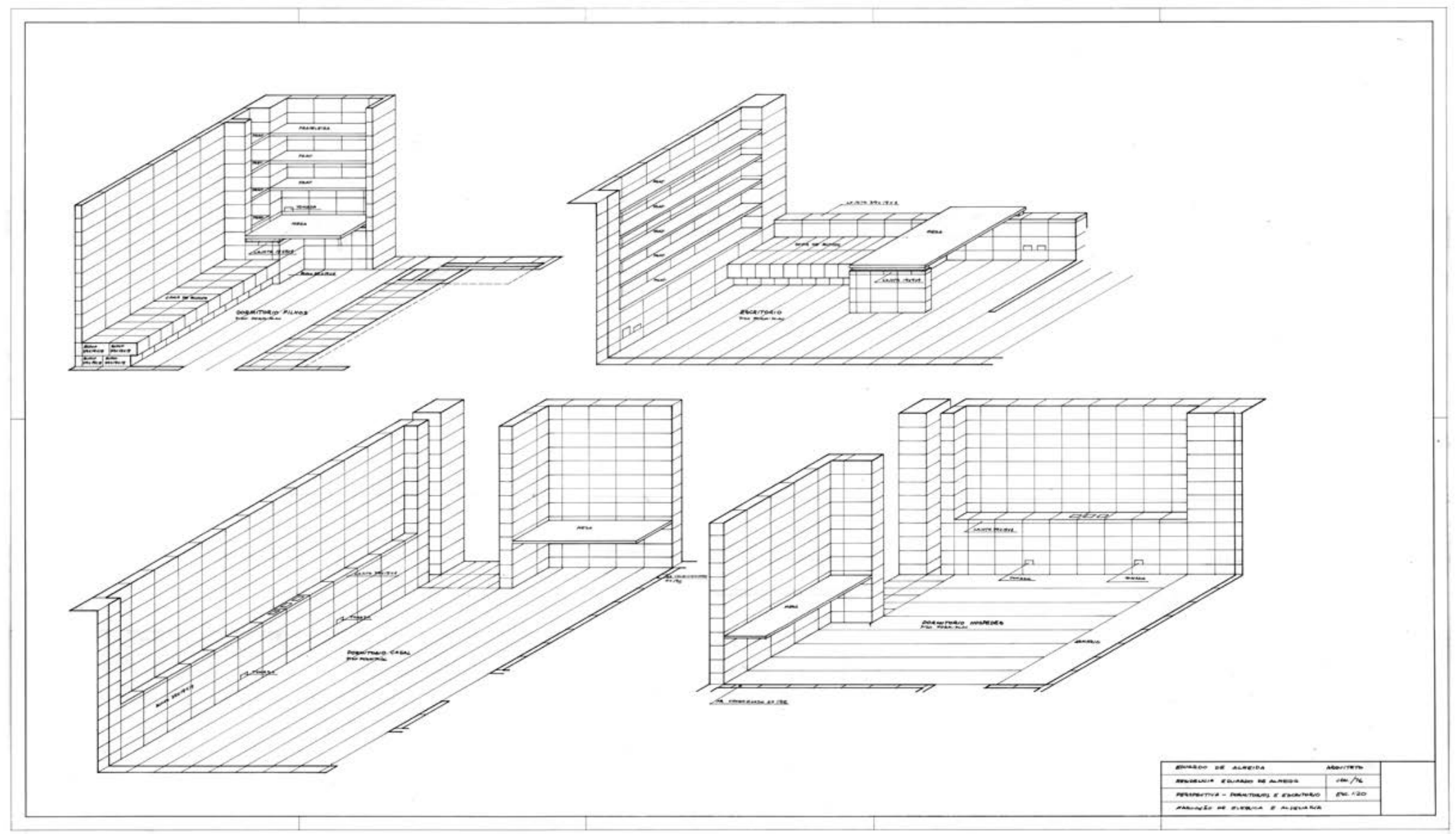

Residência da rua Carangola: perspectivas axonométricas do mobiliário

Acervo Eduardo de Almeida 


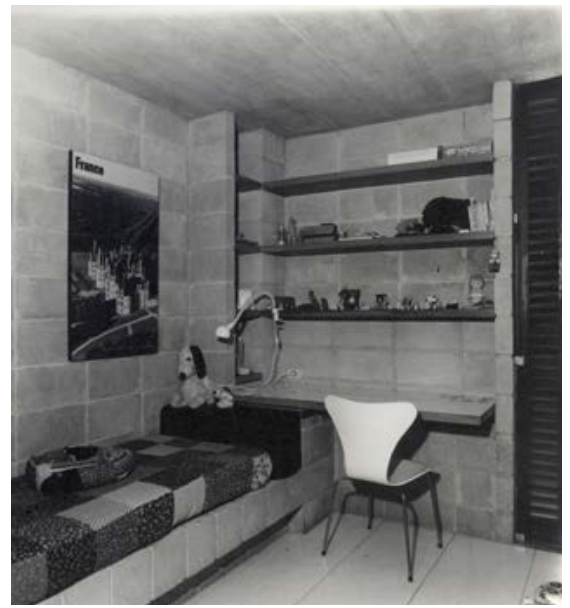

Residência da rua Carangola: mobiliário do dormitório dos filhos realizados com bloco de concreto aparente

Acervo Eduardo de Almeida

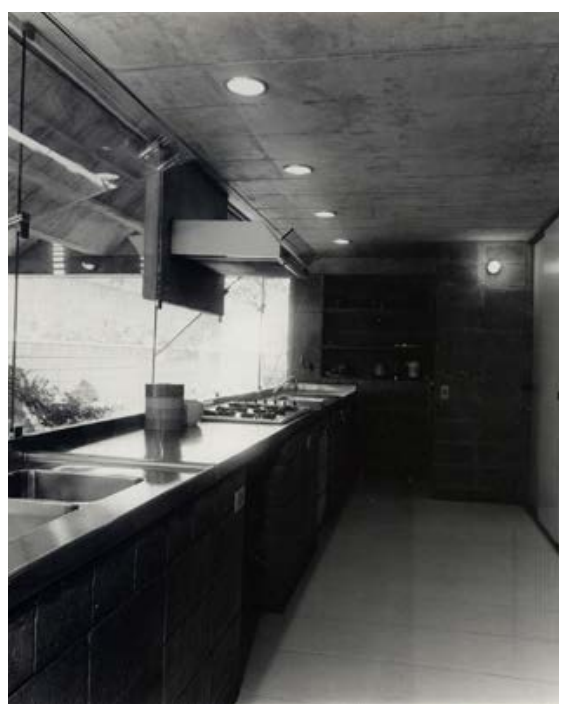

Cozinha da Residência da rua Carangola Acervo Eduardo de Almeida
Talvez o exemplo mais contundente acerca desta questão seja o projeto para sua própria residência, situada na rua Carangola, no Jardim Guedala em São Paulo, construída em 1976 a partir de uma solução onde todos os espaços que definem o edifício foram desenhados ou dimensionados em função de um único elemento construtivo: o bloco de concreto.

Nesta casa, tudo parte da rigorosa coordenação modular do elemento construtivo na definição de todos os ambientes que a compõem, sem a utilização de uma única peça seccionada. 0 raciocínio construtivo é respeitado a tal ponto que todas as alvenarias prescindem de revestimentos ou de qualquer outro tipo de acabamento, expondo a materialidade do bloco de concreto e o desenho regular das juntas a prumo.

Como consequência, os demais elementos construtivos - venezianas de alumínio, fechamentos em vidro temperado, formas das lajes e acabamentos dos pisos - bem como o mobiliário incorporado à arquitetura, seguem a rigorosa modulação.

No conjunto de desenhos do projeto executivo, a síntese entre o projeto de arquitetura e sua integração com os equipamentos e mobiliário fica evidente: perspectivas axonométricas, plantas, cortes e detalhes demonstram controle absoluto do projeto, viabilizando a construção dos ambientes, incluindo o desenho de armários, bancadas, nichos, sofás e camas. Mesmo os elementos de caráter técnico, as dependências de serviços ou áreas úmidas - como o cavalete de entrada de água e energia junto ao acesso, a cozinha e todos os sanitários - são projetados e construídos com os mesmos blocos de concreto que definem a obra como um todo.

Além do módulo básico de $39 \mathrm{~cm} \times 19 \mathrm{~cm} \times 19 \mathrm{~cm}$, a realização do projeto em todos os seus detalhes necessitou a utilização de blocos de outras dimensões já presentes no catálogo do 

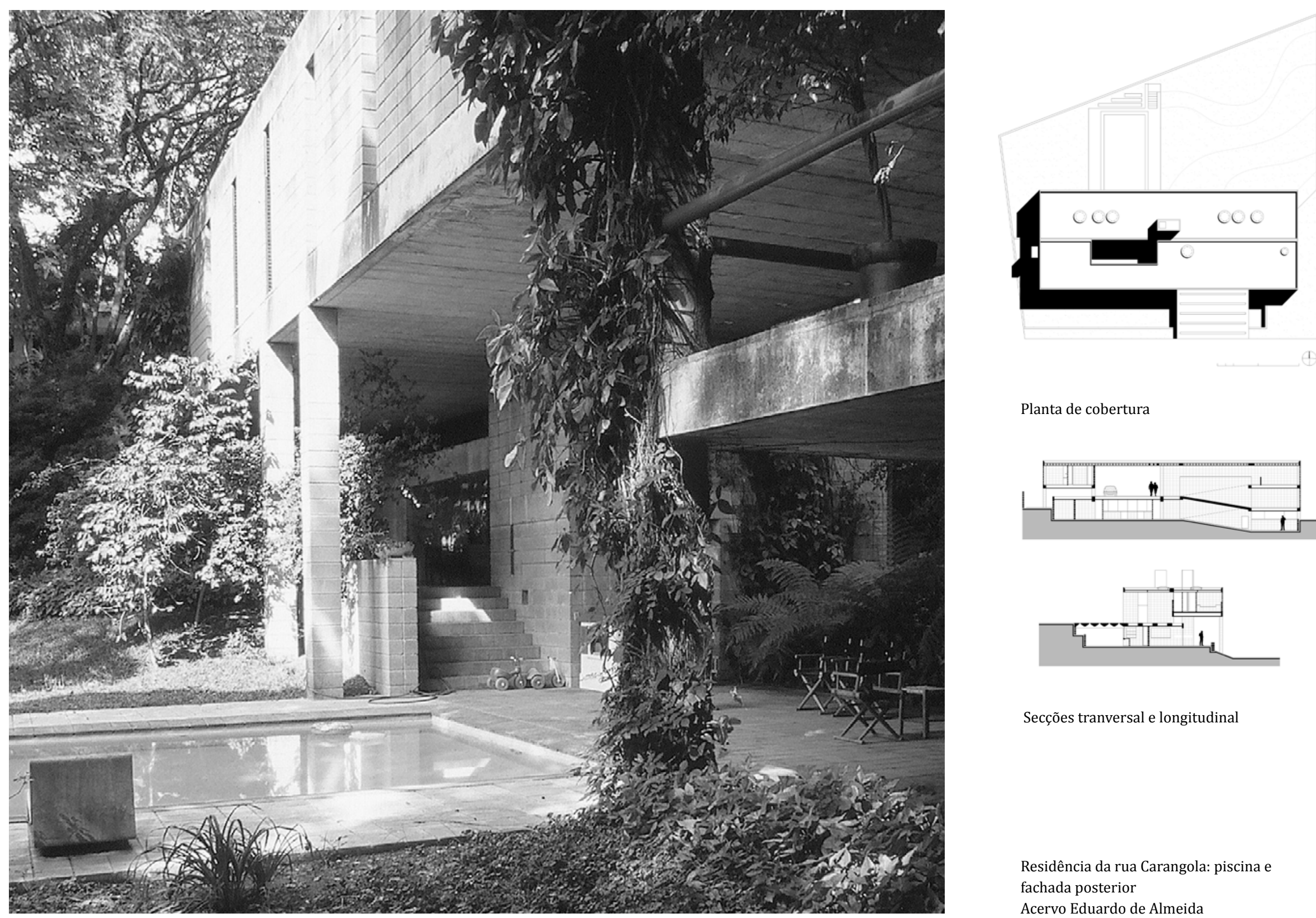

Planta de cobertura

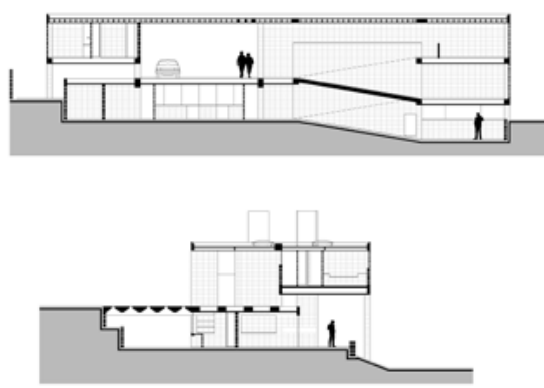

Secções tranversal e longitudinal

Residência da rua Carangola: piscina e fachada posterior

Acervo Eduardo de Almeida 

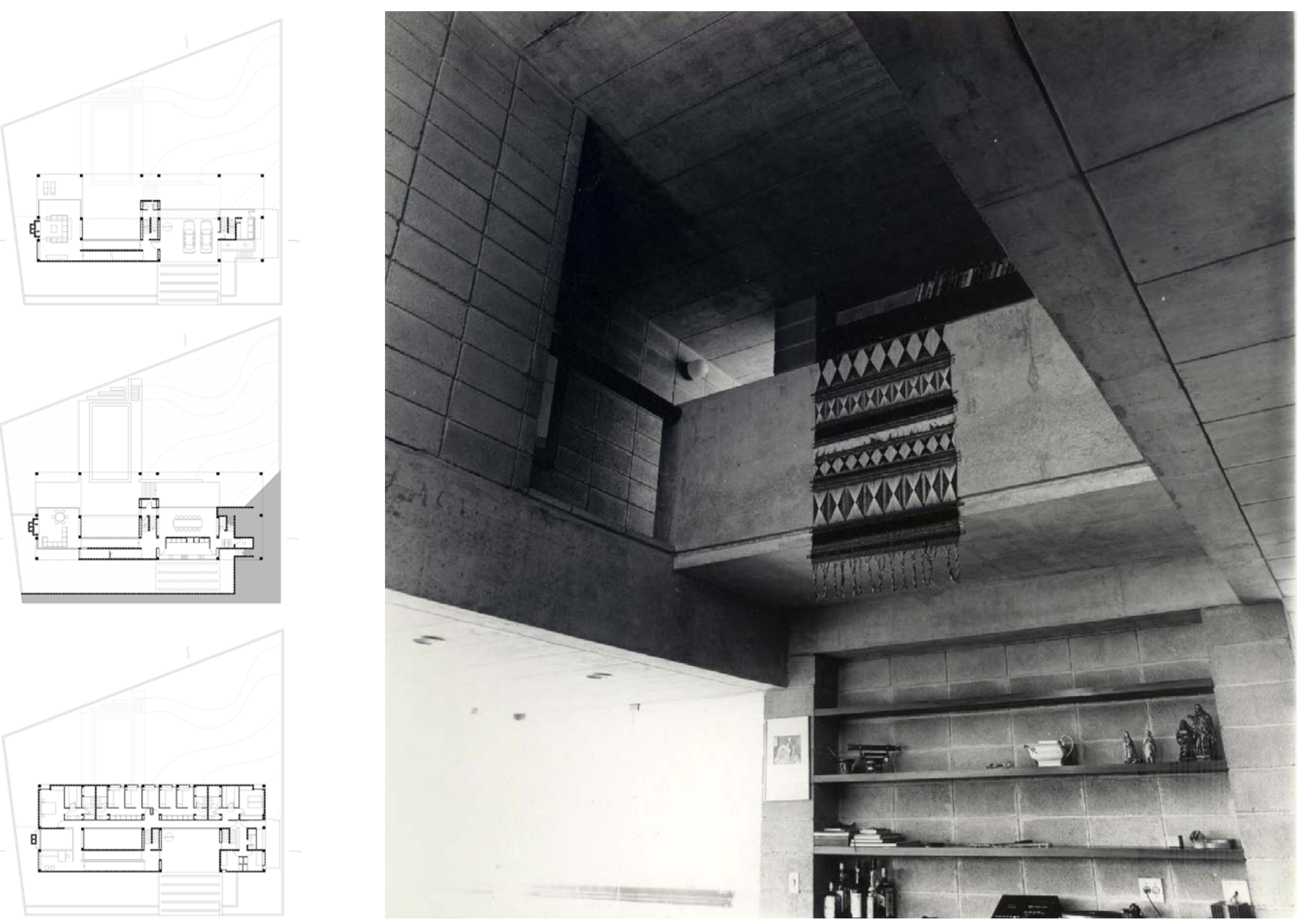

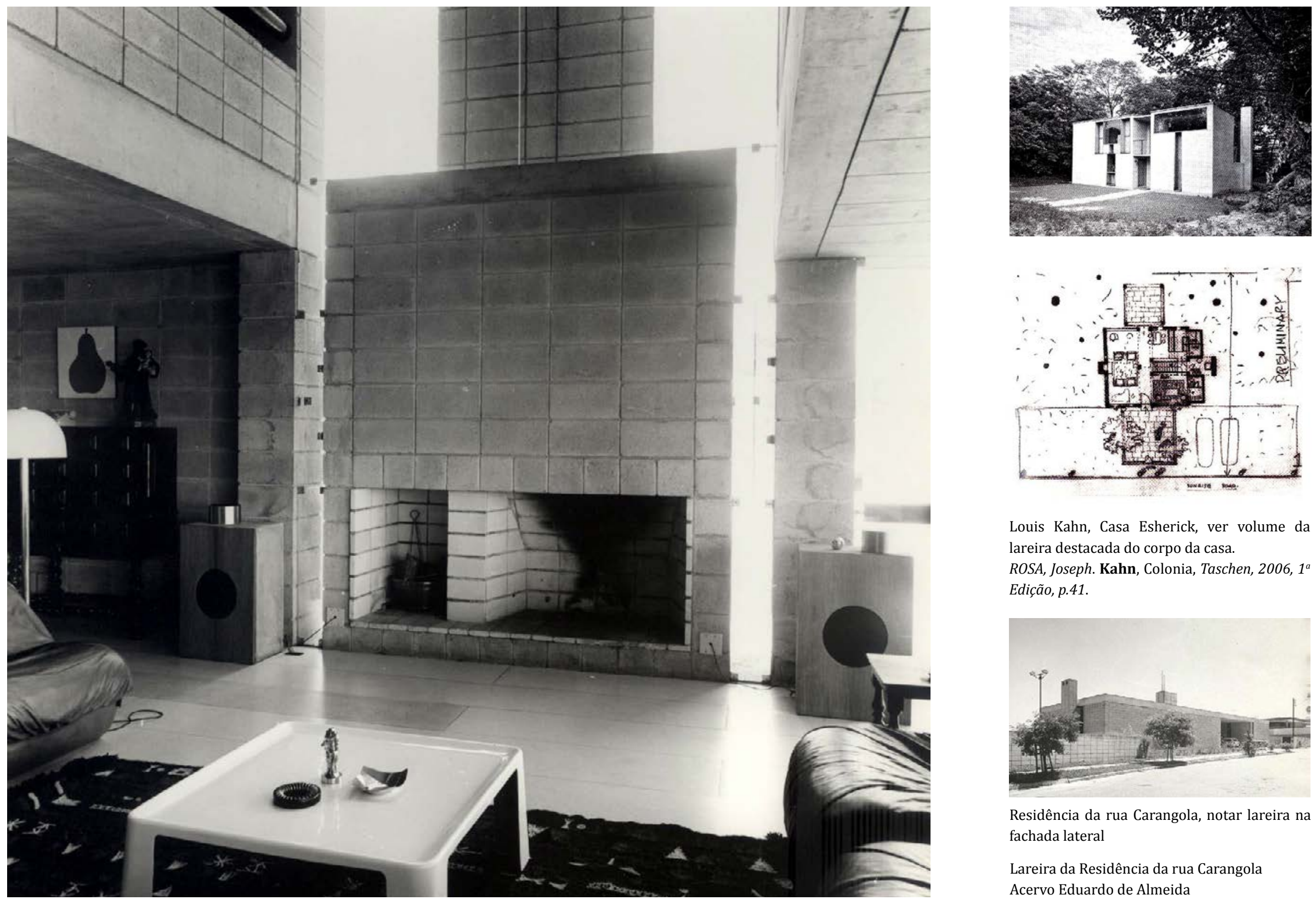

Louis Kahn, Casa Esherick, ver volume da lareira destacada do corpo da casa.

ROSA, Joseph. Kahn, Colonia, Taschen, 2006, $1^{a}$ Edição, p.41.

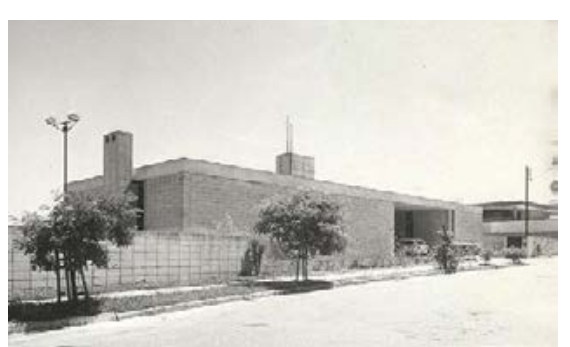

Residência da rua Carangola, notar lareira na fachada lateral

Lareira da Residência da rua Carangola Acervo Eduardo de Almeida 


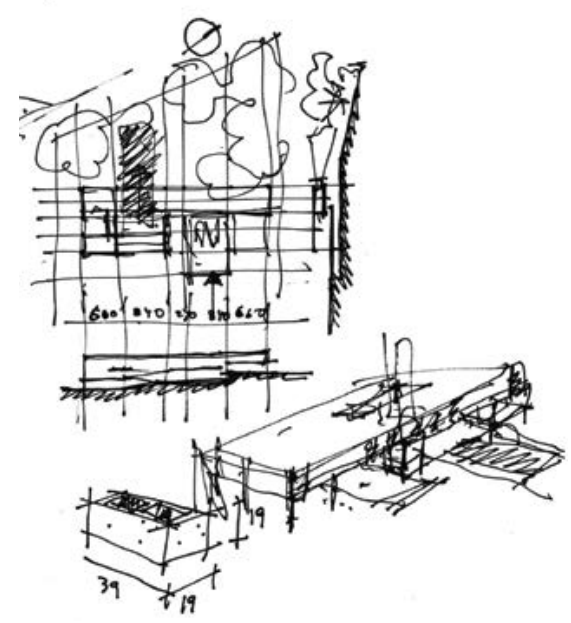

Croquis da Residência da rua Carangola realizados para o livro de Helio Piñon

Acervo Eduardo de Almeida fornecedor, exigindo ainda, no caso específico dos pilares, a fabricação de peças quadradas especiais de $39 \mathrm{~cm} \times 39 \mathrm{~cm} \times 19 \mathrm{~cm}$ que permitiram a montagem da estrutura primária com a sobreposição de um único elemento, facilitando a montagem das armações internas dos pilares e evitando sua composição com blocos menores, como revelam as tentativas presentes no anteprojeto.

O conjunto de duas lareiras sobrepostas nas salas de estar também foi totalmente construído com blocos de concreto, ainda que seu desenho sofra a influência de uma solução apresentada por Louis Kahn para a casa Escherick, onde o duto da chaminé percorre externamente o volume da casa, solta da fachada, mas totalmente visível no interior da casa por conta da utilização de um plano de vidro de grandes dimensões.

Todas as aberturas que definem a transição entre o espaço interno e o exterior são vedadas com panos de vidro temperado - solução recorrente nas obras de Eduardo e de outros arquitetos deste período - possibilitando a maior transparência possível entre os espaços pela ausência de batentes ou qualquer tipo de requadramento nas folhas que compõem portas e janelas.

Estas placas de vidro temperado foram posicionadas lado a lado com junta seca, fixadas ou movimentadas por ferragens de aço inox presentes nos catálogos dos fornecedores, com exceção do detalhe de fixação do plano de vidro posicionado ao lado da rampa, voltada ao jardim interno.

Na ausência de um sistema adequado a este caso, com a colaboração de José Antônio Seixas, Eduardo de Almeida desenvolveu um fechamento com uma paginação composta por peças trapezoidais unidas por uma ferragem - criada a partir da associação de um 


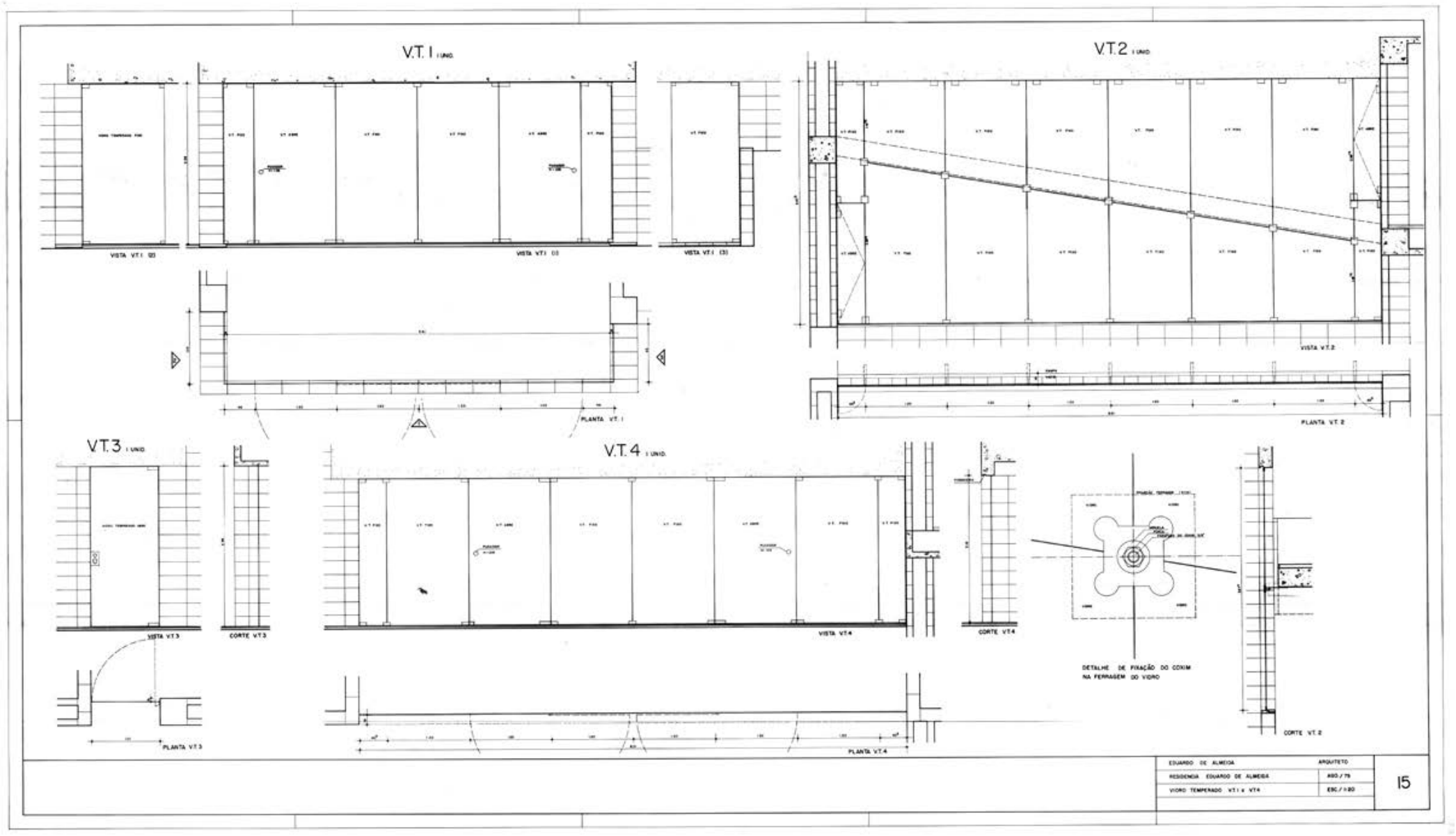




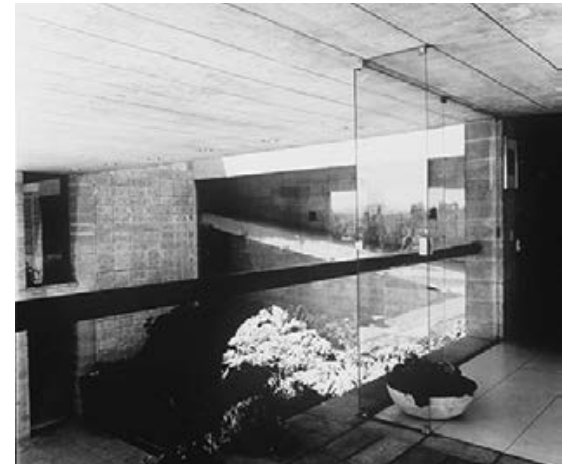

Residência da Rua Carangola - vista a partir do terraço. Jardim interno e fechamento de vidro das rampas. Notar guarda-corpo de tubo metálico.
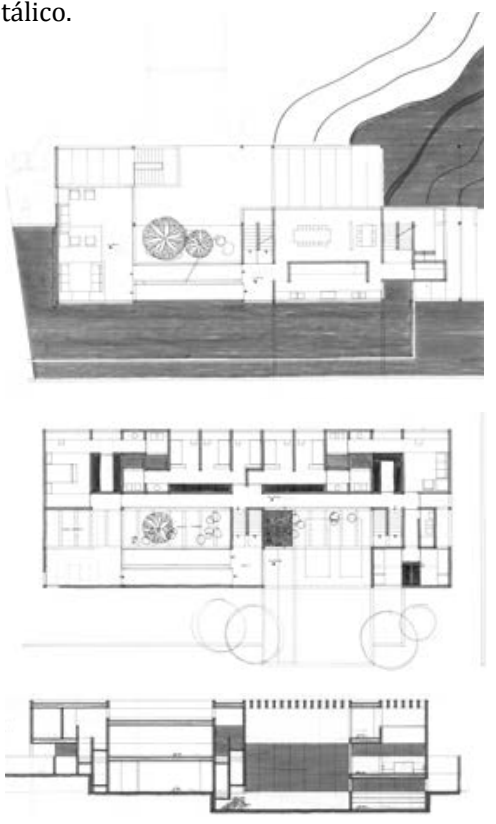

Anteprojeto e pormenores do projeto executivo (à direita) - detalhes dos painéis de vidro da Residência da Rua Carangola. Acervo Eduardo de Almeida braço metálico com um coxim ${ }^{52}$ - capaz de fixar os quatro vértices das placas de vidro às rampas e permitindo a estabilidade do conjunto, mesmo com a vibração natural desta estrutura.

Outros elementos que exigiram atenção mas foram resolvidos com extrema simplicidade são os guarda-corpos dos terraços e dos vazios internos, solucionados a partir da instalação de uma única barra horizontal a 90cm do chão. Construída com tubos de aço de 4" de diâmetro, a mesma peça foi projetada para vãos variados - de $111 \mathrm{~cm}$ a $541 \mathrm{~cm}$ - e fixada por um detalhe capaz de absorver pequenas variações de obra, ao mesmo tempo em que cria um hiato justamente no encontro entre a parede e a peça metálica onde se conectam as barras chatas em 'macho e fêmea' por meio de parafusos e porcas sextavadas.

Ao resgatar os desenhos anteriores àqueles realizados para a execução da obra, pode-se identificar que todo o partido já estava definido antes mesmo de se optar pelo emprego generalizado do bloco de concreto.

Tal constatação é revelada pelo anteprojeto desenhado com canetas hidrográficas coloridas, a exemplo dos estudos e projetos executivos realizados no período da parceria com Sérgio Bernardes em São Paulo. Sem a representação dos blocos de concreto nas plantas, cortes e elevações, a configuração é bastante próxima daquela finalmente construída, incluindo a implantação do volume no terreno e seus acessos, a distribuição do programa pelos diversos pavimentos, a circulação em meios-níveis organizada por rampas e escadas e a modulação da estrutura primária.

${ }^{52}$ Elemento de borracha adaptada de uma peça automotiva. No projeto aparece uma chamada especificando uma peça de Fusca (Volkswagen Sedan). Mas, segundo depoimento do arquiteto, a peça finalmente utilizada foi a de um Ford Corcel. 

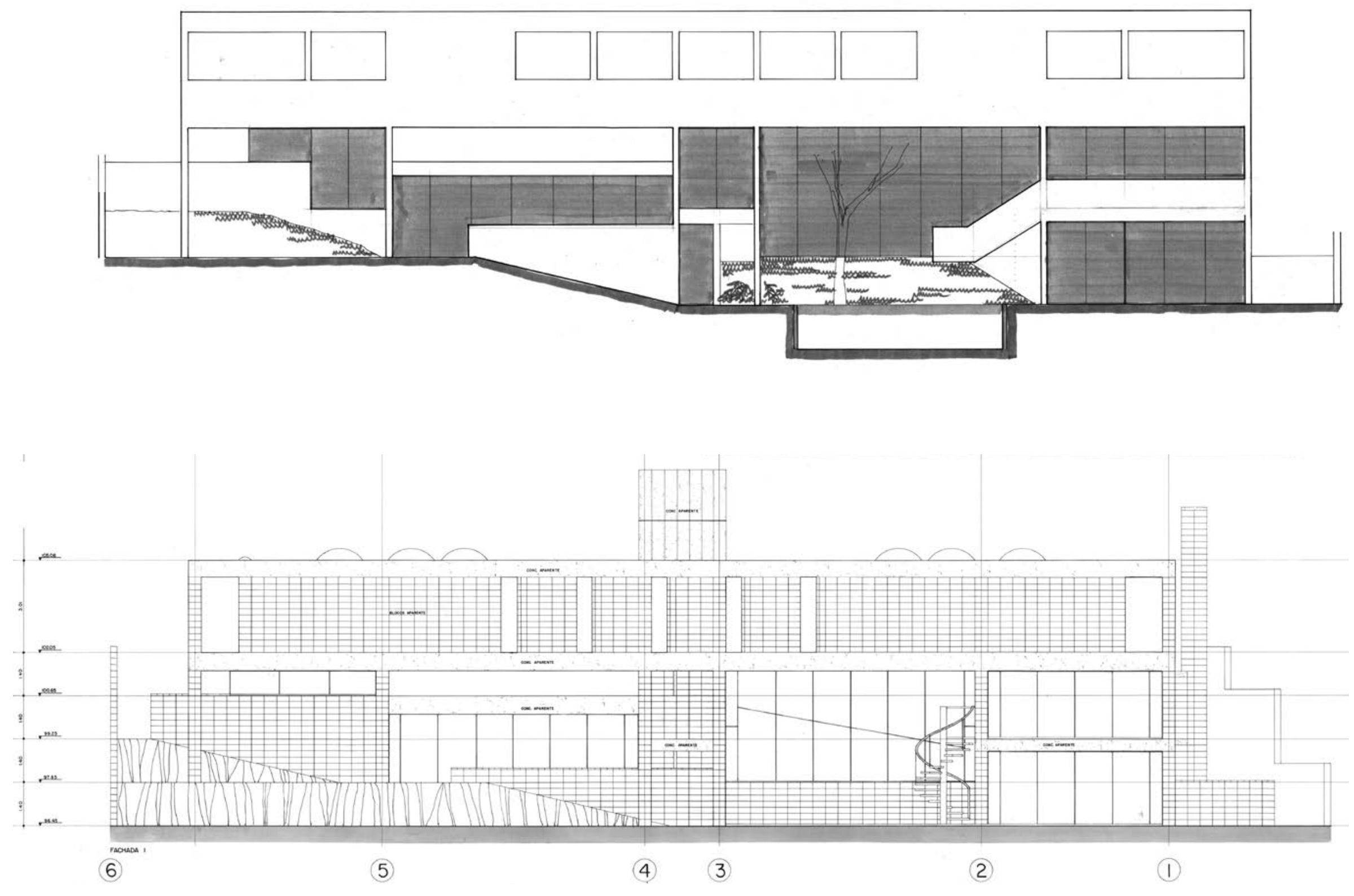


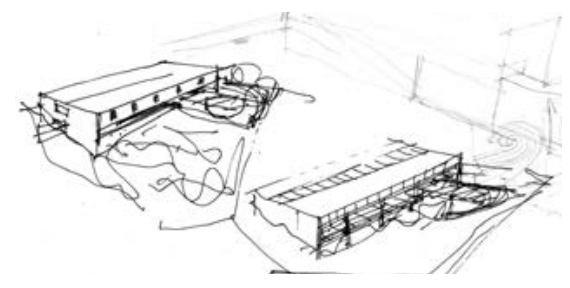

Croquis de estudos, elevação posterior da Residência da Rua Carangola

Ao lado, anteprojeto e projeto executivo da Residência da rua Carangola

Elevação posterior, notar aberturas das janelas dos dormitórios e escada entre terraço e

piscin

Acervo Eduardo de Almeida
Neste sentido, é necessário reiterar a importância do todo no desenvolvimento de suas partes, pois o fato de eleger as questões decorrentes da adoção de um determinado sistema construtivo como tema deste capítulo, não pode retirar a importância do partido arquitetônico adotado pelo arquiteto, tanto no aproveitamento da topografia quanto na organização funcional da casa, considerando os cuidados necessários com a proteção às intempéries, mas também à fluidez de sua circulação, articulando passarelas às rampas e escadas pensadas como um percurso espacial através dos ambientes internos e externos.

Uma das únicas diferenças em relação ao projeto executivo final é a presença de uma escada em dois lances, posicionada entre o terraço elevado da sala e o piso da piscina - posteriormente substituída por outra metálica helicoidal no projeto executivo, mas efetivamente nunca construída - e pela organização interna dos sanitários dos dormitórios, mesmo sendo posicionados exatamente nos pontos previstos pelo anteprojeto.

Outro desenho significativo nesta versão é a elevação posterior da casa, tanto por apresentar o desenho da escada externa, quanto por revelar as aberturas retangulares das janelas dos quartos, uma espécie de desenho de transição entre a solução final do projeto e a janela em fita representada pela perspectiva axonométrica do estudo preliminar deste projeto.

Em meio a uma folha repleta de croquis, pode-se identificar alguns estudos que revelam tentativas e dúvidas referentes à solução a ser adotada para estas aberturas: ora representadas como uma abertura linear - talvez como uma varanda - ora representadas como aberturas pontuais na fachada.

Talvez os desenhos mais representativos sobre esta questão sejam as duas elevações perspectivadas que incorporam a modulação dos blocos em junta à prumo. Estes desenhos a 


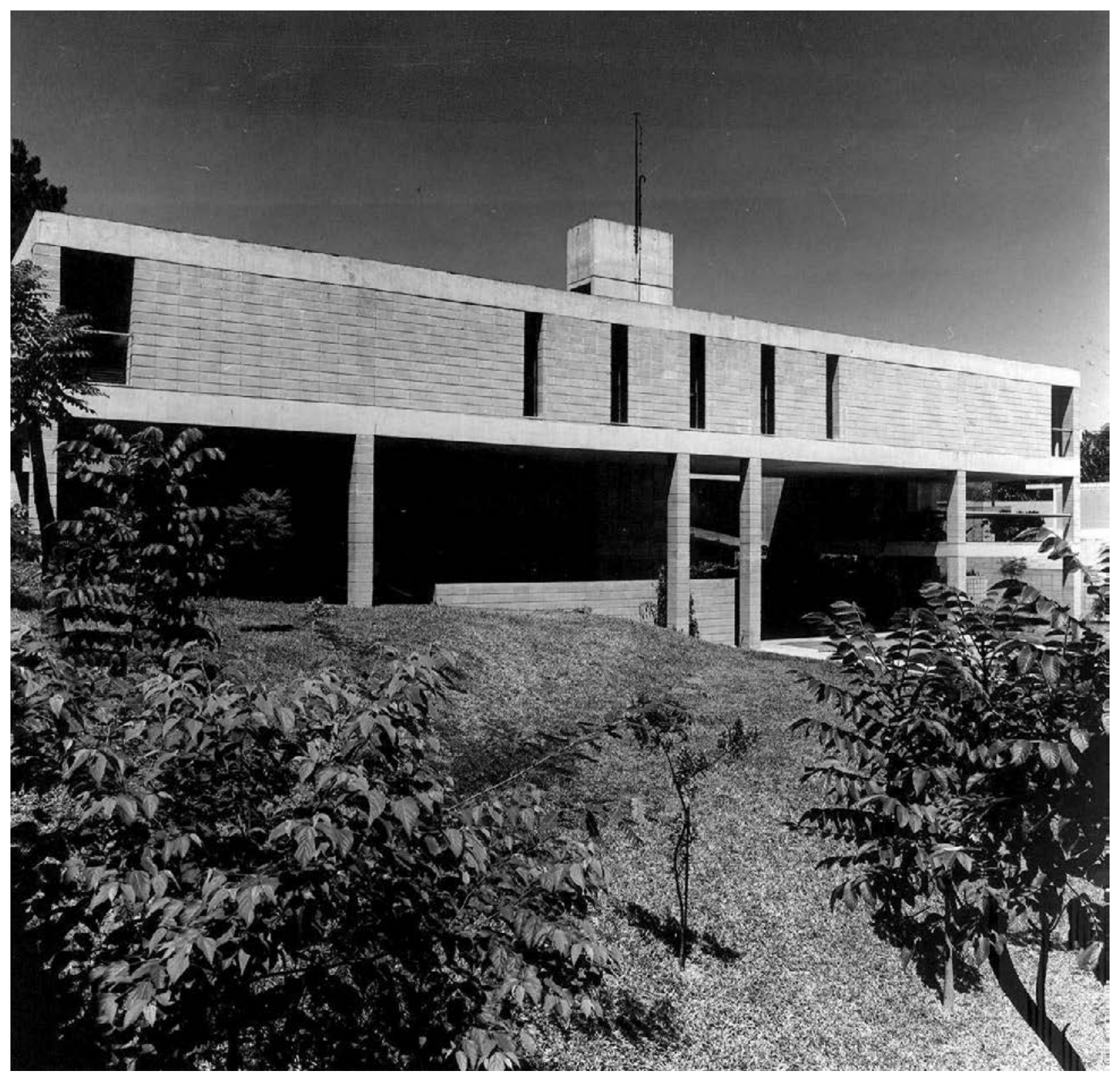

Residência da rua Carangola: elevação

posterior. Notar volume elevado dos

dormitórios e estrutura de pilares periféricos,

ambientes envidraçados recuados em relação

ao plano da fachada

Acervo Eduardo de Almeida 


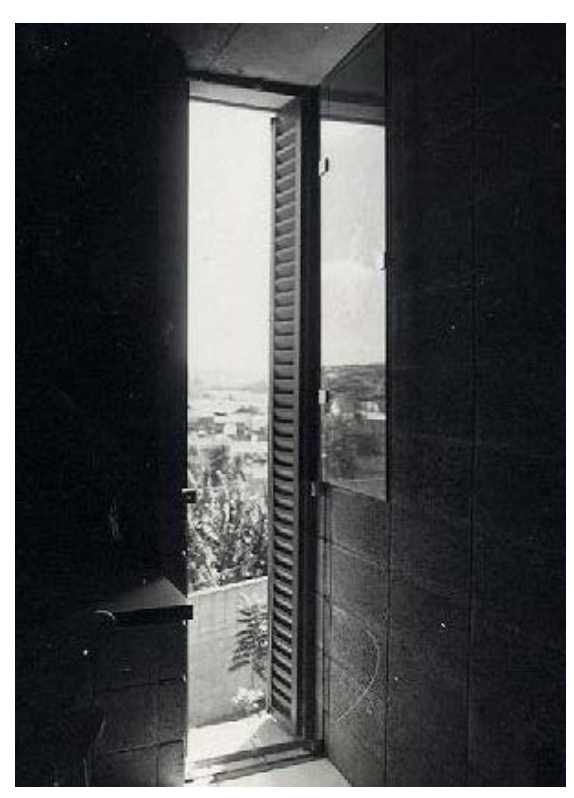

Janelas dos dormitórios. Acervo Eduardo de Almeida

Anteprojeto - Elevações Perspectivadas, notar presença dos blocos de concreto e modificação no desenho das janelas proposta para o dormitório do casal

Acervo Eduardo de Almeida lápis apresentam as mesmas aberturas retangulares dos dormitórios presentes anteriormente, ao mesmo tempo em que revelam duas aberturas verticais de piso a teto no dormitório do casal. Tal solução é reproduzida também na fachada frontal, nas aberturas dos dois dormitórios de serviços que apresentam configuração próxima à da solução final.

Este desenho nos revela que a solução dada às aberturas da fachada dos dormitórios surge a partir da adoção do sistema construtivo que define o volume, seguido pelo procedimento de supressão de algumas fiadas verticais de blocos de concreto para configurar a abertura de cada quarto.

Esta oposição entre o cheio e o vazio é reforçada pelo posicionamento das venezianas de alumínio, recuadas em relação ao plano da fachada e pintadas de preto, enfatizando o contraste entre luz e sombra. 0 detalhamento destas janelas permite que as folhas dos caixilhos, quando abertas, posicionem-se perpendicularmente à fachada, alinhadas às alvenarias que desenham os nichos das bancadas dos dormitórios, além de propiciar a necessária proteção à insolação ou à chuva.

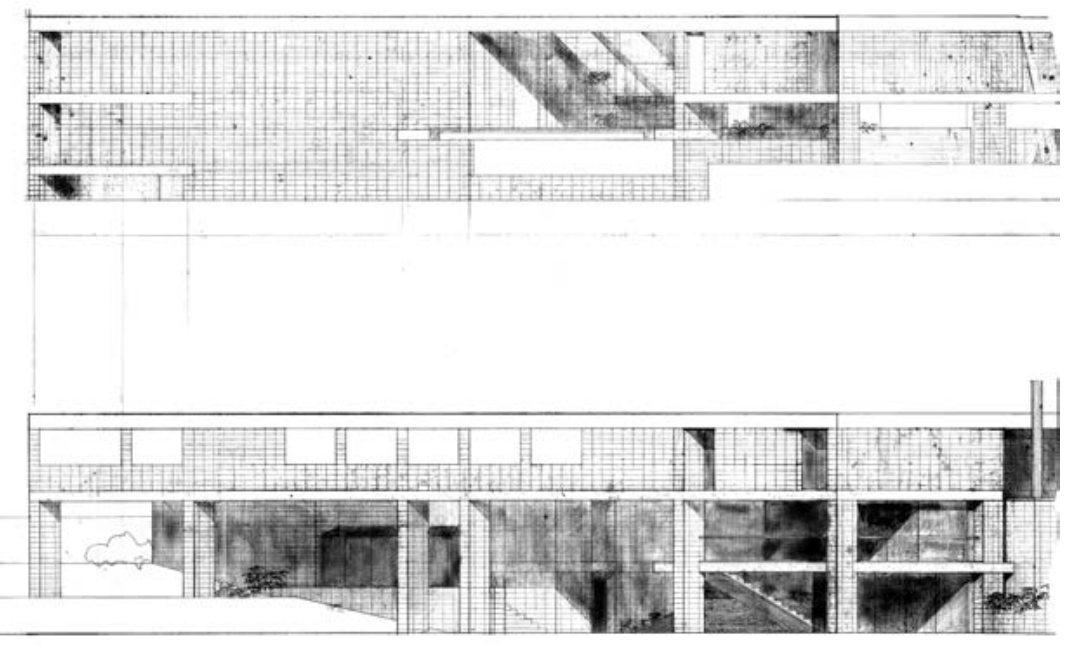




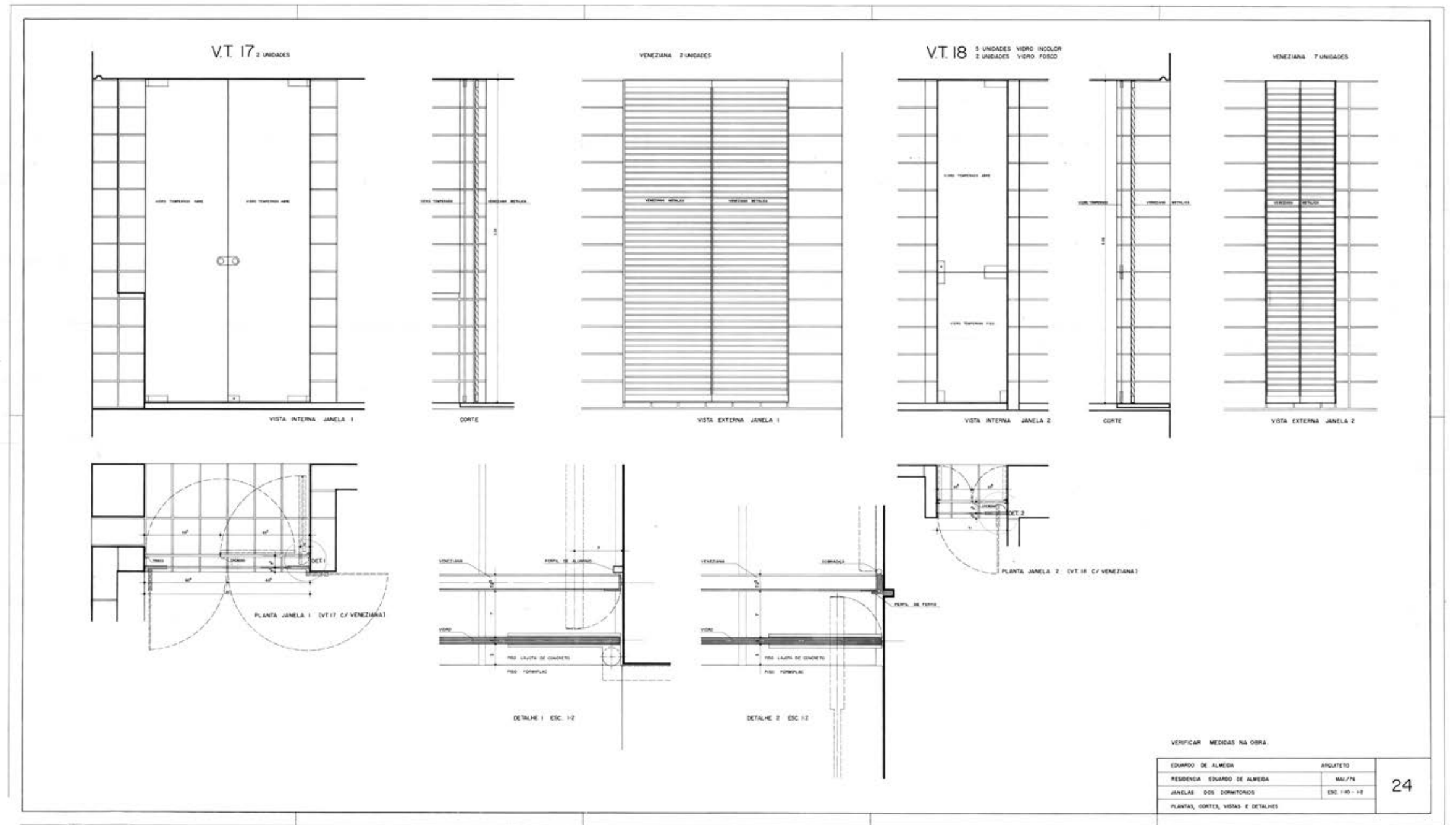

Prancha do Projeto Executivo da Residência Carangola: detalhamento das venezianas de alumínio

Ao lado, fachada posterior da Residência Carangola

Foto: Nelson Kon 


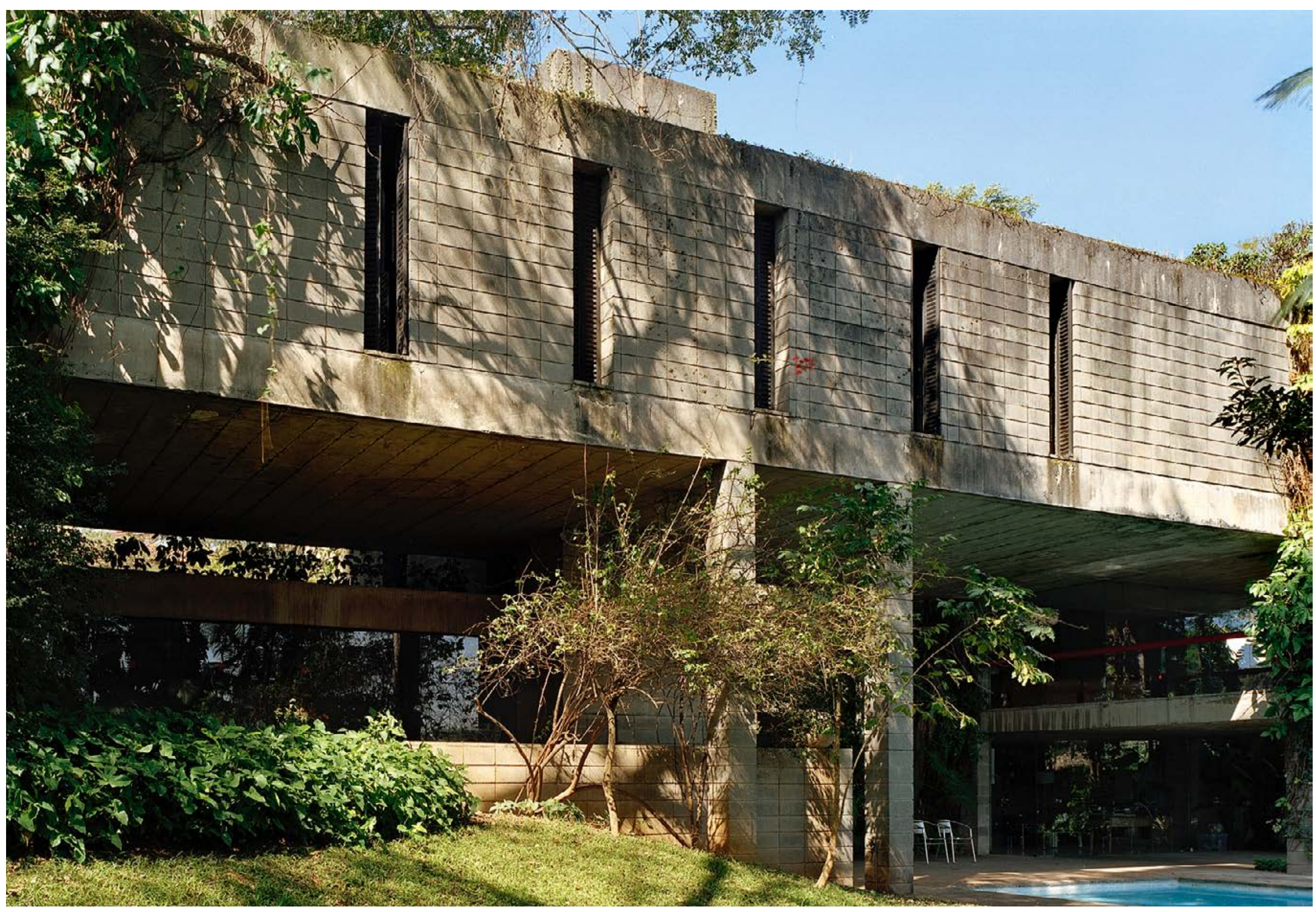



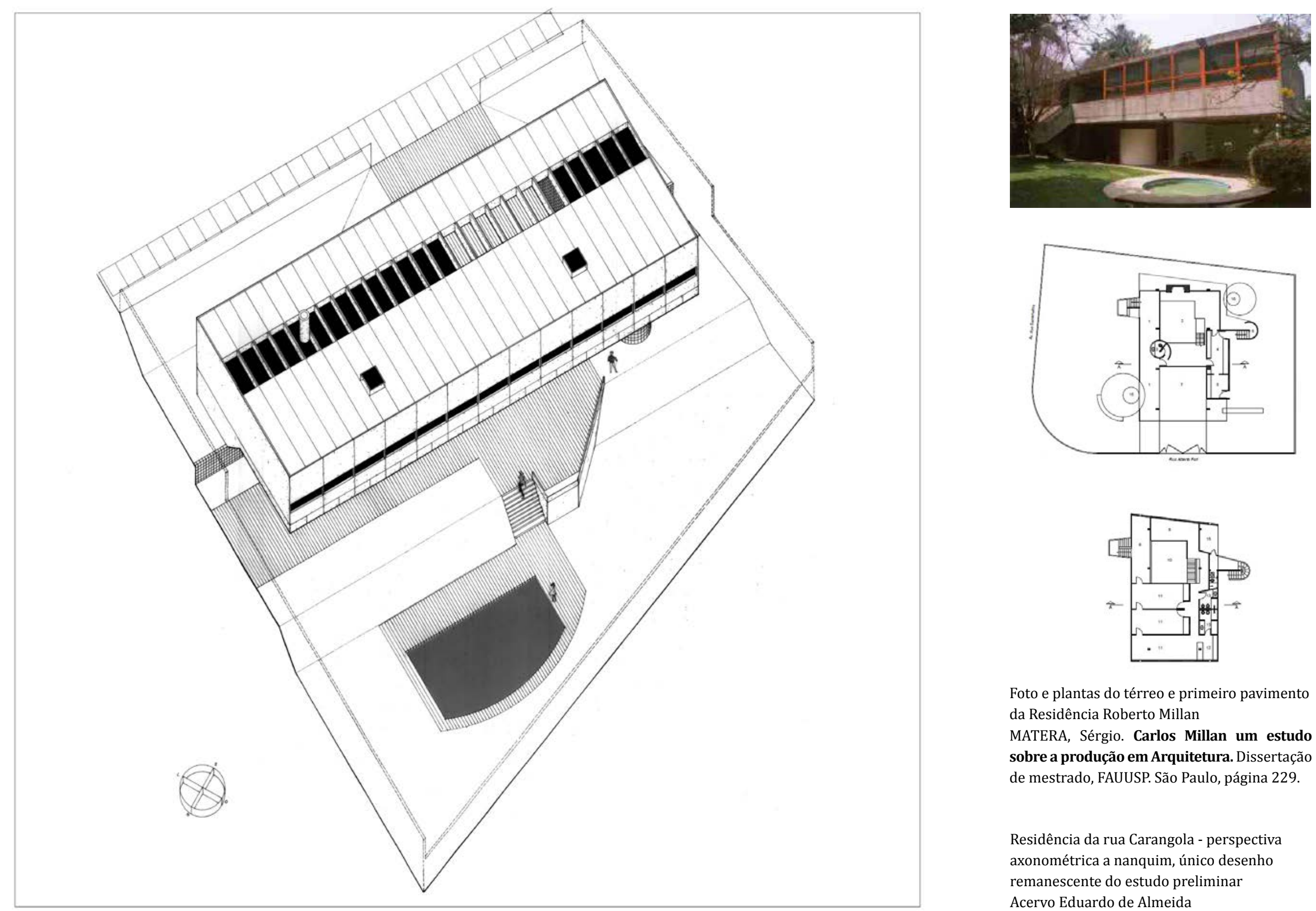

Foto e plantas do térreo e primeiro pavimento da Residência Roberto Millan

MATERA, Sérgio. Carlos Millan um estudo sobre a produção em Arquitetura. Dissertação de mestrado, FAUUSP. São Paulo, página 229.

Residência da rua Carangola - perspectiva axonométrica a nanquim, único desenho

remanescente do estudo preliminar Acervo Eduardo de Almeida 


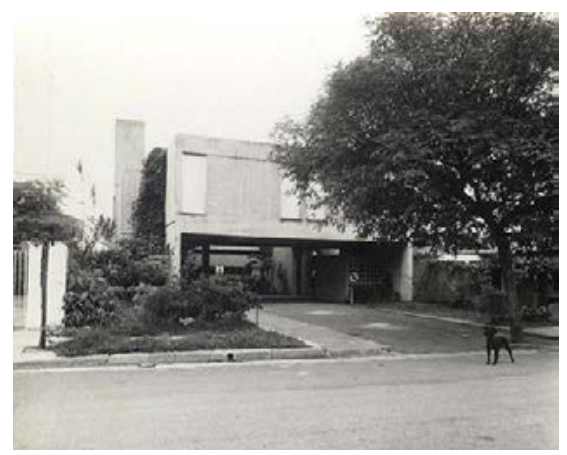

Residência Jacob Kipnis - notar janelas verticais de piso a teto.

Acervo Eduardo de Almeida

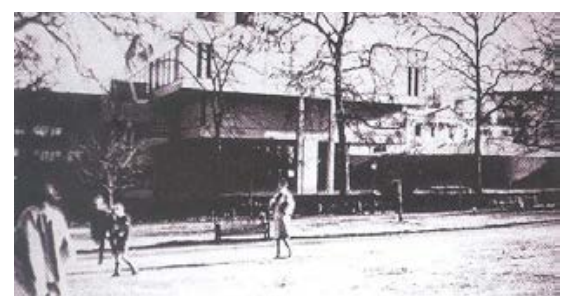

Royal College of Physicians em Londres, arquiteto Denys Lasdun

IMBRONITO, Maria Isabel. Procedimento de Projeto com base em retículas - Estudo de Casas de Eduardo de Almeida. São Paulo, Universidade de São Paulo: Tese de Doutorado apresentada à FAUUSP, 2008.

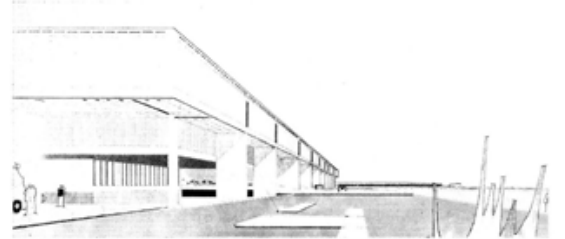

Perspectiva para o concurso Secretária da Agricultura de São Paulo

Revista Acrópole, №357, dez/1968
Tal solução de fachada reitera outros projetos de Eduardo de Almeida como a casa Kipnis, projetada e construída sete anos antes, utilizando também um sistema de blocos de concreto e janelas verticais de piso a teto (apesar de o plano de veneziana não estar recuado), conforme afirma Maria Isabel Imbronito em sua Tese de Doutoramento. ${ }^{53}$

Neste mesmo trabalho, é revelada uma possível coincidência formal com o edifício de Denys Lasdun para o Royal College of Physicians em Londres (1959) ${ }^{54}$, projeto destinado a outro uso e para uma escala absolutamente diversa, mas que nos remete a um estudo de Eduardo de Almeida para a Secretaria de Agricultura de São Paulo em 1968, premiado em segundo lugar e que também apresenta um volume maciço entrecortado por aberturas verticais e suspenso por pilares de pé-direito duplo, elementos de contraponto à horizontalidade do plano da fachada.

De acordo com uma perspectiva axonométrica a nanquim, único desenho remanescente do estudo preliminar, o projeto aproxima-se da linguagem corrente utilizada em uma série de projetos realizados em São Paulo neste período.

Ao propor um volume suspenso maciço para os dormitórios sobre uma área de estar envidraçada, Eduardo de Almeida aproxima-se de projetos de Carlos Millan, como a casa construída para seu irmão Roberto, que possui essa mesma volumetria, com a adoção de uma janela em fita - livre da interferência da estrutura - e de painéis pré-fabricados na fachada.

Neste estudo é possível identificar uma modulação que organiza todo o projeto e que determina as dimensões de todos os seus elementos construtivos, expressa pelo alinhamento rigoroso entre a estrutura das pérgolas, os montantes dos caixilhos e a modulação dos painéis

${ }^{53}$ IMBRONITO, Maria Isabel. Tese de Doutoramento: Procedimento de projeto com base em retículas: estudo de casas de Eduardo de Almeida. São Paulo, FAU USP, 2008, p. 98

${ }^{54}$ Idem, p. 134 


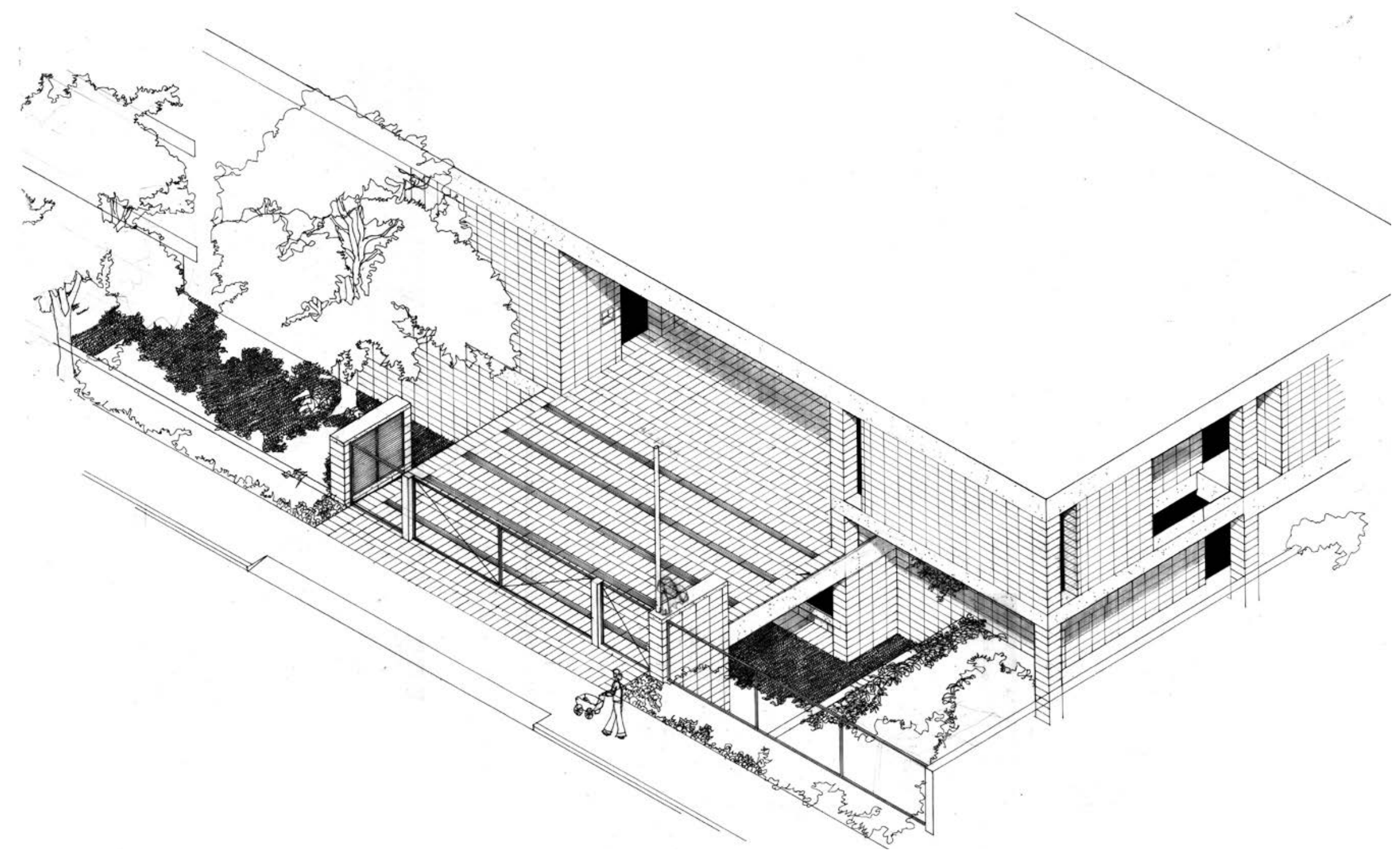


pré-fabricados da fachada. A única menção à utilização dos blocos de concreto está em um volume curvo localizado no pavimento térreo, sob o volume dos dormitórios, reafirmando a influência da casa Roberto Millan.

Apesar da diferença de linguagem entre este estudo e o projeto final, podemos afirmar que a solução não só apresenta a mesma ocupação no lote, como revela semelhança no partido de distribuição do programa pela existência de uma pérgola contínua que atravessa longitudinalmente todo o volume.

Este elemento, presente também no anteprojeto, parece posicionado sobre o jardim interno ao lado das rampas, onde também se localizam as escadas, o vazio da sala de estar e a parte posterior da garagem que, neste estudo inicial, aparece posicionada no lado esquerdo da fachada frontal, espelhada em relação à solução final.

Mais do que o espelhamento do projeto - procedimento que coincidentemente acontece em outras obras de Eduardo durante seu processo de concepção - podemos dizer que a transformação maior entre o estudo preliminar e o anteprojeto é a afirmação do volume maciço e elevado dos dormitórios, mas sem a necessidade de valorizá-lo por meio de balanços e pilares recuados. Ao contrário, os pilares de dupla altura são dispostos simetricamente ao volume da casa, seguindo os eixos transversais de $6.00 \mathrm{~m}, 8.40 \mathrm{~m}$ e $2.40 \mathrm{~m}$, posicionados junto à face do plano da fachada, mesmo aqueles existentes nas extremidades do volume.

Esta modificação parece substituir uma linguagem mais palatável e recorrente - um volume suspenso sobre uma caixa envidraçada - por uma solução incomum, aparentemente desproporcional, ainda a ser descoberta durante o processo de desenvolvimento do projeto. 

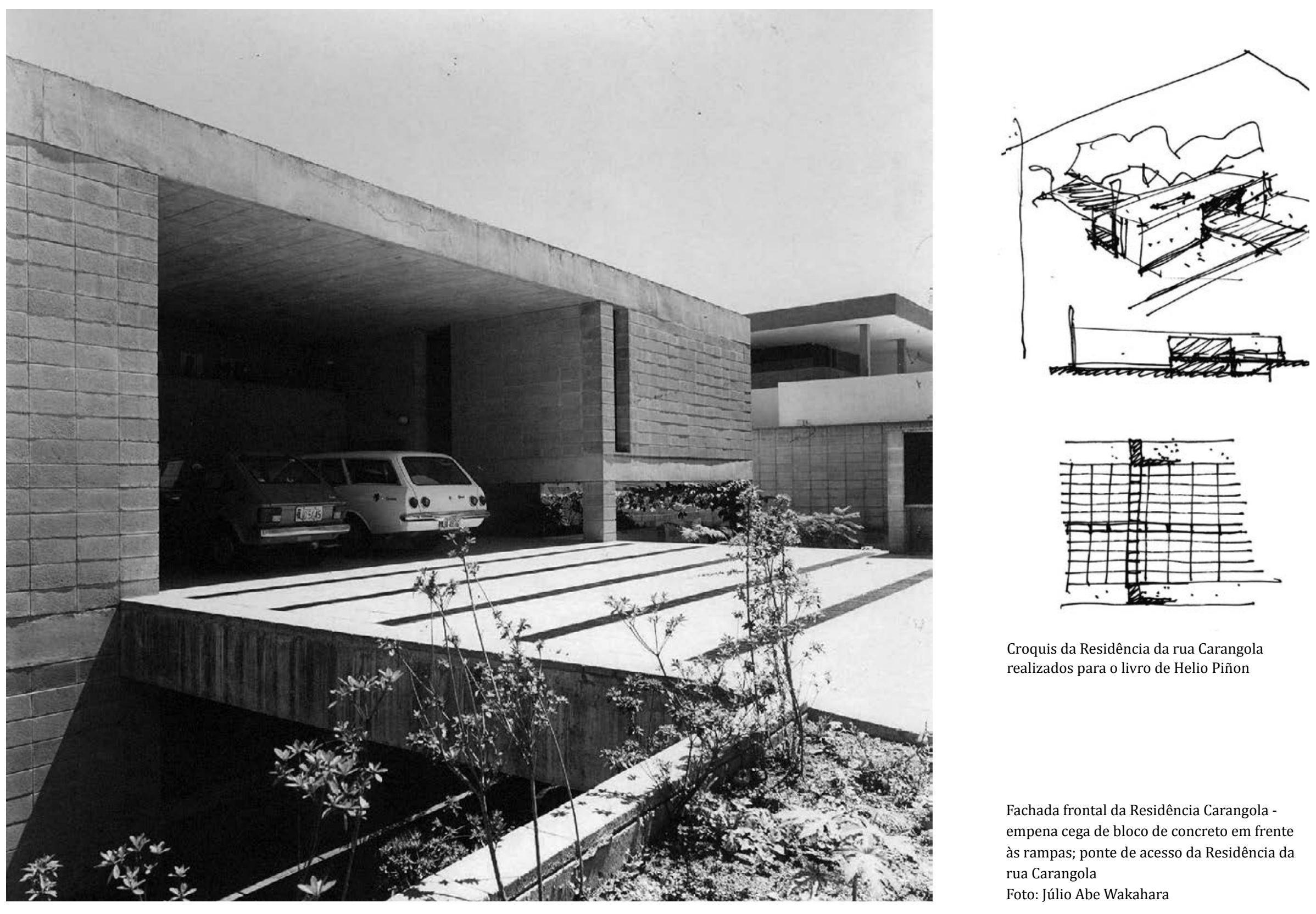

Croquis da Residência da rua Carangola realizados para o livro de Helio Piñon

Fachada frontal da Residência Carangola empena cega de bloco de concreto em frente às rampas; ponte de acesso da Residência da rua Carangola

Foto: Júlio Abe Wakahara 


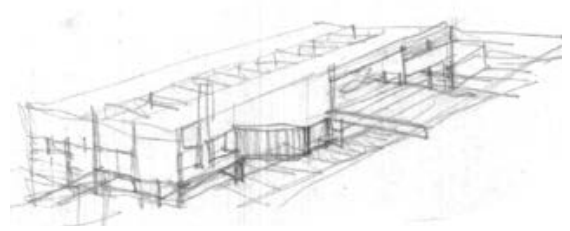

Croquis de estudo das rampas envidraçadas, não executadas no projeto final.

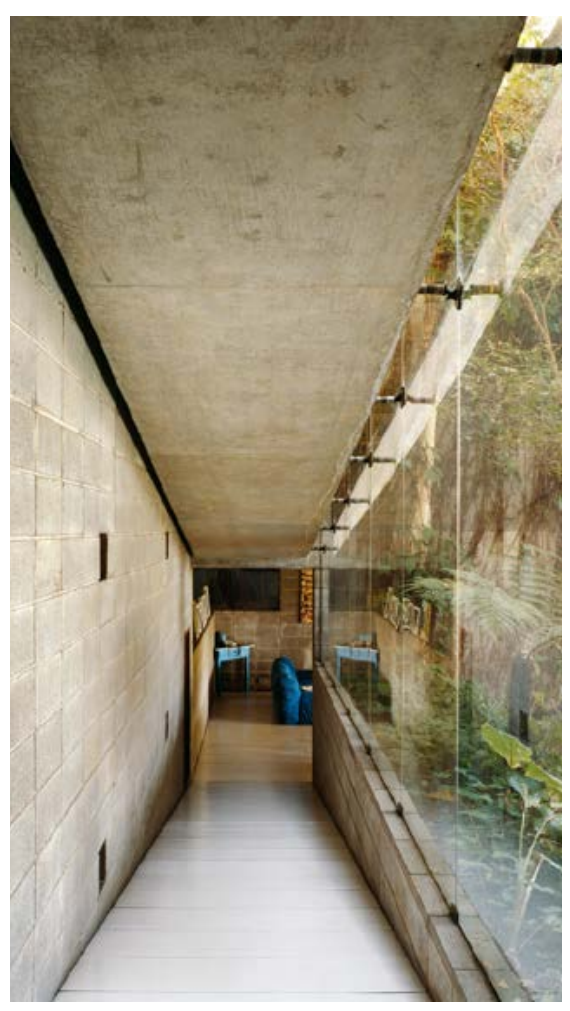

Residência Carangola - acesso da cozinha em direção à sala do pavimento inferior. Notar caixilho de vidro e jardim interno.

Foto: Nelson Kon
Ao que parece, a opção por evitar o uso de uma malha estrutural regular e flexível prioriza uma lógica estrutural atrelada ao programa, aos vazios e à circulação prevista no projeto em detrimento da solução formal do estudo preliminar.

Ao posicionar os eixos dos pilares em função dos espaços e dos elementos ordenadores do projeto - escadas, rampas e vazios - Eduardo de Almeida parece extrair para a forma exterior a própria organização e estrutura do espaço interno, expressos pela variação dos vãos entre os pilares.

A adoção de um sistema de blocos de concreto aparente para todo o projeto, ao invés de explorar a tensão entre a caixa suspensa sobre as áreas coletivas envidraçadas, entre o pesado e o leve, enfatiza o caráter do volume como um elemento unitário, monolítico, mas dotado de perfurações, planos recuados, terraços, transparências e opacidades.

Esta leitura fica mais evidente se pensarmos na solução dada à fachada junto à rua, já que a alternativa de se fazer alguns lances de rampas envidraçados foi substituída pela simples adoção de uma empena cega que escurece o percurso, ao mesmo tempo em que valoriza a presença do jardim interior. Essa escolha substitui o fechamento de vidro no primeiro lance que não poderia ser executado pelo sistema de blocos aparentes.

A adoção desta empena cega para a rua reforça o caráter monolítico do volume, ao mesmo tempo em que gera um contraste entre a horizontalidade da casa e seu espaço coberto de acesso, recuado em relação ao plano da fachada. Desenhado como continuidade à ponte que conecta a casa à rua, este espaço de pé-direito elevado, por estar em uma relação de meios níveis com os demais pisos, permite a visão tanto para a galeria de circulação dos dormitórios quanto para a varanda posterior da casa e seu jardim. 


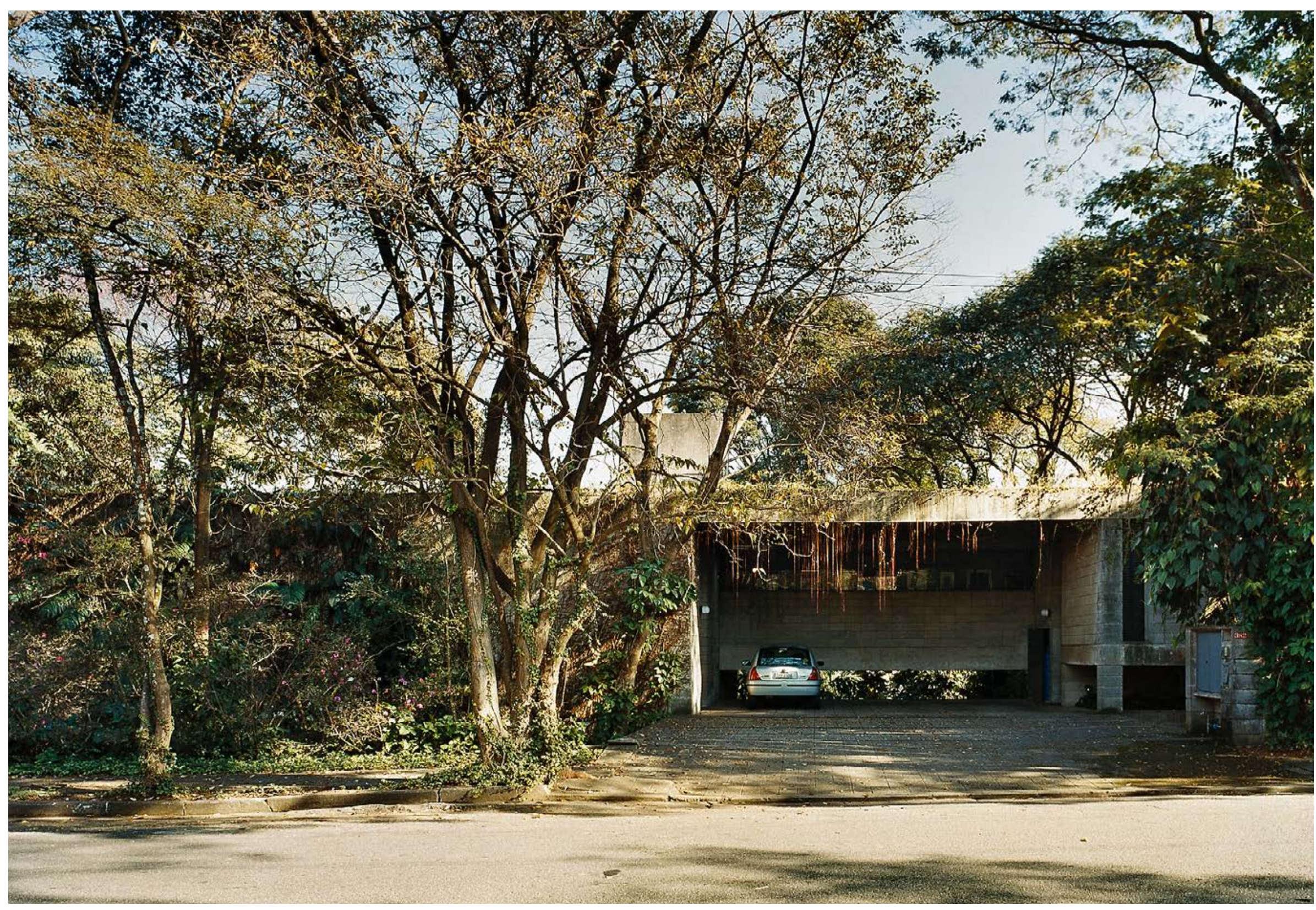


Residência Carangola

Foto do recinto de acesso com pé-direito elevado. Notar transparência em relação ao jardim posterior, circulação dos dormitórios e iluminação zenital.

Ao lado, fachada frontal. Recinto de acesso com pé-direito elevado. Notar transparência em relação ao jardim posterior e à circulação dos dormitórios.

Foto: Nelson Kon

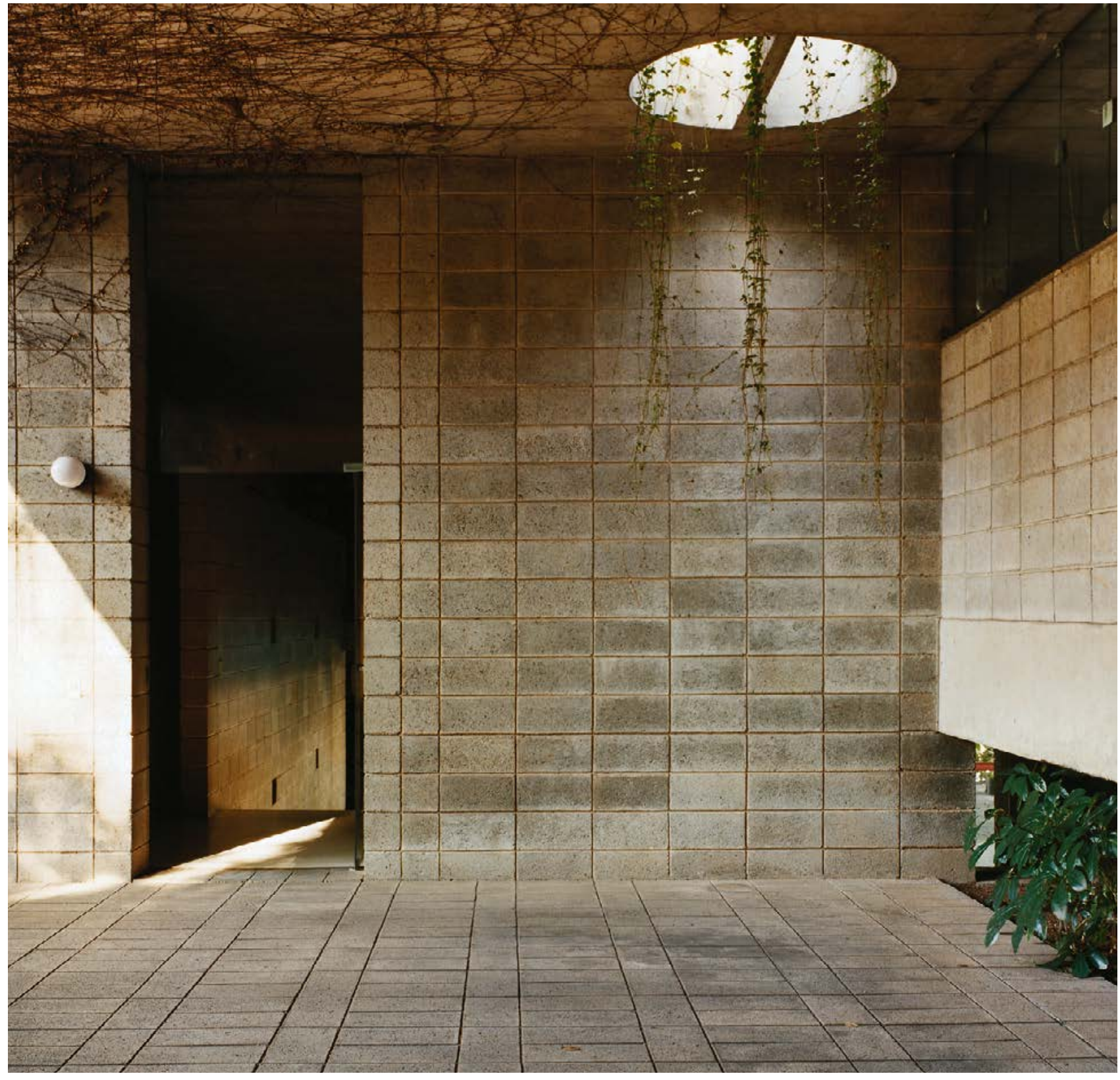




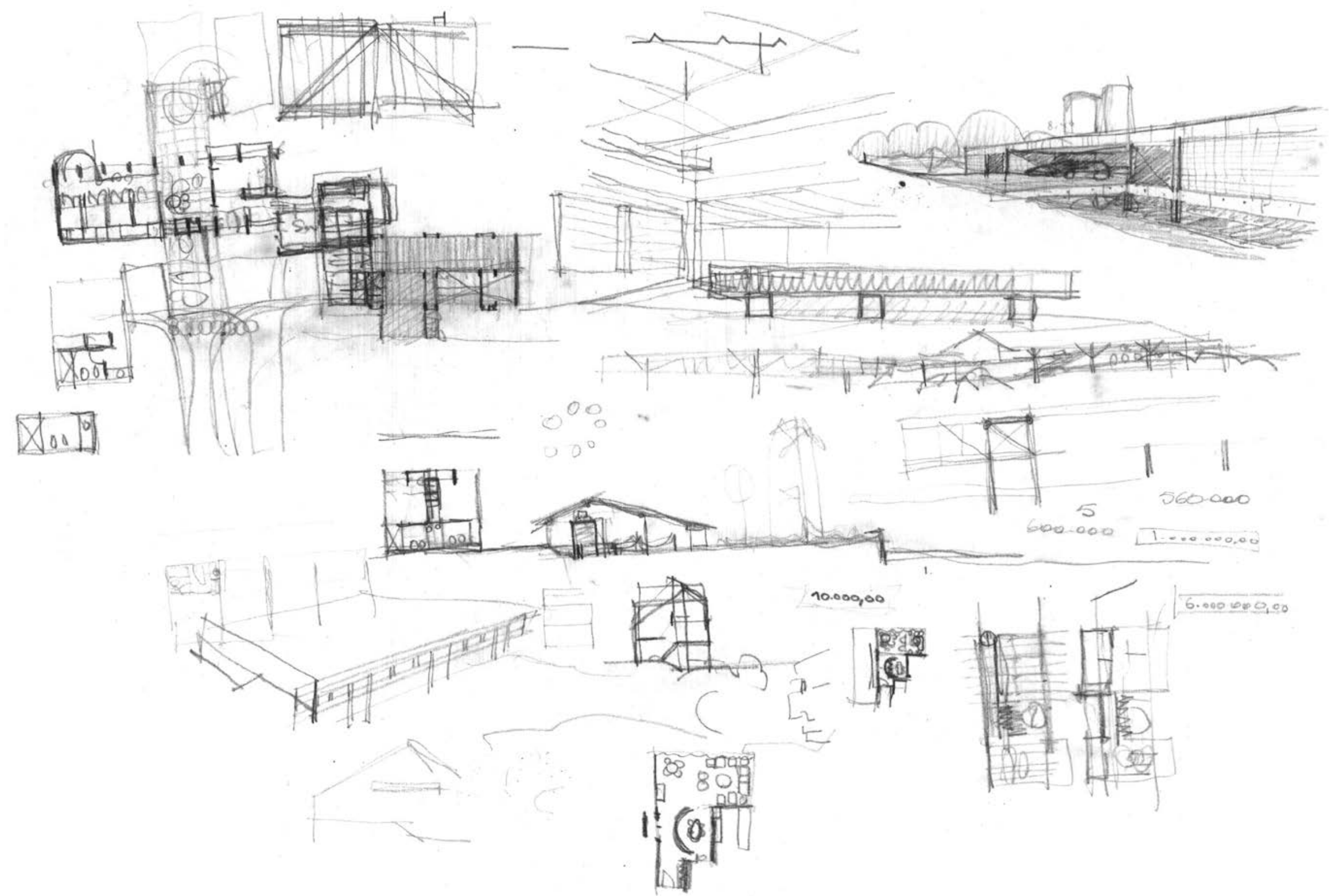




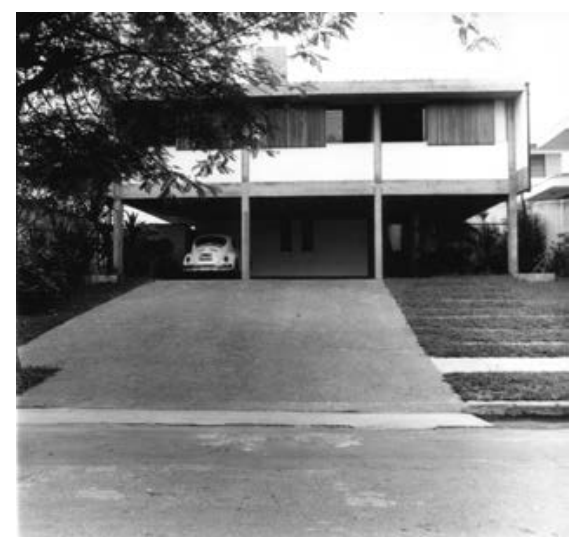

Residência Niemeyer dos Santos Foto: Júlio Abe Wakahara

Ao lado, croquis da Residência da Rua Carangola e croquis realizados por Eduardo de Almeida para a casa da Lagoinha, projetada por Carlos Millan

Acervo Eduardo de Almeida.
Esta transparência é criada por uma faixa horizontal posicionada junto ao piso de acesso sem a intermediação de vidros ou gradis - rompendo a opacidade do volume. Tal solução, já indicada no anteprojeto, é depurada no projeto final com a eliminação de uma laje intermediária de cobertura e a substituição da pérgola contínua por uma abertura zenital circular, posicionada sobre o acesso social da casa.

Este processo de síntese, que envolve a simplificação constante e a busca pela coerência interna do projeto, parece ser fruto da influência do estudo aprofundado dos projetos realizados pelo arquiteto Carlos Millan, como indica a presença de croquis da casa da Lagoinha realizados por Eduardo de Almeida e encontrados junto aos desenhos de investigação da casa da rua Carangola. Mas como um projeto tão distinto pode servir como referência para este caso? Ou a presença destes croquis são apenas coincidência e referem-se a um estudo para outro projeto realizado concomitantemente ao projeto de sua casa?

Independentemente desta dúvida, Eduardo de Almeida sempre reafirma a importância de Carlos Millan como professor e como arquiteto, pelas qualidades encontradas em seus trabalhos. De fato, as obras de Millan são reconhecidas pela simplicidade, concisão e austeridade - características presentes desde o partido inicial de projeto até o desenvolvimento coerente de seu detalhamento - e encontram correspondências na obra de Eduardo de Almeida, nos desenhos realizados para a casa Jacob Kipnis, construída em 1970, assim como na residência para Niemeyer dos Santos.

No caso da Residência Kipnis, seguindo o mesmo partido de outras residências, a implantação se vale da topografia do terreno em declive, ao mesmo tempo em que as funções são dispostas em volumes autônomos, justapostos uns aos outros de tal forma a permitir a relação de continuidade entre os diversos usos, e também a definição de espaços abertos como terraços, varandas ou pátios. 


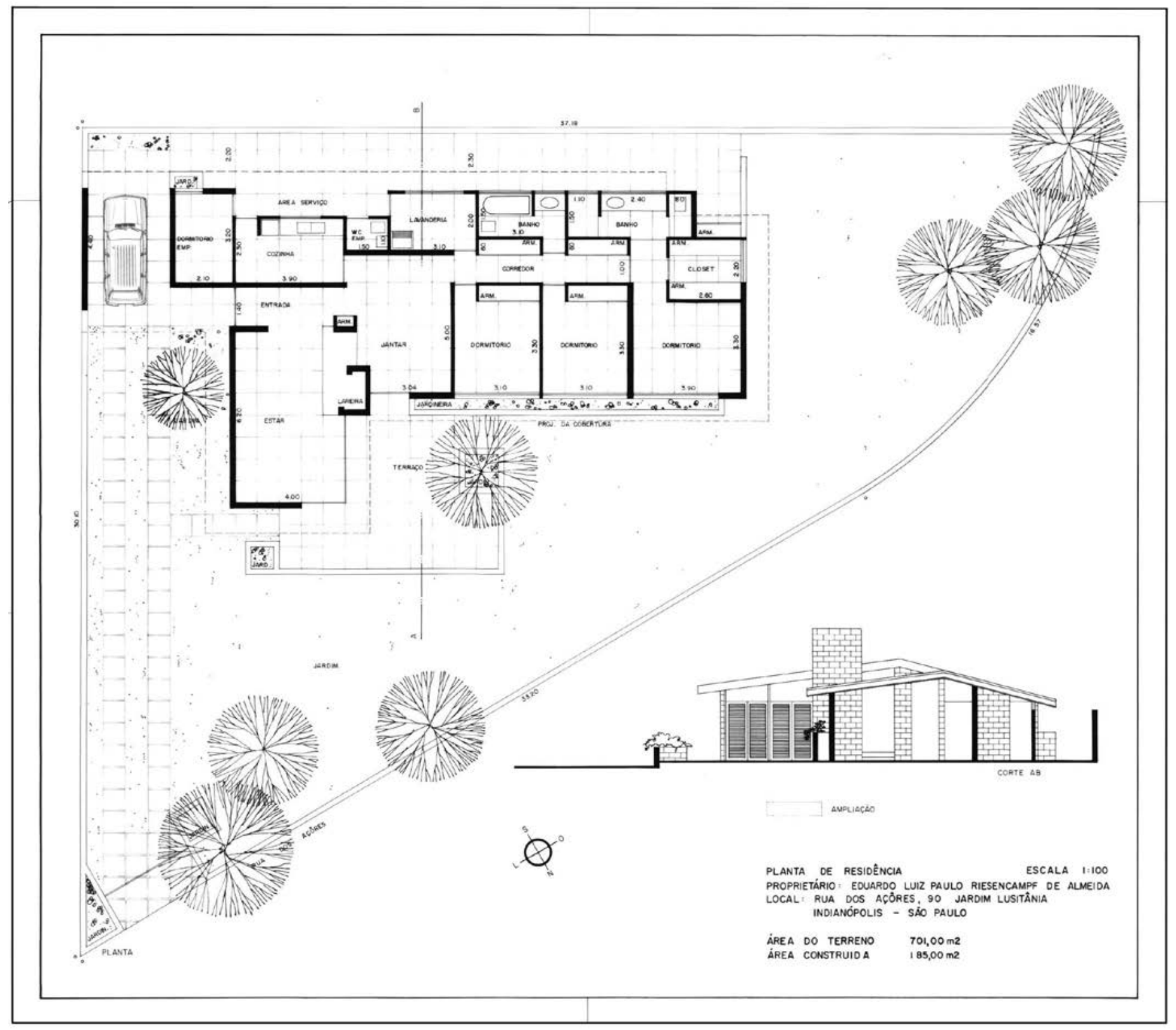




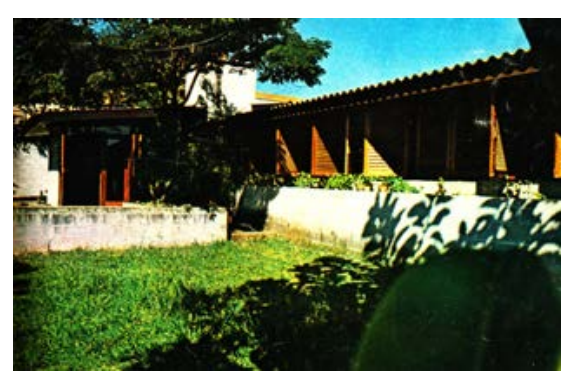

Residência da Rua dos Açores

Num lote triangular, a casa em forma de " $L$ ". Casa Cláudia, n. 94-A, julho de 1969, pág. 81.

Ao lado, desenhos do projeto para a Residência da rua dos Açores

Acervo Eduardo de Almeida
Dada a simplicidade da solução, a atenção do projeto recai sobre seu desenvolvimento exemplar, expresso pelo detalhamento, assim como pela precisão da articulação entre a estrutura de concreto armado e a alvenaria de bloco aparente, elementos corriqueiros da indústria da construção e que neste caso foram reunidos com extrema sofisticação.

O caráter tectônico destas obras aparece nos projetos de vários arquitetos neste período, com especial destaque, novamente, para as obras de Carlos Millan, das quais podemos destacar as casas já comentadas, em Perdizes, Alto de Pinheiros e Morumbi, todas elas dotadas de soluções que, de alguma forma, ecoam nos projetos de Eduardo de Almeida.

No caso específico destas três obras, além da proximidade de solução entre a casa Roberto Millan com o estudo preliminar da casa da rua Carangola, podemos citar a implantação da casa Antônio d'Elboux e seu acesso por meio de uma ponte ou o uso, ainda que pontual, dos blocos de concreto aparente na casa Nadir de Oliveira, onde Carlos Millan subverte sua finalidade natural e os utiliza como arandelas ao posicioná-los transversalmente ao plano da parede.

O uso de bloco de concreto por Eduardo de Almeida acontece em diversos projetos anteriores à esta casa, mas talvez o exemplo mais significativo seja a obra onde este elemento construtivo é empregado pela primeira vez: sua primeira residência localizada na rua dos Açores, em São Paulo.

Projetada em 1960, a casa foi implantada em um lote de esquina e apresenta uma configuração em "L", de acordo com a justaposição do bloco destinado à área social e dos dormitórios, a exemplo de várias Usonian Houses, de Frank Lloyd Wright, a partir de 1939.

Assim como nos projetos de Wright para as casas Rosenbaum, Winckler, Jacobs ou Miller, a implantação em "L" permitiu organizar o espaço em duas alas - social e íntima - que se articulavam 


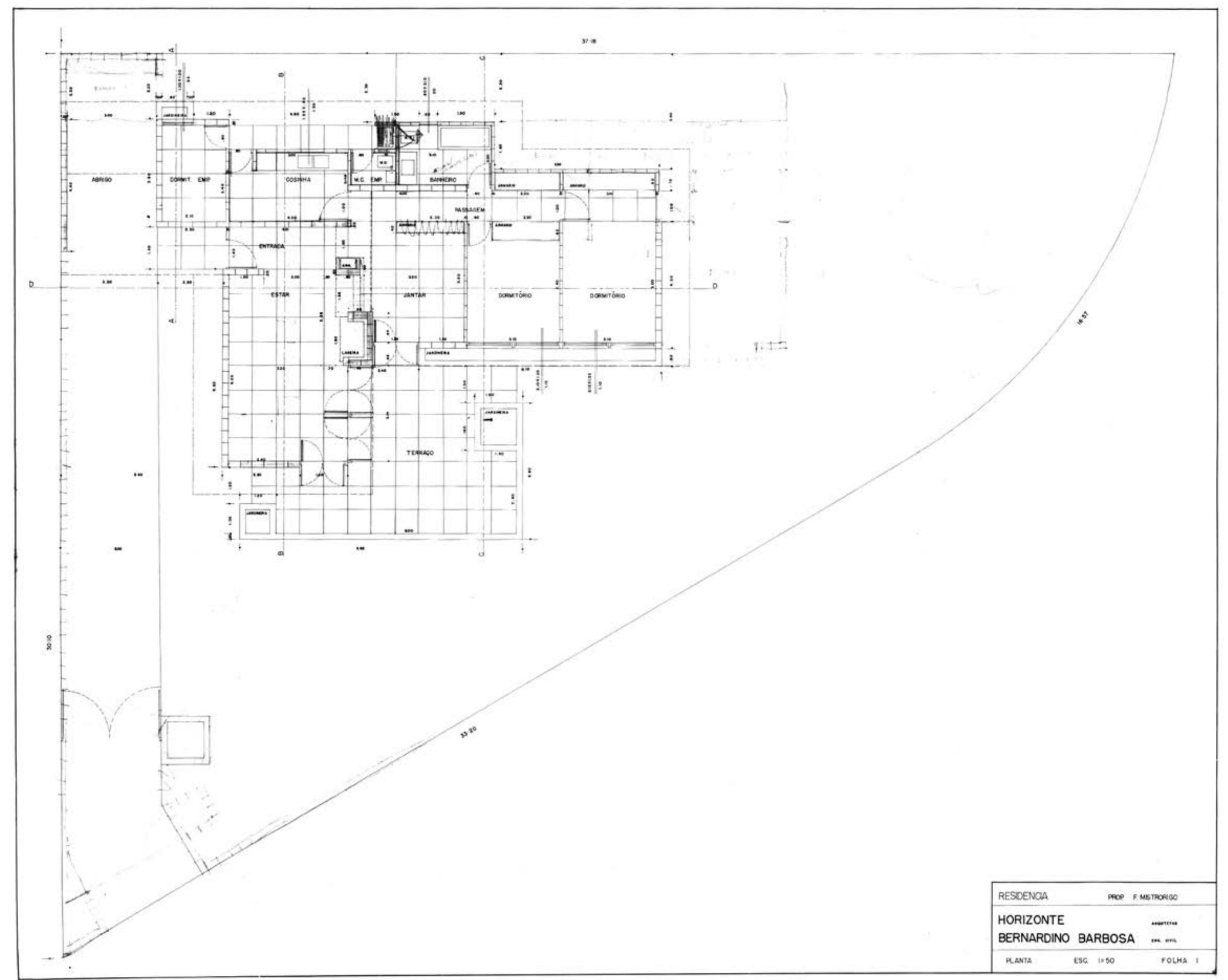



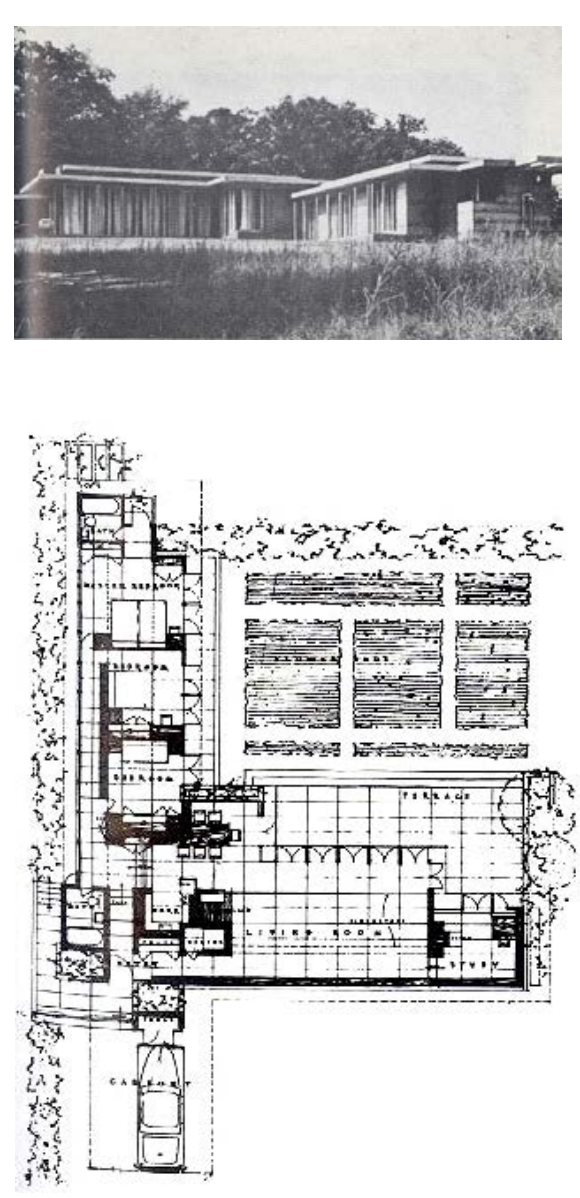

Casa S. Rosenbaum, Florence, Alabama

ZEVI, Bruno. Frank Lloyd Wright. Barcelona, Editorial Gustavo Gilli, 1993, $5^{a}$ edição, pag. 183.

Ao lado, planta do projeto executivo da Residência da rua dos Açores Acervo Eduardo de Almeida através da cozinha e demais dependências de serviço, e também pelo contraponto vertical da lareira em relação à horizontalidade do volume da casa.

Os projetos destas Usonian Houses foram concebidos como uma proposta para casas econômicas para a classe média norte-americana, baseadas nos modelos estudados para a Broadacre City, a 'cidade dos espaços amplos', e parecem ter sido utilizados como referência para vários projetos de Eduardo de Almeida em seu início de carreira, também influenciado por arquitetos como Vilanova Artigas e Carlos Millan, que já haviam realizados projetos de acentuado caráter wrightiano.

Apesar da influência de Wright no desenho da planta da casa da rua dos Açores, o sistema construtivo adotado por Eduardo de Almeida não é a estrutura de tijolos aparentes empregada em conjunto com os fechamentos duplos de lâminas horizontais de madeira, comum nas Usonian Houses e pensado como uma solução econômica para as casas da classe média, adequados à cultura construtiva daquele país.

Neste caso, a influência revelada por Eduardo de Almeida para a realização de sua casa é o conjunto habitacional do Jaçanã, projetado pelo arquiteto José Cláudio Gomes ${ }^{55}$ em 1956, também sob a influência de Frank Lloyd Wright, tanto nas ideias propostas para o plano urbanístico da área, como no desenho das residências e demais edifícios que faziam parte do projeto.

Nesse sentido, é digno de destaque o conjunto residencial do Jaçanã (1956/1958), onde experimenta o uso de blocos de concreto. Trata-se de um conjunto de habitação popular 'planejado com base nos valores humanos e não imobiliários.' Dezesseis grupos de residências geminadas ocupam o perímetro do terreno. No centro, um espaço aberto comum, integrado à comunidade. A utilização de blocos tornou mais econômica

${ }^{55}$ José Cláudio Gomes, arquiteto e urbanista formado pela FAU USP em 1953. Estudou as obras e teorias de Frank Lloyd Wright, também estagiou com Miguel Forte entre 1951 e 1953. 
José Cláudio Gomes optou pela linguagem arquitetônica dos projetos de Wright - telhados planos definindo largos beirais, janelas de canto, criação de embasamentos no contato da edificação com o solo, elementos verticais em contraponto com a horizontalidade do conjunto - adaptando a linguagem das Usonian Houses à tecnologia disponível no mercado brasileiro.

Tal adaptação coincide com os estudos de Frank Lloyd Wright iniciados em 1949 para a criação de um sistema de construção com blocos de concreto aparente chamado 'The Usonian Automatic', empregado em projetos como as casas Adelman (1951), Price (1955) ou Tonkens (1954).

Esta busca por uma nova solução, revela a percepção de Wright de que suas pesquisas iniciadas em 1938 para as Usonian Houses já não se mostravam vantajosas em termos de custo e que, portanto, não se justificavam como solução para a classe média americana que vivia fora dos grandes centros urbanos.

Este novo sistema construtivo baseado na utilização de blocos de concreto foi pensado de forma a utilizar a tecnologia da indústria para a produção das peças, em conjunto com uma mão-de-obra não especializada. Para tanto, foi projetado um requintado sistema que apresentava um conjunto elaborado e extenso de peças e formas, como blocos especiais para o recebimento de vidros, blocos perfurados para paredes de divisa externas, blocos específicos para as extremidades das edificações e peças para o arremates dos beirais, sempre buscando a simplicidade construtiva.

${ }^{56}$ IRIGOYEN, Adriana.Wright e Artigas, duas viagens. São Paulo, Atelie Editorial, 2002, p.123
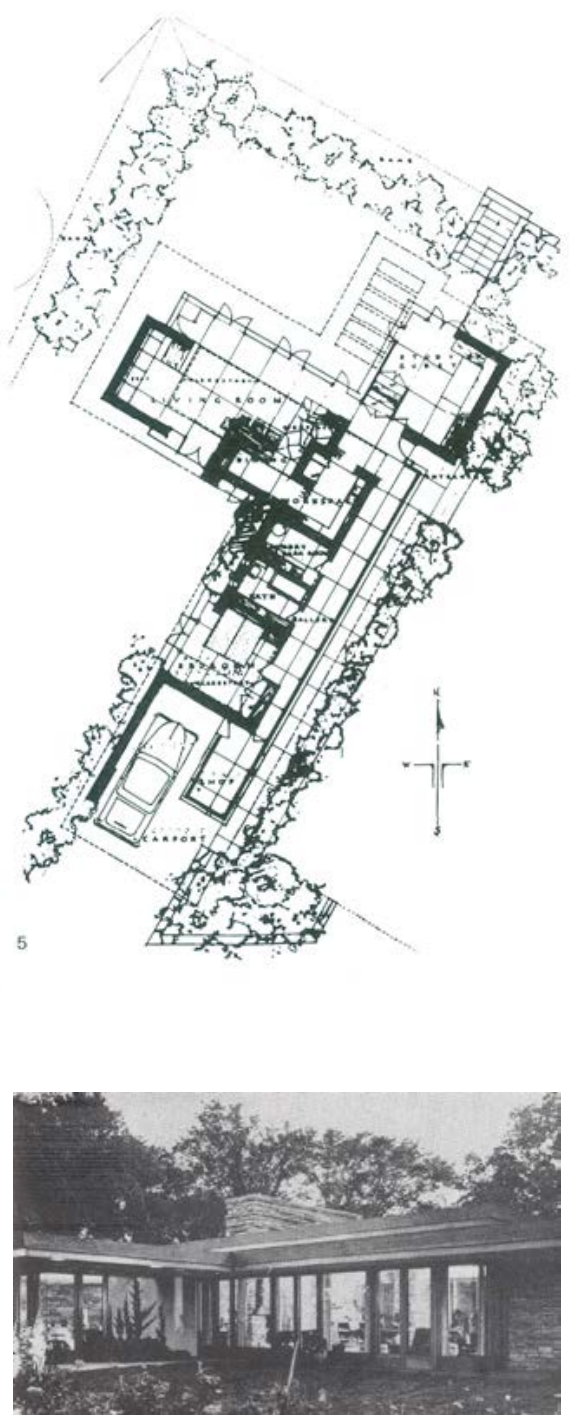

Casa A. Miller, Charles City, Iowa ZEVI, Bruno. Frank Lloyd Wright. Barcelona, Editorial Gustavo Gilli, 1993, $5^{a}$ edição, pag. 211. 

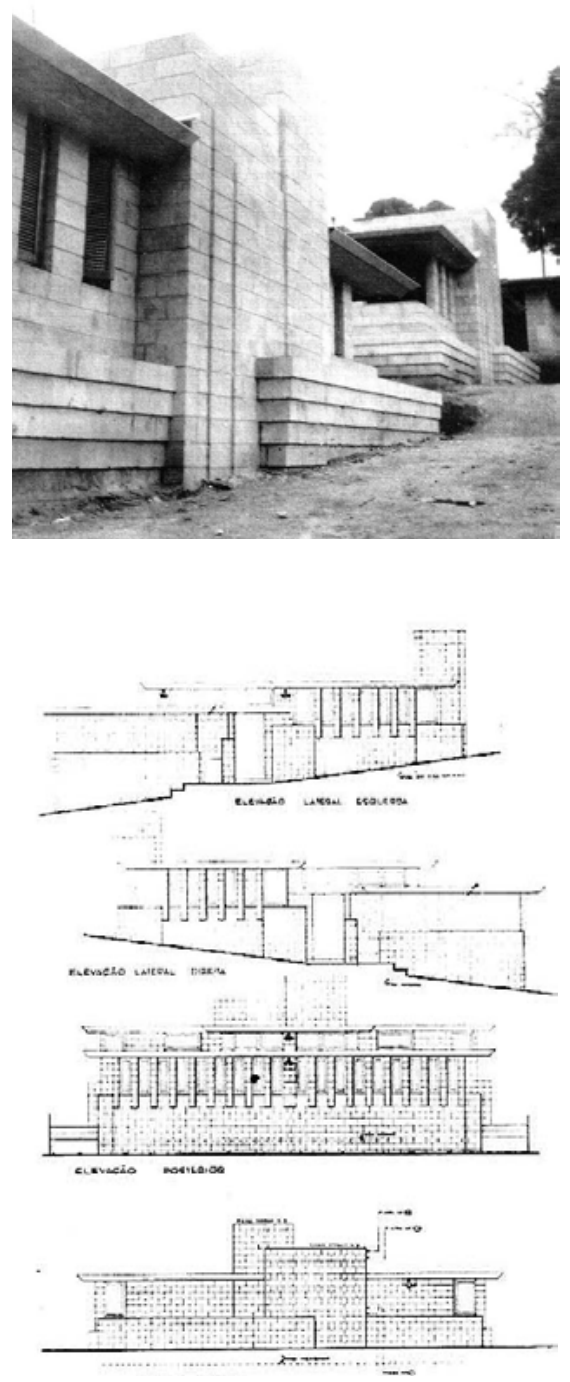

Conjunto Residencial em Jaçanã, 1956 - 1958, José Claudio Gomes

IRIGOYEN, Adriana. Wright e Artigas - Duas Viagens, São Paulo, Ateliê Editorial/ FAPESP, 2002, página 125
Mesmo sem o acesso a este repertório, o projeto do arquiteto José Cláudio Gomes foi realizado com blocos de concreto, de acordo com a realidade da indústria da construção civil brasileira, mas buscando reproduzir alguns aspectos da linguagem adotada por Wright, ora pela demarcação das linhas horizontais de cada fiada do embasamento, reforçadas pelo escalonamento vertical no assentamento dos blocos de concreto, ora pela alternância entre colunas e janelas verticais, conferindo a aparência de muros de concreto perfurados para a iluminação e ventilação, deixando claro seu conhecimento profundo sobre esta fase de Wright.

No caso de Eduardo de Almeida, mesmo tendo participado ativamente do grupo de wrightianos da FAU USP, a influência maior na utilização prática deste sistema para sua casa parece ter sido mesmo a obra de José Cláudio Gomes.

De acordo com seus depoimentos, recém saído da faculdade e sem nenhuma experiência em construção, Eduardo precisava construir sua casa pela proximidade de seu casamento, mas não sabia como fazê-lo na prática. Após visitar as obras do conjunto do Jaçanã e compreender o sistema empregado por José Cláudio Gomes, pode desenvolver o projeto da rua dos Açores a partir das soluções que havia apreendido.

Neste caso, apesar da semelhança da planta com outras obras de Wright, a linguagem empregada pelo arquiteto adota uma solução mais austera, sem a marcação dos frisos horizontais presentes na obra do arquiteto americano, também reproduzida no conjunto do Jaçanã.

A expressão de horizontalidade na obra de Wright aparece em projetos como River Forest Golf Club (1910), Ross House (1902) ou a Glasner House (1905) e surge como uma simplificação do 'Shingle Style', sistema tradicional de construção em madeira. Apesar de Cláudio Gomes utilizar um sistema diferente dos fechamentos de madeira de Wright, o projeto do conjunto habitacional do Jaçanã 


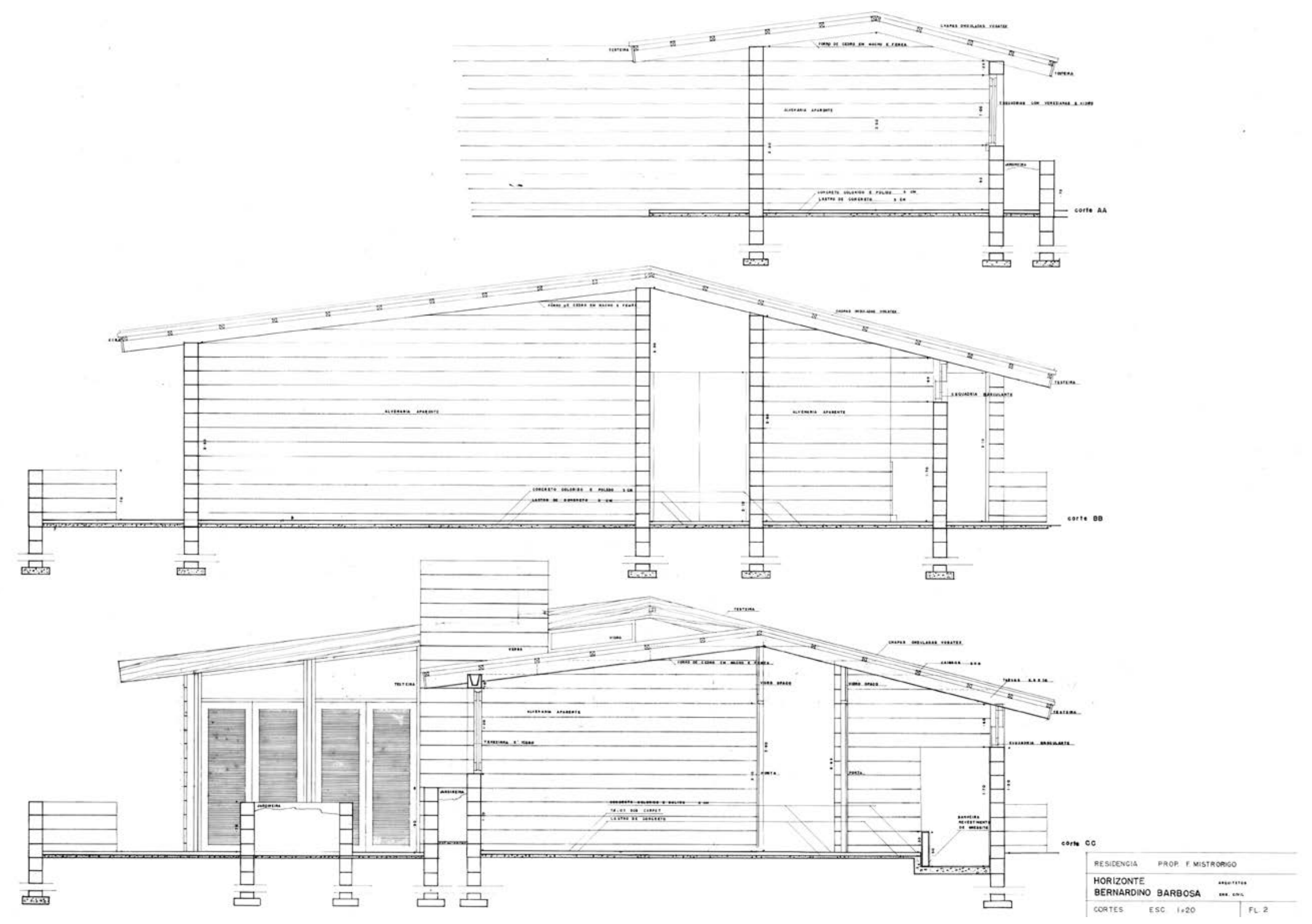


Ao Residência da rua dos Açores

Acervo Eduardo de Almeida apresenta um desenho de acentuada horizontalidade, ao demarcar as juntas horizontais entre os blocos de concreto e ocultar as linhas verticais - como o procedimento utilizado por Wright em muitos muros de tijolos aparentes.

Este recurso também foi previsto pelos cortes do projeto executivo para a casa da rua dos Açores, mas é eliminado durante a execução da obra. Eduardo de Almeida parece ter compreendido a natureza do material e assumido sua linguagem ao eliminar tais frisos, simplificando ainda mais seu processo de execução.

Como resultado, esta casa extremamente econômica e austera vale-se das qualidades deste material e de seu contraste com os elementos de madeira (caixilhos e cobertura), assim como do desenho da malha de $80 \mathrm{~cm} x 80 \mathrm{~cm}$ que ordena todos os elementos da construção, inclusive o desenho de paginação do piso interno de cimento queimado vermelho, outra citação à obra de Frank Lloyd Wright.

A utilização dos blocos aparentes no interior da casa desdobra-se em seu exterior, associados a muros que, além de posicionar a casa levemente acima do terreno natural, definem o pátio arborizado que dá continuidade ao espaço da sala de estar. Em frente aos dormitórios, um segundo muro posicionado paralelamente à ala dos quartos cria uma jardineira contínua, garantindo privacidade a estes ambientes.

A cobertura realizada com estrutura de madeira e telhas de fibrocimento, exigiu a justaposição de dois telhados de duas águas em função da geometria da planta (um para a sala e outro para o conjunto de dormitórios), sendo que a junção entre estes elementos dá-se pela continuidade do plano inclinado voltado para o fundo do lote, posicionado sobre a área da cozinha e serviços e do corredor dos dormitórios e sanitários. 
Esta configuração de telhado, como demonstrado anteriormente, utiliza a mesma solução aplicada em algumas das escolas públicas projetadas para o FECE - Fundo Estadual de Construções Escolares -, onde a continuidade de uma das águas do telhado é complementada pelo seu desdobramento em vários planos inclinados assimétricos, de acordo com a organização do programa em planta.

No caso das escolas nos municípios de Botucatu e Silveiras, também projetadas sob a influência de Frank Lloyd Wright, os telhados desdobram-se em planos inclinados de diferentes dimensões, conformando espaços de alturas variadas e adequadas a cada uso, como a sala de estar da casa da rua dos Açores de pé-direito elevado. Inicialmente construída com apenas dois dormitórios, a casa foi rapidamente ampliada, acompanhando o crescimento da família; conforme previsto no estudo inicial, o bloco dos dormitórios foi alongado para a criação de mais um quarto, além de uma alteração na área de serviços e do acréscimo no número de banheiros.

Como demonstram os croquis da ampliação, o uso do bloco como elemento construtivo guiou a definição do projeto, rigorosamente desenhado sobre a base de papel milimetrado que estabelecia o controle dimensional do conjunto, procedimento que coincide com o trabalho em conjunto com o arquiteto carioca Sérgio Bernardes.

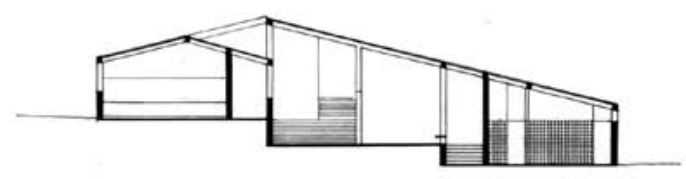

conte A.

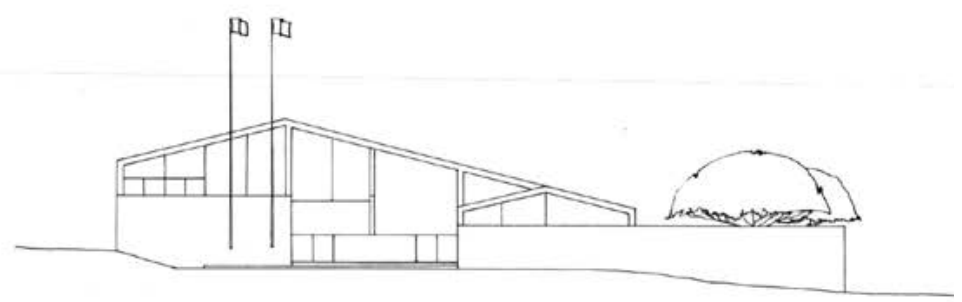

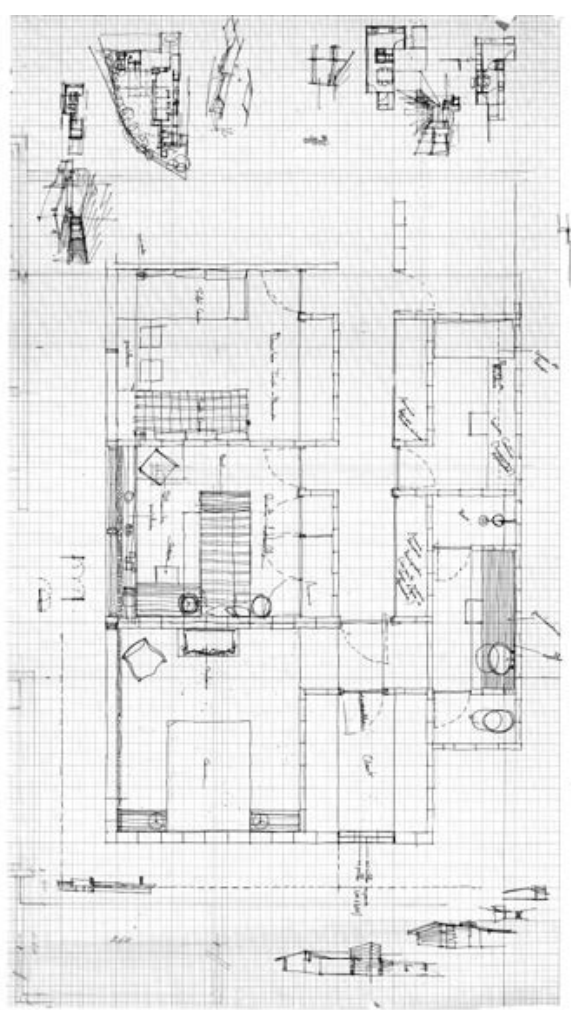

Croquis de ampliação da residência da rua dos Açores

Corte e elevação do Ginásio Estadual Vila dos Lavradores em Botucatu. Notar o desdobramento da cobertura em vários planos inclinados assimétricos.

Eduardo de Almeida 
Em Wright, a eleição dos materiais e o modo de empregá-los na construção dos edifícios faz parte da questão central de sua obra em suas diversas fases, ciente de que o resultado formal de uma construção advém destas condições e das associações que permitem a definição do espaço.

No projeto para o Unity Temple construído em Oak Park em 1906, procurando criar edifícios mais resistentes ao fogo e como uma alternativa às construções de madeira em 'balloon frame', Wright realiza um dos primeiros edifícios construídos totalmente em concreto armado moldado in loco, uma estrutura de caráter monolítico que unia, em uma única ação, a construção das paredes, estrutura, fachadas e cobertura.

Esta experiência gerou um edifício de grande interesse e força plástica, mas de alguma maneira, ainda não atendia às expectativas de Wright que, acostumado ao caráter tectônico de seus projetos, não encontrava no concreto armado uma solução convincente, talvez pela falta da articulação entre os elementos que compõem a obra.

Apesar de Wright revelar sua desconfiança em relação às características do concreto armado, a descoberta de um novo modo de utilizar esta matéria-prima, considerando os meios de produção industrial, parece dar novas direções à obra deste arquiteto, como destaca Kenneth Frampton a partir dos depoimentos do arquiteto na Architectural Record em 1929: "Eu finalmente encontrei meios mecânicos para produzir um prédio completo que pareça feito pela máquina, assim como qualquer produto deva parecer. Resistente, leve, mas não 'magro'; não perecível; plástico; sem mentiras em nenhum ponto mas feito pela máquina, mecanicamente perfeito. A estandardização como a alma da máquina está pela primeira vez nas mãos do arquiteto, diretamente na imaginação. A única limitação para construir encontra-se no limite da imaginação." ${ }^{57}$

${ }^{57}$ WRIGHT, Frank Lloyd. Frank Lloyd Wright: Writings and Buildings. P.225. in FRAMPTON, Kenneth. Tectonic Culture: the poetics of construction in nineteenth century architecture. Massachusetts Institute of Technology, 1995. 
Este novo sistema de placas de concreto componíveis surge pela primeira vez em 1906, no estudo para a casa Harry E. Browne, em Illinois, pensada como um protótipo para uma casa pré-fabricada. Apesar de não ter sido construída naquele momento, o uso deste sistema ressurge na série de quatro casas construídas na Califórnia nos anos 1920: casa Millard, conhecida como "La Miniatura", Storer, Freeman e Ennis, todas totalmente construídas pela justaposição de placas ornamentadas na construção de todos os seus ambientes.

O que nos interessa é relacionar os estudos sobre estas obras de Frank Lloyd Wright durante a década de 1920, ao contexto da produção arquitetônica brasileira, considerando o trabalho de tantos arquitetos que, de alguma maneira, sofreram esta influência na elaboração de seus projetos, como Eduardo de Almeida.

Esta produção específica das casas 'Text-tile' durante os anos 1920 e das 'Usonian Automatic' no início da década de 1950, aparece como referência indireta no projeto de Eduardo de Almeida para a rua Carangola, experiência apoiada em tantas outras que, por sua vez, também foram inspiradas em outros profissionais.

Podemos dizer que o processo de projetar envolve sucessivas versões do mesmo objeto e, consequentemente, um aprimoramento das ideias e seu rebatimento na conformação do espaços e nas decisões relacionadas ao processo de construção.

Este processo se ampara no conhecimento acumulado de outros projetos e no estudo de obras e teorias já desenvolvidos, uma conjunção entre o fazer e o pensar.

No caso específico da utilização das placas de concreto por Frank Lloyd Wright em inúmeras obras de diferentes fases de produção, parece interessante constatar a continuidade de pensamento na construção destes projetos.

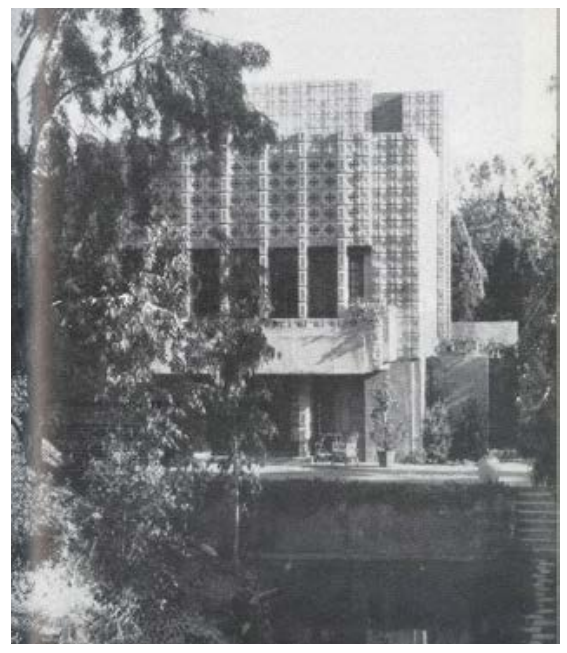

Residência Millard

ZEVI, Bruno. Frank Lloyd Wright. Barcelona, Editorial Gustavo Gilli, 1993, $5^{a}$ edição, pág. 115.
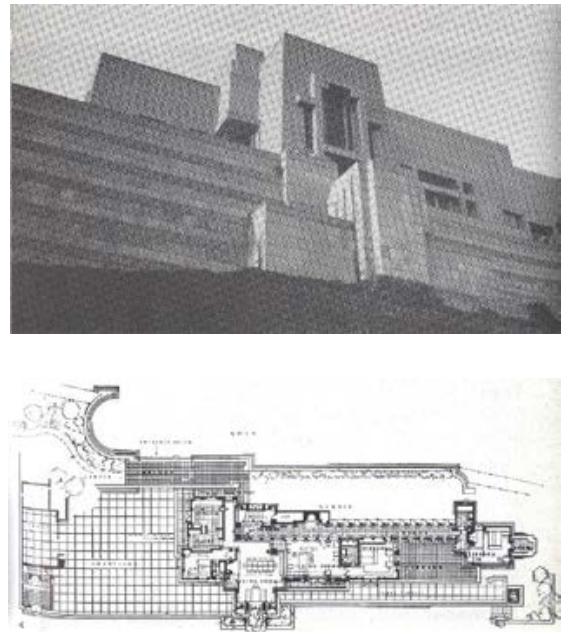

Residência Ennis

ZEVI, Bruno. Frank Lloyd Wright. Barcelona, Editorial Gustavo Gilli, 1993, 5ª edição, pág. 123. 


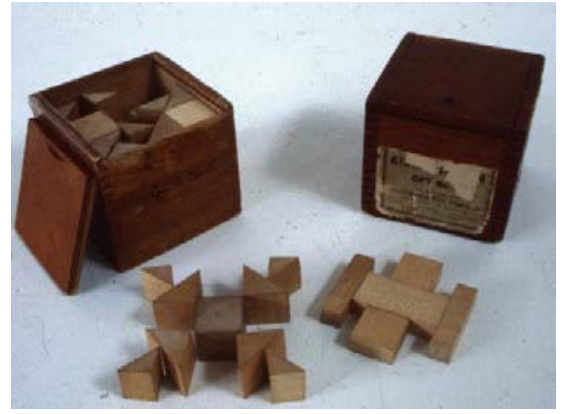

Jogo de Friedrich Froebel

http://learningmaterialswork.com/blog/tag/ friedrich-froebel/
Considerando a importância do processo de projetar, e entendendo o enfrentamento de cada obra como a construção de um pensamento arquitetônico mais amplo, talvez seja importante considerar a experiência construtiva propiciada pelos jogos de montar de Friedrich Froebel ao longo de sua infância.

Criado em 1830, este sistema de blocos foi pensado como um jogo para crianças com o objetivo de estimular o aprendizado sobre as formas geométricas, a matemática e a criatividade, por meio da composição tridimensional de peças de variados tamanhos, formas e cores. Adriana Irigoyen apresenta essa técnica em Wright: "a gênese de suas formas foi reiteradamente associada à educação de Wright no sistema Froebel, uma série de exercícios com formas básicas de madeira que favorecem o desenvolvimento do sentido de organização e a destreza manual da criança".58

Esta experiência construtiva e, de alguma forma, didática, também nos traz à lembrança um dos primeiros exercícios de projeto realizados na FAU USP, na década de 1990, sob a orientação de diversos professores, inclusive Eduardo de Almeida.

O tema propunha a realização de um centro comunitário na Praça do Relógio, na Cidade Universitária da USP, mas independentemente do programa ou do local destinado à sua construção, a questão principal era o exercício projetual a partir da construção: o único material disponível era um bloco de $80 \mathrm{~cm} \times 40 \mathrm{~cm} \times 20 \mathrm{~cm}$.

O desafio significava pensar arquitetura e seu desenvolvimento a partir do sistema construtivo, transmitindo aos alunos a importância da construção no processo projetual e, principalmente, a possibilidade das eventuais limitações serem vistas como oportunidade de invenção.

${ }^{58}$ IRIGOYEN, Adriana. Wright e Artigas, duas viagens. São Paulo, Ateliê Editorial, 2002, p.131 
Nas aulas, durante as orientações coletivas, Eduardo de Almeida comentava cada projeto desenvolvido pelos alunos, revelando as virtudes de cada proposta como também problemas decorrentes da falta de coerência entre o pensar e o fazer, das relações entre parte e todo.

De modo reiterado, Eduardo sempre orientava o respeito à natureza do material adotado como elemento de construção: 'O problema nunca é do material, mas o modo como ele é aplicado no projeto'.

Tal reflexão fica muito evidente no estudo da obra completa deste arquiteto. Em maior ou menor grau, a escolha das técnicas construtivas ao longo do processo de projeto leva a um constante trabalho de revisão, na busca pela coerência interna de cada problema. 
Lugar, construção e transparência 



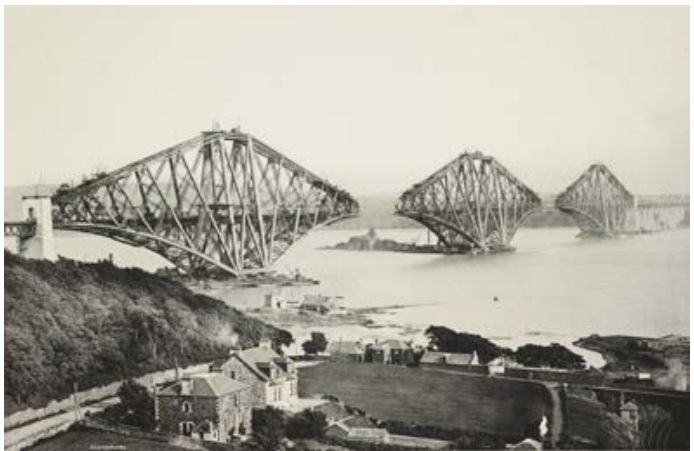

Ponte sobre o rio Forth de Benjamin Baker Disponível em <http://static.guim.co.uk/sys-images/ Guardian/Pix/audio/video/2013/3/4/1362404619786/ The-Forth-Railway-Bridge--002.jpg> Acessado em 16 de fevereiro de 2014
No primeiro capítulo do livro Padrões de Intenção $0^{59}$, Michael Baxandall descreve a ponte sobre o rio Forth, construída em 1889, por Benjamin Baker em Queensferry, na Escócia. A sistematização apresentada parte dos 'encargos' que demandaram a realização da travessia e das 'diretrizes' que direcionaram seu desenho, relacionando-os com os contextos culturais, sociais e científicos.

Baxandall considera o projeto e a obra da ponte como resposta a uma conjuntura de fatores, e sua leitura, a partir de aspectos gerais e específicos, permite organizar os motivos que levaram à construção da ponte, e de que modo se definiram suas formas.

De acordo com o relato, muitos dos fatores relacionados às 'diretrizes' se relacionam às características específicas do local - a distância entre as margens, a qualidade do solo, a existência de uma ilha no meio da travessia ou a presença de ventos fortes na região -, elementos que condicionam o desenho específico da proposta que, naturalmente, também se alimenta do próprio contexto da 'arquitetura dos engenheiros' decorrente dos novos procedimentos relacionados à industrialização.

Assim como na ponte realizada por Baker, as dificuldades impostas pelo sítio certamente direcionam o desenho adotado para a estrutura, já que suas formas necessariamente advém das reações aos locais onde se inserem.

Me refiro ao problema do terreno como suporte que delimita um projeto. A parcela de terra em torno do próprio edifício e a maneira que este se relaciona com todo o resto: com a rua, com a insolação. É a primeira questão da forma, da morfologia do terreno. O primeiro problema que enfrento é entender o tamanho do terreno, como medida, como dimensão. A maneira que vou relacionar esta superfície ao programa que tenho. Entender o terreno, entender as possibilidades que me oferece e as dificuldades que me impõem. Vale dizer - e não é nenhuma novidade - que as dificuldades residem, em geral, às próprias referências para estabelecer uma solução potente. Por esses motivos, o terreno me prende muito em qualquer solução de projeto. ${ }^{60}$

${ }^{59}$ BAXANDALL, Michael. Padrões de intenção. São Paulo, Companhia das Letras, 2006.

${ }^{60}$ ALMEIDA apud ESPALLARGAS in PIÑON, Hélio. Eduardo de Almeida. Barcelona, Edicions UPC, 2005, p.20 


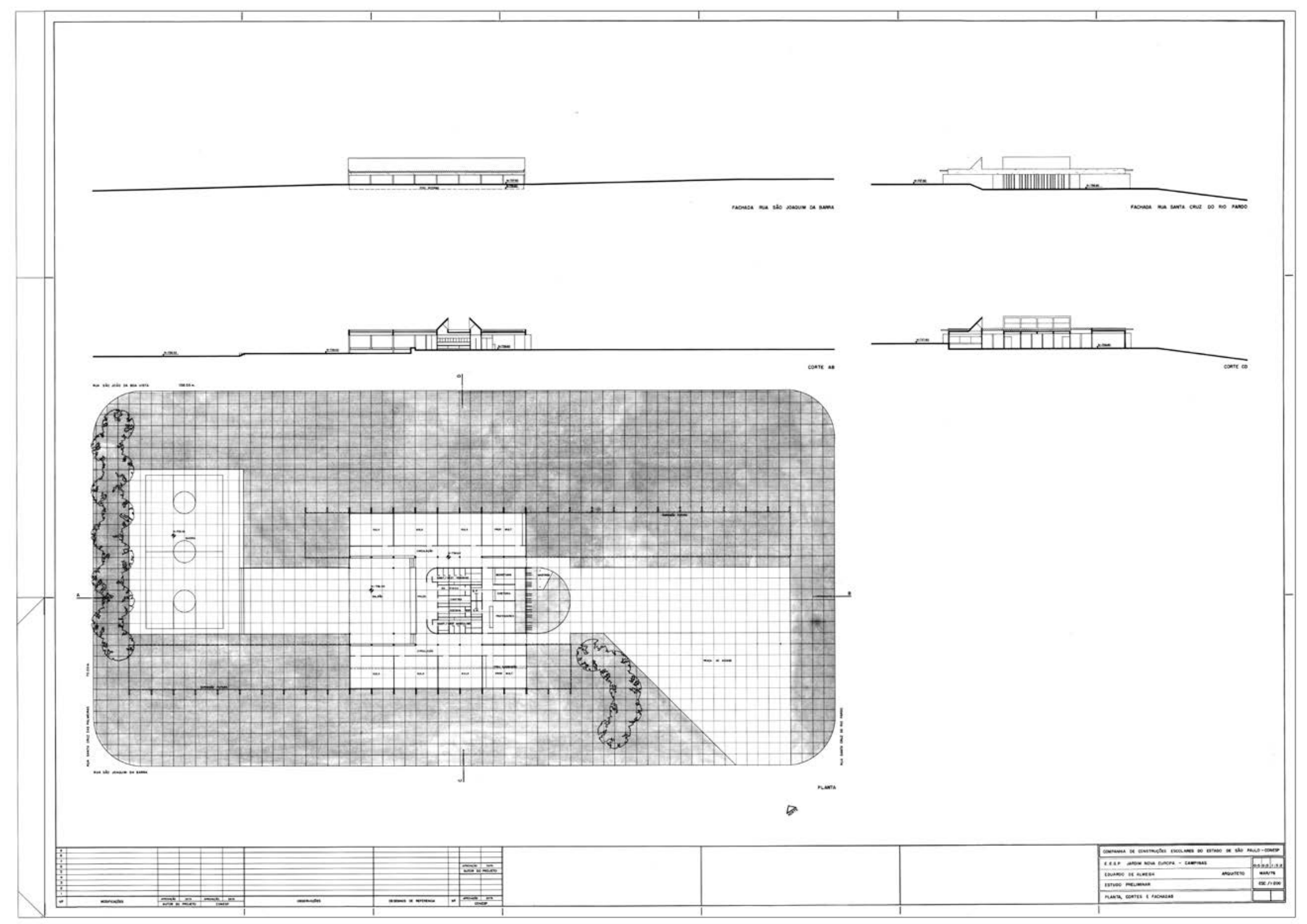


Em suas aulas na FAU USP, Eduardo de Almeida orientava o olhar dos alunos ao problema do sítio, não só à morfologia do terreno - de sua topografia - mas também aos elementos que definiam sua espacialidade: uma árvore, os vizinhos ou o caráter do entorno em que o edifício seria inserido.

Quando um trabalho de determinado aluno não evoluía, por alguma crise em relação ao próprio projeto, a orientação de Eduardo era sempre a de tentar compreender o problema. E o problema, muitas vezes, decorria da falta de entendimento do lugar.

Na ausência de alguma ideia para desenvolver um projeto, talvez pela complexidade do terreno, a orientação de Eduardo era sempre a mesma: 'aproveitar as dificuldades apresentadas pelo lugar como base para o enfrentamento do projeto'.

Esta orientação é a mesma que ele sempre empregou em seus trabalhos, no exaustivo processo de definir determinada solução em seu enfrentamento com o lugar.

Os projetos realizados por Eduardo de Almeida para uma série de três edifícios escolares para a CONESP - Companhia de Construções Escolares do Estado de São Paulo - em 1976, são exemplos didáticos para abordar a questão da implantação dos edifícios no sítio.

Tais escolas - Jardim Nova Europa, Vila Buenos Aires e Parque Brasília - limitam-se a seguir a padronização de ambientes, elementos construtivos e componentes fornecidos pela CONESP, de acordo com a sistematização das edificações escolares a serem implantadas em um curto período de tempo e em grande quantidade por todo o Estado de São Paulo.

Ao lado, prancha de estudo preliminar da

escola Jardim Nova Europa

Acervo Eduardo de Almeida 


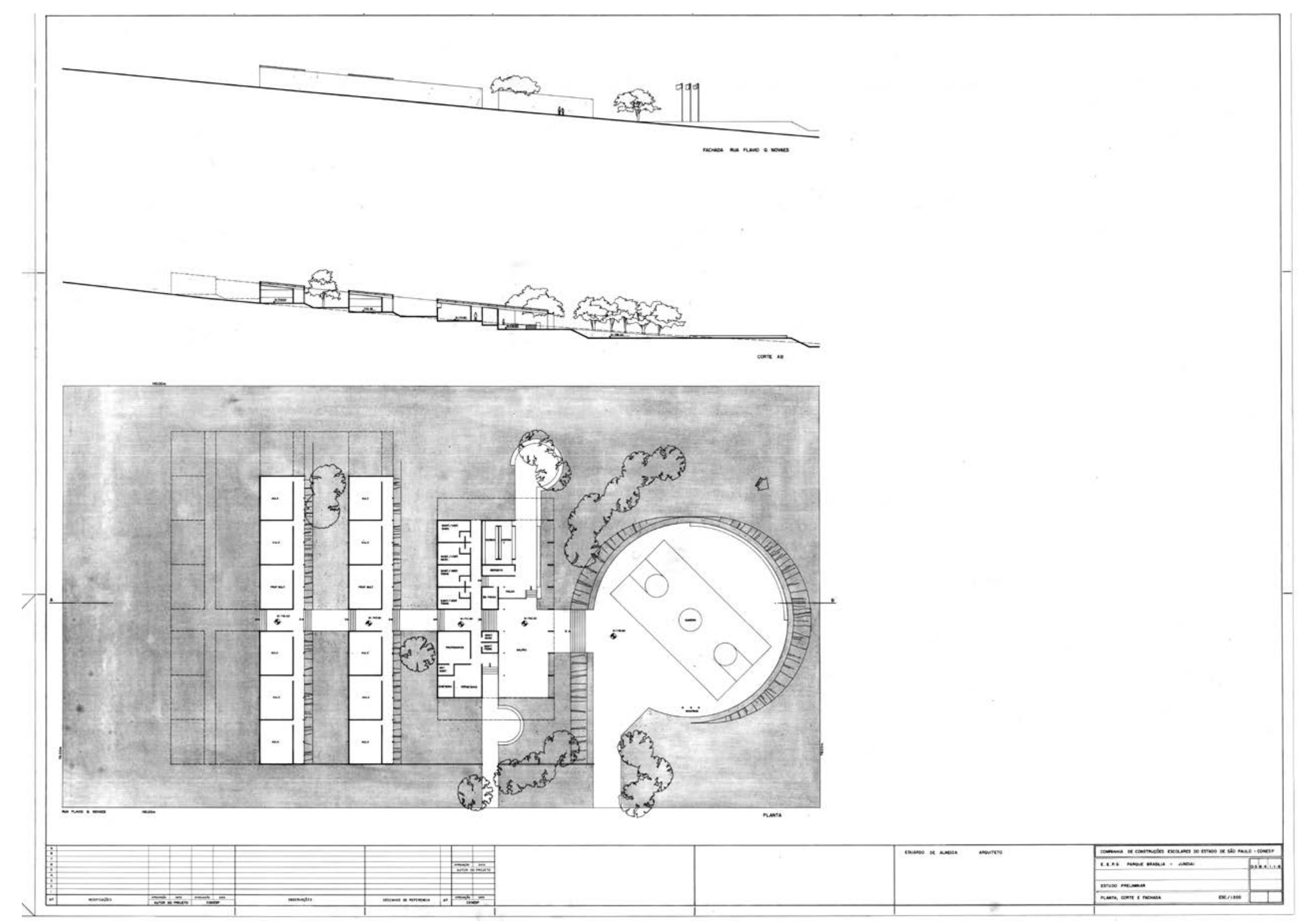


Ao lado, prancha de estudo preliminar da escola Parque Brasília

Acervo Eduardo de Almeida apenas se limitam a seguir as determinações espaciais e construtivas; no agrupamento dos diversos volumes funcionais, buscam obter uma relação econômica e adequada na relação entre edifício e terreno.

Extremamente singelos - os blocos funcionais são dispostos paralelamente no terreno de modo a respeitar suas inclinações, por meio da criação de patamares cuidadosamente desenhados quanto ao equilíbrio entre corte e aterro, inclusive naqueles destinados às quadras descobertas (em dois casos, o espaço foi posicionado em patamares de planta circular, como se o platô também fosse visto como um elemento do caderno de ambientes capaz de garantir a orientação adequada a cada caso).

Implantados em cada um dos patamares, os volumes de cada função foram conectados por um passeio coberto, definindo pequenos pátios ajardinados entre eles. Assim como nas escolas projetadas anteriormente, o espaço do galpão mereceu especial atenção, seja pelo pé-direito elevado, seja pela sua continuidade em relação ao espaço externo.

Como vimos anteriormente, parece natural em Eduardo de Almeida, que estes projetos se estruturem pela adoção irrestrita dos sistemas pré-definidos e pelo correto agrupamento de volumes de acordo com suas funções e em sua implantação no terreno.

Talvez o desenho mais intrigante seja o do estudo preliminar não construído para a escola em Parque Brasília. A partir da declividade do terreno e considerando a distribuição de todo o programa em apenas um pavimento, a cobertura se posiciona paralelamente ao perfil natural do terreno, possibilitando a proteção dos blocos escalonados sob uma cobertura contínua. 0 muro de fechamento da escola é sua própria fachada: um plano cego demarcado pelas linhas das coberturas das salas de aulas e por uma 'fresta' que marca o acesso dos alunos. 


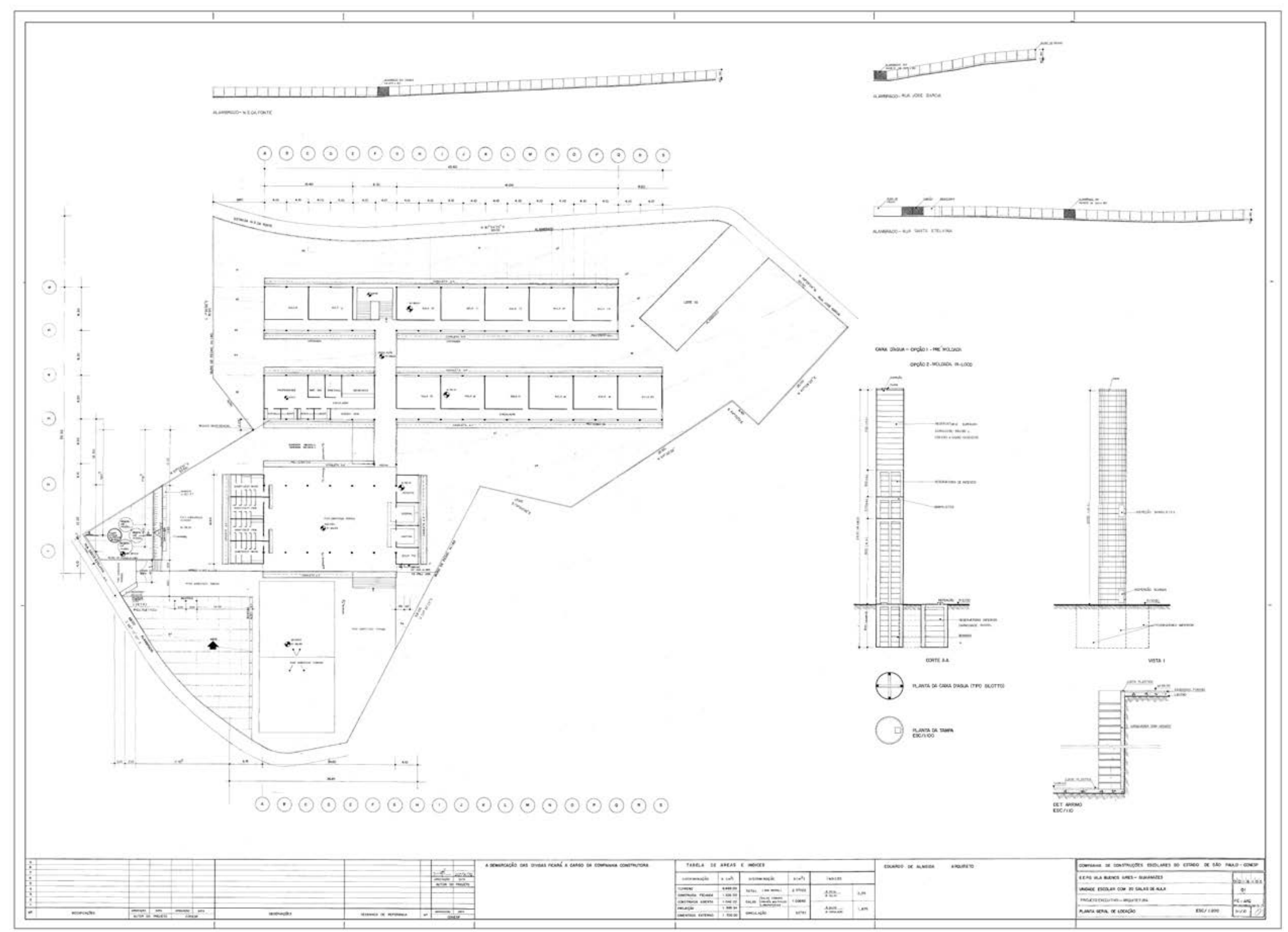


Esta solução, ainda que simples, parece transgredir as regras dos cadernos de especificações, relacionando este projeto de modo específico ao terreno, evitando o caráter genérico e automático dos projetos padronizados.

Ao fim, o projeto não foi aceito e a solução adotada seguiu o padrão das outras duas escolas, mas esta tentativa justifica uma reflexão sobre o edifício, seu sítio de implantação e os sistemas padronizados que orientaram as construções como um todo.

O pior inimigo da arquitetura moderna é a idéia do espaço considerado somente em termos de suas exigências econômicas e técnicas indiferentes às idéias do sítio. (...) Através do conceito do lugar e de seus princípios de implantação, o ambiente se torna (ao contrário) a essência da produção arquitetônica. Deste ponto, novos princípios e métodos podem ser encontrados para o desenho. Princípios e métodos que dão precedência à implantação em uma área específica. Este é um ato de conhecimento do contexto que direcionam as mudanças arquitetônicas ${ }^{61}$

Segundo Vittorio Gregotti, as investigações - teórica e prática - apresentadas pela arquitetura moderna, diante dos problemas impostos pelo pós-guerra e sua consequente sistematização perante as questões inerentes à industrialização, parecem se concentrar mais nos problemas de repetição, na definição dos tipos e na racionalização da construção a partir de elementos fabricados industrialmente.

Ao que parece, neste enfrentamento da arquitetura moderna muitos valores relacionados ao sítio e suas relações com os edifícios - questão primordial na própria história da arquitetura - parecem ter ficado em segundo plano, sendo considerados apenas em exemplos específicos, sobretudo nas obras de exceção.

Ao lado, prancha de projeto executivo da escola Vila Buenos Aires

Acervo Eduardo de Almeida
${ }^{61}$ GREGOTTI, Vittorio. New York Architectural League, October 1982, published in Section A1, $n^{\circ} 1$ (February/March, 1983), p.8., in FRAMPTON, Kenneth. Studies in Tectonic Culture: the poetics of construction in nineteenth century architecture. Massachusetts Institute of Technology, 1995. 
Sobre isso, podemos relembrar o famoso episódio sobre a casa das Canoas (1951) projetada por Oscar Niemeyer no Rio de Janeiro e conhecida pela sua exuberante cobertura de geometria livre, implantada em meio à vegetação, desenhada em função da topografia acentuada, dos atributos da natureza e de sua privilegiada vista. Como nos relembra Cecília Rodrigues dos Santos:

A casa das Canoas não poderia deixar de provocar a crítica internacional no momento da sua conclusão. O suíço Max-Bill afirmou que 'a forma livre não se justifica. Só em situações excepcionais da arquitetura. A casa de Niemeyer é um mero capricho puramente decorativo e não é obra válida ou digna de qualquer interesse.' Para o arquiteto alemão Walter Gropius tratava-se de 'uma casa muito bonita mas que não era multiplicável'. E para o crítico italiano Ernest Rogers, a retomada das formas da natureza 'orgíaca' local era uma 'confusão romântica', admitindo porém a liberdade do criador. $^{62}$

Independentemente da polêmica e da distância entre a arquitetura europeia e a obra de Oscar Niemeyer, tais comentários parecem se justificar pelo radicalismo inerente ao pensamento europeu e seu contexto cultural, econômico e político do segundo pós-guerra, muito diferente da realidade brasileira (especialmente aquela vislumbrada por Niemeyer).

No caso de Eduardo de Almeida, parece claro que ele busque atender os princípios de racionalização da construção, em sintonia com o desejado e crescente processo de industrialização no Brasil a partir dos anos 1960. Assim como parece claro que sua produção mantenha distância da obra de Oscar Niemeyer, sobretudo em sua fase de grande liberdade formal pós-Pampulha.

Nos primeiros dez anos de atuação, Eduardo de Almeida parece ter se dedicado ao problema da definição de volumes funcionais claros que, articulados de diferentes maneiras, poderiam dar resposta aos seus diversos projetos.

${ }^{62}$ SANTOS, Cecília Rodrigues. Casa das Canoas de Oscar Niemeyer: fazendo a alma cantar. in Vitruvius, Arquitextos, Setembro de 2003.

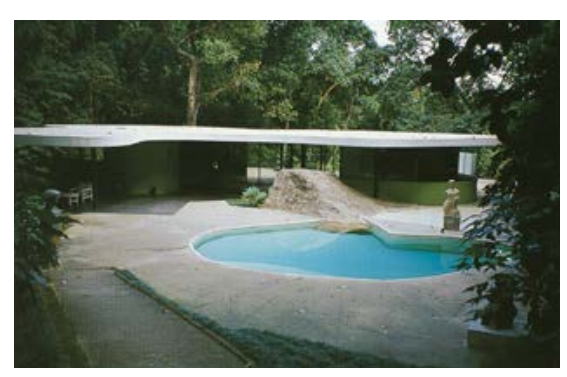

Casa das Canoas, Oscar Niemeyer ANDREOLI, Elisabetta e FORTY, Adrian (org.). Arquitetura Moderna Brasileira. London Phaidon, 2002, pág. 154 


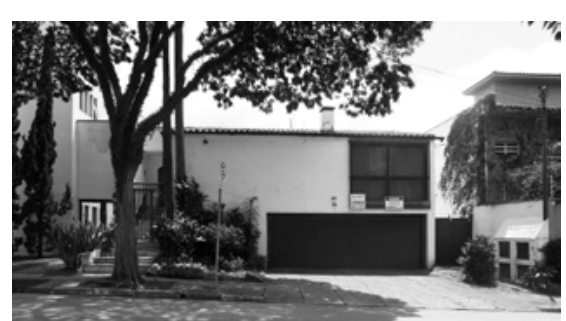

Residência Jean Nadim

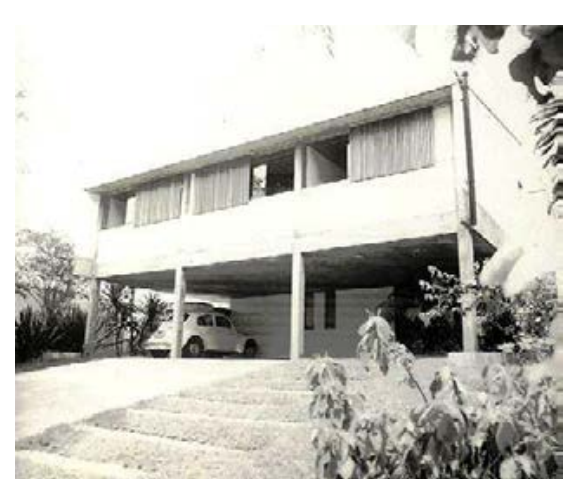

Residência Niemeyer dos Santos

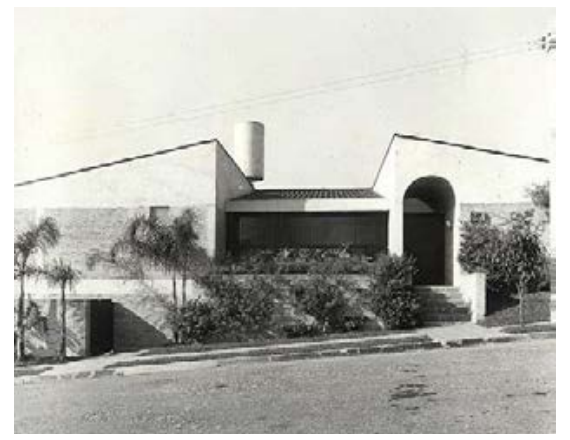

Residência Luís Alberto Guimarães

Desenhos dos módulos do Conjunto Pasárgada Acervo Eduardo de Almeida
A análise cuidadosa dos projetos desta fase - até pela influência organicista de Wright que nunca o abandonou - revela sempre o arranjo de tais volumes em cuidadoso ajuste com a topografia ou com o entorno, mas também com as questões ligadas à orientação ou ao clima.

Podemos afirmar que a diferença entre estes inúmeros projetos, embora realizados a partir da mesma estratégia, decorre justamente da relação específica de cada projeto com seu respectivo sítio.

Os dois volumes da casa Carioba, um voltado para a rua onde se posiciona o acesso de veículos, e outro voltado ao generoso recuo lateral - onde posteriormente foi implantada uma piscina valem-se da geometria do lote decorrente do sistema viário do loteamento e do consequente aproveitamento dos espaços internos em sua relação de continuidade com o jardim.

A diferença entre as casas para Jean Nadin, Niemeyer dos Santos ou Luís Alberto Guimarães, apesar de pensadas a partir do mesmo partido volumétrico, dá-se pelo modo como estas se relacionam com a topografia do lote, exigindo disposições funcionais específicas em cada caso, exatamente como nos princípios apresentados para as residências modulares do Conjunto Passárgada, projetadas para a construtora Formaespaço em 1973.
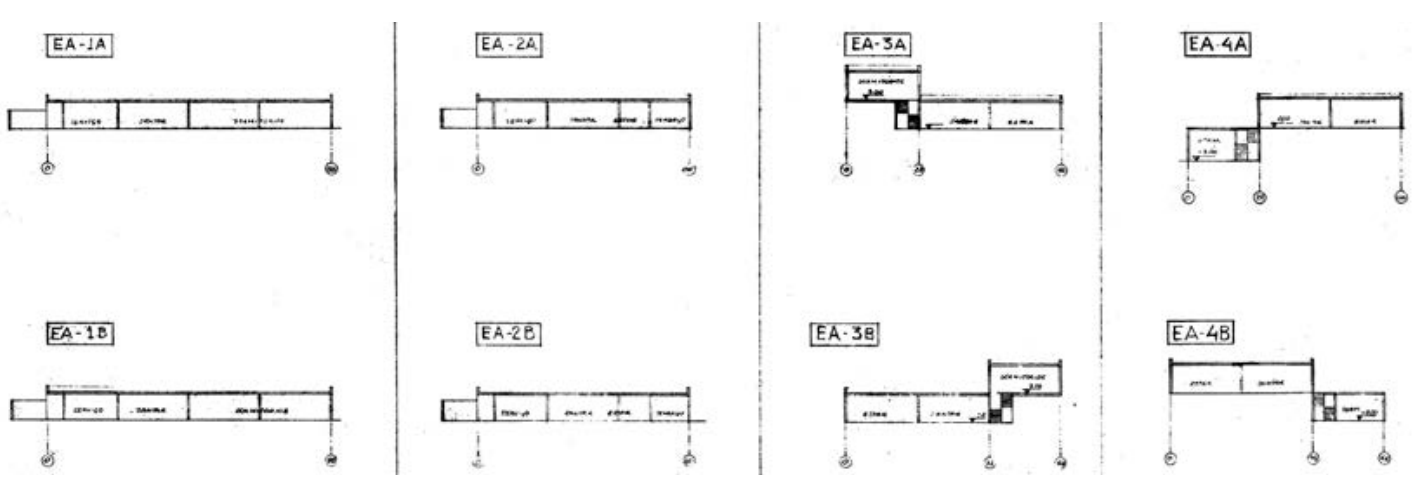


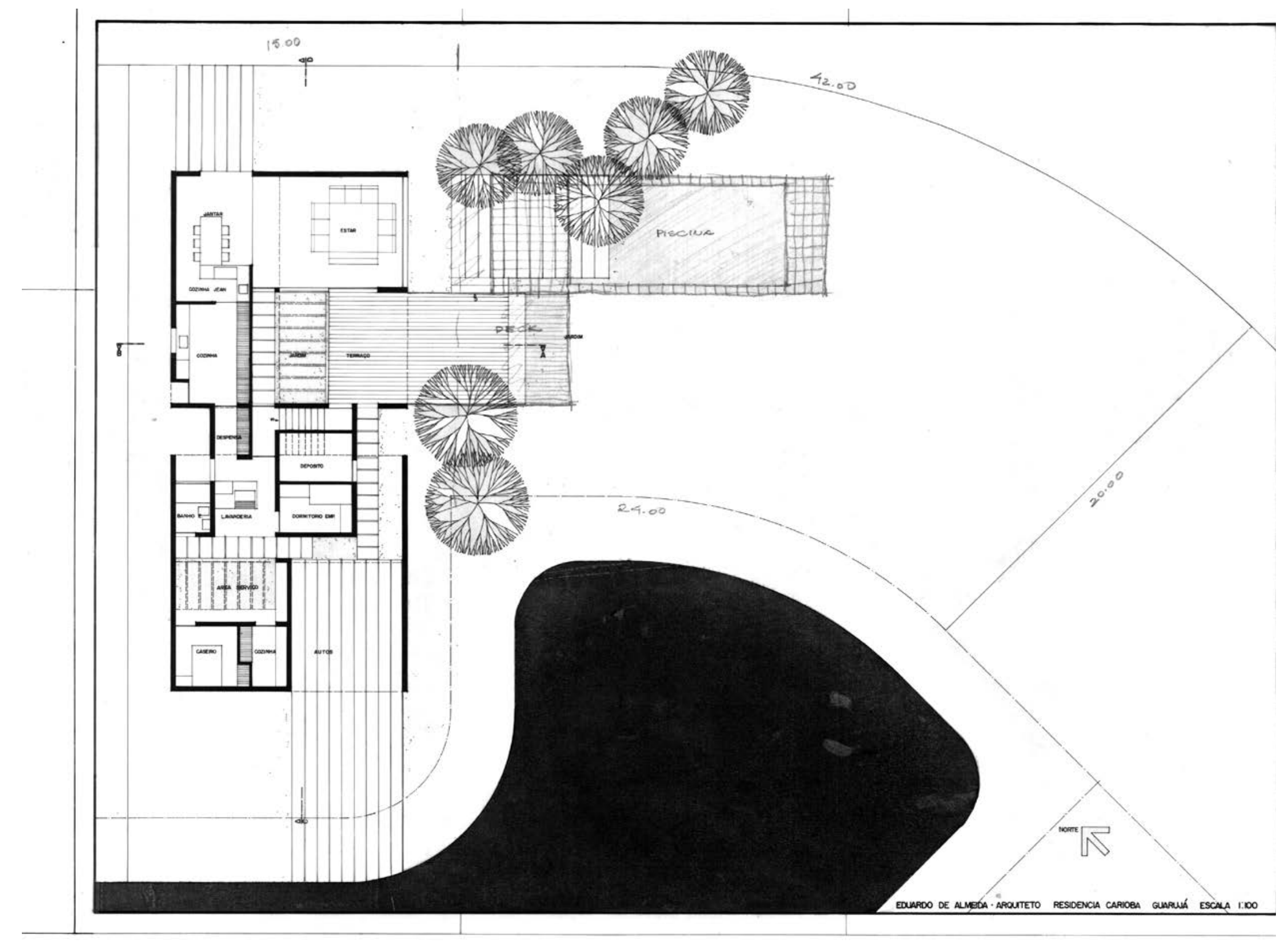




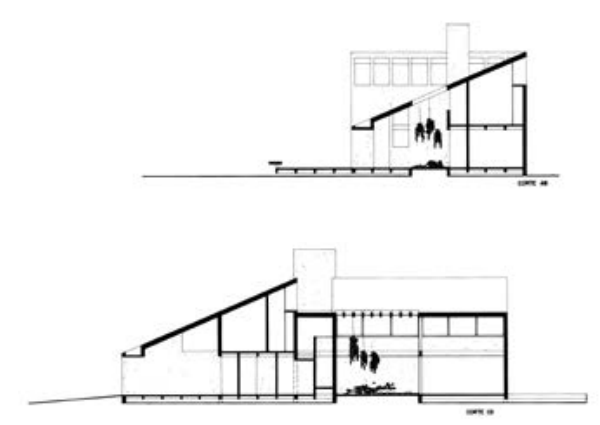

Cortes da Residência Carioba
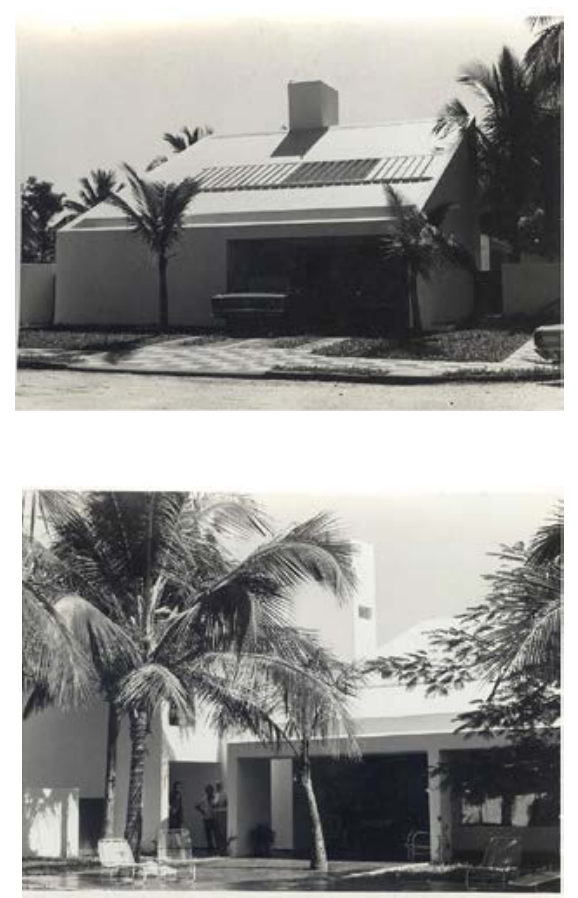

Fotos e prancha do projeto da Residência Carioba

Acervo Eduardo de Almeida
Neste mesmo ano, paralelamente a estas experiências, Eduardo de Almeida realiza um projeto excepcional para a casa de Jean Sigrist: ao analisar a topografia do terreno e o exemplo dos vizinhos, o arquiteto responde com uma solução volumétrica contundente em sua relação com o desnível existente e com o entorno.

Em depoimentos, Eduardo de Almeida relata que iniciou o projeto 'com soluções extremamente complicadas que inclusive exigiriam contenções caras e difíceis, que acabariam por descaracterizar muito o terreno, ${ }^{63}$ assim como as casas vizinhas que ocupavam o centro do lote totalmente planificado.

A solução finalmente adotada, crítica a estes exemplos, surge da conversa com a equipe e, em especial, da provocação de Iolanda Akamine Risi, jovem arquiteta colaboradora que sugeriu a Eduardo a criação de uma casa enterrada.

Apesar de reagir negativamente em um primeiro momento - "Deixe de loucura, eu não escondo ninguém!" - Eduardo de Almeida, pouco a pouco, começa a estudar esta possibilidade - " $E$ porque não?"

(...) A questão não era enterrar a casa ou não, e sim uma possibilidade de organização do projeto, adequada para o terreno e que parecia comportar inúmeras vantagens (...). E isto (...) me proporcionava um ritmo vertical e ao mesmo tempo uma modulação horizontal, que sempre me preocupa para organizar a estrutura e os espaços de maneira muito regular. À medida que ia recortando o terreno nestes níveis, fui resolvendo o projeto com um piso de acesso -que não me obrigava a cortar o terreno demasiadamente-com um piso para os espaços públicas e outro para os espaços privados, de maneira que o terraço de um nível era a cobertura do outro. (...) Me dei conta que poderia se converter em um projeto interessante e que poderia recompor a encosta da colina, completamente despedaçada pelas casas vizinhas, com profundos e incríveis cortes com elementos de contenção e monstruosidades de estilo. ${ }^{64}$

${ }^{63}$ ALMEIDA apud ESPALLARGAS in PIÑON, Hélio. Eduardo de Almeida. Barcelona, Edicions UPC, 2005, p.23
${ }^{64}$ Idem. 

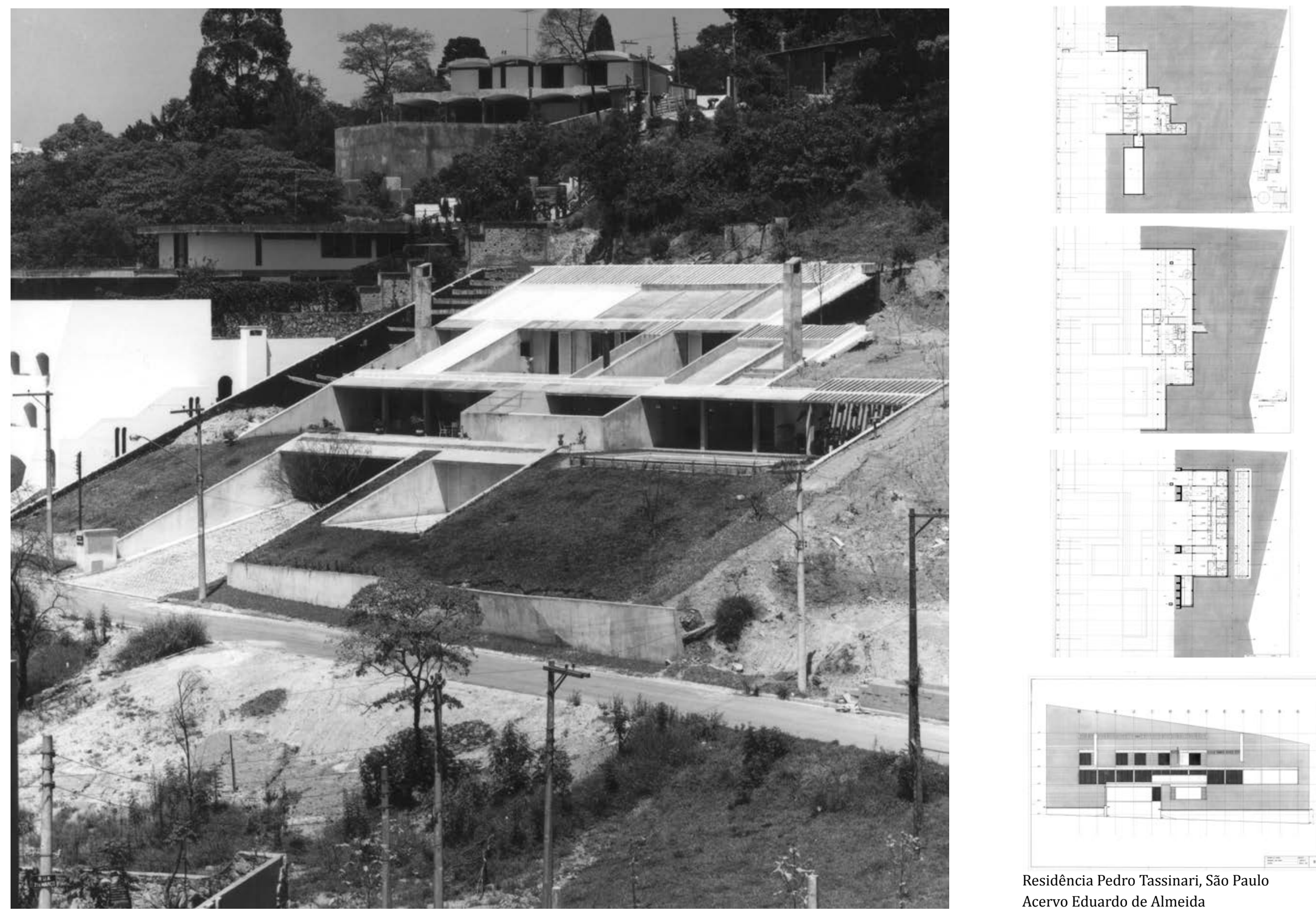

Residência Pedro Tassinari, São Paulo Acervo Eduardo de Almeida 

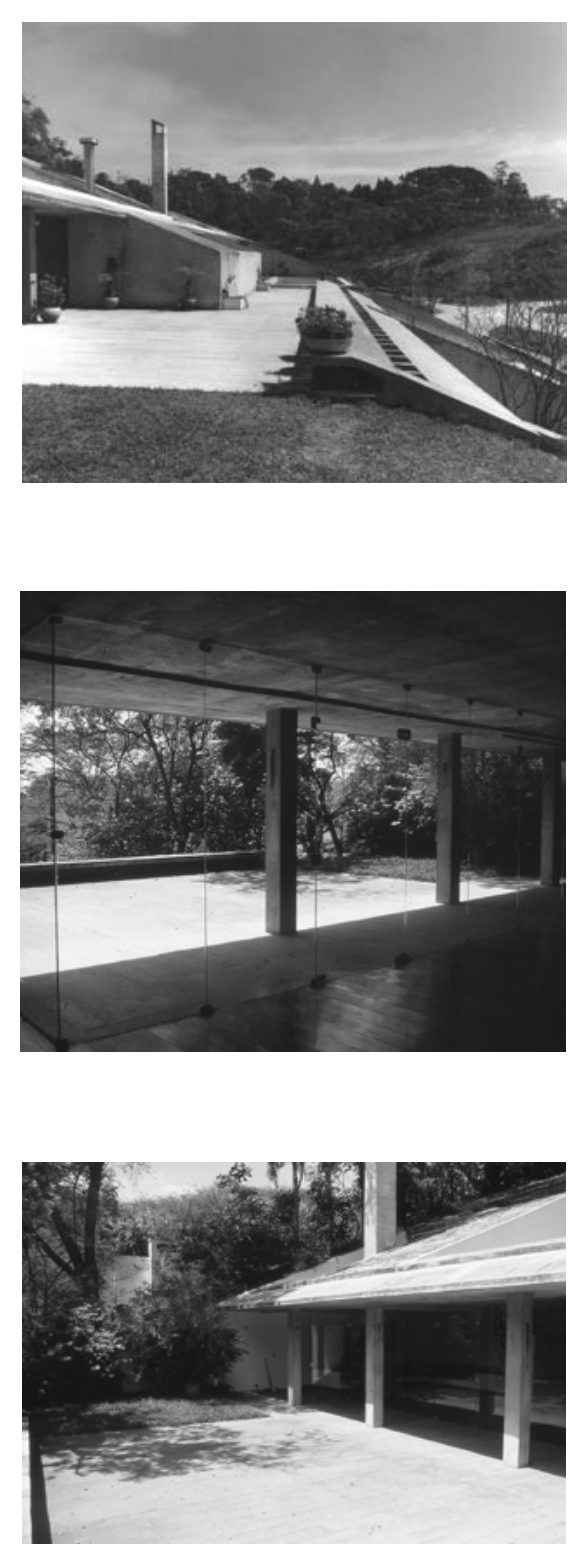

Residência Pedro Tassinari, São Paulo Acervo Eduardo de Almeida
Essa confissão é extremamente importante para discutirmos as estratégias projetuais de Eduardo de Almeida, já que podemos afirmar que inúmeros desenhos - testes de possibilidades diversas - são instrumentos de aferição, sem os quais não se pode tomar nenhuma decisão.

Importam não só as ideias, mas sobretudo como estas se comportam na transposição real e específica para cada planta. Caso não seja convencido pelo desenho, pelo resultado geral de uma solução, Eduardo de Almeida não se importa em recomeçar a testar e desenvolver outros partidos, somente adotando-os como solução efetiva depois que todo o conjunto esteja resolvido a contento.

Neste caso, a radicalidade de uma casa enterrada e 'sem fachadas' parece menos uma finalidade nela mesma, e mais a decorrência da solução de todos os fatores que Eduardo de Almeida considera como elementos importantes para uma arquitetura adequada.

Não por acaso, apesar da aparente radicalidade, a solução final se aproxima de uma construção térrea, tradicional, escalonada por patamares - salvo as proporções, não diferente da proposta para a escola em Parque Brasília -, onde cada um dos setores da casa se volta a um espaço aberto, resultando em ambientes dotados de correspondência nas relações de continuidade entre interior e exterior.

Neste caso, cada um dos pavimentos, desenhados de modo a solucionar os diferentes agrupamentos funcionais, são conjugados a partir de uma ideia de continuidade, não só do perfil natural do terreno, como da própria unidade da edificação. 



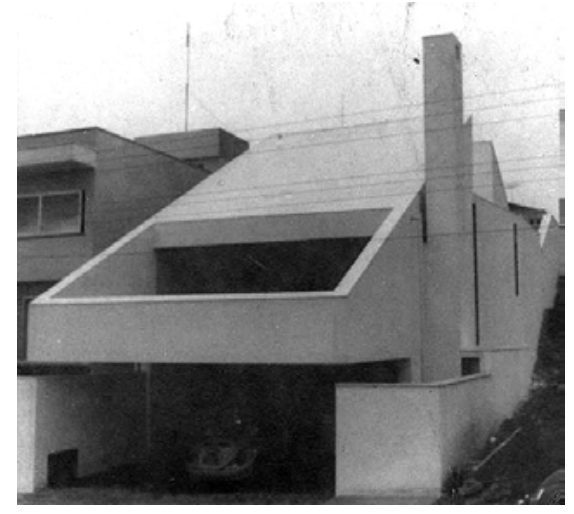

Residência Fernando de Almeida

Corte perspectivado da Residência Pedro Tassinari, São Paulo

Acervo Eduardo de Almeida
Maria Isabel Imbronito associa este projeto a inúmeras casas realizadas anteriormente, pensadas pela justaposição de volumes com coberturas inclinadas:

(...) Apesar de suas peculiaridades, a casa da encosta pode ser entendida como uma implantação inusitada de uma casa com laje inclinada. Esta casa não trabalha o balanço volumétrico, como a casa Fernando Almeida, que se projeta para fora ao mesmo tempo em que se adapta à topografia, mas trabalha inclinações e chanfros próprios de sua implantação dissimulada no terreno. ${ }^{65}$

Apesar do encadeamento natural com sua produção anterior, a casa Sigrist parece direcionar os projetos de Eduardo de Almeida para novos questionamentos, já que não mais se limita às justaposições volumétricas, buscando a unidade do objeto em seu confronto - ou adequação com a paisagem.

A casa deixa de ser um conjunto de objetos pousados sobre a topografia modificada por pesados muros de pedras - se quisermos compará-la a procedimentos organicistas de outrora - e passa a ser um conjunto edificado unitário expresso através da estrutura de concreto aparente que é, a um só tempo, fundação, volume e terreno (ainda que recomposto).

Ao renunciar a ideia de 'fachada', a edificação nos remete a ocupações primitivas, como cavernas habitadas ou como encostas perfuradas para a construção de abrigos ancestrais. A partir de uma associação como esta, podemos ponderar que a expressividade do projeto se dá pela ausência de volume e pela criação de aberturas diretamente no terreno, pelo espaço negativo em sombra apenas fechado por vidro temperado que, sem a presença de requadramentos, interferem o mínimo possível na continuidade entre o dentro e o fora.

${ }^{65}$ IMBRONITO, Maria Isabel. Tese de Doutoramento: Procedimento de projeto com base em retículas: estudo de casas de Eduardo de Almeida. São Paulo, FAU USP, 2008, p. 75 
O sentido unitário do concreto armado aparente - utilizado nos elementos estruturais de contenção ou de cobertura - só é rompido por alvenarias revestidas e pintadas de branco, simples elementos de subdivisão interna que não se confundem com a estrutura e nem recebem interferência de outros elementos construtivos, como também observa Maria Isabel Imbronito: "O batente é eliminado enquanto componente visível, deixando perceptível apenas a fresta entre a porta e a alvenaria, que é tratada com perfil de aço embutido para perfeito requadramento do vão e encaixe da porta." ${ }^{\prime 6}$

O detalhamento parece exemplificar mais uma vez a coerência interna - parte e todo - buscada pelos projetos de Eduardo de Almeida, neste caso, em um detalhamento austero e econômico que parece justificar a máxima de seu autor: 'o melhor detalhe é aquele que não se vê.'b7

Esta problemática - o lugar e a construção - parece se exemplificar de maneiras diversas em outros projetos, como por exemplo, o Clube da Metalúrgica Orlândia, de 1975.

Talvez norteado pelo programa de esporte e lazer, Eduardo de Almeida é motivado a criar um contraponto em relação aos edifícios de caráter fabril para a metalúrgica: uma sequência de coberturas em abóbodas de concreto armado, desenhadas em continuidade em relação ao solo (artificialmente construído nas relações de compensação entre corte e aterro).

Tais edifícios, cuja influência direta talvez seja a da casa Milan de Marcos Acayaba (1973), retomam soluções recorrentes da arquitetura moderna, de Niemeyer a Artigas, para ficarmos restritos à produção dos arquitetos brasileiros.

${ }^{66}$ IMBRONITO, Maria Isabel. Tese de Doutoramento: Procedimento de projeto com base em retículas: estudo de casas de Eduardo de Almeida. São Paulo, FAU USP, 2008, p. 141

${ }^{67}$ ALMEIDA apud ESPALLARGAS in PIÑON, Hélio. Eduardo de Almeida. Barcelona, Edicions UPC, 2005, p.17

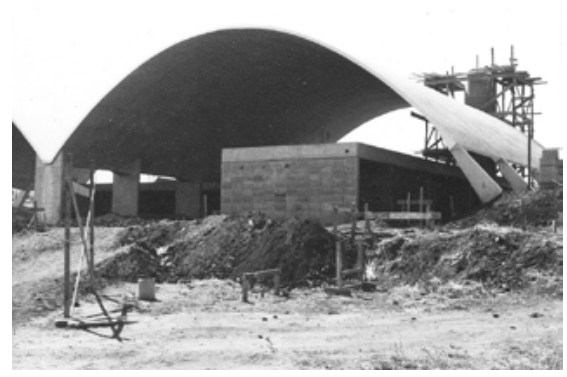

Clube da Mealúrgica Orlândia em fase de obras

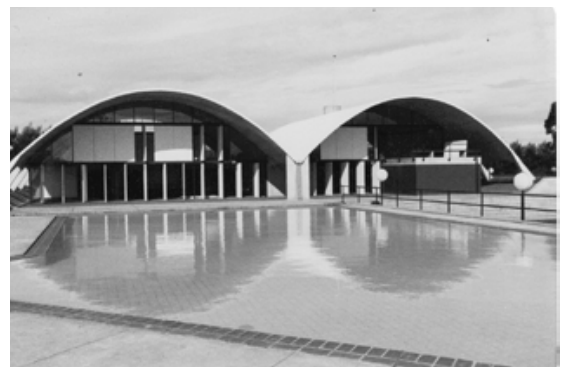

Clube da Mealúrgica Orlândia

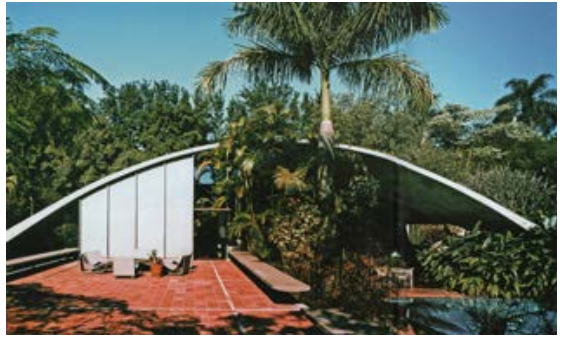

Casa Milan, Marcos Acayaba

WISNIK, Guilherme; SEGAWA, Hugo; KATINSKY, Julio; ACAYABA, Marcos. Marcos Acayaba. São Paulo, Cosac Naify, 2007 


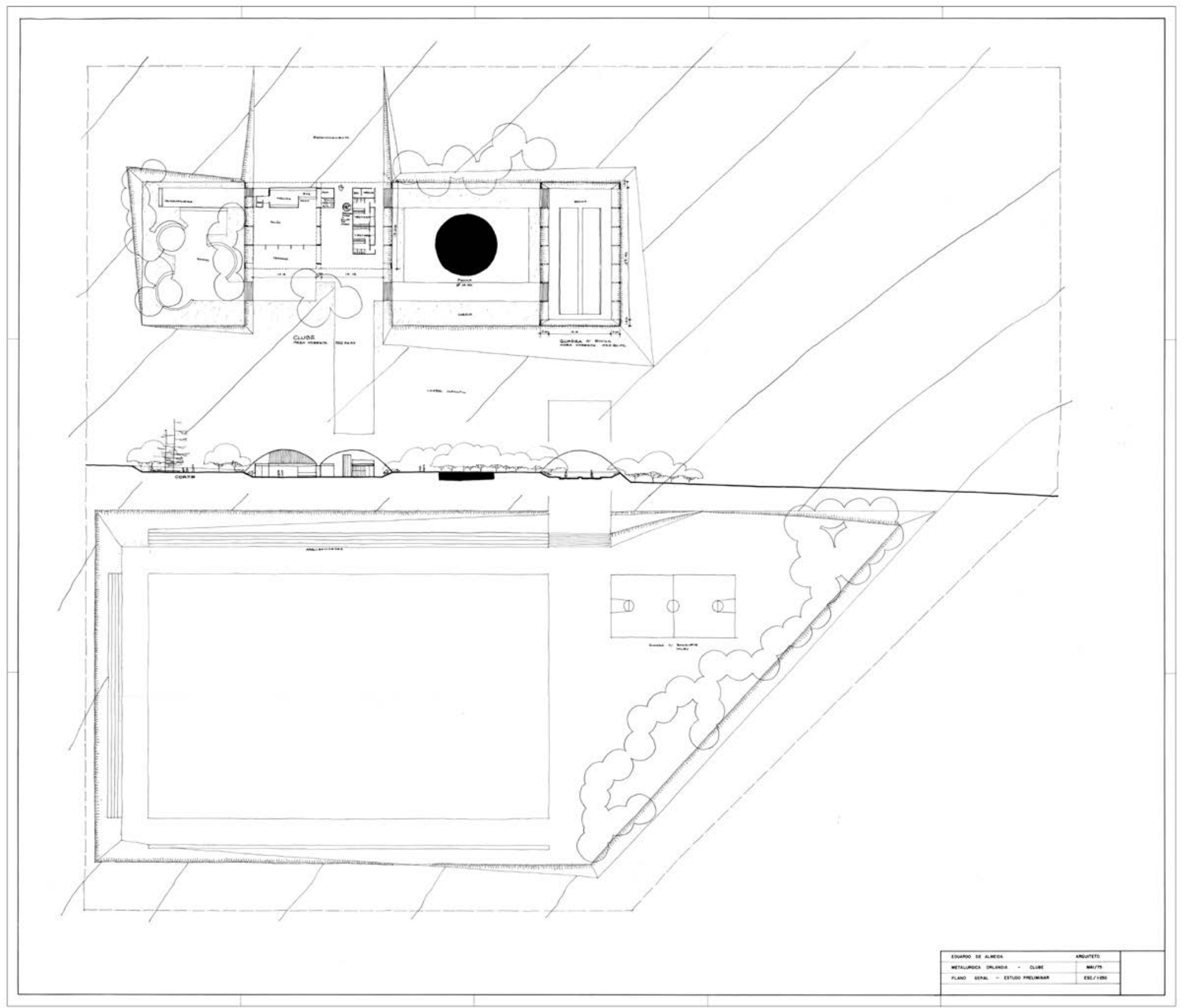


Assim como no projeto de Acayaba, a estrutura de cobertura recebe volumes autônomos em seu interior para solucionar determinados programas quando necessário, e se complementa pela utilização de planos de vidro e painéis basculantes de grandes dimensões para a ventilação natural dos ambientes.

A partir de um princípio de economia de meios, Eduardo de Almeida adota a forma capaz de obter o máximo de espaço com o mínimo de recursos materiais, coberturas curvas que, adequadas aos usos propostos para tais áreas de lazer, ancoram-se no solo de modo a anular os esforços de tração decorrentes da própria geometria utilizada.

Temos neste projeto, portanto, a adoção de uma forma, de uma volumetria, que não apenas 'pousa' no terreno, mas ao contrário, depende da interação com o solo para viabilizar sua existência, assim como a casa Sigrist.

Ao que parece, tais projetos propõem novas direções ao vínculo entre arquitetura e lugar, já que nesta produção o projeto de arquitetura não pode acontecer sem um contato preciso e conjunto com seu local de implantação.

Esta conceituação parece estar mais relacionada a uma estratégia projetual de interação entre a estrutura e o terreno, do que a adoção de formas prévias, como demonstra o projeto de Eduardo de Almeida para a segunda casa no condomínio Patrimônio do Carmo, de 1976, que se utiliza de uma linguagem diversa dos dois exemplos analisados anteriormente.

Neste caso, seguindo a declividade do terreno, o arquiteto cria uma casa binucleada em contraponto a ele, seguindo a mesma separação volumétrica e funcional de projetos anteriores. 


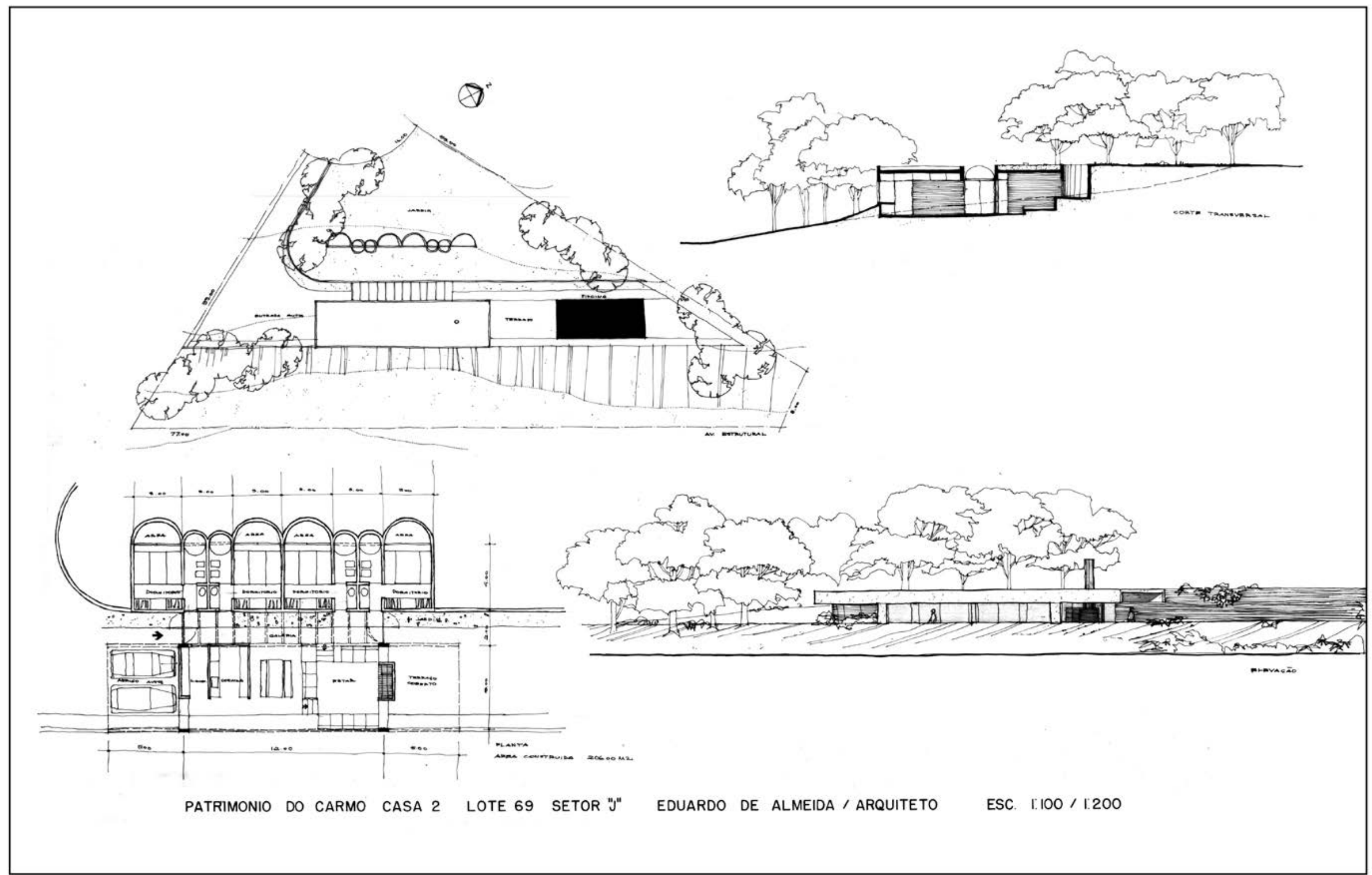

Prancha do projeto da segunda Casa do

Patrimônio do Carmo

Acervo Eduardo de Almeida 
O primeiro volume aparece incrustrado, dando continuidade ao muro de arrimo que corta o terreno, possibilitando a ampliação do jardim até a sua cobertura. 0 segundo volume se destaca, utilizando uma linguagem 'paulista': pavilhão envidraçado coberto por uma laje de concreto aparente e estruturado por duas vigas que vencem grandes balanços, com apenas duas linhas de apoios, a exemplo de projetos como a casa Ivo Viterito (1962), de Artigas, ou a casa Marcelo Nitsche (1973), de Paulo Mendes da Rocha.

Tal justaposição volumétrica, diferentemente de outros projetos de Eduardo de Almeida, não poderia se dar com o habitual emprego de uma laje plana de concreto como elemento de conexão. Ao contrário, já que os volumes se apresentam com ênfase na horizontalidade da estrutura, a solução foi criar uma cobertura curva e iluminante, justamente na conexão entre os programas, de modo a garantir a independência entre os volumes e o necessário contraste à composição.

A utilização de coberturas de vidro como elemento de conexão de volumes será retomada posteriormente em inúmeros projetos de Eduardo de Almeida, quase sempre associados à estrutura de circulação dos edifícios, como a primeira versão da casa Bracher (1989), a residência Pacheco e Silva (1993) ou até mesmo em edifícios de maior porte, como o de escritórios para a SAP (2007).

Além destas questões, a interrupção entre volumes com coberturas de vidro viabiliza o emprego de iluminação natural no centro da planta, normalmente espaços distantes das fachadas, que por sua vez sempre são utilizadas para a iluminação e ventilação dos ambientes.

Nesta casa do Patrimônio do Carmo, o fato de os dormitórios estarem enterrados não significa que não tenham qualidade ambiental, ao contrário, os muros de arrimo de geometria curva se

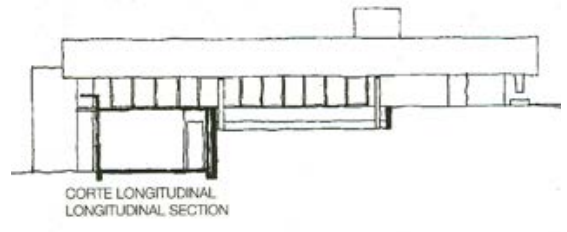

Residência Ivo Viterito, Vilanova Artigas ARTIGAS, João Batista Vilanova. Caminhos do arquitetura. 4 ed. rev. e ampl.. São Paulo, Cosac Naify, 2004, p.123 

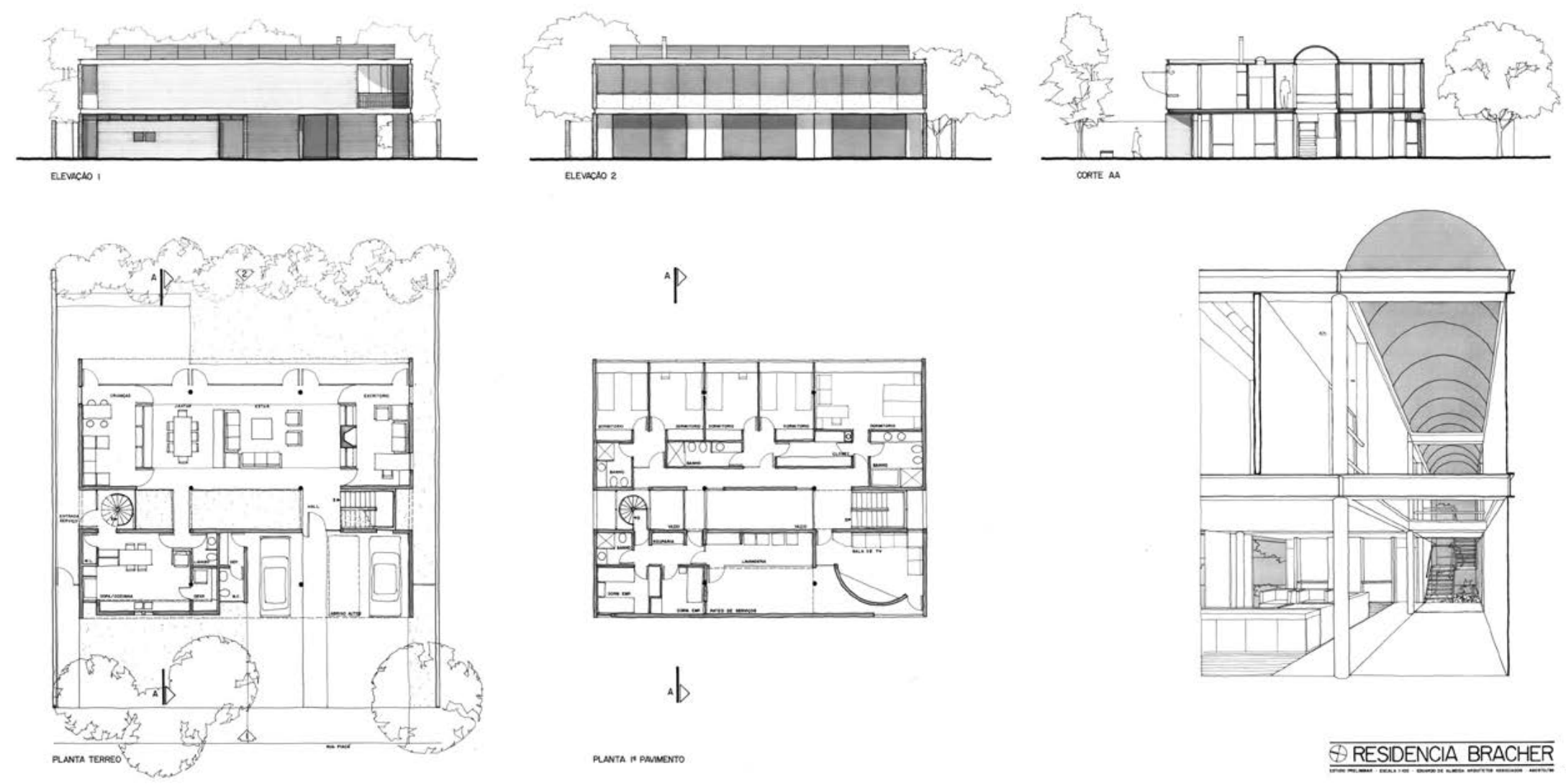

$\Phi$ RESIDENCIA BRACHER

Prancha do projeto para a primeira versão da

Residência Bracher (1989)

Acervo Eduardo de Almeida 
distanciam das janelas, criando pequenos pátios semicirculares capazes de garantir o conforto dos ambientes, revelando-se como vazios rebaixados junto ao jardim, implantados no plano de cobertura.

Segundo Kenneth Frampton, a relação entre edifício e o sítio merece ser retomada a partir dos estudo de Gottfried Semper em 'Quatro Elementos da Arquitetura' (1851) em que descreve a 'casa primordial' a partir de sua subdivisão em quatro elementos básicos:"(1) movimento de terra, (2) a lareira, (3) a grelha estrutural/cobertura, e (4) a membrana leve de fechamento." ${ }_{68}$

Nesta subdivisão, Semper classifica os edifícios em dois procedimentos fundamentais: a grelha estrutural de caráter 'tectônico', onde componentes leves e lineares são montados sob a mesma matriz espacial, e os trabalhos de movimentação de terra 'estereotômicos', onde elementos pesados são justapostos para conformar os embasamentos.

Neste singelo projeto para a segunda casa no Patrimônio do Carmo, infelizmente não construído, Eduardo de Almeida parece se utilizar da mesma contraposição entre o tectônico e o estereotômico, mas com uma diferença fundamental: o trabalho relacionado ao terreno também assume a forma de edifício, o embasamento passa a ser habitado.

Esta transposição nos remete, por exemplo, a projetos do arquiteto Vilanova Artigas, como a Garagem de Barcos do Clube Santa Paula (1961) ou a Estação Rodoviária de Jaú (1973), onde o desenho da estrutura em seu contato com o solo e o uso crescente do embasamento como espaços de fato - e não apenas elementos disciplinadores do terreno para a implantação do edifício -, parecem ser tema e preocupação crescente no enfrentamento dos projetos.

${ }^{68}$ GREGOTTI, Vittorio. New York Architectural League, October 1982, published in Section A1, $n^{\circ} 1$ (February/March, 1983), p.8., in FRAMPTON, Kenneth. Studies in Tectonic Culture: the poetics of construction in nineteenth century architecture. Massachusetts Institute of Technology, 1995.
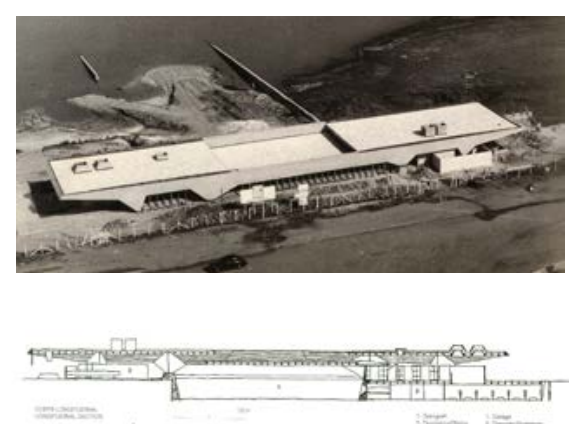

Garagem de Barcos Santa Paula, Vilanova Artigas ARTIGAS, João Batista Vilanova. Caminhos da arquitetura. 4 ed. rev. e ampl.. São Paulo, Cosac Naify, 2004, p.98 e 99 .
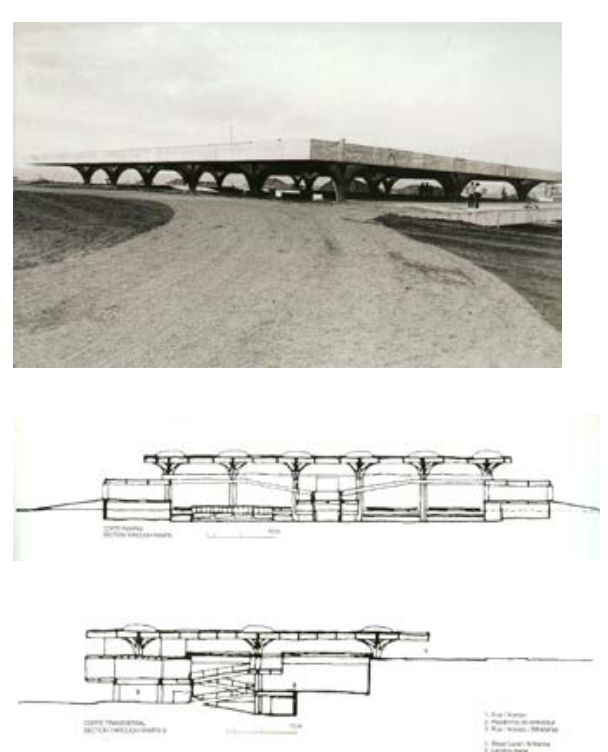

Estação Rodoviária de Jaú

ARTIGAS, João Batista Vilanova. Caminhos da arTIGAS, João Batista Vilanova. Caminhos da
arquitetura. 4 ed. rev. e ampl.. São Paulo, Cosac Naify, 2004, p.178, 181 e 183 


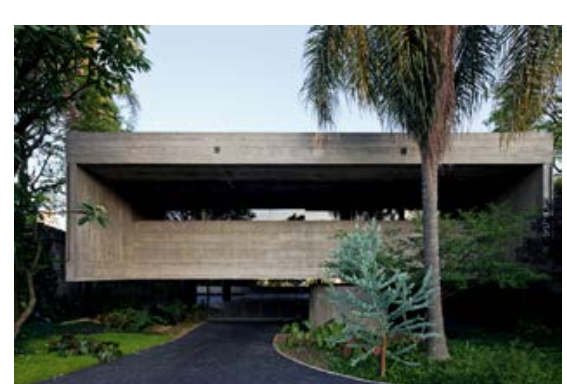

Residência Mário Masetti, Paulo Mendes da Rocha

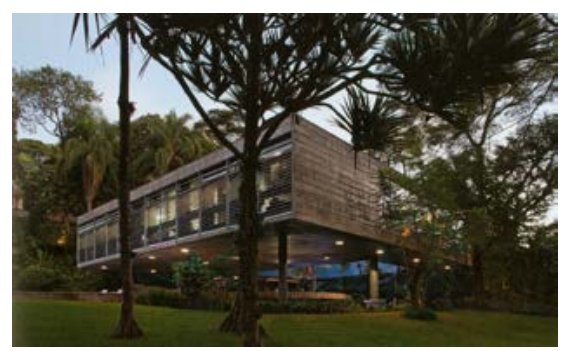

Residência James King, Paulo Mendes da Rocha PISANI, Daniele. Paulo Mendes da Rocha: Obra completa. São Paulo, Gustavo Gili, 2013, p. 117 e 118

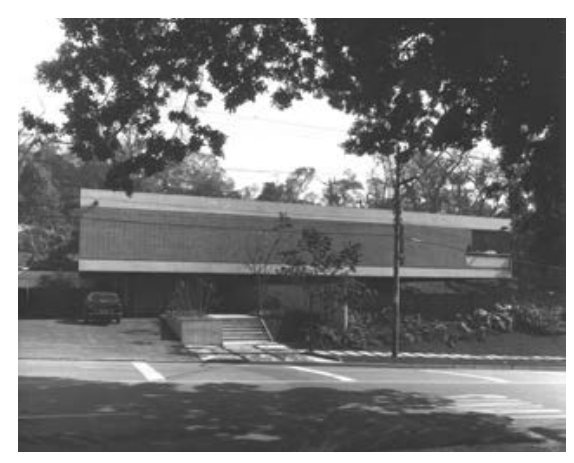

Residência Max Define

Acervo Eduardo de Almeida
Tal aproximação com a arquitetura paulista e a problemática da relação da construção com seu sítio na obra de Eduardo de Almeida parece ser bem ilustrada pelo conhecido caso do projeto para a residência Max Define, datada de 1975.

Segundo depoimento do arquiteto o anteprojeto apresentado para os clientes e já aprovado junto aos órgãos responsáveis é interrompido pelo próprio arquiteto após conhecer o projeto de Paulo Mendes da Rocha para a residência James King projetada em 1972 e então recém concluída.

Seguindo a tônica de outros trabalhos, a proposta de Paulo Mendes da Rocha para esta residência é definida por um volume suspenso de concreto armado, solução que dá continuidade espacial à área verde sob o seu volume.

Mesmo as dependências de apoio - que não deveriam se posicionar no volume principal - são devidamente rebaixadas, evitando obstruções desnecessárias junto ao espaço dos pilotis, assim como na proposta, por exemplo, para a casa de Mário Masetti no Bairro do Pacaembú (1968). No entanto, diferentemente deste projeto - um volume único suspenso por quatro pilares - a proposta para a residência James King cria um pátio descoberto interno ao volume, posicionado assimetricamente em relação ao seu perímetro.

Neste recinto, a área de pilotis amplia-se em altura, possibilitando um percurso que, primeiro, revela a continuidade espacial do exterior para o interior e, em seguida, do piso térreo para o superior, enfatizado pela escada linear de acentuado caráter escultórico, desenhada de acordo com a geometria curva e irregular do desenho do piso externo. 


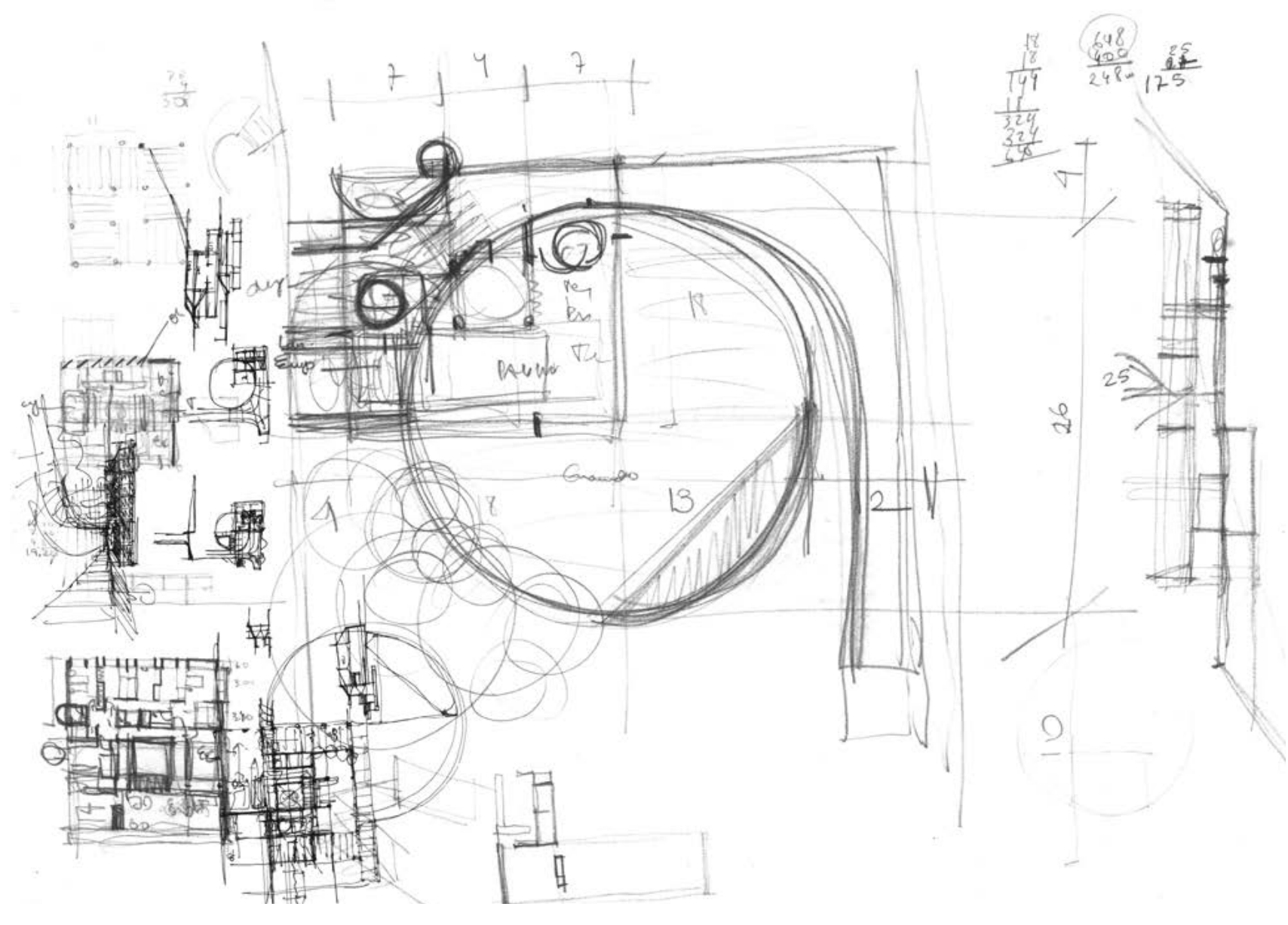



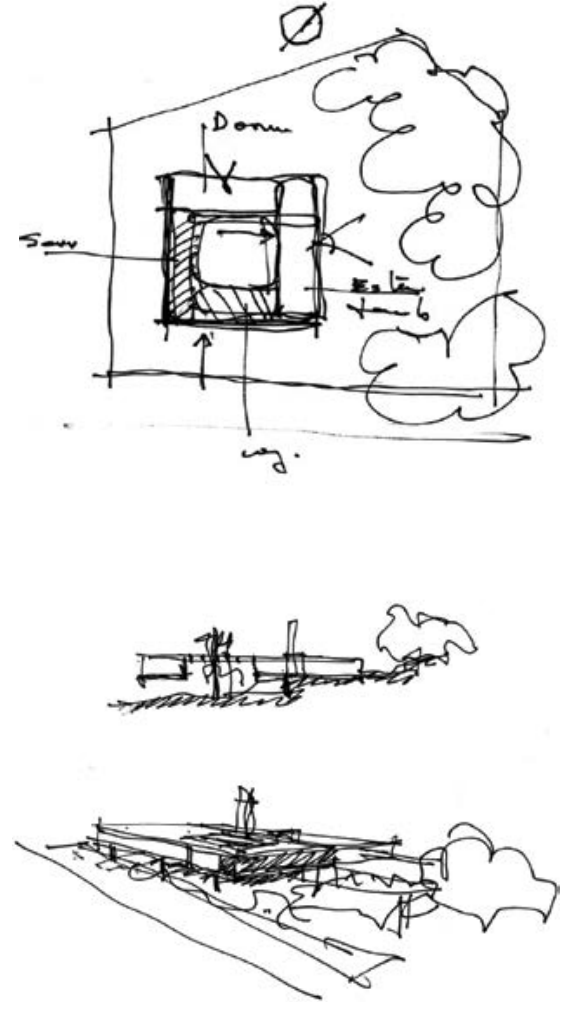

Croquis da Residência Max Define realizados para o livro de Helio Piñon
O primeiro projeto de Eduardo de Almeida para a casa Define, assim como a casa King, já apresentava uma solução de um volume de planta quadrada, com os programas dispostos ao redor de um pátio. Segundo ele, o início do trabalho considerou o terreno 'extremamente bonito, mas que tinha uma casa mal conservada, uma casa detestada pelo proprietário', e que a única ideia que 'fazia sentido era fazer uma outra casa no mesmo local, para preservar a relação com a topografia e a vegetação',69

Tal proposta poderia ser vista como uma continuidade de seus projetos para a casa de Pedro Tassinari, na praia da Baleia (1973) e uma das versões para a casa de Eugene Gordon, em Ibiúna (1974) - sobretudo pela semelhança do corte, com o emprego de coberturas inclinadas voltadas para fora - mas também somando-se estas referências de seus próprios projetos à influencia de Louis Kahn, como observa Maria Isabel Imbronito:

Apesar de não se tratar de uma referencia literal, nota-se como atributos da arquitetura de Kahn a composição volumétrica rígida e a geometrização da forma - um quadrado maior, dividido em nove quadrados menores, cada qual, por sua vez, subdividido em outros nove quadrados. ${ }^{70}$

Além destas importantes características, talvez a diferença principal em relação à solução finalmente adotada esteja na relação do volume construído com o solo. Apesar da distribuição dos programas e da definição das cotas de implantação serem basicamente as mesmas do projeto finalmente construído, o volume principal do anteprojeto estava todo posicionado sobre o solo, exceção feita apenas aos módulos destinados ao espaço de entrada de pedestres e garagem coberta.

O volume do edifício repetiria o tradicional contraste das dimensões tectônica - malha

${ }^{69}$ ALMEIDA apud ESPALLARGAS in PIÑON, Hélio. Eduardo de Almeida. Barcelona, Edicions UPC, 2005, p.32

${ }^{70}$ IMBRONITO, Maria Isabel. Tese de Doutoramento: Procedimento de projeto com base em retículas: estudo de casas de Eduardo de Almeida. São Paulo, FAU USP, 2008, p. 119 


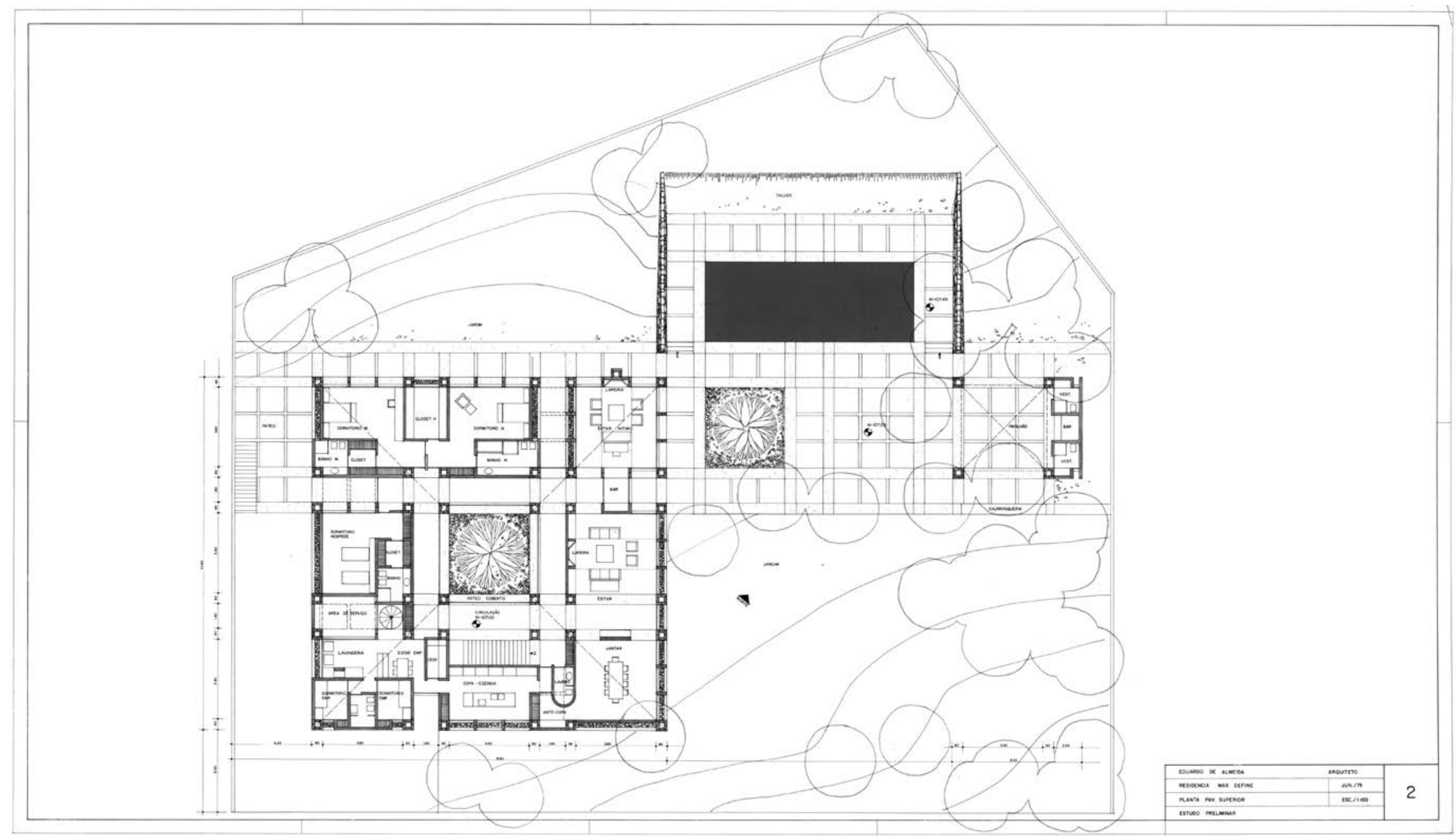

Prancha de Estudo Preliminar do Projeto para a Residência Max Define

Notar a planta quadrada e os programas

organizados ao redor do pátio central

Acervo Eduardo de Almeida 


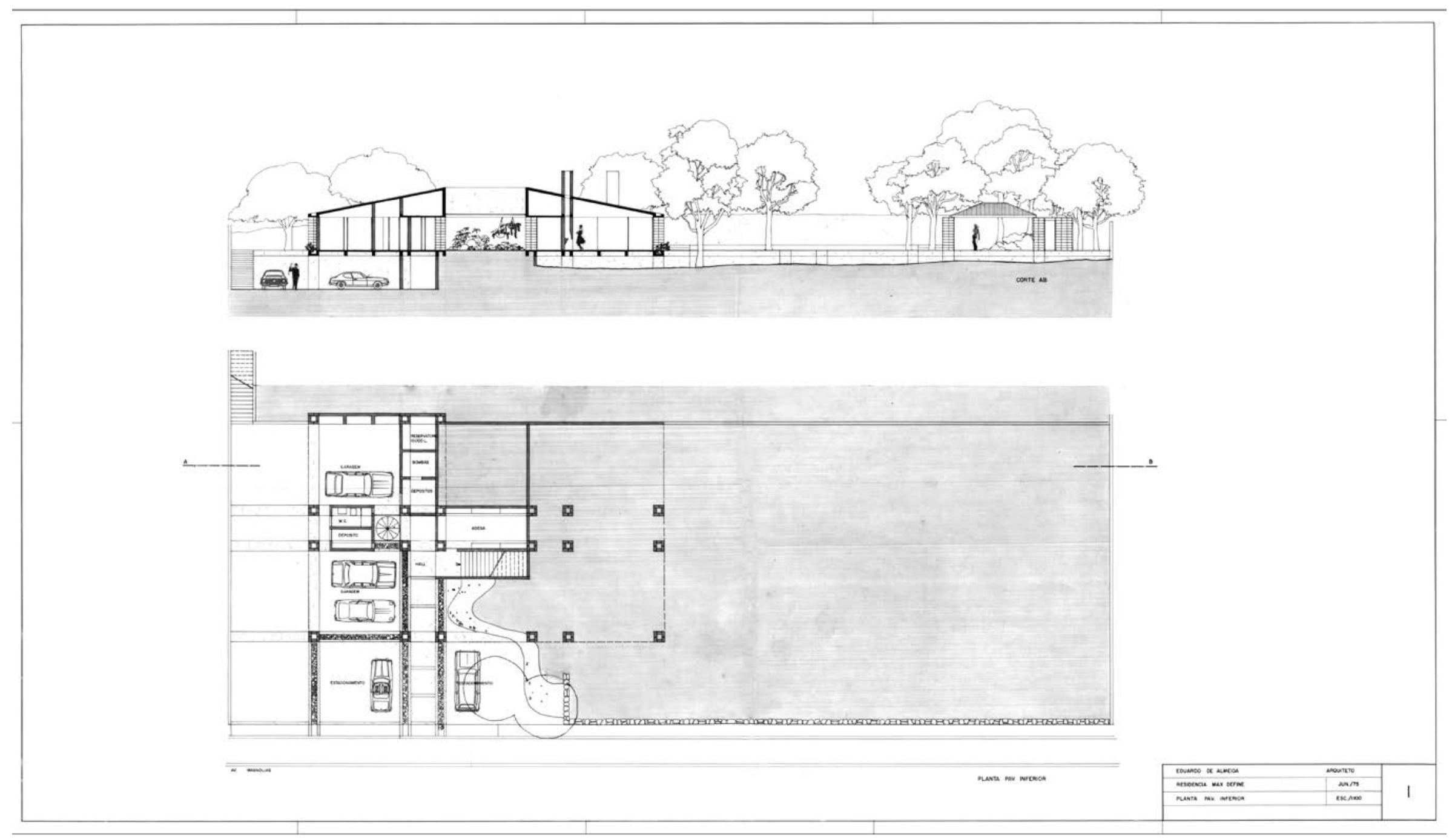

Primeiros estudos para a Residência Max Define

Notar corte com as coberturas inclinadas

voltadas para fora

Acervo Eduardo de Almeida 


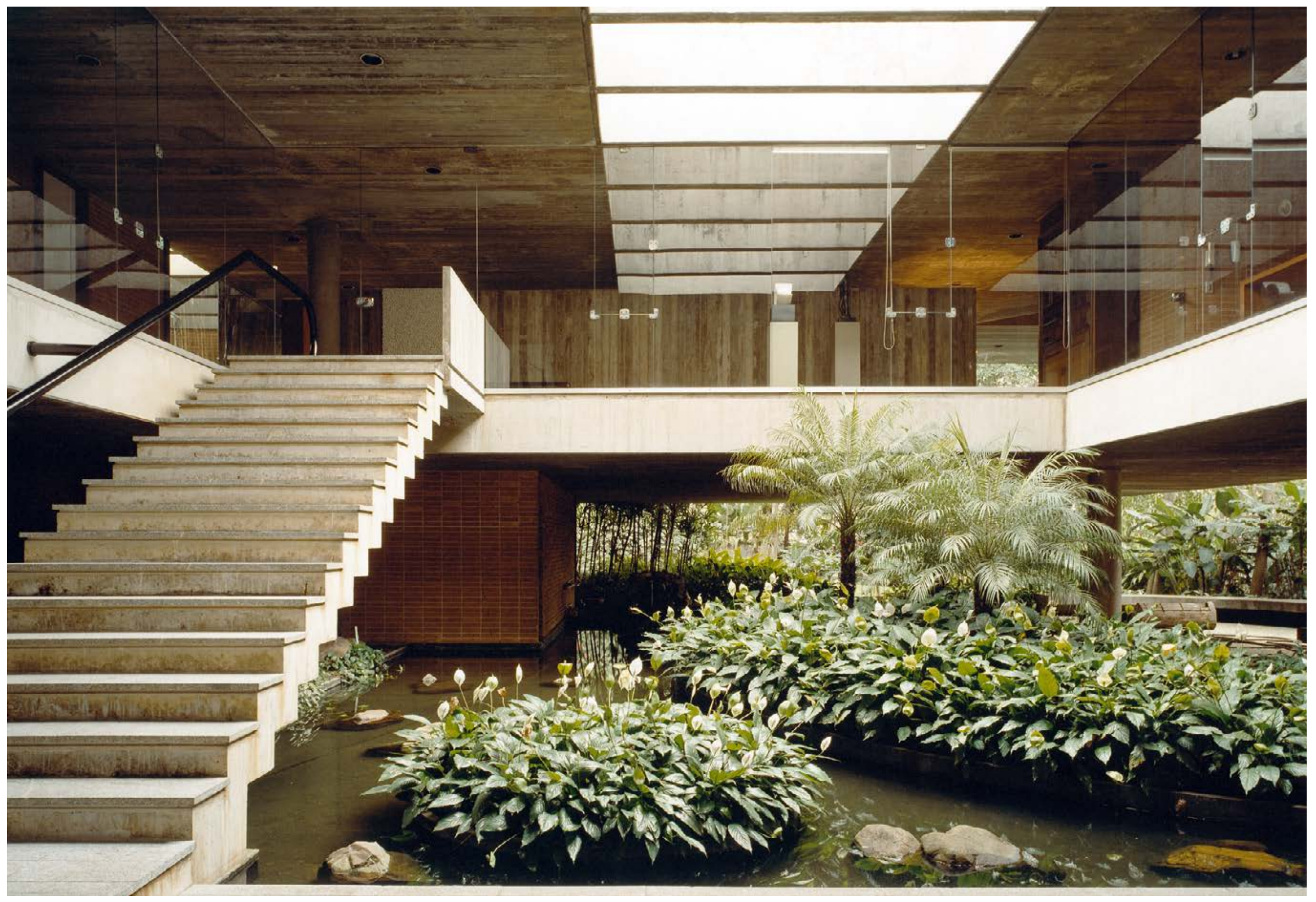


estrutural e fechamentos do volume - e estereotômica - embasamento a partir da manipulação do solo -, presentes em outros projetos de Eduardo de Almeida, onde o solo natural é cuidadosamente alterado, em equilíbrio, para permitir a construção do volume.

Então vi o projeto de Paulo Mendes da Rocha na Chácara Flora: a casa James King. Comparei aquele projeto com a casa que havia feito e me dei conta que estava equivocado, de que a casa não poderia ser como a que tinha desenhado. Talvez em outro lugar funcionaria, mas em São Paulo teria que ter outra forma. Voltei ao escritório, (...) peguei aquela planta básica com a distribuição dos ambientes, com a relação do terreno e mudei o projeto completamente até chegar ao que está aqui (...). ${ }^{71}$

De fato, a nova versão segue uma linguagem 'mais livre' na relação entre a estrutura de concreto independente e a posterior realização de divisões em alvenaria e fechamentos em vidro, absolutamente legíveis em sua autonomia, "já que os pilares comparecem, mas sem perturbar o espaço".72

Desta clareza construtiva, obtida a partir da autonomia dos elementos estruturais em relação ao todo, talvez o mais importante reflexo da nova versão tenha sido a ampliação do pavimento inferior. Todo o espaço antes ocupado por terra - agora contido por muros de arrimo de concreto armado - passa a ser um espaço vazio capaz de interligar a chegada de veículos ao jardim existente ao fundo, sob o volume da casa (agora suspenso).

Com esta alteração, o vazio interno da versão anterior foi rebaixado ao piso inferior, possibilitando a criação de um espaço maior, assimétrico em relação ao perímetro do volume, e de dupla altura, permitindo a articulação vertical entre os dois pisos, também enfatizada pela escada linear em uma das extremidades do vazio, exatamente como na casa de Paulo Mendes da Rocha.

Ao lado, foto do vazio interno da Residência Max Define

Acervo Eduardo de Almeida
${ }^{71}$ ALMEIDA apud ESPALLARGAS in PIÑON, Hélio. Eduardo de AImeida. Barcelona, Edicions UPC, 2005, p.32
${ }^{72}$ Idem, p.33 


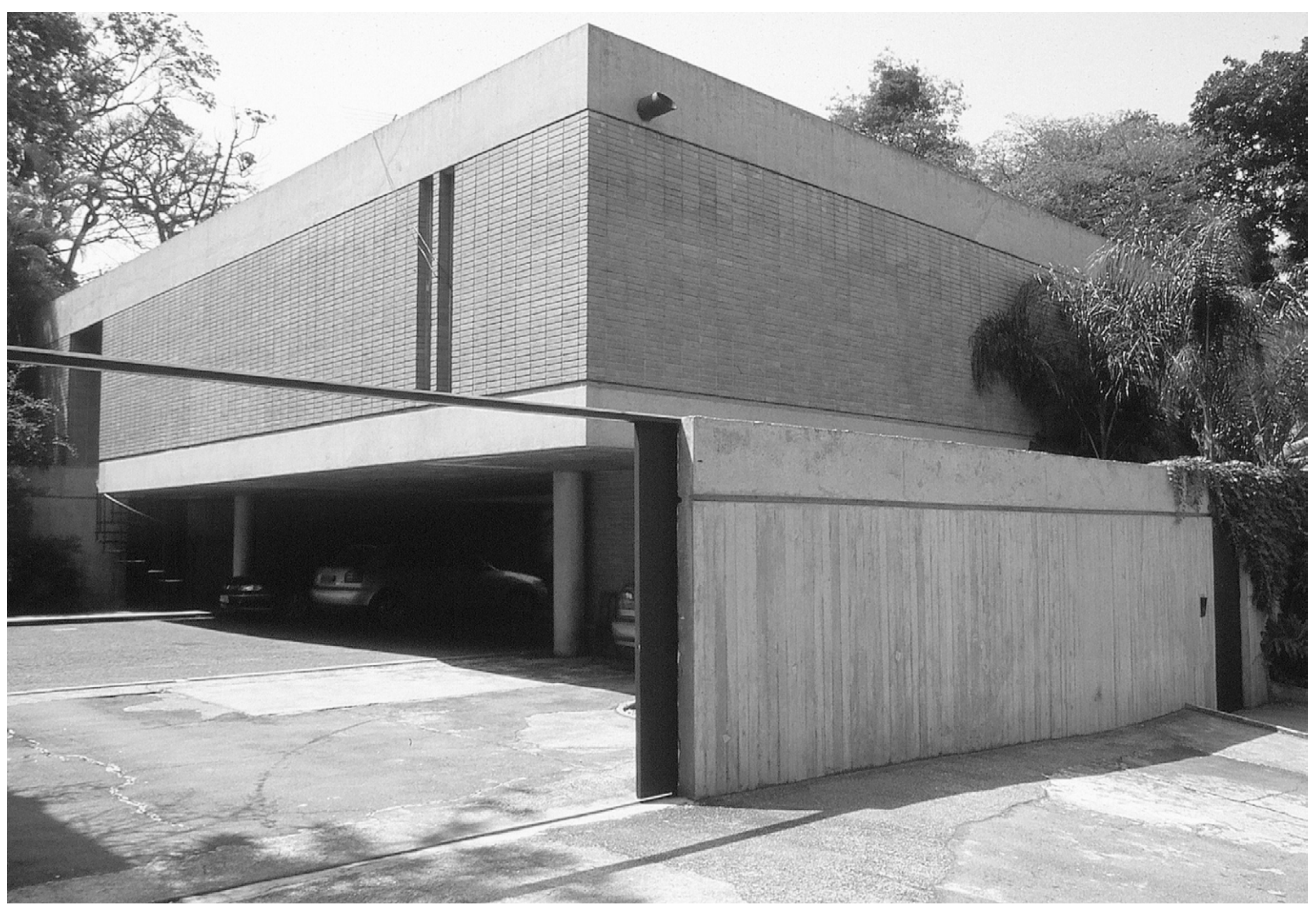



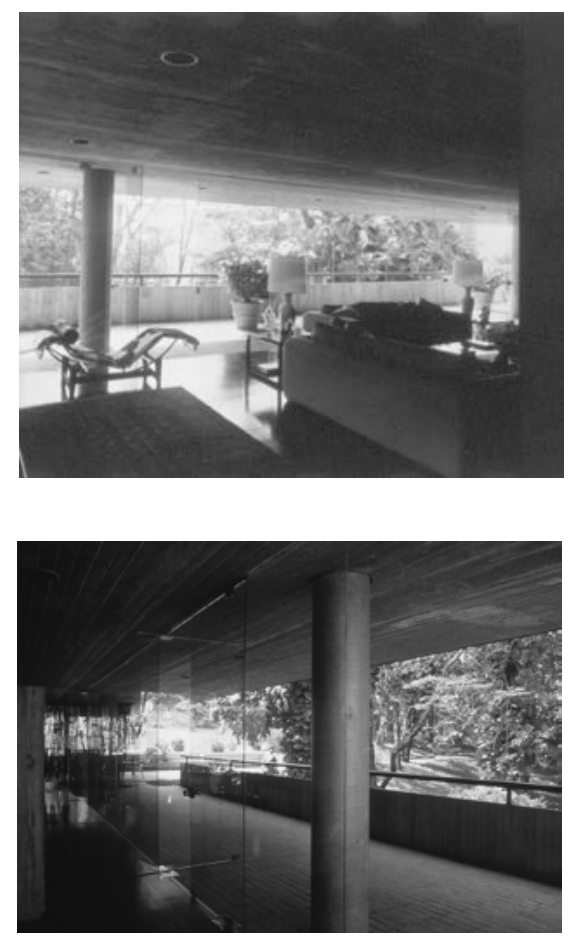

Residência Max Define Acervo Eduardo de Almeida
Apesar da clara influência da casa James King nesta nova configuração espacial obtida por Eduardo de Almeida, podemos dizer que o resultado final entre as duas obras se apresenta radicalmente diferente.

A distinção não se dá apenas pela materialidade da alvenaria de tijolos aparentes do projeto de Eduardo de Almeida, mas sobretudo à implantação do volume junto ao terreno inclinado que não cria um piloti tradicional como o da casa de Paulo Mendes da Rocha - um volume suspenso destacado do solo - mas, ao contrário, um volume que se vincula ao terreno em uma das extremidades e que, à medida que o terreno desce, se destaca da topografia modificada, sugerindo um volume totalmente suspenso em relação ao nível da rua.

Tal configuração cria um espaço vazio junto à chegada, tensionado pelo peso do volume suspenso decorrente de sua fachada praticamente cega, contraponto à outra extremidade, onde se posicionam as aberturas dos quartos, protegidas por largos beirais e pela pequena altura do volume, dado que os quartos se posicionam levemente rebaixados em relação ao jardim externo.

Do ponto de vista didático, o processo de Eduardo de Almeida neste projeto deixa clara a importância e a noção de 'referência' na disciplina arquitetônica, antes de ser tratada como 'cópia', como reprodução direta da linguagem de um determinado projeto; o uso de exemplos na realização de um trabalho se refere mais à identificação de pressupostos conceituais e na aplicação de atributos de forma coerente a cada caso.

Recordo-me da realização de alguns projetos e de seus questionamentos sobre a adoção irrefletida de soluções formais à maneira de Artigas ou de Paulo Mendes da Rocha. A questão era clara: nada contra à obra destes arquitetos, o problema residia no emprego 


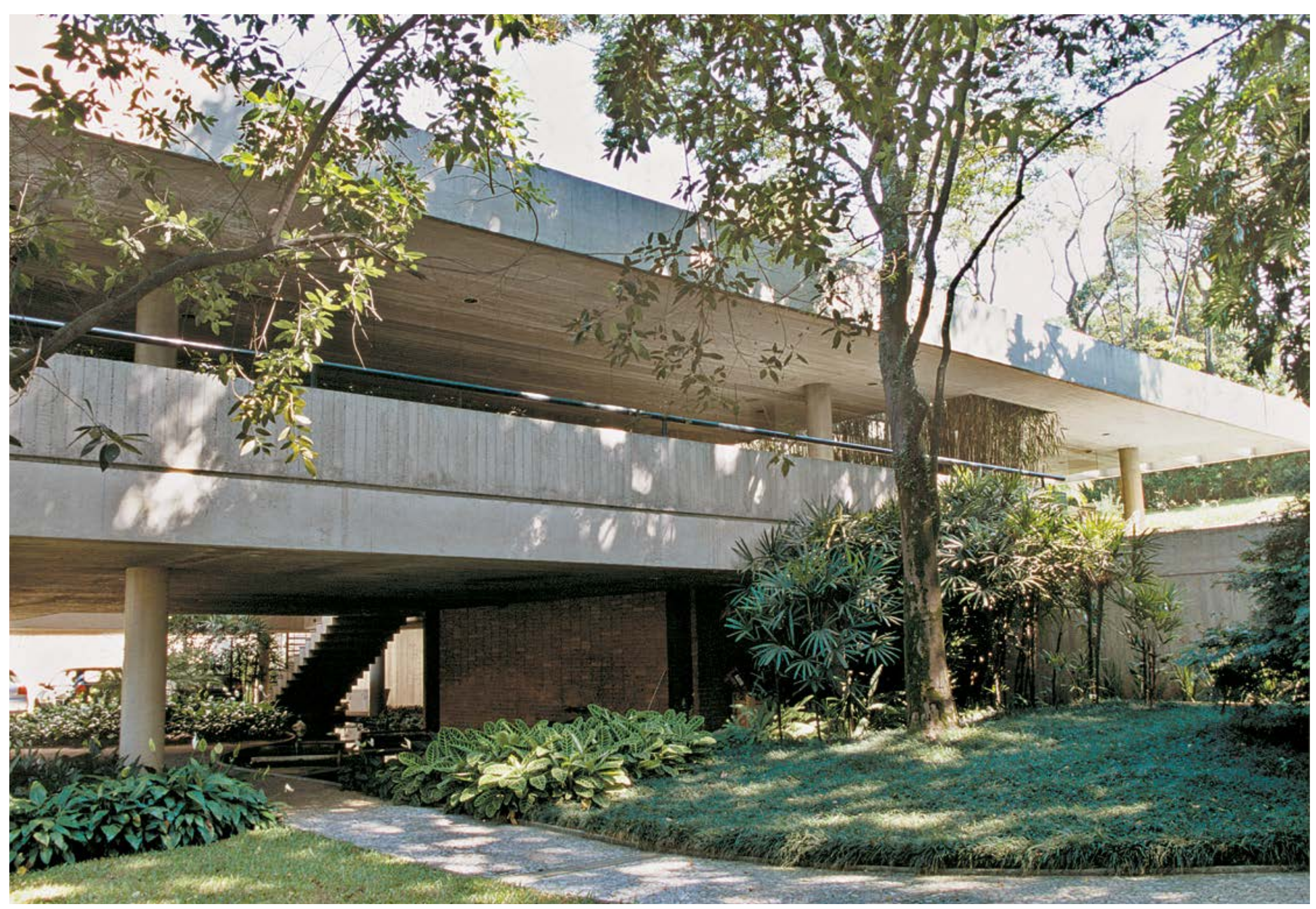


de uma determinada forma por 'vício de linguagem', em detrimento da solução coerente e adequada a cada caso.

Neste sentido, podemos dizer que o tratamento da volumetria da casa Max Define não surge de uma visão pré-concebida da forma, mas da decorrência natural da organização programática e de suas relações com o sítio.

Não por acaso, a fachada voltada à rua e ao acesso de veículos se utiliza de planos cegos de tijolos aparentes, oposição direta às aberturas dos ambientes de estar e dos dormitórios, voltados à orientação adequada - sobretudo no caso dos quartos - e à área verde preservada no terreno.

Antes de ser uma decisão de 'fachada' ou meramente funcional, o que parece importante para Eduardo de Almeida em todos os seus projetos é a noção de continuidade espacial entre o interior e o exterior, atributo decorrente da própria relação entre a construção do volume e sua disposição estratégica no terreno.

Por este motivo, na maioria de seus projetos, fechamentos de vidro de grandes dimensões intermediam a relação do dentro e do fora, buscando uma unidade espacial entre os dois a partir das relações de transparência e da noção de continuidade. Nas ordenações dos partidos, de modo geral, os espaços de uso coletivo assumem prioridade no contato com as áreas livres remanescentes de um terreno.

Segundo Herman Hetzberger, a evolução histórica da arquitetura - de suas origens como abrigo até as cidades como as conhecemos hoje - enfatiza a noção de proteção e visão, seja 
espaço, que não só influencia as relações humanas, mas também determina o modo como nos relacionamos com o ambiente, e complementa: “(...) Mas em vez de manter a oposição interiorexterior como contraste fundamental, sabemos, no século XX, que interior e exterior são conceitos relativos, que dependem de onde nós estamos e da direção para a qual olhamos."”z

Também segundo Giulio Carlo Argan, manifesta-se na arquitetura moderna o predomínio da planta em relação às perspectivas, no sentido de que esta, por ser a geradora do espaço e de suas possibilidades como utilização, também tem sua importância na definição do valor estético do edifício, já que as fachadas se desdobram a partir da articulação do espaço interior e das soluções estruturais.

Toda a experiência moderna - seja de pensamento, seja prática - nos leva a excluir uma formulação fixa e rigidamente formal do espaço: leva-nos, ao contrário, a considerar o espaço como função, e justamente no sentido matemático do termo, a pô-lo em relação contínua com o tempo, a transpô-lo do exterior (ou da natureza) para o interior, a entendê-lo antes como direcionalidade do que como medida, como continuidade do que como limite. ${ }^{74}$

Deste novo modo de conceber o espaço, sem distinção entre interior e exterior, é que justamente ocorre uma arquitetura que, como objeto fruto das necessidades humanas, não se apresenta de modo dissociado da natureza, mesmo de uma natureza construída.

Apesar de suas especificidades, pode-se afirmar que obras de arquitetos fundamentais para o estabelecimento da arquitetura moderna, como Frank Lloyd Wright, Le Corbusier e Mies van Der Rohe, os principais, - fundamentam-se na continuidade espacial interior x exterior a partir do emprego de planos de vidro e, decorrente disto, da associação do volume ao lugar.

${ }^{73}$ HERTZBERGER, Herman. Lições de Arquitetura (Prefácio). São Paulo, Martins Fontes, 1999, p.216

${ }^{74}$ ARGAN, Giulio Carlo. Arquitetura e Arte não figurativa in Projeto e Destino. São Paulo, Ática, 2001, p.140 
No caso de Eduardo de Almeida, o confronto do objeto com o território - muitas vezes limitado ao interior do lote, no caso das residências unifamiliares - configura-se como uma premissa, ponto de partida de concepção de qualquer projeto, em maior ou menor grau, desde suas primeiras obras até as últimas.

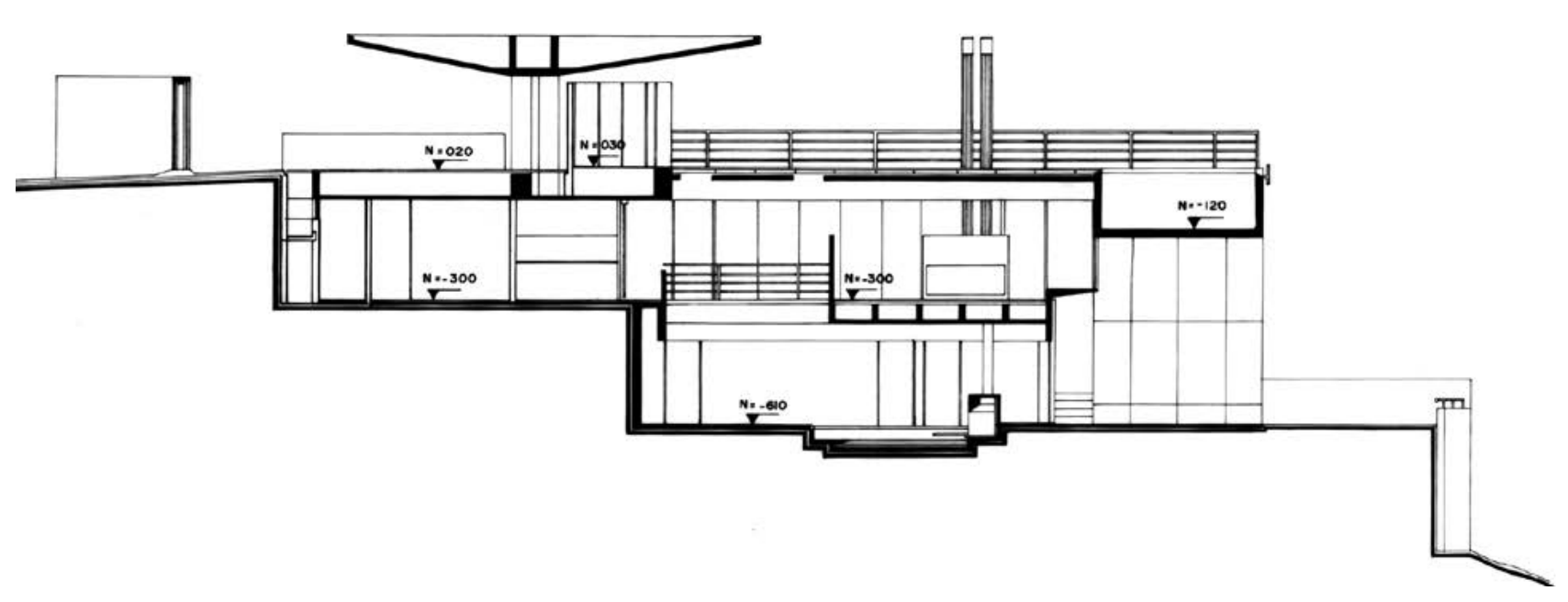

Corte da Residência Donald Ting Acervo Eduardo de Almeida 

Tecnologia e tradição 

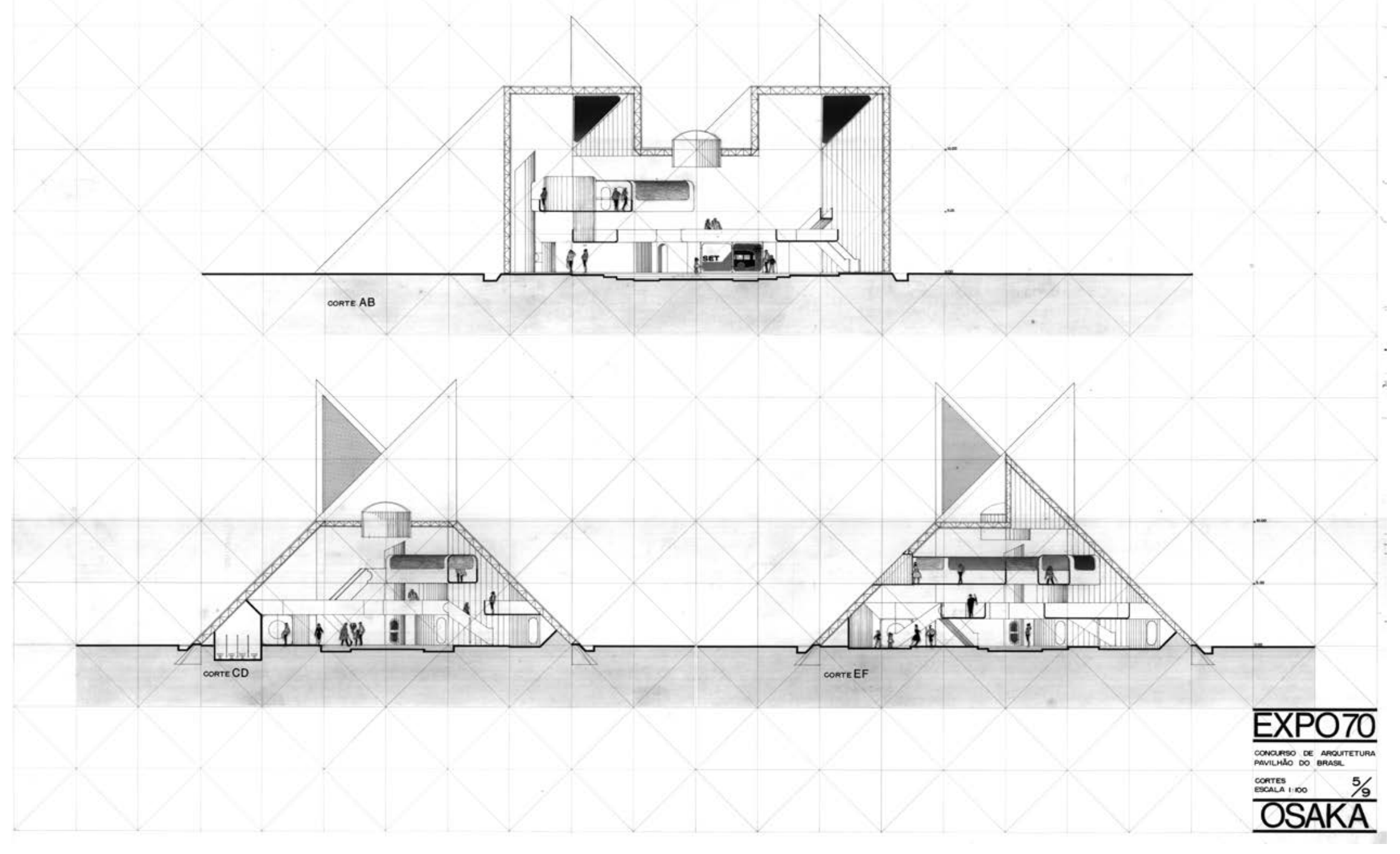
As pontes, os viadutos, as grandes lojas e por fim as primeiras construções de ferro e de cimento são o precedente direto do desenho industrial; a sua 'beleza' depende de sua perfeição técnica e de sua aderência a uma função prática; e uma vez que a técnica e a prática implicam um fazer, a ideia do belo se conectou ao fazer e não mais ao contemplar.75

Desde os primeiros anos como arquiteto, Eduardo de Almeida se mostrava interessado em uma arquitetura voltada à construção, não apenas à conceituação dos espaços e à obra acabada, mas também no entendimento coerente e racional no processo de execução.

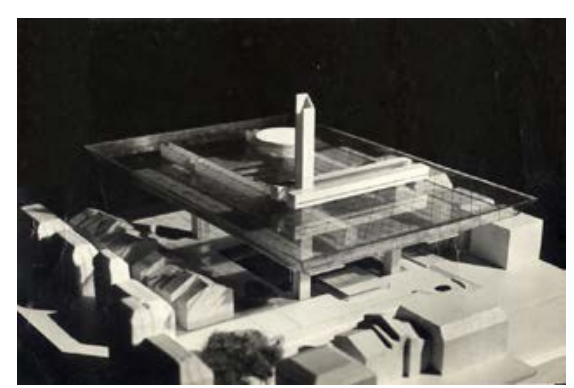

Maquete do projeto do Centro Georges Pompidou

Acervo Eduardo de Almeida

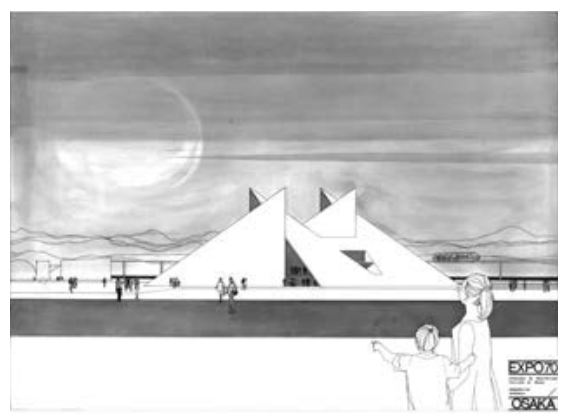

Prancha do projeto do Pavilhão de Osaka

Ao lado, prancha de cortes do projeto do Pavilhão de Osaka

Acervo Eduardo de Almeida
Como vimos anteriormente, em função do crescimento da industrialização e sua formação pela FAU USP - escola vinculada originalmente à Escola Politécnica - ou ainda pela experiência na Itália, sua produção vincula-se claramente às pesquisas tecnológicas suscitadas por cada projeto.

O emprego de estruturas metálicas, técnica até então pouco difundida no Brasil, inicia-se em projetos residenciais e no desenho de suas estruturas mistas, caso da residência para Flávio Pinho de Almeida (1961). Talvez por influência de Wright, os pilares metálicos se posicionam junto à caixilharia na tentativa de dar continuidade visual aos planos de fechamento, sem a interferência de outros materiais junto aos planos de vidro e respectivos caixilhos, viabilizando a continuidade entre interior e exterior com a menor interferência visual possível.

Estas pequenas experiências se desdobram em projetos para os concursos do Pavilhão de Osaka (1970) ou do Centro Georges Pompidou (1971) a partir do emprego de estruturas metálicas tridimensionais, certamente fruto de influências variadas como a arquitetura inglesa do grupo Archigram e a dos Metabolistas japoneses dos anos 1960, ou ainda do norteamericano Buckminster Fuller - este último, objeto de estudo de Eduardo de Almeida na disciplina para o curso de desenho industrial da FAU USP.

${ }^{75}$ ARGAN, Giulio Carlo. O desenho industrial in Projeto e Destino. São Paulo, Ática, 2001, p.117 


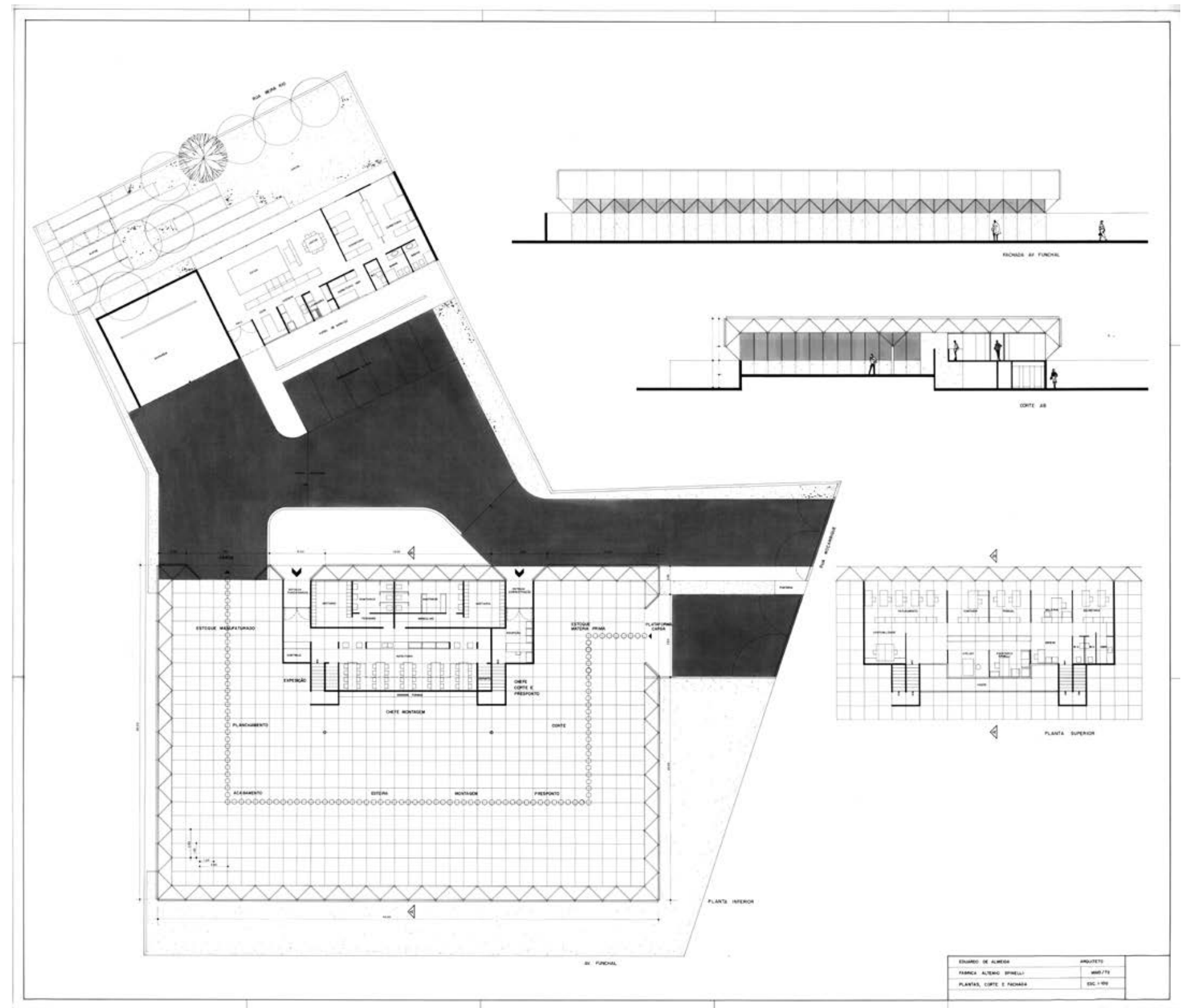




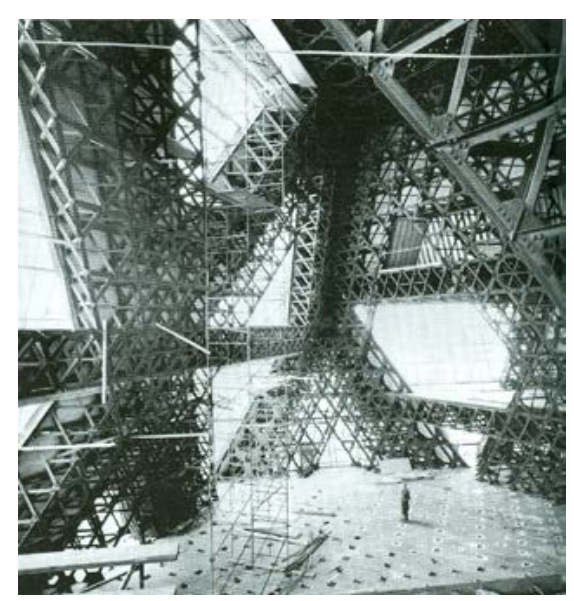

Pavilhão 'Man the Producer' BANHAM, Reyner. Megaestructuras, Futuro Urbano del Pasado Reciente. Barcelona Editorial Gustavo Gilli, 1978, p. 114

Ao lado, prancha com plantas, cortes e fachada do projeto da Fábrica Altemio Spinelli

Acervo Eduardo de Almeida
O primeiro projeto se utilizava de complexa geometria a partir de uma malha tridimensional triangular, resultando em volumes fechados de grande expressividade formal, marcados por revestimento de placas de alumínio e poucas aberturas, contraponto à fluidez da espacialidade interior. A inspiração para estas propostas decorre das experiências das Megaestruturas da década de 1960, e certamente o Pavilhão 'Man the Producer' da Exposição Internacional de Montreal, construído em 1967. ${ }^{76}$

O segundo projeto parte do novo edifício em confronto com o tecido urbano tradicional do Marais, em Paris, dada a escala característica das construções do entorno e de sua importância como patrimônio histórico. Diante destes fatores e da escala do programa proposto para 0 centro cultural Pompidou, o projeto de Eduardo de Almeida e dos irmão Dácio e David Ottoni separa as construções em dois segmentos, o primeiro como um subsolo organizado ao redor de um pátio central rebaixado, o segundo como uma estrutura de cobertura suspensa por quatro pilares, posicionado acima do gabarito do bairro e definindo um recinto coberto de grandes dimensões que se limita pelas fachadas das quadras do entorno.

Pautada pela radicalidade das estruturas metálicas tridimensionais de grande porte, a influência desses projetos se desdobram no Brasil de modo simplificado, a fim de aplicar esta técnica construtiva em um projeto para a fábrica de sapatos de Altemio Spinelli (1972), para quem Eduardo de Almeida já havia projetado a reforma de uma pequena loja na rua Oscar Freire poucos anos antes.

Considerando o organograma funcional da linha de produção definido em conjunto com os clientes, foi proposto um ambiente de rigorosa modulação com apenas dois pontos de apoio

${ }^{76}$ Obra de Guy Desbarats, do escritório Affleck, Desbarats, Lebensold \& Size, resultado de um "sistema estrutural nascido de um só elemento geométrico, idealizado por Guntis Plesums: um tetraedro." In BANHAM, Reyner. Megaestructuras, Futuro Urbano del Pasado Reciente Barcelona, Editorial Gustavo Gilli, 1978, p. 111 


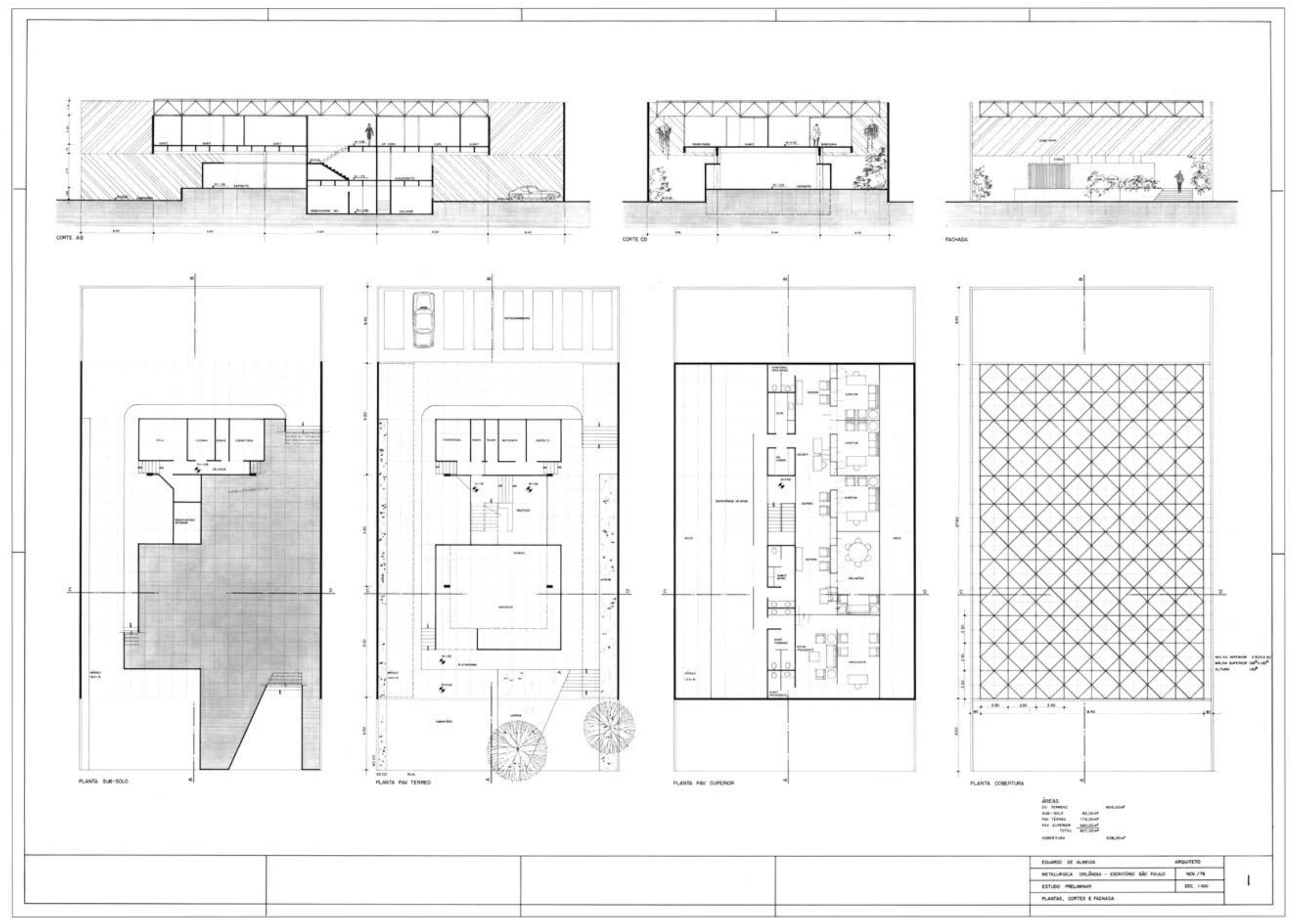




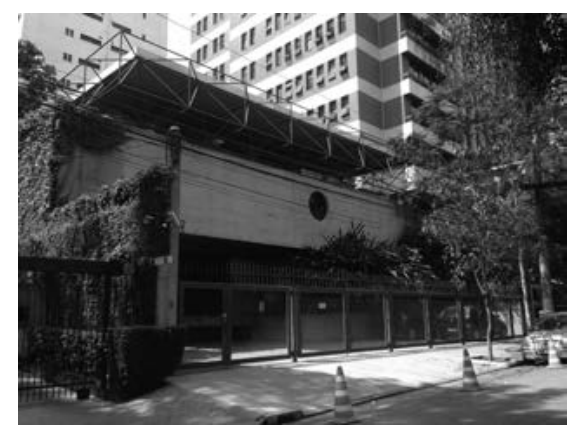

Edifício de escritórios da Metalúrgica Orlândia em São Paulo

Ao lado, prancha com plantas, cortes e fachada do projeto para os escritórios da Mtalúrgica Orlândia em São Paulo

Acervo Eduardo de Almeida internos, posicionados a partir da subdivisão da cobertura em seis submódulos principais de mesma dimensão. Os fechamentos laterais de painéis pré-fabricados são montados sobre a mesma malha estrutural, agora posicionada verticalmente e apoiada nas estruturas de concreto armado posicionadas junto ao solo.

Esta estrutura metálica tridimensional - cobertura e fechamento - gera um salão de grandes dimensões que garante a flexibilidade de uso. 0 piso destinado à área de produção é elevado de acordo com o desnível necessário às docas de carga e descarga, deslocamento que permite a criação de uma laje de concreto para escritórios no pavimento superior e, abaixo, em uma relação de meio-nível com o piso da fábrica, os espaços de apoio para funcionários.

Por motivo de custo, a solução não foi empregada nesta construção, mas reaparece pouco tempo depois por ocasião do seu projeto para os escritórios da Metalúrgica Orlândia, em São Paulo (1977), neste caso, valendo-se do fornecimento das peças industrializadas Mero da Mannesmann S.A., empresa de origem alemã responsável pelo sistema estrutural composto por tubos metálicos e nós esféricos capazes de compor tais estruturas espaciais. ${ }^{77}$

Seguindo a geometria do lote, o projeto prevê a construção de um muro de concreto armado junto às divisas, possibilitando a instalação da treliça espacial como estrutura de cobertura, sem o emprego de apoios intermediários. Sob este plano se localiza o piso destinado ao espaço de trabalho, uma laje de concreto armado apoiada por quatro pilares centrais e por duas empenas com a altura de um pavimento, também de concreto armado, situadas junto às fachadas frontal e posterior.

77 Segundo depoimento de Eduardo de Almeida, por conta da realização deste projeto foi feito um convite para conhecer a produção deste sistema na Alemanha em 1978. Eduardo também relembra das maquetes realizadas por José Antônio Seixas para testar as possibilidas espaciais possibilitadas por este sistema construtivo. 


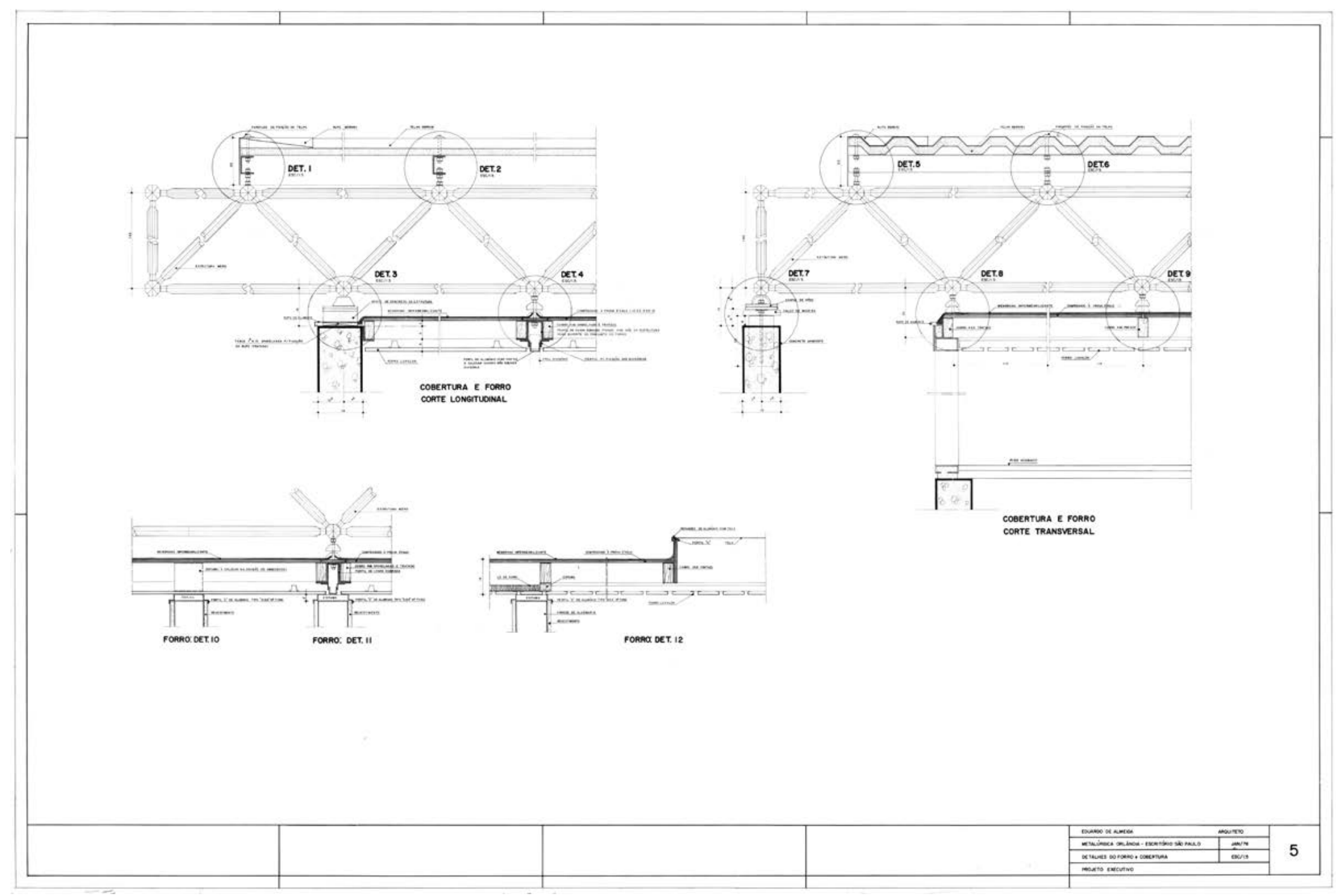

Prancha do Projeto Executivo do Escritório Morlan em São Paulo

Detalhes do forro e da cobertura

Acervo Eduardo de Almeida 


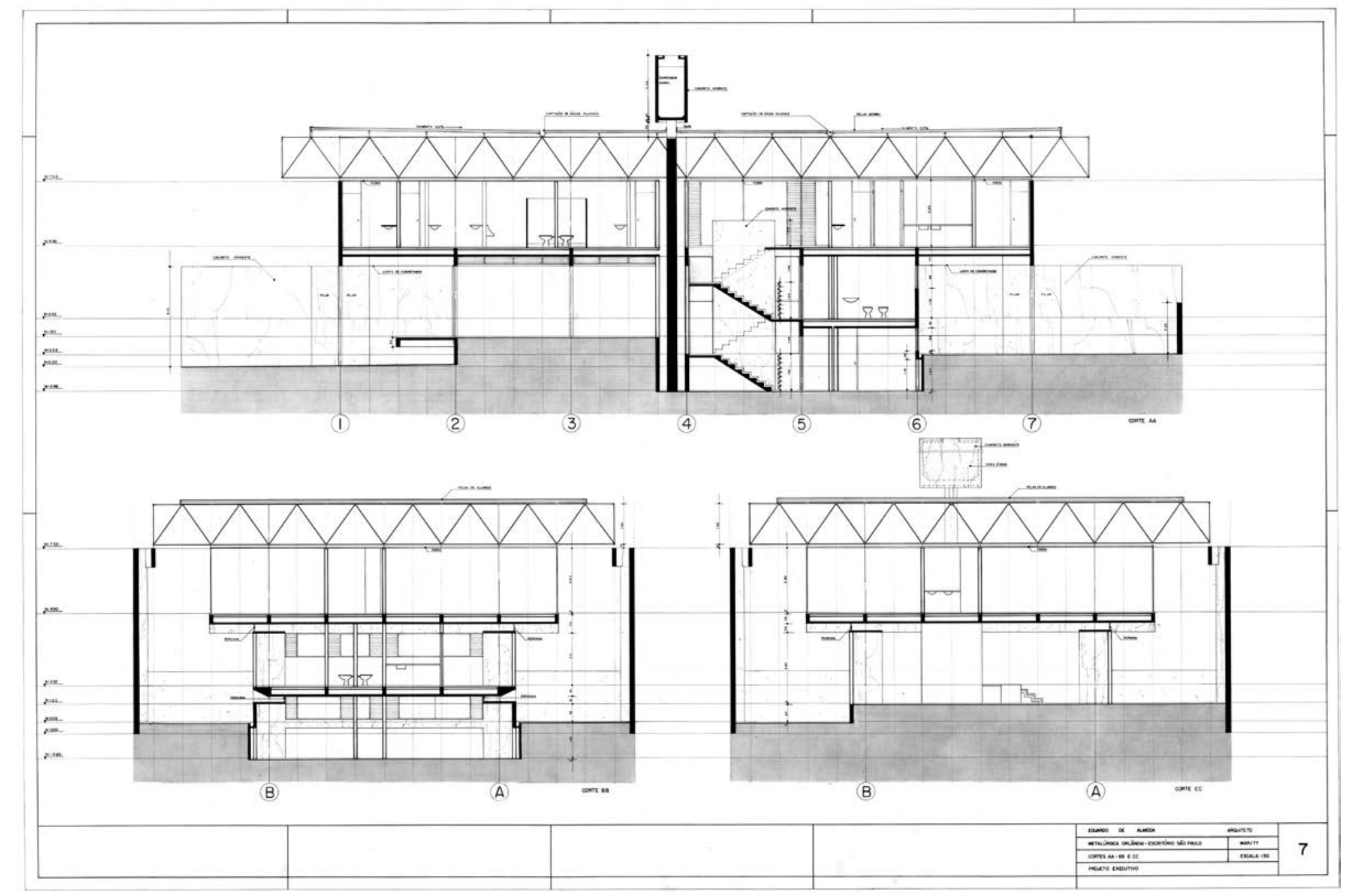

Prancha do Projeto Executivo do Escritório

Morlan em São Paulo

Cortes

Acervo Eduardo de Almeida 
A solução estrutural não só confere expressividade ao edifício pelo emprego de materiais diversos, como define um espaço de pé-direito elevado próximo à rua e que, livre de maiores interferências, permite a adequada disposição de diversos ambientes, como doca de carga e descarga, estacionamentos, depósitos, além de áreas de apoio e de caráter técnico, cada qual posicionado na cota adequada ao seu funcionamento.

No último piso, justamente no espaço vazio entre as estruturas de metal e concreto, a área foi subdividida por uma 'faixa'- assimétrica em relação ao volume - destinada às circulações, banheiros e apoios. Os dois espaços laterais restantes foram pensados como uma 'planta livre', capaz de receber as funções administrativas a partir do emprego de divisórias de madeira especialmente projetadas por Eduardo de Almeida, de modo a viabilizar o contato com as estruturas, considerando a excessiva movimentação decorrente dos grandes vãos e das diferenças de cada material.

Por conta destas características, essa realização parece antecipar um conjunto de trabalhos de Eduardo de Almeida com o arquiteto Arnaldo Martino, uma parceria iniciada em 1978 e que duraria dez anos, ${ }^{78}$ resultando em obras de grande interesse, algumas delas baseadas na experimentação tecnológica e no uso de estrutura como a própria expressão arquitetônica dos edifícios.

Segundo Eduardo de Almeida, apesar de não terem sido contemporâneos como alunos na rua Maranhão, os dois se aproximam na FAU USP, já como professores nas disciplinas de projeto. Além de compartilharem admiração mútua, a sociedade acontece pela necessidade de constituírem uma empresa uni profissional, condição para a realização de projetos (com reduções tributárias) para a CONESP - Companhia de Construções Escolares do Estado de

${ }^{78}$ A sociedade de Arnaldo Martino e Eduardo de Almeida se encerra em 1988. 
São Paulo, tendo em vista que os dois arquitetos estavam envolvidos em projetos de escolas que significava uma grande oportunidade para se realizar obras de caráter público naquele momento.

Uma das primeiras escolas projetadas no início da sociedade é a EEPG Anchieta, localizada na Vila Carmozina, Zona Leste de São Paulo. A partir da leitura do terreno - relação com as ruas e topografia - e da premissa de preservar as árvores existentes, o projeto cria a articulação de quatro volumes ao longo de um eixo de circulação central, a exemplo de outros projetos de Eduardo de Almeida.

Neste caso específico, o primeiro volume foi posicionado perpendicularmente aos demais, junto à praça de acesso de alunos implantada na cota mais alta do terreno, abrigando os programas do galpão, refeitório, cozinha, banheiros e, no mezanino, o grêmio dos alunos.

Este volume, em conjunto com o bloco administrativo posicionado transversalmente, define uma área livre junto à esquina, espaço suficiente para abrigar uma quadra poliesportiva e demais áreas de lazer externo.

No encontro entre os dois blocos, implanta-se a passagem coberta que, de acordo com a topografia do terreno, permite a conexão com os outros dois blocos de salas de aula - um deles com dois pavimentos - situados alternadamente nos patamares criados junto ao declive, viabilizando a manutenção de duas árvores existentes.

Naturalmente, o programa segue a padronização de ambientes e componentes previstos pelo caderno de especificações, exceção ao desenho da estrutura que gera uma solução mista em concreto e aço no espaço do galpão. A partir da modulação dos pilares - travados pela viga 


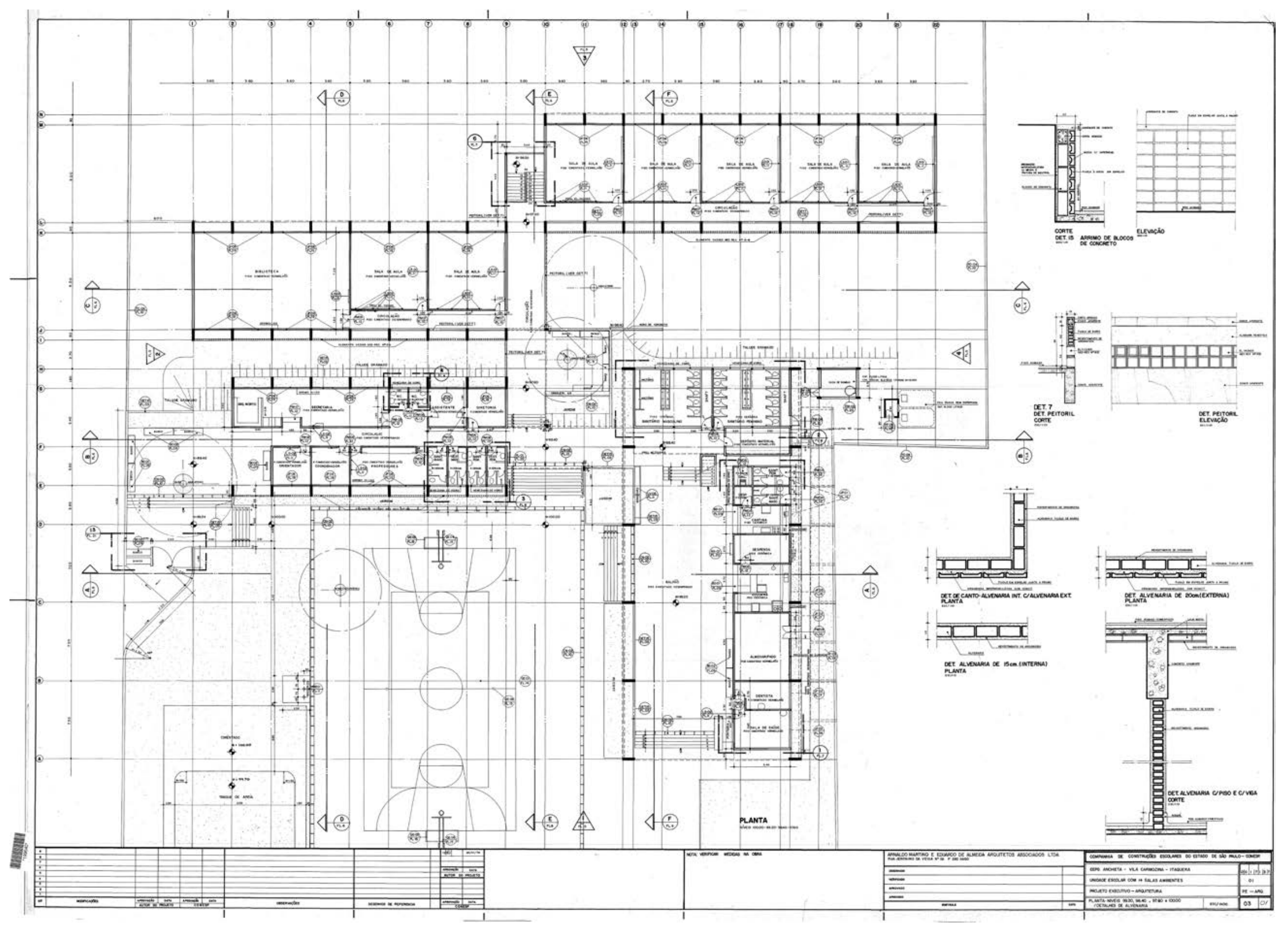




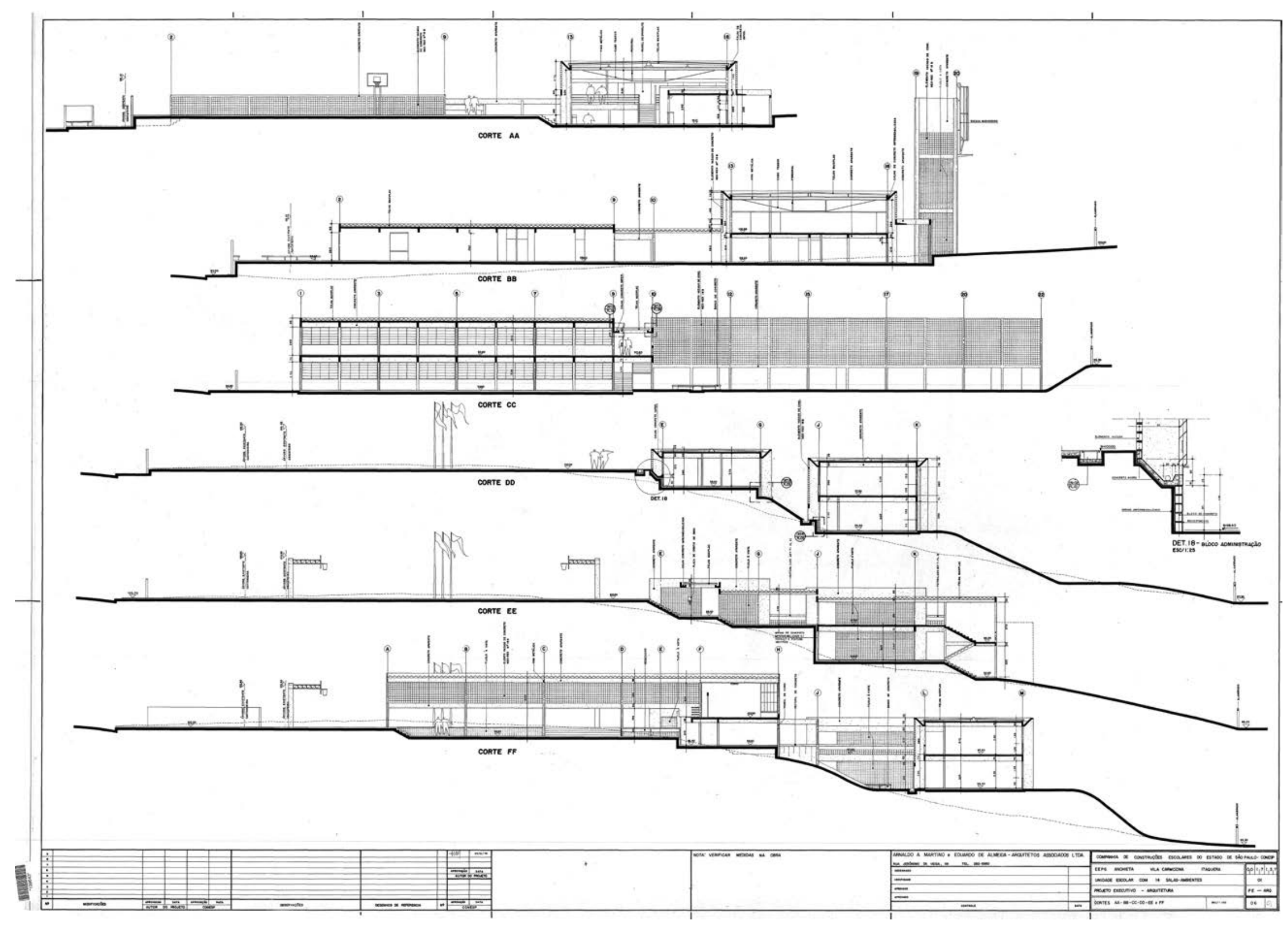




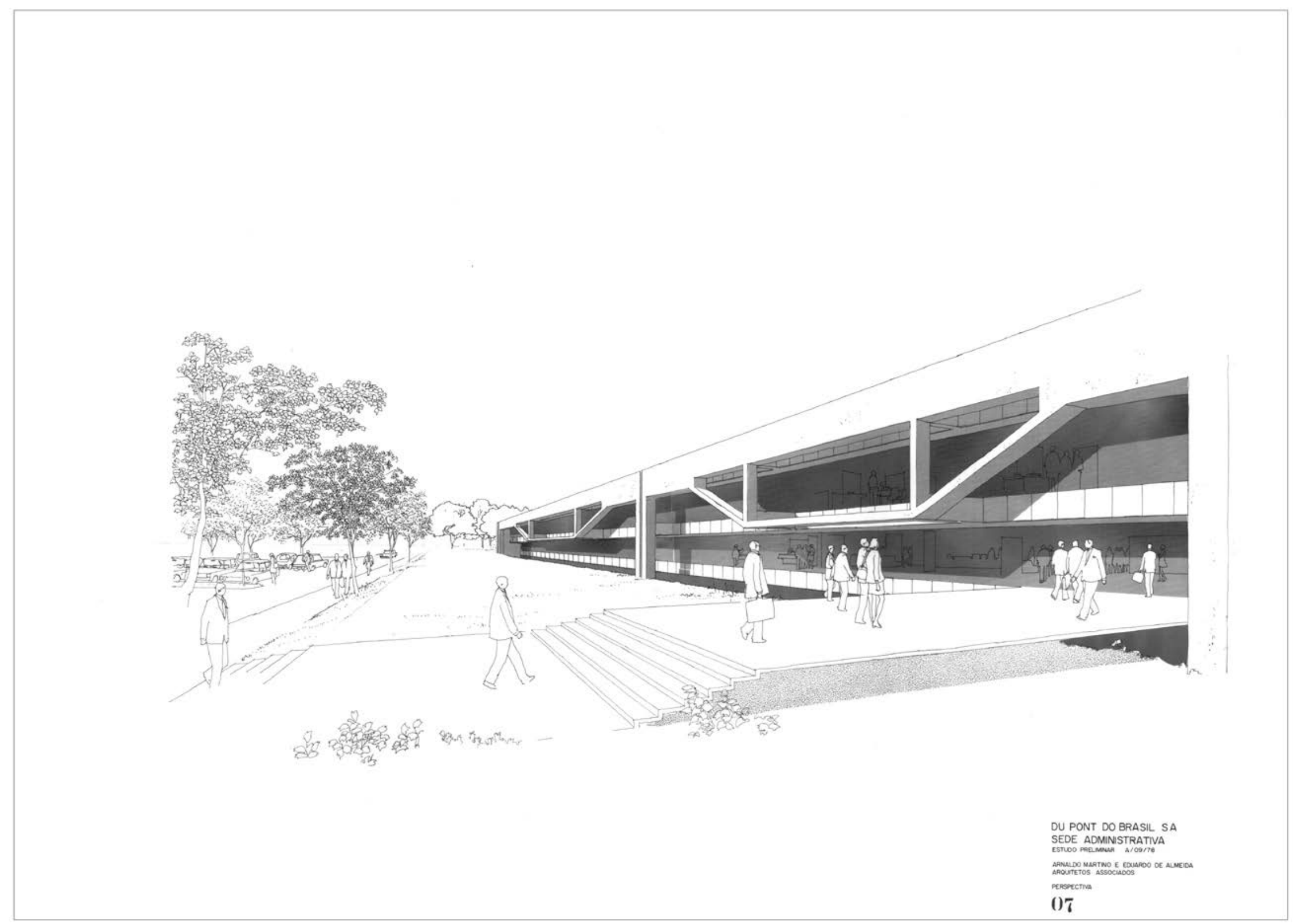




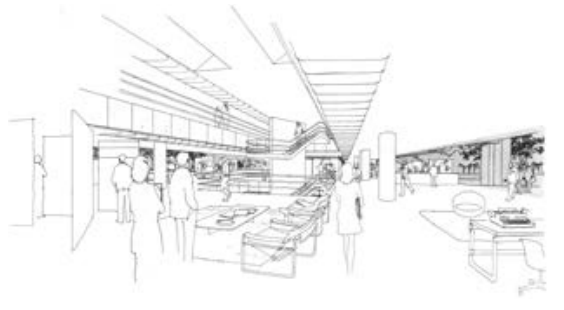

Perspectiva interna da sede administrativa da empresa Du Pont
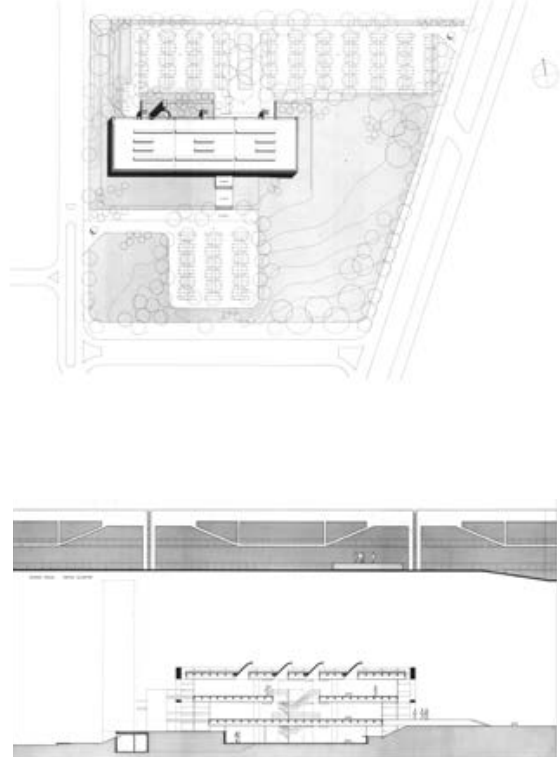

Perspectiva, implantação, elevação e corte do projeto para a sede administrativa da empresa Du Pont

Acervo Eduardo de Almeida de sustentação dos fechamentos de elemento vazado e da viga calha de secção triangular - instala-se uma sequência de vigas-vagão de aço. Extremamente leves, tanto visualmente quanto no consumo de matéria prima, é no desenho de estruturas como estas que os dois arquitetos direcionam suas investigações nos projetos posteriores.

Neste mesmo ano, com a colaboração do engenheiro Hugo Tedeschi, a dupla apresenta um projeto para a sede administrativa da empresa Du Pont em Barueri. Em uma área de grandes dimensões, o edifício de três pavimentos foi implantado no centro do terreno e, de acordo com sua topografia, permitiu a separação entre os acessos e estacionamentos para visitantes conectados ao piso intermediário - e para funcionários - com acesso pelo piso inferior.

A partir desta setorização, todos os programas de apoio, incluindo cozinha e refeitório, foram posicionados no piso rebaixado; os outros dois pisos foram tratados como espaços flexíveis de trabalho, para escritórios, complementados por áreas reservadas para visitantes e exposições, localizadas junto à esplanada de acesso.

Em seu corte transversal, podemos verificar a organização em três partes, conformando duas áreas de trabalho flexíveis laterais e uma 'faixa' central destinada às circulações verticais e horizontais, sanitários, copas, casas de máquinas e áreas de apoio, além de espaços vazios de diferentes dimensões capazes de interligar visualmente os pavimentos e difundir a iluminação natural em shed criada na laje de cobertura.

Ainda neste corte, visualiza-se o escalonamento sucessivo da fachada externa, já que os fechamentos dos pavimentos inferiores são recuados em relação aos superiores, talvez por influência do corte do edifício da FAU USP projetado por Vilanova Artigas. 

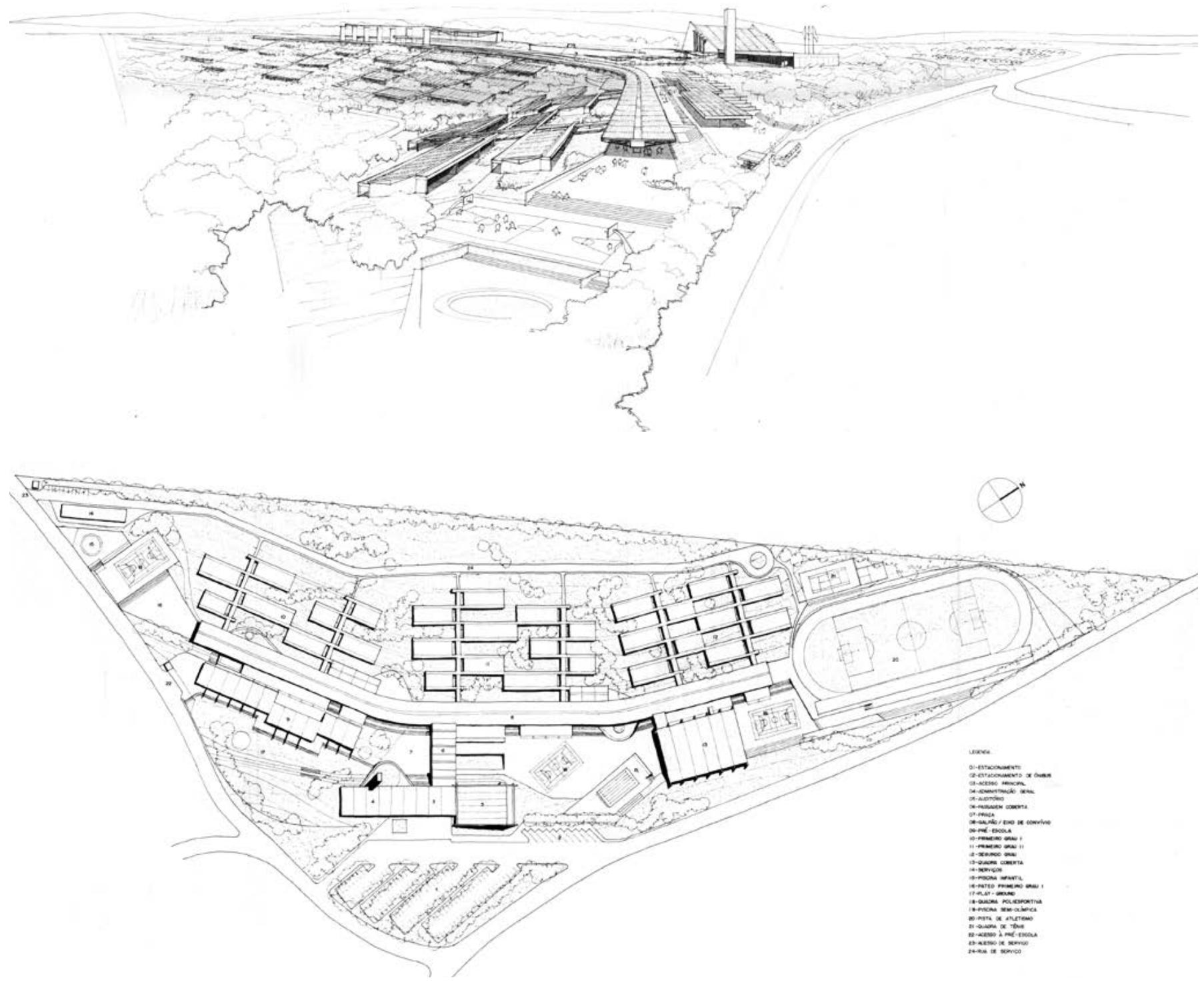

Prancha do projeto para o Colégio Porto Seguro Acervo Eduardo de Almeida 
Longitudinalmente, observa-se que o edifício é composto pela justaposição de três módulos estruturais independentes, sendo que cada um dos módulos se sustenta apenas por pilares junto à fachada, pois o desenho da empena elimina a sequência de pilares presentes no interior do edifício, assim como no prédio da FAU.

Neste caso, seguindo a experiência com estruturas vagonadas, a empena de concreto é decomposta por um engenhoso sistema de elementos resistentes à tração e à compressão, permitindo a criação de um vão de grandes dimensões que, simultaneamente, serve de apoio para a estrutura do último pavimento e elimina todos os pilares no plano da fachada do piso intermediário.

Infelizmente o projeto não chegou a ser concluído; segundo Eduardo de Almeida, os diretores da empresa o associaram à um edifício fabril. No entanto, posteriormente, proposta semelhante foi empregada novamente no estudo preliminar de uma agência bancária em Capão Bonito, em 1980 (neste caso, com apenas uma viga vagonada na fachada), também não adotada durante o desenvolvimento do projeto executivo.

Do conjunto catalogado aqui, outro exemplo que busca aplicar estruturas vagonadas é apresentado para o concurso fechado de anteprojetos para o Colégio Porto Seguro (1981) em Valinhos que, embora destinado a uma instituição de ensino particular, parte das experiências anteriores da EEPG Anchieta em Vila Carmozina - em termos de estrutura - e da EEPG Parque Brasília - considerando a sequência de pavilhões paralelos e escalonados.

Neste caso, podemos destacar a implantação sensível na topografia e a justaposição de volumes em função das estruturas de circulação, baseadas em um eixo de circulação central principal, associado a conexões transversais necessárias ao acesso de cada setor funcional da escola. 

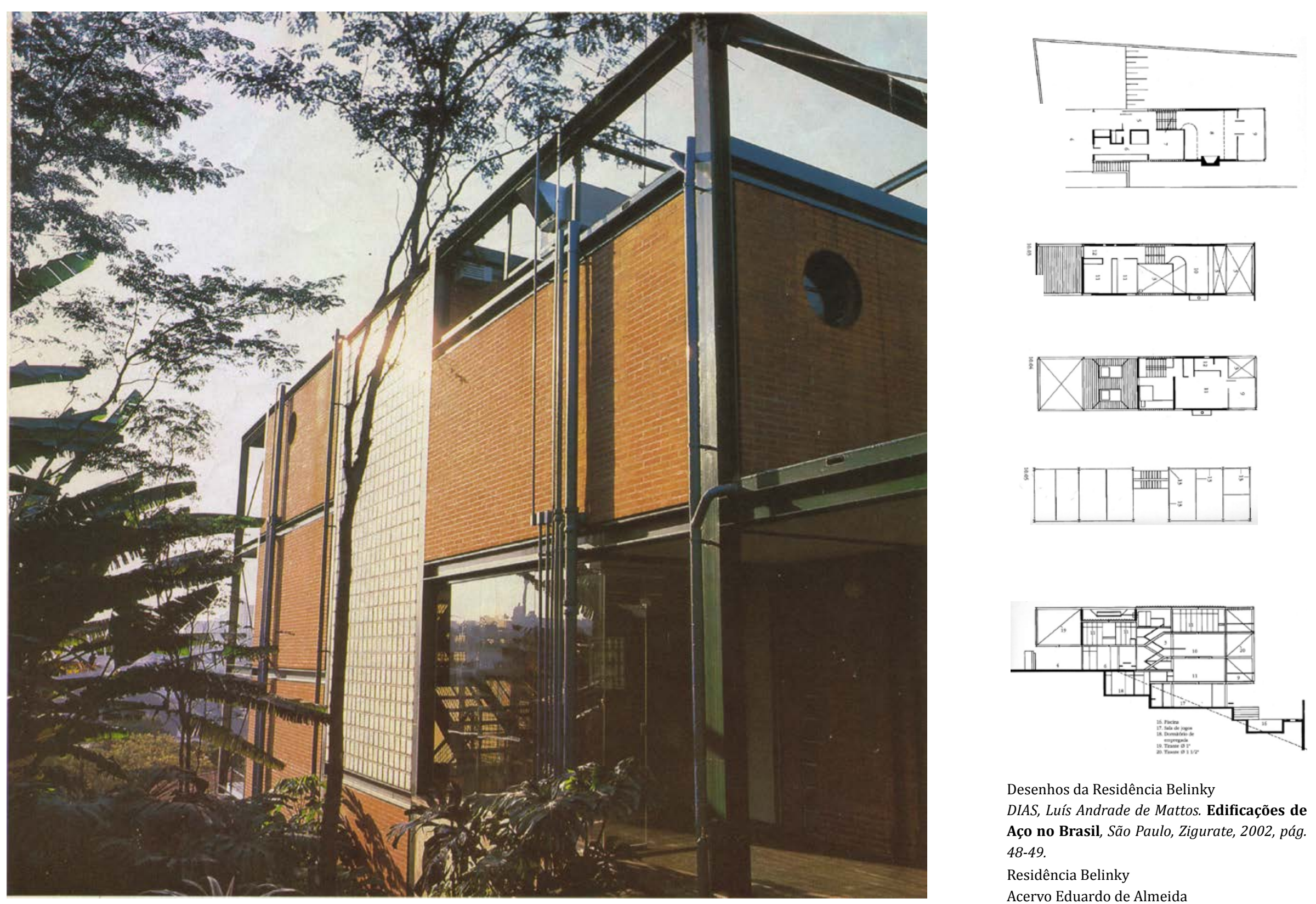

Desenhos da Residência Belinky

DIAS, Luís Andrade de Mattos. Edificações de Aço no Brasil, São Paulo, Zigurate, 2002, pág. 48-49.

Residência Belinky

Acervo Eduardo de Almeida 
Considerando seu tamanho, o projeto se assemelha a um plano urbanístico de ocupação da gleba; cada um dos setores destinados às diferentes funções parece remeter-se a diferentes projetos anteriores de Arnaldo Martino e Eduardo de Almeida.

Fica claro que o processo de trabalho destes arquitetos se baseia em sucessivas tentativas de aplicar, em diferentes ocasiões, determinados princípios de organização do programa ou de técnicas construtivas e estruturais - para ficarmos em apenas dois temas -, somando-se também às referências de obras de outros profissionais.

Destas tentativas, talvez uma das mais significativas seja o projeto da casa Sérgio Belinky, construída no bairro do Pacaembú (1980) a partir da criação de patamares junto ao desnível apresentado pelo lote. Sobre grandes muros de arrimo, foi implantada uma estrutura metálica extremamente leve, onde a disposição de cada programa em lajes posicionadas em meiosníveis foi articulada por uma escada localizada no vazio central.

Segundo Maressa Bronsztein,

a escolha da estrutura metálica foi uma decisão de projeto, pois se tratava de uma residência com sete meios-níveis e 6 metros de vão. Cada viga convencional tinha de 50 a 60 centímetros - gerando uma perda de mais 3 metros de altura que praticamente inviabilizaria o projeto -, enquanto a viga metálica precisava de apenas 20 centímetros para vencer o mesmo vão. ${ }^{79}$

De acordo com Eduardo de Almeida, a sociedade com Arnaldo Martino foi um período de muito aprendizado, sobretudo por sua inventividade em aspectos ligados à construção e ao desenho das estruturas. Embora muitas vezes afirme que a velocidade de Arnaldo Martino na resolução dos projetos não era compatível com seu modo de projetar, o resultado final das obras conjuntas se destaca por agregar as diferentes virtudes dos dois arquitetos.

${ }^{79}$ BRONSZTEIN, Maressa. Dissertação de mestrado: A experiência construtiva na obra de Arnaldo. São Paulo, FAU USP, 2013, p. 62 


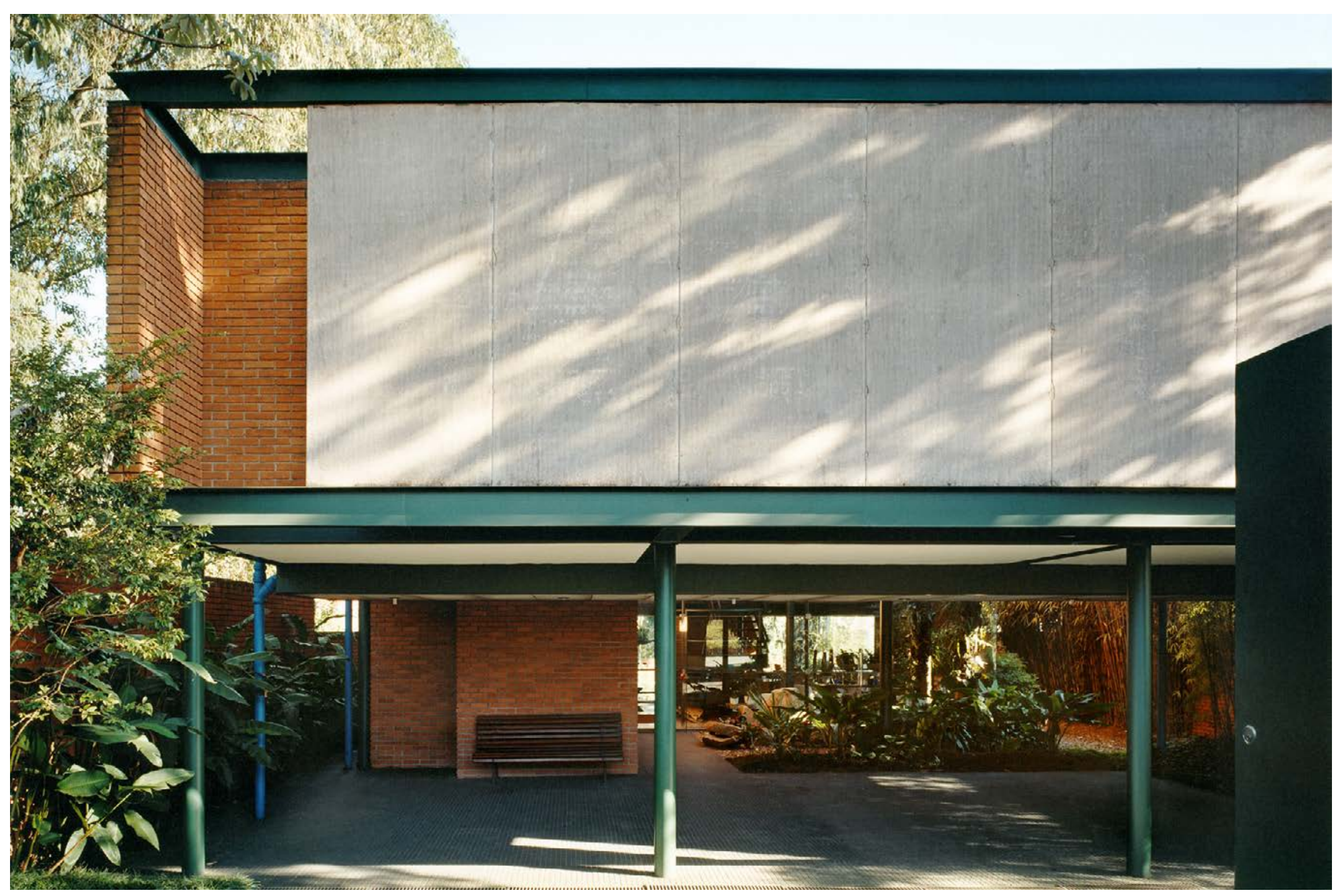


De fato, o trabalho autônomo anterior de cada um deles se apresentava de modo diverso desta produção coletiva e dos projetos realizados posteriormente, após a dissolução da sociedade em 1988.

Ao lado das investigações construtivas e das expressivas estruturas de Arnaldo Martino, podemos encontrar características sempre presentes nos projetos de Eduardo de Almeida: a organização nas soluções em planta, precisão no detalhamento e simplicidade nos tratamentos dos volumes.

No desenho, já demonstrava uma abordagem muito construtiva, eu diria que ele era muito corajoso. Por exemplo, juntos fizemos a nossa primeira experiência com estrutura metálica, numa casa no Pacaembu, $e$ fomos bem audaciosos, porque nem nós, nem a construção civil, tínhamos experiência em fazer casas com estrutura de aço da forma que nós encaramos. E fomos limpos, corretos, coerentes, foi uma experiência fantástica que nós fizemos juntos e influenciou demais o resto do meu trabalho. ${ }^{80}$

Esta experiência é retomada na residência para Paulo Vítor Oppenheim, construída no Parque dos Príncipes em 1983. Neste caso, a estrutura metálica extremamente delgada se utiliza de uma rigorosa modulação em seus componentes: pilares circulares e vigas 'I' que exigiram cuidadosos detalhes em seus encontros com os planos de fechamento de alvenaria aparente e vidro.

Do ponto de vista da organização espacial, a solução repete uma característica de inúmeros projetos dos dois arquitetos em que as áreas de serviços foram posicionadas no pavimento superior; neste caso, este setor é separado dos demais dormitórios por um pátio descoberto, espaço vazio também responsável pela distância entre a garagem e os ambientes de estar que, seguindo a topografia do terreno, desdobram-se em um nível rebaixado, próximo à piscina, ampliando de modo sensível o pé-direito da sala e a continuidade entre interior e exterior.

Ao lado, fachada da Residência Oppenheim Foto: Nelson Kon

${ }^{80}$ BRONSZTEIN, Maressa. Dissertação de mestrado: A experiência construtiva na obra de Arnaldo. São Paulo, FAU USP, 2013, p. 62 


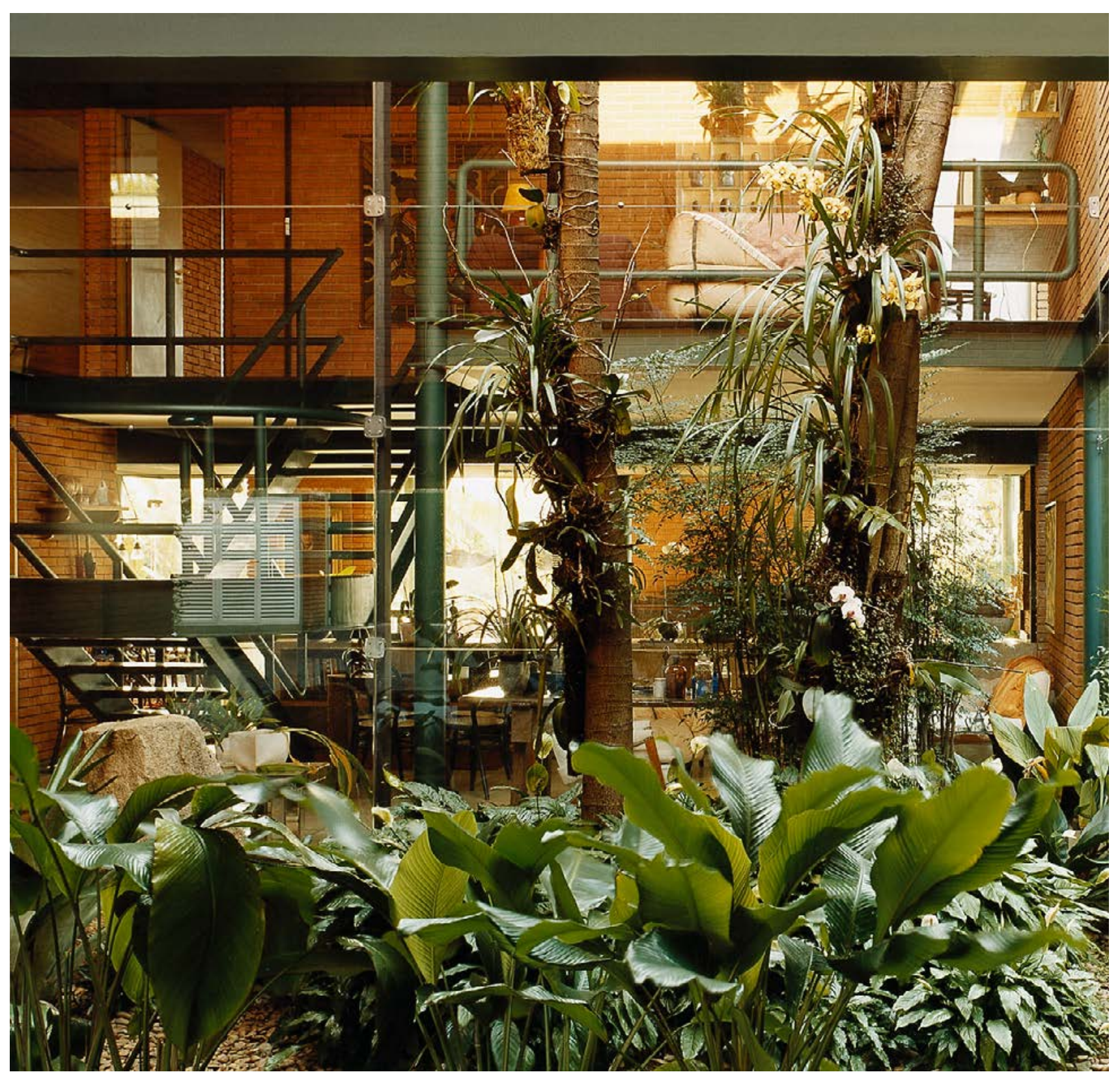

Ao lado, Prancha do Anteprojeto da Residência Oppenheim

Foto do vazio interno da Residência

Oppenheim 


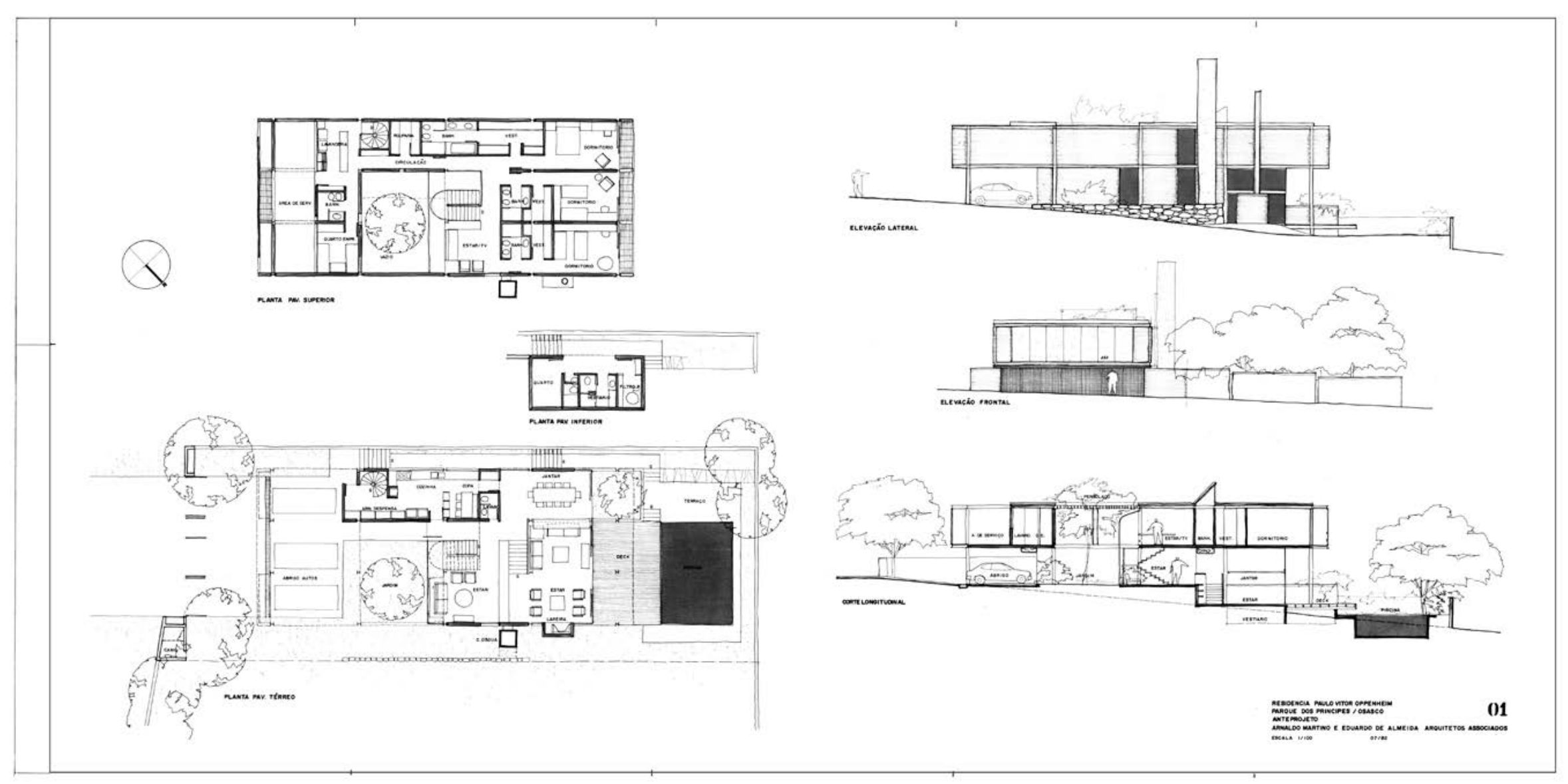



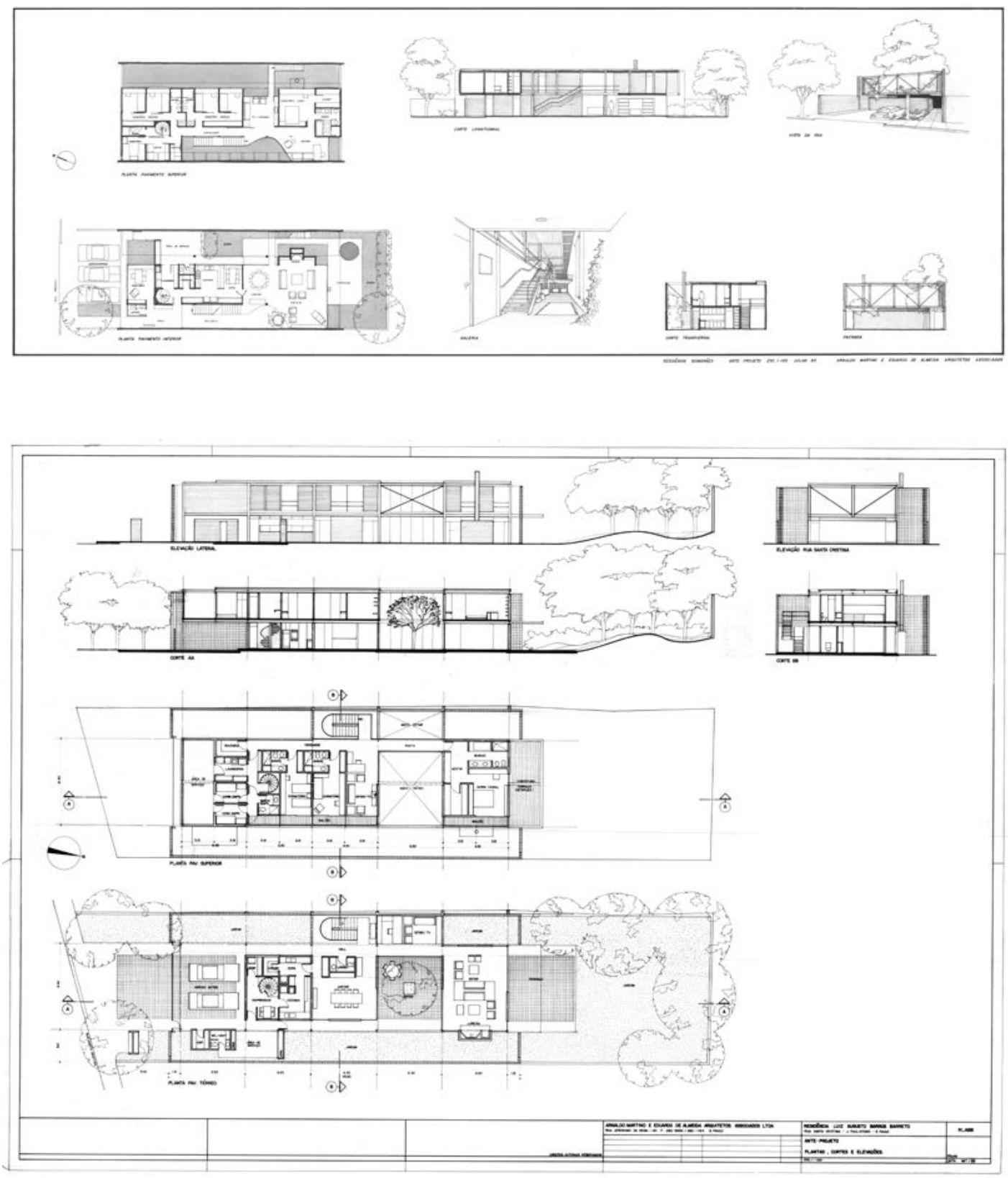

Acima, prancha do projeto da Residência Ricardo Guimarães (1985)

Abaixo, prancha do Anteprojeto da Residência Luiz Augusto Barros

Acervo Eduardo de Almeida 

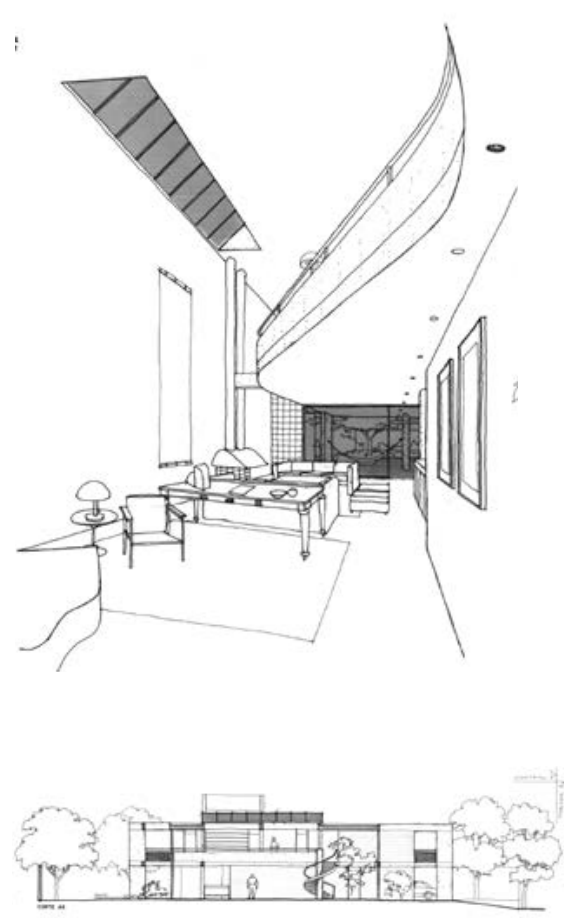

Desenhos do estudo preliminar do projeto para a Residência Ricardo Alves Lima
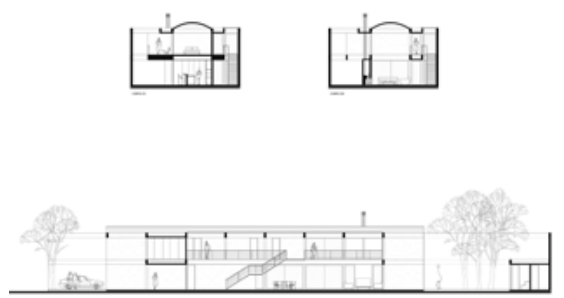

Desenhos do projeto para a Residência Ricardo Guimarães (2000)
Além do detalhamento preciso nos encontros dos diversos elementos construtivos, a intenção de se utilizar recursos materiais mínimos faz com que o edifício como um todo seja pensado a partir de sua montagem. Por este motivo, toda a infraestrutura de hidráulica, por exemplo, aparece organizada em shafts horizontais fechados por placas cimentícias, mesmo elemento que compõe a fachada cega voltada para a rua e que protege o pátio de serviços descoberto.

A clareza construtiva de tais soluções revela simplicidade e despojamento, encontrando correspondência no detalhamento e nas especificações dos materiais, a exemplo do piso de manta vinílica, simplesmente colado à laje, que não chega a revestir os topos das vigas metálicas, aparentes no desenho do chão do segundo pavimento.

Esta importante obra parece ecoar em inúmeras casas como aquelas projetadas para Luiz Augusto de Barros (1983), Luís Gelpi (1984) ou Ricardo Guimarães (1985), sempre se valendo de estruturas metálicas leves - às vezes utilizadas na composição de treliças de fachada associadas a planos cegos de alvenaria, e, principalmente, nos ambientes de uso coletivo, com fechamentos de vidro de grandes dimensões.

Embora não construídas, tais obras serão utilizadas como referência em inúmeros projetos posteriores de Eduardo de Almeida - sem a participação de Arnaldo Martino - como nas residências para Ricardo Alves Lima (1987), Ricardo Guimarães (2000) ou a segunda casa de seu filho Lalo (2002).

Em todos estes casos, o uso de estruturas metálicas leves e sistemas construtivos claros parece uma reação ao uso tradicional do concreto armado aparente corrente na arquitetura de São Paulo, conhecido como Brutalismo Paulista. 


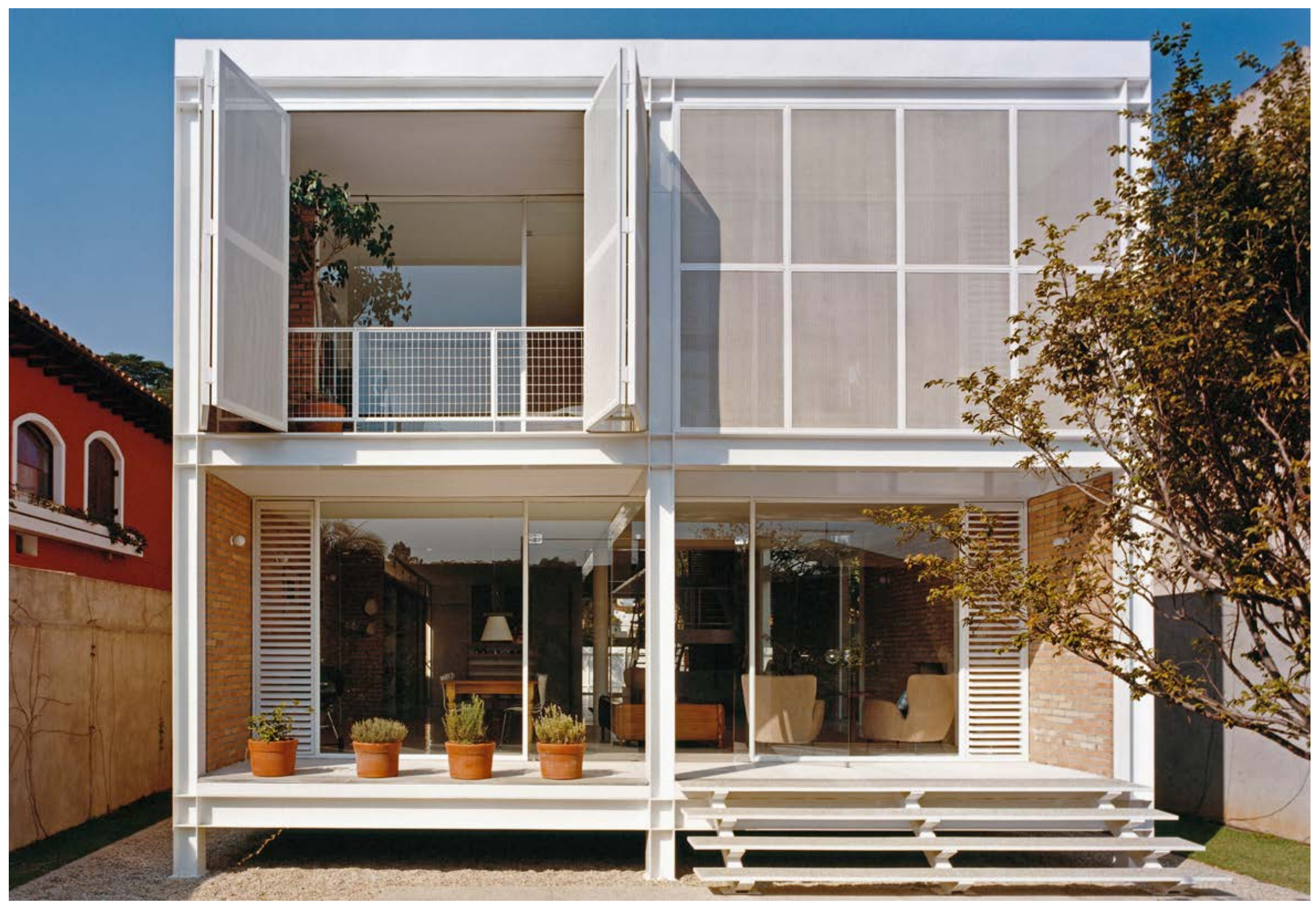



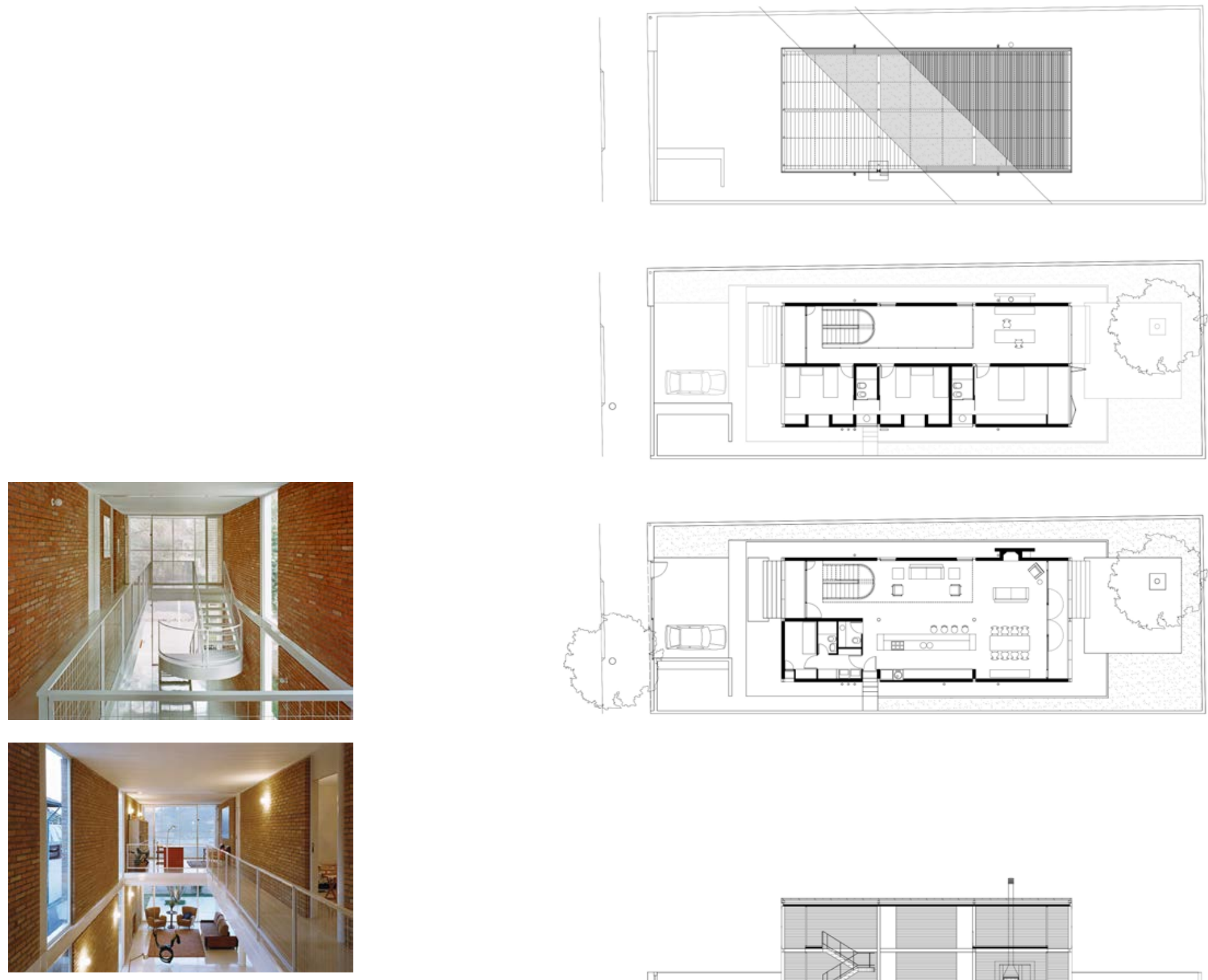

Residência Lalo de Almeida Fotos: Nelson Kon
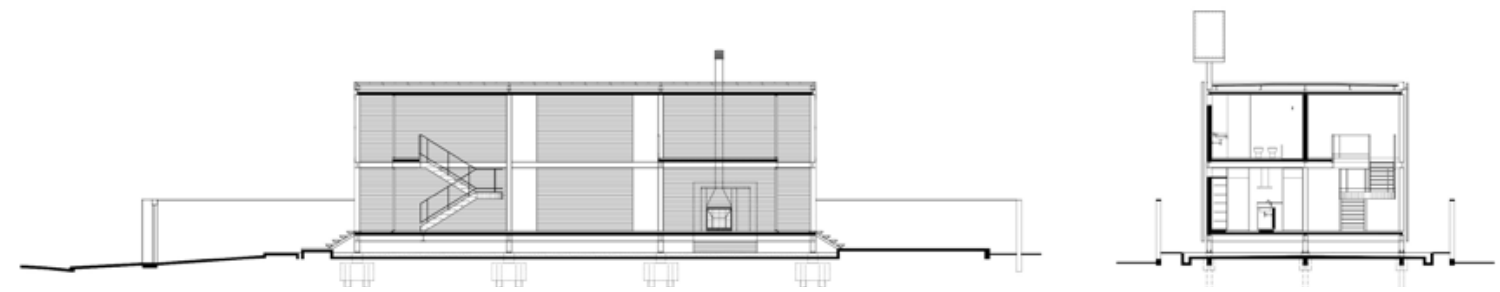


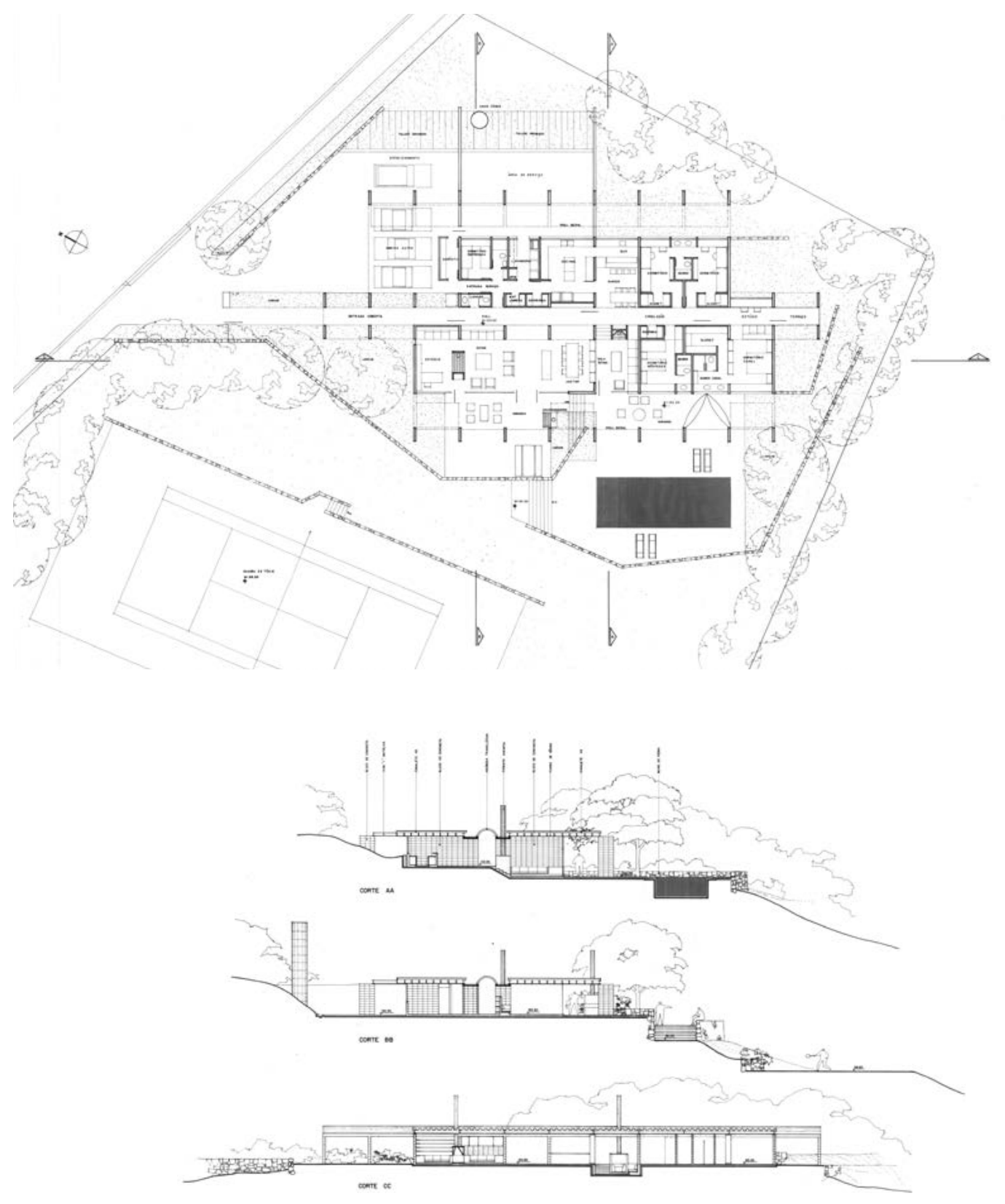

Desenhos do projeto para a Residência Manuel Riveros

Acervo Eduardo de Almeida 


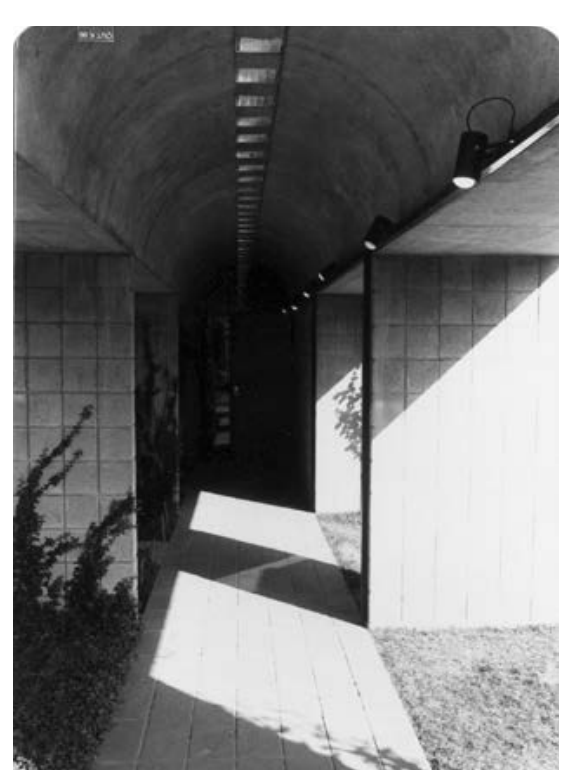

Residência José Manuel Riveros

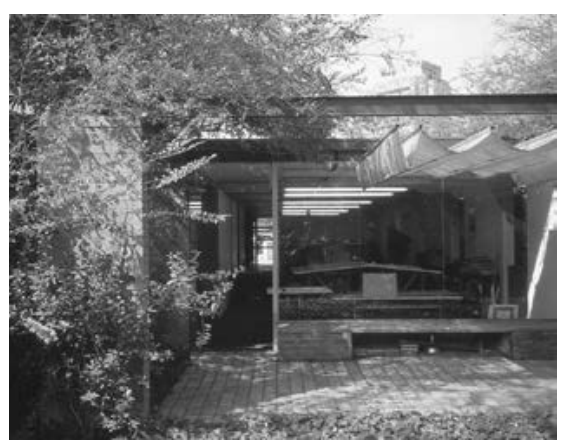

Escritório da Rua Chilon Acervo Eduardo de Almeida
De acordo com o depoimento de Arnaldo Martino, nas obras de uma série de arquitetos de São Paulo nas décadas de 1960 e 1970, o uso de grandes vãos, com pesadas estruturas, serviam como experimentação arquitetônica: "o projeto da casa era usado como um laboratório de obras maiores" ${ }^{81}$; os projetos de caráter público ou obras de maior porte não estavam 'disponíveis' para estes arquitetos.

Ainda segundo Martino, a partir dos anos 1980, as soluções construtivas "passaram a ser aplicadas na escala em que mereciam(...) e a casa retomou seu propósito e proporções

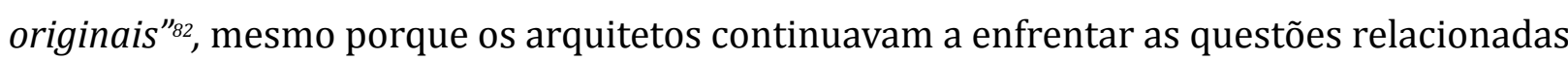
à construção, tanto a qualidade da mão de obra quanto os problemas inerentes à técnica do concreto armado:

Ao acompanhar as obras, comecei a sentir que havia uma desproporcionalidade entre o esforço de se fazer e o resultado espacial. (...) Você faz primeiro uma casa inteira de madeira, que deve ser muito bem executada, bem ajustada, no esquadro. Depois enche de concreto e demole a casa de madeira, e o resultado também é muito incerto, alguns faziam bem, outros não, e depois não se conserta mais, ele tem que ficar como foi feito $(\ldots . .)^{83}$

A reação a estes procedimentos de difícil execução foi, segundo Arnaldo Martino, a revisão na forma de construir, "no sentido de ser uma construção mais amigável com quem a faz"; começam então a utilizar estrutura metálica, "quase como uma pré-fabricação em pequena escala, e usar as alvenarias portantes". ${ }^{4}$

A partir deste pensamento, surgiram interessantes projetos como a casa para José Manuel Riveros (1980) e o próprio escritório da rua Chilon (1986) - este último projetado para

${ }^{81}$ MARTINO apud BRONSZTEIN in BRONSZTEIN, Maressa. Dissertação de mestrado: A experiência construtiva na obra de Arnaldo. São Paulo, FAU USP, 2013, p. 68

${ }^{82}$ Idem.

83 Idem

${ }^{84}$ Idem 

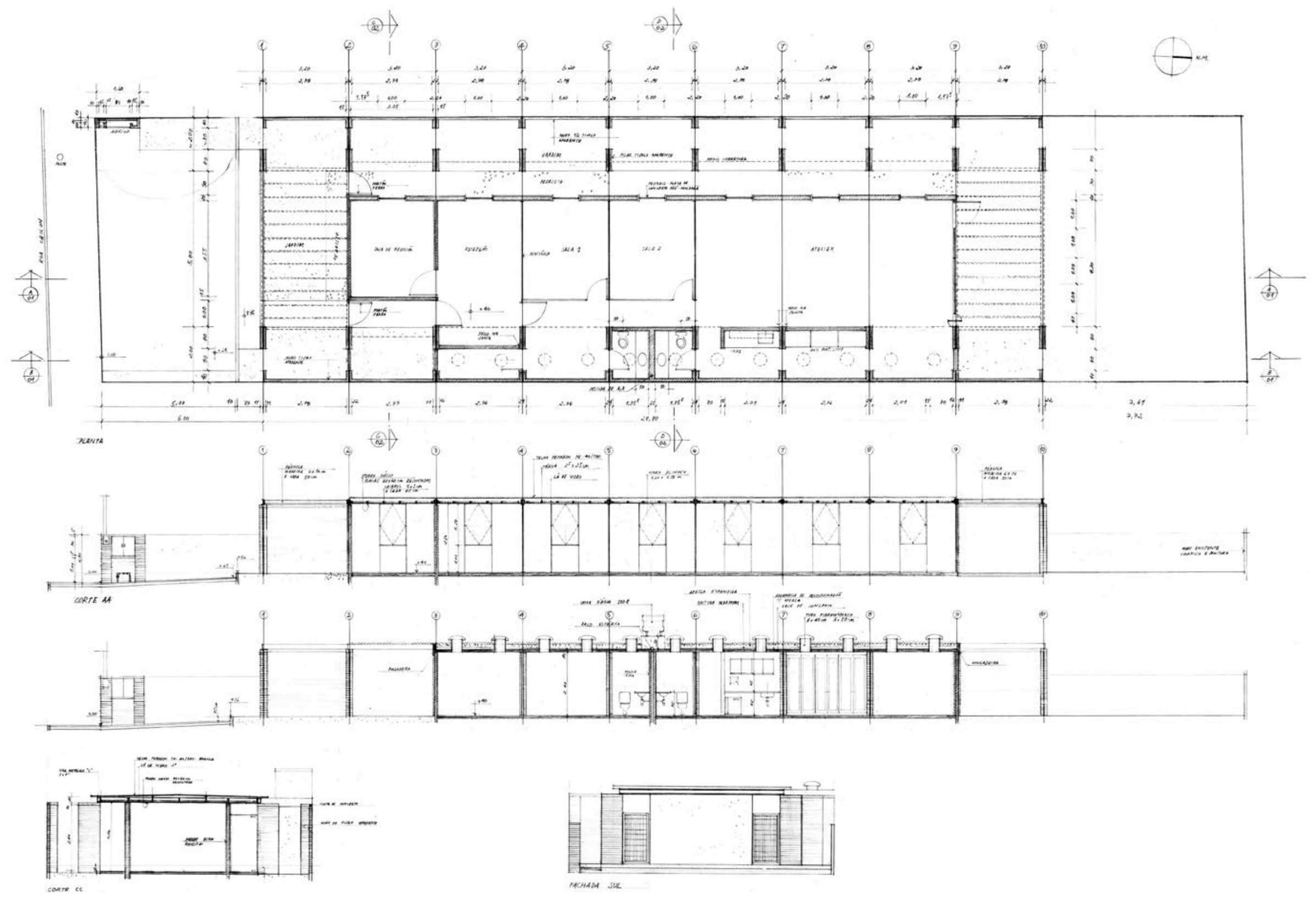


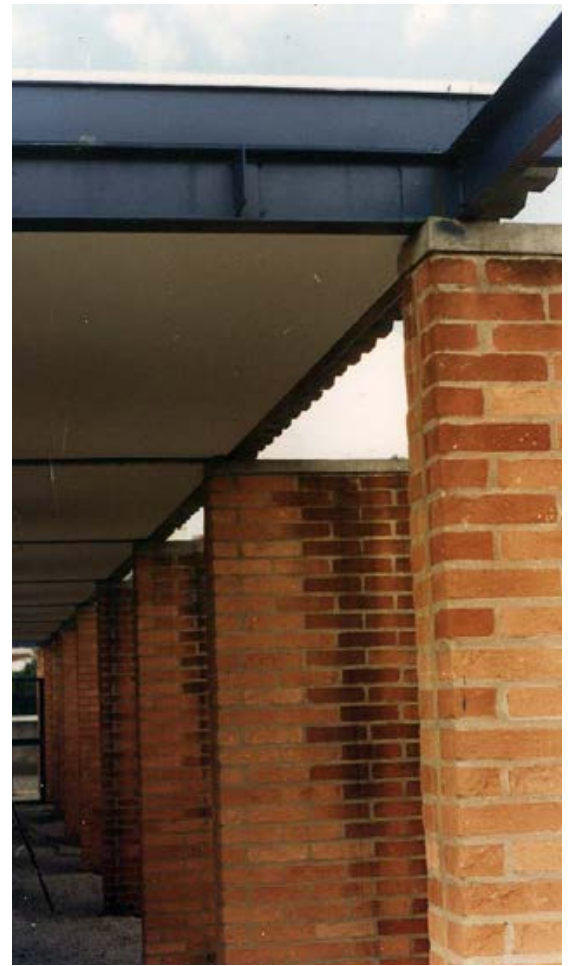

Detalhe do escritório da Rua Chilon

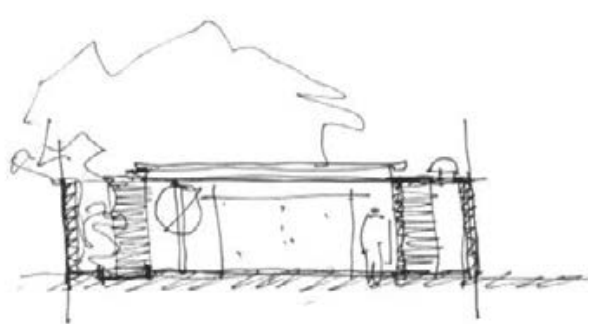

Croqui do escritório da Rua Chilon

Ao lado, desenhos do projeto para a o escritório da Rua Chilon

Acervo Eduardo de Almeida ser a sede do escritório da dupla de arquitetos, mas concluído justamente no momento da dissolução da empresa, utilizado apenas por Eduardo de Almeida nos anos seguintes.

No caso do primeiro projeto, a casa se organiza pelo tradicional eixo de circulação central capaz de interligar cada um de seus setores funcionais. Este elemento estruturador - uma cobertura de concreto armado em abóboda, dotada de iluminação zenital - é apoiado por 'placas' de alvenaria de bloco aparente, que funciona como calha de águas pluviais e também como estrutura, uma vez que recebe tanto as cargas da estrutura metálica, quanto a água de chuva proveniente da cobertura.

Do ponto de vista técnico, este plano de cobertura experimenta um sistema tradicional de telhas tipo canaleta associadas a uma camada de argila expandida, valendo-se de um sistema leve, econômico e pré-fabricado, sem deixar de considerar aspectos ligados ao conforto térmico.

A modulação desta estrutura disciplina os usos, uma vez que cada ambiente se define em conjunto com as placas que orientam as fachadas e suas relações com o exterior, sendo subdivididos em espaços menores, quando necessário, de acordo com a coordenação modular entre tais elementos.

Da mesma forma, o projeto do escritório da rua Chilon, utiliza-se de procedimentos idênticos, neste caso com alvenaria de tijolo aparente e telhas metálicas onduladas sobre forro de gesso. 0 fato do escritório implantar-se em um lote tradicional - estreito e comprido - faz com que a estrutura metálica seja posicionada próxima ao centro do lote, apoiada por placas de alvenaria de tijolos em ambos os lados, mas com uma ocupação assimétrica, já que uma das extremidades é tratada como um recuo lateral capaz de iluminar e ventilar 

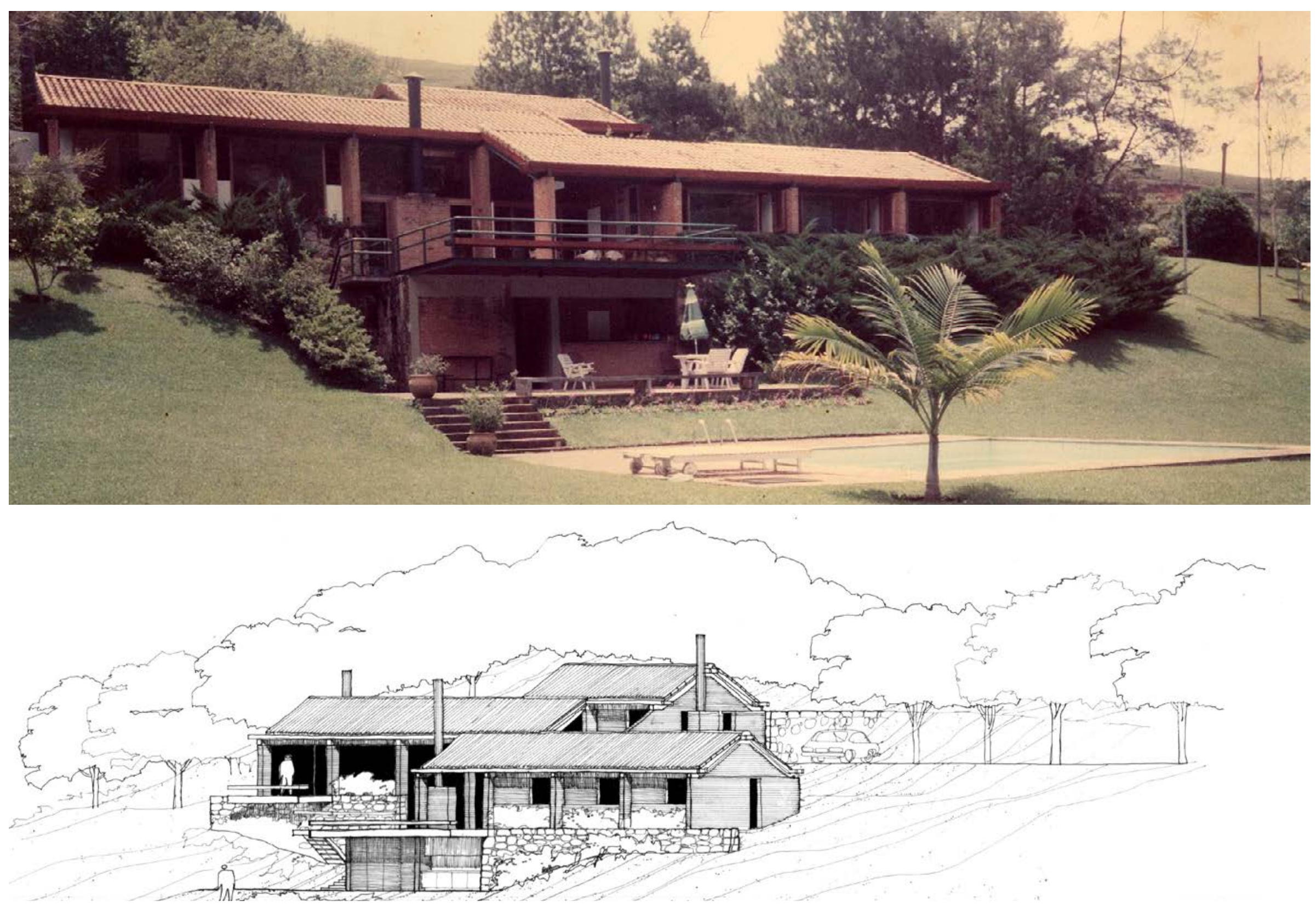


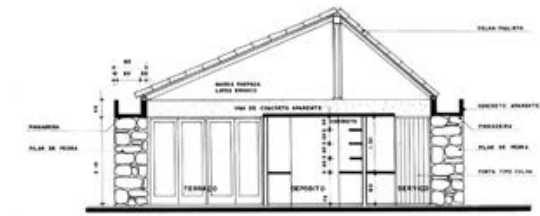

Corte da Fazenda Jatobá

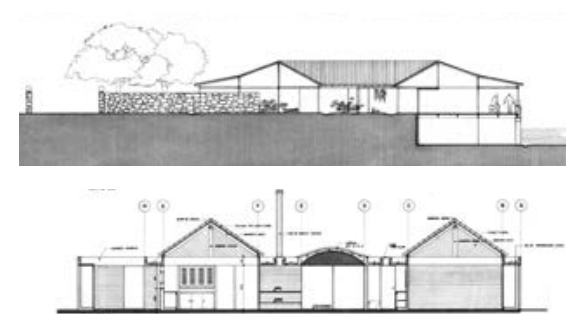

Cortes das duas versões do projeto para a Fazenda Campo dos Bois

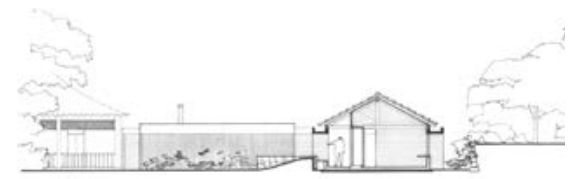

Corte da ampliação da Fazenda Olaria

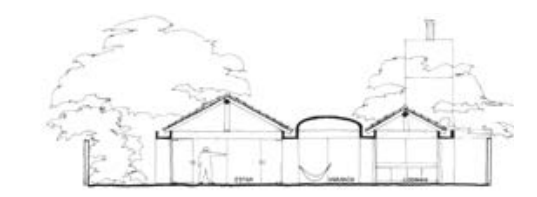

Corte da Residência Luigi Giavina

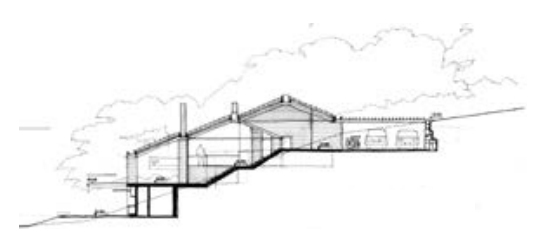

Corte da Residência Lacerda Soares

Ao lado, foto e perspectiva da Residência Lacerda Soares

Acervo Eduardo de Almeida todas as salas, enquanto a outra é coberta por uma laje de concreto e ocupada por depósitos, sanitários, copa e arquivos.

Esta organização espacial, assim como em outros projetos, separa novamente as atividades principais das áreas de apoio em 'faixas', não diferente da lógica de espaços servidos e servidores de Louis Kahn.

Mesmo que a circulação longitudinal não esteja contida em um elemento estrutural específico, como na casa Riveros, o vazio decorrente do encontro entre as áreas de trabalho e de apoio cria uma perspectiva que revela toda a dimensão do lote, desde o alinhamento da rua até o jardim localizado no fundo do terreno, em uma relação de contraste entre transparência e opacidade.

Esta estratégia de distribuir os setores funcionais ao longo de eixos de circulação, pensados a partir da justaposição de estruturas portantes com coberturas leves, parece se relacionar também a outros projetos residenciais que, diferentes dos primeiros, associam tal procedimento ao uso de coberturas inclinadas com tradicionais telhas cerâmicas.

Ao que parece, o uso de uma linguagem tradicional como a dos telhados, não significava para Arnaldo Martino e Eduardo de Almeida uma contraposição à realização de uma arquitetura claramente moderna, ao contrário, parece o elemento que permite a inserção destes objetos na paisagem com naturalidade e sem polêmica.

É o que encontramos nos projetos para a fazenda Jatobá (1977), para as duas versões para a fazenda Campo dos Bois (1978) e para a ampliação da fazenda Olaria (1980), assim como nos projetos para a casa de praia de Luigi Giavina (1980) e para a casa na Serra de Itaipava 

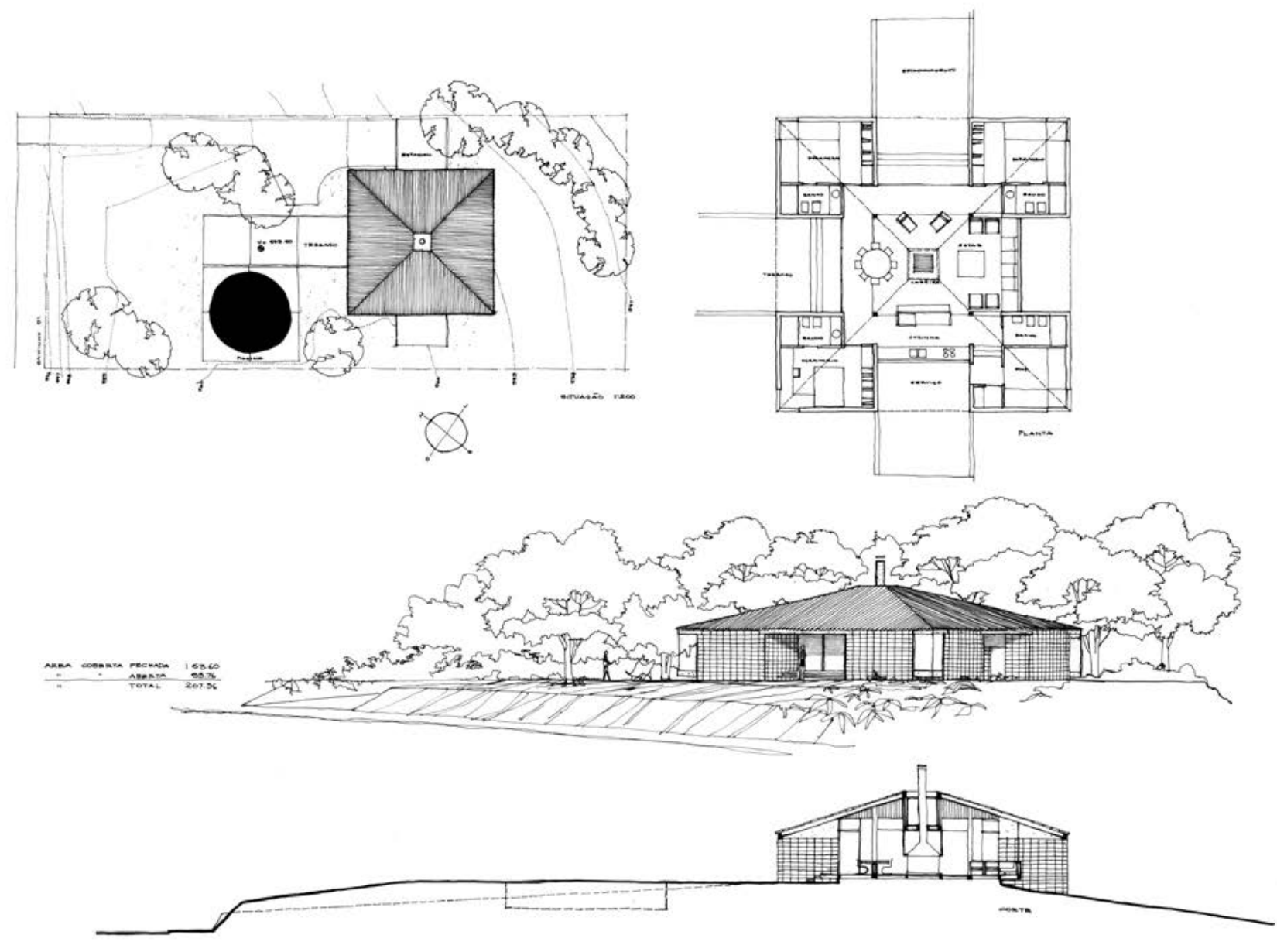

PATRIMONIO DO CARMO LOTE 5I CASA I EDUARDO DE ALMEIDA /ARQUITETO ESC. 1:100/1:200

Desenhos e fotos da primeira Residência do

Patrimônio do Carmo

Acervo Eduardo de Almeida 

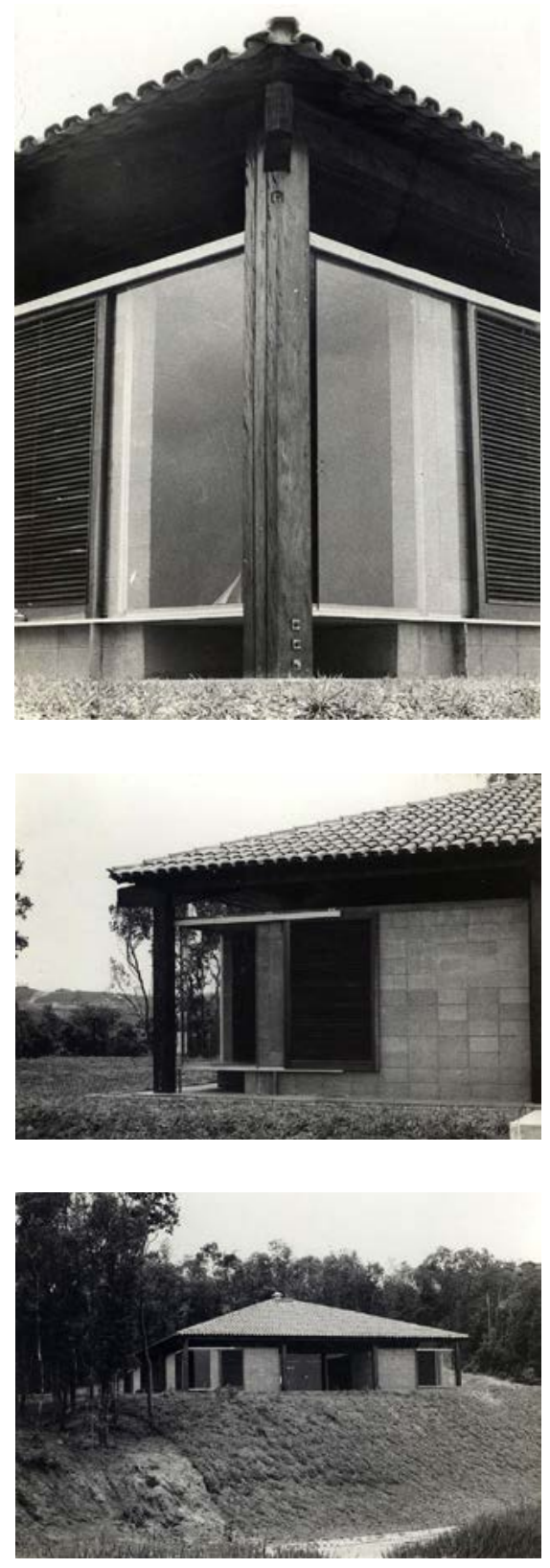

para Rodrigo Lacerda Soares (1982). Em todos estes casos, o enfrentamento dos projetos com o meio natural parece necessitar de uma aproximação com a linguagem das construções tradicionais por meio da volumetria e da materialidade de suas coberturas.

Estes exemplos se relacionam à primeira casa de Eduardo de Almeida para o condomínio Patrimônio do Carmo (1976), em que utiliza uma cobertura de quatro águas em clara referência às casas bandeiristas - pela contraposição entre 'cômodos' e 'alpendres' no plano da fachada - mas também a uma organização 'paladiana' - na organização cruciforme, por quatro elevações idênticas e pelo espaço central destinado às atividade de uso coletivo da casa. ${ }^{85}$

A constituição de uma obra como esta, sem a solicitação de um cliente específico, nos indica o interesse de Eduardo de Almeida em valorizar a tradição - de que novas formas poderiam ser criadas a partir de uma "realidade recordada"86 - cuja reinterpretação se constrói pela estrutura baseada em tipologias arquitetônicas pré-existentes, segundo Montaner, na utilização de "formas atemporais expressadas por meio de seus arquétipos":

Esta posição entende o ato criativo como o resultado da análise e de uma reflexão sobre os sistemas e espaços culturais existentes, sobre os extratos de uma herança cultural que foi decantada pela consciência histórica moderna. Estes sistemas baseados na memória se relacionam com o entorno de símbolos coletivos. $^{87}$

Essa observação não deve ser avaliada como uma descoberta isolada de Eduardo de Almeida, mas como reflexo natural de inúmeros arquitetos que, mesmo sendo formados sob os princípios da arquitetura moderna, adaptaram seus conceitos às especificidades locais.

${ }^{85}$ Verificar descrição da casa em 'Plantas de base quadrada': IMBRONITO, Maria Isabel. Tese de Doutoramento: Procedimento de projeto com base em retículas: estudo de casas de Eduardo de Almeida. São Paulo, FAU USP, 2008, p. 83

${ }^{86}$ MONTANER, Josep Maria. Sistemas arquitectónicos contemporáneos. Barcelona, Editorial Gustavo Gilli, 2009, p. 116 ${ }^{87}$ Idem 


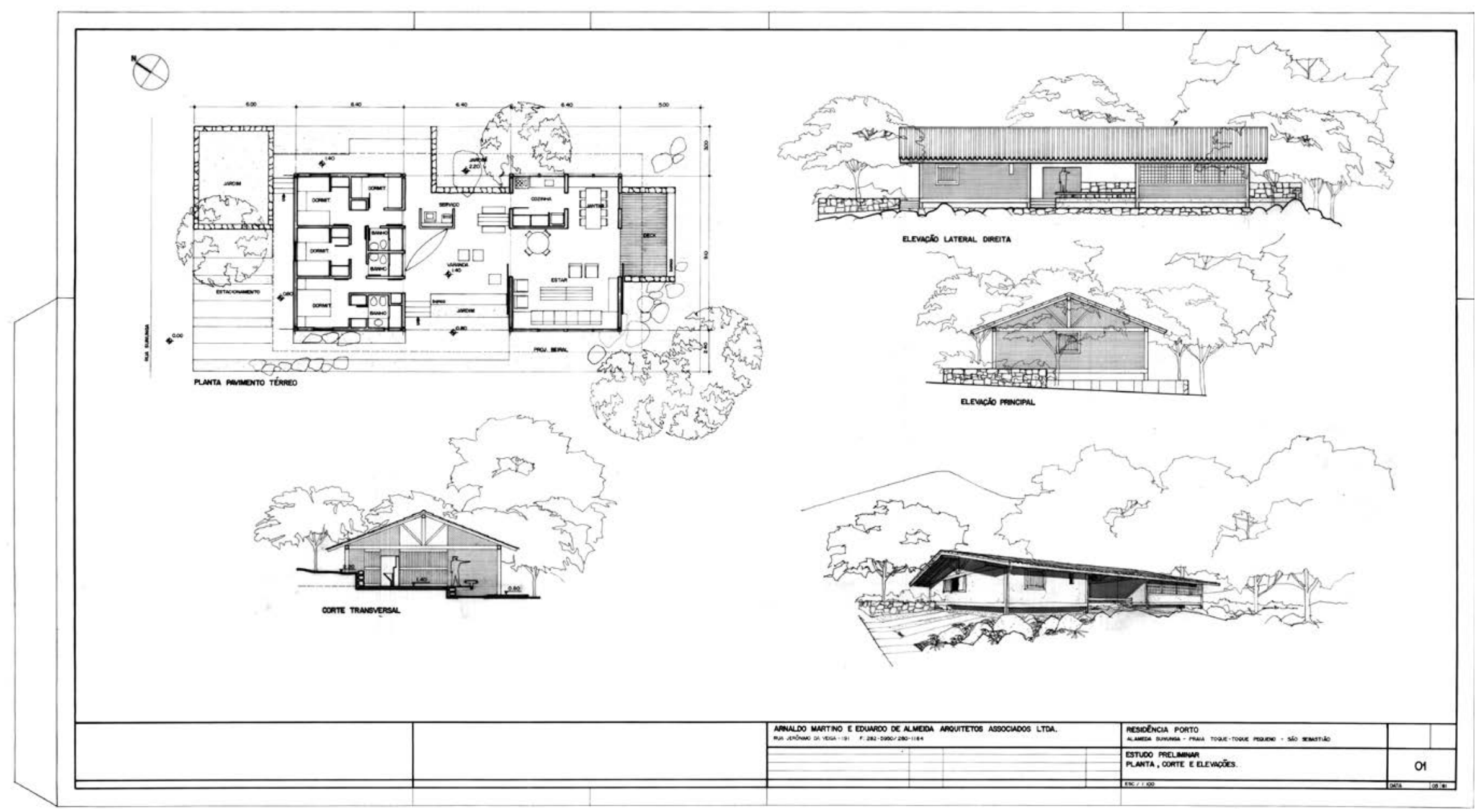



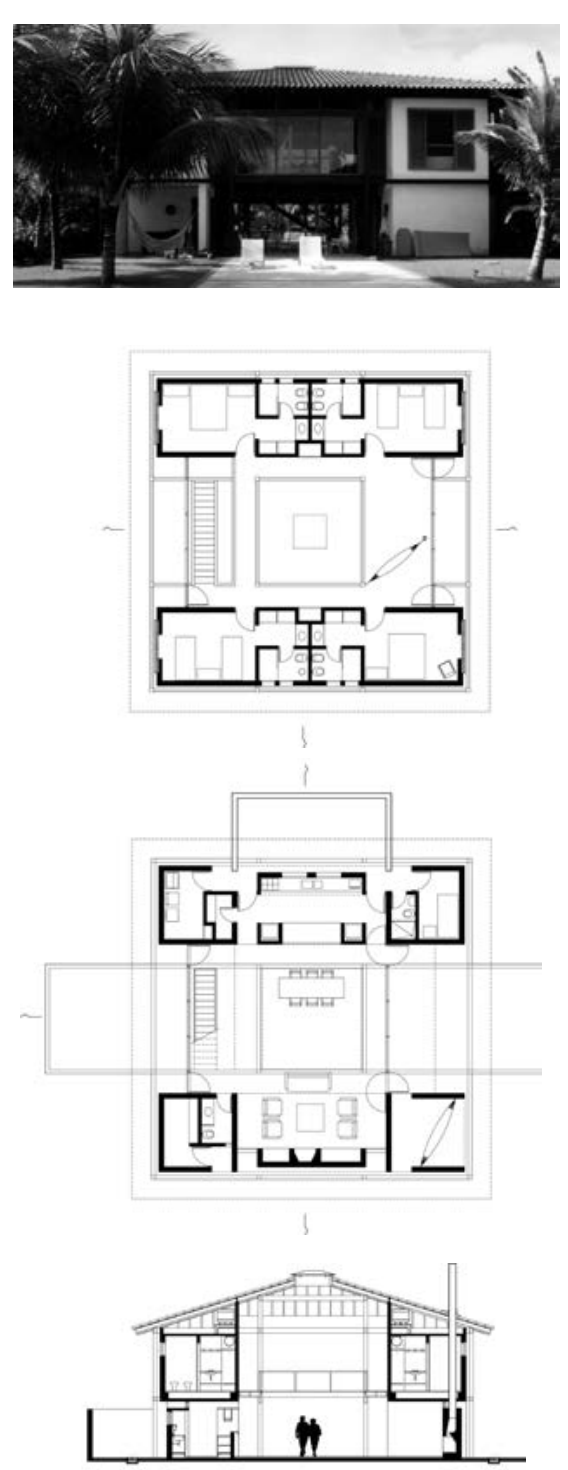

Foto e desenhos da Residência Laranjeiras

Ao lado, prancha do Estudo Preliminar da Residência Rui Porto

Acervo Eduardo de Almeida
Outro projeto que lança mão destes mesmos princípios, no caso pela influência de Carlos Millan e a conhecida casa da Lagoinha (1964), é a casa de praia para Rui Porto (1981), que se apoia em uma varanda coberta central, contraponto aos volumes presentes nas extremidades: um, destinado à sala e à cozinha, e outro, para os dormitórios e banheiros.

Este partido, contraposição de dois volumes de modo a criar um vazio articulador central presente nas casas do Patrimônio do Carmo e de Rui Porto - também é retomado em outros projetos, como a residência em Laranjeiras (1998) projetada por Eduardo de Almeida para sua família dez anos após a dissolução da sociedade com Arnaldo Martino, mas também com a cobertura em quatro águas e a estrutura independente de madeira.

Neste caso, o projeto se desenvolve em dois pavimentos e, apesar de o arquiteto frisar que a questão da cobertura com telhado cerâmico era condicionante imposta pelo condomínio, nada indica que poderia surgir um partido muito diferente deste, tanto do ponto de vista da forma quanto dos materiais.

Vale a pena lembrar que os projetos para Pedro Luis Ferreira da Silva e Ricardo Lacerda, ambos realizados no ano 2000, assim como a casa em Laranjeiras, também se utilizam de estrutura de madeira fornecida pelo engenheiro Hélio Olga, valendo-se de um sistema pré-fabricado leve, muito difundido em São Paulo a partir das obras de Marcos Acayaba.

Nos dois casos, apesar de não existirem restrições legais quanto ao material da cobertura, Eduardo de Almeida repete os telhados cerâmicos, agora em duas águas. Além disso, devido à característica comum encontrada nos dois terrenos, diferentemente da casa de Laranjeiras, as duas estruturas se implantam destacadas do lote, sobre pilares de concreto derivados dos tubulões - técnica também recorrente nos projetos de Acayaba. 


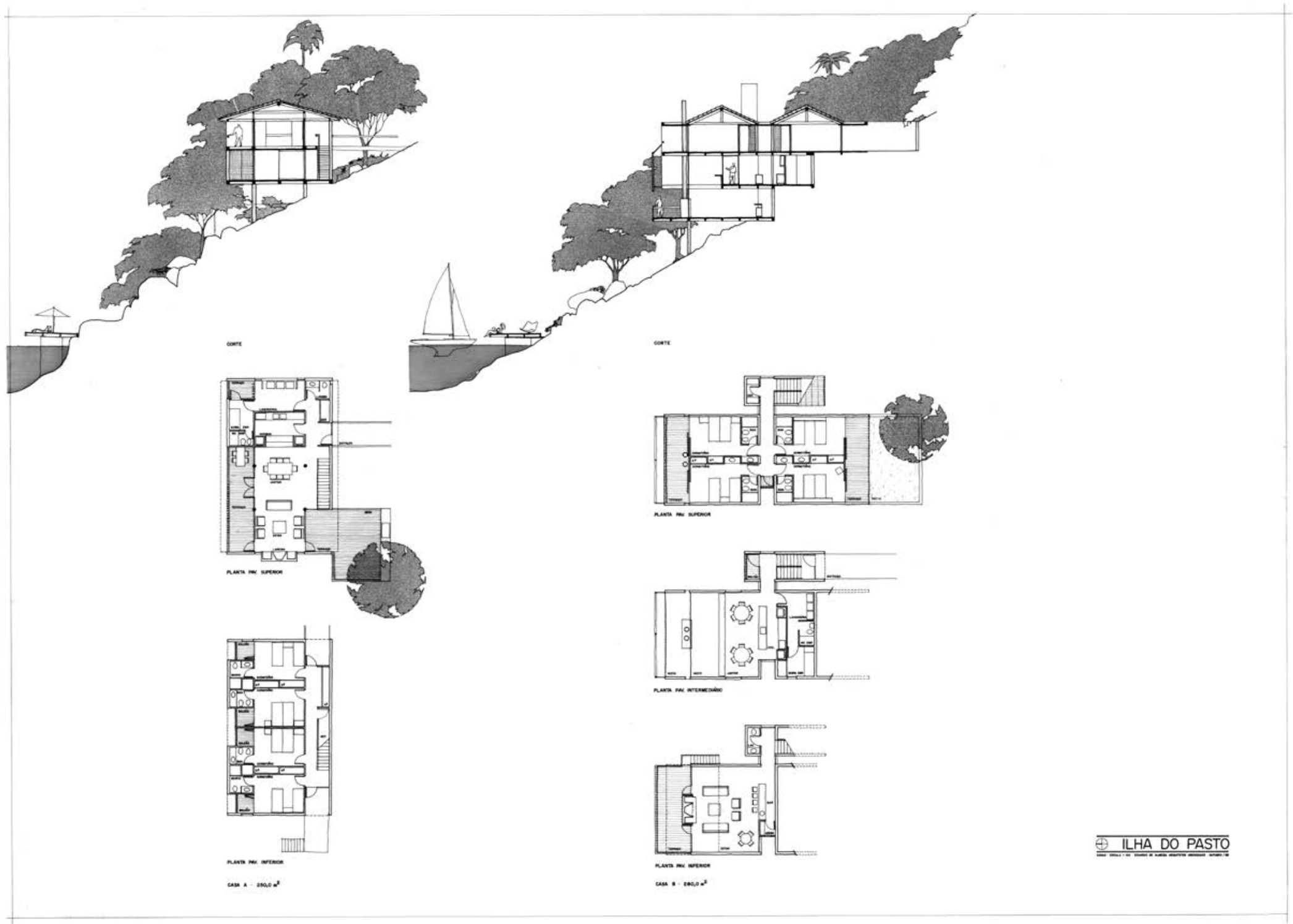

Prancha de plantas e cortes do projeto para as

Acervo Eduardo de Almeida 


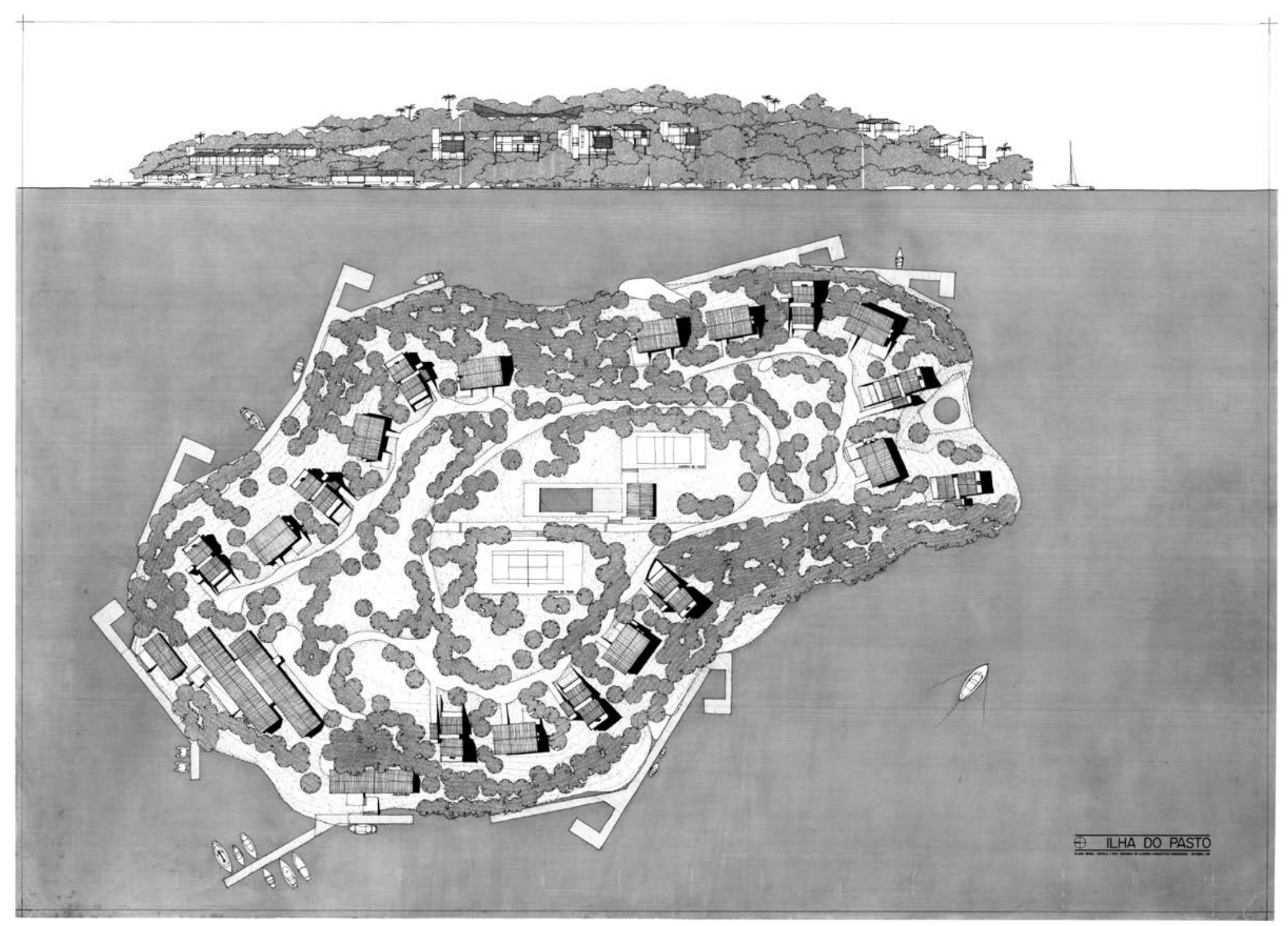

Prancha de implantação do projeto para a Ilha do Pasto

Acervo Eduardo de Almeida 


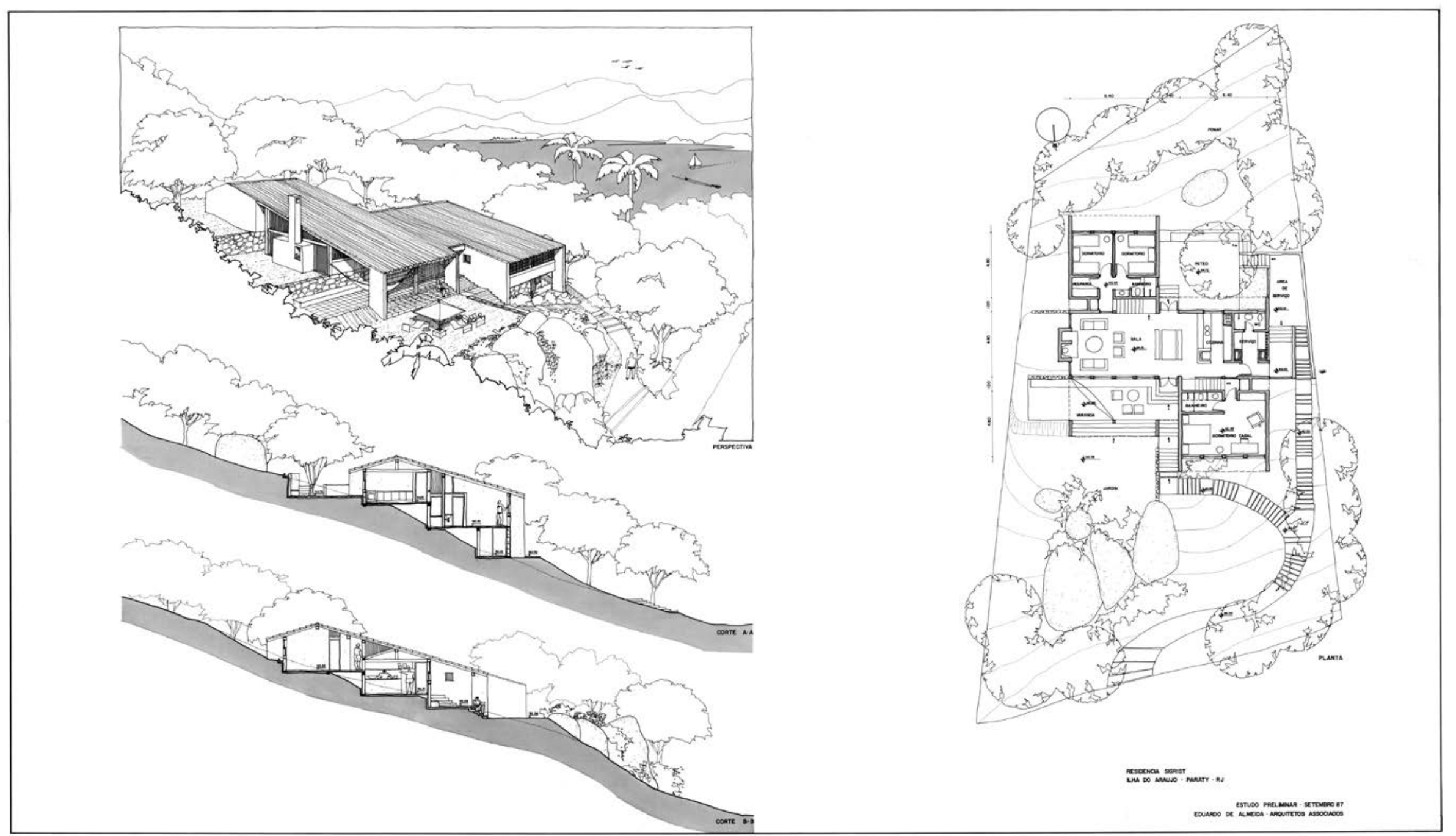

Desenhos do projeto para a Residência Sigrist na Ilha do Araújo, Paraty 


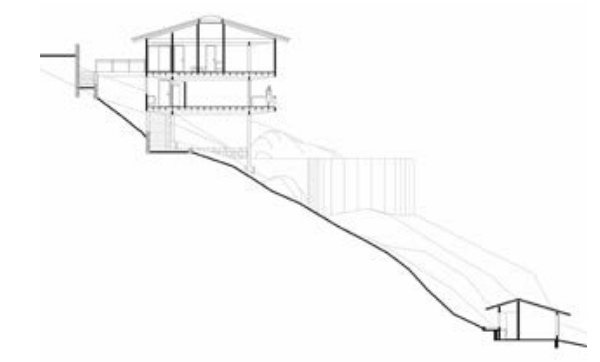

Corte da Residência Pedro Luis Ferreira da Silva

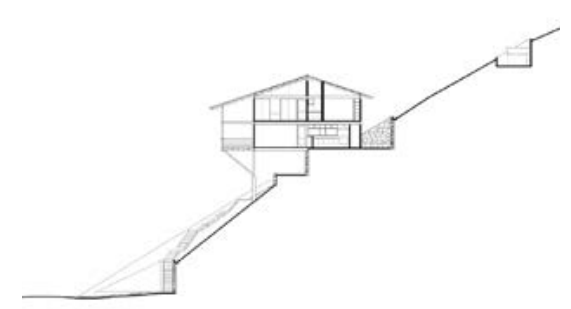

Corte da Residência Ricardo Lacerda
Enquanto a primeira se apresenta totalmente destacada do terreno, implantada paralelamente às curvas de nível, a segunda apóia-se parcialmente nos muros de pedra utilizados como contenção do terreno, a partir de uma disposição transversal à encosta. Estas diferentes soluções, pensadas a partir do mesmo sistema construtivo, parecem remeter a um projeto de Eduardo de Almeida para a Ilha do Pasto (1988), um plano de ocupação que se aprofundava na implantação destes dois modelos de residências de modo alternado, além de equipamentos coletivos, áreas esportivas e plataformas de conexão com a água.

Diferentemente deste último caso, a casa para seu antigo cliente Jean Sigrist, na Ilha do Araújo (1987) afigura-se, curiosamente, ao esquema de sua casa de São Paulo, uma construção apoiada em patamares cortados junto ao terreno, protegida por uma cobertura inclinada. No entanto, segundo depoimento de Eduardo de Almeida, dadas às condições de obra e por influência das construções de Parati, a casa se utiliza de telhas cerâmicas, alvenaria de tijolos caiada de branco e caixilhos de madeira coloridos.

Mesmo com essas características, a casa se fixa cuidadosamente no terreno, entre rochas existentes, por meio da justaposição de dois módulos de quartos - invertidos e implantados alternadamente - ao corpo longitudinal onde se situam a sala e a cozinha. Tal arranjo, também pode ser entendido como a justaposição de dois blocos paralelos e escalonados, articulados por um eixo de circulação central, onde se posiciona a mesa de jantar e a saída para a varanda e pátio externo.

Este conjunto de projetos, realizados em diferentes momentos, parece revelar um ideal de simplicidade, não apenas inerente aos demais, mas também como elemento ligado a uma memória coletiva e em sintonia com o sítio natural que, talvez por suas relações formais com a arquitetura colonial, aparece aqui denominada neste capítulo, como um conjunto de projetos voltados à 'tradição'. 


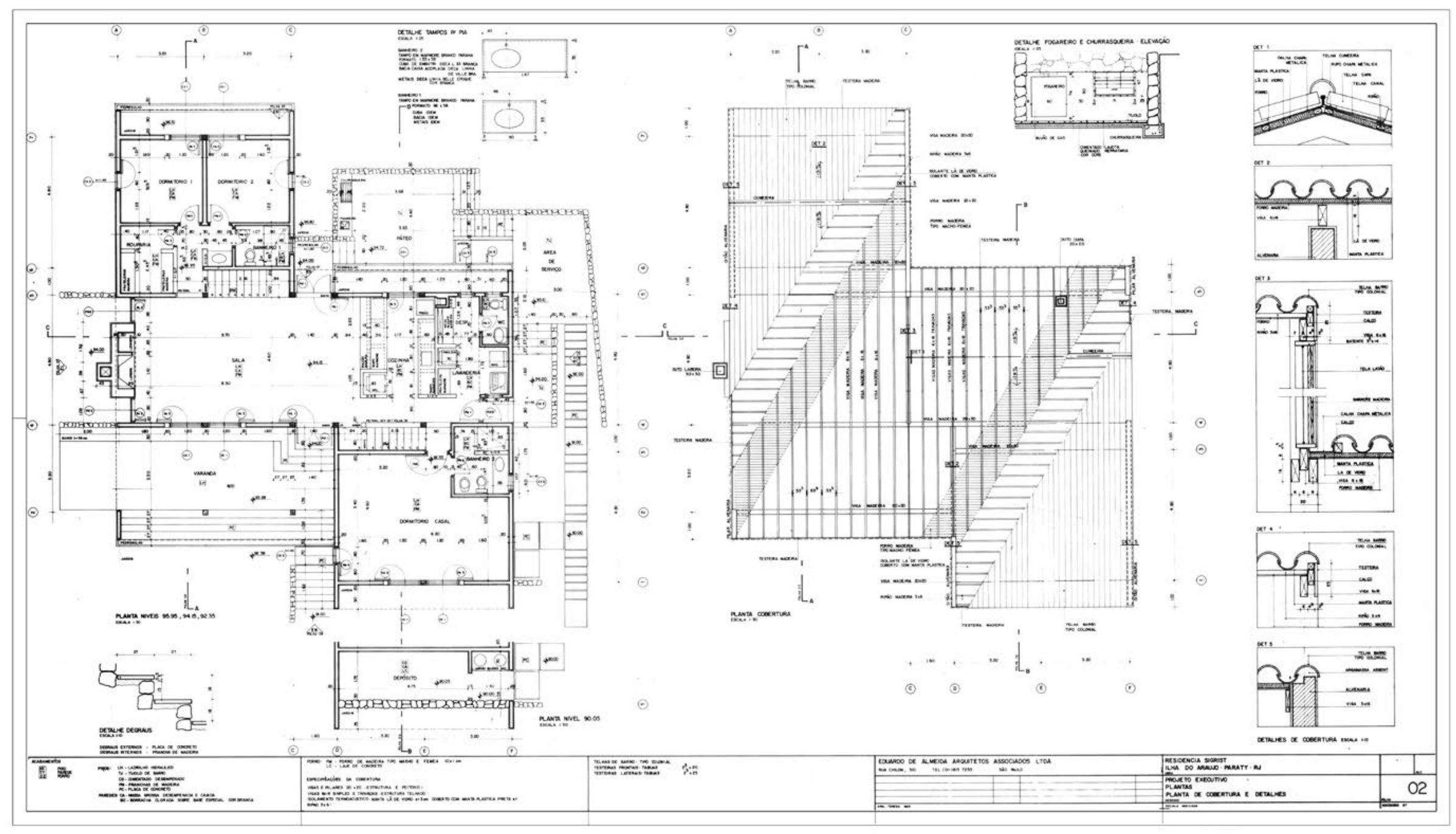

Prancha do Projeto Executivo da Residência

Sigrist na Ilha do Araújo, Paraty

Plantas e detalhes

Acervo Eduardo de Almeida 


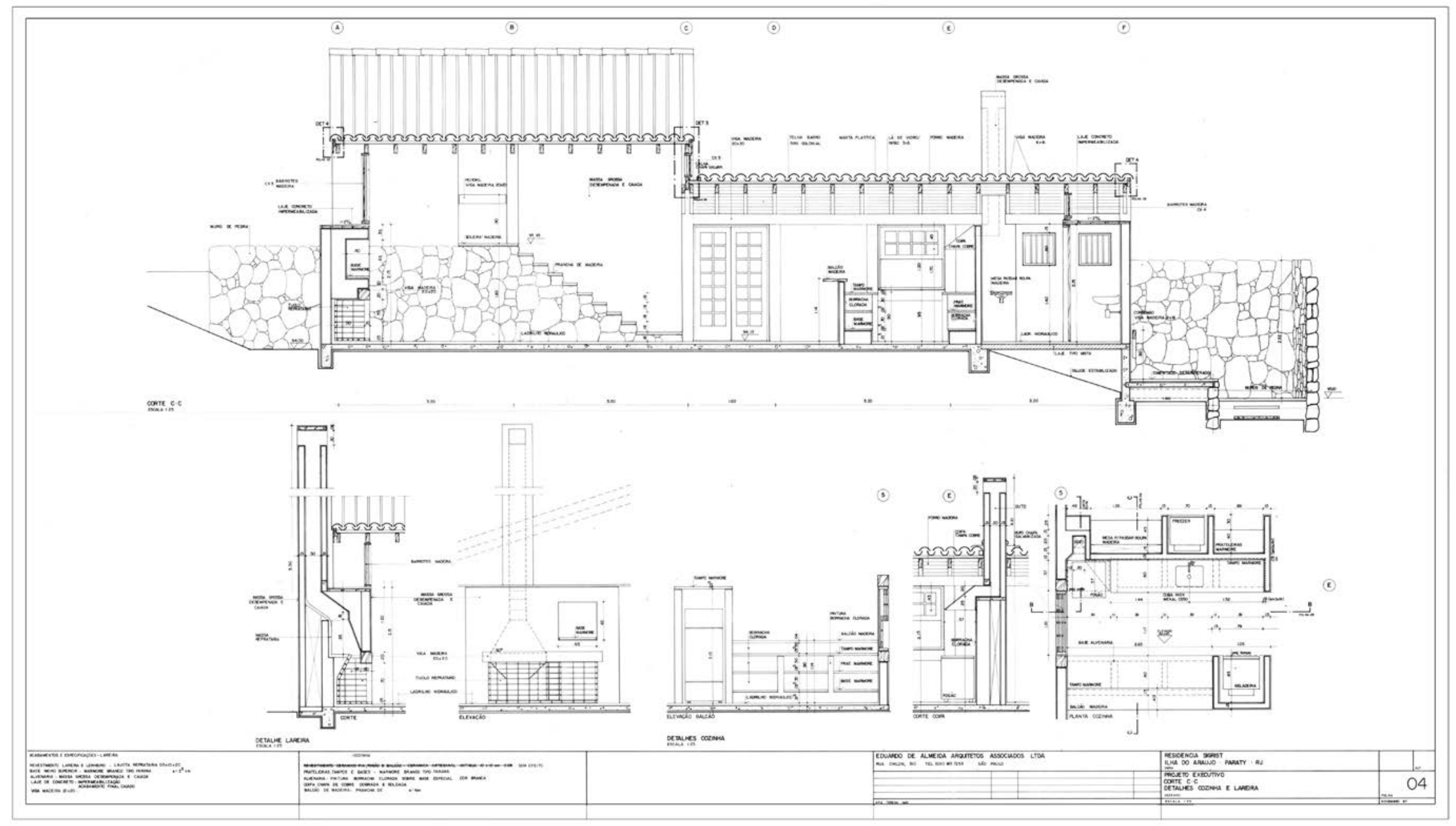

Prancha do Projeto Executivo da Residência

Sigrist na Ilha do Araújo, Paraty

Cortes e detalhes da cozinha e da lareira

Acervo Eduardo de Almeida 
Apesar de a obra de Eduardo de Almeida permitir aproximações deste tipo, podemos afirmar que tais generalizações não se aplicam em uma boa quantidade de projetos que se vinculam diretamente a esta 'tradição', mas que, de alguma forma, reaparecem mesclados a outras influências.

A despeito das estratégias que são utilizadas de modo recorrente em seus projetos, Eduardo de Almeida dá a impressão de se valer do método como base para outras expressões formais, sempre pensadas a partir de especificidades de programa, de construção ou de suas relações com o sítio.

Como já disse uma vez, ao fazer uma casa, gostaria de ser desprendido e valente o bastante para fazê-la como as casas dos caiçaras. Mas não sou assim. Creio que seria incapaz de fazê-las. Por isso faço o contrário: projeto a casa com extremo cuidado e detalhe porque, se não faço assim, tenho medo de não acertar. Este é um comentário paralelo, quase psicológico, com o qual quero dizer que quando se fazem muitas residências, sempre me dá vontade de tentar provar algo novo, algo que ainda não tenha sido feito. ${ }^{88}$

Parece claro que, para Eduardo de Almeida, o ideal de simplicidade não se dá de modo natural, mas como um trabalho calculado, somente atingido após extenuante processo de tentativas sucessivas para atingir tal simplicidade e precisão, sem a definição prévia de resultados formais a serem alcançados.

Esta abertura a soluções formais diversas nos permite dizer que, na obra deste arquiteto, tecnologia e tradição não se apresentam necessariamente de modo contraditório, pelo contrário, podem ser empregadas em conjunto em inúmeros projetos, sem que haja sobreposição ou a primazia de uma característica.

Talvez por este motivo, projetos posteriores de escolas públicas de Eduardo de Almeida e

${ }^{88}$ ALMEIDA apud ESPALLARGAS in PIÑON, Hélio. Eduardo de Almeida. Barcelona, Edicions UPC, 2005, p.19 

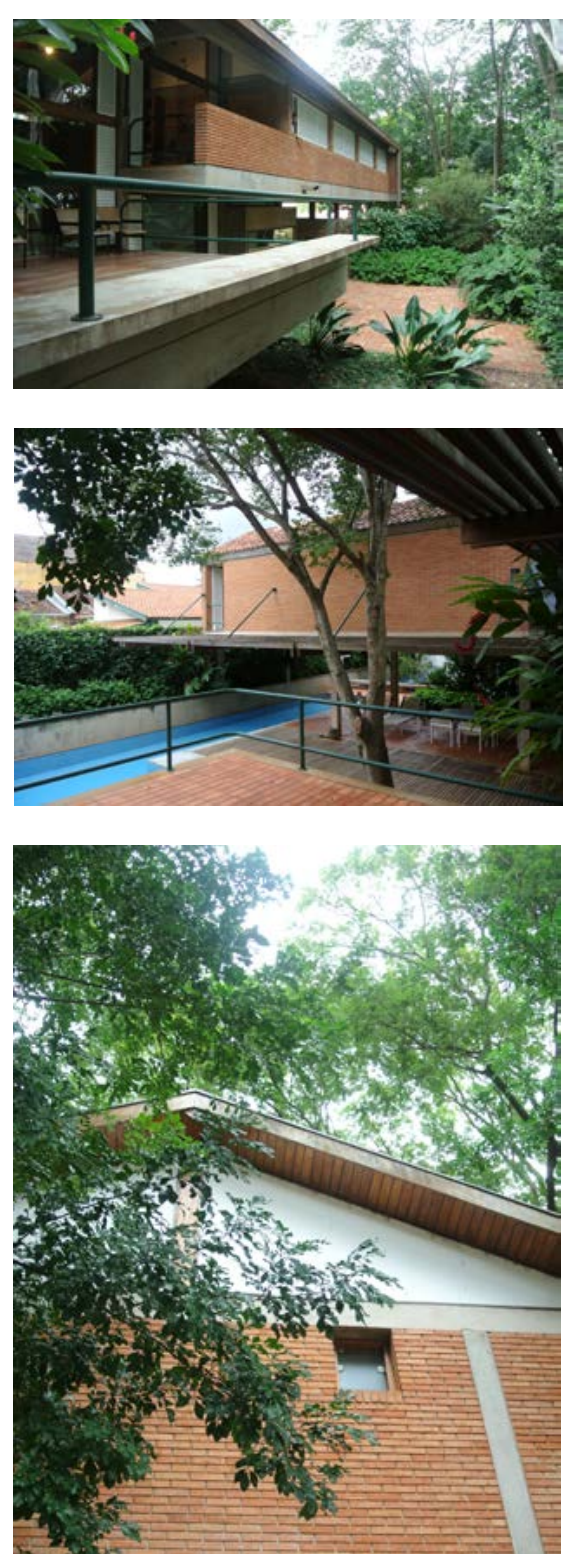

Fotos da Residência Renata Tassinari Fotos: Bruno Salvador
Arnaldo Martino apresentem características vinculadas tanto à tecnologia quanto à tradição, retomando a investigação de novos sistemas estruturais e construtivos apesar das limitações provenientes da padronização da CONESP.

No caso da EEPG Vila Albertina (1985), o partido linear adotado se utiliza de um esquema volumétrico não diferente da casa de praia de Rui Porto, ainda que usos, proporções e escalas sejam outros. Ao mesmo tempo, uma engenhosa solução estrutural para cobertura de duas águas utiliza lajes inclinadas sem vigas, estabilizadas por tirantes posicionados entre as vigas calhas, modelo estrutural idêntico ao projeto da EEPG Jardim Julieta, de 1986.

No caso da EEPG Parque Bela Vista (1985), Arnaldo Martino e Eduardo de Almeida utilizam a justaposição de três coberturas de duas águas - destinadas à administração, galpão e espaços de apoio, respectivamente - além de um quarto volume de dois pavimentos (também com cobertura de duas águas) para o conjunto de salas de aula. 0 projeto se desenvolve com 0 uso de pilares de blocos de concreto, demais alvenarias de tijolos aparentes, vigas-calha de concreto armado e estrutura de madeira com telhas cerâmicas. Deste conjunto de grande diversidade material, destaca-se a estrutura de madeira do galpão, composta por duas tesouras simétricas travadas por um cabo de aço central, responsável por anular os esforços de tração decorrentes da geometria do telhado.

Na obra destes arquitetos o emprego de materiais diversos em um mesmo projeto é recorrente, nas mais variadas possibilidades de combinação. Como a casa para Renata Tassinari (1982) que se vale de uma estrutura regular de concreto armado, com vedos de alvenarias de tijolos aparentes e, na cobertura, uma solução de estrutura de acordo com exemplos da arquitetura colonial brasileira. ${ }^{89}$

${ }^{89} \mathrm{O}$ emprego de uma viga de cumeeira de seç̧ão quadrada, posicionada em uma inclinação de 45 graus nos remete a soluções construtivas de telhados tradicionais. 


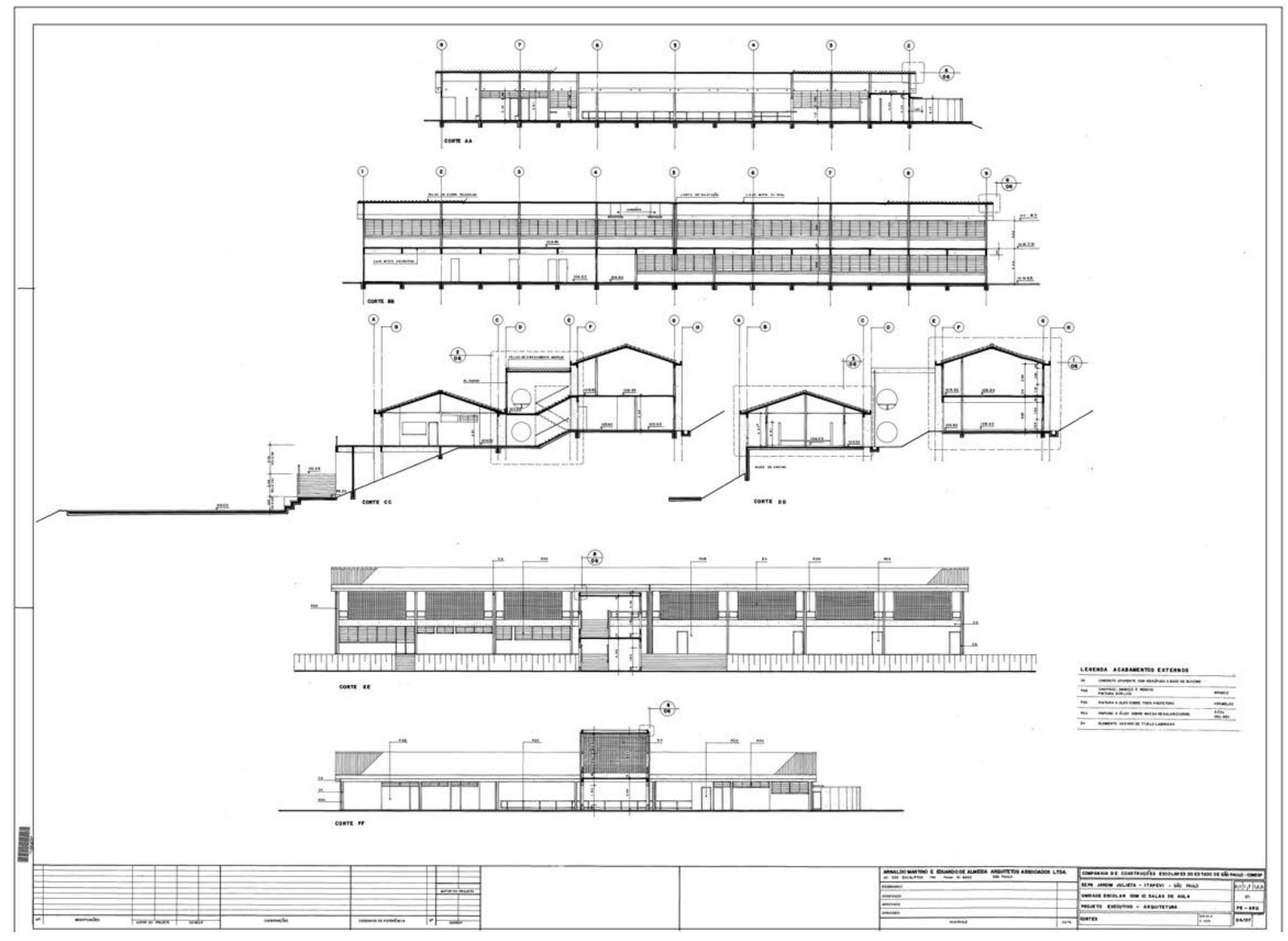

Prancha do Projeto Executivo da escola Jardim

Acervo Eduardo de Almeida 


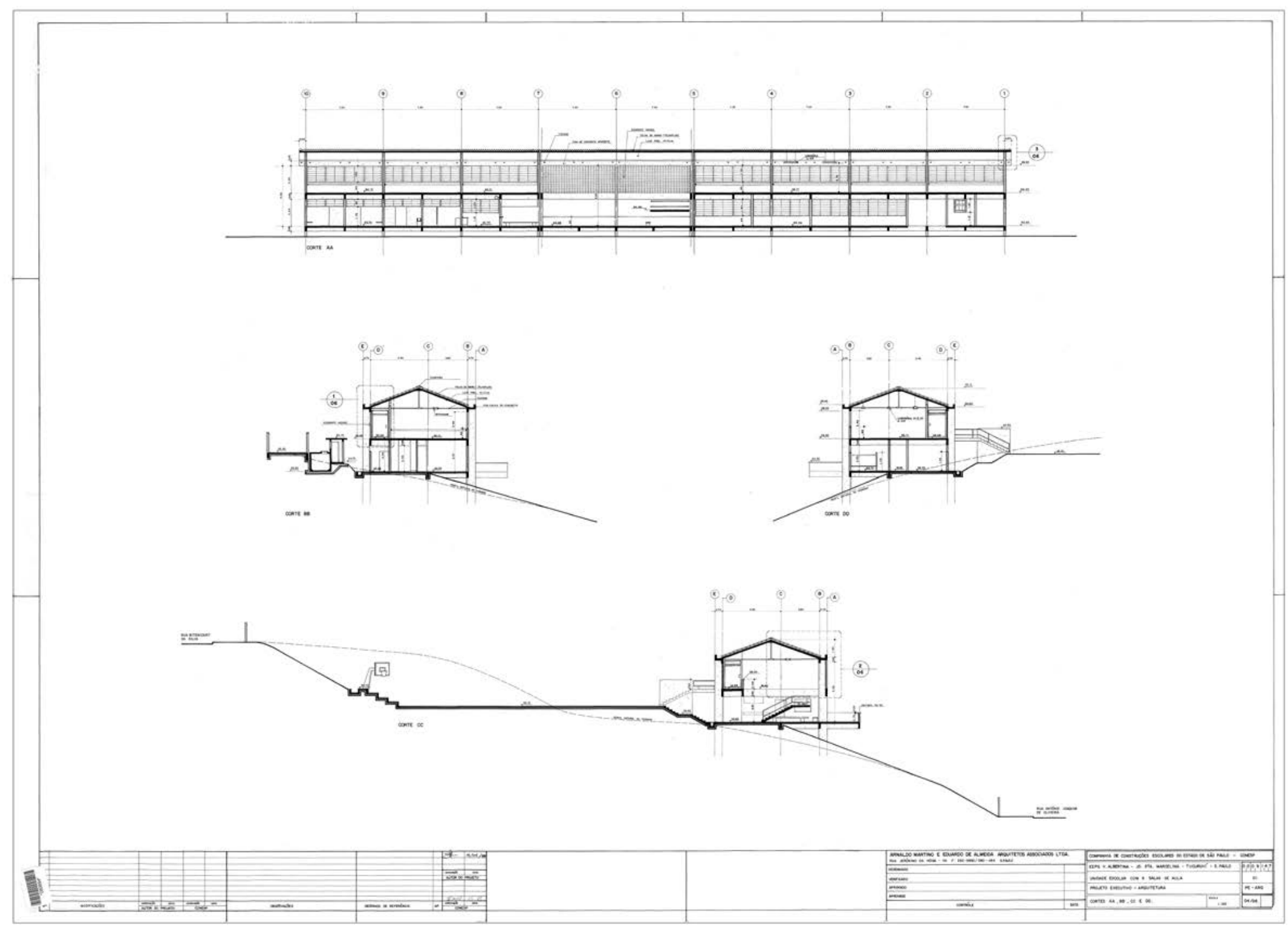

Prancha do Projeto Executivo da escola Vila

Albertina

Acervo Eduardo de Almeida 


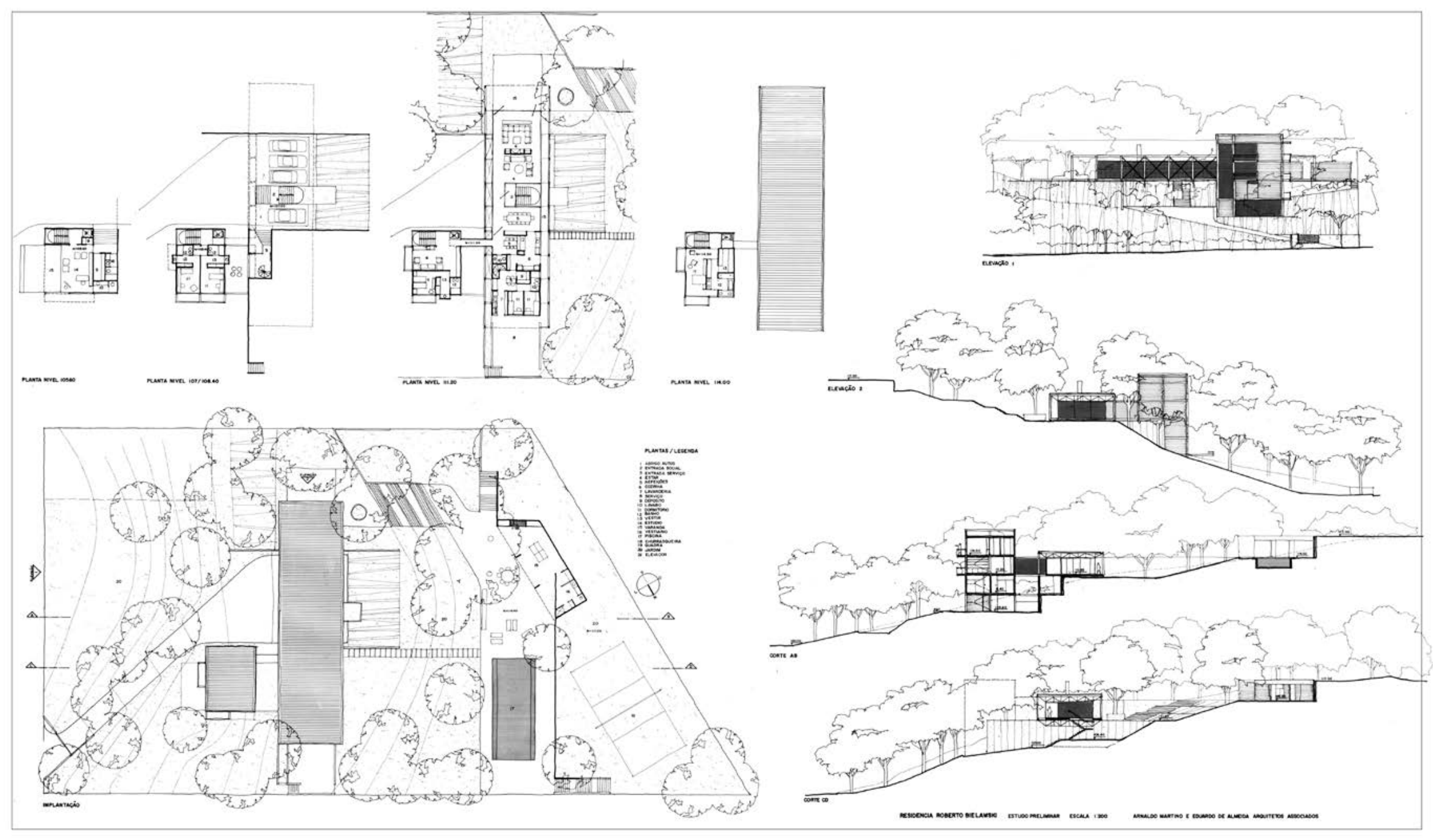

Ao lado, prancha do Estudo Preliminar do projeto para a Residência Roberto Bielawski Acervo Eduardo de Almeida 


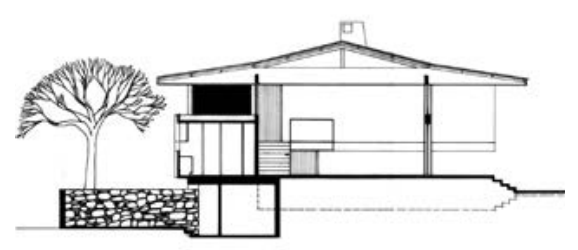

Corte da Residência Aroldo Fuganti
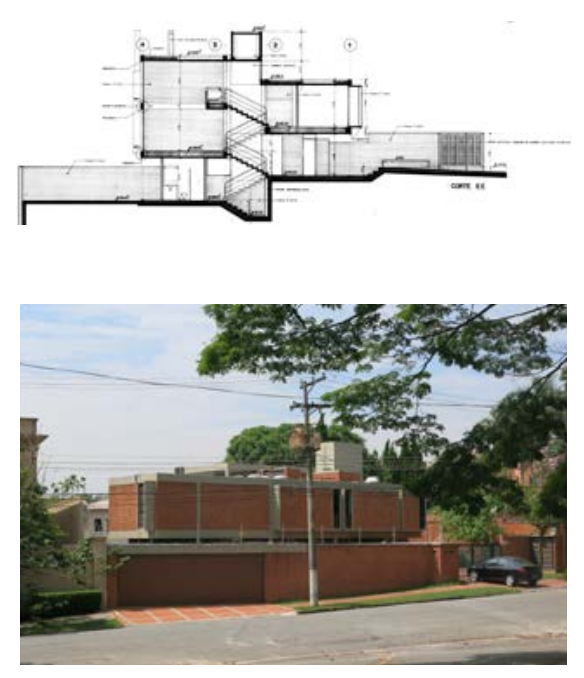

Corte e foto da Residência Mário Ciuchini Foto: Alessandra Figueiredo

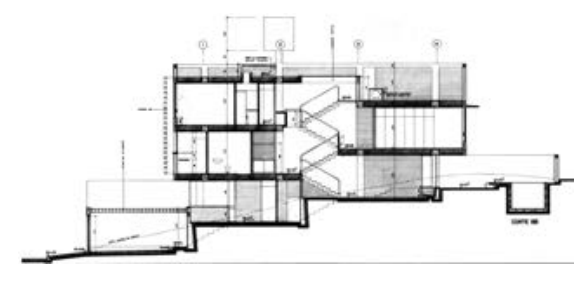

Residência Bonomi Requejo Corte longitudinal
A erudição destes dois arquitetos em relação à arquitetura tradicional brasileira se apresenta mesmo em trabalhos anteriores, como no projeto de Eduardo de Almeida para a residência Aroldo Fuganti (1970), construída em Londrina com a utilização de estrutura mista de concreto armado e madeira, sobretudo no desenho da cobertura de duas águas com dupla inclinação.

Em outros trabalhos realizados pelos arquitetos, o uso do telhado simplesmente desaparece, restando apenas a combinação de concreto e tijolos, como nas casas Mário Ciuchini (1979) ou Bonomi Requejo (1982), que também compartilham a justaposição de diversos volumes na relação de meios-níveis.

Outro caso excepcional consiste no projeto para a residência de Roberto Bielawski (1983) que, a partir da topografia em aclive do lote, cria uma casa binucleada pela justaposição volumétrica de um bloco vertical a um horizontal.

Enquanto o primeiro é construído em concreto armado e tijolos, e abriga os dormitórios em diferentes pavimentos, o segundo se situa em meia-encosta por meio de uma estrutura metálica, onde se posicionam os ambientes de estar e serviços.

Esta configuração volumétrica permite criar o acesso de veículos e visitantes sob o pavilhão horizontal, desenhado como uma ponte por meio da transformação da malha estrutural metálica em uma treliça da altura do pavimento.

Os espaços de uso coletivo voltam- se ainda para um patamar exterior onde se posiciona a piscina, complementada por uma área de lazer coberta, incrustrada no terreno. 

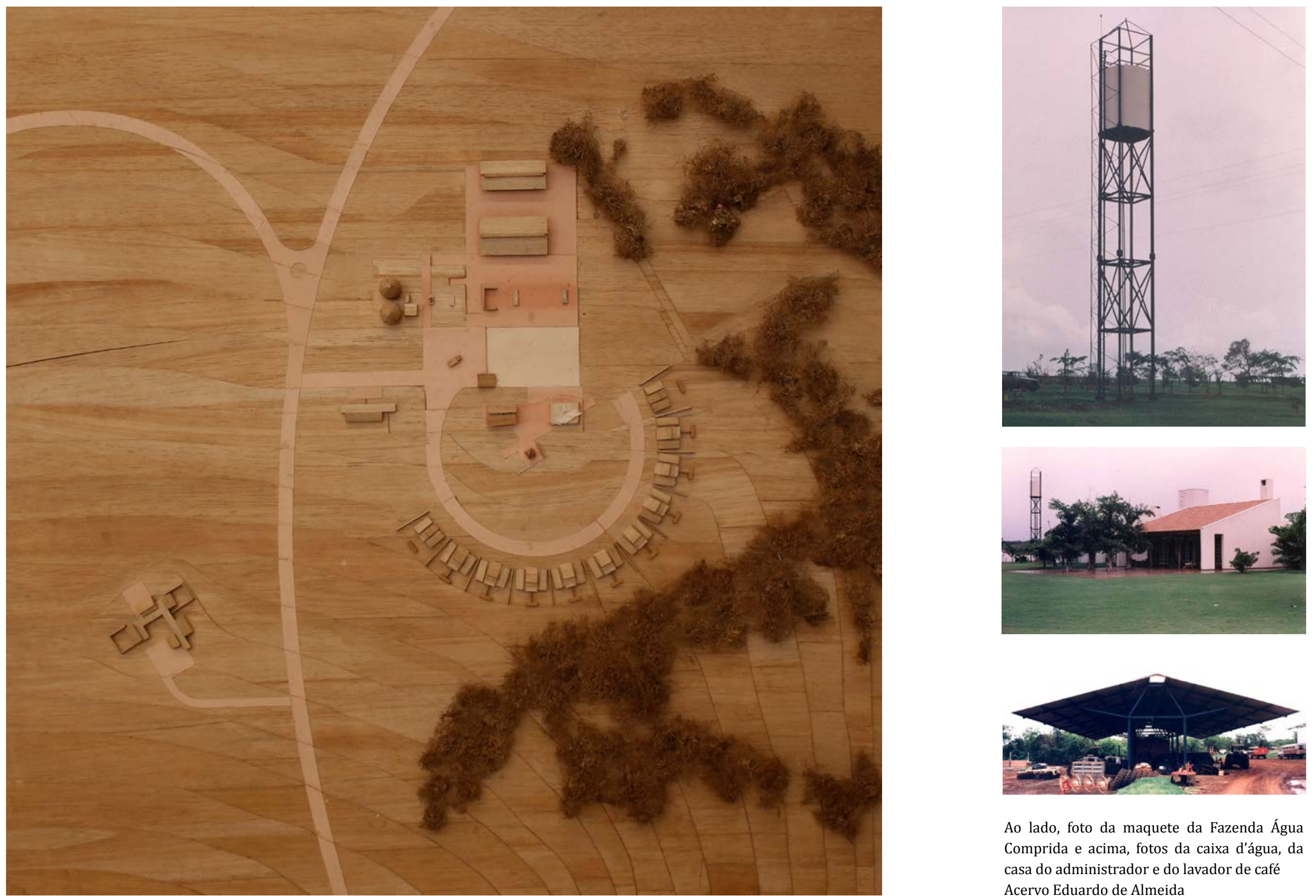

Ao lado, foto da maquete da Fazenda Água Comprida e acima, fotos da caixa d'água, da

casa do administrador e do lavador de café Acervo Eduardo de Almeida 
Este projeto parece reunir soluções decorrentes de inúmeras outras obras, agora agrupadas de modo a criar um conjunto de extrema complexidade e variedade formal. Apesar de desenvolvido completamente, o projeto não chegou a ser construído.

De qualquer forma, podemos afirmar que tais experiências se refletem na produção posterior de Eduardo de Almeida, já que esta variação de soluções, muitas vezes com aspectos ligados à tecnologia ou à tradição, continua a se mesclar de diferentes maneiras, sem que isto signifique perda de rigor ou de qualidade.

É o que podemos apreender da sequência de projetos para a Fazenda Água Comprida, que se divide em edifícios para habitação e trabalho, dispostos a partir de um plano de caráter urbanizador.

Em uma gleba de grandes dimensões, o plano de ocupação cria a separação entre os edifícios ligados à produção - pavilhões de planta retangular dispostos paralelamente - e núcleo residencial dos trabalhadores - implantação radial, definindo uma geometria em semicírculo.

Enquanto os primeiros se utilizam de estruturas metálicas leves associadas a fechamentos de telha e muros baixos de alvenaria, não diferentes das investigações estruturais com Arnaldo Martino em diversas escolas, as demais construções seguem a justaposição de volumes funcionais com coberturas inclinadas, exatamente como inúmeros projetos residenciais de Eduardo de Almeida.

Interessante notar que, justamente no encontro entre os dois setores, implantou-se o centro comunitário da fazenda, desenhado pela sobreposição de uma estrutura metálica - paralela 


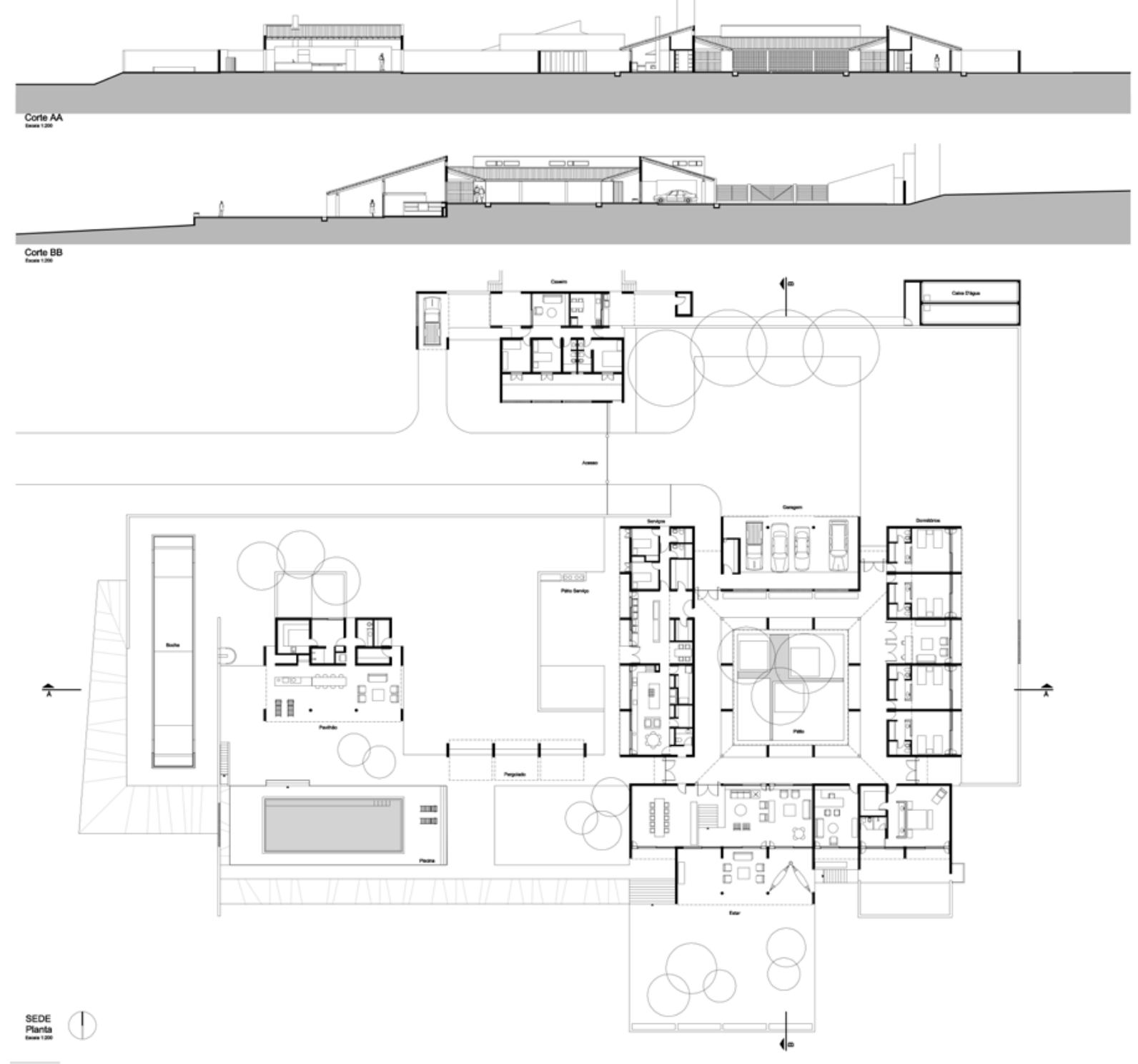

Projeto para Sede da Fazenda Água Comprida Acervo Eduardo de Almeida 

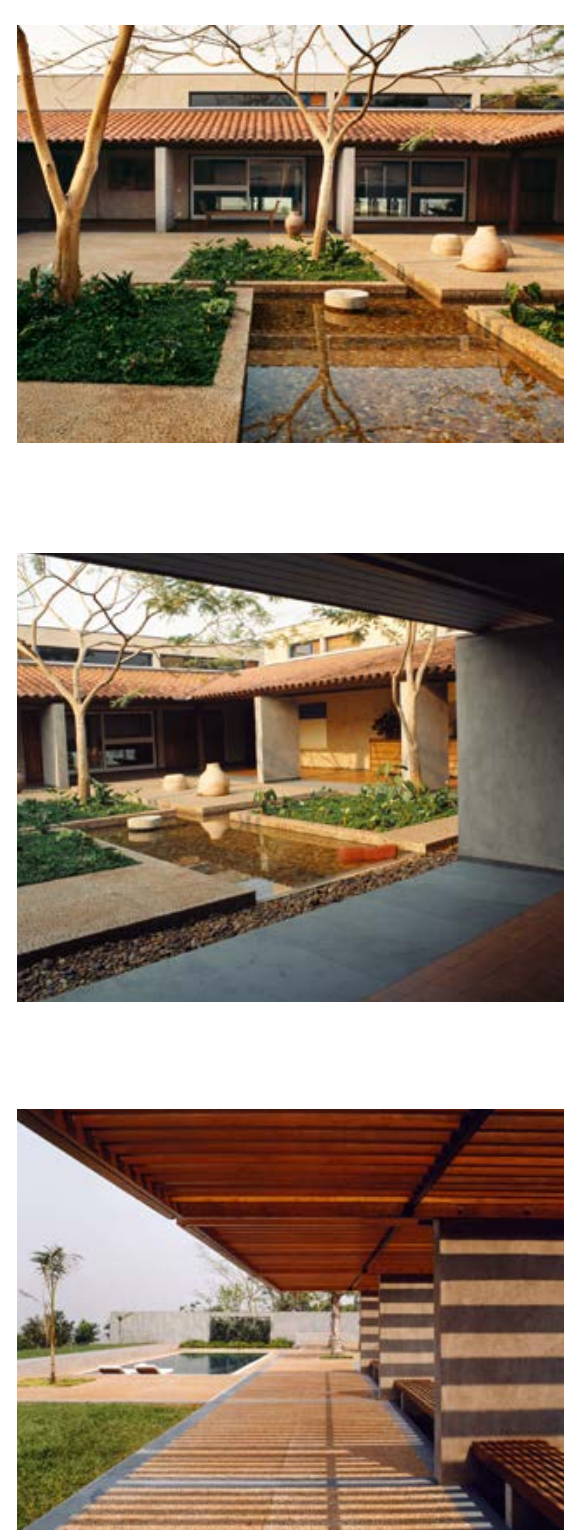

Sede da Fazenda Água Comprida Fotos: Lalo de Almeida aos edifícios ligados à produção - a uma estrutura de alvenaria e concreto oblíqua, orientada de acordo com a geometria das habitações dos trabalhadores.

Apesar deste edifício central não ter sido construído, a partir desta composição geométrica de grande complexidade é que se definiriam a implantação de outros prédios, como a sede dos escritórios ou a casa dos administradores, de acordo com o padrão construtivo das residências.

Segundo Eduardo de Almeida, a composição destas obras em volumes, associadas a extensos muros, foi pensada não só a partir de seus usos, mas também na relação com a amplitude da paisagem, tanto no intuito de demarcar a presença dos edifícios neste contexto, como também na definição de recintos menores, pátios externos em escala adequada a cada programa.

Deste conjunto, destacamos a casa Sede da Fazenda, concluída apenas em 1993, projetada de acordo com a organização de volumes ao redor de um pátio central, cuidadosamente desenhado por um espelho d'água cruciforme e apenas três árvores.

Naturalmente, a solução repete inúmeros projetos anteriores, mas se reconfigura a partir do desenho de suas coberturas desencontradas, da combinação de diferentes materiais e da relação entre os volumes e a paisagem, intermediados por platôs externos e muros extensos, às vezes intercalados por planos de elementos vazados.

Em contraponto, podemos destacar o reservatório de água vertical da fazenda que, assim como as demais construções de caráter produtivo, parece mesclar influências da linguagem high-tech de arquitetos como Norman Foster ou Richard Rogers, à uma simplicidade construtiva da arquitetura industrial tradicional, já que os elementos de contraventamento expostos se associam ao esqueleto metálico dos edifícios, revelando 


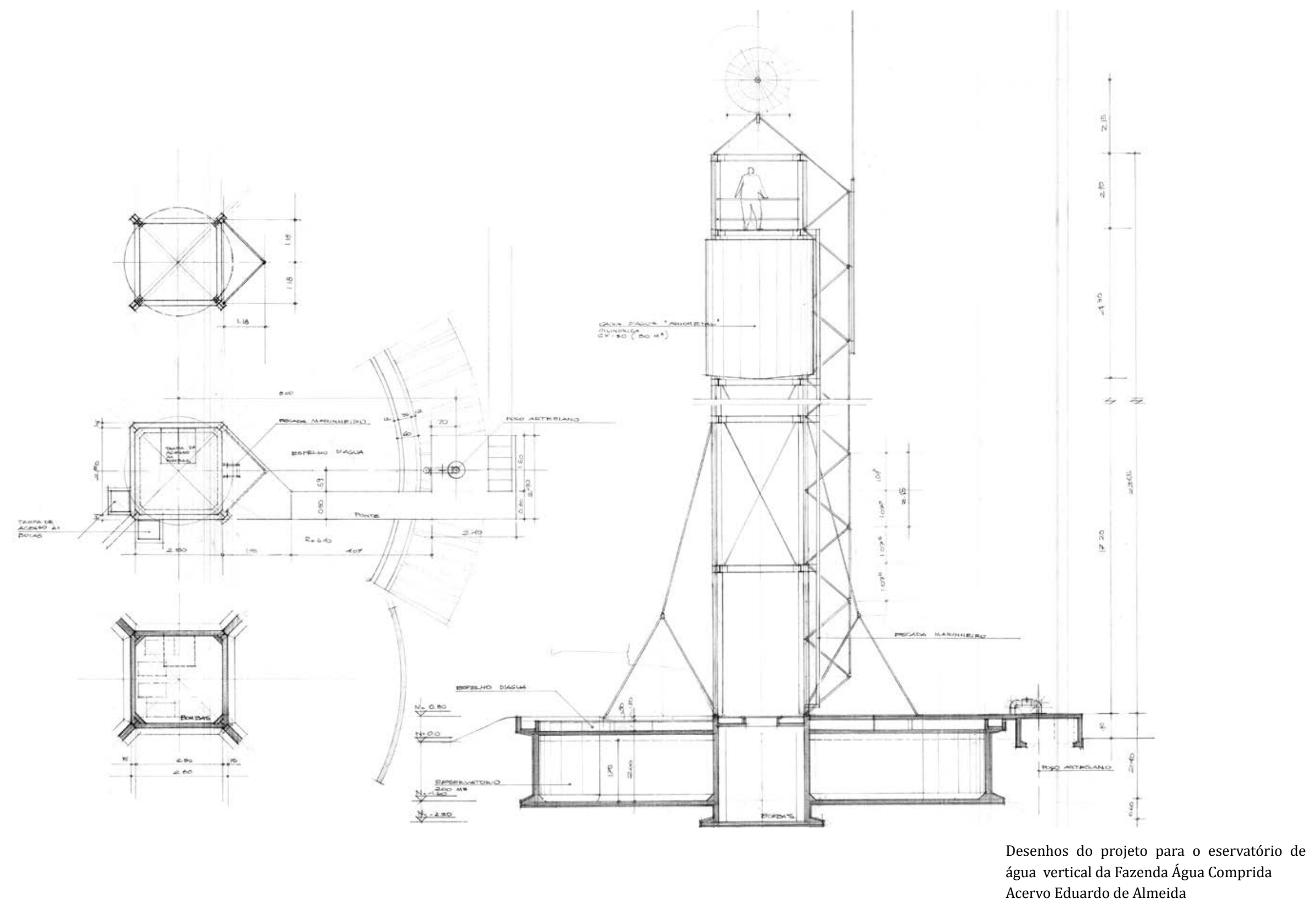




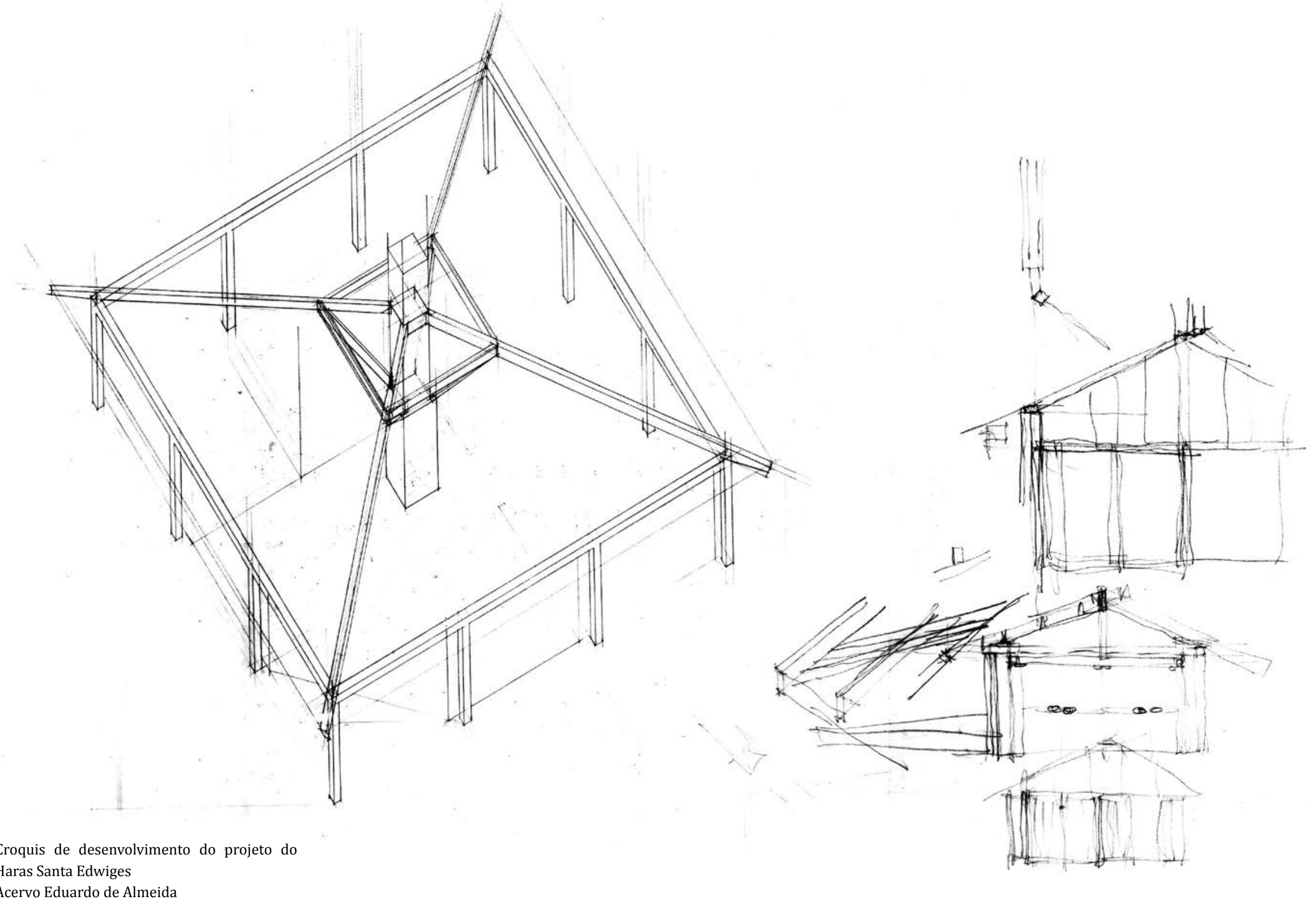

Acervo Eduardo de Almeida 
claramente suas funções estruturais como elementos expressivos de sua linguagem arquitetônica.

Condição que aparece claramente nos projetos não realizados para os edifícios para a construtora Beter na Vila Olímpia (1991) e para sua sede, na Rodovia Raposo Tavares (1992). Nos dois casos, edifícios verticais são compostos pela laje flexível para espaços de trabalho e pela justaposição das torres de circulação vertical, sanitários e demais infraestruturas. Neste último, as fachadas se expressam pela grelha da estrutura metálica com seus contraventamentos aparentes, destacada em relação aos fechamentos de vidro, que parecem reforçar a relação com a arquitetura high-tech, embora adaptada à realidade brasileira.

Apesar de se relacionarem a projetos de Louis Kahn ou Oscar Niemeyer, conforme Eduardo de Almeida, a referência formal mais próxima afigura-se a dos arquitetos Norman Foster ou Richard Rogers, respectivamente conhecidos por obras como o Hong Kong Shangai Bank e Lloyd's Bank, concluídos em 1986.

A construção destes dois edifícios acontece simultaneamente a inúmeros outros de grande porte como a Estação Ibitirama do Metrô (1989), a sede da FAPESP (1991), o Novo Teatro de São Paulo (1994), o campus da FGV (1995), o Museu Constantini (1997) ou o MAC USP da Barra Funda (2001), edificações de caráter público que não se realizaram, mas certamente direcionaram as obras de maior porte dos últimos anos, como a sede da SAP em São Leopoldo, inaugurada em 2009, a Biblioteca José e Guita Mindlin e o Instituto de Estudos Brasileiros, iniciados em 2000 e concluídos em 2012.

Entre esta produção, diversas obras de menor porte foram construídas, alternando soluções vinculadas à experiências tecnológicas diversas, com elementos formais ligados à tradição,

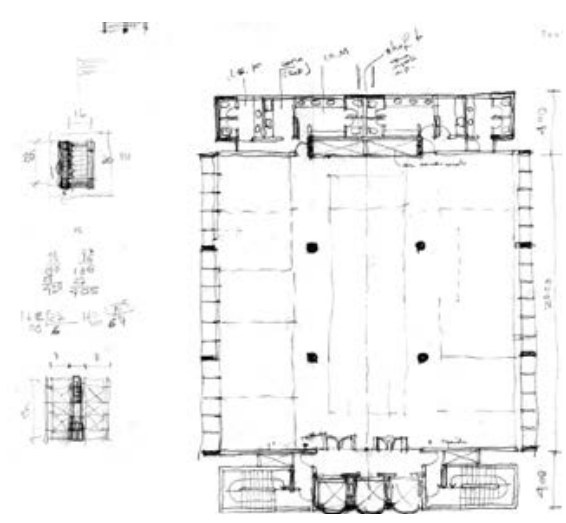

Croquis da planta do Edifício Vila Olímpia Acervo Eduardo de Almeida
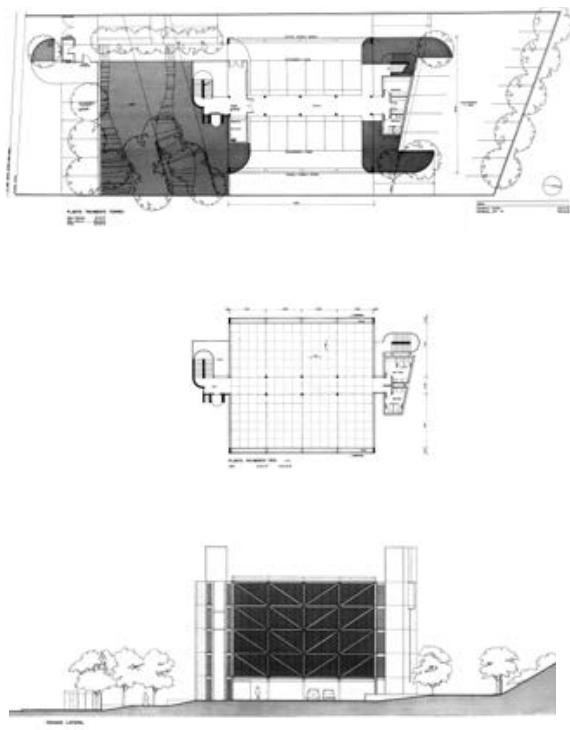

Pranchas do projeto para a sede da construtora Beter

Acervo Eduardo de Almeida 


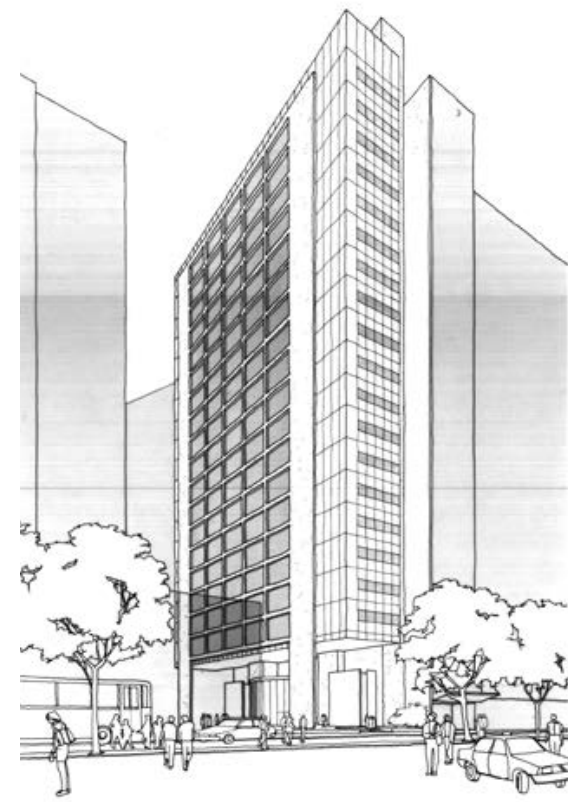

Sede da FAPESP

Perspectiva retirada de uma das prancha do concurso

Acervo Eduardo de Almeida

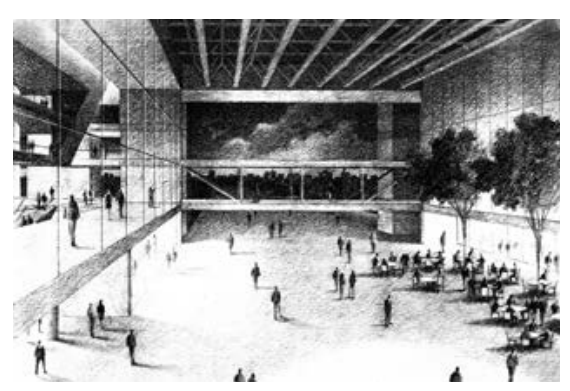

Perspectiva interna de uma das versões para o projeto do Novo Teatro de São Paulo

Acervo Eduardo de Almeida

À direita, corte do Projeto Executivo da Residência Bracher

Acervo Eduardo de Almeida como as casas para Cândido Bracher (1989), Alain Costilhes (1991), Pacheco e Silva (1993) ou Filizola (1995).

Nestes últimos casos, misturam-se materiais expressivos como muros de pedra, estruturas metálicas e coberturas inclinadas ora com telhas cerâmicas ora com telhas metálicas, sem que se revelem como elementos contraditórios.

Ao que parece, mais uma vez, a produção destas obras pode ser considerada como resultado de respostas específicas a cada caso, independentemente do programa, do sítio ou da escala, mas sempre unificada por um mesmo fazer, desenvolvido de modo coerente por meio de desenhos precisos.

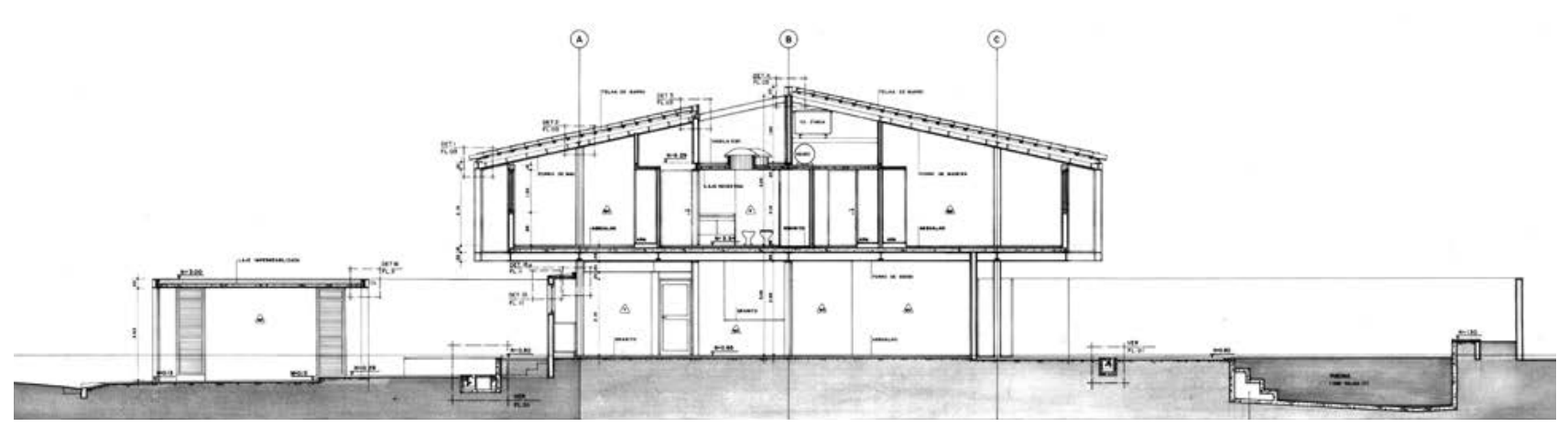



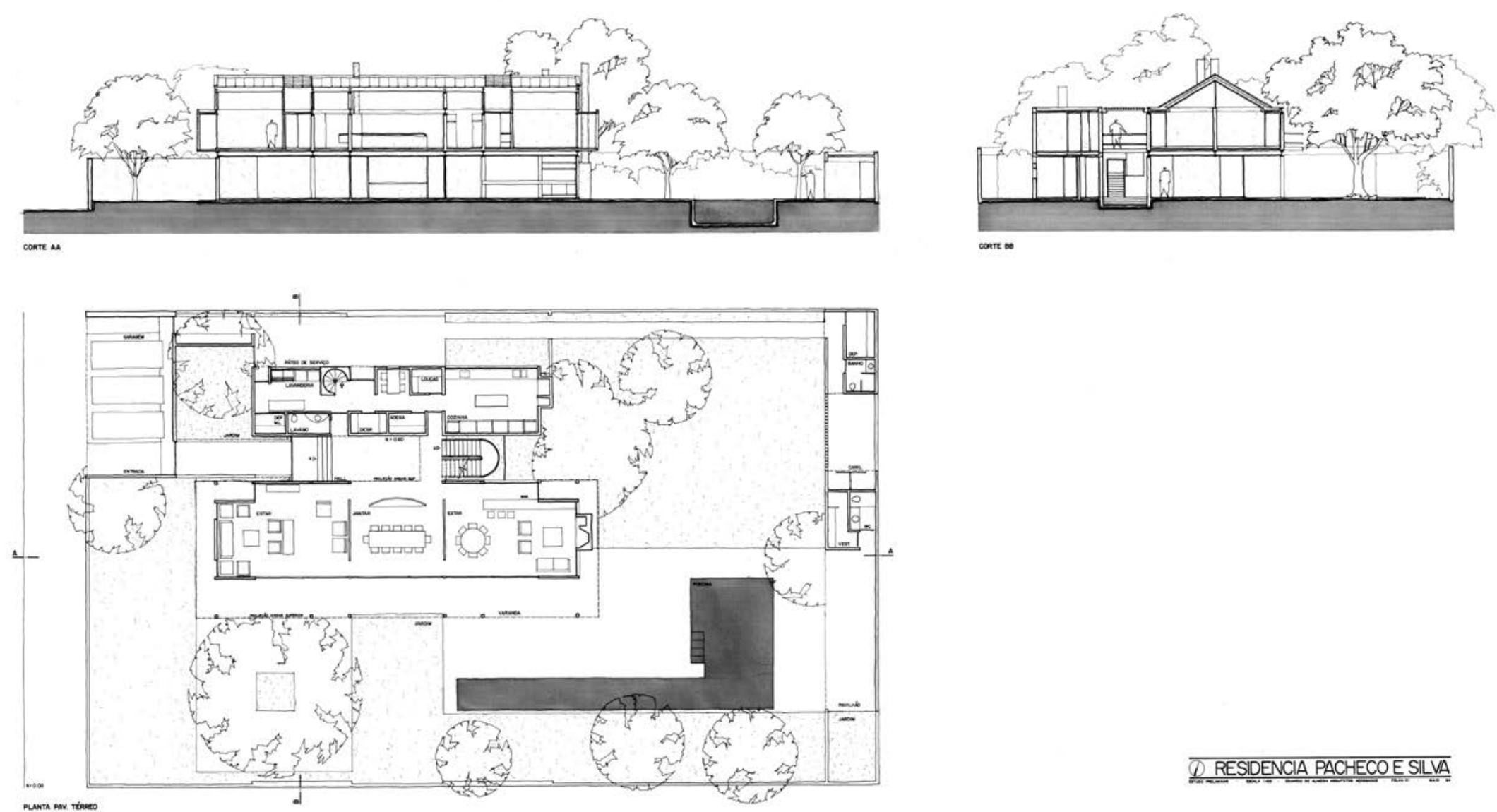

D RESIDENCIA PACHECO ESILVA 

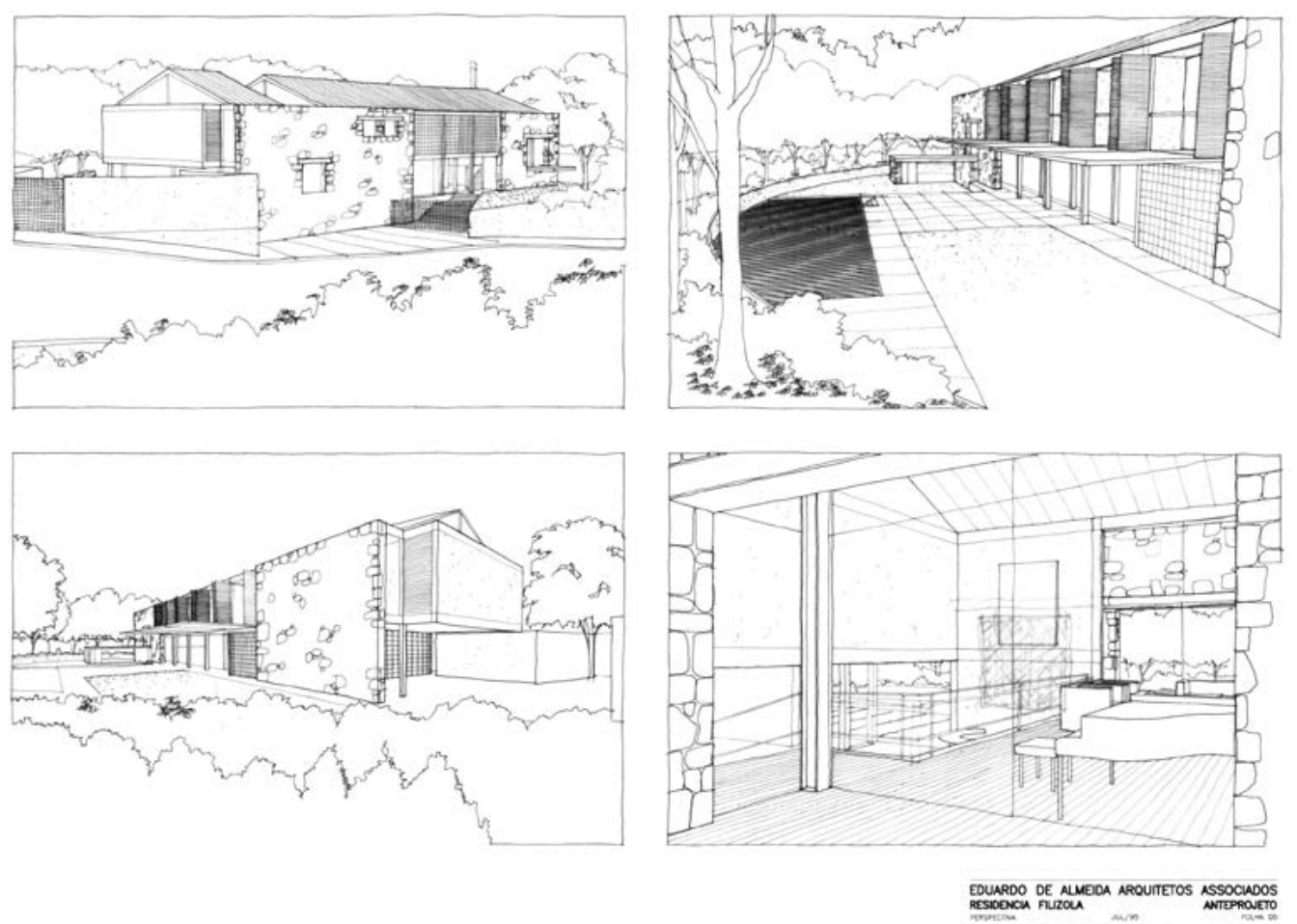

Perspectivas da Residência Filizola Acervo Eduardo de Almeida

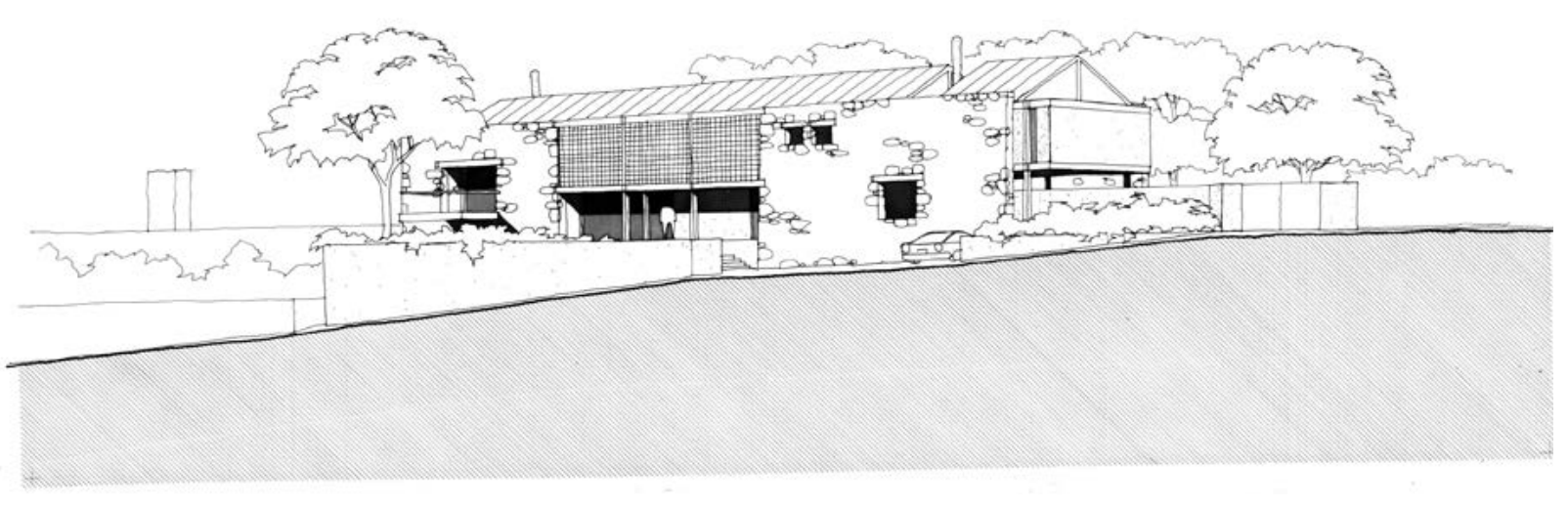




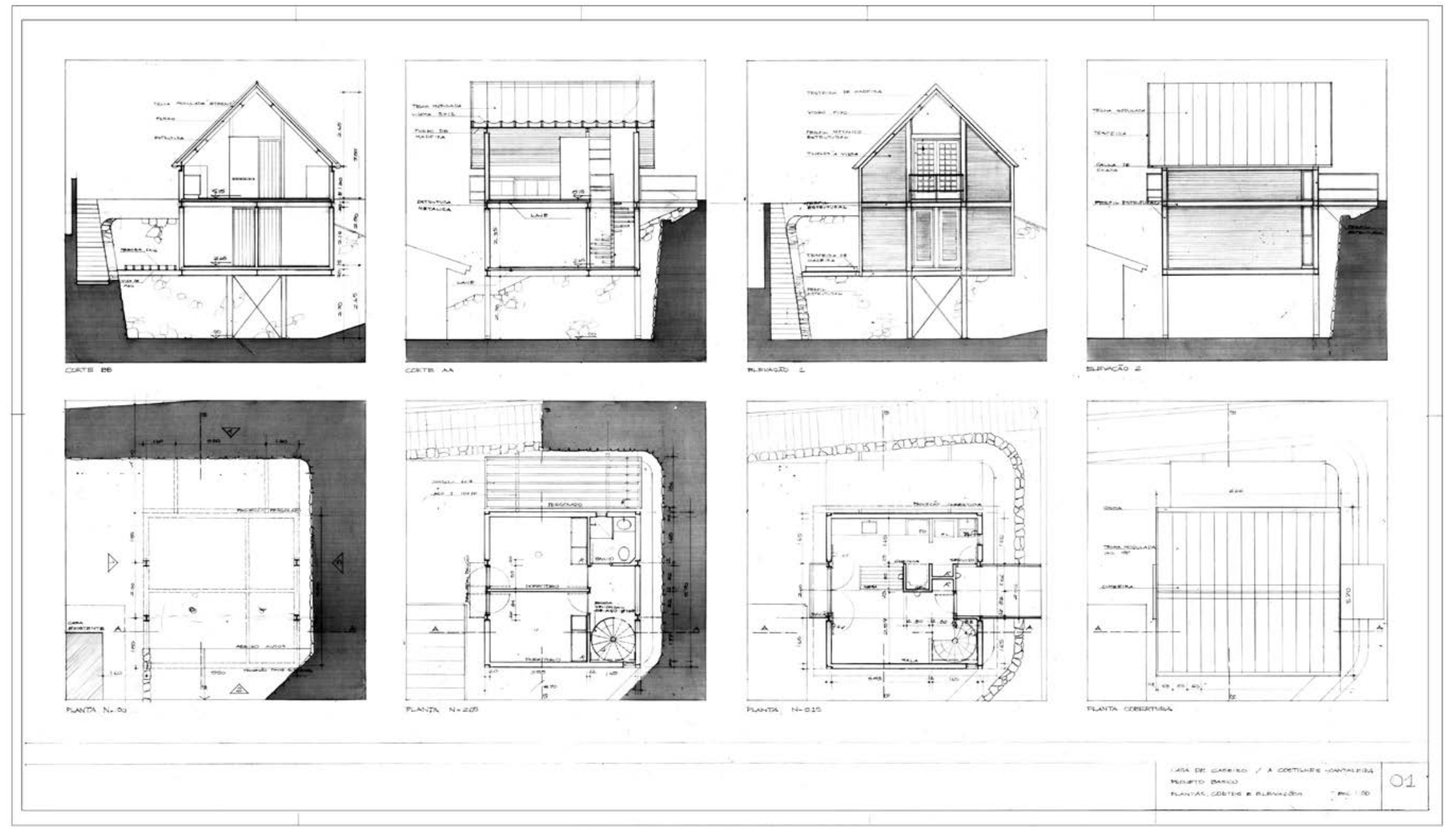

Projeto Básico da Residência Alain Costilhes Acervo Eduardo de Almeida 

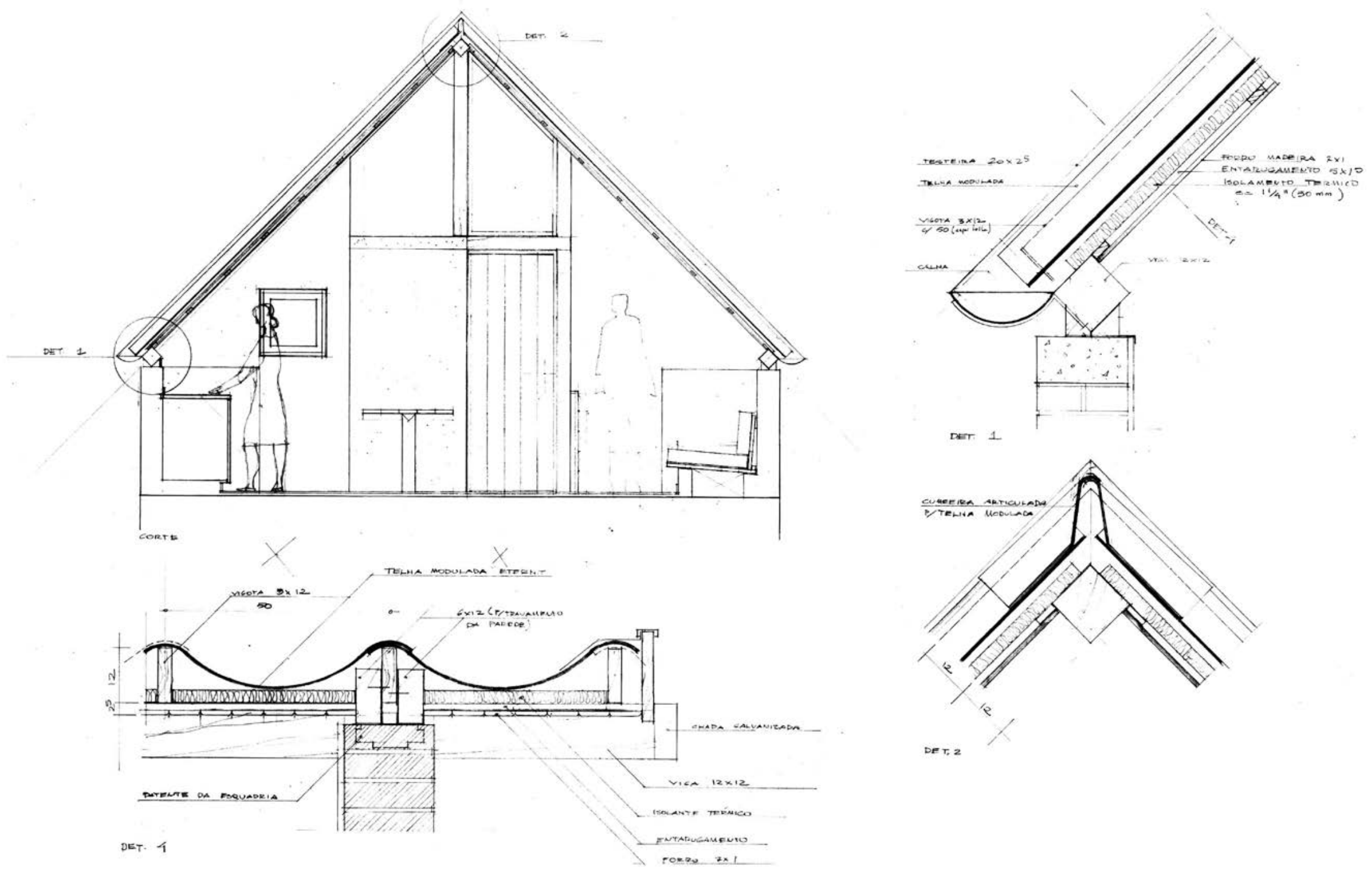

Corte e detalhes da Residência Alain Costilhes Acervo Eduardo de Almeida 


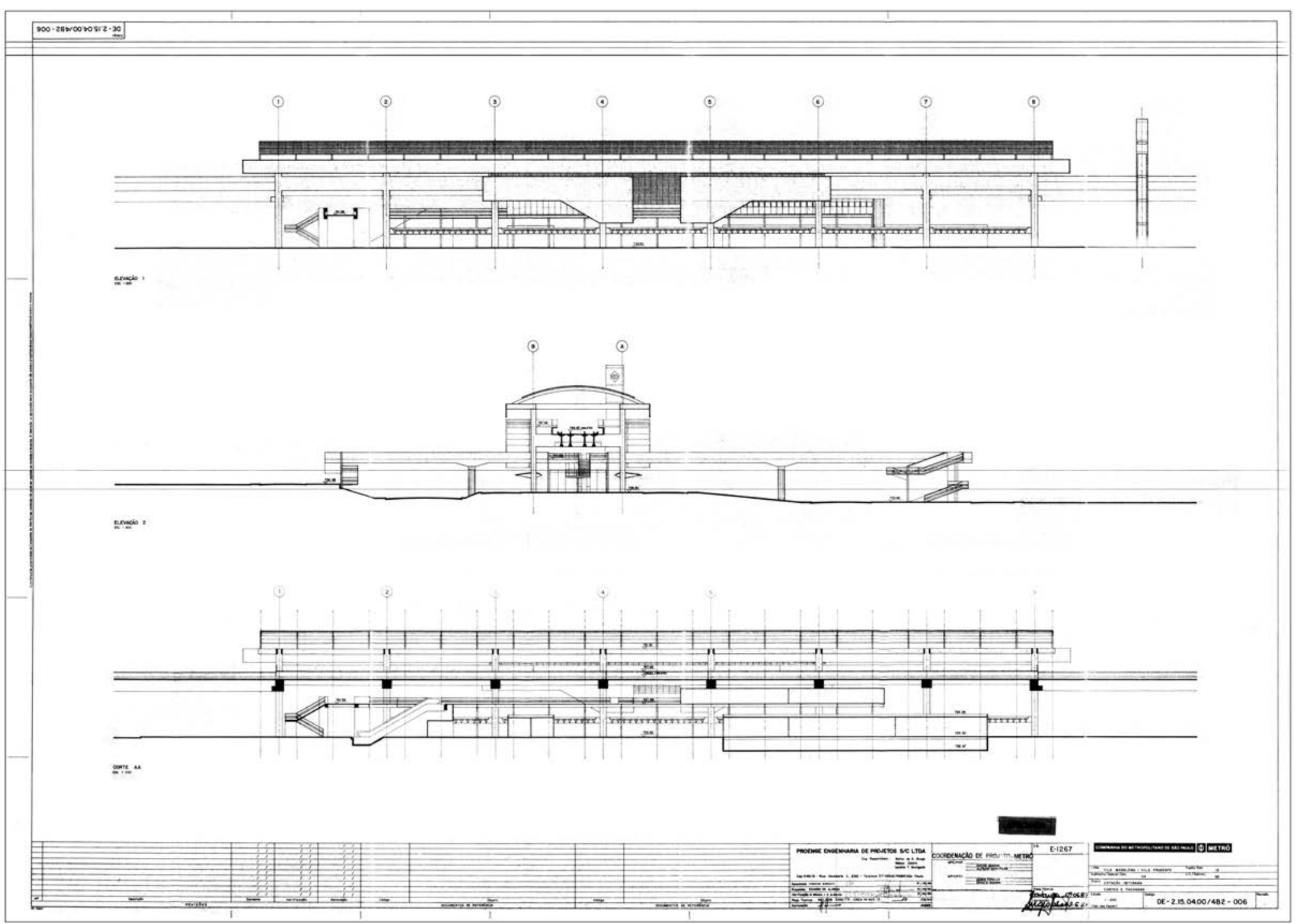

Prancha de cortes do projeto para a Estação Ibitirama do Metrô

Acervo Eduardo de Almeida 


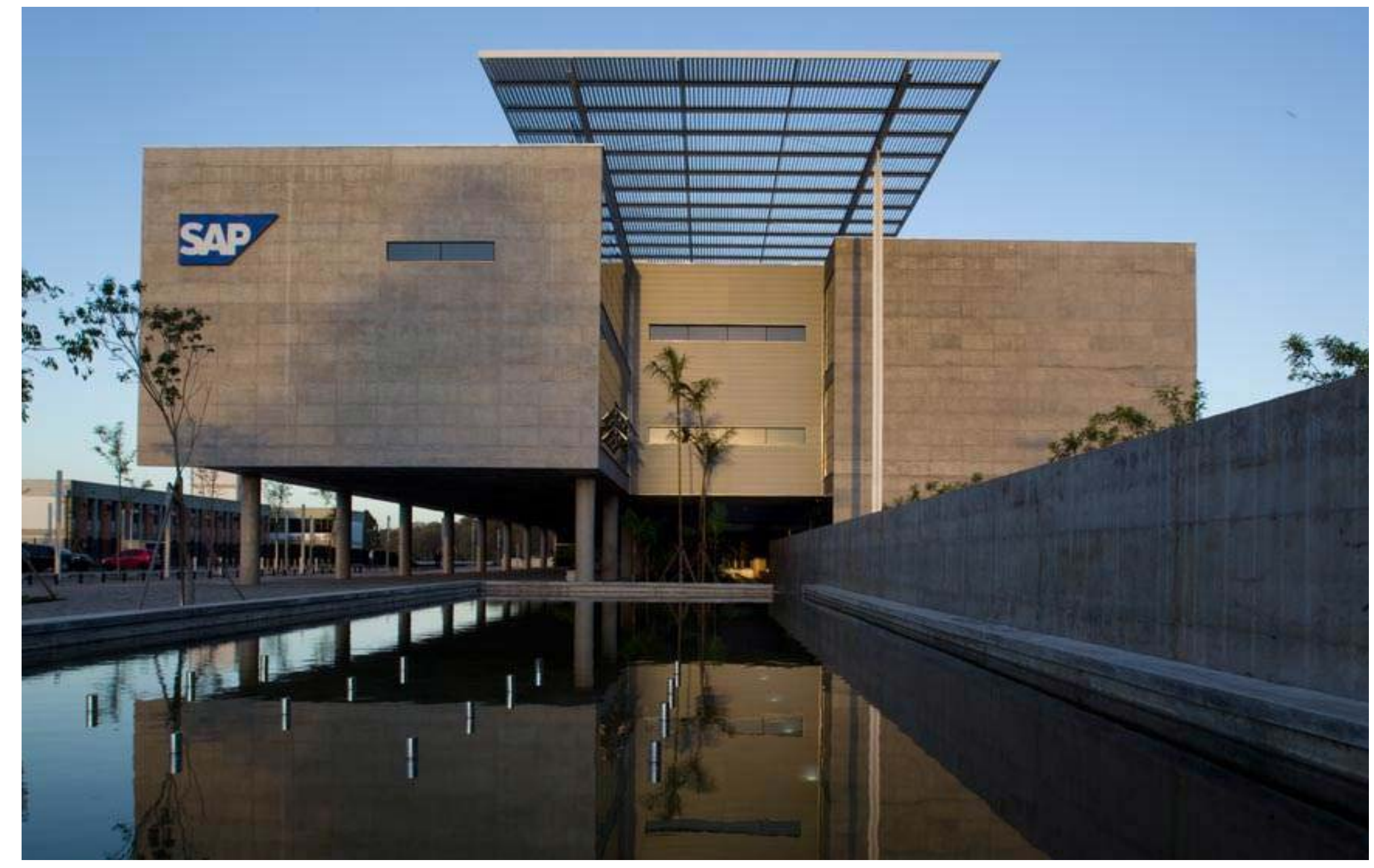

SAP Labs Brasil 



\section{Considerações Finais}




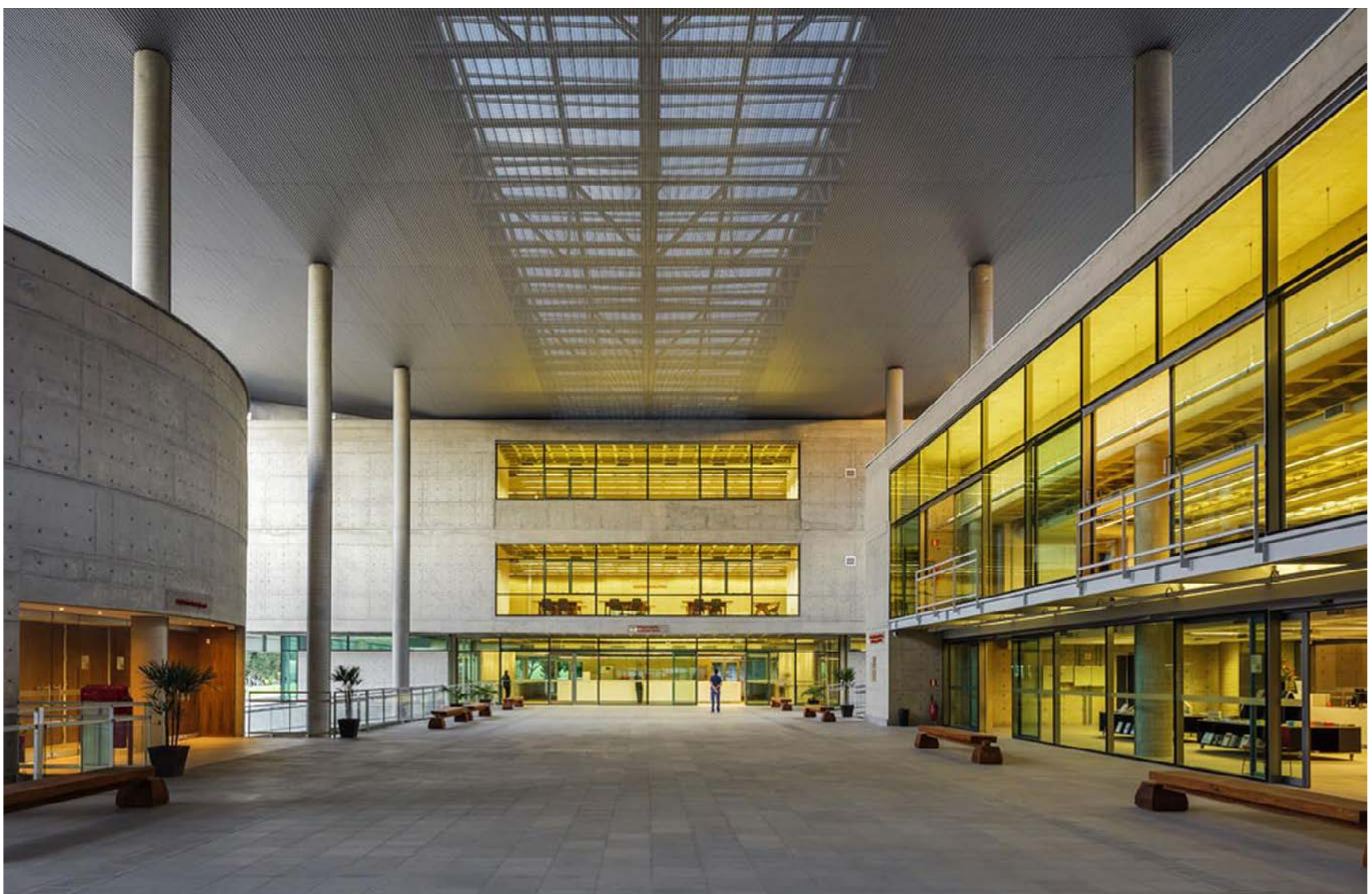

Biblioteca Guita e José Mindlin e IEB, vista do Instituto de Estudos Brasileiros, IEB, para o acervo de livros. Foto: Nelson Kon 
Em minha formação como aluno da FAU USP, tive o privilégio de contar com o convívio de professores como Abrahão Sanovicz, Arnaldo Martino, Paulo Mendes da Rocha, Marcos Acayaba e, principalmente, com Eduardo de Almeida. Senti o compromisso de publicar a obra destes arquitetos e professores, fundamentais para nossa formação, com a intenção de retransmitir este saber aos novos alunos, futuros arquitetos.

Mesmo porque, em minha própria formação como arquiteto, tão importante quanto os estudos voltados à teoria e à história, foi a aproximação prática das visitas às obras, dos estudos de projetos por meio de livros e, sobretudo, do aprendizado constante até os dias de hoje, do convívio cotidiano e enfrentamento de inúmeros projetos com o arquiteto Eduardo de Almeida.

A elaboração deste trabalho, como convém assinalar, consistiu em um longo processo de síntese da produção deste arquiteto que, apesar de ocupar escritórios de pequena dimensão, acumulou considerável quantidade de trabalhos ao longo de mais de 50 anos de profissão.

0 enfrentamento na leitura destes projetos, aqui reunidos pela primeira vez em seu conjunto completo, exigiu cuidado e atenção pois seu desenvolvimento não é linear. Ao contrário, os projetos são encadeados por avanços, pausas e retomadas de antigas soluções, sem uma cronologia clara, tendo em vista que seu fazer sofre influência de diferentes arquitetos, por vezes com opiniões opostas aos seus questionamentos.

Aparentemente contraditórios, muitos projetos mesclam soluções formais e técnicas construtivas variadas em arranjos incomuns, de tal forma que também não é possível classificar a obra de Eduardo de Almeida e inserí-la em uma produção coletiva clara, apesar de seus inúmeros pontos comuns com a Escola Paulista e com a produção de seus colegas da FAU USP.

Esta condição, guardadas as devidas proporções, assemelha-se à leitura de Guilherme Wisnik sobre a produção de Lucio Costa, já que a obra deste arquiteto "parece encarnar um sem-número de ambivalências", voltadas ao moderno e à tradição: “Contradição e ambiguidade são aspectos que, longe de diminuírem a importância ou o interesse de sua obra, ao contrário, renovam seu vigor e sua atualidade."so

${ }^{90}$ WISNIK, Guilherme. Lucio Costa. São Paulo, Cosac Naify, 2001, p.8 
Não parece acaso que Eduardo de Almeida cite inúmeras vezes este texto de Wisnik como importante referência para a revisão crítica da história da arquitetura moderna brasileira, pois assim como em sua obra, decorrente também de uma personalidade reservada e informada como a de Lucio Costa, os projetos apresentam variações que refletem as incoerências e contrastes de nosso país, embora as respostas de Eduardo estejam mais voltadas ao uso da racionalidade técnica como instrumento de construção de um "ideal de civilidade", como também afirma Wisnik.

Dentro deste panorama, a chave para a leitura das obras só foi possível a partir de minha lembrança como estudante da FAU USP, sobre a importância didática de Eduardo de Almeida para colegas de diversas gerações que nele encontraram uma generosidade incomum na orientação de projetos diversos.

Esta importância didática se traduz nesta pesquisa por meio da tentativa de ressaltar determinados aspectos presentes de modo recorrente na sua obra, uma vez que a produção efetiva se dá de forma empírica, sem uma sistematização que pudéssemos simplesmente adotar como método; ao contrário, Eduardo de Almeida sempre foi avesso a generalizações ou posições doutrinárias.

Ao mesmo tempo, o olhar para esta produção chamou atenção por sua constância, não da forma - mas do fazer -, pautado pela dedicação e crença no projeto arquitetônico, refletido em desenhos de rara qualidade, e resultando em obras classificadas pelo "rigor, concisão e apuro formal", como genericamente sempre se resumiu a obra de Eduardo de Almeida.

Esta constância, permitiu destacar algumas recorrências encontradas nas leituras dos projetos, que acabaram por definir os capítulos desta tese, mas que, por outro lado, não esgotam o tema; apenas inicia-se aqui uma possível interpretação desta obra que, agora publicada de modo completo, poderá desencadear novos estudos.

A escolha dos temas que compõem os capítulos deste trabalho, permite revelar um processo de pensamento, expresso através dos projetos, que acompanha a formação e desenvolvimento da carreira de Eduardo de Almeida como arquiteto, e também como professor. 


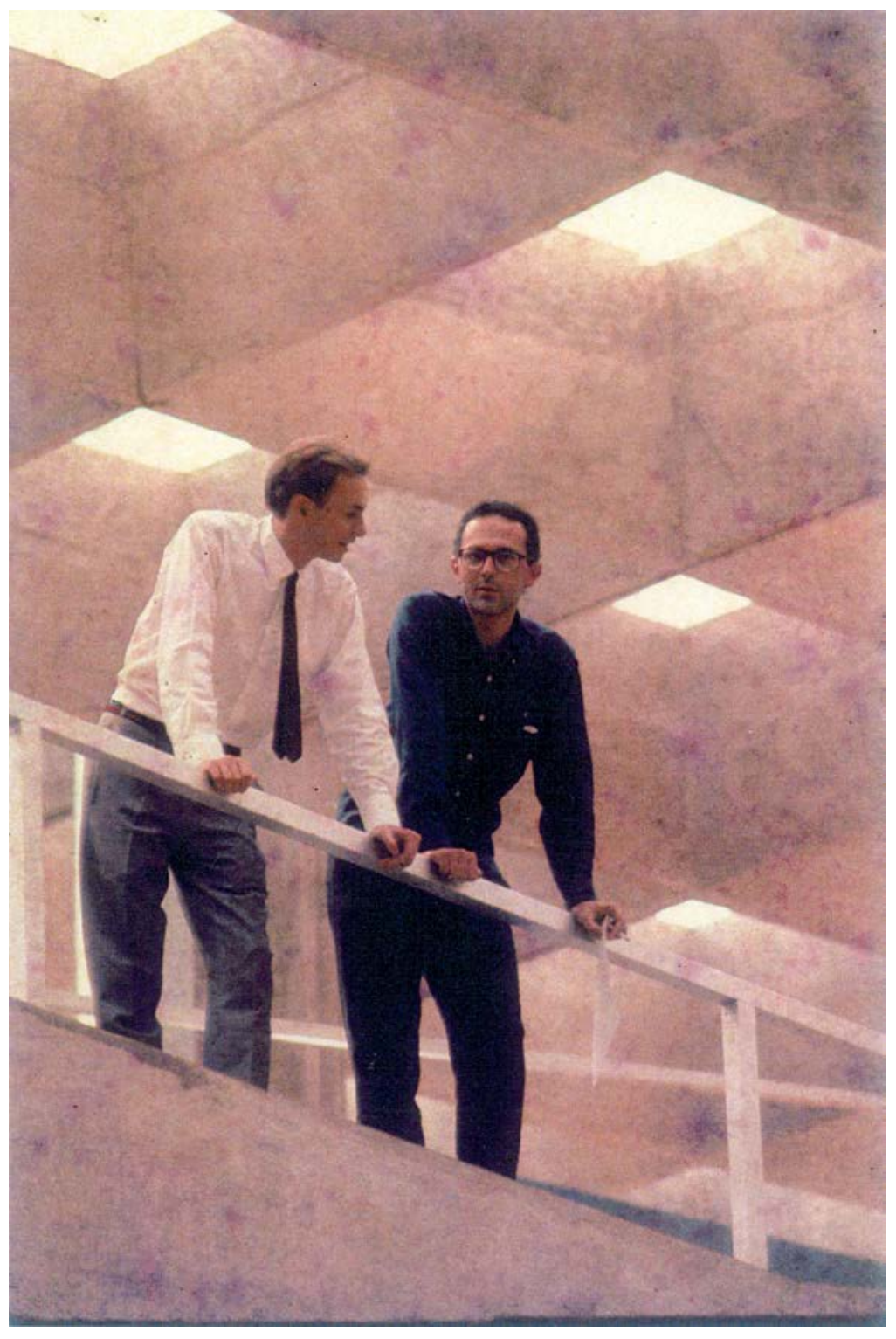

Eduardo de Almeida e João Xavier na FAU USP Foto: João Xavier 
A minuciosa leitura do projeto para a Brasiliana USP, composto pela Biblioteca José e Guita Mindlin e pelo IEB - Instituto de Estudos Brasileiros, a partir dos capítulos desta tese, poderia destacar a passagem pública através do edifício e as relações de continuidade e transparência entre os diversos blocos ou com o entorno -, bem como o desenvolvimento do projeto em coerência constante entre a parte e o todo, entre outros temas.

Mas essa análise, ao final, não foi realizada, talvez porque não seja possível ter ainda o distanciamento temporal e crítico suficiente para examinar a produção dos últimos dez anos, assim como acredito que essa realização mereça estudos mais específicos e aprofundados.

Seria natural encerrar nossa leitura com uma conclusão 'apoteótica' sobre um edifício de grande porte e de rara qualidade dentro do contexto das obras públicas brasileiras, como se esta importante realização pudesse redimir a produção de Eduardo de Almeida, até então reconhecido por uma produção aparentemente restrita a poucas e requintadas obras de caráter privado.

Ao contrário, o que se pretendeu com esta tese foi revelar uma produção ampla de alta qualidade e ressaltar a ideia de processo projetual que poderia se concentrar nos exemplos fundantes, sobretudo naqueles capazes de reafirmar as recorrências, e não apenas o resultado final e específico de obras de exceção.

Como última observação, é importante pontuar que os temas aqui desenvolvidos e a seleção de projetos que ilustram cada assunto decorrem de inúmeros trabalhos de Eduardo de Almeida que sequer foram corretamente fotografados; apenas uma ínfima parcela deles foi publicada em qualquer tipo de mídia, erro histórico que essa tese procura corrigir em alguma medida. 
Mindlin e IEB
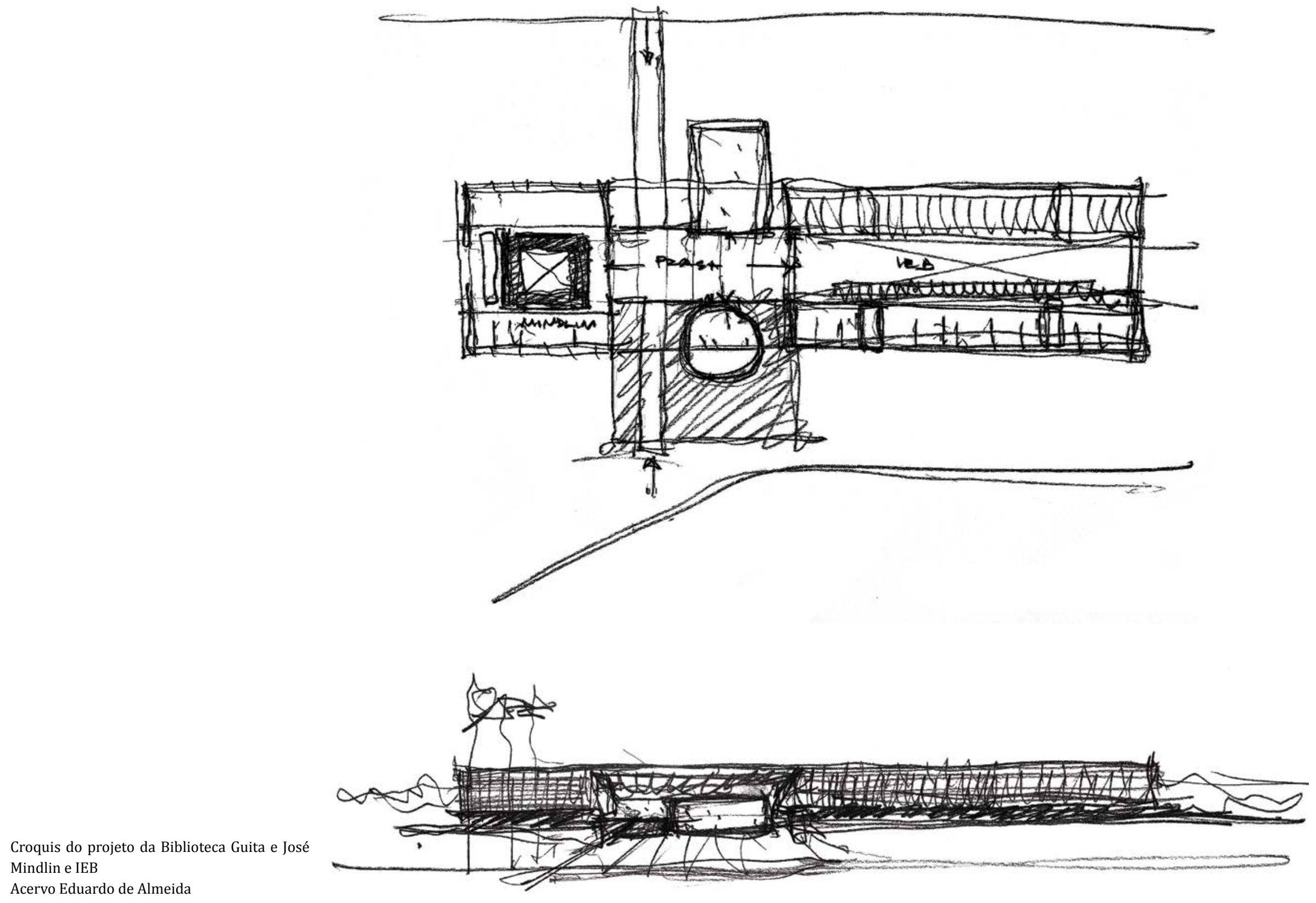

Referências bibliográficas 


\section{LIVROS, TESES E DISSERTAÇÕES}

ACAYABA, Marlene. Residências em São Paulo, Projeto, 1986.

Secretaria do Estado da Educação; Governo do Estado de São Paulo; FDE. Escolas Estaduais de Primeiro Grau: projetos arquitetônicos, 1996/1997.

AFLALO, Marcelo (org.); GAUZIN-MÜLLER, Dominique; MARTINS, Alberto; WISNIK, Guilerme (textos). Madeira como Estrutura: a história da ITA, Paralaxe, 2005.

ANDREOLI, Elisabetta e FORTY, Adrian (org.). Arquitetura Moderna Brasileira. London, Phaidon, 2002 ARANTES, Pedro Fiori. Arquitetura Nova. São Paulo, Editora 34, 2002

ARGAN, Giulio Carlo. Projeto e Destino. São Paulo, Ática, 2001

ARGAN, Giulio Carlo. Walter Gropius e a bauhaus. São Paulo, José Olympio, 2005

ARGAN, Giulio Carlo. História da Arte como história da cidade. São Paulo, Martins Fontes, 1992

ARTIGAS, João Batista Vilanova. Caminhos da arquitetura. 4 ed. rev. e ampl.. São Paulo, Cosac Naify, 2004

ARTIGAS, Rosa (org.). Paulo Mendes da Rocha, projetos 1957-1999. São Paulo, Cosac Naify, 2006

BALTANÁS, José. Le Corbusier: Promenades. Barcelona, Editorial Gustavo Gilli, 2005

BANHAM, Reyner. Megaestructuras, Futuro Urbano del Pasado Reciente. Barcelona, Editorial Gustavo Gilli, 1978 BANHAM, Reyner. Teoria e projeto na primeira era da máquina. São Paulo, Perspectiva, 1979

BAXANDALL, Michael. Padrões de intenção. São Paulo, Companhia das Letras, 2006

BENEVOLO, Leonardo. O último capítulo da arquitectura moderna. Lisboa, Edições 70, 1985

BOESIGER, Willy. Le Corbusier. Barcelona, Editorial Gustavo Gilli, 1972

BREUER, Marcel. CRANSTON, Jones. HATJE, Gerd. Marcel Breuer: Construcciones y proyectos 1921-1961.

Barcelona, Editorial Gustavo Gilli, 1963

BRONSZTEIN, Maressa. Dissertação de mestrado: A experiência construtiva na obra de Arnaldo. São Paulo, FAU USP, 2013

BROOKS, H. Allen. Writings on Wright, selected comment on Frank Lloyd Wright. London, The MIT Press, 1983

BRUAND, Yves. Arquitetura Contemporânea no Brasil. São Paulo, Perspectiva, 2008

CAMARGO, M. J.; LEMOS, J. A.; SUlTANI, A. Fábio Penteado / Ensaios de Arquitetura. 1. ed. São Paulo, Empresa das Artes, 1998

CARTER, Peter. Mies van der Rohe at work. London, Phaidon, 1999

CASTRIOTA, Leonardo Barci (org.). Arquitetura e documentação: novas perspectivas para a história da arquitetura. São Paulo, Annablume, 2011

COLQUHOUN, Alan. Modernidade e tradição clássica. São Paulo, Cosac Naify, 2004

CONDURU, Roberto. Vital Brazil. São Paulo, Cosac Naify, 2000 
CURTIS, William. Le Corbusier, Ideas and Forms. London, Phaidon, 1986

DIAS, Luís Andrade de Mattos. Edificações de Aço no Brasil, São Paulo, Zigurate Editora, 2002.

DRILLER, Joachim. BREUER HOUSES. London, Phaidon, 2000

EISENMAN, Peter. The Formal Basis of Modern Architecture. Trinity College, University of Cambridge, 1963.

Baden, Lars Muller Publishers, 2006

PEREIRA, Miguel Alves (Coord. geral); PRESTES, Lucinda Ferreira (org.). Sobre Arquitetura Brasileira e Ensino na

Virada do Século - Depoimentosde Professres Arquitetos da FAUUSP - vol. 1. São Paulo, 2008.

FERRAZ, Marcelo (org.). Vilanova Artigas: Arquitetos Brasileiros. São Paulo, Instituto Lina Bo Bardi, 1997

FERRONI, Eduardo. A dimensão urbana do edifício in Salvador Candia. São Paulo, Editora da Cidade, 2013

FRAMPTON, Kenneth. Tectonic Culture: the poetics of construction in nineteenth century architecture.

Massachusetts Institute of Technology, 1995

FRAMPTON, Kenneth. Labor, work and architecture: collected essays on architecture and design. New York,

Phaidon, 2002

FRAMPTON, Kenneth. História Crítica da arquitetura moderna. São Paulo, Martins Fontes, 2000

FUJIOKA, Paulo. Princípios da Arquitetura Organicista de Frank Lloyd Wright e suas influências na

Arquitetura Moderna Paulistana. São Paulo, FAUUSP, 2003

GARCÍA-GERMAN, Jacobo. Estrategias operativas en arquitectura: técnicas de proyecto de Price a Koolhaas.

Buenos Aires, Nobuko, 2012

FERREIRA, Avany de Francisco; de MELLO, Mirela Geiger. Arquitetura Escolar Paulista: estruturas pré-fabricadas,

2006, 1a edição.

FERREIRA, Avany de Francisco; de MELLO, Mirela Geiger. Arquitetura Escolar Paulista: anos 1950 e 1960, FDE -

Fundação para o Desenvolvimento da Educação, 2006.

Fundação Bienal. 6ª Bienal Internacional de Arquitetura de São Paulo: Viver na Cidade, 2005.

GARCIA, Mario Sergio; SÁ, Elio Gomes. OCA: arquitetura no Brasil, Victoria Books, 2005.

GIEDION, Sigfried. Espaço, tempo e arquitetura: o desenvolvimento de uma nova tradição. São Paulo, Martins

Fontes, 2004

GREGOTTI, Vittorio. Território da Arquietura. São Paulo, Editora Perspectiva, 1975

GUERRA, Abílio. Eduardo de Almeida. São Paulo, Romano Guerra, 2006

HERTZBERGER, Herman. Lições de Arquitetura. São Paulo, Martins Fontes

IMBRONITO, Maria Isabel. Dissertação de mestrado: Três edifícios de habitação para a Formaespaço: Modulares,

\section{Gemini e}

Protótipo. São Paulo, FAUUSP, 2003

IMBRONITO, Maria Isabel. Tese de Doutoramento: Procedimento de projeto com base em retículas: estudo de 
casas de Eduardo de Almeida. São Paulo, FAU USP, 2008

IRIGOYEN, Adriana.Wright e Artigas, duas viagens. São Paulo, Ateliê Editorial, 2002

JORGE, Luís Antônio. Tese de doutoramento: O Espaço Seco: Imaginário e poéticas da arquitetura moderna na América. São Paulo, FAU USP, 1999.

LIRA, José. Warchavchik: Fraturas da Vanguarda. São Paulo, Cosa Naify, 2011

KAMITA, João Masao. Vilanova Artigas. São Paulo, Cosac Naify, 2000

KAUFMANN JR, Edgar J.; GIROUARD, Mark (introdução). Fallingwater: A Frank Lloyd Wright Country House. Abbeville

Press. New York, 1986.

KOURY, Ana Paula. Grupo Arquitetura Nova. São Paulo, Romano Guerra, Edusp, Fapesp, 2003

KOURY, Ana Paula. Tese de Doutoramento: Arquitetura Construtiva, proposições para a produção material da arquitetura contemporânea no Brasil. São Paulo, FAU USP, 2005

LORD, James. Um retrato de Giacometti. São Paulo, Iluminuras, 1998

MARTINEZ, Alfonso Corona. Ensaio sobre o Projeto. Brasília, Editora Universidade de Brasília, 2000

McCARTER, Robert. On and By Frank Lloyd Wright, A Primer of Architectural Principles. London, Phaidon, 2005

MATERA, Sérgio. Carlos Millan um estudo sobre a produção em Arquitetura. Dissertação de mestrado, FAUUSP. São Paulo, Página 243.

MONEO, Rafael. Inquietação Teórica e Estratégia Projetual ns obra de oito arquitetos contemporâneos. São Paulo, Cosac Naify, 2008

MONTANER, Josep Maria. Sistemas arquitectónicos contemporáneos. Barcelona, Editorial Gustavo Gilli, 2009

MONTANER, Josep Maria. Después del movimiento moderno, arquitectura de la segunda mitad del siglo XX. Barcelona, Editorial Gustavo Gilli, 1993

NEUTRA, Richard J. Richard Neutra, La naturaliza y la vivienda. Barcelona, Editorial Gustavo Gilli, 1970

NESBITT, Kate (org.). Uma nova agenda para a arquitetura: antologia teórica 1965-1995. São Paulo, Cosac Naify,

2008

NIGGLI, Arthur. The Architects Collaborative Inc. Barcelona, Editorial Gustavo Gilli, 1971

OHTAKE, Ricardo. Vilanova Artigas. São Paulo, Instituto Tomie Ohtake, 2003

PADOVANO, Bruno. Arquitetos Brasileiros. São Paulo, ASBEA, sem data

PEREIRA, M. A. (coord.); PRESTES, L. F. Sobre Arquitetura Brasileira e Ensino na Virada do Século: Depoimentos dos Professores Arquietos da FAUUSP, FAUUSP, 2008.

PEVSNER, Nikolaus. Os pioneiros do desenho moderno. São Paulo, Martins Fontes, 1995

PIÑON, Hélio. Eduardo de Almeida. Barcelona, Edicions UPC, 2005

PIÑON, Hélio. Teoria do Projeto. Porto Alegre, Livraria do Arquiteto, 2006

PISANI, Daniele. Paulo Mendes da Rocha: Obra completa. São Paulo, Gustavo Gili, 2013. 
PONTES, Ana Paula. Dissertação de mestrado: Diálogos silenciosos: arquitetura moderna brasileira e tradição clássica. Rio de Janeiro, PUC RJ, 2004.

QUARONI, Ludovico. PROYECTAR UN EDIFICIO, ocho lecciones de arquitectura.Madrid, Xarait Ediciones, 1977

REIS FILHO, Nestor Goulart. Arquitetura de Rino Levi. In: Rino Levi. Milano: Edizioni di Comunità, 1974

REIS FILHO, Nestor Goular; BRITO, Mônica Silveira. Dois Séculos de Projetos no Estado de São Paulo: grandes

obras e urbanização. Imprensa Oficial, São Paulo, 1ae edição, V.3, 2010.

SEGRE, Roberto. Casas Brasileiras, Viana e Mosley, 2010.

SENNETT, Richard. O Artífice. São Paulo, Record, 2009

SILVA, Helena Aparecida Ayoub. Abrahão Sanovicz: o projeto como pesquisa. Volume 1. São Paulo, FAUUSP, 2004

SPIRO, Annette. Paulo Mendes da Rocha, Works and projects. Zurich, Niggli, 2002

SYKES, A. Krista (org.). O campo ampliado da arquitetura: antologia teórica 1993-2009. São Paulo, Cosac Naify,

2013

STROETER, João Rodolfo. Arquitetura e Forma. São Paulo, FAU USP, 2012

TAFURI, Manfredo. Projecto e utopia: arquitectura e desenvolvimento do capitalismo. Lisboa, Editora Presença,1985

TAFURI, Manfredo. DAL CO, Francesco. Modern Architecture 1. Milano, Electa,1976

TAFURI, Manfredo. DAL CO, Francesco. Modern Architecture 2. Milano, Electa,1976

TASSINARI, Alberto. O espaço moderno. São Paulo, Cosac Naify, 2001

THOMAZ, Dalva Thomaz. Um olhar sobre Vilanova Artigas e sua contribuição à arquitetura brasileira.

Dissertação de Mestrado, São Paulo, FAUUSP, 1997

URSPRUNG, Philip. Herzog \& de Meuron, Natural History. Montreal, Canadian Centre for Architecture and Lars

Muller, 2002

WISNIK, Guilherme. Estado Crítico, à deriva nas cidades. São Paulo, Publifolha, 2009

WISNIK, Guilherme. Lucio Costa. São Paulo, Cosac Naify, 2001

WISNIK, Guilherme; SEGAWA, Hugo; KATINSKY, Julio; ACAYABA, Marcos. Marcos Acayaba. São Paulo, Cosac Naify, 2007

VALÉRY, Paul. Eupalinos ou o arquiteto. São Paulo, Editora 34, 1999.

ZEVI, Bruno. A linguagem moderna da arquitectura. Lisboa, Publicações Dom Quixote, 1984

ZEVI, Bruno. Saber ver a arquitetura. São Paulo, Martins Fontes, 1996

ZEVI, Bruno. Frank Lloyd Wright. Barcelona, Editorial Gustavo Gilli, 1993, 5a edição.

XAVIER, Alberto; LEMOS, Carlos; CORONA. Eduardo. Arquitetura Moderna Paulista, Pini, 1983. 


\section{PERIÓDICOS}

Anteprojeto da Secretaria de Agricultura do Estado de São Paulo. Acrópole, ano 30, n. 357, dez 1968, pág. 22-24.

Residência Lalo de Almeida. Arquitetura e Construção, julho de 1999, pág. 56-61.

Presente de pai. Arquitetura e Construção, setembro de 2005, pág. 60-65.

Arquitetura e Construção, fevereiro de 2008, pág. 44-47.

Arquitetura e Construção: casas contemporâneas, pág. 26-35.

Arquitetura e Urbanismo, ano 6, n 32, outubro/novembro de 1990, pág. 20-21.

Residência em Alto de Pinheiros. Arquitetura e Urbanismo, ano11, n. 58, fevereiro/março de 1995, pág. 36-39.

Fazenda Água Comprida, MG. Arquitetura e Urbanismo, n. 88, 2000, pág. 46-49.

Arquitetura e Urbanismo, ano 26, n. 202, janeiro de 2011, pág. 65-69.

Arquitetura e Urbanismo, ano 28, n. 229, abril de 2013, pág. 38-96.

Bamboo, 2013, pág. 140-145.

Caramelo, n. 6, 1998, pág. 50/115.

Casa Cláudia, n. 94-A, julho de 1969, pág. 81.

Casa Claúdia, 1985, pág. 68-72.

Encontro e Reencontro. Casa Cláudia: Luxo, 2011/2012, pág. 76-87.

Casa e Construção, pág. 46-51.

Casa e Jardim, 1975, pág. 38-43.

Casa e Jardim, 1976, pág. 42-48

Casa e Jardim, v. 368, 1985, pág. 68-73.

Casa Vogue, n. 35-A, maio de 1978, pág. 64-71.

Desafiando a Racionalidade - artigo crítico da Profa. Cecília Rodrigues dos Santos sobre a Residência

Eduardo de Almeida. Casa Vogue, ed. 150, ano 21, n. 7, 1997, pág. 142-147.

Casa Vogue, ano 9, n. 4, 1985, pág. 104-109.

Construção São Paulo, ano XXXVI, n. 1841, maio de 1983, pág. 16.

Projetos para o Museu Constantini - Menção Honrosa (concurso internacional - Buenos Aires, Argentina).

Finestra Brasil, ano 4, n. 13, 1997, pág. 41-43.

Módulo, ed. 85, 1985, pág. 82-83.

Modern Brazilian Architecture. Process, n. 17, 1980, pág. 126-133.

Conjunto Residencial Gemini. Projeto e Construção, agosto de 1971, pág. 35-39.

Cinquentenário da Faculdade de Arquitetura e Urbanismo de São Paulo - FAUUSP - Residência Jean 
Sigrist. Projeto Design, n. 228, janeiro/fevereiro, 1999, pág. 58.

Residência Lalo de Almeida. Projeto Design, n.232, 1999, pág. 44-47.

Escolas Públicas FDE. Projeto Design, n. 236, outubro de 1999, pág. 69.

4므 Bia Prêmios/Concurso Internacional - Sede da Fazenda, Água Comprida, MG. Projeto Design, n. 239, ja-

neiro de 2000

Casa-sede e instalações da Fazenda, Água Comprida, MG. Projeto Design, n. 240, fevereiro de 2000, pág. 44-51.

Programa dividido em dois blocos é interligado por acesso transparente. Projeto Design, n. 249, novembro

de 2000, pág. 57-61.

Beleza e Criatividade - Restaurante Madelleine. Projeto Design, n. 274, dezembro de 2000.

Residência na Praia Vermelha do Sul, Ubatuba. Projeto Design, n. 285, novembro de 2003, pág. 48.

Restaurante Madelleine. Projeto Design, n. 291, maio de 2004, pág. 82-85.

Residência Unifamiliar. Projeto Design, n. 310, dezembro de 2005, pág. 68-71.

Edifício de Escritórios - Edifício-sede da SAP Labs. Projeto Design, n. 359, janeiro de 2010, pág. 38-49.

SAP Labs. Projeto Design, n. 371, janeiro de 2011, pág. 56-57.

La Scuola di São Paulo in Brasile. Concezione strutturale e ideazione architettonica. 142/143. Rassegna di Architettura e Urbanistica. Dipartimento de Ingegneria Civile, Edile, Ambientale. Facoltà di Ingegneria Civile e Industriale. Sapienza Università di Roma. Roma, Edizione Kappa, Gennaio-Agosto 2014

São Paulo Centro XXI: Entre História e Projeto, 1994, pág. 48-49.

Veja São Paulo, 20 de março de 2013, pág. 54-58.

O Estado de São Paulo, São Paulo, jan. 1969.

O Estado de São Paulo, São Paulo, pág. 9-10, jan. 1971.

O Estado de São Paulo, São Paulo, set. 1990.

O Estado de São Paulo, São Paulo, 1990.

Folha de São Paulo, São Paulo, 2006.

Folha de São Paulo, São Paulo, out. 2007.

Folha de São Paulo, São Paulo, fev. 2013.

O Estado de São Paulo, São Paulo, fev. 2013.

O Estado de São Paulo, São Paulo, mar. 2013. 


\section{SITES}

Prancha do Concurso Internacional de Arquitetura para o Centro Georges Pompidou. Disponível em:

<https://www.centrepompidou.fr/cpv/resource/ckXMzL6/rEnKgrz>. Acessado em 9 de dezembro de 2014.

SANTOS, Cecília Rodrigues. Casa das Canoas de Oscar Niemeyer: fazendo a alma cantar. in Vitruvius, Arquitextos, Setembro de 2003. Disponível em: < http://www.vitruvius.com.br/revistas/read/arquitextos/04.040/654>. Acessado em 2 de fevereiro de 2015.

\section{CRÉDITOS DAS IMAGENS}

Todas as imagens - desenhos e fotos - que estão sem créditos foram obtidos junto ao acervo do escritório Eduardo de Almeida Arquitetos Associados. 